

\section{REVISTA DE DIREITO INTERNACIONAL}

\section{BRAZILIAN JOURNAL OF INTERNATIONAL LAW}

Editora Especial para essa edição:

Professora Carina Costa de Oliveira

Editores responsáveis por essa edição:

Professor Marcelo Dias Varella

Professor Nitish Monebhurrun

Profesora Alice Rocha da Silva

ISSN 2237-1036 
REVISTA DE DIREITO INTERNACIONAL

BRASILIAN JOURNAL OF INTERNATIONAL LAW

Programa de Mestrado e Doutorado em Direito

Centro Universitário de Brasília

Reitor

Getúlio Américo Moreira Lopes

Presidente do Conselho Editorial do UniCEUB

Elizabeth Regina Lopes Manzur

Diretor do ICPD

João Herculino de Souza Lopes Filho

Coordenador do Programa de Mestrado e Doutorado e Editor

Marcelo Dias Varella

\section{Linha editorial}

A Revista de Direito Internacional (RDI) foi criada como instrumento de vinculação de trabalhos acadêmicos relacionados a temáticas tratadas pelo Direito Internacional Público e Privado. A revista é sucessora da Revista Prismas, que foi dividida em dois periódicos (junto com Revista Brasileira de Políticas Públicas), em virtude da quantidade de submissão de artigos e procura. Na busca pelo desenvolvimento e construção de visões críticas a respeito do Direito Internacional, a RDI possui sua linha editorial dividida em dois eixos:

1. Proteção internacional da pessoa humana: abrange questões referentes ao direito internacional ambiental, direito humanitário, internacionalização do direito, além de pesquisas sobre a evolução do direito dos tratados como forma de expansão do direito internacional contemporâneo.

2. Direito Internacional Econômico: abrange questões referentes aos sistemas regionais de integração, direito internacional econômico e financeiro e solução de controvérsias comerciais e financeiras. A RDI busca incentivar a pesquisa e divulgação de trabalhos relacionados as disciplinas voltadas para o estudo do Direito Internacional publicando artigos, resenhas e ensaios inéditos. A revista está aberta às mais diversas abordagens teóricas e metodológicas impulsionando a divulgação, o estudo e a prática do Direito Internacional.

\section{Comitê editorial}

Alice Rocha da Silva, Centro Universitário de Brasília

Cláudia Lima Marques, Universidade Federal do Rio Grande do Sul

José Augusto Fontoura Costa, Universidade de São Paulo

Julia Motte Baumvol, Université d'Evry Val d'Essonne

Nádia de Araújo, Pontíficia Universidade Católica do Rio de Janeiro

Nitish Monebhurrun, Centro Universitário de Brasília

\section{Layout capa}

Departamento de Comunicação / ACC UniCEUB

Diagramação

S2 Books

Disponível em:

www.rdi.uniceub.br

\section{Circulação}

Acesso aberto e gratuito

Matérias assinadas são de exclusiva responsabilidade dos autores.

Citação parcial permitida com referência à fonte. 
Revista de Direito Internacional / Centro Universitário de Brasília, Programa de Mestrado e Doutorado em Direito, volume 12, número 1 - . Brasília : UniCEUB, 2011-

Semestral.

ISSN 2237-1036

Disponível também on-line: http://www.rdi.uniceub.br/

Continuação de: Revista Prismas: Direito, Políticas Públicas e Mundialização. Programa de Mestrado em Direito do UniCEUB.

1. Direito Internacional. 2. Políticas Públicas. 3. Mundialização. I. Programa de Mestrado em Direito do UniCEUB. II. Centro Universitário de Brasília.

CDU 34(05)

Ficha catalográfica elaborada pela Biblioteca Reitor João Herculino

\section{Endereço para Permuta}

\section{Biblioteca Reitor João Herculino}

SEPN 707/907 Campus do UniCEUB

Cep 70790-075 Brasília-DF

Fone: 61 3966-1349

e-mail: biblioteca@uniceub.br 


\section{Sumário}

\section{Crônicas}

CRôNICAS DA ATUALIDADE do DiREITO INTERNACIONAL ........................................................ 2

Nitish Monebhurrun (org.)

Towards a european regulation of the importation of conflict minerals?..... 2

Nitish Monebhurrun

Keeping up with the terrorists: the EU's proposed Passenger Name Records (PNR) Directive \& european security

Eshan Dauhoo

A histórica reaproximação de Cuba e EUA

Erika Braga

A contextualização da atual reivindicação da Grécia para receber indenizações por atos da Alemanha durante a Segunda Guerra Mundial . .10

Natália da Silva Gonçalves

José Eduardo Paiva Miranda de Siqueira

Crônicas da jurisprudência do Direito Internacional (CIJ/ITLOS): Decisões da Corte Internacional de Justiça e do Tribunal Internacional Sobre o Direito do Mar .14

Nitish Monebhurrun (Org.)

Corte Internacional de Justiça

Estudo da decisão da Corte Internacional de Justiça no caso Croácia v. Servia (03/02/2015) .14

Liziane Paixão Silva Oliveira e Maria Edelvacy Marinho

Questões relacionadas com a apreensão e detenção de certos documentos e dados: (Timor Leste c. Austrália) - O reconhecimento do retorno de uma relação amigável entre Timor-Leste e Austrália e a nova decisão da CIJ, 6 de maio de 2015 . 20

Gleisse Ribeiro Alves

Tribunal Internacional sobre Direito do Mar

Caso da delimitação da fronteira marítima entre o Gana e a Costa do Marfim no Oceano Atlântico: medidas cautelares $(25 / 04 / 2015)$

Nitish Monebhurrun

Comentário à Opinião Consultiva 21 do Tribunal Internacional para o Direito Do Mar [02/04/2015] (Responsabilidade do Estado de Bandeira pela pesca ilícita, não declarada ou não regulamentada) ...............25

Carina Costa de Oliveira 
Nitish Monebhurrun (Org.)

A inclusão da responsabilidade social das empresas nos novos Acordos de Cooperação e de Facilitação dos Investimentos do Brasil: uma revolução 33

Nitish Monebhurrun

\section{O Direito do Mar Perante as JuRisdições INTERnacionais}

\section{COASTAL StATES' RIGHTS IN THE MARITIME AREAS UNDER UNCLOS}

Tullio Treves

1. The notion of maritime areas 40

2. The maritime areas under UNCLOS 40

3. The coastal states' rights in the various maritime areas: sovereignty, sovereign rights, jurisdiction...... 41

4. Limits of coastal states' rights: the rights of other states, the "Due Regard" rule ........................ 42

5. Problems of classification: role of the settlement of disputes ...................................................... 42

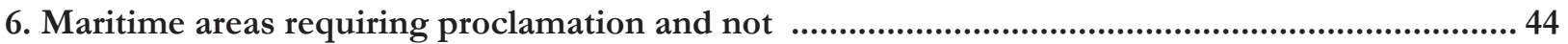

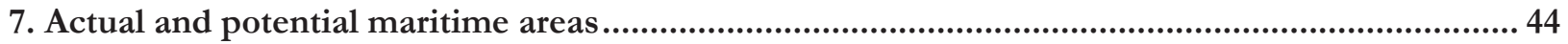

8. The special case of the continental shelf beyond $200 \mathrm{~nm}$........................................................... 45

9. Overlapping maritime areas: grey areas .......................................................................................... 46

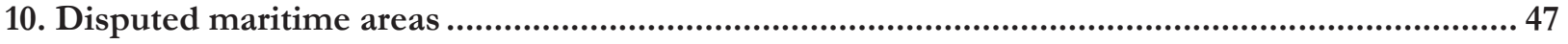

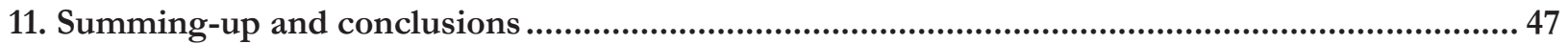

TACKling Illegal, UnRegulated ANd UnREPORTED FISHING: THE ITLOS Advisory OpINION on Flag State Responsibility for IUU fishing and the PRINCIPLE OF DUE DiligenCE ...50 Victor Alencar Mayer Feitosa Ventura

1. Introduction 50

2. Fisheries in the LOS and the conflict between principles: freedom of the seas v. sovereignty rights over natural resources

3. IUU fishing: definition and global efforts to frame the problem. 56

4. From the zonal to a more integrated approach to the management of fisheries .59

5. The Advisory Opinion of the ITLOS: avant guardisme in the Law of the Sea. 60

6. Concluding remarks. 63

References 64 
versus Japão Perante a Corte Internacional de JustiçA...........................................68

Luciana Ferna ndes Coelho

1. Introdução. 69

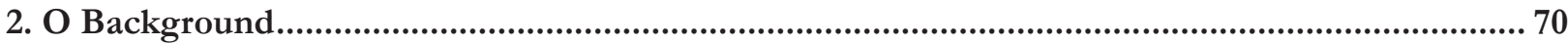

3. O critério de exame da licença especial e a (não) definição de pesquisa científica marinha.......... 74

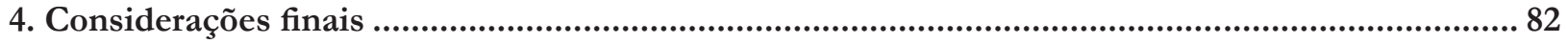

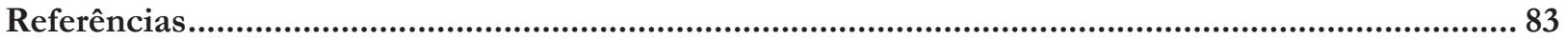

OS TRATADOS INTERNACIONAIS DE DIREITO DO MAR E SEUS EFEITOS SOBRE TERCEIROS ESTADOS ..... 86 Tiago V. Zanella

1. Introdução .87

2. Os tratados internacionais e o princípio da pacta tertiis nec nocent nec prosunt. 88

3. Os tratados internacionais de direito do mar e seus pretensos efeitos em relação a terceiros Estados.

3.1. A produção de efeitos da Convenção das Nações Unidas sobre o Direito do Mar sobre terceiros ........ 92

3.2. O Acordo de 1995 e seus efeitos sobre terceiros ............................................................................................ 99

4. Considerações finais ...........................................................................................................................103

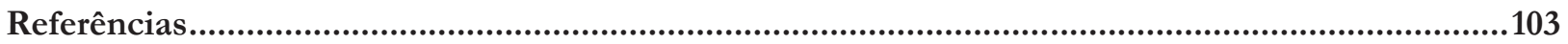

\section{Instrumentos Jurídicos PARA A Gestão do MAR}

OS LIMITES DOS TERMOS BEM PÚBLICO MUNDIAL, PATRIMÔNIO COMUM DA HUMANIDADE E BENS COMUNS PARA DELIMITAR AS OBRIGAÇÕES DE PRESERVAÇÃO DOS RECURSOS MARINHOS ............109

Carina Costa de Oliveira e Sandrine Maljean-Dubois

1. Introdução

2. Os limites da operacionalização da obrigação de cooperar para a preservação do meio ambiente marinho

3. Os limites da implementação da obrigação de due diligence para a preservação do meio ambiente marinho 118

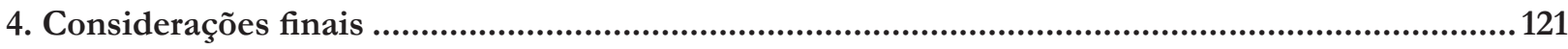

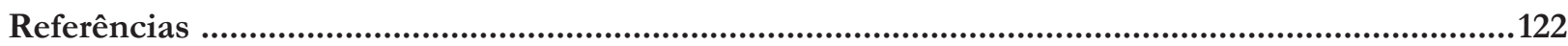

Os LIMITES do PLANEJAMENTO DA OCUPAÇÃo SUSTENTÁvEL DA ZONA COSTEIRA BRASILEIRA ... 126

Carina Costa de Oliveira e Luciana Coelho

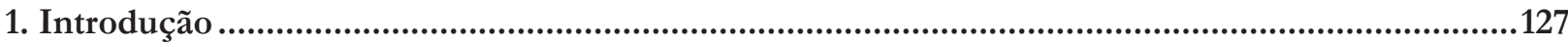

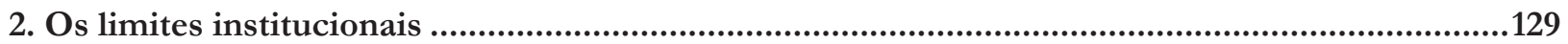

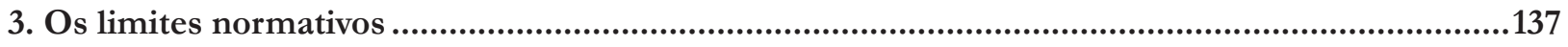




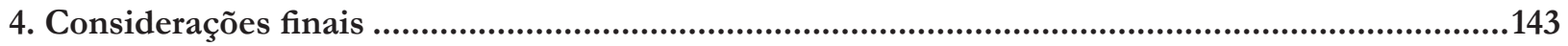

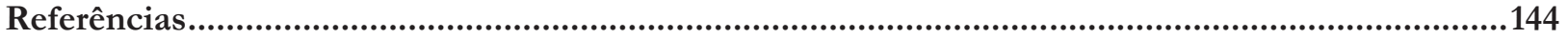

CORRENDO PARA O MAR NO ANTROPOCENO: A COMPLEXIDADE DA GOVERNANÇA DOS OCEANOS E A ESTRATÉGIA BRASILEIRA DE GESTÃO DOS RECURSOS MARINHOS .......................................... 150

Ana Flávia Barros-Platiau, Jorge Gomes do Cravo Barros, Pierre Mazzega e Liziane Paixão Silva Oliveira

1. Introdução

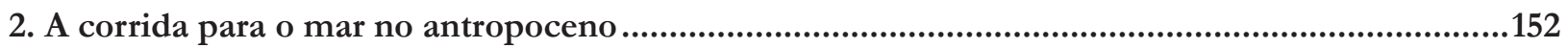

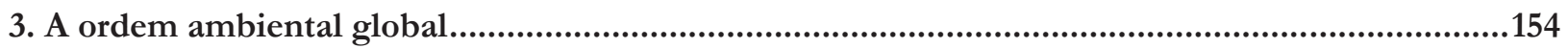

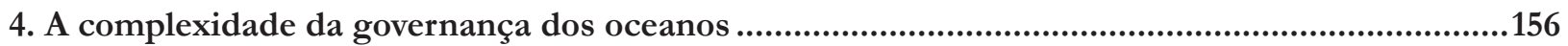

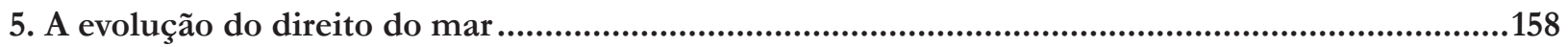

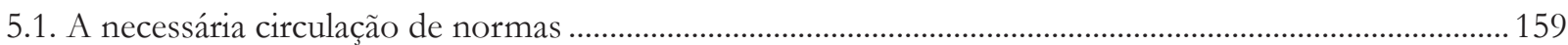

5.2. A estratégia brasileira de gestão e proteção dos recursos marinhos............................................................. 161

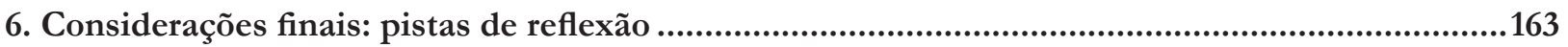

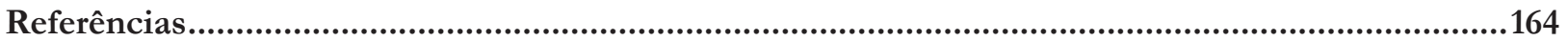

A comissão de limites da Plataforma continental (CLPC) E Os DESAFios NA delineaÇÃo DAS PLATAFORMAS CONTINENTAIS ESTENDIDAS..................................................... 170

Alexandre Pereira da Silva

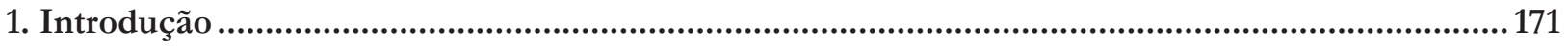

2. Plataforma continental: definição e possibilidade de expansão ....................................................171

3. A Comissão de Limites da Plataforma Continental (CLPC) ........................................................172

3.1. A CLPC: criação, mandato, composição e o prazo de 10 anos..................................................................... 173

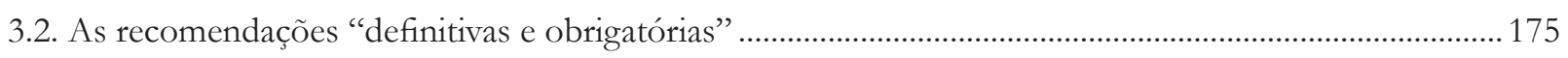

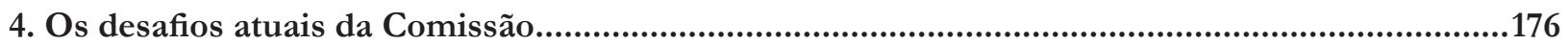

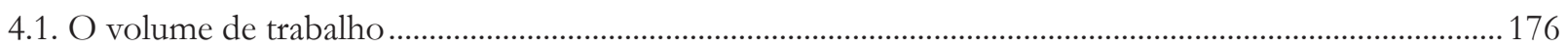

4.2. O financiamento da Comissão .............................................................................................................. 177

4.3. A Comissão e a intervenção de terceiros Estados ................................................................................... 178

5. Considerações finais .................................................................................................................182

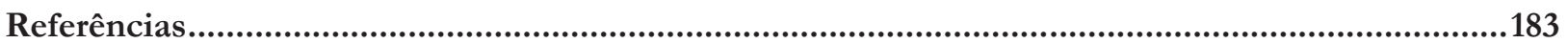

\section{A PROTEÇÃo DO MEIO AMBIENTE MARINHO}

O GRANDE JOGo do ÁrTico: REFLEXões COM BASE NA PERSPECTIVA DE EXPLORAÇão ECONÔMICA

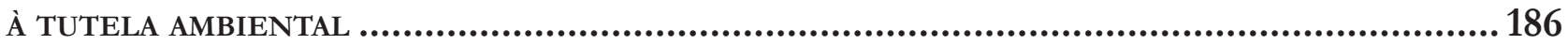

Fernando Rei e Valeria Cristina Farias

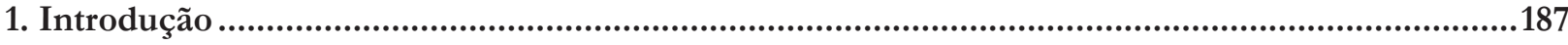


2. A Região Ártica e as mudanças climáticas...........................................................................187

3. Um gigante gelado em proporções e riquezas ...............................................................................189

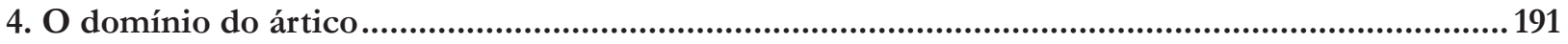

5. Regime jurídico do Ártico para tutela do meio ambiente ..........................................................193

6. Considerações finais ........................................................................................................................197

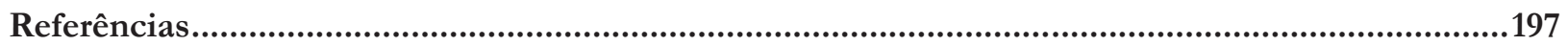

Instrumentos Públicos e Privados para a reparação do dano ambiental causado por DERRAMAMENTO DE ÓLEO NO MAR SEM ORIGEM DEFINIDA: AS MANCHAS ÓRFÃS...................... 201

Renata Brockelt Giacomitti e Katya R. Isaguirre-Torres

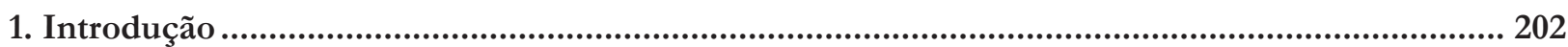

2. Poluição por derramamento de óleo no ambiente marinho: aspectos gerais ............................. 203

2.1. A Competência para fins de fiscalização do dano ambiental no ambiente marinho ..................................203

2.2. A difícil caracterização do dano ambiental por ocorrência das manchas órfãs ......................................... 204

3. Instrumentos públicos para a reparação por dano ambiental causado por manchas órfãs .......... 205

3.1. O dever imposto pelo Estado na coletivização da responsabilidade na preservação do meio ambiente

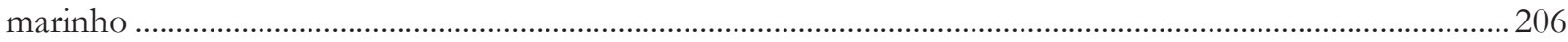

3.2. Os diferentes níveis do sistema público de fiscalização: Os Planos de Área, de Contingência e de Emergência Individual e sua eficiência no controle das manchas órfãs.......................................................................206

4. Instrumentos Privados para o controle da poluição por manchas órfãs ........................................ 208

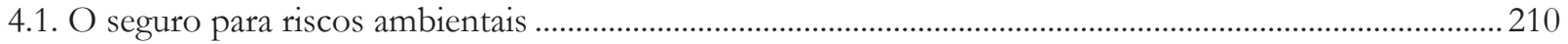

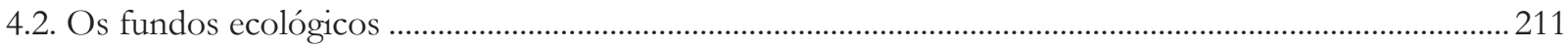

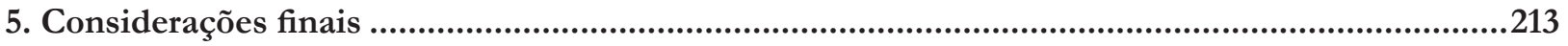

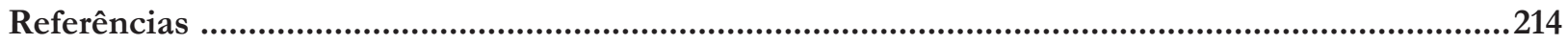

O DIREITO INTERNACIONAL PRIVADO E A RESPONSABILIDADE CIVIL EXTRACONTRATUAL POR DANOS AMBIENTAIS CAUSADOS POR TRANSPORTES MARÍTIMOS À LUZ DO DIREITO BRASILEIRO ....... 217 Inez Lopes

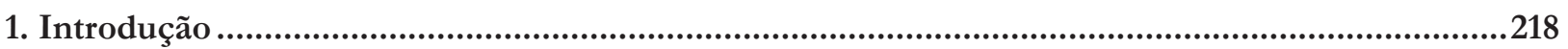

2. Globalização, transporte marítimo e meio ambiente ...........................................................219

3. O Direito internacional privado e a responsabilidade civil extracontratual nas atividades marítimas 221

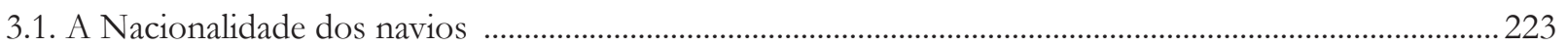

3.2. Lei aplicável à responsabilidade extracontratual por danos ambientais em direito marítimo ................ 225

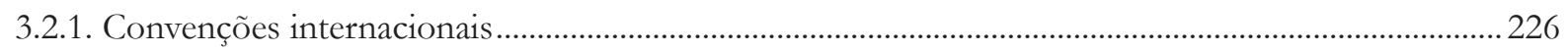




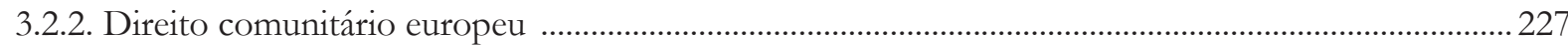

3.3. Obrigações extracontratuais: jurisdição e competência em acidentes marítimos....................................... 227

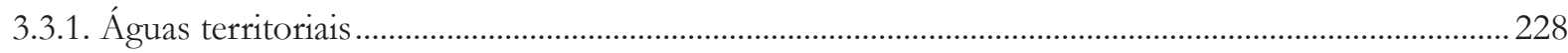

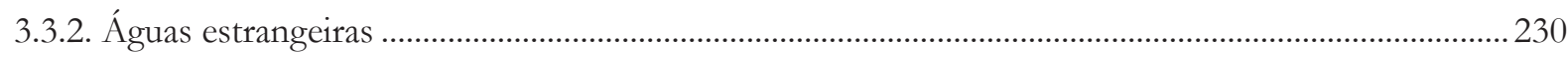

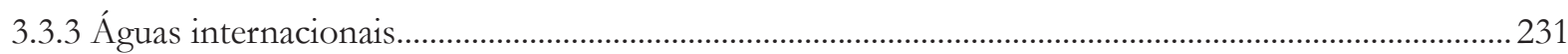

4. Os tribunais brasileiros e a competência internacional para poluição marinha de hidrocarbonetos e seus derivados causados por navios estrangeiros............................................................................ 232

4.1. O problema do conflito de competência entre justiça federal e justiça estadual ......................................234

4.2. O problema do conflito de competência entre órgãos administrativos federais e estaduais ....................235

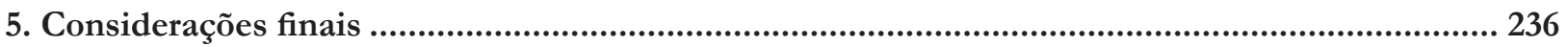

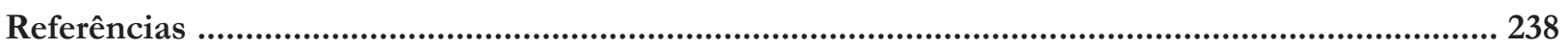

A NECESSIDADE DE REPENSAR OS MECANISMOS DE RESPONSABILIDADE AMBIENTAL EM CASO DE riscos de vazamento de petróleo na Zona Econômica Exclusiva do Brasil .............. 241

Marcelo D. Varella

1. Introdução

2. Exploração de petróleo no Brasil ..................................................................................................... 242

3. O modelo brasileiro para prevenir danos ambientais com a exploração marítima de petróleo .. 244

4. Problemas institucionais: um estudo de caso da Chevron....................................................... 245

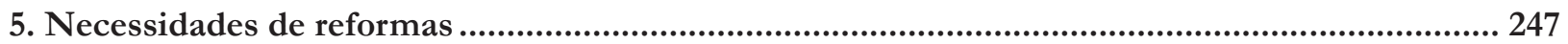

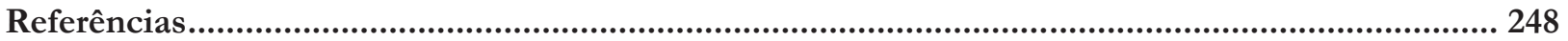

\section{Problemáticas do Direito Marítimo}

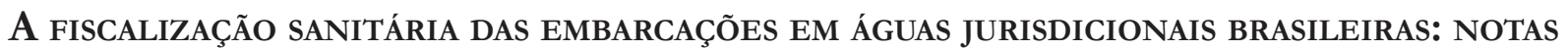
ACERCA DA (IN)EFETIVIDAdE DA SÚMUla 50 DA AGU ............................................. 251

Joedson de Souza Delgado e Ana Paula Henriques da Silva

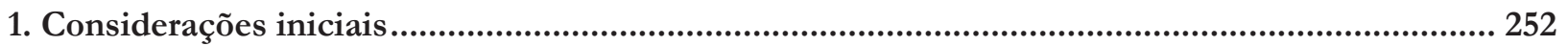

2. As ações de Vigilância Sanitária nas embarcações em águas sob jurisdição brasileira ............... 253

3. Princípio da precaução: a saúde pública e o meio ambiente marítimo protegidos...................... 256

4. Memorandum d'entente: a solução no direito comparado ....................................................... 258

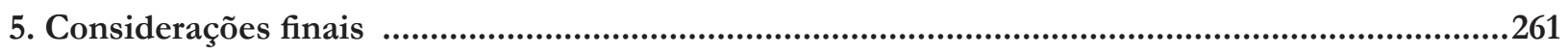

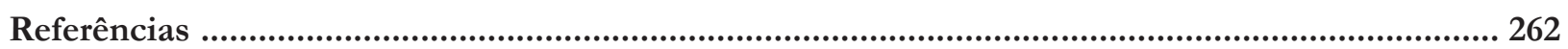

\section{A IMO E A REPRESSÃo AO ROUbO ARMADO CONTRA NAVIOS: DA RETÓRICA INTERNACIONAL À} COOPERAÇÃO REGIONAL .................................................................................265

André Panno Beirão e Charles Pacheco Piñon

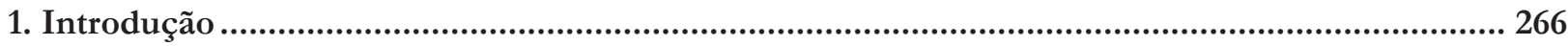


2. O roubo armado contra navios: a definição e os efeitos globais de um fenômeno regional ........ 267

2.1. Fenômenos afins, porém complexos, para entender e definir...................................................................... 267

2.2. O recrudescimento do roubo armado contra navios e suas consequências para a sociedade internacional...270

2.3. O papel dos Estados costeiros e a cooperação regional no combate ao roubo armado contra navios 271

3. A evolução da IMO e a segurança marítima .................................................................................... 273

3.1. Internacionalismo e legitimidade: da IMCO para a IMO .......................................................................... 273

3.2. Segurança no mar: o terrorismo monopoliza o debate na IMO...................................................................2 274

4. Os acordos regionais de cooperação na repressão ao roubo armado contra navios: a IMO abre o

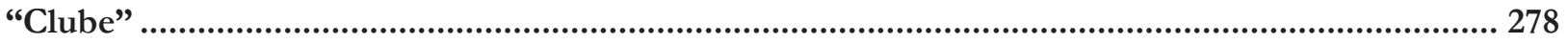

4.1. Passando para uma abordagem regional da segurança no mar ..................................................................2 278

4.2. A Ásia lidera a reação regional: o surgimento do ReCAAP.................................................................... 279

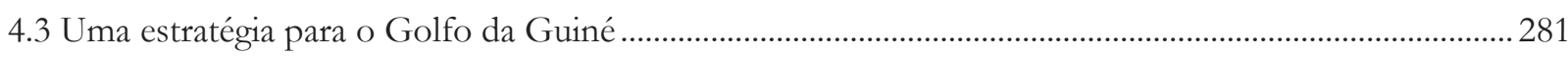

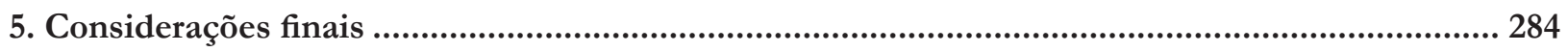

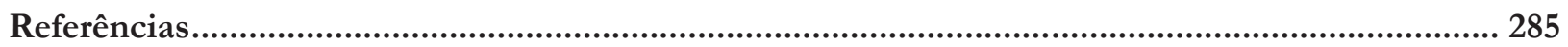

\section{O Direito do Mar diante da Pirataria}

O DIREITO INTERNACIONAL EM FACE DA PIRATARIA EM ALTO-MAR: UMA PERSPECTIVA CRÍTICA.289 Maiquel Ângelo Dezordi Wermuth e Rafaela Correa

1. Considerações iniciais: três casos que demonstram que a pirataria não é um "crime do passado" ....290

2. A pirataria em alto-mar: notícia histórica e implicações contemporâneas ...................................291

3. Percalços ao efetivo combate à pirataria: o papel da convenção de Montego Bay, da organização marítima internacional e do Tribunal Internacional do direito do mar ............................................. 294

3.1. A Organização Marítima Internacional (IMO) .........................................................................................2295

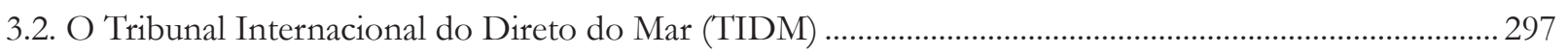

4. Considerações finais: perspectivas para combater a pirataria....................................................... 298

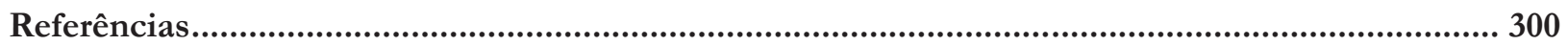

Pirataria marítima: A EXPERIÊnCia Somália ...............................................................302

Eduardo Augusto S. da C. Schneider

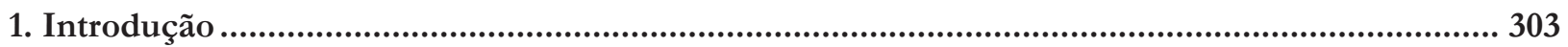

2. Breves notas sobre a definição de pirataria .............................................................................. 303

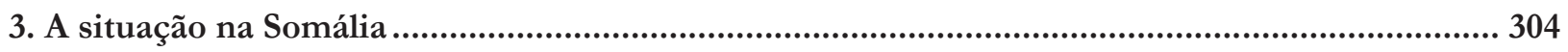

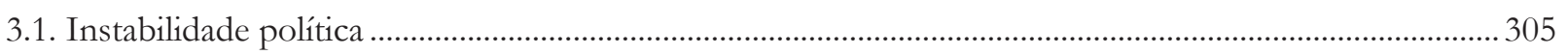

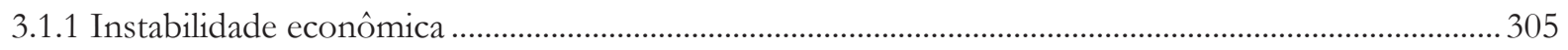

3.1.2. Território fértil para o desenvolvimento da pirataria ……………………….......................................... 306 


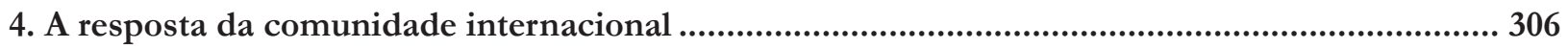

4.1. Resoluções do Conselho de Segurança das Nações Unidas: a questão somali ........................................... 307

4.2. Acordos internacionais para julgamento de suspeitos de pirataria........................................... 309

4.2.1. Adequações legislativas no Quênia: resposta de países da região .......................................................... 310

4.2.2. Adequações legislativas em Seychelles: resposta de países da região .................................................... 311

4.2.3. Adequações legislativas na Somalilândia, Puntlândia e outros Estados da região ................................ 312

4.3. Resposta de Estados com interesses na questão..........................................................................313

4.3.1. Participação da ONU por meio do Escritório das Nações Unidas sobre Drogas e Crime - ENUDC ...314

4.3.2. O envolvimento direto da Organização Marítima Internacional - OMI ............................................. 314

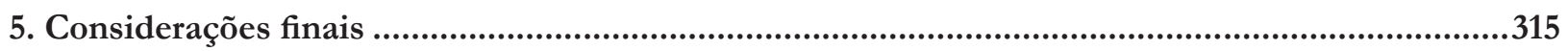

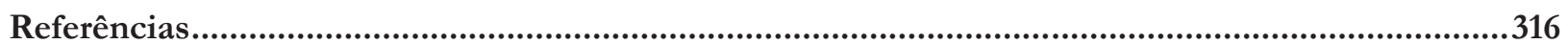

\section{Temas Gerais}

DRAWING THE LINE: ADDRESSING ALLEGATIONS OF UNCLEAN HANDS IN INVESTMENT ARBITRA-

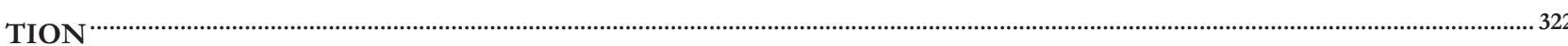

Mariano de Alba

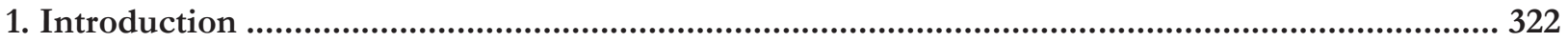

2. The clean hands doctrine in investment arbitration .................................................................. 324

3. The proposed analytical framework for cases where the clean hands doctrine is invoked .......... 326

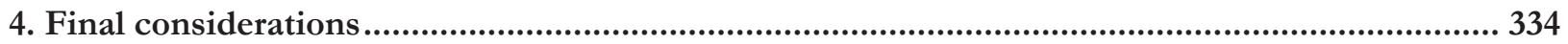

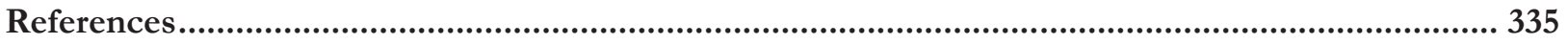

Para Que Serve a história do direito internacional?...........................................339

George Rodrigo Bandeira Galindo

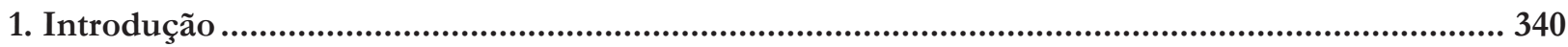

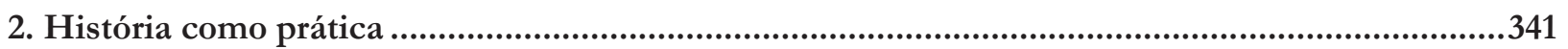

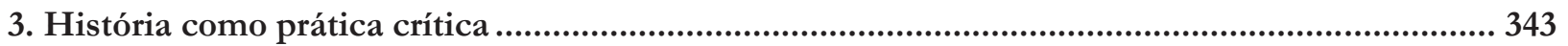

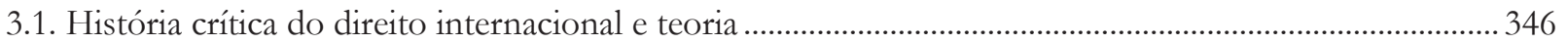

3.2. História crítica do direito internacional e ética .............................................................................................. 348

3.2.1 Historiografia do direito internacional, colonialismo e eurocentrismo................................................. 350

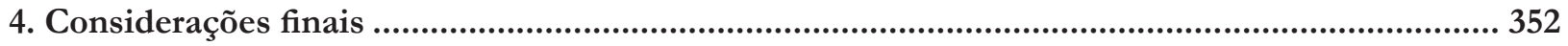

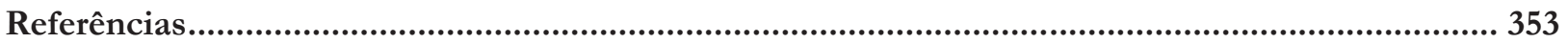

As interferências entre a Política Externa e de Segurança Comum Europeia (Pesc) e o DIREITO dAS NAÇÕES UNIDAS...........................................................................................356 Leonardo de Camargo Subtil 
2. A transformação normativo-institucional da política externa e de segurança comum na União Europeia

2.1. Do Tratado de Roma (1957) ao Tratado de Maastricht (1992).

2.2. Da Estratégia Comum Europeia (ECE) à institucionalização normativa da Estratégia Europeia de Segurança (EES) pelo Tratado de Lisboa (2009)

3. A relação paradoxal entre a política externa e de segurança comum europeia e o direito das Nações Unidas.

3.1. Da aparente autonomia à vinculação normativa da União Europeia ao Direito das Nações Unidas.... 369

3.2. A obrigatoriedade de cumprimento das Resoluções do Conselho de Segurança das Nações Unidas pela

União Europeia em matéria de política externa e de segurança comum ........................................................... 373

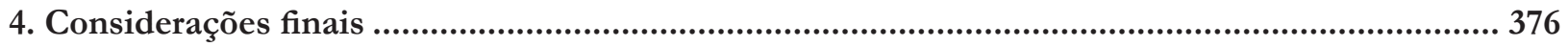

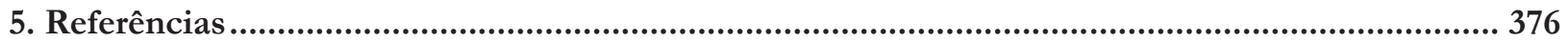

Introdução Às regras de APliCAÇão da ConvenÇão da ONU SObre Contratos de CoMPRA E VENDA INTERNACIONAL DE MERCADORIAS E O DIREITO INTERNACIONAL PRIVADO BRASI-

LEIRO ....................................................................................................380

Paul Hugo Weberbauer e Eugênia Cristina Nilsen Ribeiro Barza

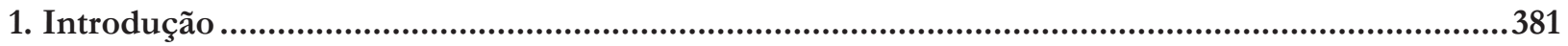

2. A Conferência de Haia, a UNCITRAL e a Convenção de Viena de 1980 .................................... 382

3. O âmbito de aplicação da Convenção de Viena 1980 ...................................................................... 385

3.1. Os três vetores do sistema de aplicação da Convenção ................................................................................ 385

3.2. O princípio da natureza dispositiva e a função negativa da autonomia da vontade ................................... 388

4. O CDC é circunstância impeditiva para aplicação da Convenção de Viena 1980? ...................... 390

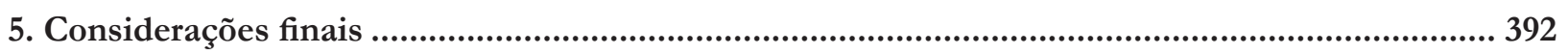

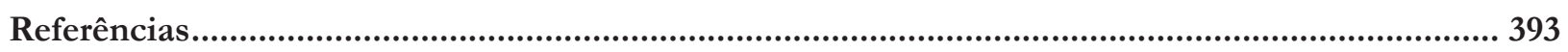

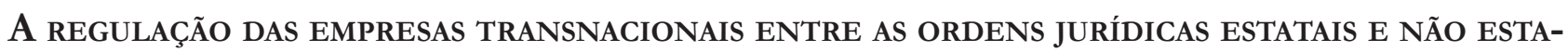

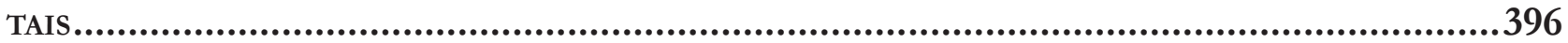

Mateus de Oliveira Fornasier e Luciano Vaz Ferreira

1. Introdução

2. Pluralismo jurídico, hipercomplexidade e policontexturalidade: novos fatores a serem sopesados na

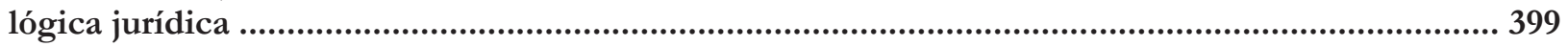

3. Conduta das empresas transnacionais e regulação pelo direito estatal ......................................... 402

4. Regulação pelo direito internacional das condutas das empresas transnacionais ....................... 404

5. Possibilidades de autorregulação das empresas transnacionais .................................................. 409

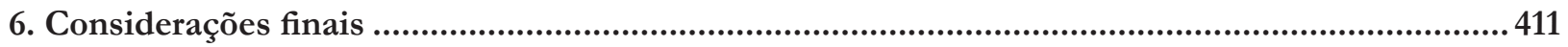

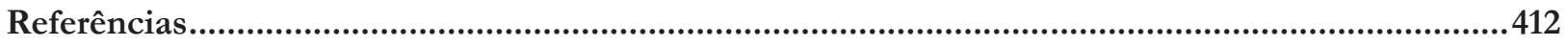


Outlawing hate SPEECH IN DEMOCRATIC States: THE CASE Against THE INHERENT Limitations doctrine concerning Article 10 (1) of the European Convention on Human Rights

Stefan Kirchner

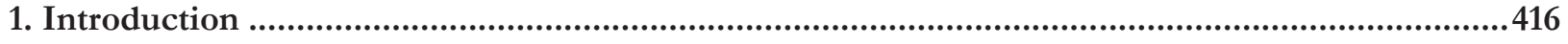

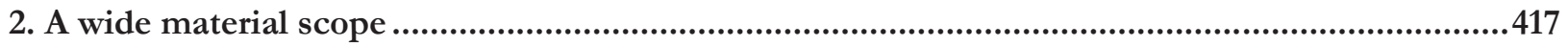

3. Narrowing the scope through implied limitations? ..........................................................................419

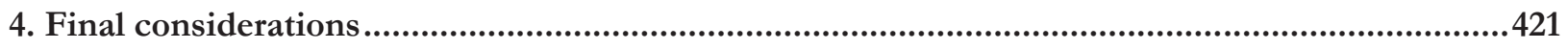

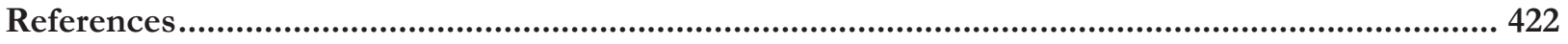

Normas Editoriais....................................................................................424

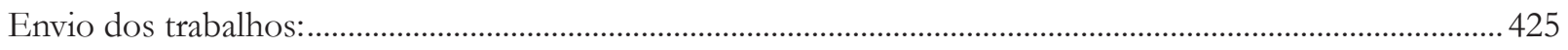





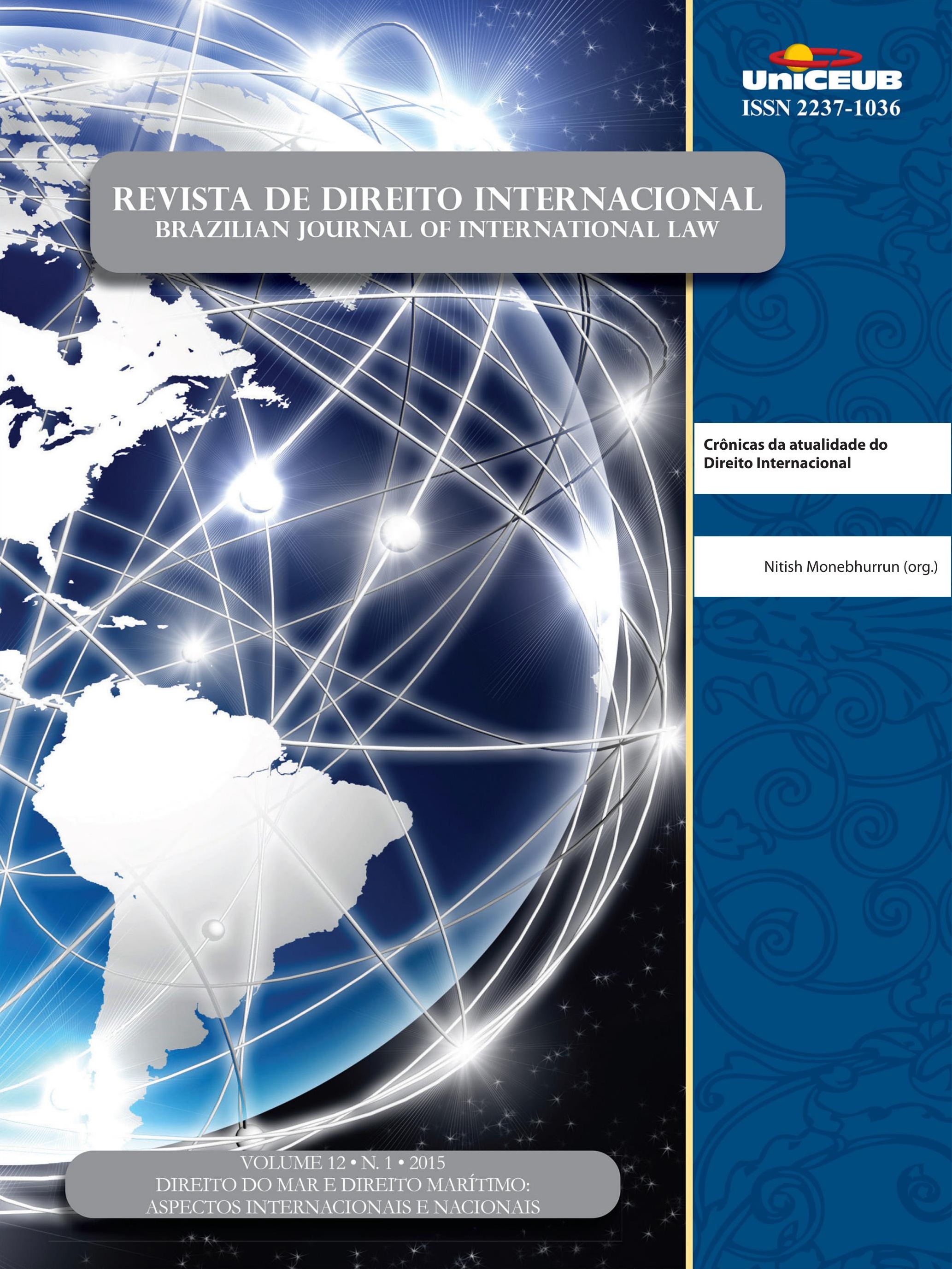




\title{
Crônicas da atualidade do Direito Internacional
}

\author{
Nitish Monebhurrun (org.)*
}

\section{TOWARDS A EUROPEAN REGULATION OF THE IMPORTATION OF CONFLICT MINERALS?}

\author{
Nitish Monebhurrun*
}

\section{INTRODUCTION}

Conflict minerals are those which are extracted from conflict zones and the latter can, in turn, be described as follows:

conflict-affected and high-risk areas' means areas in a state of armed conflict, with presence of widespread violence, collapse of civil infrastructure, fragile post-conflict areas as well as areas of weak or non-existent governance and security, such as failed states, characterised by widespread and systematic violations of human rights, as established under international law. ${ }^{1}$

This definition is provided for by a regulation project on the certification of the importers of conflict minerals which is being currently examined by the European Union's (E.U.) institutions. An original text proposed by the European Commission was discussed and amended by Parliament on the $20^{\text {th }}$ May 2015. The amended version will now be jointly analysed by the Commission, the Parliament and the Council with the aim of enacting a final regulation.

In 2010 the Dodd-Frank Act inaugurated an important regulation on conflict minerals in the United States, thereby regulating concerned companies listed on the New York - Wall Street - Stock Exchange. The act principally applies to minerals ${ }^{2}$ imported from the Democratic Republic of the Congo. The E.U.'s aim is to provide for a similar control over mining activities; however, its regulation project is not geographically restricted as it covers conflict zones in general. Mining activities sometimes support and foment armed conflicts which are correspondingly detrimental to basic $\mathrm{Hu}-$ man Rights ${ }^{3}$. The Democratic Republic of Congo is, for instance, a case in

\footnotetext{
* The author holds a PhD in International Law (Law School of Sorbonne, Paris) and acts as a Law Professor at the University Centre of Brasilia and as a Visiting Professor in the International Law Master Program of the Universidad de la Sabana, Bogotá. E-mail: nitish. monebhurrun@gmail.com
}

1 See Amendment 24 (e) of the Proposed Regulation for the Union System for Self-Certification of Importers of Certain Minerals and Metals Originating in Conflict-affected and High-risk areas (available at: < http://www.srz.com/files/upload/Conflict_Minerals_Resource_Center/European $\% 20$ Parliament $\% 20 \%$ E2\%80\%93\%20Conflict $\% 20$ Minerals $\% 20$ Legislation $\% 20 \% \mathrm{E} 2 \% 80 \% 93 \% 20$ Provisional $\% 20$ Copy $\% 20 \% \mathrm{E} 2 \% 80 \% 93 \% 20 \mathrm{May} \% 20$ 2015.pdf $>$.)

2 As per the Dodd-Frank Act, these minerals are: coltan, cassiterite, gold, wolframite or their derivatives. See section 1502, (e) (4) (A) of the Act (available at: < http:/ /www.cftc.gov/ ucm/groups/public/@swaps/documents/file/hr4173_enrolledbill.pdf>.).

3 See: Amendment no. 2 of the Proposed Regulation for the Union System for Self-Certi- 
point frequently referred to: the congolese militia and warlords maintain their stranglehold over mining pits; European companies therefore have to deal with them to have access to minerals; the revenue derived from this trade is used to fuel the conflict-related activities. In this blood mining process, child labour, forced labour, mass raping or population displacement have become a common feature, while abuses from the militia take a soaring propensity. Still, the extracted minerals - mainly "tin, tantalum and tungsten, their ores, and gold", as provided for by the E.U.'s regulation project —-, are widely used in the production process and in the supply chain of many companies. For example, these minerals are the raw materials used in the manufacture of chips which are incorporated in televisions, computers, laptops or cell phones. Therefore, they often originate from conflict-affected regions and their status of 'conflict minerals' are not revealed to consumers. In some cases, the very companies are unaware of the minerals' bloody origins. This has, accordingly, nurtured a whole complex and indirect process of - sometimes unknowingly - financing armed conflicts. The E.U. proposed regulation acts as a response to this conundrum. If the initial text proposed by the Commission was framed on voluntary and self-certification of importing companies (1), the project, as amended by Parliament, champions a compulsory certification system to organise a permanent due diligence over their supply chain (2).

\section{THE SELF-CERTIFICATION SYSTEM PROVIDED FOR BY THE INITIAL REGULATION PROJECT}

The project, as originally presented by the European Commission, proposed a self-certification mechanism and therefore obeyed to a voluntary commitment logic: companies could decide whether or not they would self-certify their activities as 'conflict-mineral free'. Informing the consumers on the mineral's origins would not be a binding obligation as per this text. Due diligence over the supply chain is therein presented as an option

fication of Importers of Certain Minerals and Metals Originating in Conflict-affected and High-risk areas. More generally, see: VEALE, Emily. Is there blood on your hands-free device? examining legislative approaches to the conflict minerals problem in the Democratic Republic of Congo. Cardozo Journal of International and Comparative Law, v. 21, 2013, p. 503-544; WOODY, Karen E. Conflict minerals legislation: the SEC's new role as diplomatic and humanitarian watchdog. Fordham Law Review, v. 81, 2012, p. 1315-1351. and corporate social responsibility is thus based upon soft norms. The draft also excluded companies which are not direct importers of minerals but which import manufactured products - telephones, computers, vehicles - which contain potential conflict minerals.

This original project is questionable in that it provides a legally strange choice to minerals importing companies: they can seemingly, if they wish so, (continue to) participate in the direct or indirect financing of armed conflict on foreign remote territories and they are, by the same token, allowed to condone human rights violations by warlords. And this conspicuously affects the right of information of consumers. The text can therefore be criticised as it erects participation in illegal mining as a choice, and the Commission seems to prefer the companies' morality — thereby trusting that they will all voluntarily abide to the self-certification policy —, to the imposition of legal duties. This is namely corrected by the amended project proposed by the European Parliament whereby self-certification is replaced by binding certification.

\section{THE COMPULSORY CERTIFICATION SYSTEM proposed by the European Parliament}

The European Parliament has substituted self-certification by certification ${ }^{4}$ : if self-certification depends on the importers' good will, certification is an organised administrative procedure with norms and criteria to which concerned companies must abide. The aim is to oblige importing companies to exercise a permanent due diligence over the whole supply chain, from the upstream source - the mines — to the downstream market ${ }^{5}$. As per the Parliament's amendments all European companies importing minerals, either as a by-product incorporated in a finished product or as a raw material, must certify that these resources have not been extracted from conflict-affected regions. These companies will accordingly have a duty of publicly reporting on their supply chain due diligence ${ }^{6}$, that is the means which have been engaged to make sure that minerals which are being used are not from conflict-affected zones. The amendments however provide for the dili-

\footnotetext{
4 See: Amendment no. 60.

5 See: Amendments 71, 91, 112.

6 See: Amendments 71, 91, 112.
} 
gentia quam in suis principle, that is, for subjective due diligence: the companies must fulfil their obligations as per their means, resources and size. And, in so doing, small and medium companies can benefit from the financial and technical support of the European Commission ${ }^{7}$. The latter would be in charge of establishing the criteria for granting the certification ${ }^{8}$ and should, for such purposes, use the OECD Due Diligence Guidance for Responsible Supply Chains of Minerals from Conflict-Affected and High-Risk Areas9. The Parliament's amendments also propose the institution of a responsible sourcing system; this means that smelters and refiners - which receive the minerals to be processed before being put on the market and which are therefore normally aware of their origins - , would be submitted to a third-party auditing to certify their activities as conflict-free. If the smelters and refiners abide to due diligence practices over their supply chain, an important part of the problem will be tackled at the upstream. The idea is to set a European Union's list of responsible smelters and refiners for more transparen$\mathrm{cy}^{10}$.

In this vein, the Parliament's proposals boldly bypass the usual debate on voluntary commitments when it comes to corporate social responsibility. If adopted, the amended project will be beneficial to European consumers in terms of transparency and access to information by revealing any potential link between a given product and conflict minerals ${ }^{11}$. It will equally be an effective means to curb the scourge of armed-conflict financing by private companies dealing with blood-stained minerals.

This said, the real outcome of the Parliament's proposed amendments will be known only after the trialogue between the Commission, the Parliament and the Council — which will, undoubtedly be influenced by lobbying pressures from civil society and from industrial groups.

\footnotetext{
7 See: Amendment no. 10.

8 See: Amendment no. 12.

9 The 2012 OECD due diligence guidance for responsible supply chains of minerals from conflict-affected and high-risk areas is available at: <http://www.oecd.org/corporate/mne/GuidanceEdition2.pdf $>$.

10 See: Amendment no. 14.

11 On consumer awareness, see: amendment no. 6.
}

\section{KEEPING UP WITH THE TERRORISTS: THE EU's proposed Passenger Name ReCORDS (PNR) DiRECTIVE \& EUROPEAN SECURITY}

Eshan Dauhoo ${ }^{12}$

There is no such thing as perfect security, only varying levels of insecurit

Salman Rushdie (2012)

\section{INTRODUCTION}

On the $7^{\text {th }}$ January 2015, France faced one of its worst security crises of the $21^{\text {st }}$ century. The world was shocked by the Charlie Hebdo terrorist attack that took 12 lives. In a show of solidarity to the victims", the slogan "Je suis Charlie" ${ }^{14}$ quickly went viral. Fast forward one month and, whether the result of some serious soul-searching or a knee-jerk reaction to the attack, the European Parliament, with a strong majority ${ }^{15}$, adopted a resolution in which it declared a commitment towards finalising a directive on EU Passenger Name Records (PNR) by the end of $2015^{16}$. A key aim of the proposed EU PNR Directive ${ }^{17}$ is to facilitate tracking the movement of potential terrorists travelling in and out of Europe.

Before putting the proposed Directive under the microscope and delving into its intricacies and implications, it is perhaps sensible to first turn to some basic questions such as, what exactly is PNR data? And how is the proposed EU PNR Directive any different from the plethora of anti-terrorism laws that already exist?

12 LLB, BSc Political Science, Postgraduate qualifications in European Law, International Law and Psychology, Head of Law (South Thames College, London, UK), eshan.dauhoo@south-thames.ac.uk

13 As well as supporting the defence of free speech

14 French for "I am Charlie"

15 The joint resolution was approved by 532 to 136 votes (36 abstentions)

16 Resolution (2015/2530 (RSP)): <http://www.europarl.europa.eu/sides/getDoc.do?pubRef=- $\% 2 \mathrm{f} \% 2 \mathrm{fEP} \% 2 \mathrm{f} \% 2 \mathrm{fTEXT} \% 2 \mathrm{~b}$ MOTION\%2bP8-RC-2015-0122\%2b0\%2bDOC\%2bXML $\% 2 \mathrm{bV} 0 \% 2 \mathrm{f} \% 2 \mathrm{fEN} \&$ language $=\mathrm{EN}>$.

17 Proposed EUPNR Directive: < http://ec.europa.eu/homeaffairs/news/intro/docs/com_2011_32_en.pdf>. 
2. What is the proposed EU PNR Directive?

PNR data refers to the basic information that is collected by airlines on their passengers regardless of the destination to which they are flying. A PNR will generally contain data such as a passenger's name, address, date of birth, telephone number, itinerary, email address and payment methods. Simply put, the proposed PNR Directive would expect airlines flying international routes both in and out of the EU to transfer certain types of data about passengers to EU Member States. The aim of this transmission is to produce a more systematic data collection, data retention and analysis by national authorities of passengers taking international flights (i.e., entering or leaving the EU). In turn, it would then be used to establish patterns of behaviour that can give a clear indication of suspect behaviour ${ }^{18}$. It has been argued that this has proven effective when it comes to detecting terrorism ${ }^{19}$ and serious international crimes.

Against the backdrop of the Charlie Hebdo attack, the ongoing conflicts in Syria and Iraq and the fear of radicalised fighters returning to Europe, the argument goes that the sooner the PNR system is introduced, the easier it will prove to track these individuals and prevent possible future terrorist attacks on European soil. It is further argued that this "intelligence armour" will not only promote security for the people of the EU, but simultaneously ensure that strict safeguards are in place in relation to the collection of passenger data.

\section{TO LEGISLATE OR NOT TO LEGISLATE?}

Considered together, the above points present a fairly convincing narrative for the proposed PNR directive as not only a quick-fix solution but serving as part of a long-term fortress against not only the "importation" of international terrorism, but also its "exportation" to countries like Syria and Iraq. That said, however, it is also important not to take these arguments at face value. After all, it should be noted that the proposed PNR is not new and whilst first introduced back in 2011, it was in fact rejected in 2013 by the European Parliament's Committee on Civil

18 Background to PNR: < http://europa.eu/rapid/press-release_ MEMO-11-60_en.htm>.

19 For example, it was said to play a key part in capturing the perpetrators of the $7 / 7$ bombing
Liberties, Justice, and Home Affairs (LIBE). Whilst rejection does not necessarily imply the existence of faults, it does send a warning signal that further dissection and analysis of the proposed piece of legislation is necessary.

One argument that critics of the proposed EU PNR directive have put forward is that there are already a multitude of EU anti-terrorism laws in place. For instance, following the 9/11 attacks, the European Arrest Warrant Framework Decision $(2002 / 584 / \mathrm{JHA})^{20}$ was introduced. There is also the possibility for EU member states to adopt laws on the retention of communications data via the EU's Directive 2002/58 on Privacy and Electronic Communications (also known as the E-Privacy Directive) ${ }^{21}$.

Furthermore, Member States already have the liberty to establish their own PNR systems. Currently, of the $28 \mathrm{EU}$ member states, the UK has the most advanced system in place, whilst many other states are either running pilot PNR systems or in the process of setting them up. As part of its external security strategy, the EU also has agreements on PNR data with Canada, Australia and the United States ${ }^{22}$. As such, it is quite plausible to question the need to introduce an EU-wide measure which, given the nature of directives, will not have direct applicability and as such will require member states to pass their own legislation to implement the directive.

The flip side to this argument could be that if it can already be done at an individual member state level, would it not make sense then to implement an EU-wide measure? After all, given the complex landscape of international terrorism and that the goal is to protect the EU people as a whole, a logical conclusion would be to introduce a centralised response that would reinforce an EU spirit of "all for one and one for all" rather than a "go it alone" one. Furthermore, this would reduce confusion and potentially cut considerable costs and duplication of resources.

Whilst the above can again tip the scales in favour of introducing the EU PNR, the legislation in question is certainly not a silver bullet. Beyond the question as to whether there are already too many anti-terrorism laws; more importantly, concerns have been raised as to whether it is legally sound. These relate to the necessity

20 EAW Decision: <http://eur-lex.europa.eu/legal-content/ EN/LSU/?uri=CELEX:32002F0584>.

21 Directive 2002/58: <http://eur-lex.europa.eu/legal-content/ $\mathrm{EN} / \mathrm{ALL} /$ ?uri=CELEX:32002L0058>.

22 PNR data is to be handed over in advance for flights from the EU to and from the said countries such that no-fly lists can be enforced 
and proportionality of the directive in relation to actual security threats, its scope in terms of types of offences it covers as well as the retention periods.

The very nature of the EU PNR is built around finding potential "suspects" that are unknown from the data of "innocent" passengers that it retained. The retention of the data of all passengers is for 5 years. Detractors argue that such blanket retention of data is neither proportionate nor necessary. How can the retention of data without links to any suspicion be proportionate? In support of this criticism, they turn to ruling of the Court of Justice of the European Union (CJEU) in Digital Rights Ireland Ltd v. Minister for Communications, Marine and Natural Resources and others (C-293/12) ${ }^{23}$. In a nutshell, this landmark case saw the CJEU ruling that the Data Retention Directive 2006/24/EC ${ }^{24}$ was disproportionate. The Court found that the blanket retention of EU citizens' personal data was a violation of human rights; more specifically, it violated the right to private life and privacy in Article 7 and Article 8 of the Charter of Fundamental Rights of the European Union (CFREU). The fact that the directive allowed for "mass surveillance" without having effective safeguards in place was considered disproportionate.

The Court has also taken a similar strong stance in Google Spain SL, Google Inc. v Agencia Española De Protección De Datos, Mario Costeja González (C-131/12) ${ }^{25}$ with what has become known as the 'right to be forgotten'. It should also be noted that the EU Parliament has referred the EU-Canada PNR agreement to the CJEU for an opinion as to whether the agreement is in line with Charter of Fundamental Rights as well as the EU Treaties. As such, the proposal to collect the data of all passengers flying into or out of Europe may be considered as disproportionate if there does not exist a link to suspicion or risk.

These are somewhat serious concerns and there has been an attempt to address these gaps via the Kirkhope Report ${ }^{26}$. Interestingly though, the recommendations were put forward only after the European Parliament

23 Digital Rights case: < http://curia.europa.eu/juris/document/ document.jsf?docid $=150642 \&$ doclang $=\mathrm{EN}>$.

24 Directive 2006/24/EC: <http://eur-lex.europa.eu/legal-content/EN/ALL/?uri=CELEX:32006L0024>.

25 Google Spain case: <http://curia.europa.eu/juris/liste. jsf?num=C-131/12>.

26 Kirkrope Report: <http://www.europarl.europa.eu/sides/ getDoc.do?pubRef=- / EP/ NONSGML+COMPARL+PE$549.223+01+\mathrm{DOC}+\mathrm{PDF}+\mathrm{V} 0 / / \mathrm{EN} \&$ language $=\mathrm{EN}>$. passed the resolution supporting the proposed PNR directive. The Report includes several changes aimed at softening the criticisms relating to rights to privacy and data protection.

The Report aims at reducing the retention period of the full PNR data from 30 to 7 days before the data is then "depersonalised". This means that the identity of passengers is hidden, but not actually removed from the database and hence upon application can be revealed. Whilst the 5 years would still stand this would only be for cases linked to terrorism (other serious transnational crimes will be reduced to 4 years). Another attempt to appease critics is the proposal to shorten the list of offences to only those linked to international travel. As such, whilst terrorism obviously remains on the list, serious crime has been replaced by "serious transnational crime". Also, another recommendation is that only highly trained protection officers will have access to the data. These amendments appear to strengthen the legal base of the proposed EU PRN Directive. Furthermore, to avoid encroaching upon fundamental rights, it has been stressed that Parliament will not support an EU PNR agreement without also finalising the adoption of an EU Data Protection Package. The aim is for negotiations for both agreements to be carried out simultaneously. This can then ensure that a comprehensive legal framework is in place catering for both data protection and data collection.

However, critics argue that these changes are merely "cosmetic" and point to Amendment 6 of the Kirkhope Report which they view as failing the proportionality test. This relates to the inclusion of intra-EU flights in the system. This was not previously mentioned in the original draft and it has the controversial effect of further extending both the power and reach of the system. This would seem to contradict much of the effort of the Report to bring a stronger dose of proportionality to the system and can potentially act as a setback in terms of the legality of the agreement and hence its overall success.

\section{THE BIGger PICTURE}

Whilst essentially linked with European security, the potential ramifications of the introduction of the EU PNR may be global; given that the details of any pas- 
senger travelling in and out of Europe will be stored on the system. This would seem fairly logical given that the proposed directive is essentially aimed at dealing with international terrorism. However, there have been some important changes to the landscape of international terrorism and European security.

Unlike the post-9/11 era, which found the EU particularly concerned with the deterritorialisation of a type of terrorism essentially located in North Africa, the Middle East and Asia; in the post-Charlie Hebdo era, the EU especially finds itself concerned with what could be described as a form of "reverse deterritorialisation". That is, EU nationals travelling to conflict zones such as Syria and Iraq as fighters and returning to the EU potentially radicalised and militarily trained. The EU fears that these individuals may then turn towards committing acts of terrorism on EU soil. This phenomenon is one of very reasons that give weight to the argument for the EU PNR. At the same time though, it also sheds light on an important weakness of the system. Many of the foreign fighters travelling from Europe, transit through Turkey in order to access Syria and Iraq. Whilst the proposed EU PNR system would be effective in revealing those who travelled to Turkey, beyond this point the system is redundant, given that Turkey is not an EU member state and as such has no PNR obligation. That said, however, the proposed EU PNR was not been put forward as the ultimate solution but more as an instrument within the EU's security toolkit.

Since $9 / 11$, the EU has also undergone a transformation in the field of counter-terrorism. It has gone from being, more or less, an irrelevance in this field to becoming a major player. Once the remit of individual member states, security (and more specifically counter-terrorism) now forms a key part of the EU agenda; and the EU PNR, is but one piece of the jigsaw that completes the European security puzzle. The picture which is starting to take form is one of a more common EU foreign policy.

This is not to say that individual member states are not also taking matters into their own hands. The UK has recently introduced the Counter-Terrorism and Security Act $2015^{27}$ to broaden its framework of counter-terrorism legislation. The Act contains a set of anti-terrorism measures in areas such as temporary restrictions

27 Counter-Terrorism and Security Act 2015: < http://www.legislation.gov.uk/ukpga/2015/6/contents/enacted/data.htm>. on travelling, data retention and prevention measures amongst others. Likewise, Germany is planning on introducing one of the toughest laws on anti-terrorism in Europe. It aims to make travelling abroad in order to receive military training a criminal offence. It is argued that this is in fact implementing the United Nations Security Council resolution 2178 on foreign "terrorist" fighters ${ }^{28}$.

\section{Concluding Remarks}

The jury is still out on whether the EU PNR will see the light of day. The key areas that will be at the centre of the controversy relate to the blanket retention of the data of all passengers and the potential extension to include intra-EU flights. Are these necessary and proportionate measures? Favour privacy too much and it may well prove hard to keep track of potential terrorists; favour security too much and the "Charlies" may feel that they are the ones being tracked rather than potential terrorists. The key will be to strike a reasonable balance between both. At the end of the day, privacy and security are two sides of the same coin.

\section{A histórica ReAproximação de CUBa e EUA}

Erika Braga ${ }^{29}$

A notícia anunciada em dezembro de 2014 surpreendeu o mundo. A restauração das relações diplomáticas entre Cuba e os EUA não parecia ser uma realidade em curto prazo, mas se concretizou diante do acordo selado entre Raul Castro e Obama. A ruptura ocorrida em 1961 resultou do fracasso sofrido pelo governo Kennedy ao tentar invadir Cuba pela Baía dos Porcos, para derrubar o governo de Fidel Castro - no comando da ilha desde 1959, após o êxito da Revolução Cubana. Desde então, as relações se deterioraram e, de certa for-

28 UNSC resolution 2178: $\mathrm{h}<\mathrm{ttp}$ ://www.securitycouncilreport.org/atf/cf/\%7B65BFCF9B-6D27-4E9C-8CD3CF6E4FF96FF9\%7D/s_res_2178.pdf $>$.

29 Advogada, Mestre em Direito Internacional Econômico (Escola de Direito da Sorbonne, Paris). E-mail: erikabraga@hotmail. com 
ma, o governo castrista se valeu das restrições impostas pelos EUA para legitimar internamente seu caráter autoritário no período pós-Guerra Fria.

Ao contrário do que permeia o senso comum, a Revolução Cubana teve inicialmente um viés nacionalista de luta contra o regime ditatorial de Fulgêncio Batista, apoiado pelos norte-americanos. A adoção do regime socialista ocorreu quando as relações diplomáticas já haviam sido rompidas, após a imposição dos embargos econômicos em $1960^{30}$ e em resposta à tentativa de invasão da ilha pelos EUA. A inabilidade da administração Kennedy facilitou a aproximação entre Cuba e URSS. Como reação na ordem bipolar da Guerra Fria, os EUA optaram por reforçar o embargo econômico ${ }^{31}$ e pressionaram os membros da OEA para expulsarem Cuba da organização ${ }^{32}$. Meses depois, mísseis soviéticos foram descobertos em território cubano, levando à escalada das tensões da Guerra Fria, que teve seu ápice na crise dos mísseis em Cuba. Em face da real possibilidade de uma guerra nuclear, Kennedy e Khrushchev recuaram; os mísseis da URSS foram retirados em troca da retirada dos mísseis americanos na Turquia.

A partir de 1962 até a dissolução da URSS, Cuba foi financiada pelo bloco socialista, que subsidiava a compra de petróleo e sustentava sua economia. No início da década de 1990, com a perda do seu grande financiador, Fidel Castro se viu obrigado a implementar um programa de reformas diante do novo e desfavorável cenário internacional. Além da queda do bloco socialista, em 1992 o congresso norte-americano promulgou o Cuban Democracy $A c t^{3}$, proibindo que terceiros países manti-

30 Em 19 de outubro de 1960, os EUA determinaram o embargo das exportações para Cuba, com exceção de alimentos e medicamentos, após a nacionalização, sem compensação, da refinaria americana. 31 Em 7 de fevereiro de 1962 o embargo foi ampliado para incluir quase todos os produtos exportáveis.

32 O Brasil abstém-se de votar contra a suspensão de Cuba na OEA, apesar de não ter sido contra os embargos impostos. Santiago Dantas redigiu o voto do Brasil, destacando o princípio legalista: na Carta de Bogotá (OEA) não existia uma cláusula democrática.

33 A lei foi definida como "A bill to promote a peaceful transition to democracy in Cuba through the application of sanctions directed at the Castro government and support for the Cuban people." e dispõe que "[t]he government of Fidel Castro has demonstrated consistent disregard for internationally accepted standards of human rights and for democratic values", acrescentando que "[t]here is no sign that the Castro regime is prepared to make any significant concessions to democracy or to undertake any form of democratic opening UNITED STATES. Cuban democracy act ("CDA") United States Code title 22. foreign relations and intercourse chapter 69. Disponível em: <http://web.archive.org/web/20041108140907/http://www. treasury.gov/offices/enforcement/ofac/legal/statutes/cda.pdf $>$. vessem relações comerciais com Cuba, sob pena de serem impedidos de comercializar com os EUA. Desde então, navios transportando bens para Cuba ficam impedidos de parar em portos norte-americanos por 180 dias. As remessas de dinheiro para a ilha também foram limitadas, intensificando a crise financeira e humanitária que assolava o país socialista remanescente.

Em 1996 o embargo foi reforçado durante o governo Clinton com a lei Helms-Burton ${ }^{34}$, após dois aviões privados que jogavam propaganda anti-Castro no território cubano terem sido abatidos. Determinou-se que empresas estrangeiras não poderiam concluir negócios nos EUA, caso fizessem transações com Cuba, sob a alegação de que estariam transacionando em propriedades roubadas dos norte-americanos ao negociar com o governo castrista. Apesar de todas as restrições, alguns países - como o Canadá e os Europeus - contestaram a legislação americana, entendida como ofensa ao princípio da igualdade soberana dos Estados e um desrespeito à liberdade de comércio e navegação.

Consideradas as limitações nesse cenário tumultuado, as reformas econômicas nas duas últimas décadas pretenderam promover uma transição gradual, diferentemente daquelas realizadas no Leste Europeu. Investimentos estrangeiros foram autorizados e entraram em grande quantidade, mudando o perfil de Cuba, com destaques para os capitais espanhol na indústria hoteleira, canadense na indústria minerária (exploração de níquel) e chinês na indústria petrolífera. Outra mudança, mais tímida, consistiu na permissão da prática de algumas atividades privadas, como táxis, restaurantes e pequenas iniciativas na agricultura.

A produção agrícola se manteve muito frágil e a escassez de produtos básicos forçou a importação de alimentos. O desafio macroeconômico se impôs diante de combinação do aumento do valor das commodities e da falta de divisas, deteriorando ainda mais o balanço de pagamentos cubano. Esse constitui um dos fatores que facilitaram a aproximação dos EUA. No ano 2000, pressionado por empresários que queriam aproveitar o mercado cubano, o congresso norte-americano promulgou o Trade Sanction Reform and Export Enhancement Act (Title IX), flexibilizando o embargo ao permitir a exportação para Cuba de alimentos, medicamentos e equipamentos mé-

Acesso em: 08 jul. 2015.

34 Em 12 de março de 1996 foi promulgada a Cuban Liberty and Democratic Solidarity Act (Helms-Burton Act). 
$\operatorname{dicos}^{35}$. A justificativa foi a emergência humanitária, mas, paradoxalmente, os EUA passaram a ser, nos últimos 15 anos, um dos maiores parceiros comerciais de Cuba.

Desde então, a conjuntura tem sido mais favorável à reaproximação. Apesar de ser uma pequena ilha, Cuba tem grande importância histórica e seu peso político no mundo é inversamente proporcional ao seu tamanho geográfico. As novas gerações de cubanos emigrados para os EUA já não são tão radicais na oposição aos irmãos Castro. Isso é relevante porque a população cubana se concentra na Florida, conhecida por ser um swing state, que decide as eleições norte-americanas. Por isso, os partidos não podem desconsiderar a opinião desses eleitores e o movimento em direção à Cuba se insere nesse contexto de política interna.

Como fator externo e variável geopolítica, destaca-se a China, que hoje tem peso considerável na América Latina. É o maior parceiro comercial de Cuba e o segundo maior da ALADI ${ }^{36}$ — da qual Cuba faz parte desde 1999 passando à frente do Brasil. Nos últimos anos, os financiamentos chineses para a América Latina foram maiores do que a soma dos financiamentos feitos pelo Banco Mundial e pelo Banco Interamericano de Desenvolvimento, credores clássicos dessa região. Além disso, Cuba é membro originário da CELAC ${ }^{37}$, que oficialmente se manifesta contra os embargos de maneira reiterada. Portanto, a reaproximação sinaliza que os EUA não querem perder influência na área onde exercem o domínio desde o início do séc. XIX com a Doutrina Monroe.

Um outro elemento de destaque nas negociações entre Cuba e EUA consistiu no protagonismo diplomático exercido pela Igreja Católica, por meio da atuação direta do Papa Francisco. Não se sabe exatamente em quais termos foi conduzida a mediação, mas um detalhe interessante que passou despercebido por muitos é que o anúncio do reatamento das relações diplomáticas aconteceu no dia do aniversário do Papa, 17 de dezembro ${ }^{38}$.

A participação dos dois chefes de Estado e o aperto de mão entre Raul Castro e Barack Obama na VII Cúpula das Américas foi um desdobramento dessa decisão histórica. O processo, entretanto, está no seu início e as análises futuras estão cheias de pontos cegos. $\mathrm{O}$ em-

35 Toda transação deve ser paga em dinheiro, adiantado, e os bens não podem ser transportados em navios cubanos.

36 Associação Latino-Americana de Integração.

37 Comunidade de Estados Latino-Americanos e Caribenhos.

38 O Papa Francisco nasceu em 17 de dezembro de 1936. bargo ainda consiste em questão importante e a forma como será abordado pelos dois países tem a indefinição como marca.

Do lado norte-americano, a suspensão depende do congresso, de maioria republicana, que não dá sinais de avanço. A lei também vincula a retirada dos embargos à adoção do regime democrático, à realização de eleições diretas, ao respeito aos direitos humanos e às liberdades civis, e à transição para economia de mercado ${ }^{39}$. Do lado cubano, alguns analistas, como Walter Russell Mead ${ }^{40}$, defendem que é conveniente para os irmãos Castro que o embargo seja mantido e que suas implicações políticas são mais complexas do que normalmente consideradas. Argumenta que eles estão com a idade avançada e uma nova geração política emerge em compasso com o provável fim do experimento socialista. Assim, a manutenção das restrições impostas pelos EUA garantiria sobrevida ao regime. Também sugere que há indícios de que os EUA prefiram transição gradual, evitando ondas de emigrantes na direção do seu território ou uma guerra civil em Cuba. Nesse ritmo, pavimentam o caminho para o diálogo com a futura elite política.

Por enquanto, a convergência de interesses entre Washington e Havana possibilitará, em breve, a abertura de embaixadas nas respectivas capitais, depois de 53 anos de embate. A Casa Branca também notificou o congresso americano sobre a retirada de Cuba da lista dos países que patrocinam o terrorismo e liberou o turismo de cidadãos americanos na ilha. Isso, naturalmente, gera efeitos além dos limites da relação bilateral. Outros Estados demonstram interesse em intensificar os laços com Cuba, a exemplo do Japão e da França. O ministro de relações exteriores japonês, Fumio Kishida, e o presidente francês, François Hollande, realizaram visita oficial ao país após o anúncio da reaproximação, indicando uma provável injeção de in-

39 Cuban Democracy Act: "Sec. 6007. Policy toward a democratic Cuban government. (a) Waiver of restrictions. The President may waive the requirements of section 1706 [22 USCS. \6005] if the President determines and reports to the Congress that the Government of Cuba. (1) has held free and fair elections conducted under internationally recognized observers; (2) has permitted opposition parties ample time to organize and campaign for such elections, and has permitted full access to the media to all candidates in the elections; (3) is showing respect for the basic civil liberties and human rights of the citizens of Cuba; (4) is moving toward establishing a free market economic system; and (5) has committed itself to constitutional change that would ensure regular free and fair elections that meet the requirements of paragraph (2)". 40 MEAD, Walter Russel. A watershed moment in U.S.-Cuba relations. Disponível em: <http://www.the-american-interest. com/2014/12/17/a-watershed-moment-in-u-s-cuba-relations/) >. Acesso em: 08 jul. 2015. 
vestimentos na economia cubana.

O cenário em longo prazo, entretanto, depende do conjunto de medidas legislativas que serão adotadas e da nova dinâmica impressa pelos corpos diplomáticos. Em termos econômicos e políticos, há quem aposte que, a partir de agora, a ilha promoverá uma abertura nos moldes dos países do Leste Europeu. Outros apontam para a possível adoção de um modelo mais semelhante ao da China, onde a economia de mercado coexiste com um regime político centralizador e autoritário.

Em paralelo, segue a indefinição - talvez até certa indiferença -, sobre o desrespeito às normas de Direitos Humanos em Cuba, reflexo tanto do regime autoritário, que priva os cidadãos de direitos e liberdades básicas, como dos embargos impostos, que causam a escassez de produtos de primeira necessidade e a miséria na ilha. Sendo a população cubana a grande vítima do jogo de forças desiguais, o enfrentamento do problema é necessário para que o restabelecimento das relações diplomáticas propicie, principalmente, o reconhecimento da primazia dos direitos fundamentais das pessoas em detrimento dos interesses exclusivos dos Estados.

Contudo, como os fatos são bastante recentes e nem todas as variáveis são conhecidas, acumulam-se incertezas e especulações. Resta observar a conversão de Cuba para o novo modelo que está sendo delineado sob os olhares do mundo e as bênçãos do Vaticano e torcer para que esse fato histórico seja capaz de transformar a sofrida realidade da ilha.

\section{A CONTEXTUALIZAÇÃo DA ATUAL REIVINDICAÇÃO DA GRÉCIA PARA RECEBER INDENIZAÇÕES POR ATOS DA Alemanha durante a Segunda Guerra Mundial}

\author{
Natália da Silva Gonçalves ${ }^{41}$ \\ José Eduardo Paiva Miranda de Siqueira ${ }^{42}$
}

41 Mestranda em Direito das Relações Internacionais pelo Centro Universitário de Brasília. Graduado em Direito pela mesma instituição. 42 Mestrando em Direito das Relações Internacionais pelo Centro Universitário de Brasília. Graduado em Direito pela mesma instituição.

\section{INTRODUÇÃO}

Atualmente, a Grécia levanta contra a Alemanha um pedido de indenização decorrente de seus atos durante a Segunda Guerra Mundial. O valor cobrado é de 278,8 milhões de euros e o governo grego inclusive ameaçou bloquear bens alemães situados em seu território.

Essa discussão já teve vários episódios ao longo dos últimos anos e agora recebeu nova atenção após a última eleição grega que estabeleceu como primeiro-ministro o líder do partido de extrema-esquerda Syriza, Alexis Tsipras.

A ocupação nazista na Grécia ocorreu entre os anos de 1940 e 1944 e resultou na morte de cerca de 250 mil gregos, além dos danos a propriedades e até mesmo um empréstimo bancário forçado.

O governo alemão alega que a questão da reparação já foi encerrada juridicamente e politicamente.

Para dificultar o problema, a Grécia está em uma situação financeira delicada e recebe empréstimos de países europeus desde 2010 para recuperar sua economia, contando com a Alemanha como principal credor. Dada a dificuldade do país de pagar os empréstimos que recebeu e continua a receber, membros do governo alemão alegam que esse novo e infundado pedido de reparações serve para desviar a atenção da atual dívida grega. Nesse sentido, vice-chanceler alemão, Sigmar Gabriel, afirmou que não se pode misturar questões de reparação de guerra com a atual dívida grega.

A presente crônica contextualiza essa demanda e avalia as medidas que já foram tomadas para solucionar o problema, considerando a persistência dos gregos em satisfazer sua necessidade de reparação e as alegações por parte da Alemanha de que o problema já fora resolvido nas esferas judicial e política.

\section{O massacre de Distomo}

Dentre os crimes cometidos durante a invasão nazista, destaca-se o massacre de Distomo, que consiste em um dos principais pilares da atual reivindicação grega.

O massacre ocorreu em junho de 1944, evento no qual centenas de pessoas foram mortas e propriedades foram destruídas. Ocorre que esse acontecimento já foi 
amplamente discutido em diversos âmbitos jurisdicionais.

Em 1995, no âmbito da jurisdição grega, sobreviventes e parentes das vítimas do massacre ajuizaram pedido de indenização por esses atos no tribunal de primeira instância de Leivadia, o qual decidiu, em 1977, que a Alemanha deveria pagar indenizações correspondentes a aproximadamente 28 milhões de euros aos peticionários. $\mathrm{O}$ tribunal entendeu que nesse caso ele possuía jurisdição para julgar uma demanda contra um Estado, uma vez que o cometimento de crimes de guerra e as flagrantes violações de normas jus cogens afastavam a imunidade estatal da Alemanha.

A Alemanha, por sua vez, apelou contra a decisão, mas a Suprema Corte Helenica, em 2000, manteve a decisão de primeira instância, reafirmando que a Alemanha não poderia se beneficiar da imunidade soberana uma vez que havia violado normas jus cogens. Votos miniritários sustentaram que não existia regra que restringisse a imunidade soberana.

Apesar dessas decisões, a Alemanha se recusou a fazer qualquer pagamento e, diante da recusa, os pedicionários buscaram um modo de fazer com que as decisões se cumprissem.

Os peticionários quiseram, então, apreender bens da Alemanha que se encontravam na Grécia, contudo, o artigo 923 do Código Grego de Procedimento Civil estabelece que o ministro da justiça deve consentir com a apreensão de bens de país estrangeiro. Ocorreu que o ministro se recusou a prestar seu consentimento.

Não obstante, em julho de 2000, alguns bens do Instituto Goethe foram acessados e a Alemanha apresentou objeção a esse procedimento perante a Corte Distrital de Atenas, a qual não acatou a objeção.

Em 2002, instâncias superiores gregas decidiram em favor da Alemanha, afirmando que a negativa de apreensão de bens era legal. Por fim, ainda em 2002, a Alta Corte Especial da Grécia decidiu de forma definitiva o assunto, reconhecendo que a Alemanha dispunha de imunidade sem restrições e não poderia ser processada por cortes gregas, uma vez que não havia nenhuma regra de direito internacional que relativizasse a imunidade estatal.

No âmbito internacional, primeiramente, o assunto foi discutido na Corte Europeia de Direitos Humanos, em julho de 2000. Na oportunidade os peticionários demandaram contra a Alemanha e a Grécia. Contudo, a
CEDH considerou o pleito inadmissível e decidiu em favor da imunidade da Alemanha. Sustentou que quando a Grécia se recusou a dar cumprimento às decisões das instâncias iniciais e decidiu não apreender bens da Alemanha, o direito internacional foi obedecido e foram observadas as boas relações entre Estados por meio do respeito à soberania. Não houve, para a Corte, norma de direito internacional que relativizasse a imunidade, nem mesmo em casos de violações de normas jus cogens.

Ao mesmo tempo em que essa discussão se desenvolvia na Grécia, a Itália igualmente discutia, em seus tribunais, o dever da Alemanha de reparar os danos cometidos durante a Segunda Guerra Mundial. Tratava-se do caso Ferrini, que foi julgado em 2004. Na jurisdição italiana, a Alemanha havia sido definitivamente condenada.

Ao observar essa situação, os peticionários gregos pediram auxílio à Itália para dar cumprimento às decisões judiciais gregas favoráveis à condenação da Alemanha. As cortes italianas acabaram por acatar a solicitação e os demandantes gregos chegaram a bloquer propriedades alemãs situadas na Itália (Villa Vigoni) com base em uma decisão de 2008 proferida pela Suprema Corte Italiana.

Diante disso, em 2008, a Alemanha ajuizou ação contra a Itália perante a Corte Internacional de Justiça e sustentou que as condenações da justiça italiana, assim como as condenações das primeiras instâncias judiciais gregas, violavam o direito alemão à imunidade estatal. A Grécia participou desse processo como terceiro interessado. A CIJ decidiu em favor da Alemanha, acatando o argumento de imunidade do país e declarando o dever da Itália de tornar sem efeito as decisões do seu país no que diz respeitos aos pedidos de cidadãos italianos e gregos.

Por fim, em 2003, no âmbito da jurisdição alemã, a Suprema Corte Federal, rejeitou o pedido dos peticionários gregos de dar cumprimentos às decisões a eles favoráveis nas instâncias gregas, decisão que foi reafirmada pela Corte Constitucional Alemã em 2006.

\section{O ACORDO DE 1960}

Em 1960, o governo alemão firmou um acordo com a Grécia e pagou determinada quantia como forma de compensação pelos atos de ocupação do país. $\mathrm{O}$ valor 
pago foi apenas parte do que exigia o governo grego, mas foram os termos que ambos os países conseguiram firmar.

Nas reivindicações atuais, o governo da Grécia afirma que as indenizações pagas estão muito aquém do valor necessário para cobrir todas as exigências, já que não cobre o pagamento pelos danos à infraestrutura do país, pelos crimes de guerra e pelo empréstimo bancário forçado que o Banco Nacional da Grécia teve que ceder ao Terceiro Reich em 1942, cujo valor corresponde hoje a aproximadamente 11 bilhões de euros.

\section{O ACORDO DE 1990}

A Alemanha argumenta também que o Tratado de Moscou de 1990 sobre a unificação alemã, conhecido como Acordo 4+2, já superou questões de compensação como essa levantada pela Grécia. Isso porque todas as possíveis reivindicações de compensação por atos cometidos pelo Terceiro Reich teriam perdido a legitimidade após esse tratado, uma vez que surgiu uma nova Alemanha após a unificação.

Ocorre que esse acordo foi firmado entre Estados Unidos, França, Reino Unido, União Soviética e as Alemanhas Ocidental e Oriental. Assim, como a Grécia não fez parte do acordo, este não poderia vinculá-la. Ademais, esse tratado não regula precisamente questões de reparação.

\section{O ACORDO DE LONDRES}

Por fim, chegou a surgir especulação sobre o Tratado de Londres, formulado em 1953, para observar se este seria hábil a deslegitimar a demanda grega.

Esse tratado teve por objetivo consolidar toda a dívida alemã desde o fim da Primeira Guerra Mundial até o período do Pós-Segunda Guerra Mundial, quando a Alemanha, ou pelo menos parte dela (Alemanha Ocidental), foi reconstruída com recursos estrangeiros. Com isso, a intenção buscou viabilizar a reestruturação econômica do país, de modo a não gerar, novamente, um ambiente propício ao totalitarismo.

Não obstante o tratado ter sido um marco importante na reestruturação da dívida da Alemanha, este é taxativo em estabelecer que não regula as indenizações decorrentes de danos de guerra, motivo pelo qual apesar de a Grécia ter sido signatária desse tratado este não saldou a dívida alemã para com o país.

\section{Considerações finais}

Conforme exposto, a discussão acerca da divida alemã para com a Grécia já teve vários episódios e a Grécia não obteve muito sucessos em seus pleitos.

No caso da reparação pelo massacre de Distomo, o assunto foi decidido em diversos âmbitos jurisdicionais e as demandas acabaram não atribuindo à Alemanha o dever de indenização às vítimas e sobreviventes do massacre. Até mesmo a Grécia, em última instância, decidiu em favor da Alemanha na época em que o debate ocorria sob sua jurisdição.

Ademais, o acordo de 1960 pagou à Grécia quantia quase insignificativa diante do que fora requerido pelo governo grego. Já o acordo de 1990 não trata especificamente de reparações pela guerra e a Grécia sequer participou do acordo. Da mesma forma, o tratado de Londres, apesar de contar com a participação da Grécia, não retira dela a possibilidade de reivindicar as indenizações, isso porque esse acordo trata da estruturação da dívida alemã gerada em razão da reconstrução do país, mas não diz respeito à dívida pelos crimes cometidos durante a Segunda Guerra Mundial.

O fato é que os danos causados pela Alemanha $\mathrm{Na}-$ zista são quase incalculáveis. Caso a Grécia recebesse toda a reparação pleiteada, isso abriria precedente para que vários outros países igualmente demandassem contra a Alemanha por completas reparações. A soma disso tudo estaria muito além do que a economia alemã pode suportar e o passado recente já demonstrou que o efeito de pesadas imposições ao país não foi positivo ou efetivo. A outra possibilidade que resta, entretanto, é a de pagamentos irrisórios perto das quantias entendidas como suficientes para cobrir as dívidas alemãs. 


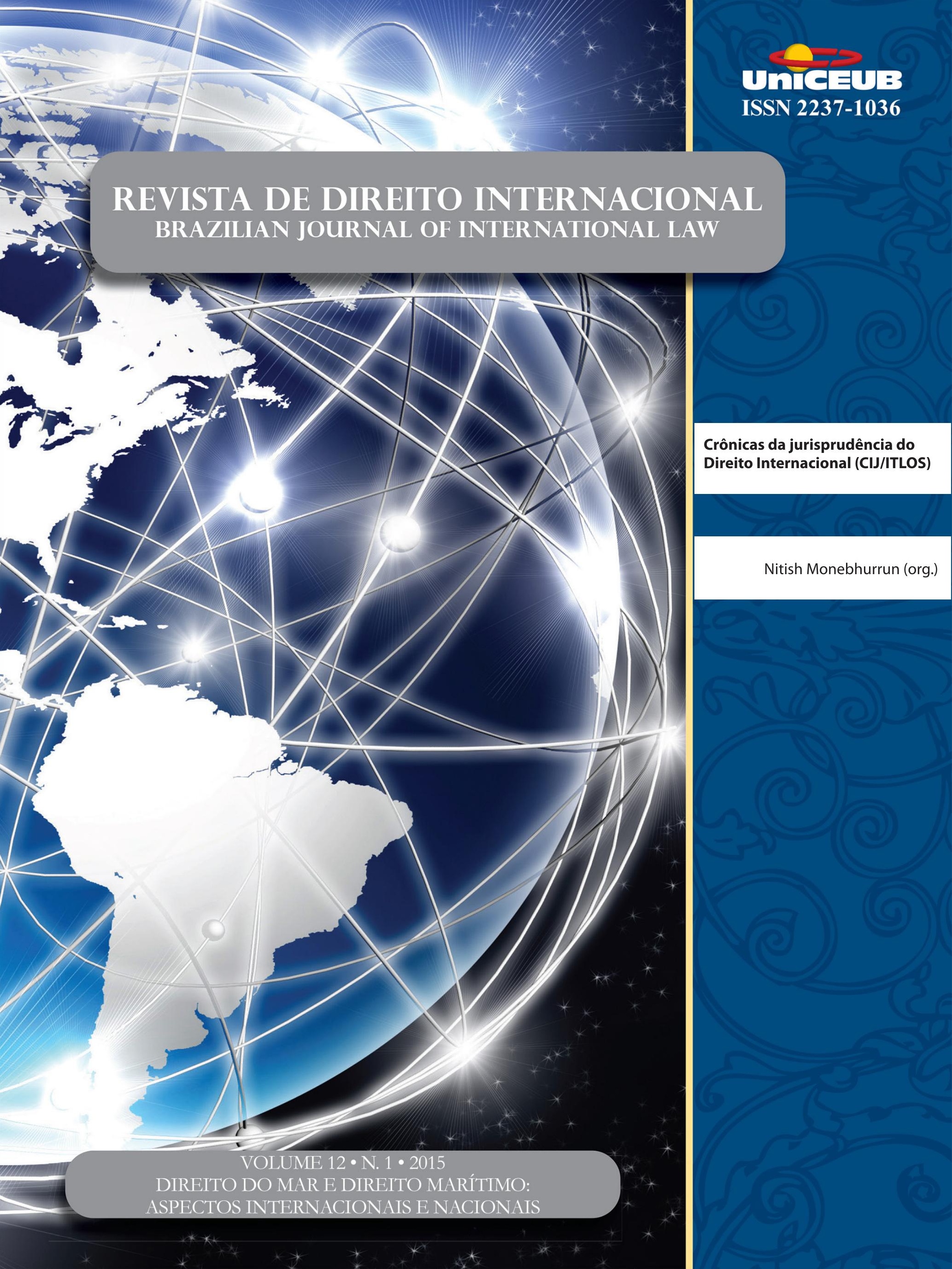




\section{Crônicas da jurisprudência do Direito Internacional (CIJ/ITLOS): decisões da}

Corte Internacional de Justiça e do Tribunal Internacional Sobre o Direito do Mar

Nitish Monebhurrun (Org.)*

\section{Corte Internacional de JustiçA - Estudo dA deCisão da Corte Internacional de Justiça no Caso Croácia v. SERVIA (03/02/2015)}

\footnotetext{
Doutor em Direito Internacional (Escola de Direito de Sorbonne, Paris); Professor de Direito (Centro Universitário de Brasília); Professor Visitante (Mestrado em Direito Internacional da Universidade Sabaná, Bogotá). E-mail: nitish.monebhurrun@gmail.com
}

** Doutora em Direito pela Université d'AixMarseille III, Mestre em Direito pela Universidade de Brasília, Coordenadora do Programa de Pós-Graduação em Direito-Mestrado em Direitos Humanos da Universidade Tiradentes, Advogada. E-mail: lizianepaixao@gmail.com

*** Doutora em Direito pela Université de Paris, Mestre em Direito pelo UniCEUB, Professora do Programa de Mestrado e Doutorado do UniCEUB, Advogada. E-mail: mariaedelvacy@yahoo.com.br

\section{Entendendo o Caso}

A contenda conhecida como "Caso Croácia v. Servia" teve início em 2 de julho de 1999 com o ingresso de petição do Governo da Croácia contra a República Federal da Iugoslávia (RFY) perante a Corte Internacional de Justiça (CIJ). Nos termos da inicial, a Croácia solicitava à Corte (a) a condenação da RFY por violação aos artigos I, II a), II b), II c), II d), III a), III b), III c), III d), III e), IV et V da Convenção sobre Genocídio, aprovada pela ONU em 9 de dezembro de 1948 e em vigor desde 12 de janeiro de 1951, bem como (b) a condenar a RFY por reparação pelos danos causados as pessoas, aos bens, a economia e ao meio ambiente da Croácia. ${ }^{2}$

Em carta enviada a CIJ em 5 de fevereiro de 2003, a República Federal da Iugoslávia (RFY) informa a Corte que, desde 4 de fevereiro de 2003, o nome

1 Igualmente denominada Convenção sobre Genocídio.

2 CORTE INTERNACIONAL DE JUSTIÇA. 2015. Sentença de 3 de fevereiro, Croácia v. Sérvia. Application of the Convention on the Prevention and Punishment of the Crime of Genocide. Disponível em: <http:/ www.icj-cij.org/docket/index.php?p1=3\&p2=3\&k=73 $\&$ case $=118 \&$ code $=$ cry\&p3 $=6>$. Acesso em: 16 jun. 2015. $\int 49$. 
do Estado passou a ser República da Servia-Montenegro. ${ }^{3}$ Posteriormente, em 2006, com a independência da Republica de Montenegro, o RFY passa a ser República Servia. ${ }^{4}$ Quando chamada a se pronunciar sobre a dissolução da RFY, a Croácia decide continuar sua demanda contra a Sérvia e o caso passou a ser Croácia v. Servia.

Em sua defesa a Sérvia expõe que são (a) "irrecevables" as demandas referentes aos atos praticados antes de 27 de abril de 1992, data em que a Servia se tornou Estado de Direito Internacional, (b) que rejeite as demandas concernentes à violação das obrigações impostas pela convenção sobre genocídio, uma vez que estas são desprovidas de fundamento jurídico e fático. ${ }^{5}$

A Sérvia alega preliminarmente que: (a) a Corte não é competente para conhecer as demandas formalizadas pela Croácia, (b) a Corte não deveria recepcionar os pedidos referentes aos atos praticados pela RFY antes de 27 de abril de 1992.

Em 2008, a Corte decide sobre os pedidos de preliminares e por dez votos contra sete reconhece a capacidade da Servia como parte na controvérsia nos termos dos artigos 34 e 35 do Estatuto da Corte ${ }^{6}$. Nas palavras

3 "Par lettre datée du 5 février 2003, la RFY a informé la Cour que, à la suite de l'adoption et de la promulgation par l'Assemblée de la RFY, le 4 février 2003, de la charte constitutionnelle de la Serbie-et-Monténégro, le nom de l'Etat de la «République fédérale de Yougoslavie» était désormais «Serbie-et-Monténégro». (CORTE INTERNACIONAL DE JUSTIÇA. 2015. Sentença de 3 de fevereiro, Croácia v. Sérvia. Application of the Convention on the Prevention and Punishment of the Crime of Genocide. Disponível em: $<$ http: / $/$ www.icj-cij.org $/$ docket $/$ index.php?p1 $=3 \& p 2=3 \& \mathrm{k}=73 \& \mathrm{c}$ ase $=118 \&$ code $=$ cry\&p3 $=6>$. Acesso em: 16 jun. 2015. s 8).

4 Antes de seguir com o estudo da contenda, cabe destacar que o entendimento desse processo envolve a compreensão das diversas dissoluções e emergências de novos Estados na região. Na década de 1980, a República Federativa Socialista da Iugoslávia (RFSY) era composta pelas Repúblicas da Bósnia-Herzegovina, Croácia, Macedônia, Montenegro, Servia e Eslovênia. Todavia, em meados da década de 1980 com a morte do Presidente Tito diversas crises se abatem sobre a RFSY e em 25 de junho de 1991 a Croácia e a Eslovênia declaram a sua independência, fato que foi acompanhado pela independência dos demais.

5 CORTE INTERNACIONAL DE JUSTIÇA. 2015. Sentença de 3 de fevereiro, Croácia v. Sérvia. Application of the Convention on the Prevention and Punishment of the Crime of Genocide. Disponível em: <http://www.icj-cij.org/docket/index.php?p1=3 $\& \mathrm{p} 2=3 \& \mathrm{k}=73 \&$ case $=118 \&$ code $=$ cry\&p $3=6>$. Acesso em: 16 jun. 2015. $\int 50$.

6 CORTE INTERNACIONAL DE JUSTIÇA. 2015. Sentença de 3 de fevereiro, Croácia v. Sérvia. Application of the Convention on the Prevention and Punishment of the Crime of Genocide. Disponível em: <http://www.icj-cij.org/docket/index.php?p1=3 $\& \mathrm{p} 2=3 \& \mathrm{k}=73 \&$ case $=118 \&$ code $=$ cry\&p $3=6>$. Acesso em: 16 jun. 2015. \57 e 58. da Corte "Dans la présente affaire, il n'est pas contesté, et il ne fait aucun doute, que les deux Parties remplissent la condition posée à l'article 34 du Statut: la Croatie et la Serbie sont des Etats aux fins du paragraphe 1 de l'article 34" ?.

No julgamento da segunda preliminar, por doze votos contra cinco, a CIJ reconhece sua competência ratione materiae nos termos do artigo IX da Convenção sobre genocídio. E por dez votos contra sete ela se declara competente para conhecer o pedido submetido pela Croácia. ${ }^{8}$

Se em 2008 a Corte julgou os pedidos preliminares solicitados pela Servia, a decisão ora em análise proferida pela CIJ em 3 de fevereiro de 2015 se refere ao julgamento dos pedidos submetidos pela Croácia na demanda inicial, quais sejam: (a) julgar-se competente para deliberar sobre os fatos ocorridos antes de 27 de abril de 1992, (b) julgar a Servia culpada por violação da Convenção sobre genocídio e (c) condenar o Governo a reparação de danos.

\section{Contexto histórico do Conflito entre 1991 E 1995}

O presente caso se refere aos fatos ocorridos no território da Croácia entre os anos de 1991 e 1995. Segundo dados demográficos coletados em março de 1991, aproximadamente 78\% dos habitantes da Croácia eram de origem croata, aproximadamente $12 \%$ da população era de origem serva que vivia próximo ao território da República da Bosnia-Herzegovina e Servia. No plano político, as tensões entre o governo croata e sua população de origem serva começa no início dos anos 90. Após a independência da Croácia um conflito armado eclode entre as forças armadas da Croácia e grupos armados opositores a independência da Croácia. Em setembro de 1991, segundo relatos do Governo da

7 CORTE INTERNACIONAL DE JUSTIÇA. 2015. Sentença de 3 de fevereiro, Croácia v. Sérvia. Application of the Convention on the Prevention and Punishment of the Crime of Genocide. Disponível em: <http://www.icj-cij.org/docket/index.php?p1=3 $\& \mathrm{p} 2=3 \& \mathrm{k}=73 \&$ case $=118 \&$ code $=$ cry\&p3 $=6>$. Acesso em: 16 jun. 2015. \59.

8 VAURS-CHAUMETTE, Anne-Laure. Si le fait l'accuse, le résultat l'excuse1: l'arrêt de la CIJ sur les exceptions préliminaires dans l'affaire Croatie/Serbie. Annuaire Français de Droit International, 2008. Paris, v. 54, p. 276-304, maio 2009. p. 278. 
Croácia, a força armada popular Iugoslávia (JNA) controlada pelo Governo da Servia se insere no combate em território croata. Nos meses finais de 1991, o JNA e as forças servias já controlavam um terço do território da Croácia.?

A comunidade internacional interveio no conflito entre o final de 1991 e o início de 1992 com o objetivo de implementar o "cessez-le-feu" e a desmilatiração de parte do território croata controlado por minoria serva e forças da RFSY. Todavia, dada a iniciativa, não obteve o êxito esperado, pois as operações militares continuaram entre as duas partes e as tentativas de paz foram fracassadas. Somente na primavera de 2015, a Croácia retoma o poder sobre a maior parte do seu território com base em operações militares. Os atos praticados na operação militar do Governo da Croácia para a reconquista da Krajina, denominada "Tempestade", foi objeto da demanda de "reconventionnelle" intentada pela Servia.

\section{A Competência da Corte para Julgar e RECEBER A DEMANDA}

A competência da Corte está disciplinada entre os artigos 34-38 do seu Estatuto. No caso Croácia v. Servia a Corte reconheceu a sua competência ratione personae, seguindo a interpretação esboçada do artigo 35, Parágrafo 2 do Estatuto no caso Bosnia-Herzegovina v. Servia, em sua decisão de $2008 .{ }^{10}$ Ao reconhecer a sua competência, a CIJ igualmente reconhece que a Servia era membro da ONU, todavia para a doutrina e parte dos juízes da Corte, como demostra a divergência de opinião nos votos individuais, tal fato não era tão cristalino. Para a maioria, a RFY era membro da ONU uma vez que os procedimentos de suspensão ou expulsão não foram realizados, e logo a Corte era competente para se pronunciar sobre o caso. Outros entendem que a Servia não era membro da ONU entre 1992 e 2000

9 CORTE INTERNACIONAL DE JUSTIÇA. 2015. Sentença de 3 de fevereiro, Croácia v. Sérvia. Application of the Convention on the Prevention and Punishment of the Crime of Genocide. Disponível em: <http://www.icj-cij.org/docket/index.php?p1=3 $\& \mathrm{p} 2=3 \& \mathrm{k}=73 \&$ case $=118 \&$ code $=$ cry\&p $3=6>$. Acesso em: 16 jun. 2015. S $60-73$.

10 Sobre o Caso Bosnia-Herzegovina v. Servia ler LAGRANGE, Evelyne. La cohérence de la chose jugée (l'affaire du génocide devant la CIJ. Annuaire Français de Droit International, 2007. Paris, v. 53, p. 1-42, 2008. p. 41-42. e logo a CIJ não era competente ratione personae. ${ }^{11}$ Se a Corte havia declarado a sua competência quanto aos fatos ocorridos após 27 de abril de 1992, ela deixou para o julgamento principal a análise da sua competência com relação aos fatos anteriores a abril de 1992.

Em fevereiro de 2015, uma vez deliberado acerca da sua competência ratione personae a Corte passou a estudar a sua competência material para aplicar a Convenção sobre genocídio entre 1991-1995.

O fundamento para a competência da CIJ no julgamento do caso em epígrafe adveio do artigo IX da Convenção sobre genocídio, nos termos do dispositivo em questão:

As controvérsias entre as Partes Contratantes relativas à interpretação, aplicação ou execução da presente Convenção, bem como as referentes à responsabilidade de um Estado em matéria de genocídio ou de qualquer dos outros atos enumerados no art. III, serão submetidas à Corte Internacional de Justiça, a pedido de uma das Partes na controvérsia ${ }^{12}$.

Logo a Corte entendeu que só poderia se pronunciar acerca da interpretação, aplicação e execução da Convenção, restando excluída de sua apreciação as violações a outras obrigações estipuladas na Convenção, ou seja, a competência prevista no artigo IX não se estende as alegações referentes à violação de normas de direito internacional em matéria de genocídio. Em tal análise a Corte retoma seu posicionamento no caso Bósnia-Herzegovina $v$. Servia e destaca que as obrigações contidas na Convenção sobre genocídio são de natureza erga omnes e que interdição ao genocídio possui caráter de norma imperativa. ${ }^{13}$

Um dos pontos controvertidos entre os juízes da Corte durante o julgamento desse caso foi o entendi-

11 CORTE INTERNACIONAL DE JUSTIÇA. 2015. Sentença de 3 de fevereiro, Croácia v. Sérvia. Application of the Convention on the Prevention and Punishment of the Crime of Genocide. Disponível em: <http://www.icj-cij.org/docket/index.php?p1=3 $\& \mathrm{p} 2=3 \& \mathrm{k}=73 \&$ case $=118 \&$ code $=$ cry\&p $3=6>$. Acesso em: 16 jun. 2015. Opinião individual do juiz Abraham, para 11-12 e 48.

12 ORGANIZAÇÃO DAS NAÇÕES UNIDAS. Resolução 96 (I), de 11 de dežembro de 1946. Convenção para a Prevenção e a Repressão do Crime de Genocídio (1948). Disponível em: <http://www.pge. sp.gov.br/centrodeestudos/bibliotecavirtual/instrumentos/genocidio.htm>. Acesso em: 16j un. 2015

13 CORTE INTERNACIONAL DE JUSTIÇA. 2015. Sentença de 3 de fevereiro, Croácia v. Sérvia. Application of the Convention on the Prevention and Punishment of the Crime of Genocide. Disponível em: <http://www.icj-cij.org/docket/index.php?p1=3\&p2=3\&k= $73 \&$ case $=118 \&$ code $=$ cry\&p3 $=6>$. Acesso em: 16 jun. 2015. §. 87. 
mento acerca da competência da Corte ratione temporis para julgar os fatos ocorridos antes de 27 de abril de 1992, data em que a RFY sucede a RFSY. Para a Corte, a Convenção sobre genocídio não limita a sua competência ratione temporis, nos termos do artigo IX da Convenção sobre Genocídio.

Para a Sérvia, os fatos ocorridos antes de 27 de abril de 1992 não podem ensejar a contenda entre ela e a Croácia, posto que, nos termos do artigo 28 da Convenção de Viena, as disposições de tratado não obrigam uma parte em relação a ato ou fato anterior a sua entrada em vigor. ${ }^{14}$ A Croácia responde que a Convenção sobre genocídio estava em vigor para a RFSY desde 29 de agosto de 1950 e como a RFY a sucedeu, ela passa a ser responsável pelos atos praticados pelo Estado anterior. ${ }^{15}$ A Corte considerou que a disposição de fundo da Convenção não impõe obrigações aos Estados antes que eles se tornem parte desta. ${ }^{16}$ Para deliberar sobre a responsabilidade da Servia antes de abril de 1992, a Corte se debruça sobre a análise da sucessão de responsabilidade entre Estados, pois como mencionado anteriormente esse caso é permeado pela sucessão de Estados.

Em sua sentença, a Corte destaca que, para verificar a responsabilidade da Servia em violar a Convenção, é preciso responder a três questionamentos: (a) os fatos alegados pela Croácia foram cometidos pela Servia e violam a Convenção sobre genocídio, (b) os atos praticados podem ser imputados a RFSY no momento em que foram cometidos, (c) supondo que a responsabilidade da RFSY foi constatada, verificar se a RFY sucedeu a essa responsabilidade. ${ }^{17}$ Após deliberação os juí-

14 CORTE INTERNACIONAL DE JUSTIÇA. 2015. Sentença de 3 de fevereiro, Croácia v. Sérvia. Application of the Convention on the Prevention and Punishment of the Crime of Genocide. Disponível em: <http://www.icj-cij.org/docket/index.php?p1=3 $\& \mathrm{p} 2=3 \& \mathrm{k}=73 \&$ case $=118 \&$ code $=$ cry\&p $3=6>$. Acesso em: 16 jun. 2014. $\int 78-80$.

15 CORTE INTERNACIONAL DE JUSTIÇA. 2015. Sentença de 3 de fevereiro, Croácia v. Sérvia. Application of the Convention on the Prevention and Punishment of the Crime of Genocide. Disponível em: <http://www.icj-cij.org/docket/index.php?p1=3 $\& \mathrm{p} 2=3 \& \mathrm{k}=73 \&$ case $=118 \&$ code $=$ cry\&p3 $=6>$. Acesso em: 16 jun. 2015. $\int 84$.

16 CORTE INTERNACIONAL DE JUSTIÇA. 2015. Sentença de 3 de fevereiro, Croácia v. Sérvia. Application of the Convention on the Prevention and Punishment of the Crime of Genocide. Disponível em: <http://www.icj-cij.org/docket/index.php?p1=3 $\& \mathrm{p} 2=3 \& \mathrm{k}=73 \&$ case $=118 \&$ code $=$ cry\&p3 $=6>$. Acesso em: 16 jun. 2015. $\int 100$.

17 CORTE INTERNACIONAL DE JUSTIÇA. 2015. Sentença de 3 de fevereiro, Croácia v. Sérvia. Application of the Convention on the Prevention and Punishment of the Crime of Genocide. zes decidiram que a RFY, logo a Servia, era responsável pelos atos de genocídio imputados a RFSY, por onze votos contra seis a Corte rejeitou a segunda exceção de incompetência levantada pela Servia e se julgou competente para conhecer a demanda da Croácia com relação aos fatos ocorridos antes de 27 de abril de $1992 .{ }^{18}$

\section{DA DECISÃO: CONDIÇõES PARA A EXISTÊNCIA DO CRIME DE GENOCÍDIO}

O conceito de genocídio utilizado pela Corte foi fundamentado no artigo II da Convenção para a prevenção e repressão do crime de genocídio. O artigo descreve dois elementos que, em conjunto, levariam à constatação de tal crime contra humanidade. $\mathrm{O}$ primeiro se refere ao elemento material descrito com base em uma lista de cinco atos que, segundo a corte, seria exaustiva. Os atos compreenderiam: "(a)assassinato de membros do grupo; (b) dano grave à integridade física ou mental de membros do grupo; (c) submissão intencional do grupo a condições de existência que lhe ocasionem a destruição física total ou parcial; (d) medidas destinadas a impedir os nascimentos no seio do grupo; e (e) transferência forçada de menores do grupo para outro grupo." O segundo elemento seria de ordem intencional, "mens rea". Qualquer um dos atos citados acima deveria ser cometido com a "intenção de destruir, no todo ou em parte, um grupo nacional, étnico, racial ou religioso" para que se pudesse configurar genocídio.

Não há, assim como o próprio artigo expressamente declara, a necessidade de se demonstrar a intenção de se destruir todo o grupo, mas apenas parte dele. Os grupos ou partes deles que foram vítimas do genocídio analisado na decisão se referem a dois grupos identificados por duas queixas, uma apresentada pela Croácia e outra pela Sérvia. A primeira apresentada pela Croácia contra Sérvia se refere à alegação de genocídio cometida pela Sérvia contra um grupo étnico croata que vivia

Disponível em: <http://www.icj-cij.org/docket/index.php?p1=3 $\& \mathrm{p} 2=3 \& \mathrm{k}=73 \&$ case $=118 \&$ code $=$ cry\&p $3=6>$. Acesso em: 16 jun. 2015. $\int 112$.

18 CORTE INTERNACIONAL DE JUSTIÇA. 2015. Sentença de 3 de fevereiro, Croácia v. Sérvia. Application of the Convention on the Prevention and Punishment of the Crime of Genocide. Disponível em: <http://www.icj-cij.org/docket/index.php?p1=3 $\& \mathrm{p} 2=3 \& \mathrm{k}=73 \&$ case $=118 \&$ code $=$ cry\&p3 $=6>$. Acesso em: 16 jun. 2015. ऽ 524 . 
em região reclamada por separatistas sérvios. A Sérvia, por sua vez, apresentou em reconvenção a acusação de que a Croácia haveria cometido genocídio contra a população sérvia que vivia em território croata.

Esse exame sobre a definição de genocídio cometido durante a guerra da Bósnia repete em parte o que foi definido pela corte no caso Bosnia-Herzégovine $v$. Servia. Nesse primeiro caso, a corte adota um conceito jurídico e não político do que seria genocídio e não reconhece a "limpeza étnica" como elemento que configuraria genocídio com base na interpretação do artigo II da Convenção ${ }^{19}$.

$\mathrm{Na}$ próxima seção, analisaremos como esses dois elementos foram apreciados pela Corte.

\section{a. Elemento material}

A Corte decidiu que o ato listado no artigo II (a) da Convenção, qual seja, "assassinato de membros do grupo" foi provado e, que mesmo a parte contrária da demanda, a Servia, não contestava a existência das mortes daquele grupo específico, apenas o objetivo. A Corte concluiu ainda que, por ser o número de vítimas majoritariamente integrante do grupo croata, se poderia inferir que o grupo foi alvo sistemático da operação conduzida pelo grupo sérvio. ${ }^{20}$

Quanto à alegação do cometimento do ato descrito no artigo II b, "dano grave à integridade física ou mental de membros do grupo", a Servia reconheceu que certos atos foram realizados, porém, alegou que tais atos não configurariam genocídio, mas de crime de guerra. A corte sustentou o entendimento de que os atos de tortura, estupro e violência sexual provados indicavam a configuração do elemento material do artigo II b. ${ }^{21}$

19 Sobre a construção de uma definição restrita do conceito de genocídio no caso Bósnia-Herzégovine v. Servia, consultar CORTEN, Olivier. Lárrêt rendu par la CIJ dans láffaire du crime de génocide ( Nosnie-Herzégovine c. Serbie): vers um assouplissement des conditions permettant déngager la responsabilité d'un État pour Génocide? Annuaire Français de Droit International, 2007. Paris, v. 53, p. 249-279, 2008. p. 252-256.

20 CORTE INTERNACIONAL DE JUSTIÇA. Croácia v. Sérvia. Decisão sobre a aplicação da convenção sobre a prevenção e a repressão do crime de genocídio, 3 de fevereiro de 2015. \ 295.

21 CORTE INTERNACIONAL DE JUSTIÇA. 2015. Sentença de 3 de fevereiro, Croácia v. Sérvia. Application of the Convention on the Prevention and Punishment of the Crime of Genocide. Disponível em: <http://www.icj-cij.org/docket/index.php?p1=3 $\& \mathrm{p} 2=3 \& \mathrm{k}=73 \&$ case $=118 \&$ code $=$ cry\&p $3=6>$. Acesso em: 16 jun. 2015, \ 360 .
No que concerne aos atos descritos no artigo II c, a Corte concluiu que a Croácia não apresentou provas capazes de determinar a autoria de tais atos ao grupo sérvio ${ }^{22}$.

A configuração do elemento material do artigo II d não foi provada. Apesar de se reconhecer a prática de estupros e violências sexuais, entendeu-se que não se provou que os atos praticados tinham por objetivo evitar a procriação entre membros do grupo ${ }^{23}$.

Como é necessária apenas a realização de um dos atos descritos no artigo II, a corte concluiu que a prova estabelecida durante o processo foi suficiente para configurar o elemento material do genocídio. Estabelecida a existência do elemento material, a Corte passou ao exame do elemento subjetivo.

\section{b. Elemento subjetivo}

A Corte inicia a análise sobre a configuração do elemento intencional do crime de genocídio pela identificação do grupo croata afetado e se este configuraria parte desse grupo conforme determina a Convenção sobre genocídio. A Corte estabeleceu três critérios que levariam à identificação dessa "parte do grupo". O primeiro critério seria quantitativo, dever-se-ia provar que a porção de pessoas afetadas representaria parte substancial do grupo. O segundo critério seria geográfico: seria necessário provar que se visava destruir parte do grupo localizado em região geográfica precisa na qual "o autor do crime exerça sua atividade e controle". O terceiro critério foi qualitativo. A prova seria estabelecida se fosse observado que a parte do grupo atingida apresentasse relevância para o resto do grupo. ${ }^{24} \mathrm{~A}$ prova de qualquer uma dessas situações descritas acima seria suficiente para o prosseguimento do exame do elemento inten-

22 CORTE INTERNACIONAL DE JUSTIÇA. 2015. Sentença de 3 de fevereiro, Croácia v. Sérvia. Application of the Convention on the Prevention and Punishment of the Crime of Genocide. Disponível em: <http://www.icj-cij.org/docket/index.php?p1=3 $\& \mathrm{p} 2=3 \& \mathrm{k}=73 \&$ case $=118 \&$ code $=$ cry\&p3 $=6>$. Acesso em: 16 jun. 2015, s 394.

23 CORTE INTERNACIONAL DE JUSTIÇA. 2015. Sentença de 3 de fevereiro, Croácia v. Sérvia. Application of the Convention on the Prevention and Punishment of the Crime of Genocide. Disponível em: <http://www.icj-cij.org/docket/index.php?p1=3 $\& \mathrm{p} 2=3 \& \mathrm{k}=73 \&$ case $=118 \&$ code $=$ cry\&p $3=6>$. Acesso em: 16 jun. 2015. $\int 400$.

24 CORTE INTERNACIONAL DE JUSTIÇA. 2015. Sentença de 3 de fevereiro, Croácia v. Sérvia. Application of the Convention on the Prevention and Punishment of the Crime of Genocide. Disponível em: <http://www.icj-cij.org/docket/index.php?p1=3 $\& \mathrm{p} 2=3 \& \mathrm{k}=73 \&$ case $=118 \&$ code $=$ cry\&p $3=6>$. Acesso em: 16 jun. 2015. \137-139. 
cional. A Corte decidiu que os croatas que viviam nas áreas afetadas constituiriam parte substancial do grupo. Mas não desenvolveu em sua fundamentação quais os critérios para identificar a parte substancial nesse caso.

Passou-se, então, para o exame da intenção. Primeiramente se discutiu como a intenção poderia ser identificada. A demonstração do dolo específico para o cometimento do genocídio pode ser alcançada pela prova da existência de um plano estatal para tal finalidade ou pela prova da ação de indivíduos desse Estado. ${ }^{25}$ Apesar de fazer essa afirmação em favor da possibilidade de atos individuais poderem responsabilizar o Estado, a Corte não desenvolve suas implicações.

A Corte se concentra em afirmar que seria necessário estabelecer uma linha de conduta tomando-se por base os atos praticados pelos autores que fossem consistentes com o objetivo de destruir parte de um grupo. A Corte definiu linha de conduta "como um conjunto coerente de ações executadas em um certo período de tempo." ${ }^{26}$ Foram utilizadas, neste estudo, provas apresentadas no Tribunal Penal Internacional para antiga Iugoslávia (TPIY) nos casos Mrkšić et $\mathrm{al}^{27}$ e Martić ${ }^{28}$. Com base nessas provas, a Corte estabeleceu a existência de uma linha de conduta. Entretanto, não bastava evidenciá-la. Dever-se-ia provar que a intenção para destruir o grupo ou parte dele seria a "única dedução razoável que se poderia fazer com base na referida linha de conduta. ${ }^{\prime 2}, 30$

25 CORTE INTERNACIONAL DE JUSTIÇA. 2015. Sentença de 3 de fevereiro, Croácia v. Sérvia. Application of the Convention on the Prevention and Punishment of the Crime of Genocide. Disponível em: <http://www.icj-cij.org/docket/index.php?p1=3 $\& \mathrm{p} 2=3 \& \mathrm{k}=73 \&$ case $=118 \&$ code $=$ cry\&p $3=6>$. Acesso em: 16 jun. 2015. \143-148.

26 CORTE INTERNACIONAL DE JUSTIÇA. 2015. Sentença de 3 de fevereiro, Croácia v. Sérvia. Application of the Convention on the Prevention and Punishment of the Crime of Genocide. Disponível em: $<$ http:/ $/$ www.icj-cij.org/docket/index.php?p1 $=3 \& \mathrm{p} 2=3 \& \mathrm{k}=73 \&$ case $=118 \&$ code $=$ cry\&p3 $=6>$. Acesso em: 16 jun. 2015. $\int 510$.

27 TPIY, case n. IT-95-13a-I. INTERNATIONAL CRIMINAL TRIBUNAL FOR THE FORMER YUGOSLAVIA. Case n. IT95-13a-I. 14 July 2003. Disponível em: < http://www.icty.org/case/ dokmanovic/4>. Acesso em: 16 jun. 2015.

28 TPIY, case n.IT 95-11. INTERNATIONAL CRIMINAL TRIBUNAL FOR THE FORMER YUGOSLAVIA. Case n. IT 9511. 2 December 1997. Disponível em: <http://www.icty.org/case/ martic/4>. Acesso em: 16 jun. 2015.

29 CORTE INTERNACIONAL DE JUSTIÇA. 2015. Sentença de 3 de fevereiro, Croácia v. Sérvia. Application of the Convention on the Prevention and Punishment of the Crime of Genocide. Disponível em: <http://www.icj-cij.org/docket/index.php?p1=3 $\& \mathrm{p} 2=3 \& \mathrm{k}=73 \&$ case $=118 \&$ code $=$ cry\&p $3=6>$. Acesso em: 16 jun. 2015. \ 417.

30 Para críticas sobre a adoção desse raciocínio ver: BONAFÉ,
Utilizando as conclusões do TPIY, a Corte constatou que os atos praticados tiveram por objetivo o deslocamento forçado do povo croata e não sérvio de uma região que se pretendia incorporar ao Estado Sérvio, de modo que este fosse etnicamente homogêneo. ${ }^{31}$ Os atos perpetrados pelo grupo sérvio e identificados no elemento material para constituição do genocídio "tiveram um propósito, o deslocamento forçado dos croatas, o que não implicaria a destruição física destes"32. Diante dessa constatação, a Corte conclui que a Croácia não conseguiu estabelecer que a única dedução razoável que se poderia fazer com base na referida linha de conduta do grupo sérvio seria a destruição do grupo étnico croata. O "dolus specialis" não foi provado. E, sendo ele um dos elementos constituintes para a determinação da responsabilidade da Servia no genocídio de parte do grupo civil croata, a corte decidiu por quinze votos contra dois pela rejeição do pedido da Croácia.

Em seu voto dissidente o juiz Cançado Trindade questiona adoção de uma intepretação restritiva no caso. Para ele, essa escolha "reduziria o crime de genocídio a um crime quase impossível de se determinar, e a Convenção sobre Genocídio a uma letra morta." ${ }^{\text {33 }}$ As provas sobre a prática do crime de genocídio pelas forças servias seriam, na opinião do juiz, irrefutáveis ao demonstrar a existência "de um esquema generalizado e sistemático de extrema violência e destruição." ${ }^{34}$

Beatrice. Responsabilité de l'Etat et responsabilité individuelle pour crime de génocide: une separation purement theorique Ordine Internazionale e diritti unami, n. 1, p. 130-136, 15 mar. 2015. p. 133-134.

31 CORTE INTERNACIONAL DE JUSTIÇA. 2015. Sentença de 3 de fevereiro, Croácia v. Sérvia. Application of the Convention on the Prevention and Punishment of the Crime of Genocide. Disponível em: $<$ http:/ $/$ www.icj-cij.org/docket/index.php?p1 =3\&p2=3\&k=73\&case $=118 \&$ code $=$ cry\&p3 $=6>$. Acesso em: 16 jun. 2015. $₫ 426$.

32 CORTE INTERNACIONAL DE JUSTIÇA. 2015. Sentença de 3 de fevereiro, Croácia v. Sérvia. Application of the Convention on the Prevention and Punishment of the Crime of Genocide. Disponível em: <http://www.icj-cij.org/docket/index.php?p1=3\&p2 $=3 \& \mathrm{k}=73 \&$ case $=118 \&$ code $=$ cry\&p $3=6>$. Acesso em: 16 jun. 2015 $\int 435$.

33 CORTE INTERNACIONAL DE JUSTIÇA. 2015. Sentença de 3 de fevereiro, Croácia v. Sérvia. Application of the Convention on the Prevention and Punishment of the Crime of Genocide. Disponível em: <http://www.icj-cij.org/docket/index.php?p1=3 $\& \mathrm{p} 2=3 \& \mathrm{k}=73 \&$ case $=118 \&$ code $=$ cry\&p $3=6>$. Acesso em: 16 jun. 2015. Decisão sobre a aplicação da convenção sobre a prevenção e a repressão do crime de genocídio, 3 de fevereiro de 2015. Voto dissidente do Juiz Cançado Trindade, \143.

34 CORTE INTERNACIONAL DE JUSTIÇA. 2015. Sentença de 3 de fevereiro, Croácia v. Sérvia. Application of the Convention on the Prevention and Punishment of the Crime of Genocide. Disponível em: <http://www.icj-cij.org/docket/index.php?p1=3 


\section{Considerações finais}

É forçoso concluir após exame da decisão do caso Croácia contra a Sérvia que a Corte Internacional de Justiça pouco avançou sobre o tema do crime de genocídio. De fato, a decisão foi previsível, tendo em vista a solução dada pela Corte em um caso anterior, Bosnia Herzégovine contra Sérvia. A Corte perdeu a oportunidade de esclarecer e aprofundar qual seria o conteúdo das regras costumeiras sobre a responsabilidade dos Estados e sobre a aplicação retroativa do artigo IX da Convenção. Nesses dois pontos se concentraram o maior número de votos dissidentes do caso.

Entretanto, em um elemento crucial para a configuração do crime de genocídio, a apreciação do elemento intencional, pouco foram as dissidências. Apenas duas. Haveria neste estudo esclarecimento a ser desenvolvido: se por um lado a Corte afirma expressamente que a responsabilidade penal individual e do Estado é diferente tanto no que concerne ao regime jurídico aplicável quanto aos seus objetivos, por outro, a corte minimiza essa diferença ao adotar um critério para aceitação da prova da intenção do crime de genocídio que se aproxima daquela exigida na responsabilidade penal individual.

O “diálogo entre juízes” 35 consiste em algo importante para o estabelecimento de coerência no sistema internacional. Nesse caso, a CIJ cita com frequência decisões da TPIY, principalmente para identificar as provas já produzidas. Essa troca é salutar. Contudo, questiona-se, nesse caso, se o uso da decisão do TPIY pela CIJ de fato contribuiu em favor da coerência. Esse questionamento se fundamenta na utilização pela CIJ da forma da apreciação de prova definida para julgar penalmente um indivíduo pelo TPIY como referência para se analisar a responsabilidade de um Estado em um crime de genocídio. Coerência pode ser estabelecida quando em uma mesma situação se aplica um mesmo fundamento, ou mesmo sistema para aferição de provas. Entretanto, nos casos analisados pelo TPIY e pela CIJ a natureza dos réus difere, o que sugeriria, ao menos, um sistema também diferenciado para o estabelecimento da prova do caráter subjetivo no caso genocídio.

$\& \mathrm{p} 2=3 \& \mathrm{k}=73 \&$ case $=118 \&$ code $=$ cry\&p $3=6>$. Acesso em: 16 jun. 2015 Decisão sobre a aplicação da convenção sobre a prevenção e a repressão do crime de genocídio, 3 de fevereiro de 2015. Voto dissidente do Juiz Cançado Trindade, $₫ 470$.

35 Sobre o tema do diálogo ver: MARINHO, Maria; TELES, Solange; OLIVEIRA, Liziane. (Org.). Diálogo entre juizes. Brasília: UniCEUB, 2014. v. 1, p. 45-60.
QUESTÕES RELACIONADAS COM A

APREENSÃO E DETENÇÃO DE CERTOS

DOCUMENTOS E DADOS: (TIMOR LESTE

C. Austrália) - O reconhecimento

DO RETORNO DE UMA RELAÇÃO AMIGÁVEL

eNTRE TIMOR-Leste e Austrália e a nOVA DECISÃO DA CIJ, 6 dE MAIO DE 2015

Gleisse Ribeiro Alves ${ }^{36}$

Em 6 de maio de 2015, a Corte Internacional de Justiça decidiu modificar sua decisão de 3 março de 2014 referente ao Caso Timor-Leste c/ Austrália. Essa revisão teve como motivo o fato de a Austrália ter solicitado à Corte autorização para entregar documentos apreendidos pertencentes ao Timor-Leste. Com esse pedido, a Austrália solicitou igualmente a suspensão das medidas cautelares impostas pela CIJ na decisão de 2014. Na sua sentença, modificada a CIJ afirmou por unanimidade que as circunstâncias novas apresentadas pela Austrália necessitavam de nova decisão da Corte.

O Caso Timor-Leste c/ Austrália teve início em 17 de dezembro de 2013 com a denúncia feita pelo Timor-Leste à CIJ, acusando a Austrália de ter apreendido e detido, por meio de seus agentes, documentos, dados e outros bens pertencentes ao Timor-Leste ou que este tenha o direito de proteger segundo as leis internacionais. Timor-Leste afirmou perante a CIJ que no dia 03 de dezembro de 2013, agentes australianos, pertencentes à Organização Australiana de Inteligência de Segurança, supostamente no âmbito de um mandado emitido pela Procuradoria-Geral da Austrália, apreenderam do gabinete da assessoria jurídica profissional e privada

36 Doutora em Direito pela Universidade Nancy 2 (França); Mestre em Direito das Relações Internacionais pelo Programa de Mestrado em Direito do Centro Universitário de Brasília (UniCEUB), Professora visitante do Programa de Mestrado em Direito: Negócios Internacionais e Europeu (Université de Lorraine, França); Pesquisadora Associada do Institut François Geny (Université de Lorraine, France); Pesquisadora Associada do REGIMEN (Université Catholique de Louvain, Bélgica) Professora de Direito Internacional, atua principalmente nas áreas: Serviços eletrônicos, Direito União Europeia e da OMC, Direitos Humanos, Gestão da Informação, Editoração científica, Gestão Governamental e Políticas Públicas. Coordenadora dos Grupos de Pesquisa CNPq: A participação da Sociedade Civil no âmbito do Mercosul; Sociedade Internacional e governança global no século XXI. CV Lattes: http:// lattes.cnpq.br/2226009228595251. E-mail: gleisse@yahoo.com 
de Timor-Leste localizado em Narrabundah (subúrbio de Canberra, território da capital Australiana), entre outras coisas, documentos, correspondências e dados contendo as comunicações privadas realizadas entre o Governo de Timor-Leste e seus assessores legais. Em especial, foram apreendidos documentos relativos ao processo de arbitragem que está em andamento entre Timor-Leste e a Austrália, nos termos do Tratado de 20 de maio de 2002 sobre o Mar do Timor.

Diante dos fatos, o Timor-Leste solicitou medidas cautelares $^{37}$ para impedir prejuízos irreparáveis provenientes do conhecimento e da divulgação dos elementos apreendidos. Assim, ele fez as seguintes solicitações à Corte: i) aplicação de medidas como o recolhimento e guarda de tais documentos; ii) que a Austrália informe quais pessoas tiveram conhecimento de tais dados; e iii) que a Austrália destrua todas as cópias de tais documentos e que assegure que não interceptará mais as comunicações entre o Timor-Leste e seus conselheiros jurídicos localizados em território australiano. Por 12 votos contra 4, a CIJ decidiu que tais documentos e dados não deveriam ser utilizados contra o Timor-Leste e que a Austrália deveria conservar e guardar tais elementos até o término do processo de arbitragem. Além disso, por 15 votos contra 1, a CIJ determinou que a Austrália não interceptasse as comunicações entre o Timor-Leste e seus conselheiros jurídicos localizados em território australiano. Nesse caso, apesar da Corte determinar que a Austrália não obstacularizasse a comunicação do Timor-Leste com seus conselheiros jurídicos, a CIJ concedeu medidas cautelares que não sanaram completamente o perigo de dano irreparável pela difusão de dados e documentos do Timor-Leste ao determinar que os estes ficassem sob a guarda da Austrália ao invés de depositados junto à Corte.

A Corte gerou dúvidas e incertezas ao instituir a aplicação de medidas cautelares apoiadas em atos unilaterais, tendo em vista estes serem fundamentados em promessas ou compromissos com caráter pouco vinculativo. No caso em espécie, a CIJ amparou sua decisão de manter os documentos e dados em poder da Austrália em compromisso por escrito apresentado por agente australiano em 21 de janeiro de 2014. Em sua decisão, a Corte argu-

37 Pedido fundamentado no artigo 41 do Estatuto da Corte Internacional de Justiça: "A Corte terá a faculdade de indicar, se julgar que as circunstâncias o exigem, quaisquer medidas provisórias que devam ser tomadas para preservar os direitos de cada parte". mentou que o procurador-geral australiano teria o poder efetivo e manifesto de assumir compromissos, obrigando a Austrália, tanto em relação ao direito interno, quanto ao direito internacional. E que não haveria razões que levassem a pensar que tal compromisso não seria cumprido, presumindo-se a boa-fé da Austrália.

Em março de 2015 a CIJ modificou a decisão proferida em 2014 em razão de um novo pedido da Austrália. Esta notificou a Corte a intenção de restituir os documentos, dados e outros bens apreendidos e pertencentes ao Timor-Leste. A essa pretensão Australiana o Timor-Leste indicou que não fazia objeção.

Para decidir sobre o pedido da Austrália, a CIJ analisou, num primeiro momento, se os fatos que motivaram a aplicação de medidas cautelares haviam mudado. Ela constatou, no seu parecer de 22 de abril de 2015, uma mudança e observou que o objeto motivador dessas medidas tinha sido a recusa da Austrália em entregar ao Timor-Leste os documentos e dados apreendido e mantidos em seu poder. Dada a evolução da posição da Austrália, a Corte considerou, que essa nova posição da Austrália gerou consequências no caso e que o fato motivador da aplicação de medidas cautelares havia cessado. A CIJ, em uma segunda etapa, observou que a restituição dos documentos e dados apreendidos só poderiam ser restituídos depois de nova decisão por parte da Corte, tendo em vista que esta deveria primeiramente autorizar a transferência e, em seguida a Corte deveria definir e estabelecer os procedimentos para a transferência e entrega dos documentos e dados. Dessa forma, a Corte concluiu pela necessidade de alterar a decisão proferida anteriormente no dia 3 de março de 2014.

Em sua nova decisão, no dia 6 de maio de 2015, a $\mathrm{CIJ}$ autorizou o retorno de itens apreendidos, mantendo a obrigação para a Austrália, de que os referidos elementos a serem restituídos deveriam ser mantidos sob sigilo até a sua transferência plena. Além disso, ela determinou que a entrega e a transferência dos documentos e dados seriam vistoriados por um agente designado pelo Timor-Leste e que da data da entrega precisava ser notificada previamente à Corte. Em sua decisão, a Corte precisou ainda a suspensão das medidas cautelas anteriormente impostas na decisão de março de 2014.

Em 15 de maio de 2015, o Timor-Leste notificou a Corte que a Austrália no dia 12 de maio restituiu os documentos apreendidos e que, portanto, o motivo do 
pleito havia cessado. Assim, em 2 de junho de 2015 o Timor-Leste comunicou à Corte Internacional de Justiça o pedido de retirada da queixa contra Austrália.

Percebe-se, portanto, o retorno da aplicação dos princípios norteadores das relações internacionais como o da confiança e do respeito mútuo. Resta saber se esses princípios irão perdurar nas negociações e no processo de Arbitragem do Tratado do Mar de Timor para o estabelecimento das fronteiras marítimas definitivas entre os dois paises, tendo em vista que o período de adiamento das negociações entre Timor-Leste e Austrália expirou a 3 de março de 2015.

\section{Tribunal InTERnACIONAL SOBRE DiReItO do Mar - Caso da delimitação da FRONTEIRA MARÍTIMA ENTRE O GANA e a Costa do Marfim no Oceano AtLÂNTICO: MEDIDAS CAUTELARES (25/04/2015)}

Nitish Monebhurrun ${ }^{38}$

\section{INTRODUÇÃo}

No dia 27 de fevereiro de 2015, a Costa do Marfim entrou com ação de pedido de medidas cautelares contra o Gana perante uma Câmara Especial do Tribunal Internacional sobre o Direito do Mar constituída para decidir sobre a delimitação marítima entre os dois Estados no Oceano Atlântico.

Ao esperar a decisão final da Câmara Especial, o requerente, a Costa de Marfim, requereu que o Gana adotasse as seguintes medidas cautelares: 1) a suspensão da exploração de petróleo na área contestada; 2) abster-se de outorgar novas autorizações de exploração; 3) a não divulgação das informações atinentes às atividades passadas, presentes ou futuros de atividades de exploração ao detrimento do Estado demandante; 4) a preservação

38 Doutor em Direito Internacional (Escola de Direito de Sorbonne, Paris), Professor do Programa de Mestrado em Direito (Centro Universitário de Brasília), Professor Visitante do Programa de Mestrado em Direito Internacional (Universidad de la Sabana, Bogotá).E-mail: nitish.monebhurrun@gmail.com

\section{As CONDIÇÕES CLÁSSICAS PARA ORDENAR MEDIDAS CAUTELARES VERIFICADAS NO CASO EM TELA}

da plataforma continental; 5) desistir de toda ação unilateral que possa afeitar os direitos do requerente bem como agravar a disputa.

Medidas cautelares são ordenadas pelos tribunais como remédios equitativos para preservar determinados direitos das partes antes que o caso seja julgado sobre os méritos ${ }^{39}$. De forma esperada, Gana, na sua contra-argumentação, pediu ao Tribunal para recusar todas as demandas da Costa do Marfim.

A questão de direito submetida à Câmara especial é, nesse caso, prosaica: ela deveria decidir se as circunstâncias justificavam a adoção de medidas cautelares. A resposta do Tribunal foi positiva e foram ordenadas algumas medidas cautelares a ambas as partes.

O caso tem interesse para os estudos de Direito Internacional, pois revisita as condições clássicas a ser cumpridas para ordenar tais medidas (2) que foram também adotadas mesmo sem reconhecer a existência de risco iminente ao meio ambiente marinho (3).

Processualmente, a Câmara Especial afirmou a sua competência prima facie (2.1) para declarar que a situação revelava riscos inerentes aos direitos soberanos protegidos da parte requerente - urgência essa justificando, portanto, a adoção de medidas cautelares (2.2).

\subsection{A afirmação da competência prima facie da Câmara Especial}

O artigo 290 da Convenção de Montego Bay relativa ao Direito do Mar estatui sobre a possibilidade que tem o Tribunal para ordenar medidas cautelares. Assim, para adotá-las, o Tribunal deve assegurar-se que tem competência prima facie para julgar o caso; as medidas decretadas devem preservar os direitos das partes ou devem servir para prevenir danos graves ao meio ambiente marinho pendente lite, isto é, enquanto o Tribunal decida ${ }^{40}$.

39 MENDELSON, Maurice. Interim Measures of Protection in cases of contested jurisdiction. British Yearbook of International Law, v. 46, n. 3, p. 259-322, 1972. p. 267.

40 Ver em especial, artigo 290 (1) da Convenção de Montego Bay. 
Antes de se pronunciar sobre qualquer aspecto de um caso, qualquer tribunal deve afirmar a sua competência. Destarte, seguindo uma lógica processual, não poderia ordenar medidas cautelares sem o reconhecimento da sua competência à montante. Entretanto, um órgão jurisdicional pode, sim, adotar medidas provisórias sem que a sua competência sobre os méritos do caso seja estabelecida. Se os fatos e a disputa não revelam, de forma geral, incompetência flagrante e manifesta, o tribunal terá competência presumida exclusivamente para poder votar as medidas. Chama-se da competência prima facie e trata-se de um princípio comumente utilizado na prática do Direito Internacional. Por exemplo, no caso Lagrand, a Corte Internacional de Justiça ordenou a adoção de medidas cautelares pelos Estados Unidos no sentido da não execução do Senhor Lagrand pendente lite ${ }^{41}$. A necessidade das ditas medidas se justifica, dessarte, pela irreversibilidade de determinada ação do Estado requerido.

No caso em tela, a Câmara Especial não estendeu-se sobre essa primeira condição: reconheceu sem muitas discussões ou polêmicas a sua competência prima facie. $\mathrm{Na}$ realidade, os Estados partes à disputa — ambos signatários da Convenção de Montego Bay —, tinham, eles próprios, reconhecido a competência prima facie da Câmara ao submeter-lhe a disputa ${ }^{42}$. Isso facilitou a decisão da Câmara e permitiu-lhe julgar a urgência das medidas cautelares pedidas.

\subsection{O reconhecimento da urgência das medidas cautelares pela Câmara Especial}

A Câmara Especial avaliou, em seguida, a questão da urgência da situação para decidir sobre a iminência das medidas provisórias, eis que, sem estas, deve existir risco real e iminente que haverá dano irreversível aos direi-

NAÇÕES UNIDAS. Convenção das Nações Unidas sobre o Direito do Mar e o Acordo Relativo à Aplicação da Parte XI da mesma Convenção. Nova York, 10 de dezembro de 1982. Disponível em: <http://www.gddc. pt/siii/im.asp?id=396>. Acesso em: 16 jun. 2015.

41 Ver CORTE INTERNACIONAL DE JUSTIÇA. 1999. Sentença de 3 de março, Caso La Grand (Alemanha v. Estados Unidos da América). Disponível em: <http://www.cedin.com.br/wp-content/ uploads/2014/05/casos-conteciosos_1999_01.pdf>. Acesso em: 16 jun. 2015, Pedido de Medidas Cautelares, p. 9.

42 CORTE INTERNACIONAL DE JUSTIÇA. 2015. Sentença de 25 de abril, Ghana v. Costa do Marfim. Disponível em: <http:// www.cedin.com.br>. Acesso em: 16 jun. 2015. Disputa sobre a delimitação marítima entre o Gana e a Costa do Marfim no Oceano Atlântico. Pedido de Medidas Cautelares, Ordem. \$37. tos em debate antes da decisão final sobre os méritos ${ }^{43}$. Esse raciocínio é também o da Corte Internacional de Justiça ${ }^{44}$. No presente caso, a Câmara reconheceu a urgência pelo risco potencial atinentes aos direitos soberanos ameaçados da Costa do Marfim (2.2.1) dos quais declina-se o direito de acesso à informação relativo à soberania do país (2.2.2).

\subsubsection{A urgência frente aos direitos soberanos ameaçados}

Se as partes à disputa expuseram os seus argumentos materiais para demonstrar ou contestar o risco, a Câmara, por sua parte, apontou que não lhe cabia, nesse momento do caso, fazer uma análise sobre os méritos para averiguar a veracidade e a existência dos direitos reivindicados ${ }^{45}$. Os juízes consideraram que o Gana tinha abertamente reconhecido a existência de uma disputa com a Costa do Marfim cujos direitos invocados abarcaram a soberania sobre o mar territorial e o subsolo o que lhe confere a capacidade jurídica para prospectar e explorar a plataforma continental com base da própria Convenção de Montego Bay. O reconhecimento da disputa implica o conhecimento que os direitos da outra parte podem efetivamente estar sendo infringidos ou ameaçados. Nessa toada, visto a relação direta entre os direitos (soberanos) reivindicados e as medidas pedidas, a Câmara Especial julgou que a demanda da Costa do Marfim era juridicamente embasada. Nos casos sobre as medidas cautelares, a demandante deve apenas provar a plausibilidade do seu pedido em uma lógica de causa-efeito, o que a Costa do Marfim logrou com sucesso também em relação ao pedido de direito de acesso à informação para os assuntos atinentes a sua soberania.

43 CORTE INTERNACIONAL DE JUSTIÇA. 2015. Sentença de 25 de abril, Ghana v. Costa do Marfim. Disponível em: <http:// www.cedin.com.br>. Acesso em: 16 jun. 2015. Disputa sobre a delimitação marítima entre o Gana e a Costa do Marfim no Oceano Atlântico. Pedido de Medidas Cautelares, Ordem, $\iint 41-42$.

44 Para uma decisão recente, ver por exemplo: Algumas atividades do Nicarágua na Fronteira. CORTE INTERNACIONAL DE JUSTIÇA. 2013. Sentença de 13 de dezembro Certain Activities carried out by Nicarágua in the Border Area (Costa Rica v. Nicarágua). Disponível em: <http://www.icj-cij.org/docket/files/150/18510.pdf>. Acesso em: 16 jun. 2015. Medidas Cautelares, Ordem, p. 405.

45 CORTE INTERNACIONAL DE JUSTIÇA. 2015. Sentença de 25 de abril, Ghana v. Costa do Marfim. Disponível em: <http:// www.cedin.com.br>. Acesso em: 16 jun. 2015. Disputa sobre a delimitação marítima entre o Gana e a Costa do Marfim no Oceano Atlântico. Pedido de Medidas Cautelares, \57. 
2.2.2. A urgência frente ao direito de acesso à informação atinente à soberania do requerente

A Costa do Marfim tinha pedido, a título de medidas cautelares, o sigilo pelo Gana das informações relacionadas aos recursos naturais disponíveis no território marítimo disputado e a sua exploração pelo Estado requerido. Como cada Estado tem o direito soberano de escolher as empresas consideradas aptas e habilitadas para explorar a sua plataforma continental, o requerente arguia que pendente lite, todas as informações e dados sobre recursos naturais não poderiam circular, ser adquiridas ou utilizadas pelo Gana, pois, em caso do reconhecimento pela Câmara da sua soberania sobre a área contestada, isso constituiria infringência dos seus direitos protegidos.

A Câmara admitiu a validade da arguição, estatuindo que os direitos atinentes à prospecção e à exploração dos recursos naturais na plataforma continental implicam o direito de ter acesso às informações sobre $\mathrm{O}$ assunto $^{46}$. A detenção dessas informações pelo Gana e a sua eventual divulgação apresentam risco para os direitos soberanos da Costa do Marfim; o risco é iminente posto que as atividades autorizadas pelo Gana estão operacionais. Por conseguinte, a Câmara especial estatuiu que a parte requerida deve adotar todas as medidas para que as informações relativas às atividades de exploração presentes, passadas ou passadas não sejam utilizadas ao detrimento da Costa do $\mathrm{Marfim}^{47}$ — a não ser que já se encontrem no domínio público.

Ora, se a Câmara Especial afirmou o risco de violação dos direitos soberanos do requerente, não foi convencida da existência de risco iminente ao meio ambiente marinho assim como o salientava a Costa do Marfim. Não obstante e de forma interessante, ordenou mesmo assim a adoção de medidas cautelares.

\section{A imposição de medidas cautelares mesmo na ausência de um risco ambiental iminente}

46 CORTE INTERNACIONAL DE JUSTIÇA. 2015. Sentença de 25 de abril, Ghana v. Costa do Marfim. Disponível em: < http:// www.cedin.com.br>. Acesso em: 16 jun. 2015. Disputa sobre a delimitação marítima entre o Gana e a Costa do Marfim no Oceano Atlântico. Pedido de Medidas Cautelares, Ordem, $\$ 94$.

47 CORTE INTERNACIONAL DE JUSTIÇA. 2015. Sentença de 25 de abril, Ghana v. Costa do Marfim. Disponível em: <http:// www.cedin.com.br>. Acesso em: 16 jun. 2015. Disputa sobre a delimitação marítima entre o Gana e a Costa do Marfim no Oceano Atlântico. Pedido de Medidas Cautelares, Ordem p. 22.
A Câmara ajuizou que embora a Costa do Marfim não tenha conseguido aportar provas contundentes de risco iminente, formando uma espada de Dâmocles sobre o meio ambiente marinho, a proteção do meio ambiente constitui obrigação estatal segundo a Convenção de Montego Bay ${ }^{48}$ - e qualquer risco, mesmo não iminente, de dano ambiental grave entra no âmbito de preocupação da jurisdição. Os Estados devem proteger o meio ambiente marinho ${ }^{49}$ e têm, outrossim, a obrigação de averiguar que as atividades dentro das suas fronteiras não sejam danosas aos outros Estados ${ }^{50}$.

A exploração da plataforma continental resulta às vezes em efeitos irreversíveis que não podem ser reparados financeiramente. A Câmara Especial sublinhou que os lucros da exploração de petróleo podem ser pagos a posteriori sob a forma de compensação, conquanto essa última não se aplica em caso de dano ambiental grave que solapa as próprias caraterísticas da plataforma. Nesse caso, qualquer valor financeiro não pode restituir o status quo ante ${ }^{51}$.

Os juízes tentaram encontrar equilíbrio nos direitos protegidos de ambas as partes. Não querendo impor ônus indevido ao Gana, eles consideraram que a medida cautelar não poderia ter como objeto o encerramento definitivo das atividades de exploração: seria uma perda financeira importante para o Estado e também para as empresas. Ademais — consideração notável —, a suspensão das atividades causaria danos ambientais sérios pela deterioração física dos equipamentos já instalados. Entrementes, a Câmara decidiu que doravante o Gana não deveria autorizar qualquer nova concessão de ex-

48 CORTE INTERNACIONAL DE JUSTIÇA. 2015. Sentença de 25 de abril, Ghana v. Costa do Marfim. Disponível em: <http:// www.cedin.com.br>. Acesso em: 16 jun. 2015. Disputa sobre a delimitação marítima entre o Gana e a Costa do Marfim no Oceano Atlântico. Pedido de Medidas Cautelares. $\iint 69-70$.

49 Artigo 192 da Convenção de Montego Bay. NAÇÕES UNIDAS. Convenção das Nações Unidas sobre o Direito do Mar e o acordo relativo à aplicação da parte XI da mesma Convenção. Nova York, 10 de dezembro de 1982. Disponível em: <http://www.gddc.pt/siii/ im.asp?id=396>. Acesso em: 16 jun. 2015.

50 CORTE INTERNACIONAL DE JUSTIÇA. Parecer Consultivo de 08 de julho de 1996: licitude da ameaça ou uso de armas nucleares. Disponível em: <http://www.cedin.com.br/wp-content/uploads/2014/05/pareceres-consultivos_1994.pdf $>$. Acesso em: 16 jun. 2015. \$29.

51 CORTE INTERNACIONAL DE JUSTIÇA. 2015. Sentença de 25 de abril, Ghana v. Costa do Marfim. Disponível em: <http:// www.cedin.com.br>. Acesso em: 16 jun. 2015. Disputa sobre a delimitação marítima entre o Gana e a Costa do Marfim no Oceano Atlântico. Pedido de Medidas Cautelares. S§89-90. 
ploração na área contestada ${ }^{52}$ porquanto deveria monitorar dita zona para prevenir qualquer dano sério ao meio ambiente marinho. $\mathrm{O}$ uso do epíteto "sério" vale ser notado, pois implica que danos ambientais 'menos sérios' são de jure toleráveis...

Com essa base, a Câmara Especial pediu que as partes forneçam futuramente um relatório, atestando do respeito por eles das medidas cautelares ${ }^{53}$ - e foram também ordenados médias da preservação do meio ambiente assim como a não agravação da disputa que incumbem a ambos a Costa do Marfim e ao Gana.

\section{Comentário À Opinião Consultiva 21 do TRIBUNAL INTERNACIONAL PARA o Direito Do Mar [02/04/2015] (RESPONSABILIDADE DO Estado dE BaNDEIRA PELA PESCA ILÍCITA, NÃO DECLARADA OU NÃO REGULAMENTADA)}

Carina Costa de Oliveira ${ }^{54}$

\section{INTRODUÇÃo}

No dia 2 de abril de 2015, foi publicada a Opinião Consultiva n. 21, submetida pela Comissão Sub-Regional de Pescas (CSRP) ao Tribunal Internacional de Direito do Mar (International Tribunal for the Law of the Sea - ITLOS). A opinião é relevante por ter analisado duas questões substanciais principais: a) a maior precisão da obrigação de due diligence para o Estado de

52 CORTE INTERNACIONAL DE JUSTIÇA. 2015. Sentença de 25 de abril, Ghana v. Costa do Marfim. Disponível em: <http:// www.cedin.com.br>. Acesso em: 16 jun. 2015. Disputa sobre a delimitação marítima entre o Gana e a Costa do Marfim no Oceano Atlântico. Pedido de Medidas Cautelares. \$§89-90 \$§99-102.

53 Os relatórios devem ser submetidos no dia 25 de maio de 2015. Ver: CORTE INTERNACIONAL DE JUSTIÇA. 2015. Sentença de 25 de abril, Ghana v. Costa do Marfim. Disponível em: <http:// www.cedin.com.br>. Acesso em: 16 jun. 2015. Disputa sobre a delimitação marítima entre o Gana e a Costa do Marfim no Oceano Atlântico. Pedido de Medidas Cautelares. S\$89-90. p. 22.

54 Professora Adjunta da Faculdade de Direito da Universidade de Brasília (UnB). Líder do Grupo de Estudos em Direito, Recursos Naturais e Sustentabilidade - GERN-UnB. E-mail: carina2318@ gmail.com bandeira no que concerne à pesca ilícita, não declarada ou não regulamentada; 2) a confirmação dos limites da responsabilidade dos Estados e das organizações internacionais pela pesca ilegal realizada por navios de suas bandeiras. Para a melhor compreensão dos problemas jurídicos analisados pelo tribunal, é necessário apresentar os fatos e as questões que foram submetidas ao tribunal.

Trata-se de um pedido de opinião consultiva feito à Corte no dia 27 de março de 2013 pelo Secretário Permanente da CSRP, tendo como fundamento a previsão no artigo 138 do Regulamento do Tribunal do Mar e no artigo 21 do Estatuto do Tribunal ${ }^{55}$. O caso inova nos pedidos de opiniões consultivas anteriormente enviados ao Tribunal, pois o pedido foi feito por uma Comissão que prevê em seu tratado constitutivo a possibilidade de fazer essa solicitação ao Tribunal do Mar. Diante desse pedido, o tribunal analisou primeiramente a sua competência para dar essa opinião, para em seguida avaliar as questões substanciais enviadas.

A principal questão processual decorreu da necessidade de interpretação da competência do tribunal para dar essa opinião, considerando que diversas Partes que intervieram no processo se manifestaram contrárias a essa competência ${ }^{56}$. O tribunal decidiu que seria competente e, portanto, enfrentou os argumentos contrários a essa posição. O principal argumento contrário foi de que a Convenção de Montego Bay não faz referência expressa à possibilidade de opinião consultiva em resposta a um pedido de uma Organização Internacional,

55 TRIBUNAL INTERNACIONAL DO DIREITO DO MAR. 2015. Parecer consultivo n. 21, de 2 de abril de 2015. Apresentado pelo Sub-Regionais de Pesca da Comissão (CSRP), Disponível em: $<$ https://www.itlos.org/fileadmin/itlos/documents/cases/case_no.21/ advisory_opinion/C21_AdvOp_02.04.pdf>. Acesso em: 16 jun. 2015. página 15. Art. 21 do Estatuto: "Le tribunal est compétent pour tous les différends et toutes les demandes quilui sont soumis conformément á la Convention et toutes les fois que cela est expressément prévu dans tout autre accord conférant compétence au Tribunal". Art. 138 do Regulamento do Tribunal do Mar: "1. Le tribunal peut donner un avis consultatif sur une question juridique dans la mesure où un accord international se rapportant aux buts de la Convention prévoit expressément qu'une demande d'un tel avis est soumise au Tribunal; 2. La demande d'avis consultative est transmise au Tribunal par tout organe qui aura été autorisé à cet effet par cet accord ou en vertu de celui-ci”.

56 TRIBUNAL INTERNACIONAL DO DIREITO DO MAR. 2015. Parecer consultivo n. 21, de 2 de abril de 2015. Apresentado pelo Sub-Regionais de Pesca da Comissão (CSRP). Disponível em: $<$ https://www.itlos.org/fileadmin/itlos/documents/cases/case_no.21/ advisory_opinion/C21_AdvOp_02.04.pdf>. Acesso em: 16 jun. 2015. \39. 
o que resultaria em decisão ultra vires ${ }^{57}$.

O artigo 138 do Regulamento foi interpretado no sentido de que o tribunal pode dar opinião consultiva sobre uma questão jurídica se o tratado constitutivo da organização internacional requerente prever que um pedido de opinião poderá ser submetido ao tribunal do mar. No caso concreto, a Convenção relativa à determinação mínima de acesso e de exploração aos recursos pesqueiros no interior das zonas marítimas sob a jurisdição (CMA) dos Estados Membros da CSRP celebrada entre 7 Estados prevê no artigo 33 a competência da Conferência dos Ministros da CSRP para habilitar o Secretário Permanente a enviar questões jurídicas ao Tribunal Internacional do Direito do $\mathrm{Mar}^{58}$. Além disso, o artigo 21 do Estatuto do Tribunal do Mar prevê que o tribunal é competente para analisar todas as controvérsias e os pedidos que são submetidos a ele de acordo com a Convenção e com os acordos que estabelecerem sua competência ${ }^{59}$. O tribunal foi favorável à interpretação de que o termo "todos os pedidos que forem feitos ao tribunal deve ser feita de maneira ampla e deve, portanto, incluir as opiniões consultivas" ${ }^{\prime 60}$. O tribunal posicionou-se de maneira independente de outros tribunais que não declararam essa competência, como a Corte Internacional de Justiça ou a Corte Permanente de Arbitragem ${ }^{61}$.

57 TRIBUNAL INTERNACIONAL DO DIREITO DO MAR. 2015. Parecer consultivo n. 21, de 2 de abril de 2015. Apresentado pelo Sub-Regionais de Pesca da Comissão (CSRP). Disponível em: $<$ https://www.itlos.org/fileadmin/itlos/documents/cases/case_no.21/ advisory_opinion/C21_AdvOp_02.04.pdf>. Acesso em: 16 jun. 2015. \ 40 e seguintes.

58 TRIBUNAL INTERNACIONAL DO DIREITO DO MAR. 2015. Parecer consultivo n. 21, de 2 de abril de 2015. Apresentado pelo Sub-Regionais de Pesca da Comissão (CSRP). Disponível em: $<$ https://www.itlos.org/fileadmin/itlos/documents/cases/case_no.21/ advisory_opinion/C21_AdvOp_02.04.pdf >. Acesso em: 16 jun. 2015. $\int 62$.

59 TRIBUNAL INTERNACIONAL DO DIREITO DO MAR. 2015. Estatuto do Tribunal Internacional do Direito do Mar, de 16 de novembro de 2016, Apresentado pelo Sub-Regionais de Pesca da Comissão (CSRP), Disponível em: <http://www.gddc.pt/siii/docs/ rar60B-1997.pdf>. Acesso em: 16 jun. 2015. Art. 21 do Estatuto do Tribunal Internacional do Direito do Mar: "Le tribunal est compétent pour tous les différends et toutes les demandes qui lui sont soumis conformément á la Convention et toutes les fois que cela est expressément prévu dans tout autre accord conférant compétence au Tribunal".

60 TRIBUNAL INTERNACIONAL DO DIREITO DO MAR. 2015. Parecer consultivo n. 21, de 2 de abril de 2015. Apresentado pelo Sub-Regionais de Pesca da Comissão (CSRP). Disponível em:<https://www.itlos.org/fileadmin/itlos/documents/cases/ case_no.21/advisory_opinion/C21_AdvOp_02.04.pdf >. Acesso em: 16 jun. 2015. \56.

61 O Tribunal fez referência a julgados que expressam a inde-
Diante desse contexto, as questões jurídicas direcionadas ao Tribunal e aceitas foram as seguintes ${ }^{62}$ : 1) Quais são as obrigações do Estado de bandeira no caso de pesca ilícita, não declarada ou não regulamentada exercidas no interior da Zona Econômica Exclusiva (ZEE) dos Estados membros da CSRP?; 2) de que modo o Estado de bandeira pode ser responsabilizado pela pesca não regulamentada realizada por navios de sua bandeira?; e 3) quando uma licença de pesca é conferida por um Estado costeiro a um navio no contexto de um Acordo Internacional com o Estado de bandeira ou com estrutura internacional, esse Estado ou essa organização pode ser responsabilizado por violações da legislação do Estado costeiro, em matéria de pesca, realizadas por esse navio?; e 4) quais são os direitos e as obrigações do Estado costeiro para assegurar a gestão sustentável dos estoques compartilhados e dos estoques de interesse comum, particularmente os de tunídeos e de pequenos pelágicos?

Para responder a essas questões, o tribunal se manifestou competente, limitando-se à análise no âmbito das questões no âmbito da ZEE dos Estados membros da $\operatorname{CSRP}^{63}$. As questões foram aceitas pelo tribunal e foram analisadas com base nas normas pertinentes ${ }^{64}$. As

pendência do Tribunal do mar para estabelecer suas competências, como o caso citado no $\int 57$ da opinião consultiva. TRIBUNAL INTERNACIONAL DO DIREITO DO MAR. 2015. Parecer consultivo n. 21, de 2 de abril de 2015. Apresentado pelo Sub-Regionais de Pesca da Comissão (CSRP). Disponível em: <https://www.itlos.org/ fileadmin/itlos/documents/cases/case_no.21/advisory_opinion/ C21_AdvOp_02.04.pdf>. Acesso em: 16 jun. 2015. (Usina Mox, Irlanda contra Reino-Unido, 2001, p. 106, \51). TRIBUNAL INTERNATIONAL DU DROIT DE LA MER. 2001. 3 décember. AFFAIRE DE L'USINE MOX (IRLANDE c. ROYAUME-UNI) Demande en prescription de mesures conservatoires Disponível em: <https://www.itlos.org/fileadmin/itlos/documents/cases/ case_no_10/Order.03.12.01.F.pdf $>$. Acesso em: 16 jun. 2015.

62 TRIBUNAL INTERNACIONAL DO DIREITO DO MAR. 2015. Parecer consultivo n. 21, de 2 de abril de 2015. Apresentado pelo Sub-Regionais de Pesca da Comissão (CSRP). Disponível em: $<$ https://www.itlos.org/fileadmin/itlos/documents/cases/case_no.21/ advisory_opinion/C21_AdvOp_02.04.pdf>. Acesso em: 16 jun. 2015. \ 64 .

63 TRIBUNAL INTERNACIONAL DO DIREITO DO MAR. 2015. Parecer consultivo n. 21, de 2 de abril de 2015. Apresentado pelo Sub-Regionais de Pesca da Comissão (CSRP). Disponível em: $<$ https://www.itlos.org/fileadmin/itlos/documents/cases/case_no.21/ advisory_opinion/C21_AdvOp_02.04.pdf>. Acesso em: 16 jun. 2015. \69.

64 Nos termos dos artigos 23 e 293 do Estatuto do Tribunal Internacional do Direito do Mar. TRIBUNAL INTERNACIONAL DO DIREITO DO MAR. 2015. Estatuto do Tribunal Internacional do Direito do Mar, de 16 de novembro de 2016, Apresentado pelo SubRegionais de Pesca da Comissão (CSRP), Disponível em: <http:// 
respostas apresentadas pelo tribunal às quatro questões citadas podem ser sintetizadas da seguinte forma: a) a confirmação da extensão da obrigação de "due diligence" para o Estado de bandeira no que concerne à pesca ilícita, não declarada ou não regulamentada; e b) a confirmação dos limites da responsabilidade dos Estados e das organizações internacionais pelos ilícitos decorrentes da pesca causada por navios de sua bandeira.

\section{A CONFIRMAÇÃO DA EXTENSÃO DA OBRIGAÇÃO DE "DUE DILIGENCE" PARA O ESTADO DE BANDEIRA NO QUE CONCERNE À PESCA ILÍCITA, NÃO DECLARADA OU NÃO REGULAMENTADA}

A opinião do tribunal com relação à responsabilidade do Estado de bandeira está em conformidade com os tratados aplicáveis à matéria e com os precedentes relacionados a esse entendimento. Diferencia-se de outras decisões e opiniões, pois a temática foi tratada diretamente pelo tribunal pela primeira vez. É relevante apresentar as definições que foram analisadas pelo tribunal para posteriormente concluir que deve ser estendida ao Estado de bandeira a responsabilidade por obrigações de "due diligence" no que tange à pesca ilícita, não declarada ou não regulamentada.

A opinião tentou, antes de tratar das questões substanciais, definir o que se entende por pesca ilícita, não declarada e não regulamentada, e o que significa a conservação dos recursos biológicos na ZEE dos Estados membros da Comissão, quais sejam, Cabo Verde, República Islâmica da Mauritânia, Senegal, República da Gâmbia, República da Guiné, República da Guiné-Bissau e República da Serra Leoa.

As definições de pesca ilícita, pesca não declarada e pesca não regulamentada, estão previstas no art. 2, parágrafo $4^{\circ}$ da CMA. A opinião consultiva lembrou que essas definições foram inspiradas no Plano de ação internacional, visando prevenir e a eliminar esse tipo de pesca, elaborado e adotado em 2001 pela $\mathrm{FAO}^{65}$ e no

www.gddc.pt/siii/docs/rar60B-1997.pdf>. Acesso em: 16 jun. 2015.

65 FOOD AND AGRICULTURE ORGANIZATION OF THE UNITED NATIONS. International plan of action to prevent, deter and eliminate illegal, unreported and unregulated fishing. 2001. Disponível em: <http://www.fao.org/docrep/003/y1224e/y1224e00.htm>. Acesso em: 15 maio 2015.
Acordo relativo às medidas tomadas pelo Estado do Porto visando prevenir e a eliminar a pesca ilícita, adotado em $2009^{66}$. Outras definições importantes foram de navio de pesca ${ }^{67}$, de estoques compartilhados ${ }^{68}$, de estoques de interesse comum $^{69}$ e de gestão sustentável do meio ambiente marinho ${ }^{70}$.

A relevância da opinião decorre do fato de que a questão da possibilidade de responsabilizar o Estado de bandeira em razão da pesca ilícita ou não regulamentada não foi abordada diretamente pela Convenção ${ }^{71}$.

66 FOOD AND AGRICULTURE ORGANIZATION OF THE UNITED NATIONS. Port State Measures Agreement. 2009. Disponível em: <http://www.fao.org/fishery/topic/166283/en>. Acesso em: 15 maio 2015.

67 TRIBUNAL INTERNACIONAL DO DIREITO DO MAR. 2015. Parecer consultivo n. 21, de 2 de abril de 2015. Apresentado pelo Sub-Regionais de Pesca da Comissão (CSRP). Disponível em: $<$ https://www.itlos.org/fileadmin/itlos/documents/cases/case_no.21/ advisory_opinion/C21_AdvOp_02.04.pdf>. Acesso em: 16 jun. 2015. \ 99 .

68 TRIBUNAL INTERNACIONAL DO DIREITO DO MAR. 2015. Parecer consultivo n. 21, de 2 de abril de 2015. Apresentado pelo Sub-Regionais de Pesca da Comissão (CSRP). Disponível em: < https://www.itlos.org/fileadmin/itlos/documents/cases/case_no.21/ advisory_opinion/C21_AdvOp_02.04.pdf>. Acesso em: 16 jun. 2015. \ 184: "Le Tribunal observe que ces expressions ne figurent pas dans la Convention. Toutefois, l'expression «stocks partagés » est définie à l'article 2, paragraphe 12, de la Convention CMA comme signifiant les «stocks de poissons se trouvant dans les zones maritimes sous juridiction de deux ou plusieurs Etats côtiers ou à la fois à l'intérieur de la zone maritime sous juridiction et dans un secteur adjacent à cette zone ».

69 TRIBUNAL INTERNACIONAL DO DIREITO DO MAR. 2015. Parecer consultivo n. 21, de 2 de abril de 2015. Apresentado pelo Sub-Regionais de Pesca da Comissão (CSRP). Disponível em: $<$ https://www.itlos.org/fileadmin/itlos/documents/cases/case_ no.21/advisory_opinion/C21_AdvOp_02.04.pdf>. Acesso em: 16 jun. 2015. \185: "Le Tribunal observe qu'il n'y a pas de définition établie de «stocks d'intérêt commun ». Il note toutefois que, dans l'exposé qu'elle a fait au cours de la procédure orale, la CSRP a donné l'explication suivante s'agissant de l'expression «stocks d'intérêt commun »: Au niveau de l'Atlantique Centre-Est, plusieurs espèces de pélagiques migrent entre les Zones économiques exclusives de deux ou plusieurs Etats (« transfrontaliers ou stocks d'intérêt commun ») et/ou entre des Zones économiques exclusives et les eaux au-delà (" stocks chevauchants »). Il s'agit donc de stocks partagés entre : deux Etats côtiers voisins, deux Etats côtiers non voisins situés de part et d'autre d'un golfe ou d'un océan ou un Etat côtier et l'Etat du pavillon de l'exploitant du stock."

70 TRIBUNAL INTERNACIONAL DO DIREITO DO MAR. 2015. Parecer consultivo n. 21, de 2 de abril de 2015. Apresentado pelo Sub-Regionais de Pesca da Comissão (CSRP). Disponível em: $<$ https://www.itlos.org/fileadmin/itlos/documents/cases/case_no.21/ advisory_opinion/C21_AdvOp_02.04.pdf>. Acesso em: 16 jun. 2015. \189; 191. A expressão é utilizada para significar conservação, desenvolvimento. O tribunal afirma que o art. 61 da Convenção dá algumas indicações do que seria a gestão sustentável.

71 O Juiz Paik em sua opinião individual manifestou-se no sen- 
Por esse motivo, trata-se de uma lacuna que foi interpretada a luz das obrigações do direito internacional ${ }^{72}$. De modo geral, os navios de pesca devem obter autorização do Estado membro da Comissão para que fique estabelecida a cota de pesca possível. Para tanto, o navio deve apresentar no porto desses Estados as declarações de captura indicadas no seu diário de pesca e não pode utilizar materiais ilegais para a sua atividade. $\mathrm{O}$ navio deve notificar ao Estado costeiro da sua entrada e da sua saída do espaço marítimo sob a jurisdição de um dos Estados membros da Comissão ${ }^{73}$. Assim, os acordos bilaterais de pesca concluídos pelos Estados membros da Comissão e Estados terceiros preveem obrigações aos navios do Estado de bandeira.

De acordo com o tribunal, o Estado de bandeira teria obrigações de "due diligence" ${ }^{74}$ e outras obrigações

tido de que a responsabilidade do Estado da bandeira em casos de pesca ilícita está de um certo modo prevista nos tratados analisados no caso. $\int 18$ da Opinião individual.

72 TRIBUNAL INTERNACIONAL DO DIREITO DO MAR. 2015. Parecer consultivo n. 21, de 2 de abril de 2015. Apresentado pelo Sub-Regionais de Pesca da Comissão (CSRP). Disponível em: $<$ https://www.itlos.org/fileadmin/itlos/documents/cases/case_no.21/ advisory_opinion/C21_AdvOp_02.04.pdf >. Acesso em: 16 jun. 2015. $\int 110$.

73 TRIBUNAL INTERNACIONAL DO DIREITO DO MAR. 2015. Parecer consultivo n. 21, de 2 de abril de 2015. Apresentado pelo Sub-Regionais de Pesca da Comissão (CSRP). Disponível em: < https://www.itlos.org/fileadmin/itlos/documents/cases/case_no.21/ advisory_opinion/C21_AdvOp_02.04.pdf>. Acesso em: 16 jun. 2015 \$ 113.

74 TRIBUNAL INTERNACIONAL DO DIREITO DO MAR. 2015. Parecer consultivo n. 21, de 2 de abril de 2015. Apresentado pelo Sub-Regionais de Pesca da Comissão (CSRP). Disponível em: $<$ https://www.itlos.org/fileadmin/itlos/documents/cases/case_no.21/ advisory_opinion/C21_AdvOp_02.04.pdf>. Acesso em: 16 jun. 2015, \ 125- 132. A obrigação de "due diligence" foi interpretada no âmbito da Corte Internacional de Justiça (CIJ) no caso Papeleras entre a Argentina e o Uruguai da seguinte forma: "Cette obligation implique la nécessité non seulement d'adopter les normes et mesures appropriées, mais encore d'exercer un certain degré de vigilance dans leur mise en œuvre ainsi que dans le contrôle administratif des opérateurs publics et privés, par exemple en assurant la surveillance des activités entreprises par ces opérateurs, et ce, afin de préserver les droits de l'autre partie. Par conséquent, la responsabilité d'une partie au statut de 1975 serait engagée s'il était démontré qu'elle n'avait pas agi avec la diligence requise, faute d'avoir pris toutes les mesures appropriées pour assurer l'application de la réglementation pertinente à un opérateur public ou privé relevant de sa juridiction" Usinas de papel no rio Uruguai (CIJ, Argentina v. Uruguai, 2010, \197). Na opinião consultiva do Tribunal do Mar sobre a responsabilidade e as obrigações dos Estados no contexto das atividades realizadas na Zona, a obrigação de due diligence foi identificada como possuindo um conteúdo variável: "Il est difficile de décrire en des termes précis le contenu des obligations de « diligence requise ». Parmi les facteurs qui rendent une telle description ardue figure le fait que la notion de diligence requise a un caractère vari- mais gerais ${ }^{75}$. Entre as primeiras, que podem ser classificadas como obrigações de comportamento e não de resultado, podem ser citadas as seguintes: a) tomar as medidas necessárias para observar se os navios de sua bandeira estão em conformidade com as leis e os regulamentos adotados pelos Estados membros da CSRP com relação aos recursos biológicos marinhos que estiverem em suas $\mathrm{ZEE}^{76}$; b) observar se os navios com a sua bandeira não realizam atividades ligadas à pesca não regulamentada nas ZEEs dos Estados membros da comissã $\mathrm{O}^{77}$; c) adotar as medidas administrativas necessárias para observar se os navios de pesca com bandeiras nacionais não realizam atividades que contrariem a preservação do meio ambiente marinho e a conservação dos recursos biológicos marinhos ${ }^{78}$; e d) permitir a subida a bordo das autoridades do Estado costeiro que pretendam investigar e controlar as atividades de pesca.

As obrigações gerais do Estado da bandeira, que não são exaustivas ${ }^{79}$, podem ser resumidas da seguinte for-

able. Elle peut changer dans le temps lorsque les mesures réputées suffisamment diligentes à un moment donné peuvent ne plus l'être en fonction, par exemple, des nouvelles connaissances scientifiques ou technologiques. Cette notion peut également changer en fonction des risques encourus par l'activité. [...] Le niveau de diligence requise doit être plus rigoureux pour les activités les plus risquées. TRIBUNAL INTERNACIONAL DO DIREITO DO MAR. 2015. Parecer consultivo n. 17, de 1 de fevereiro de 2011. Responsabilidades e as obrigações dos Estados no contexto das atividades realizadas na Zona. Disponível em: < https://www.itlos.org/en/cases/list-of-cases/case-no-17/>. Acesso em: 16 jun. 2015. \ 117.

75 TRIBUNAL INTERNACIONAL DO DIREITO DO MAR. 2015. Parecer consultivo n. 21, de 2 de abril de 2015. Apresentado pelo Sub-Regionais de Pesca da Comissão (CSRP). Disponível em: $<$ https://www.itlos.org/fileadmin/itlos/documents/cases/case_no.21/ advisory_opinion/C21_AdvOp_02.04.pdf>. Acesso em: 16 jun. 2015. \ 114.

76 TRIBUNAL INTERNACIONAL DO DIREITO DO MAR. 2015. Parecer consultivo n. 21, de 2 de abril de 2015. Apresentado pelo Sub-Regionais de Pesca da Comissão (CSRP). Disponível em: $<$ https://www.itlos.org/fileadmin/itlos/documents/cases/case_no.21/ advisory_opinion/C21_AdvOp_02.04.pdf>. Acesso em: 16 jun. 2015. S 114.

77 TRIBUNAL INTERNACIONAL DO DIREITO DO MAR. 2015. Parecer consultivo n. 21, de 2 de abril de 2015. Apresentado pelo Sub-Regionais de Pesca da Comissão (CSRP), Disponível em: $<$ https://www.itlos.org/fileadmin/itlos/documents/cases/case_no.21/ advisory_opinion/C21_AdvOp_02.04.pdf>. Acesso em: 16 jun. 2015. $\int 114$.

78 TRIBUNAL INTERNACIONAL DO DIREITO DO MAR. 2015. Parecer consultivo n. 21, de 2 de abril de 2015. Apresentado pelo Sub-Regionais de Pesca da Comissão (CSRP). Disponível em: $<$ https://www.itlos.org/fileadmin/itlos/documents/cases/case_no.21/ advisory_opinion/C21_AdvOp_02.04.pdf>. Acesso em: 16 jun. 2015. \$116; 138.

79 TRIBUNAL INTERNACIONAL DO DIREITO DO MAR. 2015. Parecer consultivo n. 21, de 2 de abril de 2015. Apresentado pelo 
ma: a) a obrigação de cooperar no contexto de casos relacionados a atividades de pesca não regulamentada praticadas por navios de sua bandeira nas ZEEs dos Estados membros da Comissão ${ }^{80}$; b) a obrigação do Estado de bandeira de agir ao receber informações de que um navio de sua bandeira está implicado em atividades de pesca não regulamentada, no sentido de investigar e de remediar a situação ${ }^{81}$.

Com relação às organizações internacionais, apesar de haver um reconhecimento de que elas podem ser responsabilizadas, não há nenhuma interpretação que vá além da responsabilidade pela "due diligence" desse sujeito. A opinião contribuiu apenas pela maior clarificação quanto à diferença entre a responsabilidade total da Organização Internacional e a possibilidade de haver responsabilidade solidária com Estados membros com relação às obrigações de "due diligence". A responsabilidade das organizações internacionais está conectada apenas àquelas competências sobre a atividade de pesca transferidas pelos Estados membros à organização. Sobre o tema concreto, apenas a União Europeia possui essa competência ${ }^{82}$. Quando a organização internacional conclui um acordo com um Estado ou com

Sub-Regionais de Pesca da Comissão (CSRP). Disponível em: $<$ https://www.itlos.org/fileadmin/itlos/documents/cases/case_no.21/ advisory_opinion/C21_AdvOp_02.04.pdf>. Acesso em: 16 jun. 2015. \ 117.

80 TRIBUNAL INTERNACIONAL DO DIREITO DO MAR. 2015. Parecer consultivo n. 21, de 2 de abril de 2015. Apresentado pelo Sub-Regionais de Pesca da Comissão (CSRP). Disponível em: $<$ https://www.itlos.org/fileadmin/itlos/documents/cases/case_no.21/ advisory_opinion/C21_AdvOp_02.04.pdf>. Acesso em: 16 jun. 2015. \140. A obrigação de cooperar foi objeto de análise no caso Mox no seguinte sentido: “[...] l'obligation de coopérer constitue, en vertu de la partie XII de la Convention et du droit international général, un principe fondamental en matière de prévention de la pollution du milieu marin. TRIBUNAL INTERNATIONAL DU DROIT DE LA MER. 2001. 3 décember. AFFAIRE DE L'USINE MOX (IRLANDE c. ROYAUME-UNI) Demande en prescription de mesures conservatoires. Disponível em: <https:// www.itlos.org/fileadmin/itlos/documents/cases/case_no_10/ Order.03.12.01.F.pdf >. Acesso em: 16 jun. 2015. p. 95; p. 110; \ 82. 81 TRIBUNAL INTERNACIONAL DO DIREITO DO MAR. 2015. Parecer consultivo n. 21, de 2 de abril de 2015. Apresentado pelo Sub-Regionais de Pesca da Comissão (CSRP). Disponível em: $<$ https://www.itlos.org/fileadmin/itlos/documents/cases/case_no.21/ advisory_opinion/C21_AdvOp_02.04.pdf>. Acesso em: 16 jun. 2015. \ 118; 119; 139.

82 TRIBUNAL INTERNACIONAL DO DIREITO DO MAR. 2015. Parecer consultivo n. 21, de 2 de abril de 2015. Apresentado pelo Sub-Regionais de Pesca da Comissão (CSRP). Disponível em: $<$ https://www.itlos.org/fileadmin/itlos/documents/cases/case_no.21/ advisory_opinion/C21_AdvOp_02.04.pdf>. Acesso em: 16 jun. 2015. \ $159 ; 163 ; 169$. outra organização, ela pode ser responsabilizada pelos eventuais descumprimentos das obrigações acordadas no tratado. Para que essas obrigações fiquem claras, os Estados membros da CSRP podem pedir à organização internacional ou aos Estados membros esclarecimentos quanto à divisão de competências para assumir responsabilidades. No caso de não haver resposta a esse questionamento, a OI e os Estados membros poderão ser solidariamente responsabilizados ${ }^{83}$.

Observa-se, portanto, que as obrigações de "due diligence" e as obrigações gerais como o dever de cooperar foram confirmadas na jurisprudência do tribunal como obrigações de comportamento. A diferença da opinião consultiva sob análise e outras decisões e opiniões consultivas, como o Caso Papeleras na CIJ e a opinião sobre a Responsabilidade e as obrigações dos Estados no contexto das atividades realizadas na Zona, é apenas temática. Houve maior precisão do conteúdo de quais seriam as obrigações específicas nessa área, mas observa-se que há ainda limitação na responsabilidade pelos possíveis danos causados pela má gestão do meio ambiente marinho.

\section{A CONFIRMAÇÃO DOS LIMITES DA RESPONSABILIDADE DOS ESTADOS E DAS ORGANIZAÇõES INTERNACIONAIS PELA REALIZAÇÃO DE ILÍCITOS CONECTADOS À PESCA}

Os limites da responsabilidade por ilícitos conectados à pesca podem ser observados tanto com relação ao Estado de bandeira do navio quanto com relação ao Estado costeiro. A opinião consultiva confirma a limitação de configuração da responsabilidade dos Estados pela má gestão do meio ambiente marinho e, no caso concreto, pela pesca ilícita. A declaração individual do juiz Wolfrum foi exatamente no sentido de que o tribunal perdeu uma oportunidade de desenvolver mais o tema da responsabilidade internacional dos Estados pela reparação de danos ${ }^{84}$. Entre os limites mais evi-

83 TRIBUNAL INTERNACIONAL DO DIREITO DO MAR. 2015. Parecer consultivo n. 21, de 2 de abril de 2015. Apresentado pelo SubRegionais de Pesca da Comissão (CSRP). Disponível em: < https:// www.itlos.org/fileadmin/itlos/documents/cases/case_no.21/advisory_opinion/C21_AdvOp_02.04.pdf>. Acesso em: 16 jun. 2015. \$ 174. 84 Essa observação foi feita em alguns parágrafos da declaração do juiz Wolfrum ( $\int 1$ a 5 ). Outros juízes também se manifestaram nesse sentido: opinião individual do juiz Lucky, \ 29; 33; 35-36 e 
dentes pode ser citada a dificuldade de delimitação das obrigações de resultado do Estado Costeiro e do Estado de Bandeira com relação à conservação e à gestão dos recursos do meio ambiente marinho bem como da obrigação de cooperar entre os Estados membros da Comissão e Estados terceiros.

Como foi analisado, a pesca ilícita pode resultar na responsabilização do Estado de bandeira apenas no caso de descumprimento das citadas obrigações de "due diligence". A obrigação de resultado não pode ser determinada sem a análise prévia da obrigação de comportamento ${ }^{85}$. Assim, se o Estado de bandeira tiver adotado todas as medidas necessárias e apropriadas para cumprir as suas obrigações de "due diligence", ele não será responsabilizado pelos eventuais danos causados ao meio ambiente marinho.

$\mathrm{Na}$ análise das obrigações de "due diligence" do Estado costeiro, observa-se que a opinião se manifesta no sentido de que esse Estado costeiro teria obrigações de "due diligence" mais amplas do que o Estado de bandeira. Há uma maior previsão de obrigações do Estado costeiro para assegurar a gestão sustentável dos estoques compartilhados e dos estoques de interesse comum, em particular dos tunídeos e de pequenos pelágico do que do Estado de bandeira. Entre as obrigações de gestão sustentável desses recursos pelo Estado costeiro podem ser citadas: a) cooperar sobre as medidas necessárias para assegurar a conservação e o desenvolvimento dos estoques ${ }^{86}$; b) assegurar que não haverá superexploração desses recursos ${ }^{87}$; e c) tomar medidas em conformidade com outras organizações que tratem do mesmo tema, como a Comissão internacional para a conservação dos tunídeos do Atlântico tanto nas ZEEs dos Estados membros da CSRP quanto em outros Estados membros de outras organizações que tratem do

opinião individual do juiz Paik, \20, 22, 25.

85 TRIBUNAL INTERNACIONAL DO DIREITO DO MAR. 2015. Parecer consultivo n. 21, de 2 de abril de 2015. Apresentado pelo Sub-Regionais de Pesca da Comissão (CSRP). Disponível em: $<$ https://www.itlos.org/fileadmin/itlos/documents/cases/case_no.21/ advisory_opinion/C21_AdvOp_02.04.pdf>. Acesso em: 16 jun. 2015. \ 129.

86 NAÇÕES UNIDAS. Convenção das Nações Unidas sobre o Direito do Mar e o acordo relativo à aplicação da parte XI da mesma convenção. Nova York, 10 de dezembro de 1982. Disponível em: <http://www.gddc. pt/siii/im.asp?id=396> . Acesso em: 16 jun. 2015.

87 NAÇÕES UNIDAS. Convenção das Nações Unidas sobre o Direito do Mar e o acordo relativo à aplicação da parte XI da mesma convenção. Nova York, 10 de dezembro de 1982. Disponível em: <http://www.gddc. pt/siii/im.asp?id=396>. Acesso em: 16 jun. 2015. Art. 61.3. mesmo tema. Há, ainda, a indicação de que o Estado deve analisar se a conservação e a gestão dos recursos estão sendo feitas de acordo com os dados científicos mais confiáveis dos quais dispõem os Estados membros da CSRP, nos termos do art. 2, parágrafo $2^{\circ}$. da Convenção de Montego Bay ${ }^{88}$.

O caso Virginia G já havia dado maior precisão às obrigações do Estado costeiro no que tange à conservação e à gestão dos recursos biológicos na ZEE, elencando as seguintes atividades: "[...] adotar as leis e os regulamentos que fixem as condições de acesso aos navios de pesca ${ }^{89}$ estrangeiros na sua ZEE" - Arts. 56, parágrafo $1^{\circ}$ e 62 parágrafo $4^{\circ}$ da Convenção. Nos termos do art. 62, parágrafo $4^{\circ}$, essas leis e regulamentos devem ser compatíveis com a Convenção. O tribunal nota que as medidas devem ser de gestão e que não há uma lista exaustiva do que pode ou não ser feito pelo Estado $\operatorname{costeiro~}^{90}$. No mesmo sentido, a opinião consultiva sob análise indica que o Estado costeiro pode adotar

[...] todas as medidas, incluindo de embarque, de inspeção de apreensão e de judicialização que sejam necessárias para assegurar o respeito às leis e aos regulamentos adotados em conformidade com a Convenção. ${ }^{91}$

Apesar de o tribunal ter se manifestado no sentido da proteção do meio ambiente marinho ${ }^{92}$, não há indi-

88 NAÇÕES UNIDAS. Convenção das Nações Unidas sobre o Direito do Mar e o acordo relativo à aplicação da parte XI da mesma convenção. Nova York, 10 de dezembro de 1982. Disponível em: <http://www.gddc. pt/siii/im.asp?id=396>. Acesso em: 16 jun. 2015. Art. 61.2.

89 TRIBUNAL INTERNACIONAL DO DIREITO DO MAR. 2014. Sentença de 14 de abril. Navio "Virginia G", caso 19, Panamá v. Guinée Bissau. Disponível em: < https://www.itlos.org/fileadmin/ itlos/documents/cases/case_no.19/pleadings/9_Annexes_to_the_ Rejoinder.pdf $>$. Acesso em: 16 jun. 2015.

90 TRIBUNAL INTERNACIONAL DO DIREITO DO MAR. 2014. Sentença de 14 de abril. Navio "Virginia G", caso 19, Panamá v. Guinée Bissau. Disponível em: < https://www.itlos.org/fileadmin/ itlos/documents/cases/case_no.19/pleadings/9_Annexes_to_the_ Rejoinder.pdf $>$. Acesso em: 16 jun. 2015. \ 212; 213.

91 TRIBUNAL INTERNACIONAL DO DIREITO DO MAR. 2015. Parecer consultivo n. 21, de 2 de abril de 2015. Apresentado pelo Sub-Regionais de Pesca da Comissão (CSRP). Disponível em: $<$ https://www.itlos.org/fileadmin/itlos/documents/cases/case_no.21/ advisory_opinion/C21_AdvOp_02.04.pdf>. Acesso em: 16 jun. 2015. \ 105.

92 Observa-se que a proteção do meio ambiente marinho tem sido central do sistema. Os recursos biológicos, a fauna e a flora marinhas fazem parte do meio marinho e que, como foi indicado no caso Atum de nadadeira Azul "a conservação dos recursos biológicos do mar constitui um elemento essencial na proteção e na preservação do meio ambiente marinho". TRIBUNAL INTERNACIONAL DO DIREITO DO MAR. 1999. Sentença de 27de Agosto. "Atum de nadadeira Azul", caso 3/7, Nova Zelandia v. Japão; 
cação de responsabilização pelo descumprimento desses objetivos. Trata-se de objetivos e não de obrigações. Há indicação de que as medidas de conservação e de gestão devem restabelecer os estoques de recursos em um nível que possa assegurar o rendimento constante máximo de acordo com fatores ecológicos e econômicos pertinentes. Para tanto, devem ser levadas em consideração as necessidades econômicas das comunidades costeiras de pescadores e as necessidades específicas de cada Estado membro da Comissão, levando-se em consideração os métodos de pescaria, as interdependências dos estoques e as normas mínimas internacionais geralmente recomendadas no plano sub-regional, regional e mundial sobre o tema. Nesse âmbito, as organizações envolvidas no tema devem trocar constantemente informações científicas disponíveis, estatísticas relacionadas à captura e outras informações pertinentes sobre a conservação dos estoques.

Os Estados e as organizações internacionais são obrigados a cooperar no intuito de obter a conservação dos estoques ${ }^{93}$. Contudo, a limitação da cooperação somente entre os Estados membros da $\operatorname{CSRP}^{94}$ reduz os possíveis efeitos para a conservação do meio ambiente marinho, considerando que o mar não tem fronteiras. Para que sejam efetivas, as medidas de conservação e de gestão de pesca devem tratar do conjunto de estoque da espécie na zona de distribuição e nos itinerários de migração $0^{95}$. Os Estados que pescam nos setores adjacentes devem se esforçar a buscar medidas necessárias à conservação desses estoques ${ }^{96}$.

Austalia v. Japão. Medidas Conservatórias. Disponível em: < https:// www.itlos.org/cases/list-of-cases/case-no-3-4/>. Acesso em: 16 jun. 2015. $\int 70$.

93 TRIBUNAL INTERNACIONAL DO DIREITO DO MAR. 2015. Parecer consultivo n. 21, de 2 de abril de 2015. Apresentado pelo Sub-Regionais de Pesca da Comissão (CSRP). Disponível em: $<$ https://www.itlos.org/fileadmin/itlos/documents/cases/case_no.21/ advisory_opinion/C21_AdvOp_02.04.pdf>. Acesso em: 16 jun. 2015. \203.

94 TRIBUNAL INTERNACIONAL DO DIREITO DO MAR. 2015. Parecer consultivo n. 21, de 2 de abril de 2015. Apresentado pelo Sub-Regionais de Pesca da Comissão (CSRP). Disponível em: $<$ https://www.itlos.org/fileadmin/itlos/documents/cases/case_no.21/ advisory_opinion/C21_AdvOp_02.04.pdf>. Acesso em: 16 jun. 2015. p. 69.

95 TRIBUNAL INTERNACIONAL DO DIREITO DO MAR. 2015. Parecer consultivo n. 21, de 2 de abril de 2015. Apresentado pelo Sub-Regionais de Pesca da Comissão (CSRP). Disponível em: $<$ https://www.itlos.org/fileadmin/itlos/documents/cases/case_no.21/ advisory_opinion/C21_AdvOp_02.04.pdf>. Acesso em: 16 jun. 2015.\$196; 198.

96 TRIBUNAL INTERNACIONAL DO DIREITO DO MAR.
Ademais, os limites da obrigação de cooperar refletem-se no que foi apontado pelo juiz Paik em sua opinião individual de que a opinião deveria ter analisado os limites entre a obrigação de cooperar do Estado membro da CSRP e os direitos do Estado costeiro de conservar e de gerir os recursos biológicos da sua ZEE ${ }^{97}$. A opinião não garantiu maior precisão com relação à obrigação de cooperar no sentido de que poderia ser descumprimento dessa obrigação o fato de o Estado se recusar a negociar, demorando para apresentar respostas ou medidas de conservação e de gestão ${ }^{98}$.

Observa-se que a opinião seguiu a interpretação clássica da obrigação de "due diligence" e de cooperação. Avançou na maior precisão das obrigações na área da pesca ilegal, garantindo maior precisão quanto às obrigações de comportamento específicas que devem adotar os Estados de bandeira e os Estados costeiros na gestão dos recursos marinhos. No entanto, observa-se que a obrigação de resultado ainda não é tratada de modo claro na opinião, como não o foi em decisões ou em opiniões consultivas anteriores, e as obrigações do Estado de bandeira podem ficar prejudicadas quando comparadas com as obrigações do Estado costeiro.

2015. Parecer consultivo n. 21, de 2 de abril de 2015. Apresentado pelo Sub-Regionais de Pesca da Comissão (CSRP). Disponível em: $<$ https://www.itlos.org/fileadmin/itlos/documents/cases/case_no.21/ advisory_opinion/C21_AdvOp_02.04.pdf>. Acesso em: 16 jun. 2015. \196.

97 TRIBUNAL INTERNACIONAL DO DIREITO DO MAR. 2015. Parecer consultivo n. 21, de 2 de abril de 2015. Apresentado pelo Sub-Regionais de Pesca da Comissão (CSRP). Disponível em: $<$ https://www.itlos.org/fileadmin/itlos/documents/cases/case_no.21/ advisory_opinion/C21_AdvOp_02.04.pdf>. Acesso em: 16 jun. 2015. Opinião individual do Juiz Paik, \31.

98 TRIBUNAL INTERNACIONAL DO DIREITO DO MAR. 2015. Parecer consultivo n. 21, de 2 de abril de 2015. Apresentado pelo Sub-Regionais de Pesca da Comissão (CSRP). Disponível em: $<$ https://www.itlos.org/fileadmin/itlos/documents/cases/case_no.21/ advisory_opinion/C21_AdvOp_02.04.pdf>. Acesso em: 16 jun. 2015. Opinião individual do Juiz Paik, \37. 


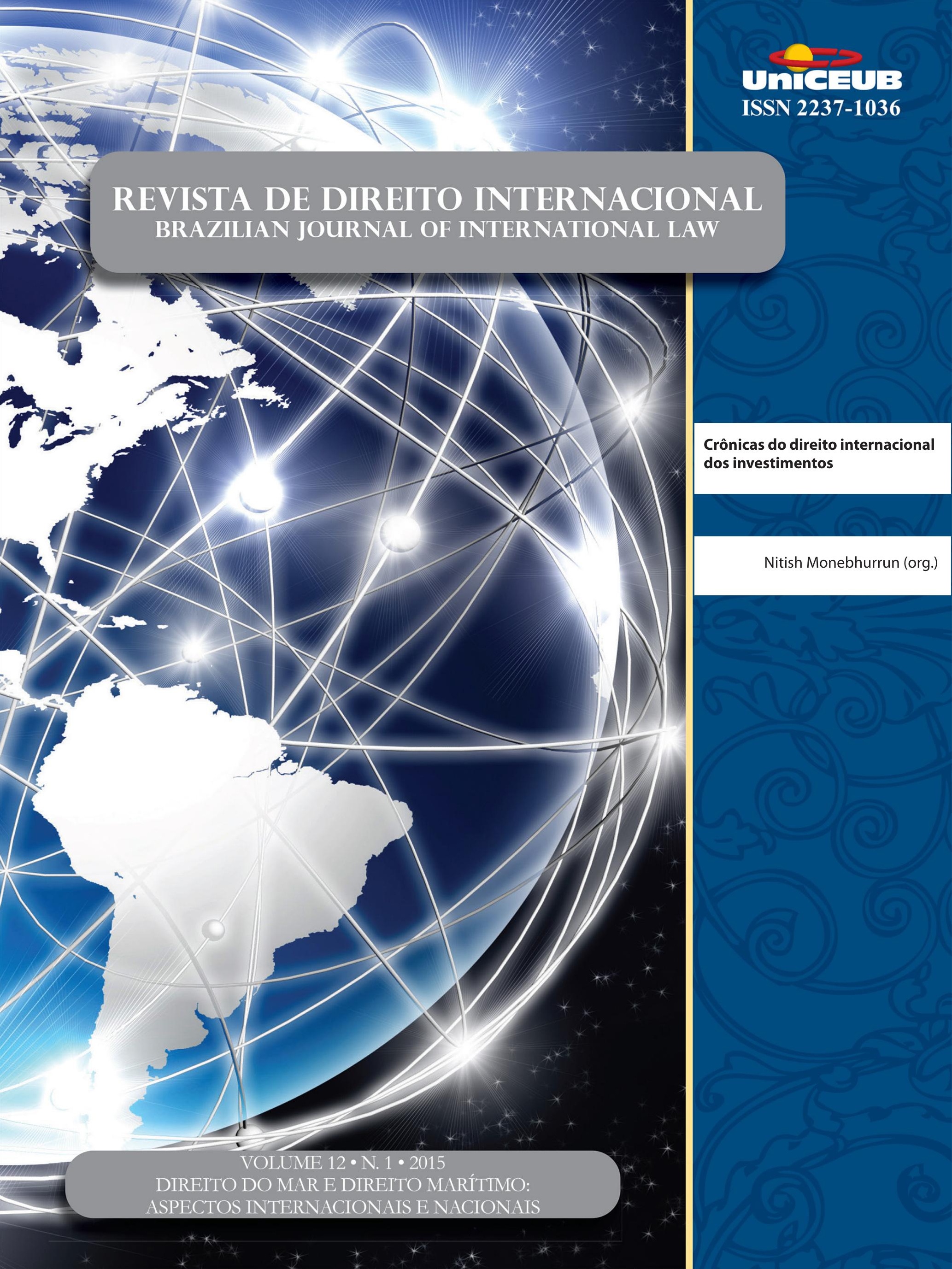




\section{Crônicas do direito internacional dos investimentos*}

Nitish Monebhurrun (Org.)

\section{A INCLUSÃO DA RESPONSABILIDADE SOCIAL DAS EMPRESAS nos novos Acordos de CoOperação e de Facilitação DOS INVESTIMENTOS DO BRASIL: UMA REVOLUÇÃO}

Nitish Monebhurrun*

O Direito Internacional dos Investimentos sempre foi criticado - e a crítica persiste - pela inexistência de obrigações impostas aos investidores. Tradicionalmente, na maioria dos acordos relativos à proteção dos investimentos, a única obrigação que incumbe aos investidores consiste no respeito do direito nacional do país anfitrião. Ao estabelecer-se, o investidor deve assegurar-se que a sua atividade esteja em conformidade com o direito interno. Entrementes, a distribuição dos direitos e das obrigações entre Estado e investidor nos acordos sempre foi voluntariamente desequilibrado. Voluntariamente, porque os Estados decidiram que assim funcionaria o sistema de proteção dos investimentos e engajaram-se a respeitar o direito de proteção máxima aos investidores. Essa é a razão pela qual os Estados têm especialmente obrigações e os investidores fruíam principalmente de direitos no Direito Internacional dos Investimentos. Segue, na realidade, a mesma lógica dos Direitos Humanos: nos sistemas internacionais de proteção dos Direitos Humanos os Estados comprometeram-se a oferecer proteção máxima aos seres humanos e têm, portanto, apenas obrigações em relação a estes, sem esperar qualquer contrapartida (direta).

Se esse desequilíbrio é aceito nos Direitos Humanos, sofre de mais críticas no Direito Internacional dos Investimentos, pois considera-se que muitas grandes empresas não merecem proteção tão alta por ser, às vezes, mais poderosas que os próprios Estados anfitriões. Tem-se essa ideia de que o direito protege a parte frágil, o que não é característica de muitos investidores. Entretanto, essa afirmação pode ser sujeita a nuanças: os investidores não são necessariamente protegidos como partes frágeis, visto que os acordos de proteção dos investimentos buscam apenas oferecer-lhes segurança jurídica em território alheio independentemente das relações de poder. É verdade que a garantia dessa proteção não justifica a ausência de obrigações da parte das empresas investidoras. Essa discussão sobre os méritos das obrigações dos investidores no Direito Internacional dos Investidores teve, contudo, um aspecto muito escolar, limitando-se às críticas — justificadas e juridicamente válidas — da sociedade civil, em especial do mundo universitário ou das organizações não governamentais.

Um passo importante, inovador e revolucionário foi recentemente feito pelo Brasil na proposta do seu modelo de Acordo sobre a Cooperação e Facilitação dos Investimentos (ACFI). Nos recentes acordos assinados com

* Doutor em Direito Internacional (Escola de Direito de Sorbonne, Paris); Professor de Direito (Centro Universitário de Brasília); Professor Visitante (Mestrado em Direito Internacional da Universidade Sabaná, Bogotá). E-mail: nitish.monebhurrun@gmail.com 
Angola, o Moçambique e o México ${ }^{1}$, foi prevista uma disposição sobre a responsabilidade social corporativa - o que pode ser considerado como uma première no âmbito do Direito Internacional. Sem preocupar-se muito com o debate, agora muito teórico, atinente à capacidade jurídica das empresas privadas para ser destinatárias de obrigações no Direito Internacional, o Brasil, com os outros países signatários impuseram-lhes uma responsabilidade social. O Estado brasileiro, que sempre mostrou grande ceticismo em relação ao Direito Internacional dos Investimento ${ }^{2}$, assina, com esses acordos, a sua entrada nesse universo jurídico, e o faz com laudável arrojo ao conferir — tão esperadas obrigações aos investidores, pelo princípio da responsabilidade social das empresas.

Essa responsabilidade, prevista pelos três acordos ${ }^{3}$,

1 O ACFI Brasil-Angola foi assinado em 01/04/2015 em Luanda. BRASIL. Ministério das Relações Exteriores. Acordo BrasilAngola de Cooperação e Facilitação de Investimentos (ACFI), Luanda, $1^{\circ}$ de abril de 2015. Disponível em: <http://www.itamaraty.gov.br/ index.php?option $=$ com_content\&view $=$ article\&id $=8520$ :acordobrasil-angola-de-cooperacao-e-facilitacao-de-investimentos-acfiluanda-1-de-abril-de-2015\&catid $=42 \&$ lang $=$ pt-BR\&Itemid $=280>$. Acesso em: 16 jul. 2015; o ACFI Brasil-Moçambique foi assinado em 21.03.2015 em Maputo. BRASIL. Ministério das Relações Exteriores. Acordo Brasil-Moçambique de Cooperação e Facilitação de Investimentos (ACFI), Maputo, 30 de março de 2015. Disponível em: $<$ http://www.itamaraty.gov.br/index.php?option=com_content \&view $=$ article\&id $=8511$ :acordo-brasil-mocambique-de-cooperacao-e-facilitacao-de-investimentos-acfi-maputo-30-de-marco-de$2015 \&$ catid $=42 \&$ lang $=p t-B R \& I t e m i d=280>$. Acesso em: 16 jul. 2015; o ACFI Brasil-México foi assinado em 26.05.2015 na Cidade de México. BRASIL. Ministério das Relações Exteriores. Acordo Brasil-México de Cooperação e Facilitacão de Investimentos. Cidade do México, 26 de maio de 2015. Disponível em: <http://www.itamaraty. gov.br $/$ index.php?option $=$ com_content $\&$ view $=$ article $\&$ id $=9890$ : acordo-brasil-mexico-de-cooperacao-e-facilitacao-de-investimentos-cidade-do-mexico-26-de-maio-de-2015\&catid $=42 \& l a n g=p t-$ BR\&Itemid $=280>$. Acesso em: 16 jul. 2015.

2 MONEBHURRUN, Nitish. Reflexão sobre os (futuros) acordos brasileiros relativos à proteção dos investimentos: os acordos de cooperação e de facilitação de investimentos. In:__ (Org.). Crônicas do direito internacional dos investimentos: 2014. Revista de Direito Internacional, Brasília, v. 11, n. 1, p. 65-72, 2015.

3 Artigo 10 dos ACFI Brasil-Angola e Brasil-Moçambique, BRASIL. Ministério das Relações Exteriores. Acordo Brasil-Mocambique de Cooperação e Facilitação de Investimentos (ACFI). Maputo, 30 de março de 2015. Disponível em: <http://www.itamaraty.gov. $\mathrm{br} /$ index.php?option $=$ com_content\&view $=$ article\&id $=8511: \mathrm{ac}$ ordo-brasil-mocambique-de-cooperacao-e-facilitacao-de-investimentos-acfi-maputo-30-de-marco-de-2015\&catid $=42 \& l a n g=p t-$ BR\&Itemid $=280>$. Acesso em: 16 jul. 2015; artigo 13 do ACFI Brasil-México, BRASIL. Ministério das Relações Exteriores. Acordo Brasil-México de Cooperação e Facilitação de Investimentos. Cidade do México, 26 de maio de 2015. Disponível em: <http://www.itamaraty. gov.br $/$ index.php?option $=$ com_content\&view $=$ article\&id $=9890$ : acordo-brasil-mexico-de-cooperacao-e-facilitacao-de-investimen- apresenta-se como autorregulação voluntária das empresas privadas no respeito da regulamentação e da política local do país anfitrião ${ }^{4}$. Tradicionalmente partes do soft law, as normas da responsabilidade social corporativa tornam-se mais vinculantes pelos ACFI.

Dessarte, pelos acordos brasileiros, os investidores comprometem-se para atuar em favor dos objetivos nacionais de desenvolvimento sustentável (1), o que se conjuga com os seus compromissos para fomentar a aceitabilidade social das suas atividades (2).

\section{Os COMPROMISSOS DOS INVESTIDORES PARA ATUAR EM FAVOR DOS OBJETIVOS DE DESENVOLVIMENTO SUSTENTÁVEL NACIONAIS}

Se alguns desses compromissos apresentam-se de forma substancialmente clássicos, mas formalmente inovadores (1.1), outros são criticáveis pela incoerência jurídica neles inerentes (1.2).

\subsection{Compromissos substancialmente clássicos, mas formalmente inovadores}

Atrelar a sua produção econômica ao objetivo do desenvolvimento sustentável implica respeitar o que o país anfitrião entende por desenvolvimento sustentável. Isso expressa-se nas políticas nacionais relevantes e formaliza-se, normalmente, no direito interno. Juridicamente, atuar no sentido do desenvolvimento sustentável significa organizar a sua atividade econômica no respeito do direito econômico, dos direitos sociais e do direito ambiental.

No acordo entre o Brasil e o México, os compromissos para obrar na construção desse objetivo são detalhados no artigo 13; nos acordos entre o Brasil e Angola e, entre o Brasil e o Moçambique, o princípio da responsabilidade social corporativa é afirmado no artigo 10, e as modalidades da sua aplicação aparecem em um anexo II. Os preâmbulos dos três acordos salientam a necessária contribuição dos investimentos internacionais para alcançar o objetivo do desenvolvimento sustentável.

tos-cidade-do-mexico-26-de-maio-de-2015\&catid=42\&lang $=\mathrm{pt}$ BR\&Itemid $=280>$. Acesso em: 16 jul. 2015.

4 Ver: UNEP. Corporate social responsibility and regional trade and investment agreements. Ottawa:United Nations Environmental Program, 2011. p. 13 
Os acordos apontam a relação estrita que existe entre investimentos e meio ambiente, e preveem que os investidores devem assegurar-se do respeito do meio ambiente durante o exercício da sua atividade 5 . $\mathrm{O}$ acordo entre o Brasil e Angola é, nesse seguimento, mais revelador por frisar que além de respeitar o direito ambiental nacional, os investidores devem utilizar tecnologia propícia para a preservação do meio ambiente ${ }^{6}$. Com isso, o pilar econômico do desenvolvimento sustentável, inerente à própria atividade do investimento, coaduna-se ao pilar ambiental e ambos juntam-se ao componente social, também fortemente presente nos ACFI.

Os acordos estatuem que os investidores devem respeitar os Direitos Humanos de forma geral e dos trabalhadores em especial, não podendo estes aceitar em qualquer isenção atinente à regulação da saúde, das normas de segurança, do meio ambiente ou do Direito do Trabalho que não seja em conformidade com a legislação nacional ${ }^{7}$. Contribuir ao desenvolvimento susten-

5 Anexo II (I) e (v) do ACFI Brasil-Angola, BRASIL. Ministério das Relações Exteriores. Acordo Brasil-Angola de Cooperação e Facilitação de Investimentos (ACFI). Luanda, $1^{\circ}$ de abril de 2015. Disponível em: <http://www.itamaraty.gov.br/index.php?option=com_co ntent\&view $=$ article $\&$ id $=8520$ : acordo-brasil - angola-de-cooperacao-e-facilitacao-de-investimentos-acfi-luanda-1-de-abril-de$2015 \&$ catid $=42 \&$ lang $=$ pt-BR\&Itemid $=280>$. Acesso em: 16 jul. 2015; Anexo II (I) do ACFI Brasil-Moçambique, BRASIL. Ministério das Relações Exteriores. Acordo Brasil-Moçambique de Cooperação e Facilitação de Investimentos (ACFI). Maputo, 30 de março de 2015. Disponível em: <http://www.itamaraty.gov.br/index.php?option=com_cont ent\&view $=$ article $\& i d=8511$ :acordo-brasil-mocambique-de-cooperacao-e-facilitacao-de-investimentos-acfi-maputo-30-de-marco-de$2015 \&$ catid $=42 \&$ lang $=$ pt-BR\&Itemid $=280>$. Acesso em: 16 jul. 2015; artigo 13(2) (a) do ACFI Brasil-México, BRASIL. Ministério das Relações Exteriores. Acordo Brasil-México de Cooperação e Facilitação de Investimentos. Cidade do México, 26 de maio de 2015. Disponível em: <http://www.itamaraty.gov.br/index.php?option=com_cont ent\&view $=$ article\&id= 9890:acordo-brasil-mexico-de-cooperacaoe-facilitacao-de-investimentos-cidade-do-mexico-26-de-maio-de$2015 \&$ catid $=42 \&$ lang $=$ pt $-B R \&$ Itemid $=280>$. Acesso em: 16 jul. 2015.

6 Anexo II (I) e (v) do ACFI Brasil-Angola. BRASIL. Ministério das Relações Exteriores. Acordo Brasil-Angola de Cooperação e Facilitação de Investimentos (ACFI). Luanda, $1^{\circ}$ de abril de 2015. Disponível em: $\quad<$ http://www.itamaraty.gov.br/index.php?option=com_co ntent\&view $=$ article \&id $=8520$ : acordo-brasil - angola-de-cooperacao-e-facilitacao-de-investimentos-acfi-luanda-1-de-abril-de$2015 \&$ catid $=42 \&$ lang $=$ pt-BR\&Itemid $=280>$. Acesso em: 16 jul. 2015

7 Artigo 13 do ACFI Brasil-México, BRASIL. Ministério das Relações Exteriores. Acordo Brasil-México de Cooperação e Facilitação de Investimentos. Cidade do México, 26 de maio de 2015. Disponível em: <http://www.itamaraty.gov.br/index.php?option=com_co ntent\&view $=$ article \&id $=9890$ :acordo-brasil - mexico-de-cooperacao-e-facilitacao-de-investimentos-cidade-do-mexico-26-demaio-de-2015\&catid $=42 \&$ lang $=$ pt-BR\&Itemid $=280>$. Acesso tável local, outrossim, significa promover e consolidar os recursos humanos, oferecendo, para tanto, formação adequada aos trabalhadores para que possam adaptar-se ao mercado diversificado decorrente dos próprios investimentos internacionais ${ }^{8}$. E, nessa mesma toada, os acordos dispõem que não pode sofrer de qualquer forma de discriminação ou de medida disciplinar o trabalhador que denuncia as práticas socialmente irresponsáveis da empresa na qual atua ou do governo local, que como cúmplice opera ${ }^{9}$. É sabido a relação embutida e,

em: 16 jul. 2015; anexo II (v) do ACFI Brasil-Moçambique, BRASIL. Ministério das Relações Exteriores. Acordo Brasil-Moçambique de Cooperação e Facilitação de Investimentos (ACFI). Maputo, 30 de março de 2015. Disponível em: <http://www.itamaraty.gov.br/ index.php?option $=$ com_content $\&$ view $=$ article $\&$ id $=8511$ : acor do-brasil-mocambique-de-cooperacao-e-facilitacao-de-investimentos-acfi-maputo-30-de- marco-de-2015\&catid $=42 \&$ lang $=$ ptBR\&Itemid $=280>$. Acesso em: 16 jul. 2015; anexo II (vi) do ACFI Brasil-Angola, BRASIL. Ministério das Relações Exteriores. Acordo Brasil-Angola de Cooperação e Facilitação de Investimentos (ACFI). Luanda, $1^{\circ}$ de abril de 2015. Disponível em: <http://www.itamaraty.gov. $\mathrm{br} /$ index.php?option $=$ com_content $\&$ view $=$ article\&id $=8520$ :acor do-brasil-angola-de-cooperacao-e-facilitacao-de-investimentos-acfiluanda-1-de-abril-de-2015\&catid $=42 \&$ lang $=$ pt-BR\&Itemid $=280>$. Acesso em: 16 jul. 2015.

8 Anexo II (iv) dos ACFI Brasil-Angola e Brasil-Moçambique, BRASIL. Ministério das Relações Exteriores. Acordo Brasil-Angola de Cooperação e Facilitação de Investimentos (ACFI). Luanda, $1^{\circ}$ de abril de 2015. Disponível em: <http://www.itamaraty.gov.br/index. php?option $=$ com_content $\&$ view $=$ article $\&$ id $=8520$ :acordo-brasilangola-de-cooperacao-e-facilitacao-de-investimentos-acfi-luanda1-de-abril-de-2015\&catid $=42 \&$ lang $=$ pt-BR\&Itemid $=280>$. Acesso em: 16 jul. 2015. e BRASIL. Ministério das Relações Exteriores. Acordo Brasil-Moçambique de Cooperação e Facilitação de Investimentos (ACFI). Maputo, 30 de março de 2015. Disponível em: < http://www.itamaraty.gov.br $/$ index.php?option $=$ com_content\&view $=$ article\&id $=$ 8511:acordo-brasil-mocambique-de-cooperacao-e-facilitacao-de-investimentos-acfi-maputo-30-de-marco-de-2015\&catid=42\&lang=pt-BR\&Itemid=280>. Acesso em: 16 jul. 2015; artigo 13 (2) (d) do ACFI Brasil-México, BRASIL. Ministério das Relações Exteriores. Acordo Brasil-México de Cooperação e Facilitação de Investimentos. Cidade do México, 26 de maio de 2015. Disponível em: < http://www.itamaraty.gov.br/index.php?option $=$ com_content\&view $=$ article\&id $=$ 9890:acordo-brasil-mexico-de-cooperacao-e-facilitacao-de-investimentos-cidade-do-mexico-26-de-maio-de-2015\&catid=42\&lang=pt-BR\&Itemid=280>. Acesso em: 16 jul. 2015.

9 Anexo II (ix) do ACFI Brasil-Moçambique, BRASIL. Ministério das Relações Exteriores. Acordo Brasil-Moçambique de Cooperação e Facilitação de Investimentos (ACFI). Maputo, 30 de março de 2015. Disponível em: <http://www.itamaraty.gov.br/index.php?option=com_cont ent\&view $=$ article\&id $=8511$ :acordo-brasil-mocambique-de-cooperacao-e-facilitacao-de-investimentos-acfi-maputo-30-de-marco-de$2015 \&$ catid $=42 \&$ lang $=$ pt-BR\&Itemid $=280>$. Acesso em: 16 jul. 2015, BRASIL. Ministério das Relações Exteriores. Acordo BrasilAngola de Cooperação e Facilitação de Investimentos (ACFI). Luanda, $1^{\circ}$ de abril de 2015. Disponível em: < http://www.itamaraty.gov.br/ index.php?option $=$ com_content\&view $=$ article \&id $=8520$ :acordobrasil-angola-de-cooperacao-e-facilitacao-de-investimentos-acfiluanda-1-de-abril-de-2015\&catid $=42 \&$ lang $=$ pt-BR\&Itemid $=280>$. 
por vezes conturbada, que existe entre investimentos internacionais e Direito do Trabalho. A título de exemplo, pode ser mencionada a ação civil pública ajuizada pela Procuradoria do Trabalho do Município do Araraquara contra a empresa Odebrecht, presumidamente envolvida em caso relativo a trabalho escravo e tráfico humano em Angola ${ }^{10}$. Prever uma fiscalização trabalhista no acordo com Angola é, destarte, relevante. Os ACFI insistem para que os investimentos não sejam feitos em detrimento do Direito Trabalhista.

Entrementes, se a responsabilidade social é bem-vinda nos ACFI — aos quais confere grande originalidade —, alguns dos compromissos são juridicamente criticáveis.

\subsection{Compromissos criticáveis pela incoerência jurídica}

Os compromissos previstos em matéria de responsabilidade social corporativa são voluntários — mesmo enraizados em acordos vinculantes. Isso significa que os investidores não têm obrigação de ser socialmente responsável, mas que se espera deles desempenho voluntário nesse sentido. Nada obstante, será visto infra como é possível tornar a responsabilidade social juridicamente vinculante.

Ora, os compromissos revelados pelos ACFI abrem-se à crítica. Dispõem, por exemplo, que os investidores se esforçarão para respeitar os Direitos Humanos ${ }^{11}$, para

Acesso em: 16 jul. 2015; anexo II (x) do ACFI Brasil-Angola; artigo 13 (2) (i) do ACFI Brasil-México, BRASIL. Ministério das Relações Exteriores. Acordo Brasil-México de Cooperação e Facilitação de Investimentos. Cidade do México, 26 de maio de 2015. Disponível em: <http://www.itamaraty.gov.br/index.php?option=com_cont ent\&view $=$ article\&id = 9890:acordo-brasil-mexico-de-cooperacaoe-facilitacao-de-investimentos-cidade-do-mexico-26-de-maio-de$2015 \&$ catid $=42 \&$ lang $=$ pt-BR\&Itemid $=280>$. Acesso em: 16 jul. 2015.

10 SÃO PAULO. Ministério Público do Trabalho. Procuradoria Regional do Trabalho da 15. Região, Procuradoria do Trabalho no Município de Araraquara. Ação Civil Pública. Processo no ${ }^{\circ} 0010230-$ 31.2014.5.15.00749. Araraquara, 13 de junho de 2014. Disponível em: $\quad<$ http://s.conjur.com.br/dl/mpt-acusa-odebrecht-supostaexploracao.pdf $>$. Acesso em: 16 jul. 2015. see also: FELLET, João. Brazil's biggest builder accused of using 'slave labour. Disponível em: <http://www.bbc.com/news/world-latin-america-27907132>. Acesso em: 16 jul. 2015.

11 Anexo II (ii) dos ACFI Brasil-Angola e Brasil-Moçambique, BRASIL. Ministério das Relações Exteriores. Acordo Brasil-Mocambique de Cooperação e Facilitação de Investimentos (ACFI). Maputo, 30 de março de 2015. Disponível em: <http://www.itamaraty.gov. $\mathrm{br} /$ index.php?option $=$ com_content\&view $=$ article\&id $=8511$ :ac ordo-brasil-mocambique-de-cooperacao-e-facilitacao-de-investi- não buscar ou aceitar isenções ilegais ${ }^{12}$, ou para que as suas atividades estejam em conformidade com a legislação nacional sobre as questões de saúde, do meio ambiente, da segurança ou do Direito Trabalhista ${ }^{13}$. Eis a grande incoerência, pois os ACFI afirmam que o devido respeito ao direito interno dos países anfitriões - o que constitui um princípio que não conhece exceções — é apenas um compromisso voluntário quando se trata dos investidores internacionais. Respeitar o direito nacional consiste em uma opção, uma possibilidade: assim é a mensagem a eles enviada. Juridicamente, essas disposições são simplesmente inadmissíveis, e poderiam até certo ponto ser consideradas inconstitucionais, o que seria óbice — justificado — à ratificação dos acordos. Essa margem de manobra perigosa oferta aos investidores abre o caminho para a sua eventual impunidade futura.

A inclusão da responsabilidade social corporativa nos ACFI é louvável; manter o seu valor jurídico em uma zona cinza convence menos. Na realidade, esperar dos investidores um "alto grau de práticas socialmente responsáveis ${ }^{14 ",}$ significa também esperar práticas e medidas mais rigoro-

mentos-acfi-maputo-30-de-marco-de-2015\&catid $=42 \&$ lang $=$ pt BR\&Itemid $=280>$. Acesso em: 16 jul. 2015; artigo 13 (2) (b) do ACFI Brasil-México, BRASIL. Ministério das Relações Exteriores. Acordo Brasil-México de Cooperação e Facilitação de Investimentos. Cidade do México, 26 de maio de 2015. Disponível em: <http://www.itamaraty.gov.br/index.php?option $=$ com_content\&view $=$ article\&id $=$ 9890:acordo-brasil-mexico-de-cooperacao-e-facilitacao-de-investimentos-cidade-do-mexico-26-de-maio-de-2015\&catid=42\&lang = pt-BR\&Itemid=280> . Acesso em: 16 jul. 2015.

12 Por exemplo: artigo 13 (2) (e) do ACFI Brasil-México. BRASIL. Ministério das Relações Exteriores. Acordo Brasil-México de Cooperação e Facilitação de Investimentos. Cidade do México, 26 de maio de 2015. Disponível em: <http://www.itamaraty.gov.br/ index.php?option $=$ com_content $\&$ view $=$ article $\&$ id $=9890$ : acor do-brasil-mexico-de-cooperacao-e-facilitacao-de-investimentoscidade-do-mexico-26-de-maio-de-2015\&catid $=42 \&$ lang $=$ pt BR\&Itemid $=280>$. Acesso em: 16 jul. 2015.

13 Anexo II (v) do ACFI Brasil-Angola. BRASIL. Ministério das Relações Exteriores. Acordo Brasil-Angola de Cooperação e Facilitação de Investimentos (ACFI). Luanda, $1^{\circ}$ de abril de 2015. Disponível em: $\quad<$ http://www.itamaraty.gov.br/index.php?option=com_co ntent\&view $=$ article $\&$ id $=8520$ : acordo-brasil - angola - de - cooperacao-e-facilitacao-de-investimentos-acfi-luanda-1-de-abril-de$2015 \&$ catid $=42 \&$ lang $=$ pt $-B R \&$ Itemid $=280>$. Acesso em: 16 jul. 2015.

14 Ver por exemplo: artigo 13 (1) do ACFI Brasil-México. BRASIL. Ministério das Relações Exteriores. Acordo Brasil-México de Cooperação e Facilitação de Investimentos, Cidade do México, 26 de maio de 2015. Disponível em: <http://www.itamaraty.gov.br/ index.php?option $=$ com_content $\&$ view $=$ article $\&$ id $=9890$ : acor do-brasil-mexico-de-cooperacao-e-facilitacao-de-investimentoscidade-do-mexico-26-de-maio-de-2015\&catid $=42 \&$ lang $=p t-$ BR\&Itemid $=280>$. Acesso em: 16 jul. 2015. 
sos que o próprio direito interno dos países anfitriões. Se estes não tiverem um direito nacional consolidado em alguns âmbitos - Direito Trabalhista, Direitos Humanos, Direito Ambiental —, não quer dizer que os investidores devem contentar-se do estrito mínimo disponível. Um comportamento socialmente responsável indica que o investidor deve manter o mesmo altíssimo nível de diligência independentemente do país onde se estabelece; um investidor brasileiro em Angola ou no Moçambique deve, portanto, comportar-se como se comportaria no Brasil, mesmo que os direitos angolanos ou moçambicano sejam mais flexíveis, mais lacunários ou menos rigorosos sobre alguns assuntos. É pelo menos isso que se entende, na prática, por responsabilidade social corporativa. É um nivelamento por cima, e não por baixo.

É também possível criticar a ausência de disposições sobre a corrupção. A corrupção constitui elemento fundamental da responsabilidade social corporativa ${ }^{15}$ e essa problemática é atinente à atuação de algumas empresas brasileira em alguns países africanos ${ }^{16}$. Essa omissão é, portanto, inesperada. Nessa perspectiva, parece que essa lacuna pode ser juridicamente superada pela interpretação dos ACFI, notadamente, do ponto (xi) do Anexo II do ACFI Brasil-Moçambique, do ponto (xii) do Anexo II do ACFI Brasil-Angola e do artigo 13 (2) (k) do Acordo Brasil-México. São disposições que indicam o respeito pelos investidores da política interna e local dos países anfitriões; implica a não interferência nesse âmbito. Poderiam atuar como cláusulas guarda-chuva para abarcar casos relacionados à corrupção. Uma forma alternativa seria contar com o incentivo à aceitabilidade social dos investimentos previsto nos ACFI.

\section{OS COMPROMISSOS DOS INVESTIDORES PARA FOMENTAR A ACEITABILIDADE SOCIAL DAS SUAS}

\footnotetext{
15 STIGLITZ, Joseph E. Regulating multinational corporations: towards principles of cross-border legal frameworks in a globalized world balancing rights with responsibilities. American University International Law Review, v. 23, n. 3, p. 451-558, 2007. p. 477; HESS, David. Enhancing the effectiveness of the foreign corrupt practices act through corporate social responsibility. Obio State Law Journal, v. 73, n. 5, p. 1122-1144, 2012.

16 Ver por exemplo: MUGGAH, Robert. What is Brazil really doing in Africa. Abr. 2015. Disponível em: < http://www.huffingtonpost.com/robert-muggah/what-is-brazil-really-doi_b_6413568. html>. Acesso em: 16 jul. 2015.
}

\section{ATIVIDADES}

A aceitabilidade social é uma doutrina que examina como uma determinada atividade econômica pode ser compatível com as expectativas da população local ${ }^{17}$. Essa doutrina é implicitamente expressada pelos ACFI. Estes estatuem que a busca da boa governança corporativa implica a elaboração e a implementação de práticas eficientes de autorregulação e de gestão cujos objetivos e efeitos sejam o desenvolvimento de uma confiança recíproca com a população local ${ }^{18}$. As atividades a serem desenvolvidas devem, deveras, ser benéficas para o progresso social e ambiental e não apenas para a economia; os preâmbulos são, sobre esse ponto, esclarecedores.

Portanto, os investimentos devem tornar-se socialmente aceitáveis; devem, consequentemente, respeitar a cultura local. Não pode ser negado que, nesse sentido, a ausência de interferência na política local revela uma transparência - em termos de corrupção - que facilita a aceitação da atividade pela sociedade. Cabe ao investidor forjar um ambiente de confiança e destilá-lo na sociedade receptora para mostrar que tudo está sendo feito em conformidade com a legislação e as regulações nacionais: é o marco da "ficha limpa" dos investidores.

Essa preocupação relativa à responsabilidade social corporativa não se limita apenas à direção das empre-

17 GENDRON, Corinne. Penser l'acceptabilité sociale: au-delà de l'intérêt, les valeurs. Revue internationale Communication sociale et publique, n. 11, p. 117-129, 2014.

18 Anexo II (vii) do ACFI Brasil-Moçambique, BRASIL. Ministério das Relações Exteriores. Acordo Brasil-Moçambique de Cooperação e Facilitação de Investimentos (ACFI). Maputo, 30 de março de 2015. Disponível em: <http://www.itamaraty.gov.br/ index.php?option $=$ com_content\&view $=$ article\&id $=8511$ : acor do-brasil-mocambique-de-cooperacao-e-facilitacao-de-investimentos-acfi-maputo-30-de-marco-de-2015\&catid $=42 \& l a n g=p t-$ BR\&Itemid=280>. Acesso em: 16 jul. 2015; anexo II (viii) do ACFI Brasil-Angola, BRASIL. Ministério das Relações Exteriores. Acordo Brasil-Angola de Cooperação e Facilitação de Investimentos (ACFI). Luanda, $1^{\circ}$ de abril de 2015. Disponível em: <http://www.itamaraty.gov. $\mathrm{br} /$ index.php?option $=$ com_content\&view $=$ article $\&$ id $=8520$ : acor do-brasil-angola-de-cooperacao-e-facilitacao-de-investimentos-acfiluanda-1-de-abril-de-2015\&catid $=42 \&$ lang $=p t-B R \& I t e m i d=280>$. Acesso em: 16 jul. 2015; artigo 13 (2) (g) do ACFI Brasil-México, BRASIL. Ministério das Relações Exteriores. Acordo Brasil-México de Cooperação e Facilitação de Investimentos. Cidade do México, 26 de maio de 2015. Disponível em: <http://www.itamaraty.gov.br/ index.php?option $=$ com_content\&view $=$ article\&id $=9890$ : acor do-brasil-mexico-de-cooperacao-e-facilitacao-de-investimentoscidade-do-mexico-26-de-maio-de-2015\&catid $=42 \& l a n g=p t-$ BR\&Itemid $=280>$. Acesso em: 16 jul. 2015. 
sas no entendimento dos ACFI: deve também englobar todas as camadas da empresa. Sendo assim, os acordos preveem que os trabalhadores devem ser informados das medidas empresariais sobre a responsabilidade social, inclusive com programas de formação profissional ${ }^{19}$. Outrossim, o que é interno à empresa é válido no que tange à sua atividade externa: dessarte, a empresa deve incitar todas as suas subsidiárias para adotar as mesmas políticas de boa governança. Em outras palavras, a empresa matriz deve exercer um dever de diligência — due diligence — na sua esfera de influência para incitar um condutor uniforme na toda cadeia de produção.

19 Anexo II (ix) do ACFI Brazil-Angola, BRASIL. Ministério das Relações Exteriores. Acordo Brasil-Angola de Cooperação e Facilitação de Investimentos (ACFI). Luanda, $1^{\circ}$ de abril de 2015. Disponível em: $\quad<$ http://www.itamaraty.gov.br/index.php?option=com_co ntent\&view $=$ article $\& i d=8520$ : acordo-brasil -angola-de-cooperacao-e-facilitacao-de-investimentos-acfi-luanda-1-de-abril-de$2015 \&$ catid $=42 \&$ lang $=$ pt-BR\&Itemid $=280>$. Acesso em: 16 jul. 2015; anexo II (viii) do ACFI Brazil-Moçambique, BRASIL. Ministério das Relações Exteriores. Acordo Brasil-Moçambique de Cooperação e Facilitação de Investimentos (ACFI). Maputo, 30 de março de 2015. Disponível em: <http://www.itamaraty.gov.br/ index.php?option $=$ com_content\&view $=$ article\&id $=8511$ : acor do-brasil-mocambique-de-cooperacao-e-facilitacao-de-investimentos-acfi-maputo-30-de-marco-de-2015\&catid $=42 \&$ lang $=$ ptBR\&Itemid $=280>$. Acesso em: 16 jul. 2015; artigo 13 (2) (h) do ACFI Brasil-México, BRASIL. Ministério das Relações Exteriores. Acordo Brasil-México de Cooperação e Facilitação de Investimentos. Cidade do México, 26 de maio de 2015. Disponível em: <http://www.itamaraty.gov.br/index.php?option $=$ com_content\&view $=$ article\&id $=$ 9890:acordo-brasil-mexico-de-cooperacao-e-facilitacao-de-investimentos-cidade-do-mexico-26-de-maio-de-2015\&catid=42\&lang=pt-BR\&Itemid=280> . Acesso em: 16 jul. 2015.
Como esses compromissos são, em princípio, voluntários o seu valor jurídico pode destarte ser questionado, pois depende da discrição das empresas. Contudo, o comportamento socialmente responsável dos investidores tem um papel fundamental em termos de gestão de disputas e de análise da responsabilidade dos Estados em futuras disputas. As demandas dos investidores serão examinadas - e aceitas - considerando o seu desempenho para atuar como empresas socialmente responsável. Um investidor cujas atividades fogem da doutrina da aceitabilidade social e da responsabilidade não seria na melhor posição para que o seu requerimento seja admitido, pois não estaria atuando com clean hands - princípio comumente utilizado nesses casos no Direito Internacional. Não poderá ele beneficiar da sua própria torpeza. As disposições dos ACFI sobre a responsabilidade social corporativa servem, dessa maneira, para interpretar os princípios sobre a proteção aos investidores: a responsabilidade social será útil para medir a devida proteção aos investidores nos casos futuros.

Lamentavelmente, os acordos não preveem um dever de reporting. Ou seja, as empresas não têm o compromisso de relatar o seu desempenho relativo à sua responsabilidade social. Eventualmente, essa fiscalização pode incumbir ao Comitê Conjunto estabelecido pelos ACFI: poderia ser interpretado como uma das suas competências implícitas. 


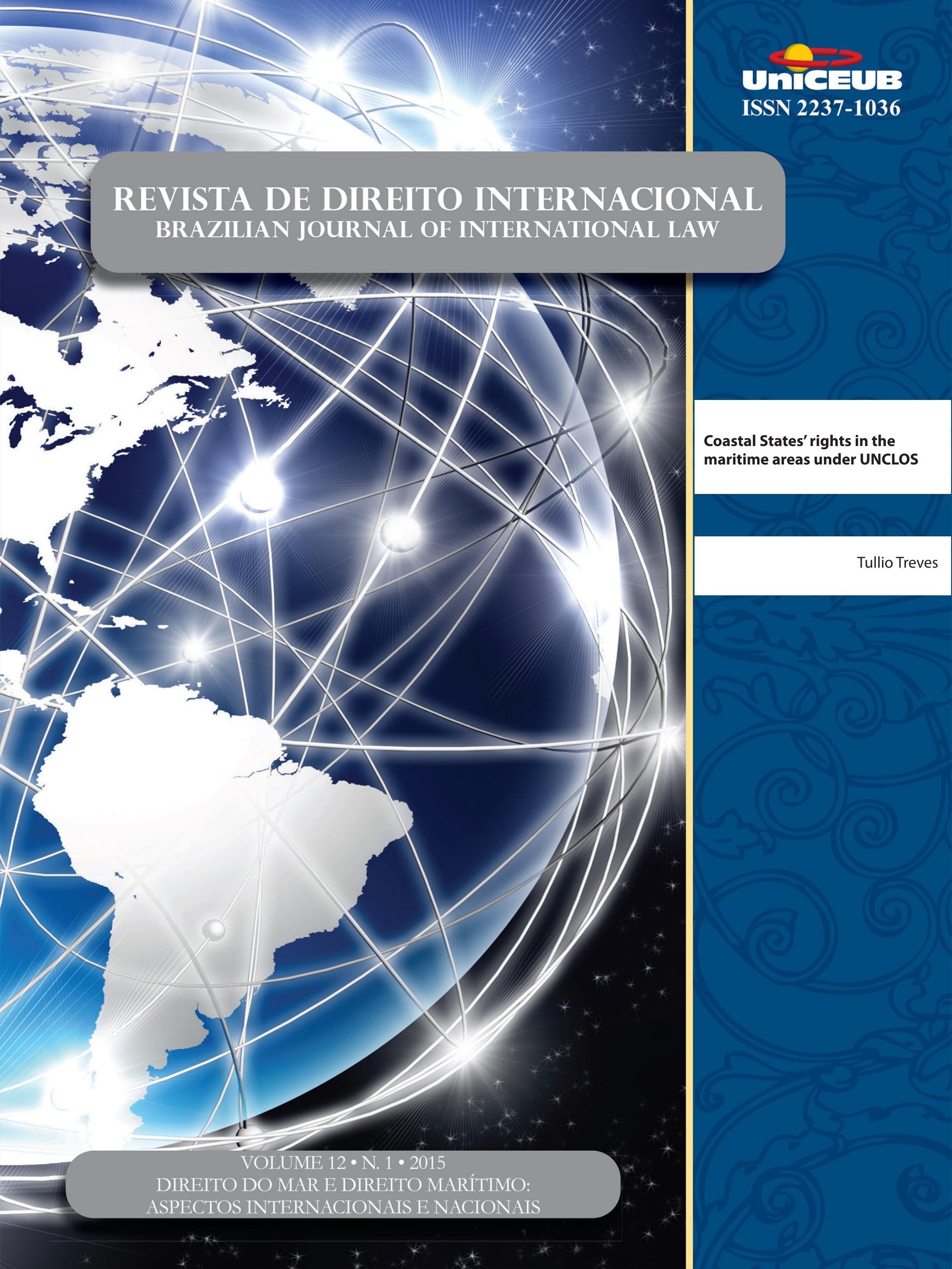




\title{
Coastal States' rights in the maritime areas under UNCLOS*
}

Tullio Treves**

\begin{abstract}
Maritime areas (or zones) are areas of the sea for which international law prescribes spatial limits and a regime. In other words, for each maritime area, international law answers two questions. First, where does it begin and where does it end? Second, which are the rights that different categories of States can exercise in it? Only the second question is of interest for the purposes of the present paper. While traditional international law knew only two maritime areas - the territorial sea and the high seas - in today's international law there are numerous different maritime areas, reflecting the variety of activities conducted in the seas in the present time. As UNCLOS is very widely ratified and in most parts considered to correspond to customary international law, in the present paper I will consider the maritime areas as described in it. There are, nonetheless, also maritime areas which are not envisaged in UNCLOS and whose compatibility with it may be discussed.
\end{abstract}

Keywords: Maritime areas. Law of the sea. UNCLOS. Coastal States' rights.

\section{THE NOTION OF MARITIME AREAS}

Maritime areas (or zones) are areas of the sea for which international law prescribes spatial limits and a regime. In other words, for each maritime area, international law answers two questions. First, where does it begin and where does it end? Second, which are the rights that different categories of States can exercise in it?

Only the second question is of interest for the purposes of the present paper.

While traditional international law knew only two maritime areas -the territorial sea and the high seas - in today's international law there are numerous different maritime areas, reflecting the variety of activities conducted in the seas in the present time.

As UNCLOS is very widely ratified and in most parts considered to correspond to customary international law, in the present paper I will consider the maritime areas as described in it. There are, nonetheless, also maritime areas which are not envisaged in UNCLOS and whose compatibility with it may be discussed.

* Invited Author

** Professor, State University of Milan; Former Judge of the International Tribunal for the Law of the Sea.

\section{The MARITIME AREAS UNDER UNCLOS}

The approach of UNCLOS is (although with exceptions) basically a "zonal" one. It sets out the rules on the law of the sea in chapters, sometimes called "parts" and sometimes "sections", concerning the different maritime 
areas.

The maritime areas envisaged by UNCLOS are

a. Internal waters. They are mentioned in various articles, but their regime is not fully elaborated, probably because it was felt that it does not entirely belong to international law,

b. The territorial sea. Specific provisions on straits complete its treatment,

c. The contiguous zone,

d. Archipelagic waters,

e. The exclusive economic zone,

f. The continental shelf,

g. The high seas,

h. The International Seabed Area, and

i. An area whose limits coincide with those of the contiguous zone, in which the coastal State may submit to its approval the removal of historic and archaeological objects (sometimes called archaeological zone).

j. It is important to distinguish between maritime areas in which the coastal States enjoys a privileged position as compared to that of other States, and maritime areas in which all States enjoy equal rights. The high seas and the International Seabed Area belong to the second category, while all the other areas listed belong to the first.

\section{The COASTAL STATES' RIGHTS IN THE VARIOUS MARITIME AREAS: SOVEREIGNTY, SOVEREIGN RIGHTS, JURISDICTION}

The rights of the coastal states according to UNCLOS consist in "sovereignty" as regards the territorial sea and archipelagic waters; in "sovereign rights" as regards the continental shelf and the resources and economic activities in the exclusive economic zone; and in "jurisdiction" as regards artificial islands, installations and structures, marine scientific research and the protection of the marine environment in the exclusive economic zone. The rights of the coastal State In the contiguous zone are indicated as rights of control, and those in the archaeological zone as right to submit to approval the removal of certain goods.

"Sovereignty", "sovereign rights" and "jurisdiction" are rights to exclusivity, namely to conduct certain activities to the exclusion of others. They are to be seen in opposition to the freedoms recognized to States in the high seas which are rights to claim non-interference by other States.

The terminology used in UNCLOS seems to suggest that the coastal States' rights indicated with the term "sovereignty" are more intense, more exclusive than "sovereign rights", and that "sovereign rights" are more intense, more exclusive than "jurisdiction". While this may be true, too much importance should not be given to a search for the difference between these concepts. The rights they entail are to be ascertained, more than by the meaning of the terms, by an analysis of the rights which specific articles of UNCLOS (for instance those set out in parts V and XIII of UNCLOS, concerning fisheries and scientific research in the EEZ) and general international law recognize to the coastal State.

Sovereignty on the territorial sea "is exercised subject to the Convention and other rules of international law" (UNCLOS art. 2, para. 3). Sovereignty on archipelagic waters "is exercised according to this Part", namely Part IV (UNCLOS art. 49, para. 3). Sovereign rights in the exclusive economic zone and on the continental shelf are recognized for "the purpose" of exploring and exploiting resources (UNCLOS art. 56, para. 1a, and 77, para. 1) or "with regard to other activities for the exploration and exploitation of the [exclusive economic] zone" (UNCLOS art. 56, para. 1(a)).

The minor importance of distinguishing between sovereign rights and jurisdiction is confirmed by article 297. This article defines limitations to compulsory jurisdiction for disputes concerning the exclusive economic zone and the continental shelf, indirectly contributing to the definition of the regime of the exclusive economic zone. Paragraph 1 considers together disputes having to do with "the exercise of sovereign rights or jurisdiction". Paragraphs 2 and 3, dealing respectively with disputes concerning marine scientific research, a subject for which the coastal State's rights are denominated "jurisdiction" in article 56, and disputes concerning fisheries, a subject included in the notion of "sovereign rights" under the same article, provide for a limitation to compulsory jurisdiction in very similar terms. 


\section{LIMITS OF COASTAL STATES' RIGHTS: THE RIGHTS OF OTHER STATES, THE "DUE REgARD" RULE}

The rights of the coastal States find their limit in the rights recognized to other States in the different maritime areas. The coastal State's sovereignty in the territorial sea is limited by the right of innocent passage of other States. The archipelagic State's sovereignty in its archipelagic waters is limited by the rights of innocent passage and of archipelagic sea lanes passage of other States. Sovereign rights on the continental shelf for the purpose of the exploration and exploitation of mineral resources, find a limit (in the absence of an overlapping exclusive economic zone) in the freedom to conduct other activities on the seabed and in the overlaying high seas waters. Sovereign rights and jurisdiction of the coastal State in the exclusive economic zone are limited by the freedoms of the high seas recognized to all States in the economic zone under article 58. The freedoms recognized to all States in the high seas are limited by the freedoms recognized therein to all States.

The exercise of rights by the coastal State and of freedoms by other States in the exclusive economic zone may, in practice, give rise to conflicts. For instance, the intensive exercise by the coastal State of its exclusive right to fishing or to explore and exploit oil and gas resources, may conflict with the freedom of navigation or of laying cables and pipelines recognized in the same area to all States.

UNCLOS repeats for this situation a rule adopted for the conflict between the exercise of freedoms by different States on the high seas (Geneva High Seas Convention, art. 2, UNCLOS, art. 87, para. 2): in the exclusive economic zone the rights of the coastal State shall be exercised with "due regard to the rights and duties of other States" (UNCLOS art. 56, para. 2) and the freedoms of all States shall be exercised with "due regard to the rights and duties of the coastal State" (art. 58, para. 3). The obligation of the coastal State to exercise its rights over the continental shelf in a manner that does "not infringe or result in any unjustifiable interference with navigation and other rights and freedoms of other States as provided for in this Convention" set out in UNCLOS article 78, para. 2, (repeating in part art. 5, para. 1, of the Geneva Continental Shelf Convention) should, in my view, be read as equivalent to art. 56, para.
2 of UNCLOS quoted above.

This reciprocal "due regard" rule does not grant priority to the rights of the coastal State or to the freedoms of other States. It is an obligation for both States to exercise their rights respecting those of the other States and to endeavour in good faith to find accommodations permitting the exercise of the rights of both. Rules granting priority to one or the other are usually adopted by agreement, as for instance it happens for the freedom of navigation of vessels of different degree of manoeuvrability on the high seas in the rules prescribed by the COLREGS.

The policy to avoid granting a preference, in the exclusive economic zone, to either the sovereign rights and jurisdiction of the coastal State or the freedoms of the other States is reflected in article 297, para. 1, of UNCLOS, one of the key rules concerning the settlement of disputes. While excluding from compulsory settlement disputes concerning the exercise by the coastal State of its sovereign rights or jurisdiction, this provision makes an exception to this exception - in other words: submits them to compulsory settlement - for disputes concerning alleged contraventions by the coastal State in regard to the freedoms recognized in article 58, and for disputes concerning the alleged action by a State exercising such freedoms in contravention of the Convention or of laws and regulations adopted by the coastal State. The situations included in these disputes are those to which the reciprocal "due regard" rule applies.

\section{Problems of classification: role of the SETTLEMENT OF DISPUTES}

As regards the regime of the exclusive economic zone, one of the most difficult questions raised by the rules of UNCLOS is to determine which activities belong to the categories for which the Convention attributes sovereign rights or jurisdiction to the coastal State, and which fall under the categories to which the freedoms of the high seas are applicable in the exclusive economic zone. This is a problem of classification. In light of the relevant provisions of UNCLOS (articles 56, 58 and 59), the problem consists in determining whether a certain activity in the exclusive economic zone is included in the list of activities under the coastal 
State's sovereign rights or jurisdiction set out in article 56 , or in the list of activities to which high seas freedoms apply under article 58 , or whether the activity cannot be considered as included in either list, according to the "default" rule of article 59.

The problem arises for issues such as the following.

- Are hydrographic surveys conducted in the exclusive economic zone to be considered "scientific research" and thus included in the coastal State's jurisdiction and require the coastal State's consent under art. 246?

- Is navigation by fishing vessels crossing the exclusive economic zone in order to reach the high seas to be considered as "navigation" and thus free form any obligation of prior notification or authorization under article 58 , para. 1 , or assimilated to fishing under article 56, para. 1?

- Is the bunkering of vessels in the exclusive economic zone to be considered as the exercise of freedom of navigation under article 58 or must it be assimilated to the activity conducted by the vessel receiving bunker so that, for instance, bunkering fishing vessels would be assimilated to fishing and fall under the sovereign rights of the coastal State under art. 56, para. 1, while bunkering a cargo vessel, or a pipeline or cable laying vessel would be assimilated to navigation or laying of cables and pipelines and thus fall under the freedom of the high seas under art. 58 , para. 1 ? Or is bunkering an activity not attributed under UNCLOS to the coastal State or to other States thus falling under the "default" article 59?

- Are military activities (or certain military activities) included in the notion of "other internationally lawful uses of the seas related" to the freedoms of navigation, overflight and laying of cables and pipelines "such as those associated with the operation of ships, aircraft and submarine cables and pipelines and compatible with the other provisions" of UNCLOS under article 58 para. 1? Or do they fall under the coastal State's jurisdiction, or are they to be considered as included in those envisaged by article 59 ?

- Are activities for the removal of historical or archaeological objects from the continental shelf beyond 24 miles from the baselines to be considered as included in the freedoms of the high seas mentioned in article 58, or within the sovereign rights and jurisdiction of the coastal State under article 56, para. 1 , or are they an example of nonattributed activities envisaged in article 59?

It is well known that each of the questions just exemplified, and similar others that could be raised, have been discussed by States and learned writers and that different opinions have been expressed. I will not enter into the substance of each of them. I would just like to observe that the answer depends on the interpretation of terms and expressions whose ambiguity was the result of compromise at the Third UN Conference on the Law of the Sea. The difficulties raised by this ambiguity - and by the consequent possibility of States to rely on their preferred interpretation - may, nonetheless, be substantially reduced by the fact that these questions of interpretation may, in most cases, be submitted - and submitted unilaterally by one party - to a judge or an arbitrator. The judgments and awards so adopted are, it is true, binding only for the parties to the dispute and for that particular dispute (UNCLOS art. 296, para. 2, and Annex VI, art. 33, paras. 1 and 2). It cannot be denied, however, that States, the international lawyers that counsel them, and, especially, judges and arbitrators called to adjudge future disputes, look at them with great respect.

So it is that when one of the questions exemplified above finds an answer in a judicial or arbitral decision, this answer enjoys authority and can be seen as an important step in clarifying the meaning of the relevant provisions.

This has happened as regards the question concerning bunkering in the exclusive economic zone which the International Tribunal for the Law of the Sea has had the opportunity to examine. In the early $M / V$ Saiga and $M / V$ Saiga Nr. 2 cases the Tribunal clearly identified solutions that may be envisaged to answer the question: bunkering under the jurisdiction of the coastal State, bunkering as a freedom of the high seas, bunkering to follow the regime of the activities conducted by the vessel receiving bunker, bunkering as a nonattributed activity under article 59. The Tribunal did not, however, consider it necessary to make a choice, as it was able to settle the dispute submitted to it on another basis. The answer came in the Virginia $G$ judgment 
of 14 April 2014. The Tribunal focused on bunkering of fishing vessels, which was the subject matter of the dispute submitted to it. The Tribunal decided that:

The regulation by the coastal State of bunkering
of foreign vessels fishing in the exclusive economic
zone is among those measures which the coastal
State may take in its exclusive economic zone to
conserve and manage its living resources under
article 56 of the Convention read together with
article 62 , paragraph 4 , of the Convention;
and added that:

This view is also confirmed by State practice which has developed after the adoption of the Convention (para. 217 of the Judgment).

The Tribunal does not generalize its decision on bunkering of fishing vessels by stating that in general bunkering is submitted to the regime applicable to the ship receiving bunker. It takes nonetheless a position - which certain judges regretted - according to which the coastal State does not have the competence it has over bunkering of foreign fishing vessels "with regard to other bunkering activities, unless it is otherwise determined in accordance with the Convention" (para. 223 of the Judgment).

\section{MARitime aReas ReQUiRING PROClamation AND NOT}

Another important distinction to be drawn between maritime areas in which the coastal State exercises exclusive rights is that between maritime zones that are automatically appurtenant to the coastal State and maritime zones which require that the coastal State has to claim or proclaims.

UNCLOS contains only one provision explicitly addressing this question. This is article 77, paragraph 3, according to which:

The rights of the coastal State over the continental shelf do not depend on occupation, effective or notional, or on any express proclamation.

It seems, however, difficult to deny that the rights of the coastal State on the territorial sea (at least up to 3 miles) are, as those on the continental shelf, automatically dependent on the exercise of the coastal State's sovereignty on its territory.

To the contrary, the coastal State's rights on archipelagic waters, on the contiguous zone, on the exclusive economic zone and on the archaeological zone cannot be exercised unless there is a proclamation, in other words, unless the claim is made known to the other States. States' practice is clear in this. These maritime areas, which are relatively new, are proclaimed by the coastal State, and no exclusionary right is claimed unless such proclamation has been made.

This distinction requires to be nuanced. In fact, the automatic right to exercise coastal State's rights raises no difficulty only for the continental shelf up to 200 $\mathrm{nm}$ from the baselines. As regards sovereignty on the territorial sea (at least beyond a minimum of three $\mathrm{nm}$ ) and the continental shelf beyond $200 \mathrm{~nm}$ a form of proclamation is necessary. Absent such a proclamation, the other States cannot know whether an area say $9 \mathrm{~nm}$ form the baseline is part of the territorial sea of the coastal State. In fact, States normally indicate in their legislation the width of their territorial sea. Absent a proclamation made at the conclusion of the procedure described in article 76 and in Annex II of UNCLOS, the outer limits are not "final and binding" under article 76, para. 8, and other States are justified in considering that the seabed beyond $200 \mathrm{~nm}$ cannot be opposed to them as continental shelf.

\section{Actual and potential maritime areas}

We may call "potential maritime areas" areas over which the coastal State is entitled to proclaim a maritime area but has not yet done so. This is the case of yet to be established archipelagic waters, of the area up to a distance of $200 \mathrm{~nm}$ from the baselines where the coastal State has not yet proclaimed an exclusive economic zone, of the area adjacent to the territorial sea and up to 24 miles from the baselines over which the coastal State is entitled to establish a contiguous (and/ or archaeological) zone. This is also the case of a 200 $\mathrm{nm}$ fishery zone which the coastal State may transform into an exclusive economic zone. This is also the case of the continental shelf beyond $200 \mathrm{~nm}$, before the delineation of its limits according to article 76 (on this case some separate development below).

What is the regime applicable to potential maritime areas of a coastal State?

The answer, in principle, is that the regime applicable is that of the maritime area existing at present. 
So the regime of the waters overlaying the continental shelf (we consider for the time being the shelf within $200 \mathrm{~nm}$ ) in case no exclusive economic zone has been proclaimed, remains the same high seas regime applicable beyond the 200 mile limit, consistently with article 78, para. 1, of UNCLOS.

There are, however, certain peculiarities which must be noted. They concern: (i) the coexistence between the activities conducted under the regime of the area under the coastal State's jurisdiction and that of the activities conducted in the areas in which the coastal State's jurisdiction is only potential, and (ii) the question as to whether the fact that a certain area is an area potentially under the coastal State's jurisdiction has an impact on the application of the "due regard" rule.

As regards the first peculiarity, two examples seem interesting. The first concerns marine scientific research, the second, fisheries. As is well known, the freedom to conduct marine scientific research beyond the limits of the exclusive economic zone is limited to the water column (UNCLOS art 257), while research on the continental shelf falls under the consent regime set out in article 246 of UNCLOS. In concrete cases it may be difficult to distinguish research on the water column from research on the shelf. For instance, is research on the impact of sea-floor vents on water temperature and currents research on the shelf or research on the water column? Conflicts may arise in case the coastal State claims the right to authorize this kind of research and the State conducting the research project claims that no authorization is required.

As regards fisheries, fishing is typically conducted in the water column and falls squarely within the freedoms of the high seas. Still, international attention has recently been drawn to the so-called "deep-sea" fisheries conducted with gear that is likely to contact the seafloor with possible damage for vulnerable ecosystems. FAO Guidelines and a European Council Regulation (N. 734/2008) have been adopted in 2008 on this subject. The freedom of deep-sea fishing cannot be exercised in the waters overlying the continental shelf without taking into due consideration that the coastal State has sovereign rights concerning sedentary species and jurisdiction for the protection of the environment.

Coming now to the second peculiarity, in determining their attitudes third States must take into account the difference between activities that are free on the high seas and cannot become submitted by decision of the coastal State to the coastal States' sovereign rights or jurisdiction and those that can. Third States may consider potential EEZs as not changing their high seas nature even in case an EEZ is established as regards those freedoms of the high seas that are mentioned in article 58 UNCLOS. In this case the application of the "due regard" rule is appropriate and sufficient. As regards activities that are free but may in the future fall under the coastal States' jurisdiction, it may be considered that something more is required.

\section{THE SPECIAL CASE OF THE CONTINENTAL SHELF BEYOND 200 NM}

The peculiarity of the potential maritime area that is the part of the continental shelf laying beyond $200 \mathrm{~nm}$ from the baselines, is that while its proclamation belongs to the sovereign decision of the coastal State, the delineation of its external limit, in order to be "final and binding" (opposable to all States parties to UNCLOS) requires a procedure, involving the intervention of an international body set up within the framework of UNCLOS, the Commission for the Limits of the Continental Shelf (CLCS), and that the outer limits must be proclaimed ("established" in the language of art. 76, para. 8) "on the basis" of the CLCS recommendation.

The procedure aims at determining whether the conditions required in article 76 are met. These conditions concern the determination of the outer edge of the continental margin according to rules of paragraphs 4 to 6 of that article. The procedure is thus not limited to the determination of the external limit of the continental shelf. As clarified in the CLCS Scientific and Technical Guidelines (para. 2.2), it also concerns the conditions for the coastal State's entitlement to that part of the shelf. The need for proclamation should, in my view, be seen as an exception to the general rule of article 77, para. 3, which states that the rights of the coastal State over the continental shelf do not depend on any express proclamation.

Once established through a proclamation on the basis of the CLCS recommendation, the regime of the continental shelf beyond $200 \mathrm{~nm}$ is the same as that of the continental shelf within $200 \mathrm{~nm}$. There are, however, two differences: 1) the coastal State is bound to 
make payments or contributions under article 82; and 2) the coastal State has, under article 246, para. 6, its discretion excluded in granting consent for scientific marine research of direct significance for the exploration or exploitation of marine resources, unless research is to be conducted in "designated areas" in that part of the shelf.

What is the regime of the continental shelf beyond $200 \mathrm{~nm}$ before its external limits have been delineated according to art. 76 ? As for other cases of potential maritime areas, the regime is that of the areas existing at present: the seabed is the seabed of the high seas and part of the International Seabed Area. Research on it remains free and open to the Authority under article 143, para. 2. The specific rules for the laying of cables and pipelines on the continental shelf set out in article 79 do not apply and freedom of laying cables and pipelines in the high seas remains applicable. Manganese nodules and other mineral resources fall under the regime of the Area.

The conclusion that the high seas regime applies is strengthened by the consideration that - contrary to the situation, considered above, of a potential exclusive economic zone above the continental shelf within $200 \mathrm{~nm}$ - in this case the potential continental shelf underneath the high seas is not something the coastal State may unilaterally proclaim making it opposable to all States parties in any case. The conditions set out in article 76 may not be satisfied and a corresponding recommendation of the CLCS may never be granted. Moreover, the outer limit will remain uncertain until proclamation under article $76(8)$.

Once the coastal state has submitted its application to the CLCS, it has made clear to the world that it has a claim to an area of the seabed beyond $200 \mathrm{~nm}$. Pending the procedure and up to proclamation on the basis of the recommendations of the CLCS the regime remains the same as described above. Still, it may be argued that the other States' behaviour in that part of the seabed and in the overlying waters should be inspired by prudence.

\section{OVERLAPPING MARITIME AREAS: GREY AREAS}

The recent Bangladesh/ India delimitation award (7 July 2014) observes that: "The Convention is reple- te with provisions that recognize to a greater or lesser degree the rights of one State within the maritime zones of another" (para. 507). We have already discussed examples of such overlapping maritime areas as regards UNCLOS articles 56 and 58 concerning the freedoms of all states in the exclusive economic zone, and the limits to the sovereign rights and jurisdiction of the coastal State in the same zone, and mentioned other examples.

Judicial and arbitral decisions, and especially those concerning the Bay of Bengal (Bangladesh v. Myanmar, decided by ITLOS in 2012, and Bangladesh v. India, decided by an Annex VII arbitral Tribunal in 2014) highlight the existence of a special type of overlap of maritime areas. This overlap characterizes the so-called grey areas which are the consequence of lateral delimitation of maritime areas continuing beyond the 200 nautical mile limit, and effected by a line different from the equidistant one. These zones lie within $200 \mathrm{~nm}$ from one of the States in dispute and beyond $200 \mathrm{~nm}$ from the other. In the Bangladesh v. India case, the delimitation line adopted divides an area which is part of Bangladesh's continental shelf beyond $200 \mathrm{~nm}$ from Bangladesh's baselines, and which is comprised within 200 miles from the Indian baselines and is consequently included in India's exclusive economic zone.

The Arbitral Tribunal (similarly to what ITLOS had decided in 2012) decided that:

Within the area beyond $200 \mathrm{~nm}$ from the coast
of Bangladesh and within $200 \mathrm{~nm}$ of the coast
of India, the boundary identified by the Tribunal
delimits only the parties' sovereign rights to explore
the continental shelf and to exploit "the mineral
and other non-living resources of the seabed and
subsoil together with living organisms belonging
to sedentary species" as set out in article 77 of
the Convention. Within this area, however, the
boundary does not otherwise limit India's sovereign
rights in the exclusive economic zone in the
superjacent waters (para. 505).

As regards the applicable regime, the Tribunal recalls the due regard rule and mentions the possibility of cooperative arrangements between the two States. In doing so it follows, in a briefer form, the ITLOS Bangladesh $v$. Myanmar Judgment, which had stated:

The Tribunal recalls in this respect that the legal regime of the continental shelf has always coexisted with another legal regime in the same area. Initially that other regime was that of the high seas and the other States concerned were those exercising high seas freedoms. Under the Convention, as a result of 
maritime delimitation, there may also be concurrent exclusive economic zone rights of another coastal State. In such a situation, pursuant to the principle reflected in the provisions of articles 56, 58, 78 and 79 and in other provisions of the Convention, each coastal State must exercise its rights and perform its duties with due regard to the rights and duties of the other. (para. 475)

There are many ways in which the Parties may ensure the discharge of their obligations in this respect, including the conclusion of specific agreements or the establishment of appropriate cooperative arrangements. It is for the Parties to determine the measures that they consider appropriate for this purpose. (para. 476)

\section{Disputed MARITIME AREAS}

There are portions of the seas over which two (or sometimes more) States claim sovereign rights or jurisdiction, where, in other words, their claims overlap. This situation can give rise to negotiations and eventually to a delimitation agreement, or to a dispute settled by a judicial or arbitral decision which draws the delimitation line.

But what is the regime of the disputed maritime area pending agreement or judicial settlement?

As regards the States whose claims overlap, two opposing concerns may inspire their attitude. On the one hand, they may try to establish as many facts as possible that strengthen their claim, for instance, granting oil exploration or exploitation licences or authorizations for fishing or conducting marine scientific research. On the other hand, they may give priority to avoiding the escalation of the dispute, abstaining from acts as those mentioned above that may cause incidents.

The first attitude is likely to prevail when one State denies all validity to the other's claims, while the second is likely to be followed by States that acknowledge that there is a dispute.

UNCLOS articles on delimitation of the exclusive economic zone and of the continental shelf contain two identical provisions (arts. 74, para. 3, and 83, para. 3) which envisage this situation. These provisions set out two obligations the parties in dispute "shall make every effort" to comply with, pending agreement on delimitation in a spirit of understanding and cooperation:

1. to enter provisional arrangements of a practical nature; and
2. during this transitional period not to jeopardize or hamper the reaching of the final agreement.

These provisions are inspired by the general idea of good faith and may provide criteria useful for assessing the conduct of the contending States. A question of interpretation of this provisions concerns the meaning of "pending agreement": does the provisions concern all the time during which there is no agreement, or only the time since negotiations have started? Further questions, which seem to deserve consideration, are whether these provisions correspond to customary law and whether they could apply also to a contested area pending delimitation of maritime zones different from the exclusive economic zone and the continental shelf.

For third States the disputed area must be considered as under the sovereign rights or jurisdiction of a coastal State, although whether such coastal State is one or the other disputing ones is not yet determined. To behave as if the disputed area belonged to one of the disputing States, for instance, by submitting to it requests for fishing or scientific research authorizations, may give rise to incidents and it may be seen, and often is seen, an unfriendly act by the other disputing State.

\section{SUMming-UP AND CONCLUSIONS}

In today's international law there is a variety of maritime zones in which the coastal State exercises sovereignty, sovereign rights or jurisdiction to the exclusion of other States. The rights of the coastal State are nevertheless limited by the rights of other States to conduct certain activities in the same areas. In the exclusive economic zone, the key rule to ensure the coexistence of the rights of the coastal State and those of other States is the "due regard" rule.

Difficulties may arise in order to classify certain activities as belonging to the category of those falling under the coastal States' rights or to those that are free for all States. The intervention of dispute-settlement bodies can be very important to solve this problem, as it has happened as regards bunkering.

Certain maritime areas are automatically appurtenant to the costal State, others require proclamation. Also for certain parts of areas included among those not requiring proclamation, such as the territorial sea 
beyond a minimum of three $\mathrm{nm}$ or the continental shelf beyond $200 \mathrm{~nm}$, a form of proclamation is nevertheless necessary.

"Potential" maritime areas, namely areas in which the coastal State is entitled to establish a maritime area, but has not done so, are under the regime of that part of the sea as it is at present, but in the application of the due regard rule States should take into account the other State is entitled to transform the potential area in an actual one. The continental shelf beyond $200 \mathrm{~nm}$ is a special case of potential area because the transformation from potential into actual, so that the eventual proclamation becomes "final and binding", requires a procedure, involving the CLCS, whose end result is uncertain as to whether the edge of the continental shelf margin is beyond $200 \mathrm{~nm}$ and, if so, as to where the external limit is.

Lateral delimitations, as those in the Bay of Bengal decisions of 2012 and 2014, adopting lines different form the equidistant one, give rise to "grey areas" lying within $200 \mathrm{~nm}$ from one State and beyond from the other. These are areas in which the delimitation line divides the continental shelf between two States while the overlying waters remain subject to the exclusive economic zone sovereign rights and jurisdiction of the State for which the grey area lies within $200 \mathrm{~nm}$. The due regard rule, and, possibly, cooperative arrangements should play a role for shaping the regime applicable to these areas.

Disputed areas may be the subject of delimitation agreements or of judicial or arbitral decisions. Pending delimitation, States in dispute sometimes try to develop practice so as to accumulate evidence of their rights and some other times abstain from exacerbating the dispute. Third States should consider the area not as free but under the jurisdiction of a State, and avoid conduct recognizing one State as entitled to rights to the exclusion of the other, lest the latter consider their attitude hostile. Articles 74, para. 3, and 83, para. 3, indicate various forms of good faith conduct the contending States shall "make every effort" to follow pending a delimitation agreement.

It may be observed, as a conclusion, that while every maritime area described in UNCLOS has its own regime consisting in rights and obligations of different categories of States, the interpretation of the provisions defining the activities to which these rights and obligations apply may give rise to difficulties. The picture of the different areas and of their regime in UNCLOS is a static one. Further difficulties arise when transformation occurs or may occur and the picture becomes dynamic. The due regard rule and good faith concepts together with the possibility of submitting the question to adjudication - may be helpful. 


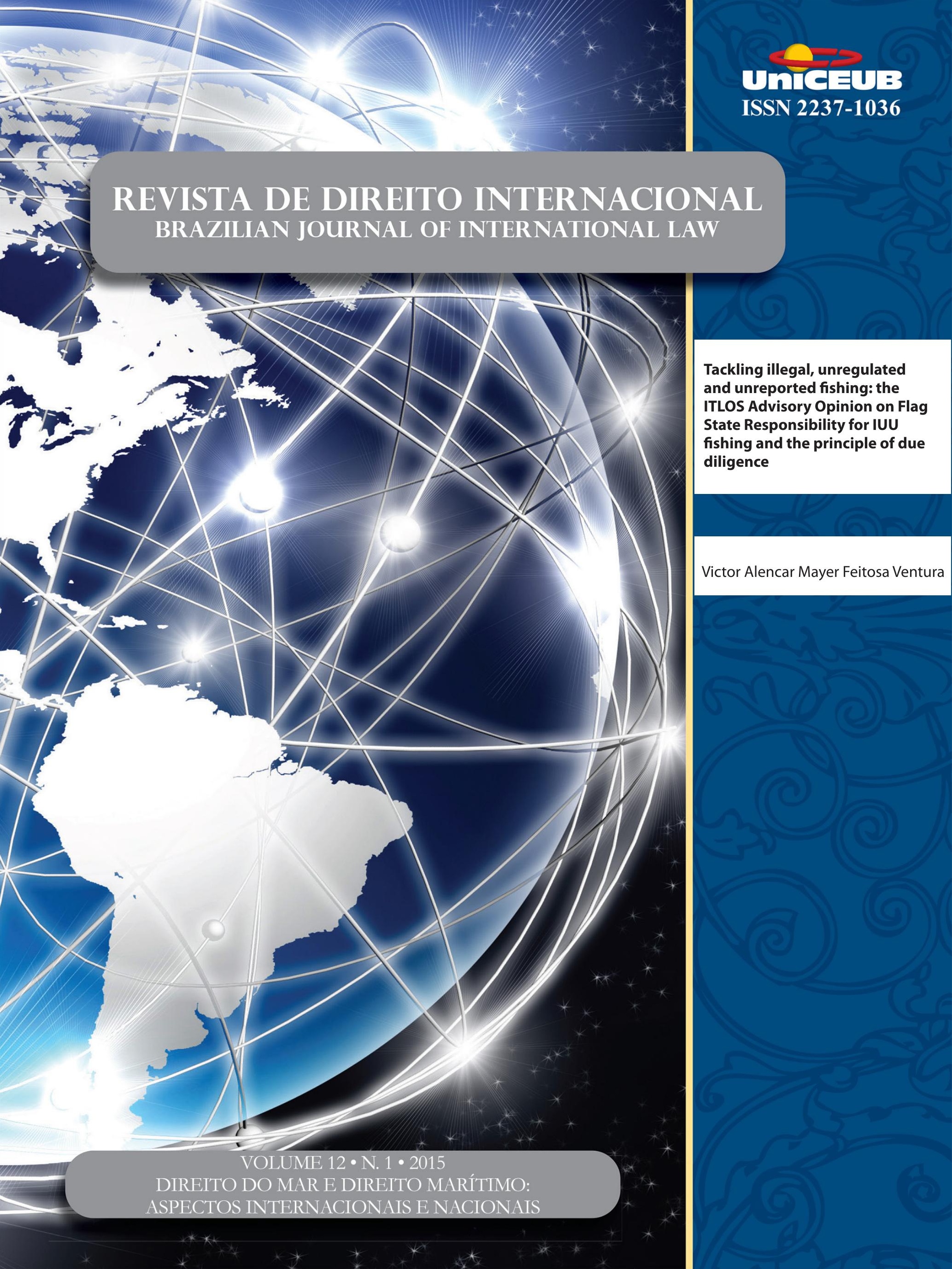




\title{
Tackling illegal, unregulated and unreported fishing: the ITLOS Advisory Opinion on Flag State Responsibility for IUU fishing and the principle of due diligence*
}

Victor Alencar Mayer Feitosa Ventura**

\begin{abstract}
One of the major challenges of the International Law of the Sea (LOS) is the overexploitation of fisheries worldwide. According to recent data, approximately $75 \%$ of the world's fisheries are either over or fully exploited, mainly due to illegal, unregulated and unreported (IUU) fishing. In order to tackle IUU fishing, a wide historical comprehension of the problem is provided in this paper, together with an investigation on the emergence of a new and integrated approach to the issue of IUU fishing. For that, the Advisory Opinion on flag state responsibility rendered by the International Tribunal for the Law of the Sea (ITLOS) of April 2015 is herein analyzed. Based on primary international sources, such as the United Nations Convention for the Law of the Sea (UNCLOS), and on specific case law, this paper aims at pinpointing the relevant role of the Tribunal in setting higher protective parameters for fisheries within the LOS. In an effort to overcome traditional approaches, the Tribunal is encrusting the environmental principle of "due diligence" in its decisions and, therefore, contributing to a fructiferous interaction between the LOS and international environmental law. Finally, the article also notes that the international society still needs to undertake reform and implementation efforts, if illegal fishing is to be overcome.
\end{abstract}

Key-words: International Law of the Sea. Illegal fishing. Integrated approach. ITLOS. Due diligence.

\section{INTRODUCTION}

In an effort to raise attention towards the need for a renewed approach to the protection of the seas, Davor Vidas and Peter Schei refer continuously to the "world ocean", a term that, according to both authors, considers seas and oceans as forming an integrated unit. ${ }^{1}$ This view is part of a greater scholarly effort to tackle traditional and isolated approaches within the Law of the Sea (LOS).

For centuries, states have been stuck to the opposing doctrines of the freedom of the seas, on the one side, and the sovereignty rights over natural resources, on the other, in a clash that has produced multiples victims: the ocean, its fauna and flora, as well as the human population that depend on the seas to survive. That approach is known as "zonal", as it divides the

** $\mathrm{PhD}$ Researcher in International Law of the Sea at the University of Hamburg. LL.M. at the Federal University of Paraíba (UFPB). Email:vfventura@gmail.com

1 VIDAS, Davor; SCHEI, Peter Johan (Ed.). The world ocean in globalization: climate change, sustainable fisheries, biodiversity, shipping regional issues. Leiden: Nijhoff, 2011. p. 2. 
seas into zones that belong either to the coastal state, or to no one. A sort of myopic fashion to glance at the world ocean that often reinforces ancient conceptions and impedes a thorough protection of the marine environment.

The zonal approach does not take into account the need for an integrated marine management, based on ecosystem considerations, without which the protection of the oceanic environment rests too difficult to be achieved. One of the major challenges of the LOS and this renewed, integrated approach is the grave issue of illegal, unreported and unregulated fishing in the seas. IUU fishing consists of a broad concept that encompasses numerous wrongful and illicit fishing capture activities. According to a definition set forward by the International Plan of Action to Prevent, Deter and Eliminate IUU fishing (IPOA-IUU), of the Food and Agriculture Organization of the United Nations (FAO), those three key terms of the concept are designed to encompass numerous wrongful and illicit fishing capture activities. Thus, "illegal" fishing is the one conducted in violation of national laws or international obligations, whereas "unreported" fishing refers to activities which "have not been reported, or have been misreported, to the relevant national authority (or to a regional fisheries management organization), in contravention of national laws and regulations". Finally, fishing activities are "unregulated" when they occur in areas where no regulatory systems exist, or in a manner that is inconsistent with the conservation and management measures of a coastal state or a regional fisheries organization. ${ }^{2}$

The problem is even more serious if one take into account the fact that fisheries around the world are source not only of health, but also of wealth. ${ }^{3}$ They are absolutely relevant to the economy and well-being of coastal communities, providing food security, job prospects, income and livelihoods as well as enabling cultural identity. Besides, fish is an in-

2 In line with the IPOA definition for IUU fishing, it ought to be noted that despite the controversial nature of "unregulated" fishing, the IPOA "is generally concerned with unregulated fishing that is likely to frustrate the achievement of sustainable fisheries". See: UNITED NATIONS. International Plan of Action to Prevent, Deter and Eliminate IUU Fishing. FAO, Committee on Fisheries, Rome, 2001. Available at: <http://www.fao.org/docrep/003/y1224e/y1224e00. htm>. Access on: 23 May 2015.

3 In his foreword to the 2014 FAO Report on "The state of world fisheries and aquaculture", José Graziano da Silva highlights the relevance of fisheries to the poorest countries, to which fish is "sometimes worth half of the total value of their traded commodities". dispensable source of protein, especially to the world's poorest countries. According to a detailed report by the FAO, approximately 158 million tons of fish landed in ports worldwide in 2012, directly employing millions of people in fishing operations. ${ }^{4}$ Besides, approximately 90 percent of all fish stocks are captured within 200 miles of shore, the traditional limit of the Exclusive Economic Zone (EEZ), ${ }^{5}$ and therefore under coastal states resources sovereignty. ${ }^{6}$ The remaining 10 percent are considered straddling stocks, or fish stock "which occurs both within the EEZ and in an area beyond or adjacent to EEZ", meaning the high seas or a neighboring economic zone. ${ }^{7}$

Nonetheless, global efforts to sustainably manage fisheries, in order to allow for the continued flow of trade, are undermined by IUU fishing. In extreme circumstances, illegal fishing can lead to the semi-collapse of fish stocks - such as those of the Patagonian toothfish during the 1990 's $-{ }^{8}$ or seriously impair efforts to rebuild depleted stocks, what makes it a grave problem in an ongoing industrial scale. In fact, pirate fishing jeopardizes regular and documented fishing operators, disturbs ecosystems, and affects fish-dependent populations throughout the globe. ${ }^{9}$

4 According to the 2014 FAO Report, those "landings" consist both of captured fish in the seas and fish bred and harvested within fish "farms", also known as aquaculture. Despite a stable amount of landings per capture (around 90 million tons yearly), global fish production has grown steadily due to increased investments in aquaculture and in more efficient distribution channels. In 2012, aquaculture alone was responsible for approximately 67 million tons of landings worldwide, i.e. almost $42 \%$ of the world's landings. See: UNITED NATIONS. The state of the world fisheries and aquaculture. FAO Fisheries and Aquaculture Department, FAO, Rome, 2014. p. 4.

5 The EEZ is one of the maritime zones established by the UNCLOS (arts. 55 to 75), which stretches up to 200 nautical miles, encompassing the territorial sea and the contiguous zone of the coastal state. Bordering the EEZ are the high seas and other adjacent national economic zones.

6 KRASKA, James. The lost dimension: food security and the South China Sea disputes. Harvard Law School National Security Journal, Online article, 2015. Availlable at: <http://harvardnsj. org/2015/02/the-lost-dimension-food-security-and-the-south-china-sea-disputes/>. Access on: 29 Apr. 2015.

7 The definition of "straddling stock" is provided by the FAO on-line glossary, and stems from article 63(2) of UNCLOS. Available at: <http://www.fao.org/faoterm/en/?defaultCollId=21>. Visited on: 21 May. 2015.

8 See: Coalition of Legal Toothfish Operators Inc. Available at: <http://www.colto.org/toothfish/>. Visited on: 22 May. 2015.

9 On the issue of overfishing in Brazilian waters, as well as on management strategies adopted to tackle this problem, see: BARROS-PLATIAU, Ana Flávia et al. Correndo para o mar no antropoceno: a complexidade da governança dos oceanos e a estratégia 
According to latest statistics published by FAO, the current global stock status reflects the following picture: 57 percent were estimated to be fully exploited, 30 percent were overexploited, and 13 percent non-fully exploited in 2012. Fisheries are non-fully exploited when the majority of the stocks is "moderately exploited", fully exploited when it is already at or very close to producing their "maximum sustainable yield", and overexploited when it is either depleted or exhausted. ${ }^{10}$ One could infer that the overexploitation herein depicted is one of the reasons why fish production per capture has stabilized, instead of sustainably increased.

The main international legal documents at hand to attack this problem are the third United Nations Convention on the Law of the Sea (UNCLOS), the 1995 United Nations Fish Stocks Agreement (UNFSA) and the FAO Code of Conduct for Responsible Fisheries (FAO, 1995), which will be later analyzed in this article. They are all unisonous in requiring the maintenance or restoration of fish stocks at levels that are capable of producing their "maximum sustainable yield" (MSY), i.e. the largest amount of fish catches that allows for the natural reproduction of stocks.

Illegally induced overfishing is a problem with a multidimensional nature, given economic, social, political, technological and legal aspects constantly interacting in defining the current status of global fisheries. For the purposes of this paper, exclusively the legal nature will be scrutinized, with special regard to the need to implement an integrated approach to the management of global fisheries, based on state of the art literature on the topic. With this goal, to comprehend the historic background of the LOS concerning the protection of living resources is paramount in assessing the most effective strategies to tackle IUU fishing.

Finally, this article aims at analyzing the Advisory Opinion on flag state responsibility for Illegal, Unregulated and Unreported (IUU) fishing of the International Tribunal for the Law of the Sea (ITLOS) and its contribution to the implementation of a renewed, ecosystem-oriented approach. Indeed, with that opinion the Tribunal reaffirmed its relevant role as a judicial body that fosters progressive interpretations on legal marine

brasileira de gestão dos recursos marinhos. In: Varella, Marcelo D. Revista de Direito Internacional, vol.12, no.1 (current edition).

10 FOOD AND AGRICULTURE ORGANIZATION OF THE UNITED NATIONS. The state of the world fisheries and aquaculture. Rome: FAO, 2012. issues. To the purpose of this paper, a special emphasis will be given on the Tribunal's understanding of the "due diligence" principle and the consequent consolidation of that originally environmental principle as one pillar of the LOS regime.

In the century when high-tech oceanic development takes off, some questions remains unanswered: what future is reserved to fisheries? Are there remedies to prevent the absolute depletion of fish stocks worldwide? Those are most serious enquiries that need be answered, and this paper is a drop in the ocean of contributions to analyze and offer possible solutions to the issue of IUU fishing.

\section{FisheRIES IN THE LOS AND THE CONFLICT BETWEEN PRINCIPLES: FREEDOM OF THE SEAS V. SOVEREIGNTY RIGHTS OVER NATURAL RESOURCES}

The Law of the Sea emerges in the context of growing "functional differentiation" within International Law. According to this phenomenon, the emergence of new subsystems is imposed by the growing complexity of contemporary problems, which, on its turn, demands global and sophisticated answers, of highly scientific and technical standards. ${ }^{11}$ For this reason, the LOS can be considered an international special regime of international law. Historically, it has been the narrative of a struggle between conflicting interests: those of maritime powers, nations with primordial interest in shipping and sailing the world's oceans, and those of coastal states interested essentially in the security of resources within their adjacent waters. ${ }^{12}$ According to that historical account, it is possible to understand the difference between "maritime" and merely "coastal" states, a distinction based on the state's ability and conditions to sail the seas.

The history of this specific realm of International Law is that of the division of the ocean between states, division into multiple jurisdictional spaces (amongst which the Exclusive Economic Zones, Continental

11 TEUBNER, Gunther; FISCHER-LESCANO, Andreas. Regime Collisions: the vain search for legal unity in the fragmentation of global law. Michigan Journal of International Law, v. 25, n. 4, 2004. 12 MCDORMAN, Ted L. The marine environment and the Caracas Convention on the Law of the Sea: a study of the third United Nations Conference on the Law of the Sea and other related marine environmental activities. Halifax: Dalhouise University Press, 1981. 
Shelves, and the high seas). Yoshifumi Tanaka names this division approach "zonal management approach", one deeply rooted in the history of LOS and resulting from the two antagonistic principles above mentioned: the principle of sovereignty and the principle of freedom (of navigation)..$^{13}$ Whilst one embodies the concept of territorial seas, the other gives place to the high seas and the freedom to navigate.

In other words, the conflicting nature of the LOS could be summed up to the ancient and opposing doctrines of "open seas" (mare liberum) and "closed seas" (mare clausum). Based on such fundamental opposition, the LOS has always been "made, changed, challenged and remade." 14 Each doctrine gives birth to different principles of the law of the sea. On the one hand, the mare liberum thesis in supported by the principle of the freedom of the seas, which had in Hugo Grotius its main defender. ${ }^{15}$ On the other, the mare clausum, defended by authors such as William Welwod.

Two of the founding fathers of International Law of the Sea, Hugo Grotius and Emmerich de Vattel, have pioneered in dedicating reflections to oceanic matters. Grotius laid the basis of the freedom of the seas principle, whereas de Vattel presented the modern concept of territorial seas, defined as jurisdictional waters, which form the territory of a state. ${ }^{16}$ Given it is not the purpose of this article to scrutinize the entire history of the LOS, a few words on the Grotian legal reasoning shall suffice to comprehend the ongoing dispute involving living resources in the seas.

In the $17^{\text {th }}$ century, following the Iberian restriction on shipping through the world's oceans, Grotius published his main thesis of the "community of the sea" and the freedom of fishing. Resorting repeatedly to analogies as well as to natural law, Grotius affirmed the basic customary rule of the Law of Nations, according

13 TANAKA, Yoshifumi. A Dual Approach to Ocean Governance: the cases of zonal and integrated management in International Law of the Sea. Paris: the Ashgate International Law Series, 2008. p. 2.

14 PIRTLE, Charles E. Military uses of ocean space and the law of the sea in the new millennium. Ocean Development and International Law, v. 31, n. 7, p. 11-32, 2000.

15 GROTIUS, Hugo. The Free Sea, trans. Richard Hakluyt, with William Welwod's Critique and Grotius's Reply, ed. David Armitage. Indianapolis: Liberty Fund, 2004. p. 95. Available at: <http:// oll.libertyfund.org/titles/859\#Grotius_0450_251>. Access on: 24 Mar. 2015.

16 VATTEL, Emmerich de. The Law of Nations: or Principles of the Law of Nature Applied to the Conduct and Affairs of Nations and Sovereigns. Philadelphia: Law Book Sellers, 1863. to which "it is lawful for any nation to go to any other and to trade with it". ${ }^{17}$ Neither the Portuguese, the Spaniards, nor the Dutch owned the oceans, and to defend this postulate, Grotius dives into the depths of Roman legal literature.

In acclaimed works of Ulpian, the Dutch author builds his central argument that the seas are by nature "open to all", and not just to citizens of a single state. For there is an abyssal distinction between conceptions of the sea as a "common good", as opposed to the seas as "public good". Given that the seas was common from its first origin, it is obvious that it cannot become entirely the property of anyone by nature. Therefore, says Grotius, "he who prohibits anyone else from fishing on the sea, whoever he is, commits a wrong." 18

Grotius examines the nature of the ocean and reaches the conclusion that the oceans, as something that cannot be limited physically, cannot be the property of one person, or people. ${ }^{19}$ Besides, provided the oceans need no cultivation to bear fruit (fish), than whatever exists inside of it is to be considered common, and any restrictions to sailing the seas or fishing should entail a legal damages action. ${ }^{20}$ De Vattel represented likewise a powerful voice against the ownership of the "open seas". In his words, "no nation has a right to take possession of the open seas or claim the sole use of it, to the exclusion of the others". This distinction between free, open seas and territorial waters marked the legal beginning of dualism between two distinct zones of the ocean.

Centuries onwards, maritime powers such as Portugal, Spain, The Netherlands, France, England, Canada, Russia, the United States, among others, sailed the seas with absolute freedom, trading with peoples from all parts of the world. Davor Vidas even relates the ideological foundation of the LOS to the mare liberum theory, and postulates that the freedom of the seas "facilitated the emergence of the forces that led to the Industrial

17 GROTIUS, Hugo. The Free Sea, trans. Indianapolis: Liberty Fund, 2004. p. 95.

18 GROTIUS, Hugo. The Free Sea, trans. Indianapolis: Liberty Fund, 2004. p. 95.

19 GROTIUS, Hugo. The Free Sea, trans. Indianapolis: Liberty Fund, 2004. p. 110.

20 After the publication of his main theses, and the reply to Welwod, it could be said that Grotius "won" the debate, because in 1609 King Phillip III of Spain and Portugal came to a temporary peace with the Dutch. The freedom of the seas was formally obtained. 
Revolution". ${ }^{21}$ Indeed, the freedom of the seas is a concept with a fascinating evolution, outcome of customary law and milestone for the free flow of commerce and communication between nations.

On the other side of the equation, coastal states that for centuries have watched the harvest of their natural resources by merchant fleets of developed countries were gradually claiming exclusivity to marine resources offshore. Consequently, after World War I traditional maritime states witnessed a stark decline in their powers within the international arena. Equally noteworthy was the increasing jurisdictional claims of developing states to secure ocean resources, mainly fisheries, which responded for a burgeoning part of their economic activity. In this juncture, the imminence of conflicts led coastal and maritime states to meet in The Hague in 1930 with the arduous task to codify the existing customary LOS. The Conference was organized by the League of Nations, but failed to produce a final document, given the already visible divergences between states.

A few years later, the continued failure to delimit the extent of territorial waters and fisheries jurisdiction stirred a move by the President of the US, which further promoted the division of the oceans. The Truman Proclamations of 1945, one on fisheries and another on the continental shelf, secured "property rights" over resources on the seabed and water column of the United States' continental shelf, and came as a model to be followed. Back then, several Latin American states took the same course of action and declared jurisdiction over their contiguous seas, triggering what McDorman names "the great expansion of coastal state jurisdiction." 22

Coastal states then advanced the national interest by controlling ocean resources, mainly fisheries, and prompted a series of "enclosures" of the adjacent waters to their coasts. This new phenomenon produced the unexpected problem of excessive claims by Latin American states due to the lack of harmonious international practice on this matter. Countries such as Brazil,

21 VIDAS, Davor; SCHEI, Peter Johan (Ed.). The world ocean in globalization: climate change, sustainable fisheries, biodiversity, shipping regional issues. Leiden: Nijhoff, 2011. p. 6.

22 See MCDORMAN, Ted. L. The marine environment [...], 1981, p. 2. Não tem na lista de referências. known for its "territorial ambitions" 23 , Argentina ${ }^{24}$ and Chile ${ }^{25}$ announced far-reaching declarations and proclaimed sovereignty over the continental shelf of whatever depth and additionally of a maritime areas extending 200 nautical miles from the shore. ${ }^{26}$ The unilateral delimitation of continental shelves by Latin American states became the rule, as Mexico, Nicaragua, Guatemala, Honduras, El Salvador and Ecuador imitated the action. $^{27}$

The rapid and unsystematic expansion of jurisdictional waters threatened the principle of the freedom of the seas and was, therefore, the raison d'etre of the 1958 Geneva Conference on the Continental Shelf. The UN-hosted Conference adopted four conventions, ${ }^{28}$ including the Convention on the Continental Shelf, and was responsible for bringing about new contributions to the LOS regime, as it fostered a "progressive development" of international law. For the first time, the basic features of the freedom of the seas principle was conversed into a treaty, and the so-called "zonal management approach" was finally codified. ${ }^{29}$ However, there was still work to be done, given that the specific

23 See VARGAS, Jorge A. Latin America and its contributions to the Law of the Sea. In: LAURSEN, Finn (Ed.). Towards a New International Marine Order. Leiden: Nijhoff, 1982. p. 58.

24 See Argentinian Declaration of 1946. Available at: <http:// legal.un.org/ilc/documentation/english/ a_cn4_30.pdf>. Visited on: 26 Apr. 2015.

25 See Chilean Declaration of 1947. Available at: <http://legal. un.org/ilc/documentation/english/ a_cn4_30.pdf>. Visited on: 26 Apr. 2015.

26 KIRCHNER, Andree. The Outer Continental Shelf: background and current developments. In: NDIAYE, Tafsir and WOLFRUM, Rüdiger. Law of the Sea, Environmental Law and Settlement of Disputes: Liber Amicorum Judge Thomas A. Mensah. Leiden: Nijhoff, 2007. p. 594.

27 Detailed information on the content of those unilateral declarations is available at ODA, Shigeru. Fifty years of the Law of the Sea: with a special section on the International Court of Justice. The Hague: Kluwer Law International, 2003. p. 19.

28 The four Conventions adopted were: the Convention on the Territorial Sea and the Contiguous Zone; the Convention on the High Seas; the Convention on Fishing and Conservation of the Living Resources of the High Seas, and the Convention on the Continental Shelf, all of them having entered into forced between 1962 and 1966. In addition, an Optional Protocol of Signature Concerning the Compulsory Settlement of Disputes was adopted, which entered into force on 30 September 1962. Available at: <http:// legal.un.org/diplomaticconferences/lawofthesea-1958/lawofthesea-1958.html>. Visited on: 27 Apr. 2015.

29 See TANAKA, Yoshifumi. A Dual Approach to Ocean Governance: the cases of zonal and integrated management in International Law of the Sea. Paris: The Ashgate International Law Series, 2008. p. 3. 
Convention on the Continental Shelf failed to specify the width of that zone, ${ }^{30}$ as well as the extent of state control over fisheries.

Less than a decade after the diplomatic Conference of 1958, disputes regarding sovereignty over natural resources on the offshore of coastal states, as well as on the high seas were still common. At that moment, the US had "landed" on the deepest underwater hole in the world, the Challengers Deep, in the Mariana Trench, ${ }^{31}$ located on the Pacific Ocean, and started worries about the possible exploitation of the seabed in ultra deep waters. As McDorman rightly points out, "the development of international ocean law owes as much to technological advancement as to scientific discovery," 32 and as such, the continental shelf regime itself, for instance, would not exist but for the introduction of ocean drilling and deep-water technologies. Such rapid technological developments inspired the idea of a fresh and more ambitious Convention on the Law of the Sea, capable of holistically addressing up-to-date issues of ocean governance worldwide.

At this moment, a new political phenomenon produced further legal consequences on the balancing between the principle of the freedom of the seas and the principle of sovereignty over natural marine resources. Indeed, as the decolonization wave shook the world, developing coastal states expanded their territorial seas and fisheries zones, therefore tightening legislative controls over their continental shelves, and consolidating a trend of jurisdictionalism over the oceans. ${ }^{33}$ Based on geographical arguments, Douglas Johnston provides a reasonable resume of the conflicting interests in the international arena. According to the author, "the naturally favored minority of states has had the strongest

30 In the words of McDorman, "the 1958 Conference did agree on a definition of the continental shelf, but that definition was formulated in such an elastic manner that it provided no useful way to determine the outer limit of the shelf". See MCDORMAN, Ted L. The marine environment [...], 1981, p. 3.

31 In 1960, the Swiss scientist Jacques Piccard designed a submersible vehicle with financial support of the U.S. Navy, and dove into the depths of the Challenger Deep, the deepest hole known in the world's oceans, in 1960

. In that occasion, the submersible Trieste descended 11.000 meters until the very bottom of the sea. The descent was expected to mark deep ocean explorations.

32 See MCDORMAN, Ted L. et al. International Ocean Law: materials and commentaries. Durham: Carolina Academic Press, 2005. p. 378.

33 See MCDORMAN, Ted L. The marine environment [...], 1981, p. 4. Não tem na lista de referências. interest in an extension of seaward limits of the continental shelf, whereas the majority of naturally unfavored states has had an interest in restricting encroachments on the international area of the deep ocean floor". ${ }^{34}$ In this juncture, opposition between principles was stronger than ever, and inspired the beginning of diplomatic conversations towards a new binding instrument.

The third United National Convention on the Law of the Sea was signed in 1982, in Montego Bay (Jamaica), and is the result of more than a decade of arduous negotiations, in one of the most impressive exercises of international negotiation in Public International Law. The cornerstone of UNCLOS III is believed to be Arvid Pardo's speech to the United Nations General Assembly in 1967, when Malta's ambassador to the UN presented a potent speech urging states to declare the seabed beyond national jurisdiction as common heritage of humankind $(\mathrm{CHH}) .{ }^{35}$ In the view of McDorman, "Arvid Pardo sought to halt this creeping jurisdictionalism by claiming that the seabed beyond national jurisdiction was the common heritage of mankind, to be managed for the benefit of all."36

As mentioned earlier, a greater change in the negotiations were the politically independent African and Asian states, which held a point of view differing significantly from those of their colonial predecessors. It was clear that the developing countries of the Third World, sympathetic to the political orientation of the so-called "Group of 77", ${ }^{37}$ played an important role in UNCLOS III negotiations. In this context, the UNCLOS III can

34 See JOHNSTON, Douglas M. The theory and history of ocean boundary making. Montreal: McGill-Queens University Press, 1988. p. 85.

35 Common space areas are regarded as regions owned by no one, though hypothetically managed by everyone. On the genderrelated issue, it should be noted that, although some reports prefer the gender-neutral equivalent "common heritage of humankind", the expression is widely quoted as "of mankind", and so will it be used on this dissertation.

36 One of the main purposes of the $\mathrm{CHH}$ principle is to protect areas beyond national jurisdiction or, when necessary, to allow exploitation in a way that enhanced the common benefit of humankind. For a detailed narrative on this principle, see GALINDO, George Rodrigo Bandeira. Quem diz bumanidade pretende enganar?: internacionalistas os usos da noção de patrimônio comum da humanidade aplicada aos fundos marinhos (1967-1994). 2006. PhD (Dissertation). Brasília: University of Brasília, 2006.

37 The political Group of 77 advocated a more radical form of $\mathrm{CHH}$ principle, based on the ideology underpinning the so-called "New International Economic Order", designed to rebalance economic relations between industrialized countries of the North and poorly developed states of the South. 
be associated to the intriguing phenomenon of the rise of coastal states, having simultaneously fulfilled old demands of sovereignty over marine resources, especially fisheries, and restricted disproportional territorial ambitions towards the seas. ${ }^{38}$

Despite challenging and long negotiations, ${ }^{39}$ the UNCLOS III has succeeded in designing a global architecture for ocean governance worldwide. It entered into force in 1994, after the sixtieth state had signed it, and has been ratified by 167 states, as to the first half of 2015. Even more importantly, "most of the significant concepts of the treaty have been absorbed by states into their national laws and practices over the last two decades." ${ }^{40}$ In fact, the Convention is often regarded as yielding quasi-universal principles, some of them grounded on customary international law of the sea, that is, in centuries of state practice..$^{41}$ In 320 articles, it managed to cover a broad range of oceanic issues, clarifying legal concepts (such as those of territorial sea, continental shelf, high seas, among others), determining seaward limits, ${ }^{42}$ and anticipating future challenges, especially the ever closer commercial exploitation of marine resources lying on the deep seabed.

The UNCLOS III, alongside other instruments, ad-

38 Regarding the tension between the freedom of the seas and sovereignty claims of Third World countries towards the ocean, it seem relevant to mention the Freedom of Navigation Program (FON) of the U.S. Navy. In force since 1979, a few years before the UNCLOS III was open to signatures, this program has the main goal of highlighting "navigation provisions of the LOS Convention to further the recognition of the vital national need to protect maritime rights throughout the world". Available at: <http://www.state. gov/e/oes/ocns/opa/maritimesecurity/>. Visited on: 28 Apr. 2015. 39 The UNCLOS III is the treaty with the longest negotiation record in the history of the United Nations. See FREESTONE, David. Problems of high seas governance. In: VIDAS, Davor; SCHEI, Peter Johan. The world ocean in globalization: climate change, sustainable fisheries, biodiversity, shipping, regional issues. Leiden: Nijhoff, 2011. p. 100. 40 See MCDORMAN, Ted L. et al. The entry into force of the Law of the Sea Convention and South-East Asia: an introductory comment. In: MATICS, K. I.; MCDORMAN, T. (Ed.). Selected papers in commemoration of the entry into force of the U.N. Convention on the Law of the Sea. Bangkok: SEAPOL, 1995. p. 5.

41 The absence of countries such the United States, Turkey, Venezuela, Israel, among others, poses a challenge to the international society, but does not impede the application of the LOS. Indeed, despite not signing the treaty, those countries are bound by customary ocean norms, mainly those concerning rights and duties of states in maritime zones such as the EEZ, CS and others. Those provisions are thus opposable even against non-states parties to the Convention.

42 On this topic, see JOHNSTON, Douglas M. The theory and history of ocean boundary making. Montreal: McGill-Queens University Press, 1988. vanced many topics that have helped consolidate the regime of the LOS. That notwithstanding, there is still much to be done on implementing these instruments. Challenges ahead of the ocean governance amount to: marine (oil) pollution, invasive alien species, habitat destruction, and, for the purpose of this contribution, poorly managed fisheries. Indeed, more than 20 years after the entry into force of the Convention, coastal states call for new protocols and agreements to address unfinished agendas, such the legal framework applicable to the high seas. ${ }^{43}$ As Vladimir Golitsyn, judge at the ITLOS, would put it, the international society needs to promote a shift from an approach that emphasizes "entitlement to", to one that highlights "responsibility for" the oceans, so as to grant application both in areas within and outside national jurisdiction, without disregarding the jurisdictional dimension. ${ }^{44}$ In the light of this "exploitation-oriented" approach, which is still perceptible in UNCLOS III, a question that, therefore, remains is to whether and how international lawyers and institutions applying the UNCLOS III could tackle one of the main challenges of current state of affairs in ocean law: the practice of IUU fishing.

\section{IUU FISHING: DEFINITION AND GLOBAL EFFORTS TO FRAME THE PROBLEM}

As pointed out at the introductory part, IUU fishing consists of a global scale problem that affects not only the sustainability of fishing stocks, but also the lives of hundreds of millions in fishing communities throughout the world that have on fishing their main subsistence source. ${ }^{45}$ When fishing is conducted in violation of internationally agreed regulations and catch quotas, consequences also reach fishers that abide by the law, stimulating, therefore, non-compliance to international duties, in a destructive downward spiral.

43 See FREESTONE, David. Problems of high seas governance. In: VIDAS, Davor; SCHEI, Peter Johan. The world ocean in globalization: climate change, sustainable fisheries, biodiversity, shipping, regional issues. Leiden: Nijhoff, 2011. p. 100.

44 See GOLITSYN, Vladimir. Major challenges of globalization for seas and oceans: legal aspects. In: VIDAS, Davor; SCHEI, Peter Johan. The world ocean in globalization: climate change, sustainable fisheries, biodiversity, shipping, regional issues. Leide: Nijhoff, 2011. p. 61. 45 See CULLIS-SUZUKI, Sarika; DANIEL, Pauly. Failing the high seas: a global evaluation of regional fisheries management organizations. Marine Policy, 2010. p. 1. 
IUU fishing is not an exclusively legal problem, and although it is not the aim of this paper to address other roots of that illegal activity, it is relevant to briefly call attention to some of the factors that contribute to the steadiness of global landings of illegally caught stocks. Rachel Baird identifies the following reasons: "the impact of the industrialization of the fishing industry; increases in both human consumption and the size of the global fishing fleet; the introduction of government subsidies which have contributed to the creation of an artificial environment of profitability; increased competition amongst fishers and the entry of large scale commercial fishing entities into the marine fishing industry IUU fishing is also very common, and even more difficult to tackle, on the high seas." ${ }^{46}$ These aspects evidence the multifaceted nature of overfishing problems, which in their turn demand integrated and holistic responses.

This is not to mention the greater challenge of tackling IUU fishing on the high seas. ${ }^{47}$ Marine living resources beyond national jurisdiction received scant attention during the negotiation of the UNCLOS III, for it focused upon the authority of coastal states respecting marine living resources within national zones. ${ }^{48}$ On the high seas, states are free to harvest (art. 116 of the Convention), although there are uncertain duties respecting cooperation and marine conservation. A normative attempt to limit flag states arbitrariness is enshrined in art. 117 on UNCLOS III, within section 2 , devoted to the conservation and management of the living resources on the high seas. According to article 117 , states must cooperate with each other in order to adopt measures (with respect to their nationals) for the conservation of living resources of the high seas. What specific measures shall be adopted is, nevertheless, va-

46 See BAIRD, Rachel J. Aspects of illegal, unreported and unregulated fishing in the Southern Ocean. Dordrecht: Springer, 2006. p. 8.

47 On the topic of the effectiveness of ocean governance in areas beyond national jurisdiction, David Freestone sees very slow progress. For that reason, the author is of the opinion that a new instrument based on agreed modern principles of LOS could be a way to tackle current problems. Such new instrument would "pull together all the various themes and sectoral responsibilities discussed above and provide some overarching system of governance of the high seas". See FREESTONE, David. Problems of high seas governance. In: VIDAS, Davor; SCHEI, Peter Johan. The world ocean in globalization: climate change, sustainable fisheries, biodiversity, shipping, regional issues. Leiden: Nijhoff, 2011. p. 130.

48 See MCDORMAN, Ted L. et al. International Ocean Law: materials and commentaries. Durham: Carolina Academic Press, 2005. p. 264-5. gue. ${ }^{49} \mathrm{On}$ this quest, enforcement of international regulations is to be done exclusively by the flag state of the offending vessel. ${ }^{50}$

In order to match issue of IUU fishing, be it on national or international levels, international lawyers and decision-makers rely on the current legal framework that not only allows for, but also demands states to cooperate with each other in facing IUU threat. Besides the UNCLOS III, as a framework convention, states have signed the Straddling Fish Stocks Agreement in New York, 1995, with the main goal of enhancing the cooperative management of fisheries resources that occur in wide areas. It provides states with solid ground for the creation of Regional Fisheries Management Organizations (RFMO), which are "the only legally mandated fisheries management bodies on the high seas". ${ }^{51}$ This means that domestic commercial fishing fleets are obliged to abide those organizations' rules in order to fish in those areas. On this particular, it should be added that observers are skeptical as to the success of those organizations in fulfilling announced goals. ${ }^{52}$

49 Interesting enough is to note that maritime states with wellequipped coastal guards have attempted in the past to act unilaterally in combating IUU fishing on the high seas. It is the case of the unilateral action of the Canadian Coast Guard, who seized the Spanish fishing trawler Estai, caught fishing immediately off Canada's EEZ $200 \mathrm{~nm}$ limits. Despite good intentions and alleged ecological necessity, "neither customary nor conventional law of the sea permits one state to forcibly seize the fishing vessel of another state on the high seas for engaging in illicit fishing on the high seas, according to McDorman. The episode was known as the "Turbot war", and was pacifically solved when the European Union and Canada entered into an agreement in April 1995. See MCDORMAN, Ted L. et al. International Ocean Law: materials and commentaries. Durham: Carolina Academic Press, 2005. p. 265.

50 Despite the introduction of a global Unique Vessel Identifier (UVI) on fishing vessels, irrespective of the flag of the ship, the responsibility to enforce international obligations lies ultimately with the flag state. The UVI is a record given to ships that ensure reliable traceability and that marks the vessel for its entire life, regardless of changes in flag. It is part of a greater international effort to create a global record of fishing vessels, an important step in fighting illicit activities at the seas. For further information, see: UNITED NATIONS. Report of the Expert Consultation on the Development of a Comprehensive Global Record of Fishing Vessels. FAO, Rome, 2008.

51 FOOD AND AGRICULTURE ORGANIZATION OF THE UNITED NATIONS. Straddling Fish Stock Agreement. New York: FAO, 1995.

52 Cullis-Suzuki and Pauly draft harsh critiques on the inability of RFMOs to achieve their main conservation goals in the high seas, due to individual and organizational problems, to the continued articulation of the principle of freedom of fishing, as well as to lack of genuine commitment. See: CULLIS-SUZUKI, Sarika; DANIEL, Pauly. Failing the high seas: a global evaluation of regional fisheries management organizations. Marine Policy, 2010. p. 7. 
Following this borderless effort to combat illicit fishing, the Organization for Economic Co-operation and Development (OECD) equipped its own fisheries division, responsible for elaborating not only reports on the status of IUU fishing, but also possible courses of actions for all actors involved. According to the methodology adopted by the reports, each of the terms contained in IUU fishing is defined as follows: $:^{53}$ "illegal fishing" is that activity "conducted by vessels of countries that are parties to a Regional Fisheries Management Organization (RFMO) but operate in violation of its rules, or operate in a country's waters without permission". "Unreported fishing" refers to that "catch not reported or misreported to national relevant authorities or RFMO". Finally, "unregulated fishing" is considered that "conducted by vessels without nationality or flying the flag of States not parties of relevant fisheries organizations and who therefore consider themselves not bound by their rules." ${ }^{54}$ Needless to highlight that these categories might cumulate in specific cases.

Another important actor in the struggle against IUU fishing is the FAO, as already pointed out in the introductory remarks. The Organization counts on a specific department and a Committee on Fisheries (COFI), based on the premise that a shortage of fishes would negatively affect food security in the planet. For that reason, the Committee has adopted in 2014 the Voluntary Guidelines for Flag State Performance, ${ }^{55}$ which establishes criteria to clarify the obligations assumed by states. Noteworthy enough, those obligations could be regarded as of "due diligence" towards port-state duties and the registration of vessels. In fact, paragraph 2 of the Guidelines establish that flag states should:

(c) prevent, deter and eliminate IUU fishing or fishing related activities in support of such fishing; (d) effectively exercise its jurisdiction and control over vessels flying its flag; (e) take measures to ensure that persons subject to its jurisdiction, including owners and operators of vessels flying its flag, do not support or engage in IUU fishing or fishing related activities in support of such fishing. ${ }^{56}$

53 The definition of IUU fishing adopted by the OECD resembles the one put forward by the IPOA-IUU adopted by the FAO and analyzed at the introductory chapter of this paper.

54 See SCHIMDT, Carl-Christian. Addressing Illegal, Unreported and Unregulated (IUU) Fishing. International Fisheries Compliance Conference, Brussels, 2004. Available at: <http://www.oecd.org/greengrowth/fisheries/34029751.pdf>. Access on: 29 Apr. 2015.

55 FOOD AND AGRICULTURE ORGANIZATION OF THE UNITED NATION. Voluntary Guidelines for Flag State Performance, Rome: FAO, 2014. Available at: <http://www.fao.org/fishery/topic/16159/en>. Visited on: 29 Apr. 2015.

56 FOOD AND AGRICULTURE ORGANIZATION OF THE UNITED NATION. Voluntary Guidelines for Flag State Perfor-
Moreover, other key soft law instruments are the Code of Conduct for Responsible Fisheries (1995) and the Rome Declaration on Illegal, Unreported and Unregulated Fishing (2005), the latter adopted by the FAO Ministerial Meeting on Fisheries. In short, the Code of Conduct has the main goal to provide "principles and standards applicable to the conservation, management and development of fisheries", covering the capture, processing and trade of fish and fishery products, and the integration of fisheries into coastal area management, according to article $1 .{ }^{57}$ The 2005 Rome Declaration calls for effective implementation efforts of already existing rules. Both the Code of Conduct and the Voluntary Guidelines confirm the leading role of FAO's action plans in tackling IUU fishing. Nonetheless, stronger coordination between international organizations (including the International Maritime Organization - IMO) and states, especially focused on increasing the accuracy of marine scientific data on fisheries, could represent a major step in fighting illegal fishing.

Finally, the UNGA Resolution 61/105, approved in 2006, calls upon states to take action immediately, individually and through regional fisheries organizations and arrangements to manage fish stocks sustainably and protect vulnerable marine ecosystems from destructive fishing practices. Indeed, according to paragraph 5, states ought to apply widely "the precautionary approach and an ecosystem approach to the conservation, management and exploitation of fish stocks." This resolution incorporates the need for a closer interplay between LOS and environmental considerations, especially the integrated approach, if the sustainable exploitation of fisheries is to succeed. Such interaction is ongoing, especially regarding the high seas framework, which according to Freestone, "was transformed by the new concerns for ecosystem maintenance and conservation of biological diversity." 58

mance. FAO, Rome: FAO, 2014. p. 6.

57 FOOD AND AGRICULTURE ORGANIZATION OF THE UNITED NATION. Code of Conduct for Responsible Fisheries. Rome, 1995. Available at: <http://www.fao.org/docrep/005/ v9878e/v9878e00.htm>. Visited on: 29 Apr. 2015.

58 See FREESTONE, David. Problems of high seas governance. In: VIDAS, Davor; SCHEI, Peter Johan. The world ocean in globalization: climate change, sustainable fisheries, biodiversity, shipping, regional issues. Leiden: Nijhoff, 2011. p. 118. 


\section{From the zonal to a more integrated APPROACH TO THE MANAGEMENT OF FISHERIES}

Grotius' assumptions underpinning the mare liberum theory are now fundamentally outdated. Unlike the panorama that the Dutch author had at hand, ocean resources are currently known to be finite, with overfishing already threatening entire species; states nowadays have all technological means to establish maritime boundaries with amazing precision; and regardless of how immense oceans are, maritime conflicts are most likely to arise, due also to an international security agenda set forward after 9/11 and the "war on terror". Confirming this rationale, Shaw considers that "the predominance of the concept of the freedom of the high seas has been modified by the realization of resources present in the sea and the seabed beyond the territorial sea." 59

The traditional approach, based on the opposition between sovereignty rights and the freedom of the seas, has proven insufficient to tackle current challenges, mainly those related to the sustainable exploitation of the world's fisheries. In line with Yoshifumi Tanaka, three main problems undermine effectiveness in fighting issues such as IUU fishing. Firstly, the separation between law and nature, when marine spaces are divided spatially. If one considers that the distance criterion ignores ecological interactions between marine species and ecological conditions, it becomes clear the need to develop a broader approach to the governance of large marine ecosystems. In the words of Tanaka, "as the ocean is a dynamic natural system, it is logical that international law of the sea must take the dynamics of nature into account", what has not been optimally happening in the past decades, as will be explained later on. ${ }^{60}$

The second main difficulty refers to the ongoing sectorial approach to different fields of LOS, such as shipping, fishing and environmental protection, thus ignoring interrelationships between marine issues. In legal literature, the need to "focus on the interplay between marine issues from holistic viewpoints" is of-

59 See SHAW, Malcolm. International Law. 6. ed. Cambridge: CUP, 2008. p. 554

60 See TANAKA, Yoshifumi. A Dual Approach to Ocean Governance: the cases of zonal and integrated management in International Law of the Sea. Paris: The Ashgate International Law Series, 2008. p. 6. ten emphasized, ${ }^{61}$ regardless of how demanding such a shift might be. Thirdly, the two traditional principles of sovereignty over marine resources and freedom to roam the seas pose challenges to the implementation of sound sustainable practices in managing fisheries and, consequently, need a revision. When it comes to the protection of marine living resources, the "freedom of the seas" loses its validity. Instead of the laissez-faire freedom system, states ought to focus on the "duty to have due regard to the rights of other States and the need of conservation for the benefit of all." ${ }^{62}$ Similarly, instead of the absolute principle of sovereignty, a legal framework capable of resolving problems of marine pollution and conservation of living resources within maritime zones of states should be stimulated.

For those reasons, the quest for a more "integrated management approach" would not only add coherence and completeness to the LOS, but also contribute to tackling IUU fishing. Such an approach is already present in international instruments, for instance, the Agenda 21, adopted after the Rio Conference of 1992, and the UN General Assembly Resolution 60/30, agreed in 2009. While the former advanced the integrated approach to the planning and management of land resources (principle 10.1), ${ }^{63}$ the latter included socio-economic aspects to the reporting and assessment of the status of marine environments (par. 89), in an attempt to grasp a broader picture of the ongoing marine conservation efforts. ${ }^{64}$ The problem lies on the fact that those international instruments use this approach in a rather loose manner, given the conceptual blurriness of "integrated". There is not a definition, but a purpose, which is to outreach the traditional approach, and face challenges more effectively, amongst which IUU fishing. ${ }^{65}$

61 Se TANAKA, Yoshifumi. A Dual Approach to Ocean Governance: the cases of zonal and integrated management in International Law of the Sea. Paris: The Ashgate International Law Series, 2008. p. 7. 62 ICJ, Fisheries Jurisdiction Case, United Kingdom v. Ireland, 1974.

63 FOOD AND AGRICULTURE ORGANIZATION OF THE UNITED NATIONS. Agenda 21, World Conference on Environment and Development. Rio de Janeiro, 1992.

64 The UN Resolution 60/30 was suggested by the Intergovernmental Oceanographic Commission of the UNESCO. Available at: <http://ioc-unesco.org/index.php?option $=\mathrm{com}_{-}$ oe\&task=viewDocumentRecord\&doc ID $=4289>$. Visited on: 29 Apr. 2015.

65 As for the concept of "international community" and its multifaceted nature, see SIMMA, Bruno; PAULUS, Andreas. The international community: facing the challenges of globalization. EJIL, v. 9, n. 2,1998 
It is now clear that the challenges to a sustainable marine governance are manifold and call for an urgent migration from sectorial responses to integrated policies, ${ }^{66}$ which would imply some steps to achieve a sound marine environmental status. Policies that take into account the multidimensional status of environmental protection and, accordingly, consider economic, technological and political factors. As Tanaka rightly puts it, "since conservation measures inevitably affect national development, there is a need to reconcile these measures with the economic, technological and political circumstances of every state." ${ }^{97}$ On an international judicial level, the advisory opinion on flag state responsibility for IUU fishing recently rendered by the ITLOS might represent a step towards a renewed, ecosystem-oriented approach to oceanic problems.

\section{The Advisory Opinion of the ITLOS: aVant guardisme In the LaW of the Sea}

The UNCLOS III is based, regarding fisheries' issues, on the principle of exclusive jurisdiction of the flag state, although the current panorama shows that the principle alone is inadequate for ensuring compliance with and enforcement of rules. Bearing these considerations in mind, and looking forward to improved manners to hold flag states responsible, the Sub-Regional Fisheries Commission (SRFC) submitted a request for advisory opinion to the International Tribunal for the Law of the Sea (ITLOS) in March 2013. ${ }^{68}$ Interesting enough, it was the first time that the full Tribunal

66 In the case of the European Union, a major step was taken with the adoption of the European Directive on Marine Strategy Framework (2008), according to which 11 qualitative descriptors outline what the document defines as "good environmental status". The main and ambitious goal of the Directive is to provide diverse and dynamic oceans and seas, which are clean, healthy and productive (overall aim of promoting sustainable use of the seas and conserving marine ecosystems). See CHURCHILL, Robin. The European Union and the challenges of marine governance: from sectoral response to integrated policy? In: VIDAS, Davor; SCHEI, Peter Johan. The world ocean in globalization: climate change, sustainable fisheries, biodiversity, shipping, regional issues. Leide: Nijhoff, 2011.

67 See TANAKA, Yoshifumi. A Dual Approach to Ocean Governance: the cases of zonal and integrated management in International Law of the Sea. Paris: the Ashgate International Law Series, 2008. p. 241.

68 Such a procedure is established in article 138 of the Rules of the Tribunal, which grants ITLOS jurisdiction over contentious and advisory cases. rendered an advisory opinion, instead of just a special chamber, and in April 2015, the ITLOS published the definitive Advisory Opinion. ${ }^{69}$

The SRFC focused, in four questions, on assessing both the responsibility and liability of flag states upon IUU fishing activities conducted within the EEZ of third party states. ${ }^{70}$ The original questions were:

1. What are the obligations of the flag State in cases where illegal, unreported and unregulated (IUU) fishing activities are conducted within the Exclusive Economic Zone of third party States?

2. To what extent shall the flag State be held liable for IUU fishing activities conducted by vessels sailing under its flag?

3. Where a fishing license is issued to a vessel within the framework of an international agreement with the flag State or with an international agency, shall the State or international agency be held liable for the violation of the fisheries legislation of the coastal State by the vessel in question?

4. What are the rights and obligations of the coastal State in ensuring the sustainable management of shared stocks and stocks of common interest, especially the small pelagic species and tuna?

The organization responsible for the request to the ITLOS is an intergovernmental organization created in 1985 by a Convention that united Cabo Verde, Gambia, Guinea, Guinea-Bissau, Mauritania, Senegal, and Sierra Leone in the struggle against the depletion of living resources off their coasts. Already on the preamble, the Sub-Regional Commission stresses the relevance of coastal states to cooperate among each other and harmonize domestic policies on fisheries, so as to rea-

69 See ITLOS. Advisory Opinion on the Request submitted to the Tribunal by the Sub-Regional Fisheries Commission. Case 21, Hamburg, 2015. For complementary views on the advisory opinion, see: OLIVEIRA, Carina Costa de, and MALJEAN-DUBOIS, Sandrine. Os limites dos termos bem público mundial, patrimônio comum da humanidade e bens comuns para delimitar as obrigações de preservação de recursos marinhos. In: Varella, Marcelo D. Revista de Direito Internacional, vol.12, no.1 (current edition). See also: OLIVEIRA, Carina Costa de. Comentário à Opinião Consultiva 21 do Tribunal Internacional para o Direito do Mar [02/04/2015] In: Varella, Marcelo D. Revista de Direito Internacional, vol.12, no.1 (current edition).

70 Flag States such as Panama and Togo are often cited as "safe havens" for irregular vessels that engage in IUU fishing activities. The practice of granting "flags of convenience" to troubled ships is also widespread, despite the detrimental effects they bear to the management of fisheries worldwide. The Environmental Justice Foundation provides detailed information on "flags of convenience" and states engaged in this practice. See ENVIRONMENTAL JUSTICE FOUNDATION. Pirates and profiteers: how pirate fishing fleets are robbing people and oceans. London, 2005. 
ch a balance between conservation and exploitation of those resources. As it could not have been different, the economic and political element of national development was present, as well as the care for the nutritional needs of local populations. ${ }^{71}$

The Sub-Regional Commission illustrates long-ranged sight and good intentions in the struggle against IUU fishing within maritime zones of its member states. Amongst the objectives of the SRFC, emphasis is added to the coordination of policies in terms of the adoption of international best practices, the development of sub-regional cooperation with regard to tracing, controls and surveillance, and the improvement of members' research capacities in fisheries sciences on the sub-regional level. Besides local efforts to repress illegal fishing, it should be praised that the Commission, which is legally entitled to stand before courtrooms, has also engaged in juridical battles in order to achieve the main goal of sustainable fishing activities.

Following the request for the advisory opinion, the Tribunal received two rounds of written statements by a plethora of international actors, including Member States to the UNCLOS III, States Parties to the 1995 Straddling Fish Stocks Agreement, ${ }^{72}$ Intergovernmental Organizations, ${ }^{73}$ as well as Non-Governmental Organizations. ${ }^{74}$ At this moment, several states raised preliminary questions alleging the lack of jurisdiction of the Tribunal to render advisory opinions. Countries such as the United States, China, Australia, Spain, the United Kingdom, Ireland, among others, have supported this claim. $^{75}$

71 In the original document, written in French, contracting states highlight "la nécessité, pour les pays riverains, de coopérer et d'oeuvrer en vue de l'harmonisation de leurs politiques en matière de préservation, de conservation et d'exploitation des ressources halieutiques de la sous-région, ainsi que le besoin de coopérer au développement de leurs industries nationales de pêche." See Convention of Sub Regional Fisheries Commission, Praia, Cabo Verde, 1985. Available at: <http://www.spcsrp.org/medias/csrp/documents/ CSRP-1993-ConvPraya.PDF>. Visited on: 25 Apr. 2015.

72 The United States presented a statement as member of this treaty, given that they have not ratified the UNCLOS III so far.

73 Important intergovernmental organizations to pronounce on this case were: the Forum Fisheries Agency, the International Union for Conservation of Nature and Natural Resources, the Caribbean Regional Fisheries Mechanism, the United Nations, the Food and Agriculture Organization of the United Nations, and the Central American Fisheries and Aquaculture Organization.

74 The World Wildlife Fund (WWF) acted as amicus curiae by submitting a brief.

75 Noteworthy is the fact that the Republic of China is known for massively engaging in IUU fishing in several regions of the
On the preliminary questions, the judges decided unanimously that the Tribunal has conventional jurisdiction to entertain requests for advisory opinions. According to the decision, the UNCLOS III does not encapsulate the contentious function of the Tribunal, whose Statute (Annex VI) allows for it. The ITLOS has jurisdiction to decide on "all matters", which encompasses more than just disputes. If it were not so, the legal wording should expressly display "disputes". That is the result of a combined interpretation of articles 21 and 138 of the Statute of the ITLOS. ${ }^{76}$ Besides, the Tribunal considered that the questions asked were legal in nature, for they were made in terms of law and demanded complex juridical interpretation in order to render an opinion. Moreover, consistent with paragraph 77 of the opinion, "the Tribunal is mindful of the fact that by answering the questions it will assist the SRFC in the performance of its activities and contribute to the implementation of the Convention." For this reason, amongst others, the ITLOS deemed it appropriate to render the advisory opinion.

As for the material content of the opinion, in general lines, the Tribunal considered that the flag state has a duty "to ensure" that vessels flying its flag abide by the law of coastal states where fishing activities are taking place. The "responsibility to ensure" is enshrined in the provisions of article 58 (3) (rights and duties of other states in the EEZ), article 62 (4) (utilization of the living resources), and article 192 (general obligation to protect and preserve the marine environment) of the UNCLOS III. The combined interpretation of those instruments leads to the conclusion that flag states have to take the necessary measures to ensure that vessels flying its flag are not engaged in IUU fishing activities.

The "responsibility to ensure" does not lead, however, to automatic liability of flag states for wrongdoing of ships flying their flags. When tackling this question, the Tribunal explicitly referred to the obligations of "due diligence" from article 125 to 140 , and made a

globe. See: LARSEN, Christina. China's illegal fishing expeditions threaten world's waters. Bloomberg Business. November 19, 2013. Available at: <http://www.bloomberg.com/bw/articles/2013-11-19/chinas-illegal-fishing-expeditions-threaten-world-waters $>$. Access on: 26 Apr. 2015.

76 Article 21 of the Statute reads, "The jurisdiction of the Tribunal comprises all disputes and all applications submitted to it in accordance with this Convention and all matters specifically provided for in any other agreement, which confers jurisdiction on the Tribunal." 
clear distinction between obligations of "due diligence" and obligations of result. ${ }^{77} \mathrm{~A}$ remarkable development is, however, the reinforcement of the principle of due diligence and of "obligations of conduct" in the LOS. According to the reasoning of the ITLOS, the obligation of due diligence

\begin{abstract}
$[\ldots]$ is not an obligation of the flag State to achieve compliance by fishing vessels flying its flag in each case with the requirement not to engage in IUU fishing in the exclusive economic zones of the SRFC Member States. The flag State is under the "due diligence obligation" to take all necessary measures to ensure compliance and to prevent IUU fishing by fishing vessels flying its flag. ${ }^{78}$
\end{abstract}

The opinion based on the obligations of "due diligence" reinforces previous international case law. The Pulp Mills on the River Uruguay case, before the International Court of Justice (ICJ), is a case in point. Comprising a dispute between Argentina and Uruguay, the contention related to the construction and operation of pollutant pulp mills on the banks of the River Uruguay, i.e. on the borders of both countries. In the best interest of this paper, it is notable that the Court outlined, although superficially, the content of due diligence obligations. The final ruling considers that such obligations "entail not only the adoption of appropriate rules and measures, but also a certain level of vigilance in their enforcement and the exercise of administrative control applicable to public and private operators, such as the monitoring of activities undertaken by such operators, to safeguard the rights of the other party." 79

Within the jurisprudence of the ITLOS, efforts to consolidate the "due diligence" principle began in 2011, when the Seabed Disputes Chamber addressed a Request of the International Seabed Authority regarding "responsibilities and obligations of states sponsoring persons and entities with respect to activities in the Area". ${ }^{80}$ The content of the "due diligence" obligation,

77 Among the obligations of due diligence established by the UNCLOS III and relating to the fighting of IUU fishing, the following deserve special attention: the obligation to inform, to cooperate (art. 64 (1) UNCLOS III), to ensure the adoption of conservation and management measures (article 61, UNCLOS III), and to undertake mutual consultations (article 300, UNCLOS III) with third states on whose coast IUU fishing activities are being conducted.

78 ITLOS, Advisory Opinion on the Request submitted to the Tribunal by the Sub-Regional Fisheries Commission. Case 21, 2015, para. 129.

79 See Pulp Mills on the River Uruguay case, (Argentina v. Uruguay), Judgment, ICJ, para. 197.

80 The ISBA is an organization created by the UNCLOS III although still vague, was scrutinized between paragraphs 110 and 120 of that opinion.

In paragraph 110, ITLOS considered that the obligation of due diligence is not an obligation of result, but an obligation of means. In fact, "[t]he sponsoring State's obligation "to ensure" is not an obligation to achieve, in each and every case, the result that the sponsored contractor complies with the aforementioned obligations. Rather, it is an obligation to deploy adequate means, to exercise best possible efforts, to do the utmost, to obtain this result. To employ terminology dear to international law, this obligation may be characterized as an obligation "of conduct" and not "of result", as well as an obligation of "due diligence". The relevance of this previous case law should not be underestimated, given that in the Advisory Opinion on flag states responsibility for IUU fishing, the Tribunal refers several times to those two decisions in order to base its legal reasoning. ${ }^{81}$

It is likely that the opinion be welcomed with skepticism, especially by coastal states who awaited more precise considerations on flag state responsibilities. It might also not have been the dream opinion expected by the international legal scholarship, because the ITLOS essentially denied to stipulate any concrete "measure" that flag states are obliged to undertake in fulfilling the "due diligence" principle. ${ }^{82}$ In fact, if the flag state

alongside the International Tribunal for the Law of the Sea. For detailed information on this treaty body, see: CHIRCOP, A. E. Operationalizing Article 82 of the United Nations Convention on the Law of the Sea: A New Role for the International Seabed Authority? Ocean Yearbook, v. 18, 2004. Institutional information on the ISBA. Available at: <https://www.isa.org.jm/> Visited on: 28 Apr. 2015. 81 The resort to analogies and to jurisprudence of the ICJ is harshly criticized by Judge Cot, who considers that this strategy weakens the Court to the eyes of the international community. His separate opinion reads: "Ma réserve principale tient au refus, par le Tribunal, d'assumer l'exercice de son pouvoir discrétionnaire de répondre ou non aux questions qui lui sont posées dans une procédure contentieuse. Pour justifier ce refus, le Tribunal s'abrite derrière la jurisprudence de la Cour internationale de Justice et déclare qu'il est bien établi qu'une demande d'avis consultatif ne doit pas être rejetée, sauf pour des " raisons décisives ». (Declaration of Judge Cot, par. 5).

82 On their separate opinions, Judges Wolfrum and Lucky have highlighted some discontent themselves. On the one hand, Judge Wolfrum considers that the advisory opinion could and should have been more detailed on its considerations, besides addressing the issue of reparation of damages, as established by the Draft Articles of the ILC on State Responsibility for Wrongful Acts (Declaration of Judge Wolfrum, par. 1). On the other hand, Judge Lucky highlighted the creative role of international judges in welcoming new approaches and considering technological advancements (Declara- 
can prove that all necessary measures to prevent IUU fishing were duly taken, it shall not be held liable for damages produced. ${ }^{83}$ In this juncture, to prove that administrative measures preceded the registration of fishing vessel could theoretically shield flag states against compensation claims. Besides such an elusiveness, the advisory opinion was also explicit in confining its effects to the EEZ of the member States to the SRFC, leaving the responsibilities of flag states for IUU fishing on the high seas for a coming opinion. ${ }^{84}$

Dissatisfactions aside, the advisory opinion ought to be praised for the positive developments it entails. Firstly, it consists of an international decision situated in an important intersection between fields of international law, and the permeability between such fields deserves to be further stimulated. In the opinion, the Tribunal approached the LOS with lenses of two different regimes of international law: principles of state responsibility and of international environmental law. ${ }^{85}$ Despite the vagueness of considerations, to invoke the principle of "due diligence" in the law of the sea, a principle still in the making, with strong environmental foundations, is to foster the shift from a purely traditional approach towards an integrated approach to the solution of ocean issues.

Secondly, although the Tribunal avoided specifically addressing the environmental facet of "due diligence" obligations, it is likely that future proceedings will ground claims on the objective breach of "due diligence" obligations. Intergovernmental organizations dedicated to fisheries governance have from now on a concrete foundation to base future claims of compensation for IUU fishing. The opinion, therefore, fosters states to adopt binding requirements, for instance, for the registration of

tion of Judge Lucky, par. 12).

83 Paragraph 146 of the Advisory Opinion reads: "the liability of the flag State does not arise from a failure of vessels flying its flag to comply with the laws and regulations of the SRFC Member States concerning IUU fishing activities in their exclusive economic zones, as the violation of such laws and regulations by vessels is not per se attributable to the flag State." See: Advisory Opinion on the Request submitted to the Tribunal by the Sub-Regional Fisheries Commission. ITLOS, Case 21, 2015.

84 Paragraph 154 reads: "the Tribunal considers that, in light of its conclusion that its jurisdiction in this case is limited to the exclusive economic zones of the SRFC Member States [...]." See: Advisory Opinion on the Request submitted to the Tribunal by the Sub-Regional Fisheries Commission. ITLOS, Case 21, 2015.

85 On the interaction between special regimes of international law, see VENTURA, Victor Alencar Mayer Feitosa. Ecologização do direito internacional bumanitário: proteção ambiental em tempos de guerra. João Pessoa: UFPB, 2014. fishing vessels. This measure would enable authorities to fight illegal fishing in a more efficient manner. Besides, those binding standards would support claims of flag state responsibility for illegal fishing, what could de-stimulate the emission of those flags of convenience and consequently represent a blow to IUU activities.

Hence, the content and extension of the principle should be systematically outlined, in order to prospectively delimit the substance of those "obligations of means" that influence the effectiveness of the struggle against IUU fishing. It is also possible that the advisory opinion be interpreted in an extensive fashion, so as to comprise maritime zones other than just the EEZ of member states to the SRFC, therefore, including the much fragile high seas. Overall, the Advisory Opinion herein analyzed builds on a history of progressive decisions rendered by the ITLOS that gradually enhance the international legal framework relating to responsibility rules within the law of the sea.

\section{Concluding Remarks}

In short, the International Law of the Sea in this century still faces the dichotomy between freedom of navigation and controlled access, which embodies a traditional approach to maritime issues. This approach, in essence, divides the ocean into several jurisdictional spaces balancing the principle of sovereignty and the principle of freedom. Nonetheless, international legal scholarship and institutions have noticed the need for a more integrated approach, which is inspiring global and regional conventions and other soft law documents.

The mare liberum can no longer exist, for it was formulated for another era, another historic moment. If applied vigorously, as the (absolute) freedom of fishing, for instance, this principle might limit effective enforcement of regulations on problems that deeply affect the ocean, such as IUU fishing. The sovereignty perception of the oceans' resources cannot represent, on the other hand, a barrier to the application of an integrated approach to the management of fisheries.

The current legal framework regarding IUU fishing provides the foundation for implementing such a renewed approach. Indeed, not only hard law, as the UNCLOS III and the 1995 Straddling Fish Stocks Agreement, but also soft law, as the Voluntary Guidelines of 
FAO and the UN Resolution 61/105, provide a relatively fertile field upon which an integrated approach may be build. However, the work of international organizations and the International Tribunal for the Law of the Sea is indispensable for the interpretation and consequent consolidation of new perspectives on ocean governance schemes. The main goal of current and future efforts ought to be the limitation of human impact on ecological systems, while taking into account contemporary demands for national development and economic growth.

For those reasons, the ITLOS was asked to render an advisory opinion on the flag state responsibility for IUU fishing activities conducted within the EEZ of third states party to the UNCLOS III. At the first moment, the Tribunal engaged in a fructiferous line of reasoning, recognizing the existence of "due diligence" obligations falling upon flag states relating to IUU fishing. Shortly afterwards, however, it refused to accept the possibility of holding a flag state liable for wrongful acts of vessels flying their flag.

Overall, despite likely skepticism of the legal literature towards the advisory opinion, considering the historical supremacy of a sectorial approach to the LOS, the opinion instigates clearly positive outcomes. Based on the principle of "due diligence", the Tribunal has not only reinforced the interaction between the LOS and other regimes, such as the law of responsibility and the environmental law, but also nurtured the shift from a purely traditional towards an integrated approach to tackling oceanic issues as grave as the IUU fishing.

\section{References}

ALLOT, Philip. Mare nostrum: a new international Law of the Sea. In: ROTHWELL, Donald R. (Ed.). Law of the Sea. Cheltenham: Edward Edgar, 2013. p. 793-816.

BAIRD, Rachel J. Aspects of illegal, unreported and unregulated fishing in the Southern Ocean. Dordrecht: Springer, 2006.

BARROS-PLATIAU, Ana Flávia et al. Correndo para o mar no antropoceno: a complexidade da governança dos oceanos e a estratégia brasileira de gestão dos recursos marinhos. In: Varella, Marcelo D. Revista de Direito
Internacional, vol.12, no.1 (current edition).

CHIRCOP, A. E. Operationalizing Article 82 of the United Nations Convention on the Law of the Sea: a New Role for the International Seabed Authority? Ocean Yearbook, v. 18, 2004.

CHURCHILL, Robin. The European Union and the challenges of marine governance: from sectoral response to integrated policy? In: VIDAS, Davor; SCHEI, Peter Johan. The world ocean in globalization: climate change, sustainable fisheries, biodiversity, shipping, regional issues. Leide: Nijhoff, 2011. p. 395-436.

CHURCHILL, Robin. Uncertainties in International High Seas Fisheries Management. Fisheries Research, v. 37, 1998.

CORTEN, Olivier. Méthodologie du droit internationale public. Bruxelles: Editions de l'Université de Bruxelles, 2009.

OLIVEIRA, Carina Costa de. Comentário à Opinião Consultiva 21 do Tribunal Internacional para o Direito do Mar [02/04/2015] In: Varella, Marcelo D. Revista de Direito Internacional, vol.12, no.1 (current edition).

OLIVEIRA, Carina Costa de, and MALJEAN-DUBOIS, Sandrine. Os limites dos termos bem público mundial, patrimônio comum da humanidade e bens comuns para delimitar as obrigações de preservação de recursos marinhos. In: Varella, Marcelo D. Revista de Direito Internacional, vol.12, no.1 (current edition).

CULLIS-SUZUKI, Sarika; DANIEL, Pauly. Failing the high seas: a global evaluation of regional fisheries management organizations. Marine Policy, 2010.

ENVIRONMENTAL JUSTICE FOUNDATION. Pirates and profiteers: how pirate fishing fleets are robbing people and oceans. London, 2005.

FOOD AND AGRICULTURE ORGANIZATION OF THE UNITED NATIONS. Code of Conduct for Responsible Fisheries. Rome: FAO, 1995.

FOOD AND AGRICULTURE ORGANIZATION OF THE UNITED NATIONS. Convention on the Law of the Sea. Montego Bay: FAO, 1982.

FOOD AND AGRICULTURE ORGANIZATION OF THE UNITED NATIONS. International Plan of Action to Prevent, Deter and Eliminate IUU Fishing. Rome: FAO, 2001. 
FOOD AND AGRICULTURE ORGANIZATION OF THE UNITED NATIONS. Pulp Mills on the River Uruguay case, Argentina v. Uruguay. Judgment, 2010, ICJ.

FOOD AND AGRICULTURE ORGANIZATION OF THE UNITED NATIONS. Report of the Expert Consultation on the Development of a Comprehensive Global Record of Fishing Vessels. Rome: FAO, 2008.

FOOD AND AGRICULTURE ORGANIZATION OF THE UNITED NATIONS. Review of the state of the world marine fisheries resources. Rome: FAO, 2014.

FOOD AND AGRICULTURE ORGANIZATION OF THE UNITED NATIONS. Rome Declaration on IUU Fishing. Rome: FAO, 2005.

FOOD AND AGRICULTURE ORGANIZATION OF THE UNITED NATIONS. Straddling Stock Fish Agreement. New York: FAO, 1995.

FOOD AND AGRICULTURE ORGANIZATION OF THE UNITED NATIONS. Voluntary Guidelines for Flag State Performance. Rome: FAO, 2014.

FREESTONE, David. Problems of high seas governance. In: VIDAS, Davor; SCHEI, Peter Johan. The world ocean in globalization: climate change, sustainable fisheries, biodiversity, shipping, regional issues. Leiden: Nijhoff, 2011. p. 99-132.

GALINDO, George Rodrigo Bandeira. Quem diz bumanidade pretende enganar?: internacionalistas os usos da noção de patrimônio comum da humanidade aplicada aos fundos marinhos (1967-1994). 2006. PhD (Dissertation). Brasilia: University of Brasília, 2006.

GOLITSYN, Vladimir. Major challenges of globalization for seas and oceans: legal aspects. In: VIDAS, Davor; SCHEI, Peter Johan. The world ocean in globalization: climate change, sustainable fisheries, biodiversity, shipping, regional issues. Leide: Nijhoff, 2011.

GROTIUS, Hugo. The Free Sea, trans. Richard Hakluyt, with William Welwod's Critique and Grotius's Reply, ed. David Armitage. Indianapolis: Liberty Fund, 2004. p. 95. Available at: <http://oll.libertyfund.org/ titles/859\#Grotius_0450_251>. Access on: 24. Mar. 2015.

INTERNATIONAL COURT OF JUSTICE. Fisheries Jurisdiction Case, United Kingdom v. Ireland, 1974.
INTERNATIONAL TRIBUNAL FOR THE LAW OF THE SEA. Advisory Opinion on the Request submitted to the Tribunal by the Sub-Regional Fisheries Commission. Hamburg, 2015.

INTERNATIONAL TRIBUNAL FOR THE LAW OF THE SEA. Advisory Opinion to the request of the International Seabed Authority regarding responsibilities and obligations of states sponsoring persons and entities with respect to activities in the Area. Hamburg, 2011.

JOHNSTON, Douglas M. The theory and history of ocean boundary making. Montreal: McGill-Queens University Press, 1988.

KIRCHNER, Andree. The Outer Continental Shelf: background and current developments. In: NDIAYE, Tafsir; WOLFRUM, Rüdiger. Law of the Sea, Environmental Law and Settlement of Disputes: Liber Amicorum Judge Thomas A. Mensah. Leiden: Nijhoff, 2007. p. 593- 611.

KRASKA, James. The lost dimension: food security and the South China Sea disputes. Harvard Law School National Security Journal, Online article, 2015. Availlable at: < http:/ / harvardnsj.org/2015/02/ the-lost-dimensionfood-security-and-the-south-china-sea-disputes/>. Access on: 29 Apr.2015.

LARSEN, Christina. China's illegal fishing expeditions threaten world's waters. Bloomberg Business. November 19, 2013. Available at: <http://www.bloomberg.com/bw/ articles/2013-11-19/china-s-illegal-fishing-expeditionsthreaten-world-waters >. Access on: 26 Apr. 2015.

LEEMANS, Eelco and RAMMELT, Thomas. Mare liberum or mare restrictum? Challenges for the Maritime Industry. In: VIDAS, Davor; SCHEI, Peter Johan. The world ocean in globalization: climate change, sustainable fisheries, biodiversity, shipping, regional issues. Leide: Nijhoff, 2011.

MCDORMAN, Ted L. et al. International Ocean Law: materials and commentaries. Durham: Carolina Academic Press, 2005.

MCDORMAN, Ted L. et al. The entry into force of the Law of the Sea Convention and South-East Asia: an introductory comment. In: MATICS, K. I.; MCDORMAN, T. (Ed.). Selected papers in commemoration of the entry into force of the U.N. Convention on the Law of the Sea. Bangkok: SEAPOL, 1995.

NORDQUIST, Myron; et al (Ed.). Freedom of navigation 
and globalization. Leiden: Nijhoff, 2015.

ODA, Shigeru. Fifty years of the Law of the Sea: with a special section on the International Court of Justice. The Hague: Kluwer Law International, 2003.

OETER, Stefan. Theorising the Global Legal Order: an Institutionalist Perspective. In: HALPIN, Andrew; ROEBEN, Volker (Ed.). Theorising the Global Legal Order. Hart: Oxford, 2009. p. 61-83.

OXMAN, Bernard. The territorial temptation: a siren song at sea. In: ROTHWELL, Donald R. (Ed.). Law of the Sea. Cheltenham: Edward Edgar, 2013. p. 3-24.

PIRTLE, Charles E. Military uses of ocean space and the law of the sea in the new millennium. Ocean Development and International Law, v. 31, n. 7, p. 11-32, 2000.

RANGEL, Vicente Marotta. Settlement of Disputes relating to the Delimitation of the Outer Continental Shelf: the role of International Courts and Arbitral Tribunals. In: ANUÁRIO BRASILEIRO DE DIREITO INTERNACIONAL, 11., 2007, Belo Horizonte: CEDIN, 2007. p. 232-247.

ROTHWELL, Donald R.; STEPHENS, Tim. Building on the strengths and addressing the challenges: the role of the Law of the Sea Institutions. Journal of Maritime Affairs, Philadelphia, v. 35, p. 131-156, 2004.

ROTHWELL, Donald R.; STEPHENS, Tim. The International Law of the Sea. Oxford: Hart, 2010.

SCELLE, George. Obssession du territoire. The Hague: Nijhoff, 1958.

SCHIMDT, Carl-Christian. Addressing Illegal, Unreported and Unregulated (IUU) Fishing. International Fisheries Compliance Conference, Brussels, 2004. Available at: <http://www.oecd.org/greengrowth/fisheries/34029751.pdf>. Access on: 29 Apr. 2015

SHAW, Malcolm. International Law. 6. ed. Cambridge: CUP, 2008.

SIMMA, Bruno; PAULUS, Andreas. The internatio- nal community: facing the challenges of globalization. EJIL, v. 9, n. 2, 1998.

SUB REGIONAL FISHERIES COMMISSION. Convention, Praia, Cabo Verde, 1985. Available at: <http:// www.spcsrp.org/medias/csrp/documents/CSRP1993-ConvPraya.PDF>. Access on: 25 Apr. 2015.

TANAKA, Yoshifumi. A Dual Approach to Ocean Governance: the cases of zonal and integrated management in International Law of the Sea. Paris: The Ashgate International Law Series, 2008.

TEUBNER, Gunther; FISCHER-LESCANO, Andreas. Regime Collisions: the vain search for legal unity in the fragmentation of global law. Michigan Journal of International Law, v. 25, n. 4, 2004.

TOMUSCHAT, Christian. International Law: ensuring the survival of mankind on the eve of a new century, RCADI, 1999.

VARGAS, Jorge A. Latin America and its contributions to the Law of the Sea. In: LAURSEN, Finn (Ed.). Towards a New International Marine Order. Leiden: Nijhoff, 1982.

VATTEL, Emmerich de. The Law of Nations: or principles of the law of nature applied to the conduct and affairs of nations and sovereigns. Philadelphia: Law Book Sellers, 1863.

VENTURA, Victor Alencar Mayer Feitosa. Ecologização do direito internacional humanitário: proteção ambiental em tempos de guerra. João Pessoa: UFPB, 2014.

VIDAS, Davor; SCHEI, Peter Johan (Ed.). The world ocean in globalization: climate change, sustainable fisheries, biodiversity, shipping regional issues. Leiden: Nijhoff, 2011.

WARNER, Robin. Protecting the oceans beyond national jurisdiction: strengthening the international law framework. Leiden: Nijhoff, 2009.

YOUNG, Margaret (Ed.). Regime interaction in International Law: facing fragmentation. Cambridge: CUP, 2012. 


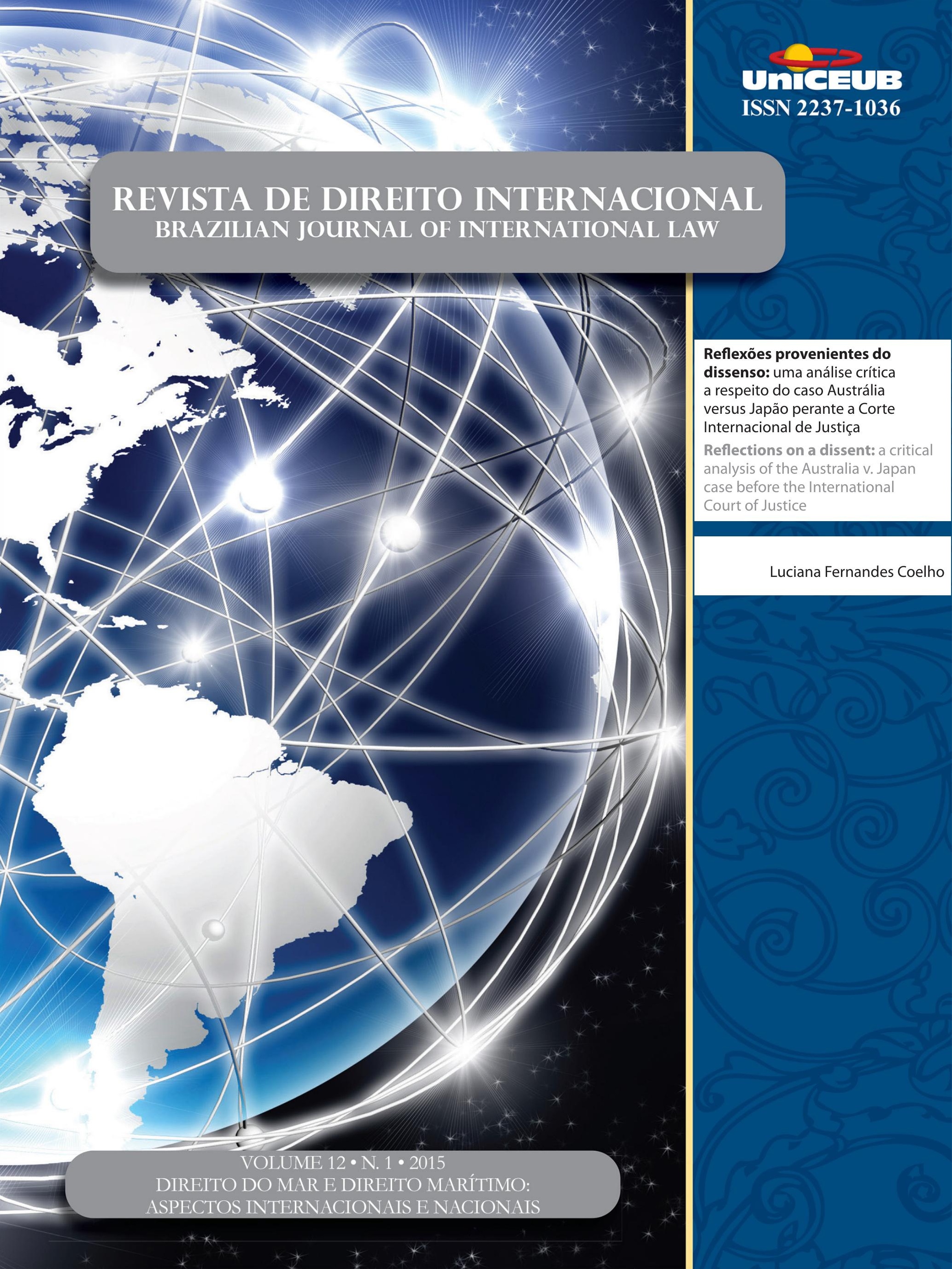




\title{
Reflexões provenientes do dissenso: uma análise crítica a respeito do caso Austrália versus Japão perante a Corte Internacional de Justiça*
}

\author{
Reflections on a dissent: a critical analysis \\ of the Australia v. Japan case before the \\ International Court of Justice
}

Luciana Ferna ndes Coelho**

\section{Resumo}

A Corte Internacional de Justiça apreciou pedido australiano contra o Japão por este ter supostamente concedido licença especial ao Projeto JARPA II sem que este tivesse fins científicos, conforme pressupõe o artigo VIII da Convenção Internacional sobre Regulação de Pesca às Baleias. Este trabalho tem por objetivo analisar criticamente a sentença do caso. Para tal, primeiramente, serão apresentadas algumas informações relevantes que contextualizam essa controvérsia. Em seguida, problematizar-se-á o mérito da sentença, enfocando dois aspectos: a metodologia do critério de exame (standard of review) e a ausência de pronunciamento da Corte sobre o conceito de pesquisa científica marinha (talvez inverter). Para tal, emprega-se o método dialético de contraposição entre os argumentos contidos na sentença e os formulados nas opiniões divergentes. A originalidade do artigo está no fato de analisar, criticamente, um caso recente, em que o Tribunal se encontra diante de uma controvérsia que envolve questões de mérito cientifico. Para tal, utilizou, de forma inédita, metodologia de análise, já empregada pela OMC em casos semelhantes, o stadard of the review. Ao final, observa-se que essa ferramenta metodológica gerou argumentos confusos, incoerentes e questionáveis, consequentemente, ao contrário de o julgamento gerar maior proteção à biodiversidade marinha, possibilitará que o Japão continue a realizar a atividade de pesca baleeira. Caso o Tribunal tivesse adotado postura sistêmica, utilizando-se das construções interpretativas realizadas por outros tribunais ou convenções internacionais a respeito da pesquisa científica marinha, a decisão poderia produzir maior estabilidade jurídica e proteção à biodiversidade.

Palavras-chave: Pesca. Baleias. Pesquisa científica. Marinha.

\section{Abstract}

The International Court of Justice tried an Australian request against Japan for having granted special license to JARPA II project, which supposedly was not for scientific purposes, as required by Article VIII of the International Convention for the Regulation of Whaling. This paper aims 
to analyze critically this trial. For that, first we present some background elements that might be help to understand the dispute. After that, we will analyze the merits of the decision focusing on two aspects: the methodological criteria adopted, standard of review, and the absence of the Court on defining marine scientific research. To do this, we employ the dialectic method, contrasting the arguments made in the judgment with those presented in the dissent opinions. The originality of the article lays in the fact that it analyses critically a recent case, wherein the Court faced scientific issues. For that purpose, the Court used a novel methodology called standard of review, already employed by WTO in similar cases. Finally, it is noticed that this methodology produced confusing, inconsistent and questionable arguments, therefore, on the contrary of providing more protection to marine biodiversity, the case will allow Japan to continue the whaling activity. If the Court had adopted a systemic approach, using the guidelines made by other courts or international conventions concerning the marine scientific research, the decision could have produced a greater legal stability and protection to biodiversity.

Keywords: Whaling. Whales. Scientific research.

\section{INTRODUÇão}

A Corte Internacional de Justiça - CIJ é identificada por alguns como o Tribunal Mundial. Para além das discussões doutrinárias invocadas por essa percepção, fato é que suas decisões são vinculantes, sem existir instancia recursal de suas decisões. Essa constatação incita reflexões como, por exemplo, a observação do poder atinente a esse tribunal e a responsabilidade inerente às teses defendidas por cada juiz, haja vista as proporções das consequências provenientes de suas decisões. No entanto, isso torna suas decisões infalíveis? Seriam elas impassíveis de críticas? Os juízes da Corte possuem expertise para apreciar todas as controvérsias apresentadas a eles?

Por óbvio que não. É notório que a tese da existência de um juiz Hércules, totalmente imparcial, que consegue abandonar suas percepções culturais e pessoais ao julgar, já está superada. É certo também que inexiste norma hipotética fundamental perfeita, limpa, branca de vícios e sem passado valorativo que mereça ser desconsiderado pelo órgão julgador no momento da aplicação da norma. Assim, deve ser pressuposto que cada argumento, cada posição, cada voto é imbuído da percepção do juiz, de sua interpretação e ideologia, de sua vivência e trajetória. No entanto, para que uma decisão jurídica seja socialmente aceita, ela deve ser imbuída de argumentos e embasada em provas suficientes para convencer à sociedade - nesse caso, poder-se-ia dizer "a sociedade dos Estados" - de sua razoabilidade.

Nesse contexto, na contramão da euforia demonstrada por alguns movimentos ambientalistas por ter o primeiro caso que versa sobre a caça às baleias julgado por tribunal internacional, o presente artigo se propõe a problematizar alguns posicionamentos, silêncios e contradições existentes na sentença do caso Whaling in the Antartic (Australia vs. Japan, New Zeland Intervening) — em especial, os decorrentes da omissão da Corte em relação ao conceito de pesquisa científica marinha e da adoção da metodologia do critério de exame, ${ }^{1}$ que, ao contrário do que os movimentos ambientalistas esperam, podem ter enfraquecido a legitimidade e a segurança jurídica da decisão.

Para tanto, realizar-se-á contraposição entre as teses acolhidas na sentença e os argumentos levantados nos votos divergentes e na doutrina. $\mathrm{O}$ estudo não pretende apontar se o Japão realiza caça de cunho comercial às baleias ou se a quantidade de baleias caçadas é ou não razoável em relação aos objetivos do Programa JARPA II. O ponto fulcral deste artigo consiste em demonstrar como a ferramenta de análise empregada pela Corte, que atesta abertura da $\mathrm{CIJ}$ ao funcionamento de outros tribunais, gerou decisão confusa e contraditória.

No caso supramencionado, a Corte foi incitada a decidir se o governo japonês violou: (i) a obrigação de manter a quota zero de caça às baleias com escopo comercial; (ii) a obrigação de não realizar caça comercial às baleias fin no Santuário Baleeiro do Oceano Austral (Southern Ocean Sanctuary); (iii) a moratória em relação à caça, captura e matança de baleias, exceto as baleias minke, por navios-fábrica ou por navios baleeiros ligados a navios-fábricas. A Austrália também solicitou que a finalidade da Segunda Fase do Programa Japonês de Pesquisa sobre as Baleias na Antártica sob Licença Especial (Seconde Phase of Japanese Whale Research Program under Special Permit in the

1 O termo "critério de exame" é uma tradução livre de "standard of the review", no original em inglês, e "critère d'examen", no original em francês. 
Antarctic - JARPA II) fosse declarada como diversa da investigação científica, ensejando a revogação de sua licença especial, e de qualquer outra que não tenha por fim realizar pesquisa científica. As obrigações violadas têm respaldo na Convenção Internacional para Regulação da Pesca a Baleias (International Convention for the Regulation of Whaling-ICRW) e em seu Cronograma anexo; na Convenção sobre o Comércio Internacional de Espécies da Fauna e Flora Selvagens Ameaçadas (Convention on International Trade in Endangered Species of Wild Fauna and Flora - CITES); e na Convenção sobre Diversidade Biológica (Convention on Biological Diversity $-C B D)^{2}$

O caso singulariza-se porque a Corte foi instada a apreciar questões de cunho eminentemente científico, ${ }^{3}$ ou seja, a classificação do Programa Jarpa II como pesquisa cientifica marinha - ou pesquisa marinha com finalidade científica - e, consequentemente, a legalidade da expedição de sua licença especial. Ademais, essa foi a primeira vez que a temática da caça às baleias com finalidade científica extrapolou os limites da Comissão Internacional para a Caça às Baleias (órgão da ICRW) e foi discutida em Tribunal Internacional. Outro aspecto que chama a atenção consiste na repercussão social e a sensibilidade que a temática da caça às baleias produz em razão do histórico de lutas da sociedade civil contra essa atividade, além das questões culturais, mitológicas, religiosas e econômicas envolvidas. Essa complexidade reflete-se na existência de somente um ponto do dispositivo em que houve unanimidade entre os juízes da Corte, qual seja, a competência do Tribunal para julgar o feito.

2 INTERNATIONAL COURT OF JUSTICE. 2014. 31 March. Whaling in the Antarctic Australia v. Japan: New Zealand intervening: mérits. Disponível em: <http://www.CIJ-cij.org/docket/index.php?p $1=3 \& \mathrm{p} 2=3 \& \mathrm{k}=64 \& \mathrm{case}=148 \& \operatorname{code}=\mathrm{aj} \& \mathrm{p} 3=4>$. Acesso em: 20 dez. 2014. p. 17.

3 Parte da doutrina identifica o litígio como uma "disputa científica", em que fatos, conhecimentos ou entendimentos científicos são necessários para a decisão. Esse tipo de controvérsia passou a ganhar notoriedade e a atrair a atenção dos juristas com base nos casos EC-Hormones e EC-Approval and Marketing of Biotech Products, julgados pelo órgão de apelação da OMC (cf. FOSTER, Caroline. Motivations and methodologies: was Japan's Whaling programme for purposes of scientific research? In: SIMPÓSIO WHALING IN THE ANTARCTIC: THE ICJ JUDGMENT AND ITS IMPLICATION, 2014, Kobe. Presentation Files and Papers... Kobe: Kobe University, 2014. Disponível em: <http://www.edu.kobe-u.ac.jp/ilaw/en/whaling_docs/paper_Foster.pdf>. Acesso em: 10 jan. 2015; FOSTER, Caroline. Public opinion and the interpretation of the World Trade Organisation's Agreement on Sanitary and Phytos Anitary Measures. Journal of International Economic Law, v. 11, n. 2, p. 427-458, Fev. 2008. Disponível em: <http://jiel.oxfordjournals.org>. Acesso em: 10 maio 2015. doi:10.1093/jie l/jgn011. p. 427-458.
Nesse contexto, o artigo será dividido em dois tópicos. O primeiro é majoritariamente descritivo, nele será apresentado o pano de fundo do caso, haja vista que, como pôde ser observado acima, a controvérsia envolve o conhecimento de Convenções e provisões jurídicas bem específicas, logo, para ser possível problematizar o caso, é necessário antes entendê-lo. Nesse ínterim, enfocar-se-á no histórico de criação da ICRW, da decretação da moratória de caça às baleias e a interpretação do artigo VIII da Convenção; serão apresentados os Projetos JARPA I e JARPA II; e como foi feita a admissibilidade do caso perante a CIJ. No segundo tópico, problematizar-se-á a metodologia empregada pelo Tribunal para reavaliar a licença especial concedida pelo Japão ao projeto, enfoque especial será dado às críticas à utilização dessa ferramenta hermenêutica e à prejudicialidade ao julgado pelo fato de a Corte ter se esquivado de definir ou estabelecer critérios para a atividade de pesquisa científica marinha. Ao longo da exposição dos argumentos considerados pela CIJ, será realizada contraposição com as teses esposadas nos votos divergentes e na doutrina.

\section{O BACKGROUND}

A sentença da CIJ está estruturada em quatro momentos. No primeiro, a Corte expôs, em ordem cronológica, os procedimentos realizados pelas partes e as alegações trazidas por cada uma a fim de apresentar e defender suas alegações. A seguir, antes de apreciar o feito, o Tribunal estabeleceu sua competência para julgá-lo. Então, adentrou ao mérito e foi construída a argumentação para responder aos pedidos formulados pela Austrália. Por fim, a Corte dispôs sobre as violações cometidas pelo Japão e quais medidas devem ser adotadas para saná-las.

Inicialmente, foi realizada uma retrospectiva dos principais momentos processuais do caso e das alegações realizadas por cada parte, comprovando a observância do princípio do contraditório. Nessa oportunidade, cumpre ressaltar, que restou claro, por exemplo, os elementos que embasaram o pedido de intervenção realizado pela Nova Zelândia e sua posterior aceitação. ${ }^{4}$

4 Em artigo apresentado no Centro de Direito Internacional da Universidade de Kobe, Tamada argumentou que o ingresso da Nova Zelândia no processo como interessado (ou interveniente) e não como parte não foi um acaso, mas uma estratégia processual entre 
A competência do Tribunal para analisar o feito parece óbvia, pois tanto a Austrália quanto o Japão e a Nova Zelândia ratificaram a cláusula facultativa de jurisdição obrigatória, segundo disposto no artigo 36.2 do Estatuto da Corte. Ocorre que a Austrália realizou reserva em relação a disputas afeitas à delimitação de zonas marítimas, incluindo o mar territorial, a zona econômica exclusiva e a plataforma continental, ou provenientes ou relacionadas à explotação de alguma área em disputa ou adjacente a qualquer zona marítima pendente de delimitação. Diante disso, o Japão alegou que as atividades realizadas pelo projeto JARPA II ocorrem no Santuário Baleeiro australiano, que se insere em área reivindicada pela Austrália como parte de sua Zona Econômica Exclusiva - ZEE e aonde realizam atividade de explotação; logo, essa hipótese configura a reserva feita pela Austrália. ${ }^{5}$

Em contrapartida, a parte demandante argumentou que a reserva somente seria aplicável a casos que tivessem por objeto a discussão da delimitação da zona econômica exclusiva, o que não seria essa hipótese. Esse entendimento foi acolhido de forma unânime por todos os juízes da CIJ que, realizando referência aos casos $A n$ glo-Iranian Oil Co. (United Kingdom v. Iran) e Fisheries Jurisdiction (Spain v. Canada), entenderam que a controvérsia não tinha como objeto a delimitação da Zona Econômica Exclusiva - ZEE australiana ou mesmo a explotação de atividade exercida na ZEE. ${ }^{6}$ Note-se que essa

esse país e a Austrália a fim de afastar a aplicação do art. 31(5) do Estatuto da ICJ de modo que o juiz neozelandês membro da Corte não fosse declarado suspeito e a Austrália ainda tivesse garantido o seu direito de nomear um juiz ad hoc. O Professor também demonstrou outros prejuízos ao Japão resultantes do desequilíbrio processual entre as partes e da pouca experiência do país, litigando perante a CIJ, situações que não são aptas a desmerecer o julgamento, mas comprovam que o conhecimento do funcionamento de um tribunal internacional é decisivo para definir a melhor estratégia processual a ser seguida e rompe com a ilusão acrítica de isonomia plena entre as partes. Cf: DAI, Tamada. Unfavourable but unavoidable procedures: procedural aspects of the whaling case. In: SIMPÓSIO WHALING IN THE ANTARCTIC: THE ICJ JUDGMENT AND ITS IMPLICATION, 2014, Kobe. Presentation Files and Papers... Kobe: Kobe University, 2014. Disponível em: <http://www.edu.kobe-u.ac.jp/ ilaw/en/whaling_sympo2014.html>. Acesso em: 10 jan. 2015.

5 INTERNATIONAL COURT OF JUSTICE. 2014. 31 March. Whaling in the Antarctic Australia v. Japan: New Zealand intervening: mérits. Disponível em: <http://www.CIJ-cij.org/docket/index.php?p $1=3 \& \mathrm{p} 2=3 \& \mathrm{k}=64 \&$ case $=148 \& \operatorname{code}=\mathrm{aj} \& \mathrm{p} 3=4>$. Acesso em: 20 dez. 2014. p. 22. WATKINS, Casey. Whaling in the Antarctic: case analysis and suggestions for the future. New York International Law Review, v. 25, n. 2, p. 49-77, 2012. p. 62.

6 INTERNATIONAL COURT OF JUSTICE. 2014. 31 March. Whaling in the Antarctic Australia v. Japan: New Zealand intervening: mé- última hipótese seria aplicável caso a Austrália tivesse suscitado a proteção da biodiversidade e dos mamíferos marinhos em razão de seus direitos como detentor da ZEE, prevista em instrumentos como a Convenção das Nações Unidas para o Direito do Mar - UNCLOS ou Convenção de Montego Bay, ${ }^{7}$ porém fica claro que as violações alegadas pela parte demandante foram cuidadosamente selecionadas de modo a afastar a temática da planificação marinha de modo a manter a jurisdição da CIJ. ${ }^{8}$

Destaca-se também que não houve menção à jurisdição da Corte em relação às Convenções CBD e CITIES, que preveem expressamente outros meios de solução de controvérsias, como as negociações e a Corte Permanente de Arbitragem, antes de acionar a CIJ. ${ }^{9}$ Em verdade, é estranho o fato de sentença sequer cita esses instrumentos internacionais, suscitados pela Austrália em sua exordial.

Importante também observar a ausência de referência na sentença ao princípio da boa-fé, argumento muito utilizado pela Austrália e pela Nova Zelândia em suas alegações. Isso pode ter ocorrido de forma proposital, pois a boa-fé relaciona-se diretamente ao ônus da prova, de forma que, se a boa-fé do Japão fosse afirmada de modo expresso, caberia à Austrália, Estado autor da ação, o ônus da prova. Em contrapartida, se houvesse manifestação de que o Japão teria violado essa presunção, caberia a este comprovar fato extintivo das alegações realizadas pela Austrália. E ainda, caso a CIJ tivesse optado por utilizar essa via argumentativa, também teria que apreciar as alegações do Juiz ad hoc Charlesworth sobre a potencial inversão do ônus da prova à luz do princípio da precaução. ${ }^{10}$ De fato, os juízes Owada e

rits. Disponível em: <http://www.CIJ-cij.org/docket/index.php? $\mathrm{p} 1=3 \& \mathrm{p} 2=3 \& \mathrm{k}=64 \& \mathrm{case}=148 \& \mathrm{code}=\mathrm{aj} \& \mathrm{p} 3=4>$. Acesso em: 20 dez. 2014 p. 22.

7 UNITED NATIONS. Montego Bay Convention. Disponível em: $<$ http://www.un.org/Depts//los/convention_agreements/texts/ unclos/unclos_e.pdf>. Acesso em: 20 nov. 2014. art. 56, 61 e 65.

8 WATKINS, Casey. Whaling in the Antarctic: case analysis and suggestions for the future. New York International Law Review, v. 25, n. 2, p. 49-77, 2012. p. 62.

9 ANTON, Donald K. Dispute concerning Japan's JARPA II Program of 'Scientific Whaling' (Australia v. Japan): a backgrounder. ANU College of Law Research Paper, n. 33-10, 2010. Disponível em: $<$ http://ssrn.com/abstract=1632722>. Acesso em: 10 jan. 2015. p. $10-11$.

10 INTERNATIONAL COURT OF JUSTICE. 2014. 31 March. Whaling in the Antarctic Australia v. Japan: New Zealand intervening: opinion dissidente de M. le Juge Abraham. Disponível em: <http:// www.CIJ-cij.org/docket/files/148/18138.pdf>. Acesso em: 20 jan. 
Abraham mencionaram em seus votos divergentes que a presunção de boa-fé do Estado japonês foi violada, pois, apesar de a sentença não realizar menção expressa à boa-fé ou a ônus da prova, coube ao Japão dar "explicações, demonstrações e justificativas" quanto à Razoabilidade e cientificidade do projeto e não à Austrália provar que o projeto tinha finalidade diversa. ${ }^{11}$

Superadas essas questões, o Tribunal adentrou ao mérito do dissídio e analisou as razões apresentadas pela Austrália para solicitar a condenação do Japão e, consequentemente, a cassação da licença especial emitida para o JARPA II. Inicialmente, procedeu-se a uma retrospectiva sobre os primeiros documentos internacionais que regulamentaram a caça às baleias e seus respectivos contextos históricos. Nesse ínterim, restou demonstrado que, ao longo da primeira metade do século XX, diante da dependência econômica mundial de produtos provenientes das baleias (seu óleo era utilizado para acender lâmpadas, os ossos para fabricar espartilhos, a carne na alimentação) $)^{12}$ e da perspectiva de relação do homem com a natureza característica daquele período, as primeiras Convenções não tinham como finalidade a proteção do meio ambiente e da biodiversidade como um fim em si mesmo, ao contrário, tinham a mera finalidade de regular a caça e o comércio de baleias, mantendo a continuidade da exploração da atividade econômica e da elevação dos lucros.

Esse foi o contexto do nascedouro da Convenção Internacional para Regulação da Pesca a Baleias de 1946 que, em seu preâmbulo, afirma explicitamente ter por

2015. p. 07. WATKINS, Casey. Whaling in the Antarctic: case analysis and suggestions for the future. New York International Law Review, v. 25 , n. 2, p. 49-77, 2012. p. 63/64. FOSTER, Caroline. Motivations and methodologies: was Japan's whaling programme for purposes of scientific research? In: SIMPÓSIO WHALING IN THE ANTARCTIC: THE ICJ JUDGMENT AND ITS IMPLICATION, 2014, Kobe. Presentation Files and Papers... Kobe: Kobe University, 2014. Disponível em: <http://www.edu.kobe-u.ac.jp/ilaw/en/ whaling_docs/paper_Foster.pdf>. Acesso em: 10 jan. 2015.

11 INTERNATIONAL COURT OF JUSTICE. 2014. 31 March. Whaling in the Antarctic Australia v. Japan: New Zealand intervening: opinion dissidente de M. le Juge Abraham. Disponível em: <http:// www.CIJ-cij.org/docket/files/148/18138.pdf>. Acesso em: 20 jan. 2015. p. 07. INTERNATIONAL COURT OF JUSTICE. 2014. 31 March. Whaling in the Antarctic Australia v. Japan: New Zealand intervening: dissenting opinion of Judge Owada. Disponível em: <http:// www.CIJ-cij.org/docket/files/148/18138.pdf>. Acesso em: 20 dez. 2014. p. 14.

12 SANDS, Philippe. Principles of international environmental law. 2. ed. Cambridge: Cambridge University Press, 2003. p. 590-591. WATKINS, Casey. Whaling in the Antarctic: case analysis and suggestions for the future. New York International Law Review, v. 25, n. 2, p. 49-77, 2012. p. 52-53. objetivo promover a conservação dos estoques e, assim, possibilitar o desenvolvimento da indústria baleeira. ${ }^{13} \mathrm{~A}$ Convenção tem como parte integrante seu cronograma (schedule), que prevê sua atualização recorrente a fim de permitir que a proteção às baleias possa ocorrer de forma dinâmica, de acordo com o número de espécies existentes, estações do ano, desenvolvimento tecnológico etc. É permitido às partes se opor às alterações realizadas no cronograma, não se vinculando a elas, porém devem fazê-lo em até 90 (noventa) dias após a notificação das alterações. ${ }^{14}$

A Convenção criou uma Comissão Internacional sobre Caça às Baleias - IWC, composta por um membro de cada um dos países signatários, com competência para, entre outras, realizar alterações ao cronograma anexo à ICRW. A IWC também é composta por um secretariado, por um Comitê Financeiro e Administrativo, por um Comitê Científico, por um Comitê Técnico e outros Subcomitês $a d$ boc. ${ }^{15} \mathrm{O}$ Comitê Científico é composto por cientistas nomeados pelos Estados parte da Convenção e poderá receber o auxílio de organizações intergovernamentais e cientistas não nomeados pelos Estados, mas com notável saber em determinada área. Entre suas atribuições está a de analisar relatórios, que devem ser remetidos em periodicidade não superior a um ano, sobre as atividades desenvolvidas pelos países por meio de licenças especiais, e emitir avaliações não vinculantes sobre estes. ${ }^{16}$ Para o julgamento em análise, as atribuições e ações

13 Decidiu-se concluir uma convenção para promover a conservação dos estoques baleeiros e, assim, manter a possibilidade de desenvolvimento da indústria baleeira (tradução livre do original: "Having decided to conclude a convention to provide for the proper conservation of whale stocks and thus make possible the orderly development of the whaling industry" INTERNATIONAL WHALING COMMISSION. International Convention for the Regulation of Whaling, Washington, 2 December, 1946. Disponível em: <https://archive.iwc.int/pages/view. php?ref $=3607 \& k=>$. Acesso em: 20 jan. 2015.

14 INTERNATIONAL WHALING COMMISSION. International Convention for the Regulation of Whaling, Washington, 2 December, 1946. Disponível em: <https://archive.iwc.int/pages/view. php? ref $=3607 \& k=>$. Acesso em: 20 jan. 2015; Preamble, art. V. ANTON, Donald K. Dispute concerning Japan's JARPA II Program of 'Scientific Whaling' (Australia v. Japan): a backgrounder. ANU College of Law Research Paper, n. 33-10, 2010. Disponível em: $<$ http://ssrn.com/abstract=1632722>. Acesso em: 10 jan. 2015. p. 02.

15 SANDS, Philippe. Principles of international environmental law. 2. ed. Cambridge: Cambridge University Press, 2003. p. 724.

16 INTERNATIONAL COURT OF JUSTICE. 2014. 31 March. Whaling in the Antarctic Australia v. Japan: New Zealand intervening: mérits. Disponível em: <http://www.CIJ-cij.org/docket/index.php?p $1=3 \& \mathrm{p} 2=3 \& \mathrm{k}=64 \&$ case $=148 \& \operatorname{code}=\mathrm{aj} \& \mathrm{p} 3=4>$. Acesso em: 20 dez. 2014. p. 27. 
da IWC e do Comitê Científico foram elementos cruciais, tanto para a tomada de decisão do Tribunal quanto para subsidiar as opiniões divergentes.

A partir da década de 1960, com a intensificação das ameaças de extinção a espécies de baleias e com o crescimento de um movimento dentro da IWC contrário a sua pesca, houve tentativa de mudança da perspectiva da Convenção, direcionando-a à proteção da biodiversidade marinha. Nesse contexto, o cronograma da ICRW foi alterado e previu em seu artigo 10(e) e 10(d) uma moratória à caça de baleias para fins comerciais, que teria início em 1986 e, inicialmente, seria revista na década de $1990 .{ }^{17}$ O Japão não tinha o propósito de aceitar essa moratória, no entanto, pressionado pelos Estados Unidos, foi obrigado a fazê-lo. ${ }^{18}$

Pouco tempo depois, a partir de 1987, o Japão iniciou o Projeto JARPA I que, com base em licença especial prevista no artigo VIII da ICRW, ${ }^{19}$ previa a necessidade da pesca de algumas espécies de baleias para fins de pesquisa científica, mais precisamente para calcular a o esto-

17 INTERNATIONAL WHALING COMMISSION. International Convention for the Regulation of Whaling, September 1946. Schedule, as amended by the Commission at the 64th Annual Meeting Panama City. Panama, July 2012. Disponível em: <https://archive. iwc.int $/$ pages $/$ view.php?ref=3606\&k=> . Acesso em: 20 jan. 2015 .. 18 ANTON, Donald K. Dispute concerning Japan's JARPA II Program of 'Scientific Whaling' (Australia v. Japan): a backgrounder. ANU College of Law Research Paper, n. 33-10, 2010. Disponível em: $<$ http://ssrn.com/abstract=1632722>. Acesso em: 10 jan. 2015. p. 04.

19 “Artigo VIII.1 Não obstante qualquer disposição contida na presente Convenção, qualquer Governo Contratante pode conceder a qualquer dos seus cidadãos uma licença especial, autorizando esse nacional a caçar, pescar e tratar baleias para fins de investigação científica, sujeitas a restrições quanto ao número e a outras condições que o Contratante Governo considere adequadas, e a caça, pesca e tratamento das baleias, de acordo com as provisões desse Artigo devem ser isentas da aplicação da presente Convenção. Cada Governo Contratante deve comunicar imediatamente à Comissão todas as licenças concedidas (tradução livre de: "Article VIII. 1. Notwithstanding anything contained in this Convention any Contracting Government may grant to any of its nationals a special permit authorizing that national to kill, take and treat whales for purposes of scientific research subject to such restrictions as to number and subject to such other conditions as the Contracting Government thinks fit, and the killing, taking, and treating of whales in accordance with the provisions of this Article shall be exempt from the operation of this Convention. Each Contracting Government shall report at once to the Commission all such authorizations which it has granted.'INTERNATIONAL WHALING COMMISSION. International Convention for the Regulation of Whaling, September 1946. Schedule, as amended by the Commission at the 64th Annual Meeting Panama City. Panama, July 2012. Disponível em: <https://archive.iwc.int $/$ pages/view.php?ref=3606\&k=>. Acesso em: 20 jan. 2015. que de baleias minke a fim de elidir algumas divergências relacionadas à moratória decretada. Apesar de as partes discordarem quanto à existência de reais contribuições desse projeto para a comunidade científica, a Corte pontuou que essa questão tinha natureza científica, logo não fazia parte da controvérsia jurídica em análise. ${ }^{20}$

No ano de 2005, com o fim do Projeto JARPA I, o Japão submeteu ao Comitê Científico um plano para a segunda fase de da pesquisa científica marinha sobre o ecossistema antártico e o manejo dos estoques de baleias, o Projeto JARPA II. Este tinha como objetivos principais: monitorar o ecossistema antártico, monitorar a competição entre espécies, analisar mudanças nos estoques ao longo do tempo e do espaço e melhorar o processo de manejo dos estoques de baleias na Antártida; para tal, previa a utilização de métodos letais e não letais a baleias do tipo minke, fin e jubarte.

Diante desses esclarecimentos, o primeiro aspecto do mérito analisado pela CIJ consistiu na interpretação que deve ser atribuída ao artigo VIII da ICRW. Isso porque, caso esse dispositivo fosse percebido como exceção à aplicação da Convenção, nenhuma das obrigações relativas à proteção ao meio ambiente e animais marinhos contidos na Convenção e em seu cronograma seriam vinculantes às pesquisas científicas concedidas sob licença especial, argumento defendido pelo Japão. Porém, caso fosse entendido como exceção restrita, as demais obrigações seriam aplicáveis, inclusive, às atividades de pesquisa científica sob licença especial, argumento defendido pela Austrália e pela Nova Zelândia. A esse respeito, a CIJ realizou interpretação conciliatória entre as duas posições, admitindo o artigo VIII como parte indissociável de um todo, portanto, devendo ser interpretada no contexto da Convenção, porém excepcionando a incidência das obrigações contidas nos artigos 10 (d) e $10\left(\right.$ e). ${ }^{21}$

A Convenção e seu Cronograma somente reconheceram a existência de três tipos de pesca às baleias: a que tem finalidade científica, a que tem finalidade comercial

20 INTERNATIONAL COURT OF JUSTICE. 2014. 31 March. Whaling in the Antarctic Australia v. Japan: New Zealand intervening: mérits. Disponível em: <http://www.CIJ-cij.org/docket/index.php?p $1=3 \& \mathrm{p} 2=3 \& \mathrm{k}=64 \&$ case $=148 \& \mathrm{code}=\mathrm{aj} \& \mathrm{p} 3=4>$. Acesso em: 20 dez. 2014. p. 40.

21 INTERNATIONAL COURT OF JUSTICE. 2014. 31 March. Whaling in the Antarctic Australia v. Japan: New Zealand intervening: mérits. Disponível em: <http://www.CIJ-cij.org/docket/index.php?p $1=3 \& \mathrm{p} 2=3 \& \mathrm{k}=64 \&$ case $=148 \& \operatorname{code}=\mathrm{aj} \& \mathrm{p} 3=4>$. Acesso em: 20 dez. 2014. p. 28-29. 
e a que visa à subsistência de grupos aborígenes. ${ }^{22} \mathrm{~A}$ esse respeito, o Tribunal acolheu as alegações da Austrália e da Nova Zelândia de que o artigo VIII seria aplicável somente às atividades de pesca unicamente destinadas a pesquisas científicas. Ressalte-se que o Juiz Antônio Augusto Cançado Trindade, que acompanhou o voto da maioria em relação a esse ponto, defendeu a aplicação do dispositivo da forma mais restrita possível para não desnaturar o propósito da Convenção e somente atividades com exclusiva destinação cientifica deveriam operar mediante licenças especiais, caso contrário o documento teria tido outra redação. ${ }^{23}$

Em contrapartida, em seu voto dissidente, o Juiz Abraham expôs que o simples fato do Japão considerar os ganhos para a indústria e o comércio baleeiro em suas atividades não seria o suficiente para desqualificar o JARPA II como um projeto de pesquisa científica. ${ }^{24}$ No mesmo sentido, o Juiz Bennounna juntou voto dissidente em que também entende ser possível que outras atividades sejam beneficiadas pela pesca de baleias ocorrida por meio de licença especial, no entanto, essas atividades devem estar relacionadas à pesquisa científica que ensejou a licença. ${ }^{25} \mathrm{~A}$ esse respeito, entende-se que essa constitui a posição mais acertada, pois, além de ser difícil distinguir a pesquisa científica da atividade comercial, conforme será melhor explicitado adiante por meio dos debates travados na Terceira Conferência das Nações Unidas sobre o Direito do Mar; o próprio texto da ICRW prevê em seu artigo VIII.2 que a carne proveniente das baleias pescadas deve ser tratada (podendo

22 INTERNATIONAL COURT OF JUSTICE. 2014. 31 March. Whaling in the Antarctic Australia v. Japan: New Zealand intervening: mérits. Disponível em: <http://www.CIJ-cij.org/docket/index.php ?p1 $=3 \& \mathrm{p} 2=3 \& \mathrm{k}=64 \&$ case $=148 \&$ code $=\mathrm{aj} \& \mathrm{p} 3=4>$. Acesso em: 20 dez. 2014. p. 30. INTERNATIONAL COURT OF JUSTICE. 2014. 31 March. Whaling in the Antarctic Australia v. Japan: New Zealand intervening: dissenting opinion of Judge Bennouna. Disponível em: $<$ http://www.CIJ-cij.org/docket/files/148/18144.pdf>. Acesso em: 20 jan. 2015. p. 05.

23 INTERNATIONAL COURT OF JUSTICE. 2014. 31 March. Whaling in the Antarctic Australia v. Japan: New Zealand intervening: separate opinion of judge Cançado Trindade. Disponível em: <http:/ / www.CIJ-cij.org/docket/files/148/18146.pdf>. Acesso em: 20 jan. 2015. p. 07.

24 INTERNATIONAL COURT OF JUSTICE. 2014. 31 March. Whaling in the Antarctic Australia v. Japan: New Zealand intervening: opinion dissidente de M. le Juge Abraham. Disponível em: < http://www.CIJcij.org/docket/files/148/18138.pdf>. Acesso em: 20 jan. 2015. p. 06. 25 INTERNATIONAL COURT OF JUSTICE. 2014. 31 March. Whaling in the Antarctic Australia v. Japan: New Zealand intervening: dissenting opinion of judge Bennouna. Disponível em: <http://www.CIJ-cij. org/docket/files/148/18144.pdf >. Acesso em: 20 jan. 2015. p. 02. ser vendida) e seus proventos serão utilizados conforme determinação do governo concessor da licença - no caso do Japão, é utilizada para subsidiar as pesquisas do Instituto para Pesquisa de Cetáceos (Institute of Cetacean Research - ICR) ${ }^{26}{ }^{27} \operatorname{logo}$, a própria Convenção possibilita a utilização dos produtos da pesca para fins diversos da investigação científica. A Corte chegou a inclinar-se a essa concepção quando, no ponto 97 do acórdão, mencionou que o fato de alguns nacionais terem motivações que vão além da pesquisa científica não desnatura a finalidade científica de determinada pesquisa, porém o fez de forma muito comedida ao ter se referido somente a indivíduos (officials). ${ }^{28}$

As considerações realizadas até este ponto contextualizaram a lide apreciada pela Corte. Apresentou-se a controvérsia em questão, o problema jurídico posto a ser decidido, o momento histórico de criação da principal convenção internacional suscitada (ICRW) e sua mudança de perspectiva, a construção dos Projetos JARPA I e JARPA II, as modalidades de pesca previstas convencionalmente e o entendimento firmado em relação à aplicação do artigo VIII da Convenção. No próximo tópico, analisar-se-á a metodologia utilizada pela corte para apreciar se a pesca de baleias realizada no âmbito do Projeto JARPA II está contida no quadro normativo do artigo VIII da ICRW e como a definição de pesquisa científica marinha foi abordada pelo Tribunal.

\section{O CRITÉRIO DE EXAME DA LICENÇA ESPECIAL E A (NÃO) DEFINIÇÃO DE PESQUISA CIENTÍFICA MARINHA}

O caso em comento tem como pano de fundo a política japonesa de condução de pesquisas científicas,

26 A Corte avalia essa disposição no ponto 94, afirmando que a simples venda da carne não descaracteriza a finalidade científica de uma pesquisa, afirmação que gera ambiguidades caso comparada com as considerações iniciais do julgamento.

27 WATKINS, Casey. Whaling in the Antarctic: case analysis and suggestions for the future. New York International Law Review, v. 25, n. 2, p. 49-77, 2012. p. 20; ARON, William; BURKE, William; FREEMAN, Milton. Scientists versus whaling: science, advocacy, and errors of judgment. Bioscience, v. 52, n. 12, p. 1137-1140, 2002. p. 1139. 28 INTERNATIONAL COURT OF JUSTICE. 2014. 31 March. Whaling in the Antarctic Australia v. Japan: New Zealand intervening: mérits. Disponível em: <http://www.CIJ-cij.org/docket/index.php?p $1=3 \& \mathrm{p} 2=3 \& \mathrm{k}=64 \&$ case $=148 \& \operatorname{code}=a j \& \mathrm{p} 3=4>$. Acesso em: 20 dez. 2014. p. 38. 
questão que foge do âmbito puramente jurídico. A esse respeito, as partes concordaram que determinar se a captura, a pesca e o tratamento de baleias mediante licença especial é para fins científicos não constitui uma discricionariedade ilimitada dos Estados. Então, a CIJ teve que construir uma forma de analisar se a captura, a pesca e o tratamento de baleias, realizados no Projeto JARPA II tinham finalidade científica, à luz do disposto no artigo VIII da ICRW.

Para realizar esse intento, sem adentrar no mérito científico, a CIJ utilizou, pela primeira vez, a metodologia do standard of review ou "critério de exame" da licença especial expedida pelo Japão ao JARPA II. Essa metodologia, já havia sido utilizada pelo Órgão de Apelação da Organização Mundial do Comércio - OMC para analisar seu Acordo sobre Medidas Sanitárias e Fitossanitárias nos casos Canada-Continued Suspension of Obligations in the EC-Hormones Dispute; US-Continued Suspension of Obligations in the EC-Hormones Dispute e Australia: Measures Affecting the Importation of Apples from New Zealand, e em que argumentos atinentes à comunidade científica também tiveram um papel central na resolução da disputa. ${ }^{29} \mathrm{Tem}$-se, portanto, um interessante caso em que a CIJ expandiu o seu regime de funcionamento e demonstrou abertura para a jurisprudência de outros tribunais e, inclusive, incorporou ferramentas utilizadas por outrem. ${ }^{30}$

29 FOSTER, Caroline. Motivations and methodologies: was Japan's Whaling programme for purposes of scientific research? In: SIMPÓSIO WHALING IN THE ANTARCTIC: THE ICJ JUDGMENT AND ITS IMPLICATION, 2014, Kobe. Presentation Files and Papers... Kobe: Kobe University, 2014. Disponível em: <http:/ / www.edu.kobe-u.ac.jp/ilaw/en/whaling_docs/paper_Foster.pdf $>$. Acesso em: 10 jan. 2015.

30 No mesmo sentido, posiciona-se FOSTER: "É notável que a Corte tenha empregado a terminologia critério de revisão como se já fosse uma técnica estabelecida na Corte. Talvez isso seja uma evidencia de que a Corte se considera como pertencente a um grupo coletivo de cortes e tribunais, em que a ideia de critério de revisão tornou-se conhecida no direito internacional, particularmente por meio das disputas comerciais, e decorrente das concepções préRodada do Uruguai de que os processos que deveriam ser desenvolvidos para a resolução das disputas comerciais multilaterais na Organização Mundial do Comércio deveriam ser vistas como uma forma de revisão e não como julgamento" (tradução livre do original: "It is notable that the Court employed the terminology of standard of review as though it were already an established technique for the Court. This is perbaps evidence that the Court considers itself as belonging to a collective group of international courts and tribunals, within which the idea of standard of review has become known to international law, particularly through trade disputes, and stemming primarily from pre-Uruguay Round conceptions that the processes to be developed for the settlement of multilateral trade disputes in the World Trade Organization should be seen as a form of review rather than ad-
Interessante notar, na esteira do que é afirmado por Foster, que, em nenhum momento na sentença, a CIJ menciona que se utilizará de uma ferramenta metodológica construída e aplicada majoritariamente no âmbito da OMC. Somente no voto dissidente do Juiz Owada é retomada a discussão sobre os limites entre a ciência e o direito enfrentados pelo Órgão de Apelação da OMC no caso Continued Suspension of Obligations in the EC-Hormones e sobre a amplitude de revisão do órgão, defende que o Estado concessor da licença tem presunção de boa-fé e que a competência de análise das bases científica e tecnológicas de determinada licença especial é da Comissão Internacional sobre Caça às Baleias, mais especificamente do Comitê Científico, de modo que somente caberia à CIJ analisar se a expedição da licença cumpre os requisitos elencados no artigo VIII e se possui motivações coerentes e forte embasamento científico. ${ }^{31}$ De forma análoga, o Juiz Yusuf acrescentou que o IWC revisou a licença concedida ao Projeto JARPA II em 2005 e não se posicionou contrário à pesquisa, enquanto o fez em oportunidades anteriores em relação a outras licenças, quando achou que não haveria enquadramento como investigação científica. ${ }^{32}$

O critério de exame é baseado, sobretudo, na ideia de deferência, ou seja, na obediência que o tribunal superior terá em relação à decisão do tribunal que proferiu a decisão e, consequentemente, à margem de apreciação para anular ou reformular a decisão do tribunal inferior. Assim, quando há baixo grau de deferência, o tribunal superior poderá anular a decisão de forma fácil, em contrapartida, quando existe alto grau de defe-

judication" (FOSTER, Caroline. Motivations and methodologies: was Japan's Whaling programme for purposes of scientific research? In: SIMPÓSIO WHALING IN THE ANTARCTIC: THE ICJ JUDGMENT AND ITS IMPLICATION, 2014, Kobe. Presentation Files and Papers... Kobe: Kobe University, 2014. Disponível em: <http:/ / www.edu.kobe-u.ac.jp/ilaw/en/whaling_docs/paper_Foster.pdf $>$. Acesso em: 10 jan. 2015). Em sentido semelhante ver: MATZLÜCK, Nele. Norm interpretation across international regimes: competences and legitimacy. In: YOUNG, Margaret (Org.). Regime interaction in international law: facing fragmentation. Cambridge: Cambridge University Press, 2012. p. 201-234.

31 INTERNATIONAL COURT OF JUSTICE. 2014. 31 March. Whaling in the Antarctic Australia v. Japan: New Zealand intervening: dissenting opinion of judge Owada. Disponível em: <http://www.CIJcij.org/docket/files/148/18138.pdf>. Acesso em: 20 dez. 2014. p. 13.

32 INTERNATIONAL COURT OF JUSTICE. 2014. 31 March. Whaling in the Antarctic Australia v. Japan: New Zealand intervening: dissenting opinion of judge Yusuf. Disponível em: < http://www.CIJcij.org/docket/files/148/18148.pdf>. Acesso em: 20 dez. 2014. p. 09. 
rência, a decisão somente poderá ser anulada caso seja evidenciado um erro contundente. Essa metodologia é particularmente familiar ao direito comunitário europeu e ao direito estadunidense, que tem sido fomentado o uso dessa ferramenta em âmbito da OMC. Situação peculiar ocorre quando essa metodologia é transmutada para o plano internacional, pois então oportuniza-se aos tribunais internacionais apreciar questões ligadas à política estatal, notadamente em setores estratégicos como: saúde, meio ambiente, biossegurança. Assim, abre-se uma janela de possibilidades aos tribunais para o desenvolvimento de práticas não fundamentadas no consentimento soberano estatal ou no entendimento das competências do órgão de solução de controvérsias no direito internacional público, o que pode gerar decisões arbitrárias, inconsistentes ou mesmo ocasionar afastamento dos Estados do meio de solução de controvérsias. Ademais, essa ferramenta trabalha com a terminologia "revisão" e não "julgamento", fato que já sinaliza para a melhor adequação dessa ferramenta a meios de solução de controvérsia não jurisdicionais ou à arbitragem. ${ }^{33}$

Transmutando esse entendimento para o caso em comento, a aplicação dessa metodologia permitiu à CIJ ir além do julgamento sobre o preenchimento dos requisitos procedimentais para o enquadramento na exceção prevista no artigo VIII ou mesmo da existência de vício, e revisar o mérito científico da licença concedida para a pesquisa científica marinha japonesa.

Nesse contexto, a Corte não seguiu estritamente nenhum dos critérios propostos pelas partes e, no parágrafo 67 da sentença, complementado pelo parágrafo 88, elencou os critérios de exame desenvolvidos para nortear a análise da licença especial concedida. Pela centralidade que esses trechos possuem na crítica empreendida neste estudo, é interessante citá-los:

67. Ao analisar a concessão de uma licença especial autorizando a captura, a pesca e o tratamento de baleias, o Tribunal irá avaliar, primeiramente, [] se o programa em que ocorrem essas atividades envolve pesquisa científica. Em segundo lugar, [II] o Tribunal irá considerar se a captura, a pesca e o tratamento de baleias é "para fins de" pesquisa científica examinando

33 FOSTER, Caroline. International Adjudication - standard of review and burden of proof: Australia-Apples and whaling in the Antarctic. Review of European Community and International Environmental Law, v. 21, n. 2, p. 80-91, 2012. Disponível em: < http://www. law.auckland.ac.nz/people/c-foster>. Acesso em: 10 jun. 2015. p. 80-85. se a concepção $0^{34}$, a implementação e os resultados obtidos pela pesquisa são razoáveis em relação à consecução dos seus objetivos declarados. Este tipo de critério de exame é objetivo. Elementos relevantes da concepção e da implementação de um programa são apresentados abaixo (ver parágrafo 88).

$[\ldots]$

88. Os objetivos declarados de um programa de pesquisa são a base de sua concepção, mas a Corte não precisa julgar o mérito científico ou a importância desses para avaliar a finalidade da caça às baleias no âmbito de um programa. Também não é atribuição da Corte decidir se a concepção e a implementação de um programa são os melhores meios possíveis para atingir os seus objetivos declarados.

Para verificar se o uso de métodos letais em um programa é para fins de investigação científica, o Tribunal irá considerar se os elementos da concepção e da implementação de um programa são razoáveis em relação aos seus objetivos científicos declarados (ver parágrafo 67 acima). Como mostrado pelos argumentos das partes, tais elementos podem incluir: [II.a] as decisões relativas à utilização de métodos letais; [II.b] a escala de utilização de amostras letais pelo programa; [II.c] a metodologia utilizada para selecionar a quantidade das amostras; [II.d] uma comparação da quantidade de amostras previstas e a quantidade efetivamente capturada; [II.e] o período de tempo de um programa; [II.f] produção científica gerada pelo programa; e [II.g] do grau em que um programa coordena suas atividades com projetos de pesquisa relacionados. ${ }^{35}$

34 Concepção é utilizada neste artigo como sinônimo ao termo "design" no original em inglês e "conception" no original em francês.

35 Tradução livre do original: "67. When reviewing the grant of a special permit authorizing the killing, taking and treating of whales, the Court will assess, first, whether the programme under which these activities occur involves scientific research. Secondly, the Court will consider if the killing, taking and treating of whales is 'for purposes of' scientific research by examining whether, in the use of lethal methods, the programme's design and implementation are reasonable in relation to achieving its stated objectives. This standard of review is an objective one. Relevant elements of a programme's design and implementation are set forth below (see paragraph 88$)$. [...] 88. The stated research objectives of a programme are the foundation of a programme's design, but the Court need not pass judgment on the scientific merit or importance of those objectives in order to assess the purpose of the killing of whales under such a programme. Nor is it for the Court to decide whether the design and implementation of a programme are the best possible means of achieving its stated objectives. In order to ascertain whether a programme's use of lethal methods is for purposes of scientific research, the Court will consider whether the elements of a programme's design and implementation are reasonable in relation to its stated scientific objectives (see paragraph 67 above). As shown by the arguments of the Parties, such elements may include: decisions regarding the use of lethal methods; the scale of the programme's 
Em relação ao primeiro item ([i] se o programa em que ocorrem essas atividades envolve pesquisa científica), a importância da pesquisa científica marinha para o desenvolvimento do direito do mar é inquestionável, seja para a proteção do ecossistema marinho e seu manejo em conformidade com o principio da precaução, seja para o descobrimento das potencialidades presentes nos fundos marinhos e na camada de água acima deles. ${ }^{36}$ Ocorre que, apesar do amplo reconhecimento dos benefícios que essa atividade proporciona para a humanidade, a ICRW não prevê definição sobre pesquisa científica, tampouco se conhece instrumento internacional que pudesse dar suporte à Corte com relação a esse termo. Em verdade, o conceito de pesquisa científica marinha chegou a ser discutido na Segunda e Terceira Conferências das Nações Unidas sobre o Direito do Mar e num estudo sobre a relação entre a Convenção das Nações Unidas sobre Direito do Mar e a Convenção sobre Biodiversidade, existindo algumas propostas. ${ }^{37}$ No entanto, não houve consenso sobre a

use of lethal sampling; the methodology used to select sample sizes; a comparison of the target sample sizes and the actual take; the time frame associated with a programme; the programme's scientific output; and the degree to which a programme co-ordinates its activities with related research projects (see paragraphs 129-132; 149; 158-159; 203-205; 214-222 below)" INTERNATIONAL COURT OF JUSTICE. 2014. 31 March. Whaling in the Antarctic Australia v. Japan: New Zealand intervening: mérits. Disponível em: <http://www. CIJ-cij.org $/$ docket $/$ index.php?p1 $=3 \& p 2=3 \& \mathrm{k}=64 \&$ case $=148 \&$ co de $=$ aj\&p $3=4>$. Acesso em: 20 dez. 2014. p. 32 e 36.

36 TANAKA, Yoshifumi. The international law of the sea. Cambridge: Cambridge University Press, 2012. p. 335-338. UNITED NATIONS. Division for Ocean Affairs and the Law of the Sea Office of Legal Affairs. Marine scientific research: a revised guide to the implementation of the relevant provisions of the United Nations Convention on the Law of the Sea. New York, 2010. p. 04-06.

37 "Na ausência de uma definição formal, pesquisa científica marinha poderia ser definida como uma atividade que envolve a coleta e a análise de informações, dados ou amostras, objetivando expandir o conhecimento da humanidade sobre o meio ambiente, e não é realizada com intento de ganho econômico. Como o objetivo consiste no desenvolvimento do conhecimento, a pesquisa cientifica marinha é caracterizada pela abertura, disseminação de dados, troca de amostras, assim como pela publicação e disseminação dos resultados das pesquisas, como previsto na Parte XIII" (tradução livre do original: "47. In the absence of a formal definition, marine scientific research could be defined as an activity that involves collection and analysis of information, data or samples aimed at increasing mankind's knowledge of the environment, and is not undertaken with the intent of economic gain. Since the object is the enhancement of knowledge, marine scientific research is characterized by openness, dissemination of data, exchange of samples, as well as publication and dissemination of research results as provided for in Part XIII" United Nations Environment Programme. Study of the relationship between the Convention on Biological Diversity and the United Nations Convention on the Law of the Sea with regard to the conservation and sustainable use of genetic resources on the deep seabed (decision II/10 of the Conference of the Parties to possibilidade de realizar uma distinção clara entre a pesquisa científica pura e a exploração - que se trata de pesquisa científica, visando identificar potencialidades comerciais. Como classificar, por exemplo, uma pesquisa realizada em Universidade que, após chegar a resultados positivos dá ensejo a novo mecanismo tecnológico que começa a ser vendido no mercado, mesmo que em pequena escala?

Embora alguns doutrinadores, como Tanaka, proponham formas de diferenciar as duas atividades, como saber se a pesquisa tem pretensões de ser publicada, haja vista que pesquisas que visam à explotação tendem a ser secretas, ${ }^{38}$ a comunidade internacional optou por não criar um conceito preciso de pesquisa científica marinha, muito embora existam tratados que contém princípios que devem nortear essa atividade, quais sejam, a) ser realizada exclusivamente com fins pacíficos; (b) ser realizada com métodos e meios científicos adequados e compatíveis com a Convenção; (c) não interferir injustificadamente com outras utilizações legítimas do mar compatíveis com a Convenção; e (d) ser realizada em conformidade com todas as normas relevantes adotadas no contexto da Convenção, incluindo as relacionadas à proteção e preservação do ambiente marinho. ${ }^{39}$ Apesar de esses princípios estarem previstos no art. 240 da Convenção das Nações Unidas para o Direito do Mar UNCLOS, tratado não invocado pelas partes, entende-se que não haveria óbice alguma em utilizá-los como ferramenta para nortear a análise do Projeto JARPA II, tendo em vista que a CIJ utilizou no mesmo julgamento um ferramental metodológico da OMC.

A esse respeito, ao analisar o grau de abertura de um tratado para considerar normas extrínsecas no processo de interpretação Mazt-Lück utiliza-se das quatro possibilidades de leitura do artigo 31(3)(c) da Convenção de Viena sobre Direito dos Tratados propostas por McLachlan, quais sejam: (1) todas as partes do tratado interpretado também devem ser parte do tratado extrínseco; (2) ao menos as partes em disputa judicial devem ser

the Convention on Biological Diversity). Disponível em: <https://www. cbd.int/doc/meetings/sbstta/sbstta-08/information/sbstta-08-inf03-rev1-en.doc >. Acesso em: 24 out. 2014.

38 TANAKA, Yoshifumi. The international law of the sea. Cambridge: Cambridge University Press, 2012. p. 335-338.

39 UNITED NATIONS. Division for Ocean Affairs and the Law of the Sea Office of Legal Affairs. Marine scientific research: a revised guide to the implementation of the relevant provisions of the United Nations Convention on the Law of the Sea. New York, 2010. p. 04-06. 
partes do tratado invocado no processo interpretativo; (3) se há disparidade das partes dos tratados, a regra do tratado em questão deve ter o status de costume international para ser aplicada; e (4) quando não há identidade completa entre as partes, a norma extrínseca deve ser implicitamente aceita ou tolerada. ${ }^{40}$ No caso em análise, os dois países - três a Nova Zelândia também for considerada — são partes das duas Convenções, logo, a primeira hipótese seria aplicável, portanto, perfeitamente possível a utilização do norte proporcionado pela UNCLOS.

Um expert, indicado pela Austrália propôs quatro critérios caracterizadores de uma pesquisa cientifica: a) objetivos definidos e alcançáveis que se propõem a contribuir com a conservação e o gerenciamento dos estoques; b) métodos apropriados, inclusive utilizando métodos letais, somente na ausência de outros; c) revisão por pares; e d) não causar efeitos adversos aos estoques. Contudo, essa proposta não foi aceita pela Corte, que também não considerou necessário aplicar nenhum princípio, identificar critérios alternativos ou propor definição geral de pesquisa científica. ${ }^{41}$ Mesmo assim, surpreendentemente, nos pontos 127 e 172 do acórdão, ela afirma que as atividades do JARPA II podem ser, genericamente, caracterizadas como pesquisa científica e no ponto 230 afirma não ser necessário identificar se o projeto tem fins comerciais. ${ }^{42}$

Em razão da importância desses argumentos para a presente crítica, cumpre transcrever os trechos da sentença:

86. Levando em consideração essas observações, a Corte não concorda que as atividades devam satisfazer os quatros critérios propostos pela Austrália para constituírem uma "pesquisa científica" no contexto do artigo VIII. Tais como foram formulados pela Austrália, esses critérios parecem refletir mais o que um dos experts invocados chamou

40 MATZ-LÜCK, Nele. Norm interpretation across international regimes: competences and legitimacy. In: YOUNG, Margaret (Org.). Regime interaction in international law: facing fragmentation. Cambridge: Cambridge University Press, 2012. p. 201-234. p. 213.

41 INTERNATIONAL COURT OF JUSTICE. 2014. 31 March. Whaling in the Antarctic Australia v. Japan: New Zealand intervening: mérits. Disponível em: <http://www.CIJ-cij.org/docket/index.php?p $1=3 \& \mathrm{p} 2=3 \& \mathrm{k}=64 \&$ case $=148 \& \operatorname{code}=\mathrm{aj} \& \mathrm{p} 3=4>$. Acesso em: 20 dez. 2014. p. 33.

42 INTERNATIONAL COURT OF JUSTICE. 2014. 31 March. Whaling in the Antarctic Australia v. Japan: New Zealand intervening: mérits. Disponível em: <http://www.CIJ-cij.org/docket/index.php?p $1=3 \& \mathrm{p} 2=3 \& \mathrm{k}=64 \&$ case $=148 \& \operatorname{code}=\mathrm{aj} \& \mathrm{p} 3=4>$. Acesso em: 20 dez. 2014. p. 44. de pesquisa científica propriamente dita do que uma forma de interpretar o termo tal qual utilizado na Convenção. A Corte não considera necessário apresentar critérios alternativos ou oferecer uma definição geral de "pesquisa científica".

127. [...] Baseado nas informações apresentadas, a Corte entende que as atividades do JARPA II envolvendo as amostras letais de baleias podem ser genericamente caracterizadas como "pesquisa científica". Não é necessário, dessa forma, no contexto do caso, examinar genericamente o conceito de "pesquisa científica" [...]

172. Ao considerar essas alegações das Partes, a Corte reitera que não pretende aqui julgar o mérito científico dos objetivos do JARPA II e que as atividades do JARPA II podem ser genericamente caracterizadas como "pesquisa científica" $[. ..] .{ }^{43}$

Ora, visando esquivar-se da análise de mérito científico, a CIJ construiu uma metodologia de exame (ou reexame) focada na finalidade do Projeto JARPA II ou, em outras palavras, na razoabilidade da decisão estatal em conceder a licença especial para o projeto. Tal estratégia originou divisão entre "pesquisa científica" e "pesquisa para fins científicos" artificial e confusa, que dá ensejo a situações absurdas como atividade que, apesar de configurar-se como pesquisa científica, não possui finalidade científica ou não teve sua licença especial concedida com finalidade científica. ${ }^{44}$ Ademais, segun-

43 Tradução livre dos seguintes trechos: "86. Taking into account these observations, the Court is not persuaded that activities must satisfy the four criteria advanced by Australia in order to constitute 'scientific research' in the context of Article VIII. As formulated by Australia, these criteria appear largely to reflect what one of the experts that it called regards as well-conceived scientific research, rather than serving as an interpretation of the term as used in the Convention. Nor does the Court consider it necessary to devise alternative criteria or to offer a general definition of 'scientific research'. 127. [...] Based on the information before it, the Court thus finds that the JARPA II activities involving the lethal sampling of whales can broadly be characterized as 'scientific research'. There is no need therefore, in the context of this case, to examine generally the concept of 'scientific research' [...]. 172. In considering these contentions by the Parties, the Court reiterates that it does not seek here to pass judgment on the scientific merit of the JARPA II objectives and that the activities of JARPA II can broadly be characterized as 'scientific research' [...]"INTERNATIONAL COURT OF JUSTICE. 2014. 31 March. Whaling in the Antarctic Australia v. Japan: New Zealand intervening: mérits. Disponível em: <http:/ $/$ www.CIJ-cij.org/docket/index.php?p1=3\&p2=3\&k= $64 \&$ case $=148 \&$ code $=$ aj\&p3 $=4>$. Acesso em: 20 dez. 2014. p. 35$36 ; 44-45 ; 54$.

44 INTERNATIONAL COURT OF JUSTICE. 2014. 31 March. Whaling in the Antartic Australia v. Japan: New Zealand intervening: dissenting opinion of judge Bennouna. Disponível em: <http://www. CIJ-cij.org/docket/files/148/18144.pdf >. Acesso em: 20 jan. 2015. p. 03. INTERNATIONAL COURT OF JUSTICE. 2014. 31 March. Whaling in the Antartic Australia v. Japan: New Zealand interven- 
do apontado pelos Juízes Owada e Yusuf, os critérios utilizados pela CIJ para identificar a razoabilidade do projeto são externos à Convenção, principal base normativa para a análise jurídica da Corte, além de serem subjetivos. Avaliar a concepção e implementação foge do campo jurídico de atuação e se inserem em atividade de cunho técnico-científico, de competência da Comissão Internacional sobre Caça às Baleias, em última instância de seu Comitê Cientifico. ${ }^{45}{ }^{4}{ }^{46}$

Nessa linha de raciocínio, Sakai complementa que:

tal metodologia adotada pela Corte também parece ser estranha. [...] O importante nesse caso é se as atividades do JARPA II envolvem pesquisa, sob respaldo do artigo VIII da ICRW. O teste para saber se a decisão estatal é objetivamente razoável, como arguido pelo Japão, deveria ter considerado como critério de exame o termo 'pesquisa para fins científicos' como um todo, e não dissociar o termo 'para fins de'. Terceiro, quando a Corte estabelece que o Japão cumpriu com suas obrigações previstas no parágrafo 30 do cronograma da ICRW, não poderia ser dito que as atividades do JARPA II foram reconhecidas como 'pesquisa científica'? Se 'a pesca científica de baleias, mesmo com falhas, continua a ser científica em sua natureza', as atividades do JARPA II continuam a ser 'pesquisa científica' ilegal? ${ }^{47}$

ing: dissenting opinion of judge Yusuf. Disponível em: $<$ http:// www.CIJ-cij.org/docket/files/148/18148.pdf>. Acesso em: 20 dez. 2014. p. 14.

45 O Juiz Yusuf acrescenta que na única oportunidade em que um padrão de avaliação baseado na razoabilidade foi utilizado foi no Caso Elettronica Sicula, mas, nessa oportunidade, o critério surgiu da Convenção e não de uma criação própria da Corte. (INTERNATIONAL COURT OF JUSTICE. 2014. 31 March. Whaling in the Antarctic Australia v. Japan: New Zealand intervening: dissenting opinion of judge Yusuf. Disponível em: <http://www.CIJ-cij.org/docket/ files/148/18148.pdf > . Acesso em: 20 dez. 2014. p. 03-04).

46 INTERNATIONAL COURT OF JUSTICE. 2014. 31 March. Whaling in the Antarctic Australia v. Japan: New Zealand intervening: dissenting opinion of judge Owada. Disponível em: <http://www.CIJcij.org/docket/files/148/18138.pdf>. Acesso em: 20 dez. 2014, p. 08.

47 Tradução livre do seguinte trecho: "Such methodology adopted by the Court also appears to be strange. [...]The matter in this case is whether the JARPA II activities would involve scientific research under Article VIII of the ICRW. The test of whether a State's decision is objectively reasonable, which Japan argues, should have been considered as a standard of review of 'for purpose of science research' as a whole, not of 'for purposes of' separately. Third, when the Court finds that Japan has complied with its obligations under paragraph 30 of the Schedule to the ICRW, may it be said that the JARPA II activities have been recognized as 'scientific research' by the Court? If 'scientific whaling, even if with flaws, remains scientific in nature' is the JARPA II activities still illegal 'science research'?" SAKAI, Hironobu. After the whaling case: its lessons from a japanese perspective. In: WHALING IN THE ANTARCTIC: THE ICJ JUDGMENT AND ITS IMPLICATION, 2014, Kyoto. Paper...
Em seguida, tendo sido acordado entre as partes que os pontos I e II são cumulativos, ${ }^{48}$ a Corte analisou se a captura, a pesca e o tratamento de baleias realizado pelo JARPA II foram desenvolvidos "para fins de" pesquisa científica. A concepção do projeto foi avaliada por meio de quatro elementos presentes no Plano de Pesquisa: a) objetivos; b) período e área de pesquisa; c) métodos utilizados e quantidade das amostras; d) possíveis repercussões das atividades nos estoques de baleias existentes. ${ }^{49}$ É interessante observar também que os elementos que configuram a concepção (ou design) do projeto são semelhantes àqueles apresentados pelo expert convocado pela Austrália, ou seja, embora os critérios elencados por ele não tenham sido considerados para a definição de pesquisa científica, parecem ter guiado a investigação das finalidades do JARPA II, muito embora a Corte não tenha feito menção explícita a isso. ${ }^{50}$

Desses elementos, o Tribunal deu ênfase aos métodos utilizados e à quantidade de amostras, mais especificamente ao uso de métodos letais e ao incremento da quantidade de amostras previstas no JARPA II em relação ao JARPA I. Sobre o uso de métodos letais, observou-se a parca fundamentação no Plano de Pesquisa e no processo para continuar utilizando-os no JARPA II, mesmo após o incremento tecnológico que permitiu outras formas de obtenção de dados em comparação ao período em que foi implantado o JARPA I. Segundo opinião da maioria dos juízes, o fato de optar pelo uso de métodos letais sem dados consistentes que demonstrem não ser possível obter os resultados propostos por métodos não letais levantou dúvidas sobre a finalidade científica da pesquisa. ${ }^{51} \mathrm{Na}$ análise da implementação do

Kyoto: Kyoto University, 2014. Disponível em: <http://www.edu. kobe-u.ac.jp/ilaw/en/whaling_docs/paper_Sakai.pdf $>$. Acesso em: 20 jan. 2015.

48 INTERNATIONAL COURT OF JUSTICE. 2014. 31 March. Whaling in the Antarctic Australia v. Japan: New Zealand intervening: mérits. Disponível em: <http://www.CIJ-cij.org/docket/index.php?p $1=3 \& \mathrm{p} 2=3 \& \mathrm{k}=64 \&$ case $=148 \& \operatorname{code}=\mathrm{aj} \& \mathrm{p} 3=4>$. Acesso em: 20 dez. 2014. p. 32.

49 INTERNATIONAL COURT OF JUSTICE. 2014. 31 March. Whaling in the Antarctic Australia v. Japan: New Zealand intervening: mérits. Disponível em: <http://www.CIJ-cij.org/docket/index.php?p $1=3 \& \mathrm{p} 2=3 \& \mathrm{k}=64 \&$ case $=148 \& \operatorname{code}=\mathrm{aj} \& \mathrm{p} 3=4>$. Acesso em: 20 dez. 2014. p. 41-44.

50 INTERNATIONAL COURT OF JUSTICE. 2014. 31 March. Whaling in the Antarctic Australia v. Japan: New Zealand intervening: dissenting opinion of judge Owada. Disponível em: <http:/ / www.CIJcij.org/docket/files/148/18138.pdf>. Acesso em: 20 dez. 2014.p. 10.

51 INTERNATIONAL COURT OF JUSTICE. 2014. 31 March. Whaling in the Antarctic Australia v. Japan: New Zealand intervening: mé- 
projeto, a Corte observou que o número de baleias pescadas até aquele momento foi inferior ao inicialmente previsto, fato que aumentou a insegurança quanto aos números apresentados na concepção do JARPA II..$^{52}$

A Corte analisou também os demais elementos identificados no parágrafo 88 como: a) tempo de duração da pesquisa; b) resultados científicos do JARPA II até aquele momento; e c) cooperação com outras instituições de pesquisa. Em relação a eles, que foram abordados de forma superficial, aquele que mais chama atenção é a alegada pouca produção acadêmica revisada por pares - novamente, o critério formulado pelo expert da Austrália foi seguido. Segundo os representantes japoneses, apesar de terem sido produzidos somente 2 artigos revisados por pares, houve também 3 apresentações em simpósios e 8 artigos apresentados ao IWC. ${ }^{53} \mathrm{~A}$ esse respeito, necessário fazer remissão às alegações realizadas pelo Juiz Owada em seu voto no qual ele rememora o pronunciamento feito pelo Presidente da IWC em 2007 sobre a relevância científica dos Projetos JARPA e JARPA II e a revisão do projeto JARPA II que seria realizada no mesmo ano do julgamento (2014), logo, não seria o caso da Corte realizar análise antecipada sobre o caráter técnico-científico do projeto, já que a entidade responsável para tal fá-lo-ia em período próximo. ${ }^{54}$

Em relação às informações produzidas pelo Japão a cada um dos sete elementos elencados no parágrafo 88, Corte Internacional de Justiça entendeu que elas foram insuficientes, duvidosas e inadequadas à concepção e implementação do projeto de pesquisa científica, desta feita julgou que o projeto JARPA II não teve finalidade científica, apesar de ter expressamente concebido essa pesquisa como científica e ter rechaçado seu enquadra-

rits. Disponível em: <http://www.CIJ-cij.org/docket/index.php? $\mathrm{p} 1=3 \& \mathrm{p} 2=3 \& \mathrm{k}=64 \& \mathrm{case}=148 \&$ code $=\mathrm{aj} \& \mathrm{p} 3=4>$. Acesso em: 20 dez. 2014. p. 40-61.

52 INTERNATIONAL COURT OF JUSTICE. 2014. 31 March. Whaling in the Antarctic Australia v. Japan: New Zealand intervening: mérits. Disponível em: <http://www.CIJ-cij.org/docket/index.php?p $1=3 \& \mathrm{p} 2=3 \& \mathrm{k}=64 \& \mathrm{case}=148 \& \operatorname{code}=\mathrm{aj} \& \mathrm{p} 3=4>$. Acesso em: 20 dez. 2014>. Acesso em: 20 dez. 2014. p. 62-65.

53 INTERNATIONAL COURT OF JUSTICE. 2014. 31 March. Whaling in the Antarctic Australia v. Japan: New Zealand intervening: mérits. Disponível em: <http://www.CIJ-cij.org/docket/index.php?p $1=3 \& \mathrm{p} 2=3 \& \mathrm{k}=64 \&$ case $=148 \& \operatorname{code}=\mathrm{aj} \& \mathrm{p} 3=4>$. Acesso em: 20 dez. 2014. p. 66.

54 INTERNATIONAL COURT OF JUSTICE. 2014. 31 March. Whaling in the Antarctic Australia v. Japan: New Zealand intervening: dissenting opinion of judge Owada. Disponível em: <http://www.CIJcij.org/docket/files/148/18138.pdf>. Acesso em: 20 dez. 2014. p. 14. mento como "pesca com fins comerciais". 55

Ora, essa conclusão, além de ter se amparado em uma distinção artificial, como já argumentado acima, criou nova modalidade de classificação para atividades que realizem pesca a baleias, haja vista que, segundo a IWC somente existiriam três modalidades: para fins científicos, para fins comerciais e para subsistência de grupos aborígenes. De outra sorte, o simples fato do Projeto JARPA II necessitar de adequações técnicas e conter imprecisões não desnatura juridicamente seu caráter e sua finalidade científica, cabendo somente ao IWC e a seu Comitê Científico apreciarem as questões de caráter técnico que necessitam serem redesenhadas a fim de compatibilizá-las com a proteção ao meio ambiente marinho, proposta pela ICRW e nos demais instrumentos internacionais referentes ao tema. ${ }^{56} \mathrm{Nessa}$ mesma linha, Watkins havia se manifestado, antes do julgamento, que "mesmo existindo um desacordo sobre os métodos científicos [utilizados no JARPA II] e se e em que medida amostras letais deveriam ser utilizadas, seria inapropriado para a CIJ tentar resolver uma disputa científica no âmbito da IWC". ${ }^{57}$

Em sentido semelhante, os Juízes Abraham e Bennouna manifestaram-se, em seus votos divergentes, que:

29. A presunção de boa-fé não é absoluta, observação que não é suficiente para levar à conclusão da Corte, a saber, que as permissões especiais expedidas pelo Japão ao projeto JARPA II

55 INTERNATIONAL COURT OF JUSTICE. 2014. 31 March. Whaling in the Antarctic Australia v. Japan: New Zealand intervening: mérits. Disponível em: <http://www.CIJ-cij.org/docket/index.php?p $1=3 \& \mathrm{p} 2=3 \& \mathrm{k}=64 \&$ case $=148 \& \operatorname{code}=\mathrm{aj} \& \mathrm{p} 3=4>$. Acesso em: 20 dez. 2014. p. 69.

56 INTERNATIONAL COURT OF JUSTICE. 2014. 31 March. Whaling in the Antarctic Australia v. Japan: New Zealand intervening: opinion dissidente de M. le Juge Abraham. Disponível em: <http:// www.CIJ-cij.org/docket/files/148/18138.pdf > . Acesso em: 20 jan. 2015. p. 10-11. INTERNATIONAL COURT OF JUSTICE. 2014. 31 March. Whaling in the Antarctic Australia v. Japan: New Zealand intervening: dissenting opinion of judge Owada. Disponível em: $<$ http:// www.CIJ-cij.org/docket/files/148/18138.pdf>. Acesso em: 20 dez. 2014. p. 14-15. INTERNATIONAL COURT OF JUSTICE. 2014. 31 March. Whaling in the Antarctic Australia v. Japan: New Zealand intervening: dissenting opinion of judge Yusuf. Disponível em: < http:// www.CIJ-cij.org/docket/files/148/18148.pdf>. Acesso em: 20 dez. 2014. p. 15-16. INTERNATIONAL COURT OF JUSTICE. 2014. 31 March. Whaling in the Antarctic Australia v. Japan: New Zealand intervening: dissenting opinion of judge Bennouna. Disponível em: $<$ http://www.CIJ-cij.org/docket/files/148/18144.pdf>. Acesso em: 20 jan. 2015. p. 06.

57 WATKINS, Casey. Whaling in the Antarctic: case analysis and suggestions for the future. New York International Law Review, v. 25, n. 2, p. 49-77, 2012. p. 68. 
não são "para fins de pesquisa científica".

Para embasar seriamente uma conclusão como essa, seria necessário, a meu ver, dispor de elementos muito sólidos, que não apareceram nos debates, e, ao contrário, foi com base em argumentos fracos, e talvez na simples dúvida, suposições e aproximações que a Corte julgou ser possível acolher os argumentos australianos. ${ }^{58}$

Infelizmente, a abordagem adotada pela maioria permanece um pouco impressionista, na medida em que se assenta essencialmente em informações, duvidas e suspeitas, baseadas em uma seleção de indicadores contidos no meio dos vários relatórios e estudos científicos. ${ }^{59}$

Outro ponto extremamente criticável no critério de exame adotado pela CIJ refere-se ao ônus da prova que foi invertido, sem que tenha havido manifestação expressa da Corte sobre o porquê de não presumir a boa-fé do Japão ou ao menos para explicar o motivo de pertencer ao demandado, e não à Austrália, o ônus de comprovar que a concepção e a implementação do Projeto JARPA II eram para fins científicos. Esse argumento também foi apresentado pelos Juízes Abraham e Owada em seus votos dissidentes ${ }^{60}$ e por parte da doutrina, a exemplo de Foster que afirma que "isso reflete um pouco a ideia de que a Corte pode de fato

58 “29. La présomption de bonne foi n'étant pas irréfragable, l'observation qui précède ne suffit certes pas à démontrer que la conclusion de la Cour, à savoir que les permis spéciaux délivrés par le Japon dans le cadre de JARPA II ne l'ont pas été «en vue de recherches scientifiques», est erronée. Mais pour fonder sérieusement une telle conclusion, il aurait fallu, selon moi, disposer d'éléments particulièrement solides, que les débats n'ont pas fait apparaitre, et c'est au contraire sur la base de faibles arguments, et parfois de simples doutes, suppositions ou approximations, que la Cour a cru pouvoir accueillir les prétentions de l'Australie" (INTERNATIONAL COURT OF JUSTICE. 2014. 31 March. Whaling in the Antarctic Australia v. Japan: New Zealand intervening: opinion dissidente de M. le Juge Abraham. Disponível em: <http://www.CIJ-cij.org/docket/files/148/18138. pdf>. Acesso em: 20 jan. 2015. p. 07).

59 "Unfortunately, the approach adopted by the majority remains somewhat "impressionistic", inasmuch as it rests essentially on queries, doubts and suspicions, based on a selection of indicators from among the mass of reports and scientific studies" INTERNATIONAL COURT OF JUSTICE. 2014. 31 March. Whaling in the Antarctic Australia v. Japan: New Zealand intervening: dissenting opinion of judge Bennouna. Disponível em: <http:/ / www.CIJ-cij.org/docket/files/148/18144.pdf>. Acesso em: 20 jan. 2015. p. 01.

60 INTERNATIONAL COURT OF JUSTICE. 2014. 31 March. Whaling in the Antarctic Australia v. Japan: New Zealand intervening: opinion dissidente de M. le Juge Abraham. Disponível em: <http:// www.CIJ-cij.org/docket/files/148/18138.pdf>. Acesso em: 20 jan. 2015. p. 07. INTERNATIONAL COURT OF JUSTICE. 2014. 31 March. Whaling in the Antarctic Australia v. Japan: New Zealand intervening: dissenting opinion of judge Owada. Disponível em: <http:// www.CIJ-cij.org/docket/files/148/18138.pdf>. Acesso em: 20 dez. 2014. p. 14. ter se inclinado para enquadrar o seu papel nesse caso como a 'revisora' da decisão do Japão, ao invés de 'julgar' a questão do cumprimento pelo Japão dos termos da ICRW, e de fato considerou que esse papel envolve afastar as regras habituais sobre ônus da prova". ${ }^{61}$

Da mesma forma, o princípio da razoabilidade foi interpretado de nova forma, não cabendo ao demandante provar que a expedição da licença especial seguiu critérios desarrazoados, mas ao Japão demonstrar a razoabilidade da fundamentação estatal. Caso o mesmo critério seja utilizado em outras ocasiões, poder-se-ia estar diante de uma forma de controle da vontade Estatal - o que, talvez, pudesse resultar em posicionar o ônus da prova à luz do princípio da precaução, tal qual defendido por Foster. ${ }^{62}$

Não se ignora a farta literatura que demonstra os esforços do Japão para controlar a atuação da IWC e para por fim às manifestações da sociedade civil e de ONGs, nem mesmo se ignora a existência de resoluções do Comitê Científico e da IWC, questionando o uso de métodos letais nas pesquisas científicas e o aumento do número de amostras requeridas. ${ }^{63}$ No entanto, com base nos apontamentos contidos nos votos divergentes e de parte da doutrina que analisou criticamente o caso, observa-se que a metodologia do "critério de exame" ou standard of review não foi a mais interessante e efetiva,

61 FOSTER, Caroline. Motivations and methodologies: was Japan's Whaling programme for purposes of scientific research? In: SIMPÓSIO WHALING IN THE ANTARCTIC: THE ICJ JUDGMENT AND ITS IMPLICATION, 2014, Kobe. Presentation Files and Papers... Kobe: Kobe University, 2014. Disponível em: <http:// www.edu.kobe-u.ac.jp/ilaw/en/whaling_docs/paper_Foster.pdf $>$. Acesso em: 10 jan. 2015. FOSTER, Caroline. International Adjudication: standard of review and burden of proof: Australia-Apples and whaling in the Antarctic. Review of European Community and International Environmental Law, v. 21, n. 2, p. 80-91, 2012. Disponível em: $<$ http://www.law.auckland.ac.nz/people/c-foster>. Acesso em: 10 jun. 2015. p. 88-90.

62 FOSTER, Caroline. Motivations and methodologies: was Japan's Whaling programme for purposes of scientific research? In: SIMPÓSIO WHALING IN THE ANTARCTIC: THE ICJ JUDGMENT AND ITS IMPLICATION, 2014, Kobe. Presentation Files and Papers... Kobe: Kobe University, 2014. Disponível em: <http:/ / www.edu.kobe-u.ac.jp/ilaw/en/whaling_docs/paper_Foster.pdf $>$. Acesso em: 10 jan. 2015.

63 TEULINGS, Jasper. Peaceful protests against whaling on the high seas: a human rights-based approach. In: SYMMONS, Clive R. (Ed.). Selected contemporary issues in the law of the sea. Netherland: M. Nijhoff, 2011. v. 68. p. 221-248. p. 222. ANTON, Donald K. Dispute concerning Japan's JARPA II program of 'scientific whaling' (Australia v. Japan): a backgrounder. ANU College of Law Research Paper, n. 33-10, 2010. Disponível em: <http://ssrn.com/abstract $=1632722>$. Acesso em: 10 jan. 2015. p. 06. 
pois deu margem a críticas procedimentais e materiais ao ter "criado" um critério de análise sobre a finalidade de uma pesquisa científica. Ademais, a ferramenta metodológica também particularizou bastante os elementos analisados, de modo a dificultar com que o julgamento possa ser utilizado como precedente para estimular o fim da pesca às baleias em países como Noruega e Islândia. Até mesmo em relação ao Japão, observa-se que, em sendo realizadas revisões ao Projeto JARPA II, adequando-o a critérios com fundamentação estatal coerente, seria perfeitamente possível ao país apresentar novo plano de pesquisa científica à IWC e conseguir nova licença para pesca às baleias. Logo, a CIJ, apesar de ter inovado ao utilizar nova metodologia de análise, absteve-se de adotar uma interpretação sistêmica em relação à adoção da construção já empreendida por outros tratados e tribunais em relação à pesquisa científica marinha, fato que impossibilitou uma atuação protetiva ao meio ambiente marinho.

\section{Considerações finais}

A Corte Internacional de Justiça é mundialmente reconhecida por seus julgamentos vinculantes e pela influência que suas construções jurídicas têm na condução da política externa dos países. Diante dessa constatação, é essencial que todas as suas decisões sejam embasadas em argumentos jurídicos robustos e de difícil refutação.

Diante do exposto, observa-se que no caso Whaling in the Antartic (Australia vs. Japan, New Zeland Intervening) foi empregada a metodologia de critério de exame, já utilizada em âmbito da OMC. Com base nesta, a análise sobre a legalidade da concessão da licença especial, nos moldes do artigo VIII da ICRW foi realizado em duas grandes etapas. Na primeira, a CIJ analisou se as atividades desenvolvidas no bojo do Projeto JARPA II envolvem pesquisa científica. $\mathrm{Na}$ oportunidade, a Corte absteve-se de criar uma definição de pesquisa científica marinha, utilizar outra extrínseca existente ou mesmo de aplicar princípios e/ou parâmetros interpretativos extrínsecos que pudessem esclarecer quais elementos devem ou não devem estar presentes em uma pesquisa científica marinha.

Na segunda etapa, a CIJ avaliou se as atividades desenvolvidas no bojo do Projeto JARPA II são "para fins de" pesquisa científica. Para tal, a concepção e imple- mentação do projeto foram analisadas nos seguintes critérios: a utilização de métodos letais; a quantidade de amostras letais utilizadas; a metodologia utilizada para selecionar a quantidade das amostras; uma comparação entre a quantidade de amostras previstas e a quantidade efetivamente capturada; prazo previsto para duração; a produção científica gerada pelo programa; e o grau de cooperação do projeto com outros semelhantes.

Conforme restou demonstrado, a estratégia de análise escolhida pelo Tribunal não foi efetiva, pois gerou argumentos confusos (pautados em critérios externos à Convenção, divisão da análise da classificação em pesquisa em duas fases); incoerentes (inversão não expressa do ônus da prova, supressão do principio da boa-fé) e questionáveis (necessidade de comprovar a razoabilidade de uma decisão estatal). O que, ao contrário de proporcionar maior segurança jurídica e proteção à biodiversidade marinha, gerará insegurança e oportunizará a permanência da atividade de pesca às baleias.

De fato, segundo aponta CLAPHAM, no dia 18 de abril de 2014 - portanto, logo após o julgamento o Ministro da Agricultura do Japão anunciou que iria apresentar ao IWC um projeto para novo programa de pesquisa para as baleias da Antártida e também que iria continuar a operar o Projeto JARPA II, somente realizando algumas adequações, como reduzir o número de amostras de baleias. ${ }^{64}$

Nesse ínterim, apesar da grande exultação com que a Austrália, Nova Zelândia e as ONGs e movimentos sociais que militam a favor da proteção da biodiversidade marinha receberam o resultado do julgamento, pouco irá mudar na condução da política japonesa em relação ao tratamento da pesca às baleias, pois o critério metodológico de análise escolhido pela CIJ foi particularista e preocupou-se em apontar os erros e inexatidões do JARPA II, ao invés de ter estabelecido (ou cristalizado) critérios, ao menos normativos e políticos, que pudessem nortear a classificação de uma pesquisa como tendo finalidade científica ou comercial. Em verdade, entende-se ainda que, seguindo os argumentos expostos pelo juiz Bhandari, haveriam sim elementos aptos a concluir que o projeto teria finalidade comercial, ${ }^{65}$ o que levaria

64 CLAPHAM, Phillip J. Japan's whaling following the International Court of Justice ruling: brave new world - Or business as usual? Marine Policy, v. 51, p. 238-241, Jan. 2015.

65 INTERNATIONAL COURT OF JUSTICE. 2014. 31 March. Whaling in the Antarctic Australia v. Japan: New Zealand intervening: separate opinion of judge Bhandari. Disponível em: <http://www.icj- 
a uma argumentação mais coerente e, caso o Japão ainda buscasse realizar pesquisa científica com baleias, teria que realizar mudanças estruturais em seu projeto.

Num contexto mais geral ainda, englobando países como a Noruega e Groelândia, que igualmente ainda pescam baleias para fins comerciais e não são parte do cronograma da ICRW, o emprego dos princípios estabelecidos na UNCLOS para pesquisa científica marinha pela CIJ ou das construções normativas empreendidas por outros tratados e tribunais seria mais efetivo para consolidar no sistema jurídico uma noção sobre pesquisa científica marinha e, dessa forma, fortalecer a proteção à biodiversidade marinha.

\section{REFERÊNCIAS}

ANTON, Donald K. Dispute concerning Japan's JARPA II program of 'scientific whaling' (Australia v. Japan): a backgrounder. ANU College of Law Research Paper, n. 33-10, 2010. Disponível em: <http://ssrn.com/ abstract $=1632722>$. Acesso em: 10 jan. 2015.

ARON, William; BURKE, William; FREEMAN, Milton. Scientists versus whaling: science, advocacy, and errors of judgment. Bioscience, v. 52, n. 12, p. 1137-1140, 2002.

CLAPHAM, Phillip J. Japan's whaling following the International Court of Justice ruling: brave new world Or business as usual? Marine Policy, v. 51, p. 238-241, Jan. 2015.

DAI, Tamada. Unfavourable but unavoidable procedures: procedural aspects of the whaling case. In: SIMPÓSIO WHALING IN THE ANTARCTIC: THE ICJ JUDGMENT AND ITS IMPLICATION, 2014, Kobe. Presentation Files and Papers... Kobe: Kobe University, 2014. Disponível em: <http://www.edu.kobe-u. ac.jp/ilaw/en/whaling_sympo2014.html>. Acesso em: 10 jan. 2015.

FOSTER, Caroline. International Adjudication - standard of review and burden of proof: Australia-Apples and whaling in the Antarctic. Review of European Community and International Environmental Law, v. 21, n. 2, p. 8091, 2012. Disponível em: <http://www.law.auckland. ac.nz/people/c-foster>. Acesso em: 10 jun. 2015

cij.org/docket/files/148/18156.pdf>. Acesso em: 20 jan. 2015. p. 05-11.
FOSTER, Caroline. Motivations and methodologies: was Japan's Whaling programme for purposes of scientific research? In: SIMPÓSIO WHALING IN THE ANTARCTIC: THE ICJ JUDGMENT AND ITS IMPLICATION, 2014, Kobe. Presentation Files and Papers... Kobe: Kobe University, 2014. Disponível em: <http:/ / www.edu.kobe-u.ac.jp/ilaw/en/whaling_docs/paper_ Foster.pdf>. Acesso em: 10 jan. 2015.

FOSTER, Caroline. Public opinion and the interpretation of the World Trade Organisation's Agreement on Sanitary and Phytos Anitary Measures. Journal of International Economic Law, v. 11, n. 2, p. 427-458, Fev. 2008. Disponível em: <http://jiel.oxfordjournals.org>. Acesso em: 10 maio 2015. doi: 10.1093/jie 1/jgn011.

INTERNATIONAL COURT OF JUSTICE. 2014. 31 March. Whaling in the Antarctic Australia v. Japan: New Zealand intervening: dissenting opinion of judge Bennouna. Disponível em: <http://www.CIJ-cij.org/docket/ files/148/18144.pdf>. Acesso em: 20 jan. 2015.

INTERNATIONAL COURT OF JUSTICE. 2014. 31 March. Whaling in the Antarctic Australia v. Japan: New Zealand intervening: dissenting opinion of judge Owada. Disponível em: <http://www.CIJ-cij.org/docket/files/148/18138.pdf>. Acesso em: 20 dez. 2014.

INTERNATIONAL COURT OF JUSTICE. 2014. 31 March. Whaling in the Antarctic Australia v. Japan: New Zealand intervening: dissenting opinion of judge Yusuf. Disponível em: <http://www.CIJ-cij.org/docket/files/148/18148.pdf>. Acesso em: 20 dez. 2014.

INTERNATIONAL COURT OF JUSTICE. 2014. 31 March. Whaling in the Antarctic Australia v. Japan: New Zealand intervening: mérits. Disponível em: <http://www. CIJ-cij.org/docket $/$ index.php?p1 $=3 \& p 2=3 \& \mathrm{k}=64 \& \mathrm{c}$ ase $=148 \&$ code $=$ aj\&p3 $=4>$. Acesso em: 20 dez. 2014.

INTERNATIONAL COURT OF JUSTICE. 2014. 31 March. Whaling in the Antarctic Australia v. Japan: New Zealand intervening: opinion dissidente de M. le Juge Abraham. Disponível em: <http://www.CIJ-cij.org/docket/ files/148/18138.pdf>. Acesso em: 20 jan. 2015.

INTERNATIONAL COURT OF JUSTICE. 2014. 31 March. Whaling in the Antarctic Australia v. Japan: New Zealand intervening: separate opinion of judge Bhandari. Disponível em: <http://www.icj-cij.org/docket/files/148/18156.pdf>. Acesso em: 20 jan. 2015.

INTERNATIONAL COURT OF JUSTICE. 2014. 
31 March. Whaling in the Antarctic Australia v. Japan: New Zealand intervening: separate opinion of judge Cançado Trindade. Disponível em: < http://www.CIJ-cij.org/docket/files/148/18146.pdf>. Acesso em: 20 jan. 2015.

INTERNATIONAL WHALING COMMISSION. International Convention for the Regulation of Whaling. Washington, 2 December, 1946. Disponível em: <https:// archive.iwc.int $/$ pages $/$ view.php?ref $=3607 \& \mathrm{k}=>$. Acesso em: 20 jan. 2015.

INTERNATIONAL WHALING COMMISSION. International Convention for the Regulation of Whaling. September 1946. Schedule, as amended by the Commission at the 64th Annual Meeting Panama City. Panama, July 2012. Disponível em: <https://archive.iwc.int/pages/ view.php?ref=3606\&k=> . Acesso em: 20 jan. 2015.

MATZ-LÜCK, Nele. Norm interpretation across international regimes: competences and legitimacy. In: YOUNG, Margaret (Org.). Regime interaction in international law: facing fragmentation. Cambridge: Cambridge University Press, 2012. p. 201-234.

SAKAI, Hironobu. After the whaling case: its lessons from a japanese perspective. In: WHALING IN THE ANTARCTIC: THE ICJ JUDGMENT AND ITS IMPLICATION, 2014, Kyoto. Paper... Kyoto: Kyoto University, 2014. Disponível em: <http://www.edu.kobe-u. ac.jp/ilaw/en/whaling_docs/paper_Sakai.pdf $>$. Acesso em: 20 jan. 2015.

SANDS, Philippe. Principles of international environmental law. 2. ed. Cambridge: Cambridge University Press,
2003.

TANAKA, Yoshifumi. The international law of the sea. Cambridge: Cambridge University Press, 2012.

TEULINGS, Jasper. Peaceful protests against whaling on the high seas: a human rights-based approach. In: SYMMONS, Clive R. (Ed.). Selected contemporary issues in the law of the sea. Netherland: M. Nijhoff, 2011. v. 68. p. 221-248.

UNITED NATIONS Environment Programme. Study of the relationship between the Convention on Biological Diversity and the United Nations Convention on the Law of the Sea with regard to the conservation and sustainable use of genetic resources on the deep seabed (decision II/10 of the Conference of the Parties to the Convention on Biological Diversity). Disponivel em: <https://www.cbd.int/doc/meetings/sbstta/sbstta-08/information/sbstta-08-inf-03-rev1-en.doc $>$. Acesso em: 24 out. 2014.

UNITED NATIONS. Division for Ocean Affairs and the Law of the Sea Office of Legal Affairs. Marine scientific research: a revised guide to the implementation of the relevant provisions of the United Nations Convention on the Law of the Sea. New York, 2010.

UNITED NATIONS. Montego Bay Convention. Disponível em: <http://www.un.org/Depts//los/convention_agreements/texts/unclos/unclos_e.pdf $>$. Acesso em: 20 nov. 2014.

WATKINS, Casey. Whaling in the Antarctic: case analysis and suggestions for the future. New York International Law Review, v. 25, n. 2, p. 49-77, 2012. 


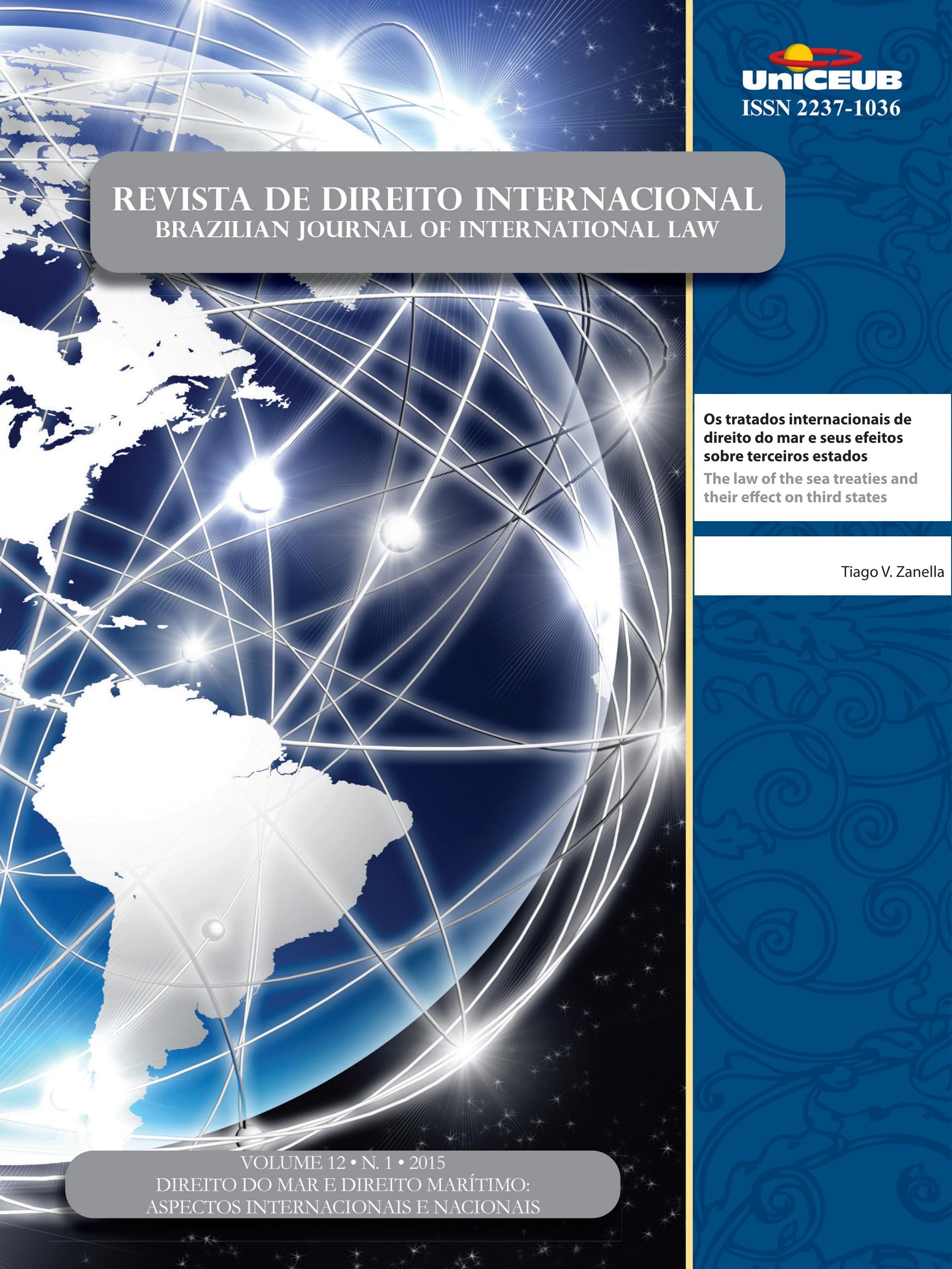




\section{Os tratados internacionais de direito do mar e seus efeitos sobre terceiros estados*}

\section{The law of the sea treaties and their effect on third states}

Tiago V. Zanella**

\section{Resumo}

O objetivo deste artigo consiste em analisar os efeitos dos tratados internacionais de direito do mar sobre terceiros Estados não signatários. Este constitui um dos ramos do direito internacional em que os tratados mais possuem a pretensão de gerar efeitos sobre terceiros. Isso em virtude da necessidade de resposta coletiva aos problemas marítimos, em especial aos de caráter ambiental. Para tal, o presente artigo inicia-se apresentando análise geral da questão para, posteriormente, investigar o tema específico. Nesse ponto, são estudados dois tratados de direito do mar para entender que, apesar da aparente difusão de efeitos sobre terceiros, ainda não há a real criação de obrigações ou direitos aos Estados não signatários dos tratados internacionais de direito do mar. Dessa maneira, este artigo aborda um tema essencial que ainda é pouco estudado, sobretudo na doutrina brasileira, com o objetivo de elucidar algumas importantes questões e implicações desse ramo do direito.

Palavras-chave: Tratados internacionais. Direito do mar. Efeitos dos tratados.

\section{Abstract}

The purpose of this article is to analyse the effects of law of the sea international treaties on non-signatory third States. This is one of the branches of international law where the treaties are most keen on generating effects on third parties. This is due to the need of a collective response to maritime problems, especially with regard to the environment. As such, this article starts by making a general analysis of the matter, and then it investigates the specific theme. At this point, two law of the sea treaties are studied in order to understand that, despite the apparent spread of effects on third parties, there is still no actual creation of obligations or rights to non-signatory States of the international treaties on law of the sea. Thus, this article tackles an essential theme that has not been very much studied, especially in the Brazilian legal theory, in order to clarify some important issues and implications of this branch of Law.

Keywords: International treaties. Law of the sea. Effects of treaties. 


\section{INTRODUÇÃO}

Um dos princípios fundamentais do direito internacional constitui o da pacta tertiis nec nocent nec prosunt, pelo qual um tratado não gera efeitos para produzir direitos ou obrigações aos Estados não signatários ${ }^{1}$. Isto é, em relação a terceiros não membros, os tratados são res inter alios $\operatorname{acta}^{2}$. Esse princípio determina que os Estados só estão vinculados aos acordos que expressamente consentirem, preservando-se, assim, a autonomia da sua vontade ${ }^{3}$. Isso significa que, como regra geral de direito internacional e em conformidade com a igualdade soberana e com a consequente liberdade de escolha, os Estados só estão comprometidos a cumprirem os acordos internacionais a que decidiram vincular-se $\mathrm{s}^{4}$.

Todavia, com o desenvolvimento do direito internacional e a produção de novos tratados, versando sobre os mais diversos tópicos, a temática da produção de efeitos desses documentos sobre terceiros Estados vem à tona. Isso em razão, muitas vezes, da necessidade de efetivação de determinado texto ou da proteção de um direito caro a toda sociedade internacional. Assim, há situações que poderiam ser entendidas como exceções ao

1 Nesse sentido, entre tantos outros, BASTOS, Fernando Loureiro. Algumas considerações sobre a produção de efeitos dos tratados de proteção do ambiente no espaço marinho. In: MIRANDA, Jorge (Coord.). Estudos em homenagem ao Professor Doutor Sérvulo Correia. Coimbra: Coimbra, 2010. v. 4. p. 301-341; p. 302 e ss.; FERRI, Nicola. Trade measures for conservation of fisheries and third states: an evolutionary trend in international law. 2009, $456 \mathrm{f}$. Tesi (dottorato) - Università degli Studi di Milano-Bicocca, Milano, 2012. p. 1 e ss.; PEREIRA, André Gonçalves; QUADROS, Fausto de. Manual de direito internacional público. 3. ed. Lisboa: Almedina, 2011. p. 245 e ss.; MIRANDA, Jorge. Curso de direito internacional público. 5. ed. Lisboa: Principia, 2012. p. 77; DINH, Nguyen Quoc; DAILLIER, Patrick; PELLET, Alain. Direito internacional público. 2. ed. Lisboa: Fundação Calouste Gulbenkian, 2003. p. 239. Ainda, para uma análise geral ver, entre outros, FITZMAURICE, Malgosia. Third parties and the law of treaties. Max Planck Yearbook of United Nations Law, Netherlands, v. 6, n. 1, p. 37-137, Jan. 2002.

$2 \mathrm{Ou}$, na expressão completa: res inter alios acta allis nec prodest nec nocet

3 Sobre a questão, resume FERRI, Nicola. Trade measures for conservation of fisheries and third states: an evolutionary trend in international law. 2009, 456 f. Tesi (dottorato) - Università degli Studi di Milano-Bicocca, Milano, 2012. p. 1: "The principle of pacta tertiis basically acknowledges voluntarism as a fundamental trait of international law and it has been recognized in states' practice to an extent that its existence has never been questioned".

4 Nesse sentido, CAHIER, Philippe. Le problème des traités a l'égard des États tiers. Recueil des Cours da Académie de Droit International, Paris, v. 143 , p. 589-736, 1974. p. 599, na medida em que a posição contrária conduziria "à permettre une ingérence inadmissible d'Etats dans les affaires des autres Etats". pacta tertiis, nomeadamente ${ }^{5}$ a cláusula da nação mais favorecida ${ }^{6}$; o artigo $103^{7}$ e o artigo $2, n^{\circ} 6^{8}$ da Carta das Nações Unidas; e os chamados tratados objetivos?. Contudo, em nenhuma das situações pode-se entender que há real exceção ao princípio de que os tratados só geram efeitos às partes contratantes ${ }^{10}$. O que existe, em geral, são particularidades que não devem ser confundidas com a possibilidade de os tratados produzirem

5 Não iremos analisar neste estudo com profundidade cada caso, uma vez que o objetivo é investigar especificamente os efeitos em terceiros Estados apenas dos tratados internacionais de proteção do ambiente marinho. Para análise geral sobre todos esses aspectos ver BASTOS, Fernando Loureiro. Algumas considerações sobre a produção de efeitos dos tratados de proteção do ambiente no espaço marinho. In: MIRANDA, Jorge (Coord.). Estudos em homenagem ao Professor Doutor Sérvulo Correia. Coimbra: Coimbra, 2010. v. 4. p. 301-341. p. 307-314.

6 Sobre a questão consultar USTOR, Endre. Most-favoured-nation clause. In: UNITED NATIONS. Yearbook of the International Law Commission, 1970. New York: United Nations, 1972. v.2, p. 199242. p. 204 e ss.; SCHWARZENBERGER, Georg. International law as applied by international courts and tribunals: international constitutional law. London: Stevens and Sons, 1986. v. 3. p. 243 e ss.

7 Sobre a questão, consultar BERNHARDT, Rudolf. Article 103. In: SIMMA, Bruno (Ed.). The charter of the United Nations: a commentary. 2. ed. Oxford: Oxford University Press, 2002. v. 2. p. 11161125. p. 1292-1302; CONFORTI, Benedetto. The law and practice of the United Nations. 3. ed. Netherlands: Martinus Nijhoff Publishers, 2005. p. 10 e ss.; MACDONALD, Ronald. The charter of the United Nations as a world constitution. In: SCHMITT, Michael N. (Ed.). International law across the spectrum of conflict. essays in honour of professor L. C. Green on the occasion of his eightieth birthday. Newport: Naval War College, 2000. (International Law Studies, 75). p. 263-300.

8 Sobre a questão, consultar VITZTHUM, Wolfgang Graf. Article 2 (6). In: SIMMA, Bruno (Ed.). The charter of the United Nations. a commentary. 2. ed. Oxford: Oxford University Press, 2002. v. 2. p. 140-148; FASSBENDER, Bardo. UN security council reform and the right of veto: a constitutional perspective. Netherlands: Kluwer Law International, 1998.; CONFORTI, Benedetto. The law and practice of the United Nations. 3. ed. Netherlands: Martinus Nijhoff Publishers, 2005. p. 128-129.

9 Sobre a questão ver FITZMAURICE, Malgosia. Third parties and the law of treaties. Max Planck Yearbook of United Nations Law, Netherlands, v. 6, n. 1, p. 37-137, Jan. 2002. p. 44; 66-83; RAYFUSE, Rosemary Gail. Non-flag state enforcement in high seas fisheries. Netherlands: Martinus Nijhoff Publishers, 2004. p. 84 e ss.; CHINKIN, Christine. Third parties in international law. Oxford: Clarendon Press, 1993. p. 35 e ss.; WALDOCK, Humphrey. Document A/CN.4/156 and Add.1-3: Second report on the law of treaties. In: UNITED NATIONS. Yearbook of The International Law Commission, 1963. New York: United Nations, 1964. v. 2. p. 36-94. p. 26-33.

10 Nesse mesmo sentido, em termos gerais, BASTOS, Fernando Loureiro. Algumas considerações sobre a produção de efeitos dos tratados de proteção do ambiente no espaço marinho. In: MIRANDA, Jorge (Coord.). Estudos em homenagem ao Professor Doutor Sérvulo Correia. Coimbra: Coimbra, 2010. v. 4. p. 301-341. p. 247: “[...] em matéria de efeitos dos tratados quanto a terceiros, a regra res inter alios acta só admite as excepções constantes na CV". 
efeitos relevantes para terceiros ${ }^{11}$.

Entretanto, o direito do mar - em especial na regulação jurídica do alto mar - é, talvez, o ramo do direito mais propício para que os tratados possam gerar efeitos a terceiros não signatários ${ }^{12}$. Isso ocorre basicamente por duas razões: em primeiro lugar, em virtude de sua natureza jurídica ${ }^{13}$, o alto mar não está suscetível a qualquer apropriação, imposição de jurisdição ou soberania ${ }^{14}$; em segundo lugar, em matéria de proteção ambiental, trata-se de um meio em que as medidas lê-se tratados — só são realmente eficazes quando cumpridas por todos os Estados interessados ${ }^{15}$. Isto é, não gera nenhum efeito protetivo e de conservação se, por exemplo, dois Estados celebram um tratado de proteção e regulação da capacidade máxima de pesca de determinada espécie, enquanto um terceiro, não membro, pesca acima da capacidade de reprodução da espécie.

Desse modo, a intenção deste estudo consiste em analisar a possibilidade de produção de efeitos de tra-

11 Sobre a questão, afirma BASTOS, Fernando Loureiro. Algumas considerações sobre a produção de efeitos dos tratados de proteção do ambiente no espaço marinho. In: MIRANDA, Jorge (Coord.). Estudos em homenagem ao Professor Doutor Sérvulo Correia. Coimbra: Coimbra, 2010. v. 4. p. 301-341. p. 337: "A regra pacta tertiis nec nocent nec prosunt não comporta qualquer excepção, não fazendo sentido referir a potencialidade dos tratados concluídos pelos Estados para produzirem efeitos em relação a terceiros, dado que os exemplos comumente referenciados se limitam a ser formas específicas de produção de efeitos em relação às partes".

12 Nesse sentido FRANCKX, Erik. Pacta Tertiis and the Agreement for the Implementation of the Provisions of the United Nations Convention on the Law of the Sea of 10 December 1982 Relating to the Conservation and Management of Straddling Fish Stocks and Highly Migratory Fish Stocks. Quebec: FAO, June 2000. (FAO Legal Papers Online, 8). Disponível em: <http://www.fao.org/fileadmin/user_upload/legal/docs/ lpo8.pdf>. Acesso em: 13 jul. 2015.

13 Sobre a questão ver, por todos, ZANELLA, Tiago Vinicius. Curso de direito do mar. Curitiba: Juruá, 2013. p. 233-239.; MELLO, Celso D. de Albuquerque. Alto mar. Rio de Janeiro: Renovar, 2001. p. 13-20.

14 Nesse sentido, resume GUEDES, Armando M. Marques. Direito do mar. 2. ed. Coimbra: Coimbra, 1998. p. 249: “[...]o Alto Mar [esta] aberto a todas as nações, nenhum Estado podia legitimamente pretender submeter qualquer parte dele à sua soberania."

15 Nesse sentido BASTOS, Fernando Loureiro. Algumas considerações sobre a produção de efeitos dos tratados de proteção do ambiente no espaço marinho. In: MIRANDA, Jorge (Coord.). Estudos em homenagem ao Professor Doutor Sérvulo Correia. Coimbra: Coimbra, 2010. v. 4. p. 301-341. p. 328.; e ainda, resumidamente, ZANELLA, Tiago Vinicius. Água de lastro: um problema ambiental global. Curitiba: Juruá, 2010. p. 33: "É notório, quando estudamos as questões ambientais de caráter global, que nenhum país é capaz de tratar e resolver os problemas ambientais sozinho. Todos os Estados estão envolvidos e somente com a cooperação de todos, as questões ambientais globais poderão ser resolvi- das de maneira mais eficaz." tados internacionais sobre terceiros Estado não signatários. Em especial, no que tange ao direito do mar, por ser um dos ramos do direito em que há maior pretensão de se criar deveres e obrigações a terceiros. Isto em razão da necessidade de resposta coletiva aos problemas marítimos, em especial aos de caráter ambiental.

\section{Os TRATADOS INTERNACIONAIS E O PRINCíPIO DA PACTA TERTIIS NEC NOCENT NEC PROSUNT}

O princípio da pacta tertiiis, de origem consuetudinária ${ }^{16}$, encontra-se atualmente positivado na Convenção de Viena sobre os Direitos dos Tratados, de $1969^{17}$, no artigo 34, que estabelece: "um tratado não cria obrigações nem direitos para um terceiro Estado sem o seu consentimento"18. Essa regra, por ser norma estruturante do direito internacional ${ }^{19}$, determina que a produção de efeitos dos tratados em terceiros depende necessariamente do consentimento desses Estados.

Além da disposição convencional, a jurisprudência internacional tem sistematicamente reafirmado sua existência e aplicação ${ }^{20}$. Não por acaso, já em 1960, no

16 Nesse sentido, por todos FRANCKX, Erik. Pacta Tertiis and the Agreement for the Implementation of the Provisions of the United Nations Convention on the Law of the Sea of 10 December 1982 Relating to the Conservation and Management of Straddling Fish Stocks and Highly Migratory Fish Stocks. Quebec: FAO, June 2000. (FAO Legal Papers Online, 8). Disponível em: < http://www.fao.org/fileadmin/user_upload/ legal/docs/lpo8.pdf>. Acesso em: 13 jul. 2015. p. 5.

17 UNITED NATIONS. Vienna Convention on the law of treaties. Concluded at Vienna on 23 May 1969. Disponivel em: < https:// treaties.un.org/doc/Publication/UNTS/Volume\%201155/volume-1155-I-18232-English.pdf>. Acesso em: 13 jul. 2015.

18 Pode-se citar também o artigo 2, no1 da CVDT: g) "parte" significa um Estado que consentiu em se obrigar pelo tratado e em relação ao qual este esteja em vigor; h) "terceiro Estado" significa um Estado que não é parte no tratado. UNITED NATIONS. Vienna Convention on the law of treaties. Concluded at Vienna on 23 May 1969. Disponivel em: < https://treaties.un.org/doc/Publication/UNTS/Volume\%201155/volume-1155-I-18232-English. pdf $>$. Acesso em: 13 jul. 2015.;" Para uma análise sobre cada disposição da CVDT a respeito dos efeitos ver FITZMAURICE, Malgosia. Third parties and the law of treaties. Max Planck Yearbook of United Nations Law, Netherlands, v. 6, n. 1, p. 37-137, Jan. 2002. p. 39-46.

19 BASTOS, Fernando Loureiro. Algumas considerações sobre a produção de efeitos dos tratados de proteção do ambiente no espaço marinho. In: MIRANDA, Jorge (Coord.). Estudos em homenagem ao Professor Doutor Sérvulo Correia. Coimbra: Coimbra, 2010. v. 4. p. 301-341. p. 616.

20 Historicamente, já em 1926 a Corte Permanente de Justiça Internacional (CPJI) decidia que: "A treaty only creates law as between the States which are parties to it; in case of doubt, no rights can be 
quinto relatório sobre os direitos dos tratados da ILC (International Law Commission), Gerald Fitzmaurice afirmava que esse princípio era tão evidente que não eram necessárias maiores digressões em sua defesa, pois já se encontrava consolidado no direito internacional ${ }^{21}$. Ou, como destaca Christos L. Rozakis, esse princípio "bas accompanied the operation of treaties since time immemorial"22.

No entendo, a Convenção de Viena de 1969 trouxe em seu bojo algumas situações em que um tratado pode gerar direitos ou obrigações sobre terceiros ${ }^{23}$. Em primeiro lugar, no artigo 35, a Convenção aborda os tratados que criam obrigações para terceiros não signatários. Determina o texto convencional que os tratados podem gerar efeitos para produzir obrigações a terceiros, desde que este aceite "expressamente, por escrito, essa obrigação" 24 . Isto é, existe a necessidade de expresso consentimento, nomeadamente por escrito ${ }^{25}$.

deduced from it in favour of third States". (Acórdão no 7 de 25 de maio de 1925. German Interests in Polish Upper Silesia [Germ. v. Pol.] 1926 P.C.I.J. [ser. A] No. 7 [May 25], Par. 82.). Disponível em: <http://www.worldcourts.com/pcij/eng/decisions/1926.05.25_ silesia.htm>. Acesso em: 25 ago. 2013. Para um estudo mais detalhado sobre as jurisprudências nesse sentido, ver FITZMAURICE, Malgosia. Third parties and the law of treaties. Max Planck Yearbook. of United Nations Law, Netherlands, v. 6, n. 1, p. 37-137, Jan. 2002. p. 612-615.

21 UNITED NATIONS. Yearbook of the International Law Commission, 1960. Documents of the twelfth session including the report of the Commission to the General Assembly. New York: United Nations, 1961. v. 2. Disponivel em: <http://legal.un.org/ $\mathrm{docs} /$ ?path $=. . /$ ilc/publications $/$ yearbooks/english/ilc_1960_ v2.pdf\&lang=EFS >. Acesso em: 25 abr. 2015: "Pacta tertiis nee nocent nee prosunt - The general principles referred to in this paragraph, which constitute the foundation of the rules of treaty law relating to third States, are so fundamental, self-evident and wellknown, that they do not really require the citation of much authority in their support. They derive, at any rate as concerns the question of obligation, from the general principle of consent as being the foundation of the treaty obligation".

22 ROZAKIS, Christos L. Treaties and third states: a study in the reinforcement of the consensual standards in international law. ZaoRV, Berlin, v. 35, p. 1-40, 1975. p. 4.

23 Sobre a questão, CHINKIN, Christine. Third parties in international law. Oxford: Clarendon Press, 1993. p. 40-41; FITZMAURICE, Malgosia. Third parties and the law of treaties. Max Planck Yearbook of United Nations Law, Netherlands, v. 6, n. 1, p. 37-137, Jan. 2002. p. 54-55, que afirma que na prática, às vezes, é bastante difícil diferenciar entre obrigações e direitos.

24 UNITED NATIONS. Vienna Convention on the law of treaties. Concluded at Vienna on 23 May 1969. Disponivel em: < https:// treaties.un.org/doc/Publication/UNTS/Volume\%201155/volume-1155-I-18232-English.pdf>. Acesso em: 13 jul. 2015. Art. 35.

25 Sobre a questão ver NAPOLETANO, Guido. Some remarks on treaties and third states under the Vienna convention on the law of treaties. The Italian Yearbook of International Law, v. 3, 1977, p. 8283.
Em segundo lugar, tem-se no artigo 36 a possibilidade de tratados gerarem efeitos para produzir direitos a terceiros não membros. Para tal, basta que as partes do tratado, por meio de alguma disposição convencional, atribuam direitos ao Estado não signatário, que deve consentir: "presume-se o seu consentimento até indicação em contrário, a menos que o tratado disponha diversamente"26. Assim, bastaria a presunção de consentimento para o tratado criar direitos a terceiros. Ou seja, o tratado pode criar direitos até o momento em que o Estado não signatário se posicione contra e não aceite estas prerrogativas criadas ${ }^{27}$.

Em resumo, o consentimento do terceiro Estado, seja nas obrigações ou nos direitos, é imprescindível. Pode-se inclusive aludir que esses efeitos não surgem do tratado, mas de uma espécie de acordo colateral ${ }^{28}$ entre os Estados partes e o terceiro não membro. Esta é inclusive a disposição do artigo 37 da CVDT, que determina: a) para as obrigações: só podem ser revogadas com o consentimento das partes e do terceiro Estado; b) para os direitos: não podem ser revogados pelas partes sem o consentimento do terceiro Estado ${ }^{29}$.

Em suma, a produção de efeitos dos tratados sobre terceiros fica dependente do consentimento destes, independente do momento em que se dá ${ }^{30}$. Nesse viés,

26 UNITED NATIONS. Vienna Convention on the law of treaties. Concluded at Vienna on 23 May 1969. Disponivel em: <https:// treaties.un.org/doc/Publication/UNTS/Volume\%201155/volume-1155-I-18232-English.pdf>. Acesso em: 13 jul. 2015. Art. 36. 27 Sobre a questão ver FITZMAURICE, Malgosia. Third parties and the law of treaties. Max Planck Yearbook of United Nations Law, Netherlands, v. 6, n. 1, p. 37-137, Jan. 2002. p. 51-55.

28 Expressão utilizada, entre outros, por PEREIRA, André Gonçalves; QUADROS, Fausto de. Manual de direito internacional público. 3. ed. Lisboa: Almedina, 2011. p. 246; MAZZUOLI, Valerio de Oliveira. Curso de direito internacional público. 5. ed. São Paulo: RT, 2011. p. 268; DINH, Nguyen Quoc; DAILLIER, Patrick; PELLET, Alain. Direito internacional público. 2. ed. Lisboa: Fundação Calouste Gulbenkian, 2003. p. 249.

29 Sobre a questão, consultar ROZAKIS, Christos L. Treaties and third states: a study in the reinforcement of the consensual standards in international law. ZaoRV, Berlin, v. 35, p. 1-40, 1975. p. 21-27; FITZMAURICE, Malgosia. Third parties and the law of treaties. Max Planck Yearbook of United Nations Law, Netherlands, v. 6, n. 1, p. 37-137, Jan. 2002. p. 56-57.

30 Sobre a questão, afirma BASTOS, Fernando Loureiro. Algumas considerações sobre a produção de efeitos dos tratados de proteção do ambiente no espaço marinho. In: MIRANDA, Jorge (Coord.). Estudos em homenagem ao Professor Doutor Sérvulo Correia. Coimbra: Coimbra, 2010. v. 4. p. 301-341. p. 304: "Esse consentimento pode ter lugar no momento em que se gera o acordo subjacente ao compromisso internacional ou ser expresso num momento posterior à sua negociação, assinatura, manifestação do consentimento a 
levando-se em conta a disciplina jurídica do direito internacional, não existem regras obrigatórias quanto ao modo de adesão ou consentimento a um regime convencional $^{31}$. Assim, os terceiros Estados podem consentir com os efeitos das obrigações ou direitos explicitamente, como por escrito, ou implicitamente, por meio de um comportamento ${ }^{32}$. Entretanto, esse consentimento deve ser manifesto e inequívoco, não sendo admitida sua presunção ${ }^{33}$.

Pode-se citar como modo de aceitação implícita de obrigações por terceiros de tratados que não tenham ratificado, o artigo $5^{\circ}, \mathrm{n}^{\circ} 4$ da Convenção Internacional para a Prevenção da Poluição Causada por Navios (MARPOL 73/78) 34: "Com respeito a navios de Governos não contratantes da Convenção, as Partes deverão aplicar as exigências da presente Convenção tanto quanto for necessário para assegurar que nenhum tra-

estar vinculado ou entrada em vigor para as outras partes".

31 Nesse sentido ROZAKIS, Christos L. Treaties and third states: a study in the reinforcement of the consensual standards in international law. ZaoRV, Berlin, v. 35, p. 1-40, 1975. p. 5; ou, como lecionam PEREIRA, André Gonçalves; QUADROS, Fausto de. Manual de direito internacional público. 3. ed. Lisboa: Almedina, 2011. p. 174: "[...] nenhuma razão parece haver para que o Direito Internacional não aceite a validade dos tratados verbais e até dos tratados tácitos ou implícitos".

32 Nesse sentido NAPOLETANO, Guido. Some remarks on treaties and third states under the Vienna convention on the law of treaties. The Italian Yearbook of International Law, v. 3, p. 75-91, 1977. p. 86-89; BASTOS, Fernando Loureiro. Algumas considerações sobre a produção de efeitos dos tratados de proteção do ambiente no espaço marinho. In: MIRANDA, Jorge (Coord.). Estudos em homenagem ao Professor Doutor Sérvulo Correia. Coimbra: Coimbra, 2010. v. 4. p. 301-341. 304-305.

33 Sobre a questão, destaca BASTOS, Fernando Loureiro. Algumas considerações sobre a produção de efeitos dos tratados de proteção do ambiente no espaço marinho. In: MIRANDA, Jorge (Coord.). Estudos em homenagem ao Professor Doutor Sérvulo Correia. Coimbra: Coimbra, 2010. v. 4. p. 301-341. p. 305-306: "Mas, importa sublinhá-lo, seja a manifestação do consentimento explícita ou implícita, a vontade do Estado tem de ser manifesta e inequívoca no sentido de estar vinculado ao compromisso internacional concreto. Nesses termos, o consentimento a estar vinculado não pode ser presumido, nomeadamente tendo em consideração a participação em compromissos internacionais semelhantes ou anteriores, haja ou não identidade das partes contratantes".

34 MARPOL 73/78. Convenção Internacional para a Prevenção da Poluição Causada por Navios. Londres 17 de Fevereiro de 1978. (versão brasileira promulgada por meio do Decreto $\mathrm{n}^{\circ} 2.508$ de 4 de março de 1998). BRASIL. Decreto $n^{\circ} 2.508$, de 4 de março de 1998. Promulga o Convenção Internacional para a Prevenção da Poluição Causada por Navios, concluída em Londres, em 2 de novembro de 1973, seu Protocolo, concluído em Londres, em 17 de fevereiro de 1978, suas Emendas de 1984 e seus Anexos Opcionais III, IV e V. Disponível em: < http://www.planalto.gov.br/ccivil_03/decreto/ D2508.htm>. Acesso em: 13 jul. 2015. tamento mais favorável foi dado a tais navios" 35 . Deve-se então ter em conta, em primeiro lugar, que o texto convencional regula, entre outros, o acesso ao porto por navio estrangeiro; e em segundo lugar, que a própria MARPOL 73/78 determina que o Estado costeiro pode recusar a entrada nos seus portos por navios que não atenderam "às disposições da presente Convenção" ${ }^{36}$. Desse modo, pode-se interpretar a entrada de navios de Estados não signatários da convenção em portos estrangeiros de Estados membros, como a aceitação implícita desse tratado internacional, com suas obrigações e direitos ${ }^{37}$.

Questão completamente diversa diz respeito ao dever dos terceiros de respeitarem os tratados celebrados entre outros Estados $^{38}$. Por tratar-se de obrigação erga

35 MARPOL 73/78. Art. $5^{\circ}, \mathrm{n}^{\circ} 4$. BRASIL. Decreto $n^{\circ} 2.508$, de 4 de março de 1998. Promulga o Convenção Internacional para a Prevenção da Poluição Causada por Navios, concluída em Londres, em 2 de novembro de 1973, seu Protocolo, concluído em Londres, em 17 de fevereiro de 1978, suas Emendas de 1984 e seus Anexos Opcionais III, IV e V. Disponível em: < http://www.planalto.gov.br/ ccivil_03/decreto/D2508.htm>. Acesso em: 13 jul. 2015. Exemplo citado também por BASTOS, Fernando Loureiro. Algumas considerações sobre a produção de efeitos dos tratados de proteção do ambiente no espaço marinho. In: MIRANDA, Jorge (Coord.). Estudos em homenagem ao Professor Doutor Sérvulo Correia. Coimbra: Coimbra, 2010. v. 4. p. 301-341. p. 305, cit. 20.

36 MARPOL $73 / 78$. Art. $5^{\circ}, \mathrm{n}^{\circ} 3$. MARPOL 73/78. Art. $5^{\circ}, \mathrm{n}^{\circ} 4$. BRASIL. Decreto $n^{\circ} 2.508$, de 4 de marco de 1998. Promulga o Convenção Internacional para a Prevenção da Poluição Causada por Navios, concluída em Londres, em 2 de novembro de 1973, seu Protocolo, concluído em Londres, em 17 de fevereiro de 1978, suas Emendas de 1984 e seus Anexos Opcionais III, IV e V. Disponível em: <http://www.planalto.gov.br/ccivil_03/decreto/D2508.htm>. Acesso em: 13 jul. 2015

37 Nesse sentido, BASTOS, Fernando Loureiro. Algumas considerações sobre a produção de efeitos dos tratados de proteção do ambiente no espaço marinho. In: MIRANDA, Jorge (Coord.). Estudos em homenagem ao Professor Doutor Sérvulo Correia. Coimbra: Coimbra, 2010. v. 4. p. 301-341 p. 305, cit. 20; HANDL, Günther. Regional arrangements and third state vessels: is the pacta tertiis principle being modified. In.: RINGBOM, Henrik (Ed.). Competing norms in the law of the marine environmental protection: focus on ship safety and pollution prevention. Hague: Kluwer Law International, 1997. p. 217-240. p. 221-222, que trata da questão da "no more favorable treatment" (NMFT); FITZMAURICE, Malgosia. Expression of consent to be bound by a treaty as developed in certain environmental treaties. In: KLABBERS, Jan (Ed.). Essays on the law of treaties: a collection of essays in honour of Bert Vierdag. Hague: Martinus Nijhoff Publishers, 1998. p. 59-80. p. 78-79.

38 Nesse sentido PEREIRA, André Gonçalves; QUADROS, Fausto de. Manual de direito internacional público. 3. ed. Lisboa: Almedina, 2011. p. 246; MIRANDA, Jorge. Curso de direito internacional público. 5. ed. Lisboa: Principia, 2012. p. 79; ROZAKIS, Christos L. Treaties and third states: a study in the reinforcement of the consensual standards in international law. ZaoRV, Berlin, v. 35, p. 1-40, 1975. p. 2; ou, como resume BASTOS, Fernando Loureiro. Algumas consid- 
omnes, é dever de toda a sociedade internacional respeitar e não interferir na execução dos tratados celebrados entre outros Estados ${ }^{39}$. Pode-se exemplificar a questão com os tratados bilaterais de demarcação de fronteiras. Nesses casos, os terceiros possuem o dever de respeitar os limites tracejados pelos países em questão. Todavia, deve-se ter em mente que tal situação não constitui exceção ao princípio da pacta tertiis, pois se trata apenas de efeito difuso do tratado que deve ser respeitado pelos sujeitos de direito internacional em razão da sua oponibilidade erga omnes ${ }^{40}$.

Em resumo, temos que o princípio da pacta tertiis nec nocent nec prosunt não comporta qualquer exceção. Isto é, para que um tratado possa produzir efeitos para gerar obrigações ou direitos a terceiro não signatário, há, necessariamente, que haver o consentimento deste, seja explícito ou implícito.

\section{OS TRATADOS INTERNACIONAIS DE DIREITO DO MAR E SEUS PRETENSOS EFEITOS EM RELAÇÃO A TERCEIROS ESTADOS}

Na regulação jurídica da utilização dos espaços marítimos, sobretudo do alto mar, temos duas situações aparentemente antagônicas que se alvitram no direito do mar. De um lado, o princípio da lei de pavilhão, pelo qual, regra geral, aplica-se sobre qualquer embarcação em alto mar apenas a legislação do seu Estado de bandeira ${ }^{41}$. Nenhum terceiro pode intervir na atuação de

erações sobre a produção de efeitos dos tratados de proteção do ambiente no espaço marinho. In: MIRANDA, Jorge (Coord.). Estudos em homenagem ao Professor Doutor Sérvulo Correia. Coimbra: Coimbra, 2010. v. 4. p. 301-341. p. 303: "Com efeito, sendo a capacidade de concluir vinculações internacionais uma das prerrogativas da subjectividade internacional, a produção de efeitos desses compromissos não deverá ser entravada por aqueles que neles não participam, na medida em que na situação oposta se estaria em presença de uma interferência ilegítima na sua autonomia de actuação".

39 TELES, Patrícia Galvão. Obligations Erga Omnes in international. Revista Jurídica da Associação Acadêmica da Faculdade de Direito de Lisboa, Lisboa, n. 20, p. 73-137, Nov. 1996; TAMS, Christian J. Enforcing obligations Erga Omnes in international law. Reino Unido: Cambridge University Press, 2005.

40 Nesse sentido PEREIRA, André Gonçalves; QUADROS, Fausto de. Manual de direito internacional público. 3. ed. Lisboa: Almedina, 2011. p. 247.; ou ainda MAZZUOLI, Valerio de Oliveira. Curso de direito internacional público. 5. ed. São Paulo: RT, 2011. p. 266-267, que denomina tais situações como "Efeito difuso de reconhecimento de uma situação jurídica objetiva".

41 Nesse sentido, como determinou o ITLOS no The $M / V$ "S $A I$ - um navio estrangeiro em alto mar para lhe impor sua jurisdição ${ }^{42}$. Por outro lado, temos que o espaço marítimo, sobretudo o alto mar, necessita de maior proteção, que ultrapasse o velho princípio para efetivamente gerar os efeitos esperados ${ }^{43}$.

Em termos práticos, independe da posição do terceiro Estado, a conclusão de tratados multilaterais que estabelecem normas de direito internacional podem necessitar de resposta coletiva. Assim, alguns autores afirmam que o princípio da pacta tertiis pode não ser tão rigoroso como se acreditava ${ }^{44}$. Desse modo, quando se trata de direito do mar, em especial no que concerne a proteção do meio marítimo, pode-se argumentar, num primeiro momento, que existe a necessidade de excepcionar o pacta tertiis por meio de mecanismos jurídico-internacionais que gerem efeitos sobre terceiros.

Todavia, estaríamos diante de uma produção de direito internacional criada por alguns Estados com o fim de estabelecer normas a terceiros, independentemente do seu consentimento. Assim, não se pode afirmar

GA" (No. 2) Case (Saint Vincent and the Grenadines v. Guinea),1 de julho de 1999, par. 65: "Determination of the criteria and establishment of the procedures for granting and withdrawing nationality to ships are matters within the exclusive jurisdiction of the flag State". Ver ainda CNUDM. Art. 90, no 1. BRASIL. Decreto n $n^{\circ} 1.530$, de 22 de junho de 1995. Declara a entrada em vigor da Convenção das Nações Unidas sobre o Direito do Mar, concluída em Montego Bay, Jamaica, em 10 de dezembro de 1982. Disponível em: <http:/ /www.planalto. gov.br/ccivil_03/decreto/1995/D1530.htm>. Acesso em: 13 jul. 2015. Sobre a questão ver BASTOS, Fernando Loureiro. $A$ internacionalização dos recursos naturais marinhos. Lisboa: AAFDL, 2005. p. 609-615.; Ainda, sobre as restrições à liberdade dos mares em geral, as práticas proibidas e as possibilidades de interferências em alto mar ver ZANELLA, Tiago Vinicius. Curso de direito do mar. Curitiba: Juruá, 2013. p. 262-276.

42 Nesse sentido, por todos, HANDL, Günther. Regional arrangements and third state vessels: is the pacta tertiis principle being modified. In: RINGBOM, Henrik (Ed.). Competing norms in the law of the marine environmental protection: focus on ship safety and pollution prevention. Hague: Kluwer Law International, 1997. p. 217-240. p. 228-229.

43 FERRI, Nicola. Trade measures for conservation of fisheries and third states: an evolutionary trend in international law. 2009, $456 \mathrm{f}$. Tesi (dottorato) - Università degli Studi di Milano-Bicocca, Milano, 2012. p. 7.

44 Nesse sentido, CHINKIN, Christine. Third parties in international law. Oxford: Clarendon Press, 1993. p. 138, afirma que a Convenção de Viena "was drafted in a sufficiently flexible way to allow future development of international law"; na mesma linha HANDL, Günther. Regional arrangements and third state vessels: is the pacta tertiis principle being modified. In: RINGBOM, Henrik (Ed.). Competing norms in the law of the marine environmental protection: focus on ship safety and pollution prevention. Hague: Kluwer Law International, 1997. p. 217-240. p. 221., que destaca que o princípio da pacta tertiis pode aceitar exceções. 
que existe real excepcionalização da pacta tertiis, mas tão somente efeitos convencionais reflexos em relação a terceiros. Os Estados não estão realmente obrigados a cumprir disposições de tratados que não são signatários. Isto é, o que se pretende é influenciar esses terceiros a seguir as normas e regras de direito do mar, mas não obrigá-los a cumprir tais disposições ${ }^{45}$.

Não se vislumbra nos tratados internacionais nem na jurisprudência evolução tão significativa do direito internacional a ponto de superar a autonomia da vontade e a liberdade soberana de cada Estado, para vinculá-lo sem seu consentimento. Mesmo nos casos de proteção ambiental marinha não se pode admitir que um tratado possa gerar efeitos para criar obrigações ou direitos a terceiros sem a sua aceitação. Tal possibilidade geraria poder a um grupo de Estados, mais ou menos organizados, de criar normas aplicáveis a outros Estados que não as aceitem. Isto é, traria enorme insegurança jurídica, no modelo atual de desenvolvimento do direito internacional a possibilidade de alguns países vincularem, por meio de tratados internacionais, terceiros Estados que não assentirem. Seria uma superação inaceitável, pelo menos nesse momento e atual de desenvolvimento internacional, do princípio da autonomia da vontade dos Estados e uma afronta insuperável de sua soberania.

O que se pretende, então, é unicamente influenciar o comportamento de terceiros Estados. Essa influência ocorre, sobretudo, no processo de normatização dos espaços fora da jurisdição estatal e, em especial, nas matérias de proteção ambiental. Isto em razão da necessidade de envolvimento dos terceiros sob pena de invalidar o regime jurídico de proteção ambiental. Assim, para a efetividade dessa influência, há a necessidade de algum elemento de ligação entre os Estados, a fim de que o comportamento de determinado país consiga gerar o efeito esperado de guiar o comportamento do terceiro de modo efetivo ${ }^{46}$.

45 Nesse sentido BASTOS, Fernando Loureiro. Algumas considerações sobre a produção de efeitos dos tratados de proteção do ambiente no espaço marinho. In: MIRANDA, Jorge (Coord.). Estudos em homenagem ao Professor Doutor Sérvulo Correia. Coimbra: Coimbra, 2010. v. 4. p. 315.

46 Nesse sentido BASTOS, Fernando Loureiro. Algumas considerações sobre a produção de efeitos dos tratados de proteção do ambiente no espaço marinho. In: MIRANDA, Jorge (Coord.). Estudos em homenagem ao Professor Doutor Sérvulo Correia. Coimbra: Coimbra, 2010. v. 4. p. 301-341. p. 316-317., que destaca: "Isso significa, como é evidente, que a eficácia dos efeitos reflexos de regime convencional está dependente da existência de uma qualquer conexão com o
Diante do exposto, passamos a analisar dois tratados de direito do mar e seus pretensos efeitos sobre terceiros. Em primeiro lugar, a Convenção das Nações Unidas sobre o Direito do Mar, por se tratar do principal documento desse ramo do direito, sendo inclusive denominada de "Constituição dos Oceanos". Em segundo lugar, o chamado Acordo de 1995 (Acordo para Implementação das Disposições da Convenção das Nações Unidas sobre o Direito do Mar, de 10 de dezembro de 1982, sobre a Conservação e Ordenamento de Populações de Peixes Transzonais e de Populações de Peixes Altamente Migratórios), em razão da sua importância para a regulação e proteção das populações pesqueiras no mundo e, também, para entender quais os efeitos sobre terceiros de tratados de direito do mar ambientais.

\subsection{A produção de efeitos da Convenção das Nações Unidas sobre o Direito do Mar sobre terceiros}

Iniciados os trabalhos da III Conferência sobre o Direito do Mar, foi estabelecido pelas partes que as questões deveriam ser debatidas e as decisões ocorreriam por meio de consenso, utilizando para tal um Gentleman Agreement, que foi anexado como modelo de negociação ao regulamento geral da Conferência ${ }^{47}$. Ainda, decidiu-se que as matérias seriam deliberadas e aprovadas em bloco, utilizando-se para isso do método do package deal ${ }^{\text {H8 }}$. O processo de negociação não se deu de forma

terceiro Estado, nomeadamente na existência de uma relação entre o Estado parte e o Estado não parte. Caso contrário, a influência que possa ter na modelação dos comportamentos de terceiros será muito diminuta, na medida em que estará na dependência exclusiva da sua vontade de colaborar".

47 Sobre o processo de elaboração da CNUDM, consultar TANAKA, Yoshifumi. The International law of the sea. New York: Cambridge University Press, 2012. p. 24-29.; ROCHA, Rosa Maria Souza Martins. O mar territorial: largura e natureza jurídica. Porto: Universidade Portucalense, 1996. p. 180-250.; ZANELLA, Tiago Vinicius. Curso de direito do mar. Curitiba: Juruá, 2013. p. 86-92.; DUPUY, René-Jean. L'ocean partagé: analyse d'une negociation: Conference des Nations Unies sur le droit de la mer. Paris: A. Pedone, 1979.; $\mathrm{KOH}$, Tommy, T. B.; JAYAKUMAR, Shnmungan. The negotiating processo of the third United Nations Conference on the Law of the Sea. In: NORDQUIST, Myron H. United Nations Convention on the Law of the Sea, 1982: a commentary. Dordrecht: Martinus Nijhoff Publishers, 1982. v. 1. p. 22-134.

48 Em relação ao modelo negociação, suas vantagens e desvantagens, consultar: EUSTIS, Robert D. Procedures and techniques of multinational negotiation: the LOS III model. Virginia Journal of International Law, Virginia, v. 17, n. 2, p. 214-256, Winter, 1977.; CAMINOS, Hugo; MOLITOR, Michael R. Progressive development of international law and the package deal. The American Journal 
pacata, uma vez que havia diversos interesses em jogo, além do extenso conjunto de temas a serem decididos para chegar a um texto final consensual, que agradasse a todos, e com pretensa aplicação universal ${ }^{49}$. Ademais, a necessidade do package deal tornou o processo muito lento e sujeito a articulações por meio de instrumentos políticos, em detrimento dos aspectos jurídicos e técnicos, permitindo que qualquer grupo mais ou menos organizado pudesse bloquear a tomada de decisão ${ }^{50}$. Vale destacar que, em razão desse formato de negociação, a CNUDM não aceita nenhum tipo de reserva ${ }^{51}$.

Dessa forma, o processo de elaboração da Convenção de Montego Bay foi bastante demorado: iniciou-se em 1973 e, após 11 sessões, muitos debates e discussões, terminou em $1982^{52}$. Nos dias em que fica aberta

of International law, Washington, v. 79, n. 4, p. 871-890, Oct. 1985; ROCHA, Rosa Maria Souza Martins. O mar territorial: largura e natureza jurídica. Porto: Universidade Portucalense, 1996. p. 198-200.; Sobre a necessidade de se utilizar o método do package deal, afirmou o embaixador do Peru Arias Schreiber, falando em nome do Grupo dos 77 na $183^{\circ}$ reunião plenária da $11^{\circ}$ sessão, em 22 de setembro de 1982: "In negotiating and adopting the [Law of the Sea] Convention, the Conference had borne in mind that the problems of ocean space were closely interrelated and had to be dealt with as a whole. The "package deal" approach ruled out any selective application of the Convention". UN Doc. A/CONF.62/SR.183, at 3-4 (prov. 1982). UNITED NATIONS CONFERENCE ON THE LAW OF THE SEA, 3., 1982, Jamaica. Plenary Meetings, Summary Records and Verbatim Records, as well as Documents of the Conference, Resumed Eleventh Session and Final Part Eleventh Session and Conclusion...Jamaica: United Nations, 1982. v. 17. Disponivel em: <http://legal.un.org/ diplomaticconferences/lawofthesea-1982/docs/vol_XVII/a_conf62_sr-183.pdf>. Acesso em: 22 set. 2014.

49 Nesse sentido, destaca BASTOS, Fernando Loureiro. A internacionalização dos recursos naturais marinhos. Lisboa: AAFDL, 2005. p. 194: "A Convenção tem na sua origem dois objectivos muito ambiciosos. Por um lado, conseguir transformar numa vinculação internacional unitária uma extraordinariamente extensa agenda, em que se incluíam praticamente todos os assuntos relacionados com a utilização dos oceanos em tempo de paz. E, por outro lado, fazê-lo de uma forma consensual, de modo a criar um regime que pudesse vir a ter participação e aplicação universais".

50 Nesse sentido CAMINOS, Hugo; MOLITOR, Michael R. Progressive development of international law and the package deal. The American Journal of International Law, Washington, v. 79, n. 4, p. 871-890, Oct. 1985. p. 886-887.; EUSTIS, Robert D. Procedures and techniques of multinational negotiation: the LOS III model. Virginia Journal of International Law, Virginia, v. 17, n. 2, p. 214-256, Winter, 1977. p. 217.

51 BRASIL. Decreto $n^{\circ} 1.530$, de 22 de junho de 1995. Declara a entrada em vigor da Convenção das Nações Unidas sobre o Direito do Mar, concluída em Montego Bay, Jamaica, em 10 de dezembro de 1982. Disponível em: <http://www.planalto.gov.br/ccivil_03/ decreto/1995/D1530.htm>. Acesso em: 13 jul. 2015. Art. 309.

52 A CNUDM teve 130 votos a favor, 17 abstenções e 4 votos contrários (Estados Unidos da América, Israel, Turquia e Venezuela). Nesse sentido ROCHA, Rosa Maria Souza Martins. O mar ter- para assinaturas, a CNUDM obtém 119 rubricas $^{53}$, batendo recorde histórico e consagrando, o texto, como o de maior adesão de todo o direito internacional ${ }^{54}$. No dia final reservado para as assinaturas, em 09 de dezembro de 1984, a Convenção já contava com $159^{55}$.

Não obstante essa aparente impressão de completa adesão ao texto convencional, os Estados industrializados não assinaram a CNUDM. É o caso, por exemplo, dos Estados Unidos, Alemanha, Reino Unido ${ }^{56}$. Estes, além de não assinarem, deixaram claro que não o fariam em razão das significativas mudanças no regime jurídico dos fundos marinhos, o que não lhes agradava ${ }^{57}$.

No entanto, para que esse novo regime tivesse eficácia, era fundamental a participação desses Estados desenvolvidos por dois motivos principais. Primeiro, seriam eles os principais contribuintes e financiadores do regime ${ }^{58}$; segundo, para a implementação dessa nova ordem jurídica aplicável à área, era necessário que todos os Estados a aceitassem, sobretudo os desenvolvidos, com o risco de diferentes regulamentos serem aplicá-

ritorial: largura e natureza jurídica. Porto: Universidade Portucalense, 1996. p. 208.

53 Entre 6 e 10 de dezembro de 1982, a Convenção foi assinada por 117 Estados, pela delegação das ilhas Cook e da Namíbia.

54 Nesse sentido ROCHA, Rosa Maria Souza Martins. O mar territorial: largura e natureza jurídica. Porto: Universidade Portucalense, 1996. p. 208.; ZANELLA, Tiago Vinicius. Curso de direito do mar. Curitiba: Juruá, 2013. p. 339.

55 Dados do Escritório do representante especial do secretáriogeral para o direito do mar. LAW OF THE SEA BULLETIN. New York: United Nation, n. 4, Feb. 1985. Disponível em: < http://www. un.org/depts/los/doalos_publications/LOSBulletins/bulletinpdf/ bulE4.pdf>. Acesso em: 13 jul. 2015.

56 Nesse sentido ANDREOLA, Susana Cordenonsi. Fundos marinhos: regulamentação pelo direito internacional. Juruá: Curitiba, 2010. p. 120.; ROCHA, Rosa Maria Souza Martins. O mar territorial: largura e natureza jurídica. Porto: Universidade Portucalense, 1996. p. 208-209.; WOOD, Michael C. International seabed authority: the first four years. Max Planck Yearbook of United Nations Law, Heidelberg, v. 3, p. 173-241, 1999. p. 179.

57 Sobre a questão, por todos, resume WOOD, Michael C. International seabed authority: the first four years. Max Planck Yearbook of United Nations Law, Heidelberg, v. 3, p. 173-241, 1999. p. 179: "But it was soon clear that the Convention, as adopted, would not secure the participation of industrialized States because of the provisions for deep seabed mining". Ainda, afirma BASTOS, Fernando Loureiro. A internacionalização dos recursos naturais marinhos. Lisboa: AAFDL, 2005. p. 226.: "A raiz desse desacordo residia numa construção projectada com objectivos primacialmente ideológicos, sem qualquer relação com os parâmetros correntes de exploração dos recursos naturais não vivos existentes nesse espaço".

58 Nesse sentido, PLATZODER, Renate. Substantive changes in a multilateral treaty before its. Entry into force: the case of the 1982 United Nations. Convention on the Law of the Sea. European Jounal of International Law, New York, v. 4, n. 3, p. 390-402; 1993. p. 391. 
veis ao mesmo espaço marinho. Esse motivo leva a outras consequências que impossibilitariam a aplicação, por exemplo, do princípio do Patrimônio Comum da Humanidade $^{59}$. Ora, não há como aplicar tal princípio a apenas algumas nações enquanto outras exploram a região livremente, sem a regulamentação inerente ao princípio $^{60}$.

$\mathrm{O}$ artigo $308^{\circ}$ da CNUDM determinou que a "Convenção entra em vigor 12 meses após a data de depósito do sexagésimo instrumento de ratificação ou de

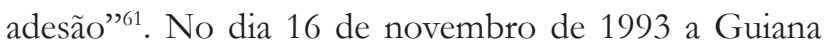
deposita a $60^{\circ}$ ratificação junto ao Secretário-geral da ONU, o que colocava a questão da entrada em vigor da CNUDM em um ano ${ }^{62}$. A comunidade internacional deparou-se então com um dilema: ou a Convenção

59 Sobre a questão ver ANDERSON, David H. Resolution and agreement relating to the implementation of part xi of the UN Convention on the Law of the Sea: a general assessment. ZaoRV, Berlin, v. 55, p. 275-289, 1995. p. 278; GUNTRIP, Edward. The common heritage of mankind: an adequate regime for managing the deep seabed? Melbourne Journal of International Law, Parkville, v. 4, n. 2, p. 376-405, 2003; WOOD, Michael C. International seabed authority: the first four years. Max Planck Yearbook of United Nations Law, Heidelberg, v. 3 p. 173-241, 1999. p. 174 e ss.

60 E, mesmo após o Acordo de 1994, a efetivação desse princípio passou a ser relativizada por alguns doutrinadores. Pode-se destacar nesse contexto a opinião de TRINDADE, Antônio Augusto Cançado. A nova dimensão do direito internacional público. Brasília: Instituto Rio Branco, 2003. v. 1. p. 117: "O exame do Acordo sobre a Implementação da Parte XI da Convenção das Nações Unidas sobre Direito do Mar à luz do princípio do Patrimônio Comum da Humanidade e do regime originalmente definido na Convenção de Montego Bay revela de maneira cândida que, após o Acordo de 1994, o conceito jurídico de patrimônio comum da humanidade, pelo menos em relação à Área, sofreu um grande abalo, um esvaziamento significativo que o aproximou em muito do antigo conceito de res communis omnium do Direito Romano". Nossa opinião, como destaca ZANELLA, Tiago Vinicius. Curso de direito do mar. Curitiba: Juruá, 2013. p. 338. é que "o Acordo de 1994 pode ser classificado como um texto que casou um esvaziamento substancial no princípio de Patrimônio Comum da Humanidade", mas não afastou esse princípio como uma norma estruturante do Direito do Mar para os fundos marinhos.

61 BRASIL. Decreto $n^{0} 1.530$, de 22 de junho de 1995. Declara a entrada em vigor da Convenção das Nações Unidas sobre o Direito do Mar, concluída em Montego Bay, Jamaica, em 10 de dezembro de 1982. Disponível em: <http://www.planalto.gov.br/ccivil_03/ decreto/1995/D1530.htm>. Acesso em: 13 jul. 2015 Art. 308.

62 Sobre a questão, destaca FERRI, Nicola. Trade measures for conservation of fisheries and third states: an evolutionary trend in international law. 2009, 456 f. Tesi (dottorato) - Università degli Studi di Milano-Bicocca, Milano, 2012. p. 92: "Due to the conflict of interests between developing states and maritime powers during UNCLOS III - which was not limited to issues related to fisheries - it took twelve years for the LOSC to enter into force, an event that happened one year after the date of deposit of the sixtieth instrument of ratification". entrava em vigor como estava, sem a participação dos Estados industrializados e sem a efetividade necessária, ou encontrava-se uma solução para alcançar a universalidade na participação, de forma a salvaguardar o regime jurídico geral instituído pela CNUDM aos oceanos ${ }^{63}$.

A solução apresentada foi um dos melhores exemplos de pragmatismo que o sistema internacional poderia encontrar ${ }^{64}$. Em termos teóricos, um texto de difícil qualificação perante o direito internacional vigente ${ }^{65}$. $\mathrm{Na}$ prática, uma solução eficaz que resolveu o problema da falta de adesão dos Estados industrializados e universalizou definitivamente a $\mathrm{CNUDM}^{66}$. A fórmula adotada não foi nem a adoção de uma nova convenção sobre o direito do mar (ou pelo menos relativo aos fundos marinhos), nem a revisão da Convenção de 1982, mas sim um texto anexo com interpretações à Parte XI da CNUDM: o Acordo relativo à Implementação da Parte XI da Convenção das Nações Unidas sobre o Direito do Mar, assinado em 3 de junho de 1994 na cidade de Nova Yorque ${ }^{67}$. Foi apenas após a adoção desse acordo

63 Sobre a questão, resume WOOD, Michael C. International seabed authority: the first four years. Max Planck Yearbook of United Nations Law, Heidelberg, v. 3, p. 173-241, 1999. p. 174: "The original Part XI regime effectively precluded industrialized States from joining the Convention for more than a decade, putting at risk the whole project for a modern constitution for the oceans".

64 Nesse sentido BASTOS, Fernando Loureiro. A internacionalização dos recursos naturais marinhos. Lisboa: AAFDL, 2005. p. 225.

65 Sobre a questão MARTINS, Ana Maria Guerra. O acordo relativo à aplicação da Parte XI da Convenção das Nações Unidas sobre o Direito do Mar de 1982 na óptica do direito dos tratados. Revista Jurídica, Lisboa, n. 24, p. 21-51, maio 2001. p. 32-51.

66 Nesse sentido NADAN, Satya N. The efforts undertaken by the United Nations to ensure universality of the convention. In: MILES, Edward L.; TREVES, Tullio (Ed.). The Law of the Sea: new worlds, new discoveries. Honolulu: Law of the Sea Institute, 1993. p. 349-378. p. 352.

67 Para um estudo mais aprofundado sobre o Acordo de 1994, consultar BASTOS, Fernando Loureiro. A internacionalização dos recursos naturais marinhos. Lisboa: AAFDL, 2005. p. 225-252.; Sobre a questão MARTINS, Ana Maria Guerra. O acordo relativo à aplicação da Parte XI da Convenção das Nações Unidas sobre o Direito do Mar de 1982 na óptica do direito dos tratados. Revista Jurídica, Lisboa, n. 24, p. 21-51, maio 2001; TREVES, Tullio. The agreement completing the UN law of the sea convention: formal and procedural aspects. In: NORDQUIST, Myron H.; MOORE, John Norton (Ed.). Entry into force of the law of the sea convention. Netherlands: Kluwer Law International, 1995. p. 99-118.; OXMAN, Bernard H. The agreement and the Convention. American Journal of International Law, Washington, v. 88, n. 4, p. 687-696, 1994.; ou ainda, sobre as consequências do acordo de 1994, como destaca ZANELLA, Tiago Vinicius. Curso de direito do mar. Curitiba: Juruá, 2013. p. 341: "De forma expressa o texto limita-se a criar interpretações e condições para a aplicação da Parte XI. Na prática, altera de forma substancial a regulamentação relativa à Área. Nesse sentido, o Acordo de 1994 
que a CNUDM conseguiu a ratificação das maiores potências e uma real efetividade no sistema internacional ${ }^{68}$. Antes do Acordo de 1994, a participação na Convenção praticamente se resumia aos Estados em desenvolvimento, com exceção talvez da Islândia ${ }^{69}$.

Atualmente 167 Estados já ratificaram a Convenção das Nações Unidas sobre o Direito do $\mathrm{Mar}^{70}$, englobando em seu ordenamento jurídico grande parte de países da sociedade internacional e, sobretudo, quase todos os Estados mais desenvolvidos ${ }^{71}$. Todavia, a questão que se colocou logo após o fim da III Conferência das $\mathrm{Na}$ ções Unidas sobre o Direito do Mar, que deu origem a CNUDM, com seus problemas, em especial a falta de adesão dos Estados industrializados, ainda permanece ${ }^{72}$. Isto é, resta saber se os terceiros Estados, que ainda não são signatários da Convenção de Montego Bay, sofrem os efeitos desse texto convencional para possuírem direitos e deveres perante o direito internacional criado

pode ser classificado como um texto que casou um esvaziamento substancial no princípio de Patrimônio Comum da Humanidade".

68 Nesse sentido, resume ANDERSON, David H. Resolution and agreement relating to the implementation of part xi of the UN Convention on the Law of the Sea: a general assessment. ZaoRV, Berlin, v. 55, p. 275-289, 1995. p. 289: “The Agreement has quickly attracted signatures or support for provisional application from all the significant industrialised states, as well as from significant developing states, including several parties to the Convention". Ou ainda, como afirma FERRI, Nicola. Trade measures for conservation of fisheries and third states: an evolutionary trend in international law. 2009, $456 \mathrm{f}$. Tesi (dottorato) - Università degli Studi di Milano-Bicocca, Milano, 2012. p. 94.: "The importance of the Agreement in facilitating the ratification process of the LOSC has been crucial, as per the expectations of the UN Secretary General which had conducted technical consultations between 1990 and 1993 to promote universal participation to the LOSC".

69 Nesse sentido BASTOS, Fernando Loureiro. A internacionalização dos recursos naturais marinhos. Lisboa: AAFDL, 2005. p. 231.

70 Dados disponíveis em: UNITED NATION. Division for Ocean Affairs and the Law of The Sea. Chronological lists of ratifications of, accessions and successions to the Convention and the related Agreements as at 3 October 2014. Jan. 2015. Disponível em: <http://www.un.org/ Depts/los/reference_files/chronological_lists_of_ratifications. htm\#Agreement for the implementation of the provisions of the Convention relating to the conservation and management of straddling fish stocks and highly migratory fish stocks $>$. Acesso em: 27 abr. 2015.

71 Nesse sentido ANDERSON, David H. Resolution and agreement relating to the implementation of part xi of the UN Convention on the Law of the Sea: a general assessment. ZaoRV, Berlin, v. 55, p. 275-289, 1995. p. 289.; GUNTRIP, Edward. The common heritage of mankind: an adequate regime for managing the deep seabed? The common heritage of mankind. Melbourne Journal of International Law, Parkville, v. 4, n. 2, p. 376-405, 2003. p. 386 e ss.

72 Neste sentido FITZMAURICE, Malgosia. Third parties and the law of treaties. Max Planck Yearbook of United Nations Law, Netherlands, v. 6, n. 1, p. 37-137, Jan. 2002. p. 109 e ss. pela $\mathrm{CNUDM}^{73}$.

Em primeiro lugar, nota-se que a Convenção de 1982 traz em seu articulado, por inúmeras vezes, algumas expressões que podem dar a entender que o texto se aplica aos Estados, mesmo os não signatários: "all States" " "any State" 75 e "every State" "T6. Tais expressões, utilizadas em detrimento de "States Parties", podem levar à crença de que a CNUDM possui dispositivos que se aplicam aos Estados, gerando efeitos para criar direitos ou obrigações a terceiros ${ }^{77}$.

Como analisado anteriormente, segundo a Convenção de Viena de 1969, os tratados internacionais podem gerar obrigações (art. 35) ou direitos (art. 36) para terceiros. Para isso, resumidamente, existe a necessidade da intenção do tratado em gerar tais efeitos e também, necessariamente, o consentimento do Estado terceiro, seja explicitamente, como por escrito, ou implicitamente, por meio de um comportamento ${ }^{78}$.

Dito isso, a utilização das expressões gerais (como “all States" - "todos os Estados") pela CNUDM, pode indicar que o texto teve a intenção de gerar efeitos para

73 Sobre a questão, questiona-se BUTLER, William E. Custom, treaty, State practice and the 1982 Convention. Marine Policy, Amsterdam, v. 12, n. 3, p. 182-186, July, 1988. p. 185: "How may nonparties to the 1982 Convention be affected by interpretations of the Convention?"

74 BRASIL. Decreto $n^{0} 1.530$, de 22 de junho de 1995. Declara a entrada em vigor da Convenção das Nações Unidas sobre o Direito do Mar, concluída em Montego Bay, Jamaica, em 10 de dezembro de 1982. Disponível em: <http://www.planalto.gov.br/ccivil_03/decreto/1995/D1530.htm>. Acesso em: 13 jul. 2015. Arts. 17, 52, 58, $61 \mathrm{n}^{\circ} 5,79 \mathrm{n}^{\circ} 1,86,87 \mathrm{n}^{\circ} 1$ e $2,100,108 \mathrm{n}^{\circ} 1,109 \mathrm{n}^{\circ} 1,112 \mathrm{n}^{\circ} 1,116$, $117,119 \mathrm{n}^{\circ} 2,141,205,217 \mathrm{n}^{\circ} 7,238,256,257,260,274,276 \mathrm{n}^{\circ} 2$.

75 BRASIL. Decreto $n^{\circ} 1.530$, de 22 de junho de 1995. Declara a entrada em vigor da Convenção das Nações Unidas sobre o Direito do Mar, concluída em Montego Bay, Jamaica, em 10 de dezembro de 1982. Disponível em: <http://www.planalto.gov.br/ccivil_03/ decreto/1995/D1530.htm>. Acesso em: 13 jul. 2015. Arts. 62 no 4, $95,96,100,101,105,108 n^{\circ} 2,109 n^{\circ} 2,119 n^{\circ} 3,216,217 n^{\circ} 6,218$ $\mathrm{n}^{\circ} 3,223,228 \mathrm{n}^{\circ} 2,297 \mathrm{n}^{\circ} 3,301$.

76 BRASIL. Decreto $n^{\circ} 1.530$, de 22 de junho de 1995. Declara a entrada em vigor da Convenção das Nações Unidas sobre o Direito do Mar, concluída em Montego Bay, Jamaica, em 10 de dezembro de 1982. Disponível em: <http://www.planalto.gov.br/ccivil_03/ decreto/1995/D1530.htm>. Acesso em: 13 jul. 2015. Arts. 3, 90, 91, 94, 98, 99, 105, 113, 114, 115, $211 \mathrm{n}^{\circ} 3$.

77 O maior defensor de tal tese é LEE, Luke T. The law of the sea convention and third states. The American Journal of International Law, Washington, v. 77, n. 3, p. 541-568, July, 1983.

78 BASTOS, Fernando Loureiro. Algumas considerações sobre a produção de efeitos dos tratados de proteção do ambiente no espaço marinho. In: MIRANDA, Jorge (Coord.). Estudos em homenagem ao Professor Doutor Sérvulo Correia. Coimbra: Coimbra, 2010. v. 4. p. 301-341. p. 304-305. 
os Estados, signatários ou não ${ }^{79}$. Contudo, em geral, restou demonstrado que não era a intenção dos Estados gerar tais obrigações, muito menos direitos aos não membros $^{80}$. Tal disposição fica clara no discurso do embaixador do Peru Arias Schreiber, falando em nome do Grupo dos 77 (que na verdade inclúa cerca de 120 Estados) na $185^{\circ}$ reunião da Terceira Conferência das Nações Unidas sobre o Direito do Mar, em 10 de dezembro de 1982, dia final das assinaturas da CNUDM: "[...] that the negotiation and adoption of this treaty as an indivisible package excludes the possibility of its selective implementation and that no State can claim that the new rules and rights established by the Convention apply to that State if it is not a party to the Convention's1.

Além disso, interpretar a utilização dessas expressões gerais como um convite para terceiros Estados obterem direitos ou obrigações perante o texto convencional seria ignorar as regras de interpretação de tratados, sobretudo o artigo 31 da CVDT ${ }^{82}$. As expressões gerais utilizadas no contexto da CNUDM "e à luz de seu objetivo e finalidade" 83 - como "todos os Estados" - não podem ser interpretadas como oposição

79 Nesse sentido LEE, Luke T. The law of the sea convention and third states. The American Journal of International Law, Washington, v. 77 , n. 3, p. 541-568, July, 1983. p. 544-553.

80 Nesse sentido SCHWEISFURTH, Theodor. International treaties and third states. ZaoRV, Berlin, v. 45, p. 653-674, 1985. p. 672; FITZMAURICE, Malgosia. Third parties and the law of treaties. Max Planck Yearbook of United Nations Law, Netherlands, v. 6, n. 1, p. 37-137, Jan. 2002. p. 109.

81 Disponível em: <http://legal.un.org/diplomaticconferences/ lawofthesea-1982/docs/vol_XVII/a_conf-62_sr-185.pdf>. Acesso em: 30 set. 2014. p. 22, par. 157. Todavia, vale destacar que houve algumas declarações de Estados ao assinar a CNUDM a favor dos efeitos sobre terceiros Estados. Como destaca LEE, Luke T. The law of the sea convention and third states. The American Journal of International Law, Washington, v. 77, n. 3, p. 541-568, July, 1983. p. 548: "Among the declarations submitted pursuant to Article 310 of the Convention to date, only that of Iran specifically denies 'third states' rights to certain provisions of the Convention, including those of transit passage through Straits".

82 Sobre a questão, afirma SCHWEISFURTH, Theodor. International treaties and third states. ZaoRV, Berlin, v. 45, p. 653-674, 1985. p. 672-673: "This seems to be a rather contrived argumentation, too contrived to be convincing. In trying to as certain the "intent" of the parties to the treaty only from some circumstances of its conclusion, and only from unilateral instruments (speeches and declarations), Lee disregards the rules of treaty interpretation as laid down in Art.31 et seq. of the Vienna Convention".

83 UNITED NATIONS. Vienna convention on the law of treaties. Concluded at Vienna on 23 May 1969. Disponivel em: < https:// treaties.un.org/doc/Publication/UNTS/Volume\%201155/volume-1155-I-18232-English.pdf>. Acesso em: 13 jul. 2015. Art. 31, n. 1. à expressão "Estados partes", mas sim às expressões "Estados costeiros", "Estados sem litoral", "Estados arquipelágicos", "Estados em desenvolvimento". Isto é, quando a Convenção se refere a "todos os Estados", está fazendo menção aos países sujeitos ao texto, ou seja, aos signatários, independentemente de serem interiores, em desenvolvimento, arquipélagos ou outro ${ }^{84}$. Qualquer entendimento contrário seria afronta, desde logo, à ideia do package deal e da proibição de reservas da CNUDM. Isso porque seria inviável a Convenção criar apenas algumas obrigações ou direitos a terceiros e não vincular esses Estados à integralidade do texto convencional ${ }^{85}$.

Em segundo lugar, pode-se argumentar que a Convenção de Montego Bay, de certa forma, e em alguns aspectos, pode ser entendida como tratado objetivo ${ }^{86}$. Esses tratados podem ser, resumidamente, entendidos como aqueles que criam situações jurídicas objetivas ou regimes objetivos que produzem perante toda a sociedade internacional o efeito de exortação de reconhecimento ${ }^{87}$. Isto é, seriam aqueles tratados que, em

84 Nesse sentido SCHWEISFURTH, Theodor. International treaties and third states. ZaoRV, Berlin, v. 45, p. 653-674, 1985. p. 672-673.

85 Nesse sentido SCHWEISFURTH, Theodor. International treaties and third states. ZaoRV, Berlin, v. 45, p. 653-674, 1985. p. 673.; WOLFRUM, Rüdiger. The legal order for the seas and oceans. In: NORDQUIST, Myron H.; MOORE, John Norton (Ed.). Entry into force of the law of the sea convention. Netherlands: Kluwer Law International, 1995. p. 161-190. p. 161-190., p. 169, que afirma (note 49, p. 182): "The package deal approach has been regarded as a corollary of the pacta tertiis nec docent nec present rule".

86 Nesse sentido LEE, Luke T. The law of the sea convention and third states. The American Journal of International Law, Washington, v. 77, n. 3, p. 541-568, July, 1983. p. 565. Sobre a questão destaca ARROW, Dennis W. Seabeds, soverignty and objective regimes. Fordham International Law Journal, New York, v. 7, n. 2, p. 169-243, 1984. p. 169-170: "Nevertheless, the argument will undoubtedly be maintained by some that broad participation in the UNCLOS regime, or some intrinsic characteristic of the treaty itself, will have rendered it, at some point in time, an 'objective regime' capable of binding third-party non signatory states (probably including the United States) without their consent". Em sentido próximo, afirma VUKAS, Budislav. L'utilisation pacifique de la mer, dénucléarisation et désarmement. In: __ The law of the sea: selected writings. Leiden: Martinus Nijhoff Publishers, 2004. p. 157-204. p. 176: "Parmi les traités représentant des "régimes objectifs", on cite ceux qui ont trait à la navigation dans les canaux et les détroits, à la démilitarisation et la neutralisation et à l'exploitation d'espaces marins".

87 Sobre o conceito, destaca FERRI, Nicola. Trade measures for conservation of fisheries and third states: an evolutionary trend in international law. 2009, 456 f. Tesi (dottorato) - Università degli Studi di Milano-Bicocca, Milano, 2012. p. 129-130: “The concept of objective regimes originated in the works of the ILC relating to the law of treaties in connection to the existence of treaties that were capable 
razão de sua natureza e finalidade, criariam obrigações de efeito erga omnes, gerando efeitos de - para além de respeitar o disposto no tratado e não impedir seu cumprimento pelos signatários — reconhecimento e cumprimento das disposições convencionais ${ }^{88}$. Tal conceito tem sido particularmente utilizado para enquadrar alguns tratados relativos ao regime jurídico dos espaços internacionais ${ }^{89}$, como é o caso do Tratado Antártico ${ }^{90}$. Porém, para além disso, em seu âmbito têm-se incluído tratados de desmilitarização de territórios específicos ${ }^{91}$, a liberdade de navegação marítima e em rios internacionais ou a regulamentação de vias de comunicação internacionais, como alguns estreitos ${ }^{92}$.

to create obligations and rights for third states. It appeared already as a very controversial topic "the Commission considered whether treaties creating so- called 'objective regimes', that is, obligations and rights valid erga omnes, should be dealt with separately as a special case".

88 Para um maior aprofundamento no conceito e demais questões relativas aos regimes objetivos consultar, entre outros: SALERNO, Francesco. Treaties Establishing Objective Regimes. In: CANNIZZARO, Enzo (Ed.). The law of treaties beyond the Vienna Convention. Oxford: Oxford University Press, 2011. p. 225-243.; FITZMAURICE, Malgosia. Third parties and the law of treaties. Max Planck Yearbook of United Nations Law, Netherlands, v. 6, n. 1, p. 37-137, Jan. 2002.

89 Nesse sentido BASTOS, Fernando Loureiro. Algumas considerações sobre a produção de efeitos dos tratados de proteção do ambiente no espaço marinho. In: MIRANDA, Jorge (Coord.). Estudos em homenagem ao Professor Doutor Sérvulo Correia. Coimbra: Coimbra, 2010. v. 4. p. 301-341. p. 312; RAGAZZI, Maurizio. The concept of international obligations erga omnes. Oxford: Clarendon Press, 1997. p. 37-41.; ROZAKIS, Christos L. Treaties and third states: a study in the reinforcement of the consensual standards in international law. ZaoRV, Berlin, v. 35, p. 1-40, 1975. p. 11.

90 Em relação à questão, consultar SIMMA, Bruno. The Antarctic Treaty as a treaty providing for an 'Objective Regime'. Cornell International Law Journal, New York, v. 19, n. 2, p. 189-209, Spring, 1986.; FITZMAURICE, Malgosia. Third parties and the law of treaties. Max Planck Yearbook of United Nations Law, Netherlands, v. 6, n. 1, p. 37-137, Jan. 2002. p. 121-137; CHARNEY, Jonathan I. The Antarctic system and customary international law. In: SCOVAZZI, Tullio; FRANCIONI, Francesco (Ed.). International law for Antarctica. Netherlands: Martinus Nijhoff Publishers, 1996. p. 51-101. p. 62 e ss.; Em termos gerais, sobre o direito internacional e o continente antártico, ver SCOVAZZI, Tullio; FRANCIONI, Francesco. International law for Antartica. Netherlands: Martinus Nijhoff Publishers, 1996.

91 Como, por exemplo, é o caso das Ilhas Aaland. Sobre a questão ver HANNIKAINEN, Lauri. The continued validity of the demilitarised and neutralised status of the Aland Islands. Zaorv, Berlim, v. 54, p. 614-651, 1994.

92 Sobre a questão, por todos, afirma FITZMAURICE, Malgosia. Third parties and the law of treaties. Max Planck Yearbook of United Nations Law, Netherlands, v. 6, n. 1, p. 37-137, Jan. 2002. p. 66: "There is also a third theory that applies to a particular type of treaties such as establishing freedom of navigation in international rivers and in maritime waterways; treaties which provide for neutralisa-
O tema dos tratados objetivos é bastante complexo e com grandes consequências para o direito internacional. Se entendido de maneira ampla e sem restrições, esses tratados podem significar grave relativização ao princípio da pacta tertiis nec nocent nec prosunt ${ }^{3}$. Diante disso, nos preparativos e discussões para a elaboração do texto da Convenção de Viena sobre o Direito dos Tratados de 1969, observou-se a possibilidade de inclusão de artigo referente ao tema ${ }^{94}$. Contudo, por maioria, decidiu-se não inserir os tratados objetivos no texto e não tratá-los com um regime diferente das demais convenções internacionais ${ }^{95}$. Esse posicionamento demonstra a real dificuldade da sociedade e do direto internacional em excepcionar o princípio da pacta tertiis.

Nesse sentido, os tratados que criam esses regimes objetivos, para gerar efeitos sobre terceiros, precisam, necessariamente, do consentimento destes ${ }^{96}$. Seja este

tion or demilitarisation of particular territories or areas; or possibly the Antarctic Treaty. This category is considered by some lawyers as belonging to a special category of so-called 'objective regimes'." 93 Nesse sentido TAMS, Christian J. Enforcing obligations Erga Omnes in international law. Reino Unido: Cambridge University Press, 2005. p. 81.; FITZMAURICE, Malgosia. Third parties and the law of treaties. Max Planck Yearbook of United Nations Law, Netherlands, v. 6, n. 1, p. 37-137, Jan. 2002. p. 72 e ss.;

94 Sobre a questão, ver SCHWEISFURTH, Theodor. International treaties and third states. ZaoRV, Berlin, v. 45, p. 653-674, 1985. p. 665 e ss.; ROZAKIS, Christos L. Treaties and third states: a study in the reinforcement of the consensual standards in international law. ZaoRV, Berlin, v. 35, p. 1-40, 1975. p. 9 e ss.; FITZMAURICE, Malgosia. Third parties and the law of treaties. Max Planck Yearbook of United Nations Law, Netherlands, v. 6, n. 1, p. 37-137, Jan. 2002. p. 72 e ss.; O texto do artigo proposto por WALDOCK, Humphrey. Document A/CN.4/156 and Add.1-3: Second report on the law of treaties. In: UNITED NATIONS. Yearbook of The International Law Commission, 1963. New York: United Nations, 1964. v. 2. p. 3694P. 26 foi: "Article 63. - Treaties providing for objective regimes: A treaty establishes an objective régime when it appears from its terms and from the circumstances of its conclusion that the intention of the parties is to create in the general interest general obligations and rights relating to a particular region, State, territory, locality, river, waterway or to a particular area of sea, seabed or air space; provided that the parties include among their number any State having territorial competence with reference to the subject matter of the treaty, or that any such State has consented to the provision in question". 95 Sobre a questão, destaca ROZAKIS, Christos L. Treaties and third states: a study in the reinforcement of the consensual standards in international law. ZaoRV, Berlin, v. 35, p. 1-40, 1975. p. 9: "The rejection of the idea of accepting into the domain of positive inter- national law the theoretical notion of 'objective regimes' constitutes a very good indication of the Commission's feelings as to the proper role of treaties in the domain of current international relations".

96 Nesse sentido, reusme FITZMAURICE, Malgosia. Third parties and the law of treaties. Max Planck Yearbook of United Nations Law, Netherlands, v. 6, n. 1, p. 37-137, Jan. 2002. p. 74 "The effec- 
explícito ou implícito. Por exemplo, ao utilizar um estreito internacional regularmente, o Estado demonstra sua aceitação pelo regime jurídico imposto àquele espaço marítimo e fica sujeito a respeitar suas regras e normas de navegação ${ }^{97}$. Não se pode admitir que esses tratados objetivos criem explicitamente direitos e, sobretudo, obrigações a terceiros que não as aceitem ${ }^{98}$. Isso, todavia, não quer dizer que os terceiros Estados não possuam o dever de respeitar o tratado celebrado entre as partes ${ }^{99}$.

De todo modo, a caracterização da Convenção sobre Direito do Mar como um tratado objetivo é de difícil sustentação. Não se pode, de modo algum, argumentar que a CNUDM, em sua totalidade, cria um regime objetivo para os mares e espaços marítimos. Isso porque a Convenção cria normas para além de regular espaços marítimos internacionais. Pode-se alegar então que partes do texto criariam regimes objetivos. Todavia, tal argumentação contraria sobremaneira a ideia consensual do package deal. Além disso, a Convenção contém disposições que indicam que ela não teve a intenção de tentar criar um regime objetivo geral com seu texto normativo: a necessidade de ratificação, de um número mínimo de participantes, a possibilidade de denúncia do

tiveness of an objective regime on third states is conditioned upon their consent, which may be express, or may be implied through acquiescence by its refraining to manifest its opposition within a specified period from the deposit of a treaty with the SecretaryGeneral of the United Nations".

97 Sobre a questão, as palavras de BASTOS, Fernando Loureiro. Algumas considerações sobre a produção de efeitos dos tratados de proteção do ambiente no espaço marinho. In: MIRANDA, Jorge (Coord.). Estudos em homenagem ao Professor Doutor Sérvulo Correia. Coimbra: Coimbra, 2010. v. 4. p. 301-341. p. 313, são bastante ilustrativas: "Com efeito, ao actuarem em consonância com a regulamentação convencional existente - por exemplo, a relativa à utilização de um canal internacional - os Estados estão a demonstrar que a aceitam. O que significa que, a partir de então, devem passar a respeitá-la em todas as situações em que possam ter um interesse relevante na regulamentação jurídico-internacional em causa”.

98 Como resume SCHWEISFURTH, Theodor. International treaties and third states. ZaoRV, Berlin, v. 45, p. 653-674, 1985. p. 666: "Thus treaties establishing 'objective regime' cannot be considered as exceptions to Arts. 34-38 of the Vienna Convention."

99 Não se pode, de forma alguma, confundir os dois institutos. Como resume BASTOS, Fernando Loureiro. Algumas considerações sobre a produção de efeitos dos tratados de proteção do ambiente no espaço marinho. In: MIRANDA, Jorge (Coord.). Estudos em homenagem ao Professor Doutor Sérvulo Correia. Coimbra: Coimbra, 2010. v. 4. p. 301-341. p. 303: "Questão distinta da produção de efeitos em relação a terceiros é a obrigação genérica que impende sobre todos os Estados de respeitarem os tratados que tenham sido concluídos por terceiros Estados [...]" tratado, a impossibilidade de reservas ${ }^{100}$.

Diante desse quadro geral, entendemos que a CNUDM não gera efeitos para criar obrigações ou direitos para Estados terceiros ${ }^{101}$. A não ratificação da Convenção de 1982 isenta o Estado de qualquer obrigação perante o texto e, em especial, não cria nenhum direito para o terceiro não signatário. Isto é, ou o Estado se vincula à CNUDM, com todas as suas obrigações e direitos, ou não se pode lhe exigir o cumprimento do tratado, nem lhe conceder nenhum benefício por essa razão ${ }^{102}$.

Por outro lado, atualmente, a Convenção de Montego Bay já se encontra, em grande parte, vinculada diretamente ao direito consuetudinário ${ }^{103}$. Isto é, diversas disposições convencionais já formam costume internacional, com capacidade para vincular terceiros Estados ou até mesmo toda a comunidade interacional ${ }^{104}$. Diante

100 Sobre a questão, afirma ARROW, Dennis W. Seabeds, soverignty and objective regimes. Fordham International Law Journal, New York, v. 7 n. 2, p. 169-243, 1984. p. 169-170. p. 227, que ainda afirma "UNCLOS, as a result, is unlikely ever to be recognized as an 'objective regime' except by way of obiter dicta in a future decision which will undoubtedly be more narrowly explicable based on UNCLOS prospective status as customary international law".

101 Nesse mesmo KOLODKIN, A. L.; ANDRIANOV, V. V.; KISELEV, V. A. Legal implications of participation or non-participation in the 1982 Convention. Marine Policy, Amsterdam, v. 12, n. 3, p. 187-191, 1988. p. 190 e ss.; BUTLER, William. E. Custom, treaty, State practice and the 1982 Convention. Marine Policy, Amsterdam, v. 12, n. 3, p. 182-186, July, 1988. p. 185 e ss.;

102 Como afirmou Tommy Koh, que presidiu a III Conferência das Nações Unidas sobre o Direito do Mar: "although the Convention consists of a series of compromises, they are for an integral whole. This is why the Convention does not provide for reservations. It is therefore, not possible for States to pick what they do not like. In international law, as in domestic law, rights and duties go hand in hand. It is therefore, legally impermissible to claim rights under the Convention without being willing to assume the correlative duties". KOH, Tommy, T. B.; JAYAKUMAR, Shnmungan. The negotiating processo of the third United Nations Conference on the Law of the Sea. In: NORDQUIST, Myron H. United Nations Convention on the Law of the Sea, 1982: a commentary. Dordrecht: Martinus Nijhoff Publishers, 1982. v. 1. p. 22-134.

103 Sobre a questão ver ONG, David M. International environmental law's customary dilemma: betwixt general principle and treaty rules. The irish yearbook of international law. Oxford, v. 1, p. 3-60, 2008.; HARRISON, James. Making the law of the sea: a study in the development of international law. Cambridge: Cambridge University Press, 2011. p. 48.; BERNHARDT, Rudolf. Custom and treaty in the law of the sea. Recueil des cours de l'académie de droit international de La Haye. Paris, v. 205, p. 252-329, 1987.; SIOUSSOURAS, Petros. The formation of customary rights in the international law ofthe sea: the case ofland-locked States. Revue Hellénique de Droit International, Athens, v. 54, n. 1, p. 299-317, 2001.

104 Pode-se citar nesse contexto a questão da liberdade dos mares já analisada no capítulo anterior. 
disso, o temor pela falta de universalidade da CNUDM, após sua assinatura, ou mesmo após entrar em vigor, perde importância no atual desenvolvimento do direito do mar. Assim, apenas por não gerar efeitos para criar obrigações ou direitos sobre terceiros, em diversos aspectos - sobretudo os mais relevantes - a Convenção de 1982 colaborou para criar um regime de direito consuetudinário internacional que regula a utilização dos mares pela sociedade internacional ${ }^{105}$.

\subsection{O Acordo de 1995 e seus efeitos sobre terceiros}

O Acordo para Implementação das Disposições da Convenção das Nações Unidas sobre o Direito do Mar, de 10 de dezembro de 1982, sobre a Conservação e Ordenamento de Populações de Peixes Transzonais e de Populações de Peixes Altamente Migratórios ${ }^{106}$ Acordo de 1995 - foi assinado em Nova Iorque em agosto de 1995, sob os auspícios das Nações Unidas ${ }^{107}$. O principal objetivo desse acordo consiste em dar efetividade às regras da CNUDM no que diz respeito à pesca em alto mar, sobretudo incentivando e regulamentando a cooperação internacional sobre a questão. A Convenção de 1982 se limita a termos gerais, a criar um "regime quadro" para a proteção ambiental dos mares. Fica então a encargo, de um lado, da sociedade internacional de celebrar acordos específicos para a prevenção de cada tipo de poluição marítima; e, de outro lado, fica também

105 Tal disposição não se confunde de forma alguma com os efeitos sobre terceiros dos tratados internacionais. Pelo contrário, como determina o artigo 38 da CVDT, 1969: "Nada nos artigos 34 a 37 impede que uma regra prevista em um tratado se torne obrigatória para terceiros Estados como regra consuetudinária de Direito Internacional, reconhecida como tal”. BRASIL. Decreto $n^{\circ} 2.508$, de 4 de marco de 1998. Promulga o Convenção Internacional para a Prevenção da Poluição Causada por Navios, concluída em Londres, em 2 de novembro de 1973, seu Protocolo, concluído em Londres, em 17 de fevereiro de 1978, suas Emendas de 1984 e seus Anexos Opcionais III, IV e V. Disponivel em: <http://www.planalto.gov.br/ ccivil_03/decreto/D2508.htm>. Acesso em: 13 jul. 2015.

106 Utiliza-se a versão brasileira desse acordo, promulgada por meio do decreto n. 4.361 BRASIL. Decreto $n^{\circ} 4.361$, de 5 de setembro de 1998. Promulga o Acordo para Implementação das Disposições da Convenção das Nações Unidas sobre o Direito do Mar de 10 de dezembro de 1982 sobre a Conservação e Ordenamento de Populações de Peixes Transzonais e de Populações de Peixes Altamente Migratórios. Disponivel em: <http://www.planalto.gov.br/ccivil_03/decreto/2002/D4361.htm>. Acesso em: 13 jul. 2015.

107 Para uma análise mais aprofundada do Acordo de 1995, seu enquadramento e normatização, ver BASTOS, Fernando Loureiro. A internacionalização dos recursos naturais marinhos. Lisboa: AAFDL, 2005. p. 685-694. a responsabilidade de cada Estado efetivar, na sua legislação interna, o controle da degradação ambiental dos mares e da punição aos infratores ${ }^{108}$.

Desse modo, o Acordo de 1995 vem para efetivar e regulamentar de forma mais precisa o regime jurídico da pesca em alto mar. Todavia, como destaca Fernando Loureiro Bastos: "A conclusão do Acordo de 1995 não pode ser considerada, contudo, como um ponto final na disputa sobre o conteúdo da liberdade de pesca no alto mar" ${ }^{109}$. Pelo contrário, o Acordo constitui o ponto de partida para uma maior efetivação da proteção dos recursos pesqueiros nessa zona marítima.

A questão que se coloca consiste em saber se o Acordo de 1995 ultrapassa o princípio da pacta tertiis para atingir terceiros. Para tal, uma análise mais detalhada nos seus articulados se faz necessária. Em primeiro lugar, nesse contexto, o artigo $8^{\circ}, n^{\circ} 4$, mesmo não fazendo parte da seção do Acordo que trata do cumprimento e da execução (Parte VI), merece atenção. Esse dispositivo introduz a ideia geral de que o acesso aos recursos pesqueiros em determinada região do alto mar é restrito aos Estados que são membros de uma organização de gestão das pescarias sub-regionais ou regionais; ou para aqueles que concordam em aplicar a conservação e as medidas de gestão instituídas por tal organização; ou ainda na ausência dessa organização regional, participar em acordos de conservação e gestão inseridos diretamente entre as partes interessadas ${ }^{110}$.

À primeira vista, essa disposição parece excepcionar o pacta tertiis ao criar obrigações e deveres aos Estados não membros, como a impossibilidade de exploração dos recursos. Todavia, tal interpretação, além afrontar

$108{ }^{109}$ VUKAS, Budislav. L'utilisation pacifique de la mer, dénucléarisation et désarmement. In: __ The law of the sea: selected writings. Leiden: Martinus Nijhoff Publishers, 2004. p. 157-204, p. 207-228, Leiden-Boston; 2004. p. 226; L LOUKA, Elli. International environmental law: fairness, effectiveness, and world order. Cambridge: Cambridge University Press, 2006. p. 167; ANTUNES, Nuno Marques. Estudos em direito internacional público. Coimbra: Almedina, 2004. p. 25

109 BASTOS, Fernando Loureiro. Algumas considerações sobre a produção de efeitos dos tratados de proteção do ambiente no espaço marinho. In: MIRANDA, Jorge (Coord.). Estudos em homenagem ao Professor Doutor Sérvulo Correia. Coimbra: Coimbra, 2010. v. 4. p. 301-341. p. 330.

110 Acordo de 1995. Art. 8, n 4. Sobre esse dispositivo, afirma BROTONS, Antonio Remiro et al. Derecho internacional. Madrid: Tirant lo Blanch, 2007. p. 985: "se trata de una autentica provocación normativa que hace temblar principios fundamentales del Derecho de los Tratados, y las libertades de la alta mar, atendiendo a la satisfacción de un designio superior, que impone la cooperación". 
o direito dos tratados, vai contra o basilar princípio da liberdade dos mares. Embora o artigo em questão use apenas o termo "Estados" — em detrimento de "Estados partes"), a sua aplicação fica restrita aos signatários do Acordo de 1995. Isto é, fora do estrito âmbito convencional, essa disposição deve permanecer ineficaz, uma vez que dificilmente pode ser considerado como fazendo parte do direito consuetudinário ${ }^{111} 112$.

Em segundo lugar, o artigo 17, único dispositivo da Parte IV (Não Membros e Não Participantes), numa primeira leitura, pode dar a entender que cria obrigações a terceiros Estados quando afirma: a) que um Estado que não seja membro de uma organização ou acordo regional não será liberado da obrigação de cooperar, em conformidade com a Convenção de 1982 e o presente Acordo, na conservação dos recursos pesqueiros ${ }^{113}$;

111 Nesse sentido FRANCKX, Erik. Pacta tertiis and the agreement for the implementation of the provisions of the United Nations Convention on the Law of the Sea of 10 december 1982 relating to the conservation and management of straddling fish stocks and highly migratory fish stocks. Quebec: FAO, June 2000. (FAO Legal Papers Online, 8). Disponível em: <http://www.fao.org/fileadmin/user_upload/legal/docs/ lpo8.pdf>. Acesso em: 13 jul. 2015 p. 14; FREESTONE, David; MAKUCH, Zen. The new international environmental law of fisheries: the 1995 United Nations straddling stocks agreement. Yearbook of International Environmental Law, Netherlands, v. 7, n. 1, p. 3-51; 1996. p. 34, para quem este artigo "would only be binding on parties to the [1995] Agreement, inter se". Em sentido contrário DELONE, Elizabeth. Improving the management of the Atlantic tuna: the duty to strengthen the ICCAT in light of the 1995 Straddling Stocks Agreement. New York University Environmental Law Journal, New York, v. 6, n. 3, p. 656-673, 1996. p. 633-634: "Non-parties to the Agreement may not fish within the area of the organization's jurisdiction. This provision is crucial as it affirmatively denies the legitimacy of the principle of freedom of the high seas and effectively puts an end to the inefficient and harmful free-rider problem.

112 Num viés jurisprudencial sobre a questão, o ITLOS no Southern Bluefin Tuna Cases (New Zealand v. Japan; Australia v. Japan), Provisional Measures, mesmo considerando o aumento de captura pelos Estados não partes (par. 76), decidiu que apenas as três partes estavam vinculadas ao acordo regional e deveriam submeter a decisão de mérito a um tribunal arbitral. Todos os documentos disponíveis em: TRIBUNAL INTERNATIONAL DU DROIT DE LA MER. Affaires n. 3 et 4: affaires du thon à nageoire bleue (Nouvelle-Zélande c. Japon; Australie c. Japon), mesures conservatoires. Disponível em: <https://www.itlos.org/index.php?id=62\&L=1>. Acesso em: 12 out. 2014. Sobre o caso, ver ANDO, Nisuke. The southern bluefin tuna case and dispute settlement under the United Nations Convention on the Law of the Sea: a japanese perspective. In: NDIAYE, Tafsir Malick; WOLFRUM, Rüdiger (Ed.). Law of the sea, environmental law and settlement of disputes: Liber Amicorum jugde Thomas A. Mensah. Netherlands: Martinus Nijhoff Publishers, 2007. p. 867-876.

113 BRASIL. Decreto $n^{\circ} 4.361$, de 5 de setembro de 2002. Promulga o Acordo para Implementação das Disposições da Convenção das Nações Unidas sobre o Direito do Mar de 10 de dezembro de 1982 sobre a Conservação e Ordenamento de Populações de Peixes b) que esse terceiro Estado não autorizará suas embarcações explorarem as populações de peixes sujeitas às medidas de conservação estabelecidas por essa organização ou acordo regional ${ }^{114}$; c) que os Estados que forem membros dessas organizações ou acordos regionais poderão solicitar aos navios pesqueiros de terceiros que cooperem plenamente na implementação das medidas de conservação e ordenamento estabelecidas por essa organização ou acordo ${ }^{115}$.

Entretanto, em nenhum momento, o Acordo de 1995 traz reais obrigações a terceiros. Trata-se, como destacam Peter Örebech, Ketill Sigurjonsson e Ted Mcdorman ${ }^{116}$, de mera semântica, sem a capacidade, ou a intenção, de gerar efeitos sobre não signatários. Pelo contrário, a intenção nessa perspectiva é influenciar esses terceiros Estados. Como o próprio artigo 17, $\mathrm{n}^{\circ}$ 4, deixa claro, os Estados membros dessas organizações ou acordo regionais "tomarão medidas compatíveis com o presente Acordo e com o direito internacional para coibir as atividades de embarcações que comprometam a eficácia de medidas sub-regionais ou regionais de conservação e ordenamento" ${ }^{117}$. Isto é, os Estados membros pode-

Transzonais e de Populações de Peixes Altamente Migratórios. Disponivel em: <http://www.planalto.gov.br/ccivil_03/decreto/2002/ D4361.htm>. Acesso em: 13 jul. 2015. Art. 17, no 1.

114 BRASIL. Decreto $n^{\circ} 4.361$, de 5 de setembro de 2002. Promulga o Acordo para Implementação das Disposições da Convenção das Nações Unidas sobre o Direito do Mar de 10 de dezembro de 1982 sobre a Conservação e Ordenamento de Populações de Peixes Transzonais e de Populações de Peixes Altamente Migratórios. Disponivel em: <http://www.planalto.gov.br/ccivil_03/decreto/2002/ D4361.htm>. Acesso em: 13 jul. 2015. Art. 17, no 2.

115 BRASIL. Decreto $n^{\circ} 4.361$, de 5 de setembro de 2002. Promulga o Acordo para Implementação das Disposições da Convenção das Nações Unidas sobre o Direito do Mar de 10 de dezembro de 1982 sobre a Conservação e Ordenamento de Populações de Peixes Transzonais e de Populações de Peixes Altamente Migratórios. Disponivel em: <http://www.planalto.gov.br/ccivil_03/decreto/2002/ D4361.htm>. Acesso em: 13 jul. 2015. Art. 17, nº 3.

116 ÖREBECH, Peter; SIGURJONSSON, Ketill; MCDORMAN, Ted. The 1995 United Nations straddling and highly migratory fish stocks agreement: management, enforcement and dispute settlement. The International Journal of Marine and Coastal Law, v.13, Issue 2, p. 119-141; 1998, p. 124: "such language is designed to create obligations for non-parties to the 1995 Agreement, but mere semantics cannot overcome the principle that treaties are only binding upon ratifying states".

117 BRASIL. Decreto $n^{\circ} 4.361$, de 5 de setembro de 2002. Promulga o Acordo para Implementação das Disposições da Convenção das Nações Unidas sobre o Direito do Mar de 10 de dezembro de 1982 sobre a Conservação e Ordenamento de Populações de Peixes Transzonais e de Populações de Peixes Altamente Migratórios. Disponivel em: <http://www.planalto.gov.br/ccivil_03/decreto/2002/ D4361.htm>. Acesso em: 13 jul. 2015. Art. 17, nº 4. 
rão apenas tomar medidas para dissuadir os terceiros de praticar atividades exploratórias prejudiciais ao meio marinho. Além disso, quando o texto determina que tais medidas devem respeitar o Acordo de 1995, bem como o direito internacional geral, impõem que deve-se ter em mente, entre outros, o respeito ao princípio da jurisdição exclusiva do Estado da bandeira ${ }^{118}$.

Em terceiro lugar, o artigo 21 constitui a pedra angular da parte no cumprimento e execução do Acordo de 1995, e talvez até mesmo do acordo como tal ${ }^{119}$. Isso porque possibilita a fiscalização, em qualquer área de alto mar, de uma embarcação de pesca de um Estado parte por um navio de outro Estado ${ }^{120}$. Contudo, o texto deixa claro que esta fiscalização apenas pode ser realizada em embarcações de "outro Estado parte do presente Acordo" e não de terceiros. Em outras palavras, dada a definição fornecida pelo Acordo de "Estados Partes" 121 , a possibilidade de fiscalização em alto mar de navios, que arvorem bandeira de outro Estado, não contraria o princípio da pacta tertiis. Isto em razão da necessidade de o Estado aceitar essa possibilidade, se vinculando ao Acordo de $1995^{122}$.

118 Nesse sentido BASTOS, Fernando Loureiro. Algumas considerações sobre a produção de efeitos dos tratados de proteção do ambiente no espaço marinho. In: MIRANDA, Jorge (Coord.). Estudos em homenagem ao Professor Doutor Sérvulo Correia. Coimbra: Coimbra, 2010. v. 4. p. 301-341. p. 332, que ainda destaca na note 88: "Daqui resulta que, em conformidade com a Convenção de 1982, os Estados que pescam no alto mar só estão obrigados a respeitar as limitações à liberdade de pesca que constam do Direito Internacional costumeiro e dos compromissos internacionais a que aceitaram expressamente vincular-se em particular quando se esteja em presença de acordos internacionais de âmbito regional".

119 COLBURN, Jamison E. Turbot wars: straddling stocks, regime theory, and a new U.N. agreement. Journal of Transnational Law and Policy, Florida, v. 6, p. 323-366, Spring, 1997. p. 335 descreve o artigo 21 como "a pivotal evolutionary development of the international legal order of fisheries".

120 BRASIL. Decreto $n^{\circ} 4.361$, de 5 de setembro de 2002. Promulga o Acordo para Implementação das Disposições da Convenção das Nações Unidas sobre o Direito do Mar de 10 de dezembro de 1982 sobre a Conservação e Ordenamento de Populações de Peixes Transzonais e de Populações de Peixes Altamente Migratórios. Disponivel em: <http://www.planalto.gov.br/ccivil_03/decreto/2002/ D4361.htm>. Acesso em: 13 jul. 2015. Art. 21, no 1.

121 BRASIL. Decreto $n^{\circ} 4.361$, de 5 de setembro de 2002. Promulga o Acordo para Implementação das Disposições da Convenção das Nações Unidas sobre o Direito do Mar de 10 de dezembro de 1982 sobre a Conservação e Ordenamento de Populações de Peixes Transzonais e de Populações de Peixes Altamente Migratórios. Disponivel em: < http://www.planalto.gov.br/ccivil_03/decreto/2002/ D4361.htm>. Acesso em: 13 jul. 2015. Art. 2. (a): "A expressão 'Estados Partes' se refere a Estados que acordaram em observar o disposto no presente Acordo e para os quais o Acordo está em vigor". 122 Nesse sentido FRANCKX, Erik. Pacta Tertiis and the agreement
Em quarto lugar, temos o artigo 23 que permite como também obriga - o Estado do porto a "inspecionar documentos, equipamentos de pesca e o produto da pesca a bordo de embarcações de pesca quando essas embarcações estiverem voluntariamente atracadas em seus portos ou terminais em alto-mar" ${ }^{\prime 23}$. Ainda, os Estados do porto poderão proibir atracagens e baldeações quando se tiver determinado que o produto da pesca foi obtido de maneira que compromete a eficácia de medidas de conservação dos recursos de pesca em alto-mar ${ }^{124}$. Esse controle pelo Estado do porto com

for the implementation of the provisions of the United Nations Convention on the Law of the Sea of 10 December 1982 relating to the conservation and management of straddling fish stocks and highly migratory fish stocks. Quebec: FAO, June 2000. (FAO Legal Papers Online, 8). Disponível em: <http://www.fao.org/fileadmin/user_upload/legal/docs/ lpo8.pdf>. Acesso em: 13 jul. 2015. p. 17, para o qual “ [...] the ascertainment that the consensual nature of international law has been fully respected by Art. 21 (1). States are only bound by what they freely committed themselves to. For states only party to the 1982 Convention, the exclusive jurisdiction of the flag state will continue to apply"; Ainda, nesse mesmo sentido OXMAN, Bernard $\mathrm{H}$. The international commons, the international public interest and new modes of international lawmaking. In: DELBRÜCK, Jost (Ed.) New trends in international lawmaking: international 'legislation' in the public interest: proceedings of an International Symposium of the Kiel Walther-Schücking-Institute of International Law March 6 to 8, 1996. Berlim: Ducker e Humblot; 1996. p. 21-60. p. 21; FREESTONE, David; MAKUCH, Zen. The new international environmental law of fisheries: the 1995 United Nations straddling stocks agreement. Yearbook of International Environmental Law, Netherlands, v. 7, n. 1, p. 3-51; 1996. p. 36.; Em sentido contrário DELBRÜCK, Jost. Laws in the public interest: some observations on the foundations and identification of erga omnes norms in international law. In: GÖTZ, Volkmar; SELMER, Peter; WOLFRUM, Rüdiger (Ed.). Liber amicorum Günther Jaenicke - Zum 85 Geburtstag. Berlin: Springer, 1998. p. 17-36. p. 27-28 que defende que o Acordo cria obrigações erga omnes, pois "protecting endangered species is so overwhelming that no State may be permitted not to comply with the protective regimes regardless of whether or not it has consented to the creation of the regime".

123 BRASIL. Decreto $n^{\circ} 4.361$, de 5 de setembro de 2002. Promulga o Acordo para Implementação das Disposições da Convenção das Nações Unidas sobre o Direito do Mar de 10 de dezembro de 1982 sobre a Conservação e Ordenamento de Populações de Peixes Transzonais e de Populações de Peixes Altamente Migratórios. Disponivel em: <http://www.planalto.gov.br/ccivil_03/decreto/2002/ D4361.htm >. Acesso em: 13 jul. 2015. Art. 21, $\mathrm{n}^{\circ} 2$.

124 BRASIL. Decreto $n^{\circ} 4.361$, de 5 de setembro de 2002. Promulga o Acordo para Implementação das Disposições da Convenção das Nações Unidas sobre o Direito do Mar de 10 de dezembro de 1982 sobre a Conservação e Ordenamento de Populações de Peixes Transzonais e de Populações de Peixes Altamente Migratórios. Disponivel em: <http://www.planalto.gov.br/ccivil_03/decreto/2002/ D4361.htm>. Acesso em: 13 jul. 2015. Art. 21, no 3. A discussão sobre a inserção deste artigo na conferência preparatório, foi, segundo BARSTON, Ronald. United Nations conference on straddling and highly migratory fish stocks. Marine Policy, v. 19, Issue 2, p. 159-166; 1995 , p. 164, o tópico que mais causou debates entre os Estados 
relação a assuntos de pesca tem sido rotulado como grande avanço jurisdicional do Acordo de $1995^{125}$. Todavia, nessa perspectiva, também, não se pode classificar como afronta ao pacta tertiis. O controle e jurisdição do Estado do Porto trata-se unicamente do poder de soberania e do Estado costeiro sobre os navios ancorados em seu território. Isto é, o Estado parte não precisa aceitar navios que operem a exploração pesqueira de maneira irregular, sob o ponto de vista da conservação. Além disso, uma vez atracado voluntariamente, a embarcação se sujeita às regras impostas pelo Estado costeiro, podendo inclusive ser inspecionada pelas autoridades locais $^{126}$.

Por fim, em quinto lugar, o artigo 33, no 2 destaca que "os Estados partes tomarão medidas compatíveis com o presente Acordo e o direito internacional para coibir as atividades de embarcações desfraldando o pavilhão nacional de não partes que comprometam a efetiva implementação do presente Acordo" ${ }^{127}$. Mais uma vez, como o fez no artigo $17, n^{\circ} 4$, o Acordo estimula os Estados partes a influenciarem, por meio dos efeitos convencionais reflexos, os terceiros a se sujeitarem às

participantes.

125 Nesse sentido FREESTONE, David; MAKUCH, Zen. The new international environmental law of fisheries: the 1995 United Nations straddling stocks agreement. Yearbook of International Environmental Law, Netherlands, v. 7, n. 1, p. 3-51; 1996. p. 37.

126 Nesse sentido, destaca PEPE, Lorenzo Schiano di. Port state control as an instrument to ensure compliance with international marine environmental obligations. In: KIRCHNER, Andree. International marine environmental law: institutions, implementation and innovations. Hague: Kluwer Law International, 2004. p. 137-156. (International Environmental Law and Policy Series, 64). p. 156: "by exercising their powers to inspect foreign vessels, in fact, port States not only promote implementation and enforcement by flag States of existing and applicable international standards and rules, but also directly fulfill their own basic obligation, enshrined in article 192 of the Montego Bay Convention, to "protect and preserve the marine environment". Já para FRANCKX, Erik. Pacta Tertiis and the agreement for the implementation of the provisions of the United Nations Convention on the Law of the Sea of 10 December 1982 relating to the conservation and management of straddling fish stocks and highly migratory fish stocks. Quebec: FAO, June 2000. (FAO Legal Papers Online, 8). Disponível em: <http://www.fao. org/fileadmin/user_upload/legal/docs/lpo8.pdf $>$. Acesso em: 13 jul. 2015. p. 20: "Unless a country explicitly agrees by subscribing to the 1995 Agreement, this particular provision does not bind nonparties".

127 BRASIL. Decreto $n^{\circ} 4.361$, de 5 de setembro de 2002. Promulga o Acordo para Implementação das Disposições da Convenção das Nações Unidas sobre o Direito do Mar de 10 de dezembro de 1982 sobre a Conservação e Ordenamento de Populações de Peixes Transzonais e de Populações de Peixes Altamente Migratórios. Disponivel em: <http://www.planalto.gov.br/ccivil_03/decreto/2002/ D4361.htm >. Acesso em: 13 jul. 2015. Art. 33, no 2 . regras de conservação pesqueiras. Nesse viés, o Acordo procura incentivar os signatários a utilizarem seu poder de influência sobre terceiros para colaborarem com a preservação dos recursos naturais de peixes em alto mar. O dispositivo não afronta o princípio da pacta tertiis, pelo contrário, o objetivo do texto consiste em tão somente estimular esses chamados efeitos convencionais reflexos em relação a terceiros ${ }^{128}$.

Analisando-se sistematicamente esses dispositivos convencionais do Acordo, chega-se a conclusão de que o argumento que o texto constitui uma relativização do princípio da pacta tertiis não merece acolhimento. Pelo contrário, uma análise cuidadosa parece demonstrar que esse acordo não cria obrigações para terceiros, mas apenas para os Estados partes. Por vezes, isso é explicitamente indicado pelos termos do Acordo de 1995, caso em que não há maiores dúvidas. Em outros casos, o texto não é tão explícito, mas, mesmo assim, o contexto sugere que os Estados não tinham a intenção de abrir novos caminhos no que diz respeito ao princípio da pacta tertiis ${ }^{129}$.

Em suma, tem-se que o Acordo de 1995 não excepcionaliza o princípio da pacta tertiis para criar obrigações e direitos para terceiros não signatários. O que o texto procura consiste em induzir os Estados membros a influenciar os terceiros para que cumpram voluntariamente as regras de proteção e conservação dos recursos pesqueiros em alto mar.

128 Nesse mesmo sentido, afirma BASTOS, Fernando Loureiro. Algumas considerações sobre a produção de efeitos dos tratados de proteção do ambiente no espaço marinho. In: MIRANDA, Jorge (Coord.). Estudos em homenagem ao Professor Doutor Sérvulo Correia. Coimbra: Coimbra, 2010. v. 4. p. 301-341. p. 333-334: “Tendo em consideração a redacção do $\mathrm{n}^{\circ} 4$ do artigo 17 e do no 2 do artigo 33, aos Estados é concedida uma relativa margem de manobra na escolha das 'medidas' que considerem mais adequadas ao objectivo de dissuadir os navios de terceiros Estados de levarem a cabo 'actividades prejudiciais'. São referidos dois limites à concretização dessas 'medidas': o Acordo de 1995 e o direito internacional".

129 Sobre a questão, destaca BASTOS, Fernando Loureiro. Algumas considerações sobre a produção de efeitos dos tratados de proteção do ambiente no espaço marinho. In: MIRANDA, Jorge (Coord.). Estudos em homenagem ao Professor Doutor Sérvulo Correia. Coimbra: Coimbra, 2010. v. 4. p. 301-341. p. 330-331: "A impossibilidade de avançar com uma resposta concreta a esses problemas não ficou a dever-se, como é evidente, a nenhuma deficiência de concepção ou de redacção, mas ao facto de os negociadores do Acordo de 1995 não terem legitimidade para lhe atribuírem efeitos em relação a terceiros Estados não partes84, em consonância com o respeito da regra da relatividade dos tratados. 


\section{Considerações finais}

Diante do exposto, tem-se que não se vislumbra no direito internacional uma real superação do velho princípio da pacta tertiis nec nocent nec prosunt, pelo qual um tratado internacional não gera efeitos para produzir direitos ou obrigações a terceiros Estados. Ou seja, regra geral, os tratados são res inter alios acta para os países não membros.

$\mathrm{O}$ atual desenvolvimento do direito internacional não permite a superação da regra que os tratados só produzem efeitos para seus signatários. Não obstante as disposições especiais contidas na CVDT 1969, os países só estão vinculados ao que se sujeitarem deliberadamente. Isto é, existe a possibilidade de tratados criarem obrigações ou direitos a terceiros, mas somente se estes assim consentirem. Mesmo os tratados internacionais de extrema importância para o direito internacional, como é o caso da Convenção das Nações Unidas sobre o Direito do Mar, não têm a capacidade de gerar esses efeitos em terceiros. A aplicação dos dispositivos convencionais da CNUDM fica limitada aos seus signatários, não obstante o regime consuetudinário que o texto positivou ou colaborou sobremaneira para a criação. Isto é, o perigo da falta de efetividade do texto não se justifica pois, apesar de não gerar efeitos sobre terceiros, a CNUDM já foi ratificada pela maioria dos Estados do sistema internacional e, em especial, ajudou a criar um direito costumeiro que se aplica universalmente.

Em relação à proteção do meio marinho, tem-se maior necessidade de aplicação das normas protetivas a todos os sujeitos. Isso ocorre em virtude da necessidade de efetivação dos tratados que versam sobre as matérias de conservação dos recursos naturais e proteção do ambiente marinho serem aplicados de modo mais universal, sobretudo no que diz respeito ao alto mar, em razão da sua natureza jurídica, os tratados precisam receber efetivação maior, visto que é imperativo, para a proteção ambiental da região, que todos cooperem. De outra maneira, um texto que verse sobre a conservação de determinada espécie, por exemplo, ficaria sem eficácia e perderia seu objetivo.

Entretanto, mesmo para essas situações, não se pode admitir o afastamento do pacta tertiis, sob pena de alguns Estados criarem normas aplicáveis a terceiros que não as consentiram. Isso seria excessiva afronta ao princípio da autonomia da vontade e da liberdade soberana dos
Estados no sistema internacional. Dessa forma, o que se pretende nesses casos é influenciar o comportamento de terceiros Estados para se sujeitarem às normas de conservação e proteção marinhas. Todavia, deve ficar claro que esses tratados têm o condão apenas de produzir efeitos convencionais reflexos em relação a terceiros e não obrigá-los a cumprir compromissos ou dispositivos convencionais aos quais não estão vinculados.

\section{ReferênCias}

ANDERSON, David H. Resolution and agreement relating to the implementation of part xi of the UN Convention on the Law of the Sea: a general assessment. ZaoRV, Berlin, v. 55, p. 275-289, 1995.

ANDO, Nisuke. The southern bluefin tuna case and dispute settlement under the United Nations Convention on the Law of the Sea: a japanese perspective. In: NDIAYE, Tafsir Malick; WOLFRUM, Rüdiger (Ed.). Law of the sea, environmental law and settlement of disputes: Liber Amicorum jugde Thomas A. Mensah. Netherlands: Martinus Nijhoff Publishers, 2007. p. 867-876.

ANDREOLA, Susana Cordenonsi. Fundos marinhos: regulamentação pelo direito internacional. Juruá: Curitiba, 2010 .

ANTUNES, Nuno Marques. Estudos em direito internacional público. Coimbra: Almedina, 2004.

ARROW, Dennis W. Seabeds, soverignty and objective regimes. Fordham International Law Journal, New York, v. 7, n. 2, p. 169-243, 1984.

BASTOS, Fernando Loureiro. A internacionalização dos recursos naturais marinhos. Lisboa: AAFDL, 2005.

BASTOS, Fernando Loureiro. Algumas considerações sobre a produção de efeitos dos tratados de proteção do ambiente no espaço marinho. In: MIRANDA, Jorge (Coord.). Estudos em homenagem ao Professor Doutor Sérvulo Correia. Coimbra: Coimbra, 2010. v. 4. p. 301-341.

BERNHARDT, Rudolf. Custom and treaty in the law of the sea. Recueil des Cours de L'Académie de droit international de La Haye. Paris, v. 205, p. 252-329, 1987.

BERNHARDT, Rudolf. Article 103. In: SIMMA, Bruno (Ed.). The charter of the United Nations: a commentary. 2. ed. Oxford: Oxford University Press, Oxford, 2002. v. 2. p. 1116-1125. 
BRASIL. Decreto $n^{0} 1.530$, de 22 de junho de 1995. Declara a entrada em vigor da Convenção das Nações Unidas sobre o Direito do Mar, concluída em Montego Bay, Jamaica, em 10 de dezembro de 1982. Disponivel em: <http://www.planalto.gov.br/ccivil_03/decreto/1995/D1530.htm>. Acesso em: 13 jul. 2015.

BRASIL. Decreto no 2.508, de 4 de março de 1998. Promulga o Convenção Internacional para a Prevenção da Poluição Causada por Navios, concluída em Londres, em 2 de novembro de 1973, seu Protocolo, concluído em Londres, em 17 de fevereiro de 1978, suas Emendas de 1984 e seus Anexos Opcionais III, IV e V. Disponivel em: <http://www.planalto.gov.br/ccivil_03/decreto/ D2508.htm>. Acesso em: 13 jul. 2015.

BRASIL. Decreto $n^{\circ} 4.361$, de 5 de setembro de 2002. Promulga o Acordo para Implementação das Disposições da Convenção das Nações Unidas sobre o Direito do Mar de 10 de dezembro de 1982 sobre a Conservação e Ordenamento de Populações de Peixes Transzonais e de Populações de Peixes Altamente Migratórios. Disponível em: <http://www.planalto.gov.br/ccivil_03/ decreto/2002/D4361.htm>. Acesso em: 13 jul. 2015.

BRASIL. Decreto no 7.030, de 14 de dezembro de 2009. Promulga a Convenção de Viena sobre o Direito dos Tratados, concluída em 23 de maio de 1969, com reserva aos Artigos 25 e 66. Disponivel em: <http://www.planalto.gov.br/ccivil_03/_Ato2007-2010/2009/Decreto/ D7030.htm>. Acesso em: 13 jul. 2015.

BROTONS, Antonio Remiro et al. Derecho internacional. Madrid: Tirant lo Blanch, 2007.

BUTLER, William. E. Custom, treaty, State practice and the 1982 Convention. Marine Policy, Amsterdam, v. 12, n. 3, p. 182-186, July, 1988.

CAHIER, Philippe. Le problème des traités a l'égard des États tiers. Recueil des Cours da Académie de Droit International, Paris, v. 143, p. 589-736, 1974.

CAMINOS, Hugo; MOLITOR Michael R. Progressive development of international law and the package deal. The American Journal of International law, Washington, v. 79, n. 4, p. 871-890, Oct. 1985.

CHARNEY, Jonathan I. The Antarctic system and customary international law. In: SCOVAZZI, Tullio; FRANCIONI, Francesco (Ed.). International Law for Antartica. Netherlands: Martinus Nijhoff Publishers, 1996. p. 51-101.
CHINKIN, Christine. Third parties in international law. Oxford: Clarendon Press, 1993.

COLBURN, Jamison E. Turbot wars: straddling stocks, regime theory, and a new U.N. agreement. Journal of Transnational Law and Policy, Florida, v. 6, p. 323-366, Spring, 1997.

CONFORTI, Benedetto. The law and practice of the United Nations. 3. ed. Netherlands: Martinus Nijhoff Publishers, 2005.

DELBRÜCK, Jost. Laws in the public interest: some observations on the foundations and identification of erga omnes norms in international law. In: GÖTZ, Volkmar; SELMER, Peter; WOLFRUM, Rüdiger (Ed.). Liber amicorum Günther Jaenicke - Zum 85 Geburtstag. Berlin: Springer, 1998. p. 17-36.

DELONE, Elizabeth. Improving the management of the Atlantic tuna: the duty to strengthen the ICCAT in light of the 1995 straddling stocks agreement. New York University Environmental Law Journal, New York, v. 6, n. 3, p. $656-673,1996$.

DINH, Nguyen Quoc; DAILLIER, Patrick; PELLET, Alain. Direito internacional público. 2. ed. Lisboa: Fundação Calouste Gulbenkian, 2003.

DUPUY, René-Jean. L'ocean partagé: analyse d'une negociation: Conference des Nations Unies sur le droit de la mer. Paris: A. Pedone, 1979.

EUSTIS, Robert D. Procedures and techniques of multinational negotiation: the LOS III model. Virginia Journal of International Law, Virginia, v. 17, n. 2, p. 214256, Winter, 1977.

FASSBENDER, Bardo. UN security council reform and the right of veto: a constitutional perspective. Netherlands: Kluwer Law International, 1998.

FERRI, Nicola. Trade measures for conservation of fisheries and third states: an evolutionary trend in international law. 2009, 456 f. Tesi (dottorato) - Università degli Studi di Milano-Bicocca, Milano, 2012.

FITZMAURICE, Malgosia. Expression of consent to be bound by a treaty as developed in certain environmental treaties. In: KLABBERS, Jan (Ed.). Essays on the law of treaties: a collection of essays in honour of Bert Vierdag. Hague: Martinus Nijhoff Publishers, 1998. p. 59-80.

FITZMAURICE, Malgosia. Third parties and the law 
of treaties. Max Planck Yearbook of United Nations Law, Netherlands, v. 6, n. 1, p. 37-137, Jan. 2002.

FRANCKX, Erik. Pacta Tertiis and the agreement for the implementation of the provisions of the United Nations Convention on the Law of the Sea of 10 December 1982 relating to the conservation and management of straddling fish stocks and highly migratory fish stocks. Quebec: FAO, June 2000. (FAO Legal Papers Online, 8). Disponível em: <http://www. fao.org/fileadmin/user_upload/legal/docs/lpo8.pdf $>$. Acesso em: 13 jul. 2015.

FREESTONE, David; MAKUCH, Zen. The new international environmental law of fisheries: the 1995 united nations straddling stocks agreement. Yearbook of International Environmental Law, Netherlands, v. 7, n. 1, p. 3-51; 1996.

GUEDES, Armando M. Marques. Direito do mar. 2. ed. Coimbra: Coimbra, 1998.

GUNTRIP, Edward. The common heritage of mankind: an adequate regime for managing the deep seabed? The common heritage of mankind. Melbourne Journal of International Law, Parkville, v. 4, n. 2, p. 376-405, 2003.

HANDL, Günther. Regional arrangements and third state vessels: is the pacta tertiis principle being modified. In: RINGBOM, Henrik (Ed.). Competing norms in the law of the marine environmental protection: focus on ship safety and pollution prevention. Hague: Kluwer Law International, 1997. p. 217-240.

HANNIKAINEN, Lauri. The continued validity of the demilitarised and neutralised status of the Aland Islands. Zaorv, Berlim, v. 54, p. 614-651, 1994.

HARRISON, James. Making the law of the sea: a study in the development of international law. Cambridge: Cambridge University Press, 2011.

KOH, Tommy, T. B.; JAYAKUMAR, Shnmungan. The negotiating processo of the third United Nations Conference on the Law of the Sea. In: NORDQUIST, Myron H. United Nations Convention on the Law of the Sea, 1982: a commentary. Dordrecht: Martinus Nijhoff Publishers, 1982. v. 1. p. 22-134.

KOLODKIN, A. L.; ANDRIANOV, V. V.; KISELEV, V. A. Legal implications of participation or non-participation in the 1982 Convention. Marine Policy, Amsterdam, v. 12, n. 3, p. 187-191, 1988.

LAW OF THE SEA BULLETIN. New York: United Nation, n. 4, Feb. 1985. <http://www.un.org/depts/
los/doalos_publications/LOSBulletins/bulletinpdf/ bulE4.pdf>. Acesso em: 13 jul. 2015.

LEE, Luke T. The law of the sea convention and third states. The American Journal of International Law, Washington, v. 77, n. 3, p. 541-568, July, 1983.

LOSA, Jorge Pueyo. Derecho del mar y libertad de pesca: sobre las organizaciones regionales de ordenación pesquera y el acuerdo de 1995. In: LOSA, Jorge Pueyo; URBINA, Julio Jorge (Coord.). La cooperacion internacional en la ordenacion de los mares y oceanos. Madrid: Iustel, 2009. p. 159-183.

LOUKA, Elli. International environmental law: fairness, effectiveness, and world order. Cambridge: Cambridge University Press, 2006.

MACDONALD, Ronald. The charter of the United Nations as a world constitution. In: SCHMITT, Michael N. (Ed.). International law across the spectrum of conflict. essays in honour of professor L.C. Green On the occasion of his eightieth birthday. Newport: Naval War College, 2000. (International Law Studies, 75). p. 263-300.

MARTINS, Ana Maria Guerra. O acordo relativo à aplicação da Parte XI da Convenção das Nações Unidas sobre o Direito do Mar de 1982 na óptica do direito dos tratados. Revista Jurídica, Lisboa, n. 24, p. 21-51, maio 2001.

MAZZUOLI, Valerio de Oliveira. Curso de direito internacional público. 5. ed. São Paulo: RT, 2011.

MELLO, Celso D. de Albuquerque. Alto mar. Rio de Janeiro: Renovar, 2001.

MIRANDA, Jorge. Curso de direito internacional público. 5. ed. Lisboa: Principia, 2012.

NADAN, Satya N. The efforts undertaken by the United Nations to ensure universality of the convention. In: MILES, Edward L.; TREVES, Tullio (Ed.). The law of the sea: new worlds, new discoveries. Honolulu: Law of the Sea Institute, 1993. p. 349-378.

NAPOLETANO, Guido. Some remarks on treaties and third states under the Vienna convention on the law of treaties. The Italian Yearbook of International Law, v. 3, p. 75-91, 1977.

ONG, David M. International environmental law's customary dilemma: betwixt general principle and treaty rules. The Irish Yearbook of International Law. Oxford, v. 1, p. 3-60, 2008. 
ÖREBECH, Peter; SIGURJONSSON, Ketill; MCDORMAN, Ted. The 1995 United Nations straddling and highly migratory fish stocks agreement: management, enforcement and dispute settlement. The International Journal of Marine and Coastal Law, Hague, v. 13, n. 2, p. 119-141, 1998.

OXMAN, Bernard H. The agreement and the convention. American Journal of International Law, Washington, v. 88, n. 4, p. 687-696, 1994.

OXMAN, Bernard H. The international commons, the international public interest and new modes of international lawmaking. In: DELBRÜCK, Jost (Ed.) New trends in international lawmaking: international 'legislation' in the public interest: proceedings of an International Symposium of the Kiel Walther-Schücking-Institute of International Law March 6 to 8, 1996. Berlim: Ducker e Humblot; 1996. p. 21-60.

PEPE, Lorenzo Schiano di. Port state control as an instrument to ensure compliance with international marine environmental obligations. In: KIRCHNER, Andree. International marine environmental law: institutions, implementation and innovations. Hague: Kluwer Law International, 2004. p. 137-156. (International Environmental Law and Policy Series, 64).

PEREIRA, André Gonçalves; QUADROS, Fausto de. Manual de direito internacional público. 3. ed. Lisboa: Almedina, 2011.

PLATZODER, Renate. Substantive changes in a multilateral treaty before its. entry into force: the case of the 1982 United Nations Convention on the Law of the Sea. European Jounal of International Law, New York, v. 4, n. 3, p. 390-402; 1993.

RAGAZZI, Maurizio. The concept of international obligations erga omnes. Oxford: Clarendon Press, 1997.

RAYFUSE, Rosemary Gail. Non-slag State enforcement in high seas fisheries. Netherlands: Martinus Nijhoff Publishers, 2004.

ROCHA, Rosa Maria Souza Martins. O mar territorial: largura e natureza jurídica. Porto: Universidade Portucalense, 1996.

ROZAKIS, Christos L. Treaties and third states: a study in the reinforcement of the consensual standards in international law. ZaoRV, Berlin, v. 35, p. 1-40, 1975.

SALERNO, Francesco. Treaties establishing objective regimes. In: CANNIZZARO, Enzo (Ed.). The law of treaties beyond the Vienna Convention. Oxford: Oxford University Press, 2011. p. 225-243.

SCHWARZENBERGER, Georg. International law as applied by international courts and tribunals: international constitutional law. London: Stevens and Sons, 1986. v. 3.

SCHWEISFURTH, Theodor. International treaties and third States. ZaoRV, Berlin, v. 45, p. 653-674, 1985.

SCOVAZZI, Tullio; FRANCIONI, Francesco. International law for Antarctica. Netherlands : Martinus Nijhoff Publishers, 1996.

SIMMA, Bruno. The Antarctic Treaty as a treaty providing for an 'objective regime'. Cornell International Law Journal, New York, v. 19, n. 2, p. 189-209, Spring, 1986.

SIOUSSOURAS, Petros. The formation of customary rights in the international law ofthe sea: the case ofland-locked States. Revue Hellénique de droit International, Athens, v. 54, n. 1, p. 299-317, 2001.

TAMS, Christian J. Enforcing obligations Erga Omnes in international law. Reino Unido: Cambridge University Press, 2005.

TANAKA, Yoshifumi. The international law of the sea. New York: Cambridge University Press, 2012.

TELES, Patrícia Galvão. Obligations Erga Omnes in international. Revista Jurídica da Associação Acadêmica da Faculdade de Direito de Lisboa, Lisboa, n. 20, p. 73-137, Nov. 1996.

TREVES, Tullio. The agreement completing the UN Law of the Sea Convention: formal and procedural aspects. In: NORDQUIST, Myron H.; MOORE, John Norton (Ed.). Entry into force of the Law of the Sea Convention. Netherlands: Kluwer Law International, 1995. p. 99-118.

TRIBUNAL INTERNATIONAL DU DROIT DE LA MER. Affaires n. 3 et 4: affaires du thon à nageoire bleue (Nouvelle-Zélande c. Japon; Australie c. Japon), mesures conservatoires. Disponível em: <https://www. itlos.org/index.php?id=62\&L=1>. Acesso em: $21 \mathrm{fev}$. 2015.

TRINDADE, Antônio Augusto Cançado. A nova dimensão do direito internacional público. Brasília: Instituto Rio Branco, 2003. v. 1.

UNITED NATION. Division for Ocean Affairs and the Law of The Sea. Chronological lists of ratifications of, accessions and successions to the Convention and the related agre- 
ements as at 3 October 2014. Jan. 2015. Disponível em: <http://www.un.org/Depts/los/reference_files/chronological_lists_of_ratifications.htm\#Agreement for the implementation of the provisions of the Convention relating to the conservation and management of straddling fish stocks and highly migratory fish stocks $>$. Acesso em: 21 fev. 2015.

UNITED NATIONS CONFERENCE ON THE LAW OF THE SEA, 3., 1982, Jamaica. Plenary meetings, summary records and verbatim records, as well as documents of the conference, resumed eleventh session and final part eleventh session and conclusion...Jamaica: United Nations ,1982. v. 17. Disponivel em: <http://legal.un.org/diplomaticconferences/lawofthesea-1982/docs/vol_XVII/a_conf62_sr-183.pdf>. Acesso em: 13 jul. 2015.

UNITED NATIONS. Vienna Convention on the law of treaties. Concluded at Vienna on 23 May 1969. Disponivel em: <https://treaties.un.org/doc/Publication/UNTS/ Volume\%201155/volume-1155-I-18232-English.pdf $>$. Acesso em: 13 jul. 2015.

UNITED NATIONS. Yearbook of the International Law Commission, 1960. Documents of the twelfth session including the report of the Commission to the General Assembly. New York: United Nations, 1961. v. 2. Disponivel em: <http://legal.un.org/docs/?path=../ ilc/publications/yearbooks/english/ilc_1960_ v2.pdf\&lang=EFS $>$. Acesso em: 25 abr. 2015.

USTOR, Endre. Most-favoured-nation clause. In: UNITED NATIONS. Yearbook of the International Law Commission, 1970. New York: United Nations, 1972. v. 2, p. 199-242.
VITZTHUM, Wolfgang Graf. Article 2 (6). In: SIMMA, Bruno (Ed.). The charter of the United Nations. a commentary. 2. ed. Oxford: Oxford University Press, 2002. v. 2. p. 140-148.

VUKAS, Budislav. International law and the pollution of the sea. In: The law of the sea: selected writings. Leiden: Martinus Nijhoff Publishers, 2004. p. 207-228.

VUKAS, Budislav. L'utilisation pacifique de la mer, dénucléarisation et désarmement. In: The law of the sea: selected writings. Leiden: Martinus Nijhoff Publishers, 2004. p. 157-204.

WALDOCK, Humphrey. Document A/CN.4/156 and Add.1-3: second report on the law of treaties. In: UNITED NATIONS. Yearbook of The International Law Commission, 1963. New York: United Nations, 1964. v. 2. p. 36-94.

WOLFRUM, Rüdiger. The legal order for the seas and oceans. In: NORDQUIST, Myron H.; MOORE, John Norton (Ed.). Entry into force of the law of the sea convention. Netherlands: Kluwer Law International, 1995. p. 161190.

WOOD, Michael C. International seabed authority: the first four years. Max Planck Yearbook of United Nations Law, Heidelberg, v. 3, p. 173-241, 1999.

ZANELLA, Tiago Vinicius. Água de lastro: um problema ambiental global. Curitiba: Juruá, 2010.

ZANELLA, Tiago Vinicius. Curso de direito do mar. Curitiba: Juruá, 2013. 


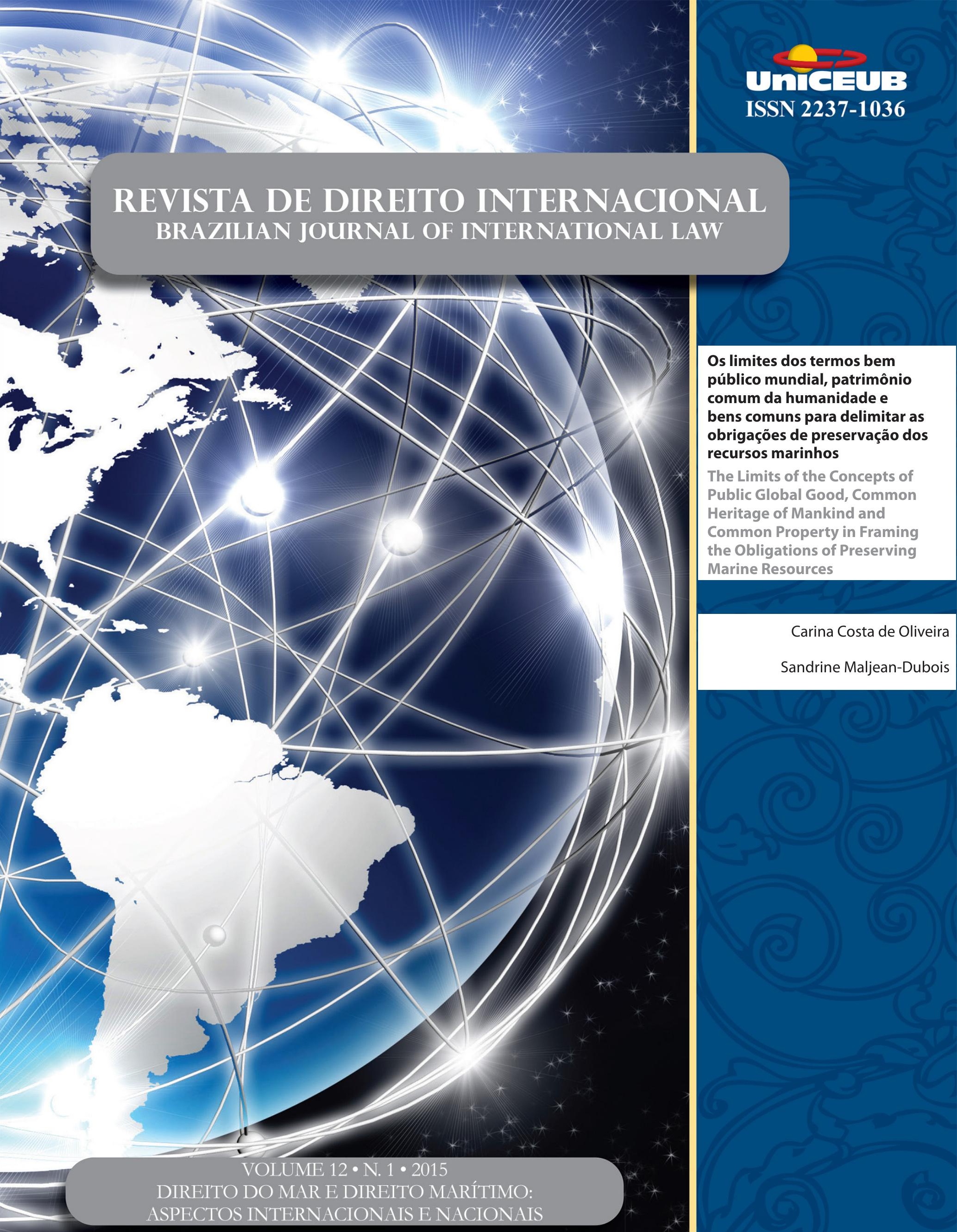




\title{
Os limites dos termos bem público mundial, patrimônio comum da humanidade e bens comuns para delimitar as obrigações de preservação dos recursos marinhos*
}

\author{
The Limits of the Concepts of Public Global \\ Good, Common Heritage of Mankind \\ and Common Property in Framing the \\ Obligations of Preserving Marine Resources
}

\author{
Carina Costa de Oliveira** \\ Sandrine Maljean-Dubois ${ }^{* * *}$
}

\section{Resumo}

Bem público mundial, patrimônio comum da humanidade e bens comuns são conceitos utilizados para compreender politicamente e legalmente o regime dos recursos marinhos. Contudo, esses conceitos são limitados em sua capacidade de delimitar as obrigações dos Estados e das Organizações Internacionais pela conservação desses recursos. Mesmo que o conteúdo desses termos possa ser questionado, eles direcionam, por meio de suas abstrações, o debate relacionado aos recursos marinhos. A existência desses termos, científicamente ou não, não pode ser ignorada. Para entender a contribuição desses conceitos para os debates jurídicos relacionados à preservação dos recursos marinhos, eles devem estar articulados com obrigações mais precisas tais como a obrigação de cooperar e a obrigação de diligência. Nesse sentido, esse artigo analisa como esses conceitos podem ser combinados com obrigações mais específicas para que tenham aplicação mais convincente e útil no que concerne à preservação dos recursos marinhos.

Palavras-chave: Preservação dos recursos marinhos. Diligência. Cooperação. Obrigações.

* Artigo convidado

** Professora Adjunta da Faculdade de Direito da Universidade de Brasília. Doutora em Direito pela Université Paris II- Panthéon Assas. Coordenadora do Grupo de Estudos em Direito, Recursos Naturais e Sustentabilidade.

*** Diretora de pesquisa no CNRS. Diretora do Centre d'Etudes et de Recherches Internationales et Communautaires (CERIC, UMR 7318 Université Paul Cézanne / CNRS). Professora e pesquisadora em direito internacional e direito europeu ambiental em seu conjunto (criação, implementação e efetividade), tendo dirigido diversas obras coletivas e publicado um grande número de artigos científicos nesse âmbito.

\section{Abstract}

Global public goods, common heritage and global commons are concepts used to understand the legal and the political regime of marine resources. However, these concepts are limited when it comes to determine the obligations of States and International Organizations regarding marine resources conservation. If, for this reason, their intrinsic purpose can be questioned, these concepts nevertheless dominate, in their abstraction, the debate on marine resources. Their existence, whether cientific or not, can therefore not be denied or ignored. To understand what they can concretely offer to the legal discussions on marine resources, they must be articulated with the more precise legal obligations such as the obligation to cooperate 
and the duty of due diligence, as applied to marine resources. Accordingly, this article studies how these concepts can be combined to more concrete obligations so as to have a convincing application.

Keywords: Marine resources preservation. Due diligence. Cooperation. Obligations.

\section{INTRODUÇÃo}

A proliferação de termos vagos e imprecisos dificulta e posterga a delimitação de obrigações relacionadas à preservação do meio ambiente marinho. Conceitos como bem público mundial, bens comuns e patrimônio comum da humanidade estão muitas vezes desconectados de normas capazes de implementá-los. O debate relacionados à tragédia dos comuns ${ }^{1}$ permanece atual, principalmente quando se analisa as estatísticas do aumento da superexploração de recursos marinhos em alto- $\operatorname{mar}^{2}$ e a busca desenfreada pela exploração de recursos em regiões inóspitas como o Ártico e a Antártica $^{3}$. É relevante, portanto, fazer breve apresentação dos conceitos sobre bem público mundial e a relação deste com os recursos marinhos vivos e não vivos, e a delimitação das obrigações internacionais relacionadas à preservação dos recursos marinhos.

1 Ver sobre o tema: OSTROM, E. Governing the commons, the evolution of institutions for collective actions. Cambridge: Cambridge university Press, 1990; HELLER, M. A. The Tragedy of the Anticommons: Property in the Transition from Marx to Markets. Harvard Law Review, 111, p. 622, 1998. p. 622 ets; LOGEAT, C. Les biens privés affectés à l'utilité publique. Paris: L'harmattan, 2011; PARANCE, Béatrice; VICTOR, Jacques de Saint. Repenser les comuns. Paris: CNRS éd., 2014.

2 Ver sobre o tema, por exemplo, as estatísticas elaboradas pela FAO sobre a pesca em alto-mar. Disponível em: < http://www.fao. org/fishery/statistics/en>. Acesso em: 05 maio 2015.

3 Ver sobre o tema as seguintes notícias: Euronews, 13 de maio de 2015. Shell recebe luz verde para a prospeção no Ártico. Disponível em:<http://pt.euronews.com/2015/05/13/shell-recebe-luz-verdepara-a-prospecao-no-artico/>. Acesso em: 10 maio 2015 ; The New York Times, 12 de maio de 2015.Aumentando barreiras em Seattle para repelir gigante petrolífero. Disponível em: $<$ http://www. nytimes.com/2015/05/12/us/grabbing-paddles-in-seattle-to-wardoff-an-oil-giant.html?_r=5>. Acesso em: 20 maio 2015. Para análise de estatísticas na Antártica ver: <https://www.ccamlr.org/en/document/publications/ccamlr-statistical-bulletin-vol-25>. Acesso em: 15 jun. 2015. Ver ainda: REID, Keith. Conserving Antarctica from the Bottom Up: Implementing UN General Assembly Resolution 61/105 in the Commission for the Conservation of Antarctic Marine Living Resources (CCAMLR). In: Ocean Y.B., n. 25 (131), 2011; ROSSI, Christopher R. A particular kind of the grotian tendency and the global commons in a time of high arctic change. In: Int'l $\mathrm{L}$ \& Int'l Rel, n. 11 (1), 2015.
De modo geral, a terminologia bens públicos mundiais não é clara e muito menos precisa. $\mathrm{O}$ termo tem sido utilizado e citado em textos jurídicos em áreas como saúde ${ }^{4}$, meio ambiente ${ }^{5}$, comércio $^{6}$, informação e, por ter sido utilizado reiteradamente, justifica-se a análise da função e do conteúdo deste. O conceito tem como origem os trabalhos de alguns economistas ${ }^{8}$. As organizações internacionais contribuíram, consideravelmente, com o debate sobre o termo desde a publicação do Programa das Nações Unidas para o Desenvolvimento (PNUD) em 1999 intitulada Les biens publics à l'échelle mondiale: la coopération internationale an XXIème siècle $e^{9}$ Esse relatório foi seguido por outros documentos do PNUD ${ }^{10}$ e por documentos realizados por outras

4 Ver: BOIDIN, Bruno. La santé, bien public mondial ou bien marchand: réflexions à partir des expériences africaines. Villeneuve d'Ascq: Presses Universitaires du Septentrion, 2014; GARTNER, David. Global public goods and global health. Duke J. Comp. \& Int'l L., n. 22 (303), 2011-2012.

5 Ver: MORGERA, Elisa. Bilateralism at the Service of Community Interests? Non-judicial Enforcement of Global Public Goods in the Context of Global Environmental Law. The European Journal of International Law, v. 23, n. 3, p. 748-753, 2012; MEYER, Timothy. Global public goods, governance risk and international energy. Duke J. Comp. \& Int'l L., v. 22, n. 319, 2011-2012; KRISCH, Nico. The decay of consent: international law in an age of global public goods. The American Journal of International Law, v. 108, n. 1, p. 16-21, jan. 2014.

6 STAIGER, R.W. Report on the International Trade Regime for the International Task Force on Global Public Goods. 2006. Disponível em: $<$ http://www.regeringen.se/contentassets/4e 7cc9afcd2444d38d5 b507bb6cf9b49/global-public-goods-international-trade>. Acesso em: 10 jun. 2015; MAVROIDIS, Petros C. Free Lunches? WTO as Public Good, and the WTO's View of Public Goods. The European Journal of International Law, v. 23, n. 3, p. 731-742, 2012; CAFAGGI, Fabrizio. Private regulation and the production of global public goods and private 'bads'. The European Journal of International Law, v. 23, n. 3, p. 695-718, 2012; PETERSMANN, Ernst-Ulrich. International Economic Law, "Public Reason" and Multilevel Governance of Interdependent Public Goods". Journal of International Economic Law, n. 14, p. 23-76, 2011.

7 Ver: DG/99/2/KM, UNESCO, Discurso de Kö̈chiro Matsuura, Diretor geral na ocasião do Sommet mondial des régulateurs sur Internet et les nouveaux services. UNESCO, 30 nov. 1999.

8 Ver os trabalhos de P. Samuelson, nos anos 50. Ver ainda: HEATHCOTE, S. Les biens publics mondiaux et le droit international. Quelques réflexions à propos de la gestion de l'intérêt commun. L'Observateur des Nations Unies, n. 13, p. 143, 2002. Ver o texto do Bodansky que retoma a origem do termo nos textos de David Hume e de Adam Smith: BODANSKY, Daniel. What's in a Concept? Global Public Goods, International Law, and Legitimacy. The European Journal of International Law, v. 23, n. 3, p. 652-654, 2012.

9 Ver sobre o tema: KAUL I.; GRUNBERG, I.; STERN, M. A. International Cooperation in the 21st Century. Oxford: Oxford University Press, 1999.

10 Ver, por exemplo: KAUL, Inge et al. Providing Global Public Goods: Managing Globalization. New York: Oxford University Press, 2003. 
organizações como o Banco Mundial ${ }^{11}$. Outras instituições nacionais também se dedicaram a trabalhar o conteúdo do bem público mundial no âmbito, por exemplo, da ajuda ao desenvolvimento ${ }^{12}$.

Observa-se que o termo tem sido utilizado para tratar de desafios de amplitude mundial, com peculiaridades para cada área temática ${ }^{13}$. Alguns artigos jurídicos abordaram o tema sob as seguintes perspectivas: demonstrar as deficiências institucionais gerais no contexto do direito internacional público para enquadrar os bens públicos mundiais, tais como a centralidade do consenso nas negociações dos sujeitos de direito internacional ${ }^{14}$, a capacidade e os limites de tratados bilaterais em contribuir com a gestão dos bens públicos mundiais ${ }^{15}$ e a necessidade de instrumentos processuais e substancias para a implementação dos objetivos do termo ${ }^{16}$; analisar como o direito internacional pode contribuir com questões de governança e de legitimidade das instituições para organizar a gestão desses bens ${ }^{17}$; conectar os bens públicos mundiais a obrigações erga omnes $^{18}$; avaliar questões específicas como a gestão da

11 BANCO MUNDIAL. Effective Use of Development finance for International Public Goods. Global Development Finance, Washington DC, 2001.

12 Ver por exemplo : AGENCIA FRANCESA DE DESENVOLVIMENTO. Biens publics mondiaux et développement: de nouveaux arbitrages pour l'aide ?. Documento de trabalho n. 3, Paris, sept. 2005.

13 Ver sobre o tema: BODANSKY, Daniel. What's in a Concept? Global Public Goods, International Law, and Legitimacy. The European Journal of International Law, v. 23, n. 3, p. 651-668, 2012.

14 KRISCH, Nico. "The decay of consent: international law in an age of global public goods". The American Journal of International Law, v. 108, n. 1, p. 1-40, jan. 2014.

15 MORGERA, Elisa. "Bilateralism at the Service of Community Interests? Non-judicial Enforcement of Global Public Goods in the Context of Global Environmental Law". The European Journal of International Law, v. 23, n. 3, p. 743-767, 2012.

16 NOLLKAEMPER, André. "International Adjudication of Global Public Goods: The Intersection of Substance and Procedure". The European Journal of International Law, v. 23 n. 3, p. 769- 791, 2012.

17 SHAFFER, Gregory. "International Law and Global Public Goods in a Legal Pluralist World". The European Journal of International Law, v. 23, n. 3, p. 669-693, 2012; BODANSKY, Daniel. "What's in a Concept? Global Public Goods, International Law, and Legitimacy". The European Journal of International Law, v. 23, n. 3, p. 653, 2012. No mesmo sentido: CAFAGGI Fabrizio, CARON, David D. "Global Public Goods amidst a Plurality of Legal Orders: A Symposium". The European Journal of International Law, v. 23, n. 3, p. 645, 2012.

18 BODANSKY, Daniel. "What's in a Concept? Global Public Goods, International Law, and Legitimacy". The European Journal of International Law, v. 23, n. 3, p. 653, 2012. Ver ainda: BENZING, Markus. Community Interests in the Procedure of International produção de energia ${ }^{19}$. Uma perspectiva que merece ser analisada, e que não foi objeto de um estudo atilado, refere-se à articulação de obrigações próprias e precisas ao conteúdo dos bens públicos mundiais, objeto sobre o qual esse artigo pretende se aprofundar no que concerne à gestão dos recursos marinhos.

As características principais dos bens públicos mundiais constituem a não rivalidade e a não exclusividade ${ }^{20}$. Significa dizer que não existe rivalidade entre potenciais utilizadores do bem, pois todos poderiam utilizá-lo sem reduzir a disponibilidade deste para o uso de outros interessados. Contudo, a terminologia bem público mundial parece não ser a mais adequada, pois, nos termos do dicionário Salmon de direito internacional público ${ }^{21}$, o bem é um « elemento móvel ou imóvel suscetível de apropriaçã $\mathrm{O}^{22}$ », o que pode parecer estar em contradição com a noção de bem público mundial. Além disso, público se opõe, normalmente, a privado. Para um jurista, o adjetivo evoca a dominialidade pública, caracterizada pela inaliabilidade desta. Tendo procedência do direito interno, a distinção entre público e privado não pode ser transposta sem modificações ao âmbito internacional. $\mathrm{O}$ adjetivo mundial é, sem dúvida, a parte do tripé que resulta em menos dificuldade. Ele marca a escala global da questão. No entanto, global é muitas vezes apenas uma das perspectivas de ação para um problema. A gestão dos oceanos, por exemplo, é multiescalar, indo do local ao global simultaneamente. Dito de outra forma, mesmo que mundial, um bem público necessita de ação nas esferas local, nacional e internacional.

Pode-se questionar, ainda, de que modo o termo "público" difere-se do termo "comum". Por que falar de bem público ao invés de bem comum, considerando-se que o termo "público" não tem sentido na ordem jurídica internacional enquanto o termo "comum" já está juridicamente consagrado (interesse comum da humanidade, patrimônio comum da humanidade, etc.)? Mas, mesmo que "comum" já esteja juridicamente consagra-

Courts and Tribunals. The Law and Practice of International Courts and Tribunals, n. 5, p. 374, 2006.

19 MEYER, Timothy. Global public goods, governance risk and international energy. Duke J. Comp. \& Int'l L., v. 22, n. 319, 20112012.

20 BODANSKY, Daniel. What's in a Concept? Global Public Goods, International Law, and Legitimacy. The European Journal of International Law, v. 23, n. 3, p. 652, 2012.

21 SALMON, J. (Dir.). Dictionnaire de droit international public. Bruxelles: Bruylant, 2001. p. 126.

22 O texto original tem o seguinte conteúdo: Élément mobilier ou immobilier susceptible d'appropriation. 
do, qual é essa comunidade?23. Não há comunidade jurídica que represente a comunidade sociológica, mais ou menos existente, que esteja submetida à mesma ordem jurídica ${ }^{24}$.

Segundo o PNUD, o termo público é justificado pelo triângulo de publicness no qual se inscrevem esses bens. Mais precisamente, o bem público mundial é três vezes mundial: público em seu consumo, e o acesso a esse bem é livre e não exclusivo; público no processo de participação, processo político aberto e inclusivo; público na distribuição de privilégios, diante da qual todos podem se beneficiar ${ }^{25}$. Constata-se que, atualmente, raros são os bens públicos mundiais que possam refletir, simultaneamente, essas três características. Esses objetivos só poderão ocorrer no contexto da existência de uma sociedade internacional, sendo esta apenas um projeto e não uma realidade. Em suma, o bem público mundial ainda não exprime regime jurídico peculiar, específico. Trata-se de qualificação não jurídica, apesar das diversas referências em diferentes áreas do direito internacional. Essa constatação não significa que não possam ser atribuídos compromissos e obrigações específicas para a gestão dos chamados bens públicos mundiais. É possível vinculá-los, por exemplo, a terminologias consolidadas no direito internacional que possuem algumas das características dos bens públicos mundiais.

No que tange aos recursos vivos e não vivos marinhos, a terminologia bem público mundial encontra parentesco no âmbito dos recursos marinhos no conceito patrimônio comum da humanidade ${ }^{26}$, com relação aos

23 JOUANNET, E. L'idée de communauté humaine. In: ARCHIVES de philosophie du droit. La mondialisation entre illusion et utopia. t. 47 , p. 191.

24 JOUANNET, E. L'idée de communauté humaine. In: ARCHIVES de philosophie du droit. La mondialisation entre illusion et utopia. t. 47 , p. 191.

25 PNUD. Providing Global Public Goods: Managing Globalization 25 Questions \& Answers. New York: UNDP/ODS, 2002, p. 3-5. Disponível em: <http://web.undp.org/globalpublicgoods/globalization/pdfs/ques-ans.pdf>. Acesso em: 10 maio 2015.

26 Ver sobre o tema: MERCURE, P.F. L'échec des modèles de gestion des ressources naturelles selon les caractéristiques du concept de patrimoine commun de l'humanité. Revue de droit d'Ottawal Ottawa Law Review, v. 28, p. 45, 1996- 1997; TRÉBULLE, F.G. La propriété à l'éprewve du patrimoine commun: le renouveau du domaine universel. Études offertes au professeur Malinvaud, Lexis Nexis. 2007; FRANCKX, Erik. The International Seabed Authority and the Common Heritage of Mankind: The Need for States to Establish the Outer Limits of their Continental Shelf. The International Journal of Marine and Coastal Law, n. 25, p. 543-567, 2010;

LODGE, Michael W. The Common Heritage of Mankind. The International Journal of Marine and Coastal Law, n. 27, p. 733-742, 2012; fundos marinhos; e no termo bens comuns ${ }^{27}$ utilizado para caracterizar recursos sobrejacentes aos fundos marinhos. Diante de um contexto no qual o patrimônio comum da humanidade tem vocação para ser aplicado aos espaços ou aos recursos, não é necessariamente o caso do bem público mundial. No caso deste, a sua utilização não está conectada à internacionalização ou à apropriação de um bem, mas à efetiva cooperação para a efetiva e concreta gestão deste. Por esse ângulo, o termo pode complementar e ampliar o conteúdo dos termos patrimônio comum da humanidade e bem comum para corresponder, mais precisamente, à noção de cooperação para a preservação do recurso ${ }^{28}$. Esse efeito de cooperação pode ser constatado em regimes de res communis, nos chamados bens comuns. Por outro lado, o regime do patrimônio comum da humanidade se diferencia do conceito de bem público mundial em virtude da possibilidade de uso exclusivo dos fundos marinhos em determinadas circunstâncias. Contudo, essa possibilidade de uso exclusivo por meio, por exemplo, de contratos de exploração dos fundos marinhos, não afasta a utilidade da análise de instrumentos que possam implementar a obrigação de cooperação para a gestão dos recursos marinhos no âmbito da apropriação particular ou coletiva ${ }^{29}$.

NOYES, John E. The common heritage of mankind: past, present, and future. Denv. J. Int'l L. \& Pol'y, n. 20, 447, 2011-2012; BASLAR, Kemal. The Concept of the Common Heritage of Mankind in International Law. Hague: Nijhoff Publishers, 1998; SHACKELFORD, Scott J. The Tragedy of the Common Heritage of Mankind. Stan Envtl LJ, n. 28, 2009; JOYNER, C. Legal Implications of the Concept of the Common Heritage of Mankind. Int'l \& Comp. LQ, n. 35, 1986.

27 PARANCE, Béatrice; VICTOR, Jacques de Saint. Repenser les comuns. Paris: CNRS éd. 2014; DEBLOCK, Christian; DELAS, Olivier. Le bien commun comme réponse politique à la mondialisation. Bruxelles: Bruylant, 2003; GORDILLO, José Luis. La Protección de los bienes comunes de la humanidad: un desafío para la política y el derecho del siglo XXI. Madrid: Editorial Trotta , 2006; KU, Charlotte. The Concept of Res Communis in International Law. History of European Ideas, v. 12, n. 4, 1990.

28 A relevância do conceito bem público mundial para a cooperação já foi destacada por alguns autores a exemplo de: BARRETT, Scott. Why Cooperate? The Incentive to Supply Global Public Goods. Oxford: Oxford University Press, 2007; CAFAGGI Fabrizio, CARON, David D. Global Public Goods amidst a Plurality of Legal Orders: A Symposium. The European Journal of International Law, v. 23 , n. 3 , p. 645,2012 . Sobre a conexão entre a preservação do meio ambiente e a necessidade de cooperação ver: MORGERA, Elisa. Bilateralism at the Service of Community Interests? Non-judicial Enforcement of Global Public Goods in the Context of Global Environmental Law. The European Journal of International Law, v. 23, n. 3, p. 748-753, 2012.

29 Sobre o tema do regime da propriedade individual e coletiva no contexto dos bens públicos mundiais ver: CAFAGGI, Fabrizio. 
Em suma, efeito útil da terminologia bem público mundial, no âmbito dos recursos marinhos, consiste em articular os termos já consagrados no direito internacional público para ampliá-los por meio da conexão a obrigações relacionadas à preservação dos recursos. Entre as obrigações específicas consolidadas em direito internacional, podem ser citadas a obrigação de cooperar e a obrigação de due diligence. Outras obrigações poderiam ser citadas, tal como a obrigação de agir em conformidade com o princípio da precaução ${ }^{30}$. No entanto, não se pode afirmar que a obrigação citada já esteja consolidada no direito internacional. Outro critério de seleção das obrigações consistiu no possível impacto nacional e internacional da obrigação, o que é aplicável às duas obrigações mencionadas. Assim, é relevante analisar a configuração da obrigação de cooperação (1) e de due diligence (2) no contexto da preservação dos recursos do meio ambiente marinho, considerando-se que há limites consideráveis para essa operacionalização.

\section{Os LIMITES DA OPERACIONALIZAÇÃO DA OBRIGAÇÃO DE COOPERAR PARA A PRESERVAÇÃO DO MEIO AMBIENTE MARINHO}

O conteúdo de gestão do bem público mundial ainda não contribui com a operacionalização da obrigação de cooperar para a preservação do meio ambiente marinho. Considerando que o termo bem público mundial ainda não é juridicamente operatório, outros termos cuja utilização seja mais consolidada no direito internacional devem ser analisados. Os bens comuns, por exemplo, possuem contorno jurídico mais claro no que concerne ao regime aplicado aos recursos marinhos existentes no alto-mar ${ }^{31}$. Por sua vez, o termo patrimônio comum da

Private regulation and the production of global public goods and private 'bads'. The European Journal of International Law, v. 23, n. 3, p. 703-707, 2012. Ver, especificamente, p. 796.

30 Sobre o tema ver: MALJEAN-DUBOIS, Sandrine. The Role of International Law in the Promotion of the Precautionary Principle. Disponível em: <http://www.iales-aides.com/ uploads/1/3/9/6/13963183/the_role_of_international_law_ in_the_promotion_of_the_precautionary_principle_-_sandrine_ maljean-dubois.pdf $>$. Acesso em: 15 jun. 2015; MARR, Simon. The Southern Bluefin Tuna Cases: The Precautionary Approach and Conservation and Management of Fish Resources. European Journal of International Law, v. 11, n. 04, p. 815-831, 2000.

31 Ver sobre o tema: KAYE, Stuart. Enforcement Cooperation in Combating Illegal and Unauthorized Fishing: An Assessment of Contemporary Practice. Berkeley J. Int'l L., n. 32, 2014, p. 316-329; humanidade possui contornos mais delimitados no que tange à gestão dos fundos marinhos. Antes de analisar o conteúdo de cooperação existente nos dois termos já consolidados no direito internacional, demonstrar-se-á que a obrigação de cooperação para a preservação dos recursos marinhos existe no direito internacional.

O princípio da cooperação consiste em princípio geral do direito internacional público ${ }^{32}$ e do direito internacional ambiental em particular. A ação conjunta dos Estados em razão de um interesse comum pode ser evidenciada em diversos tratados na área ambiental, principalmente nos preâmbulos ${ }^{33}$ nos quais se exige

TELESETSKY, Anastasia. Laundering Fish in the Global Undercurrents: Illegal, Unreported, and Unregulated Fishing and Transnational Organized Crime. Ecology L.Q., n. 41, p. 939-998, 2014; MELLO, Celso D. De Albuquerque. Alto-mar. Rio de Janeiro: Renovar, 2001. O termo bens comuns será utilizado no contexto do regime de res communis.

32 Ver: Carta das Nações Unidas, art. 1², inciso 3; artigo 11. 1; artigo 13. 1. a), b); Declaração 2625(XXV) relativa aos princípios do direito internacional relacionados às relações amigáveis e à cooperação entre os Estados.

33 Convenção das Nações Unidas sobre a luta contra a desertificação nos países gravemente atingidos pela seca ou pela desertificação em particular na África: "Reconnaissant que la désertification et la sécheresse constituent un problème de dimension mondiale puisqu'elles touchent toutes les régions du monde, et qu'une action commune de la communauté internationale s'impose pour lutter contre la désertification et/ou atténuer les effets de la sécheresse"; Convenção internacional sobre a regulamentação da caça à baleia (2 de dezembro de 1946) " [...] les nations du monde ont intérêt à sauvegarder, au profit des générations futures, les grandes ressources naturelles représentées par l'espèce baleinière »; Convenção Africana sobre a Conservação da Natureza e dos Recursos Naturais (Convenção da Argéria, 1968), "Desireux d'entreprendre une action individuelle et collective en vue de la conservation, de l'utilisation et du développement de ce capital par l'établissement et le maintien de son utilisation rationnelle pour le bien-être présent et futur de l'humanité", "Affirmant que la conservation de l'environnement mondial est une préoccupation commune à l'humanité tout entière" (Convenção de Maputo, 2003); Convenção sobre o comércio internacional de espécies de fauna e de fauna selvagens ameaçadas de extinção (Washington, 3 de março de 1973), "Reconnaissant que la faune et la flore sauvages constituent de par leur beauté et leur variété un élément irremplaçable des systèmes naturels, qui doit être protégé par les générations présentes et futures". O preâmbulo da Convenção sobre a conservação de espécies migratórias que pertençam à fauna selvagem dispõe que: “[...] Reconnaissant que la faune sauvage, dans ses formes innombrables, constitue un élément irremplaçable des systèmes naturels de la terre, qui doit être conservé pour le bien de l'humanité; Conscientes de ce que chaque génération humaine détient les ressources de la terre pour les générations futures et a la mission de faire en sorte que ce legs soit préservé et que, lorsqu'il en est fait usage, cet usage soit fait avec prudence; Convenção-quadro das Nações Unidas sobre Mudanças Climáticas (1992), "Conscientes que les changements du climat de la planète et leurs effets néfastes sont un sujet de préoccupation pour l'humanité tout entière"; "Conscientes que le caractère planétaire des changements 
a cooperação entre os sujeitos de direito internacional. Exemplos de cooperação podem ser observados em resultados do Protoloco de Montreal sobre a Camada de Ozônio ${ }^{34}$ e sobre o Protocolo de Kyoto na área do clima por meio de instrumentos sofisticados como mecanismos financeiros. Em outras áreas, também existem mecanismos financeiros originais que permitem fornecer uma base financeira para a cooperação internacional tal como uma porcentagem das passagens de avião com o objetivo de contribuir para a compra de medicamentos (UNITAID) $^{35}$, ou de vacinas ${ }^{36}$. Porém, mesmo que

climatiques requiert de tous les pays qu'ils coopèrent le plus possible et participent à une action internationale, efficace et appropriée, selon leurs responsabilités communes mais différenciées, leurs capacités respectives et leur situation sociale et économique" (preâmbulo); "Il incombe aux Parties de préserver le système climatique dans l'intérêt des générations présentes et futures, sur la base de l'équité et en fonction de leurs responsabilités communes mais différenciées et de leurs capacités respectives. Il appartient, en conséquence, aux pays développés parties d'être à l'avant-garde de la lutte contre les changements climatiques et leurs effets néfastes" (artigo 3, \$1). A obrigação de cooperação no campo do meio ambiente é enunciada de um modo geral na Declaração do Rio sobre o meio ambiente e o desenvolvimento: «Os Estados devem cooperar com um espírito de parceria mundial em via de conservar, de proteger e de restabelecer a saúde e a integridade do ecossistema terrestre" (princípio 7). A Declaração destaca a aplicação do princípio no âmbito científico e técnico (princípio 9), no domínio comercial (princípio 12), ou ainda no que tange à notificação aos Estados das catástrofes naturais e a outras situações de urgência da mesma ordem suscetíveis de efeitos transfronteiriços (principe 18), ou ainda a informação e a consulta aos Estados suscetíveis de serem afetados pelas atividades que podem ter efeitos transfronteiriços sobre o meio ambiente (princípio 19). A Declaração termina pelo princípio 27 segundo o qual "Os Estados e os povos irão cooperar de boa-fé e imbuídos de um espírito de parceria para a realização dos princípios consubstanciados nesta Declaração, e para o desenvolvimento progressivo do direito internacional no campo do desenvolvimento sustentável”.

34 SCHEMEIL, Y. Des types purs de ressources mondiales communes non marchandes? AFSP / Section d'Etudes Internationales - Colloque Les biens publics mondiaux. Pau, 2001. p. 4. Essas análises poderão ser relativizadas no futuro. Ver: "Summary of the Fourteenth Meeting of the Parties to the Montréal Protocol and the Sixth Conference of the Parties to the Vienna Convention, 25-29 novembro 2002". Earth Negociations Bulletin, v. 19, n. 24, p. 16. Ver, ainda, a análise de THEYS, J.; FAUCHEUX, S.; NOËL, J.F. La guerre de l'ozone. Futuribles, n. 125, p. 51-66, out. 1988; FAUCHEUX S.; NOËL, J. F. Les menaces globales sur l'environnement, Paris: Repères La Découverte, 1990. 35 A contribuição sobre os bilhetes de avião destinados a financiar o acesso dos países mais pobres aos medicamentos contra a malária, a tuberculose e a AIDs por meio de uma facilidade internacional de compras de medicamentos (UNITAID) conta hoje com a contribuição de mais de 27 Estados. UNITAID reune os fundos necessários para comprar os medicamentos, centraliza os pedidos diante de um grupo grande de compradores. Pode, portanto, fazer pedidos em grande quantidades e obter os melhores preços. Sobre o tema ver: <http://www.unitaid.eu/>. Acesso em: 15 jun. 2015. 36 IFFIM (International Finance Facility for Immunisation - Facilidade internacional para a vacinação) tem mobilizado milhões de existam compromissos vinculantes ou não vinculantes, a efetividade desses instrumentos ainda é questionável.

A obrigação de cooperação em matéria ambiental também está presente no direito do mar. Por exemplo, a Convenção de Montego Bay prevê no artigo 192 uma obrigação geral de que "Os Estados possuem a obrigação de proteger e de preservar o meio marinho". Os costumes também são fonte de reconhecimento da obrigação, o que pode ser constatado em alguns julgados relacionados ao tema do mar: "[...] obrigação de cooperar constitui, em virtude da parte XII da Convenção de Montego Bay e do direito internacional geral, um princípio fundamental em matéria de prevenção da poluição do meio marinho do qual decorrem direitos que podem ser garantidos pelo Tribunal [...]"37.

No âmbito da Corte Internacional de Justiça (CIJ), pode ser citada a decisão de 2010 no Caso Papeleiras que afirmou a existência de uma obrigação geral de cooperação em matéria de meio ambiente, no seguintes termos: "[...] obrigação de realizar uma avaliação do impacto ambiental quando a atividade puder causar um risco prejudicial importante em um contexto transfronteiriço, em particular diante de um recurso compartilhado" 38 . Assim, um dos instrumentos de cooperação relacionados à proteção ambiental, destacado pela Corte, consistiu na avaliação de impacto ambiental. Ainda sobre a avaliação, a Corte afirmou que trata-se de "[...] prática aceita amplamente pelos Estados nos últimos anos", e, ainda, uma "obrigação de diligência e um dever de prevenção" sem indicar, no entanto, se essa cooperação é uma obrigação costumeira ou convencional ${ }^{39}$. Com base nessa decisão, verifica-se que a avaliação de impacto ambiental não cumpre apenas o papel de autorização do projeto. A Corte afirma que uma vez que as operações tenham começado, uma fiscalização contínua dos efeitos do projeto ao meio ambiente deve ser monitorada durante todo o projeto ${ }^{40}$.

dólares anualmente para lidar com o tema. Ver os relatórios de mobilização financeira em: <http://www.iffim.org/finance/trusteesreports-and-financial-statements/>. Acesso em: 20 jun. 2015.

37 TRIBUNAL INTERNACIONAL DO DIREITO DO MAR. Iranda c. Reino Unido, The Mox Plant Case, decisão das medidas provisórias no dia 3 de dezembro de 2001, parágrafo 82.

38 "[...] obligation de procéder à une évaluation de l'impact sur l'environnement lorsque l'activité industrielle projetée risque d'avoir un impact préjudiciable important dans un cadre transfrontière, et en particulier sur une ressource partagée".

39 Artigo 41.

40 TRIBUNAL INTERNACIONAL DO DIREITO DO MAR. Iranda c. Reino Unido, The Mox Plant Case, decisão das medidas 
Perante esse cenário, serão analisados os limites da preservação do meio ambiente marinho por meio do regime de res communis(a) e do patrimônio comum da humanidade (b) para a implementação da obrigação de cooperação, a fim de preservar os recursos marinhos.

Os limites do regime de res communis

O regime jurídico res communis pode não contribuir com a implementação da cooperação dos sujeitos de direito internacional para a preservação dos recursos marinhos. A superexploração dos recursos, avaliada por meio de relatórios e de julgados, no âmbito da $\mathrm{FAO}^{41}$, da $\mathrm{CIJ}^{42}$, entre outras organizações, evidencia a falta de instrumentos substanciais e processuais que operacionalizem a cooperação. O principal recurso marinho que pode ser utilizado como objeto de análise desse regime é o recurso pesqueiro. Portanto, a pesca será central na análise da implementação do regime de res communis para a preservação do meio ambiente marinho. Considerando que o conteúdo do bem público mundial é a cooperação, é pertinente relacioná-lo ao regime de res communis, bem como demonstrar os limites do termo bem comum para a implementação da obrigação de cooperação dos Estados para a gestão dos recursos marinhos que estiverem em áreas sob a jurisdição dos Estados ou em áreas que estiverem além das jurisdições nacionais.

A Tragedy of commons de Hardin de $1968^{43}$ descreve o abuso no uso dos bens comuns: em razão de os bens serem comuns, o seu acesso é livre e não regulado, o que resulta potencialmente em sua superexploração. Se a "desafetação patrimonial permite [...] a liberdade de uti-

provisórias no dia 3 de dezembro de 2001, parágrafo 205.

41 Ver sobre o tema, por exemplo, as estatísticas elaboradas pela FAO sobre a pesca em alto-mar. Disponível em: < http://www.fao. org/fishery/statistics/en>. Acesso em: 05 maio 2015.

42 Ver um dos últimos casos julgados pela Corte Internacional de Justiça, o caso Austrália c. Japão, caso Baleias, decisão de 31 de março de 2014. Ver: OLIVEIRA, Liziane Paixão Silva; MARINHO, Maria Edelvacy. O caso Austrália c. Japão perante a Corte Internacional de Justiça, Decisão, 31 de março de 2014. In: MONEBHURRUN, Nitish. Decisões da corte internacional de justiça e do tribunal internacional sobre o direito do mar. RDI, Brasília, v. 12, n. 2, p. 4349, 2014. Ver ainda: MALJEAN-DUBOIS, Sandrine; KERBRAT, Yann. La Cour Internationale de Justice face aux enjeux de protection de l'environnement : réflexions critiques sur l'arrêt du 20 avril 2010 , Usines de pâte à papier sur le fleuve Uruguay (Argentine c. Uruguay). RGDIP, n. 1, t. CXV, p. 39-75, 2011. Ver ainda: Caso julgado pelo Tribunal Internacional do Direito do Mar, Southern Bluefin Tuna (New Zealand-Japan, Australia-Japan), Medida provisória, agosto de 1999.

43 HARDIN, Garrett. The Tragedy of the Commons. Science 13, v. 162, p. 1243-1248, dez. 1968. lização" ela não providencia meios " contra os apetites individuais" $"$. Caracterizada pela liberdade de acesso e por uma liberdade ilimitada de exploração, o regime tradicional de res communis não é capaz de limitar, por si só, o risco de degradação e de esgotamento dos recursos ${ }^{45}$.

Prolongando-se o res communis do direito romano, cultivado em seguida pelos juristas teólogos do século XVI (Vitoria, Suarez) e posteriormente sistematizado pela escola de direito natural de Grotius, ele consiste em realizar um esforço para triunfar contra todos por meio de um comportamento autocentrado nas atividades territoriais concorrentes ${ }^{46}$. A melhor ilustração é fornecida pelo alto-mar, destinado à livre utilização de todos, aberto à liberdade de navegação para todas as bandeiras ${ }^{47}$. Trata-se da velha questão doutrinária do século XVII : mare clausum (Selden) contra mar liberum (Grotius). O último triunfou no final. $\mathrm{O}$ artigo $87 \mathrm{da}$ Convenção de Montego Bay dispõe que "O alto-mar está aberto a todos os Estados, que eles sejam costeiros ou sem litoral"; o art. 89 indica que "Nenhum Estado não pode legitimamente pretender submeter qualquer parte do alto-mar à sua soberania".

A tendência natural da sociedade internacional é de afetação, de apropriação: a soberania estatal é "expasionista por sua dinâmica inerente, exclusivista por sua própria lógica ${ }^{48}$. Assim, diversos aspectos em direito do mar reforçam esse ímpeto de afetação: reconhecimento do princípio da liberdade internacional de navegação nas vias internacionais (rios e lagos compartilhados, canais internacionais); princípio da passagem inofensiva no mar territorial (enquanto que o Estado costeiro exerce sua soberania). A constatação é conhecida, mas em que medida a noção de bem público mundial pode evitar essa tragédia? A noção pode auxiliar na interpretação do termo no sentido da cooperação entre os sujeitos de direito internacional para a gestão dos recursos marinhos.

A cooperação pode ser implementada tanto na Zona, área que está além dos espaços sob a jurisdição dos Es-

44 DUPUY, Pierre-Marie. Droit international public. Paris: Dalloz, 11ème éd. 2012. p. 819.

45 KISS, A. C. La notion de patrimoine commun de l'humanité. RCADI, t. 175, p. 243, 1982.

46 DUPUY, Pierre-Marie. Droit international public. Paris: Dalloz, 11ème éd. 2012. p. 819.

47 DUPUY, Pierre-Marie. Droit international public. Paris: Dalloz, 11ème éd. 2012. p. 819.

48 DUPUY, Pierre-Marie. Droit international public. Paris: Dalloz, 11ème éd. 2012. p. 819. 
tados, quanto nas áreas que estiverem sob a jurisdição dos Estado, mais precisamente, nas Zonas Econômicas Exclusivas. A imprecisão das obrigações específicas nessa área, sobretudo no que tange à atividade de pesca, é evidente tanto para o Estado de bandeira do navio quanto para o Estado costeiro ${ }^{49}$. A opinião consultiva 21 do Tribunal do mar destacou algumas dessas obrigações aplicáveis a sete Estados do continente africano ${ }^{50}$.

No contexto da Convenção relativa à determinação mínima de acesso e de exploração aos recursos pesqueiros no interior das zonas marítimas sob a jurisdição (CMA) dos Estados Membros da Comissão Sub-Regional de Pescas (CSRP), que foi objeto de análise pelo Tribunal do mar na opinião consultiva n. 21, podem ser observadas algumas lacunas no que tange à cooperação dos Estados com relação à pesca ilegal. Há maior previsão de obrigações do Estado costeiro relacionadas à gestão sustentável dos estoques compartilhados e dos estoques de interesse comum, em particular dos tunídeos e de pequenos pelágico, que previsão de obrigações para o Estado de bandeira. Entre as obrigações de gestão sustentável desses recursos pelo Estado costeiro podem ser citadas: a) cooperar sobre as medidas necessárias para assegurar a conservação e o desenvolvimento dos estoques $^{51}$; b) assegurar que não haverá superexploração desses recursos ${ }^{52}$; c) tomar medidas em conformidade com outras organizações que tratem do mesmo tema, como a Comissão internacional para a conservação dos tunídeos do Atlântico tanto nas ZEEs dos Estados membros da CSRP quanto em outros Estados membros de outras organizações que tratem do mesmo tema. Há, ainda, a indicação de que o Estado deve verificar se a preservação e a gestão dos recursos estão sendo feitas de acordo com os dados científicos mais confiáveis dos quais dispõem os Estados membros da CSRP, nos termos do art. 2, parágrafo $2^{\circ}$ da Convenção de Montego Bay ${ }^{53}$.

O caso Virginia G já havia dado maior precisão

49 Ver sobre o tema: KAYE, Stuart. Enforcement Cooperation in Combating Illegal and Unauthorized Fishing: An Assessment of Contemporary Practice. Berkeley J. Int'l L., n. 32, p. 316-329, 2014; TELESETSKY, Anastasia. Laundering Fish in the Global Undercurrents: Illegal, Unreported, and Unregulated Fishing and Transnational Organized Crime. Ecology L.Q., n. 41, p. 939-998, 2014.

50 Cabo Verde, República Islâmica da Mauritânia, Senegal, República da Gâmbia, República da Guiné, República da GuinéBissau e República da Serra Leoa.

51 TRIBUNAL INTERNACIONAL DO DIREITO DO MAR. parágrafo 189. Art. 61.2 da Convenção de Montego Bay.

52 Art. 61.3 da Convenção de Montego Bay.

53 Art. 61.2 da Convenção de Montego Bay. às obrigações do Estado costeiro no que tange à preservação e à gestão dos recursos biológicos na ZEE, elencando as seguintes atividades ${ }^{54}$ : “[...] adotar as leis e os regulamentos que fixem as condições de acesso aos navios de pesca estrangeiros na sua ZEE - arts. 56, parágrafo $1^{\circ}$ e 62 parágrafo $4^{\circ}$ da Convenção". Nos termos do art. 62, parágrafo $4^{\circ}$, essas leis e regulamentos devem ser compatíveis com a Convenção. O tribunal nota que as medidas devem ser de gestão e que não há uma lista exaustiva do que pode ou não ser feito pelo Estado costeiro ${ }^{55}$. No mesmo sentido, a opinião consultiva 21 indica que o Estado costeiro pode adotar “[...] todas as medidas, incluindo de embarque, de inspeção de apreensão e de judicialização que sejam necessárias para assegurar o respeito às leis e aos regulamentos adotados em conformidade com a Convenção" 56 .

Uma grande limitação da cooperação na área da gestão da pesca refere-se ao fato de que não há obrigações gerais para todos os Estados, mas apenas para os Estados membros de comissões de pesca específicas ${ }^{57}$. Essas obrigações reduziriam possíveis efeitos negativos na preservação do meio ambiente marinho considerando que o mar não tem fronteiras. Para que sejam efetivas, as medidas de preservação e de gestão de pesca devem tratar do conjunto de estoque das espécies em toda a zona de distribuição e em todos os itinerários de migração ${ }^{58}$. Os Estados que pescam nos setores adjacentes devem implementar medidas necessárias à preservação desses estoques ${ }^{59}$. Nesse sentido, a noção de bem público mundial pode ressaltar e enfatizar a necessidade de melhor gestão desses recursos tanto no âmbito local quanto no nacional e internacional.

Ademais, os limites da obrigação de cooperar refletem-se no que foi apontado pelo juiz Paik de que a opi-

54 Sobre o tema ver: OLIVEIRA, Carina Costa de; GONÇALVES, Natália da Silva. Comentários ao caso m/v "Virginia" (Panamá c. Guiné-Bissau), 14 de abril de 2014. In: MONEBHURRUN, Nitish. Decisões da corte internacional de justiça e do tribunal internacional sobre o direito do mar. RDI, Brasília, v. 12, n. 2, p. 55-63, 2014.

55 TRIBUNAL INTERNACIONAL DO DIREITO DO MAR. Navio “Virginia G”, Panamá v. Guinée-Bissau, decisão de 14 de abril de 2014, parágrafos 212 e 213.

56 TRIBUNAL INTERNACIONAL DO DIREITO DO MAR. Opinião Consultiva n. 21, parágrafo 105.

57 TRIBUNAL INTERNACIONAL DO DIREITO DO MAR. Opinião consultiva n. 21, parágrafo 69.

58 TRIBUNAL INTERNACIONAL DO DIREITO DO MAR. Opinião consultiva n. 21, parágrafos 196 e 198.

59 TRIBUNAL INTERNACIONAL DO DIREITO DO MAR. Opinião consultiva n. 21, parágrafo 196. 
nião consultiva 21 deveria ter analisado os limites entre a obrigação de cooperar do Estado membro da Comissão de Pesca envolvida na opinião e os direitos do Estado costeiro de preservar e de gerir os recursos biológicos da sua $\mathrm{ZEE}^{60}$. A opinião não garantiu maior precisão com relação à obrigação de cooperar no sentido de que poderia ser um descumprimento dessa obrigação o fato de o Estado se recusar a negociar, demorando para apresentar respostas ou medidas de preservação e de gestão ${ }^{61}$.

Nota-se que os avanços na seara da interpretação da obrigação de cooperação estão vinculados à maior precisão de obrigações específicas de cooperação para todos os Estados no âmbito internacional. Houve avanço, por exemplo, nas obrigações dos Estados costeiros na gestão da pesca ilegal nas áreas sob a jurisdição dos membros da Comissão que solicitou a opinião consultiva n. 21. No entanto, as obrigações gerais de cooperação ainda não contêm maior precisão. Outras áreas, como a liberdade de navegação, também devem ser objeto de análise mais precisa no que tange à preservação dos recursos. Além dos limites do regime de res communis, é relevante avaliar os limites do regime de patrimônio comum da humanidade para fomentar a cooperação no sentido da preservação dos recursos marinhos.

Os limites do regime de patrimônio comum da humanidade

O conteúdo do patrimônio comum da humanidade ${ }^{62}$ ainda é limitado no que concerne à preservação dos recursos marinhos. Em princípio, essa qualificação organiza a gestão comum teoricamente sustentável dos recursos sob esse regime ${ }^{63}$. Para avaliar os limites desse regime

60 TRIBUNAL INTERNACIONAL DO DIREITO DO MAR Opinião individual do juiz Paik, parágrafo 31.

61 TRIBUNAL INTERNACIONAL DO DIREITO DO MAR. Opinião individual do juiz Paik, parágrafo 37.

62 Ver sobre o tema: KISS, A. C. La notion de patrimoine commun de l'humanité. RCADI, t. 175, p. 103, 1982 e s; LODGE, Michael W. The Common Heritage of Mankind. The International Journal of Marine and Coastal Law, n. 27, p. 733-742, 2012; NOYES, John E. The common heritage of mankind: past, present, and future. Denv. J. Int'l L. \& Pol'y, n. 20, p. 447, 2011-2012; BASLAR, Kemal. The Concept of the Common Heritage of Mankind in International Law. Hague: Nijhoff Publishers, 1998; SHACKELFORD, Scott J. The Tragedy of the Common Heritage of Mankind. Stan Envtl LJ, n. 28, 2009; JOYNER, C. Legal Implications of the Concept of the Common Heritage of Mankind. Int'l \& Comp. LQ, n. 35, 1986; BARDONNET, D. Le projet de convention de 1912 sur le Spitsberg et le concept de patrimoine commun de l'humanité. Mélanges René-Jean Dupuy. In: HUMANITÉ et droit international. Paris: Pedone, 1991. p. 13.

63 O espaço terrestre (Antártica), o espaço extratosférico, o es- jurídico para a preservação dos recursos marinhos, com um conteúdo de cooperação para a gestão do bem, devem ser analisados o conceito de patrimônio comum da humanidade, os limites desse conteúdo para garantir a cooperação na gestão dos recursos marinhos e o exemplo dos limites da qualificação da Antártica e do Ártico.

O conceito de patrimônio comum da humanidade aplicado aos fundos marinhos foi tratado pela primeira vez pelo Embaixador de Malta na Assembleia Geral da $\mathrm{ONU}^{64}$. A Convenção de Montego Bay (1982) estabeleceu regime internacional de gestão dos fundos em benefício da humanidade sob a gestão da Autoridade para os fundos marinhos. No entanto, o Acordo de implementação de 1994 esvaziou o conteúdo da parte XI da Convenção de Montego Bay. Esse acordo foi necessário em razão da oposição de alguns Estados desenvolvidos de ratificar a Covenção que finalmente entrou em vigor em $1995^{65}$. Não se sabe, portanto, de que forma os princípios da Convenção serão aplicados.

Por sua vez, o tribunal de direito do mar testemunhou, por meio de opinião consultiva, a sua posição de que tem o objetivo de dar um conteúdo substancial ao regime do patrimônio comum da humanidade ${ }^{66}$. Nesse sentido, podem ser indicados como exemplo os parágrafos seguintes: "O papel do Estado patrocinador, tal como foi anunciado na Convenção, é de contribuir com a realização do interesse comum de todos os Estados por meio da aplicação correta do princípio do patrimônio comum da humanidade, o que necessita configurar de modo fidedigno as obrigações anunciadas na parte $\mathrm{XI}^{\prime{ }^{67}}$. Cita-se, ainda, a seguinte passagem:

no contexto da obrigação dos Estados de auxiliarem a Autoridade que age representando a humanidade, quando ele determina quais são as medidas razoavelmente apropriadas, o Estado patrocinador tem de ter em conta de modo objetivo as opções

paço da lunar e o espaço marinho. EDELMAN, B. Entre personne humaine et matériau humain : le sujet de droit. In: HERMITTE, M.-A., EDELMAN, B.: L'homme, la nature et le droit. Paris: Bourgois, 1988. p. 136 ; KISS, A. C. La notion de patrimoine commun de l'humanité. RCADI, t. 175, p. 103, 1982. e s.

64 Ver a Resolução 2749 (XXV) de 16 de dezembro de 1970.

65 DUPUY, Pierre-Marie. Droit international public. Paris: Dalloz, 11 ème éd. 2012. p. 741.

66 TRIBUNAL INTERNACIONAL DO DIREITO DO MAR. Câmara para a resolução de controvérsias relacionadas aos fundos marinhos, Opinião consultiva n. 17 do dia $1^{\circ}$ fevereiro 2011, "Responsabilidade e obrigações dos Estados que patrocinam as pessoas e as entidades no contexto das atividades realizadas na Zona".

67 TRIBUNAL INTERNACIONAL DO DIREITO DO MAR. Opinião consultiva n. 17, parágrafo 76. 
que se apresentam de modo razoável, oportuna e favorável à toda a humanidade. Ele deve agir de boa-fé, em particular quando os seus atos possam prejudicar os interesses de toda a humanidade ${ }^{68}$.

A sua aplicação também foi invocada no contexto da Antártica. Entretanto, os Estados signatários do tratado de Washington se recusaram a passar do conceito de interesse comum para o conceito de patrimônio comum da humanidade. No preâmbulo da Convenção de Camberra, bem como no preâmbulo do Protocolo de Madri, o interesse da humanidade é reafirmado na motivação das Partes contratantes, mas sem existir nenhuma referência à noção de patrimônio comum. Este parece dificilmente conciliável com as reivindicações de soberania dos Estados que se entendem possuidores da região $0^{69}$. Na prática, no entanto, isso não impede que os Estados adotem regras de proteção mais rigorosas que pareçam em seu conteúdo àquelas que qualificam o patrimônio comum da humanidade ${ }^{70}$.

No Ártico, sabe-se que as mudanças climáticas abrem novas perspectivas para a navegação e para a exploração de petróleo. A questão de domínio dessa área voltou ao debate. A Declaração de Illulissat, adotada por cinco Estados ribeirinhos (Canadá, Dinamarca, Estados-Unidos, Noruega e Rússia) durante a conferência sobre o oceano Ártico, no dia 28 de maio de 2008, exclui uma apropriação do oceano Ártico pelos Estados ribeirinhos. Ao mesmo tempo, a Conferência afastou a perspectiva de elaboração de um regime jurídico internacional específico para a aplicação de um direito comum do mar para a região.

Percebe-se que o regime de patrimônio comum da humanidade é limitado no que concerne à implementação da obrigação de cooperação para a gestão dos recursos marinhos. Mesmo que esse regime tenha sido elaborado antes da moda dos bens públicos mundiais, é relevante buscar uma operacionalização desse termo por meio da previsão de obrigações específicas conectadas à cooperação dos sujeitos de direito internacional.

Além da obrigação de cooperar, a obrigação de due diligence requer análise específica de seus limites para a preservação dos recursos marinhos.

68 TRIBUNAL INTERNACIONAL DO DIREITO DO MAR. Opinião consultiva n. 17, parágrafo 230. Ver, ainda, o parágrafo 122. 69 GUILLAUME, G. Le statut de l'Antarctique. Refléxions sur quelques problèmes récents. In: MÉLANGES offert à René-Jean Dupuy, 1991. p. 174. 70 Esse aspecto está refletido no Protocolo de Madri.

\section{Os LIMITES DA IMPLEMENTAÇÃO DA OBRIGAÇÃO DE DUE DILIGENCE PARA A PRESERVAÇÃO DO MEIO AMBIENTE MARINHO}

A obrigação de due diligence ${ }^{71}$ sugere o maior direcionamento dos sujeitos de direito internacional para a gestão dos recursos marinhos, mas ainda com diversos limites. As obrigações de due diligence representam a obrigação dos Estados de adotarem instrumentos substancias e processuais relacionados ao controle das atividades que estão sob a sua gestão. É relevante examinar o seu conceito, a sua variabilidade e as críticas relacionadas à dificuldade de implementação dessas obrigações no sentido da preservação dos recursos marinhos.

Os Estados possuem obrigações de due diligence no que se refere a diversas atividades no mar tanto em áreas sob a sua jurisdição quanto nos espaços que não estão sob a sua jurisdição. Espera-se dos Estados e das Organizações Internacionais (OIs) condutas que evitem a emergência de possíveis danos. Trata-se de obrigação de conduta, o que já foi indicado em decisões e em opiniões consultivas da no âmbito da Corte Internacional de Justiça (CIJ) e do Tribunal Internacional do Direito do Mar. Na decisão de 20 de abril de 2010 no caso Papeleiras, a CIJ avaliou que:

[...] observa que o princípio da prevenção, sendo uma regra costumeira, possui a sua origem na diligência requerida ('due diligence') do Estado sobre o seu território. Trata-se de uma obrigação, de todos os Estados, de não utilizar o seu território com finalidades contrárias aos direitos de outros Estados (Détroit de Corfou, Royaume-Uni c. Albanie, decisão 1949, p. 22) ${ }^{72}$. [...] O Estado deve utilisar todos os meios à sua disposição para evitar que as atividades que ocorram no seu território ou em todo espaço que esteja sob a sua jurisdição não causem prejuízo ao meio ambiente de um outro Estado. A Corte estabeleceu que essa obrigação faz parte do corpo de regras do direito internacional do meio ambiente ${ }^{73}$.

71 TRIBUNAL INTERNACIONAL DO DIREITO DO MAR. Opinião consultiva n. 17, parágrafos 117 a 120 . Disponível em: <https://www.itlos.org/fileadmin/itlos/documents/cases/ case_ no_17/17_adv_op_010211_en.pdf >.

72 CORTE INTERNACIONAL DE JUSTIÇA. Caso Papeleras no Rio Uruguai (Argentina v. Uruguai). Julgamento de 20 de Abril de 2010, parágrafo 187, “[...] observe que le principe de prévention, en tant que règle coutumière, trouve son origine dans la diligence requise ('due diligence') de l'État sur son territoire. Il s'agit de 'l'obligation, pour tout État, de ne pas laisser utiliser son territoire aux fins d'actes contraires aux droits d'autres États' (Détroit de Corfou (RoyaumeUni c. Albanie), fond, arrêt, C.I.J. Recueil 1949, p. 22)".

73 CORTE INTERNACIONAL DE JUSTIÇA. Caso Papeleras 
As obrigações de due diligence também foram citadas nas opiniões consultivas n. $17^{74}$ e $21^{75}$ do Tribunal Internacional de Direito do Mar com o mesmo sentido do que foi interpretado no âmbito da CIJ.

Observa-se que o conceito de due diligence é variável ${ }^{76}$. $\mathrm{Na}$ análise da forma pela qual o Estado tenha sido ou não diligente serão levadas em consideração as condições do Estado para cumprir essas obrigações ${ }^{77}$. O problema dessa variação consiste em identificar qual seria o conteúdo mínimo de diligência que poderia ser exigida de todos os Estados no que tange à preservação dos recursos marinhos. Diante dos limites da contribuição da interpretação das obrigações de due diligence para a preservação dos recursos marinhos, é relevante analisar

no Rio Uruguai (Argentina v. Uruguai). Julgamento de 20 de Abril de 2010, parágrafo 101, "En effet, l'État est tenu de mettre en œuvre tous les moyens à sa disposition pour éviter que les activités qui se déroulent sur son territoire, ou sur tout espace relevant de sa juridiction, ne causent un préjudice sensible à l'environnement d'un autre État. La Cour a établi que cette obligation 'fait maintenant partie du corps de règles du droit international de l'environnement". Pode ser citado o parágrafo 197: "Cette obligation implique la nécessité non seulement d'adopter les normes et mesures appropriées, mais encore d'exercer un certain degré de vigilance dans leur mise en œuvre ainsi que dans le contrôle administratif des opérateurs publics et privés, par exemple en assurant la surveillance des activités entreprises par ces opérateurs, et ce, afin de préserver les droits de l'autre partie. Par conséquent, la responsabilité d'une partie au statut de 1975 serait engagée s'il était démontré qu'elle n'avait pas agi avec la diligence requise, faute d'avoir pris toutes les mesures appropriées pour assurer l'application de la réglementation pertinente à un opérateur public ou privé relevant de sa juridiction" Usinas de papel no rio Uruguai".

74 Na opinião consultiva do Tribunal do Mar sobre a responsabilidade e as obrigações dos Estados no contexto das atividades realizadas na Zona, a obrigação de due diligence foi identificada como possuindo um conteúdo variável: "Il est difficile de décrire en des termes précis le contenu des obligations de « diligence requise . Parmi les facteurs qui rendent une telle description ardue figure le fait que la notion de diligence requise a un caractère variable. Elle peut changer dans le temps lorsque les mesures réputées suffisamment diligentes à un moment donné peuvent ne plus l'être en fonction, par exemple, des nouvelles connaissances scientifiques ou technologiques. Cette notion peut également changer en fonction des risques encourus par l'activité. [...] Le niveau de diligence requise doit être plus rigoureux pour les activités les plus risquées. (TRIBUNAL INTERNACIONAL DO DIREITO DO MAR, Opinião consultiva n. 17 , parágrafo 117 ).

75 TRIBUNAL INTERNACIONAL DO DIREITO DO MAR. Pedido de Opinião Consultiva feita pela Comissão Sub-regional de pesca (SRFC). Opinião consultiva n. 21, de 2 de april de 2015, parágrafos 131 a 139. Disponível em: < https://www.itlos.org/ fileadmin/itlos/documents/cases /case_no.21/advisory_opinion/ C21_AdvOp_02.04.pdf $>$.

76 TRIBUNAL INTERNACIONAL DO DIREITO DO MAR. Opinião consultiva n. 17, parágrafo 117.

77 TRIBUNAL INTERNACIONAL DO DIREITO DO MAR. Opinião consultiva n. 17, parágrafo 117. os exemplos dos limites da preservação dos recursos pesqueiros em áreas sob a jurisdição dos Estados e os limites do regime do patrimônio comum da humanidade para a preservação dos recursos marinhos.

Os limites da preservação dos recursos pesqueiros em área sob a jurisdição dos Estados

As obrigações de due diligence são insuficientes para garantir a devida preservação dos recursos pesqueiros em área sob a jurisdição dos Estados. A opinião consultiva n.21 do Tribunal do Mar, que abordou a responsabilidade do Estado de bandeira pela pesca ilícita, constitui exemplo interessante, pois está em conformidade com os tratados aplicáveis à matéria e com os precedentes relacionados à interpretação das obrigações de due diligence dos Estados. Além disso, ela evidencia os limites dessas obrigações para a preservação dos recursos marinhos.

A opinião consultiva n. 21 interpretou as obrigações de due diligence com relação à pesca na área sob a jurisdição dos Estados. O tribunal do mar, antes de analisar as questões substanciais do pedido da opinião consultiva, definiu o que se entende por pesca ilícita, não declarada e não regulamentada ${ }^{78}$, e o que significa a preservação dos recursos biológicos na ZEE dos Estados membros da Comissão previamente citada ${ }^{79}$. Outras definições importantes foram de navio de pesca $^{80}$, de estoques compartilhados ${ }^{81}$ e de estoques de interesse comum ${ }^{82}$.

78 As definições de pesca ilícita, pesca não declarada e pesca não regulamentada estão previstas no art. 2, parágrafo $4^{\circ}$ da CMA. A opinião consultiva lembrou que essas definições foram inspiradas no Plano de ação internacional visando a prevenir e a eliminar esse tipo de pesca, elaborado e adotado em 2001 pela FAO. Disponível em: <http://www.fao.org/docrep/003/y1224e/y1224e00.htm>. Acesso em: 15 maio 2015; e no Acordo relativo às medidas tomadas pelo Estado do Porto visando a prevenir e a eliminar a pesca ilícita, adotado em 2009. Disponível em: < http:/ / www.fao. org/fishery/topic/166283/en Parágrafo 91>. Acesso em: 15 maio 2015.

79 Cabo Verde, República Islâmica da Mauritânia, Senegal, República da Gâmbia, República da Guiné, República da Guiné-Bissau e República da Serra Leoa. TRIBUNAL INTERNACIONAL DO DIREITO DO MAR. Opinião Consultiva n. 21, parágrafo 189, 191. A expressão é utilizada para significar conservação, desenvolvimento. O tribunal afirma que o art. 61 da Convenção dá algumas indicações do que seria a gestão sustentável.

80 TRIBUNAL INTERNACIONAL DO DIREITO DO MAR. Opinião Consultiva n. 21, parágrafo 99.

81 TRIBUNAL INTERNACIONAL DO DIREITO DO MAR. Opinião Consultiva n. 21, parágrafo 184: "Le Tribunal observe que ces expressions ne figurent pas dans la Convention. Toutefois, l'expression stocks partagés est définie à l'article 2, paragraphe 12, de la Convention CMA comme signifiant les stocks de poissons se trouvant dans les zones maritimes sous juridiction de deux ou plusieurs Etats côtiers ou à la fois à l'intérieur de la zone maritime sous juridiction et dans un secteur adjacent à cette zone".

82 TRIBUNAL INTERNACIONAL DO DIREITO DO MAR, Opinião Consultiva n. 21, parágrafo 185: 'Le Tribunal observe qu'il 
De modo geral, os navios de pesca devem obter autorização do Estado membro da Comissão para que fique estabelecida a cota de pesca possível. Para tanto, o navio deve apresentar no porto desse Estado as declarações de captura indicadas no seu diário de pesca e não pode utilizar materiais ilegais para a sua atividade. $O$ navio deve notificar o Estado costeiro da sua entrada e da sua saída do espaço marítimo sob a jurisdição de um dos Estados membros da Comissão ${ }^{83}$.

De acordo com o tribunal, o Estado de bandeira do navio teria obrigações de due diligence relacionadas à pesca ilegal ${ }^{84}$. Podem ser citadas as seguintes obrigações específicas: a) tomar as medidas necessárias para verificar se os navios de sua bandeira estão em conformidade com as leis e os regulamentos adotados pelos Estados membros da CSRP com relação aos recursos biológicos marinhos que estiverem em suas $Z_{E E} E^{85}$; b) verificar se os navios com a sua bandeira não realizam atividades ligadas à pesca não regulamentada nas ZEEs dos Estados membros da comissão $0^{86}$; c) adotar as medidas administrativas necessárias para verificar se os navios de pesca com bandeiras nacionais não realizam atividades que contrariem a preservação do meio ambiente marinho e a conservação dos recursos biológicos $\operatorname{marinhos}^{87}$; d) permitir a subida à bordo das autoridades do Estado costeiro que pretendam investigar e controlar as atividades de pesca.

Como foi analisado na opinião consultiva, a pesca ilícita pode resultar na responsabilização do Estado de bandeira apenas no caso de descumprimento das citadas obrigações de due diligence. A obrigação de re-

n'y a pas de définition établie de stocks d'intérêt commun. Il note toutefois que, dans l'exposé qu'elle a fait au cours de la procédure orale, la CSRP a donné l'explication suivante s'agissant de l'expression stocks d'intérêt commun: Au niveau de l'Atlantique Centre-Est, plusieurs espèces de pélagiques migrent entre les Zones économiques exclusives de deux ou plusieurs Etats (transfrontaliers ou stocks d'intérêt commun) et/ ou entre des Zones économiques exclusives et les eaux au-delà (stocks chevauchants). Il s'agit donc de stocks partagés entre : deux Etats côtiers voisins, deux Etats côtiers non voisins situés de part et d'autre d'un golfe ou d'un océan ou un Etat côtier et l'Etat du pavillon de l'exploitant du stock".

83 TRIBUNAL INTERNACIONAL DO DIREITO DO MAR. Opinião Consultiva n. 21, parágrafo 113.

84 TRIBUNAL INTERNACIONAL DO DIREITO DO MAR. Opinião Consultiva n. 21, parágrafos 125- 132.

85 TRIBUNAL INTERNACIONAL DO DIREITO DO MAR. Opinião Consultiva n. 21, parágrafo 114.

86 TRIBUNAL INTERNACIONAL DO DIREITO DO MAR. Opinião Consultiva n. 21, parágrafo 114.

87 TRIBUNAL INTERNACIONAL DO DIREITO DO MAR. Opinião Consultiva n. 2, Parágrafos 116, 138. sultado não pode ser determinada sem a análise prévia da obrigação de comportamento ${ }^{88}$. Se o Estado de bandeira tiver adotado todas as medidas necessárias e apropriadas para cumprir as suas obrigações de conduta, ele não será responsabilizado pelos eventuais danos causados ao meio ambiente marinho. Esse é um dos principais limites das obrigações dos Estados por due diligence. Apesar de ter existido maior precisão do conteúdo das obrigações relacionadas à pesca ilegal, ainda há limitação na transposição dessa análise para a garantia de uma gestão adequada dos recursos marinhos por meio de obrigações de comportamento e de resultado. Além desse tema, cabe o estudo dos limites do regime do patrimônio comum da humanidade para a preservação dos recursos marinhos.

b) Os limites do regime do patrimônio comum da humanidade para a preservação dos recursos marinhos

As obrigações de due diligence dos Estados e das OIs ainda não estão bem delimitadas no que concerne à gestão dos fundos marinho. Tendo como base a perspectiva de bem público mundial, no que tange à ampliação do conteúdo da patrimonialização para um conteúdo de gestão, poderá existir maior implementação de obrigações conectadas à preservação dos recursos marinhos. Assim, apresentar-se-á o contexto da exploração e da investigação dos fundos marinhos, a articulação entre as obrigações de due diligence e a preservação dos fundos marinhos e os limites dessas obrigações para chegar ao objetivo citado.

O contexto das atividades nos fundos marinhos é de que ainda não há contratos de explotação (exploitation), mas há alguns contratos de exploration ${ }^{89}$ de sulfetos polimetálicos ${ }^{90}$. A despeito da potencialidade ainda indeterminada dos danos no âmbito da investigação, e da inexistência de casos concretos julgados sobre danos decorrentes dessas atividades, já há indicação de obrigações diretas dos Estados perante a Autoridade dos fundos marinhos ${ }^{91}$ e dos critérios da obrigação de due

88 TRIBUNAL INTERNACIONAL DO DIREITO DO MAR. Opinião Consultiva n. 21, parágrafo 129.

89 No sentido de investigação comercial, de prospecção.

90 Autoridade para os fundos marinhos. Status of contracts for exploration in the Area. Twenty-First Session Official Documents. ISBA/21/C/8. Kingston, Jamaica, 2 junho de 2015. Disponível em: <https://www. isa.org.jm/sites/default/files/files/documents/isba-21c-8_1.pdf>. Acesso em: 20 jun. 2015.

91 Entre as obrigações diretas dos Estados, podem ser citadas obrigações indicadas nas Regulações elaboradas pela Autoridade dos Fundos Marinhos e obrigações previstas na Convenção de Mon- 
diligence que devem ser observados pelos Estados. A implementação das obrigações de due diligence no contexto dos fundos marinhos pode ser configurada no direcionamento do Estado "patrocinador" no controle e na regulação dos operadores públicos e privados que exploram e que investigam os fundos marinhos.

Sobre o tema, a opinião consultiva n. 17 do Tribunal do mar esclareceu alguns aspectos relacionado à responsabilidade do Estado patrocinador. O tribunal entendeu que o Estado tem a obrigação de conduta de criar normas e regulamentos para garantir que a empresa contratante siga um corpo normativo ambiental mínimo. Entre as medidas de prevenção que devem ser adotadas pelo Estado, podem ser citadas a exigência de estudo de impacto ambiental ${ }^{92}$ e a existência de um corpo normativo que garanta a implementação da obrigação de reparar o dano em caso de descumprimento ${ }^{93}$. Não é suficiente a realização de um contrato de exploração com a empresa pública ou privada. Deve existir arcabouço

tego Bay. Pode ser citada a Regulação de Nódulos Polimetálicos de 2010 e a Regulação de Sulfetos Polimetálicos de 2010. A esse respeito ver: AUTORIDADE INTERNACIONAL DE FUNDOS MARINHOS. Decision of the Assembly of the International Seabed Authority relating to regulations on prospecting and exploration for polymetallic sulphides in the Area. ISBA/16/A/12/Rev.1. Sixteenth Season Official Documents. Kingston, Jamaica. 15 nov. 2010. Disponível em: <http://www.isa.org.jm/files/documents/EN/16Sess/Assembly/ ISBA-16A-12Rev1.pdf>. Acesso em: 10 jun. 2015. Além disso, outra regulação que é citada com frequência é a seguinte: AUTORIDADE INTERNACIONAL DE FUNDOS MARINHOS. Decision of the Council of the International Seabed Authority relating to amendments to the Regulations on Prospecting and Exploration for Polymetallic Nodules in the Area and related matters. ISBA/19/C/17. Nineteenth Season Official Documents. Kingston, Jamaica, 22 julho de 2013. Disponível em: < https://www.isa.org.jm/sites/default/files/files/documents/ isba-19c-17_0.pdf>. Ver sobre o tema: TRIBUNAL INTERNACIONAL DO DIREITO DO MAR. Opinião consultiva n. 17, parágrafos 121 a 140. Disponível em: <https://www.itlos.org/fileadmin/itlos/documents/cases/ case_no_17/17_adv_op_010211_ en.pdf $>$. Acesso em: 10 jun. 2015.

92 Ver parágrafo 148 da opinião consultiva que indica que o Estudo de Impacto Ambiental não deve ser entendido como um costume em direito internacional ambiental. O EIA deve ser requerido no momento de consultas e de notificações, nos termos do art. 142 da Convenção de Montego Bay. Essa obrigação está relacionada, portanto, ao direito interno dos Estados. Ver sobre o tema: Case note: "Responsibilities and obligations of states sponsoring persons and entities with respect to activities in the area: the international tribunal of the law of the sea's recent contribution to international environmental law". RECIEL 20 (2) 2011, p. 211.

93 Ver sobre o tema: LIMA, Gabriela Garcia B. Caso do Parecer consultivo do Tribunal Internacional de Direito do Mar de $1^{\circ}$ de fevereiro de 2011. In: MONEBHURRUN, Nitish. Decisões da corte internacional de justiça e do tribunal internacional sobre o direito do mar. RDI, Brasília, v. 12, n. 2, p. 20-26, 2014. normativo capaz de responsabilizar devidamente a empresa pública ou privada por eventuais danos causados pela exploração. Caso a empresa tenha a nacionalidade de outro país, é necessário que o seu Estado de origem também assine o plano de trabalho, sujeitando-se a eventual responsabilização.

A opinião consultiva afirmou que o Estado patrocinador não pode ser responsabilizado pelos atos de suas empresas quando tiver tomado as medidas que lhe eram razoavelmente exigíveis, isto é, tenha procedido com a devida diligência ${ }^{94}$. Observa-se que uma das maiores dificuldades consiste em poder responsabilizar um Estado pelo descumprimento de uma obrigação de due diligence. As obrigações não são tão específicas e deixam margem à uma avaliação indevida do conteúdo mínimo necessário para demonstrar o cumprimento dessas obrigações. Se o Estado demonstrar que foi diligente, ele não será responsabilizado subsidiariamente pelos eventuais danos causados pela empresa patrocinada, de acordo com o que foi estabelecido pela opinião consultiva ${ }^{95}$. Ou seja, caso a diligência fique provada, o Estado não será responsabilizado pelos eventuais danos ambientais que ocorrerem. Trata-se de limitação para a preservação ambiental, pois não apenas as obrigações de conduta devem ser consideradas para a responsabilização do Estado, mas também as obrigações de resultado. Há limites consideráveis para que o conteúdo de gestão dos chamados bens públicos mundiais possa resultar em uma possível responsabilização do Estado pela falta de preservação do meio ambiente marinho.

\section{Considerações finais}

Apesar de o termo bem público mundial não ser operatório e jurídico, ele destaca a falta de precisão, no âmbito do direito internacional, das obrigações específicas dos sujeitos de direito internacional no que tange à preservação dos recursos marinhos. As questões globais requerem respostas internacionais e nacionais, mas poucas obrigações internacionais exigem que os Estados forneçam e implementem essas respostas. É

94 TRIBUNAL INTERNACIONAL DO DIREITO DO MAR. Opinião n. 17, parágrafos 213 a 217. Disponível em: https://www. itlos.org/fileadmin/itlos/documents/cases/ case_no_17/17_adv_ op_010211_en.pdf. Acesso em: 15 jun. 2015.

95 TRIBUNAL INTERNACIONAL DO DIREITO DO MAR. Opinião Consultiva no. 17, parágrafos 204. 
conveniente questionar se as categorias ou os instrumentos do direito internacional, consolidadas no direito do mar, são capazes de garantir a devida preservação dos recursos marinhos. Alguns aspectos tornaram-se evidentes nessa análise: o valor interpretativo do bem público mundial; o conteúdo limitado dos regimes de res communis e de patrimônio comum da humanidade para a preservação dos recursos marinhos; a necessidade de maior precisão do conteúdo das obrigações de cooperar e das obrigações de due diligence tanto na sua aplicação em âmbito nacional quanto em internacional.

O bem público mundial não tem capacidade de gerar efeitos jurídicos, atualmente, e não há indícios de que ele o faça em breve. Uma das possíveis contribuições do termo para a preservação dos recursos marinhos é de caráter interpretativo, contribuindo para a apreciação de institutos jurídicos já consolidados no direito internacional. O conteúdo do bem público mundial de cooperação é o aspecto central que deve pautar a gestão desses recursos. As categorias jurídicas mais próximas do conceito de bem público mundial são o bem comum e o patrimônio comum da humanidade. Todavia, ambos os institutos estão mais conectados à internacionalização e à patrimonialização do que à gestão, o que os distancia da implementação da obrigação de cooperar e de prevenir no direito internacional.

Tanto a obrigação de cooperar quanto a obrigação de due diligence, ambas consolidadas no direito internacional, possuem conteúdo impreciso no que tange à preservação dos recursos marinhos. Como os recursos vivos e não vivos estão presentes nas áreas sob jurisdição nacional e internacional, as obrigações dos Estados nos dois âmbitos devem ser mais precisas e detalhadas para que sejam operacionalizáveis diante de tribunais nacionais e internacionais.

O desafio, portanto, é utilizar os regimes jurídicos já existentes, como a res communis ou o patrimônio comum da humanidade, com um conteúdo mais preciso e conectado às obrigações ligadas à preservação dos recursos marinhos. Caso a ampliação dessa interpretação não seja possível, o conceito de bem público mundial pode ser útil na condução dos Estados na implementação de medidas específicas para a conservação dos recursos marinhos que estiverem sob a sua jurisdição, como na Zona Econômica Exclusiva. A atividade que demonstra contornos mais precisos e mais claros com relação a essas obrigações de cooperar e de diligência é a pesca que já foi objeto de in- terpretações do Tribunal Internacional para o Direito do Mar. Outras atividades, como a navegação e a exploração de recursos nos fundos marinhos, ainda requerem maior precisão no que concerne às obrigações específicas conectadas à preservação dos recursos marinhos.

\section{ReferênCias}

AGENCIA FRANCESA DE DESENVOLVIMENTO. Biens publics mondiaux et développement : de nouveaux arbitrages pour l'aide ?. Documento de trabalho n. 3, Paris, sept. 2005.

BANCO MUNDIAL. Effective Use of Development finance for International Public Goods. Global Development Finance, Washington DC, 2001.

BARDONNET, D. Le projet de convention de 1912 sur le Spitsberg et le concept de patrimoine commun de l'humanité. Mélanges René-Jean Dupuy. In: HUMANITÉ et droit international. Paris: Pedone, 1991.

BARRETT, Scott. Why Cooperate? The Incentive to Supply Global Public Goods. Oxford: Oxford University Press, 2007.

BASLAR, Kemal. The Concept of the Common Heritage of Mankind in International Law. Hague: Nijhoff Publishers, 1998.

BENZING, Markus. Community Interests in the Procedure of International Courts and Tribunals. The Law and Practice of International Courts and Tribunals, n. 5, p. 369-408, 2006.

BODANSKY, Daniel. What's in a Concept? Global Public Goods, International Law, and Legitimacy. The European Journal of International Law, v. 23, n. 3, p. 651-668, 2012.

BOIDIN, Bruno. La santé, bien public mondial ou bien marchand: réflexions à partir des expériences africaines. Villeneuve d'Ascq: Presses Universitaires du Septentrion, 2014.

CAFAGGI Fabrizio, CARON, David D. Global Public Goods amidst a Plurality of Legal Orders: A Symposium. The European Journal of International Law, v. 23, n. 3, p. 643-649, 2012.

CAFAGGI, Fabrizio. Private regulation and the production of global public goods and private 'bads'. The European Journal of International Law, v. 23, n. 3, p. 695718, 2012. 
DEBLOCK, Christian; DELAS, Olivier. Le bien commun comme réponse politique à la mondialisation. Bruxelles: Bruylant, 2003.

DUPUY, Pierre-Marie. Droit international public. Paris: Dalloz, 11 ème éd. 2012.

EDELMAN, B. Entre personne humaine et matériau humain : le sujet de droit. In: HERMITTE, M.-A., EDELMAN, B.: L’homme, la nature et le droit. Paris: Bourgois, 1988.

FAUCHEUX S.; NOËL, J. F. Les menaces globales sur l'environnement, Paris: Repères La Découverte, 1990.

FRANCKX, Erik. The International Seabed Authority and the Common Heritage of Mankind: The Need for States to Establish the Outer Limits of their Continental Shelf. The International Journal of Marine and Coastal Law, n. 25, p. 543-567, 2010.

GARTNER, David. Global public goods and global health. Duke J. Comp. \& Int'l L., n. 22 (303), 2011-2012.

GIDEL, Gilbert. Le droit international Public de la Mer. Recueil Sirey. 1934. Tomo I, II e III.

GORDILLO, José Luis. La Protección de los bienes comunes de la humanidad: un desafío para la política y el derecho del siglo XXI. Madrid: Editorial Trotta, 2006.

GUILLAUME, G. Le statut de l'Antarctique. Refléxions sur quelques problèmes récents. In: MÉLANGES offert à RenéJean Dupuy, 1991.

HARDIN, Garrett. The Tragedy of the Commons. Science 13, v. 162, p. 1243-1248, dez. 1968. HEATHCOTE, S. Les biens publics mondiaux et le droit international. Quelques réflexions à propos de la gestion de l'intérêt commun. L'Observateur des Nations Unies, n. 13, p. 143, 2002.

HELLER, M. A. The Tragedy of the Anticommons: Property in the Transition from Marx to Markets. Harvard Law Review, 111, p. 622, 1998.

JOUANNET, E. L'idée de communauté humaine. In: ARCHIVES dephilosophie du droit. La mondialisation entre illusion et utopia. t. 47, p. 191.

JOYNER, C. Legal Implications of the Concept of the Common Heritage of Mankind. Int'l \& Comp. LQ, n. 35, 1986.

KAUL I.; GRUNBERG, I.; STERN, M. A. International
Cooperation in the 21st Century. Oxford: Oxford University Press, 1999.

KAUL, Inge et al. Providing Global Public Goods; Managing Globalization. New York: Oxford University Press, 2003.

KAYE, Stuart. Enforcement Cooperation in Combating Illegal and Unauthorized Fishing: An Assessment of Contemporary Practice. Berkeley J. Int'l L., n. 32, p. 316-329, 2014.

KISS, A. C. La notion de patrimoine commun de l'humanité. RCADI, t. 175, 1982.

KRISCH, Nico. The decay of consent: international law in an age of global public goods. The American Journal of International Law, v. 108, n. 1, p. 1-40, jan. 2014.

KU, Charlotte. The Concept of Res Communis in International Law. History of European Ideas, v. 12, n. 4, 1990.

LIMA, Gabriela Garcia B. Caso do Parecer consultivo do Tribunal Internacional de Direito do Mar de $1^{\circ}$ de fevereiro de 2011. In: MONEBHURRUN, Nitish. Decisões da corte internacional de justiça e do tribunal internacional sobre o direito do mar. RDI, Brasília, v. 12, n. 2, p. 20-26, 2014.

LODGE, Michael W. The Common Heritage of Mankind. The International Journal of Marine and Coastal Law, n. 27, p. 733-742, 2012.

LOGEAT, C. Les biens privés affectés à l'utilité publique. Paris: L'harmattan, 2011.

MALJEAN-DUBOIS, Sandrine. The Role of International Law in the Promotion of the Precautionary Principle. Disponível em <http://www.iales-aides. com/uploads/1/3/9/6/13963183/the_role_of_international_law_in_the_promotion_of_the_precautionary_principle_-_sandrine_maljean-dubois.pdf $>$. Acesso em: 15 jun. 2015.

MALJEAN-DUBOIS, Sandrine; KERBRAT, Yann. La Cour Internationale de Justice face aux enjeux de protection de l'environnement : réflexions critiques sur l'arrêt du 20 avril 2010 , Usines de pâte à papier sur le fleuve Uruguay (Argentine c. Uruguay). RGDIP, n. 1, t. CXV, p. 39-75, 2011.

MARR, Simon. The Southern Bluefin Tuna Cases: The Precautionary Approach and Conservation and Management of Fish Resources. European Journal of International Law, v. 11, n. 04, p. 815-831, 2000. 
MAVROIDIS, Petros C. Free Lunches? WTO as Public Good, and the WTO's View of Public Goods. The European Journal of International Law, v. 23, n. 3, p. 731-742, 2012.

MELLO, Celso D. De Albuquerque. Alto-mar. Rio de Janeiro: Renovar, 2001.

MERCURE, P. F. L'échec des modèles de gestion des ressources naturelles selon les caractéristiques du concept de patrimoine commun de l'humanité. Revue de droit d'Ottawa. Ottawa Law Review, v. 28, 1996- 1997.

MEYER, Timothy. Global public goods, governance risk and international energy. Duke J. Comp. \& Int'l L., v. 22, n. 319, 2011-2012.

NOLLKAEMPER, André. International Adjudication of Global Public Goods: The Intersection of Substance and Procedure. The European Journal of International Law, v. 23 n. 3, p. 769-791, 2012.

NOYES, John E. The common heritage of mankind: past, present, and future. Denv. J. Int'l L. \& Pol'y, n. 20, p. $447,2011-2012$.

OLIVEIRA, Liziane Paixão Silva; MARINHO, Maria Edelvacy. O caso Austrália c. Japão perante a Corte Internacional de Justiça, Decisão, 31 de março de 2014. In: MONEBHURRUN, Nitish. Decisões da corte internacional de justiça e do tribunal internacional sobre o direito do mar. RDI, Brasília, v. 12, n. 2, p. 43-49, 2014.

OLIVEIRA, Carina Costa de; GONÇALVES, Natália da Silva. Comentários ao caso m/v "Virginia" (Panamá c. Guiné-Bissau), 14 de abril de 2014. In: MONEBHURRUN, Nitish. Decisões da corte internacional de justiça e do tribunal internacional sobre o direito do mar. $R D I$, Brasília, v. 12, n. 2, p. 55-63, 2014.

OSTROM, E. Governing the commons, the evolution of institutions for collective actions. Cambridge: Cambridge university Press, 1990.

PARANCE, Béatrice; VICTOR, Jacques de Saint. Repenser les comuns. Paris: CNRS éd., 2014.

PETERSMANN, Ernst-Ulrich. International Economic Law, "Public Reason" and Multilevel Governance of Interdependent Public Goods. Journal of International
Economic Law, n. 14, p. 23-76, 2011.

PNUD. Providing Global Public Goods: Managing Globalization. 25 Questions \& Answers. New York: UNDP/ ODS, 2002. p. 3-5. Disponível em: <http://web.undp. org/globalpublicgoods/globalization/pdfs/ques-ans. pdf > . Acesso em: 10 maio 2015.

REID, Keith. Conserving Antarctica from the Bottom Up: Implementing UN General Assembly Resolution 61/105 in the Commission for the Conservation of Antarctic Marine Living Resources (CCAMLR). Ocean Y.B., n. 25 (131), 2011.

ROSSI, Christopher R. A particular kind of the grotian tendency and the global commons in a time of high arctic change. In: Int'l L \& Int'l Rel, n. 11 (1), 2015.

SALMON, J. (Dir.). Dictionnaire de droit international public. Bruxelles: Bruylant, 2001.

SCHEMEIL, Y. Des types purs de ressources mondiales communes non marchandes? AFSP / Section d'Etudes Internationales - Colloque Les biens publics mondiaux. Pau, 2001.

SHACKELFORD, Scott J. The Tragedy of the Common Heritage of Mankind. Stan Envtl LJ, n. 28, 2009.

SHAFFER, Gregory. International Law and Global Public Goods in a Legal Pluralist World. The European Journal of International Law, v. 23, n. 3, p. 669-693, 2012.

STAIGER, R.W. Report on the International Trade Regime for the International Task Force on Global Public Goods. 2006. Disponível em: <http://www.regeringen.se/contentasset s/4e7cc9afcd2444d38d5b507bb6cf9b49/global-publicgoods-international-trade>. Acesso em: 10 jun. 2015.

TELESETSKY, Anastasia. Laundering Fish in the Global Undercurrents: Illegal, Unreported, and Unregulated Fishing and Transnational Organized Crime. Ecology L.Q., n. 41, p. 939-998, 2014.

THEYS, J.; FAUCHEUX, S.; NOËL, J.F. La guerre de l'ozone. Futuribles, n. 125, p. 51-66, out. 1988.

TRÉBULLE, F. G. La propriété à l'épreuve du patrimoine commun: le renouveau du domaine universel. Études offertes an professeur Malinvand, Lexis Nexis. 2007. 


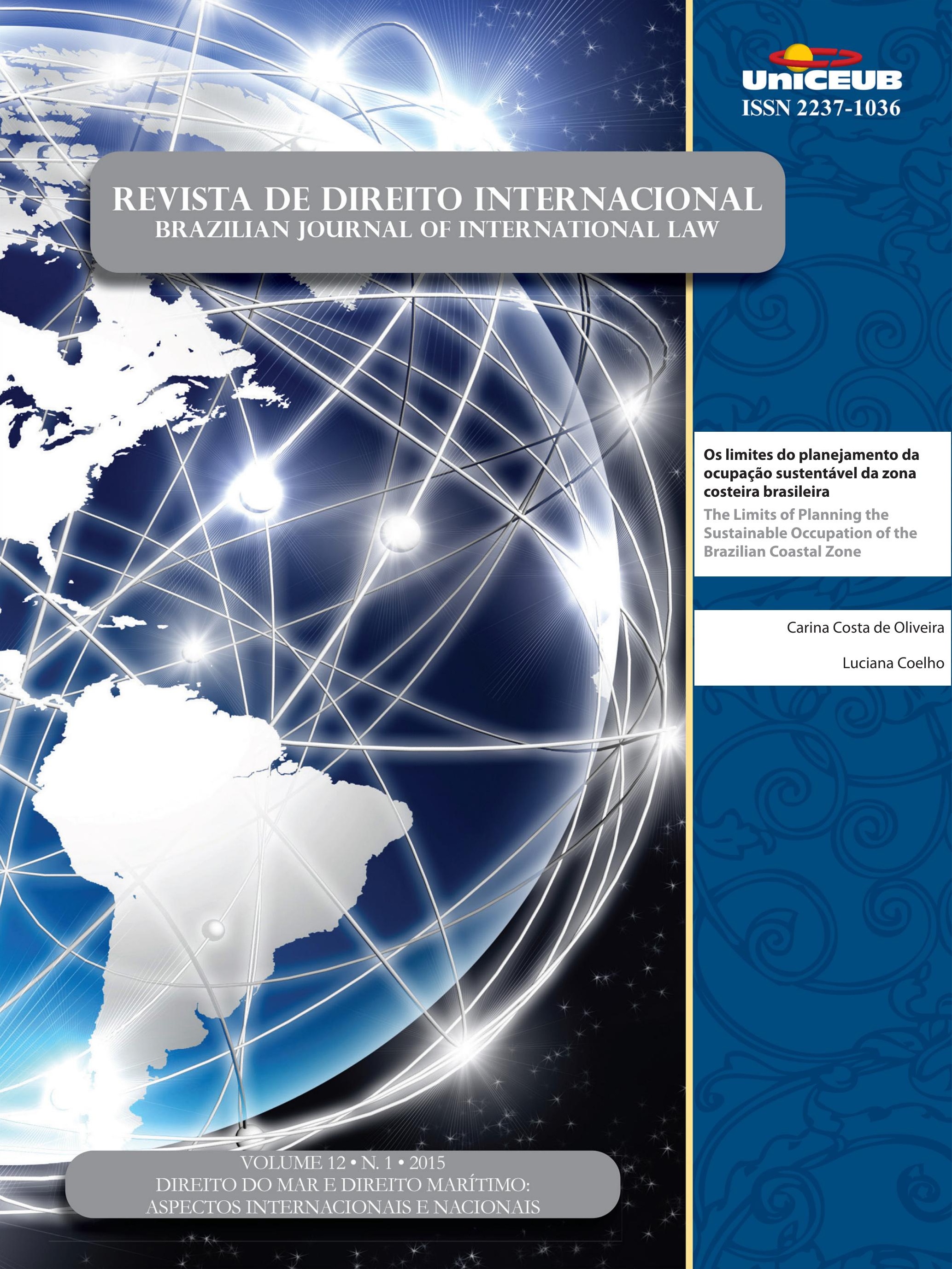




\title{
Os limites do planejamento da ocupação sustentável da zona costeira brasileira*
}

\author{
The Limits of Planning the Sustainable \\ Occupation of the Brazilian Coastal Zone
}

\author{
Carina Costa de Oliveira** \\ Luciana Coelho***
}

\section{Resumo}

Há limites institucionais e normativos no planejamento da ocupação sustentável da zona costeira brasileira. Embora exista demasiada quantidade de normas e instituições voltadas para o gerenciamento dessa área, a ocupação desta é realizada desordenadamente. Em relação à faixa terrestre da zona costeira, a análise da atividade de construção civil demonstrou a ausência de critérios objetivos precisos que determinem a competência para licenciar e para fiscalizar as atividades na área. A propósito da faixa marítima, a gestão pela Autoridade Marítima não garante a gestão dos usos múltiplos da zona costeira. Com relação aos limites normativos, a pluralidade de termos e institutos aplicáveis à zona costeira, como bem comum de uso do povo, bem da União, terreno de marinha e patrimônio nacional, resulta na interpretação imprecisa da natureza jurídica da zona costeira. Lacunas e omissões relevantes, como a previsão de uma restrição geral de construir em determinada extensão do litoral nacional, demonstram o descuido dosentes federativos na busca pela melhor administração e normatização da área. A planificação do espaço marítimo brasileiro poderá ocorrer somente após sanados os diversos limites institucionais e normativos presentes e incrustados na ocupação da zona costeira brasileira.

Palavras-chave: Zona costeira. Planejamento. Ocupação. Construções. Proteção do meio ambiente.

\section{Abstract}

There are institutional and normative limits when planning the sustainable occupation of the Brazilian coastal zone. Although there are many norms and institutions focused on the management of this area, its occupation is carried out disorderly. Regarding the terrestrial part of the coastal zone, the analysis of construction activities developed in the Brazilian coastal zone reveals a lack of objective criteria to determine the competent authority to grant permission for this activity and to supervise the activities performed in the area. For the maritime part, the management by the Maritime Authority does not guarantee the management of the multiple uses of the coastal zone. Concerning the normative limits, the large amount of legal concepts that can be applied to the coastal zone, such as commons, bem 
da União, terreno de marinha and patrimônio nacional, results in an inaccurate interpretation of the legal nature of the coastal zone. Significant gaps and omissions, such as lack of a general restriction to build a certain extension of the coastal zone, expresses the disregard of all federal entities in the pursuit of a better management and regulation of this zone. In this context, the Brazilian maritime planning can only be made after solving out the various institutional and regulatory problems related to the occupation of the Brazilian coastal zone.

Keywords: Coastal zone. Construction. Occupation. Maritime planning. Environmental protection.

\section{INTRODUÇÃo}

O planejamento da ocupação sustentável da zona costeira brasileira é realizado de forma desordenada em razão de limites institucionais e normativos existentes no sistema jurídico brasileiro. Com mais de $8.000 \mathrm{~km}$ de litoral, as atividades de exploração do território marítimo brasileiro não são realizadas de forma hormoniosa com a proteção ao meio ambiente, tanto na faixa terrestre como na faixa marítima da zona costeira. A gestão dessa região está prevista na Lei n. ${ }^{\circ}$ 7.661/1988 e no Decreto n. ${ }^{\circ}$ 5.300/2004, no entanto, a gestão sustentável ainda não foi implementada. Questões como a erosão do solo, a poluição e a exploração excessiva dos recursos vivos e não vivos são algumas das consequências resultantes do impacto que atividades como construções irregulares na zona costeira podem causar. Nesse contexto, é relevante: definir a zona costeira brasileira, o litoral e a zona marítima; demonstrar a inexistência da planificação do espaço marítimo no Brasil; e delimitar as atividades de exploração que serão analisadas neste estudo cujo objetivo consiste em demonstrar os limites institucionais e normativos para alcançar um planejamento do território marítimo nacional sustentável.

A zona costeira brasileira é definida como o espaço geográfico de interação entre ar, mar e terra, incluindo os recursos renováveis ou não, que se estende em uma faixa terrestre e uma faixa marítima ${ }^{1}$. Trata-se de região

1 BRASIL. Lei $n^{\circ} 7.661$ de 16 de maio de 1998. Disponível em: $<$ http://www.planalto.gov.br/ccivil_03/leis/17661.htm>. Acesso em: 04 ago. 2015; BRASIL. Decreto n 5.300, de 07 de dezembro de 2004. Disponível em: < http://www.planalto.gov.br/ccivil_03/_ato20042006/2004/decreto/D5300.htm>. Acesso em: 10 jul. 2014. Cf. FREITAS, Mariana Almeida Passos de. Zona Costeira e Meio Am- vulnerável, especialmente pelo contingente populacional que habita a região, pela rica concentração de fauna e flora explorável economicamente e pelo número intenso de atividades econômicas ali desenvolvidas. ${ }^{2}$ Essa região é constitucionalmente tutelada como patrimônio nacional, cujo desenvolvimento deve ocorrer de forma sustentável. $^{3}$

A faixa marítima é delimitada com a dimensão de 12 milhas náuticas, contadas da linha de base estabelecida, de acordo com a Convenção das Nações Unidas sobre o Direito do Mar de 1982 (UNCLOS), enquanto a faixa terrestre possui largura variável ${ }^{4}$. Esta é composta por uma área indicada na Relação de Municípios abrangidos pela faixa terrestre da zona costeira, que deve ser periodicamente revisada pelo Ministério do Meio Ambiente (MMA) $)^{5}$, compreendendo mais ou menos 395 Municípios, distribuídos em 17 estados costeiros ${ }^{6}$. Esses Municípios sofrem influência dos fenômenos ocorrentes na zona costeira, podendo ser ou não defrontantes com o mar, conforme parâmetros estabelecidos no Decreto $5.300 / 2004 .^{7}$

biente. Curitiba: Juruá, 2005. p. 23-32. Cf. BRASIL. Lei no 7.661 de 16 de maio de 1998. Disponível em: <http://www.planalto.gov.br/ ccivil_03/leis/17661.htm>. Acesso em: 04 ago. 2015. artigo 2º parágrafo único; Cf. BRASIL. Comissão Interministerial para os Recursos do Mar. Resolução no 01, de 21 de novembro de 1990. Disponível em: < https://www.mar.mil.br/secirm/document/ataseresolucoes/ resolucao-1-1994.pdf>. Acesso em: 05 ago. 2015.

2 FREITAS, Vladimir Passos de; FREITAS, Dario Almeida Passos de. A proteção do meio ambiente na zona costeira. In: GRANZIERA, Maria Luiza Machado; GONÇALVES, Alcindo (Org.). Os problemas da zona costeira no Brasil e no mundo. Santos: Universitária Leopoldianum, 2012. p. 257-277. p. 258.

3 BRASIL. Constituição (1988). Constituição da República Federativa do Brasil. Disponível em: <http://www.planalto.gov.br/ ccivil_03/constituicao/constituicao.htm>. Acesso em: 05 ago. 2014. BRASIL. Lei no 12.651 de 25 de maio de 2012. Disponível em: <http://www.planalto.gov.br/ccivil_03/_Ato2011-2014/2012/ Lei/L12651.htm\#art83>. Acesso em: agosto 2014.

4 Sobre o tema ver: SILVA, Solange Teles da. Planejamento urbano na Zona Costeira. In: Compedi. In: CONGRESSO NACIONAL DO CONPEDI, 14., 2005, Fortaleza. Anais eletrônico... Manaus: CONPEDI, 2006. Disponível em: http://www.conpedi.org.br/manaus/ arquivos/anais/XIVCongresso/151.pdf. Acesso em: 4 ago. 2015.

5 BRASIL. Decreto n $n^{\circ}$ 5.300, de 07 de dezembro de 2004. Disponível em: <http://www.planalto.gov.br/ccivil_03/_ato2004-2006/2004/ decreto/D5300.htm>. Acesso em: 10 jul. 2014. Parágrafo primeiro. 6 BRASIL. Ministério do Meio Ambiente. Limites da Zona Costeira. Disponível em: <http://www.mma.gov.br/gestao-territorial/gerenciamento-costeiro/a-zona-costeira-e-seus-m\%C3\%BAltiplos-usos/ caracteristicas-da-zona-costeira>. Acesso em: 09 nov. 2014.

7 BRASIL. Decreto n $n^{\circ}$ 5.300, de 07 de dezembro de 2004. Disponível em: <http://www.planalto.gov.br/ccivil_03/_ato2004-2006/2004/ decreto/D5300.htm>. Acesso em: 10 jul. 2014. Artigo 4 ${ }^{\circ}$, incisos e parágrafos. 
Embora a Relação de Municípios seja variável, não se constata uma atualização periódica da lista pelo MMA, o que resulta em uma incerteza jurídica quanto à área exata da zona costeira ${ }^{8}$. Ademais, Estados e Municípios podem requerer a inclusão ou a exclusão de sua localização na zona costeira, o que pode alterar constantemente a dimensão da área. Outras lacunas também são constantemente ressaltadas por autores ${ }^{9}$, como as incertezas relacionadas à falta de coordenação entre a gestão da zona costeira, a gestão das bacias hidrográficas e a gestão ambiental. A zona costeira tem como unidade de gestão o Município, enquanto a gestão dos recursos hídricos utiliza como unidade territorial as bacias hidrográficas. Estas, por sua vez, não consideram a influência das atividades marinhas nas partes baixas da bacia, no estuário ${ }^{10}$. No mesmo sentido, a gestão ambiental é competência de todos os entes federativos, ou seja, União, Estados e Municípios, o que muitas vezes gera conflito em razão da falta de delimitação precisa das competências ambientais normativas e administrativas relacionadas à zona costeira. ${ }^{11}$

O Decreto 5.300/2004 integra ao Plano Nacional de Gerenciamento Costeiro (PNGC) a gestão da orla marítima. Essa região está contida na zona costeira e compreende uma faixa de largura variável de interface entre o mar e a terra, cujos limites marítimos e terrestres estão previstos no art. 23 da citada norma ${ }^{12}$. A diferen-

8 Os Municípios integrantes da zona costeira estão citados no Anexo B do Plano Nacional de Gerenciamento Costeiro II (PNGC II), Resolução CIRM no 005/1997. BRASIL. Ministério do Meio Ambiente. Plano Nacional de Gerenciamento Costeiro (PNGC II). 1997. Disponível em: <http://www.mma.gov.br/images/arquivo/80033/0.PNGC-II97\%20Resolucao05_97.CIRM.pdf $>$. Acesso em: 15 out. 2014.

9 Sobre o tema ver: LOITZENBAUER, Ester; MENDES, Carlos André Bulhões. A faixa terrestre da zona costeira e os recursos hídricos na região hidrográfica do Atlântico Sul. Revista de Gestão Costeira Integrada, Lisboa, v. 14, n. 1, p. 81-94, mar. 2014. p. 84.

10 Sobre o tema ver: LOITZENBAUER, Ester; MENDES, Carlos André Bulhões. A faixa terrestre da zona costeira e os recursos hídricos na região hidrográfica do Atlântico Sul. Revista de Gestão Costeira Integrada, Lisboa, v. 14, n. 1, p. 81-94, mar. 2014. p. 84.

11 BRASIL. Constituição (1988). Constituição da República Federativa do Brasil. Disponível em: < http://www.planalto.gov.br/ccivil_03/constituicao/constituicao.htm>. Acesso em: 05 ago. 2014. Artigo 23, inciso VI.

12 "Art. 23. I - marítimo: isóbata de dez metros, profundidade na qual a ação das ondas passa a sofrer influência da variabilidade topográfica do fundo marinho, promovendo o transporte de sedimentos; II - terrestre: cinquenta metros em áreas urbanizadas ou duzentos metros em áreas não urbanizadas, demarcados na direção do continente a partir da linha de preamar ou do limite final de ecossistemas, tais como as caracterizadas por feições de praias, dunas, ciação entre a zona costeira e a orla marítima suscita questionamentos relacionados aos limites, às funções $\mathrm{e}$ às competências dessas duas áreas. A orla é objeto de planejamentos específicos, como o Projeto Orla, ${ }^{13}$ que tem como função implementar a gestão integrada da orla entre o MMA e o Ministério do Planejamento e Gestão, por meio da Secretaria do Patrimônio da União (SPU/MP). O objetivo consiste em ordenar o espaço litorâneo sob o domínio da União, organizar o seu uso múltiplo e a sua ocupação. Objetivos similares estão previstos no PNGC, por exemplo, no art. $5^{\circ}$ parágrafo $2^{\circ}$, da Lei n. ${ }^{\circ} 7.661 / 88$ que dispõe sobre a possibilidade de previsão do uso do solo, do subsolo e das águas nos planos nacional, estadual e municipal de gerenciamento costeiro, estipulando a prevalência da norma mais restritiva.

Um tema que é tratado de modo diverso por diferentes normas é a praia, componente da orla marítima. Ela é classificada como bem público de uso comum do povo, conforme art. 10 da Lei n. ${ }^{\circ} 7.661 / 98$ e pelo art. 21 do Decreto 5.300/2004. Em contrapartida, a Constituição Federal dispõe, em seu artigo 20, inciso IV, que são bens da União: "as ilhas fluviais e lacustres nas zonas limítrofes com outros países; as praias marítimas; as ilhas oceânicas e as costeiras, excluídas, destas, as que contenham a sede de Municípios, exceto aquelas áreas afetadas ao serviço público e a unidade ambiental federal, e as referidas no art. 26, II". Esses tratamentos normativos diversos podem gerar efeitos consideráveis nas autorizações de atividades que podem ou não ser realizadas na praia.

Além da Zona Costeira e da chamada Zona Litorânea, o Brasil possui vasta área oceânica delimitada internamente pela Lei 8.617/93 e coordenada pela Comissão Interministerial para os Recursos do Mar (CIRM) ${ }^{14}$. A

áreas de escarpas, falésias, costões rochosos, restingas, manguezais, marismas, lagunas, estuários, canais ou braços de mar, quando existentes, onde estão situados os terrenos de marinha e seus acrescidos" (BRASIL. Decreto n ${ }^{\circ} 5.300$, de 07 de dezembro de 2004. Disponível em: <http://www.planalto.gov.br/ccivil_03/_ato2004-2006/2004/ decreto/D5300.htm>. Acesso em: 10 jul. 2014).

13 BRASIL. Ministério do Meio Ambiente. Projeto Orla. Disponível em: <http://www.mma.gov.br/gestao-territorial/gerenciamentocosteiro/projeto-orla>. Acesso em: 18 out. 2014.

14 A CIRM foi criada pelo Decreto $\mathrm{n}^{\circ} 74.557$, competente para regular os assuntos relativos à consecução da Política Nacional para os Recursos do mar (PNRM), de acordo com o Decreto n ${ }^{\circ} 3.939$, de 26 de setembro de 2001. Brasil. Decreto no 74.557, de 12 de setembro de 1974. Disponível em: < http:/ / www.planalto.gov.br/ccivil_03/decreto/Antigos/D74557.htm>. Acesso em: 05 ago. 2015. 
chamada zona marinha ${ }^{15}$ ou espaço marinho, constituído pelo Mar Territorial ${ }^{16}$, pela Zona Contígua ${ }^{17}$, pela Zona Econômica Exclusiva $(\mathrm{ZEE})^{18}$ e pela Plataforma Continental ${ }^{19}$ compreende atualmente 3,5 milhões de $\mathrm{km}^{2}$, podendo atingir 4,5 milhões de $\mathrm{km}^{2}$ com a extensão da Plataforma Continental. O mar territorial constitui bem da União, de acordo com o artigo 20, inciso VI da Constituição Federal, enquanto apenas os recursos naturais da plataforma continental e da zona econômica exclusiva são bens da União, de acordo com o inciso $\mathrm{V}$ do mesmo dispositivo constitucional.

A existência de normas, de planos e de programas de gestão para cada espaço específico gera inseguran-

15 BRASIL. Ministério do Meio Ambiente. Zona Costeira e Marinha. Disponível em: <http://www.mma.gov.br/biodiversidade/biodiversidade-aquatica/zona-costeira-e-marinha>. Acesso em: 15 out. 2014.

16 Doze milhas marítimas, medidas a partir da linha de baixa-mar do litoral continental e insular. BRASIL. Lei no 8.617 de 04 de janeiro de 1993. Disponível em: <http://www.planalto.gov.br/ccivil_03/leis/ 18617.htm>. Acesso em: 05 out. 2014. Art. 1.

17 A zona contígua é uma faixa que se estende entre doze e vinte e quatro milhas, nela o Brasil possui competências para realizar medidas fiscalizatórias para evitar e reprimir infrações no seu território ou no seu mar territorial (BRASIL. Lei $n^{\circ} 8.617$ de 04 de janeiro de 1993. Disponível em: <http://www.planalto.gov.br/ccivil_03/leis/ 18617.htm>. Acesso em: 05 out. 2014. Art. $4^{\circ}$ e $5^{\circ}$ ).

$18 \mathrm{Na}$ zona econômica exclusiva — que compreende uma faixa estendida entre doze e duzentas milhas marítimas, contadas a partir da linha de base — o Brasil não possui soberania plena, mas somente para "fins de exploração, aproveitamento, conservação e gestão dos recursos naturais vivos e não vivos, das águas sobrejacentes ao leito do mar, do leito do mar e seu subsolo, e no que se refere a outras atividades com vistas à exploração e ao aproveitamento da zona para fins econômicos". Nessa região, a regulamentação da proteção e da preservação do meio marítimo; da construção, operação e uso de todos os tipos de ilhas artificiais, instalações e estruturas só pode ser realizada pelo Brasil; porém, a liberdade de navegação e sobrevoo e os demais usos do mar internacionalmente lícitos são permitidos aos demais Estados. O Brasil exerce soberania para fins de exploração dos recursos naturais vivos e não vivos e pode regulamentar de maneira exclusiva sobre a investigação científica marinha, a proteção e preservação do meio marinho, a construção, operação e o uso de todos os tipos de ilhas artificiais, instalações e estruturas (BRASIL. Lei $n^{\circ} 8.617$ de 04 de janeiro de 1993. Disponível em: <http://www. planalto.gov.br/ccivil_03/leis/18617.htm>. Acesso em: 05 out. 2014. art. $\left.6^{\circ}-10\right)$.

19 A plataforma continental compreende: o leito e o subsolo das áreas submarinas que se estendem além do seu mar territorial, em toda a extensão do prolongamento natural de seu território terrestre, até o bordo exterior da margem continental, ou até uma distância de duzentas milhas marítimas das linhas de base, a partir das quais se mede a largura do mar territorial, nos casos em que o bordo exterior da margem continental não atinja essa distância (BRASIL. Lei n ${ }^{\circ}$ 8.617 de 04 de janeiro de 1993. Disponível em: <http:/ / www.planalto. gov.br/ccivil_03/leis/18617.htm>. Acesso em: 05 out. 2014. Art. 11-13). ça jurídica, pois há pluralidade de normas, muitas vezes contraditórias, aplicáveis a áreas similares. Ao mesmo tempo, há outros temas que deveriam ser tratados de modo conjunto, como a interface entre as bacias hidrográficas ou o planejamento urbano e a zona costeira, mas ainda há limites para essas conexões. Para analisar se a delimitação desses espaços como costeiro, litorâneo e marítimo tem contribuído ou não para a segurança jurídica das atividades na região, é fundamental selecionar uma atividade como foco de estudo. Nesse caso, a construção civil constitui uma das atividades que pode ocorrer tanto na faixa terrestre quanto na faixa marítima da zona costeira, podendo ser potencialmente causadora de dano ao meio ambiente. Portanto, trata-se de tema que possibilita boa análise das incoerências normativas e institucionais no Brasil para a gestão sustentável dessa área.

O artigo irá se concentrar nas construções imobiliárias nas faixas terreste e marítima da zona costeira. As ocupações atreladas às atividades portuária e petrolífera não serão abordadas neste trabalho, pois a regulação desta normativa é específica e seus problemas jurídicos são diferentes. A gestão dos resíduos, da qualidade da água e da relação entre as bacias hidrográficas e a zona costeira também não serão objeto do presente artigo.

Considerando-se esse cenário, verifica-se a existência de limites institucionais (I) e normativos (II) em relação à gestão sustentável da ocupação da zona costeira. No caso do Brasil, não se trata de ausência, mas de pluralidade de instrumentos aplicáveis a essa região, mas que não são suficientemente precisos e claros para garantir a segurança jurídica nessa região.

\section{Os LiMites INSTITUCIONAIS}

Os limites institucionais para a gestão sustentável da zona costeira são perceptíveis na faixa terrestre e na faixa marítima. No primeiro caso, os limites mais evidentes relacionam-se às competências das entidades da federação para a proteção do meio ambiente. Em relação à faixa marítima, a gestão do planejamento costeiro é limitada, pois essas atribuições são concentradas na Autoridade Marítima (AM), cujas competências estão ligadas, sobretudo, às atividades de navegação. É relevante apresentar, primeiramente, a organização federativa brasileira no que concerne à proteção ambiental e à 
gestão da zona costeira para facilitar a compreensão dos limites institucionais.

A Constituição Federal estabelece, em seu artigo 225, que o meio ambiente ecologicamente equilibrado, de modo geral, é bem de uso comum das presentes e futuras gerações. No entanto, há reconhecimento expresso de alguns biomas que merecem proteção especial no art. $225, \sqrt{ } 4^{\circ}$, entre eles consta a Zona Costeira. O texto prevê que: "a Floresta Amazônica brasileira, a Mata Atlântica, a Serra do Mar, o Pantanal Mato-Grossense e a Zona Costeira são patrimônio nacional, e sua utilização far-se-á, na forma da lei". ${ }^{20}$ Resta compreender qual é o significado do reconhecimento da Zona Costeira como patrimônio nacional, para além do sentido meramente retórico, e qual é a distinção entre bem do patrimônio nacional e bem de uso comum do povo.

A competência legislativa relativa à elaboração de planos nacionais ou regionais de ordenação do território é da União. ${ }^{21}$ Destarte, à primeira vista, questões sobre o gerenciamento costeiro, cujo impacto dificilmente se limita ao âmbito local, alcançando proporções regionais ou nacionais, são do interesse do Instituto Brasileiro do Meio Ambiente e dos Recursos Naturais Renováveis (IBAMA), autarquia federal executora do Sistema $\mathrm{Na}$ cional do Meio Ambiente. ${ }^{22}$

Em relação às atividades de cunho administrativo na zona costeira, tem-se que, além do IBAMA, a faixa marítima da zona costeira é gerenciada pela Autoridade

20 BRASIL. Constituição (1988). Constituição da República Federativa do Brasil. Disponível em: < http://www.planalto.gov.br/ccivil_03/constituicao/constituicao.htm>. Acesso em: 05 ago. 2014.

21 Cf.: Art. 21. Compete à União: IX - elaborar e executar planos nacionais e regionais de ordenação do território e de desenvolvimento econômico e social; Art. 23. É competência comum da União, dos Estados, do Distrito Federal e dos Municípios: VI - proteger o meio ambiente e combater a poluição em qualquer de suas formas; VII preservar as florestas, a fauna e a flora; Art. 24. Compete à União, aos Estados e ao Distrito Federal legislar concorrentemente sobre: VI - florestas, caça, pesca, fauna, conservação da natureza, defesa do solo e dos recursos naturais, proteção do meio ambiente e controle da poluição; VIII - responsabilidade por dano ao meio ambiente, ao consumidor, a bens e direitos de valor artístico, estético, histórico, turístico e paisagístico. BRASIL. Constituição (1988). Constituição da República Federativa do Brasil. Disponível em: <http://www.planalto.gov.br/ccivil_03/constituicao/constituicao.htm>. Acesso em: 05 ago. 2014.

22 BRASIL. Constituição (1988). Constituição da República Federativa do Brasil. Disponível em: <http://www.planalto.gov.br/ccivil_03/constituicao/constituicao.htm>. Acesso em: 05 ago. 2014. BRASIL. Lei 6.938 de 31 de agosto de 1981. Disponível em: < http:/ / www.planalto.gov.br/ccivil_03/leis/16938.htm>. Acesso em: 4 out. 2014. Art. $6^{\circ}$, IV.
Marítima no que tange às construções realizadas nessa área, tendo como objetivo principal preservar a segurança da atividade de navegação ${ }^{23}$. A competência da AM deve ser anvaliada de modo crítico, tendo vem vista a necessidade da gestão integrada da zona costeira com outras atividades realizadas na área como a pesca e a proteção da biodiversidade marinha.

Nesse ínterim, é pertinente verificar os problemas relacionados à identificação do órgão de proteção ambiental competente para autorizar a ocupação sustentável da zona costeira (A); para, em seguida, apresentar os problemas da gestão integrada da zona costeira ligados à competência da AM para autorizar construções na área marítima (B).

A) A identificação do órgão de proteção ambiental competente para autorizar a ocupação sustentável da zona costeira

A identificação do órgão de proteção ambiental competente para autorizar a ocupação sustentável da zona costeira constitui um dos limites institucionais da gestão da zona costeira em relação à construção civil. Observa-se que a competência comum entre União, Estados e Municípios resulta em alguns conflitos no que tange ao órgão competente para o licenciamento ambiental de atividades na zona costeira. É relevante demonstrar que a causa desse conflito era a pouca clareza na delimitação da competência de cada ente federativo, o que foi parcialmente esclarecido pela Lei Complementar n. ${ }^{\circ} 140$ de 08 de dezembro de 2011, principalmente pela utilização aleatória de critérios para definir a competência de cada ente.

Antes da edição da Lei Complementar 140/2011, que cria regras para a cooperação nos processos de licenciamento ambiental, entre a União, os Estados, o Distrito Federal e os Municípios, havia interpretações diversas quanto ao ente competente para realizar o licenciamento ambiental de empreendimentos localizados na zona costeira. Os tribunais utilizavam alguns critérios, dispostos no art. 10 da Lei 6.938/81 (alterado pela norma supramencionada), como o interesse preponderante, a dimensão do impacto e a localização da unidade de conservação para determinar se um órgão estadual ou a União deveria ser competente para o licenciamento. No entanto, esses critérios eram deveras

23 BRASIL. Lei $n^{\circ} 9.966$ de 28 de abril de 2000. Disponível em: <http://www.planalto.gov.br/ccivil_03/leis/L9966.htm>. Acesso em: 4 out. 2014. Art. $2^{\circ}$, inciso XXII. 
abstratos e davam margem à subjetividade do órgão administrativo e judicial no momento de licenciar ou julgar licenças expedidas. Ademais, em diversos momentos, a norma supracitada mencionava ser competência supletiva do ente federal a concessão do licenciamento ambiental, porém não havia critérios objetivos que norteassem as hipóteses em que a competência supletiva devesse ser utilizada. De fato, em casos extremos, como quando a autoridade estadual omitia-se, restava claro identificar que o IBAMA deveria suprir a ausência estadual. No entanto, a jurisprudência analisada dos 5 Tribunais Regionais Federais nacionais demonstra que a quase unanimidade dos magistrados utilizava a competência supletiva como regra e não como exceção.

A esse respeito, cita-se o julgado abaixo, proveniente do TRF1, cuja controvérsia tratava de prédio que seria construído em região de dunas, já existindo licenciamento ambiental concedido pelo órgão estadual. O caso ilustra a confusão realizada nos tribunais em utilizar o argumento da proteção constitucional ao meio ambiente ecologicamente equilibrado como fundamento para requerer a atuação supletiva do IBAMA como regra:

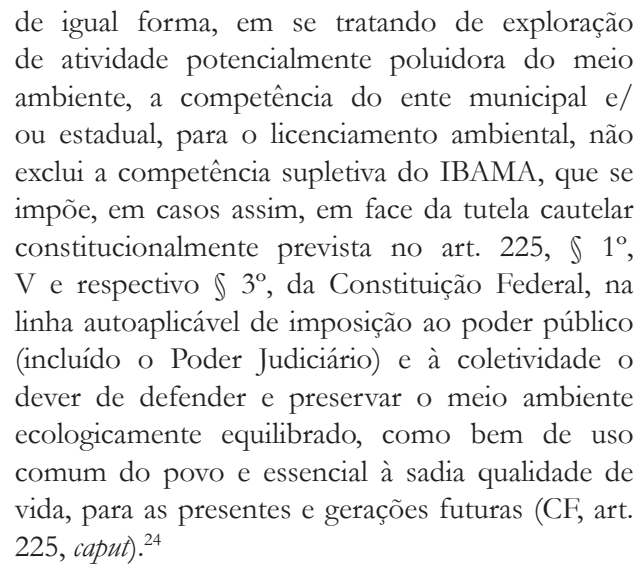

24 BRASIL. Tribunal Regional Federal da Primeira Região. Agravo de Instrumento. AG 183530620124010000 MA 0018353 06.2012.4.01.0000. Quinta Turma. Agravante: Delman Rodrigues Incorporações Ltda. Agravado: Ministério Público Federal. Relator: Des. Souza Prudente. Brasília, 31 de setembro de 2013. Disponível em: <http://trf-1.jusbrasil.com.br/jurisprudencia/24138498/ agravo-de-instrumento-ag-183530620124010000-ma0018353-0620124010000-trf1>. Acesso em: 5 ago. 2015. De forma similar, cf. BRASIL. Tribunal Regional Federal da Segunda Região. Apelação Cível. AC 200651080008781. Sexta Turma Especializada. Apelante: Denival da Silva Ferraz e outros. Apelado União Federal, Município de Araruama; IBAMA. Relator (a): Des. Federal Carmen Silvia Lima de Arruda. Rio de Janeiro, 31 de março de 2014. Disponível em: <http://trf-2.jusbrasil.com.br/jurisprudencia/25091049/ac-apelacao-civel-ac-200651080008781-trf2/ inteiro-teor-120459970>. Acesso em: 5 ago. 2015, nesse caso, para defender a necessidade da atuação do ente federal, a juíza afirmou
Rememore-se, também, que a lei 6.938 data de período anterior à atual Carta Magna, motivo pelo qual ela não contemplava a atuação municipal na proteção do meio ambiente. Com o advento da Constituição de 1988 e a autonomia que esta direcionou aos Municípios, impelia à criação de novo instrumento que permitisse a eles, entes mais próximos das populações afetadas pelo gerenciamento costeiro, maior ingerência sobre a política de zoneamento urbano e de licenciamento ambiental. ${ }^{25}$ Nesse contexto, a Lei Complementar (LC) n. ${ }^{\circ}$ 140/2011 logrou êxito em estabelecer expressamente a unicidade do órgão licenciador, bem como dispor sobre as hipóteses de atuação supletiva e de atuação subsidiária dos entes federativos, contribuindo para suprir a lacuna apontada acima ${ }^{26}$.

que toda a zona costeira é uma propriedade da União, ou seja, tanto a parte terrestre quanto a parte marítima da zona costeira nacional — que contém algumas municipalidades — seriam propriedade da União); BRASIL. Tribunal Regional Federal da Segunda Região. Agravo de Instrumento. AG 2012.02.01.004859-3. Quinta Turma Especializada. Agravante: IBAMA. Agravado: Thiago Cunha de Almeida. Relator: Des. Federal Marcus Abraham. Rio de Janeiro, 29 de janeiro de 2013. Disponível em: <http://trf-2.jusbrasil. com.br/jurisprudencia/23376162/ag-agravo-de-instrumento-ag201202010048593-trf2/inteiro-teor-111700881>. Acesso em: 5 ago. 2015; BRASIL. Tribunal Regional Federal da Segunda Região. Agravo de Instrumento. AG 2012.02.01.005724-7. Quinta Turma Especializada. Agravante: Ministério Publico Federal. Agravado: Aluísio Leal Santos. Relator: Des. Federal. Marcus Abraham. Rio de Janeiro, 28 de maio de 2013. Disponível em: < http://trf-2.jusbrasil.com.br/jurisprudencia/23610800/ag-agravo-de-instrumento-ag201202010057247-trf2/inteiro-teor-111757639>. Acesso em: 5 ago. 2015.

25 BRASIL. Lei $n^{\circ}$ 6.938, de 31 de agosto de 1981. Disponível em: $<$ http://www.planalto.gov.br/ccivil_03/leis/16938.htm>. Acesso em: 4 out. 2014. Art. 10; GUERRA, Sérgio. Licenciamento Ambiental de Acordo com a LC 140/2011. Revista de Direito Ambiental, São Paulo, v. 17, n. 66, p. 153-179, abr./jun. 2012. p. 155.

26 Art. 14. $\int 3^{\circ}$ O decurso dos prazos de licenciamento, sem a emissão da licença ambiental, não implica emissão tácita nem autoriza a prática de ato que dela dependa ou decorra, mas instaura a competência supletiva referida no art. 15. Art. 15. Os entes federativos devem atuar em caráter supletivo nas ações administrativas de licenciamento e na autorização ambiental, nas seguintes hipóteses: I - inexistindo órgão ambiental capacitado ou conselho de meio ambiente no Estado ou no Distrito Federal, a União deve desempenhar as ações administrativas estaduais ou distritais até a sua criação; II - inexistindo órgão ambiental capacitado ou conselho de meio ambiente no Município, o Estado deve desempenhar as ações administrativas municipais até a sua criação; e III - inexistindo órgão ambiental capacitado ou conselho de meio ambiente no Estado e no Município, a União deve desempenhar as ações administrativas até a sua criação em um daqueles entes federativos. Art. 16. A ação administrativa subsidiária dos entes federativos dar-se-á por meio de apoio técnico, científico, administrativo ou financeiro, sem prejuízo de outras formas de cooperação. Parágrafo único. A ação subsidiária deve ser solicitada pelo ente originariamente detentor da atribuição nos termos 
Especificamente em relação à divisão das competências para realizar o licencimento ambiental para a construção em região costeira, a LC 140 dispõe no art. $7^{\circ}$ parágrafo único ${ }^{27}$ que a União tem competência para promover o licenciamento: de empreendimentos e atividades localizados ou desenvolvidos no mar territorial, na plataforma continental ou na zona econômica exclusiva; em unidades de conservação instituídas pela União, exceto em Áreas de Proteção Ambiental (APAs) em dois ou mais Estados.

$\mathrm{O}$ art. $9^{\circ}$, inciso XIV elenca expressamente as competências dos Municípios em relação à concessão do licenciamento ambiental. $\mathrm{O}$ art. $8^{\circ}$, por sua vez, prevê que é competência dos Estados:

\begin{abstract}
XIV - promover o licenciamento ambiental de atividades ou empreendimentos utilizadores de recursos ambientais, efetiva ou potencialmente poluidores ou capazes, sob qualquer forma, de causar degradação ambiental, ressalvado o disposto nos arts. $7^{\circ}$ e $9^{\circ}$;

Art. $9^{\circ}$ São ações administrativas dos Municípios:
\end{abstract}

XIV - observadas as atribuições dos demais entes federativos previstas nesta Lei Complementar, promover o licenciamento ambiental das atividades ou empreendimentos:

a) que causem ou possam causar impacto ambiental de âmbito local, conforme tipologia definida pelos respectivos Conselhos Estaduais de Meio Ambiente, considerados os critérios de porte, potencial poluidor e natureza da atividade. ${ }^{28}$

Constata-se que a lei buscou compatibilizar os critérios já utilizados da autoridade instituidora e da abrangência do possível dano com as inovações de dotar os Estados de competência residual e da criação de Comissão Tripartite Nacional, órgão de caráter técnico, responsável pela proposição de tipologia de atividades com

desta Lei Complementar (BRASIL. Lei Complementar $n^{\circ} 140$, de 08 de dezembro de 2011. Disponível em: <http://www.planalto.gov.br/ ccivil_03/leis/lcp/Lcp140.htm>. Acesso em: 10 nov.2014).

27 Art. $7^{\circ}$, parágrafo único. O licenciamento dos empreendimentos cuja localização compreenda concomitantemente áreas das faixas terrestre e marítima da zona costeira será de atribuição da União exclusivamente nos casos previstos em tipologia estabelecida por ato do Poder Executivo, a partir de proposição da Comissão Tripartite Nacional, assegurada a participação de um membro do Conselho Nacional do Meio Ambiente (CONAMA) e considerados os critérios de porte, potencial poluidor e natureza da atividade ou empreendimento. BRASIL. Lei Complementar $n^{\circ} 140$, de 08 de dezembro de 2011. Disponível em: <http://www.planalto.gov.br/ccivil_03/ leis/lcp/Lcp140.htm>. Acesso em: 10 nov.2014

28 BRASIL. Lei Complementar n 140, de 08 de dezembro de 2011. Disponível em: <http://www.planalto.gov.br/ccivil_03/leis/lcp/ Lcp140.htm>. Acesso em: 10 nov.2014. maior risco de degradação ao meio ambiente.

Ressalta-se, ainda, a disposição contida no art. 13, caput e parágrafos $1^{\circ}$ e $2^{\circ}$ que possibilita a manifestação não vinculativa dos demais entes federativos ao órgão responsável pela licença ou autorização. Avalia-se que esse dispositivo buscou concatenar o principio da proteção integral ao meio ambiente com a unicidade do órgão licenciador. Isso porque, conforme já relatado acima, em diversos casos estudados, ainda sob o auspício da legislação anterior, construções que possuíam licença concedida por órgão municipal ou estadual, algumas delas já sendo desenvolvidas há anos, tiveram que ser suspensas em razão da manifestação de interesse do IBAMA na lide e, na quase totalidade deles, o judiciário acabava vinculando-se ao posicionamento do ente federal, utilizando argumentos confusos e, por vezes, incoerentes. A título de exemplo, apresenta-se o julgado abaixo que versa sobre uma ação civil pública que buscava a reparação de dano ambiental ocasionado em razão da construção de um muro de contenção e edificação sobre costão rochoso da Ilha Grande. Esta está inserida na Área de Proteção Ambiental de Tamoios, unidade de conservação instituída pelo Estado do Rio de Janeiro. Nesse caso o magistrado atribui a competência do IBAMA para realizar o licenciamento ambiental pelo mero fato de a construção se inserir em área de zona costeira, sem demonstrar se existiria algum impacto de âmbito regional ou nacional:

[...] nesse quadrante, a despeito de a construção empreendida pelo Demandado se situar na Área de Proteção Ambiental de Tamoios - unidade de conservação criada pelo Estado do Rio de Janeiro (Decreto $\mathrm{n}^{\circ}$ 9.452/86) e administrada pelo INEA (Instituto Estadual do Ambiente/RJ) -, o interesse nacional na lide está claramente delineado nos argumentos expendidos na inicial da ação coletiva, que apontam a ocorrência de edificação irregular, sem prévio licenciamento ambiental, ocasionando degradação ambiental em virtude da alteração das características naturais de região localizada em Zona Costeira, considerada constitucionalmente patrimônio nacional (art. 225, $\left.₫ 4^{\circ}, \mathrm{CF}\right)^{29}$.

29 BRASIL. Tribunal Regional Federal da Segunda Região. Agravo de Instrumento. AG 2012.02.01.004859-3. Quinta Turma Especializada. Agravante: IBAMA. Agravado: Thiago Cunha de Almeida. Relator: Des. Federal Marcus Abraham. Rio de Janeiro, 29 de janeiro de 2013. Disponível em: <http://trf-2.jusbrasil. com.br/jurisprudencia/23376162/ag-agravo-de-instrumento-ag201202010048593-trf2/inteiro-teor-111700881>. Acesso em: 5 ago. 2015. Contrariando esse entendimento, e verificando a adequação do particular às regras estaduais de proteção ao meio ambiente, a despeito do manifesto interesse do IBAMA: "Entendo que o em- 
Diante desses casos, não se questiona o fato de que a intervenção do IBAMA no processo de licenciamento tenha proporcionado maior lisura e proteção ao meio ambiente, isso porque os entes estaduais e municipais, por vezes, não possuem capacidade técnica e recursos suficientes para exercer suas atividades de forma satisfatória. Argumenta-se que essa incapacidade estrutural, que não possuía respaldo normativo, não poderia ser utilizada genericamente a ponto de suprimir as competências dos órgãos estadual e municipal, visando suprir por meio judicial insuficiências administrativas.

Mesmo em decisões em que se busca argumentos mais precisos para se justificar a intervenção do IBAMA em razão da configuração do interesse nacional da área, argumentos ligados ao patrimônio nacional ainda são utilizados. Não se questiona o resultado da decisão, mas sim os argumentos que são utilizados para sustentá-la. Por exemplo, pode ser citado um caso de empreendimento localizado em Área de Preservação Permanente como o mangue, com proteção específica na Lei $n^{\circ}$ 4.771/65. Nessa circunstância, há julgados no sentido de que o IBAMA seria o órgão competente não apenas pela omissão do órgão estadual competente, mas pelo fato de que a Zona Costeira seria patrimônio nacional, como pode ser verificado abaixo:

2. a ação civil pública originária foi ajuizada pelo
Parquet Federal, que busca o reconhecimento da
competência do IBAMA para o licenciamento
ambiental de empreendimento sito, segundo
afirma, na Zona Costeira (Loteamento Jardim
Fortaleza), com exigência de apresentação de
estudo de impacto ambiental e relatório de impacto
do meio ambiente. 3. Segundo vistoria realizada

preendimento compatibilizou o uso e a sustentabilidade do meio. A área urbana será ocupada, porém com baixa densidade ocupacional, acompanhada de projetos de manutenção e andou na esteira das declarações periciais, está de acordo com a legislação vigente, sendo a área costeira, o terreno de marinha e a restinga legal e legitimamente respeitados, associados a um empreendimento urbano devidamente licenciado pelos órgãos municipal e estadual, como é de direito conforme seu tamanho (inferior a $100 \mathrm{ha}$ e destinado a ocupação de cerca de 400 pessoas), nos termos de toda a legislação supratranscrita. Não procede, então, a pretensão original do Ministério Público Federal de vedar qualquer empreendimento no local. Ante o exposto, voto por negar provimento aos recursos de apelação da União, do Ministério Público Federal e do IBAMA, para julgar improcedente esta Ação Civil Pública” (BRASIL. Tribunal Federal da Quarta Região. Recurso Especial em Apelação Cível. $A C n^{o}$ 0000959-87.2009.404.7216/SC. Terceira Turma. Recorrente: IBAMA. Recorrido: Territorial Garopaba Ltda. Relator(a): Des. Maria Lúcia Luz Leiria. Porto Alegre, 19 de agosto de 2012. Disponível em: <http://www.jusbrasil.com.br/diarios/64854576/trf-4-judicial-17-01-2014-pg-75>. Acesso em: 5 ago. 2015. pelo órgão ambiental, a área do loteamento está encravada em borda de manguezal, em bacia de inundação do Rio Cocó, sofrendo a influência das marés e em campo de duna. [...] Constatouse, em procedimento administrativo, em tais áreas, o desmonte de dunas fixas, o desmatamento e a abertura de vias de acesso e terraplanagem, tudo sem licenciamento ambiental. 5. In casu, como a área do loteamento está inserta em borda de manguezal, em bacia de inundação do Rio Cocó, sofrendo a influência das marés, ou seja, como se trata de área de interação entre mar e terra, então, tem-se que se está diante de área integrante de Zona Costeira. Em função dessa localização, considerando-se que se trata de área patrimonial nacional, por expressa dicção do Texto Constitucional, evidencia-se a competência do IBAMA para o licenciamento ambiental de empreendimentos que pretendam nela de estabelecer, ações humanas essas que não poderão prescindir de EIA e de RIMA. ${ }^{30}$

Verifica-se que há insegurança jurídica na identificação clara de qual órgão deve ser competente para o licenciamento ambiental de empreendimentos na zona costeira. Por um lado, o poder municipal está normalmente mais próximo do empreendimento e do empresário e, além disso, possui competência para realizar o zoneamento urbano. Dessa forma, esse ente teria melhores condições de avaliar a possível extensão do dano de uma construção e de identificar a boa-fé e a capacidade técnica do empresário para realizar o em-

30 BRASIL. Tribunal Regional Federal da Quinta Região. Agravo de Instrumento. AGTR 107968/CE - 0009668-67.2010.4.05.0000. Primeira Turma. Agravante: Ministério Público Federal. Agravado: Construtora Waldyr Diogo Ltda e outros. Relator : Des. Federal Francisco Cavalcanti. Recife, 03 de maio de 2012. Disponível em: $<$ http://www.jusbrasil.com.br/diarios/37330603/trf-5-jud-25-052012-pg-57>. Acesso em: 5 ago. 2015. Num sentido similar cf.: BRASIL. Tribunal Federal da Quarta Região. Apelação Cível. AC 500022869.2010.404.7216/SC. Vice-Presidência. Apelante: Orlando Ivã larionoff. Apelado: IBAMA. Relator: Des. Federal Luiz Fernando Wowk Pentead. Porto Alegre, 02 de outubro de 2014. Disponível em: $<$ http://trf-4.jusbrasil.com.br/jurisprudencia/143419040/apelacao-civel-ac-50002286920104047216-sc-5000228-6920104047216/ inteiro-teor-143419116>. Acesso em: 5 ago. 2015; BRASIL. Tribunal Federal da Quarta Região. Recurso Especial em Apelação Cível. AC 0000959-87.2009.404.7216/SC. Terceira Turma. Recorrente: IBAMA. Recorrido: Territorial Garopaba Ltda. Relator(a): Des. Maria Lúcia Luz Leiria. Porto Alegre, 19 de agosto de 2012. Disponível em: <http://www.jusbrasil.com.br/diarios/64854576/trf-4-judicial-17-01-2014-pg-75>. Acesso em: 5 ago. 2015; BRASIL. Tribunal Regional Federal da Quarta Região. Apelação Cível. AC 0004571 88.2003.404.7201/SC. Terceira Turma. Apelante IBAMA; Ministério Público Federal. Apelado: Município de Itapoá/SC. Relator (a): Des. Federal Maria Lúcia Luz Leiria. Porto Alegre, 1 de fevereiro de 2011. Disponível em: <http://trf-4.jusbrasil.com.br/jurisprudencia/18575379/apelacao-civel-ac-7201-sc-0004571-8820034047201trf4/inteiro-teor-18575380>. Acesso em: 5 ago. 2015. 
preendimento $^{31}$. Por outro lado, o órgão federal possui, teoricamente, maior capacidade técnica e orçamentária para avaliar riscos, além de conceber estudos de impacto em níveis regionais ou nacionais e não estar restrito à região local. Antes da Lei Complementar n. 140, muitos julgados interpretaram no sentido de que toda construção na zona costeira tem impacto nacional em razão de sua condição de patrimônio nacional, o que resultou na indicação da competência do IBAMA para o licenciamento da atividade, embora o PNGC seja expresso ao afirmar que o critério para a concessão da licença deve ser o da extensão do dano ${ }^{32}$. Caberá, nesse momento, aguardar a aplicação dos dispositivos de coordenação existentes da LC n. ${ }^{\circ} 140$ a fim de verificar se haverá maior precisão dos critérios que serão utilizados para determinar a competência da União, do Estado ou do Município para licenciar esses empreendimentos, haja vista que, nenhum dos julgados encontrados nos endereços eletrônicos dos Tribunais Regionais Federais nacionais já tenha aplicado a citada lei.

Além desse limite institucional, identifica-se a existência de questões prejudiciais à gestão sustentável e integrada da zona costeira decorrentes da competência da Autoridade Marítima para autorizar as construções nessa área.

B) Os problemas de gestão integrada da zona costeira ligados à competência da Autoridade Marítima para autorizar as construções nessa região

Os problemas ligados à competência da Autoridade Marítima (AM) para autorizar construções na região costeira estão relacionados, entre outros motivos, à prioridade dada à navegação. Os usos múltiplos da zona costeira não são coordenados de forma a propiciar que o planejamento da zona costeira pudesse ser dividido de forma equânime ou razoável entre os órgãos competentes. Diversos órgãos federais e estaduais também têm suas respectivas competências relacionadas à gestão da zona costeira, como o Ministério da Pesca e o IBAMA, ou os órgãos estatais responsáveis por elaborar o

31 Cf.: Art. 30. Compete aos Municípios: VIII - promover, no que couber, adequado ordenamento territorial, mediante planejamento e controle do uso, do parcelamento e da ocupação do solo urbano. BRASIL. Constituição (1988). Constituição da República Federativa do Brasil. Disponível em: <http://www.planalto.gov.br/ccivil_03/ constituicao/constituicao.htm>. Acesso em: 05 ago. 2014.

32 BRASIL. Decreto no 5.300, de 07 de dezembro de 2004. Disponível em: <http://www.planalto.gov.br/ccivil_03/_ato2004-2006/2004/ decreto/D5300.htm>. Acesso em: 10 jul. 2014.
Zoneamento Ecológico-Econômico da zona costeira, o que intensifica a complexidade da gestão integrada dessa região. É pertinente avaliar os limites da AM para conduzir a uma gestão integrada da zona costeira em razão, por exemplo, da centralidade que a atividade de navegação desempenha entre as competências da AM e da ausência de coordenação de sua atuação com a de outros órgãos federais e/ou estaduais.

A AM, nos termos do Regimento da Comissão Interministerial para os Recursos do Mar (CIRM) ${ }^{33}$, tem a competência para exercer a coordenação das atividades desta $^{34}$. Ela aprecia, entre outras competências, "O planejamento de atividades relacionadas com os recursos do mar, propondo ao Presidente da República prioridades para os programas e projetos que o integram" ${ }^{35}$. A lei que dispõe sobre a prevenção, o controle e a fiscalização da poluição causada por lançamento de óleo e outras substâncias nocivas ou perigosas em águas sob jurisdição nacional prevê no art. $2^{\circ}$ inciso XXII que

Autoridade Marítima é a autoridade exercida
diretamente pelo Comandante da Marinha,
responsável pela salvaguarda da vida humana e
segurança da navegação no mar aberto e hidrovias
interiores, bem como pela prevenção da poluição
ambiental causada por navios, plataformas e suas
instalações de apoio [...]" ${ }^{36}$

Nota-se que as atribuições da AM abarcam o planejamento de todas as atividades marinhas, mas a sua competência principal está conectada à atividade de navegação.

Apesar da Política Nacional para os Recursos do Mar (PNRM) ${ }^{37}$ orientar no sentido do desenvolvimento coordenado das atividades no mar territorial, na ZEE e na

33 BRASIL. Comissão Interministerial para os Recursos do Mar. Resolução no 01, de 21 de novembro de 1990. Disponível em: < https://www.mar.mil.br/secirm/document/ataseresolucoes/resolucao-1-1994.pdf>. Acesso em: 05 ago. 2015.

34 BRASIL. Comissão Interministerial para os Recursos do Mar. Resolução no 01, de 21 de novembro de 1990. Disponível em: < https://www.mar.mil.br/secirm/document/ataseresolucoes/resolucao-1-1994.pdf>. Acesso em: 05 ago. 2015.

35 BRASIL. Comissão Interministerial para os Recursos do Mar. Resolução no 01, de 21 de novembro de 1990. Disponível em: < https://www.mar.mil.br/secirm/document/ataseresolucoes/resolucao-1-1994.pdf>. Acesso em: 05 ago. 2015, artigo 5º inciso II.

36 BRASIL. Lei $n^{0} 9.966$ de 28 de abril de 2000. Disponível em: $<$ http://www.planalto.gov.br/ccivil_03/leis/L9966.htm>. Acesso em: 4 out. 2014.

37 BRASIL. Decreto $n^{0} .5 .377$ de 23 de fevereiro de 2005. Disponível em: <http://www.planalto.gov.br/ccivil_03/_Ato20042006/2005/Decreto/D5377.htm>. Acesso em: 06 ago. 2015. 
plataforma continental ${ }^{38}$, a navegação não está integrada entre as atividades que devem ser objeto dessa gestão integrada. $\mathrm{O}$ art. $3^{\circ}$ da PNRM prevê quais são os recursos vivos e não vivos marinhos que devem ser objeto de gestão integrada dos ambientes costeiro e oceânico ${ }^{39}$, quais sejam: os recursos pesqueiros, a diversidade biológica, os minerais, os recursos energéticos, a aquicultura, as atividades turísticas. Contudo, a lei exclui expressamente o transporte marítimo de cargas ${ }^{40}$. Portanto, embora a CIRM seja a instituição competente para coordenar a consecução da PNRM, nos termos do artigo $8^{\circ}$ da Política, há separação entre a atividade de navegação e as demais.

Há uma norma específica que estabelece os procedimentos para a realização de obras sob, sobre e às margens das águas jurisdicionais brasileiras ${ }^{41}$. A Marinha do Brasil tem a competência de avaliar a execução de obras nessa área e de emitir pareceres quanto ao "ordenamento do espaço aquaviário e à segurança da navegação, sem prejuízo das obrigações do interessado perante os demais órgãos responsáveis pelo controle da atividade em questão" "42. O Diretor de Portos e Costas (DPC) é o representante da Autoridade Marítima para a Segurança do Tráfego Aquaviário e tem, entre outras competências, "determinar a elaboração de normas da Autoridade Marítima relativas à execução de obras, dragagens, pesquisa e lavra de minerais sob, sobre e às margens das águas sob jurisdição nacional". As Capitanias (CP), Delegacias (DL) e Agências (AG) devem ser consultadas antes do início da execução das obras públicas localizadas na área em questão ${ }^{43}$.

38 BRASIL. Decreto $n^{0} .5 .377$ de 23 de fevereiro de 2005. Disponível em: <http://www.planalto.gov.br/ccivil_03/_Ato2004-2006/2005/ Decreto/D5377.htm>. Acesso em: 06 ago. 2015, artigo $2^{\circ}$.

39 BRASIL. Decreto $n^{0} .5 .377$ de 23 de fevereiro de 2005. Disponível em: <http://www.planalto.gov.br/ccivil_03/_Ato20042006/2005/Decreto/D5377.htm>. Acesso em: 06 ago. 2015Acesso em: out. 2014, artigo $7^{\circ}$.

40 BRASIL. Decreto $n^{0} .5 .377$ de 23 de fevereiro de 2005. Disponível em: <http://www.planalto.gov.br/ccivil_03/_Ato20042006/2005/Decreto/D5377.htm>. Acesso em: 06 ago. 2015, artigo 3.

41 BRASIL. Marinha do Brasil. Normas da autoridade marítima para obras, dragagens, pesquisa e lavra de minerais sob, sobre e às margens das águas jurisdicionais brasileiras: NORMAM 11/DPC. 2003. Disponível em: <https://www3.dpc.mar.mil.br/normam/N_11/normam11.pdf $>$. Acesso em: 05 ago. 2015.

42 BRASIL. Marinha do Brasil. Normas da autoridade marítima para obras, dragagens, pesquisa e lavra de minerais sob, sobre e às margens das águas jurisdicionais brasileiras: NORMAM 11/DPC. 2003. Disponível em: <https://www3.dpc.mar.mil.br/normam/N_11/normam11.pdf>. Acesso em: 05 ago. 2015. Capítulo 1, 0102, a) - Competência.

43 BRASIL. Marinha do Brasil. Normas da autoridade marítima para
As atividades que estão sob a competência da Autoridade Marítima, representada pelos seus diversos órgãos, são: obras em geral ${ }^{44}$; portos ou instalações portuárias, cais, píeres, molhes, trapiches, marinas ou similares ${ }^{45}$ que podem ou não ser precedidas de aterro que requer documentos adicionais que comprovem que não haverá danos à navegação; viveiros para aquicultura ${ }^{46}$, com uma breve indicação das competências do Ministério da Pesca nesse contexto; autorização para lançamento de petrechos para atração e/ou captura de pescado ${ }^{47}$; lançamento de cabos e dutos submarinos ou estruturas similares ${ }^{48}$; construção de pontes rodoviárias ou similares sobre águas ${ }^{49}$; plataformas e unidades de produção de petróleo ou gás ${ }^{50}$; flutuantes ou outras embarcações fundeadas não destinadas à navegação ${ }^{51}$. A AM não pre-

obras, dragagens, pesquisa e lavra de minerais sob, sobre e às margens das águas jurisdicionais brasileiras: NORMAM 11/DPC. 2003. Disponível em: $<$ https://www3.dpc.mar.mil.br/normam/N_11/normam11.pdf>. Acesso em: 05 ago. 2015. Capítulo 1, 0103.

44 BRASIL. Marinha do Brasil. Normas da autoridade marítima para obras, dragagens, pesquisa e lavra de minerais sob, sobre e às margens das águas jurisdicionais brasileiras: NORMAM 11/DPC. 2003. Disponível em: <https://www3.dpc.mar.mil.br/normam/N_11/normam11.pdf>. Acesso em: 05 ago. 2015. 0106.

45 BRASIL. Marinha do Brasil. Normas da autoridade marítima para obras, dragagens, pesquisa e lavra de minerais sob, sobre e às margens das águas jurisdicionais brasileiras: NORMAM 11/DPC. 2003. Disponível em: <https://www3.dpc.mar.mil.br/normam/N_11/normam11.pdf>. Acesso em: 05 ago. 2015. 0107.

46 BRASIL. Marinha do Brasil. Normas da autoridade marítima para obras, dragagens, pesquisa e lavra de minerais sob, sobre e às margens das águas jurisdicionais brasileiras: NORMAM 11/DPC. 2003. Disponível em: <https://www3.dpc.mar.mil.br/normam/N_11/normam11.pdf>. Acesso em: 05 ago. 2015. 0108.

47 BRASIL. Marinha do Brasil. Normas da autoridade marítima para obras, dragagens, pesquisa e lavra de minerais sob, sobre e às margens das águas jurisdicionais brasileiras: NORMAM 11/DPC. 2003. Disponível em: $<$ https://www3.dpc.mar.mil.br/normam/N_11/normam11.pdf $>$. Acesso em: 05 ago. 2015. 0109.

48 BRASIL. Marinha do Brasil. Normas da autoridade marítima para obras, dragagens, pesquisa e lavra de minerais sob, sobre e às margens das águas jurisdicionais brasileiras: NORMAM 11/DPC. 2003. Disponível em: $<$ https://www3.dpc.mar.mil.br/normam/N_11/normam11.pdf $>$. Acesso em: 05 ago. 2015. 0110.

49 BRASIL. Marinha do Brasil. Normas da autoridade maritima para obras, dragagens, pesquisa e lavra de minerais sob, sobre e às margens das águas jurisdicionais brasileiras: NORMAM 11/DPC. 2003. Disponível em: <https://www3.dpc.mar.mil.br/normam/N_11/normam11.pdf>. Acesso em: 05 ago. 2015. 0111.

50 BRASIL. Marinha do Brasil. Normas da autoridade marítima para obras, dragagens, pesquisa e lavra de minerais sob, sobre e às margens das águas jurisdicionais brasileiras: NORMAM 11/DPC. 2003. Disponível em: $<$ https://www3.dpc.mar.mil.br/normam/N_11/normam11.pdf $>$. Acesso em: 05 ago. 2015. 0113.

51 BRASIL. Marinha do Brasil. Normas da autoridade marítima para obras, dragagens, pesquisa e lavra de minerais sob, sobre e às margens das águas jurisdicionais brasileiras: NORMAM 
cisa emitir o seu parecer em casos de requerimentos de obras em rios não navegáveis. Diante dessas competências estabelecidas, nota-se uma preocupação central da atuação da AM nas atividades que possam gerar insegurança à navegação.

A despeito da competência central conectada à navegação, a Norman 11 prevê a necessidade de coordenação entre a AM, o Ministério da Pesca e órgãos ambientais. No entanto, os instrumentos previstos para essa coordenação são limitados, pois prepondera a centralidade da navegação diante de outras atividades. Por exemplo, a Norman prevê que o Ministério da Pesca deve encaminhar consulta à CP com jurisdição sobre a área onde se pretende realizar o projeto para que seja dado um parecer. Após manifestação contrária ou favorável à atividade da $\mathrm{CP}$, o processo é encaminhado ao DN para a apreciação dos aspectos de sua competência. A apreciação dos órgãos da Marinha está diretamente conectada à análise dos prejuízos que podem ser causados à navegação, de acordo com o seguinte artigo da Norman 11:

[...] nos espaços físicos intermediários entre áreas aquícolas ou seus conjuntos, circunscritos aos limites dos parques aquícolas, não será gerada nenhuma restrição de acesso e de tráfego, ou outra, devendo essa circunstância ser enunciada no projeto de delimitação dos parques e área aquícolas e ratificada no parecer do Representante da Autoridade Marítima. Caso haja necessidade de restrição a quaisquer atividades que venham afetar a segurança da navegação, a salvaguarda da vida humana no mar, a prevenção da poluição por embarcação e o ordenamento do tráfego aquaviário, deverá haver previsão no projeto específico encaminhado pelo MPA a anuência expressa no parecer conclusivo emitido pelo Representante da Autoridade Marítima [...]. Em situações especiais, onde houver comprometimento total da segurança da navegação e da preservação da normalidade do tráfego aquaviário, a princípio, não será emitido parecer favorável às instalações de criatórios, viveiros ou equipamentos similares utilizados na aquicultura. ${ }^{52}$

A Norman 11 faz menção à necessidade de coordenação das atividades nessa área com o Zoneamento Ecológico-Econômico e com o respectivo Plano de

11/DPC. 2003. Disponível em: <https://www3.dpc.mar.mil.br/ normam/N_11/normam11.pdf>. Acesso em: 05 ago. 2015, 0114.

52 BRASIL. Marinha do Brasil. Normas da autoridade marítima para obras, dragagens, pesquisa e lavra de minerais sob, sobre e às margens das águas jurisdicionais brasileiras: NORMAM 11/DPC. 2003. Disponível em: <https://www3.dpc.mar.mil.br/ normam/N_11/normam11.pdf>. Acesso em: 05 ago. 2015.
Gestão Costeira dos Planos de Gerenciamento Costeiro Estadual e Municipal. Entretanto, não há previsão específica de como essa coordenação ocorrerá a fim de promover a gestão integrada dos usos múltiplos da zona $\operatorname{costeira}^{53}$. É relevante apontar que há poucos Estados que tenham instituído o zoneamento estadual, instrumento central na gestão integrada das atividades, com destaque para os zoneamentos de São Paulo e do Ceará ${ }^{54}$. Ademais, muitos Estados também não elaboraram os seus Planos de Gerenciamento Costeiro Estadual ${ }^{55}$ ou normas relacionadas à pesca ${ }^{56}$, o que compartilha a

53 Entre os pontos destacados no VII Plano Setorial para os Recursos do Mar, aprovado pelo Decreto $\mathrm{n}^{\circ}$ 6.678, de 08 de dezembro de 2008, D.O.U de 09/12/2008, está a "A mitigação dos danos causados pela erosão costeira demandará estudos para a identificação, o dimensionamento e o impacto ambiental para viabilizar o uso dos granulados na reconstituição de perfis de praia". BRASIL. Decreto $n^{\circ}$ 6.678, de 8 de dezembro de 2008. Disponível em: <http:// www.planalto.gov.br/ccivil_03/_Ato2007-2010/2008/Decreto/ D6678.htm > . Acesso em: 05 ago. 2015. Ver sobre o tema: RUFINO, Gilberto d'Avila. Patrimônio costeiro e seus fundamentos jurídicos. In: MORAES, Antônio Carlos Robert; ZAMBONI, Adenilson (Org.). Subsídios para um projeto de gestão. Brasília: MMA, 2004. (Projeto Orla).

54 Sobre o tema, ver: SODRÉ, Marcelo Gomes. Zoneamento Ecológico-econômico e zoneamento costeiro: algumas polêmicas jurídicas In: GRANZIERA, Maria Luiza Machado; GONÇALVES, Alcindo (Org.). Os problemas da zona costeira no Brasil e no mundo. Santos: Universitária Leopoldianum, 2012. p. 116-141. p. 120.

55 Leis estaduais sobre o tema de zonas costeiras: SÃO PAULO. Lei $n^{\circ} 10.019$ de 3 de julbo de 1998. Dispõe sobre o Plano Estadual de Gerenciamento Costeiro e dá outras providências. Disponível em: <http://www.al.sp.gov.br/repositorio/legislacao/lei/1998/lei10019-03.07.1998.html>. Acesso em: 05 ago. 2015; CEARÁ. Lei no 13.796, de 30 de junho de 2006. Institui a Política Estadual de Gerenciamento Costeiro, e o Plano Estadual de Gerenciamento Costeiro e dá outras providências. Disponível em: <http:/ /www.al.ce.gov.br/ legislativo/legislacao5/leis2006/13796.htm>. Acesso em: 05 ago. 2015; ESPÍRITO SANTO. Lei ñ 5.816, de 22 de dezembro de 1998. Institui o Plano Estadual de Gerenciamento Costeiro do Espírito Santo. Disponível em: < http://www.meioambiente.es.gov.br/web/ Lei_5816.htm>. Acesso em: 05 ago. 2015. ver: RUFINO, Gilberto d'Ávila. Royalties do petróleo e diretos dos Municípios produtores: elementos para análise e discussão. Disponível em: <www.ijlitoral.org >. Acesso em: 05 nov. 2012; RUFINO, RUFINO, Gilberto d'Ávila. Royalties do petróleo para Municípios costeiros. Disponível em: <www.ijlitoral.org>. Acesso em: 11 nov. 2012.

56 Exemplos de normas estaduais sobre a pesca: SÃO PAULO. Lei $n^{\circ} 11.165$, de 27 de junho de 2002. Institui o Código de Pesca e Aqüicultura do Estado. Disponível em: < http://www.al.sp.gov.br/ repositorio/legislacao/lei/2002/lei-11165-27.06.2002.html>. Acesso em: 05 ago. 2015; RIO GRANDE DO SUL. Lei $n^{\circ} 11.886$, de 2 de janeiro de 2003. Dá nova redação ao artigo $1^{\circ}$. da Lei Estadual n. 8.676, de 14 de julho de 1988, que determina a obrigatoriedade de demarcação das áreas de pesca, lazer ou recreação, nos Municípios com orla marítima, lacustre e fluvial Disponível em: $<$ http://www. legislacao.sefaz.rs.gov.br/Site/Document.aspx?inpKey=102719\&in pCodDispositive $=\&$ inpDsKeywords=> . Acesso em: 05 ago. 2015; RIO DE JANEIRO. Lei no 2.423, de 17 de agosto de 1995. Disci- 
responsabilidade pelas lacunas identificadas na gestão costeira. Há, também, procedimentos que a prefeitura municipal deve intervir juntamente com a Autoridade Marítima ${ }^{57}$.

Um projeto de lei de 2013 tenta modificar a lógica da gestão do meio ambiente costeiro, sobretudo da faixa marítima, criando o Bioma marinho ${ }^{58}$. Essa mudança poderia resultar na gestão integrada da zona costeira e da zona oceânica, tendo como objeto central de tutela o bioma e não as atividades desenvolvidas nessa área. O que se observa hoje constitui a gestão costeira da faixa marinha centralizada na navegação. Todavia, trata-se apenas de projeto de lei que ainda está em tramitação, podendo levar anos para sua aprovação ou sofrer emendas que desnaturem a sua estrutura atual.

A gestão integrada depende não apenas da atividade dos órgãos federais, como a Autoridade Marítima, mas também dos órgãos estaduais e municipais que detêm competências constitucionais ligadas às atividades realizadas na zona costeira que envolvam interesses regional ou local ${ }^{59}$. A gestão deve ter como base as peculiaridades do meio ambiente marinho e das atividades desenvolvidas na área, sem concentração específica em uma das atividades.

Além das insuficiências institucionais apontadas, existem limites normativos que dificultam a gestão integrada da zona costeira brasileira, alguns deles serão destacados a seguir.

\section{Os LIMITES NORMATIVOS}

No Brasil, a normatização da zona costeira ocorreu de forma desordenada e mais centralizada na peculiari-

plina a pesca nos cursos d'água do Estado do Rio de Janeiro e adota outras providências. Disponível em: <http://gov-rj.jusbrasil.com. br/legislacao/150735/lei-2423-95>. Acesso em: 05 ago. 2015.

57 BRASIL. Ministério de Minas e Energia. Departamento Nacional de Produção Mineral. Portaria n 441, de 11 de dezembro de 2009. Disponível em: <http://www2.dnpm.gov.br/conteudo.asp?IDSe $\mathrm{cao}=67 \&$ IDPagina $=84 \&$ IDLegislacao $=589>$. Acesso em: 5 ago. 2015.

58 BRASIL. Camara dos Deputados. Projeto de lei 6969 de 17 de dezembro de 2013. Disponível em: <http://www.camara.gov.br/ proposicoesWeb/fichadetramitacao?idProposicao $=604557>$. Acesso em: 5 ago. 2015.

59 FREITAS, Vladimir Passos de; FREITAS, Dario Almeida Passos de. A proteção do meio ambiente na zona costeira. In: GRANZIERA, Maria Luiza Machado; GONÇALVES, Alcindo (Org.). Os problemas da zona costeira no Brasil e no mundo. Santos: Universitária Leopoldianum, 2012. p. 257-277. p. 260. dade de cada atividade desenvolvida nessa área do que na gestão sustentável dos usos múltiplos da zona costeira. Há quantidade expressiva de normas, por vezes contraditórias, aplicáveis a um mesmo espaço. Os limites decorrentes desse fenômeno podem ser constatados tanto pela possibilidade de ocupação desordenada da zona costeira em razão da utilização imprecisa de conceitos (A) como pela necessidade de restrição geral à construção no litoral (B).

A) A possibilidade de ocupação desordenada da zona costeira em razão da utilização imprecisa de conceitos

A possibilidade de ocupação desordenada da zona costeira tem como uma de suas causas a utilização imprecisa, pelos tribunais nacionais, dos seguintes termos: "bem de uso comum do povo"; "bens da União" e "patrimônio nacional". Em alguns casos, não é realizada nenhuma diferenciação entre os termos que acabam sendo empregados como sinônimos. Em outros, a aplicação legislativa acaba sendo correta, porém, por causa da utilização de argumentos confusos e pouco precisos, as decisões abrem margem à interposição de recursos, o que resulta em um prolongamento da ação judicial por um período imcompatível com a lógica de preservação da zona costeira. Dessa forma, a maior precisão com relação ao regime jurídico aplicável à zona costeira pode permitir maior segurança jurídica às pessoas públicas e privadas que gerem e que ocupem a região. Para tanto, é fundamental definir os três termos supracitados, demonstrar a utilização imprecisa dos conceitos nas decisões e identificar em que medida esse emprego ambíguo contribui para a ocupação desordenada da zona costeira.

Com relação ao termo patrimônio nacional, o $\$ 4^{\circ}$ do art. 225 da Constituição Federal seleciona alguns biomas nacionais que, por serem essenciais à preservação da biodiversidade, necessitam de proteção diferenciada. Desse modo, o citado dispositivo determina que: "a Floresta Amazônica brasileira, a Mata Atlântica, a Serra do Mar, o Pantanal Mato-Grossense e a Zona Costeira são patrimônio nacional, e sua utilização far-se-á, na forma da lei, dentro de condições que assegurem a preservação do meio ambiente, inclusive quanto ao uso dos recursos naturais" ${ }^{\prime 0}$. Mas, qual seria o quadro jurí-

60 Cf.: BRASIL. Constituição (1988). Constituição da República Federativa do Brasil. Disponível em: <http://www.planalto.gov.br/ ccivil_03/constituicao/constituicao.htm>. Acesso em: 05 ago. 2014. 
dico aplicável a um bem elevado ao status de patrimônio nacional?

Entende-se que o status de patrimônio nacional é uma qualificação que se sobrepõe ao titulo de propriedade, atribuído a algumas áreas reconhecidamente relevantes para a manutenção dos Biomas nacionais para as gerações futuras. Porquanto, exige-se do possuidor, por meio de lei, a adoção de cuidados que assegurem a preservação dos recursos naturais ali existentes ${ }^{61}$. Não haveria qualquer relação direta com o pertencimento à União ou mesmo com a possibilidade de fruição indiscriminada da zona costeira por toda a coletividade.

Por outro lado, o caput do mesmo art. 225 dispõe que o meio ambiente ecologicamente equilibrado é bem de uso comum do povo que deve ser preservado para as gerações presentes e futuras. ${ }^{62}$ Os bens de uso comum do povo são caracterizados por pertencerem à coletividade, serem inalienáveis e não permitirem usucapião, não obstante possam ser utilizados mediante cobrança de valor. A legislação brasileira infraconstitucional indica como exemplos: os rios, mares, estradas, ruas, praças e a praia. ${ }^{63}$

Os bens da União, por sua vez, estão elencados no art. 20 da Constituição Federal. Entre eles, interessa para essa análise citar os seguintes:

\begin{abstract}
IV - as ilhas fluviais e lacustres nas zonas limítrofes com outros países; as praias marítimas; as ilhas oceânicas e as costeiras, excluídas, destas, as que contenham a sede de Municípios, exceto aquelas áreas afetadas ao serviço público e a unidade ambiental federal, e as referidas no art. 26, II;
\end{abstract}

61 Cf.: "Patrimônio Nacional - conjunto de bens pertencentes à Nação Brasileira, de uso comum, cujas características especiais, de valor histórico, paisagístico, sócio-econômico, ambiental ou outras características congêneres, lhe conferem "status" especial, exigindo a preservação de suas condições básicas de existência". BRASIL. Ministério do Meio Ambiente. Plano Nacional de Gerenciamento Costeiro (PNGC II). 1997. Disponível em: < http://www.mma. gov.br/images/arquivo/80033/0.PNGC-II97\%20Resolucao05_97. CIRM.pdf>. Acesso em: 15 out. 2014. SILVA, Solange Teles da. Direito fundamental ao meio ambiente ecologicamente equilibrado: avanços e desafios. Revista de Direito Ambiental, São Paulo, v. 12, n. 48, p. 225-245, out./dez. 2007. p. 233).

62 Cf.: BRASIL. Constituição (1988). Constituição da República Federativa do Brasil. Disponível em: <http://www.planalto.gov. br/ccivil_03/constituicao/constituicao.htm>. Acesso em: 05 ago. 2014).

63 BRASIL, Lei $n^{\circ} 10.406$, de 10 de janeiro de 2002. Disponível em: <http://www.planalto.gov.br/ccivil_03/leis/2002/110406.htm >. Acesso em: 05 ago. 2015. Artigo 99 e seguintes. BRASIL. Lei n 7.661 de 16 de maio de 1998. Disponível em: <http://www.planalto.gov.br/ ccivil_03/leis/17661.htm>. Acesso em: 04 ago. 2015. Artigo 10.
VI - o mar territorial;

VII - os terrenos de marinha e seus acrescidos;[...]

Dessa forma, tanto a praia, como o mar territorial e os terrenos da marinha estão contidos nas classificações de "bem de uso comum do povo" e "bem da União".

Sobre esse tema, o Decreto 5.300 define a zona costeira em seu artigo $3^{\circ}$ como região de interação entre mar, ar e terra, compreendendo uma faixa marítima de até 12 milhas náuticas e uma faixa terrestre que corresponde aos limites de determinados Municípios que sofrem influencia dos fenômenos ocorrentes na zona costeira. Posto isso, identifica-se que, em relação à faixa marítima, é pacífica sua natureza jurídica como bem da União por expressa previsão constitucional. Contudo, quanto à faixa terrestre, não há precisão com relação ao que pode ou não ser apropriado por particulares. Há interpretações, por exemplo, no sentido de que a classificação da zona costeira como patrimônio nacional não impede a sua apropriação por particulares. A designação como patrimônio nacional somente ressalta a necessidade de proteção específica da região em razão de sua importância ecossistêmica ${ }^{64}$.

A esse respeito, o STF se posicionou em sede de Recurso Extraordinário interposto pelo Estado de São Paulo contra decisão do Tribunal de Justiça do Estado de São Paulo que o condenou ao pagamento de indenização a particular que teve seu direito de propriedade limitado por meio da criação de uma Estação Ecológica. No caso, a Suprema Corte acenou positivamente quanto ao exercício dos direitos decorrentes da propriedade de área localizada em uma região integrante da zona costeira, dizendo que essa faixa não seria propriedade da União:

[...] o preceito consubstanciado no art. 225, par. $4^{\circ}$, da Carta da República, além de não haver convertido em bens públicos os imóveis particulares abrangidos pelas florestas e pelas matas nele referidas (Mata atlântica, Serra do Mar, Floresta Amazônica brasileira), também não impede a utilização, pelos próprios particulares, dos recursos naturais existentes naquelas áreas que estejam sujeitas ao domínio privado, desde que observadas as prescrições legais e respeitadas as condições necessárias à preservação ambiental ${ }^{65}$.

64 FREITAS, Vladimir Passos de; FREITAS, Dario Almeida Passos de. A proteção do meio ambiente na zona costeira. In: GRANZIERA, Maria Luiza Machado; GONÇALVES, Alcindo (Org.). Os problemas da zona costeira no Brasil e no mundo. Santos: Universitária Leopoldianum, 2012. p. 257-277. p. 258.

65 BRASIL. Supremo Tribunal Federal. Recurso Extraordinário. 
Uma forma de compatibilizar esse entendimento firmado pela Suprema Corte com a disposição prevista no caput do art. $225 \mathrm{da} \mathrm{CF}$, em relação à parte terrestre da zona costeira, seria mitigar as características do bem de uso comum do povo por meio de uma adequação aos planos de zoneamento territorial dos Municípios. Outra alternativa seria coincidir os limites terrestres da zona costeira às dimensões terrestres da orla marítima, descrita no art. 23, Decreto 5.300/2004. Embora essa previsão requeira mudança legislativa, seria de maior coerência, pois permitiria um gerenciamento mais intenso das áreas diretamente influenciadas pela faixa marítima, prevenindo a degradação provocada por grandes projetos imobiliários.

Foram encontradas algumas decisões em consonância com esse entendimento, a exemplo da seguinte, que versa sobre construção realizada em área de promontório, localizado na Mata Atlântica, em dimensões superiores às permitidas pelo licenciamento concedido pelo órgão ambiental estadual:

\begin{abstract}
[...] é em nome do interesse coletivo que insistimos na proteção da Mata Atlântica, como meio para salvaguardar a proteção da diversidade biológica, das nascentes, da qualidade e disponibilidade da água. Em larga escala, somados os impactos desta propriedade com a propriedade vizinha, e ainda a outra e mais aquela, as pequenas ações exploratórias particulares acabam produzindo uma grande e comunitária perda generalizada, duradoura e de difícil recuperação. Não se trata de radicalizar a dicotomia entre o público e o privado, espoliando o bem particular em nome de um suposto bem coletivo teórico que ignora a pessoa. E não se trata de decidir pela supremacia da individualidade ignorando o impacto social das intervenções. Esta é uma falsa dicotomia. ${ }^{66}$
\end{abstract}

RE 134297 SP. Primeira Turma. Recorrente: Estado de São Paulo. Recorridos: Paulo Ferreira Ramos e Cônjuge. Relator: Min. Celso de Mello. Brasília, 13 de junho de 1995. Disponível em<http://stf. jusbrasil.com.br/jurisprudencia/745994/recurso-extraordinario-re134297-sp>. Acesso em: 05 ago. 2015.

66 Ver BRASIL. Tribunal Federal da Quarta Região. Apelação Cível. AC 5000228-69.2010.404.7216/SC. Vice-Presidência. Apelante: Orlando Ivã larionoff. Apelado: IBAMA. Relator: Des. Federal Luiz Fernando Wowk Pentead. Porto Alegre, 02 de outubro de 2014. Disponível em: <http:// trf-4.jusbrasil.com.br/jurisprudencia/143419040/apelacao-civelac-50002286920104047216-sc-5000228-6920104047216/inteiroteor-143419116>. Acesso em: 5 ago. 2015. No mesmo sentido: BRASIL. Tribunal Federal da Quarta Região. Recurso Especial em Apelação Cível. AC no 0000959-87.2009.404.7216/SC. Terceira Turma. Recorrente: IBAMA. Recorrido: Territorial Garopaba Ltda. Relator(a): Des. Maria Lúcia Luz Leiria. Porto Alegre, 19 de agosto de 2012. Disponível em: <http://www.jusbrasil.com.br/ diarios/64854576/trf-4-judicial-17-01-2014-pg-75>. Acesso em: 5
Em contrapartida, verifica-se que essa posição não é perene e que ainda há tribunais que utilizam os conceitos de patrimônio nacional e de bem de uso comum do povo de forma imprecisa. Nesse sentido, segue o trecho abaixo da ementa de Agravo de Instrumento interposto pelo IBAMA contra decisão que reconhecia a competência estadual para julgar controvérsia relativa a construção realizada em costão rochoso localização em Área de Proteção Ambiental instituída pelo Estado do Rio de Janeiro. Nesse caso, já citado anteriormente neste artigo, o argumento utilizado pelo relator no seu voto, transcrito abaixo, não é claro em relação aos motivos que comprovaram que o interesse é de âmbito nacional:

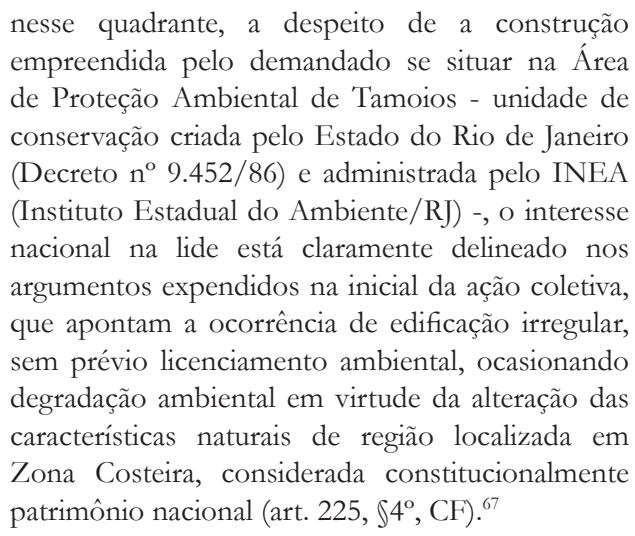

Ilustrativamente, cita-se também trecho do voto da relatora, que foi seguido pelos demais desembargadores, em Apelação Cível em que donos de quiosques construídos em região de restinga questionavam decisão da administração pública que determinava a retirada das construções. A magistrada incorreu em impropriedade ao afirmar que a zona costeira é bem público da União:

ago. 2015;. BRASIL. Tribunal Regional Federal da Quarta Região. Apelação Cível. AC 0004571-88.2003.404.7201/SC. Terceira Turma. Apelante IBAMA; Ministério Público Federal. Apelado: Município de Itapoá/SC. Relator (a): Des. Federal Maria Lúcia Luz Leiria. Porto Alegre, 1 de fevereiro de 2011. Disponível em: <http://trf-4. jusbrasil.com.br/jurisprudencia/18575379/apelacao-civel-ac-7201sc-0004571-8820034047201-trf4/inteiro-teor-18575380>. Acesso em: 5 ago. 2015;. BRASIL. Tribunal Regional Federal da Quinta Região. Agravo de Instrumento. AGTR 107968/CE - 000966867.2010.4.05.0000. Primeira Turma. Agravante: Ministério Público Federal. Agravado: Construtora Waldyr Diogo Ltda e outros. Relator: Des. Federal Francisco Cavalcanti. Recife, 03 de maio de 2012. Disponível em: <http://www.jusbrasil.com.br/diarios/37330603/ trf-5-jud-25-05-2012-pg-57>. Acesso em: 5 ago. 2015.

67 BRASIL. Tribunal Regional Federal da Segunda Região. Agravo de Instrumento. AG 2012.02.01.004859-3. Quinta Turma Especializada. Agravante: IBAMA. Agravado: Thiago Cunha de Almeida. Relator: Des. Federal Marcus Abraham. Rio de Janeiro, 29 de janeiro de 2013. Disponível em: <http://trf-2.jusbrasil.com.br/jurisprudencia/23376162/ag-agravo-de-instrumento-ag-201202010048593-trf2/ inteiro-teor-111700881>. Acesso em: 5 ago. 2015 
[...] não obstante as zonas costeiras serem bens públicos da União, é certo também que a Zona Costeira, nos termos do art. 225, $\int 4^{\circ}$, da $\mathrm{CF} / 88$, é, ao lado da Floresta Amazônica Brasileira, da Mata Atlântica, da Serra do Mar, do Pantanal MatoGrossense, uma área definida pela própria Carta Magna, diante da expressiva diversidade biológica destes biomas, como "patrimônio nacional", o que assinala que os regionalismos não devem se sobrepor aos interesses ambientais nacionais. Em outras palavras, ainda que exista sim um interesse estadual, distrital ou municipal, é certo que sempre existirá, nestes ecossistemas, um interesse de extensão em todo o território nacional. ${ }^{68}$

Portanto, conforme restou demonstrado, ainda há casos em que os conceitos de bem comum do povo, bem da União e patrimônio nacional são utilizados de forma indiscriminada e confusa, enfraquecendo a motivação das decisões judiciais, possibilitando interpretações diversas e dando margem à interposição de recursos. Esse fato reduz a proteção ambiental, tanto em âmbito administrativo, pois os órgãos gestores municipais, estaduais e federal não possuem parâmetros claros de atuação, quanto em âmbito judicial, já que cada órgão julgador desenvolve uma hermenêutica diferente sobre os institutos jurídicos.

Em relação à parte marítima da zona costeira, é relevante assinalar a necessidade de estipular uma restrição geral de construir na faixa litoral, que não existe no quadro normativo nacional e tem gerado efeitos positivos

68 BRASIL. Tribunal Regional Federal da Segunda Região. Apelação Cível. AC 200651080008781. Sexta Turma Especializada. Apelante: Denival da Silva Ferraz e outros. Apelado União Federal, Município de Araruama; IBAMA. Relator (a): Des. Federal Carmen Silvia Lima de Arruda. Rio de Janeiro, 31 de março de 2014. Disponível em: <http://trf-2.jusbrasil.com.br/jurisprudencia/25091049/acapelacao-civel-ac-200651080008781-trf2/inteiro-teor-120459970>. Acesso em: 5 ago. 2015 (nesse caso, a Juíza afirmou que toda a zona costeira faz parte dos bens da União, ou seja, tanto a parte marítima quanto a parte terrestre da zona costeira brasileira — que engloba a região de alguns Municípios — faria parte dos bens da União). De forma semelhante: BRASIL. Tribunal Regional Federal da Segunda Região. Agravo de Instrumento. AG 2012.02.01.004859-3. Quinta Turma Especializada. Agravante: IBAMA. Agravado: Thiago Cunha de Almeida. Relator: Des. Federal Marcus Abraham. Rio de Janeiro, 29 de janeiro de 2013. Disponível em: <http://trf-2. jusbrasil.com.br/jurisprudencia/23376162/ag-agravo-de-instrumento-ag-201202010048593-trf2/inteiro-teor-111700881>. Acesso em: 5 ago. 2015; BRASIL. Tribunal Regional Federal da Segunda Região. Agravo de Instrumento. AG 2012.02.01.005724-7. Quinta Turma Especializada. Agravante: Ministério Público Federal. Agravado: Aluísio Leal Santos. Relator: Des. Federal. Marcus Abraham. Rio de Janeiro, 28 de maio de 2013. Disponível em: < http://trf-2. jusbrasil.com.br/jurisprudencia/23610800/ag-agravo-de-instrumento-ag-201202010057247-trf2/inteiro-teor-111757639>. Acesso em: 5 ago. 2015. em países que adotaram essa política.

B) A necessidade de restrição geral de construir na zona costeira brasileira

No Brasil não há uma restrição geral de construir no litoral brasileiro. Essa omissão possibilita que cada Município preveja regras locais de ocupação da zona costeira. Algumas previsões legais contribuem à proteção geral dessa zona, como a propriedade pública dos terrenos de marinha ou a proteção ao meio ambiente, mas essa proteção não cobre uma dimensão específica. Nesse contexto, é essencial compreender os motivos da inexistência de proteção geral de uma faixa da zona costeira e a contribuição dos terrenos de marinha e das normas ambientais para limitar a atividade da construção civil na zona costeira.

O primeiro projeto legislativo do Plano Nacional para o Gerenciamento Costeiro, o Projeto n. ${ }^{\circ}$ 3.759/1984, previa uma distância específica de faixa litorânea de 12 milhas náuticas e de $12 \mathrm{~km}$ de largura na faixa terrestre. ${ }^{69}$ Essa medida não foi adotada no projeto seguinte, o Projeto 216-A/1987, que resultou na Lei n. ${ }^{\circ}$ 7.661/1988. Na França, por exemplo, o artigo L. 146-4III do código de urbanismo prevê 100 metros de faixa litorânea onde não é possível construir. ${ }^{70}$ Outros países preveem uma faixa litorânea de proteção da zona costeira de mais de 50 metros $^{71}$. No Brasil não há uma lei geral que possa interditar a construção na faixa terrestre da zona costeira, pois a competência para o planejamento do espaço urbano pertence aos municípios.

Há Estados que possuem normas sobre esse assunto, como a Constituição do Estado da Paraíba, que prevê que os Municípios devem seguir alguns parâmetros específicos para construir na zona costeira. São eles: nas zonas já construídas, é obrigatório respeitar uma distân-

69 MACHADO, Paulo Affonso Leme. Direito ambiental brasileiro. 21. ed. São Paulo: Malheiros, 2012. p. 1070.

70 Artigo L146-4-III do Código de Urbanismo francês: "En dehors des espaces urbanisés, les constructions ou installations sont interdites sur une bande littorale de cent mètres à compter de la limite haute du rivage ou des plus hautes eaux pour les plans d'eau intérieurs". Sobre esse tema ver LOITZENBAUER, Ester; MENDES, Carlos André Bulhões. A faixa terrestre da zona costeira e os recursos hídricos na região hidrográfica do Atlântico Sul. Revista de Gestão Costeira Integrada, Lisboa, v. 14, n. 1, p. 81-94, mar. 2014. p. 349.

71 Sobre esse tema ver: NOIN Daniel. La population des littoraux du monde. L'information géographique, Paris, v. 63, n. 2, p. 65-73, 1999. Disponível em: <http://www.persee.fr/web/revues/home/prescript/article/ingeo_0020-0093_1999_num_63_2_2632>. Acesso em: 4 ago. 2015. 
cia de 12,90 metros, enquanto, para as zonas que não possuem construções, é necessário respeitar a distância de $150 \mathrm{~m}$ do litoral marítimo ${ }^{72}$. Porém, essa não é a realidade de todo o país.

Alguns instrumentos podem contribuir com a proteção da zona costeira. Nesse sentido, os terrenos de marinha - que existem desde o século XIX, quando o país ainda era colônia de Portugal — são um dos instrumentos mais interessantes no direito brasileiro. Trata-se de um mecanismo que garante a propriedade da União sobre o litoral.

Os terrenos de marinha estão previstos na CF como bem público, sob a propriedade a União ${ }^{73}$. O Decreto-lei n. ${ }^{\circ}$ 9.760/46 prevê, em seu artigo $2^{\circ}$, uma distância horizontal do terreno de marinha fixado a 33 metros em direção à parte terrestre, com base em uma linha específica $^{74}$ definida pelo órgão público competente pela gestão dos bens da União ${ }^{75}$. A importância dessa zona decorre de sua fixação como propriedade da União: por consequência, em relação a essa área, aplica-se e é exercido um regime jurídico que deve ser seguido pelas pessoas privadas que se encontram sob uma concessão. Assim, se o Estado decide utilizar essa região, ele não precisa indenizar aqueles aos quais tenha sido concedida a utilização dessa região. As pessoas privadas podem utilizar os terrenos de marinha, mas devem pagar retribuição à União. Ademais, esta pode conceder a utilização

72 MACHADO, Paulo Affonso Leme. Direito ambiental brasileiro. 21 ed. São Paulo: Malheiros, 2012, p. 1069.

73 BRASIL. Constituição (1988). Constituição da República Federativa do Brasil. Disponível em: < http://www.planalto.gov.br/ccivil_03/constituicao/constituicao.htm>. Acesso em: 05 ago. 2014, artigo 20, inciso VII.

74 BRASIL. Decreto-lei no 9.760, de 05 de setembro de 1946. Disponível em: <http://www.planalto.gov.br/ccivil_03/decreto-lei/del9760. htm>. Acesso em: 05 ago. 2015. BRASIL. Constituição (1988). Constituição da República Federativa do Brasil. Disponível em: <http:/ / www.planalto.gov.br/ccivil_03/constituicao/constituicao.htm>. Acesso em: 05 ago. 2014artigo 20, inciso VII.

75 Secretaria do Patrimônio da União (SPU). Alguns casos postulando a mudança dessa linha já foram submetidos aos tribunais nacionais, pois os proprietários não estão de acordo que essa linha seja medida de modo unilateral pela administração pública. Ver sobre o tema: BRASIL. Tribunal Regional Federal da Quarta Região. Acordão. Processo 1998.7204.003633-7. Terceira Turma. Relator: Des. Federal Fernando Quadros. Porto Alegre, 30 de novembro de 2010; BRASIL. Supremo Tribunal Federal. Medida Cautelar na Ação Direta de Inconstitucionalidade. ADI 4264 MC/PE. Tribunal Pleno. Requerente: Assembléia Legislativa do Estado de Pernambuco. Requerido: Presidente da República. Relator: Min. Ricardo Lewandowski. Brasília, 16 de março de 2011. Disponivel em: <http://redir.stf.jus.br/ paginadorpub $/$ paginador.jsp?doc $\mathrm{TP}=\mathrm{AC} \& \operatorname{doc} \mathrm{ID}=623508>$. Acesso em: 05 ago. 2015. dessa área a particulares que ofereçam serviço público, como os serviços portuários ${ }^{76}$. A obrigação de pagar uma taxa de ocupação está prevista no Decreto-Lei e a sua legalidade foi confirmada em muitas decisões judiciais $^{77}$. Atualmente, existem projetos de Emenda Constitucional e de revisão legislativa que tentam extinguir os terrenos de marinha; até o momento, esses projetos não põem fim ao regime dos terrenos de marinha ${ }^{78}$. Alguns deles baseiam-se no argumento de que esse bem deve ser privatizado, pois seu pertencimento à esfera públi-

76 A reserva de território para o uso portuário segundo o Programa Geral de Autorizações da Agência Nacional de Transportes em vias navegáveis (ANTAQ). Ver sobre o tema: AGENCIA NACIONAL DE TRANSPORTES AQUAVIARIOS. PGO Plano Geral de Outorgas: apresentações. Disponível em : <http://www.antaq.gov. br/portal/Portos_PGO.asp>. Acesso em 10 set. 2014.

77 BRASIL. Tribunal Regional Federal da Segunda Região. Apelação/Reexame Necessário. APELRE 200851020028899 RJ. Sexta Turma Especializada. Apelante: União Federal. Apelado: Leonardo Almendra Honorato e Outros. Relator (a). Des. Federal: Carmen Silvia Lima Arruda. Rio de Janeiro, de 2014. Disponível em: <http://trf-2.jusbrasil.com.br/jurisprudencia/160029380/ apelacao-reexame-necessario-apelre-200851020028899-rj/inteiroteor-160029517>. Acesso em: 06 ago. 2015; BRASIL. Superior Tribunal de Justiça. Recurso Especial. Resp. $n^{\circ}$ 1183546/ES. Segunda Turma. Recorrente: S/A A Gazeta e Outros. Recorrido: União. Relator: Min. Mauro Campbel Marques. Brasília, 08 setembro de 2010. Disponível em: <http://stj.jusbrasil.com.br/jurisprudencia/16376533/recurso-especial-resp-1183546-es-2010-0040958-3/ relatorio-e-voto-16978062>. Acesso em: 05 ago. 2015.

78 Por exemplo: BRASIL. Câmara dos deputados. Projeto de Emenda Constitucional $n^{\circ}$ 603, de 1998. Disponível em: <http://www2. camara.leg.br/atividade-legislativa/comissoes/comissoes-temporarias/especiais/52a-legislatura/pec-603-98-terrenos-de-marinha $>$. Acesso em 06 ago. 2015; BRASIL. Câmara dos deputados. Projeto de Emenda Constitucional $n^{\circ}$ 53, de 2007. Disponível em: <http:// www.camara.gov.br/proposicoesWeb/fichadetramitacao?idPropo sicao $=349704>$. Acesso em 06 ago. 2015; BRASIL. Senado Federal. Projeto de Emenda Constitucional $n^{\circ} 56$, de 2009. Disponível em: $<$ http://www.senado.leg.br/atividade/materia/detalhes.asp?p_ cod_mate $=95166>$. Acesso em 06 ago. 2015; BRASIL. Câmara dos deputados. Projeto de Emenda Constitucional n ${ }^{\circ} 39$, de 2011. Disponível em: <http://www.camara.gov.br/proposicoesWeb/fichadetramitac ao?idProposicao=508965>. Acesso em 06 ago. 2015; BRASIL. Câmara dos deputados. Projeto de lei $n^{\circ}$ 6623, de 2006. Disponível em: $<$ http://www.camara.gov.br/proposicoesWeb/fichadetramitacao ?idProposicao=313821>. Acesso em 06 ago. 2015; BRASIL. Câmara dos deputados. Projeto de lei $n^{\circ}$ 6752, de 2010. Disponível em: $<$ http://www.camara.gov.br/proposicoesWeb/fichadetramitacao ?idProposicao=465829>. Acesso em 06 ago. 2015; BRASIL. Câmara dos deputados. Projeto de lei $n^{0}$ 1082, de 2011. Disponível em: $<$ http://www.camara.gov.br/proposicoesWeb/fichadetramitacao?i dProposicao=498619>. Acesso em 06 ago. 2015; BRASIL. Senado Federal. Projeto de Emenda Constitucional $n^{\circ}$ 256, de 2011. Disponível em: <http://www.senado.gov.br/atividade/materia/detalhes. asp?p_cod_mate $=100239>$. Acesso em 06 ago. 2015; BRASIL. Câmara dos deputados. Projeto de lei $n^{0} 1117$, de 2011. Disponível em: <http://www.camara.gov.br/proposicoesWeb/fichadetramitacao?i dProposicao=498959> . Acesso em 06 ago. 2015. 
ca deu-se em um contexto de necessidade de segurança na zona costeira durante a colonização - situação inexistente atualmente. Outros projetos sustentam que os terrenos de marinha deveriam ser considerados como propriedade dos Municípios ou dos Estados e não da União $^{79}$. Os proprietários de terrenos ligados a essas regiões argumentam que já pagam os impostos atinentes à propriedade e que não devem pagar também o foro, taxa relacionada com a ocupação de terrenos públicos ${ }^{80}$.

Defende-se que, de forma contrária ao acima descrito, os projetos deveriam ter feito proposições para aumentar as funções dos terrenos de marinha. Por exemplo, eles poderiam ter sugerido a integração da função de proteção ao meio ambiente ou de planejamento urbano de forma a contribuir com o planejamento da zona costeira, o que não foi feito ${ }^{81}$. Portanto, seria interessante que os terrenos de marinha fossem definidos de forma mais abrangente concedendo-lhes atribuições mais amplas do que sua atual função de proteção da navegação e da segurança da zona costeira. Destaca-se o fato de que os terrenos de marinha fazem parte da zona costeira e, por esse motivo, também são considerados patrimônio nacional ${ }^{82}$. Por esse motivo, essa área não deve ser protegida somente por leis federais, mas igualmente pelas normas locais, como o Plano Diretor da Cidade.

A zona costeira pode ser protegida ainda pelas normas ambientais ${ }^{83}$ e por dispositivos sobre o urbanismo.

79 BRASIL. Senado Federal. Projeto de Emenda Constitucional n ${ }^{\circ}$ 256, de 2011. Disponível em: <http://www.senado.gov.br/atividade/materia/detalhes.asp?p_cod_mate $=100239>$. Acesso em 06 ago. 2015; BRASIL. Câmara dos deputados. Projeto de Emenda Constitucional $n^{\circ}$ 39, de 2011. Disponível em: <http://www.camara.gov.br/proposicoesWeb $/$ fichadetramitacao?idProposicao $=508965>$. Acesso em 06 ago. 2015.

80 BRASIL. Câmara dos deputados. Projeto de lei ñ 6752, de 2010. Disponível em: <http://www.camara.gov.br/proposicoesWeb/fic hadetramitacao?idProposicao=465829> . Acesso em 06 ago. 2015.

81 Para um estudo dos projetos ver: ARZABE, Jorge. Gestão da zona costeira e os terrenos de marinha. 2011. 60 f. Trabalho de Conclusão de Curso (Especialista) - Curso Intensivo de Pós-Graduação em Administração Pública, Programa FGV Management, Fundação Getúlio Vargas, Brasília, 2011. p. 31.

82 Sobre o tema ver: RUFINO, Gilberto d'Avila. Patrimônio costeiro e seus fundamentos jurídicos. In: MORAES, Antônio Carlos Robert; ZAMBONI, Adenilson (Org.). Subsídios para um projeto de gestão. Brasília: MMA, 2004. (Projeto Orla). p. 65 e ss.

83 ALMEIDA, José Mauro de Lima O. de. Terrenos de marinha, proteção ambiental e as cidades. Belém: Paka-Tatu, 2008. p. 54. DE FREITAS, Vladimir Passos. FREITAS, Vladimir Passos de; FREITAS, Dario Almeida Passos de. A proteção do meio ambiente na zona costeira. In: GRANZIERA, Maria Luiza Machado; GONÇALVES,
De maneira geral, os terrenos de marinha não são considerados como áreas de proteção permanente ou unidades de conservação. Em contrapartida, como há áreas protegidas localizadas na zona costeira, esse território pode ser protegido por normas ambientais. Um caso interessante que ilustra essa possibilidade de proteção ocorreu na Ação Civil Pública, proposta pelo Ministério Público para a demolição de alguns prédios que tinham sido construídos numa área de proteção permanente. O juiz confirmou que as construções não poderiam ter sido realizadas nas áreas de proteção de Saco do Cais, de Paraty-Mirim — situado na cidade de Paraty —, porque se tratava de Área de Proteção Permanente conhecida como Cairuçu e, consequentemente, faltava a autorização do órgão ambiental competente para a construção civil. A decisão afirma que "[...] essa atitude causou prejuízos ao meio ambiente, pois, em razão da construção desses edifícios, houve uma mudança das características naturais da zona costeira" ${ }^{\prime 4}$. Ademais, é interessante apontar que alguns tribunais, em matéria ambiental, já se declararam competentes para julgar ações relacionadas a terrenos de marinha ${ }^{85}$.

Alcindo (Org.). Os problemas da zona costeira no Brasil e no mundo. Santos: Universitária Leopoldianum, 2012. p. 257-277.

84 “"...] esse ato causou danos ao meio ambiente, uma vez que, em decorrência das construções, não obstante estivessem embargadas, foram alteradas as características naturais da zona costeira", BRASIL. Tribunal Regional Federal da Segunda Região. Ação Cível. AC n. ${ }^{\circ}$ 487271. Sexta Turma especializada. Rio de Janeiro, em 19 de março de 2012. No mesmo sentido ver: BRASIL. Tribunal Regional Federal da Segunda Região. Ação Cível. AC 585795. Sétima turma especializada. Rio de Janeiro, 30 de outubro de 2013; ADI 4264 MC/PE. Tribunal Pleno. Requerente: Assembléia Legislativa do Estado de Pernambuco. Requerido: Presidente da República. Relator: Min. Ricardo Lewandowski. Brasília, 16 de março de 2011. Disponivel em: <http://redir.stf.jus.br/paginadorpub/paginador. jsp?docTP=AC\&docID=623508 $>$. Acesso em: 05 ago. 2015 ; BRASIL. Tribunal Regional Federal da Primeira Região. Apelação Cível. AC 350 BA 1998.33.01.000350-0. Sexta Turma. Apelante: Golden Beach Hotel Ltda. Apelado: União Federal. Relator(a): Des. Federal Maria Isabel Gallotti Rodrigues. Brasília, 31 de maio de 2014. Disponível em: <http://trf-1.jusbrasil.com.br/jurisprudencia/2259097/apelacao-civel-ac-350-ba-19983301000350-0/inteiroteor-100767490>. Acesso em: 5 ago. 2015.

85 BRASIL. Tribunal Regional Federal da Segunda Região. Resolução $\mathrm{n}^{\circ}$ 39, de 05 de abril de 2005. Disponível em: <http://www2. trf4.jus.br/trf4/controlador.php?acao=pagina_visualizar\&id_pagina $=147>$ Acesso em: 06 ago. 2015. Sobre o tema ver: DE FREITAS, Vladimir Passos. DE FREITAS, FREITAS, Vladimir Passos de; FREITAS, Dario Almeida Passos de. A proteção do meio ambiente na zona costeira. In: GRANZIERA, Maria Luiza Machado; GONÇALVES, Alcindo (Org.). Os problemas da zona costeira no Brasil e no mundo. Santos: Universitária Leopoldianum, 2012. p. 257-277. p. 270. 
A zona costeira é igualmente protegida por normas urbanísticas. As construções na borda da praia ou próximas a propriedades protegidas por seu patrimônio cultural são constantemente sancionadas. Há casos nos quais os tribunais autorizaram a demolição de quiosques construídos nas praias ${ }^{86}$ ou próximos a propriedades protegidas pelo patrimônio cultural ${ }^{87}$. No primeiro, a demolição dos quiosques foi autorizada pelo tribunal, porque sua construção ocorreu sem considerar nenhuma das normas urbanísticas da municipalidade nem o regime dos terrenos de marinha. $\mathrm{Na}$ decisão, o juiz mencionou a obrigação dos Municípios de seguir ${ }^{88}$ "as linhas e diretrizes do Projeto Orla, ${ }^{89}$ que tem por finalidade a elaboração e a implementação do Plano de Gestão Integrado do litoral municipalidades". No que concerne às propriedades protegidas por seu valor cultural, um caso interessante versa sobre a demolição de construções que foram realizadas em frente a um bar na zona costeira, situado ao lado do Museu Arqueológico de Itaipu, em Niterói. As construções bloqueavam o caminho que conduzia ao Museu. A decisão foi favorável à demolição com base em argumentos ambientais, em argumentos relacionados à inclusão dos terrenos de marinha como bens da União e no argumento do respeito, inclusive pela iniciativa privada, ao "projeto de urbanismo elaborado pela municipalidade". De acordo com a decisão,

[...] o Museu Arqueológico de Itaipu é um monumento culturalmente protegido pelo DecretoLei 25 de 30 de novembro de 1937, cujo artigo 30 proíbe todas as construções nas proximidades do prédio que possam reduzir sua visibilidade ${ }^{90}$.

86 BRASIL. Tribunal Regional Federal da Segunda Região. Ação Cível. AC n. ${ }^{\circ}$ 620555. Rio de Janeiro, 27 de outubro de 2014.

87 BRASIL. Tribunal Regional Federal da Segunda Região. Ação Cível. $A C n{ }^{\circ}{ }^{\circ} 382728$. Quinta turma especializada, Rio de Janeiro, 10 de novembro de 2010.

88 "Sustenta que, ao agir dessa forma, o Município de Araruama atendeu às diretrizes do Projeto Orla, que tem como finalidade elaborar e implementar um Plano de Gestão Integrada - PGI da orla marítima e fluvial dos Municípios brasileiros".

89 BRASIL. Ministério do Meio Ambiente. Projeto Orla. Disponível em: <http://www.mma.gov.br/gestao-territorial/gerenciamentocosteiro/projeto-orla>. Acesso em: 18 out. 2014.

90 P. 8 da decisão: "Nos termos da Informação no 235/93 apresentada pelo IPHAN, à fl. 290, aquela construção [...] é prejudicial à ambiência do monumento tombado, pois contraria o projeto urbanístico elaborado para o local pela prefeitura (o qual se encontra em análise por este Instituto). O Museu de Arqueologia de Itaipu é um monumento tombado (cf. Ofício 67/95, do IPHAN, à fl. 291), sendo a sua proteção conferida pelo Decreto-lei 25, de 30 de novembro de 1937 (que organiza a proteção do patrimônio histórico e artístico nacional), cujo art. 18 veda qualquer construção, na vizinhança de imóveis tombados, que lhes impeça ou reduza a visibilidade, sob pena de retirada ou destruição e multa de $50 \%$ do valor das obras
No contexto da elaboração dos Planos de Gestão Integrada da Zona Costeira, que se insere na competência das municipalidades, os parâmetros ambientais, sociais e econômicos devem ser abordados de forma conjunta. Por exemplo, os critérios de proteção do meio ambiente deveriam considerar as áreas protegidas, as condições de utilização das praias, a presença de lixo e a possibilidade de exploração de recursos naturais ${ }^{91}$. Parâmetros sociais, como a presença de comunidades tradicionais, o turismo, a urbanização, os serviços de fornecimento de água também devem ser considerados, assim como critérios econômicos como a especulação imobiliária, os usos agrícola, mineral, petrolífero, a pesca, a navegação, as atividades portuárias e o turismo. Os indicadores de qualidade da gestão das zonas costeiras pelos Municípios poderiam ser baseados em parâmetros nacionais ${ }^{92}$. Os recursos financeiros deveriam ser distribuídos às municipalidades de maneira proporcional à efetivação dos Planos municipais de Gestão Integrada ${ }^{93}$.

\section{Considerações finais}

A análise realizada demonstrou alguns dos entraves de cunho institucional e normativo que o planejamento da ocupação sustentável da zona costeira brasileira enfrenta, tanto em sua faixa marítima quanto em sua faixa terrestre. Contribuiu, ainda, com a identificação de imprecisões conceituais que não são devidamente aclaradas pelos poderes competentes, tais como bem comum de uso do povo, patrimônio nacional e bem da União. Constata-se, portanto, limites consideráveis no âmbito

proibidas". BRASIL. Tribunal Regional Federal da Segunda Região. Apelação Civil. AC 200351020031062 RJ 2003.51.02.003106-2. Quinta Turma Especializada. Apelante: Bar e Restaurante Ancora Ltda. Apelado: Ministério Público Federal. Relator: Des. Federal Fernando Marques. Rio de Janeiro, 2010. Disponível em: <http:// trf-2.jusbrasil.com.br/jurisprudencia/17549680/apelacao-civel-ac200351020031062-rj-20035102003106-2/inteiro-teor-103757871>. Acesso em: 06 ago. 2015.

91 ARZABE, Jorge. Gestão da zona costeira e os terrenos de marinha. 2011. 60 f. Trabalho de Conclusão de Curso (Especialista) - Curso Intensivo de Pós-Graduação em Administração Pública, Programa FGV Management, Fundação Getúlio Vargas, Brasília, 2011. p. 26. 92 ARZABE, Jorge. Gestão da zona costeira e os terrenos de marinha. 2011. 60 f. Trabalho de Conclusão de Curso (Especialista) - Curso Intensivo de Pós-Graduação em Administração Pública, Programa FGV Management, Fundação Getúlio Vargas, Brasília, 2011. p. 28. 93 ARZABE, Jorge. Gestão da zona costeira e os terrenos de marinha. 2011. 60 f. Trabalho de Conclusão de Curso (Especialista) - Curso Intensivo de Pós-Graduação em Administração Pública, Programa FGV Management, Fundação Getúlio Vargas, Brasília, 2011. p. 31. 
administrativo, legislativo e judiciário, nos entes da federação, para atuar na gestão da zona costeira. Esses limites, enquanto não superados, permitirão a ocupação indevida e insustentável da zona costeira brasileira.

Com relação aos limites institucionais, apesar do amplo número de entes competentes para administrar a proteção ambiental da zona costeira, não há dispositivos claros sobre a competência de cada um no que concerne à zona costeira.

Espera-se que a LC 140/2001 contribua com interpretações mais precisas quanto às competências de cada ente federativo. As competências da Autoridade Marítima para a faixa marítima da zona costeira também não são precisas e acabam por centralizar a gestão dessa área para a atividade da navegação. O que deve ser priorizado é a gestão dos usos múltiplos da zona costeira, o que ainda não pode ser vizualizado no Brasil.

No que tange aos limites normativos, a imprecisão de conceitos gerais relacionados à zona costeira, como bem de uso comum do povo, bem da União e patrimônio nacional resultam em uma insegurança jurídica para a região. Essa imprecisão de dispositivos normativos vulnerabiliza os biomas característicos da zona costeira, além de dificultar o controle do que pode ou não pode ser construído na zona costeira.

Diante desse contexto, parece mais adequado resolver primeiramente os problemas de interpretação dos conceitos, de definições e de imprecisões para, em seguida, realizar a gestão sustentável e integrada da zona costeira e apenas posteriormente integrar essa gestão à planificação do espaço marinho brasileiro.

\section{REFERÊNCIAS}

AGENCIA NACIONAL DE TRANSPORTES AQUAVIARIOS. PGO Plano Geral de Outorgas: apresentações. Disponível em: <http://www.antaq.gov.br/ portal/Portos_PGO.asp>. Acesso em 10 set. 2014.

ALMEIDA, José Mauro de Lima O. de. Terrenos de marinha, proteção ambiental e as cidades. Belém: Paka-Tatu, 2008.

ARZABE, Jorge. Gestão da zona costeira e os terrenos de marinha. 2011. 60 f. Trabalho de Conclusão de Curso (Especialista) - Curso Intensivo de Pós-Graduação em Administração Pública, Programa FGV Management, Fundação Getúlio Vargas, Brasília, 2011.
BRASIL. Câmara dos Deputados. Decreto n ${ }^{\circ} 74.557$, de 12 de setembro de 1974. Disponível em: <http://www. planalto.gov.br/ccivil_03/decreto/Antigos/D74557. htm>. Acesso em: 05 ago. 2015.

BRASIL. Câmara dos deputados. Projeto de Emenda Constitucional $n^{0}$ 39, de 2011. Disponível em: <http://www. camara.gov.br/proposicoesWeb/fichadetramitacao?idP roposicao=508965> . Acesso em 06 ago. 2015.

BRASIL. Câmara dos deputados. Projeto de Emenda Constitucional $n^{\circ}$ 53, de 2007. Disponível em: <http://www. camara.gov.br/proposicoesWeb/fichadetramitacao?idP roposicao $=349704>$. Acesso em 06 ago. 2015.

BRASIL. Câmara dos Deputados. Projeto de Emenda Constitucional no 603, de 1998. Disponível em: <http:/ / www2.camara.leg.br/atividade-legislativa/comissoes/ comissoes-temporarias/especiais/52a-legislatura/pec603-98-terrenos-de-marinha>. Acesso em 06 ago. 2015.

BRASIL. Câmara dos deputados. Projeto de lei ñ 1082, de 2011. Disponível em: <http://www.camara.gov. br/proposicoesWeb/fichadetramitacao?idProposic ao $=498619>$. Acesso em 06 ago. 2015.

BRASIL. Câmara dos deputados. Projeto de lei ñ 1117 , de 2011. Disponível em: <http://www.camara.gov. br/proposicoesWeb/fichadetramitacao?idProposic ao $=498959>$. Acesso em 06 ago. 2015.

BRASIL. Câmara dos deputados. Projeto de lei $n^{\circ}$ 6623, de 2006. Disponível em: <http://www.camara.gov. br/proposicoesWeb/fichadetramitacao?idProposic ao $=313821>$. Acesso em 06 ago. 2015.

BRASIL. Câmara dos deputados. Projeto de lei n 6752, de 2010. Disponível em: <http://www.camara.gov. $\mathrm{br} /$ proposicoesWeb/fichadetramitacao?idProposic ao $=465829>$. Acesso em 06 ago. 2015.

BRASIL. Câmara dos Deputados. Projeto de lei 6969 de 17 de dezembro de 2013. Disponível em: <http://www. camara.gov.br/proposicoesWeb/fichadetramitacao?idP roposicao=604557>. Acesso em: 5 ago. 2015.

BRASIL. Comissão Interministerial para os Recursos do Mar. Resolução no 01, de 21 de novembro de 1990, Disponível em: <https://www.mar.mil.br/secirm/document/ataseresolucoes/resolucao-1-1994.pdf $>$. Acesso em: 05 ago. 2015.

BRASIL. Constituição (1988). Constituição da República Federativa do Brasil. Disponível em: <http://www. planalto.gov.br/ccivil_03/constituicao/constituicao. 
htm>. Acesso em: 05 ago. 2014.

BRASIL. Decreto n $n^{0} 5.300$, de 07 de dezembro de 2004. Disponível em: <http://www.planalto.gov.br/ccivil_03/_ ato2004-2006/2004/decreto/D5300.htm>. Acesso em: 10 jul. 2014.

BRASIL. Decreto ñ. 5.377 de 23 de fevereiro de 2005. Disponível em: <http://www.planalto.gov.br/ccivil_03/_ Ato2004-2006/2005/Decreto/D5377.htm>. Acesso em: 06 ago. 2015.

BRASIL. Decreto n ${ }^{\circ}$ 6.678, de 8 de dezembro de 2008. Disponível em: <http://www.planalto.gov.br/ccivil_03/_Ato2007-2010/2008/Decreto/D6678.htm>. Acesso em: 05 ago. 2015.

BRASIL. Decreto-lei ñ 9.760, de 05 de setembro de 1946. Disponível em: <http://www.planalto.gov.br/ccivil_03/ decreto-lei/del9760.htm>. Acesso em: 05 ago. 2015.

BRASIL. Lei Complementar $n^{\circ} 140$, de 08 de dezembro de 2011. Disponível em: <http://www.planalto.gov.br/ccivil_03/leis/lcp/Lcp140.htm>. Acesso em:10 nov.2014.

BRASIL. Lei no 6.938, de 31 de agosto de 1981. Disponível em: <http://www.planalto.gov.br/ccivil_03/leis/16938. htm>. Acesso em: 4 out. 2014.

BRASIL. Lei n 7.661 de 16 de maio de 1998. Disponível em: <http://www.planalto.gov.br/ccivil_03/leis/17661. htm>. Acesso em: 04 ago. 2015.

BRASIL. Lei ño 8.617 de 04 de janeiro de 1993. Disponível em: <http://www.planalto.gov.br/ccivil_03/leis/18617. htm>. Acesso em: 05 out. 2014.

BRASIL. Lei no 9.966 de 28 de abril de 2000. Disponível em: <http://www.planalto.gov.br/ccivil_03/leis/ L9966.htm>. Acesso em: 4 out. 2014.

BRASIL, Lei $n^{0}$ 10.406, de 10 de janeiro de 2002. Disponível em: <http://www.planalto.gov.br/ccivil_03/ leis/2002/110406.htm >. Acesso em: 05 ago. 2015. Artigo 99 e seguintes. BRASIL. Lei no 7.661 de 16 de maio de 1998. Disponível em: <http://www.planalto.gov.br/ ccivil_03/leis/17661.htm>. Acesso em: 04 ago. 2015.

BRASIL. Lei $n^{\circ} 12.651$ de 25 de maio de 2012. Disponível em: < http://www.planalto.gov.br/ccivil_03/_ Ato2011-2014/2012/Lei/L12651.htm\#art83>. Acesso em: agosto 2014.

BRASIL. Marinha do Brasil. Normas da autoridade maritima para obras, dragagens, pesquisa e lavra de minerais sob, sobre $e$ às margens das águas jurisdicionais brasileiras: NORMAM
11/DPC. 2003. Disponível em: <https://www3.dpc. mar.mil.br/normam/N_11/normam11.pdf $>$. Acesso em: 05 ago. 2015.

BRASIL. Ministério de Minas e Energia. Departamento Nacional de Produção Mineral. Portaria no 441, de 11 de dežembro de 2009. Disponível em: <http://www2.dnpm. gov.br $/$ conteudo.asp?IDSecao $=67 \&$ IDPagina $=84 \&$ ID Legislacao $=589>$. Acesso em: 5 ago. 2015.

BRASIL. Ministério do Meio Ambiente. Limites da Zona Costeira. Disponível em: <http://www.mma.gov. $\mathrm{br} /$ gestao-territorial/gerenciamento-costeiro/a-zona-

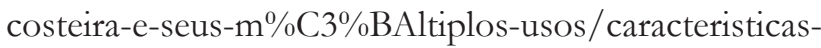
da-zona-costeira>. Acesso em: 09 nov. 2014.

BRASIL. Ministério do Meio Ambiente. Plano Nacional de Gerenciamento Costeiro (PNGC II). 1997. Disponível em: <http://www.mma.gov.br/images/arquivo/80033/0.PNGC-II97\%20Resolucao05_97.CIRM. pdf $>$. Acesso em: 15 out. 2014.

BRASIL. Ministério do Meio Ambiente. Projeto Orla. Disponível em: <http://www.mma.gov.br/gestao-territorial/gerenciamento-costeiro/projeto-orla>. Acesso em: 18 out. 2014.

BRASIL. Ministério do Meio Ambiente. Zona Costeira e Marinha. Disponível em: <http://www.mma.gov.br/ biodiversidade/biodiversidade-aquatica/zona-costeirae-marinha>. Acesso em: 15 out. 2014.

BRASIL. Senado Federal. Projeto de Emenda Constitucional $n^{0}$ 56, de 2009. Disponível em: <http://www. senado.leg.br/atividade/materia/detalhes.asp?p_cod_ mate $=95166>$. Acesso em 06 ago. 2015 .

BRASIL. Senado Federal. Projeto de Emenda Constitucional $n^{\circ}$ 256, de 2011. Disponível em: <http://www. senado.gov.br/atividade/materia/detalhes.asp?p_cod_ mate $=100239>$. Acesso em 06 ago. 2015 .

BRASIL. Superior Tribunal de Justiça. Recurso Especial. Resp no 1183546/ES. Segunda Turma. Recorrente: S/A A Gazeta e Outros. Recorrido: União. Relator: Min. Mauro Campbel Marques. Brasília, 08 setembro de 2010. Disponível em: <http://stj.jusbrasil. com.br/jurisprudencia/16376533/recurso-especialresp-1183546-es-2010-0040958-3/relatorio-e-voto-16978062>. Acesso em: 05 ago. 2015.

BRASIL. Supremo Tribunal Federal. Medida Cautelar na Ação Direta de Inconstitucionalidade. ADI 4264 MC/PE. Tribunal Pleno. Requerente: Assembléia Le- 
gislativa do Estado de Pernambuco. Requerido: Presidente da República. Relator: Min. Ricardo Lewandowski. Brasília, 16 de março de 2011. Disponivel em: <http://redir.stf.jus.br/paginadorpub/paginador. jsp?docTP $=$ AC\&docID $=623508>$. Acesso em: 05 ago. 2015.

BRASIL. Supremo Tribunal Federal. Recurso Extraordinário. RE 134297 SP. Primeira Turma. Recorrente: Estado de São Paulo. Recorridos: Paulo Ferreira Ramos e Cônjuge. Relator: Min. Celso de Mello. Brasília, 13 de junho de 1995. Disponível em<http://stf.jusbrasil. com.br/jurisprudencia/745994/recurso-extraordinario-re-134297-sp>. Acesso em: 05 ago. 2015.

BRASIL. Tribunal Regional Federal da Primeira Região. Agravo de Instrumento. AG 183530620124010000 MA 0018353-06.2012.4.01.0000. Quinta Turma. Agravante: Delman Rodrigues Incorporações Ltda. Agravado: Ministério Público Federal. Relator: Des. Souza Prudente. Brasília,31 de setembro de 2013. Disponível em: < http:/ / trf-1.jusbrasil.com.br/jurisprudencia/24138498/ agravo-de-instrumento-ag-183530620124010000-ma0018353-0620124010000-trf1>. Acesso em: 5 ago. 2015.

BRASIL. Tribunal Regional Federal da Primeira Região. Apelação Cível. AC 350 BA 1998.33.01.0003500. Sexta Turma. Apelante: Golden Beach Hotel Ltda. Apelado: União Federal. Relator(a): Des. Federal Maria Isabel Gallotti Rodrigues. Brasília, 31 de maio de 2014. Disponível em: <http://trf-1.jusbrasil. com.br/jurisprudencia/2259097/apelacao-civel-ac350-ba-19983301000350-0/inteiro-teor-100767490>. Acesso em: 5 ago. 2015.

BRASIL. Tribunal Regional Federal da Quarta Região. Acordão. Processo 1998.7204.003633-7. Terceira Turma. Relator: Des. Federal Fernando Quadros. Porto Alegre, 30 de novembro de 2010.

BRASIL. Tribunal Federal da Quarta Região. Apelação Cível. AC 5000228-69.2010.404.7216/SC. Vice-Presidência. Apelante: Orlando Ivã larionoff. Apelado: IBAMA. Relator: Des. Federal Luiz Fernando Wowk Pentead. Porto Alegre, 02 de outubro de 2014. Disponível em: <http://trf-4.jusbrasil.com. br/jurisprudencia/143419040/apelacao-civel-ac50002286920104047216-sc-5000228-6920104047216/ inteiro-teor-143419116>. Acesso em: 5 ago. 2015.

BRASIL. Tribunal Federal da Quarta Região. Re- curso Especial em Apelação Cível. $A C n^{0} 0000959-$ 87.2009.404.7216/SC. Terceira Turma. Recorrente: IBAMA. Recorrido: Territorial Garopaba Ltda. Relator(a): Des. Maria Lúcia Luz Leiria. Porto Alegre, 19 de agosto de 2012. Disponível em: <http://www. jusbrasil.com.br/diarios/64854576/trf-4-judicial-1701-2014-pg-75>. Acesso em: 5 ago. 2015.

BRASIL. Tribunal Regional Federal da Quarta Região. Apelação Cível. AC 0004571-88.2003.404.7201/SC. Terceira Turma. Apelante IBAMA; Ministério Público Federal. Apelado: Município de Itapoá/SC. Relator (a): Des. Federal Maria Lúcia Luz Leiria. Porto Alegre, 1 de fevereiro de 2011. Disponível em: < http://trf-4. jusbrasil.com.br/jurisprudencia/18575379/apelacaocivel-ac-7201-sc-0004571-8820034047201-trf4/inteiroteor-18575380>. Acesso em: 5 ago. 2015.

BRASIL. Tribunal Regional Federal da Quinta Região. Agravo de Instrumento. AGTR 107968/CE - 000966867.2010.4.05.0000. Primeira Turma. Agravante: Ministério Público Federal. Agravado: Construtora Waldyr Diogo Ltda e outros. Relator : Des. Federal Francisco Cavalcanti. Recife, 03 de maio de 2012. Disponível em: $<$ http://www.jusbrasil.com.br/diarios/37330603/trf5-jud-25-05-2012-pg-57>. Acesso em: 5 ago. 2015.

BRASIL. Tribunal Regional Federal da Segunda Região. Ação Cível. $A C$ n. ${ }^{\circ} 487271$. Sexta Turma especializada. Rio de Janeiro, em 19 de março de 2012.

BRASIL. Tribunal Regional Federal da Segunda Região. Ação Cível. AC 585795. Sétima turma especializada. Rio de Janeiro, 30 de outubro de 2013.

BRASIL. Tribunal Regional Federal da Segunda Região. Ação Cível. $A C$ n. ${ }^{\circ}$ 620555. Rio de Janeiro, 27 de outubro de 2014.

BRASIL. Tribunal Regional Federal da Segunda Região. Ação Cível. $A C$ n. ${ }^{\circ} 382728$. Quinta turma especializada, Rio de Janeiro, 10 de novembro de 2010.

BRASIL. Tribunal Regional Federal da Segunda Região. Agravo de Instrumento. AG 2012.02.01.0048593. Quinta Turma Especializada. Agravante: IBAMA. Agravado: Thiago Cunha de Almeida. Relator: Des. Federal Marcus Abraham. Rio de Janeiro, 29 de janeiro de 2013. Disponível em: <http://trf-2.jusbrasil.com.br/ jurisprudencia/23376162/ag-agravo-de-instrumentoag-201202010048593-trf2/inteiro-teor-111700881>. Acesso em: 5 ago. 2015. 
BRASIL. Tribunal Regional Federal da Segunda Região. Agravo de Instrumento. AG 2012.02.01.0057247. Quinta Turma Especializada. Agravante: Ministério Publico Federal. Agravado: Aluísio Leal Santos. Relator: Des. Federal. Marcus Abraham. Rio de Janeiro, 28 de maio de 2013. Disponível em: < http://trf-2. jusbrasil.com.br/jurisprudencia/23610800/ag-agravode-instrumento-ag-201202010057247-trf2/inteiro-teor-111757639>. Acesso em: 5 ago. 2015.

BRASIL. Tribunal Regional Federal da Segunda Região. Agravo de Instrumento. AG 2012.02.01.0048593. Quinta Turma Especializada. Agravante: IBAMA. Agravado: Thiago Cunha de Almeida. Relator: Des. Federal Marcus Abraham. Rio de Janeiro, 29 de janeiro de 2013. Disponível em: < http://trf-2.jusbrasil.com.br/ jurisprudencia/23376162/ag-agravo-de-instrumentoag-201202010048593-trf2/inteiro-teor-111700881>. Acesso em: 5 ago. 2015.

BRASIL. Tribunal Regional Federal da Segunda Região. Apelação Civil. AC 200351020031062 RJ 2003.51.02.003106-2. Quinta Turma Especializada. Apelante: Bar e Restaurante Ancora Ltda. Apelado: Ministério Público Federal. Relator: Des. Federal Fernando Marques. Rio de Janeiro, 2010. Disponível em: < http:/ / trf-2.jusbrasil.com.br/jurisprudencia/17549680/apelacao-civel-ac-200351020031062-rj-20035102003106-2/ inteiro-teor-103757871>. Acesso em: 06 ago. 2015.

BRASIL. Tribunal Regional Federal da Segunda Região. Apelação Cível. AC 200651080008781. Sexta Turma Especializada. Apelante: Denival da Silva Ferraz e outros. Apelado União Federal, Município de Araruama; IBAMA. Relator (a): Des. Federal Carmen Silvia Lima de Arruda. Rio de Janeiro, 31 de março de 2014. Disponível em: <http://trf-2.jusbrasil.com. br/jurisprudencia/25091049/ac-apelacao-civel-ac200651080008781 -trf2/inteiro-teor-120459970>. Acesso em: 5 ago. 2015.

BRASIL. Tribunal Regional Federal da Segunda Região. Apelação/Reexame Necessário. APELRE 200851020028899 RJ. Sexta Turma Especializada. Apelante: União Federal. Apelado: Leonardo Almendra Honorato e Outros. Relator (a). Des. Federal: Carmen Silvia Lima Arruda. Rio de Janeiro, de 2014. Disponível em: $\quad<$ http://trf-2.jusbrasil.com.br/jurisprudencia/160029380/apelacao-reexame-necessario-apelre200851020028899-rj/inteiro-teor-160029517>. Acesso em: 06 ago. 2015.
BRASIL. Tribunal Regional Federal da Segunda Região. Resolução no 39, de 05 de abril de 2005. Disponível em: $\quad<$ http://www2.trf4.jus.br/trf4/controlador. php?acao=pagina_visualizar\&id_pagina $=147>$ Acesso em: 05 ago. 2015.

BRASIL. Tribunal Regional Federal da Segunda Região. Apelação Civil. AC 200351020031062 RJ 2003.51.02.003106-2. Quinta Turma Especializada. Apelante: Bar e Restaurante Ancora Ltda. Apelado: Ministério Público Federal. Relator: Des. Federal Fernando Marques. Rio de Janeiro, 2010. Disponível em: < http:/ / trf-2.jusbrasil.com.br/jurisprudencia/17549680/apelacao-civel-ac-200351020031062-rj-20035102003106-2/ inteiro-teor-103757871>. Acesso em: 06 ago. 2015.

CEARÁ. Lei no 13.796, de 30 de junho de 2006. Institui a Política Estadual de Gerenciamento Costeiro, e o Plano Estadual de Gerenciamento Costeiro e dá outras providências. Disponível em: <http://www.al.ce.gov.br/ legislativo/legislacao5/leis2006/13796.htm>. Acesso em: 05 ago. 2015.

ESPÍRITO SANTO. Lei no 5.816, de 22 de dezembro de 1998. Institui o Plano Estadual de Gerenciamento Costeiro do Espírito Santo. Disponível em: <http://www. meioambiente.es.gov.br/web/Lei_5816.htm>. Acesso em: 05 ago. 2015.

FREITAS, Vladimir Passos de; FREITAS, Dario Almeida Passos de. A proteção do meio ambiente na zona costeira. In: GRANZIERA, Maria Luiza Machado; GONÇALVES, Alcindo (Org.). Os problemas da zona costeira no Brasil e no mundo. Santos: Universitária Leopoldianum, 2012. p. 257-277.

GRANZIERA, Maria Luiza Machado; GONÇALVES, Alcindo (Org.). Os problemas da zona costeira no Brasil e no mundo. Santos: Universitária Leopoldianum, 2012.

FREITAS, Mariana Almeida Passos de. Zona Costeira e Meio Ambiente. Curitiba: Jurua, 2005.

FREITAS, Vladimir Passos de; FREITAS, Dario Almeida Passos de. A proteção do meio ambiente na zona costeira. In: GRANZIERA, Maria Luiza Machado; GONÇALVES, Alcindo (Org.). Os problemas da zona costeira no Brasil e no mundo. Santos: Universitária Leopoldianum, 2012. p. 257-277.

GUERRA, Sérgio. Licenciamento Ambiental de Acordo com a LC 140/2011. Revista de Direito Ambiental, São Paulo, v. 17, n. 66, p. 153-179, abr./jun. 2012. 
LOITZENBAUER, Ester; MENDES, Carlos André Bulhões. A faixa terrestre da zona costeira e os recursos hídricos na região hidrográfica do Atlântico Sul. Revista de Gestão Costeira Integrada, Lisboa, v. 14, n. 1, p. 81-94, mar. 2014.

MACHADO, Paulo Affonso Leme. Direito ambiental brasileiro. 21 ed. São Paulo: Malheiros, 2012.

NOIN. Daniel. La population des littoraux du monde. L'information géographique, Paris, v. 63, n. 2, p. 65-73, 1999. Disponível em: < http://www.persee.fr/web/revues/home/prescript/article/ingeo_0020-0093_1999_ num_63_2_2632>. Acesso em: 4 ago. 2015.

RIO DE JANEIRO. Lei ñ 2.423, de 17 de agosto de 1995. Disciplina a pesca nos cursos d'água do Estado do Rio de Janeiro e adota outras providências Disponível em: $<$ http://gov-ri.jusbrasil.com.br/legislacao/150735/lei2423-95>. Acesso em: 05 ago. 2015.

RIO GRANDE DO SUL. Lei $n^{\circ} 11.886$, de 2 de janeiro de 2003. Dá nova redação ao artigo $1^{\circ}$. da Lei Estadual n. 8.676, de 14 de julho de 1988, que determina a obrigatoriedade de demarcação das áreas de pesca, lazer ou recreação, nos Municípios com orla marítima, lacustre e fluvial Disponível em: <http://www.legislacao.sefaz. rs.gov.br/Site/Document.aspx?inpKey=102719\&inpC odDispositive $=\&$ inpDsKeywords $=>$. Acesso em: 05 ago. 2015.

RUFINO, Gilberto d'Avila. Patrimônio costeiro e seus fundamentos jurídicos. In: MORAES, Antônio Carlos Robert; ZAMBONI, Adenilson (Org.). Subsidios para um projeto de gestão. Brasília: MMA, 2004. (Projeto Orla).

RUFINO, Gilberto d'Ávila. Royalties do petróleo e diretos dos Municípios produtores: elementos para análise e discussão.
Disponível em: <www.ijlitoral.org>. Acesso em: nov., 2012.

RUFINO, Gilberto d'Ávila. Royalties do petróleo para Municipios costeiros. Disponível em: <www.ijlitoral.org>. Acesso em: nov., 2012.

SÃO PAULO. Lei no 10.019 de 3 de julho de 1998. Dispõe sobre o Plano Estadual de Gerenciamento Costeiro e dá outras providências. Disponível em: <http://www. al.sp.gov.br/repositorio/legislacao/lei/1998/lei-1001903.07.1998.html>. Acesso em: 05 ago. 2015.

SÃO PAULO. Lei no 11.165, de 27 de junho de 2002. Institui o Código de Pesca e Aqüicultura do Estado. Disponível em: <http://www.al.sp.gov.br/repositorio/legislacao/lei/2002/lei-11165-27.06.2002.html>. Acesso em: 05 ago. 2015.

SILVA, Solange Teles da. Direito fundamental ao meio ambiente ecologicamente equilibrado: avanços e desafios. Revista de Direito Ambiental, São Paulo, v. 12, n. 48, p. 225-245, out./dez. 2007.

SILVA, Solange Teles da. Planejamento urbano na Zona Costeira. In: Compedi. In: CONGRESSO NACIONAL DO CONPEDI, 14., 2005, Fortaleza. Anais eletrônico... Manaus: CONPEDI, 2006. Disponível em: http://www. conpedi.org.br/manaus/arquivos/anais/XIVCongresso/151.pdf. Acesso em: 4 ago. 2015.

SODRÉ, Marcelo Gomes. Zoneamento Ecológicoeconômico e zoneamento costeiro: algumas polêmicas jurídicas In: GRANZIERA, Maria Luiza Machado; GONÇALVES, Alcindo (Org.). Os problemas da zona costeira no Brasil e no mundo. Santos: Universitária Leopoldianum, 2012. p. 116-141. 


\title{
Correndo para o mar no antropoceno: a complexidade da governança dos oceanos e a estratégia brasileira de gestão dos recursos marinhos*
}

\author{
Race to the sea in the anthropocene: the \\ complexity of oceans governance and the \\ brazilian strategy for the marine resources \\ management
}

\author{
Ana Flávia Barros-Platiau** \\ Jorge Gomes do Cravo Barros*** \\ Pierre Mazzega**** \\ Liziane Paixão Silva Oliveira*****
}

* Recebido em 10/04/2015

Aprovado em 04/06/2015

** Professora em Relações Internacionais da Universidade de Brasília (UnB). Atualmente em pós-doutorado no CERIC (Université Aix Marseille) pelo projeto "A Estratégia Brasileira na Gestão de Recursos Vivos e Não-vivos do Mar ”, CAPES/Brasil. E-mail: anaflavia@teaser.fr

*** Geólogo. Ex-Professor da Universidade de Brasília e ex-Assessor em Geologia da 4a. CCR, Ministério Público Federal. E-mail: jorgecravobarros@gmail.com

**** Diretor de Pesquisa no CNRS, UMR5563 Géosciences Environnement Toulouse (Universidade de Toulouse, França). Email:pmazzega@gmail.com

***** Professora de Direito Ambiental na Universidade Tiradentes, Coordenadora do Programa de Pós-Graduação em Direito da Universidade Tiradentes/Mestrado em Direitos Humanos, atualmente em Pós-doutorado no CERIC (Université Aix-Marseille). E-mail: lizianepaixao@gmail.com

\section{Resumo}

Partindo da premissa que estamos na época geológica do Antropoceno, este artigo tem por objetivo sugerir orientações para a estratégia brasileira de gestão e proteção de recursos marinhos, considerando a evolução do direito do mar e o contexto multilateral atual desde 1973, quando iniciou-se a III Conferência sobre o Direito do Mar sob a égide da ONU. Primeiramente são descritas transformações profundas no contexto internacional, o que justifica o interesse do artigo e a adoção do conceito de "ordem global ambiental". Tal ordem é definida pela complexidade crescente da governança dos oceanos e pela corrida para o mar de países emergentes, dentre os quais o Brasil. Em contraposição, é analisada a lenta evolução do direito do mar, conduzindo à imprescindibilidade de maior circulação de normas entre diversos espaços convencionais. Finalmente, são abordados os principais traços da estratégia brasileira relativa aos recursos do mar, com o fito de esclarecer que a primeira sugestão é de uma abordagem mais integrada da questão marítima no arcabouço político-legal, principalmente para a regulação do uso dos recursos e da reparação de eventuais danos. A segunda sugestão concerne às parcerias estratégicas, em virtude do pleito brasileiro de extensãoda Plataforma Continental. Por fim, participar mais ativamente das reuniões multilaterais é essencial para o Brasil, que constitui um global player ambiental, mas não é uma potência marítima. A originalidade do artigo reside na análise, empregando conceitos de relações internacionais e direito internacional, propondo ideias para o Brasil ganhar capacidade de interlocução à altura de suas ambições marítimas.

Palavras-chave: Amazonia Azul. Antropoceno. Brasil. Circulação de normas. Complexo de regimes. Governança dos oceanos. 
Abstract

Taking into account the fact that we are in the Anthropocene epoch, this article aims at suggesting ways the Brazilian strategy for the protection and management of marine resources could be improved. First, the deep changes in the international context are discussed, leading to the concept of "global environmental order". The rising complexity of oceans governance and the race to the sea, including new emerging competitors, such as China and Brazil, are the key features of the global order. While those changes were fast, the evolution of the international environmental law was so slow it is now urgent to improve the circulation of norms related to the regulation of sustainable use of resources and damage reparation, notably on the high seas. In this context, the Brazilian strategy is encouraged to admit that an integrated institutional approach is necessary to forge the national interests more clearly. Had Brazil done so, it would have a better international image. The second suggestion concerns the improvement of its strategic partnerships, since Brazil is pleading the extension of the Continental Platform. Finally, since Brazil is an environmental global player, but not one related to sea issues, it is mandatory Brazil participates more actively in multilateral meetings. The main interest of this article is to analyse international relations and international law concepts to suggest how Brazil could have a voice as strong as its maritime ambitions.

Keywords: Blue Amazon. Anthropocene. Brazil. Norms circulation. Ocean governance. Regimes complex.

\section{INTRODUÇÃO1}

Apesar do atual debate acalorado entre cientistas, tem se consolidado, nos últimos anos, o consenso relativo ao início da nova época geológica, chamada de Antropoceno. Ele corresponderia à época das negociações no âmbito da III Conferência das Nações Unidas sobre o Direito do Mar de 1973, que levou à assinatura da Convenção das Nações Unidas sobre Direito do Mar

1 Pesquisa financiada pela CAPES, projeto "A Estratégia Brasileira na Gestão de Recursos Vivos e Não-vivos do Mar» Edital n.43/ Ciências do Mar e Agence Nationale de Recherche (França), projeto CIRCULEX < ANR-12-GLOB-0001-03 CIRCULEX>, do CERIC , Université Aix Marseille
(UNCLOS) em $1982^{2}$. Passadas mais de quatro décadas de avatares ambientais e institucionais, nota-se que os primeiros evoluiram mais rapidamente do que os segundos ${ }^{3}$. Consequentemente, a governança dos oceanos tornou-se ainda mais complexa, revelando crescente e necessária circulação de normas regulatórias das atividades humanas. Nesse contexto, diversos países têm assumido interesse renovado pelos recursos marinhos em razão de dois fatores: a preocupação generalizada com a segurança energética e alimentar nacional, bem como o acelerado desenvolvimento tecnológico (principalmente de países emergentes). Sendo o Brasil ${ }^{4}$ um deles, cabe então analisar esse contexto internacional para orientar a estratégia brasileira, usando como pano de fundo as profundas mudanças estruturais que conduziram ao que se convém denominar "ordem ambiental global".

Nesse sentido, o principal objetivo do artigo consiste em discutir o contexto internacional contemporâneo, com base em uma abordagem político-jurídica, para informar os tomadores de decisão e o juristas brasileiros. O recorte temporal é de 1973 a 2014, ou seja, das negociações que levariam à assinatura da UNCLOS até 2014, ano que marca o fim da ordem ambiental internacional do século XX. O ano de 2015 marcará o final dos Objetivos de Desenvolvimento do Milênio (ODM) e o início dos Objetivos de Desenvolvimento Sustentável $(\mathrm{ODS})^{5}$, bem como a realização da Conferência das Partes à Convenção-Quadro das Nações Unidas

2 A Convenção das Nações Unidas sobre Direito do Mar entrou em vigor somente em novembro de 1994.

3 Outros artigos desta edição partem da mesma premissa. Ver Oliveira, Carina Costa de e Maljean-Dubois, Sandrine. Os limites dos termos bem público mundial, patrimônio comum da humanidade e bens comuns para delimitar as obrigações de preservação dos recursos marinhos. Também da Silva, Alexandre Pereira. A comissão de limites da plataforma continental (CLPC) e os desafios na delineação das plataformas continentais estendidas. Revista de Direito Internacional, vol.12, no.1. (nesta edição).

4 O Brasil é considerado um global player nas questões ambientais, ou seja, ator com influência para orientar os resultados de negociações multilaterais, por diversas razões. A principal é a sua capacidade de interlocução na maior parte da agenda ambiental, como temas afetos a florestas e diversidade biológica, porém as questões relativas ao mar são ainda exceção. Sobre florestas e clima, ver CARVALHO, Fernanda. The brazilian position on forests and climate change from 1997 to 2012: from veto to proposition. Revista Brasileira de Politica Internacional, Rio de Janeiro, v. 55, n. spe, p. 144-169, 2012.

5 UNITED NATIONS. Department of Economic and Social Affairs. Goal 14: conserve and sustainably use the oceans, seas and marine resources for sustainable development. Disponível em: <http://una-gp.org/clancyt/files/goals/goal14.pdf>. Acesso em: 23 mar. 2015. 
sobre Mudanças do Clima (UNFCCC) em Paris (COP 21), cuja ambição constitui a assinatura de tratado internacional cogente com vocação universal ${ }^{6}$. Apesar da importância indiscutível do regime climático sobre os oceanos e seus recursos, esse tema será tratado neste artigo de forma secundária. Da mesma forma, teria sido interessante estudar em profundidade o pleito brasileiro de extensão da Plataforma Continental para além das 200 milhas junto à Comissão de Limites da ONU, porém a Fundação Alexandre Gusmão (FUNAG) publicou no ano passado duas excelentes obras sobre o tema, com abordagem primordialmente político-legal, e disponíveis on-line. Assim, o presente artigo dialoga com textos recentes tanto da diplomacia brasileira quanto do direito internacional, sem perder de vista a produção científica nas ciências da vida, especialmente da revista Nature, e dados oficiais do sistema ONU e de outras instituições pertinentes?

\section{A CORRIDA PARA O MAR NO ANTROPOCENO}

$\mathrm{Na}$ história Ocidental, a verdadeira corrida para o mar geralmente começa com as grandes navegações e o cruzamento dos oceanos, levando inclusive à constatação que foi uma primeira versão da globalização ${ }^{8}$. Uma das principais motivações para a aventura marítima era a "descoberta" de novas terras e riquezas. Logo, a apropriação de recursos naturais ${ }^{9}$ foi objetivo central das civilizações ao longo dos séculos e um desafio de regulação para os atores institucionais que seriam criados com o passar do tempo.

6 CONFÉRENCE DES PARTIES DE LA CONVENTIONCADRE DES NATIONS UNIES SUR LES CHANGEMENTS CLIMATIQUES, 21., 2015, Paris. Procédure eletrônicos... Paris: UNFCC, 2015. Disponível em: < http://www.cop21.gouv.fr/fr>. Acesso em: 23 mar.2015.

7 Ver também da Silva, Alexandre Pereira. A comissão de limites da plataforma continental (CLPC) e os desafios na delineação das plataformas continentais estendidas. Revista de Direito Internacional, vol.12, no.1. (nesta edição).

8 GOIS, Ancelmo; BARROS-PLATIAU, Ana Flávia. Direito internacional e globalização face as questões de direitos humanos. In: RIBEIRO, M.; MAZZUOLI, Valério (Coord.). Direito internacional dos direitos humanos: estudos em homenagem à professora Flávia Piovesan. Curitiba: Juruá, 2004. p. 57-71.

9 No caso dos recursos marinhos, o texto aborda a proteção e gestão de recursos vivos e não vivos, também definidos como bióticos e abióticos, ou biológicos e minerais. Interessa particularmente a exploração de petróleo e nódulos metálicos, como também a pesca e a caça de espécies migratórias e os corais.
Desde o século XVI, países desenvolvidos ocidentais exploraram e colonizaram territórios que eram habitados por populações autoctonas, dividindo a arena internacional em duas metades asimétricas, inclusive para a construção do direito internacional público, e iniciando o que se conveniou denominar clivagem Norte/Sul, ou seja, países desenvolvidos versus países em desenvolvimento ${ }^{10}$. Entretanto, tal clivagem torna-se cada vez mais sutil com o fortalecimento acelerado de economias de países que não tinham tanta capacidade de interlocução no cenário político internacional no passado recente, entre eles, para citar apenas alguns, China, Índia e Brasi $1^{11}$. A escolha dos três justifica-se por duas razões principais. Primeiramente, nenhuma análise com dimensão internacional pode ignorar a irrupção da China como ator de primeira grandeza, mesmo que sua participação política em foruns multilaterais ainda não corresponda à sua potência econômica, marítima e climática ${ }^{12}$. Segundo, a China tem intensificado o seu esforço para integrar a ordem liberal ocidenta $1^{13}$ ao tornar-se membro das organizações intergovernamentais, principalmente a OMC, e também ao criar meios de articulação política com Brasil e Índia, principalmente no BRICS e BASIC, e em menor medida, em outras questões, como a climática ${ }^{14}$. Sendo China e Índia duas novas potências tecno-

10 Clivagem que persiste de modo geral na agenda ambiental e de desenvolvimento, como na Plataforma Intergovernamental de Biodiversidade e Serviços Ecossitêmicos (IPBES) INTERGOVERNMENTAL platform on biodiversity and ecosystem services. 2015. Disponível em: <http://www.ipbes.net/>. Acesso em: 23 mar. 2015. Ver também MORIN, Jean-Frédéric; ORSINI, Amandine. Essential concepts of global environmental governance. Abingdon: Routledge, 2014. Ver também DELEUIL, Thomas. Le statut des pays en voie de développement dans les Accords Multilatéraux Environnementaux. 2014. $\mathrm{f}$ Thèse $(\mathrm{PhD})$ - Centre d'Etudes et de Recherches Internationales et Communautaires (CERIC, CNRS UMR 7318), Faculté de Droit d'Aix en Provence, Université Paul Cézanne Aix-Marseille, Marseille 2014.

11 Estima-se que o interesse brasileiro pelos recursos marinhos intensificou-se nos anos 1960, com a descoberta de petróleo offshore. 12 Para o conceito de potência climática, ver VIOLA, Eduardo; FRANCHINI, Matías; RIBEIRO, Thaís. Sistema internacional de begemonia conservadora: democracia e governança global na era da crise climática. São Paulo: Annablume, 2013.

13 PRANTL, Jochen. Taming hegemony: informal institutions and the challenge to western liberal order. The Chinese Journal of International Politics, Oxford, v. 7, n. 4, p. 449-482, Winter, 2014.

14 Sobre BRICS e clima, ver GOLDEMBERG, José; VIOLA, Eduardo. BRICS e as mudanças climáticas. 2014. Disponível em: $<$ http://politicaexterna.com.br/2580/brics-e-mudancas-climaticas/> . Acesso em: 19 mar. 2015. Sobre a Cúpula do BRICS de Fortaleza em 2014, Ver BECARD, Danielly; BARROS-PLATIAU, Ana Flávia; OLIVEIRA, Carina. Brasil, a China e a VI Cúpula do BRICS. Contexto Internacional, v. 37, n. 1, 2015. No prelo. 
lógicas com alto potencial de crescimento nas próximas décadas, é natural que se preocupem com a apropriação de recursos marinhos. No caso chinês, o potencial de conflitos no mar da China revela-se extremamente importante na agenda nacional em razão de dois casos recentes, mas que fogem ao escopo deste estudo: o contencioso com o Vietnam que reflete a ambição chinesa para a região e o acidente nuclear de Fukushima no Japão, que contaminou o mar, ambos de 2014. Esses dois casos demonstram a fragilidade das instituições internacionais em aportar respostas concretas à $\mathrm{China}^{15}$ e serão objeto de reflexão em pesquisa futura.

Finalmente, seria arriscado defender o conceito de "nova corrida para o mar" em termos econômicos e ambientais como fez James Moltz ${ }^{16}$ em relação aos submarinos nucleares, posto que a corrida é contínua, e na maioria das vezes os Estados e empresas não revelam seus interesses, muito menos o escopo e objeto de suas atividades no alto-mar. Todavia, é possível afirmar que houve « ondas de interesse $»^{17}$ no passado recente, que o comportamento de um país influência os demais e que a irrupção dos países emergentes nas inovações tecnológicas pertinentes trouxe novo alento à corrida ora em curso, ou em vias de planejamento ${ }^{18}$. Em larga medida, as negociações multilaterais para regular a proteção e o acesso aos recursos marinhos são calcadas nessas ondas de interesse, como foi o caso da UNCLOS.

Concomitantemente às negociações multilaterais para estabelecer a $\mathrm{UNCLOS}^{19}$, um número crescente de

15 Sobre as obrigações positivas do Estado e as lacunas do direito internacional público e do sistema ONU, ver ALFAIA JR., José Roberto. Reclamar ou intervir? As obrigações positivas do estado em situações de desastre ambiental. 2014. f. Tese (Doutorado) - Instituto de Relações Internacionais, Universidade de Brasília, Brasília, 2014.

16 MOLTZ, James Clay. Submarine and autonomous vessel proliferation: implications for future strategic stability at sea. Disponível em: <http://calhoun.nps.edu/handle/10945/34355 em 2012>. Acesso em: 23 mar. 2015.

17 A criação da ZEE foi um caso. O interesse de certos paises pelos fundos marinhos fora de suas respectivas jurisdições, pelo Artico e a Antartida sao outros casos relevantes. Restam ainda os diferendos entre paises sobre a posse de ilhas, por exemplo, dos quais as Malvinas interessa diretamente ao Brasil.

18 Como destacado, a China é o maior investidor emergente e o caso mais interessante atualmente. Em menor medida, Rússia, Brasil, India, Chile, México, Tailândia, entre outros, são casos relevantes. Sobre a Antártica, ver SAMPAIO, Daniela. Antarctica and international cooperative practices. São Paulo: International Studies Association, March 2014. (working paper). Disponível em: <http:// www.academia.edu/10185759/Antarctica_and_International_Cooperative_Practices_working_paper>. Acesso em: 23 mar. 2015.

19 Ela entrou em vigor apenas em 1994. cientistas defende que iniciou-se uma nova época geológica, o Antropoceno ${ }^{20}$, estabelecida com base nos impactos das atividades humanas sobre o Planeta ${ }^{21}$. Contudo, ainda está sob discussão se o seu início poderia ser cientificamente comprovado, e, em caso positivo, se deveria ser marcado pelo momento dos aproximadamente 500 testes nucleares entre 1945 e $1963^{22}$, ou pelo uso desenfreado de recursos renováveis e não renováveis, sem esquecer a produção de plásticos, de aluminio, de fertilizantes e de petróleo com chumbo ${ }^{23}$.

A provável nova época geológica, ainda não reconhecida oficialmente pelas sociedades científicas ${ }^{24}$, tem como fundamento os impactos visíveis das atividades

20 CRUTZEN, P. J.; STOERMER, E. F. The Anthropocene. Global Change Newsletter, v. 41, p. 17-18, May. 2000. Eles são reconhecidos entre cientistas como os responsáveis pelo termo. Em 2011, The Economist havia publicado "Welcome to the Anthropocene", politizando o debate. WELCOME to the Anthropocene. The Economist, May, 2011. Disponível em: <http://www.economist.com/ node/18744401>. Acesso em: 23 mar. 2015. Ver também LEWIS, Simon L.; MASLIN, Mark A. Defining the Anthropocene. Nature News, n. 519, 171-180, 12 March 2015. MONASTERSKY, Richard. Anthropocene: the human age. Nature, n. 519, p. 144-147, 12 March 2015. Disponível em: <http://www.nature.com/news/anthropocene-the-human-age-1.17085> . Acesso em: 22 mar. 2015.

21 Dentre os maiores impactos, estão o aquecimento global, a elevação dos níveis oceânicos, a acidificação oceânica e a erosão da camada de ozônio. MONASTERSKY, Richard. Anthropocene: the human age. Nature, n. 519, p. 144-147, 12 March 2015. Disponível em: <http://www.nature.com/news/anthropocene-the-humanage-1.17085>. Acesso em: 22 mar. 2015. Tais impactos conduzem a diferentes propostas sobre o início do Antropoceno. Sobre impactos do clima, ver o Relatório do IPCC de 2014, AR5 Synthesis Report. INTERGOVERNMENTAL PANEL ON CLIMATE CHANGE. Chapter Climate Change 2014: Synthesis report, summary for policymakers. Disponível em: <http://www.ipcc.ch/pdf/assessment-report/ar5/syr/AR5_SYR_FINAL_SPM.pdf $>$. Acesso em: 22 mar. 2015.

22 Segundo Monastersky, tais testes nucleares deixaram uma camada radiotiva nos sedimentos geologicos. Apesar de Zalasiewicz entender que seria o "candidate for the lest-worst boundary", Finney alerta que nos fundos marinhos os ultimos 70 anos deixaram uma camada de sedimentos que não chega a um milimetro. MONASTERSKY, Richard. Anthropocene: the human age. Nature, n. 519, p. 144-147, 12 March 2015. Disponível em: < http://www. nature.com/news/anthropocene-the-human-age-1.17085>. Acesso em: 22 mar. 2015.

23 Crutzen sugeriu inicialmente a Revolução Industrial. Mas seu grupo Anthropocene Working Group analisou o periodo entre 1570 e 1620, quando os colonizadores Europeus exterminaram 50 milhões de indígenas nas Américas e a taxa de CO2 caiu significativamente. MONASTERSKY, Richard. Anthropocene: the human age. Nature, n. 519, p. 144-147, 12 March 2015. Disponível em: <http:// www.nature.com/news/anthropocene-the-human-age-1.17085>. Acesso em: 22 mar. 2015.

24 A Revista Nature, por exemplo, iniciou o ano de 2015 com vários artigos sobre o tema. 
humanas sobre o Planeta Terra. Certo é que se trata mais de uma necessária politização do problema da sustentabilidade da humanidade no longo prazo e de sua responsabilização, do que de questão puramente científica. Em outras palavras, importa transpor das ciências biológicas para os processos decisórios e regulatórios que os impactos causados pelas atividades humanas são insustentáveis.

Importante destacar também a coincidência dos fatores relatados acima e suas externalidades, ou seja, as crescentes taxas de poluição e a impunidade dos responsáveis, a exploração mal-regulada de recursos marinhos biológicos e minerais, a raridade de reparação aos danos causados ${ }^{25}$, países emergentes reformando a geopolítica ${ }^{26}$, necessidade de segurança energética e alimentar, fragilidade do regime de não proliferação nuclear, que tornaram-se os grandes desafios do Antropoceno e do direito do mar. De todo modo, nada impede o uso político e legal do conceito de Antropoceno para fins de mudanças comportamentais enquanto se espera um consenso científico mais consolidado, nos moldes do IPCC $^{27}$ e da Plataforma Intergovernamental de Biodiversidade e Serviços Ecossitêmicos (IPBES). Segundo especialistas das ciências exatas e biológicas, é possível monitorar as mudanças ecológicas e mostrar que tais atividades antrópicas estão influenciando de forma definitiva a evolução das espécies, o desaparecimento de outras, modificando a estrutura de redes tróficas marinhas em escala global ${ }^{28}$, no derretimento de geleiras e

25 PROST, Mario; TORRES, Camprubi. Against fairness? international environmental law, disciplinary bias and pareto justice. Leiden Journal of International Law, v. 25, n. 2, p. 379-396, 2012.

26 China tirou mais pessoas da pobreza, ou seja, vivendo com menos de um dólar norte-americano por dia, na última década do que todos os outros países juntos. China e India combinadas ainda têm mais pessoas vivendo abaixo da linha de pobreza do que todo o resto do mundo. Estima-se que a segurança energética e alimentar deles esteja diretamente ligada aos recursos marinhos no futuro próximo, como também dos demais países emergentes, que ainda exploram pouco tais recursos. No caso brasileiro, merece destaque também a ZOPACAS, zona livre de armas nucleares criada em função da liderança brasileira nas negociações e do consenso sobre a segurança nas duas costas do Atlântico. Resolução 41/11 da Assembléia Geral das Nações Unidas, de 1986.

27 Painel Intergovernamental sobre Mudança do Clima. Note-se que o 5 Relatorio nao aprofundou nas conclusões cientificas, pois foi decidido de se adotar a estrégia de consolidaçao das conclusoes do relatorio precedente para manter a legitimidade do processo.

28 Um estudo recente com 200 modelos de redes tróficas mostrou que entre 1880 e 2007 a sobrepesca conduziu a uma redução de dois terços da biomassa dos peixes predadores, induzindo a uma modificação das redes tróficas marinhas em escala global. CHRISTENSEN, V. et al. A century of fish biomass decline in the ocean. elevando o nível dos oceanos ${ }^{29}$, na ampliação de zonas mortas $^{30}$ nas zonas costeiras, como demonstrado abaixo, e em outros eventos climáticos extremos.

Figura 1 - Zonas mortas

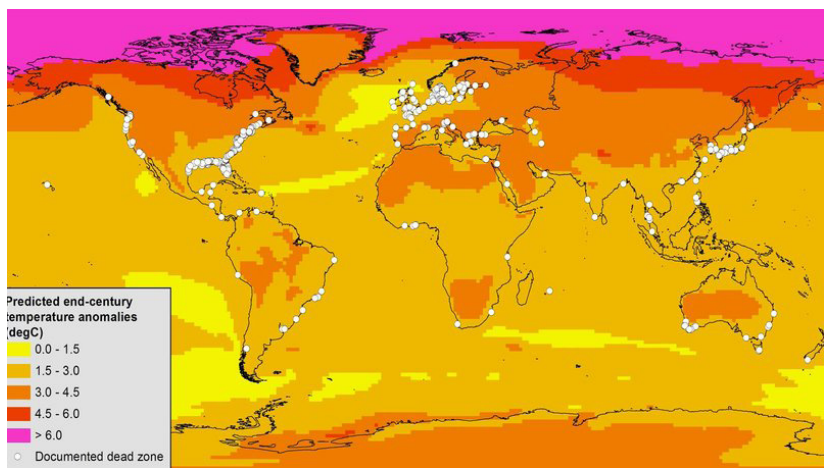

Fonte: <http://www.smithsonianmag.com/sciencenature/ocean-dead-zones-are-getting-worseglobally-due-climate-change-180953282/?no-ist>.

This map of known dead zones (white dots) shows how much annual air temperatures are expected to change by 2080-2099 compared with 1980-1999. (Keryn Gedan and Andrew Altieri/Smithsonian).

Nesse sentido, ante a irrefutabilidade dos impactos perigosos da atividade humana para o Planeta, cabe defender o início da nova ordem ambiental, que tornou-se global com o advento do Antropoceno, marcando o fim da ordem ambiental internacional descrita por Wagner Ribeiro, em 2001.

\section{A ORDEM AMBIENTAL GLOBAL}

Em 2007, Andrew Hurrell escreveu sobre a ordem global (política) ${ }^{31}$ e algumas mudanças importantes, in-

Marine Ecology Progress Series, n. 512, p. 155-166, 9 Oct. 2014.

29 Entre 1880 e 2009 o nível médio dos mares aumentou em cerca de $210 \mathrm{~mm}$. A taxa de elevação dos níveis dos mares a tendência a crescer, com um valor de $1.4+/-0.4 \mathrm{~mm} /$ ano desde os anos 1960. CHURCH, J.; WHITE, N. Sea-level rise from the late 19th to the early 21 st Century. Surveys in Geophysics, v. 32, n. 4/5, p. 585-602, sept. 2011.

30 "Dead zones" em inglês são as zonas paupérrimas em diversidade biológica, em função da poluição, acidificação, e dos impactos causados pela navegação, exploração e, mais recentemente, instalação de parques eólicos no litoral, entre outros. Sobre o clima, ver ZIELINSKI, Sarah. Ocean dead zones are getting worse globally due to climate change. Disponível em: <http://www.smithsonianmag.com/ science-nature/ocean-dead-zones-are-getting-worse-globally-dueclimate-change-180953282/?no-ist>. Acesso em: 21 mar. 2015.

31 HURRELL, Andrew. On global order: power, values, and the 
cluindo o fortalecimento de Estados não ocidentais ${ }^{32} \mathrm{e}$ mudanças profundas na ordem político-econômica ${ }^{33}$. Ele propos três quadros analíticos tomando-se por base os principais atores internacionais : os Estados soberanos, as instituições multilaterais e o fortalecimento de atores não estatais, como mercado e redes de atores cívicos. $\mathrm{Na}$ mesma época, foram definitivamente consolidados conceitos centrais para a diplomacia contemporânea, tais como : "zona econômica exclusiva", "plataforma continental", "áreas protegidas em alto-mar", "áreas protegidas além da jurisdição nacional ", "direito ambiental global"34, "regime global de diversidade biológica" 35 , " países emergentes"36, "powershift "37, "potências climáticas "38, "risco de falência sistêmica" "39, "Chinafrica"

Atualmente, convém argumentar que os Estados não conseguem cooperar de forma adequada para a regulação das relações internacionais; e as instituições multilaterais também escontram-se aquém do necessário para contribuir com a organização de legítima comunidade internacional, levando ao que se chama de crise do multilateralismo ${ }^{41}$. Infelizmente, na última década, a

constitution of International Society. Oxford: Oxford University Press, 2007.

32 IKENBERRY, John. The future of the liberal world order. internationalism after America. Foreign Affairs, New York, v. 90, n. 3, p. 56-68, May/June, 2011.

33 PRANTL, Jochen. Taming hegemony: informal institutions and the challenge to western liberal order. The Chinese Journal of International Politics, Oxford, v. 7, n. 4, p. 449-482, Winter, 2014.

34 YANG, T.; PERCIVAL, R. V. The emergence of global environmental law. 2009. Disponível em: <http://digitalcommons.law.scu.edu/ $\mathrm{cgi} /$ viewcontent. cgi? article $=1714 \&$ context $=$ facpubs, ou http: $/ /$ ssrn.com/abstract=1269157> . Acesso em: 21 fev. 2015.

35 INOUE, Cristina. Projetos de cooperação internacional, comunidades epistêmicas e conceito de regime global de biodiversidade : o caso de Mamirauá. In: CARVALHO, Maria Izabel; SANTOS, Maria Helena (Org.). O século 21 no Brasil e no mundo. São Paulo: Edusc, 2006

36 MORIN, Jean-Frédéric; ORSINI, Amandine. Essential concepts of global environmental governance. Abingdon: Routledge, 2014.

37 NYE, Joseph. Understanding 21st century power shifts. Disponível em: <http://www.europeanfinancialreview.com/?p=2743.June 24, 2011>. Acesso em: 21 fev. 2015.

38 VIOLA, Eduardo; FRANCHINI, Matías; RIBEIRO, Thaís. Sistema internacional de hegemonia conservadora: democracia e governança global na era da crise climática. São Paulo: Annablume, 2013.

39 Argumento empregado pelo Brasil para justificar a necessidade de reformas profundas no sistema ONU, principalmente no Conselho de Segurança, o qual não reflete mais a distribuição de poder mundial.

40 Sobre dado tema ver: CHINAAFRICA: accueil le magazine du nouveau monde. Paris: SLB, 2015. Disponível em: < http://www. chinafrica.info/\#home>. Acesso em: 24 fev. 2015.

41 Atualmente, estima-se que a Comissão de Limites da ONU cooperação multilateral não avançou satisfatoriamente, o que explica a lacuna entre os desafios de gestão e proteção de recursos marinhos por meio de ação coletiva, das quais o direito do mar consiste em exemplo emblemático.

Do ponto de vista dos atores internacionais, cabe destacar que a ordem internacional ambiental, construída ao longo do século XX, foi fortemente promovida pelos países desenvolvidos, principalmente os Europeus $^{42}$, mesmo que a história do direito marítimo seja diferente em alguns aspectos ${ }^{43}$. Para a gestão e proteção dos recursos marinhos, as principais instituições multilaterais são: a Assembleia Geral da ONU (AGNU), Autoridade Internacional para os Fundos Marinhos (AIFM), Tribunal do Mar (ITLOS), Comissão de Limites da Plataforma Continental (CLPC), Programa das Nações Unidas para o Meio Ambiente (PNUMA), Organização Marítima Internacional (OMI), Organização das Nações Unidas para a Educação, a Ciência e a Cultura (UNESCO), Processo informal e consultativo da ONU sobre oceanos e direito do mar (UNICPOLOS) ${ }^{44}$ e também a Comissão Mundial de Áreas Protegidas (CMAP), Fundo Mundial para a Natureza (WWF) e a International Union for Conservation of Nature (IUCN).

leve mais de vinte anos para analisar as novas demandas, por exemplo. Para o caso brasileiro, ver FIGUEIRÔA, Christiano Sávio Barros. Limites exteriores da plataforma continental do Brasil conforme o direito do mar. Brasilia: Fundação Alexandre de Gusmão/MRE, 2014. Disponível em: <http://funag.gov.br/loja/download/1100-Limites_ exteriores_da_plataforma_continental_do_Brasil_conforme_o_Direito_do_Mar.pdf>. Acesso em: 22 mar. 2015.

42 BOULET, Romain; BARROS-PLATIAU, Ana; MAZZEGA, Pierre. 35 years of multilateral environmental agreements ratifications: a network analysis. In: INTERNATIONAL WORKSHOP "NETWORK ANALYSIS IN LAW, 2, 2014, Krakow. Anais... Cambridge: Harvard College, 2014. No prelo.

43 As análises das ratificações das convenções demonstra diferenças interessantes entre o direito ambiental e o direito marítimo, que não podem ser tratadas no escopo desta análise por uma questão de foco. Os países desenvolidos demoraram mais a ratificar a UNCLOS do que aqueles em desenvolvimento. Austrália e Alemanha foram os primeiros países desenvolvidos a ratificar em 1994, após a ratificação de 64 países em desenvolvimento. UNITED NATIONS. Division for Ocean Affairs and the Law of The Sea. Chronological lists of ratifications of, accessions and successions to the Convention and the related Agreements as at 3 October 2014. Jan. 2015. Disponível em: <http://www. un.org/Depts/los/reference_files/chronological_lists_of_ratifications.htm\#Agreement for the implementation of the provisions of the Convention relating to the conservation and management of straddling fish stocks and highly migratory fish stocks $>$. Acesso em: 21 mar. 2015.

44 UN Open-ended Informal Consultative Process on Oceans and the Law of the Sea. 
A ordem ambiental global é, por sua vez, definitivamente marcada pela irupção de atores não estatais, ou atores privados, principalmente do setor econômico, comercial e tecnológico. No caso do mar, o setor petroleiro é extremamente relevante ${ }^{45}$. Diferentemente das análises que os separavam, na ordem global os setores públicos e privados estão cada vez mais imbricados, como havia assinalado Edith Brown-Weiss em $1998^{46}$.

Entretanto, conceitos como "ordem internacional" e "sociedade internacional" continuam prevalecendo na teoria de relações internacionais, sobretudo para autores que consideram o Estado como principal ator. No Brasil, a obra de Wagner Ribeiro sobre a ordem internacional ambiental, de 2001, ainda é excelente referencial, rica de reflexões ainda pertinentes. Contudo, este artigo adota o conceito de ordem ambiental global, marcando definitivamente o fim da ordem internacional por meio de mudança paradigmática que abre novas possibilidades de análise.

Primeiro, leva em conta o impacto da mudança de época geológica causada pelas atividas antropocêntricas. Impacto este que deveria ser estimado na assunção da obrigação positiva do Estado de proteger o meio ambiente em geral, e o marinho em particular, por ser o menos protegido e cada vez mais vulnerável e cobiçado. Segundo, evita a repetição infinita do termo "nova ordem internacional", haja vista sua utilização com o fim do sistema internacional bipolar ápos o desmoronamento do bloco soviético. Novos desafios elencados acima constituem uma terceira razão, notadamente no que concerne aos impactos climáticos, descritos no Relatório AR5 do Painel Intergovernamental sobre $\mathrm{Mu}$ danças do Clima (IPCC) publicado em março de 2015. Por fim, as atividades humanas mais inovadoras e às vezes mais perigosas, como a prospecção de petróleo e minerais em águas profundas, pesca em larga escala, transporte de material radioativo, exploração de zonas polares $^{47}$, produção de energia, biopirataria e turismo de

45 No caso brasileiro, representantes da Petrobrás participam ativamente da política nacional sobre recursos marinhos e dos debates interinstitucionais. Em outros países, o setor petroleiro, mesmo quando privado, pode ter forte influência nos processos decisórios. 46 BROWN WEISS, Edith. The changing structure of iternational law. In: PRIEUR, M.; LAMBRECHTS, C.(Ed.). Les hommes et l'environnement: quels droits pour le XXIe siècle? Etudes en hommage à Alexandre Kiss. Paris: Frison-Roche, 1998.

47 MARQUES, Fabrício. Corrida sobre o gelo. Disponível em: $\quad<$ http://www.revistapesquisa.fapesp.br/wp-content/uploads/2012/04/032-037_1941.pdf?f0d91f>. Acesso em: 25 mar. 2015. massa são alguns exemplos que se somam aos tradicionais desafios de poluição, perda de diversidade biológica, sobrepesca de algumas espécies e pirataria ${ }^{48}$. Assim, mesmo não oferecendo uma lista exaustiva de desafios relativamente recentes como o Antropoceno, fica claro que a governança dos oceanos tornou-se muito mais complexa em termos científicos e tecnológicos também.

Dois pontos completam a lista e caracterizam a ordem global ambiental, e portanto merecem debate mais aprofundado no escopo deste artigo: a complexidade da governança dos oceanos e a lenta evolução do direito do mar.

\section{A Complexidade da Governança dos OCEANOS}

Com o acirramento da corrida por recursos marinhos, aumenta esponencialmente a complexidade ${ }^{49} \mathrm{da}$ governança dos oceanos. Como exposto acima, aumentaram os interesses dos Estados, os meios tecnológicos, os desafios de regulação e a necessidade de ação coletiva institucionalizada para a sua efetiva regulação e controle. Por isso, o conceito de complexidade torna-se central.

Naturalmente, a governança dos oceanos implica a partipação de diversos tipos de atores, como os Estados, com suas perrogativas exclusivas de regulação normativa ; as empresas, indo das multinacionais às locais ; e os mais diversos atores da sociedade civil. Pensar nos usuários nos levaria ao fato que quase metade da população mundial vive a menos de $150 \mathrm{~km}$ da zona $\operatorname{costeira}^{50}$. Mesmo sem evocar uma teoria de poder, fica claro que cada ator ocupa espaço específico na estrutura e controla uma parte mais ou menos importante dos

48 MICHAEL, J. et al. Navigating the maritime piracy regime complex. Global Governance: a review of multilateralism and international organizations, v. 19, n. 1, p. 93-104, Jan./March, 2013. Os autores demonstram o papel central do setor privado nos debates e a ausência de um "norm entrepreneur" forte.

49 Sobre a complexidade normativa, ver: BOURCIER, Danièle; MAZZEGA, Pierre; BOULET, Romain. Visualizer la compléxité du droit. Disponível em: <https://pierremazzega.files.wordpress. com/2010/02/2009bourcieretal-bruylant.pdf $>$. Acesso em: 23 mar. 2015.

50 Em 2010 o UN Atlas revelou: "44 percent of us live in coastal areas". SIIRILÄ, Erkki. UN Atlas: 44 percent of us live in coastal areas. Jan. 2010. Disponível em: <http://coastalchallenges. com/2010/01/31/un-atlas-60-of-us-live-in-the-coastal-areas / >. Acesso em: 23 mar. 2015. 
instrumentos que orientam as tomadas de decisão, bem como a definição da natureza e do conteudo das medidas implementadas (políticas públicas, regulação jurídica, econômica ou acordos de cooperação por exemplo). Em outros termos, a natureza das relações dos atores depende profundamente do status, papel e interesses de cada um deles.

Tal miríade de interações, denominada "governança em redes" 51 atravessa em todos os sentidos os "estratos" da organização política (do global ao local, o que corresponde à imagem da ordem “ ultrapassada ") e conduz à ideia de sistema, ou de sociedade. Contudo, o sistema apresenta vários traços de complexidade : a) ele é aberto, imerso num sistema mais vasto e sem limites definidos (interferências com esferas do comércio, da segurança, das finanças etc.) ; b) ele se auto-organiza dinamicamente por meio de ações executadas e de sua estrutura evolutiva ; c) os efeitos que ele induz são muito pouco previsíveis, menos ainda no médio e longo prazos; d) é dificil se produzir uma " imagem ", um conhecimento preciso em dado momento, e caso seja possível, tal conhecimento já nasceria parcialmente obsoleto.

Eis algumas razões que nos conduzem a buscar novas formas de governança dos oceanos : estabelecer regras simples entre os atores elementares de modo que emerja em seguida de suas interações individuais o resultado esperado (preservação dos recursos marinhos vivos, gestões racionais e equitativa dos recursos marinhos minerais, dos espaços etc.). Tal emergência integra necessariamente a interpretação de regras pelos atores e o uso que delas fazem ${ }^{52}$. No futuro, essa questão será central a qualquer reflexão para tornar o direito do mar instrumento legítimo e eficaz, congruente com os desafios do desenvolvimento sustentável das nossas sociedades.

Do ponto de vista da complexidade, surge a seguinte questão : os modos tradicionais de regulação são bem

51 CARLSSON, L.; SANDSTRÖM, A. Network governance of the commons. International Journal of the Commons, v. 2, n. 1, p. 33-54. 2008. Ver também HUPPÉ, G. A.; CREECH, H.; KNOBLAUCH, D. The frontiers of networked governance. IISD Report, The International Institute for Sustainable Development, $40 \mathrm{p}$. 2012. Disponível em: < http://www.iisd.org/publications/frontiersnetworked-governance $>$. Acesso em: 22 mar. 2015.

52 PIT'T, J.; SCHAUMEIER, J.; ARTIKIS, A. The axiomatisation of socio-economic principles for self-organising systems. ACMTransactions on Autonomous and Adaptive Systems, v. 7, n. 4, p. 1-39, Dec. 2012. Disponível em: <http://dx.doi.org/10.1145/2382570.2382575>. Acesso em: 22 mar. 2015. adaptados aos desafios ambientais contemporâneos? Precisamente em termos de resultados, três argumentos fundamentais e interligados nos conduzem a certo ceticismo relativo à eficiência da atual abordagem de regulação dos espaços e dos recursos marinhos ${ }^{53}$. Primeiro, as abordagens correntes da governança negligenciam um fato essencial aos problemas ambientais, ou seja, que uma parte da mediação entre atores não é realizada por meios institucionais e políticos, mas pelos próprios atores independentemente. Os recursos marinhos (e em boa medida o meio ambiente marinho) são rivais : ao modificar o estado deles (por exemplo quantitativo : estoques ; qualitatvo: poluição), cada ator muda as condições de acesso e de uso (e podemos adicionar de regulação) dos mesmos recursos pelos outros atores. Por outro lado, os recursos "impõem” as leis fisico-químicas e biológicas da sua própria evolução (dinâmicas ecológicas, climáticas, distribuição espacial de recursos herdade da história geológica etc. $)^{54}$. Enfim, certos recursos, notadamente aqueles vivos, não são exclusivos, ou dificilmente o são. A criação de ZEE tende a resolver o problema por meio de regulação negociada. Entretanto, no caso de recursos vivos, como os estoques de peixes ${ }^{55}$, o respeito às regras é difícil de se garantir. Pelo menos duas propriedades genéricas identificadas como indispensáveis à preservação de um bem comum não são asseguradas ${ }^{56}$ : a) a identificação clara de delimitação do reservatório de recursos e quem tem direito ao seu uso ${ }^{57}$; b) a possibilidade de assegurar (a custo viável) monitoramento do estado do recurso e vigilância do comportamento dos usuários.

Tomando em consideração essas fortes incertezas cognitivas, os atores (decisores, reguladores, usuários etc.) desenvolvem estratégias comportamentais baseadas sobre preferências em evolução constante, e crenças regularmente revisitadas, como processos de aprendiza-

53 OSTROM, ELinor. Coping with the tragedy of the commons. Annual Review of Political Science, v. 2, p. 493-535, June 1999.

54 Esta simples constatação opõe uma franca reprovação ao que de acordo com o Discurso do Método (1637) de René Descartes tornou-se um tipo de máxima de um certo projeto de desenvolvimento : "se rendre comme maitre et possesseur de la nature."

55 Ver A política comunitária para pesca. COMISSÃO EUROPÉIA. A politica comum das pescas: gestão das pescas na UE. Disponível em: < http://ec.europa.eu/fisheries/cfp/index_pt.htm>. Acesso em: 22 mar. 2015.

56 OSTROM, Elinor. Governing the commons: the evolution of institutions for collective action. Cambridge: Cambridge University Press, 1990.

57 Como o paradigma clássico do "passageiro clandestino" (freerider) de Olson, 1971. 
do sobre os efeitos das suas respectivas posições estratégicas em relação aos demais atores. ${ }^{58}$ Isto é, particularmente verdadeiro para os Estados que integram alianças mais ou menos efêmeras, como G20, ZOPACAS e BRICS, pois mesmo que discutam de outras agendas como do comércio ou da segurança - têm incidência sobre suas ambições ambientais.

Levando-se em consideração as três grandes categorias de atividades humanas nos oceanos, a saber : navegação, pesca e mineração, não é dificil argumentar a complexidade da regulação internacional e o grande potencial de conflitos de interesses. Voltando-se ao contexto de assimetria econômica e tecnológica com a emergência de economias grandes em países ainda em desenvolvimento, a questão torna-se ainda mais interessante para futuras pesquisas. Dessa feita, a complexidade político-legal é construída por mecanismos de comando e controle, normalmente top-down, ou seja, estabelecidos em nível internacional ou regional e depois internalizados, sem que haja sistematicamente a garantia das condições necessárias para sua respectiva aplicação interna, como se discutirá a seguir.

\section{A eVOLUÇão do DIREITO do MAR}

Em termos amplos, a história do direito do mar pode ser descrita pela liberdade de navegação e do regime "first arrived first served" dos séculos anteriores ao XVII, seguida de sua lenta restrição no século XVIII com o conceito de mar territorial e o uso recorrente do direito consuetudinário. No século XIX, os contenciosos no Mar de Bering reforçaram a restrição à liberdade dos mares. No mesmo sentido, a maior regulação das atividades de navegação, pesca e mineração ao longo do

58 O estudo deste tipo de "wicked problems" dispõe de um quadro de análise na interface entre ciências políticas. FUNTOWICZ, S. O.; RAVETZ, J. R. Science for the post-normal age. Futures, v. 25, n. 7, p. 739-755, Sept. 1993. HEAD, B. W.; ALFORD, J. Wicked problems: implications for public policy and management. Administration and Society, v. 20, n. 10, p. 1-29, Mar. 2013. Disponível em: <http:// aas.sagepub.com/content/early/2013/03/27/0095399713481601. full.pdf>. Acesso em: 22 mar. 2015. E teoria da decisãoem KØRNØV, L.; THISSEN, W. A. H. Rationality in decision- and policy-making: implications for strategic environmental assessment. Impact Assessment and Project Appraisal, v. 18, n. 3, p. 191-200, 2010. e SHEPHERD, N. G.; MAYNARD, R. The influence of context on the strategic decision-making process: a review of the literature. International Journal of Management Reviews, v. 16, n. 3, 2014, p. $340-$ 364, 2014. século XX foi marcada pelo interesse geral em limitar a apropriação de recusos fora de jurisdições nacionais, a exploração excessiva de recursos halieuticos, e a poluição. No caso dos navios, os artigos 217, 218 e 220 da UNCLOS marcaram o fim do regime exclusivo da bandeira do Estado $^{59}$, por exemplo.

No passado foi difícil iniciar o debate sobre como regular atividades fora das jurisdição nacional dos países membros do sitema $\mathrm{ONU}^{60}$, porém, atualmente, há consenso relativamente consolidado sobre o interesse geral da humanidade e a necessidade de regulação conjunta para garantir às gerações futuras o direito de ter acesso a recursos que existem hoje, formando o cerne do que se convencionou chamar princípio do desenvolvimento sustentável. Menos louvável porém mais realista, a verdadeira motivação de grande parte dos Estados consiste em evitar que uns aproveitem mais do que os outros dos recursos marinhos em alto-mar, apreensão generalizada de países costeiros e ilhas em relação às potências tecnológicas ${ }^{61}$, cujo sucesso mais conhecido foi a proposta na ONU do então embaixador Pardo, maltês, que levou ao conceito de patrimônio comum da humanidade ${ }^{62}$.

Se o direito dividia os bens sem dono em res nullius e res communis, os avanços tecnológicos colocam em xeque muitas das certezas jurídicas construídas ao longo do século $\mathrm{XX}^{63}$. Atualmente, consolida-se o interesse geral na gestão coletiva de bens comuns, e nenhum Estado pode explorar os fundos marinhos sem despertar interesse ou preocupação de outros Estados. Exemplo disso, nota-se em relação a uma interpretação cada vez mais restritiva do princípio da soberania ${ }^{64}$ e do direito

59 SCOVAZZI, Tullio. Marine protected areas on the high seas: some legal and policy considerations. The International Journal of Marine and Coastal Law. v. 19, n. 1, p. 01-17, 2004.

60 CHURCHILL, R. R.; LOWE, A. V. The law of the sea. 3. ed. Manchester: University Press, 1999.

61 De forma geral, potências tecnológicas são os países desenvolvidos, que investiram muito na prospecção marinha de recursos vivos e não vivos. Países emergentes integram cada vez melhor a lista, notadamente a China, e outros países em desenvolvimento tem ambições desmesuradas, como no caso da Antártida.

62 KISS, Alexandre. Droit international de l'environnement. Paris: A. Pedone, 1989.

63 GAJA, Giorgio. The protection of general interestsin the international community. Leiden: Brill, 2013. (The Hague Academy collected courses online, 364).

64 SASSEN, Saskia. Losing control? Sovereignty in the age of globalization. New York: Columbia University Press, 2015. Trata da proliferação de códigos e instituições nos regimes internacionais de direitos humanos e comerciais que desafiam o princípio basilar 
inocente de passagem nos mares, bem como uma interpretação mais atualizada do direito costumeiro ${ }^{65}$. A pesca em alto-mar é um caso interessante, bem como no caso de outros animais migratórios de longas distâncias e das baleias. Entretanto, como mencionado, a evolução do direito internacional ambiental em geral e marítimo em particular é muito mais lenta do que as mudanças ambientais, políticas e econômicas desde a década de 1970. Em 1989, Martine Rémond-Goullioud ${ }^{66}$ já havia explicado que a evolução institucional é por definição lenta, visto que consiste em reação às mudanças sociais e ambientais. Consequentemente, o regime legal para o alto-mar é incompleto e inadequado para atingir o objetivo de gestão e proteção dos recursos. As lacunas que limitam sua efetividade, são de governança, regulatória, substantivae de implementação ${ }^{67}$.

Atualmente, apesar das divisões em várias areas, direito ambiental, comercial, maritimo, nuclear, direitos humanos, direito dos transportes, entre outros, e o direito privado, é importante pensar em conceitos que permitam algum tipo de integração, ou ao menos, de circulação de normas, no sentido que as boas práticas já implementadas alhures podem ser adaptadas para outras realidades politico-legais. Um deles é sem dúvida o conceito de "complexo de regimes" como um conjunto de regimes específicos colocados junto de forma desordenada ${ }^{68}$. Dentre os elementos destacados para o

da soberania nacional. OLIVEIRA, Liziane. A convenção sobre diversidade biologica e o principio de soberania nacional. 2006. 176 f. Dissertação (Mestrado em Direito) - Faculdade de Direito, Universidadede Brasilia, Brasília, 2006. ALFAIA JR., José Roberto. Reclamar ou intervir? As obrigações positivas do estado em situações de desastre ambiental. 2014. f. Tese (Doutorado) - Instituto de Relações Internacionais, Universidade de Brasília, Brasília, 2014.

65 "The present challenges of international law of the sea are to be found in the practical capacity of States to adapt and change old principles to conform with new needs". SCOVAZZI, Tullio. Direito internacional público. Haia: Academia de Direito da Haia, 2000. p. 232. 66 REMOND-GOUILLOUD, M. Du droit de détruire. Paris: Universitaires de France, 1989.

67 RAYFUSE, R.; WARNER, R. M. Securing a sustainable future for the oceans beyond national jurisdiction: the legal basis for an integrated cross-sectoral regime for high seas governance for the 21st century. International Journal of Marine and Coastal Law, v. 23, n. 3, p. 399-421, 2008.

68 "which are loosely coupled sets of specific regimes". KEOHANE, Robert O.; VICTOR, David G. The regime complex for climate change. Perspectives on Politics, v. 9, n. 1, p. 7-23, Mar, 2011. Disponível em: <http://ilar.ucsd.edu/assets/001/501988.pdf>. Acesso em: 22 mar. 2015. RAUSTIALA, Kal; VICTOR, David G. The regime complex for plant genetic resources. International Organization, v. 58, p. 277-309, Spring 2004. DREZNER, Daniel W. The power and peril of international regime complexity. Perspectives on caso do clima e que podem ser retomados para o caso da governança dos oceanos, estão os regimes legais sob auspício da ONU, acordos bilaterais e regionais, relatórios de autoridades científicas (experts), grupos como o G20, políticas subnacionais, e mais distante, regras econômicas e comerciais. Keohane e Victor defendem que o complexo de regimes permite maior flexibilidade e capacidade adaptativa, posto que a organização da arquitetura da governança seria simplificada. Ao contrário, Orsini, Morin e Young defendem que o complexo de regimes pode criar obstáculos ou oportunidades, dependendo se são fragmentados, centralizados ou den$\operatorname{sos}^{69}$. No caso do complexo de regimes do mar, que é indubitavelmente fragmentado ao extremo tanto do ponto de vista setorial quanto geográfico, e determina o sucesso da governança oceânica, pode-se argumentar que a circulação de normas não é apenas imprescindível, mas urgente. Sabendo-se que uma governança oceânica centralizada ou unificada não passa de ideal político-legal, defende-se neste artigo que os espaços convencionais tenham ao menos um framework conceitual forte, como foi ambição da UNCLOS e da CDB, e que as obrigações internacionais por eles determinadas sejam compatíveis entre eles, na medida do possível.

\subsection{A necessária circulação de normas}

A literatura especializada em direito internacional ambiental e relações internacionais tende a descrever a complexidade da governança ambiental em termos da fragmentação e da sobreposição de regimes ${ }^{70}$ e normas. Em termos amplos, a Comissão da ONU sobre Direito Internacional abordou o problema na publicação "Fragmentation of international law: difficulties arising from the diversification and expansion of international law" "71. No mesmo sentido, Daillier e Pellet afirmaram que o direito internacional ambiental era uma " colcha

Politics, v. 7, n. 1, p. 65-70, Mar. 2009.

69 ORSINI, Amandine; MORIN, Jean- Frédéric; YOUNG, Oran. Regime complexes: a buzz, a boom, or a boost for global governance? Global Governance, v. 19, n. 1, p. 27-39, Jan./Mar. 2013. 70 Para a teoria de relações internacionais, ver a obra de Oran Young nos últimos vinte anos sobre as questões ambientais.

71 KOSKENNIEM, Martti. Fragmentation of international law: difficulties arising from the diversification and expansion of international: report of the study group of the International Law Commission. 13 Apr. 2006. Disponível em: < http://legal.un.org/ilc/ documentation/english/a_cn4_1682.pdf>. Acesso em: 27 mar. 2015. 
de retalhos "72; Sandrine Maljean-Dubois destacou a ausência de hierarquia entre espaços convencionais ${ }^{73}$; Mireille Delmas-Marty ${ }^{74}$ publicou ampla pesquisa sobre o pluralismo jurídico ordenado em termos de atores, fatores e processos; Mario Prost destacou as lacunas do direito internacional ${ }^{75}$; e Marcelo Dias Varella se dedicou ao estudo da internacionalização do direito e sua complexidade $^{76}$. A lista de pesquisadores é longa, refletindo a pesquisa internacional publicada nas últimas duas décadas. No caso específico do mar, o ecossistema marinho e o costeiro foram abordados em capítulos separados até no Millenium Ecosystem Assessment ${ }^{77}$, apesar das relações fortes entre eles.

Todavia, se de um lado observa-se a fragmentação da governança ambiental, observa-se igualmente, nos últimos anos, o aparecimento de mecanismos e processos político-legais que permitem certa coerência entre regimes coexistentes, a ampliação do diálogo entre operadores de direito e processos de transposição de normas, o que se define neste artigo como "circulação de normas" "78. Diversos são os mecanismos e processos que permitem tal circulação e conduezm aos tratados multilaterais, tais como os atores, as agendas de negociação, os princípios jurídicos, e os conceitos estruturantes, como o de interesse geral da humanidade.

No caso da proteção da biodiversidade no mar, por exemplo, merecem destaque a Convenção sobre Diver-

72 DAILLIER, Patrick; PELLET. Alain. Droit international public. Paris: LGDJ, 2002.

73 MALJEAN-DUBOIS, Sandrine. La mise en oeuvre du droit international de l'environnement. Paris: IDDRI, 2003. (les Notes de L'iddri, n. 4) Disponível em: <http://www.peacepalacelibrary.nl/ebooks/ files/337934460.pdf>. Acesso em: 27 mar. 2015.

74 DELMAS-MARTY, Mireille. Les forces imaginantes du droit: le pluralisme ordonné. Paris: Seuil, 2006.

75 PROST, Mario. Unitas multiplex: unites et fragmentations en droit international. Bruxelles: Bruylant, 2013.

76 VARELLA, Marcelo. Internationalization of law: globalization, international law and complexity. Brasília: Centro Universitário de Brasília, 2013.

77 HASSAN, Rashid; SCHOLES, Robert; ASH, Neville. Ecosystems and human well-being: current state and trends: findings of the Condition and Trends Working Group. Washington: Millennium Ecosystem Assessment, 2005. (The Millennium Ecosystem Assessment Series; v. 1). Disponível em: <http://www.millenniumassessment.org/en/Condition.html>. Acesso em: 27 mar. 2015.

78 Esta seção é fortemente baseada dos resultados de pesquisa do projeto CIRCULEX iniciado em 2013, financiado pela ANR francesa e sob a direção de Sandrine Maljean-Dubois. MALJEAN-DUBOIS, Sandrine. La mise en oeuvre du droit international de l'environnement. Paris: IDDRI, 2003. (les Notes de L’iddri, n. 4) Disponível em: <http:// www.peacepalacelibrary.nl/ebooks/files/337934460.pdf>. Acesso em: 27 mar. 2015. sidade Biologica (CDB, 1992), a Convenção das Nações Unidas sobre o Direito do Mar sobre a Conservação e Ordenamento de Populações de Peixes Transzonais e de Populações de Peixes Altamente Migratórios (Convenção de Montego Bay, 1982), Convenção de Bona sobre a Conservação das Espécies Migradoras Pertencentes à Fauna Selvagem (1979), Convenção sobre o Comércio Internacional de Espécies da Fauna e Flora Selvagem em Perigo de Extinção (CITES,1973), Tratado da Antártida (1959), Convenção de Genebra sobre a Pesca e a Conservação de Recursos Vivos do Alto Mar (1958). Além disso, houve proliferação significativa de convenções regionais e convenções setoriais sobre a poluição marinha e a pesca principalmente, das quais podem-se destacar o Protocolo Relativo a Áreas Especialmente Protegidas e Diversidade Biológica no Mediterrâneo (1995).

Finalmente, os debates sobre recursos situados além da jurisdição nacional ganharam novo alento ${ }^{79}$. Cada tratado tem uma história própria, e impõe obrigações que nem sempre são compatíveis com uma visão sistêmica dos desafios atuais. Certamente, os regimes internacionais não são independentes dos interesses dos Estados que os promoveram, ou seja, os espaços convencionais acima foram, em larga medida, codificados sob a liderança de potências marítimas tradicionais, as mesmas que construiram a ordem ambiental internacional ao longo do século passado. Ademais, destaque-se a necessidade de incluir atores subnacionais nos processos regulatórios ${ }^{80}$.

Nesse sentido, a circulação de normas deve ser entendida como resultado de algo bem mais amplo, que é a abordagem da questão do mar como um sistema vivo que interage com a zona costeira e com a terrestre ${ }^{81}$.

79 Ad Hoc Open-ended Informal Working Group to study issues relating to the conservation and sustainable use of marine biological diversity beyond areas of national jurisdiction, paragrafo $73 \mathrm{da}$ résolução 59/24 da AGNU. UNITED NATIONS. Resolution adopted by the General Assembly, 4 of February of 2005. Oceans and the law of the sea. Disponível em: <http://www.unga-regular-process.org/ images/Documents/un\%20a-res-59-24.pdf>. Acesso em: 22 mar. 2015. Ver também UNITED NATIONS. Oceans and the law of the sea: letter dated 25 July 2014 from the Co-Chairs of the Ad Hoc Open-ended Informal Working Group to the President of the General Assembly. Disponível em: <http://www.un.org/depts/los/ biodiversityworkinggroup/documents/BBNJreport_69_177.pdf $>$. Acesso em: 22 mar. 2015.

80 Dois casos interessantes: o estado da California nos EUA e do estado de São Paulo no Brasil, que atuam de forma crescentemente independente de suas respectivas diplomacias.

81 Um exemplo central e ao mesmo tempo complexo, foi demon- 
Ademais, concentra diversos ramos do direito, e uma vasta diversidade de atores, do federal ao local no caso brasileiro. Ela é necessária, ou seja, não opcional, como primeiro passo para uma reforma maior do regime legal global, para torná-lo mais integrado e trans-setorial ${ }^{82}$. No caso do Brasil, no mesmo sentido, o ordenamento nacional precisa ser discutido com base na fragmentação atual ${ }^{83}$ e da circulação de normas internacionais, regionais, nacionais e sub-nacionais, que inclua também os atores locais, como as comunidades de pesca.

\subsection{A estratégia brasileira de gestão e proteção dos recursos marinhos}

Por sua megadiversidade biológica e a riqueza mineral, o Brasil tem o duplo desafio de gestão e proteção dos recursos ambientais sob sua tutela, mas também fora de sua jurisdição. Nesse sentido, impõe-se a questão relativa aos desafios relativos à navegação, pesca e mineração, notadamente a poluição, sobrepesca, biopirataria e a bioinvasão ${ }^{84}$, bem como práticas diversas que causam danos ao meio ambiente marinho e costeiro. Ademais, como salientou Figuerôa:

strado que a ausencia de eventos climaticos extremos na costa brasileira é relativa aos serviços ambientais ecossitemicos, como os amazônicos. NOBRE, Antônio. O futuro climático da Amazônia: relatório de avaliação científica. São José dos Campos: ARA, 2014. Disponível em: <http://www.ccst.inpe.br/wp-content/uploads/2014/10/Futuro-Climatico-da-Amazonia.pdf>. Acesso em: 22 mar. 2015.

82 "In view of escalating threats to the oceans from existing and emerging uses and form the impacts of climate change, transformation to a legal regime better suited to integrated, cross-sectoral management and preservation of vital ocean ecosystem services and resilience may no longer be a luxury, but rather a necessity.".

83 In Oliveira, Carina Costa de e Coelho, Luciana. Os limites do planejamento da ocupação sustentável da zona costeira brasileira. Revista de Direito Internacional, vol.12, no.1. (nesta edição).

84 "Bioinvasão ou invasão biológica é o ato ou efeito de um ou mais organismos invadirem e se estabelecerem em ambientes onde não haviam registros anteriores para a espécie. Entretanto, existem dois tipos de invasões: expansões e introduções. As expansões consistem na dispersão de organismos por mecanismo natural e as introduções ocorrem quando as espécies são transportadas por atividades humanas, intencionalmente ou não, para uma área onde não ocorriam". SOUZA, Rosa Cristina de. Água de lastro: uma ameaça à biodiversidade. In: REUNIÃO ANUAL DA SBPC, 62, 2010, Natal. Ciências do mar: herança para o futuro, Anais... Natal: SBPC, 2010. Disponível em: < http://www.sbpcnet.org.br/livro/62ra/mesas_redondas $/ \mathrm{MR} \% 20$ Rosa $\% 20$ Cristina $\% 20$ Corr $\%$ C $3 \%$ AAa $\% 20$ Luz\%20de\%20Souza.pdf>. Acesso em: 02 abr. 2015. Ver também: OLIVEIRA, C. C. Critérios jurídicos para a responsabilidade civil decorrente de bioinvasão: o caso do coral-sol. A Ressurgência, Niterói, v. 7, p. 21-22, 2013.
A importância econômica e estratégica para o país da extensão da plataforma continental além das $200 \mathrm{M}$ elevou-se significativamente. Atualmente os blocos do pré-sal em atividade comercial na plataforma continental brasileira estão muito próximos das $200 \mathrm{M}$ de nossas linhas de base, a 50 $\mathrm{km}$ desse limite. ${ }^{85}$

Oficialmente,

o Brasil dispõe de estratégia e política nacional que abrangem os temas principais relacionados a oceanos, mares e zonas costeiras, incluindo seus recursos naturais, vivos ou não-vivos. A Política Nacional para os Recursos do Mar (PNRM), aprovada por Decreto Presidencial de 12 de maio de 1980 , tem como propósitos a promoção da integração do mar territorial, da zona econômica exclusiva e da plataforma continental ao espaço brasileiro, e a exploração racional e o uso sustentável dos recursos do mar. Compreendidos como recursos vivos, minerais, energéticos e biotecnológicos da coluna de água, solo e subsolo marinho, que apresentem interesse para o desenvolvimento econômico e social do País, além de sustentabilidade ecológica. ${ }^{86}$

A Comissão Interministerial para os Recursos do Mar (CIRM) ${ }^{87}$ é vinculada ao Ministério da Defesa, composta por Ministérios da Defesa, Relações Exteriores, Minas e Energia, Agricultura, e Transportes, sua finalidade é

Submeter ao Presidente da República, por
intermédio do Ministro de Estado da Defesa, as
diretrizes propostas para a consecução da PNRM;
Apreciar o planejamento de atividades relacionadas
com os recursos do mar, propondo ao Presidente
da República prioridades para os programas e
projetos que o integram; Coordenar a elaboração
de planos e programas plurianuais e anuais, comuns

$85{ }^{86}$ FIGUEIRÔA, Christiano Sávio Barros. Limites exteriores da plataforma continental do Brasil conforme o direito do mar. Brasilia: Fundação Alexandre de Gusmão/MRE, 2014. Disponível em: <http:// funag. gov.br/loja/download/1100-Limites_exteriores_da_plataforma_ continental_do_Brasil_conforme_o_Direito_do_Mar.pdf >. Acesso em: 22 mar. 2015.

86 BRASIL. Ministério do Meio Ambiente. Diversidade biológica marinha e costeira. Disponível em: <http://www.mma.gov.br/estruturas/chm/_arquivos/2relat_cap1_Marinha.pdf>. Acesso em: 22 mar. 2015.

87 Segundo a Marinha: "A Comissão Interministerial para os Recursos do Mar (CIRM), criada pelo Decreto no 74.557, de 12 de setembro de 1974, revogado pelo Decreto no 3.939 , de 26 de setembro de 2001, alterado pelos Decretos nos: 4.815 , de 20 de agosto de 2003; 6.107, de 2 de maio de 2007; 6.484, de 17 de junho de 2008; 6.756, de 2 de fevereiro de 2009 e 6.979 , de 8 de outubro de 2009 tem a finalidade de coordenar os assuntos relativos à consecução da Política Nacional para os Recursos do Mar (PNRM)". BRASIL. Comissão Interministerial para os Recursos do Mar. Seja bem-vindo ao nosso site. Disponível em: <http:/ / www.mar.mil.br/secirm/portugues/principal.html>. Acesso em: 22 mar. 2015. 
e setoriais; Sugerir as destinações de recursos financeiros para incrementar o desenvolvimento das atividades relacionadas com o mar e com a Antártica, por meio de dotações orçamentárias ou de outras fontes, internas ou externas; Acompanhar os resultados e propor as alterações da PNRM; Acompanhar os resultados e propor as alterações na execução do Programa Antártico Brasileiro (PROANTAR); e Emitir pareceres e sugestões relativos aos assuntos e atividades relacionadas com os recursos do mar, quando determinado pelo Presidente da República. ${ }^{88}$

A Comissão também tem papel central no Plano de Levantamento da Plataforma Continental Brasileira (Leplac) ${ }^{89}$. É responsavel pela implementação dos Planos Setoriais para os Recursos do Mar (PSRM), que são quadrienais e editados desde 1982. O VIII PSRM, que se encerra em 2015, foi debatido com cientistas e atores não estatais, dentre os seus quatorze objetivos encontram-se o aumento do conhecimento científico, a proteção das Unidades de Conservação marinhas e costeiras e das zonas protegidas marinhas ${ }^{90}$.

Para os recursos sob jurisdição brasileira, há vasta literatura geopolítica sobre a necessidade de defesa armada dessas riquezas, dentre as quais vale destacar o Livro Branco de Defesa Nacional ${ }^{91}$ e a Estratégia Nacional de Defesa ${ }^{92}$. Nas ciências biológicas, encontra-se qualidade mundialmente reconhecida de estudos sobre temas afetos ao mar, porém ainda muito aquém do que o Brasil poderia elaborar. Na pesquisa jurídica e política, curiosamente, o mar foi plutôt preterido ${ }^{93}$. Entretanto, as pesquisas e relatórios oficiais recentes apontam para

88 BRASIL. Ministério do Desenvolvimento, Indústria e Comércio Exterior. Comissão Interministerial para os Recursos do Mar - CIRM (MD). Disponível em: <http://www.mdic.gov.br/sitio/interna/ interna.php?area $=1 \&$ menu $=785 \& \mathrm{refr}=482>$. Acesso em: $22 \mathrm{mar}$. 2015.

89 BRASIL. Ministério da Defesa. O Plano de Levantamento da Plataforma Continental Brasileira: LEPLAC. Disponível em: <https://www. mar.mil.br/dhn/dhn/ass_leplac.html>. Acesso em: 22 mar. 2015.

90 BRASIL. Comissão Interministerial para os Recursos do Mar. Resolução n. 6, de 29 de novembro de 2011. Disponível em: < https:// www.mar.mil.br/secirm/documentos/atas/resolucao-6-2011.pdf>. Acesso em: 22 mar. 2015.

91 Descreve o ambiente estratégico do século XXI com atenção para o Atlântico Sul. BRASIL. Ministério da Defesa. O livro branco de defesa nacional. 2012. Disponível em: < http://www.defesa.gov.br/ arquivos/2012/mes07/end.pdf>. Acesso em: 22 mar. 2015.

92 BRASIL. Ministério da Defesa. Estratégia nacional de defesa. Disponível em: <http://www.defesabr.com/MD/md_estrategia.htm>. Acesso em: 22 mar. 2015.

93 Ver GRANZIEIRA, Maria; GONÇALVES, Alcindo (Org.) Os problemas da zona costeira no Brasil e no mundo. Santos: Unisantos, 2012. Disponível em: <https://www.unisantos.br/edul/public/pdf/zonacosteira.pdf $>$. Acesso em: 22 mar. 2015. a imediata necessidade de integração das instituições, políticas e normas, levando ao conceito de "gestão integrada", tanto da zona costeira com a marinha, como no caso da Amazônia Azul com a Amazonia Legal (ou verde $)^{94}$.

Nesse sentido, a primeira sugestão para a estratégia nacional consiste em abordar a questão marinha de forma mais integrada, considerando os poderes Executivo, Legislativo e Judiciário, mas também os atores subnacionais do mercado e da sociedade, inclusive a local, como destacado acima. Ressalte-se que a estratégia brasileira atualmente encontra-se concentrada no Executivo, o que não facilita a regulação efetiva das questões relativas ao mar em nivel nacional ${ }^{95}$. Em outros termos, o diálogo nacional ainda é fragmentado, por vezes inexistente, tornando a construção do interesse nacional um discurso estranho a atores pertinentes no enfrentamento dos desafios. O consenso sobre os interesses nacionais é primordial, pois como dizem os navegadores, "só há vento favorável para quem sabe onde vai ".

Para os recursos fora de sua jurisdição, é interesse do País investir em tecnologias e pesquisa científica que confortem a sua posição de país emergente e potência ambiental e climática, pois ainda está longe de ser potência marítima. Logo, desenvolver pesquisas na Antártida constitui parte importante da estratégia brasileira. Assim, a segunda sugestão para a estratégia nacional é o fortalecimento de parcerias estratégicas ${ }^{96} \mathrm{com}$ foco específico no mar, o que ainda não existe de forma integrada. França (Guiana Francesa) ao Norte e Uruguai ao Sul são dois interlocutores primordiais com relação ao pleito nacional de extensão da Plataforma Continental, como bem explica Figuerôa ${ }^{97}$.

94 BARROS, Jorge et al. Amazonie bleue et la projection brésilienne sur l'avenir. Revista Outre Terre, Paris, v. 1, n. 42, p. 204-212, 2015. doi: $10.3917 /$ oute1.042.0204.

95 OLIVEIRA, Carina; MONTALVERNE, Tarin; AMARAL JR., Alberto. A implementação no Brasil da obrigação de conservar o meio ambiente marinho: algumas lacunas na preservação da biodiversidade marinha. In: MENEZES, Wagner (Org.). Direito do mar Desafios e Perspectivas. Belo Horizonte: Arraes, 2014. v. 1. p. 250-266. 96 Constitui o ato 3 da Simulação da Estratégia Nacional de Defesa. BRASIL. Ministério da Defesa. Estratégia nacional de defesa. Disponível em: <http://www.defesabr.com/MD/md_estrategia.htm>. Acesso em: 22 mar. 2015. Sobre o conceito e uma análise acadêmica das relações exteriores do Brasil, ver ALTEMANI, H.; LESSA, Antônio Carlos (Org.). Parcerias estrategicas do Brasil: os significados e as experiencias tradicionais. Belo Horizonte: Fino Traço, 2013. v. 1. 97 FIGUEIRÔA, Christiano Sávio Barros. Limites exteriores da plataforma continental do Brasil conforme o direito do mar. Brasília: Fundação Alexandre de Gusmão/MRE, 2014. Disponível em: <http://funag. 
A terceira sugestão constitui a maior participação nacional nos mecanismos multilaterais que constroem a governança dos oceanos. O Brasil precisa participar ativamente dos debates sobre a biodiversidade fora das àreas sob jurisdição nacional, zonas marinhas protegidas, regras de navegação, mineração offshore, combate à pirataria e à biopirataria, dentro e fora das organizações intergovernamentais. Além de participar das agendas de negociação multilateral e bilateral, é importante ratificar os tratados que nos interessam com maior celeridade, e cuidar de sua transposição ao plano interno. $\mathrm{O}$ Brasil ratificou a UNCLOS em dezembro de 1988 (36 Estado), mas a Parte XI apenas em outubro de 2007 (131 ${ }^{\circ}$ Estado). Em março de 2000 ratificou a provisão sobre Populações de Peixes altamente Migratórios $\left(26^{\circ}\right.$ Estado) ${ }^{98}$. Porém, apenas em 2002, o Decreto n. 4631 promulgou o Acordo para Implementação das Disposições da Convenção das Nações Unidas sobre o Direito do Mar de 10 de dezembro de 1982 sobre a Conservação e Ordenamento de Populações de Peixes Transzonais e de Populações de Peixes Altamente Migratórios. Ou seja, foram vinte anos de transposição ao plano nacional, porém isso não significa sua efetiva adoção pelos atores brasileiros, como é o caso atualmente.

Por último, em ordem, mas não em importância, é imprescindível conduzir reforma do arcabouço institucional nacional para que o Brasil administre de facto e de jure seus recursos de forma sustentável, em nome do interesse geral da humanidade e das gerações futuras. Logo, considerando que o Atlântico não constitui obstáculo natural, mas sim uma via de navegação auspiciosa, além de participar mais ativamente de debates multilaterais, a estratégia brasileira deve ser fortalecida no sentido de maior aproximação com seus vizinhos sul-americanos e africanos, como ja é o caso. Globalmente, a estratégia brasileira tomou os rumos corretos, porém ainda carece de reformas institucionais que promovam o diálogo de autoridades nacionais para evitar os entraves burocráticos atuais, a competição interna

gov.br/loja/download/1100-Limites_exteriores_da_plataforma_ continental_do_Brasil_conforme_o_Direito_do_Mar.pdf $>$. Acesso em: 22 mar. 2015.

98 UNITED NATIONS. Division for Ocean Affairs and the Law of The Sea. Chronological lists of ratifications of, accessions and successions to the convention and the related agreements as at 3 October 2014. Jan. 2015. Disponível em: <http://www.un.org/Depts/los/reference_files/chronological_lists_of_ratifications.htm\#Agreement for the implementation of the provisions of the Convention relating to the conservation and management of straddling fish stocks and highly migratory fish stocks >. Acesso em: 21 fev. 2015. por competências regulatórias e o aumento das lacunas no direito e na política.

\section{Considerações finAis: PISTAS dE REFLEXÃo}

Os países emergentes entraram com força na corrida para o mar no momento em que a comunidade científica e política discute sobre a gravidade dos impactos da atividade humana para o Planeta, ou seja, na época do Antropoceno. Constata-se a grande complexidade dos desafios relativos à proteção e à gestão dos recursos marinhos compartilhados, tanto os vivos quanto os não vivos, os quais explicam, mas não justificam, a fragilidade das organizações intergovernamentais multilaterais, a ineficácia do direito internacional público, e a dificil concertação política a nível estatal. Estes são os traços da ordem global ambiental, quando a humanidade coloca em risco a sua própria perenidade por não conseguir criar um arcabouço normativo regulatório para suas atividades no mar. Nesse sentido, a circulação de normas parece uma proposta tanto factível quanto imediata para o avanço dos debates que levem às obrigações positivas dos Estados de proteger e gerir, e dos demais atores por eles representados ou regulados, principalmente os atores do mercado e do setor da tecnologia.

Essa ordem ambiental global interessa particularmente às autoridades brasileiras, ante a megadiversidade nacional, a potencialidade da zona do Pré-Sal, e principalmente pelo potencial que o País tem de se tornar potência econômica no futuro. Para tanto, três pistas de reflexão são propostas. A primeira consiste na integração das instituições nacionais para que haja maior coerência na formulação do interesse nacional. A segunda constitui o fortalecimento de parcerias estratégicas com foco específico no mar, o que ainda não existe. A terceira consiste na maior participação nacional nos mecanismos multilaterais, regionais e bilaterais que constróem a governança dos oceanos. Por último, é imprescindível a reforma institucional nacional para que o Brasil administre concretamente seus recursos de forma sustentável, em nome do interesse geral da humanidade e das gerações futuras, como defendia Alex Kiss. 


\section{REFERÊNCIAS}

ALFAIA JR., José Roberto. Reclamar ou intervir? As obrigações positivas do estado em situações de desastre ambiental. 2014. f. Tese (Doutorado) - Instituto de Relações Internacionais, Universidade de Brasília, Brasília, 2014.

ALTEMANI, H.; LESSA, Antônio Carlos (Org.). Parcerias estrategicas do Brasil: os significados e as experiencias tradicionais. Belo Horizonte: Fino Traço, 2013. v. 1.

BARROS, Jorge et al. Amazonie bleue et la projection brésilienne sur l'avenir. Revista Outre Terre, Paris, v. 1, n. 42, p. 204-212, 2015. doi: 10.3917/oute1.042.0204.

BECARD, Danielly; BARROS-PLATIAU, Ana Flávia; OLIVEIRA, Carina. Brasil, a China e a VI Cúpula do BRICS. Contexto Internacional, v. 37, n. 1, 2015. No prelo.

BEIRÃO, André; PEREIRA, Antonio(Org.). Reflexões sobre a Convenção do Direito do Mar. Brasília: FUNAG, 2014. Disponível em: <http://funag.gov.br/loja/ download/1091-Convencao_do_Direito_do_Mar. pdf>. Acesso em: 22 mar. 2015.

BOULET, Romain; BARROS-PLATIAU, Ana; MAZZEGA, Pierre. 35 years of multilateral environmental agreements ratifications: a network analysis. In: INTERNATIONAL WORKSHOP NETWORK ANALYSIS IN LAW, 2, 2014, Krakow. Anais... Cambridge: Harvard College, 2014. No prelo.

BOURCIER, Danièle; MAZZEGA, Pierre; BOULET, Romain. Visualizer la compléxité du droit. Disponível em: <https://pierremazzega.files.wordpress. com/2010/02/2009bourcieretal-bruylant.pdf $>$. Acesso em: 23 mar. 2015.

BRASIL. Comissão Interministerial para os Recursos do Mar. Resolução n. 6, de 29 de novembro de 2011. Disponível em: <https://www.mar.mil.br/secirm/documentos/ atas/resolucao-6-2011.pdf>. Acesso em: 22 mar. 2015.

BRASIL. Comissão Interministerial para os Recursos do Mar. Seja bem-vindo ao nosso site. Disponível em: <http://www.mar.mil.br/secirm/portugues/principal. html>. Acesso em: 22 mar. 2015.

BRASIL. Ministério da Defesa. Estratégia nacional de defesa. Disponível em: <http://www.defesa.gov.br/arquivos/2012/mes07/lbdn.pdf>. Acesso em: 22 mar. 2015.
BRASIL. Ministério da Defesa. O livro branco de defesa nacional. 2012. Disponível em: <http://www.defesa.gov. br/arquivos/2012/mes07/lbdn.pdf $>$. Acesso em: 22 mar. 2015.

BRASIL. Ministério da Defesa. O Plano de Levantamento da Plataforma Continental Brasileira: LEPLAC. Disponível em: <https://www.mar.mil.br/dhn/dhn/ass_leplac. html>. Acesso em: 22 mar. 2015.

BRASIL. Ministério do Desenvolvimento, Indústria e Comércio Exterior. Comissão Interministerial para os Recursos do Mar - CIRM (MD). Disponível em: <http://www.mdic.gov.br/sitio/interna/interna. php?area $=1 \&$ menu $=785 \&$ refr $=482>$. Acesso em: 22 mar. 2015.

BRASIL. Ministério do Meio Ambiente. Diversidade biológica marinha e costeira: Disponível em: <http://www. mma.gov.br/estruturas/chm/_arquivos/2relat_cap1_ Marinha.pdf>. Acesso em: 22 mar. 2015.

CARLSSON, L.; SANDSTRÖM, A. Network governance of the commons. International Journal of the Commons, v. 2, n. 1, p. 33-54, 2008.

CARVALHO, Fernanda. The Brazilian position on forests and climate change from 1997 to 2012: from veto to proposition. Revista Brasileira de Política Internacional, Rio de Janeiro, v. 55, n. spe, p. 144-169, 2012.

CHINAAFRICA: accueil le magazine du nouveau monde. Paris: SLB, 2015. Disponível: <http://www. chinafrica.info/\#home>. Acesso em: 24 fev. 2015.

CHRISTENSEN, V. et al. A century of fish biomass decline in the ocean. Marine Ecology Progress Series, n. 512, p. 155-166, 9 Oct. 2014.

CHURCH, J.; WHITE, N. Sea-level rise from the late 19th to the early 21 st century. Surveys in Geophysics, v. 32, n. $4 / 5$, p. 585-602, sept. 2011.

CHURCHILL, R. R.; LOWE, A. V. The law of the sea. 3. ed. Manchester: University Press, 1999.

COMISSÃO EUROPÉIA. A política comum das pescas: gestão das pescas na UE. Disponível em: <http:// ec.europa.eu/fisheries/cfp/index_pt.htm>. Acesso em: 22 mar. 2015.

CONFÉRENCE DES PARTIES DE LA CONVENTION-CADRE DES NATIONS UNIES SUR LES CHANGEMENTS CLIMATIQUES, 21, 2015, Paris. 
Procédure eletrônicos... Paris: UNFCC, 2015. Disponível em: <http://www.cop21.gouv.fr/fr>. Acesso em: 23 mar.2015.

CRUTZEN, P. J.; STOERMER, E. F. The anthropocene. Global Change Newsletter, v. 41, p. 17-18, May. 2000.

DAILLIER, Patrick; PELLET. Alain. Droit international public. Paris: LGDJ, 2002.

DELEUIL Thomas. Le statut des pays en voie de développement dans les Accords Multilatéraux Environnementaux. 2014. f. Thèse (PhD) - Centre d'Etudes et de Recherches Internationales et Communautaires (CERIC, CNRS UMR 7318), Faculté de Droit d'Aix en Provence, Université Paul Cézanne Aix-Marseille, Marseille 2014.

DELMAS-MARTY, Mireille. Les forces imaginantes $d u$ droit: le pluralisme ordonné. Paris: Seuil, 2006.

DREZNER, Daniel W. The power and peril of international regime complexity. Perspectives on Politics, v. 7, n. 1, p. 65-70, Mar. 2009.

FIGUEIRÔA, Christiano Sávio Barros et al. O direito dos fundos marinhos internacionais: o patrimônio comum da humanidade 20 após a Convenção de Montego Bay. In: TRINDADE, Antônio Augusto Cançado (Org.). A nova dimensão do direito internacional. Brasília: FUNAG, 2005. p. 29-175.

FIGUEIRÔA, Christiano Sávio Barros. Limites exteriores da plataforma continental do Brasil conforme o direito do mar. Brasilia: Fundação Alexandre de Gusmão/MRE, 2014. Disponível em: <http://funag.gov.br/loja/ download/1100-Limites_exteriores_da_plataforma_ continental_do_Brasil_conforme_o_Direito_do_Mar. pdf $>$. Acesso em: 22 mar. 2015.

FUNTOWICZ, S. O.; RAVETZ, J. R. Science for the post-normal age. Futures, v. 25, n. 7, p. 739-755, Sept. 1993.

GAJA, Giorgio. The protection of general interestsin the international community. Leiden: Brill, 2013. (The Hague Academy collected courses online, 364).

GOIS, Ancelmo; BARROS-PLATIAU, Ana Flávia. Direito internacional e globalização face as questões de direitos humanos. In: RIBEIRO, M.; MAZZUOLI, Valério (Coord.). Direito internacional dos direitos bumanos: estudos em homenagem à professora Flávia Piovesan. Curitiba: Juruá, 2004.
GOLDEMBERG, José; VIOLA, Eduardo. BRICS e as mudanças climáticas. 2014. Disponível em: <http:// politicaexterna.com.br/2580/brics-e-mudancas-climaticas/>. Acesso em: 19 mar. 2015.

GRANZIEIRA, Maria; GONÇALVES, Alcindo (Org.) Os problemas da zona costeira no Brasil e no mundo. Santos: Unisantos, 2012. Disponível em: <https://www.unisantos.br/edul/public/pdf/zonacosteira.pdf $>$. Acesso em: 22 mar. 2015.

GRANZIERA, Maria Luiza; GONÇALVES, Alcindo. Os problemas da zona costeira no Brasil e no mundo. São Paulo: Universitária Leopoldianum, 2012.

HASSAN, Rashid; SCHOLES, Robert; ASH, Neville. Ecosystems and human well-being: current state and trends: findings of the Condition and Trends Working Group. Washington: Millennium Ecosystem Assessment, 2005. (The Millennium Ecosystem Assessment Series; v. 1). Disponível em: <http://www.millenniumassessment. org/en/Condition.html>. Acesso em: 27 mar. 2015.

HEAD, B. W.; ALFORD, J. Wicked problems: implications for public policy and management. Administration and Society, v. 20, n. 10, p. 1-29, Mar. 2013. Disponível em: <http://aas.sagepub.com/content/ear ly/2013/03/27/0095399713481601.full.pdf $>$. Acesso em: 22 mar. 2015.

HURRELL, Andrew. On global order: power, values, and the constitution of international society. Oxford: Oxford University Press, 2007.

IKENBERRY, John. The future of the liberal world order. internationalism after america. Foreign Affairs, New York, v. 90, n. 3, p. 56-68, May/June, 2011.

INOUE, Cristina. Projetos de cooperação internacional, comunidades epistêmicas e conceito de regime global de biodiversidade: o caso de Mamirauá. In: CARVALHO, Maria Izabel; SANTOS, Maria Helena (Org.). O século 21 no Brasil e no mundo. São Paulo: Edusc, 2006.

INTERGOVERNMENTAL PANEL ON CLIMATE CHANGE. Chapter Climate Change 2014: synthesis report, summary for policymakers. Disponível em: <http://www.ipcc.ch/pdf/assessment-report/ar5/ syr/AR5_SYR_FINAL_SPM.pdf $>$. Acesso em: 22 mar. 2015.

INTERGOVERNMENTAL platform on biodiversity and ecosystem services. 2015. Disponível em: < http:/ / www.ipbes.net/>. Acesso em: 23 mar.2015. 
KEOHANE, Robert O.; VICTOR, David G. The regime complex for climate change. Perspectives on Politics, v. 9, n. 1, p. 7-23, 2011. Disponível em: < http://ilar. ucsd.edu/assets/001/501988.pdf >. Acesso em: 22 mar. 2015.

KISS, Alexandre. Droit international de l'environnement. Paris: A. Pedone, 1989.

KØRNØV, L.; THISSEN, W. A. H. Rationality in decision and policy-making: implications for strategic environmental assessment. Impact Assessment and Project Appraisal, v. 18, n. 3, p. 191-200, 2010.

KOSKENNIEM, Martti. Fragmentation of international law: difficulties arising from the diversification and expansion of international: report of the study group of the international law commission. 13 Apr. 2006. Disponível em: <http://legal.un.org/ilc/documentation/ english/a_cn4_1682.pdf>. Acesso em: 27 mar. 2015.

MALJEAN-DUBOIS, Sandrine. La mise en couvre du droit international de l'environnement. Paris: IDDRI, 2003. (les Notes de L'iddri, n. 4) Disponível em: < http://www. peacepalacelibrary.nl/ebooks/files/337934460.pdf $>$. Acesso em: 27 mar. 2015.

MARQUES, Fabrício. Corrida sobre o gelo. Disponível em: <http://www.revistapesquisa.fapesp.br/wp-content/ uploads/2012/04/032-037_1941.pdf?f0d91f>. Acesso em: 25 mar. 2015.

MASLIN, Mark A. Defining the anthropocene. Nature News, n. 519, p. 171-180, 12 Mar. 2015.

MICHAEL, J. et al. Navigating the maritime piracy regime complex. Global Governance: a review of multilateralism and international organizations, v. 19, n. 1, p. 93-104, Jan./Mar., 2013.

MOLTZ, James Clay. Submarine and autonomous vessel proliferation: implications for future strategic stability at sea. Disponível em: <http://calhoun.nps.edu/ handle/10945/34355 em 2012>. Acesso em: 23 mar. 2015.

MONASTERSKY, Richard. Anthropocene: the human age. Nature, n. 519, p. 144-147, 12 March 2015. Disponível em: <http://www.nature.com/news/anthropocene-the-human-age-1.17085>. Acesso em: 22 mar. 2015.

MORIN, Jean-Frédéric; ORSINI, Amandine. Essential concepts of global environmental governance. Abingdon: Routledge, 2014.
NOBRE, Antônio. O futuro climático da Amaẑônia: relatório de avaliação científica. São José dos Campos: ARA, 2014. Disponível em: <http://www.ccst.inpe.br/ wp-content/uploads/2014/10/Futuro-Climatico-daAmazonia.pdf> . Acesso em: 22 mar. 2015.

NYE, Joseph. Understanding 21st century power shifts. Disponível em: <http://www.europeanfinancialreview. com/?p=2743.June 24, 2011 > . Acesso em: 21 fev. 2015.

OLIVEIRA, C. C. Critérios jurídicos para a responsabilidade civil decorrente de bioinvasão: o caso do coralsol. A Ressurgência, Niterói, v. 7, p. 21-22, 2013.

OLIVEIRA, Carina; MONTALVERNE, Tarin; AMARAL JR., Alberto. A implementação no Brasil da obrigação de conservar o meio ambiente marinho: algumas lacunas na preservação da biodiversidade marinha. In: MENEZES, Wagner (Org.). Direito do mar: desafios e perspectivas. Belo Horizonte: Arraes, 2014. v. 1. p. 250266.

OLIVEIRA, Liziane. A convenção sobre diversidade biológica e o princípio de soberania nacional, 2006. 176 f. Dissertação (Mestrado em Direito) - Faculdade de Direito, Universidadede Brasilia, Brasilia, 2006.

ORSINI, Amandine; MORIN, Jean- Frédéric; YOUNG, Oran. Regime complexes: a buzz, a boom, or a boost for global governance? Global Governance, v. 19, n. 1, p. 27-39, Jan./Mar. 2013.

OSTROM, Elinor. Coping with the tragedy of the commons. Annual Review of Political Science, v. 2, p. 493-535, June 1999.

OSTROM, Elinor. Governing the commons: the evolution of institutions for collective action. Cambridge: Cambridge University Press, 1990.

PITT, J.; SCHAUMEIER, J.; ARTIKIS A. The axiomatisation of socio-economic principles for self-organising systems. ACM Transactions on Autonomous and Adaptive Systems, v. 7, n. 4, p. 1-39, Dec. 2012. Disponível em: <http://dx.doi.org/10.1145/2382570.2382575>. Acesso em: 22 mar. 2015.

PRANTL, Jochen. Taming hegemony: informal institutions and the challenge to western liberal order. The Chinese Journal of International Politics, Oxford, v. 7, n. 4, p. 449-482, Winter, 2014.

PROST, Mario. Unitas multiplex: unites et fragmentations en droit international. Bruxelles: Bruylant, 2013. 
PROST, Mario; TORRES, Camprubi. Against fairness? International environmental law, disciplinary bias and pareto justice. Leiden Journal of International Law, v. 25, n. 2, p. 379-396, 2012.

RAUSTIALA, Kal; VICTOR, David G. The regime complex for plant genetic resources. International Organization, v. 58, p. 277-309, Spring 2004.

RAYFUSE, R.; WARNER, R. M. Securing a sustainable future for the oceans beyond national jurisdiction: the legal basis for an integrated cross-sectoral regime for high seas governance for the 21 st century. International Journal of Marine and Coastal Law, v. 23, n. 3, p. 399-421, 2008.

REMOND-GOUILLOUD, M. Du droit de détruire. Paris: Universitaires de France, 1989.

RIBEIRO, Wagner. Ordem ambiental internacional. São Paulo: Contexto, 2001.

SAMPAIO, Daniela. Antarctica and international cooperative practices. São Paulo: International Studies Association, March 2014. (working paper). Disponível em: < http:// www.academia.edu/10185759/Antarctica_and_International_Cooperative_Practices_working_paper>. Acesso em: 23 mar. 2015.

SASSEN, Saskia. Losing control? Sovereignty in the age of globalization. New York: Columbia University Press, 2015.

SCOVAZZI, Tullio. Direito internacional público. Haia: Academia de Direito da Haia, 2000. p. 232.

SCOVAZZI, Tullio. Marine protected areas on the high seas: some legal and policy considerations. The International Journal of Marine and Coastal Law. v. 19, n. 1, p. 01-17, 2004.

SHEPHERD, N. G.; MAYNARD, R. The influence of context on the strategic decision-making process: a review of the literature. International Journal of Management Reviews, v. 16, n. 3, 2014, p. 340-364, 2014.

SIIRILÄ, Erkki. UN atlas: 44 percent of us live in coastal areas. Jan. 2010. Disponível em: <http://coastalchallenges.com/2010/01/31/un-atlas-60-of-us-live-inthe-coastal-areas/>. Acesso em: 23 mar. 2015.

SOUZA, Rosa Cristina de. Água de lastro: uma ameaça à biodiversidade. In: REUNIÃO ANUAL DA SBPC, 62, 2010, Natal. Ciências do mar: herança para o futuro, Anais... Natal: SBPC, 2010. Disponível em: <http:// www.sbpcnet.org.br/livro/62ra/mesas_redondas/ MR\%20Rosa \%20Cristina\%20Corr\%C3\%AAa $\% 20$ Luz\%20de\%20Souza.pdf>. Acesso em: 02 abr. 2015.

UNITED NATIONS. Division for Ocean Affairs and the Law of The Sea. Chronological lists of ratifications of, accessions and successions to the convention and the related agreements as at 3 October 2014. Jan. 2015. Disponível em: $<$ http://www.un.org/Depts/los/reference_files/chronological_lists_of_ratifications.htm\#Agreement for the implementation of the provisions of the Convention relating to the conservation and management of straddling fish stocks and highly migratory fish stocks $>$. Acesso em: 21 fev. 2015.

UNITED NATIONS. Department of Economic and Social Affairs. Goal 14: conserve and sustainably use the oceans, seas and marine resources for sustainable development. Disponível em: <http://una-gp.org/clancyt/ files/goals/goal14.pdf>. Acesso em: 23 mar. 2015.

UNITED NATIONS. Oceans and the law of the sea: letter dated 25 July 2014 from the Co-Chairs of the Ad Hoc Open-ended Informal Working Group to the President of the General Assembly. Disponível em: <http:// www.un.org/depts/los/biodiversityworkinggroup/documents/BBNJreport_69_177.pdf>. Acesso em: 22 mar. 2015.

UNITED NATIONS. Resolution adopted by the General Assembly, 4 of February of 2005: Oceans and the law of the sea. Disponível em: <http://www.unga-regularprocess.org/images/Documents/un\%20a-res-59-24. pdf>. Acesso em: 22 mar. 2015.

VARELLA, Marcelo. Internationalization of law: globalization, international law and complexity. Brasília: Centro Universitário de Brasília, 2013.

VIDAS, Davor; SCHEI, Peter Johan. The world ocean in globalization: challenges and responses for the anthropocene epoch. Leiden: Martinus Nihhoff Publishers, 2011.

VIOLA, Eduardo; FRANCHINI, Matías; RIBEIRO, Thaís. Sistema internacional de hegemonia conservadora: democracia e governança global na era da crise climática. São Paulo: Annablume, 2013.

WELCOME to the Anthropocene. The Economist, May, 2011. Disponível em: <http://www.economist.com/ node/18744401>. Acesso em: 23 mar. 2015.

YANG, T.; PERCIVAL, R. V. The emergence of global 
environmental law. 2009. Disponível em: < http://digitalcommons.law.scu.edu/cgi/viewcontent.cgi?articl $\mathrm{e}=1714 \&$ context $=$ facpubs, ou http://ssrn.com/abstract $=1269157>$. Acesso em: 21 fev. 2015.
ZIELINSKI, Sarah. Ocean dead zones are getting worse globally due to climate change. Disponível em: <http://www. smithsonianmag.com/science-nature/ocean-deadzones-are-getting-worse-globally-due-climate-change180953282/?no-ist>. Acesso em: 21 mar. 2015. 


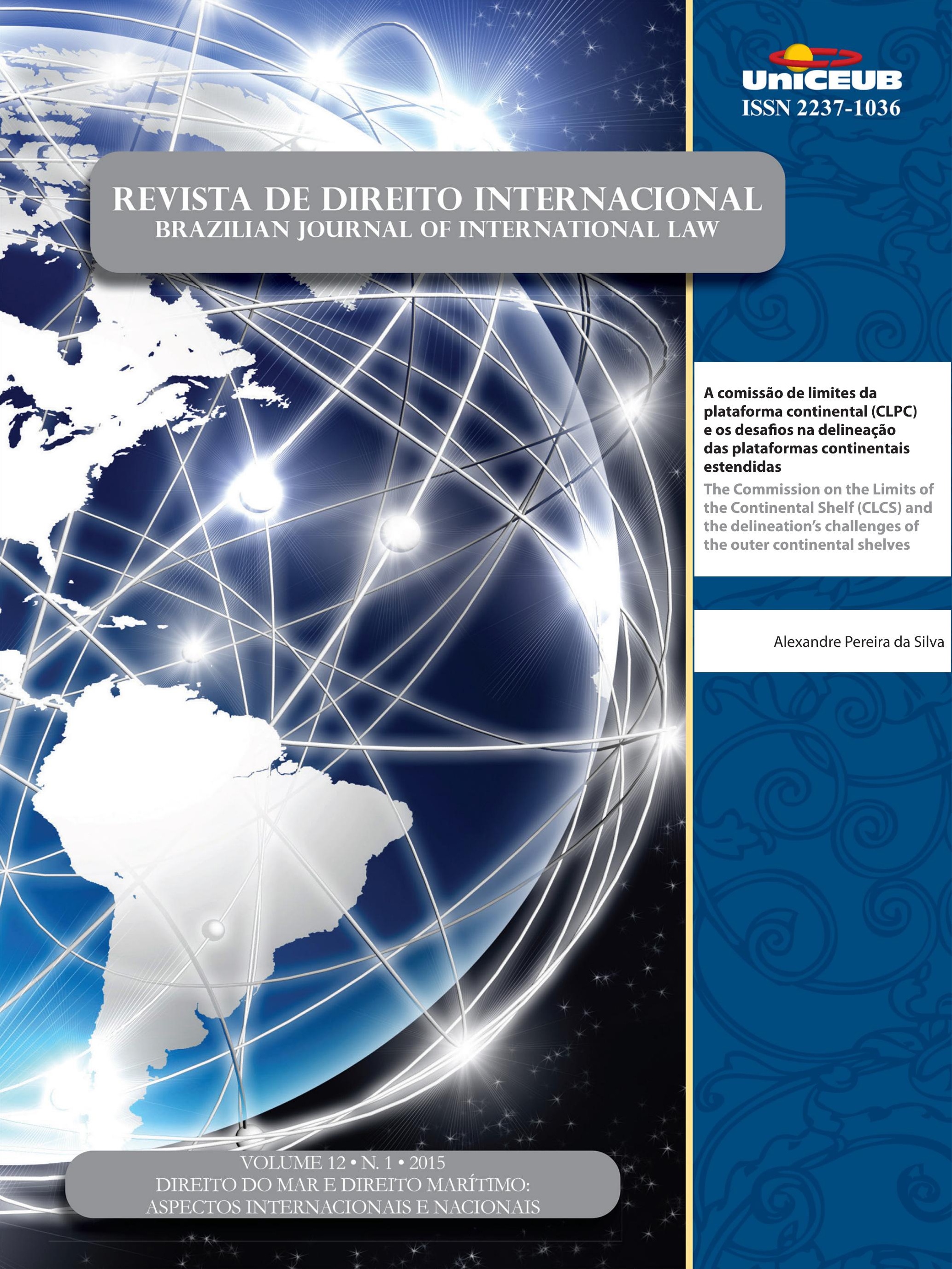




\title{
A comissão de limites da plataforma continental (CLPC) e os desafios na delineação das plataformas continentais estendidas*
}

\author{
The Commission on the Limits of \\ the Continental Shelf (CLCS) and the \\ delineation's challenges of the outer \\ continental shelves
}

Alexandre Pereira da Silva**

\section{Resumo}

O objetivo deste artigo consiste em analisar o papel que a Comissão de Limites da Plataforma Continental (CLPC) vem desempenhando no processo de delineação das plataformas continentais estendidas. Este estudo estruturou-se em uma perspectiva teórico-prática, por meio da qual a atuação da CLPC foi utilizada como paradigma para descrever os debates acadêmicos em torno da possibilidade de os Estados costeiros ampliarem suas plataformas continentais além do limite das 200 milhas marítimas. Dessa forma, o trabalho apresenta alguns resultados para a hipótese de que a CLPC vem enfrentando sérios desafios no desempenho de suas funções: considerável volume de trabalho, restrições financeiras e a participação de terceiros Estados interessados nas submissões de Estados costeiros. Por fim, a contribuição original do presente trabalho consiste em traçar um painel da CLPC desde sua formação até o momento atual, agregando debates teóricos com casos práticos apresentados à CLPC.

Palavras-chave: Direito do Mar. Plataforma Continental. Comissão de Limites da Plataforma Continental. Desafios.

\section{Abstract}

The goal of this paper is to analyze the role of the Commission on the Limits of the Continental Shelf (CLCS) in the developing of the outer continental shelves delineation process. The research was structured in a theoretical and practical approach; the performance of the CLCS was used as a paradigm to describe the academic debates around the possibility of coastal States to extend their continental shelves beyond 200 nautical miles. In that way, the study presents some results for the hypothesis that the CLCS is facing serious challenges in the performance of its duties: considerable workload, financial restrictions and the third party intervention in the coastal States' submissions. Finally, the original contribution of the present work consists of drawing a picture of the CLCS since its formation to the

** Pós-Doutor em Direito pela Schulich School of Law, Dalhousie University, Halifax, Canadá. Professor Adjunto de Direito Internacional da Faculdade de Direito do Recife/ Universidade Federal de Pernambuco (FDR/ UFPE). E-mail: lpsilva.alexandre@gmail.com

Recebido em 27/04/2015 Aprovado em 06/06/2015 
present date, adding theoretical debates with practical cases presented to the CLCS.

Keywords: Law of the Sea. Continental Shelf; Commission on the Limits of the Continental Shelf. Challenges.

\section{INTRODUÇÃO}

O papel da Comissão de Limites da Plataforma Continental (doravante Comissão ou CLPC) é bastante peculiar, visto que a maioria dos Estados não utilizará dos seus serviços. Todavia, as decisões e recomendações tomadas pela Comissão irão exercer impacto sobre toda a sociedade internacional. Isso ocorre porque toda expansão da plataforma continental de um Estado costeiro, além do limite das 200 milhas marítimas, tem como consequência a diminuição da Área, considerada patrimônio comum da humanidade.

Assim, a Comissão criada para examinar os pleitos estatais sobre as questões relacionadas com o estabelecimento dos limites exteriores da plataforma continental, ou seja, além do limite inicial das 200 milhas marítimas, sofre pressão de dois lados. De um lado, dos Estados costeiros que buscam maximizar seus pleitos e, de outro, dos Estados sem litoral e geograficamente desfavorecidos, que não contam com plataforma continental ou não têm possibilidade de expandi-la e que, por conseguinte, não têm interesse em um aumento das plataformas continentais dos Estados costeiros.

O objetivo principal deste artigo é, portanto, em, um primeiro momento, examinar a possibilidade prevista no artigo 76 da Convenção das Nações Unidas sobre o Direito do Mar (CNUDM) de extensão da plataforma continental além das 200 milhas marítimas, para, em um segundo momento, analisar os principais aspectos que levaram à criação da CLPC, seu atual funcionamento, o trabalho por ela desenvolvido até esse momento e, na parte final, observar os desafios que vem enfrentando para cumprir seus fins e que certamente serão incrementados nos próximos anos.

\section{Plataforma continental: definição e POSSIBILIDADE DE EXPANSÃO}

Uma das principais novidades da CNUDM consiste na nova definição jurídica da plataforma continental consagrada no artigo 76 do texto convencional, consideravelmente diferente da que constava na Convenção sobre a Plataforma Continental, que fora aprovada na I Conferência das Nações Unidas sobre o Direito do Mar (1958).

Segundo a Convenção sobre a Plataforma Continental de 1958, esta era conceituada como o "leito do mar e o subsolo das regiões submarinas [...] até uma profundidade de 200 metros ou, para além deste limite, até ao ponto onde a profundidade das águas superjacentes permita a exploração dos recursos naturais das ditas regiões" (artigo $1^{\circ}$ ).

A definição de plataforma continental consagrada nesta Convenção não foi baseada exclusivamente em características geológicas ou geomorfológicas. Além disso, tratava-se de um sistema claramente impreciso, complicado e virtualmente impraticável, já que envolvia, de um lado, uma profundidade específica das águas (200 metros) e, de outro, um critério indefinido de aproveitamento.

Já a definição de plataforma continental consagrada no artigo 76 da CNUDM tampouco é baseada de maneira exclusiva em características geológicas ou geomorfológicas. No entanto, utiliza-se de outros dois critérios para definir plataforma continental. Nos termos do artigo 76.1: "a plataforma continental de um Estado costeiro compreende o leito e o subsolo das áreas submarinas [...] em toda a extensão do prolongamento natural do seu território terrestre, até ao bordo exterior da margem continental ou até uma distância de 200 milhas marítimas". Ou seja, neste artigo 76.1 a CNUDM utilizou-se de dois critérios para fixar os limites da plataforma continental, o critério geomorfológico (margem continental) e o critério da distância (200 milhas marítimas). Ou, como resumem exemplarmente Robert Smith e George Taft, o parágrafo $1^{\circ}$ do artigo 76 “define a plataforma continental de uma maneira em que é cientificamente embasada, legalmente defensável e politicamente aceitável". ${ }^{1}$

De acordo com a publicação oficial da Divisão de Assuntos Oceânicos e Direito do Mar, órgão das Na-

1 SMITH, Robert; TAFT, George. Legal Aspects of the Continental Shelf. In: COOK, Peter J.; CARLETON, Chris M. Continental Shelf Limits: the scientific and legal interface. Oxford: Oxford University Press, 2000.p. 17-24. p. 17. Tradução do original: "defines the continental shelf in a manner which is scientifically based, legally defensible, and politically acceptable". 
ções Unidas (UN Division of Ocean Affairs and the Law of the Sea-DOALOS):

Tal como empregado pelo artigo 76, "massa terrestre" e "margem continental" são conceitos científicos geomorfológicos, enquanto "território terrestre" e "plataforma continental" são conceitos jurídicos. [...] O território terrestre é parte emersa enquanto a plataforma continentalé a parte submersa ou, como a definição coloca, o prolongamento natural do território terrestre. Entretanto, o conceito jurídico de território e de plataforma continental é definido tomando como referência os conceitos científicos de massa terrestre e margem continental. Em outras palavras, a combinação das duas definições dispõe que (i) o território do Estado costeiro se estende sob as águas; (ii) a plataforma continental constitui-se na extensão submersa do território terrestre do Estado; e (iii) o limite exterior dessa extensão é medida tomando como referência o prolongamento submerso da massa terrestre, isto é, a "margem continental". A margem continental é tão-somente um parâmetro, uma referência, da plataforma continental "jurídica". Dependendo de inúmeras circunstâncias geomorfológicas a plataforma continental "jurídica" pode ser maior ou menor que a margem continental. ${ }^{2}$

Dessa forma, o Estado costeiro tem duas opções: i) fixar sua plataforma continental até uma distância máxima de 200 milhas marítimas, contadas a partir das linhas de base, independentemente dos fatores geológicos ou geomorfológicos da mesma; ou, ii) poderá estender sua plataforma continental até o bordo exterior da margem continental, desde que este limite não exceda 350 milhas marítimas ou uma distância que não exceda 100 milhas marítimas da isóbara de 2.500 metros.

2 UNITED NATIONS. Division for Ocean Affairs and the Law of the Sea, Office of Legal Affairs. Training Manual for Delineation of the Outer Limits of the Continental Shelf beyond 200 nautical miles and for Preparation of Submissions to the Commission on the Limits of the Continental Shelf. New York: United Nations, 2006. p. I-18. Tradução do original: "As used in article 76, "land mass" and "continental margin" are scientific (geomorphological) concepts, whereas "land territory" and "continental shelf" are legal concepts. [...]The land territory is the emerged part whereas the continental shelf is the submerged or, as the definition puts it, the natural prolongation of the land territory. The legal concepts of territory and continental shelf, however, are defined with reference to the scientific concepts of land mass and continental margin. In other words, the two definitions combined declare that (i) the territory of a coastal State extends under water; (ii) the continental shelf constitutes the submerged prolongation of its land territory; and (iii) the outer limit of such prolongation is measured with reference to the submerged prolongation of the land mass, i.e., the "continental margin". The continental margin is just a yardstick, a reference, for the determination of the "legal" continental shelf. Depending on the various geomorphological circumstances the "legal" continental shelf can be wider or narrower that the continental margin." (grifos do original).
Na hipótese de o Estado costeiro utilizar-se do segundo critério, ou seja, expandir sua plataforma continental além do limite inicial das 200 milhas marítimas, os parágrafos 4 a 7 do artigo 76 fornecem "fórmulas" específicas e "restrições" para os fins de delineação da plataforma continental além das 200 milhas marítimas.

Para traçar esse limite exterior da plataforma continental, os Estados costeiros usam uma das duas fórmulas: unir, mediante linhas retas que não excedam 60 milhas marítimas do pé do talude continental, nesse caso, essa linha é a demarcação oficial $3 / 4$ além dessa linha estão os fundos marinhos $3 / 4$ e pode ser estendida até o limite máximo de 350 milhas marítimas dos quais se mede o mar territorial; ou, "100 milhas marítimas de isóbara de 2.500 metros, que é uma linha que une profundidades de 2.500 metros", isto é, pode ir além mesmo das 350 milhas marítimas. Os Estados podem se utilizar de quaisquer das duas medidas de opção para fazer a sua proposta de expansão à CLPC. A intenção é a de permitir que os Estados costeiros maximizem seus pedidos dentro dos parâmetros estabelecidos para o limite exterior da plataforma continental. ${ }^{3}$

Como se trata de um procedimento complexo, especialmente porque os Estados podem combinar diferentes elementos das fórmulas, criando, dessa maneira, uma combinação difícil de decifrar, os Estados decidiram criar um órgão técnico, a Comissão de Limites da Plataforma Continental (CLPC), com a missão principal de examinar os dados e outros elementos de informação apresentados pelos Estados costeiros sobre os limites exteriores da plataforma continental nas zonas em que tais limites se estenderem além das 200 milhas marítimas e formular recomendações "definitivas e obrigatórias", nos termos do parágrafo 8 do artigo 76.

\section{A Comissão de Limites da Plataforma Continental (CLPC)}

A Comissão de Limites da Plataforma Continental é um dos três órgãos criados pela CNUDM, os outros dois foram a Autoridade Internacional dos Fundos Marinhos e o Tribunal Internacional do Direito do Mar. O artigo 76 e o Anexo II da CNUDM tratam de seus

3 CAVNAR, Anna. Accountability and the Commission on the Limits of the Continental Shelf: deciding who owns the ocean floor. Cornell International Law Journal, v. 42, p. 397, 2009. 
principais aspectos. Trata-se de órgão técnico instituído para examinar os dados apresentados pelos Estados costeiros sobre os limites exteriores da plataforma continental, ou seja, sobre a plataforma continental além das 200 milhas marítimas.

\subsection{A CLPC: criação, mandato, composição e o prazo de 10 anos}

A ideia do estabelecimento de uma comissão técnica para analisar as submissões estatais sobre os limites exteriores da plataforma continental foi levantada pela primeira vez pelos Estados Unidos na terceira sessão de trabalhos (1975) da III Conferência das Nações Unidas sobre o Direito do Mar. Na sessão seguinte, também o Canadá e o Japão propuseram uma comissão nos mesmos moldes. ${ }^{4}$

A criação da CLPC não sofreu grande oposição dos grupos ou de Estados de maneira isolada. Isso porque havia o entendimento de que a fórmula para a definição da plataforma continental estipulada no artigo 76 da CNUDM tornava-a mais científica e técnica e os negociadores compreendiam a importância e o papel relevante que teria uma comissão para examinar os aspectos técnicos e científicos da plataforma continental estendida. ${ }^{5}$

A Comissão é composta por 21 membros, peritos em geologia, geofísica ou hidrografia, eleitos pelos Estados-partes da Convenção entre seus nacionais, "tendo na devida conta a necessidade de assegurar uma representação geográfica equitativa os quais prestarão serviços a título pessoal", eleitos para um mandato de cinco anos, que poderá ser renovado (artigo $2^{\circ}$, Anexo II).

A CLPC tem, entre suas funções:

\begin{abstract}
a) examinar os dados e outros elementos de informação apresentados pelos Estados costeiros sobre os limites exteriores da plataforma continental nas zonas em que tais limites se estenderem além de 200 milhas marítimas e formular recomendações de conformidade com o artigo 76 e a declaração de entendimento adotada em 29 de Agosto de 1980 pela Terceira Conferência das Nações Unidas sobre o Direito do Mar;

b) prestar assessoria científica e técnica, se o Estado costeiro interessado a solicitar, durante a preparação dos dados referidos na alínea a).
\end{abstract}

4 SUAREZ, Suzette V. The outer limits of the continental shelf: legal aspects of their establishment. Berlin: Springer, 2008. p. 76.

5 SUAREZ, Suzette V. The outer limits of the continental shelf: legal aspects of their establishment. Berlin: Springer, 2008. p. 78.
Dessa forma, quando um Estado costeiro tiver a intenção de expandir os limites da plataforma continental além das 200 milhas marítimas, nos termos previstos no artigo 76 da CNUDM, o Estado costeiro deverá apresentar as informações científicas e técnicas que apoiam seu pleito para a CLPC. Nos termos do artigo $4^{\circ}$ do Anexo II, o Estado costeiro tem um prazo de 10 anos seguintes à entrada em vigor da CNUDM para apresentar essas informações.

Em decorrência das dificuldades para o cumprimento dessa obrigação, já que o artigo 76 não ajudava os Estados costeiros na preparação técnica da submissão da proposta de expansão da plataforma continental, a Reunião dos Estados-partes da Convenção (States Parties to the United Nations Convention on the Law of the SeaSPLOS), adotou em 13 de maio de 1999, as Diretrizes Técnicas e Científicas (Scientific and Technical Guidelines) ${ }^{6}$. As Diretrizes Técnicas e Científicas são especialmente importantes porque a Convenção entrou em vigor internacionalmente em 16 de novembro de 1994 e a ausência até então de diretrizes técnicas era considerada com uma desvantagem para os Estados costeiros que já eram parte da CNUDM, que consideravam o documento técnico de importância crucial para os Estados que pretendiam fazer uma proposta de submissão. ${ }^{7}$

Posteriormente, o prazo de dez anos seguintes à entrada em vigor da Convenção - que ocorreria em 16 de novembro de 2004 - foi alterado por decisão dos Estados-partes da Convenção (SPLOS/72). Portanto, o prazo de dez anos passou a viger a partir data da aprovação das Diretrizes Técnicas e Científicas, em 13 de maio de 1999, encerrando-se, em 13 de maio de 2009, para aqueles Estados que já haviam ratificado a CNUDM na data de entrada em vigor internacional do tratado. ${ }^{8}$

Uma vez mais, frente a um desejo de alguns Estados costeiros, especialmente de Estados em desenvol-

6 CLCS/11.13 May 1999. Scientific and Technical Guidelines of the Commission on the Limits of the Continental Shelf. Disponível em: <http:// daccess-dds-ny.un.org/doc/UNDOC/GEN/N99/171/08/IMG/ N9917108.pdf?OpenElement>. Acesso em: 25 apr. 2015.

7 CARLETON, Chris. Article 76 of the UN Convention on the Law of the Sea - implementation problems from the technical perspective. The International Journal of Marine and Coastal Law, v. 21, n. 3, p. 288, 2006.

8 Conforme visto no Capítulo 1, item 1.5.1.3, essa decisão foi tomada pela Reunião dos Estados-partes da CNUDM. SPLOS/72, 29 May 2001. Decision regarding the date of commencement of the ten-yearperiod for making submissions to the Commission on the Limits of the Continental Shelf set out in article 4 of Annex II to the United Nations Convention on the Law of the Sea. 
vimento, no sentido de que o prazo de dez anos fosse novamente estendido, a Reunião dos Estados-partes decidiu que esse prazo reputar-se-ia observado com a transmissão ao Secretário-Geral da ONU de "informação preliminar indicativa dos limites exteriores da plataforma continental além das 200 milhas marítimas e uma descrição do estágio de preparação e da data prevista para o envio da proposta" (SPLOS/183) ${ }^{9}$. Contudo, essa informação preliminar apresentada não será examinada pela CLPC, e, tampouco, prejudica uma futura submissão completa por parte do Estado costeiro.

Como salienta Bjorn Kunoy, ainda que a permissão prevista no documento SPLOS/183 se referisse particularmente aos Estados em desenvolvimento em cumprir o disposto no artigo $4^{\circ}$ do Anexo II da CNUDM, bem como a decisão que consta no parágrafo 'a' do documento SPLOS $/ 72^{10}$, alguns Estados costeiros desenvolvidos, casos da Espanha e França, aproveitaram a brecha e também apresentaram apenas informações preliminares e parciais sobre os limites exteriores da plataforma continental. ${ }^{11}$

$\mathrm{O}$ artigo $4^{\circ}$ do Anexo II é silente sobre as eventuais consequências da não apresentação à Comissão da proposta de expansão da plataforma continental dentro desse prazo de dez anos. Podem-se vislumbrar duas hi-

9 SPLOS/183, 20 June 2008. Decision regarding the workload of the Commission on the Limits of the Continental Shelf and the ability of States, particularly developing States, to fulfil the requirements of article 4 of annex II to the United Nations Convention on the Law of the Sea, as well as the decision contained in SPLOS/72, paragraph (a). Tradução do original: "[...] preliminary information indicative of the outer limits of the continental shelf beyond 200 nautical miles and a description of the status of preparation and intended date of making a submission". 10 SPLOS/183, 20 June 2008. O parágrafo mencionado por Kunoy tem a seguinte redação: "Recognizing that some coastal States, in particular developing countries, including small island developing States, continue to face particular challenges in submitting information to the Commission in accordance with article 76 of the Convention and article 4 of annex II to the Convention, as well as the decision contained in SPLOS/72, paragraph (a), due to a lack of financial and technical resources and relevant capacity and expertise, or other similar constraints" (grifo nosso).

11 KUNOY, Bjorn. Disputed Areas and the 10-Year Time Frame: a Legal Lacuna? Ocean Development \& International Law, v. 41, p. 115, 2010. Veja-se, por exemplo, os termos da proposta parcial da Espanha sobre os limites exteriores da plataforma continental na parte oeste das ilhas Canárias: "De acuerdo con la disposición de SPLOS/183 del 20 Junio de 2008, España puede presentar antes del 13 Mayo de 2009, únicamente información preliminar indicativa de los límites exteriores de la plataforma continental más allá de las 200 millas marinas y una descripción del estado de preparación y de la fecha prevista de envío de la presentación, para cualquiera de las áreas parciales que considere oportuna". póteses: a primeira seria que o Estado costeiro perderia o direito de apresentar proposta de submissão à CLPC; a segunda seria de que a Comissão não teria a obrigação de aceitar uma proposta depois do prazo limite. ${ }^{12}$

Contudo são apenas conjecturas. Não há qualquer tipo de penalidade caso o Estado costeiro não consiga apresentar sua submissão à CLPC no prazo de dez anos. A CNUDM não traz previsão nesse sentido e não há, tampouco, contexto político ou jurídico que autorize uma conclusão em contrário, o que certamente seria evidenciado explicitamente no texto final da Convenção.

Durante a Reunião dos Estados-partes da CNUDM, realizada em junho de 2001, ficou registrado que:

\begin{abstract}
Algumas delegações assinalaram que a Convenção não estipulava nenhuma consequência jurídica para o caso de que um Estado não fizesse uma apresentação à Comissão. Várias delegações assinalaram o princípio de que os direitos dos Estados costeiros sobre sua plataforma continental eram inerentes, e que o incumprimento do prazo de 10 anos especificado no artigo $4^{\circ}$ do Anexo II não afetaria negativamente os direitos que não dependiam da ocupação, real ou fictícia, bem como de nenhuma reclamação expressa, como consta do parágrafo $3^{\circ}$ do artigo 77 da Convenção..$^{13}$
\end{abstract}

Todavia, os Estados devem considerar o prazo de dez anos e medir esforços para que tal limite seja respeitado ${ }^{14}$. Nesse sentido, é interessante considerar o caso da Federação Russa: em 2001, o Estado russo foi o primeiro a fazer uma submissão à uma plataforma continental estendida à CPLC. A resposta inicial da Comissão, no ano seguinte, não atendeu à integralidade do pedido russo. De acordo com os parágrafos 38-41 das recomendações encaminhadas à Federação Russa, a

12 ELFERINK, Alex G. Oude. Article 76 of the LOSC on the definition of the Continental Shelf: questions concerning its interpretation from a legal perspective. The International Journal of Marine and Coastal Law, v. 21, n. 3, p. 279, 2006.

13 SPLOS/73, 14 June 2001. Report of the Eleventh Meeting of State Parties. Tradução do original: "Some delegations pointed out that there was no legal consequence stipulated by the Convention if a State did not make a submission to the Commission. Several delegations underscored the principle that the rights of the coastal State over its continental shelf were inherent, and that non-compliance with the 10-year time period specified in article 4 of annex II would not adversely affect those rights, which did not depend on occupation, effective or notional, or any express proclamation, as stated in article 77, paragraph 3, of the Convention".

14 TAFT, George. The United Nations Convention on the Law of the Sea: The Commission on the Limits of the Continental Shelf - a Force for Enhancing Stability in the Oceans (or Not). Ocean Yearbook, v. 24, p. 162, 2010. 
CLPC expressava que não havia reservas à proposta de extensão da plataforma continental no mar de Bering e no mar de Barents. Contudo, no tocante ao mar de Okhotsk, a Comissão sugeriu que fosse realizada uma proposta parcial adicional, acompanhada de esforços para solucionar questões jurisdicionais com o Japão. $\mathrm{Na}$ parte central do Ártico, a Comissão recomendou uma proposta revista. Como resultado dessa manifestação da CLPC, a Federação Russa passou, a partir de 2003, a realizar estudos adicionais sobre a plataforma continental, especialmente no Ártico. ${ }^{15}$

Tomando-se como referência o prazo de dez anos previsto no artigo $4^{\circ}$ do Anexo II, imaginava-se que o "prazo razoável" mencionado no artigo $8^{\circ}$ do Anexo II não poderia superar esses dez anos ${ }^{16}$. No entanto, somente em 28 de fevereiro de 2013 a Federação Russa apresentou uma submissão parcial revista no tocante ao mar de Okhotsk. E, mesmo superado o prazo de dez anos, a Comissão aceitou as informações apresentadas pelo país.

\subsection{As recomendações "definitivas e obrigatórias"}

Um dos pontos mais controversos sobre a atuação da Comissão é o que trata sobre o alcance de suas recomendações. Como frisado acima, uma das missões da CLPC é formular recomendações em conformidade com o artigo 76. Essa função conduz a um dos pontos mais importantes e mais controversos deste artigo, que é o parágrafo $8^{\circ}$, visto que, na parte final desse dispositivo, consta que a

[...] Comissão fará recomendações aos Estados costeiros sobre questões relacionadas com o estabelecimento dos limites exteriores da sua plataforma continental. Os limites da plataforma continental estabelecidos pelo Estado costeiro com base nessas recomendações serão definitivos e obrigatórios.

A questão sobre o real alcance das recomendações da CLPC foi tema de debate ainda nos primeiros anos de negociações da III Conferência. Por exemplo, a União Soviética sugeriu que ao invés de se utilizar a palavra "decisão", fosse utilizado o termo "recomendação",

15 SILVA, Alexandre Pereira da. A Rússia avança no Ártico. Boletim Meridiano 47, v. 15, n. 142, p. 122, mar./abr. 2014.

16 MACNAB, Ron; PARSON, Lindsay. Continental Shelf Submissions: the record to date. The International Journal of Marine and Coastal Law, v. 21, n. 3, p. 311, 2006. para referir-se às manifestações futuras da Comissão. Outras delegações, percebendo a mudança de poder da Comissão para o Estado costeiro tentaram fortalecer as consequências jurídicas das recomendações da Comissão como, por exemplo, a proposta informal de Cingapura de que a frase "tendo em conta essas recomendações" ("taking into account these recommendations") devesse ser entendida como "deve estar de acordo com essas recomendações" ("shall be in accordance with these recommendations"). Já próximo da parte final dos trabalhos da III Conferência, a expressão "tendo em conta essas recomendações", foi substituída por "com base nessas recomendações" ("on the basis of these recommendations"), mas associada à expressão "definitivos e obrigatórios" ("final and binding"). ${ }^{17}$

Nessa linha, de um lado, a expressão "tendo em conta essas recomendações" deixava ampla margem de manobra para os Estados costeiros e deixava implícita a ideia de que o Estado costeiro poderia simplesmente estabelecer seus limites exteriores "tendo em conta essas recomendações" da Comissão, mas poderia, da mesma maneira, rejeitar aspectos significativos das recomendações da CLPC. Por outro lado, a expressão adotada na versão final do artigo 76.8, diz muito pouco sobre as reais implicações da expressão "com base nessas recomendações". ${ }^{18}$

$\mathrm{Na}$ hipótese de que um Estado costeiro venha discordar das recomendações, deve apresentar à Comissão "dentro de um razoável uma proposta revista ou uma nova proposta" (artigo $8^{\circ}$, Anexo II) ${ }^{19}$. Decorrente dessa previsão legal, pode se criar uma interminável situação de "ping-pong", ou seja, submissão por parte do Estado costeiro, depois recomendações da Comissão, nova submissão por parte do Estado costeiro, novas recomendações da Comissão etc. Mesmo que o Estado costeiro atue de boa-fé e a Comissão eventualmente

17 SUAREZ, Suzette V. The outer limits of the continental shelf: legal aspects of their establishment. Berlin: Springer, 2008. p. 213-214.

18 ELFERINK, Alex G. Oude. Article 76 of the LOSC on the definition of the Continental Shelf: questions concerning its interpretation from a legal perspective. The International Journal of Marine and Coastal Law, v. 21, n. 3, p. 280, 2006.

19 Por exemplo, essa é a situação atual do pleito brasileiro a uma plataforma continental estendida. O Brasil foi o segundo Estado a realizar uma submissão à CLPC em maio de 2004 (CLCS/42). No entanto, do total da área reivindicada pelo Brasil, a Comissão não concordou com cerca de $190.000 \mathrm{~km}^{2}$, ou seja, cerca de $20 \%$ da área estendida além das 200 milhas marítimas (CLCS/54, 4 April 2007). Recentemente, o Brasil encaminhou à CLPC (10 de abril de 2015) uma submissão parcial revista sobre a região sul do Brasil. 
consiga alcançar um consenso, é importante notar que não há qualquer previsão legal que ponha fim a esse processo de "ping-pong". ${ }^{20}$

Assim, qual seria o verdadeiro papel da CLPC na delineação dos limites exteriores da plataforma continental? Para Ted McDorman, "uma certeza é que é o Estado costeiro, e não a Comissão, quem tem a capacidade jurídica de fixar os limites exteriores da margem continental do Estado" 21 . Nesse mesmo sentido, Alex Oude Elferink afirma que à "Comissão não foi dado o poder de indicar se o Estado costeiro atuou com bases nas suas recomendações. Outros Estados podem levantar questões com o Estado costeiro". ${ }^{22}$

Na mesma linha, também estão Smith e Taft:

A Comissão não estabelece os limites do bordo
exterior da plataforma continental; isto continua
sendo função do Estado costeiro, após a
apresentação de informações pertinentes à definição
dos limites exteriores e recomendações feitas pela
Comissão. Caso as recomendações da Comissão
sejam aceitas pelo Estado costeiro, este estabelecerá
os limites exteriores baseado nas recomendações da
Comissão; estes limites serão finais e obrigatórios.

Portanto, o correto entendimento das recomendações "definitivas e obrigatórias" da CLPC é que essas devem ser compreendidas da seguinte maneira: são re-

20 MCDORMAN, Ted L. The role of the Commission on the Limits of the Continental Shelf: a technical body in a political world. The International Journal of Marine and Coastal Law, v. 17, n. 3, p. 306, 2002.

21 MCDORMAN, Ted L. The role of the Commission on the Limits of the Continental Shelf: a technical body in a political world. The International Journal of Marine and Coastal Law, v. 17, n. 3, p. 306, 2002. Tradução do original: "[...] one certainty is that it is the coastal state, not the Commission, which has the legal capacity to set the state's outer limit of the continental margin".

22 ELFERINK, Alex G. Oude. Article 76 of the LOSC on the definition of the Continental Shelf: questions concerning its interpretation from a legal perspective. The International Journal of Marine and Coastal Law, v. 21, n. 3, p. 281, 2006. Tradução do original: "The Commission has not been given the power to indicate if a coastal state has acted on the basis of its recommendations. Other states can raise this matter with a costal state".

23 SMITH, Robert; TAFT, George. Legal Aspects of the Continental Shelf. In: COOK, Peter J.; CARLETON, Chris M. Continental Shelf Limits: the scientific and legal interface. Oxford: Oxford University Press, 2000. p. 17-24. p. 20. Tradução do original: “The Commission does not establish the outer limit of the continental shelf; that remains the function of the coastal State following submission of information pertaining to the definition of the outer limit and the recommendation by the Commission. If the Commission's recommendations are acceptable to the coastal State, then the State may establish the outer limits in a manner based on the Commission's recommendations; those limits are the final and binding". comendações. Tão-somente recomendações, que podem servir ao Estado costeiro para definir os limites exteriores da plataforma continental estendida além das 200 milhas marítimas, mas que não impedem que esse mesmo Estado costeiro fixe limites distintos, dentro do estipulado no artigo 76.5. Nessa hipótese, no entanto, outros Estados poderão contestar esses limites, já que o procedimento previsto no artigo 76 não teria sido plenamente obedecido. ${ }^{24}$

\section{Os desafios atuais da Comissão}

A CLPC tem enfrentado importantes desafios para cumprir suas funções, entre esses destacam-se: o volume de trabalho, o financiamento para o funcionamento da Comissão e a atuação dos terceiros Estados nas submissões dos Estados costeiros.

\subsection{O volume de trabalho}

O maior desafio que a Comissão já vem enfrentando e que certamente será agravado nos próximos anos versa sobre o volume de trabalho a ser analisado por seus membros. Esse acúmulo de trabalho da CLPC dá-se porque o número de Estados costeiros que apresentaram informações à Comissão é muito superior ao previsto durante os trabalhos da III Conferência das Nações Unidas.

Conforme previsto no $5^{\circ}$ do Anexo II da CNUDM, “a não ser que a Comissão decida de outro modo, deve funcionar por intermédio de subcomissões compostas de sete membros, designados de forma equilibrada tomando em conta os elementos específicos de cada proposta encaminhada pelo Estado costeiro". Em razão dos resultados da Reunião dos Estados-partes (SPLOS/144 e SPLOS/148), a Comissão decidiu na sua $18^{a}$ sessão (CLCS/52), de outubro de 2006, que:

Somente três subcomissões funcionarão
simultaneamente enquanto consideram as
submissões. As submissões devem ser colocadas em
ordem em que são recebidas. A submissão seguinte
deve ser apreciada por uma subcomissão somente
depois de uma das três subcomissões de trabalho
apresentar suas recomendações à Comissão.

24 SILVA, Alexandre Pereira da. O novo pleito brasileiro no mar: a plataforma continental estendida e o Projeto Amazônia Azul. Revista Brasileira de Politica Internacional, v. 56, n. 1, p. 113-114, 2013.

25 Esse ponto foi ratificado também no Regulamento da CLPC (CLCS/40/Rev. 1), adotado em abril de 2008, no artigo 51, em espe- 
Em um estudo realizado pela Comissão em setembro de 2009, quando haviam sido recebidas 51 submissões, a expectativa era de que os trabalhos da CLPC se estenderiam até 2030. Mas, nesse cenário não eram consideradas a apresentação de novas propostas e submissões revistas por parte de Estados costeiros que já tinham apresentados submissões, propostas de Estados costeiros que ainda tinham prazo para apresentá-las, submissões em áreas disputadas, submissões de novos Estados-partes na CNUDM e submissões decorrentes das então 44 Informações Preliminares apresentadas. ${ }^{26}$

Em abril de 2015, mais de cinco anos passados desse estudo da Comissão, os números do volume de trabalho são ainda mais expressivos: são 77 submissões apresentadas - não incluídas as propostas revistas-, além de 45 Informações Preliminares.

Várias delegações têm expressado preocupações com a carga de trabalho da Comissão e destacado a necessidade de seguir melhorando os métodos de trabalho, de forma a assegurar que as submissões sejam examinadas em um prazo razoável. Foi lembrado também que o número de Estados costeiros que, segundo o inicialmente previsto, formularam submissões era quatro vezes superior ao número estimado quando se redigiu o artigo $5^{\circ}$ do Anexo II da CNUDM (SPLOS/263).

A título de exemplo, o caso da nova submissão parcial da Dinamarca, apresentada em dezembro de 2014, uma das últimas submetidas à CLPC até o momento, trata de uma reivindicação de aproximadamente 900.000 quilômetros quadrados de plataforma continental estendida somente no Ártico, na região da plataforma continental no norte da Groenlândia, cuja área é vinte vezes maior do que a própria Dinamarca. Em razão da grande quantidade de reivindicações pendentes a serem examinadas pela CLPC, é provável que esse pleito dinamarquês leve de dez a quinze anos para ser avaliado. ${ }^{27}$

cial no parágrafo $4^{\circ}$. Tradução do original: "Only three subcommissions shall function simultaneously while considering submissions. The submissions shall be queued in the order they are received. The submission next in line shall be taken for consideration by a subcommission only after one of the three working subcommissions presents its recommendations to the Commission".

26 UNITED NATIONS. Presentation to burean MSP. Disponível em: <http://www.un.org /Depts/los/clcs_new/workload / presentation_to_bureau_msp_2009.pdf>. Acesso em: 25 abr. 2015.

27 BARENTS OBSERVER. Denmark claims North Pole. Disponível em: <http://barentsobserver.com/en/arctic/2014/12/denmarkclaims-north-pole-15-12>. Acesso em: 25 abr. 2015.

\subsection{O financiamento da Comissão}

Outro desafio, diretamente ligado à questão do volume de trabalho da CLPC, é o tema do financiamento da Comissão e que se reflete no próprio funcionamento do órgão.

Ainda que prestem "serviços a título pessoal", as despesas dos membros da Comissão são cobertas pelos Estados que patrocinaram a indicação dos membros e não pelas Nações Unidas. É o que dispõe o parágrafo $5^{\circ}$ do artigo $2^{\circ}$ do Anexo II da CNUDM: "O Estado-Parte que tiver apresentado a candidatura de um membro da Comissão custeará as despesas do mesmo enquanto prestar serviço na Comissão". Esse dispositivo é repetido no artigo $9^{\circ}$ do Regulamento da Comissão, aprovado em abril de 2008 (CLCS/40/Rev. 1).

Essa circunstância gera algumas situações inusitadas. Por exemplo, segundo o documento CLCS/85, de 24 de setembro de 2014, que trata das atividades desenvolvidas pela Comissão no último período de sessões - 21 de julho a 5 de setembro de 2014 ( $35^{\circ}$ período de sessões) — dois de seus membros não puderam assistir a todas as sessões de trabalhos "por falta de apoio financeiro". ${ }^{28}$

A Reunião dos Estados-partes da CNUDM considerou, recentemente, que esse tipo de apoio financeiro impede que Estados em desenvolvimento e pequenos países insulares se vejam possibilitados de designar membros para a Comissão. Nesse sentido, foi lembrado que o requisito de dez anos para apresentação de uma proposta à CLPC foi flexibilizado pela Reunião dos Estados-partes no passado para enfrentar certos problemas relativos à aplicação da CNUDM e que esse tipo de flexibilização poderia ser novamente utilizado nesse caso da obrigação financeira (SPLOS/263).

Outra questão que preocupa os membros da Comissão refere-se à questão do seguro de saúde durante as reuniões de trabalho em Nova Iorque. De acordo com

28 Vide CLCS/85, 24 September 2014, Progress of Work in the Commission on the Limits of the Continental Shelf: "[...] Mr. Jaoshvili attended the session from 2 to 5 September 2014, indicating that he had been unable to attend the entire session owing to a lack of adequate financial support. Mr. Uścinowicz attended the session from 11 August to 5 September, indicating that he had not been able to attend the earlier part of the session owing to a lack of adequate financial support". Os dois membros da Comissão mencionados, são da Geórgia e da Polônia, respectivamente. Essa situação de falta de apoio financeiro aos membros para participarem dos trabalhos da Comissão é frequentemente mencionado nos documentos da CLPC. 
a Resolução da Assembleia Geral das Nações Unidas 68/70, de 9 de dezembro de 2013, a Comissão solicitou que o Secretário-Geral da ONU examine possíveis opções para oferecer a cobertura de um seguro de saúde aos membros da Comissão procedentes de Estados em desenvolvimento. Esse ponto foi reafirmado na Reunião dos Estados-partes da CNUDM, de junho de 2014:

\begin{abstract}
Reitera a obrigação nos termos da Convenção que os Estados cujos especialistas estejam servindo à Comissão de custear os gastos desses especialistas que tenham indicado enquanto desempenham funções relacionadas com a Comissão, incluindo a prestação de assistência médica, e insta os Estados a envidar todos os esforços para assegurar a plena participação desses especialistas no trabalho da Comissão, incluindo as reuniões das subcomissões, de acordo com a Convenção. ${ }^{29}$
\end{abstract}

Essa situação muito possivelmente será agravada no futuro, porque em virtude da decisão da $21^{a}$ Reunião dos Estados-partes relativa ao volume de trabalho da Comissão (SPLOS/229), foi incluída a solicitação para que a Comissão examine a possibilidade de reunir-se em Nova Iorque por até 26 semanas. Atualmente, a CLPC reúne-se em três períodos de sessões de sete semanas, cada uma, incluídas sessões plenárias, em um total de 21 semanas de reuniões da Comissão e suas subcomissões. ${ }^{30}$

A fim de enfrentar os frequentes problemas financeiros, o presidente da Comissão solicitou, em maio de 1999, que os Estados-partes considerassem a possibilidade de criação de um fundo fiduciário (trust fund) para financiar a participação dos membros dos países em desenvolvimento nos trabalhos da Comissão. A criação do fundo fiduciário voluntário foi aprovada em outubro de 2000 durante os trabalhos da 55 a Assembleia Geral das Nações Unidas. O fundo é atualmente administrado pela Divisão de Assuntos Oceânicos e Direito do Mar, Escritório de Assuntos Jurídicos (DOALOS).

De acordo com o último relatório sobre os progressos dos trabalhos da Comissão (CLCS/85), de 24 de setembro de 2014, durante as duas últimas reuniões de

29 Tradução do original: "Reiterates the obligation of States under the Convention whose experts are serving on the Commission to defray the expenses of the experts they have nominated while in performance of Commission duties, including the provision of medical coverage, and urges these States to do their utmost to ensure the full participation of those experts in the work of the Commission, including the meetings of subcommissions, in accordance with the Convention".

30 SPLOS/229, 16 June 2011, Decision regarding the workload of the Commission on the Limits of the Continental Shelf. trabalhos $\left(34^{\mathrm{a}}\right.$ e $\left.35^{\mathrm{a}}\right)$, o fundo fiduciário proporcionou assistência financeira de aproximadamente US $\$ 170.000$ em cada uma das reuniões para oito membros de Estados em desenvolvimento. Nos termos do relatório, em junho de 2014, o fundo fiduciário tinha um saldo aproximado de US\$670.000. ${ }^{31}$

\subsection{A Comissão e a intervenção de terceiros Estados}

Outro importante desafio que a Comissão vem enfrentando refere-se à apresentação de notificação de terceiros Estados às submissões de Estados costeiros.

O artigo 83 da CNUDM dispõe obrigação conjunta tanto para o Estado costeiro que faz a submissão como para os terceiros Estados envolvidos no processo na CLPC. O artigo 83.1 coloca que "a delimitação da plataforma continental entre Estados com costas adjacentes ou situadas frente a frente deve ser feita por acordo, de conformidade com o direito internacional". O artigo 83.3 complementa ao dispor que "enquanto não se chegar a um acordo conforme o previsto no parágrafo $1^{\circ}$, os Estados interessados [...] nada devem fazer que possa comprometer ou entravar a conclusão do acordo definitivo".

Quanto ao papel da Comissão, quando houver disputas entre Estados sobre a delimitação da plataforma continental o artigo $9^{\circ}$ do Anexo II coloca que "as decisões da Comissão não devem prejudicar os assuntos relacionados com a delimitação entre Estados com costas adjacentes ou situadas frente a frente" ${ }^{32}$. Para muitos juristas, esse dispositivo limita o papel da CLPC de fazer recomendações e a coloca em uma posição passiva por dois motivos: i) a Comissão não exerce função em determinar ou influenciar negociações sobre os limites da plataforma continental entre Estados quando há so-

31 Além desse fundo fiduciário, existe também um outro fundo fiduciário no âmbito da Comissão que foi criado para auxiliar os Estados em desenvolvimento, particularmente os Estados menos desenvolvidos e os pequenos Estados insulares em desenvolvimento, na preparação das submissões à Comissão e no cumprimento do disposto no artigo 76 da CNUDM. Também segundo esse relatório (CLCS/85), esse fundo fiduciário, em julho de 2014, tinha um saldo de aproximadamente US\$1.306.000.

32 Esse dispositivo é repetido no artigo 46.2 do Regulamento da Comissão e colocado de maneira ligeiramente diferente no artigo 76.10 da CNUDM: "As disposições do presente artigo não prejudicam a questão da delimitação da plataforma continental entre Estados com costas adjacentes ou situadas frente a frente". 
breposição de pedidos sobre plataformas continentais estendidas; e, ii) a Comissão não deve se envolver em assuntos referentes à determinação dos limites exteriores da plataforma continental estendida de um Estado costeiro quando exista uma disputa com outro Estado sobre tal limite. ${ }^{33}$

Se um Estado costeiro toma a iniciativa de informar à Comissão sobre uma disputa de limites envolvendo sua submissão, aplica-se o Anexo I do Regulamento da CLPC conjuntamente com o artigo 46 desse mesmo Regulamento. Nos termos do parágrafo $1^{\circ}$ desse dispositivo, os Estados envolvidos em controvérsias que surjam a respeito da delimitação da plataforma continental não estão privados do direito de apresentar suas submissões à Comissão. Nessas circunstâncias, a Comissão bem como o Estado que apresentou a submissão deve seguir o previsto no Anexo I do Regulamento da CLPC. Nos termos do parágrafo $1^{\circ}$ do Anexo I: "A Comissão reconhece que a competência sobre as questões relativas às controvérsias que surjam em relação ao estabelecimento dos limites exteriores da plataforma continental cabe aos Estados".

Esse dispositivo, portanto, reconhece o direito exclusivo dos Estados 3/4 tanto o que apresentou a submissão como os terceiros Estados 3/4 de decidirem per si se existe a disputa e o direito de solucionarem a controvérsia entre eles.

Já o parágrafo $2^{\circ}$ do Anexo I do Regulamento dispõe que, nos casos em que exista uma controvérsia com respeito à delimitação da plataforma continental entre Estados adjacentes ou outras controvérsias territoriais ou marítimas pendentes, a Comissão será informada da controvérsia pelo Estado costeiro que fez a submissão. Enquanto isso, a Comissão receberá garantias que, na medida do possível, a submissão não prejudicará questões relativas à fixação dos limites entre os Estados. ${ }^{34}$

$\mathrm{Na}$ hipótese de um Estado costeiro não cumprir a mencionada obrigação de informar à Comissão a respeito da controvérsia com outros Estados, a Comissão tem que ser informada da disputa pelos terceiros Es-

33 GAU, Michael Sheng-Ti. Third Party Intervention in the Commission on the Limits of the Continental Shelf Regarding a Submission Involving a Dispute. Ocean Development \& International Law, v. 40, p. 63, 2009.

34 GAU, Michael Sheng-Ti. Third Party Intervention in the Commission on the Limits of the Continental Shelf Regarding a Submission Involving a Dispute. Ocean Development \& International Law, v. 40, p. 64, 2009. tados. Nesse caso, os terceiros Estados devem intervir por meio de notificações dirigidas à Comissão no sentido de informar a CLPC da controvérsia. Contudo, isso não impede que o terceiro Estado esteja impedido de enviar uma notificação quando o Estado que apresentou a submissão cumpriu sua obrigação de informar sobre a disputa.

Portanto, em caso de disputa territorial ou marítima: "a Comissão não considerará nem qualificará uma submissão apresentada por qualquer dos Estados envolvidos na disputa" (parágrafo 5(a) do Anexo I do Regulamento). Contudo, na parte final desse dispositivo: "a Comissão poderá considerará uma ou mais submissões em áreas sob disputa com o consentimento prévio de todos Estados que estejam envolvidos nesta controvérsia". ${ }^{35}$

Vejam-se as duas situações possíveis previstas no parágrafo 5(a) do Anexo I do Regulamento da Comissão.

\section{A) Apresentação de notificação}

$\mathrm{Na}$ hipótese de apresentação de uma notificação, seguem-se as regras inscritas no artigo 50 do Regulamento da Comissão:

O Secretário-Geral notificará prontamente, por intermédio dos canais apropriados, a Comissão e os Estados-membros das Nações Unidas, incluídos os Estados-partes da Convenção, o recebimento da apresentação, e tornará público o resumo, incluídas todas as cartas e coordenadas mencionadas no parágrafo 9.1.4 das Diretrizes e contidas no respectivo resumo, uma vez concluída a tradução do resumo mencionado no artigo 47 , parágrafo $3^{\circ} .^{36}$

E no artigo 51.1 do Regulamento da Comissão:

Após o recebimento da submissão pelo Secretário-
Geral, o exame da submissão deverá ser incluído
na agenda provisória da próxima reunião ordinária
da Comissão preparada nos termos do artigo $5^{\circ}$
e do parágrafo $2^{\circ}$ do Anexo III, desde que essa
sessão, quando convocada em conformidade com

35 Tradução do original: "[...] the Commission shall not consider and qualify a submission made by any of the States concerned in the dispute $[\ldots]$ the Commission may consider one or more submissions in the areas under dispute with prior consent given by all States that are parties to such a dispute".

36 Tradução do original: "The Secretary-General shall, through the appropriate channels, promptly notify the Commission and all States Members of the United Nations, including States Parties to the Convention, of the receipt of the submission, and make public the executive summary including all charts and coordinates referred to in paragraph 9.1.4 of the Guidelines and contained in that summary, upon completion of the translation of the executive summary referred to in rule 47 , paragraph 3". 
o Artigo $2^{\circ}$, seja realizada não antes de três meses após a data em que o Secretário-Geral publique o resumo, incluídas todas as cartas e coordenadas mencionadas no artigo $50.3^{37}$

Dessa forma, e com base nesses dois dispositivos, o momento para que o terceiro Estado envie a notificação é entre a manifestação de recebimento pelo Secretário-Geral das Nações Unidas e o exame da submissão pela Comissão. Entre esses dois momentos, há, pelo menos, três meses para que o terceiro Estado tome a iniciativa de enviar a notificação. ${ }^{38}$

A apresentação de notificação por parte de terceiros Estados pode ser considerada como frequente. Entre os diversos casos, vale uma menção aos dois casos analisados abaixo:

i) no pleito da Federação Russa (2001), cinco Estados enviaram notificações, sendo que três não eram partes da CNUDM (Canadá, Dinamarca ${ }^{39}$ e Estados Unidos), além de Japão e Noruega.

Tanto o Canadá como a Dinamarca manifestaram-se no sentido de não terem condições de formar uma opinião sobre o pleito russo e por isso não estavam em posição de determinar se tinham preocupações com a submissão. Contudo, isso não implicava qualquer tipo de concordância ou aquiescência com a submissão da Federação Russa. ${ }^{40}$

37 Tradução do original: "Upon receipt of a submission by the Secretary-General, the consideration of that submission shall be included in the provisional agenda of the next ordinary session of the Commission prepared in accordance with rule 5 and paragraph 2 of annex III, provided that that session, as convened in accordance with rule 2 , is held not earlier than three months after the date of the publication by the Secretary-General of the executive summary including all charts and coordinates referred to in rule 50".

38 GAU, Michael Sheng-Ti. Third Party Intervention in the Commission on the Limits of the Continental Shelf Regarding a Submission Involving a Dispute. Ocean Development \& International Law, v. 40, p. 65, 2009.

39 Canadá e Dinamarca posteriormente depositaram seus instrumentos de ratificação. O Canadá em 7 de novembro de 2003 e a Dinamarca em 16 de novembro de 2004. Os Estados Unidos ainda não são parte da CNUDM.

40 "The Permanent Mission of Canada to the United Nations $[\ldots]$ is not in position to determine whether it agrees with the Russian Federation's Arctic continental shelf submission without the provision of further supporting data to analyse and that Canada's inability to comment at this point should not be interpreted as either agreement or acquiescence by Canada to the Russian Federation's submission". CANADA. Notification regarding the submission made by the Russian Federation to the Commission on the Limits of the Continental Shelf. 26 February 2002. Disponível em: <http://www.un.org/depts/los/ clcs_new/submissions_files/rus01/CLCS_01_2001_LOS_CANtext.pdf>. Acesso em: 25 abr. 2015. "Denmark is not able to form an opinion on the Russian submission. A qualified assessment would
Já a notificação enviada pela representação permanente norueguesa nas Nações Unidas registrou seu desacordo com a submissão russa com base no artigo 51 do Regulamento da Comissão:

A delimitação da plataforma continental entre a Noruega e a Federação Russa ainda não foi resolvida e é objeto de consultas em curso. A questão sobre a delimitação não resolvida no mar de Barents portanto deve ser considerada como uma "disputa marítima" para os propósitos do artigo 5(a) do Anexo I do Regulamento da Comissão. ${ }^{41}$

As notificações do Japão e dos Estados Unidos foram no sentido de desafiar a submissão da Federação Russa. Os norte-americanos registraram que: "acreditam que a submissão tenha grandes falhas no que se refere à plataforma continental no Ártico". Além disso, a notificação dos Estados Unidos tecia comentários específicos sobre as formações geológicas submarinas árticas de Alpha-Mendeleev e Lomonosov, finalizando no entendimento de que: "A submissão da Federação Russa é particularmente complexa e deve ser considerada de maneira deliberada". ${ }^{42}$

A notificação do Japão foi ainda mais veemente, apresentando em anexo um mapa e coordenadas geográficas, para rejeitar o exame pela Comissão de quatro ilhas (Etorofu, Kunashiri, Shikotan e Habomai), incluídas no pleito russo que criavam uma zona econômica exclusiva e plataforma continental com base em ocupação de território japonês desde o término da Segunda

require more specific data. Such absence of opinion at this moment does not imply Denmark's agreement or acquiescence to the Russian Federation's submission". DENMARK. Notification regarding the submission made by the Russian Federation to the Commission on the Limits of the Continental Shelf. 26 February 2002. Disponivel em: <http:// www.un.org/depts/los/clcs_new/submissions_files/rus01/ CLCS_01_2001_LOS_DNKtext.pdf>. Acesso em: 25 abr. 2015. 41 NORWAY. Notification regarding the submission made by the Russian Federation to the Commission on the Limits of the Continental Shelf, 2 April 2002. Disponível em: <http://www.un.org/depts/los/clcs_new/ submissions_files/rus01/CLCS_01_2001_LOS_NORtext.pdf $>$. Acesso em: 25 abr. 2015. Tradução do original: "Federation has not yet been settled and is the object of ongoing consultations. The unresolved delimitation issue in the Barents Sea is therefore to be considered as a "maritime dispute" for the purpose of rule 5 (a) Annex I to the Rules of Procedure of the Commission".

42 UNITED STATES OF AMERICA. Notification regarding the submission made by the Russian Federation to the Commission on the Limits of the Continental Shelf, 18 March 2002. Disponivel em: <http:// www.un.org/depts/los/clcs_new/submissions_files/rus01/ CLCS_01_2001_LOS_USAtext.pdf>. Acesso em: 25 abr. 2015. Tradução do original: "[...] believes that the submission has major flaws as it relates to the continental shelf in the Arctic [...] The Russian Federation submission is particularly complex and should be considered in a deliberate manner". 
Guerra Mundial. Nesse sentido:

Os mapas ilustram como águas russas a zona econômica exclusiva e a plataforma continental ao redor das Quatro Ilhas, que são território japonês inerente [...] A situação decorrente da ocupação ilegal das Quatro Ilhas pela antiga União Soviética depois do término da Segunda Guerra Mundial tem continuado até hoje [...] Pelos motivos acima mencionados, o Governo do Japão solicita à Comissão, no exame da submissão da Federação Russa, não tomar qualquer medida que possa prejudicar a questão territorial das Quatro Ilhas ou a delimitação da plataforma continental e da zona econômica exclusiva entre o Japão e a Federação Russa [...]. ${ }^{43}$

ii) na submissão apresentada pelo Brasil em 2004, também houve uma notificação de um terceiro Estado. Nesse caso, diferentemente, do que ocorreu no pleito russo, não se tratava de um país vizinho ou com limites marítimos próximos, mas dos Estados Unidos. A notificação norte-americana registrou suas diferenças em relação à espessura dos sedimentos apresentados na proposta brasileira e a espessura dos sedimentos encontrada nos registros públicos disponibilizados:

Em diversos pontos, os Estados Unidos observaram que há diferenças entre a espessura dos sedimentos apresentados no resumo brasileiro e a espessura dos sedimentos encontrada nos registros públicos disponibilizados [...] os Estados Unidos sugerem que a Comissão pode querer examinar os dados da espessura sedimentar do Brasil com atenção. ${ }^{44}$

Em outro ponto da notificação dos Estados Unidos, a oposição refere-se à cadeia de Vitória-Trindade, nes-

43 JAPAN. Notification regarding the submission made by the Russian Federation to the Commission on the Limits of the Continental Shelf. 14 March 2002. Disponível em: <http://www.un.org/depts/los/clcs_new/ submissions_files/rus01/CLCS_01_2001_LOS_JPNtext.pdf>. Acesso em: 25 abr. 2015. Tradução do original: "The maps illustrate as Russian waters the exclusive economic zone and the continental shelf around the Four Islands, which are inherent Japanese territory [...] The situation arising from the illegal occupation of the Four Islands by the former Soviet Union after the end of World War II has continued to this day [...] For the above-mentioned reasons, the Government of Japan requests the Commission, in its consideration of the submission by the Russian Federation, not to take any action that would prejudge the territorial issue of the Four Islands or delimitation of the continental shelf and the exclusive economic zone between Japan and the Russian Federation [...]".

44 UNITED STATES OF AMERICA. Notification regarding the submission made by the Brazil to the Commission on the Limits of the Continental Shelf, 9 September 2004. Disponível em: < http:/ / www.un.org/ Depts/los/clcs_new/submissions_files/bra04/clcs_02_2004_los_ usatext.pdf>. Acesso em: 25 abr. 2015. Tradução do original: "In several places, the United States observed that there are differences between the sediment thickness as presented in the Brazilian summary and the sediment thickness derived from the publicly available sources $[\ldots]$ the United States suggests that the Commission may want to examine Brazil's sediment thickness data carefully". ses termos:

Os Estados Unidos têm dúvidas de que essa região ["Vitória-Trindade"] faça parte da margem continental brasileira além das 200 milhas marítimas a partir das linhas de base das quais se mede a largura do mar territorial. Os Estados Unidos sugerem que a Comissão tenha uma abordagem cuidadosa no exame desta região. ${ }^{45}$

Contudo, a Comissão não aceitou a notificação enviada pelos Estados Unidos, mesmo reconhecendo que o Anexo II da CNUDM e o Regulamento da CLPC estabelecem a função que os demais Estados podem desempenhar no exame dos dados e do material a ser apresentado pelo Estado costeiro sobre os limites exteriores da plataforma continental além das 200 milhas marítimas.

No entendimento da Comissão, somente os Estados com costas adjacentes, confrontantes ou outras controvérsias territoriais ou marítimas pendentes podem fazer tal solicitação à Comissão. Dessa forma, pediu à subcomissão que examinava o pleito brasileiro que desconsiderasse as observações da carta dos Estados Unidos durante o exame da submissão brasileira ${ }^{46}$. Posteriormente, o representante dos Estados Unidos manifestou sua contrariedade, afirmando que não existe nenhum óbice no Anexo II da CNUDM à que a CLPC aceitasse as considerações de outros Estados. ${ }^{47}$

Para Edwin Egede, ainda que outros Estados e a Autoridade Internacional dos Fundos Marinhos não tenham em termos estritos possibilidade de colocar questionamentos sobre a proposta de plataforma continental estendida, esses terceiros interessados também teriam interesse em proteger os recursos da Área 3/4

45 UNITED STATES OF AMERICA. Notification regarding the submission made by the Brazil to the Commission on the Limits of the Continental Shelf, 9 September 2004. Disponível em: < http:/ / www.un.org/ Depts/los/clcs_new/submissions_files/bra04/clcs_02_2004_los_ usatext.pdf $>$. Acesso em: 25 abr. 2015. Tradução do original: "The United States doubt whether the feature in question ["Vitoria Trindade Ridge"] is part of Brazil's continental margin beyond 200 nautical miles from the baselines which the territorial sea is measured. The United States suggests that the Commission takes a cautious approach with regard to this feature".

46 CLCS/42, 14 September 2004. Statement by the Chairman of the Commission on the Limits of the Continental Shelf on the progress of work in the Commission.

47 UNITED NATIONS. Carta de 25 de outubro de 2004 da vicerepresentante dos Estados Unidos embaixadora Anne W. Patterson ao Subsecretário-Geral e Consultor Jurídico das Nações Unidas Sr. Nicolas Michel. Disponível em: <http://www.un.org/depts/los/clcs_ new/submissions_files/bra04/clcs_2004_los_usatext_2.pdf $>$. Acesso em: 25 abr. 2015. 
patrimônio comum da humanidade $3 / 4$, considerando o fato de que o aumento da plataforma continental estendida representa uma diminuição da Área. Assim, para Egede, a CLPC não deveria ignorar as comunicações de outros Estados e da própria Autoridade Internacional dos Fundos Marinhos, mas ao contrário, considera-las nos seus méritos no sentido de determinar se são ou não pertinentes. ${ }^{48}$

\section{B) Consentimento prévio}

A outra hipótese prevista no parágrafo 5(a) do Anexo I do Regulamento da Comissão é a de que sejam examinadas uma ou mais submissões em áreas sob disputa, desde que haja consentimento prévio de todos Estados que estejam envolvidos na controvérsia. Nenhuma submissão, contudo, foi encaminhada à CLPC nesses termos.

Alguns Estados costeiros apresentarem submissões conjuntas de limites exteriores (joint submissions). Esse tipo de proposta conjunta tem uma série de vantagens para os Estados envolvidos, como por exemplo, cooperação internacional, diminuição de custos e, mais importante, a possibilidade de que a Comissão faça recomendações "definitivas e obrigatórias" sobre toda a área envolvida, evitando, dessa maneira, a disputa sobre áreas sobrepostas, se houvesse a submissão de propostas apresentadas em separado.

Veja-se, por exemplo, a submissão conjunta apresentada por França, Irlanda, Espanha e Reino Unido na área do mar Celta e da baía de Biscaia:

\footnotetext{
[...] a submissão anexa é de natureza conjunta, compreendendo um único projeto preparado coletivamente e de forma colaborada pelos quatro Estados costeiros. Para cada um dos quatro Estados costeiros a submissão conjunta anexa representa uma submissão parcial no tocante à parcela dos limites exteriores da plataforma continental pertencente a todos os quatro Estados costeiros que se encontra além das 200 milhas marítimas das linhas de base a partir das quais se medem seus respectivos mares territoriais. Essa parte da plataforma não é objeto de qualquer disputa e, na perspectiva dos quatro Estados costeiros, seu exame pela Comissão não prejudicará os assuntos relacionados com a delimitação de fronteiras entre os quatro Estados costeiros e com os demais Estados. ${ }^{49}$
}

48 EGEDE, Edwin. Submission of Brazil and Article 76 of the Law of the Sea Convention (LOSC) 1982. The International Journal of Marine and Coastal Law, v. 21, n. 1, p. 41, 2006.

49 UNITED NATIONS. Commission on the Limits of the Continental Shelf (CLCS) Outer limits of the continental shelf beyond 200 nautical miles from the baselines: Submissions to the Commission: Joint submission
Outras submissões conjuntas apresentadas à CLPC foram: Ilhas Maurício e Seicheles na região do "Mascarene Plateau" (CLCS/62, 1 December 2008), Estados Federados da Micronésia, Papua-Nova Guiné e Ilhas Salomão relativa ao "Ontongo Java Plateau" (CLCS/66, 5 May 2009), Malásia e Vietnã na parte sul do Mar da China Meridional (CLCS/64, 6 May 2009), França e África do Sul na área do arquipélago de Crouzet e das ilhas do Príncipe Eduardo (CLCS/68, 6 May 2009) e Cabo Verde, Gâmbia, Guiné, Guiné-Bissau, Mauritânia, Senegal e Serra Leoa nas áreas do oceano Atlântico adjacente a costa ocidental da África (encaminhada à Comissão em 25 de setembro de 2014). ${ }^{50}$

\section{Considerações finais}

A Comissão de Limites da Plataforma Continental é um órgão técnico criado pela Convenção das Nações Unidas sobre o Direito do Mar para examinar os dados apresentados pelos Estados costeiros sobre os limites exteriores da plataforma continental, ou seja, além das 200 milhas marítimas, nos termos do artigo 76 da CNUDM.

Os trabalhos da Comissão iniciaram-se de fato quando a Federação Russa apresentou a primeira submissão estatal em dezembro de 2001. E, desde esse momento, houve considerável incremento no volume de trabalho da CLPC. Além disso, o número de Estados costeiros que já fizeram ou que ainda farão submissões à Comis-

by France, Ireland, Spain and the United Kingdom of Great Britain and Northern Ireland. Disponível em: <http://www.un.org/ depts/los/clcs_new/submissions_files/submission_frgbires.htm $>$. Acesso em: 25 abr. 2015. Tradução do original: “[...] the enclosed submission is of a joint nature, comprising a single project prepared collectively and collaboratively by the four coastal States. For each of these four coastal States the enclosed joint submission represents a partial submission in respect of a portion only of the outer limits of the continental shelf appurtenant to all four coastal States that lie beyond 200 nautical miles from their baselines from which the breadth of their respective territorial seas are measured. This portion of shelf is not the subject of any dispute and, in the view of the four coastal States, its consideration by the Commission will not prejudice matters relating to the delimitation of boundaries between the four coastal States and any other States".

50 UNITED NATIONS. Submissions, through the Secretary-General of the United Nations, to the Commission on the Limits of the Continental Shelf, pursuant to article 76, paragraph 8, of the United Nations Convention on the Law of the Sea of 10 December 1982. Disponível em: <http:// www.un.org/Depts/los/clcs_new/commission_submissions. htm>. Acesso em: 25 abr. 2015. 
são é cerca de quatro vezes superior ao originalmente imaginado durante os trabalhos da III Conferência das Nações Unidas sobre o Direito do Mar (1973-1982).

Agregue-se a esse fato uma crônica dificuldade financeira da Comissão que limita muito sua capacidade de funcionamento. O desejo por parte dos Estados costeiros de que as submissões sejam examinadas em um "prazo razoável" não encontra necessariamente resposta em maior apoio financeiro à CLPC. O aumento do número de semanas das iniciais vinte e uma, para vinte e seis, tampouco trará bons resultados, se persistir a situação em que alguns membros da Comissão não conseguem assistir todas as sessões de trabalhos por falta de recursos financeiros.

As intervenções de terceiros Estados, por meio de notificações endereçadas à CLPC, acabam trazendo um desafio adicional aos seus trabalhos. Isso ocorre porque ainda que sejam notificações de caráter técnico, a Comissão acaba se envolvendo em situações em que os interesses estatais são muito distintos e há um potencial conflitivo considerável $3 / 4$ caso das plataformas continentais estendidas no Ártico 3/4 ou, como ocorreu no caso da manifestação norte-americana no pleito brasileiro, em que a Comissão rejeitou o exame da notificação dos Estados Unidos, criando uma situação de contraposição aos interesses de terceiros Estados, ao limitar a apresentação de notificações somente aos Estados com costas adjacentes, confrontantes ou outras controvérsias territoriais ou marítimas pendentes à situação a ser examinada.

Dessa forma, levantando diversos pontos, com especial destaque para os desafios atuais e por meio da análise de casos concretos, o presente artigo procurou discutir o importante papel que vem desempenhando a Comissão de Limites da Plataforma Continental na delineação das plataformas continentais além do limite das 200 milhas marítimas.

\section{REFERÊNCIAS}

BARENTS OBSERVER. Denmark claims North Pole. Disponível em: <http://barentsobserver.com/en/ $\operatorname{arctic} / 2014 / 12 /$ denmark-claims-north-pole-15-12>. Acesso em: 25 abr. 2015.

CARLETON, Chris. Article 76 of the UN Convention on the Law of the Sea-implementation problems from the technical perspective. The International Journal of $\mathrm{Ma}$ rine and Coastal Law, v. 21, n. 3, p. 287-308, 2006.

CAVNAR, Anna. Accountability and the Commission on the Limits of the Continental Shelf: deciding who owns the ocean floor. Cornell International Law Journal, v. 42, p. 387-440, 2009.

EGEDE, Edwin. Submission of Brazil and Article 76 of the Law of the Sea Convention (LOSC) 1982. The International Journal of Marine and Coastal Law, v. 21, n. 1, p. 33-55, 2006.

ELFERINK, Alex G. Oude. Article 76 of the LOSC on the definition of the Continental Shelf: questions concerning its interpretation from a legal perspective. The International Journal of Marine and Coastal Law, v. 21, n. 3, p. 269-285, 2006.

GAU, Michael Sheng-Ti. Third Party Intervention in the Commission on the Limits of the Continental Shelf Regarding a Submission Involving a Dispute. Ocean Development \& International Law, v. 40, p. 61-79, 2009.

KUNOY, Bjorn. Disputed Areas and the 10-Year Time Frame: a Legal Lacuna? Ocean Development \& International Law, v. 41, p. 112-130, 2010.

MACNAB, Ron; PARSON, Lindsay. Continental Shelf Submissions: the record to date. The International Journal of Marine and Coastal Law, v. 21, n. 3, p. 309-322, 2006.

MCDORMAN, Ted L. The role of the Commission on the Limits of the Continental Shelf: a technical body in a political world. The International Journal of Marine and Coastal Law, v. 17, n. 3, p. 301-324, 2002.

SILVA, Alexandre Pereira da. A Rússia avança no Ártico. Boletim Meridiano 47, v. 15, n. 142, p. 20-27, mar./ abr. 2014.

SILVA, Alexandre Pereira da. O novo pleito brasileiro no mar: a plataforma continental estendida e o Projeto Amazônia Azul. Revista Brasileira de Politica Internacional, v. 56, n. 1, p. 104-125, 2013.

SMITH, Robert; TAFT, George. Legal Aspects of the Continental Shelf. In: COOK, Peter J.; CARLETON, Chris M. Continental Shelf Limits: the scientific and legal interface. Oxford: Oxford University Press, 2000. p. 17-24.

SUAREZ, Suzette V. The outer limits of the continental shelf: legal aspects of their establishment. Berlin: Springer, 2008. 
TAFT, George. The United Nations Convention on the Law of the Sea: The Commission on the Limits of the Continental Shelf - a Force for Enhancing Stability in the Oceans (or Not). Ocean Yearbook, v. 24, p. 151-169, 2010.
UNITED NATIONS. Division for Ocean Affairs and the Law of the Sea, Office of Legal Affairs. Training Manual for Delineation of the Outer Limits of the Continental Shelf beyond 200 nautical miles and for Preparation of Submissions to the Commission on the Limits of the Continental Shelf. New York: United Nations, 2006. 


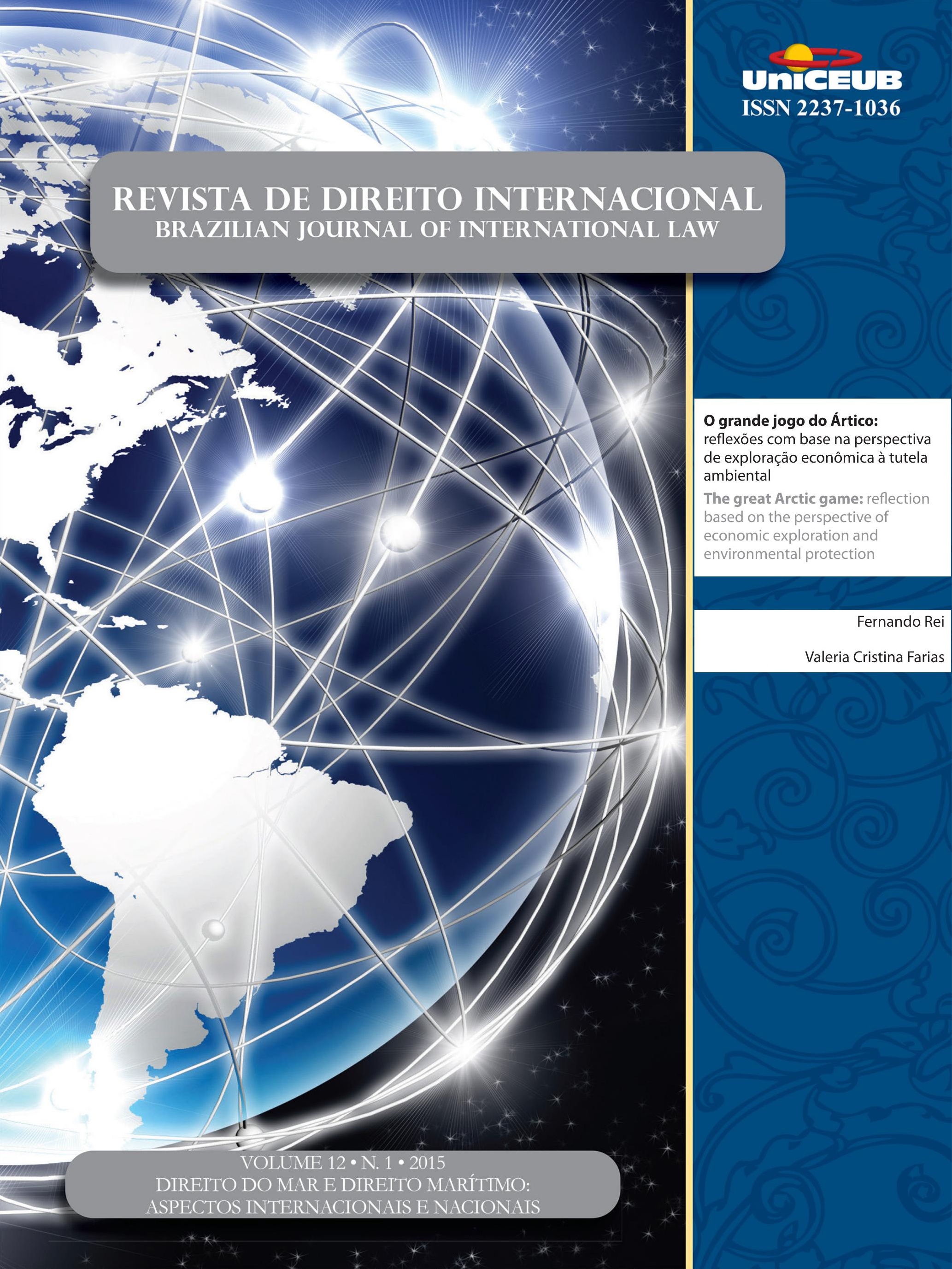




\section{O grande jogo do Ártico: reflexões com base na perspectiva de exploração econômica à tutela ambiental*}

\author{
The great Arctic game: reflection based on \\ the perspective of economic exploration and \\ environmental protection
}

\author{
Fernando Rei ${ }^{* *}$ \\ Valeria Cristina Farias ${ }^{* * *}$
}

* Recebido em 26/04/2015 Aprovado em 16/06/2015

** Professor Titular de Direito Ambiental da Fundação Armando Alvares Penteado - FAAP; Professor do Programa de Doutorado em Direito Ambiental Internacional da Universidade Católica de Santos; Diretor Científico da SBDIMA (Sociedade Brasileira de Direito Internacional do Meio Ambiente). E-mail: fernandorei@ig.com.br.

*** Procuradora do Estado de São Paulo, Professora de Direito da Universidade Paulista (UNIP) e Escola Superior de Administração, Marketing e Comunicação (ESAMC). E-mail: vfarias@sp.gov.br.

\section{Resumo}

O Ártico constitui uma das maiores regiões do planeta, com relevância econômica por suas riquezas minerais, localização estratégica entre os continentes da Euroásia e América, e grande fluxo de comércio internacional. O aquecimento global está intensificando o degelo do Polo Ártico e abrindo a possibilidade de se transformar em opção rentável de navegação marítima. O presente artigo propõe análise do regime jurídico que o disciplina, principalmente no que se refere à navegabilidade e tutela ambiental. Serão abordadas suas características geográficas, a origem e os motivos das disputas internacionais, visando delimitar e reconhecer o seu domínio, traçando-se comparativo com o regime internacional que rege e tutela a Antártica. O estudo possibilitará concluir que o regime jurídico existente não é suficiente para conferir a tutela ambiental do Ártico, necessária diante dos impactos ambientais que podem advir de sua exploração marítima.

Palavras-chave: Polo Ártico. Novas rotas de navegação. Regime jurídico. Tutela ambiental.

\section{Abstract}

The Arctic is one of the largest regions of the world, with economic relevance for its mineral wealth, strategic location between the continents of Eurasia and America and major international trade flows. Global warming is intensifying the melting of the Arctic Pole and opening the possibility of becoming profitable option of shipping. This article proposes an analysis of the legal framework that discipline, especially as regards the navigability and environmental protection. Will be addressed their geographical characteristics, the origin and motives of international disputes aiming to define and recognize your domain, by drawing a comparison with the international regime governing guardianship and Antarctica. The study will enable to conclude that the existing legal framework is not enough to provide the necessary environmental protection of the Arctic, on the environmental impacts that may arise from its maritime exploration. 
Keywords: Arctic Pole. New shipping routes. Legal framework. Environmental protection.

\section{INTRODUÇÃO}

O "Eldorado" é uma lenda espanhola que descreve as aventuras de um rei tão abastado que, além de construir uma cidade em ouro e tesouros indescritíveis, quando subia ao trono ou saía em combate costumava cobrir o seu corpo de ouro em pó que lhe conferia aspecto dourado, originando o termo "Eldorado", que em espanhol significa "O Dourado" (O Homem Dourado).

Ao longo da era de colonização das Américas essa lenda foi disseminada pelos índios, acreditando-se que o "Eldorado" poderia estar em diversas regiões da América, intensificando as explorações em busca desse tesouro escondido e a despeito da sua natureza lendária, contribuiu para a descoberta de várias reservas de ouro e prata, levando algumas regiões e civilizações ao colapso.

Atualmente, o Ártico ressurge como o "Eldorado" da era moderna pela sua localização estratégica no planeta, situado na convergência da América, Europa e Ásia ${ }^{1}$, e pelas riquezas minerais estimadas em $25 \%$ das reservas mundiais de hidrocarbonetos ${ }^{2}$. Em tempos modernos em que as reservas de gás e petróleo estão se esgotando, o domínio na exploração do Ártico representa um degrau capaz de conduzir um Estado à condição de potência econômica futura.

Além das riquezas minerais, o aquecimento global está intensificando o degelo da região, viabilizando novas rotas estratégicas de navegação marítima como outrora ocorrera com a aviação após o primeiro voo trans-ártico. A sua utilização como rota marítima pode representar revolução no comércio mundial, porque implica significativa redução dos custos logísticos, encurta a distância percorrida entre os oceanos Pacífico e Atlântico, facilita as comunicações e relações comerciais entre o Ocidente e o Oriente, beneficiando a economia dos países adjacentes.

O presente trabalho pretende desenvolver algumas reflexões acerca da necessidade de adaptação da tutela jurídica da região, para que possa disciplinar a atividade marítima e considerar as suas peculiaridades ambientais.

1 SIMIELLI, Maria Elena. Geoatlas. São Paulo: Ática, 2011.

2 SCIENCE FOR A CHANGING WORLD. US Geological Survey. Disponível em: <www.usgs.gov>. Acesso em: 11 jun. 2015.
O artigo foi estruturado em quatro seções. A primeira traça os contornos geográficos e conceituais da Região Ártica, ressaltando a sua importância para o equilíbrio ambiental e a influência do aquecimento global sobre o oceano gelado. A segunda seção descreve as rotas que vêm sendo cobiçadas como opção de exploração econômica e possíveis implicações ambientais na utilização. A terceira seção analisa o regime jurídico que disciplina o Ártico, traçando-se comparativo com a Antártica e enfatizando as disputas de domínio territorial na região, motivadas por interesses econômicos, finalizando, na última seção, com as conclusões desse estudo.

\section{A Região Ártica e as mudanças climáticas}

A Região Ártica constitui uma das maiores do planeta.

Fazendo-se uma descrição geográfica, o Círculo Polar Ártico está localizado a sessenta e seis graus e trinta e três segundos de latitude norte $\left(66^{\circ} 33^{\prime} \mathrm{N}\right)$, inclui o Ártico (extensão marítima coberta de forma permanente por gelo ${ }^{3}$ ); o Polo Norte (ponto norte geográfico da terra) e o Oceano Ártico, que banha a costa norte da América do Norte, Euroásia e várias ilhas. Sua extensão territorial litorânea é de aproximadamente doze milhões de quilômetros quadrados ${ }^{5}$, povoada por cinco milhões de habitantes ${ }^{6}$ e domínio territorial dividido entre a Groelândia (nação autônoma do Reino da Dinamarca), Ilhas Faroe (território dinamarquês), Alasca (território dos Estados Unidos), Sibéria (território da Rússia), Canadá e Noruega. A Finlândia, Suécia e Islândia não possuem extensão territorial costeira ao Ártico, não exercendo domínio sobre ele, mas em razão da proximidade territorial e utilização do Oceano Ártico participam das discussões que envolvem a região, juntamente com os países lindeiros, integrando o Conselho do Ártico ${ }^{7}$, fórum regional criado em 1996, para discussão de interesses da região.

3 As temperaturas mínimas nessa região atingem -67,7 graus Celsius. SIMIELLI, Maria Elena. Geoatlas. São Paulo: Ática, 2011.

4 MELLO, Celso de Albuquerque. Curso de direito internacional público. 14. ed. Rio de Janeiro: Renovar, 2002.

5 SIMIELLI, Maria Elena. Geoatlas. São Paulo: Ática, 2011.

6 SIMIELLI, Maria Elena. Geoatlas. São Paulo: Ática, 2011.

7 Fórum Intergovernamental para discussão de assuntos de interesse do Ártico, estabelecido em 1996. Será melhor abordado no item 5 - Regime Jurídico do Ártico para Tutela do Meio Ambiente. 
Embora não seja considerada continente, ocupa área de importância estratégica, despontando como promissora alternativa econômica para exploração da pesca, reservas minerais de diamante, ouro, prata, cobre, ferro, platina, carvão e urânio ${ }^{8}$, estimando-se a existência de reservas de petróleo e gás natural. As perspectivas de exploração econômica intensificam as disputas de domínio territorial, que ganham proporções maiores em razão da deficiência do seu regime jurídico.

O Ártico é estruturalmente diferente da Antártica, pois é composto de um extenso oceano coberto por gelo, localizado no Polo Norte, não submetido a nenhuma região continental ${ }^{9}$ e a Antártica consiste em uma grande área de terra firme, coberta por gelo e localizada no Polo Sul ${ }^{10}$, formando uma gigantesca ilha circular que envolve um espaço territorial continental e um espaço marítimo. Embora diferentes em estrutura, são indispensáveis para o controle do equilíbrio climático e ecológico global, porque concentram "os principais focos frios de toda a Terra, distribuindo-os ao resto do planeta por meio da atmosfera e oceano" ${ }^{11}$.

Assim como outras regiões do planeta, o Ártico também está sendo afetado pelas alterações climáticas, decorrentes de fenômenos naturais recorrentes, que observam certa sazonalidade dependente de fatores também naturais, como a intensidade do sol e o efeito estufa. O efeito estufa representa a capacidade do planeta de guardar o calor que irradia durante o dia, devolvendo-o à atmosfera durante a noite e permitindo manter a temperatura média da Terra. Essa reação química é possível em razão da concentração de gases de efeito estufa na atmosfera, gás com capacidade de absorção de calor ${ }^{12}$.

O desenvolvimento tecnológico e o advento da industrialização modificaram os padrões de consumo humano e revolucionaram os meios de produção, alterando a interferência antrópica sobre o meio ambiente e inaugurando um processo, não mais abandonado, de

8 BORRESEN, Jacob. The great Artic game. Heartland Eurasian Review of Geopolitics, Roma, n. 2, p. 5-77, 2008.

9 GOUVEIA, Jorge Bacelar. Manual de direito internacional público. Rio de Janeiro: Renovar, 2005.

10 SILVA, G. E. do Nascimento; ACCIOLY, Hildebrando. Manual de direito internacional público. São Paulo: Saraiva, 2002.

11 GONZALEZ, Margarita Yela. Investigación polar española. Revista Ejército, Madrid, n. 793, p. 17-22, 2007. Número extraordinario: Las Fuerzas Armadas en la Antártida.

12 VIOLA, Eduardo José. Perspectivas da governança e segurança climática global. Revista Plenarium, Brasília, v. 5, n. 5, p. 173-196, 2008. afetação climática, pelo acréscimo indiscriminado de gases de efeito estufa na atmosfera. A combinação entre o crescimento populacional mundial, as emissões de gases de efeito estufa decorrentes da industrialização, a crescente utilização e dependência das fontes energéticas fósseis, o desmatamento e outros comportamentos poluentes são exemplos de atividades antrópicas que podem contribuir para as alterações do clima, porque aumentam a proporção de gases de efeito estufa na atmosfera, contribuindo para o efeito estufa.

Dados científicos registrados pelo IPCC (Intergovernmental Panel on Climate Change - Painel Intergovernamental sobre Mudanças Climáticas) ${ }^{13}$, no quarto relatório divulgado em 2007, identificaram alterações climáticas na Região Ártica, com considerável variação das temperaturas e significativa tendência de aquecimento. Esse aumento de temperatura tem reduzido a extensão e a espessura de gelo no mar Ártico, provocando o aquecimento do oceano e permafros $t^{4}$; influenciando na fauna, com riscos à sobrevivência dos ursos polares e outros animais; afetando a flora, com ameaça a subsistência e cultura das populações tradicionais, mas, por outro lado, permitindo maior navegabilidade pelo oceano, por meio de rotas economicamente rentáveis.

Os estudos do IPCC também apontam uma possível interligação entre o aquecimento do Ártico e fenômenos naturais extremos em outras regiões. A esse respeito, ressalte-se as ondas de calor analisadas em julho e agosto de 2010, na Rússia, causando incêndios que destruíram duzentos mil hectares de florestas e deixaram milhares de pessoas desabrigadas ${ }^{15}$; o inverno rigoroso ocorrido em meados de 2012 em alguns países da Europa, entre eles Inglaterra, Reino Unido, Escócia e País de Gales ${ }^{16}$ e o gradativo desaparecimento de ilhas, submer-

13 O IPCC é um painel científico ligado às Nações Unidas que avalia o conhecimento existente no mundo sobre mudança climática global. WORLD METEOROLOGICAL ORGANIZATION. Intergovernmental panel on climate change: fifth assessment report (AR5). Disponível em: <http://www.ipcc.ch/>. Acesso em: 10 maio 2014. 14 de solo permanentemente congelado, que apresenta temperatura abaixo de zero por pelo menos dois anos consecutivos, encontrado na região do Ártico, com diferentes características e formatos (International Permafrost Association).

15 APÓS onda de calor e incêndios florestais a Rússia enfrenta a questão climática. Disponível em: <http://www.ecodebate.com. br/2010/08/25/apos-onda-de-calor-e-incendios-florestais-a-russiaenfrenta-a-questao-climatica/>. Acesso em: 21 maio 2014.

16 INVERNO rigoroso causa prejuízos e faz vítimas na Europa. Disponível em <http://g1.globo.com/bom-dia-brasil/noticia/2012/12/inverno-rigoroso-causa-prejuizos-e-faz-vitimas-naeuropa.html>. Acesso em: 21 maio 2014. 
sas pelo aumento do nível dos oceanos, como o caso de Tuvalu, no Oceano Pacífico.

As alterações climáticas no Ártico não podem ser ignoradas ou tratadas isoladamente como problemas regionais, pois suas consequências são relevantes para o equilíbrio do meio ambiente global, merecendo atenção especial e regime jurídico que seja adequado à preservação desse status quo.

A intensificação da utilização do Ártico como rota marítima pode acelerar o processo de degelo no Ártico e contribuir, ainda mais, para o aquecimento global sob duas vertentes, a diminuição da distribuição dos focos de frio e calor pela atmosfera e oceano ${ }^{17}$, além da liberação de gás metano na atmosfera, pelo degelo do permafrost, que intensifica o efeito estufa e, em comparação com o dióxido de carbono, é muito mais impactante ${ }^{18}$.

\section{UM GIGANTE GELADO EM PROPORÇÕES E RIQUEZAS}

Atualmente, noventa por cento das cargas que circulam entre os continentes são transportadas pela via marítima ${ }^{19}$. A possibilidade de navegabilidade pelas águas do Ártico pode representar revolução no comércio mundial porque implica significativa redução dos custos logísticos, encurta a distância percorrida entre os portos situados entre o oceano Atlântico e Pacífico, incrementando a economia dos países adjacentes ${ }^{20}$.

Essa perspectiva começa a ganhar corpo com a variação térmica observada no Ártico em razão do aquecimento global, responsável pela alteração no caráter de cobertura do oceano, tornando o gelo mais fino e frágil, com possibilidade de transformá-lo em oceano livre de gelo durante o verão. Estudo realizado por pesquisadores da University of California, Los Angeles (UCLA), concluiu que no final dos anos 2050 será possível a travessia

17 GONZALEZ, Margarita Yela. Investigación polar española. Revista Ejército, Madrid, n. 793, p. 17-22, 2007. Número extraordinario: Las Fuerzas Armadas en la Antártida.

18 WORLD METEOROLOGICAL ORGANIZATION. Intergovernmental panel on climate change: fifth assessment report (AR5). Disponível em: <http://www.ipcc.ch/>. Acesso em: 10 maio 2014. 19 INTERNATIONAL MARINE ORGANIZATION. Introduction to IMO. Disponível em <www.imo.org>. Acesso em: 16 abr. 2014.

20 SILVA, Marcos V. M. O oceano Ártico: oportunidades da nova fronteira marítima. Revista Antíteses, Londrina, v. 7, n. 13, p. 228-253, 2014. por navios mercantes durante o verão, sem que haja a necessidade da utilização de navios quebra-gelo ${ }^{21}$.

O degelo do Ártico trouxe à evidência outras rotas já existentes, mas pouquíssimo utilizadas em razão do congelamento permanente: a Rota do Mar do Norte (Northern Sea Route), a Passagem do Noroeste (Northwest Passage), a Ponte do Ártico (Artic Bridge Route) e a Rota Marítima Transpolar (Artic Bridge Route) ${ }^{22}$.

A Rota do Mar do Norte constitui o caminho mais curto entre a Europa e a Ásia. Foi inaugurada pela União Soviética, em 1931, para transporte nacional, e liberada para embarcações estrangeiras em 1991, apesar de ser utilizada majoritariamente pelos russos ${ }^{23}$. Tem comprimento de duas mil e seiscentas milhas náuticas, junto à fronteira da Rússia ${ }^{24}$, necessitando do auxílio de navios quebra-gelo para viabilizar a travessia. Em setembro de 2009, dois navios mercantes alemães conseguiram atravessar a passagem com a ajuda de quebra-gelos russos ${ }^{25}$.

A Passagem do Noroeste favorece a ligação entre o Nordeste da Ásia, ao norte de Xangai e o nordeste da América do Norte. Margeia o litoral do Canadá ${ }^{26}$ e é formada por estreitos que possibilitam a ligação entre o Oceano Atlântico e Pacífico, percorrendo as ilhas do Ártico Canadense. Os estreitos possibilitam outras duas alternativas marítimas, a Rota Sul (por meio de Peel Sound, em Nunavut), considerada tortuosa pela enorme presença de canais de pouca profundidade, impondo restrições de calado e a Rota Norte que se desenvolve por meio do Estreito de MacClure, mais direta e cobiçada, porém propensa a maior incidência de icebergs ${ }^{27}$.

21 SMITH, Laurence C.; STEPHENSON, Scott R. New Trans-Artic shipping routes navigable by midcentury. Disponível em: < http://www. pnas.org/content/110/13/E1191.full>. Acesso em: 23 abr. 2015.

22 SILVA, Marcos V. M. O oceano Ártico: oportunidades da nova fronteira marítima. Revista Antíteses, Londrina, v. 7, n. 13, p. 228-253, 2014.

23 AGUILAR, Sergio Luiz Cruz. Direito do mar, poder naval e relações internacionais: os recentes casos do Ártico e do Mar da China. In: BARBOSA JR., Ilques; MORE, Rodrigo Fernandes. (Org.). Amazônia azul: política, estratégia e direito para o oceano do Brasil. Rio de Janeiro: Femar, 2012. p. 78-99. p.84.

24 O'ROURKE, Ronald. Changes in the Artic: background and issues for congress. 2014. Disponível em: <https://www.fas.org/ sgp/crs/misc/R41153.pdf>. Acesso em: 21 maio 2014.

25 KEFFERPUTZ, Roderick; BOCHKAREV, Danila. Expanding the EU's institutional capacities in the Arctic Region. Berlim: Heinrich Boell Foundation, 2008.

26 SILVA, Marcos V. M. O oceano Ártico: oportunidades da nova fronteira marítima. Revista Antíteses, Londrina, v. 7, n. 13, p. 228-253, 2014.

27 O'ROURKE, Ronald. Changes in the Artic: background and 
A Ponte do Ártico liga os portos de Murmansk (Rússia) e de Narvik (Noruega) ao porto de Churchill (Canadá), pela baía de Hudson ${ }^{28}$ e, finalmente, a Rota Marítima Transpolar, ainda inviável pelo congelamento, mas que poderá ser navegável a partir de 2050, segundo projeções científicas, utiliza as partes centrais do Ártico, encurtando ainda mais a travessia entre o Atlântico e Pacífico ${ }^{29}$.

Essa localização estratégica, permitindo a utilização como rota alternativa, bem como as perspectivas de exploração de suas riquezas minerais justificam a cobiça pela região, acirrando disputas em termos de domínio.

Para garantir seus interesses econômicos, os países lindeiros começaram a intensificar o patrulhamento naval na região, ostentando e afirmando sua soberania nas respectivas fronteiras, como é o caso da Dinamarca, que estabeleceu naquele local comando militar e da Noruega que possui um batalhão do exército para proteção de seu território no Ártico (o Artic Battalion) ${ }^{30}$, desencadeando desentendimentos vários entre os países fronteiriços e tensões internacionais permanentes.

Porém, os países com maiores apetites soberanos são os Estados Unidos e Rússia, que possuem bases militares instaladas na região ${ }^{31}$. A Rússia, inclusive, não hesita em demonstrar ostensivamente suas pretensões econômicas no oceano gelado. Em 2 de fevereiro de 2007, dois submarinos russos imergiram após nove horas submersos sob a calota polar, fincando uma bandeira russa em titânio inoxidável há quatro mil, duzentos e sessenta e um metros de profundidade ${ }^{32}$, causando grande desconforto internacional.

Além dos países lindeiros, a comunidade internacional também cobiça o Ártico e estende seus olhares e interesses sobre ele, na esperança da divisão dos louros econômicos que se concretizarão no futuro e a expec-

issues for congress. 2014. Disponível em: < https://www.fas.org/ sgp/crs/misc/R41153.pdf>. Acesso em: 21 maio 2014.

28 SILVA, Marcos V. M. O oceano Ártico: oportunidades da nova fronteira marítima. Revista Antiteses, Londrina, v. 7, n. 13, p. 228-253, 2014.

29 SILVA, Marcos V. M. O oceano Ártico: oportunidades da nova fronteira marítima. Revista Antiteses, Londrina, v. 7, n. 13, p. 228-253, 2014.

30 GARON, Richard; LASSERRE, Frederic; LE ROY, Jérôme. Is there an arms race in the Artic? Journal of Military and Strategic Studies, Calgary, v. 14, n. 3/4, p. 1-56, Mar. 2012.

31 SIMIELLI, Maria Elena. Geoatlas. São Paulo: Ática, 2011.

32 KOPP, Dominique. Guerra Fria sobre o Ártico. Revista Le Monde Diplomatique Brasil, São Paulo, v. 1, n. 2, set. 2007. Disponível em: <http://www.diplomatique.org.br/acervo. php?id=2072\&tipo $=$ acervo $>$. Acesso em: 12 abr. 2014. tativa de serem considerados como patrimônio comum da humanidade. A esse respeito, França, Holanda, Alemanha, Polônia, Espanha, Reino Unido, China, Itália, Japão, República da Coreia, Singapura e Índia possuem assento no Conselho do Ártico, na qualidade de observadores, sem direito a voto, mas contribuindo na construção da agenda e discussão de interesses regionais. $\mathrm{O}$ mesmo se diga em relação a comunidades locais ${ }^{33} \mathrm{e}$ várias organizações não governamentais e intergovernamentais, que participam com status de observadores.

Não bastasse o evidente conflito econômico, que pode desenterrar uma nova "guerra fria" 34 , os riscos ambientais também precisam ser considerados. Embora o aquecimento global esteja intensificando o degelo do Ártico, a navegação pelas novas rotas ainda é uma missão difícil, disponível em reduzidas épocas do ano e dependente da utilização de navio quebra-gelo ${ }^{35}$, cujos estudos acerca dos impactos ambientais são incipientes e ainda incertos.

A adoção dessas rotas implica a necessidade de utilização de navios quebra-gelo, seja no sistema de escolta de navios mercantes, facilitando a travessia ou como suporte nas hipóteses de resgate e salvamento. Essa nova opção de mercado não passou despercebida e a Rússia já explora a atividade na Rota Marítima Norte, cobrando pelos serviços. Além da perspectiva de renda, os navios quebra-gelo, antes de tudo, são manifestação ostensiva da soberania estatal sobre a região, garantindo e reforçando a presença e ocupação sobre o Ártico. A Rússia possui trinta e sete navios quebra-gelo em operação, com perspectivas de acréscimo de mais quatro que se encontram em construção; o Canadá possui seis; os Estados Unidos, cinco; a Dinamarca, quatro e a Noruega, $\mathrm{um}^{36}$.

33 Sensível a representações paradiplomáticas, o Conselho do Ártico abre espaço para membros de comunidades locais. Além dos oito países-membros e dos observadores, o órgão é composto por delegações das etnias Inuit, Athabaska, Gwich'in, Sami e Aleut, além da Associação Russa dos Povos Indígenas do Norte (Raipon).

34 O discurso e a política do governo russo identificam a região como patrimônio nacional e uma de suas prioridades, identificandoo como propensa a um conflito militar no futuro, particularmente em razão da exploração de seus recursos. Nesse sentido: KEFFERPUTZ, Roderick; BOCHKAREV, Danila. Expanding the EU's institutional capacities in the Arctic Region. Berlim: Heinrich Boell Foundation, 2008.

35 O'ROURKE, Ronald. Changes in the Artic: background and issues for congress. 2014. Disponível em: <https://www.fas.org/ sgp/crs/misc/R41153.pdf>. Acesso em: 21 maio 2014.

36 SILVA, Marcos V. M. O oceano Ártico: oportunidades da nova fronteira marítima. Revista Antiteses, Londrina, v. 7, n. 13, p. 228-253, 
Os impactos dessa utilização indiscriminada de navios quebra-gelo ainda são desconhecidos, cabendo ressalvar os riscos de desastres ambientais, envolvendo embarcações mercantes, que podem impactar não só a região Ártica e países próximos, mas o planeta total.

A economia que se pretende obter com a redução da distância de navegação entre a Ásia e Europa, pelas rotas Árticas, com certeza contribuirá para a diminuição do consumo de combustíveis fósseis, mas pode causar impacto ambiental pelo depósito de fuligem na neve e gelo, resultante da queima de combustível, intensificando o derretimento polar ${ }^{37}$.

Essa incerteza ambiental e até mesmo os riscos da travessia ainda não foram capazes de desestimular a navegação pelo Ártico. Em agosto de 2013, o navio cargueiro Yong Sheng, de bandeira chinesa, virou notícia no Brasil e no mundo porque saiu do porto de Dalian, na China e se dirigiu até Roterdã, na Holanda, sem passar pela rota tradicional do Canal de Suez. Navegando exclusivamente pelo oceano Ártico, o Yong Sheng economizou duas semanas de viagem e milhares de litros de combustível ${ }^{38}$.

Afora os riscos já mencionados, devem ser considerados os possíveis impactos ambientais aos habitats naturais do fundo do oceano e superfície, bem como a poluição marinha causada pelas embarcações, como a descarga de lixo doméstico, a descarga de água de lastro, perda de óleo e poluição acidental. Esses riscos precisam ser gerenciados, máxime em razão das peculiaridades da travessia que é rica em icebergs, sob pena de se repetirem os danos já observados no incidente, envolvendo o Exxon Valdez ${ }^{39}$, em uma região em que as medidas mitigadoras serão praticamente impossíveis.

A título de exemplo, em 2010, o navio-tanque Nanny, carregado com nove milhões de litros de óleo diesel, encalhou em um banco de areia no oceano Ártico canadense. Parte do combustível foi bombeada para

2014.

37 BERGH, Trond Flisnes apud GOMIDE, Camilo. Tecnologia: para quebrar o gelo. Revista Planeta, Rio de Janeiro, v. 492, out. de 2013. Disponível em: <http://revistaplaneta.terra.com.br/secao/ tecnologia/para-quebrar-o-gelo>. Acesso em: 15 jun. 2015.

38 BERGH, Trond Flisnes. Apud GOMIDE, Camilo. Tecnologia: para quebrar o gelo. Revista Planeta, Rio de Janeiro, v. 492, out. de 2013. Disponível em: <http://revistaplaneta.terra.com.br/secao/ tecnologia/para-quebrar-o-gelo>. Acesso em: 15 jun. 2015.

39 Navio petroleiro que encalhou na costa do Alasca, em março de 1989, despejando milhares de barris de petróleo no mar e causando um dos maiores desastres ambientais. outro petroleiro, permitindo a recondução do cargueiro à rota original e evitando um desastre ambiental de proporções gigantescas ${ }^{40}$.

Nesse sentido, Ulrich Beck ${ }^{41}$ sustenta que o desenvolvimento dos processos industriais e a globalização proporcionaram e continuam proporcionando desenvolvimento econômico e social, mas, paradoxalmente, acarretam efeitos negativos, como desastres ambientais, financeiros ou sociais, que irradiam globalmente. Os riscos da sociedade atual não podem ser medidos em contornos espaciais ou temporais, porque atingem toda a sociedade, a natureza completa, o mundo de forma globalizada, despertando crise de identificação sobre o que realmente é essencial, sobre os riscos que realmente a sociedade deseja enfrentar. Essa busca incessante por novas fontes de riqueza, por novos mercados e novos produtos conduz ao que o autor identificou como "sociedade de risco", pois carrega, intrinsecamente, uma incerteza quanto à segurança global e, portanto, não pode ser tratada ou gerenciada em escala individual.

Não há como negar que a utilização do Ártico como rota alternativa navegável estará sujeita aos riscos decorrentes das intempéries climáticas, as possibilidades de erro humano, os defeitos intrínsecos das embarcações e a possível influência no equilíbrio ecológico decorrente da utilização de navios quebra-gelo em larga escala. A grande indagação que merece resposta é se a sociedade internacional está ciente e disposta a assumir esse novo risco. Em tempos em que os santuários ecológicos estão se extinguindo gradativamente e a gravidade dos problemas globais exige respostas eficientes, talvez fosse interessante o debate acerca da preservação e conservação das geleiras do Ártico, para que as atividades antrópicas não acelerem o processo natural de seu derretimento.

\section{O dOMÍNIO dO ÁRTICO}

O Ártico não está regulado por tratado internacional específico que tutele sua extensão e recursos naturais ${ }^{42}$.

40 PRESSE, France. Petroleiro encalhado no Ártico canadense volta à rota. Disponível em: <http://g1.globo.com/mundo/noticia/2010/09/petroleiro-encalhado-no-artico-canadense-volta-arota.html>. Acesso em: 15 jun. 2015.

41 BECK, Ulrich; GIDDENS, Anthony; LASCH, Scott. Modernização reflexiva: política, tradição e estética na ordem social moderna. São Paulo: Unesp, 1995.

42 A esse respeito existem propostas de submeter o Ártico ao 
Sua regulação jurídica é fracionada, submetida às diversas soberanias que detém o domínio do mar territorial que sobre ele se projeta e na parte relativa ao alto mar, submete-se ao regime jurídico da Conferência das $\mathrm{Na}$ ções Unidas sobre Direito do Mar (CNUDM) e outros tratados internacionais genéricos.

Até o início do século XX a região praticamente passou despercebida, não havendo registros de incidentes relevantes, talvez em virtude da dificuldade de navegação e exploração econômica da região. Com o término da Primeira Guerra Mundial e a realização do primeiro voo trans-ártico (em 1926), a corrida e disputa pelo seu domínio tomou forma e endereço certos ${ }^{43}$. Canadá, Dinamarca, Rússia, Noruega e Estados Unidos encabeçaram a disputa pela região e ainda hoje reivindicam o exercício da soberania por todo o Ártico (incluindo o alto mar), com vistas a sua exploração exclusiva ${ }^{44}$.

Inicialmente, a reivindicação territorial do Ártico baseava-se na teoria dos setores, desenvolvida originalmente em 1906, no Clube Naval de Nova Iorque e defendida internacionalmente por Pascal Poirier, senador do Canadá $(1907)^{45}$. Posteriormente, em 1928, W. Lakhtine, doutrinador soviético, reproduziu a teoria em uma obra literária ${ }^{46}$. A teoria dos setores pretendia justificar o direito de domínio dos países lindeiros sobre o Ártico, projetando um triângulo setorial com a base correspondente aos respectivos territórios e cuja extensão atingiria o triângulo projetado sobre o oceano até o limite angular do polo norte, estabelecendo-se vértice comum a esses ângulos. $\mathrm{O}$ domínio seria estabelecido pela projeção desse triângulo imaginário, independente de efetiva ocupação ou até mesmo de eventual im-

mesmo regime jurídico implantado na Antártida, que será analisado no item 5, Regime Jurídico do Ártico para Tutela do Meio Ambiente. 43 MARQUES JÚNIOR, José Carlos; MARQUES, Rafael Diogenes. Disputas territoriais no Ártico à luz da Convenção das Nações Unidas sobre o direito do mar de 1982. Revista Geopolítica, Ponta Grossa, v. 3, n. 02, p. 139-152, jul. 2012. Disponível em: <http://www.revistageopolitica.com.br/ojs/ojs-2.2.3/index.php/ rg/oai>. Acesso em: 22 abr. 2014.

44 MATTOS, Adherbal Meira. Direito internacional público. 2. ed. Rio de Janeiro: Renovar, 2002.

45 MATTOS, Adherbal Meira. Direito internacional público. 2. ed. Rio de Janeiro: Renovar, 2002.

46 MARQUES JÚNIOR, José Carlos; MARQUES, Rafael Diogenes. Disputas territoriais no Ártico à luz da Convenção das Nações Unidas sobre o direito do mar de 1982. Revista Geopolítica, Ponta Grossa, v. 3, n. 02, p. 139-152, jul. 2012. Disponível em: $<$ http://www.revistageopolitica.com.br/ojs/ojs-2.2.3/index.php/ rg/oai>. Acesso em: 22 abr. 2014. possibilidade de efetuar tal ocupação ${ }^{47}$. Foi construída para tentar justificar a anexação do Ártico aos países lindeiros, ignorando-se o aspecto da ocupação efetiva, imprescindível nos procedimentos dessa natureza e justificava-se nas próprias particularidades da região, que praticamente inviabiliza a habitação permanente de seres humanos, partindo do pressuposto que somente os Estados que margeiam o oceano estariam aptos a estabelecer razoável ocupação e tutela sobre ela ${ }^{48}$.

Tais reivindicações não chegaram a ser reconhecidas internacionalmente e com a adesão do Canadá, Dinamarca, Rússia e Noruega à CNUDM, a teoria dos setores perdeu a razão de ser, pois totalmente incompatível com seus termos.

A CNUDM estabelece que cada Estado detém soberania para delimitar, de forma unilateral e sem qualquer interferência externa, a extensão de sua plataforma, desde que limitada a 200 milhas marítimas. Se a pretensão envolver extensão superior, mas dentro de um limite total de 350 milhas marítimas da linha da base, o reconhecimento internacional é possível, mas fica condicionado à submissão da Comissão sobre Limites da Plataforma Continental (CLPC), órgão competente para analisar o pedido e formular recomendação ao Estado interessado, se o caso (artigo 76, parágrafo 8, da CNUDM).

O mecanismo que permite a ampliação da extensão da plataforma continental não contribuiu para o esfriamento das disputas no Ártico. No entanto, embora essa delimitação resulte de um exercício de soberania dos Estados, reconhecido no artigo $3^{\circ}$, da CNUDM, com base no momento em que aderiram à convenção, renunciaram à parcela dessa soberania no que tange às pretensões que excedem os limites convencionados, trazendo à tona a fragilidade jurídica da teoria dos setores, ante a inviabilidade de reconhecimento de domínio além das 350 milhas marítimas.

Poderíamos admitir a legitimidade da reivindicação pelos Estados Unidos, eis que não aderiram à Convenção do Mar e, a princípio, não estariam limitados aos seus contornos. Ocorre que os limites reconhecidos

47 MATTOS, Adherbal Meira. Direito internacional público. 2. ed. Rio de Janeiro: Renovar, 2002.

48 MARQUES JÚNIOR, José Carlos; MARQUES, Rafael Diogenes. Disputas territoriais no Ártico à luz da Convenção das Nações Unidas sobre o direito do mar de 1982. Revista Geopolítica, Ponta Grossa, v. 3, n. 02, p. 139-152, jul. 2012. Disponível em: <http://www.revistageopolitica.com.br/ojs/ojs-2.2.3/index.php/ rg/oai>. Acesso em: 22 abr. 2014. 
formalmente foram decorrentes de larga discussão entre a comunidade internacional e com origem nos costumes internacionais ${ }^{49}$, o que autoriza admitir que ainda que não a tenha subscrito, os Estados Unidos também teriam suas pretensões limitadas à extensão de 350 milhas marítimas e entendimento diverso fatalmente seria rechaçado pela comunidade internacional.

No mais, a extensão que extrapola a plataforma continental, denominada na CNUDM como Área e definida como "o leito do mar, os fundos marinhos, e o seu subsolo além dos limites da jurisdição nacional" ${ }^{50}$, não se sujeita às jurisdições estatais e recebeu tratamento diferenciado, sendo considerada como patrimônio comum da humanidade, insuscetível de apropriação individual de qualquer Estado. A exploração da Área se dá de acordo com a convenção e é administrada pela Autoridade Internacional dos Fundos Marinhos, localizada na Jamaica.

Observa-se que a disputa por soberania sobre o Ártico deve ser considerada com muita parcimônia pela comunidade internacional, pois a pretexto de se reconhecer as reivindicações de extensão das respectivas plataformas continentais, corre-se o risco de atribuir praticamente toda a região Ártica ao controle exclusivo dos cinco países lindeiros, restando diminuta parte de Área, concentrada na parte central e totalmente coberta de gelo. Isso representaria uma multiplicidade de regulação jurídica, porque cada Estado, exercendo sua soberania, estabeleceria a forma de utilização e exploração de sua parcela territorial.

Não há como aceitar esse fatiamento do Ártico pelos Estados que o margeiam, devendo ser reservada parcela significativa do oceano na qualidade de mare liberum, ou seja, com regime jurídico de alto-mar, não sujeito a qualquer jurisdição estatal e de interesse e tutela global, como forma de garantir, ainda que reflexamente, a tutela ambiental da região.

49 STOKKE, Olav Schram. A legal regime for the Arctic? Interplay with the Law of the Sea Convention. Marine Policy, Amsterdam, v. 31, n. 4, p. 409-414, 2007. Disponível em: <http://www.fni.no/ doc\&pdf/oss-mp-2007.pdf>. Acesso em: 22 abr. 2015.

50 Artigo $1^{\circ}$., I, "a”, da CNUDM. ORGANIZAÇÃO DAS NAÇÕES UNIDAS. Resolução da Assembleia da República n. 60-B/97. Convenção das Nações Unidas sobre o Direito do Mar e o Acordo Relativo à Aplicação da Parte XI da mesma Convenção. Disponível em: <http://www.gddc.pt/siii/docs/rar60B-1997.pdf>. Acesso em: 22 abr. 2015.

\section{Regime jurídico do Ártico para tUtela do MEIO AMBIENTE}

Enquanto a região da Antártica possui tratados específicos de preservação ambiental (Tratado da Antártica e Protocolo de Madri), o Ártico é regulado na parte territorial pela legislação interna dos respectivos Estados e em alto mar, pela CNUDM, que instituiu regime jurídico amplo e não específico, insuficiente para atender as peculiaridades da região, impedir ou afastar a aplicação de vários outros documentos internacionais de proteção dos mares e oceanos ${ }^{51}$.

O regime jurídico da Antártica não foi construído especificamente para garantir a tutela ambiental, mas evoluiu de forma contínua para atender às suas peculiaridades, sendo expresso no sentido de garantir que a região não possa ser objeto de disputa internacional, elevando-a ao patamar de reserva natural, destinada a cooperação entre os povos e a ciência ${ }^{52}$.

O Tratado da Antártica, firmado em 1959, em Washington $^{53}$, foi originalmente negociado para solucionar as disputas de soberania que envolviam a região. Estabeleceu que os Estados signatários, ainda que por prazo determinado ${ }^{54}$, abririam mão da soberania sobre o continente, utilizando-o somente para pesquisa científica e para fins pacíficos, vedando-se qualquer atividade militar, salvo as realizadas para efeito científico ou para fins pacíficos (artigo I). Embora o artigo IV tenha sido específico no sentido de reconhecer que a adesão aos termos do documento não importaria renúncia ou diminuição às reivindicações de soberania territorial na Antártica, pode-se afirmar que os Estados se conformaram com a função atribuída ao continente, concluindo-se que o regime jurídico adotado foi extremamente eficiente, conduzindo à construção de um verdadeiro santuário ecológico. Prova disso é que esgotado o prazo estabelecido no Tratado, os Estados partes poderiam

51 JOYNER, Christopher C. The legal regime for the Arctic Ocean. Journal of Transnational Law \& Policy, Florida, v. 18, n. 9, p. 195-249, Spring, 2009.

52 NOWLAN, Linda. Artic legal regime for environmental protection. Gland: IUCN, 2001.

53 Inicialmente firmado por doze países que reivindicavam soberania sobre a Antártica: África do Sul, Argentina, Austrália, Bélgica, Chile, Estados Unidos, França, Japão, Noruega, Nova Zelândia, Reino Unido e União Soviética. Posteriormente recebeu adesão de vários outros países.

54 Nos termos do artigo XII, 2.a, os ajustes vigorariam por trinta anos. 
convocar nova reunião para modificação dos ajustes, entretanto não houve interesse pontual na sua modificação, demonstrando que o espírito cooperativo conduziu à estabilidade e institucionalização do regime.

Entre vários outros preceitos, os principais fundamentos do Tratado da Antártica é o uso pacífico da região e dos recursos naturais; a liberdade e cooperação nas pesquisas científicas e a divisão justa e igualitária dos benefícios advindos dos recursos e pesquisas. Destaca-se o seu contorno protetivo, até mesmo do risco das próprias atividades científicas, estabelecendo a proibição de qualquer explosão nuclear ou depósito de lixo atômico no continente (artigo V).

Em 1972, as partes signatárias do Tratado firmaram a Convenção para Conservação das Focas Antárticas (Convention for the Conservation of Antarctic Seals-CCAS) ${ }^{55}$ e, em 1980, a Convenção sobre a Conservação dos Recursos Vivos Marinhos Antárticos (The Convention on the Conservation of Antarctic Marine - CCAMLR). A primeira foi firmada para proibir a captura e morte das espécies de foca enumeradas no documento e a segunda para controlar a pesca do krill ${ }^{56}$ (fonte de alimento de várias espécies da Antártica) e proibir a exploração de recursos vivos da região (aves, pinguins, elefantes-marinhos, peixes e outras espécies, com exceção das focas e baleias, objeto de tratados específicos).

Complementando o Sistema do Tratado da Antártica (Antarctic Treaty System - ATS), o Protocolo sobre Proteção Ambiental para o Tratado da Antártica, conhecido como Protocolo de Madri (firmado em 1991 e que entrou em vigor em 1998, após a ratificação dos países membros consultivos), impede a exploração mineral que não seja para fins de pesquisa pelo prazo de cinquenta anos, estabelecendo normas tendentes, especificamente, a preservação ambiental da região. Os anexos do Protocolo também se destinam a tutelar os aspectos relativos a depósito de lixo na região, poluição marinha, tutela da flora e fauna, representando um arcabouço legislativo internacional de suma importância, seja pela riqueza da regulamentação, seja pela eficácia de seu conteúdo, que foi capaz de conter a ânsia exploratória por riquezas naturais e minerais abundantes no local.

No âmbito do regime jurídico da Antártica, o sistema prevê as Reuniões das Partes Consultivas (ATCMs)

55 Entrou em vigor em 1978.

56 Crustáceo semelhante ao camarão. como foro para discussão e deliberação de medidas, que são tomadas por consenso das Partes Consultivas e entram em vigor após a ratificação no âmbito interno dos respectivos Estados. Assim, após o Tratado de Madri, as partes solucionam questões de interesse da Antártica por meio das medidas deliberadas pelas ATCMS, adaptando o regime às necessidades observadas. Podem, também, adotar decisões e resoluções, sem caráter vinculativo, que não implicam obrigações para as partes ${ }^{57}$.

Da análise geral do regime jurídico da Antártica, observa-se que há vedação expressa de qualquer tipo de exploração comercial, elevando-a ao pedestal de "reserva natural, dedicada a paz e à ciência" ${ }^{58}$. No Ártico, ao contrário, não há regulação específica da tutela ambiental.

A primeira tentativa de regulação do Ártico foi a Estratégia para a Proteção do Meio Ambiente Ártico (Artic Environmental Protection Strategy - AEPS), aprovada pela Declaração sobre a Proteção do Meio Ambiente Ártico (Declaration on Protection of the Artic Environment), em 1991. O instrumento de soft law, sem conteúdo vinculante robusto, foi firmado pelos oito países que compõem a região, visando à cooperação ambiental para definição e redução dos impactos, controle e monitoramento de poluentes no mar Ártico, proteção do meio ambiente marinho, bem como para garantir a proteção, recuperação da qualidade ambiental e utilização sustentável dos recursos naturais. Para viabilizar o plano de ação instituído na AEPS, foram constituídos grupos de trabalho e as várias discussões que se seguiram afloraram a necessidade de ampliar a estratégia para outras necessidades além da proteção ambiental, instituindo-se o Conselho do Ártico, como fórum de discussão dos assuntos de interesse da região.

O Conselho do Ártico foi instituído por meio da Declaração de Ottawa, em 1996 e, embora constituído como fórum para a promoção da cooperação, coordenação e interação entre os Estados e habitantes do Ártico em questões relativas ao desenvolvimento sustentável e proteção ambiental, ele pouco contribuiu para uma regulação específica e universal ${ }^{59}$, servindo basicamente

57 CONFERENCE ON ANTARCTICA. 1959. The Antarctic Treaty System. Whashington: Secretariat of the Antarctic Treaty, 1959. Disponível em: <http://www.ats.aq/e/ats.htm>. Acesso em: 14 jun. 2015.

58 Protocolo de Madri.

59 LENNON, Erika. A tale of two poles: a comparative look at the legal regimes in the Arctic and the Antarctic. Sustainable Develop- 
para a defesa dos interesses dos Estados lindeiros, prevendo a admissão de outros interessados ${ }^{60}$, mas na qualidade de meros observadores, sem direito de voto.

Em 2011, durante Reunião Ministerial do Conselho do Ártico realizada em Nuuk, Canadá, Dinamarca, Finlândia, Islândia, Noruega, Rússia, Suécia e Estados Unidos firmaram o Acordo de Cooperação em Matéria de Aeronáutica e Busca e Salvamento Marítimo no Ártico (Agreement on Cooperation on Aeronautical and Maritime Search and Rescue in the Arctic). Considerado o primeiro instrumento de hard law, ou seja, legalmente obrigatório, entrou em vigor em 2013, estabelecendo, em termos gerais, a cooperação entre os signatários, para monitoramento de acidentes, formação de equipe e estrutura técnica para respostas rápidas nas hipóteses de acidentes ocorridos nos limites de soberania de cada parte.

Em 2013, outro instrumento vinculativo foi firmado durante a Reunião Ministerial realizada em Kiruna, o Acordo de Cooperação em Matéria de Petróleo, Poluição Marinha, Preparação e Resposta no Ártico (Agreement on Cooperation on Marine Oil Pollution Preparedness and Response in the Arctic), cujo objetivo constitui viabilizar a cooperação, coordenação e assistência mútua entre as partes contra poluição marinha por hidrocarbonetos, em razão de incidentes que ocorram ou possam constituir ameaça aos países signatários.

Embora seja possível identificar um interesse dos países lindeiros na prevenção de acidentes ambientais no Ártico, nenhum desses instrumentos jurídicos estabeleceu limitações à sua utilização ou instituiu tutela efetiva e preventiva do meio ambiente. $\mathrm{Na}$ verdade, estabeleceram regras de cooperação para minimizar eventuais impactos que possam ser decorrentes de acidentes ambientais em áreas sujeitas à sua soberania.

Várias outras iniciativas de regulação do Ártico podem ser citadas, como o Conselho Nórdico ${ }^{61}$, o Con-

ment Law \& Policy, Washington, v. 8, n. 3, p. 32-35, 65-66, Spring, 2008.

60 O Brasil e outras potências emergentes, como Índia e China, têm pressionado o Conselho Ártico para serem aceitos como observadores, mas a ideia é rechaçada por alguns dos integrantes, como Canadá e Rússia. MELO, Max Miliano. Brasil busca vaga no Conselho Ártico, mas outros países são contrários. Correio Braziliense, edição de 16 de janeiro de 2012. Disponível em: <http://www.correiobraziliense.com.br/>. Acesso em: 26 abr. 2015.

61 Organização criada pela Dinamarca, Suécia, Noruega e Islândia, em 1952, para cooperação em assuntos de interesse dos países integrantes. A Finlândia foi aceita em 1955. selho Saami ${ }^{62}$, a Conferência Circumpolar Inuit ${ }^{63}$, o Comitê Internacional de Ciência do Ártico ${ }^{64}$ e o Conselho Euro-Ártico do Mar de Barents ${ }^{65}$. Percebe-se a existência de governança ambiental no Ártico, mas infelizmente ainda incapaz de determinar um regime jurídico internacional específico para a região e, nas questões ambientais, a única alternativa consiste em recorrer aos tratados internacionais genéricos.

Nesse particular, a CNUDM dispõe sobre a proteção e preservação do meio ambiente marinho por meio do artigo 192, que estabelece obrigação geral de tutela e do artigo 194, que reforça a proteção, estipulando que os Estados devem tomar as medidas necessárias para tutelar o meio marinho, prevenindo, reduzindo e controlando a poluição, qualquer que seja a sua fonte.

Embora não contenha uma regulação específica para o Ártico, o artigo 234 prevê tutela geral das áreas cobertas de gelo, autorizando os Estados costeiros a regularem individualmente a matéria dentro de seus respectivos limites territoriais, estabelecendo dispositivos legais para prevenção, redução e controle da poluição do meio marinho proveniente de embarcações, desde que não sejam discriminatórios. Ao relegar aos Estados lindeiros as medidas protetivas sobre as áreas cobertas de gelo, a CNUDM incentivou fortemente a prevalência de regimes regionais de gestão $0^{66}$, fracionando e enfraquecendo a tutela do Ártico. Não deu preferência e

62 Conselho criado por grupos étnicos do Ártico (os Saami ou Lapões), para a integração e defesa dos direitos sobre a terra e recursos naturais. SAAMI COUNCIL. The Saami Council. Disponível em: <http:/ / www.saamicouncil.net/?deptid=1116>. Acesso em: 14 jun. 2015.

63 Organização Internacional não Governamental para defesa dos interesses do grupo étnico Inuit, localizada no Canadá. INUIT CIRCUMPOLAR COUNCIL CANADA. Welcome to ICC Canada's. Disponível em: <http://www.inuitcircumpolar.com>. Acesso em: 14 jun. 2015.

64 Organização Internacional não Governamental, que visa apoiar e facilitar a cooperação da investigação no Ártico, com representantes de vários países, inclusive os países Árticos (International Arctic Science Committee). INTERNATIONAL ARCTIC SCIENCE COMMITTEE. Welcome to LASC. Disponível em: <http://www. iasc.info/>. Acesso em: 14 jun. 2015

65 Fórum intergovernamental e inter-regional para cooperação relativa à região de Barents, composto pela Rússia, Dinamarca, Islândia, Noruega, Finlândia, Suécia e a Comissão Europeia (Barents Euro-Arctic Council). BEAC: Barents Euro-Arctic Council. Disponível em: <http://www.beac.st/en>. Acesso em: 15 jun. 2015. 66 STOKKE, Olav Schram. A legal regime for the Arctic? Interplay with the Law of the Sea Convention. Marine Policy, Amsterdam, v. 31, n. 4, p. 409-414, 2007. Disponível em: <http://www.fni.no/ doc\&pdf/oss-mp-2007.pdf>. Acesso em: 22 abr. 2015. 
não considerou os interesses globais ambientais, mas os estritamente unilaterais e por vezes, eminentemente econômicos, dos países costeiros.

No que se refere à Área, o artigo 136 assevera que os recursos minerais sólidos, líquidos ou gasosos localizados naquele local não podem ser apropriados por um só Estado, por constituírem patrimônio comum da humanidade, concluindo-se que os fundos marítimos e oceânicos situados fora dos limites soberanos estatais não são suscetíveis de apropriação individual pelos Estados, sendo acessível, portanto, a todos e reservados para fins e objetivos pacíficos. Os recursos minerais eventualmente encontrados na Área só podem ser explorados no interesse de toda humanidade, considerando-se as necessidades dos países mais necessitados ${ }^{67}$. Disso resulta que nenhum Estado pode se apropriar, reivindicar ou exercer soberania sobre a Área (artigo 137), mas, paradoxalmente, nenhum Estado pode ser privado ou limitado na sua utilização, desde que o faça para fins pacíficos.

Quanto à responsabilidade por poluição ou atividades desenvolvidas na Área, a CNUDM dispõe que os danos causados em razão do não cumprimento pelo Estado-parte ou organização internacional das suas obrigações implicam responsabilidade internacional, admitindo, inclusive, a responsabilização conjunta e solidária dos responsáveis que atuarem conjuntamente (artigo 139). Essa responsabilização, no entanto, pode ser excluída se demonstrado pelo Estado, que embora o dano tenha sido causado por pessoa jurídica por ele patrocinada, foram tomadas todas as medidas necessárias e apropriadas para assegurar o cumprimento das exigências previstas no tratado (artigo 153, parágrafo 4).

Além da CNUDM, outros documentos procuraram tutelar o meio marinho e as atividades no Ártico: a Convenção de Genebra sobre o Alto Mar (firmada em 1958), que visa disciplinar a poluição por óleo e rejeitos radioativos (artigos 24 e 25); a Convenção sobre Prevenção da Poluição Marinha pelo Alijamento de Dejetos e outros Materiais (firmada em 1972) e a Convenção para a Prevenção da Poluição por Navios (firmada em 1973 e conhecida como MARPOL) que visam disciplinar a poluição por outros meios que não óleo; o Acordo sobre a Conservação dos Ursos Polares (firmada em 1973 e conhecida como Tratado Urso Polar), que visa

67 SOARES, Guido Fernando. Curso de direito internacional público. São Paulo: Atlas, 2003. v. 1. tutelar essa espécie habitante do Ártico.

Recentemente, a International Maritime Organization (IMO), agência de navegação marítima da ONU, após dois anos de negociações, aprovou, em 15 de maio de 2015, um conjunto de regras que se aplicam às embarcações marítimas que navegam em águas polares e visam garantir a segurança de passageiros e do próprio staff. Chamado de Código Polar, entrará em vigor em 01 de janeiro de 2017, dispondo, basicamente, sobre a construção das embarcações, os equipamentos de segurança obrigatórios, treinamento de pessoal para as operações de busca e salvamento, exigindo conformidade com as normas da Convenção Internacional para a Salvaguarda da Vida Humana no Mar (SOLAS) e a Convenção Internacional para a Prevenção da Poluição por Navios (MARPOL). Embora reúna alguns dispositivos que se destinam à tutela ambiental, não veda ou limita a navegação comercial e turística pelo Ártico.

Da análise desses documentos internacionais, embora não se possa dizer que a região Ártica seja totalmente desprovida de regulação, não é possível concluir que a tutela ambiental esteja garantida.

Ao contrário da Antártica, no Ártico, a utilização do oceano como rota comercial não foi vedada e sequer se admite possa ser limitada, visto que pela regra geral da CNUDM, o alto mar é aberto à navegação por navios de todas as nações (ficando o navio sujeito às leis do pavilhão da embarcação); as zonas de exploração exclusivas admitem a navegação estrangeira pacífica e, pelas regras locais, cada Estado lindeiro dispõe de soberania sobre o seu mar territorial, podendo utilizá-lo para navegação.

Não há regramento especifico que considere as particularidades da região e limite a exploração comercial ${ }^{68}$. Embora possa ser identificado um regramento internacional ambiental, com certeza é insuficiente para garantir que acidentes não ocorrerão no Ártico, não há como garantir tutela especifica do oceano gelado, principalmente se considerarmos as dificuldades dessa navegação e que os aspectos econômicos que envolvem a questão não se coadunem de forma ética com a tutela ambiental.

68 KOIVUROVA, Timo. Environmental protection in the Artic and Antartic: can the polar regimes learn from each other? International Journal of Legal Information, v. 33, Summer 2005. 


\section{Considerações finais}

A questão do Ártico é multidimensional, passa pela exploração de recursos, segurança, comércio internacional, mudanças climáticas, política externa dos Estados, entre outros. Há, portanto, dinâmica que não pode ser ignorada pelo Direito Internacional e pelas Relações Internacionais.

O controle de corredores marítimos, o domínio tecnológico e os impactos ambientais são fatores estratégicos que não devem ser ignorados pelos principais atores do sistema internacional, que não estão circunscritos aos países circumpolares, uma vez que pretendem compartilhar sua exploração e utilizar livremente suas rotas.

Entretanto, a região Ártica não possui regime jurídico específico e ao longo da história se percebe que os interesses territoriais e econômicos preponderaram sobre a preocupação e tutela ambiental.

O Conselho do Ártico, instituído como fórum de discussão para a promoção da cooperação, coordenação e interação entre os Estados e habitantes do Ártico, embora tenha como norte o desenvolvimento sustentável e proteção ambiental da região, pouco contribuiu para uma regulação específica e universal. Primeiramente porque, embora admita a participação da comunidade internacional, não lhe confere direito a voto, fazendo com que a pauta de discussões, decisões e deliberações fiquem limitadas aos oito países-membros, diretamente interessados na exploração econômica da região.

Além disso, os tratados firmados no âmbito do Conselho, embora tenham evoluído e conferido obrigatoriedade aos signatários, não atribuíram ao meio ambiente a relevância que se esperava.

O advento da CNUDM, embora tenha contribuído para justificar o não reconhecimento das pretensões de domínio por todo o Ártico, não foi capaz de resolver ou solucionar as disputas territoriais e econômicas dos países lindeiros.

Da mesma forma, as normas existentes na CNUDM e demais documentos internacionais não impedem a utilização do Oceano Ártico como rota marítima alternativa, prevendo a responsabilidade por danos ambientais, mecanismo insuficiente para garantir que acidentes não ocorrerão. O regime jurídico do Ártico não impede a utilização de navios quebra-gelo, cujos estudos são incipientes e os riscos às calotas polares e ao entorno da região ainda não foram suficientemente pesquisados e analisados.
A construção de regime jurídico específico e principalmente voltado à preocupação ambiental, como o existente na Antártica e que conte com a participação da comunidade internacional é indispensável e deveria ser repensado, pois não somente a Antártica, mas também o Ártico, são regiões importantíssimas para o controle das mudanças climáticas e para o equilíbrio ambiental do planeta.

O conflito de interesses existente entre os países lindeiros sinaliza que o futuro do Ártico pode não ser tão bonito como as geleiras que lhes são próprias. A busca incessante por uma nova alternativa econômica — o "Eldorado" moderno — pode conduzir a efeitos deletérios de difícil reparação, pois o Ártico não é visto como um ambiente a ser protegido para o bem do mundo, mas apenas como um potencial em recursos naturais escondidos.

Por outro lado, a Antártica, embora diversa em sua composição e estrutura, é um bom exemplo a ser seguido.

Reservar ao Ártico o status de reserva natural, ainda que somente na parte do mare liberum, seria uma opção viável de conservação da região e tutela das calotas polares, que embora afetadas pelo aquecimento global não precisam ser ainda mais castigadas pela ganância humana.

\section{REfERÊNCIAS}

AGUILAR, Sergio Luiz Cruz. Direito do mar, poder naval e relações internacionais: os recentes casos do Ártico e do Mar da China. In: BARBOSA JR., Ilques; MORE, Rodrigo Fernandes. (Org.). Amazônia azul: política, estratégia e direito para o oceano do Brasil. Rio de Janeiro: Femar, 2012. p. 78-99.

APÓS onda de calor e incêndios florestais a Rússia enfrenta a questão climática. Disponível em: <http:/ / www.ecodebate.com.br/2010/08/25/apos-onda-decalor-e-incendios-florestais-a-russia-enfrenta-a-questao-climatica/>. Acesso em: 21 maio 2014.

BEAC: Barents Euro-Arctic Council. Disponível em: <http://www.beac.st/en>. Acesso em: 15 jun. 2015.

BECK, Ulrich; GIDDENS, Anthony; LASCH, Scott. Modernização reflexiva: política, tradição e estética na ordem social moderna. São Paulo: Unesp, 1995.

BORRESEN, Jacob. The great Artic game. Heartland Eurasian Review of Geopolitics, Roma, n. 2, p. 5-77, 2008. 
CONFERENCE ON ANTARCTICA. 1959. The Antarctic Treaty System. Whashington: Secretariat of the Antarctic Treaty, 1959. Disponível em: <http://www.ats. aq/e/ats.htm>. Acesso em: 14 jun. 2015.

GARON, Richard; LASSERRE, Frederic; LE ROY, Jérôme. Is there an arms race in the Artic? Journal of Military and Strategic Studies, Calgary, v. 14, n. 3/4, p. 1-56, Mar. 2012.

GOMIDE, Camilo. Tecnologia: para quebrar o gelo. Revista Planeta, Rio de Janeiro, v. 492, out. de 2013. Disponível em: <http://revistaplaneta.terra.com.br/secao/tecnologia/para-quebrar-o-gelo $>$. Acesso em: 15 jun. 2015.

GONZALEZ, Margarita Yela. Investigación polar española. Revista Ejército, Madrid, n. 793, p. 17-22, 2007. Número extraordinario: Las Fuerzas Armadas en la Antártida.

GOUVEIA, Jorge Bacelar. Manual de direito internacional público. Rio de Janeiro: Renovar, 2005.

INTERNATIONAL ARCTIC SCIENCE COMMITTEE. Welcome to IASC. Disponível em: <http://www. iasc.info/>. Acesso em: 14 jun. 2015.

INTERNATIONAL MARINE ORGANIZATION. Introduction to IMO. Disponível em: <www.imo.org>. Acesso em: 16 abr. 2014.

INTERNATIONAL PERMAFROST ASSOCIATION. What is permafrost? Permafrost Distribution. Disponível em: <http://ipa.arcticportal.org/publications/occasional-publications/what-is-permafrost $>$. Acesso em: 10 abr. 2015.

INUIT CIRCUMPOLAR COUNCIL CANADA. Welcome to ICC Canada's. Disponível em: <http:/ / www.inuitcircumpolar.com>. Acesso em: 14 jun. 2015.

INVERNO rigoroso causa prejuízos e faz vítimas na Europa. Disponível em: <http://g1.globo.com/bomdia-brasil/noticia/2012/12/inverno-rigoroso-causaprejuizos-e-faz-vitimas-na-europa.html $>$. Acesso em: 21 maio 2014.

JOYNER, Christopher C. The legal regime for the Arctic Ocean. Journal of Transnational Law \& Policy, Florida, v. 18, n. 9, p. 195-249, Spring, 2009.

KEFFERPUTZ, Roderick; BOCHKAREV, Danila. Expanding the EU's institutional capacities in the Arctic Region. Berlim: Heinrich Boell Foundation, 2008.
KOIVUROVA, Timo. Environmental protection in the Artic and Antartic: can the polar regimes learn from each other? International Journal of Legal Information, Chicago, v. 33, n. 2, p. 203-208, Summer 2005.

KOPP, Dominique. Guerra Fria sobre o Ártico. Revista Le Monde Diplomatique Brasil, São Paulo, v. 1, n. 2, set. 2007. Disponível em: <http://www.diplomatique.org. br/acervo.php?id=2072\&tipo=acervo $>$. Acesso em: 12 abr. 2014.

LENNON, Erika. A tale of two poles: a comparative look at the legal regimes in the Arctic and the Antarctic. Sustainable Development Law \& Policy, Washington v. 8, n. 3, p. 32-35, 65-66, Spring, 2008.

MARQUES JÚNIOR, José Carlos; MARQUES, Rafael Diogenes. Disputas territoriais no Ártico à luz da Convenção das Nações Unidas sobre o direito do mar de 1982. Revista Geopolítica, Ponta Grossa, v. 3, n. 02, p. 139-152, jul. 2012. Disponível em: <http://www.revistageopolitica.com.br/ojs/ojs-2.2.3/index.php/rg/ oai>. Acesso em: 22 abr. 2014.

MATTOS, Adherbal Meira. Direito internacional público. 2. ed. Rio de Janeiro: Renovar, 2002.

MELLO, Celso de Albuquerque. Curso de direito internacional público. 14. ed. Rio de Janeiro: Renovar, 2002.

MELO, Max Miliano. Brasil busca vaga no Conselho Ártico, mas outros países são contrários. Correio Braziliense, edição de 16 de janeiro de 2012. Disponível em: $<$ http://www.correiobraziliense.com.br/>. Acesso em: 26 abr. 2015.

NOWLAN, Linda. Artic legal regime for environmental protection. Gland: IUCN, 2001.

ORGANIZAÇÃO DAS NAÇÕES UNIDAS. Resolução da Assembleia da República n. ${ }^{\circ}$ 60-B/97. Convenção das Nações Unidas sobre o Direito do Mar e o Acordo Relativo à Aplicação da Parte XI da mesma Convenção. Disponível em: <http://www.gddc.pt/siii/docs/ rar60B-1997.pdf>. Acesso em: 22 abr. 2015.

O'ROURKE, Ronald. Changes in the Artic: background and issues for congress. 2014. Disponível em: <https:/ / www.fas.org/sgp/crs/misc/R41153.pdf>. Acesso em: 21 maio 2014.

PRESSE, France. Petroleiro encalhado no Ártico canadense volta à rota. Disponível em: <http://g1.globo.com/mundo/noticia/2010/09/petroleiro-encalhado-no-articocanadense-volta-a-rota.html>. Acesso em: 15 jun. 2015. 
SAAMI COUNCIL. The Saami Council. Disponível em: $<$ http:/ / www.saamicouncil.net/?deptid=1116>. Acesso em: 14 jun. 2015.

SCIENCE FOR A CHANGING WORLD. US Geological Survey. Disponível em: <www.usgs.gov>. Acesso em: 11 jun. 2015.

SILVA, G. E. do Nascimento; ACCIOLY, Hildebrando. Manual de direito internacional público. São Paulo: Saraiva, 2002.

SILVA, Marcos V. M. O oceano Ártico: oportunidades da nova fonteira marítima. Revista Antiteses, Londrina, v. 7, n. 13, p. 228-253, 2014.

SIMIELLI, Maria Elena. Geoatlas. São Paulo: Ática, 2011.

SMITH, Laurence C.; STEPHENSON, Scott R. New Trans-Artic shipping routes navigable by midcen- tury. Disponível em: <http://www.pnas.org/content/110/13/E1191.full>. Acesso em: 23 abr. 2015.

SOARES, Guido Fernando. Curso de direito internacional público. São Paulo: Atlas, 2003. v. 1.

STOKKE, Olav Schram. A legal regime for the Arctic? Interplay with the Law of the Sea Convention. Marine Policy, Amsterdam, v. 31, n. 4, p. 409-414, 2007. Disponível em: <http://www.fni.no/doc\&pdf/ossmp-2007.pdf>. Acesso em: 22 abr. 2015.

VIOLA, Eduardo José. Perspectivas da governança e segurança climática global. Revista Plenarium, Brasília, v. 5, n. 5, p. 173-196, 2008.

WORLD METEOROLOGICAL ORGANIZATION. Intergovernmental panel on climate change: fifth assessment report (AR5). Disponível em: <http://www.ipcc.ch/>. Acesso em: 10 maio 2014. 


\section{Instrumentos Públicos e Privados para a reparação do dano ambiental causado por derramamento de óleo no mar sem origem definida: as manchas órfãs*}

Renata Brockelt Giacomitti**

Katya R. Isaguirre-Torres ${ }^{* * *}$

\section{Resumo}

O objetivo do presente trabalho é analisar os mecanismos utilizados para a reparação do dano ambiental nos casos de derramamento de óleo sem origem definida, comumente conhecido como "manchas órfãs". Sua ocorrência no ambiente marinho é relevante e a problemática desafia o jurista a buscar soluções por meio dos instrumentos públicos e privados que são utilizados no âmbito nacional e internacional para implementar o direito do mar e o direito marítimo. Para isso, valendo-se da revisão bibliográfica e da observação participante, o artigo analisa os direitos e deveres de fiscalização e controle, assim como a responsabilidade decorrente das elaborações dos planos de contingência, de área e de emergência individual. Em seguida observou-se a legislação nacional sobre o tema e concluiu-se que o atual sistema de responsabilidade não é suficiente para solucionar a questão, justificando o apoio na legislação internacional que busca resolver o tema, em especial a Convenção de Lugano. Por fim, concluiu-se que a mescla de mecanismos públicos e privados, como o Seguro para Riscos Ambientais e os Fundos Ecológicos, pode contribuir para a eficiência na gestão e reparação do dano decorrente da poluição por óleo sem origem definida. A complexidade do ambiente marinho traz uma importante limitação para a teoria da responsabilidade civil ambiental e o caso das manchas órfãs é um exemplo que retrata a especificidade do ambiente marinho e justifica a relevância dessa discussão para a busca de eficiência na gestão marítima por meio da interação entre agentes públicos e privados como preconiza a constituição.

Palavras-chave: Dano ambiental. Manchas órfãs. Responsabilidade. Fundos ecológicos.

\section{Abstract}

The aim of this study is to analyze the mechanisms used for the repair of environmental damage in case of oil spill without defined origin, commonly known as "orphan spots". Their occurrence in the marine environment is 
relevant and problematic challenges the lawyer to seek solutions through public and private instruments that are used in the national and international levels to implement the law of the sea and maritime law. Making use of literature review and participant observation, the article analyzes the rights and duties of supervision and control, as well as the liability of elaboration of contingency plans, area plans and individual emergency plans. Then there was the brazilian national legislation on the subject and found that the current accountability system is not enough to resolve the issue, justifying support in international law that seeks to address the issue, particularly the Lugano Convention. Finally, it was concluded that a mix of public and private mechanisms, such as insurance for Environmental Risk and the Ecological Funds can contribute to the efficient management and repair of damage resulting from oil pollution without defined origin. The complexity of the marine environment brings an important limitation to the theory of environmental responsibility and the case of orphan spots is an example that depicts the specificity of the marine environment and justifies the relevance of this discussion to the pursuit of efficiency in maritime management through interaction between public and private actors as recommended by the Brazilian Constitution.

Keywords: Environmental damage. Orphaned spots. Responsibility. Ecological funds.

\section{INTRODUÇão}

Cobrindo quase $70 \%$ da superfície terrestres, as zonas costeiras e marítimas são responsáveis por grande parte das trocas comerciais ocorridas. Atualmente, pelos mares circulam aproximadamente 50 mil navios de porte oceânico que transportam $80 \%$ do comércio mundial. $\mathrm{O}$ aumento do número de embarcações circulando pelos oceanos acarreta um acréscimo do número de incidentes marítimos cujas consequências têm sido prejudiciais ao ambiente marinho ${ }^{1}$. Por se tratar de um problema que desconhece fronteiras jurídico-políticas, esse tipo de poluição tem preocupado a comunidade mundial nas últimas décadas, culminando, em 1954, na primeira Convenção Internacional para a prevenção da

1 Cf. ZANELla, Tiago Vinicius. Agua de lastro: um problema global. Curitiba: Juruá, 2010. poluição do mar por óleo. De lá para cá, foram vários os instrumentos criados nesse mesmo escopo.

Em um derramamento de óleo dito "comum", é possível que seja estabelecido o local de origem do óleo e, por consequência, o nexo de causalidade entre o evento e o dano, de forma que se impute ao sujeito causador do dano ambiental o dever de repará-lo. O caso do derramamento de óleo sem origem definida, comumente conhecido como manchas órfãs, tem preocupado a comunidade marítima por que esse tipo de poluição torna muito difícil determinar a fonte poluidora, seja por que tais manchas se deslocam pelo movimento das marés, seja pela sua localização se situar em rotas nas quais transitam diversas embarcações.

No Brasil não existem levantamentos nacionais e/ ou regionais que tragam dados unificados da ocorrência dessas manchas órfãs. Isso por que todo o sistema fiscalizatório brasileiro se encontra em fase de integração, dependendo da implementação dos Planos de Área (PA) regionais, como se explicará adiante.

Ao detectar uma mancha órfã, os órgãos ambientais integrantes do Sistema Nacional de Meio Ambiente (SISNAMA), designados para as atividades de fiscalização, bem como os agentes da Autoridade Marítima local (Lei no 9.605/1998, art. 70) possuem o dever legal de lavrar o auto de infração ambiental e instaurar o competente processo administrativo. Contudo, os órgãos responsáveis, muitas vezes, optam tão somente por comunicar à Autoridade Portuária sobre o incidente (responsável pelo Plano de Área), de modo que ocorra a contenção e a limpeza da área afetada, não lavrando o competente auto de infração tampouco instaurando o respectivo inquérito administrativo, justamente pela impossibilidade de imputação de responsabilidade a um sujeito poluidor, visto que indefinido ${ }^{2}$.

2 Durante a elaboração da pesquisa acadêmica da primeira autora, verificou-se a inexistência de um banco de danos a nível nacional. A Diretoria de Portos e Costas, por meio do ofício no 50-33/DPC-MB, apresentou relação, de 2007 ao início de 2014, de todas as descargas ocorridas em âmbito nacional em que havia suspeita de derramamento de óleo oriundo de embarcações e, após investigação, não foi possível a identificação de seus autores. "Contudo, após indagar ao setor responsável por esse tipo de investigação, de abrangência local (Capitania dos Portos do Paraná - Departamento de Segurança do Tráfego Aquaviário, Divisão de Inspeção Naval), fui informada de que as informações repassadas para a DPC somente ocorrem nos casos de derramamento de óleo quando é possível efetuar a coleta de material e quando existe suspeita de que o responsável seja determinada (ou determinadas) embarcações. Nos casos em que apenas se verifica uma mancha de óleo, mas não são vislumbrados 
Dessa forma, os custos de reparação do meio ambiente, conforme se verá na sequência, devem ser arcados pelo Poder Executivo Federal (Decreto $\mathrm{n}^{\circ}$ $8.127 / 2013$, artigo $27, \mathbb{\int} 2^{\circ}$ ). Para evitar a imposição desse custo ambiental ao Estado, é preciso avaliar quais os instrumentos públicos e privados que podem ser aplicados ao caso a fim de buscar soluções economicamente equilibradas e socialmente justas, sem que tais custos recaiam sobre o Estado, o que onera indiretamente toda a sociedade.

A problemática envolvendo as manchas órfãs atualmente permanece vinculada ao âmbito do poder de polícia da Administração Pública. Essa discussão não ocorre no âmbito do poder judiciário, não existindo ações que examinem o caso nos tribunais e, desse modo, não há jurisprudência específica sobre o tema; e isso se dá por duas condições. A primeira decorre do sistema de monitoramento e controle do ambiente marinho, o qual ainda se encontra em fase de implementação e integração no Brasil. A segunda surge do sistema de responsabilidade que, mesmo nos casos em que a responsabilidade é objetiva, como a ambiental, exige a determinação do nexo causal ligando autor e danos. No entanto, é extremamente relevante avaliar de que maneira o sistema jurídico pode apresentar respostas a fim de evitar que os custos da reparação recaiam unicamente à União. Isso porque, como preconiza a legislação ambiental, todos os agentes poluidores, sejam essas pessoas de direito público ou privado, deverão assumir as consequências administrativas, civis e penais voltadas à recuperação da área degradada e, quando isso não for possível, serão responsabilizados a ressarcir a sociedade pelo quantum indenizatório equivalente à degradação de um direito que a Constituição da República reconhece como sendo de caráter fundamental.

O sistema jurídico traz instrumentos públicos de controle do ambiente marinho, por meio de uma rede de planos de zoneamento de âmbito regional e nacio-

responsáveis (manchas órfãs), não é realizado nenhum tipo de registro formal do incidente". (GIACOMITTI, Renata Brockelt. Derramamento por óleo no mar por manchas órfãs e a responsabilidade por dano socioambiental. 2014. 123 f. Dissertação (Mestrado) - Programa de Pós-Graduação em Meio Ambiente e Desenvolvimento, Universidade Federal do Paraná, Curitiba, 2014). Ademais, na mesma pesquisa acadêmica, demonstrou-se que o Instituto Brasileiro do Meio Ambiente (IBAMA) não possui registro nacional; que a Agência Nacional do Petróleo (ANP) identificou onze ocorrências de manchas órfãs, no período de março de 2012 até março de 2014; e que o Instituto Estadual do Ambiente (INEA) identificou 89 ocorrências entre 1983 e FEV2014, apenas para citar alguns dados. nal, os quais são exigidos pelo Estado de todos os empreendedores que exploram atividades ligadas ao uso econômico dos oceanos. Além destes, o artigo procura avaliar em que medida os instrumentos privados de coletivização da responsabilidade, que surgem no Pós Revolução Industrial e que comumente já são utilizados no sistema de seguros obrigatórios, podem contribuir para uma maior eficiência do controle da poluição no mar. Os seguros ambientais e os fundos ecológicos, desse modo, são avaliados neste artigo como instrumentos úteis para a recuperação das áreas degradadas nos casos das manchas órfãs ${ }^{3}$.

\section{Poluição por derRamamento de Óleo no AMBIENTE MARINHO: ASPECTOS GERAIS}

Buscando compreender o panorama jurídico afeto ao meio ambiente marinho, antes de abordar os instrumentos públicos e privados para reparação do dano ambiental, faz-se necessário apontar as competências fiscalizatórias, bem como demonstrar a dificuldade na caracterização das manchas órfãs.

\subsection{A Competência para fins de fiscalização do dano ambiental no ambiente marinho}

Quando da ocorrência de um dano ambiental, a primeira questão passa por determinar a competência do ente federativo encarregado da fiscalização. A competência para proteção do meio ambiente é comum para a União, os Estados, o Distrito Federal e os Municípios, conforme o art. 23, inciso VI, da CF/88. A Lei Complementar no 140/2011, ao regulamentar a divisão de competências previstas no art. $23 \mathrm{da} \mathrm{CF} / 88$, estabelece que, nos casos que envolvam licenciamentos na zona costeira, uma Comissão Tripartite Nacional formulará as bases para determinação do ente licenciador conforme os critérios de porte, potencial poluidor e natureza da atividade ou empreendimento. Recentemente o Decre-

3 Nota das autoras: quanto à metodologia, por meio da revisão bibliográfica se buscou a análise doutrinária e normativa voltadas à proteção do ambiente marinho, com foco na poluição marinha por derramamento de óleo sem origem definida. Considera-se também o acúmulo de conhecimentos práticos da primeira autora, enquanto Assessora Jurídica em unidade da Marinha do Brasil, desde 2008, a qual desenvolveu esse trabalho sob o apoio da metodologia da observação participante durante seus estudos para elaboração da dissertação de mestrado, sob orientação da segunda autora. 
to de $\mathrm{n}^{\circ} 8.437$, de 22 de abril de 2015, detalha os casos de licenciamento que ficam sob a responsabilidade do governo federal e, no seu artigo $3^{\circ}$, inciso VII, destaca a responsabilidade da União para os casos de petróleo e outros hidrocarbonetos fluidos no ambiente marinho e em zonas de transição terra-mar (off-shore $)^{4}$.

A fiscalização e controle, portanto, cabe ao órgão federal, recordando-se que o artigo 20, incisos V e VI, da $\mathrm{CF} / 88$ insere o mar territorial e os recursos naturais da zona econômica exclusiva e da plataforma continental como bens da União. A União poderá, também, pela responsabilidade que possui na definição do Plano Nacional de Gerenciamento Costeiro (Lei de $n^{\circ} 7.661 / 88$, complementada pelos Decretos de $\mathrm{n}^{\mathrm{o}} 5.300 / 2004$ e $5.377 / 2005)$, demandar pela corresponsabilidade dos Estados e Municípios que se situem na costa brasileira, os quais, por sua vez, devem elaborar seu Planos regionais e locais. Em resumo, o gerenciamento costeiro, no Brasil, é capitaneado pela União Federal e seu controle é exercido por meio de uma rede de entes federativos os quais, em conjunto, devem pautar suas ações na busca da eficiência na prevenção e reparação do dano.

Inicialmente, é importante destacar que o Brasil é signatário da Convenção Internacional sobre Preparo, Resposta e Cooperação em Caso de Poluição por Óleo (OPRC/90), a qual integra o sistema jurídico pátrio por intermédio do Decreto de no 2.870/1998. Essa Convenção determinou a obrigatoriedade de criação de um Sistema nacional para incidentes de poluição por óleo, sistema implementado pela Lei de $n^{\circ} 9.966 / 2000$. Mais especificamente para o controle da poluição por derramamento de óleo e substâncias derivadas no ambiente aquático, a Lei de $n^{\circ} 9.966 / 2000$ cria um dever para toda a sociedade de informar imediatamente ao órgão ambiental competente, a Capitania dos Portos (agente da Autoridade Marítima), e a Agência Nacional do Petróleo qualquer incidente que possa gerar dano ou ameaça de danos às águas sob jurisdição nacional.

Paralelo ao dever de informação, o artigo $\mathrm{n}^{\circ} 27 \mathrm{da}$ Lei de $n^{\circ} 9.966 / 2000$ estabelece os deveres de fiscalização e controle, e as respectivas atribuições dos órgãos ambientais federal (IBAMA), estaduais e municipais, da

4 Sobre o tema, sugere-se a leitura de interessante artigo: In Varella, Marcelo D. A necessidade de repensar os mecanismos de responsabilidade ambiental em caso de riscos de vazamento de petróleo em alto-mar no Brasil. Revista de Direito Internacional, vol.12, no.1. (nesta edição) agência reguladora (ANP) e da Autoridade Marítima, definindo, assim, os contornos do que poderia ser identificado como um microssistema jurídico para a poluição por óleo em águas sob jurisdição nacional.

\subsection{A difícil caracterização do dano ambiental por ocorrência das manchas órfãs}

A teoria da responsabilidade objetiva surge para apresentar respostas às mudanças sociais, uma vez que, em situações como as originadas pelo dano ambiental, resta impossível ou muito difícil a caracterização da responsabilidade pelo clássico sistema da culpabilidade. Como evidencia José Rubens Morato Leite e Melissa Ely Mello a objetividade da responsabilidade pelo dano ambiental, seja essa determinada pela teoria do risco integral ou pelo risco da atividade ${ }^{5}$, é apontada como uma boa resposta do sistema jurídico ao dano ambiental, porém, sua determinação acarreta desafios, tal como no caso das manchas órfãs ${ }^{6}$, visto a natureza do fato e, como consequência, a impossibilidade de demonstração da existência do nexo de causalidade entre o sujeito causador do dano (que é desconhecido) e o dano propriamente dito.

Tais dificuldades se ligam ao que Antônio H. Benjamin identifica como "estrutura quadrangular dano-nexo-causal-causador-vítima"”, restando localizadas na

5 Nota das autoras: o tema da responsabilidade ambiental pelo risco integral ou risco criado exige um aprofundamento que foge aos objetivos do presente estudo, que se concentra na avaliação dos instrumentos específicos para a poluição por óleo. Todavia, observamos que há certa divergência no tocante a considerar se a responsabilidade surge pelo proveito que surge da exploração de determinada atividade econômica ou se o dever subsiste integralmente, sem aplicação das excludentes de responsabilidade. A jurisprudência tem se manifestado pela adoção do risco integral em termos de reparação/ prevenção/precaução do dano ambiental.

6 "A substituição progressiva da responsabilidade tradicional para a responsabilidade objetiva traz consigo um evidente resultado de facilitar a proteção dos prejudicados. A objetivação da responsabilidade representa certamente um avanço, exime o prejudicado da prova da culpa, mas não é suficiente para deixar este em situação totalmente satisfatória, considerando que ele, com vista à imputação da responsabilidade, deverá evidenciar o penoso liame de causalidade entre o fato e a lesão". LEITE, José Rubens Morato; MELO, Melissa Ely. As funções preventivas e precaucionais da responsabilidade civil por danos ambientais. Sequência: Estudos Jurídicos e Políticos, Florianópolis, v. 28, n. 55, p. 195-218, jan. 2007. Disponível em: <https://periodicos.ufsc.br/index.php/sequencia/ article/view/15053>. Acesso em: 13 jun. 2015. doi:http://dx.doi. org $/ 10.5007 / 15053$.

7 BENJAMIN, Antônio Herman de Vasconcellos. Responsabilidade civil pelo dano ambiental. Revista de Direito Ambienta, São Paulo, 
determinação do ônus probatório ${ }^{8}$. O dano ambiental normalmente é produto de diferentes ações, ou seja, a multicausalidade das fontes de poluição representa real obstáculo para que o processamento da responsabilidade atinja o real poluidor. Cabe acrescentar, ainda, que os efeitos da poluição podem se revelar imediatamente ou podem se projetar no futuro, situação que desafia a caracterização do dano, bem como de suas vítimas. Dessa feita, percebe-se que, ainda que se tenham produzidos avanços como o princípio da proteção integral, a inclusão da responsabilidade por danos ambientais futuros (com base no artigo n 187 do Código Civil) e a responsabilidade vinculada ao risco abstrato ou incerto, a dificuldade probatória remanesce como um dos pontos que necessita ser repensado com a máxima urgência para a concretização do direito fundamental ao meio ambiente.

No caso da poluição do ambiente marinho por manchas órfãs, tais obstáculos são reforçados pela complexidade inerente ao ambiente de estudo, em especial para a determinação do nexo causal e da dimensão do dano,

v. 3, n. 9, p. 5-52, jan./mar. 1998. p. 11.

8 A jurisprudência pátria ressalta a essencialidade do nexo de causalidade em inúmeros julgados, tais como em casos de usos passados e ocupação de áreas de restinga, (BRASIL. Tribunal Regional Federal (4. Região). Apelação/Reexame Necessário. APL n. 5004877-63.2012.4.04.7101. Terceira Turma. Apelante: Ministério Público Federal. Apelado: Luiz Hidalgo dos Santos. Relator: Des. Federal Fernando Quadros da Silva. Porto Alegre, 31 de julho de 2014. Disponível em: <http://www2.trf4.jus.br/ trf4/controlador.php?acao=consulta_processual_resultado_ pesquisa\&txtValor $=5004877-63.2012 .404 .7101 \&$ selOrigem $=R$ S\&chkMostrarBaixados $=1 \&$ selForma $=$ NU\&hdnRefId $=$ \&txtP alavraGerada=> . Acesso em: 05 ago. 2015.); ou em casos de responsabilidade omissiva/comissiva de poluição por óleo; (BRASIL. Tribunal BRASIL. Tribunal Regional Federal (4. Região). Apelação Cível. AC 5001112-21.2011.404.7101. Quarta Turma. Apelante: Ministério Publico Federal; PETROBRAS Transporte S.A./TRANSPETRO. Apelado: Os mesmos. Relator: Des. Federal. Vivian Josete Pantaleão Caminha. Porto Alegre, 06 de agosto de 2014. Disponível em: <http://www2.trf4.jus.br/trf4/controlador. php?acao=consulta_processual_resultado_pesquisa\&selForma $=\mathrm{N}$ U\&txtValor $=50011122120114047101 \&$ selOrigem $=$ TRF $\&$ chkMos trarBaixados=1>. Acesso em: 05 ago. 2015); ou na determinação da responsabilidade penal ambiental (BRASIL. Tribunal Regional Federal (4. Região). Apelação Criminal. ACR 2007.72.08.0023280. Oitava Turma. Apelante: Ministério Publico Federal. Apelado: Carlos Rogerio Gonçalves; Jaco Moacir Schreiner Maran. Relator: Juiz Federal. João Pedro Gebran Neto. Porto Alegre, 02 de julho de 2014. Disponível em: <http://www2.trf4.jus.br/trf4/controlador. php?acao $=$ consulta_processual_resultado_pesquisa\&selForma $=\mathrm{N}$ U\&txtValor $=200772080023280 \&$ chkMostrarBaixados $=$ S\&selOrige $\mathrm{m}=$ TRF \&hdnRefId $=40 \mathrm{ae} 18317 \mathrm{da} 53 \mathrm{f} 4 \mathrm{bbda} 15 \mathrm{a} 58 \mathrm{abca} 7 \mathrm{afc} \& \mathrm{txtPala}$ vraGerada=ajoK $>$. Acesso em: 05 ago. 2015). Íntegra dos julgados disponíveis em: www.trf4.gov.br . pois a poluição se desloca com o movimento das marés. Assim, o estudo desse tipo de poluição exige compreender os fluxos de marés, as inter-relações entre espécies e os modelos de uso e apropriação dos recursos naturais pelos diferentes países do globo. Soma-se a isso a ausência de fronteiras bem definidas, quando em comparação com os limites territoriais, que tornam os mares e oceanos verdadeiras áreas de atuação compartilhada, ainda que sejam passíveis de limitações atinentes à soberania. Para isso, a busca de qualidade ambiental dos oceanos e mares exige ações integradas, locais e globais, para a eficiência no combate das diferentes formas de poluição que causem a degradação das águas e das espécies; comprovando o que afirma Vasco Pereira da Silva, que reconhece a multilaterais das relações jurídicas ambientais, isso por que elas "não têm apenas como sujeitos a administração e o poluidor (potencial ou efetivo) mas também a vítima da poluição"”.

Outro aspecto a ser abordado nas manchas órfãs é o da multiplicidade das vítimas, que podem ser aquelas diretamente atingidas ou ainda, quando considerado o caráter difuso do direito fundamental ao meio ambiente, toda a sociedade. Soma-se a dificuldade de apontar o real causador do dano, pois um foco de poluição dispersa no meio líquido pode ser resultado de uma ou de inúmeras operações diferentes, isto é, uma macha de óleo no oceano pode ser resultado de uma ou de várias instalações e/ou embarcações.

O que se busca nesta investigação é, portanto, demonstrar os instrumentos públicos e privados existentes para a reparação do dano ambiental marinho ocasionado por derramamento de óleo, por manchas órfãs, efetuando uma análise crítica do Decreto $n^{\circ} 8.127 / 2013$ que introduz na legislação marinha a necessidade de zoneamentos integrados para o devido controle da poluição.

\section{INSTRUMENTOS PÚBLICOS PARA A REPARAÇÃO POR DANO AMBIENTAL CAUSADO POR MANCHAS ÓRFÃS}

Além das medidas administrativas e judiciais, o Sistema Nacional do Meio Ambiente (SISNAMA) prevê uma série de instrumentos para prevenção e controle

9 SILVA, Vasco Pereira da. Verde cor de direito: lições de direito do ambiente. Coimbra: Almedina, 2002. p. 34. 
do dano ambiental. Dentre eles, para o objetivo específico da análise proposta neste artigo, se destaca o zoneamento ambiental, previsto no art. $9^{\circ}$, incisos II da Lei $n^{\circ}$ 6938/81. O zoneamento é um instrumento para a gestão ambiental, caracterizado por mapeamentos que busquem equilibrar os diferentes usos dos recursos naturais pelos grupos sociais. A realização desse zoneamento deve ser coordenada pelo Estado, ao qual cabe estabelecer mecanismos e instrumentos que garantam o equilíbrio entre preservação e uso econômico dos recursos naturais.

\subsection{O dever imposto pelo Estado na coletivização da responsabilidade na preservação do meio ambiente marinho}

A definição de responsabilidade indireta surge da interpretação constitucional do art. 225 da CF/ 88 porque a consagração do meio ambiente ecologicamente equilibrado como um direito fundamental de caráter difuso traz ínsita uma ordem de deveres que se inserem não só para a Administração Pública como também aos particulares. Indiretamente responsáveis serão aqueles sujeitos de direito privado que, para além da responsabilidade administrativa, assumem deveres para com o meio ambiente pelo uso do recurso natural, ou ainda pelo desempenho de atividades econômicas, interpretação que se extrai da análise constitucional conjugada com a Lei de $n^{\circ}$ 6.938/1981, a qual reconhece os princípios ambientais de prevenção-precaução-reparação e do poluidor-pagador, dentre outros.

Assim, a Lei de ${ }^{\circ} 9.966 / 2000$, em seu artigo $2^{\circ}$, inciso XXIII, define a Autoridade Portuária como sendo responsável pela administração do porto organizado, sendo de sua competência fiscalizar as operações portuárias e zelar para que os serviços se realizem com regularidade, eficiência, segurança e respeito ao meio ambiente.

As pessoas físicas ou jurídicas que trabalham diretamente com as embarcações também têm atribuições de responsabilidade de diferentes ordens, tais como o dever de informar os casos de poluição no ambiente marinho. Assim, o proprietário ou o armador detém, por sua vez, deveres de cooperação para a busca da qualidade do ambiente marinho. Apenas para esclarecer a figura do armador não necessariamente será coincidente com a figura do proprietário, podendo ser o responsável pela condução da atividade econômica do transporte marí- timo. Além do proprietário e do armador, os agentes marítimos, prepostos ou auxiliares dos transportes marítimos também assumem deveres de cooperação ambiental e realizam a fiscalização informal das atividades que ocorrem no litoral dos estados (especialmente dentro do mar territorial e zona econômica exclusiva). O Decreto de $\mathrm{n}^{\circ}$ 8.127/2013 reconhece a responsabilidade indireta dos agentes privados, posto que, no artigo 14 , responsabiliza o comandante do navio, seu representante legal, ou o responsável pela operação, independentemente das medidas tomadas para controle do incidente, em comunicar imediatamente aos órgãos competentes a ocorrência de poluição por óleo em águas sob jurisdição nacional. O mecanismo de fiscalização e controle público, portanto, tem em si o dever de coordenar as ações de todos aqueles que se valem da exploração do ambiente marinho para fins comerciais e não comerciais.

\subsection{Os diferentes níveis do sistema público de fiscalização: Os Planos de Área, de Contingência e de Emergência Individual e sua eficiência no controle das manchas órfãs}

Os sistemas de fiscalização e controle exigem, de acordo com a Lei $n^{\circ} 9.966 / 2000$, zoneamento multiescalar para o combate da poluição por óleo. Seus componentes são: o Plano Nacional de Contingência, os Planos de Área e os Planos de Emergência Individual. Tais documentos têm por objetivo organizar o monitoramento e a prevenção dos danos e os requisitos para elaboração de cada um deles são estabelecidos pelo Decreto de $n^{\circ}$ $4.871 / 2003$, recentemente alterado pelo Decreto de $n^{\circ}$ $8.127 / 2013$. Vistos no conjunto esses documentos integram um sistema de controle de três níveis de atuação.

O Plano de Emergência Individual (PEI) é o documento que deve ser elaborado por portos organizados, instalações portuárias, terminais, dutos, sondas terrestres, plataformas e suas instalações de apoio, refinarias, estaleiros, marinas, clubes náuticos e instalações similares. Esse documento sistematiza os procedimentos de resposta no caso de incidência de poluição por óleo em águas jurisdicionais brasileiras e é condição para o licenciamento dessas atividades. Conforme já previa o art. $4^{\circ}$ da Resolução de no 398/2008, do Conselho Nacional do Meio Ambiente (CONAMA), esse plano deve prever procedimentos que garantam uma atuação rápida e eficaz nos casos de poluição por óleo. Sua concepção é a de que, ao implantar um PEI, a atividade empresa- 
rial deve ser capaz de responder, de forma satisfatória, quando a ocorrência de derramamento de óleo é identificada. Portanto, será o PEI a ferramenta de primeiro nível para atuação nos casos de poluição por óleo.

O Plano de Área (PA), por sua vez, é um documento que formaliza a criação de um acordo de cooperação entre as instituições (públicas e privadas) que atuam em uma mesma região, por isso exige a integração dos Planos de Emergência Individuais. Esse documento procura retratar informações cartográficas, de sensibilidade ambiental e de diferentes aspectos, a fim de possibilitar uma visão macroespacial que permita o monitoramento dos impactos ambientais e as diferentes estratégias de prevenção. A responsabilidade pela elaboração do PA é das Autoridades Portuárias locais e das entidades exploradoras de plataformas de petróleo e respectivas instalações de apoio, sob a coordenação do órgão ambiental competente, conforme determinação legal (Decreto de $\mathrm{n}^{\circ} 4.871 / 2003$, artigo $3^{\circ}$ ). O PA corresponde ao segundo nível de controle da poluição por óleo.

É exatamente nos Planos de Área que há a primeira referência na legislação nacional dos casos de poluição por "manchas órfãs". O artigo $4^{\circ}$, inciso V, do Decreto $\mathrm{n}^{\circ} 4.871 / 2003$ recebeu uma alteração por meio do Decreto $n^{\circ} 8.127 / 2013$, estabelecendo dentre os requisitos obrigatórios do Plano de Área a "identificação dos critérios para a disponibilização e reposição ou ressarcimento dos recursos" previstos nos PEI e PA previstos para casos de poluição por óleo de origem desconhecida.

Essa previsão identifica a obrigatoriedade de dimensionar os custos financeiros e operacionais que serão alocados para a recuperação ambiental em casos dessa natureza. Em casos de ser detectada a poluição por manchas órfãs quaisquer pessoas jurídicas de direito público e privado da área de abrangência podem acionar o mecanismo previsto no $\mathrm{PA}^{10}$ para dar início a reparação ou ressarcimento do dano causado.

10 Nota das autoras: o Estado do Paraná está em fase de elaboração do seu Plano de Área, o qual conta com a presença de sete integrantes: Administração dos Portos de Paranaguá e Antonina (APPA); Petrobrás Transporte S.A. (TRANSPETRO); Terminais de Contêineres de Paranaguá S.A (TCP); Cattalini Terminais Marítimos Ltda.; União Volpak Brasterminais Armazéns Gerais Ltda.; FOSPAR S.A.; e Terminal da Ponta do Felix. Estas últimas quatro empresas elaboraram um plano de cooperação protocolado no órgão ambiental (IAP) no ano de 2013, porém, por não se tratar do Plano de Área propriamente dito, não há obrigatoriedade de inclusão do caso das manchas órfãs.
Dessa forma, a intenção do Decreto parece ser a de dividir os custos de reparação do dano ambiental provocado pelas manchas órfãs dentre todos aqueles que se utilizam do mar para sua operação econômica e que se enquadrem no conceito de "instalação" portuária (definição essa prevista no art. $2^{\circ}, \mathrm{V}$, do Decreto $\left.n^{\circ} 8.127 / 2013\right)$. Porém, o Decreto não detalha quais seriam os instrumentos econômicos que poderiam ser utilizados para esse fim, tampouco como se dará a sua instituição, fazendo surgir uma dúvida acerca de como será organizado o sistema de reparação para os casos de manchas órfãs. Porém, ao instalar a obrigatoriedade dentre todos os que se encontrem na área de abrangência do PA, resta claro que a sua natureza jurídica é típica das operações consorciadas público-privadas.

O Plano Nacional de Contingência, por sua vez, foi instituído pelo Decreto de $n^{\circ} 8.127 / 2013$ e tem como objetivo a coordenação de diferentes órgãos e instituições da administração pública federal junto a entidades privadas para o desenvolvimento de diretrizes, estratégias e ações voltadas a prevenir os casos de poluição por óleo. A estrutura organizacional do Plano Nacional de Contingência (PNC) insere o Ministério do Meio Ambiente como autoridade superior e lhe confere a competência de coordenar e articular os órgãos do Sistema Nacional do Meio Ambiente (SISNAMA) para apoiar as ações previstas e desenvolvidas, respectivamente, pelo Comitê Executor, o Grupo de Acompanhamento e Avaliação e o Comitê de Suporte. A competência de cada integrante dessa estrutura organizacional é detalhada no capítulo II do citado Decreto.

O acionamento do Plano Nacional de Contingência, admitido neste estudo como o terceiro nível de controle da Poluição por Óleo, pode ocorrer pelo comandante do navio, seu representante legal, ou o responsável pela operação de uma instalação sempre que detectada qualquer caso de poluição por óleo em que tenham sidos ineficazes a atuação tanto do poluidor, quanto do Plano de Área, conforme análise do artigo 18 do Decreto $n^{\circ}$ $8127 / 2013$.

O grupo de acompanhamento e avaliação detém a responsabilidade de qualificar se o incidente terá ou não abrangência nacional, sendo um dos critérios estabelecidos pelo artigo 17, a necessidade de identificação se o acidente ocorre dentro ou fora do espaço delimitado nos Planos de Área, o que é importante para determinação do local que suportará o ônus da reparação do dano 
ambiental. Portanto, sendo a origem da poluição desconhecida, a determinação da responsabilidade ocorrerá com base na determinação do local, o que determina a obrigatoriedade de acionar os mecanismos de controle previstos no PA da ocorrência.

O Decreto de $n^{\circ} 8.127 / 2013$ imputa a responsabilidade pelo dano ambiental ao poluidor direto. $\mathrm{Na}$ hipótese desse agente não ser identificado, os custos da reparação e a recuperação da área degradada será de responsabilidade do governo federal, de acordo com o art. $27, \mathbb{2}$, que assim dispõe: "Enquanto não identificado o poluidor, os custos relativos às atividades de resposta e mitigação serão cobertos pelo Poder Executivo Federal". Cabe acrescentar que o Decreto de $n^{\circ} 4.871 / 2003$ deixa a cargo dos integrantes do Plano de Área estabelecerem como ocorrerá o ressarcimento pelos custos decorrentes das manchas órfãs.

A análise crítica do Sistema Integrado de controle da Poluição por óleo levanta problemas recorrentes da fiscalização dos órgãos ambientais, que não possuem corpo técnico suficiente para realizar a vigilância das atividades e os desdobramentos da sobreposição da competência material comum que não foi suficientemente resolvida pelas propostas da Lei Complementar $n^{\circ} 140 / 2011$.

Além disso, segundo Iris Poffo ${ }^{11}$, os integrantes dos PA "não chegam a um consenso acerca do compartilhamento dos recursos materiais em situação de emergência e o devido ressarcimento". A autora ressalta, ainda, que muitos PAs e PEIS elaborados após as Resoluções do CONAMA de n 293/2001 e 398/2008 trazem um conteúdo incompleto, o que dificulta as aprovações pelos órgãos ambientais e que acarreta muitas vezes a demora na implementação das suas estratégias de ação, causando risco e colocando a área em situação de fragilidade ambiental. A relevância da crítica consiste na constatação de que as empresas que elaboram o PEI estariam cumprindo requisitos legais, e não utilizando o Plano elaborado como forma de mitigação dos problemas ambientais (ocorridos quando de derramamentos de óleos).

Sobre o caso das manchas órfãs, a obrigatoriedade de que o PA contemple os critérios para a disponibi-

11 POFFO, Iris Regina Fernandes. Introdução ao tema planos de contingência. São Paulo: CETESB, mar. 2012. Disponível em: $<$ http://emergenciasquimicas.cetesb.sp.gov.br/wp-content/uploads/sites/53/2013/12/cetesb.pdf > . Acesso em: 05 ago. 2015. p. 31-32. lização e reposição ou ressarcimento dos recursos faz surgir uma importante uma reflexão: em que medida o Decreto $\mathrm{n}^{\circ} 8.127 / 2013$ (artigo 27, $\sqrt{ } 2^{\circ}$ ) realmente estabelece as bases para que se criem mecanismos privados de coletivização da responsabilidade para tratar dos custos das manchas órfãs? Essa reflexão é relevante por que a multilateralidade das relações jurídicas no campo ambiental não pode simplesmente fazer com que o Estado responda pelo dano causado.

Vale ressaltar que a compreensão da necessidade da elaboração dos planos para a devida proteção do ambiente marinho constitui elemento essencial para que a proteção do direito fundamental do meio ambiente não fique restrita apenas à discussão econômica, isto é, que apenas sirva de internalização do custo ambiental nas atividades empresariais, mas sim, que realmente se volte para estratégias que envolvam agentes públicos e privados para a defesa da qualidade de vida.

\section{Instrumentos Privados para o controle DA POLUIÇÃO POR MANCHAS ÓRFÃS}

A obrigatoriedade do Estado na fiscalização ambiental não lhe acarreta diretamente a absorção única dos custos decorrentes da reparação. Nos casos em que ocorre um dano ambiental, deve o poluidor reparar o prejuízo por ele gerado, sob pena de haver um enriquecimento sem causa. Este ocorre quando determinado poluidor se beneficia do meio ambiente (extraindo dele recursos para benefício próprio ainda que para auferir lucros posteriores) e ocasiona um dano socioambiental, não arcando com os custos decorrentes dessa reparação ${ }^{12}$.

Assim, as despesas necessárias ao controle da poluição devem ser imputadas aos sujeitos que a causaram, pois, além de auferir os benefícios financeiros decor-

12 Autora portuguesa de referência na principiologia ambiental afirma, tendo como fundamento o princípio do poluidor-pagador: "Nenhuma dessas hipóteses [a 'solução negociada' e a intervenção directa estadual com imputação dos custos à coletividade] é uma verdadeira alternativa a uma política de proteção do ambiente fundada sobre o PPP [Princípio do Poluidor Pagador], pois ambas constituem uma legitimação do enriquecimento sem cauda dos poluidores, à custa de toda a sociedade ou dos indivíduos que não tiveram oportunidade ou os meios jurídicos de se fazer compensar pela lesão dos seus direitos ou interesses". ARAGÃO, Maria Alexandra de Souza. O princípio do poluidor pagador. Coimbra: Coimbra Editora, 1997. (Studia Iuridica, 23). p. 194. 
rentes da extração do recurso natural, beneficiar-se-iam duplamente caso não reparassem os danos ambientais decorrentes dessa exploração. Em outras palavras, o explorador do recurso natural aufere vantagem, na medida em que nossa sociedade, por questões socioeconômicas, não atribui valor econômico ao bem ambiental considerando o tempo em que tal bem demorou em se formar (visto que apenas a abundância do recurso é suficiente para determinar seu "preço"). É nessa medida que se entende que o sujeito poluidor estaria beneficiando-se duplamente caso extraísse um bem ambiental e ainda poluísse o meio ambiente, enquanto bem de uso comum do povo e essencial à sadia qualidade de vida, sem ser economicamente responsável pelos custos decorrentes de tal reparação.

E todas as vezes em que o sujeito poluidor não for responsabilizado pelo dano causado, é a sociedade que responde por tal reparação, seja nos custos diretos de reparação do dano, seja nos custos decorrentes do prejuízo ocasionado ao meio ambiente degradado. Nesse mesmo sentido argumenta Antônio Leitão Amaro ${ }^{13}$, ao esclarecer que a não imputação dos custos ao poluidor faz com que estes recaiam na coletividade em geral.

É com base nesse raciocínio que se acredita que o Decreto no ${ }^{\circ} 8.127 / 2013$, ao imputar ao Estado (Poder Executivo Federal) os custos decorrentes das manchas órfãs, acaba por ser conivente com a prática de poluição ambiental, uma vez que tal ação encoraja os poluidores a manter atitudes prejudiciais à coletividade, para manutenção de valores competitivos.

Já existe legislação internacional que trata sobre a responsabilização dos danos decorrentes de poluição. Na Europa, a Convenção Europeia sobre Responsabi-

13 AMARO, António Leitão. Tal pai tal filho: os caminhos cruzados do Princípio do Poluidor Pagador e da Responsabilidade Ambiental. Revista Jurídica do Urbanismo e do Ambiente, Coimbra, n. 23/24, p. 9-108, jan./dez. 2005. p. 19; 23: As despesas necessárias ao controle da poluição deveriam ser imputadas os sujeitos que a causaram. Do contrário haveria "um enriquecimento sem causa do poluidor que se aproveita dos recursos econômicos da utilização e degradação dos recursos naturais sem, por isso, compensar seus titulares (que poderão ser a coletividade em geral ou, os proprietários particulares nos casos de recursos naturais juridicamente inseridos em propriedade privada)". "O Princípio do Poluidor Pagador foi originalmente adotado como um princípio econômico, segundo o qual os custos da destruição ambiental não deveriam ser suportados pela sociedade por meio dos impostos, mas pela pessoa que causou a poluição. A preocupação inicial subjacente era a de sã concorrência, estendendose depois a preocupação de eficiência econômica, e só mais tarde a motivos de justiça social e ambiental". lidade Civil por danos resultantes de Atividades Perigosas para o Meio Ambiente (assinada em Lugano, em 1993) regulamenta as questões relativas a responsabilidade na ocorrência de acidentes envolvendo produção, manipulação, armazenamento ou descarga de substâncias perigosas, e também produção, cultura, manipulação, armazenamento, utilização, destruição, eliminação e libertação de organismos geneticamente modificados e de certos microrganismos ${ }^{14}$. Essa convenção estabelece que a reparação do dano é limitada ao custo das medidas de reconstituição que efetivamente foram concretizadas.

No caso de poluição marinha causada por hidrocarbonetos, o responsável pelo dano ambiental é o explorador da atividade perigosa que a exercia no momento do acidente, podendo ser estendido tal entendimento (responsabilidade solidária a todos os que atuaram sucessivamente no controle da atividade) quando o dano resulta de um fato contínuo. Apesar de se utilizar a responsabilidade objetiva, há necessidade de indicação de quem explora a atividade para que ocorra a responsabilização quando da ocorrência do dano ambiental. Dessa sorte, não se vislumbra aplicação dessa Convenção para o caso das manchas órfãs, por se tratar de pacto ligado ao contexto dos países europeus, os quais, posteriormente à abertura de sua ratificação no ano de $1993^{15}$, acabaram por estabelecer a Diretiva de no 2004/35/ CE, do Parlamento Europeu e do Conselho, de 21 de abril de 2004. A importância dessa Convenção é recordada neste estudo para fixar a responsabilidade de todos aqueles que exploram a atividade, e não apenas para o transportador, trazendo a proposta da identificação do potencial do poluidor para fins da determinação do nexo causal.

$\mathrm{Na}$ legislação brasileira, pode-se traçar paralelo com a Política Nacional de Resíduos Sólidos (Lei $\mathrm{n}^{\circ}$ 12.305/2010) para o caso das manchas órfãs. No artigo $3^{\circ}$ (inciso XVII) da lei, é trazido importante concei-

14 Convenção Europeia sobre Responsabilidade Civil por danos resultantes de Atividades Perigosas para o Meio Ambiente (assinada em Lugano, em 1993). CONSEIL DE L'EUROPE. Convention sur la responsabilité civile des dommages résultant d'activités dangereuses pour l'environnement. Lugano, 1993). Disponible dans: <http://conventions.coe.int/treaty/fr/Treaties/Html/150.htm>. Accès: 10 mars 2014.

15 Nota das autoras: no entanto, a ausência de ratificação dessa Convenção, obriga a utilizar de sua referência como apenas uma referência teórica para se pensar nas estratégias de reparação do dano ambiental. 
to em matéria ambiental: o da responsabilidade compartilhada pelo ciclo de vida do produto. Ou seja, são indicados os responsáveis por minimizar o volume de resíduos sólidos e rejeitos gerados, de modo a reduzir os impactos causados à saúde humana e à qualidade ambiental decorrentes do ciclo de vida dos produtos. Essa lei atribui àqueles que se beneficiam do produto (sejam fabricantes, importadores, distribuidores, comerciantes, consumidores ou outros) a responsabilidade compartilhada para que ocorra a correta destinação deste.

No tocante aos óleos, há a previsão legal (Lei no $12.305 / 2010$, artigo $33, \int 3^{\circ}$ ) de que os fabricantes, importadores, distribuidores e comerciantes de óleo lubrificante assegurem a implementação e operacionalização do sistema de logística reserva, que consiste no conjunto de ações, procedimentos e meios destinados a viabilizar a coleta e a restituição dos resíduos sólidos ao setor empresarial, para reaproveitamento, em seu ciclo ou em outros ciclos produtivos, ou outra destinação final ambientalmente adequada (artigo $3^{\circ}$, XII). Desse modo, conjugando as ideias da logística reversa junto com o princípio do poluidor-pagador, seriam os sujeitos indicados no artigo $33, \int 3^{\circ}$ da referida lei corresponsáveis pela reparação dos danos ambientais decorrentes do derramamento de óleo, especialmente os sem origem definida.

A Resolução do CONAMA de no 362/2005 impõe ao gerador e ao revendedor o dever de receber o óleo lubrificante usado ou contaminado. Tal norma é bastante clara ao atribuir a responsabilidade de fiscalização aos órgãos ambientais (artigo. 22 a 24). Entretanto, o Estado brasileiro não disponibiliza da estrutura necessária para que os órgãos ambientais atuem no sentido de fazer cumprir as normas existentes, seja por falta de pessoal, seja por falta de estrutura.

No caso das manchas órfãs, a responsabilidade pode e deve ser dimensionada para as instalações e/ou os agentes públicos e privados que se encontram no perímetro de sua ocorrência. A efetiva implantação dos PAs e PEIs facilitaria muito a aplicação dessa responsabilidade, pois ambos os instrumentos exigem zoneamento preciso e detalhado. Até que sejam devidamente postos em operação, a mera localização da mancha já poderia predefinir o dever de agir para a reparação da área degradada, utilizando-se da verossimilhança e do potencial do poluidor para concorrer ao dano causado.

Os instrumentos econômicos utilizados para que seja efetiva a aplicação do princípio do poluidor-pagador são diversos e podem se dividir entre impostos ou taxas, fundos ecológicos; e seguros. Desses instrumentos privados se destacam, para os fins desse artigo, o seguro de responsabilidade civil ambiental e os fundos ecológicos.

\subsection{O seguro para riscos ambientais}

O seguro para riscos ambientais está baseado em um contrato firmado entre uma sociedade seguradora que se obriga, mediante o pagamento do prêmio, a garantir os interesses do segurado, contra riscos predeterminados, conforme o montante estabelecido na apólice. A fundamentação legal dessa modalidade de Seguro de Responsabilidade Civil, encontrada no art. 787 do Código Civil de 2002, vem ganhando corpo na doutrina especialmente sobre sua eficiência para a reparação do dano ambiental.

A contratação de um seguro pela empresa para casos de eventuais danos ambientais é uma consequência da aplicação do poluidor-pagador e tem legitimidade e coerência com a Política Nacional do Meio Ambiente, pela análise do art. $9^{\circ}$, inciso XIII. Como aduz Paulo Afonso Leme Machado

a existência de um organismo que vá garantir o
pagamento da reparação do dano poderá influir
beneficamente no espírito dos juízes, livrando-os
da preocupação sobre a possibilidade de o poluidor
fazer frente às despesas imediatas de indenização ${ }^{16}$.

No entanto, quando os custos de reparação do dano ambiental forem superiores à previsão de ressarcimento da apólice, os valores excedentes serão suportados diretamente pelo segurado, não sendo de forma alguma a limitação de valores uma justificativa para descumprimento do mandamento constitucional de reparação integral dos danos causados, conforme previsão constante do $\int 2^{\circ}$ do art. 225 da CF/88. Uma última observação é a de que a sistemática de seguros voltados a cobrir eventuais danos ambientais jamais será interpretada como uma autorização de poluir, ou ainda, como afirma Fernando Noronha, uma diminuição da função preventiva da responsabilidade objetiva ${ }^{17}$, sendo meramente uma estratégia de prevenção voltada para assegurar a

16 MACHADO, Paulo Affonso Leme. Direito ambiental brasileiro. 22 ed. São Paulo: Malheiros, 2014. p. 422.

17 NORONHA, Fernando. Direito das obrigacõoes. São Paulo: Saraiva, 2003. v. 1. p. 547. 
reparação integral dos danos.

A temática dos seguros de responsabilidade civil para riscos da poluição por óleo no ambiente marinho ainda não é explorada na jurisprudência com densidade, especialmente para casos de manchas órfãs. Em pesquisa realizada junto ao repertório de jurisprudência do Superior Tribunal de Justiça (STJ) em seleção para amostragem de julgados explorando o período temporal entre os anos de 2010 a 2015 no tema de seguros ambientais, foram encontradas 11 ocorrências, e destas 6 tratam dos seguros de riscos ambientais no ambiente de trabalho, três abordam a questão do seguro-defeso do pescador e apenas um acórdão da pesquisa trata do seguro marítimo, porém, analisando-se a legitimidade passiva da armadora e da seguradora da embarcação sinistrada.

Os seguros para riscos ambientais, no entanto, não serão muito utilizados nos casos de manchas órfãs por que esse mecanismo apresenta maior funcionalidade quando se identifica o poluidor, especialmente por que a empresa contratante é que inicia o mecanismo comunicando o sinistro ambiental para a seguradora. É possível que o poluidor reconheça sua responsabilidade pela mancha, realizando uma autodenúncia para a Autoridade Portuária e fazendo surgir o dever de comunicação para a seguradora. No entanto, essa hipótese de reconhecimento de responsabilidade, de acordo com o art. 787, $\int 2^{\circ}$ do Código Civil $^{18}$, é vedada ao segurado sem que haja anuência expressa da seguradora. Todavia, há que se avaliar a constitucionalidade dessa limitação tendo em vista o art. 225 da CF/88, uma vez que é dever de todos na sociedade zelar pela proteção do meio

18 A jurisprudência criada em torno da avaliação dessa proibição majoritariamente reconhece que o sentido da lei é o de obstar que o segurado atue por conta própria, sem a participação da seguradora. A título de exemplo, cita-se a decisão proferida pelo Desembargador Mauro Pereira Martins, do Tribunal de Justiça do Rio de Janeiro, em apelação cível que examina o teor da limitação contida no $\$ 2^{\circ}$ do art. 787 do Código Civil. Como afirma o relator, tal norma deve ser interpretada na coerência do sistema jurídico "Contudo, não se pode extrair da norma a obrigação do segurado de faltar com a verdade". O Relator observa ainda que uma interpretação que conclua para esse impedimento "está em antinomia às cláusulas gerais, de observância obrigatória pelos contratantes, como a boa-fé e a função social do contrato" (RIO DE JANEIRO. Tribunal de Justiça. Apelação. APL 00656119720088190038 RJ 0065611-97.2008.8.19.0038. Décima Terceira Câmara Cível. Agravante: Tokio Marine Seguradora. Agravado: Gabriela da Silva Ferreira; Marco Antônio Pires Silva. Relator: Des. Mauro Pereira Martins. Rio de Janeiro, 17 de junho de 2015. Disponível em: $<$ http://tj-rj.jusbrasil.com.br/jurisprudencia/201915118/apelacaoapl-656119720088190038-rj-0065611-9720088190038/inteiro-teor-201915129>. Acesso em: 05 ago. 2015). ambiente.

\subsection{Os fundos ecológicos}

Os fundos ecológicos, por sua vez, são estratégias de coletivização da responsabilidade, fenômeno que Fernando Noronha identifica como uma das consequências diretas da ampliação dos danos suscetíveis de reparação com o crescimento dos casos da responsabilidade civil no Pós-Revolução Industrial ${ }^{19}$. A experiência de coletivização da responsabilidade no sistema jurídico brasileiro surge das alternativas criadas pelo Sistema de Previdência e também do seguro obrigatório de Automóveis (DPVAT), não sendo necessariamente uma novidade para a legislação pátria. No entanto, seu uso, em casos de dano ambiental, vem ganhando corpo na doutrina justamente para hipóteses nas quais a ocorrência é relevante e a autoria seja de difícil caracterização. No caso das manchas órfãs a criação de fundos de reparação previstos nos Planos de Área, parece ser a medida mais eficiente na busca da necessária reparação integral do dano.

Sobre a implementação dos fundos autônomos, Danny Monteiro da Silva ${ }^{20}$ destaca que estes são importantes na medida em que fortalecem o conceito de responsabilidade compartilhada dos danos ambientais. Esse conceito [responsabilidade compartilhada] significa que todos os que atuam nesse ramo de atividade necessitam ter a consciência da importância da integração harmoniosa entre o desenvolvimento desta com o meio ambiente $^{21}$.

19 Diz o autor: "Se a expansão dos danos suscetíveis de reparação é importante, ela ainda é aspecto menor se posto em confronto com os fenômenos da objetivação e da responsabilização. Estes são dois aspectos de maior relevância na transformação da responsabilidade civil contemporânea, mesmo que não abarquem a totalidade da evolução e ainda que os três fenômenos estejam interligados: afinal, a objetivação e a coletivização também não deixam de tutelar a necessidade sentida pela sociedade de não deixar dano nenhum sem reparação". NORONHA, Fernando. Direito das obrigações. São Paulo: Saraiva, 2003. v. 1. p. 541.

20 SILVA, Danny Monteiro da. Dano ambiental e sua reparação. Curitiba: Juruá, 2011. p. 319: "Tais fundos representam, na atualidade, o máximo expoente do novo sistema de responsabilidade compartilhada para a reparação dos danos ambientais, o qual surge em substituição ao antigo sistema de responsabilidade civil, tradicionalmente baseado no princípio clássico da responsabilidade individual".

21 SILVA, Danny Monteiro da. Dano ambiental e sua reparação. Curitiba: Juruá, 2011. p. 320: explica que foram dois os fatores que contribuíram para o surgimento dos fundos ecológicos: a necessidade da realização de atividades potencialmente danosas ao meio ambiente, mas que são importantes para a sociedade moderna; e a 
Com a criação dos fundos ecológicos para os casos de manchas órfãs, o ordenamento jurídico traria solução não apenas para a reparação efetiva dos danos ambientais, como também para as ações coletivas ou individuais que exijam indenizações decorrentes de danos crônicos ocorridos no meio ambiente marinho. A crítica efetuada contra os fundos ecológicos seria no sentido de que estes enfraqueceriam o princípio do poluidor-pagador. Danny Monteiro da Silva discorda de tal posicionamento, pois considera que o processo de socialização de danos ambientais, "inerente aos mecanismos de indenização conjunta, devolve o sentido a tais princípios, no momento em que os setores implicados vertem suas contribuições ao fundo, de forma proporcional ao risco de contaminação ${ }^{222 "}$. Maria Alexandra de Souza Aragão ${ }^{23}$, por sua vez, defende a criação desses fundos, desde que os valores sejam oriundos da imposição de impostos indiretos que incidam sobre a atividade que é fonte principal do potencial dano.

Caso seja percebida a necessidade de implementação de um fundo ecológico, no estado brasileiro, para os casos de ocorrência de poluição sem origem definida, pode-se tomar como inspiração a lei norte-americana, Oil-discharge prevention and pollution Control Act, de 1990, que alterou a Lei da Água Limpa e traz a previsão para perdas econômicas causadas pela poluição de origem desconhecida ${ }^{24}$. A agência de Proteção Ambiental Norte-Americana (United States Environmental Protect Agency EPA) é o órgão regulador e instrumentalizador de todo o sistema de responsabilidade e prevenção para os casos de poluição por óleo. A característica do sistema de proteção é semelhante à forma brasileira, pois prevê a

falta de adequabilidade do mercado de seguros para os problemas surgidos com os seguros ambientais: "O surgimento dos fundos autônomos para reparação e recuperação conjunta do ambiente, como mecanismos auxiliares à reparação dos danos ambientais, se deve a dois fatores complementares: por um lado, a necessidade da sociedade moderna de exercer certas atividades tidas como essenciais para a vida social, mas que são, ao mesmo tempo, potencialmente arriscadas do ponto de vista ambiental, tais como o transporte marítimo de petróleo e derivados ou o transporte, a manipulação ou utilização, em qualquer processo industrial, de infinitas substâncias altamente tóxicas ou nocivas para o meio; por outro lado, em razão das dificuldades enfrentadas pelo mercado de seguros, para se adaptar e tornar-se apto a lidar com as especificidades do dano ambiental" [sem destaque no original].

22 SILVA, Danny Monteiro da. Dano ambiental e sua reparação. Curitiba: Juruá, 2011. p. 324.

23 ARAGÃO, Maria Alexandra de Souza. O princípio do poluidor pagador. Coimbra: Coimbra Editora, 1997. (Studia Iuridica, 23). p. 127-128.

24 Cf. MACHADO, Paulo Affonso Leme. Direito ambiental brasileiro. 22 ed. São Paulo: Malheiros, 2014. p. 423. necessidade de monitoramento e fiscalização por meio de elaboração de planos que tragam dados referentes à sensibilidade ambiental, à cadeia de instalações operantes na área, dente outros.

No contexto desse sistema de fiscalização e controle foi estabelecido o Superfund, como é conhecido pelo senso comum a Lei de Responsabilidade, Compensação e Recuperação Ambiental Norte-americana (Comprehensive Environmental Response Compensation and Liability Act-CERCLA). Nas palavras de Danny Monteiro da Silva, "[o Superfund é] considerado pela doutrina como o modelo mais completo de fundo de reparação, integrante de um complexo e avançado sistema integrado de responsabilidade por danos ambientais ${ }^{25}$ ". De um modo geral, os resíduos perigosos que estejam afetando ecossistemas ou pessoas são destinados para locais adequados (depósitos de resíduos perigosos), após limpeza das regiões afetadas. Os valores para descontaminação das áreas são custeados pelos causadores diretos dos danos (quando identificados) e pelo fundo. Destaca-se que o Superfund é acionado quando, ao menos inicialmente, não é possível indicar a responsabilidade pela contaminação ambiental ${ }^{26}$. O Superfund não contempla os casos em que são ocasionados danos pessoais ou patrimoniais de ordem privada, cuja reparação depende de ações civis próprias.

Outro fundo americano é o Oil Spill Liability Trust Fund, implementado pelo Oil Pollution Act, voltado para a prevenção, o monitoramento, a remoção e a imposição de medidas relacionadas com o derramamento de óleo. Existe previsão expressa de que esse fundo deve arcar com os casos em que os custos decorrentes de danos ambientais não possam ser reclamados junto aos responsáveis ${ }^{27}$.

No Brasil há diferentes fundos voltados a captação de recursos para casos de reparação ambiental. Eles existem nas três esferas da federação e se voltam à busca de recursos que possam financiar a proteção ambiental. $\mathrm{Na}$ esfera federal, desatacam-se o Fundo Nacional do Meio Ambiente (FNMA), o Fundo Nacional de Desenvolvimento Florestal (FNDF) ligado ao Serviço Florestal Brasileiro do Ministério do Meio Ambiente (MMA);

25 SILVA, Danny Monteiro da. Dano ambiental e sua reparação. Curitiba: Juruá, 2011. p. 336.

26 SILVA, Danny Monteiro da. Dano ambiental e sua reparação. Curitiba: Juruá, 2011. p. 337.

27 SILVA, Danny Monteiro da. Dano ambiental e sua reparação. $\mathrm{Cu}-$ ritiba: Juruá, 2011. p. 339. 
o Fundo de Defesa dos Direitos Difusos (FDDD), ligado ao Ministério da Justiça; o Fundo Amazônia, operado pelo Banco Nacional de Desenvolvimento Econômico e Social (BDNES) juntamente com o MMA, dentre outros ${ }^{28}$.

No entanto, a grande maioria desses fundos opera com o deslocamento de recursos por parte de ente privados de forma voluntária, geralmente caracterizando doações que podem se originar, por exemplo, de medidas mitigadoras previstas no licenciamento ambiental pelo empreendedor. Dentre eles, o mais conhecido é o Fundo Nacional do Meio Ambiente (FNMA), instituído pela Lei $n^{\circ} 7.797 / 1989$, o qual tem por objetivo o desenvolvimento de projetos que visem o uso racional e sustentável de recursos naturais, incluindo a manutenção, melhoria ou recuperação da qualidade ambiental no sentido de elevar a qualidade de vida da população brasileira (artigo $1^{\circ}$ da citada lei). Os recursos financeiros desse fundo (artigo $2^{\circ}$ ) provem de dotações orçamentárias da União; de recursos resultantes de doações, contribuições em dinheiro, valores, bens móveis e imóveis, que venha a receber de pessoas físicas e jurídicas; de rendimentos de qualquer natureza, que venha a auferir como remuneração decorrente de aplicações do seu patrimônio; ou outros, destinados por lei.

Os fundos ecológicos no Brasil, dessa forma, não incorporam ainda a coletivização da responsabilidade, tal qual ocorre nos fundos existentes como o DPVAT, nosso exemplo mais conhecido de fundo de responsabilidade, em que a propriedade do veículo basta para dar origem a obrigatoriedade da contribuição. Como bem observa Paulo Affonso Leme Machado, espera-se do legislativo iniciativa para que a Política Nacional Brasileira "institua um fundo comum para evitar as incertezas de autoria em termos de poluição" 29 .

No caso das manchas órfãs, a previsão de que os Planos de Área contenham sistema de custeio das operações para recuperação da área degradada, pode ser entendida como importante precedente para a caracteriza-

28 O repasse e a composição desses fundos ambientais são analisados no artigo de SOTERO, João Paulo; LEME, Taciana Neto. Financiamento ambiental no Brasil: a contribuição do IBAMA. In: ENCONTRO DA SOCIEDADE BRASILEIRA DE ECONOMIA ECOLÓGICA, 8., 2009, Cuiabá. Anais... Cuiaba: Ecoeco, 2009. Disponível em: < http://www.ecoeco.org.br/conteudo/publicacoes/encontros/VIII/GT4-7-11-20090531185743.pdf>. Acesso em: 13 jun. 2015.

29 MACHADO, Paulo Affonso Leme. Direito ambiental brasileiro. 22 ed. São Paulo: Malheiros, 2014. p. 424. ção de um fundo ecológico. Infelizmente, a redação do Decreto poderia ser mais contributiva caso fizesse referência expressa aos fundos ecológicos. A ausência dessa menção, no entanto, em nada prejudica a análise de que essa composição é possível e pode apresentar resultados satisfatórios, a fim de que os custos relacionados com o controle, monitoramento e reparação das manchas órfãs sejam suportados coletivamente por todos os entes públicos e privados que se encontrem operacionalizando atividades na área da ocorrência.

\section{Considerações finais}

A complexidade do ambiente marinho traz dificuldades para que o sistema jurídico consiga apresentar boas soluções em termos de reparação ambiental. O caso das manchas de óleo de origem desconhecida, conhecidas como "manchas órfãs", trazem ainda maior complexidade ao tema especialmente por que a ausência de identificação do poluidor impossibilita a formação do nexo causal. As iniciativas legislativas recentes, como a promulgação do Decreto de $\mathrm{n}^{\circ} 8.127 / 2013$, parecem conduzir a uma solução para a questão quando vincula os Planos de Área a dimensionar os custos para prevenção e reparação dos danos de origem desconhecida.

Pensa-se que esse é um passo importante para a busca da eficiência na reparação ambiental, uma vez que abre a possibilidade de discutir a necessidade da coletivização da responsabilidade entre todos os empreendedores que se valem dos mares e oceanos para sua atividade produtiva. Ao que tudo indica, a alteração ocorrida no art. $4^{\circ}$, inciso V, do Decreto n ${ }^{\circ} 4.871 / 2003$ de planejamento de custeio das ações voltadas à reparação das manchas órfãs pode ser entendida como um valioso precedente para que se estabeleça uma espécie de fundo ecológico nos casos de incerteza de autoria em casos de poluição.

A criação de um fundo ecológico destinado a reparação dos danos ambientais marinhos sem indicação de autoria, tal qual se procurou ilustrar no caso das manchas órfãs, indiretamente aponta a necessidade de se aprofundarem os estudos acerca dos mecanismos públicos e privados que possam fazer valer os deveres que surgem para toda a sociedade em termos de concretização do direito fundamental ao meio ambiente ecologicamente equilibrado. Por fim, é preciso ressaltar que os 
estudos dos mecanismos de coletivização da responsabilidade devem procurar ir além do sistema de compensações econômicas ou da mera internalização do custo ambiental no processo produtivo, concentrando-se especialmente na medida da eficiência e da capacidade de retorno à qualidade ambiental, elemento indispensável para a vida saudável e o almejado equilíbrio entre preservação-conservação e apropriação dos recursos naturais.

\section{REFERÊNCIAS}

AMARO, António Leitão. Tal pai tal filho: os caminhos cruzados do Princípio do Poluidor Pagador e da Responsabilidade Ambiental. Revista Jurídica do Urbanismo e do Ambiente, Coimbra, n. 23/24, p. 9-108, Jan./dez. 2005.

ARAGÃO, Maria Alexandra de Souza. O princípio do poluidor pagador. Coimbra: Coimbra Editora, 1997. (Studia Iuridica, 23).

BENJAMIN, Antônio Herman de Vasconcellos. Responsabilidade civil pelo dano ambiental. Revista de Direito Ambiental, São Paulo, v. 3, n. 9, p. 5-52, jan./mar. 1998.

BRASIL. Tribunal Regional Federal (4. Região). Apelação Cível. AC 5001112-21.2011.404.7101. Quarta Turma. Apelante: Ministério Publico Federal; PETROBRAS Transporte S.A./TRANSPETRO. Apelado: Os mesmos. Relator: Des. Federal. Vivian Josete Pantaleão Caminha. Porto Alegre, 06 de agosto de 2014. Disponível em: <http://www2.trf4.jus.br/trf4/controlador.php?acao $=$ consulta_processual_resultado_pesquis a\&selForma $=$ NU\&txtValor $=50011122120114047101$ \&selOrigem $=\mathrm{TRF} \&$ chkMostrarBaixados $=1>$. Acesso em: 05 ago. 2015.

BRASIL. Tribunal Regional Federal (4. Região). Apelação Criminal. ACR 2007.72.08.002328-0. Oitava Turma. Apelante: Ministério Publico Federal. Apelado: Carlos Rogerio Gonçalves; Jaco Moacir Schreiner Maran. Relator: Juiz Federal. João Pedro Gebran Neto. Porto Alegre, 02 de julho de 2014. Disponível em: < http:// www2.trf4.jus.br/trf4/controlador.php?acao $=$ consulta_processual_resultado_pesquisa\&selForma $=$ NU\&tx tValor $=200772080023280 \&$ chkMostrarBaixados $=S \& \mathrm{~s}$ elOrigem $=$ TRF $\&$ hdnRefId $=40$ ae $18317 \mathrm{da} 53$ f4bbda $15 \mathrm{a}$
58abca7afc\&txtPalavraGerada $=$ ajoK $>$. Acesso em: 05 ago. 2015.

BRASIL. Tribunal Regional Federal (4. Região). Apelação/Reexame Necessário. APL n. 5004877. 63.2012.4.04.7101. Terceira Turma. Apelante: Ministério Público Federal. Apelado: Luiz Hidalgo dos Santos. Relator: Des. Federal Fernando Quadros da Silva. Porto Alegre, 31 de julho de 2014. Disponível em: <http:// www2.trf4.jus.br/trf4/controlador.php?acao $=$ consulta_ processual_resultado_pesquisa\&txtValor $=5004877$ 63.2012.404.7101\&selOrigem $=$ RS\&chkMostrarBaixa dos $=1 \&$ selForma $=$ NU\&hdnRefId $=\&$ txtPalavraGera da $=>$. Acesso em: 05 ago. 2015.

CONSEIL DE L'EUROPE. Convention sur la responsabilité civile des dommages résultant d'activités dangereuses pour l'environnement. Lugano, 1993). Disponible dans: <http:// conventions.coe.int/treaty/fr/Treaties/Html/150. htm>. Accès: 10 mars 2014.

GIACOMITTI, Renata Brockelt. Derramamento por óleo no mar por manchas órfãs e a responsabilidade por dano socioambiental. 2014. 123 f. Dissertação (Mestrado) - Programa de Pós-Graduação em Meio Ambiente e Desenvolvimento, Universidade Federal do Paraná, Curitiba, 2014.

LEITE, José Rubens Morato; MELO, Melissa Ely. As funções preventivas e precaucionais da responsabilidade civil por danos ambientais. Sequência: Estudos Jurídicos e Políticos. Florianópolis, v. 28, n. 55, p. 195-218, jan. 2007. Disponível em: <https://periodicos.ufsc.br/index.php/sequencia/article/view/15053>. Acesso em: 13 jun. 2015. doi:http://dx.doi.org/10.5007/15053.

MACHADO, Paulo Affonso Leme. Direito ambiental brasileiro. 22 ed. São Paulo: Malheiros, 2014.

NORONHA, Fernando. Direito das obrigações. São Paulo: Saraiva, 2003. v. 1.

POFFO, Iris Regina Fernandes. Introdução ao tema planos de contingência. São Paulo: CETESB, mar. 2012. Disponível em: <http://emergenciasquimicas.cetesb. sp.gov.br/wp-content/uploads/sites/53/2013/12/cetesb.pdf>. Acesso em: 05 ago. 2015.

RIO DE JANEIRO. Tribunal de Justiça. Apelação. APL 00656119720088190038 RJ 0065611 97.2008.8.19.0038. Décima Terceira Câmara Cível. Agravante: Toko Marine Seguradora. Agravado: Gabriela da Silva Ferreira; Marco Antônio Pires Silva. Relator: Des. Mauro Pereira Martins. Rio de Janeiro, 
17 de junho de 2015. Disponível em: <http://tj-rj.jusbrasil.com.br/jurisprudencia/201915118/apelacaoapl-656119720088190038-rj-0065611-9720088190038/ inteiro-teor-201915129>. Acesso em: 05 ago. 2015.

SILVA, Danny Monteiro da. Dano ambiental e sua reparação. Curitiba: Juruá, 2011.

SILVA, Vasco Pereira da. Verde cor de direito: lições de direito do ambiente. Coimbra: Almedina, 2002.

SOTERO, João Paulo; LEME, Taciana Neto. Financiamento ambiental no Brasil: a contribuição do IBAMA. In: ENCONTRO DA SOCIEDADE BRASILEIRA DE ECONOMIA ECOLÓGICA, 8., 2009, Cuiabá.
Anais... Cuiaba: Ecoeco, 2009. Disponível em: < http:// www.ecoeco.org.br/conteudo/publicacoes/encontros/ VIII/GT4-7-11-20090531185743.pdf>. Acesso em: 13 jun. 2015.

UNITED STATES ENVIRONMENTAL PROTECTION AGENCY. Oil Pollution Prevention Regulations. Available at: <http://www.epa.gov/superfund/contacts/infocenter/spcc.htm>. Access on: 14 Apr. 2014.

ZANELLA, Tiago Vinicius. Agua de lastro: um problema global. Curitiba: Juruá, 2010. 


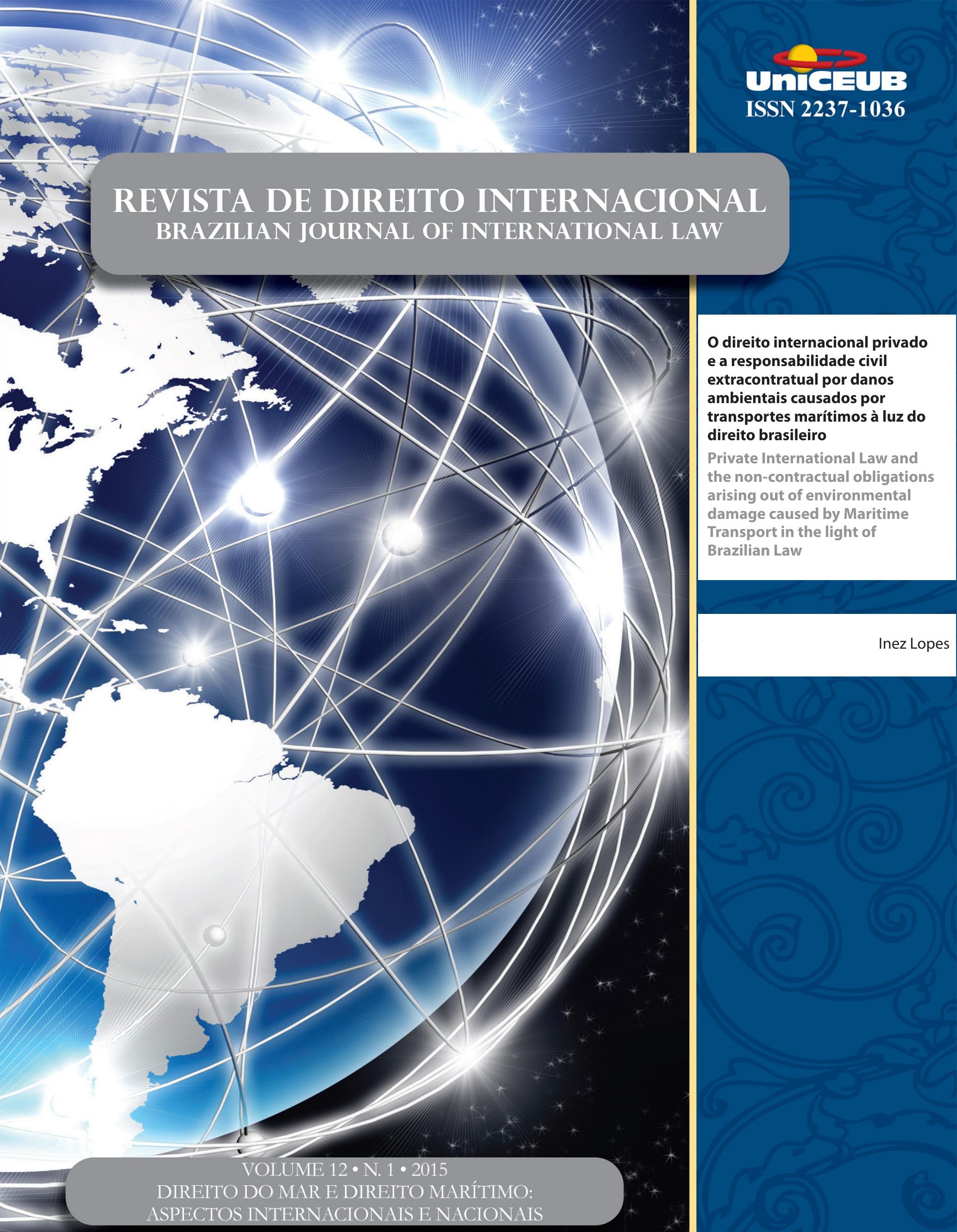




\title{
O direito internacional privado e a responsabilidade civil extracontratual por danos ambientais causados por transportes marítimos à luz do direito brasileiro*
}

\author{
Private International Law and the non- \\ contractual obligations arising out of \\ environmental damage caused by Maritime \\ Transport in the light of Brazilian Law
}

Inez Lopes**

\section{Resumo}

Mais de 90\% do comércio internacional é realizado por meio de transportes marítimos, sendo a indústria da navegação uma das maiores do mundo em geração de riquezas e de empregos. Paralelamente, é uma das atividades potencialmente poluidora ao meio ambiente marinho, uma vez que mais de $50 \%$ da carga comercializada é considerada perigosa ou nociva. Atualmente, os transportes marítimos são responsáveis por $12 \%$ da poluição marinha, que podem ocorrer em águas territoriais ou águas internacionais. Por sua vez, a lei da bandeira ou do pavilhão constitui um elemento de conexão importante para se determinar a responsabilidade do agente causador do dano. Contudo, há a possibilidade de os navios arvorarem outra bandeira que não a de sua nacionalidade, além das bandeiras de conveniência. Desse modo, o presente artigo objetiva estudar a responsabilidade civil extracontratual por danos ambientais marinhos causados por transportes marítimos nas situações privadas internacionais à luz do direito brasileiro, considerando-se os danos em águas territoriais e em alto-mar, limitando-se à análise de casos de poluição por óleo e outras substâncias nocivas ou perigosas. A partir da análise qualitativa, o texto discute questões referentes à nacionalidade do navio, e os problemas referentes à responsabilização dos navios que utilizam bandeiras de conveniência. Analisa as regras de direito internacional privado quanto à lei aplicável na responsabilidade extracontratual e a adoção da lex damni aos casos de danos ambientais. Com relação à competência internacional, aplica-se a regra do forum damni, a fim de oferecer maior segurança e previsibilidade aos litígios transfronteiriços. Todavia, ainda há necessidade de se aperfeiçoar a cooperação jurídica transfronteiriça em matéria ambiental.

Palavras-chave: Direito internacional privado. Responsabilidade civil extracontratual. Danos ambientais. Poluição marinha. Transportes marítimos.

** Professora-adjunta de Direito Internacional Privado da Universidade de Brasília (UnB). Doutora e Mestre em Direito Internacional pela Universidade de São Paulo (USP). Mestre em Globalização e Políticas Trabalhistas pela Universität Kassel/FHW Berlin. Ex-Coordenadora-Geral de Cooperação Jurídica Internacional em Matéria Civil do Ministério da Justiça (DRCI/SNJ/MJ). Coordenadora do Grupo de Estudos em Direito Internacional Privado, do Comércio Internacional e Direitos Humanos (CNPq).E-mail: inezlopes@unb.br 


\section{Abstract}

Over $90 \%$ of international trade is carried out through maritime transport and shipping is one of the world's great industries in generating wealth and jobs. At the same time, it is one of potentially polluting activities to the marine environment, since more than $50 \%$ packaged goods and bulk cargoes transported by sea can be dangerous or harmful. Currently, maritime transport accounts for $12 \%$ of marine pollution, which may occur in territorial waters or international waters. In turn, the law of the flag is an important connecting factor to determine the agent's liability for causing the damage. However, it is possible for ships to fly another flag than of its nationality in addition to flags of convenience. Thus, this article aims to study the non-contractual liability for environmental damage caused by marine shipping in private international relations in the light of Brazilian law, considering the damage in territorial waters and on the high seas, limited to the analysis of cases of pollution by oil and other harmful or dangerous substances. From the qualitative analysis, the paper discusses issues related to ship's nationality, and problems relating to accountability ships using flags of convenience. It also analyzes the rules of private international law and the applicable law in non-contractual liability and the adoption of lex damni to cases of environmental damage. In regard to international jurisdiction, it is applied the rule of forum damni in order to provide greater certainty and predictability on cross-border disputes. However, there is still need to improve cross-border legal cooperation on environmental issues.

Keywords: Private international law. Non-contractual liability. Environmental damages. Marine pollution. Maritime transports.

\section{INTRODUÇÃo}

A indústria da navegação é responsável pelo grande fluxo de mercadorias no comércio internacional. Os principais motivos são o custo operacional em comparação aos demais meios de transporte e a capacidade de armazenamento de mercadorias, desde matérias-primas e produtos tecnológicos de alto valor agregado. Apesar disso, a atividade marítima é considerada de alto risco e, de acordo com os critérios da Organização Marítima
Internacional $(\mathrm{OMI})^{1}$, mais de $50 \%$ dos produtos embalados e de cargas a granel podem ser considerados perigosos ou nocivos ao meio ambiente, dependendo do tipo de carga que é transportada, como por exemplo, os produtos a granel, contendo líquidos ou sólidos inflamáveis, materiais radioativos, petróleo e seus derivados e lixo.

Entende-se por transportes marítimos os transportes aquaviários destinados ao deslocamento de pessoas e de mercadorias em águas territoriais (águas interiores e marítimas) e em águas internacionais (alto-mar). O direito marítimo regula as atividades comerciais realizadas por navegação, bem como as atividades de exploração dos recursos naturais marinhos vivos e não vivos de águas interiores.

O direito ambiental, por sua vez, regula as atividades de navegação, a fim de evitar danos ao patrimônio marinho. A potencialidade de dano é elevada e as normas internas e internacionais visam estabelecer uma harmonização nos mecanismos preventivos de poluição, assim como de responsabilidade do poluidor e de sua obrigação de reparar ou prejuízo.

Desse modo, a efetividade na proteção dos recursos marinhos, vivos e não vivos, depende da participação de todos os stakeholders da sociedade internacional, como as empresas (instituições econômicas) e a sociedade civil (instituições sociais), em sentido amplo, além dos Estados e das organizações internacionais (instituições políticas). Os danos causados ao meio ambiente marinho é um tema global e depende da cooperação internacional entre os Estados para estabelecer regras comuns para uma gestão pública internacional sustentável, tanto no uso quanto na exploração de recurso vivos e não vivos que constituem se bem público global.

A responsabilidade civil por danos ao meio ambiente marinho pode ser internacional, responsabilizando os Estados por danos causados por embarcações que estejam em seu território e causem prejuízos às populações de Estados vizinhos ou em águas internacionais quando o dano for provocado por embarcação que arvore sua bandeira. Nas relações privadas internacionais, as em-

1 ORGANIZAÇÃO MARÍTIMA INTERNACIONAL. IMO and dangerous goods at sea: The transport by sea of dangerous and harmful goods, including marine pollutants and wastes Focus on IMO. May 1996. Disponível em: < http:/ /www.imo.org/blast/blastDataHelper.asp?data_id $=7999 \&$ filename $=$ IMDGdangerousgoodsf ocus1997.pdf>. Acesso em: 12 jul. 2014. 
presas de navegação, nacionais e estrangeiras, podem ser responsabilizadas pelos prejuízos nas operações comerciais internacionais, seja de natureza contratual, seja extracontratual, como é o caso da poluição marinha, causada por vazamento de substâncias altamente perigosas e nocivas, como hidrocarbonetos.

Este trabalho objetiva em especial estudar o direito internacional privado e a responsabilidade extracontratual por danos ambientais marinhos decorrentes das atividades de navegação, em especial as regras de conexão sobre conflitos de leis e de jurisdição, bem como a questão da nacionalidade dos navios e os problemas referentes à responsabilização dos navios que utilizam bandeiras de conveniência. Visando atingir seu propósito, este artigo está dividido em três partes. A primeira parte estuda o desenvolvimento do comércio marítimo internacional, o fenômeno da globalização e o marco regulatório na relação entre transporte marítimo e meio ambiente. A segunda parte estuda o direito internacional privado e a responsabilidade civil extracontratual nas atividades marítimas. A partir da análise qualitativa, analisa as regras de direito internacional privado quanto à lei aplicável na responsabilidade extracontratual e a adoção da lex damni aos casos de danos ambientais. Com relação à competência internacional, aplica-se a regra do forum damni, a fim de oferecer maior segurança e previsibilidade aos litígios transfronteiriços. Por meio do método analítico, a terceira parte estuda a jurisprudência dos tribunais brasileiros com relação às regras de competência internacional para poluição marinha de hidrocarbonetos e seus derivados, causado por navios, bem como os conflitos de competência judiciária e administrativa.

\section{GLobalizAÇÃo, tRANSPORTE MARÍtIMO E MEIO AMBIENTE}

O comércio marítimo internacional é tão antigo quanto a história da civilização humana. Contudo, até o início do século XX, as legislações se limitavam a estabelecer responsabilidades civis para reparação patrimonial, como no caso de colisão ou abalroamento e, também, de ordem administrativa para responsabilizar a tripulação das embarcações.

Embora a história tenha registrado a existência de relações comerciais internacionais nas antigas civiliza- ções, o marco inicial na história do desenvolvimento do direito do comércio internacional surge na Idade Média. De acordo como Schmitthoff ${ }^{2}$, a característica internacional do antigo direito do comerciante na Idade Média decorria de quatro fatores. O primeiro fator tinha efeito unificador da lei de mercado, e era quase tão universal quanto a lei da igreja. O segundo tinha relação com a universalidade da alfândega marítima (portuária). Esse fator apareceu com os fenícios e os gregos, cujas regras estavam reunidas nas leis de Rodes, entre 600 e 800 a.C. Nesse período surgiu o repertório (repositórios) de decisões e de costumes, tais como o Rôles d'Oleron, na França, Consuldado del Mar, de Barcelona, e tantos outros, e o último se tornou mais tarde o Código Marítimo do Mediterrâneo. O terceiro fator referia-se aos tribunais especiais que lidavam com as disputas comerciais. Interessante notar que esses tribunais eram constituídos metade por jurados nativos e metade por comerciantes estrangeiros, conhecidos como "half-tongue juries". O último fator estava relacionado à atividade do tabelião, que, na Idade Média, era um praticante universal e versátil, e lidava basicamente com o trabalho jurídico comercial.

Os comerciantes europeus criaram um conjunto de normas costumeiras internacionais que regulavam as práticas e costumes da comunidade cosmopolita ${ }^{3}$. Esse período ficou conhecido com a antiga lex mercatoria. Essas normas foram se espalhando pela Europa, devido ao fato de os comerciantes aplicarem essas regras nas suas transações comerciais internacionais, independentemente do lugar da negociação, fossem em mercados nacionais, fossem em centros estrangeiros, e também da lei local.

Outra importante fase do desenvolvimento do direito do comércio internacional ocorreu entre os séculos XVII e XIX, marcado pela incorporação das leis dos comerciantes - conjunto de leis internacionais costumeiras - ao ordenamento jurídico interno em diversos países. Em outras palavras, a inserção da antiga lex mercatoria no sistema nacional dos Estados.

Nesse período, as atividades desenvolvidas pela comunidade do comércio internacional deram origem a

2 CHENG, Chia-Jui (Ed.). Clive M Schmitthoff's Select Essays on International Trade Law. Dordrecht: Martinus Nijhoff Publishers; Boston, London: Graham \& Trotman, 1982. p. 207

3 CHENG, Chia-Jui (Ed.). Clive M Schmitthoff's Select Essays on International Trade Law. Dordrecht: Martinus Nijhoff Publishers; Boston, London: Graham \& Trotman, 1982. p. 206. 
novos costumes internacionais. Foram criadas novas formas de contratos de venda internacional, como os contratos com cláusulas Free on Board (FOB). ${ }^{4}$ e Cost, Insurance and Freight $(\mathrm{CIF})^{5}$. Mais tarde, surgiu o crédito bancário comercial, usado como meio de pagamento nos negócios de exportação.

A globalização não é um processo novo. Analisando-se a concepção de globalização econômica, o final do século XIX e o princípio do XX (1870-1914) foram marcados por um fenômeno semelhante ao da globalização do final do século XX. Nesse contexto, Ianni afirma que a globalização evoluiu do mercantilismo, passando pelo colonialismo, imperialismo, multinacionalismo e transnacionalismo, transformando-se em um modo de produção global ${ }^{6}$.

Nesse sentido, o fenômeno da globalização está profundamente vinculado à ordem econômica internacional marcada pela aceleração do mercado, com a expansão do comércio internacional e de investimentos financeiros internacionais. Por sua vez, a distribuição da produção mundial é realizada por transporte marítimo em mais de $90 \%$ do volume comercializado no mundo, isso significa que "o transporte marítimo é um dos fatores mais importantes da globalização e ao mesmo tempo a globalização é um dos fatores mais importantes de demanda no transporte marítimo". ${ }^{7}$ Ademais, o eterno triângulo formado por produtores, fabricantes e mercados está unido por meio de transportes. ${ }^{8}$

Com o objetivo de estabelecer um marco regulatório sobre direito marítimo, a Organização Marítima Internacional (IMO) foi criada em 1948, inicialmente como Organização Intergovernamental Marítima Consultiva, uma agência especializada do sistema das Nações Uni-

4 O primeiro caso de contrato f.o.b. foi entre Wackerbarth v. Masom em 1812.

5 O primeiro caso de contrato c.i.f. foi entre Tregelles v. Sewell em 1862.

6 IANNI, Otavio. Teoria da globalização. Rio de Janeiro: Civilização Brasileira, 1997.

7 POCUCA, Milojka; ZANNE Marina. Globalization, International Trade and Maritime Transport. Disponível em: <http://www. google.com.br $/$ url? sa $=$ t\&rct $=j \& q=\&$ esrc $=s \&$ source $=$ web\&cd $=1 \&$ ved $=0 \mathrm{CCkQFjAA \& url}=$ http $\% 3 \mathrm{~A} \% 2 \mathrm{~F} \% 2 \mathrm{Fwww}$.fpp.uni-lj. si\%2Fmma_bin.php\%3Fid\%3D2010101801382606\&ei=cd5CVe3 EOuTbsASIIYC4Cw\&usg=AFQjCNE5Mo84x6uOhgE_TQRHgmQBkgnxA\&sig2=6EtfrO-byPWfFjysUpHpqA\&bvm=bv.921894 99,d.cWc >. Acesso em: 9 mar. 2015.

8 ORGANIZAÇÃO MARÍTIMA INTERNACIONAL. International Shipping Facts and Figures. Maritime Knowlegde Centre, 2012. p. 6. das, a fim de promover uma navegação marítima mais segura e, também, para maior efetividade na prevenção e no controle de poluição marinha. Seus trabalhos tiveram início em 1959, e é responsável pela construção de um arcabouço jurídico internacional, tais como Convenção Internacional para Salvaguarda da Vida Humana no Mar (SOLAS 74) e do Protocolo relativo 1988 (SOLAS 88), a Convenção Internacional para Prevenção da Poluição por Navios e seu Protocolo de 1978 (MARPOL 73/78) entre outros. Atualmente a instituição conta com 170 membros $^{9}$ e seus trabalhos. Estudos da OMI revelam que o transporte marítimo é o meio mais eficiente e eficaz em termos de custos e de confiança no transporte de mercadorias em nível global, facilitando o comércio e ajudando a criar prosperidade entre povos e nações.

Por seu turno, a Conferência das Nações Unidas sobre Comércio e Desenvolvimento (UNCTAD), agência especializada do sistema das Nações Unidas que objetiva promover o comércio e desenvolvimento entre as nações, exerce importante trabalho sobre comércio marítimo, com a compilação de informações estatísticas sobre o transporte marítimo no mundo. A UNCTAD publica anualmente uma série estudos intitulada "O Transporte Marítimo" (Review of Maritime Law) desde 1968, com o propósito promover a transparência dos mercados de transportes marítimos assim como apresentar uma análise de sua evolução.

As atividades de navegação trazem em si o problema da responsabilidade civil, contratual e extracontratual, assim como toda manifestação da atividade humana traz em si o problema da responsabilidade ${ }^{10}$, uma vez que são consideradas atividades de alto risco em potencial, pois se destinam ao transporte de pessoas e coisas. Ao transporte marítimo é atribuída, ainda, a função de entregar ou enviar notícias, podendo ser reconhecida a reponsabilidade por danos em caso de demora culposa ou de informação errônea transmitida. O presente trabalho se limita a estudar apenas os casos de responsabilidade civil por danos ao meio ambiente marinho, de recursos vivos e não vivos.

A relação entre proteção internacional do meio ambiente e o direito marítimo estabelece obrigações

9 Dados obtidos <http://www.imo.org >. Acesso em: 17 abr. 2015.

10 Ver DIAS, José de Aguiar. Da responsabilidade civil. 10. ed. Rio de Janeiro: Forense, 1997. 
a todos os stakeholders. De um lado temos a obrigação dos Estados de controlar as atividades que estão sob sua jurisdição de tal modo que não causarem danos ao meio ambiente de outros Estados ou além dos limites da jurisdição nacional, conforme dispõem os princípios $2^{\circ}$ da Declaração do Rio sobre Meio Ambiente e Desenvolvimento, de $1992^{11}$ e 21 da Declaração de Estocolmo sobre Meio Ambiente Humano, de 1972, ${ }^{12}$ a chamada poluição transfronteiriça, responsabilizando os Estados em caso de danos. De outro, as pessoas privadas têm a obrigação de usar os espaços territoriais que estão sob a jurisdição do Estado e os espaços comuns que estão sob a proteção do direito internacional de modo a não causar danos.

A Convenção das Nações Unidas sobre Direito do Mar (CNUDM) define poluição introdução pelo homem, direta ou indiretamente, de substâncias ou de energia no meio marinho, incluindo os estuários, sempre que esta provoque ou possa vir a provocar efeitos nocivos, tais como danos aos recursos vivos e à vida marinha, riscos à saúde do homem, entrave às atividades marítimas, incluindo a pesca e as outras utilizações legítimas do mar, alteração da qualidade da água do mar, no que se refere à sua utilização, e deterioração dos locais de recreio ${ }^{13}$; e aos Estados o dever de não transferir danos ou riscos ou de não transformar um tipo de poluição em outro nos termos do artigo 195.

Além disso, a convenção consagra o princípio da cooperação internacional em níveis global, regional e local na formulação e elaboração de regras e normas de uso sustentável domar, bem como práticas e procedimentos recomendados de caráter internacional que sejam compatíveis com o tratado para a proteção e preservação do meio marinho, tendo em conta as características próprias de cada região, conforme o artigo 197.

11 Princípio 2 - "Os Estados, de acordo com a Carta das Nações Unidas e com os princípios do direito internacional, têm o direito soberano de explorar seus próprios recursos segundo suas próprias políticas de meio ambiente e de desenvolvimento, e a responsabilidade de assegurar que atividades sob sua jurisdição ou seu controle não causem danos ao meio ambiente de outros Estados ou de áreas além dos limites da jurisdição nacional".

12 Princípio 21 - "De acordo com a Carta das Nações Unidas e com os princípios do direito internacional, os Estados têm o direito soberano de explorar seus próprios recursos, de acordo com a sua política ambiental, desde que as atividades levadas a efeito, dentro da jurisdição ou sob seu controle, não prejudiquem o meio ambiente de outros Estados ou de zonas situadas fora de toda a jurisdição nacional".

13 CNUDM, artigo $1^{\circ}, 1$ (4).
Importante salientar que a poluição marinha não é apenas causada por transportes marítimos, objeto do presente trabalho, mas também por outras atividades que são realizadas em portos, na exploração econômica dos espaços marítimos, incluindo os fundos do mar entre outros ${ }^{14}$. O Grupo Conjunto de Expertos OMI/ FAO/UNESCO-COI/OMM/OMS/OIEA/ONU/ PNUMA sobre Aspectos Científicos de Proteção do Meio Ambiente Marinho (Joint Group of Experts on the Scientific Aspects of Marine Environmental Protection - GESAMP) realizou estudos sobre a poluição marinha e levantou as principais causas. ${ }^{15}$

Esses estudos revelaram que a poluição causada por transportes marítimos representa um total de 12\% do total. A principal causa de poluição marinha é de origem terrestre incluindo rios, estuários, dutos e instalações de descarga, por lançamento de esgoto, lixos urbanos e industriais ao meio ambiente marinho. A responsabilidade civil é um importante instrumento jurídico para garantir a punição daquele que causou poluição, além dos casos mais graves que enseja a responsabilidade criminal, seja pessoa natural ou jurídica causadora do dano.

\section{O DiREITO INTERNACIONAL PRIVADO E A RESPONSABILIDADE CIVIL EXTRACONTRATUAL NAS ATIVIDADES MARÍTIMAS}

A relação entre o direito internacional privado e o direito marítimo é consequência do fenômeno da globalização econômica que intensificou o comércio entre as nações, diluindo as fronteiras dos Estados. A indústria da navegação é uma das maiores do mundo, uma vez que o transporte marítimo constitui o principal meio de distribuir a produção mundial, em virtude do custo e da possiblidade de carregar diversos produtos. Nesse cenário, "as fronteiras nacionais oferecem poucos impedimentos às empresas multinacionais" ${ }^{16}$. Isso potencializa

14 SCOVAZZI., Tullio. Chapter 13 Maritime Accidents with Particular Emphasis on Liability and Compensation for Damage from the Exploitation of Mineral Resources of the Seabed, p. 287-320. In: GUTTRY, Andrea; GESTRI, Marco; VENTURINI, Gabriella (Ed.). International disaster response law. Hague: T.M.C. Asser Press, 2012.

15 Ver: ORGANIZAÇÃO MARÍTIMA INTERNACIONAL. International Shipping Facts and Figures. Maritime Knowlegde Centre, 2012. p. 6.

16 ORGANIZAÇÃO MARÍTIMA INTERNACIONAL. International Shipping Facts and Figures. Maritime Knowlegde Centre, 2012. p. 6. 
o surgimento de situações jurídicas internacionais ou litígios transfronteiriços decorrentes de relações contratuais ou extracontratuais relacionados à navegação.

A bandeira do navio constitui um elemento de conexão importante para a solução de litígios transfronteiriços (cross-border litigations). Assim, o direito internacional privado buscar determinar a jurisdição competente e a lei aplicável aos conflitos em direito marítimo, dando maior segurança aos negócios jurídicos transnacionais. Ademais, a bandeira define a nacionalidade do navio e a jurisdição em que está registrado. Por seu turno, sob a perspectiva do comércio internacional, a nacionalidade do navio é essencial para garantir os direitos tarifários originários estabelecidos pelos países em acordos comerciais bilaterais ou multilaterais, tais como nas áreas de livre comércio, uniões aduaneiras ou nos mercados comuns.

Estudando a história do direito marítimo, a relação contratual era regida pela lei do lugar em que o ato era concluído (locus regit actum) ou no caso da responsabilidade extracontratual prevalecia a lei do pavilhão ou da nacionalidade do navio. De acordo com Carbone, esta "solution encore aujourd'hui acceptee, tout au moins dans les cas ou: i) le navire se trouve dans des espaces maritimes non soumis a la souverainete de l'Etat cotier et ii) il releve de la lex loci actus pour determiner la loi applicable a ces actes et faits". ${ }^{17}$

Os litígios transfronteiriços em direito marítimo podem decorrer tanto de obrigações contratuais quanto extracontratuais, em face de ser uma atividade de risco. Ibars afirma que a poluição marinha por navios pode ser classificada como voluntária ou acidental, e esta ocorre como consequência de um caso fortuito enquanto a primeira decorre das atividades normais do navio ou de práticas marítimas. ${ }^{18}$ As atividades cotidianas de navios e embarcações nem sempre provocam grandes derramamentos de hidrocarbonetos, por exemplo, mas nem por isso suas atividades diminuem o potencial de causar dano ao meio ambiente marinho.

A responsabilidade contratual decorre do inadimplemento de obrigações assumidas nos termos do contrato avençado. No direito marítimo, as obrigações

17 CARBONE, Sergio M. Conflits de lois en droit maritime. The Hague Academy of International Law, 2009. p. 201.

18 IBARS, Ingrid Sisteré. Corporate Social Responsibility in the Shipping Business. Master Thesis. Supervisor: Proshanto K. Mukherjee. Faculty of law Lund University. Sweden: Spring, 2013. contratuais podem surgir da compra e venda de navios, da contratação de serviços de transporte marítimo de mercadorias e de passageiros em um cruzeiro, do contrato de trabalho a bordo do navio, de contrato de direito reais sobre o navio dado em garantia, dos contratos de afretamento etc. Com fundamento no princípio da autonomia da vontade, as partes signatárias de um contrato podem escolher o direito aplicável, total ou parcialmente, e estabelecer uma cláusula arbitral em seus contratos comerciais ou um acordo arbitral para dirimir potenciais conflitos em direito marítimo.

Por seu turno, a responsabilidade extracontratual surge de uma relação não contratual na qual a pessoa, natural ou jurídica, que causar dano a outrem, tem a obrigação de reparar os prejuízos sofridos. $\mathrm{O}$ ato que causou o dano poderá ser lícito, ilícito ou por risco. De acordo como o artigo 186 do Código Civil (CC), aquele que, por ação ou omissão voluntária, negligência ou imprudência, violar direito e causar dano a outrem, ainda que exclusivamente moral, comete ato ilícito. Ademais, o artigo 187 do CC afirma que também comete ato ilícito o titular de um direito que, ao exercê-lo, excede manifestamente os limites impostos pelo seu fim econômico ou social, pela boa-fé ou pelos bons costumes.

Assim, o objetivo da responsabilidade civil consiste em "restabelecer situações abaladas por atos ilícitos por terceiros, como elemento essencial para a vida em sociedade". ${ }^{19}$ Nos termos do artigo 927 do CC, aquele que, por ato ilícito causar dano a outrem, fica obrigado a repará-lo independentemente de culpa, ou quando a atividade normalmente desenvolvida pelo autor do dano implicar, por sua natureza, risco para os direitos de outrem.

Com relação aos atos ilícitos nas relações privadas internacionais, aquelas que estão conectadas a dois ou mais ordenamentos jurídicos, o direito internacional privado busca estabelecer regras de direito aplicável à responsabilidade extracontratual por danos causados por navios ou embarcações, nacionais ou estrangeiros. Destaca-se, ainda, que no caso de dano ao meio ambiente marinho, a responsabilidade é objetiva, independentemente de culpa, e caberá ao navio poluidor a reparação do dano, objetivando principalmente a restituio in integrum e não apenas o pagamento de indenização pelos prejuízos.

19 ANTUNES, Paulo de Bessa. Dano ambiental: uma abordagem conceitual. Rio de Janeiro: Lumen Juris, 2000. p. 118. 


\subsection{A Nacionalidade dos navios}

As relações jurídicas em direito marítimo são complexas em função de sua própria natureza internacional. Embora haja discussão sobre a questão de se atribuir nacionalidade a coisas, este não é o objeto do presente trabalho, limitando-se apenas a discutir o tratamento jurídico dado ao navio. A ideia de nacionalidade dos navios "exprime conexão entre um dado conjunto de situações de que são sujeitos o proprietário, o armador, o comandante, a tripulação e os passageiros, entre outros, com alguma relação com o navio, e um determinado Estado" 20 . A nacionalidade do navio cria um vínculo jurídico-administrativo para determinar o lugar do registro de matrícula em um país e, consequentemente, o direito de arvorar a sua bandeira.

Em princípio, cada Estado é livre para definir os critérios para que um navio ou embarcação possa arvorar a sua bandeira ou o seu pavilhão, conforme dispõe ao artigo 91 da Convenção das Nações Unidas sobre Direito do Mar (CNUDM). Esta é uma regra de caráter geral que busca estabelecer regras uniformes no direito marítimo, bem como o direito do Estado de regular os bens que estão ou circulam em seu território.

O conceito de navio está relacionado à ideia de meio de transporte por água, destinado ao deslocamento de pessoas e mercadorias. Nos termos do artigo 11 da Lei 2180/54, considera-se "embarcação mercante toda construção utilizada como meio de transporte por água, e destinada à indústria da navegação, quaisquer que sejam as suas características e lugar de tráfego". Por seu turno, a Lei no 9.966/2000 define navio como "embarcação de qualquer tipo que opere no ambiente aquático, inclusive hidrofólios, veículos a colchão de ar, submersíveis e outros engenhos flutuantes", de acordo como o artigo $2^{\circ}, \mathrm{V}$. Contudo, no jogo do comércio internacional, o navio apresenta uma dimensão política com base no critério quantitativo de participação dos países na indústria da navegação. Nesse contexto, Agripino afirma que

[...] o navio, espécie do gênero embarcação, é a ferramenta principal desse setor relevante da economia mundial, no qual o Direito e a Economia devem na-

20 PINHEIRO, Luís de Lima. Temas de direito marítimo: o navio em direito internacional. Disponível em: <http://www.oa.pt/ upl/\%7Ba7992dcf-4940-4738-acd7-c9fc7e4e58c1\%7D.pdf>. Acesso em: 12 fev. 2014. vegar juntos para que haja o seu desenvolvimento, mas para que isso ocorra é preciso que as instituições funcionem com eficácia, tendo como marco fundamental a Constituição Federal. ${ }^{21}$

À luz do direito brasileiro, é por meio do registro da propriedade que se estabelece a nacionalidade de embarcações, conforme determina a Lei 7.652/1988, que dispõe sobre o registro da propriedade marítima, dos direitos reais e demais ônus e registro do armador. Nesse contexto, o Tribunal Marítimo decidiu que

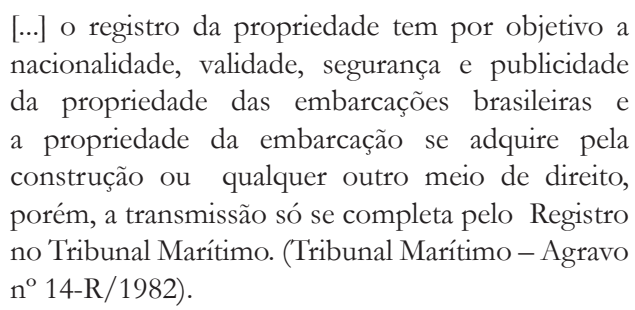

Destaca-se, ainda, o controle administrativo dos Estados sobre embarcações nacionais e estrangeiras, por intermédio de suas autoridades locais, para realizar vistorias em navios estrangeiros a fim de se examinar se estes estão cumprindo os termos da Convenção MARPOL $73 / 78$.

Contudo, de acordo com os estudos realizados pela Conferência das Nações Unidas para Comércio e Desenvolvimento (UNCTAD),

just as today most ships fly a flag that is different
from that of the owner's nationality, owners are
increasingly locating their companies in third
countries/economies, adding a possible third
dimension to the nationality of a ship and its
owner. A ship's nationality is defined by the nation
whose flag it flies, while the owner may have a
different nationality, and the owner's company that
controls the vessel may be based in a third country/
economy. These different dimensions render the
historical concept of "national fleets" more blurred
and less meaningful.

Atualmente, o Brasil ${ }^{23}$ é o país que possui a maior frota de navios da América Latina e Caribe, seguido por Venezuela e Chile, em termos localização de proprieda-

21 CASTRO JUNIOR, Osvaldo Agripino de. Principais aspectos do direito marítimo e sua relação com a Lex Mercatoria e Lex Maritima. Revista Sequência Estudos Jurídicos e Políticos, v. 31, n. 61, p. 195-225, dez. 2010. p. 203.

22 CONFERÊNCIA DAS NAÇÕES UNIDAS SOBRE COMÉRCIO E DESENVOLVIMENTO. Review of maritime transport. Geneva: United Nations Publication, 2014. p. 32.

23 CONFERÊNCIA DAS NAÇÕES UNIDAS SOBRE COMÉRCIO E DESENVOLVIMENTO. Review of maritime transport. Geneva: United Nations Publication, 2014. p. 39. 
de efetiva (beneficial ownership location), que é diferente do critério da nacionalidade do proprietário efetivo (ultimate owner's nationality).

Os navios ou embarcações têm direito de arvorar a bandeira brasileira quando inscritas no registro de propriedade marítima, de propriedade de pessoa física residente e domiciliada no país ou de empresa brasileira; ou sob contrato de afretamento a casco nu, por empresa brasileira de navegação, condicionado à suspensão provisória de bandeira no país de origem, de acordo o com o artigo $3^{\circ}$ da Lei 9.432/1997. O contrato de afretamento a casco nu estabelece ao afretador os direitos de posse uso e controle da embarcação, por tempo determinado, incluindo o direito de designar o comandante e a tripulação. Além disso, a lei estabelece cria o sistema de registro especial brasileiro - (REB), regulamentado pelo Decreto n ${ }^{\circ} 2.256 / 1997$, de caráter suplementar ao registro de propriedade marítima e de competência do Tribunal Marítimo. O REB autoriza o registro das embarcações estrangeiras afretadas a casco nu, com suspensão de bandeira de origem.

Por sua vez, o Código de Bustamante (artigos 274 a 284) afirma que a lei do pavilhão regula as formas de publicidade requeridas para a transmissão da propriedade de um navio e que a nacionalidade dos navios se prova pela patente de navegação e a certidão do registro, e tem a bandeira como sinal distintivo aparente. Além disso, São de ordem pública internacional as regras sobre a nacionalidade dos proprietários de navios e dos armadores, assim como dos oficiais e da tripulação.

O direito marítimo é um direito complexo na medida em que nem sempre há correlação do proprietário efetivo do navio com a bandeira. $\mathrm{O}$ direito do pavilhão pode ter origem contratual de afretamento, atribuindo o direito, uso e controle sobre a embarcação. Contudo, isso não exime a reponsabilidade da empresa estrangeira, nem da empresa brasileira contratante, respondendo ambos solidariamente em caso de dano.

Embora haja a possibilidade de o navio arvorar mais de uma bandeira, a CNUDM restringe a utilização segundo as conveniências de seus proprietários perante exercício de direitos contra terceiros, conforme artigo 92. De acordo com o estatuto dos navios, a norma geral é que os navios naveguem sob a bandeira de um só Estado e, somente em casos excepcionais previstos expressamente em tratados internacionais ou no texto da própria convenção. Em alto-mar, o navio está sob a jurisdição exclusiva do Estado da bandeira ou do pavilhão. Limita o direito de mudar de bandeira durante uma viagem ou em porto de escala, com exceção de transferência efetiva da propriedade ou de mudança de registo.

Agripino destaca que os navios de bandeira de conveniência, além de serem os maiores poluidores do meio ambiente, por não se submeter ao rigor fiscalizatório, são mais propensos a serem usados pelos terroristas. Para aumentar a segurança no setor, é necessária uma ação cooperativa multilateral ${ }^{24}$. No mesmo sentido, Martins assevera que

Os Registros Abertos de Bandeiras de Conveniência
(BDC) se caracterizam por oferecer total facilidade
para registro, incentivos de ordem fiscal, não
imposição de vínculo entre o Estado de Registro
e o navio. Ademais, tais Estados não exigem e nem
fiscalizam, com o devido rigor, o cumprimento e
a adoção das normas e regulamentos nacionais
ou internacionais sobre as embarcações neles
registradas. Simultaneamente às vantagens
econômicas oferecidas por tais registros, ainda se
elencam legislações e regulamentos menos severos
sobre segurança e equipamento de bordo, que não
exigem nenhum vínculo entre Estado de Registro
e navio.

Observa-se, ainda, que outro fator que atinge o mercado petrolífero e de transportes é a generalização das bandeiras de conveniência, adotadas como estratégia de redução de custos e de competitividade. ${ }^{26}$

No que tange aos acidentes causados por transporte marítimo em território brasileiro, o relatório da CETESB sobre ocorrências envolvendo petróleo e derivados no Brasil, no período de 1960 a 2012 informa que foram registrados quarenta e dois casos de vazamento por petróleo e seus derivados (lançamento no meio ambiente marinho de metanol, óleo lubrificante, nafta e de mistura oleosa). Ainda segundo o relatório revela que a maior parte desses acidentes foi causada por transportes marítimos, (acidentes de navegação por motivos diversos), representando $42 \%$ do total de acidentes (18

24 CASTRO JUNIOR, Osvaldo Agripino de. Principais aspectos do direito marítimo e sua relação com a Lex Mercatoria e Lex Maritima. Revista Sequência Estudos Jurídicos e Políticos, v. 31, n. 61, p. 195-225, dez. 2010. p. 204.

25 MARTINS, Eliane M. Octaviano. Segurança Marítima vis-à- vis Desenvolvimento Sustentável. Revista CEJ, Brasília, ano 11, n. 37, p. 103-107, abr./jun. 2007. p. 104.

26 MARTINS, Eliane M. Octaviano. Segurança Marítima vis-à- vis Desenvolvimento Sustentável. Revista CEJ, Brasília, ano 11, n. 37, p. 103-107, abr./jun. 2007. p. 104 
acidentes), sendo a maioria em áreas portuárias, por navios petroleiros. Apesar disso, o relatório constatou uma diminuição das ocorrências envolvendo transporte marítimo com petroleiros. Esses acidentes foram julgados pela justiça federal, órgão cuja competência é definida em razão da aplicação do tratado internacional sobre poluição por óleo, conforme dispõe ao artigo 109, III, da CF.

\subsection{Lei aplicável à responsabilidade extracontratual por danos ambientais em direito marítimo}

Determinar a lei aplicável é uma das tarefas do direito internacional privado para buscar soluções aos litígios transfronteiriços. No direito marítimo, estabelecer apenas como regra de conexão a aplicação do princípio da lei do pavilhão ou bandeira pode não ser a mais adequada às relações privadas internacionais, considerando-se que o evento poderá ocorrer em diferentes espaços limitados pelo direito internacional: mar territorial, zona econômica exclusiva ou alto-mar, por exemplo.

O problema da regra da lei da bandeira é que muitas vezes a lei aplicável não tem conexão com o caso. Cheshire adverte que a regra de conexão da lei da bandeira não funciona quando houver uma colisão entre dois navios arvorando diferentes bandeiras e os navios frequentemente arvoram bandeiras de conveniência e, consequentemente, a lei aplicável poderia ser a do Panamá, apesar de as partes e o evento não terem conexão com o país. ${ }^{27}$

Os principais problemas de direito marítimo estão relacionados às bandeiras de conveniência, nas quais as empresas de navegação buscam obter vantagens oferecidas pelo Estado da bandeira, como benefícios tributários e as de encargos trabalhistas. Isso traz problema para as práticas leais ao comércio marítimo internacional e é por isso que a CNUDM limita os direitos dos navios que arvoram duas bandeiras simultaneamente.

O atual código comercial Lei $n^{\circ} 556 / 1850$, que regula o comércio marítimo, não apresenta regras claras sobre a lei aplicável no caso de responsabilidade extracontratual. O artigo 529 assevera que o capitão é responsável por todas as perdas e danos que, por culpa sua,

27 CHESHIRE, Peter North; FAWCETT, James; CARRUTHERS, Janeen. Cheshire, North \& Fawcett: Private International Law. Oxford: OUP, 2008. p. 859. omissão ou imperícia, sobrevierem ao navio ou à carga; sem prejuízo das ações criminais a que a sua malversação ou dolo possa dar lugar. No caso de dano causado por abalroação, o Título XI estabelece regras específicas sobre responsabilidade. De acordo com o artigo 749 , sendo um navio abalroado por outro, o dano inteiro causado ao navio abalroado e à sua carga será pago por aquele que tiver causado a abalroação, se esta tiver acontecido por falta de observância do regulamento do porto, imperícia, ou negligência do capitão ou da tripulação; fazendo-se a estimação por árbitros. No caso de a abalroação ocorrer em alto-mar e o navio abalroado for obrigado a procurar porto de arribada para poder consertar, e se perder nessa derrota, a perda do navio presume-se causada pela abalroação, nos termos do artigo 751 do Código Comercial.

Observa-se que o código não se estabelece a lei aplicável em caso de dano, mas apenas se determina a responsabilidade do navio que causou o dano: aplica-se a lei da bandeira do navio causador do dano ou a lei local onde o dano ocorreu?

A Lei de Introdução às Normas de Direito Brasileiro é omissa quanto à lei aplicável às obrigações não contratuais, estabelecendo apenas regras de conflitos para as obrigações contratuais, aplicando-se a regra do locus regit actum e da lex loci celebrationis, ou seja, a lei do país onde o ato for constituído, conforme dispõe o artigo $9^{\circ}$.

A Emenda na Comissão no 56/2012 ao novo Projeto de Lei no 1.572/2011, que tramita na Câmara dos Deputados, visa instituir o novo código comercial e a ele foi pedida a inclusão um novo livro relativo ao Direito Marítimo. Este livro de lei dispõe especificamente sobre a lei aplicável ao direito marítimo no título II, que trata do âmbito de aplicação do Direito Comercial Marítimo, na qual dispõe Para os efeitos desse Código, consideram-se águas sob jurisdição nacional as águas compreendidas pelo mar territorial, as águas situadas nos limites da Zona Econômica Exclusiva e, além desta, as águas sobrejacentes à Plataforma Continental, conforme artigo 12.

Além disso, o projeto estabelece que os fatos e atos originados em embarcações que produzirem efeitos no Brasil são regidos pelas leis brasileiras, ainda que iniciados no território estrangeiro ou em alto-mar (artigo 14). Já os fatos e atos provenientes de embarcações que tiverem início em águas sob jurisdição nacional regem-se pelas leis brasileiras, respeitadas as leis do Estado 
em que produzirem efeito, conforme artigo 15. Por sua vez, os direitos reais e os privilégios de ordem privada sobre embarcações regem-se pela lei de sua nacionalidade (artigo 16). Com relação às medidas assecuratórias de direito, estas são reguladas pela lei do país onde se encontrar a embarcação, conforme dispõe o artigo 17 do projeto. Quanto às avarias, regulam-se pela lei brasileira quando a carga se originar ou se destinar ao Brasil ou for transportada sob o regime de trânsito aduaneiro (artigo 18).

Observa-se que o Código Comercial atual além não trazer disposições claras acerca da lei aplicável aos acidentes de navegação, dispõe apenas sobre a responsabilidade civil extracontratual fundada apenas no ilícito civil de natureza patrimonial do proprietário navio pela perda de sua propriedade, responsabilizando o navio causador do dano. Ressalta-se que, para resolver os conflitos, as partes podem recorrer à arbitragem comercial.

Já o novo projeto de lei esclarece as regras sobre lei aplicável às relações privadas internacionais decorrentes das atividades marítimas. Primeiro estabelece a regra de conexão lex loci, aplica-se a lei brasileira para os fatos e os atos ocorridos em águas sob jurisdição nacional. Contudo, reconhece a aplicação extraterritorial da lei do Estado, como por exemplo, no caso de aplicação de sanções administrativas à tripulação do navio, ainda que o fato ou ato tenha ocorrido no exterior. No que tange aos direitos reais e de hipoteca, a regra de conexão é a lexpatriae, ou seja aplica-se a lei da nacionalidade do navio ou embarcação, conforme dispõe atualmente o artigo $3^{\circ}$ da Lei no 9.432/1997e do Decreto no 2.256/1997.

Assim, no caso de responsabilidade extracontratual por danos causados por embarcações, a regra geral sobre lei aplicável é a da lex fori quando o ato ilícito ocorrer em águas brasileiras.

O projeto ainda trata da responsabilidade do armador, na qual atribui responsabilidade extracontratual por danos ambientais, conforme determina o projeto no artigo 147:

Art. [147]. As disposições relativas à limitação da responsabilidade não são aplicáveis:

I - às reclamações derivadas de operações de salvamento da própria embarcação ou de contribuição por avaria grossa;

II - às reclamações por dano ao meio ambiente;

III - às despesas de remoção de destroços;
IV - às reclamações por danos nucleares, quando proibida a limitação de responsabilidade;

$\mathrm{V}$ - aos créditos trabalhistas do capitão e membros da tripulação ou de qualquer outro empregado do armador que se encontre a bordo da embarcação ou cujas funções se relacionem com a sua operação (grifo nosso).

A previsibilidade das regras aplicáveis aos conflitos de leis no direito marítimo dá maior segurança jurídica, incluindo não apenas aquelas previsíveis nas obrigações contratuais, mas por se tratar de atividades de risco, há possibilidade de responsabilização extracontratual por danos patrimoniais e ao meio ambiente.

Em alto-mar, a regra geral é da lei da bandeira ou do pavilhão do causador do dano. Contudo, há, ainda, a necessidade de se aperfeiçoar os instrumentos de responsabilidade civil em alto-mar, que como bem afirma Soares "a poluição do meio ambiente por lançamento deliberado no alto-mar tem sido a forma usual de os Estados e empresas desfazerem-se dos resíduos industriais, urbanos e hospitalares, da maneira menos custosa do que destruí-los em terra ou nela manterem em depósito"28.

A regra de conexão para se determinar a lei aplicável à poluição marinha causada por navios é a lex loci damni. Na prática, busca-se uma proteção mais efetiva do meio ambiente marinho, com fundamento nos princípios da precaução e do poluidor-pagador e, também, em razão da natureza peculiar da indústria de navegação ser considerada de risco, levando-se em conta a carga transportada, potencializando em graus o risco de danos ao meio marinho.

Portanto, o poluidor tem a obrigação de recuperar e/ou indenizar pelos danos causados por navios ao meio ambiente marinho, de acordo com a Política $\mathrm{Na}$ cional do Meio Ambiente ${ }^{29}$, aplicando-se a lei brasileira e independentemente da nacionalidade do navio.

\subsubsection{Convenções internacionais}

No caso de danos ambientais causados por navios, as convenções internacionais não estabelecem regras

28 SOARES, Guido Fernandes Silva. Direito internacional do meio ambiente: emergência, obrigações e responsabilidades. São Paulo: Atlas, 2001. p. 226.

29 Ver artigo $4^{\circ}$, BRASIL. Lei no 6.938, de 31 de agosto de 1981. Disponível em: <http://www.planalto.gov.br/ccivil_03/Leis/ L6938.htm>. Acesso em: 07 ago. 2015. 
sobre o direito aplicável. Deduz-se, portanto, que in dubio pro natura, com fundamento no princípio da precaução do direito ambiental. Assim aplica-se a lei brasileira quando o dano correr em mar territorial, as águas situadas nos limites da Zona Econômica Exclusiva e, além desta, as águas sobrejacentes à Plataforma Continental, com fundamento na lex loci damni. Nesse sentido, de acordo com Bernasconi,

\begin{abstract}
A lei do lugar do dano (lex damni) também pode ser protetiva aos interesses do requerente na medida em que, muitas vezes, correspondem ao local de sua residência e ao lugar onde seu imóvel está localizado. Esta também se justifica pelo fato de que a principal função da lei de responsabilidade é a reparação de uma lesão e não a punição de uma falta, tanto que a responsabilidade objetiva desempenha um papel importante quando o ambiente é lesado. ${ }^{30}$
\end{abstract}

No âmbito doméstico, a Lei $n^{\circ} 9.966 / 2000$ estabelece os princípios básicos a serem obedecidos na movimentação de óleo e outras substâncias nocivas ou perigosas em portos organizados, instalações portuárias, plataformas e navios em águas sob a jurisdição nacional. Esta lei é aplicável aos casos de poluição por óleo quando ausentes os pressupostos da aplicação da Convenção Internacional para a Prevenção da Poluição Causada por Navios (Convenção MARPOL 73/78), conforme dispõe o parágrafo único do artigo $1^{\circ}$. Assim, a lei doméstica tem natureza complementar às Convenções internacionais MARPOL 73/78, CLC/69 e OPRC/90.

Ademais, a jurisprudência dos tribunais estatais, federais e do Tribunal do Mar demonstra aplicação tanto das normas internacionais uniformizadoras de direito marítimo quanto das normas de direito interno para responsabilização por danos ao meio ambiente marinho. A dicotomia entre o direito internacional e o direito interno tem engendrado conflitos de competência entre a justiça federal e a justiça estadual. Em alto-mar, os navios estão sujeitas a regra da lei da bandeira ou do pavilhão, em conformidade com o artigo 92 da CNUDM.

\subsubsection{Direito comunitário europeu}

No âmbito do direito internacional privado comunitário, o Regulamento (CE) no 864/2007 do Parlamento

30 BERNASCONI, Christophe. Civil liability resulting from transfrontier environmental damage: a case for the Hague Conference? Disponível em: <http://www.hcch.net/upload/wop/gen_pd8e.pdf>. Acesso em: 14 ago. 2014
Europeu e do Conselho da União Europeia (Regulamento Roma II) estabelece as regras de lei aplicável às obrigações extracontratuais em geral.

O preâmbulo do regulamento em seu parágrafo 24 define danos ambientais como a alteração adversa de um recurso natural, como a água, o solo ou o ar, ou a deterioração do serviço de um recurso natural em benefício de outro recurso natural ou do público, ou a deterioração da variabilidade entre organismos vivos.

De acordo com o artigo $7^{\circ}$ relativo a danos ambientais,

A lei aplicável à obrigação extracontratual que decorra de danos ambientais ou de danos não patrimoniais ou patrimoniais decorrentes daqueles é a que resulta da aplicação do ${ }^{\circ} 1$ do artigo $4^{\circ}$, salvo se a pessoa que requer a reparação do dano escolher basear o seu pedido na lei do país onde tiver ocorrido o dano.

Por sua vez, o artigo $4^{\circ}$ dispõe sobre a regra geral:

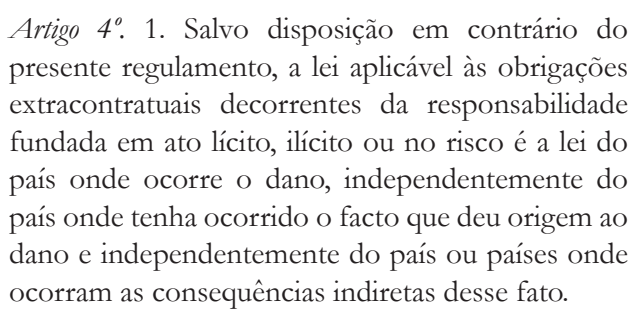

Desse modo, as regras estão claras quanto à lei aplicável aos danos ocorridos em águas territoriais dos Estados membros da União Europeia. Entretanto, o problema reside em se determinar a lei aplicável em alto-mar, considerando as bandeiras de conveniência, uma vez que nem sempre têm conexão com a poluição marinha. Como afirma Cheshire, a identificação da lei aplicável por danos ocorridos em alto-mar não é uma questão fácil. ${ }^{31}$

\subsection{Obrigações extracontratuais: jurisdição e competência em acidentes marítimos}

A competência judicial internacional estabelece critérios para se conhecer os litígios transfronteiriços. Com fundamento na soberania estatal, cada país define os critérios de competência internacional, concorrente ou exclusiva, nos limites de seu território. A eficácia extraterritorial dos atos judiciais se baseia no princípio

31 CHESHIRE, Peter North; FAWCET'T, James; CARRUTHERS, Janeen. Cheshire, North \& Fawcett. Private International Law. Oxford: OUP, 2008. p. 860. 
da cooperação jurídica internacional. Nos casos de responsabilidade extracontratual em direito marítimo, qual o foro competente para resolver os litígios transfronteiriços: domicílio do réu, o lugar onde tiver de ser cumprida a obrigação de reparar o dano ou o lugar do fato danoso?

Há uma pluralidade de fontes normativas sobre questões referentes às obrigações extracontratuais tanto de direito interno (considerando os diversos ordenamentos jurídicos) quanto em direito internacional público e em direito internacional privado. Os efeitos dos danos plurilocalizados podem atingir tanto pessoas quanto bens conectados a diversos ordenamentos jurídicos, seja pelo estatuto pessoal seja pelo objeto ou pelo ato ou fato jurídico.

Para se estudar a jurisdição e a competência para julgar a responsabilidade civil por danos causados por navios ou embarcações ao meio ambiente marinho, deve-se ter em conta se o fato ocorreu em águas territoriais ou em águas internacionais.

\subsection{1. Águas territoriais}

As águas territoriais são aquelas que estão sob o domínio do Estado, e ao direito marítimo compete estabelecer os regimes jurídicos especiais sobre os espaços marítimos. A Convenção das Nações Unidas sobre Direito do Mar (CNUDM) afirma que a soberania do Estado costeiro estende-se além do seu território e das suas águas interiores e, no caso de Estado arquipélago, das suas águas arquipelágicas, a uma zona de mar adjacente designada pelo nome de mar territorial. Essa soberania estende-se ao espaço aéreo sobrejacente ao mar territorial, bem como ao leito e ao subsolo desse mar, conforme dispõe o artigo $2^{\circ}$ da CNUDM.

O Estado exerce, ainda, direito de soberania para fins de exploração e aproveitamento, conservação e gestão dos recursos naturais, vivos ou não vivos das águas sobrejacentes ao leito do mar, do leito do mar e seu subsolo, e no que se refere a outras atividades com vista à exploração e aproveitamento da zona para fins econômicos e jurisdição sobre a zona econômica exclusiva para a proteção e preservação do meio marinho, de acordo como o artigo $56 \mathrm{da}$ CNUDM.

Além disso, o Estado costeiro exerce direitos de soberania sobre a plataforma continental para efeitos de exploração e aproveitamento dos seus recursos naturais, conforme disposto no artigo 77 da CNUDM. Já o alto-mar é aberto a todos os Estados costeiros e sem litoral, tendo o direito de fazer navegar os navios que arvorem sua bandeira.

Nesse contexto, a definição dos espaços marinhos no plano internacional foi importante para se determinar as competências judiciais, administrativas e tributárias sobre o direito de navegação. Igualmente, reconhece a soberania territorial dos Estados sobre as águas interiores, incluindo o mar territorial, plataforma continental e zona econômica exclusiva.

O princípio da precaução engendra políticas públicas para evitar o dano. Os instrumentos de fiscalização e monitoramento das atividades marítimas são importantes, considerando a potencialidade do risco de poluição marinha em face do conteúdo da carga transportada. Nesse sentido, a Lei $n^{\circ} 9.966 / 2000^{32}$ estabelece regras para a prevenção, o controle e a fiscalização da poluição causada por lançamento de óleo e outras substâncias nocivas ou perigosas em águas sob a jurisdição nacional. Essa lei classifica, ainda, as substâncias nocivas ou perigosas em quatro categorias de $\mathrm{A}$ a $\mathrm{D}$, do mais alto ao mais baixo em grau de risco, tanto para a saúde das pessoas como para o ecossistema aquático, em conformidade com as normas estabelecidas pela Convenção MARPOL 73/78.

Por sua vez, o Decreto $n^{\circ} 8.127 / 2013$, que instituiu o Plano Nacional de Contingência para Incidentes de Poluição por Óleo em Águas sob Jurisdição Nacional, define águas marítimas brasileiras como todas aquelas sob a jurisdição nacional que não sejam interiores. São águas marítimas:

$$
\begin{aligned}
& \text { a) as águas abrangidas por uma faixa de doze milhas } \\
& \text { marítimas de largura, medidas a partir da linha } \\
& \text { de base reta e da linha de baixa-mar, conforme } \\
& \text { indicação das cartas náuticas de grande escala, } \\
& \text { reconhecidas oficialmente no Brasil - mar territorial; } \\
& \text { b) as águas abrangidas por uma faixa que se estende } \\
& \text { das doze às duzentas milhas marítimas, contadas a } \\
& \text { partir das linhas de base que servem para medir o } \\
& \text { mar territorial, que constituem a zona econômica } \\
& \text { exclusiva; e } \\
& \text { c) as águas sobrejacentes à plataforma continental, } \\
& \text { quando esta ultrapassar os limites da zona } \\
& \text { econômica exclusiva. }
\end{aligned}
$$

32 Regulamentada pelo Decreto no 4136/2002, que dispõe sobre a especificação das sanções aplicáveis às infrações às regras de prevenção, controle e fiscalização da poluição causada por lançamento de óleo e outras substâncias nocivas ou perigosas em águas sob jurisdição nacional. 
A harmonização entre o direito interno e o direito internacional é essencial para dar maior segurança jurídica às atividades de navegação. Desse modo, nota-se que as normas internas e internacionais reconhecem a jurisdição dos Estados sobre as águas territoriais e, consequentemente, a competência das autoridades administrativas (fiscalizatórias) e judiciais no caso de acidentes marítimos e incidentes da navegação, incluindo aqueles que causarem danos ao meio ambiente marinho.

À luz do direito brasileiro, a regra de conexão para determinar a competência internacional sobre responsabilidade civil extracontratual é a do forum damni, isto é, o tribunal do Estado onde ocorreu o dano. O Código de Processo Civil (CPC) em matéria de competência judicial internacional estabelece que:

Art. 88. É competente a autoridade judiciária brasileira quando:

I - o réu, qualquer que seja a sua nacionalidade, estiver domiciliado no Brasil;

II - no Brasil tiver de ser cumprida a obrigação;

III — a ação se originar de fato ocorrido ou de ato praticado no Brasil. (grifo nosso).

Por seu turno, o Novo CPC -Lei no 13.105/2015, no capítulo referente aos limites da jurisdição nacional, estabelece que:

Art. 21. Compete à autoridade judiciária brasileira processar e julgar as ações em que:

I - o réu, qualquer que seja a sua nacionalidade, estiver domiciliado no Brasil;

II - no Brasil tiver de ser cumprida a obrigação;

III - o fundamento seja fato ocorrido ou ato praticado no Brasil. (grifo nosso).

Ademais, a jurisdição civil é regida pelas normas processuais brasileiras, ressalvadas as disposições específicas previstas em tratados, convenções ou acordos internacionais de que o Brasil seja parte, nos termos do artigo 13 do Novo CPC. Destarte, com fundamento na norma processual, observa-se que, na jurisprudência brasileira, aplica-se a regra do forum damni, isto é, a autoridade judicial brasileira é competente para julgar os casos de poluição marinha em águas territoriais (mar territorial, plataforma continental e zona econômica exclusiva).

Por sua vez, o Tribunal Marítimo, criado em 1931, é órgão administrativo vinculado ao Ministério da Marinha e auxiliar do poder judiciário, nos termos do artigo $1^{\circ}$ da Lei no $2.180 / 1954$. De acordo com o artigo 10, o Tribunal Marítimo exerce jurisdição sobre:

a) embarcações mercantes de qualquer nacionalidade, em águas brasileiras;

b) embarcações mercantes brasileiras em alto-mar, ou em águas estrangeiras;

c) embarcações mercantes estrangeiras, em altomar, nos casos de estarem envolvidas em qualquer acidente marítimo ou incidente de navegação, no qual tenha pessoa física brasileira perdido a vida ou sofrido ferimentos graves, ou que tenham provocado danos graves a navios ou a instalações brasileiras ou no meio marinho, de acordo com as normas do Direito Internacional;

$[\ldots]$

e) os marítimos estrangeiros, em território ou águas territoriais brasileiras;

l) toda pessoa jurídica ou física envolvida, por qualquer forma ou motivo, em acidente ou fato da navegação, respeitados os demais instrumentos do Direito Interno e as normas do Direito Internacional.

Com relação à competência internacional, o Tribunal Marítimo é competente para julgar tanto acidentes de navegação, tais como, naufrágio, encalhe, colisão, abalroação, água aberta, explosão, incêndio, arribada, alijamento e avaria, como fatos da navegação, tais como mau aparelhamento ou a impropriedade da embarcação, a alteração da rota, má estivação da carga entre outros enumerados no artigo $14 .^{33}$

Observa-se que a jurisdição sobre questões em águas interiores não é absoluta, mas concorrente. A jurisdição é exclusiva para exercer o poder de polícia, tais como a fiscalização e aplicação de multas a navios estrangeiros que agem contrariamente às normas brasileiras. Por outro lado, a jurisdição pode ser concorrente, ainda que se trate de coisa julgada em relação às obrigações contratuais. Em 1935, o caso da Cia. de Navegação Lóide Brasileiro, proprietária do navio Campos, foi condenada por tribunal arbitral argentino a ressarcir os danos causados ao navio inglês Westminster em razão do abalroamento entre ambos, em águas territoriais argentinas. $\mathrm{O}$ laudo concluiu pela culpa do capitão do navio brasileiro. Nesse contexto, o Tribunal Marítimo Administrativo (TMA) em nota no Processo no 186 (1938) nesse caso ementou:

33 Importante destacar que s decisões do Tribunal Marítimo, quanto a matéria técnica referente aos acidentes e fatos de navegação têm valor probatório e se presumem certas, sendo porém suscetíveis de reexame pelo Poder Judiciário Art. 18 
Jurisdições concorrentes. Embora se trate de coisa julgada, nenhum dispositivo legal, ou regra de direito internacional, veda ao Estado o direito de examinar e punir administrativamente os atos funcionais de seus jurisdicionados no estrangeiro. ${ }^{34}$

De acordo com essa decisão, o Tribunal Marítimo reconheceu a competência do tribunal arbitral argentino para os fatos ocorridos em seu mar territorial, reconheceu a responsabilidade do capitão do navio brasileiro para efeitos de reparação civil, de caráter meramente patrimonial pelos danos materiais causados ao lesado. Contudo, entendeu que, em virtude da lei do pavilhão, o tribunal brasileiro era também competente para julgar e aplicar as penalidades de ordem administrativa ao causador do acidente, o capitão ou qualquer membro de sua tripulação.

$\mathrm{Na}$ União Europeia, o artigo $7^{\circ}$, parágrafo $2^{\circ}$, do Regulamento (EU) no 1215/2012 do Parlamento Europeu e do Conselho relativo à competência judiciária, ao reconhecimento e à execução de decisões em matéria civil e comercial estabelece que as pessoas domiciliadas num Estado-membro podem ser demandadas em outro Estado-membro. O regulamento dispõe sobre competências especiais e, em relação à matéria extracontratual atribui competência ao tribunal do lugar onde ocorreu o dano ou poderá ocorrer o fato danoso. Nesse sentido, Caravaca afirma que este artigo outorga competência aos tribunais de um determinado lugar, e não somente a dos tribunais de um Estado-membro em seu conjunto. Não obstante, podem ocorrer casos em que a competência dos tribunais de um Estado-membro seja clara, mas não seja possível identificar com precisão o órgão judicial competente desse Estado. É o caso de ilícitos verificados a bordo de navios e aeronaves. ${ }^{35}$

Nessa seara, a Emenda na Comissão no 56/2012 do Projeto de Lei $n^{\circ}$ 1.572/2011 sobre Direito Comercial Marítimo, que tramita na Câmara dos Deputados, propõe a criação de regras especiais de Direito Processual Marítimo. Com relação à competência internacional, sem prejuízo das normas gerais de processo civil, o artigo 229 determina a competência da autoridade judiciária brasileira com relação a embarcações brasileiras, em qualquer lugar que se encontrem; para conhecer de

34 TRIBUNAL MARÍTIMO ADMINISTRATIVO. Processo $n^{\circ}$ 186/1938. Disponível em: <https://www.mar.mil.br/tm/download/anuario/1936_1940/186.pdf>. Acesso em: 15 fev. 2014.

35 CARAVACA, Alfonso-Luis Calvo; GONZÁLEZ, Javier Carrascosa. Derecho internacional privado. 14. ed. Granada: Comares, 2014. v. 1. p. 1.125 . ações de embargo de embarcação ${ }^{36}$ estrangeira que se encontre em águas jurisdicionais brasileiras, independentemente do local de cumprimento da obrigação, ainda que esta não se origine de fato ocorrido ou de ato praticado no Brasil; e com relação às demais pretensões envolvendo embarcações estrangeiras, quando se encontrarem em águas jurisdicionais brasileiras.

\subsection{2. Águas estrangeiras}

As águas estrangeiras são consideradas aquelas que estão sujeitas à jurisdição do Estado estrangeiro, tendo competência legislativa e jurisdicional. De acordo com Cheshire, os tribunais ingleses tradicionalmente têm aplicado uma abordagem literal do local do dano, quando o ato ou fato ocorrer em águas territoriais. ${ }^{37}$

Destarte, observa-se que a regra geral para estabelecer competência para julgar em águas estrangeiras é forum damni estrangeira. Assim, nos casos de uma empresa de navegação brasileira ter causado dano em águas marítimas internas dever acionar os instrumentos da cooperação jurídica internacional para dar eficácia extraterritorial aos atos judicias do tribunal competente. Nesse caso, a carta rogatória é um dos principais instrumentos para comunicação de atos e obtenção de provas no exterior nos casos de litígios transfronteiriços por danos causados por transportes marítimos.

$\mathrm{Na}$ Carta Rogatória n $1.433 / \mathrm{BE}$, a autoridade belga formulou um pedido de cooperação jurídica internacional para que se procedesse à inquirição da Empresa de Navegação Elcano S/A, a respeito da acusação de violação da lei relativa à proteção do meio marinho ocorrido no mar territorial belga (lex loci dammi). Apesar da impugnação sob a alegação de ofensa à ordem pública pela empresa brasileira, o Superior Tribunal de Justiça (STJ) acolheu a impugnação apenas parcialmente para solicitar ao juiz belga (rogante) o questionário das perguntas a serem formuladas à empresa e a cópia da legislação mencionada no pedido rogatório, notadamente à relativa a responsabilização penal da pessoa jurídica. Ao

36 O Embargo de Embarcação, definido no artigo 231 do Projeto de Lei, refere-se à tutela judicial de urgência, que visa impedir a saída de embarcações, brasileiras ou estrangeiras, das águas jurisdicionais brasileiras. O objetivo é caucionar a dívida, nos termos da lei da embarcação estrangeira e quando o navio nacional não disponha de outro patrimônio no país.

37 CHESHIRE, Peter North; FAWCET'T, James; CARRUTHERS, Janeen. Cheshire, North \& Fawcett: Private International Law. Oxford: OUP, 2008. p. 859. 
agravo regimental da carta rogatória foi negado provimento em face de a diligência não ofender a soberania nacional e nem a ordem pública e que "os temas que a empresa brasileira pretende ver analisados dizem respeito ao mérito da controvérsia, insuscetível de apreciação no procedimento rogatório". Ao Superior Tribunal de Justiça não compete analisar causa a ser decidida no exterior (forum damni).

Desse modo, observa-se que a regra geral para a competência internacional para julgar os casos de responsabilidade extracontratual em caso de poluição marinha é a regra do forum damni. Nessa diretriz, Caravaca sustenta que “o tribunal que corresponde ao 'lugar do dano' é um tribunal que pode devolver seu trabalho jurisdicional de maneira efetiva e real, com qualidade jurídica e a um custo reduzido, isto é, de maneia diferente". ${ }^{38}$

Em consequência, o reconhecimento da competência para julgar casos de responsabilidade civil extracontratual por danos marinhos é essencial para facilitar o reconhecimento e homologação de sentença estrangeira e assegurar seus efeitos extraterritoriais.

\subsection{3 Águas internacionais}

A complexidade do direito marítimo é mais acentuada quando ocorrem atos lícitos, ilícitos ou por riscos causados por transportes marítimos, seja a bordo do navio, seja por atos externos causados pelo navio. Embora os navios em mar internacional estejam sujeitos à regra da lei da bandeira ou do pavilhão, essa regra não se entende a competência internacional, uma vez que nem sempre é a regra que mais se aproxima do caso. No caso de poluição marinha, a responsabilidade objetiva é do poluidor-pagador. Mas se o navio arvorar duas ou mais bandeiras de conveniência, torna-se mais difícil a sua responsabilização, assim como os navios piratas, por exemplo.

Por seu turno, o direito brasileiro atribui competência ao Tribunal Marítimo para julgar embarcações mercantes brasileiras em alto-mar, ou em águas estrangeiras e, também, embarcações mercantes estrangeiras em alto-mar, no caso de estarem envolvidas em qualquer

38 CARAVACA, Alfonso-Luis Calvo; GONZÁLEZ, Javier Carrascosa. Derecho internacional privado. 14. ed. Granada: Comares, 2014. v. 1. p. 1.125. O problema continua em se estabelecer as regras de competência em alto-mar, principalmente quando se tratar de navios que arvoram bandeiras de conveniência. acidente marítimo ou incidente de navegação, no qual tenha pessoa física brasileira perdido a vida ou sofrido ferimentos graves, ou que tenham provocado danos graves a navios ou a instalações brasileiras ou ao meio marinho, de acordo com as normas do Direito Internacional. ${ }^{39} \mathrm{O}$ tribunal marítimo tem julgado os casos em alto-mar aplicando as leis brasileiras, como ementados nos casos abaixo:

\section{Ementa: B/M "SANTA MARTA II". Pane de máquinas, deixando a embarcação à deriva em alto-mar. Deficiência de manutenção. Negligência. Condenação. (Tribunal Marítimo, Processo $\mathrm{n}^{\circ}$ 15.684, Data do Julgamento: 18/06/1996). \\ Ementa: Abalroamento em alto-mar. Causa: ma interpretação das Regras do R IPEAM. Condenação. (Tribunal Marítimo, Processo $\mathrm{n}^{\circ}$ 7.758, Data do Julgamento: 03/05/1977). \\ Ementa: Naufrágio de navio estrangeiro em alto mar. Incompetência do Tribunal Marítimo. Tribunal Marítimo, Processo $n^{\circ}$ 944, Data do Julgamento: 17/01/1950).}

A CNUDM estabelece regras sobre jurisdição penal em caso de abalroamento ou de qualquer outro incidente de navegação ocorrido a um navio no alto-mar que possa acarretar uma responsabilidade penal ou disciplinar para o capitão ou para qualquer outra pessoa ao serviço do navio, nas quais os procedimentos penais e disciplinares contras essas pessoas só podem ser iniciados perante as autoridades judiciais ou administrativas a competência do Estado de bandeira ou perante as do Estado do qual essas pessoas sejam nacionais, conforme o artigo 97.

No que tange à imunidade de jurisdição, o artigo define os casos em que os navios ou embarcações de um Estado estarão submetidos exclusivamente à lei do pavilhão/bandeira em mar internacional, conforme dispõe os artigos 95 e 96 da CNUDM. São eles: os navios de guerra no alto-mar, que gozam de completa imunidade de jurisdição relativamente a qualquer outro Estado que não seja o da sua bandeira e os navios utilizados unicamente em serviço oficial não comercial. Os navios pertencentes a um Estado ou por ele operados e utilizados unicamente em serviço oficial não comercial gozam, no alto-mar, de completa imunidade de jurisdição relativamente a qualquer Estado que não seja o da sua bandeira.

39 Lei no 2180/1954, artigo 10. 


\section{OS TRIBUNAIS BRASILEIROS E A COMPETÊNCIA INTERNACIONAL PARA POLUIÇÃO MARINHA DE HIDROCARBONETOS E SEUS DERIVADOS CAUSADOS POR NAVIOS ESTRANGEIROS}

O transporte marítimo é considerado de alto risco quando carrega substâncias nocivas ou perigosas que, se descarregada nas águas, é capaz de gerar riscos ou causar danos à saúde humana, ao ecossistema aquático ou prejudicar o uso da água e de seu entorno. Busca-se, assim, um equilíbrio entre as atividades de navegação e o meio ambiente, com políticas e medidas de proteção ao meio ambiente marinho, assim como a das populações que habitam o entorno e, algumas delas, dependem do mar como fonte de subsistência, como as atividades dos pescadores.

Os principais casos de poluição marinha por petróleo e seus derivados no Brasil foram causados por transportes marítimos, incluindo navios nacionais e estrangeiros. Esses casos foram apreciados pelos tribunais brasileiros que reconhecem a responsabilidade objetiva, independentemente de culpa do agente. Ainda que o dano causado seja de pouca gravidade e a empresa tenha tomado todas as medidas necessárias à contenção e recolhimento do óleo derramado da embarcação, isso não a desqualifica como poluidora-pagadora, aplicando-se o próprio princípio de que aquele que causar danos ao meio ambiente ficará sujeito a sanções penais e administrativas, sem prejuízo da obrigação de promover a reparação dos danos ocasionados. Na Apelação Cível julgada pelo Tribunal Regional Federal (TRF) da $3^{\text {a }}$ Região, o juiz destacou que "mesmo que se considere a sua quantidade e adoção das medidas necessárias à sua imediata contenção e remoção, há de se ponderar que o derramamento de óleo no mar sempre ocasionará um dano ao meio ambiente, pois provocará um desequilíbrio à fauna e à flora locais". ${ }^{40}$

As empresas exploradoras de petróleo e seus derivados também podem ser responsabilizadas por danos ao

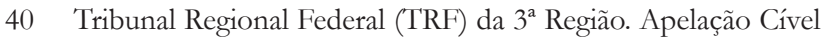
nº10607 SP 0010607-88.2011.4.03.6104, Relator: juiz convocado Roberto Jeuken, data de julgamento: 06/11/2014, Terceira Turma. Ementa: Ação civil pública. Indenização. Dano ambiental. Derramamento de óleo no mar. Responsabilidade objetiva. Indenização devida. Valor monetário da indenização. Proposta emitida conforme critério estabelecido pela CETESB. Peculiaridades do caso concreto. Princípios da razoabilidade e da proporcionalidade. Honorários advocatícios incabíveis. meio ambiente marinho causados por óleo, principalmente em áreas de domínio do Estado, como no caso da zona econômica exclusiva. Veja-se o exemplo da área do pré-sal. Varella ressalta que embora as empresas estejam investindo recursos financeiros muito elevado para a extração do petróleo, há um grande potencial de impacto ambiental. Nesse sentido, o autor afirma que "e ste cenário formidável sublinha a importância de um quadro jurídico correto para evitar desastres graves". ${ }^{41}$

O artigo IX da Convenção Internacional sobre Responsabilidade Civil em Danos Causados por Poluição por Óleo, de 1969, ${ }^{42}$ estabelece a competência internacional dos Estados

1. Quando um incidente tiver causado dano por poluição num território, incluindo o mar territorial de um ou mais estados contratantes, ou quando em tal território, incluindo o mar territorial, foram tomadas medidas preventivas para evitar ou minimizar o dano pela poluição, as ações para Indenização somente poderão ser impetradas nos tribunais desse ou desses estados contratantes. [...]

2. Cada Estado contratante deverá se assegurar de que seus tribunais são competentes para conhecer tais ações de indenização.

Assim, a convenção visa harmonizar os direitos nacionais aos padrões internacionais, aplicando-se a regra do forum damni, independentemente da lei da bandeira ou do pavilhão. A vantagem do reconhecimento da competência internacional do local do dano afasta o forum shopping e tem maior aproximação com o evento danoso. Assim, os tribunais brasileiros são competentes para julgar os danos ocorridos em mar territorial e na zona econômica exclusiva.

Em 1987, o navio de bandeira liberiana, atracado no Porto do São Sebastião casou dano ambiental por derramamento de óleo em razão de defeito na válvula, que provocou o transbordo do tanque. Foi lavrado o auto de infração e aplicação de multa. O Supremo Tribunal Federal (STF) negou seguimento ao recurso extraordinário e manteve a decisão do Tribunal Regional Federal da $3^{a}$ Região, uma vez que "envolveria a reapreciação do conjunto probatório que permeia a causa, bem assim da legislação infraconstitucional pertinente, o que é inadmissível

41 In Varella, Marcelo D. A necessidade de repensar os mecanismos de responsabilidade ambiental em caso de riscos de vazamento de petróleo em altomar no Brasil. Revista de Direito Internacional, vol.12, no.1. (nesta edição).

42 Aprovada pelo Decreto Legislativo $\mathrm{n}^{\circ} 74$ de 30 de setembro de 1976 e promulgada pelo Decreto n ${ }^{\circ}$ 79.437, de 28 de março de 1977. 
em recurso extraordinário, podendo configurar apenas ofensa indireta ou reflexa à Constituição da República." ${ }^{43}$ Ademais, manteve a multa aplicada no auto de infração pela Capitania dos Portos e determinou como lei aplicável a Lei $n^{\circ}$. 5.357/67, que dispõe sobre as infrações aplicáveis aos navios e terminais, marítimos ou fluviais, que derramarem ou lançarem óleo ou detritos em mar territorial brasileiro. $\mathrm{O}$ acórdão a quo declarou que

\begin{abstract}
quanto ao outro fundamento deduzido, para justificar que a multa imposta é indevida, consistente na alegação de que o óleo derramado no mar foi imediatamente recolhido, não se caracterizando a infração, pois foi evitada a poluição, ou seja, não se consumou o dano ambiental, não merece prosperar, pois, o procedimento de sindicância instaurada para apurar as causas do derramamento do óleo, estimou em 75 metros cúbicos o volume de óleo derramado, ou seja, 75.000 litros, poluindo as águas do Canal de São Sebastião. E, ainda que tenha sido bem-sucedida a operação de recolhimento do óleo, promovida pelos órgãos competentes brasileiros, conforme consta do relatório do CODEL (Comitê de Defesa do Litoral), tal fato não afasta o evidente dano ambiental causado pelo navio, resultando sim em prejuízos irreversíveis ao meio ambiente, considerando inclusive o teor do auto de exame pericial acostado aos autos. ${ }^{44}$
\end{abstract}

Nos contratos de afretamento, a empresa brasileira que contrata navio nacional, ou estrangeiro para transporte de óleo, responde objetiva e solidariamente por todos os danos causados ao meio ambiente marinho. O Superior Tribunal de Justiça (STJ) manteve a decisão afirmando que "a contratação do navio, aí incluída a tripulação, foi feita pela ré. Logo, os responsáveis pela desastrada manobra de atracação, que resultou no vazamento do óleo, eram agentes da ré, pessoa jurídica prestadora de serviço público que detém o monopólio da exploração, transporte e refino do óleo bruto". Além disso, "se a empresa, ré, escolheu mal seus agentes, agiu com negligência e deve responder pelos prejuízos que esses contratados, na qualidade de prepostos, causaram ao exercer o trabalho de sua responsabilidade (fl. 709)." ${ }^{45}$

43 BRASIL. Supremo Tribunal Federal. Recurso Extraordinário, RE $n^{\circ}$ 630236/SP. Relator Ministro Dias Toffoli. Brasília, 08 de novembro de 2013.

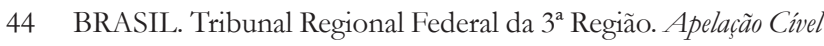
$n^{\circ} 56072$ SP 96.03.056072-3. Turma suplementar da Segunda Seção Direito Administrativo. Relator: juiz convocado Valdeci dos Santos. Brasília, 27 de março 2008. Ementa: Derramamento de óleo. Canal de São Sebastião. Navio de bandeira liberiana. Dano ambiental. Leis n. 5.357/67 E 6.831/81. Auto de infração. Multa. Validade.

45 BRASIL. Superior Tribunal de Justiça. Agravo Recurso Especial $n^{\circ}$ 259.879-SP. Relator: Min. Luis Felipe Salomão. Brasília, 21 de novembro de 2013.
Em outro caso de poluição marinha, um navio de bandeira estrangeira, fretado por empresa brasileira, lançou ao mar de cerca de 500 (quinhentos) litros de petróleo provenientes da operação de descarregamento, em 1993. A Comissão Estadual de Controle Ambiental do Estado do Rio de Janeiro lavrou auto de infração contra a empresa brasileira, Petrobras, pelo dano ao meio ambiente. Em razão disso, a empresa petrolífera ingressou com ação judicial contra o Estado do Rio de Janeiro objetivando anular a multa imposta alegando tanto a incompetência do órgão estadual para aplicação da penalidade quanto à ausência de caracterização objetiva do ato ilícito por ser parte ilegítima para figurar no polo passivo da obrigação. Em sua defesa, a empresa sustentou, ainda, que somente o proprietário da embarcação estrangeira poderia responder pelo dano ambiental, uma vez que a empresa brasileira não possuía qualquer ingerência na direção do navio, afastando-se assim, o dever in elegendo ou in vigilando sobre a tripulação. $\mathrm{O}$ STJ negou provimento ao recurso especial, mantendo sentença monocrática que decidiu que "a pessoa física ou jurídica, de direito público ou privado, responsável direta ou indiretamente e, por atividade de degradação ambiental (art. $3^{\circ}$, inciso IV, da Lei no 6.938/81)". No caso, a empresa brasileira é responsável em razão do risco de sua atividade em causar danos ambientais, que consubstancia o nexo causal de sua responsabilidade, independentemente, de o derramamento de óleo ter ocorrido por culpa da embarcação contratada. ${ }^{46} \mathrm{O}$ ministro relator destacou, ainda, que

[...] merecem tratamento diverso os danos ambientais provocados por embarcação de bandeira estrangeira contratada por empresa nacional cuja atividade, ainda que de forma indireta, seja a causadora do derramamento de óleo, daqueles danos perpetrados por navio estrangeiro a serviço de empresa estrangeira, quando então resta irretorquível a aplicação do art. $2^{\circ}$, do Decreto $n^{\circ} 83.540 / 79$.

Ademais, a empresa tem o direito de ação de regresso contra o culpado mesmo na responsabilidade objetiva em face de suportar o ônus da indenização. O STJ decidiu que a eventual exoneração da recorrente por culpa de terceiro poderá ser aferida em ação regressiva, inter partes. Assim, o poluidor (responsável direto ou indireto) por poluição marinha tem a obrigação de indenizar e/ou reparar os danos causados tanto ao meio ambiente

46 BRASIL. Superior Tribunal de Justiça. Recurso Especial $n^{\circ}$ 467.212-RJ (2002/0106671-6). Relator: Min. Luiz Fux. Brasília, 28 de outubro de 2003. 
quanto a terceiros afetados, independentemente da existência de culpa, sem obstar a aplicação das penalidades administrativas impostas.

Em outro caso, um navio, de bandeira alemã, deu causa a vazamento de óleo no mar, em 2 de maio de 1990, como consequência de manobra errônea para o tanque lastre n. 1, no estuário de Santos, na região do canal de Piaçaguera, no Porto de Santos/SP. O STJ manteve a sentença de primeira instância que fundamentou a fixação do valor indenizatório em parecer emitido pela CETESB, que concluiu que

O derramamento de óleo causou dano ecológico, ao relatar os efeitos que o produto causa aos ecossistemas marinhos por ele infestados, a saber morte direta por reconhecimento e asfixia, morte direta por intoxicação, redução da taxa de fertilização, incorporação de substâncias carcinogênicas, efeitos dito subletais (morte ecológica) e outros ${ }^{47}$

Além disso, o STJ declarou que tanto os artigos $3^{\circ}$ e $4^{\circ}$ da $6.938 / 81$ quanto o artigo $1^{\circ}$ da Convenção Internacional sobre Responsabilidade Civil em Danos Causados por Poluição de Óleo (CLC-69) se prestariam para alterar o conteúdo do julgamento, pois "consignam a qualificação de poluidor e a consequente necessidade de recuperar a área ambiental e a imposição do dever de indenizar pelos danos causados, como ocorreu na espécie”. Manteve, ainda, a decisão quanto ao início a contagem dos juros de mora, que incide a partir da ocorrência do evento poluidor.

Outro acidente que causou poluição ao meio ambiente marinho e prejuízos à população foi o naufrágio do comboio oceânico, composto por duas embarcações na Baía da Babitonga, na região de São Francisco do Sul/SC, com o vazamento de óleo 107 m3. Segundo o desembargador, o laudo técnico produzido pela Universidade da Região de Joinville (UNIVILLE), na Medida Cautelar de Produção Antecipada de Provas realizada para instruir a Ação Civil Pública,

[...] atestou, de forma inequívoca, que o vazamento de óleo causou a morte de várias espécies de animais marinhos da região, afetando, inclusive, a reprodução destes, uma vez que ovos e larvas de peixes sofreram com o impacto ambiental, criandose a expectativa de que efeitos do incidente deveriam perdurar por aproximadamente três anos. ${ }^{48}$

47 BRASIL. Superior Tribunal de Justiça. Recurso Especial $n^{\circ}$ 735.534-SP. Relator: Min. Castro Meira. Brasília: 20 de novembro de 2008.

48 BRASIL. Superior Tribunal de Justiça. Agravo em Recurso Especial no 530.673-SC. Relator: Min. Buzzi. Brasília, 8 de agosto de 2014.
Além disso, o STJ negou provimento ao agravo em recurso especial, já que na CLC-1969 resta claro que a sua aplicação diz respeito à poluição por óleo decorrente do transporte marítimo de óleo a granel, não alcançando a poluição por óleo decorrente de incidentes com navios cuja carga seja diversa da prevista na Convenção, como é o caso dos autos, que trata de transporte interno, via marítima, de bobinas de aço. ${ }^{49}$. Assim, ficou demonstrado que o acidente causou grande derramamento de óleo e afetou a vida da população, incluindo a dos pescadores, que exerciam suas atividades laborais na região. O STJ manteve a decisão dos tribunais inferiores, mantendo a indenização por danos materiais e morais aos pescadores. ${ }^{50}$

Em todos os casos analisados, verificou-se que não se discutiu a questão da nacionalidade dos navios estrangeiros, mas apenas a questão de fundo que foi a poluição marinha e a responsabilização pelos prejuízos causados ao meio ambiente e à população.

\subsection{O problema do conflito de competência entre justiça federal e justiça estadual}

O comércio internacional por vias marítimas tem impactos ambientais nas atividades portuárias (implantação dos portos e operações portuárias) e nas atividades de navegação propriamente dita, no percurso de um porto a outro. Isso quer dizer que ele pode ocorrer tanto em águas territoriais quanto em águas internacionais. Quando ocorre um acidente supostamente causado por transporte marítimo, independentemente da nacionalidade, em território nacional, surge o conflito de competência para propor a ação civil pública: é competente o juiz da justiça estadual (o do local do dano conforme o artigo $2^{\circ}$ da Lei $n^{\circ} 7357 / 85$ ) ou da justiça federal (conforme dispõe o artigo 109, I, da CF)?

A posição do STJ reconhece a competência da justiça federal quando demonstrado o interesse da União, ou quando se trata de bens lesados de propriedade da União, descritos no artigo 20 da Constituição Federal (CF). Por sua vez, o artigo 109, III, da CF, determina

49 BRASIL. Tribunal Regional Federal da $4^{a}$ Região. Agravo de Instrumento $n^{\circ}$ 90505220104040000 SC 0009050-52.2010.404.0000. Quarta Turma. Relator: Marga Inge Barth Tessler. Brasília, 02 de junho de 2010. Data de Publicação: D.E. 14/06/2010.

50 BRASIL. Superior Tribunal de Justiça. Agravo Em Recurso Especial $n^{\circ}$ 530.673-SC. Relator: Min. Marco Buzzi. Brasília, 8 de agosto de 2014 . 
que compete aos juízes federais processar e julgar as causas fundadas em tratado ou contrato da União com Estado estrangeiro ou organismo internacional.

O objetivo da inserção do inciso III no artigo 109 foi atribuir à justiça federal as causas que envolvem tratados internacionais que criam obrigações para o Estado brasileiro de interesses públicos subjetivos, chamados tratados-contratos e não os tratados normativos de caráter geral. Embora o tratado seja classificado quanto à matéria em tratado-contrato e tratado-lei, a doutrina afasta esse entendimento de que o tratado internacional pode ser acordado para diversos propósitos como contratos, normas, acordos políticos, assim como estabelecer regras para entrada e saída de meios de transporte marítimos por exemplo. Nesse contexto, Waldock afirma que "the relevant distinction, it is increasingly recognised, is between particular law-making and general law-making treaties rather than between treaty-contacts and treaty-laws" ${ }^{\prime \prime}$.

Desse modo, a justiça federal deve ser competente para os tratados que criam normas ou estabeleçam obrigações particulares para atender aos interesses das partes envolvidas, ou seja, naquelas em que o Estado brasileiro (União) tenha interesse particular sobre a questão e não para os tratados internacionais de maneira geral. Nesse sentido, quando se tratar de poluição marinha de hidrocarbonetos e seus derivados objetivando a condenação do poluidor-pagador, haverá interesse da União na proteção de um bem público. No caso de acidentes marítimos em comarca onde não há justiça federal, o STJ decidiu o conflito de competência:

CONFLITO DE COMPETENCIA. AC̄̃̃O CIVIL PÚBLICA. DANO AMBIENTAL. VAZAMENTO DE GASOLINA NO ESTUARIO DE SANTOS. COMARCA SEDE DE VARA FEDERAL. INTERESSE DA UNIÃO. CONTROVERSIA REGIDA POR CONVENÇÃO INTERNACIONAL. COMPETENCIA DOS JUIZES FEDERAIS. A ação civil pública, proposta com base na lei n. 7347, de 24 de julho de 1985, deve ser ajuizada no foro do local onde ocorreu o dano (art. $2^{\circ}$.). Tratando-se de comarca em que não ha juiz federal, será competente o juiz de direito do estado, em primeiro grau, para processar e julgar a ação, conforme a regra excepcional do artigo 109, $\int 3^{\circ}$, da Carta Magna. Sendo o local sede de Vara Federal, aos juízes federais compete o processo e julgamento, não só pelo interesse da união na causa,

51 WALDOCK, Humphrey. General course on public international law. p. 76 como porque assim se procede em todas as causas fundadas em tratado ou contrato da União com Estado estrangeiro ou organismo internacional (art. 109, I e III, CF). ${ }^{52}$

Enquanto a competência legislativa seja concorrente entre União, Estados e | Municípios, cabendo ao último a competência residual, a competência judiciária também é concorrente entre a justiça federal e estadual para os litígios transfronteriços, gerando problemas na atuação prática para soluções rápidas aos danos ambientais, principalmente de substâncias classificadas altamente poluidoras. Ações conjuntas entre os órgãos do Poder Judiciário são essenciais para a proteção efetiva do meio ambiente da responsabilização dos causadores dos danos, independentemente da nacionalidade das embarcações.

\subsection{O problema do conflito de competência entre órgãos administrativos federais e estaduais}

Além dos problemas relacionados à competência judiciária concorrente em conflitos transnacionais, há também conflitos de competência no exercício do poder de polícia dos órgãos administrativos. No que tange à aplicação de multas por danos causados ao meio ambiente marinho, os órgãos federais e estudais têm competência fiscalizatória, conferindo-lhes a atribuição de aplicar penalidades definidas. Segundo o entendimento da jurisprudência brasileira, a competência da Capitania dos Portos (União) não é exclusiva, mas complementar a dos órgãos estaduais, conforme a ementa abaixo:

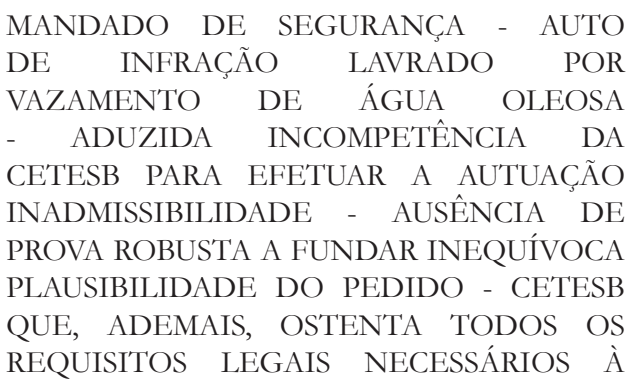

52 BRASIL. Superior Tribunal de Justiça. Conflito de Competência $n^{\circ}$ 3389 SP 1992/0019685-3. Relator: Min. Hélio Mosimann. Brasília, 25 de maio de 1993, S1 - Primeira Seção. Data de Publicação: DJ 21.06.1993 p. 12330 RSTJ vol. 50 p. 30); BRASIL. Superior Tribunal de Justiça. Conflito de Competência n $n^{\circ} 389$ / SP. Relator: Min. Hélio Mosimann. Brasília, 25 de maio de 1993; BRASIL. Superior tribunal de Justiça. Embargos de Declaração no Conflito de Competência no 2473- SP. Relator: Min. Antônio De Pádua Ribeiro. Brasília, 20 de abril de 1993. Veja também os conflitos de competência no STJ, $\mathrm{n}^{\circ}$ 2.473/ SP e no $16.863 /$ SP. 
AUTUAÇÃODEQUEM PRATICA ATIVIDADE LESIVA AO MEIO AMBIENTE NO ESTADO DE SÃO PAULO - APELO DESPROVIDO..$^{53}$

Desse modo, o entendimento com relação à multa é de se evitar a ocorrência do bis in idem, e que o poluidor-pagador pague duas vezes.

Por sua vez, nos casos de interesses de particulares afetados pela poluição marinha, as ações de indenização por pessoas lesadas em acidentes causados por transporte marítimo por poluição por óleo, a competência é da justiça estadual. Contudo, em alguns casos, se questiona se haveria interesse jurídico da União no feito, ou de órgão federal como o IBAMA, por exemplo, o que afastaria a competência estadual ou quando chamada ao processo deve se manifestar, conforme a decisão a seguir:

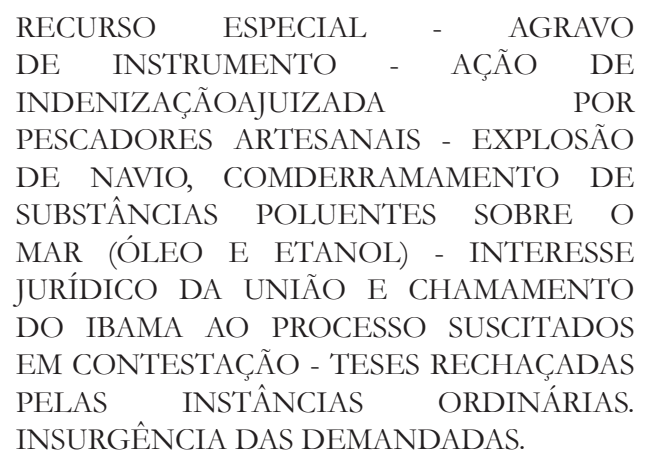

1. Não se conhece da tese de afronta ao art. 535 do CPC quando aparte recorrente não indica precisamente, nas razões articuladas no recurso especial, as omissões em que supostamente incorreu o acórdão recorrido. Incidência da Súmula n. 284/ STF. 2. Competência da Justiça Federal. Suposta incidência de convenção internacional (art. 109, III, da CF/88). Inocorrência. Demanda cuja causa de pedir não veicula tema afeto ao aludido órgão do Poder Judiciário. No caso dos autos, além de a ação indenizatória não se encontrar lastrada em qualquer convenção internacional, com ela não se objetiva a reparação de danos ambientais (causados a bens da União), mas sim o ressarcimento dos prejuízos suportados, em tese, por particulares (pescadores), em face da impossibilidade de desenvolverem a pesca na região atingida pelo desastre ambiental. 3. A alegação de existência de interesse jurídico da União, formulada por uma das partes em ação indenizatória, mas sem subsumir-se a qualquer das formas de intervenção de terceiro provocada (chamamento ao processo, denunciação à lide ou nomeação à autoria - arts. 62, 70 e 77 do CPC), não enseja o automático deslocamento do feito para a Justiça Federal. 4. À luz do Enunciado n.

53 SÃO PAULO. Tribunal de Justiça do Estado de São Paulo. Apelação $n^{\circ}$ 0247845-35.2009.8.26.0000. Relator: Renato Nalini. São Paulo, 16 de junho de 2011, Câmara Reservada ao Meio Ambiente.
150 da Súmula do STJ, compete à Justiça Federal decidir sobre a existência de interesse jurídico espontaneamente revelado pela União. Hipótese concreta em que o órgão estatal não manifestou qualquer interesse voluntário em intervir na lide. 5 . Eventual existência de demanda regressiva proposta pela União contra os responsáveis pelo dano ambiental, em razão do pagamento de benefício extraordinário aos pescadores (a título de segurodesemprego), não traduz manifestação espontânea do ente político na presente contenda reparatória de danos morais em materiais. 6. Em havendo pedido expresso de chamamento do IBAMA (autarquia federal) ao processo, é de rigor a remessa dos autos à Justiça Federal, a fim de aquilatar a presença de interesse da União que justifique o processamento da ação perante o aludido órgão do Poder Judiciário. 7. Recurso especial conhecido em parte, e, nesta extensão, parcialmente provido. ${ }^{54}$

A dicotomia entre interesses públicos e privados e ente justiça federal e estadual e entre os órgãos administrativos tem gerado problemas práticos para os profissionais na defesa dos interesses daqueles que sofrem prejuízos causados por poluição marinha.

Por fim, nota-se que esses casos de conflitos de competência entre as autoridades judiciárias, federal e estadual, assim como a competência dos órgãos administrativos no exercício do poder de polícia, como órgãos fiscalizatórios, em casos danos ao meio ambiente marinho devem ter em conta a reparação do dano ou da pessoa lesada. Esse é o objetivo principal da responsabilidade civil extracontratual, que, nos casos de poluição marinha, de baixo ou alto grau, a responsabilidade é objetiva, solidária e independe de culpa. Assim, a prestação judiciária deve ser efetiva de modo a responsabilizar o poluidor, que além de recuperar a área degradada, tem o dever de indenizar as pessoas lesadas.

\section{Considerações finais}

A responsabilidade civil extracontratual por danos ambientais marinhos causados por transportes marítimos está consagrada no direito brasileiro tanto no campo normativo quanto na responsabilização do poluidor-pagador pelos tribunais administrativos e judiciais. Contudo, as regras de direito internacional privado relacionados especificamente à responsabilidade civil

54 BRASIL. Superior Tribunal de Justiça. Recurso Especial $n^{\circ}$ 1.187.097-PR 2010/0056034-0. Quarta Turma. Relator: Min. Marco Buzzi. Brasília, 16 de abril de 2013. 
extracontratual não estão consagradas expressamente no direito brasileiro, nem no âmbito do Mercosul. Em sentido diametralmente oposto, houve um grande avanço no sobre o assunto na União Europeia a partir da criação do Regulamento (CE) no 864/2007 relativo à lei aplicável às obrigações extracontratuais, conhecido como "Roma II". Essa norma de direito internacional privado comunitário além de prever normas gerais de direito aplicável, adota regras específicas para diversas matérias incluindo a de danos ambientais. A certeza da lei aplicável a litígios transnacionais torna o resultado mais previsível e facilita a cooperação jurídica internacional, oferece maior segurança jurídica para o reconhecimento e execução de sentenças estrangeiras.

De acordo com a análise jurisprudencial dos tribunais brasileiros, a lei aplicável é a lei local onde o dano ocorreu, lex damni. Assim, aplica-se a lei nacional aos casos de poluição marinha ocorridos em águas brasileiras (mar territorial, zona econômica exclusiva e as águas sobrejacentes à plataforma continental) causados por transportes marítimo, nacionais ou estrangeiras, independentemente da lei da bandeira do navio. A lex damni é a regra de maior aproximação do fato para não penas punir o poluidor mas principalmente para reparar o dano. Nesse sentido, as embarcações estrangeiras estão sujeitas às leis brasileiras quando em águas domésticas.

A Organização Marítima Internacional (OMI) constitui a principal instituição no seio do sistema das Nações que exerce um papel importante nas políticas públicas globais para o direito marítimo. Busca-se estabelecer um equilíbrio entre as atividades econômicas da indústria da navegação e o meio ambiente marinho, reconhecido como um bem público global. A OMI é responsável pela construção de um arcabouço jurídico e pela unificação do direito marítimo, com a adoção de inúmeras convenções internacionais, para promover a segurança na navegação, evitando colisões de navios no mar, e, também, prevenir a poluição marinha, principalmente por substâncias altamente perigosas e nocivas ao meio ambiente marinho. Entretanto, não há regras claras sobre a lei aplicável aos casos de poluição marinha que ocorrem em alto-mar.

Além disso, as fontes para a responsabilização extracontratual por danos ao meio ambiente marinho, causados por transportes marítimos são tanto as normas internas quanto as normas internacionais, quando os tratados internacionais tiverem sido ratificados e ou ade- ridos e incorporadas ao ordenamento jurídico interno.

No caso de colisão ou abalroamento, aplica-se a regra da lex fori. Desse modo, aplica-se a lei local do acidente. Em alto-mar a regra geral é a lei da bandeira ou do pavilhão do causador do dano. Porém, as regras estabelecidas na Convenção das Nações Unidas sobre Direito do Mar não garantem direitos daqueles que utilizam as bandeiras de conveniência.

Contudo, apesar da harmonização entre as normas internas e internacionais, observa-se uma verdadeira fragmentação na aplicação das fontes ao caso concreto em relação às competências dos tribunais brasileiros.

São competentes as autoridades administrativas e judiciais quando o ato ou fato ocorrerem em águas sob a jurisdição nacional. Contudo, considerando os efeitos dos danos plurilocalizados, a jurisdição não é absoluta, mas concorrente. Desse modo, em caso de colisão em águas estrangeiras ou internacionais, o Tribunal Marítimo tem competência para examinar e punir administrativamente os atos ilícitos praticados pela tripulação do navio, por imprudência ou negligência.

Ademais, as autoridades administrativas locais, federais e estaduais também são competentes como órgãos fiscalizadores, com poderes para a aplicação de medidas administrativas, como a lavratura do auto de infração e a consequente aplicação de multa. A aplicação de sanções administrativas a navios independe de sua nacionalidade.

As empresas brasileiras se vinculam a navios ou a embarcações estrangeiras por contratos de afretamento, e respondem objetiva e solidariamente aos danos. Além disso, as empresas de navegação têm questionado perante o Poder Judiciário a validade dessas multas em razão da competência ser da justiça federal ou estadual. A posição dos tribunais brasileiros ocorre no sentido de validar o ato administrativo, mas afastar o bis in idem.

Com relação à competência para julgar os litígios por danos ao meio ambiente marinho, o direito brasileiro atribui competência tanto à justiça estadual quanto à federal. Aplica-se a regra do forum damni. Há um verdadeiro conflito de competência em direito interno que leva a inúmeros questionamentos na justiça brasileira para se determinar a competência, onerando aqueles que sofreram diretamente o dano. Isso afeta a efetividade da prestação jurisdicional e o princípio da economia processual. 
Notam-se nos julgados referentes aos conflitos de competência interna entre justiça estadual e federal é um campo normativo bastante intenso, pois as regras de competência são definidas pelos tribunais levando-se em consideração três elementos: a pessoa que sofreu o dano, o ato ou fato lícito ou ilícito e a lei aplicável ao caso concreto.

Nos casos de responsabilidade extracontratual por danos ambientais causados por transportes marítimos, a competência para julgar os prejuízos sofridos pelas pessoas é da justiça estadual, independentemente da lei aplicável ao caso concreto. É o caso de pescadores que tiveram suas atividades interrompidas por causa da poluição marinha, estes têm direito à reparação por danos materiais (indenização por lucros cessantes) e danos morais (em razão do sofrimento dos pescados pela privação das condições de trabalho), a contar data em que o dano ocorreu. As embarcações estrangeiras são responsáveis pelos danos causados e as empresas vinculadas pelos contratos de afretamento respondem objetiva e solidariamente, devendo reparar os prejuízos sofridos pelas pessoas vítimas do acidente. A nacionalidade do navio é uma questão secundária, cabendo, todavia, ação de regresso da empresa condenada ao poluidor de fato.

Nos casos de responsabilidade extracontratual por danos ambientais causados por transportes marítimos, a competência para julgar o ato lícito ou ilícito é concorrente, isto é, atribui-se competência tanto a justiça estadual quanto a federal. As competências se diferenciam pela lei aplicável ao caso concreto. De acordo com o entendimento jurisprudencial do Superior Tribunal de Justiça, a competência será da justiça federal para processar e julgar a ação civil pública com a finalidade de reparar os danos ao meio ambiente marinho causados por vazamento ou derramamento de hidrocarbonetos em duas situações: (i) quando houver interesse da União, por constituírem bens de sua propriedade os terrenos de marinha e o mar territorial; e (ii) quando a causa estiver fundada em Convenção Internacional sobre Responsabilidade Civil em Danos Causados por Poluição por Óleo.

Em relação à competência internacional, o Superior Tribunal de Justiça reconhece a aplicação do forum damni. Assim, o tribunal estrangeiro é competente para processar e jugar os casos de responsabilidade extracontratual por poluição marinha, incluindo os navios de bandeira brasileira, causadores do dano. Além disso, os Estados devem assegurar a responsabilidade civil extracontratual transfronteiriça por poluição marinha causada por pessoas privadas, seja pelo reconhecimento e execução de decisões estrangeiras, seja pelo cumprimento das diligências solicitadas por cartas rogatórias ou auxílio direto. Utilizar-se-á, os mecanismos da cooperação jurídica internacional para assegurar ao Estado em que ocorreu o dano, a reparação do meio ambiente lesado, com a restitutio in intergrum, sempre que possível, assim como a indenização às vítimas. Em caso de dúvida, devem-se aplicar os princípios in dubio pro societas e in dubio pro natura.

\section{REFERÊNCIAS}

ANTUNES, Paulo de Bessa. Dano ambiental: uma abordagem conceitual. Rio de Janeiro: Lumen Juris, 2000.

BERNASCONI, Christophe. Civil liability resulting from transfrontier environmental damage: a case for the Hague Conference? Disponível em: <http://www.hcch.net/ upload/wop/gen_pd8e.pdf>. Acesso em: 14 ago. 2014.

BOYLE, A. E. Globalising Environmental Liability: the interplay of national and international law. Journal of Environmental Law, v. 17, n. 1, p. 3-26, 2005.

CARAVACA, Alfonso-Luis Calvo; GONZÁLEZ, Javier Carrascosa. Derecho internacional privado. 14. ed. Granada: Comares, 2014. v. 1.

CARBONE, Sergio M. Conflits de lois en droit maritime. The Hague Academy of International Law, 2009.

CASTRO JUNIOR, Osvaldo Agripino de. Principais aspectos do direito marítimo e sua relação com a Lex Mercatoria e Lex Maritima. Revista Sequência Estudos Jurídicos e Políticos, v. 31, n. 61, p. 195-225, dez. 2010,

CHENG, Chia-Jui (Ed.). Clive M Schmitthoff's Select Essays on International Trade Law. Dordrecht: Martinus Nijhoff Publishers; Boston, London: Graham \& Trotman, 1982.

CHESHIRE, Peter North; FAWCETT, James; CARRUTHERS, Janeen. Cheshire, North \& Fawcett. Private International Law. Oxford: OUP, 2008.

COMPANHIA AMBIENTAL DO ESTADO DE SÃO PAULO. Tabela 1. Ocorrências envolvendo petróleo e derivados no Brasil (1960-2012). Disponível em: <http:/ / www.cetesb.sp.gov.br/userfiles/file/emergencias-qui- 
micas/panorama-geral/Principais-Acidentes-Brasiltab1.pdf>. Acesso em: 10 mar. 2014.

CONFERÊNCIA DAS NAÇÕES UNIDAS SOBRE COMÉRCIO E DESENVOLVIMENTO. Review of maritime transport. Geneva: United Nations Publication, 2014.

IANNI, Otavio. Teoria da globalização. Rio de Janeiro: Civilização Brasileira, 1997.

IBARS, Ingrid Sisteré. Corporate Social Responsibility in the Shipping Business. Master Thesis. Supervisor: Proshanto K. Mukherjee. Faculty of law Lund University. Sweden: Spring, 2013.

ILA. Report. International Law Association Berlin Conference (2004) Transnational Enforcement Of Environmental Law, 2004.

MARTINS, Eliane M. Octaviano. Desenvolvimento sustentável e transportes marítimos. Revista Direitos Fundamentais \& Democracia, v. 1, 2007.

MARTINS, Eliane M. Octaviano. Segurança Marítima vis-à-vis Desenvolvimento Sustentável. Revista CEJ, Brasília, ano 11, n. 37, p. 103-107, abr./jun. 2007.

ORGANIZAÇÃO MARÍTIMA INTERNACIONAL. Focus on IMO. Imo and dangerous goods at sea. May 1996, Disponível em: < http://www.imo.org/blast/blastDataHelper.asp?data_id $=7999 \&$ filename $=$ IMDGdangero usgoodsfocus1997.pdf>. Acesso em: 12 jul. 2014.

ORGANIZAÇÃO MARÍTIMA INTERNACIONAL. International Shipping Facts and Figures. Maritime Knowleg- de Centre, 2012.

PINHEIRO, Luís de Lima. Temas de direito maritimo: o navio em direito internacional. Disponível em: <http://www.oa.pt/upl/\%7Ba7992dcf-4940-4738acd7-c9fc7e4e58c1\%7D.pdf>. Acesso em: 12 fev. 2014. POCUCA, Milojka; ZANNE Marina. Globalization, International Trade and Maritime Transport. Disponível em: $<$ http:/ / www.google.com.br/url?sa $=$ t\&rct=j\&q=\&esr $\mathrm{c}=\mathrm{s} \&$ source $=$ web\&cd $=1 \& v e d=0 \mathrm{CCkQFjAA \& url}=\mathrm{htt}$ $\mathrm{p} \% 3 \mathrm{~A} \% 2 \mathrm{~F} \% 2 \mathrm{Fwww.fpp} . u n i-1 j . s i \% 2 \mathrm{Fmma}$ bin.php $\% 3$ Fid\%3D2010101801382606\&ei $=$ cd5CVe3EOuTbsAS IlYC4Cw\&usg=AFQjCNE5Mo84x6uOhgE_TQRHgmQBkgnxA\&sig2=6EtfrO-byPWfFjysUpHpqA\&bvm =bv.92189499,d.cWc >. Acesso em: 9 mar. 2015.

SCOVAZZI., Tullio. Chapter 13 Maritime Accidents with Particular Emphasis on Liability and Compensation for Damage from the Exploitation of Mineral Resources of the Seabed, p. 287-320. In: GUTTRY, Andrea; GESTRI, Marco; VENTURINI, Gabriella (Ed.). International disaster response law. Hague: T.M.C. Asser Press, 2012.

SOARES, Guido Fernandes Silva. Direito internacional do meio ambiente: emergência, obrigações e responsabilidades. São Paulo: Atlas, 2001.

Varella, Marcelo D. A necessidade de repensar os mecanismos de responsabilidade ambiental em caso de riscos de vazamento de petróleo em alto-mar no Brasil. Revista de Direito Internacional, vol.12, no.1. (nesta edição).

WALDOCK, Humphrey. General course on public international law. 


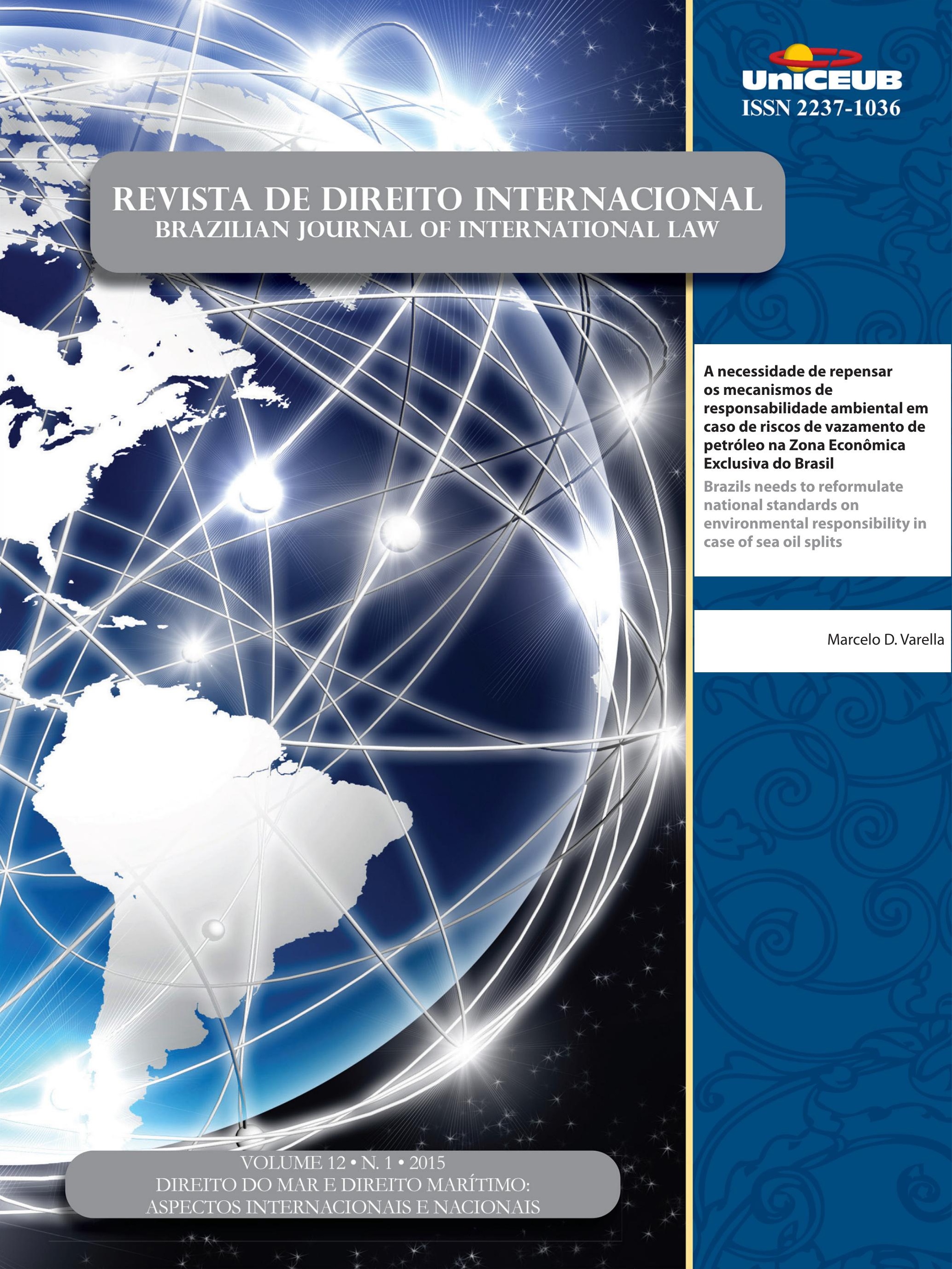




\title{
A necessidade de repensar os mecanismos de responsabilidade ambiental em caso de riscos de vazamento de petróleo na Zona Econômica Exclusiva do Brasil*
}

\author{
Brazils needs to reformulate national \\ standards on environmental responsibility in \\ case of sea oil splits
}

Marcelo D. Varella**

\section{Resumo}

O Brasil tornou-se um dos mais importantes produtores de petróleo na Zona Econômica Exclusiva. No entanto, parte relevante da exploração ocorre na Zona Econômica Exclusiva, além da jurisdição civil e penal brasileira. Os órgãos de controle têm dificuldades em aplicar multas e penas, como bem demonstra os casos dos vazamentos recentes. Além disso, o valor das multas é incompatível com a natureza das atividades econômicas. Assim, é preciso rever a legislação e os mecanismos extrajurídicos de efetividade do direito ambiental, para a proteção do meio ambiente marinho.

Palavras-chaves: Produção de petróleo no pré-sal; responsabilidade ambiental; zona econômica exclusiva.

\section{Abstract}

Brazil has become one of the most important producers of oil at sea. However, the relevant part of the production occurs in the Exclusive Economic Zone, outside Brazilian civil and criminal jurisdiction. Government hasn't competence to control, impose penalties as shows recent cases of oil leaks. In addition, the amount of dammages is incompatible with the nature of these economic activities. Thus, it is necessary to review the legal framework and find extra-legal mechanisms of effectiveness of environmental law for the protection of the marine environment.

Keywords: Oil production on pre-salt area; environmental responsibility; economic exclusive zone.

\section{INTRODUÇÃo}

O arcabouço jurídico brasileiro para exploração de petróleo é frágil no tocante à responsabilidade das empresas envolvidas. A falta de jurisdição na Zona Econômica Exclusiva, aliada à baixa capacidade de controle das

\footnotetext{
** Professor do Centro Universitário de Brasília. Doutor em Direito pela Universidade de Paris. Livre-Docente pela USP. Pesquisador do CNPq. Email: marcelodvarella@gmail.com
} 
agências governamentais leva a um cenário importante de risco. É preciso repensar o quadro jurídico em vigor, para ampliar as possibilidades de prevenção e reparação de danos.

O Brasil agora está tentando consolidar sua ascensão como a sexta maior economia do mundo, ultrapassando o Reino Unido. Parte do crescimento econômico brasileiro é atrelado a expansão da exploração petrolífera. A crise na Petrobrás decorrente da operação Lava Jato, da Política Federal, retardou o processo, mas a produção da Petrobrás off shore apenas aumenta a cada ano. O investimento em tecnologia, em especial nas tecnologias de produção de petróleo nacionais, criou economia dinâmica e aumentou o número de multinacionais interessadas na exploração de petróleo no Brasil. Novas descobertas transformaram o Brasil de importador em exportador de petróleo.

Um compromisso correspondente a regulamentar a exploração de petróleo e proteger o ambiente, no entanto, não ocorreu no Brasil. O quadro normativo permanece frágil e não está estruturado o suficiente para responder aos riscos apresentados pela exploração de petróleo na plataforma continental.

Recentemente, em 2011, o Brasil experimentou um grande problema de poluição ambiental com a produção de petróleo em águas profundas na plataforma continental. Um acidente em uma plataforma de perfuração da Chevron lançou milhares de barris de petróleo no mar. $\mathrm{O}$ acidente, embora de dimensões muito menores do que outros acidentes no exterior, destaca fragilidades no quadro jurídico e institucional brasileiro, bem como na capacidade de resposta em casos de emergência, pontos fracos que devem ser corrigidos no futuro.

Nesse artigo, descrevemos os recentes avanços na exploração de petróleo offshore, necessários para compreender a necessidade de proteção ambiental. Em seguida, avaliamos a efetividade das regras de proteção ambiental aplicáveis ao petróleo produzido na Zona Econômica Exclusiva, portanto, fora do território brasileiro, em especial na camada pré-sal.

Concluímos o ensaio, discutindo a necessidade de um sistema de responsabilidade compartilhada, mas diferenciada, entre empresas privadas e instituições públicas consiste no melhor mecanismo para assegurar melhor proteção do ambiente.

\section{Exploração de petróleo no Brasil}

O Brasil iniciou produção nacional de petróleo na década de 1930 com várias empresas estrangeiras. Em 1953, o governo federal nacionalizou a produção de petróleo, excluindo todas as empresas estrangeiras e criando estatal Petróleo do Brasil SA (Petrobras). Petrobras tornou-se empresa de capital aberto, controlada pelo governo federal. ${ }^{1}$ Em 1989, o governo do presidente Fernando Henrique Cardoso reabriu exploração petrolífera nacional a empresas estrangeiras em $1993 .^{2}$

Em 2003, após o aumento substancial de capital, a Petrobras e empresas estrangeiras descobriram novas reservas de petróleo em várias partes do país, predominantemente na plataforma continental. Essas descobertas resultaram na expansão rápida da produção nacional. Em 2006, a produção de petróleo no Brasil superou a demanda doméstica pela primeira vez, e as exportações, aumentaram significativamente. ${ }^{3}$ O Brasil exporta petróleo bruto e alguns derivados, mas continua a importar gasolina e outros produtos.

Em 2007, a paisagem nacional da exploração do petróleo mudou profundamente. A Petrobras descobriu enormes reservas de petróleo em águas ultraprofundas ao largo da sua costa, na chamada camada do pré-sal. ${ }^{4}$ Até então, nenhum país tinha produzido como base em óleo tais profundidades, 5000-8000 metros abaixo do oceano e a 180 milhas da costa. A camada de petróleo do pré-sal se estende cerca de 500 milhas com base em

1 A Petrobras é uma das mais antigas empresas estatais nacionais de petróleo em todo o mundo. Desenvolve atividade em toda a cadeia petrolífera. Em agosto de 2000, a Petrobras emitiu US \$4,3 bilhões em um IPO no Brasil e NYSE, não só para os investidores institucionais, mas também para as pessoas. Mais de 400.000 brasileiros e muitos investidores compraram ações da empresa. GOLDSTEIN, Andrea. The emergence of multilatinas: the Petrobras experience. Universia Business Review, Madrid, n. 25, p. 98-111, 2010.

2 LUCCHESI, Celso Fernando. Petróleo. Estudos Avançados, São Paulo, v. 12, n. 33, p. 17-40, maio/ago. 1998. p. 3.

3 SEABRA, Alessandra Aloise de et al. A Provincia promissora fazer pré-sal. Revista Direito GV, São Paulo, v. 7, n. 1, p. 57-74, jan./jun. 2011.

4 Cada país tem costal, de acordo com a Convenção das Nações Unidas sobre o Direito do Mar, uma Zona Económica Exclusiva (ZEE). O ZEE normalmente inclui 200 milhas náuticas (cerca de 370 quilômetros) a partir da linha de base costeira do país. O território nacional, onde os Estados têm jurisdição legal, vai até 12 milhas marítimas, mas o monopólio sobre a exploração económica do mar e de fundo marinho vai muito além, a 200 milhas náuticas. Os países podem solicitar uma extensão da ZEE em algumas circunstâncias, de acordo com a Comissão das Nações Unidas sobre os Limites da Plataforma Continental regra (CLCS). 
estado de Santa Catarina até o estado do Espírito Santo, dentro da Zona Económica Exclusiva (veja o polígono no mapa abaixo). Novos achados foram descobertos recentemente em toda a área. Em meados de 2012, foram confirmados mais de 15 bilhões de barris. Se as estimativas de 50 a 80 bilhões de barris de petróleo e gás forem confirmadas, o Brasil será o sexto maior possuidor de reservas de petróleo e gás, depois da Arábia Saudita, Irã, Iraque, Kuwait, e os EAU. ${ }^{6}$

Figura 1 - Mapa da área do pré-sal

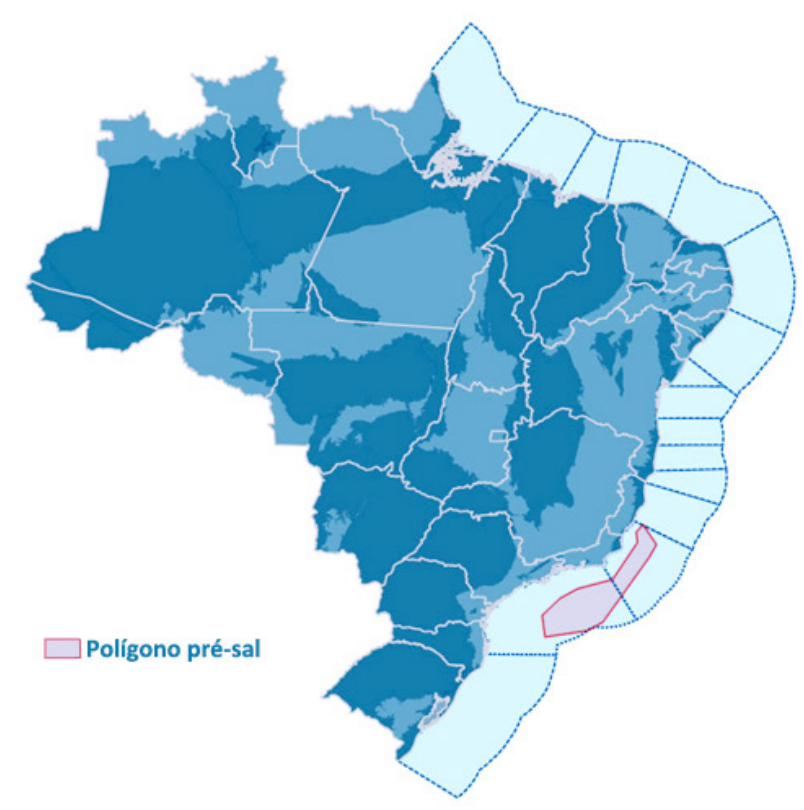

Fonte: Agência Nacional de Petróleo (ANP).

Vários especialistas argumentavam que a extração de petróleo da área do pré-sal seria impossível, já que os custos seriam proibitivos e a tecnologia ainda não existia. Para viabilizar a produção, a Petrobrás precisou obter mais de US $\$ 220$ bilhões por meio de venda de ações na bolsa de valores.

O Governo brasileiro considerou que seria também necessário rever o quadro jurídico sobre exploração petrolífera e proteção ambiental. ${ }^{5}$ Até as descobertas do pré-sal, o Brasil tinha um conjunto de normas favorável ao investimento estrangeiro na exploração de petróleo, mas pouco sobre segurança e proteção ao meio ambiente. O país havia realizado concessões de exploração em determinados blocos a empresas estrangeiras para a produção offshore. Quando a Petrobras abriu-se ao

5 PERGUNTAS e respostas: pré-sal. Set. 2009. Disponível em: $<$ http://veja.abril.com.br/idade/exclusivo/perguntas_respostas/ pre-sal/>. Acesso em: 08 out. 2013. investimento estrangeiro, cerca de $60 \%$ do seu capital pertencia a fundos de investimento estrangeiros.

O governo brasileiro decidiu, em 2010, recapitalizar a empresa em processo aberto e expandiu o seu papel na administração da empresa. Em troca de número de ações, o governo nacional concedeu Petrobras o direito de extrair 5 bilhões de barris de petróleo, o que aumentou o valor de mercado da empresa. Foi a maior operação de capital de história das bolsas de valores em todo o mundo, somando US\$ 64,5 bilhões. ${ }^{6}$ Quaisquer investidores poderiam comprar ações da empresa durante esse processo. Em virtude do aporte de recursos, a participação do governo brasileiro aumentou para $47,8 \%$ da capitalização total da empresa, dando o controle do governo nas decisões da empresa e na divisão dos lucros.

O Congresso brasileiro modificou a legislação sobre exploração de petróleo. A Petrobras deveria participar diretamente de pelo menos $30 \%$ de qualquer projeto de exploração. ${ }^{7} \mathrm{O}$ novo quadro jurídico aumentou os royalties do governo sobre novos contratos de petróleo. Uma vez que a participação na empresa era maior e a cobrança de royalties também havia aumentado, o Estado receberia uma participação mais importante da exploração de petróleo no país. Criou-se então um fundo nacional alimentado pelos royalties e outros lucros do petróleo para promover novos investimentos, principalmente em educação e saúde, mas também na proteção do ambiente, ciência e tecnologia em todo o país.

O quadro jurídico, os poços localizados fora da área do pré-sal permaneceram inalterados. Muitas empresas estrangeiras já haviam iniciado a produção no Brasil, como Anadarko, Devon, a Exxon-Mobil, BG Group, Petrogal, Repsol, Shell, Devon, EnCana, SK e UK Gas Company e se decidiu honrar os compromissos firmados. $^{8}$

A produção offshore representa hoje $94,3 \%$ da produção nacional de petróleo do Brasil e 75,8\% da produção

6 ELLSWORTH, Brian. Petrobras to sell $\$ 65$ billion stock in record offer. Disponível em: <http://www.reuters.com/article/2010/09/03/ us-petrobras-idUSTRE6821FX20100903>. Acesso em: 08 out. 2013.

7 BRASIL. Lei no 12.351, de 22 de dezembro de 2010. Disponível em: <http://www.planalto.gov.br/ccivil_03/_Ato2007-2010/2010/ Lei/L12351.htm>. Acesso em: 08 out. 2013. Art. 10, I, c.

8 AGÊNCIA NACIONAL DO PETRÓLEO, GÁS NATURAL E BIOCOMBUSTIVEIS. Página principal. Disponível em: $<$ hwww. anp.gov.br>. Acesso em: 08 out. 2013. 
nacional de gás. Empresas estrangeiras, como Peregrino, a Statoil, Ostra, e Shell controlar alguns dos locais de perfuração mais produtivos, fora da pré-sal. No entanto, a produção das reservas de pré-sal vem aumentando a cada ano e já ultrapassa os 700 mil barris por dia. ${ }^{9}$ Os investimentos maciços nas reservas do pré-sal mostram o quão importante a produção de petróleo em águas profundas vai se tornar nos próximos anos. Ele também prenuncia muitos desafios.

Em suma, as empresas estão investindo recursos financeiros muito elevados, e eles estão usando uma tecnologia nunca antes utilizada no mundo, em uma área fora da jurisdição penal do Estado, com grande potencial de impacto ambiental. Ao mesmo tempo, o óleo é considerado indispensável para o desenvolvimento do país. Esse cenário formidável sublinha a importância de um quadro jurídico correto para evitar desastres graves.

\section{O MODELO BRASILEIRO PARA PREVENIR DANOS AMBIENTAIS COM A EXPLORAÇÃO MARÍTIMA DE PETRÓLEO}

O principal instrumento legal para a exploração de petróleo no Brasil consiste na Lei n ${ }^{\circ} 9.966$ de 28 de abril de 2000, que tem suas origens nas Convenções Internacionais para a Prevenção da Poluição por Navios de 1973 e 1978; na Convenção Internacional sobre a Responsabilidade Civil por Danos da Poluição por Óleo, de 1969, alterada em 1992; e na Convenção Internacional sobre Preparo, Resposta e Cooperação em caso de Poluição por Óleo, de 1995. Essas normas delineiam quatro níveis de risco para os ecossistemas marinhos: alta, média, moderada e baixa. ${ }^{10}$

Cada plataforma deve ter o equipamento necessário para lidar com acidentes de petróleo. As especificações de cada equipamento dependem de estudo técnico, com base nas dimensões e localização da plataforma, os métodos de controle operacional, as qualificações e o número de pessoas envolvidas, bem como o cronograma

9 INFORME CONJUNTURA E INFORMAÇÃO. Rio de Janeiro: ANP, 200?. Disponível em: <www.anp.gov.br>. Acesso em: 8 maio 2015.

10 Os limites da responsabilidade civil extracontratual podem ser vistos neste número em LOPES, I. O direito internacional privado e a responsabilidade civil extracontratual por danos ambientais causados por transportes marítimos à luz do direito brasileiro in Revista de Direito Internacional, v. 12, n.1, 2015. para a implementação do projeto de exploração. ${ }^{11}$ As normas definem regras para evitar a poluição, exigências de relatórios periódicos, obrigações para as empresas públicas e privadas de instituir planos preventivos para evitar a poluição marinha.

A análise dos aspectos de engenharia de exploração de petróleo e da segurança das operações deve ser aprovado pela Agência Nacional do Petróleo, Gás e Biocombustíveis (ANP) e realizado antes da implementação do projeto. Alguns aspectos também são controlados pela Marinha, que deve atestar a conformidade das plataformas em relação à segurança da navegação, à capacidade de armazenamento, e à prevenção de acidentes.

A principal diferença operacional entre os sistemas brasileiro e americano refere-se ao fato de que, nos Estados Unidos, técnicos especializados da própria empresa devem controlar plataformas de perfuração in loco, o tempo todo. Há menos controle do Estado, mas sanções mais severas em caso de problemas. No Brasil, uma equipe de funcionários públicos visita e fiscaliza a plataforma durante três ou quatro dias e controlam os principais riscos operacionais. Há maior controle do Estado e menor responsabilização em caso de danos. De acordo com a ANP, há menos chances de acidentes. $^{12}$

O sistema brasileiro baseia-se num modelo de comando e controle. Ele impõe sanções, e funcionários do governo controlam cada plataforma pessoalmente. As normas exigem que cada plataforma tenha plano adequado às suas características particulares. Os fiscais deve controlar cada detalhe. O Instituto Brasileiro de Proteção Ambiental (IBAMA) e da Agência Nacional de Petróleo, Gás Natural e Biocombustíveis devem fornecer pessoal aos sites para supervisionar os detalhes da extração e produção.

Duas semelhanças preocupantes entre as autoridades regulatórias brasileiras e americanas se destacam. Em primeiro lugar, a mesma agência responsável pela promoção da produção de petróleo historicamente tem sido também responsável por controlar e fiscalizar as operações de segurança ambiental. Como nos Esta-

11 Art. 5. da Lei 9.966, de 2000. BRASIL. Lei $n^{\circ}$ 9.966, de 28 de abril de 2000. Disponível em: <http://www.planalto.gov.br/ccivil_03/leis/L9966.htm>. Acesso em: 08 out. 2013.

12 Entrevista com Rafael Neves Moura, chefe da Operacional e Segurança Ambiental da Agência Nacional de Petróleo e Gás, em 2013. 
dos Unidos, a mesma agência responsável por aumentar a produção de petróleo é a responsável pela segurança das plataformas. Esse acúmulo de funções constitui um erro cometido nos Estados Unidos, muito criticado nas decisões judiciais decorrentes do acidente da BP e que poderia ser evitado no Brasil. Além disso, há claramente falta de pessoal para realizar a fiscalização, o que, aliás, se repete em quase todos os departamentos responsáveis por qualquer fiscalização no país.

A ANP prevê a publicação de plano de contingência nacional a ser negociado e aprovado pela ANP em cooperação com órgãos ambientais ${ }^{13}$. As discussões continuam, particularmente após o acidente da BP no Golfo do México nos Estados Unidos e do acidente da Chevron no Brasil, mas nenhuma lei ou princípios ainda não foram acordados. ${ }^{14}$

Além disso, o Brasil não tem normas para proteger áreas sensíveis, como os ecossistemas marinhos de alta biodiversidade. $\mathrm{O}$ artigo 28 da lei sobre a exploração de petróleo exige que o governo delinear áreas protegidas, onde a exploração de petróleo, transporte e poluição associada são proibidos. No entanto, o governo brasileiro não realizou essas delimitações geográficas.

\section{Problemas institucionais: Um estudo de caso da Chevron}

O acidente da Chevron ocorreu a 40 milhas da costa do Rio de Janeiro, fora da área do pré-sal, mas também além do mar territorial brasileiro. ${ }^{15} \mathrm{O}$ poço estava sendo perfurado a 1200 metros de profundidade, teoricamente mais controlável do que qualquer poço na camada mais profunda pré-sal, onde as pressões e condições são muito mais difíceis de se lidar. Em 8 de novembro de 2011, a Petrobrás identificou a mancha de óleo na superfície e, por meio de um veículo operado remotamente, localizou sete rachaduras no fundo do mar. As maiores

13 Para o Plano Nacional de Contigência, veja o artigo de GIACOMITTI, R. B e ISAGUIRRE-TORRES, K. R. Instrumentos públicos e privados para a reparação do dano ambiental causado por derramamento de óleo no mar sem origem definida: as manchas órfãs in Revista de Direito Internacional, v. 12, n.1, 2015.

14 Entrevista com o Gerente de Segurança Operacional da Agência Nacional de Petróleo e Gás no Brasil, em Dezembro de 2012.

15 A Chevron detém uma concessão nesta plataforma de petróleo com a Petrobras. (Número do contrato 48.000,003896/97-20). rachaduras tinham cerca 1000 pés de comprimento. ${ }^{16} \mathrm{O}$ total de petróleo derramado foi de cerca de 4600 barris.

O Instituto Nacional de Proteção Ambiental e a Agência Nacional de Petróleo ordenaram que Chevron iniciasse imediatamente a execução do seu plano de contingência. O plano havia sido formulado pela Chevron e foi previamente aprovado pelos órgãos ambientais nacionais do Brasil como pré-requisito para obtenção da concessão e início da produção de petróleo. ${ }^{17}$

Embora a Chevron tivesse identificado no seu plano de contingência o equipamento que usaria para responder a um evento como este, o equipamento não foi posicionado no Brasil, mas sim nos Estados Unidos! Consequentemente, a Chevron não foi capaz de controlar a descarga, que foi estimada pelo IBAMA em três mil barris. ${ }^{18} \mathrm{Em}$ março de 2012, a Chevron identificou a segunda vazamento de óleo, menor, a apenas 2 milhas do primeiro.

Uma vez que Chevron não tinha o equipamento necessário, a Petrobrás iniciou seu plano de contingência. Contudo, o vazamento se tornou maior do que deveria. Ao final do processo, a Petrobras gastou USD 748.423 para lidar com o problema e a Chevron gastou outros USD 173.934.000. ${ }^{19}$

Durante o processo judicial, a Chevron argumentou que uma única empresa normalmente não tem equipamento disponível para o seu plano de contingência em cada plataforma. Para reduzir custos, é comum compartilhar essas instalações com outras companhias petrolíferas na mesma área. As autoridades consideraram que o investimento na prevenção era demasiado baixo para evitar riscos consideráveis. Em 2011, a Petrobras, por exemplo, investiu apenas $0,022 \%$ do seu orçamento na proteção do ambiente e apenas $0.092 \mathrm{em} \mathrm{2012.{ } ^ { 2 0 }}$

16 Relatório da Petrobras, ligado ao Processo n. 02000.002345 / 2011-4.

17 Relatório da Petrobras, ligado ao Processo n. 02000.002345 / 2011-4.

18 Relatório da Petrobras, ligado ao Processo n. 02000.002345 / 2011-4.

19 BRASIL. Procuradoria da República no Estado do Rio de Janeiro $20^{\circ}$ Ofício. Meio Ambiente e patrimônio cultural. Termo de compromisso de ajustamento de conduta que entre si celebram de um lado o Ministério Público Federal e de outro Cheuron Brasil Upstream Frade LTDA., Chevron América Latina Marketing LLC e Transocean Brasil Ltda. com a interveniência da Agência Nacional do Petróleo, Gás Natural e Biocombustiveis - ANP e do Instituto Brasileiro do Meio Ambiente e dos Recursos Naturais Renováveis- Ibama. Rio de Janeiro, 13 de Setembro de 2013. Disponível em: <http://s.conjur.com.br/dl/tac-chevron-mp-ibama. pdf>. Acesso em: 15 jul. 2015.

20 BRASIL. Tribunal de Contas da União. Relatório de Audito- 
O IBAMA aplicou à Chevron multa de US\$ 22 milhões, a pena máxima existente. A ANP aplicou segunda multa de US\$12 milhões. A Chevron recorreu da primeira multa no Judiciário, que anulou a pena do IBAMA. Em seguida, a Chevron concordou em pagar a multa da ANP. ${ }^{21}$ As duas principais acusações contra a empresa eram de que esta não possuía o equipamento exigido pelo plano de contingência e que tinha adulterado as imagens do fundo do mar rachado obtidas pelo veículo operacional remoto, para minimizar o problema.

Poucos meses depois, antes da investigação chegar ao fim, um segundo vazamento de óleo ocorreu no mesmo local de perfuração. Como no primeiro exemplo, a pressão utilizada na extração foi maior do que o fundo do mar suportava e fissuras se desenvolveram, permitindo o vazamento de óleo.

De acordo com um relatório da Agência Nacional de Meio Ambiente (IBAMA), ${ }^{22}$ o acidente foi o resultado de vários erros cometidos pela Chevron: falha no cálculo das condições reais de exploração, medições imprecisas de riscos potenciais, fracasso do plano de contingência, omissão de informações, falta de limpeza do oceano depois do vazamento de óleo, falta de êxito no controle do processo de exploração. O plano de contingência foi formulado com base em um projeto de

ria. TC-037.197/2011-8. Plenário. Órgão Entidade: Petróleo Brasileiro S.A.(Petrobras). Interessado: Tribunal de Contas da União. Relator: Relator: Min. José Jorge de Vasconcelos Lima. Brasília, 22 de outubro de 2014. Disponível em: <portal2.tcu.gov.br/portal/.../037.197\%20(Campo\%20de\%20Frade).rtf>. Acesso em: 15 jul. 2015. p. 13; 18.

21 Chevron pagou $\mathrm{R} \$ 42.8566 .010$ porque antecipou o pagamento. BRASIL. Procuradoria da República no Estado do Rio de Janeiro $20^{\circ}$ Ofício. Meio Ambiente e patrimônio cultural.. Termo de compromisso de ajustamento de conduta que entre si celebram de um lado o Ministério Público Federal e de outro Chevron Brasil Upstream Frade LTDA., Chevron América Latina Marketing LLC e Transocean Brasil Ltda. com a interveniência da Agência Nacional do Petróleo, Gás Natural e Biocombustiveis - ANP e do Instituto Brasileiro do Meio Ambiente e dos Recursos Naturais Renováveis- Ibama. Rio de Janeiro, 13 de Setembro de 2013. Disponível em: <http://s.conjur.com.br/dl/tac-chevron-mp-ibama. pdf>. Acesso em: 15 jul. 2015. p. 11.

22 INSTITUTO NACIONAL DE MEIO AMBIENTE. Nota Informativa CPEG/DILIC/IBAMA n ${ }^{\circ}$ 01/12 de 05 de Janeiro de 2012. Disponível em: <http://www.mma.gov.br/port/conama/ processos/DC218947/ParecerIBAMA.pdf.>. Acesso em: 09 maio 2015. Ver BRASIL. Tribunal de Contas da União. Relatório de Auditoria. TC-037.197/2011-8. Plenário. Órgão Entidade: Petróleo Brasileiro S.A.(Petrobras). Interessado: Tribunal de Contas da União. Relator: Relator: Min. José Jorge de Vasconcelos Lima. Brasília, 22 de outubro de 2014. Disponível em: <portal2.tcu.gov.br/por$\mathrm{tal} / . . . / 037.197 \% 20$ (Campo\%20de $\% 20$ Frade).rtf $>$. Acesso em: 15 jul. 2015. p. 11 extração de menor escala muito e não era realista no local explorado real. Parece que o plano foi preparado para outras áreas e reutilizados pela Chevron.

Uma segunda investigação, envolvendo a Petrobras e a Chevron, realizada pela ANP, concluiu que (i) várias unidades em operação não tinham passado por auditorias por parte do Sistema de Gestão de Segurança Operacional (SGSO); (ii) nenhuma inspeção preliminar das plataformas ou instrumentos tinha sido realizada para confirmar a existência e a condição de elementos críticos de segurança da central no momento da aprovação da Documentação de Segurança Operacional (DSO); e (iii) as investigações de incidentes não respeitavam aos regulamentos necessários, e os resultados não foram amplamente divulgados, conforme exigido. ${ }^{23}$

A Chevron suspendeu todas as suas atividades no Brasil, e seus executivos deixaram o país até meados de 2012, quando a empresa pediu permissão para reiniciar as atividades de extração no mesmo local de produção. Em abril de 2013, a produção foi reiniciada e intensificada a partir de março de 2014.

O Ministério Público Federal iniciou dois processos contra a Chevron e as duas empresas responsáveis pelas operações da plataforma e pelo plano de contingência - Transocean e Halliburton. A primeira ação foi por danos civis. A segunda buscava a aplicação de sanções penais, solicitando US $\$ 10$ bilhões em danos e a prisão dos dezessete funcionários da Chevron responsáveis pelas falhas que levam ao desastre ${ }^{24}$. O Tribunal de Justiça do Rio Criminal rejeitou finalmente a ação penal em 20 de fevereiro de 2013, porque o acidente ocorrera fora da jurisdição penal brasileira. Nos casos do pré-sal, essa seria a regra.

A Chevron defendeu-se na ação civil com os mesmos argumentos, alegando que o acidente tinha ocorrido fora do território brasileiro. Conforme determinado pela Convenção das Nações Unidas sobre o Direito do

23 OPERAÇÃO no Campo Frade: primeira produção teve início em 2009. Disponível em: <https://www.chevron.com.br/negocios/exploracao-producao-petroleo/campo-frade.aspx > Acesso em: 09 maio 2015.

24 Solicitava-se o valor da condenação em 20 bilhões de reais, aproximadamente US \$ 10 bilhões, em 2013. BRASIL. Ministério Público Federal. Procuradoria da República no Município de Campos dos Goytacazes (RJ). Ação Civil Pública com Pedidos de Liminar. Campos dos Goytacazes, 02 de abril de 2012. Disponível em: $<$ http://s.conjur.com.br/dl/acao-civil-publica-chevron-mpf.pdf $>$. Acesso em: 09 maio 2015. 
Mar (CNUDM), existem três áreas mais adentro, com diferentes status legais: o mar territorial, a zona contígua, e na zona econômica exclusiva. O mar territorial começa no litoral normal e se estende para fora $12 \mathrm{mi}$ lhas náuticas. A zona contígua se estende até 24 milhas náuticas. A zona econômica exclusiva, na qual ocorre a maior parte da produção brasileira de petróleo, se estende a 200 milhas náuticas da costa. Em situações em que a plataforma continental se estende mais de 200 milhas náuticas da costa, na zona econômica exclusiva, estende-se à mesma distância, até 350 milhas náuticas, embora apenas no fundo do mar. ${ }^{25}$

Dentro da zona econômica exclusiva, o Estado costeiro tem o direito soberano de explorar e extrair recursos naturais, vivos ou não. Ele também tem jurisdição para proteger e preservar os ambientes marinhos localizados naquele local ${ }^{26}$. No entanto, não há nenhuma competência penal sobre os fatos acontecidos na área pelo Brasil, exceto se a bandeira da nave for brasileira.

No caso Chevron, a Justiça Federal do Rio de Janeiro decidiu pela sua incompetência porque o acidente ocorreu fora do território brasileiro (na Zona Econômica). Este parece ser um dos principais desafios da exploração da camada pré-sal no Brasil. Uma vez que a zona se encontra fora da jurisdição nacional, o Brasil tem o monopólio da exploração, mas não tem jurisdição criminal e civil. O Ministério Público Federal recorreu dessa decisão. ${ }^{27}$

Em setembro de 2013, a Chevron assinou acordo com a Procuradoria da República, o IBAMA, e a ANP para pagar quase US $\$ 48$ milhões, recursos que seriam investidos em medidas preventivas e de precaução para melhorar a capacidade de acompanhamento do IBAMA para evitar novos derrames de hidrocarbonetos. ${ }^{28} \mathrm{~A}$ Chevron se comprometei a implementar o plano de emergência; manter duas instalações fluviais para evitar os derrames de petróleo e outros danos, integradas

25 Ver TREVES, Tullio. Coastal States' rights in the maritime areas under UNCLOS in Revista de Direito Internacional, v. 12, n.1, 2015.

26 Ver art. 56 de Convenção das Nações Unidas sobre o Direito do Mar. NAÇÕES UNIDAS. Convenção das Nações Unidas sobre o Direito do Mar e o acordo relativo à aplicação da parte XI da mesma convenção. Nova York, 10 de dezembro de 1982. Disponível em: < http://www. gddc.pt/siii/im.asp?id=396>. Acesso em: 16 jun. 2015.

27 Não houve nenhuma decisão no momento da elaboração deste capítulo. No entanto, a primeira decisão provavelmente seria confirmada.

$28 \mathrm{R} \$ 95.160 .000,00$. TAC - Chevron com um sistema de medição automática por raios infravermelhos para detectar óleo no mar, com imagens de ROV; instalar uma estação climática com sensores de vento; e implementar múltiplos sensores com saída para o mar disponível para o IBAMA. A ação penal continua, independentemente do acordo.

Em relação ao vazamento de petróleo Chevron, a Petrobras transferiu a responsabilidade para a prospecção de petróleo para Chevron. De acordo com a legislação brasileira, a Petrobras seria solidariamente responsável pelos danos, independentemente de culpa. No entanto, no Acordo de Operação Conjunta entre a Petrobras e a Chevron, afirma-se que, em caso de negligência grave ou dolo, a Chevron responde sozinha por qualquer indenização. Assim, a Chevron admitiu pagaria todas as multas sozinha. ${ }^{29}$

O Tribunal de Contas do Brasil realizou uma segunda auditoria em relação à responsabilidade da Petrobras para o acidente. Decidiu que a Petrobras deveria melhorar o seu plano de contingência. Sugeriu também que o IBAMA fosse mais exigente nas suas fiscalizações, inclusive fechando plataformas por falta de segurança, o que traria resultados mais efetivos, por gerar impactos econômicos mais significativos a empresas do que multas que representam um percentual ínfimo dos custos de operação.

\section{NeCESSIDADES DE REFORMAS}

Há vários obstáculos jurídicos e de políticas públicas para a proteção efetiva do meio ambiente, com a expansão do pré-sal, como os maiores riscos da produção, a falta de jurisdição, falta de pessoal suficiente e de instrumentos de responsabilidade compartilhada das empresas.

No tocante ao aumento dos riscos, a exploração de petróleo em águas ultraprofundas, em virtude das di-

29 Testemunho da diretora da ANP, ao Congresso . CAMBRIARD, Magda Maria de Regina apud. BRASIL. Congresso Nacional. Comissão Parlamentar Mista de Inquerito n. 302: destinada a investigar irregularidades envolvendo a empresa Petróleo Brasileiro S/A (PETROBRAS), ocorridas entre os anos de 2005 e 2014 e relacionadas à compra da Refinaria de Pasadena, no Texas (EUA); ao lançamento de plataformas inacabadas; ao pagamento de propina a funcionários da estatal; e ao superfaturamento na construção de refinarias - CPMIPETRO”: relatório final. Brasília, dez. 2014. Disponível em: <www.petrobras.com.br/lumis/portal/file/fileDownload>. Acesso em: 15 jul. 2015. 
ficuldades tecnológicas, a alta pressão e outros fatores ambientais, leva ao menor controle dos fatores de acidentes. Trata-se de nova tecnologia que exige esforços em proteção ambiental similares àqueles investidos na produção. ${ }^{30}$

A falta de jurisdição penal e cível do Estado brasileiro sobre essa região poderia ser compensada com a possibilidade de aplicação de sanções mais severas no âmbito administrativo, como a interdição da produção ou mesmo multas contratuais no processo de concessão de blocos de exploração. Por se tratarem de pessoas jurídicas, as penalidades econômicas podem ter efeitos mais importantes do que eventuais multas.

O valor das multas, por sua vez, deve ser proporcional aos valores oriundos da exploração de petróleo. Como vimos acima, as multas têm valor representativo, mas nesse universo de investimentos, acabam representando parcelas insignificantes do faturamento. Nesse caso, o ordenamento jurídico deve mudar sua lógica de sanção e não fixar valores monetários, mas percentuais de faturamento, como ocorre no direito da concorrência ou do combate à corrupção, por exemplo. Nesse caso, os contratos de concessão devem prever a possibilidade do valor da multa ser arbitrado em virtude do grau de culpa e da imputabilidade da empresa.

O órgão responsável pelas multas administrativas não pode ser o mesmo órgão responsável pelo estímulo à produção de petróleo. Como ficou bem evidente em outras experiências internacionais, a exemplo dos Estados Unidos, trata-se de sistema altamente ineficaz. Nos contratos de concessão, é importante destacar a possibilidade do IBAMA e não da ANP de fixar os valores adequados de multas, bem como a impossibilidade de continuar a exploração no país.

\section{REFERÊNCIAS}

AGÊNCIA NACIONAL DO PETRÓLEO, GÁS NATURAL E BIOCOMBUSTIVEIS. Página principal. Disponível em: < http://www.anp.gov.br>. Acesso em: 08 out. 2013.

30 BARROS-PLATIAU, A., BARROS et alii. Correndo para o mar antropoceno: a complexidade da governança dos oceanos e a estratégia brasileira dos recursos marinhos in Revista de Direito Internacional, v. 12, n. 1, 2015
BARROS-PLATIAU, A., BARROS et al. Correndo para o mar antropoceno: a complexidade da governança dos oceanos e a estratégia brasileira dos recursos marinhos in Revista de Direito Internacional, v. 12, n. 1, 2015

BRASIL. Congresso Nacional. Comissão Parlamentar Mista de Inquérito n. 302: destinada a investigar irregularidades envolvendo a empresa Petróleo Brasileiro S/A (PETROBRAS), ocorridas entre os anos de 2005 e 2014 e relacionadas à compra da Refinaria de Pasadena, no Texas (EUA); ao lançamento de plataformas inacabadas; ao pagamento de propina a funcionários da estatal; e ao superfaturamento na construção de refinarias - CPMIPETRO”: relatório final. Brasília, dez. 2014. Disponível em: <http://www.petrobras.com.br/lumis/portal/ file/fileDownload>. Acesso em: 15 jul. 2015.

BRASIL. Ministério Público Federal. Procuradoria da República no Município de Campos dos Goytacazes (RJ). Ação Civil Pública com Pedidos de Liminar. Campos dos Goytacazes, 02 de abril de 2012. Disponível em: $<$ http://s.conjur.com.br/dl/acao-civil-publica-chevron-mpf.pdf $>$. Acesso em: 09 maio 2015.

BRASIL. Procuradoria da República no Estado do Rio de Janeiro $20^{\circ}$ Ofício. Meio Ambiente e patrimônio cultural. Termo de compromisso de ajustamento de conduta que entre si celebram de um lado o Ministério Público Federal e de outro Chevron Brasil Upstream Frade LTDA., Chevron América Latina Marketing LLC e Transocean Brasil Ltda. com a interveniência da Agência Nacional do Petróleo, Gás Natural e Biocombustiveis - ANP e do Instituto Brasileiro do Meio Ambiente e dos Recursos Naturais Renováveis - Ibama. Rio de Janeiro, 13 de Setembro de 2013. Disponível em: < http://s. conjur.com.br/dl/tac-chevron-mp-ibama.pdf $>$. Acesso em: 15 jul. 2015.

BRASIL. Tribunal de Contas da União. Relatório de Auditoria. TC-037.197/2011-8. Plenário. Órgão Entidade: Petróleo Brasileiro S.A.(Petrobras). Interessado: Tribunal de Contas da União. Relator: Relator: Min. José Jorge de Vasconcelos Lima. Brasília, 22 de outubro de 2014. Disponível em: <portal2.tcu.gov.br/ portal/.../037.197\%20(Campo\%20de $\% 20$ Frade).rtf $>$. Acesso em: 15 jul. 2015.

ELLSWORTH, Brian. Petrobras to sell $\$ 65$ billion stock in record offer. Disponível em: <http://www.reuters.com/article/2010/09/03/us-petrobras-idUSTRE6821FX20100903 >. Acesso em: 08 out. 2013 
GIACOMITTI, R. B e ISAGUIRRE-TORRES, K. R. Instrumentos públicos e privados para a reparação do dano ambiental causado por derramamento de óleo no mar sem origem definida: as manchas órfãs in Revista de Direito Internacional, v. 12, n.1, 2015.

GOLDSTEIN, Andrea. The emergence of multilatinas: the Petrobras experience. Universia Business Review, Madrid, n. 25, p. 98-111, 2010.

INFORME CONJUNTURA E INFORMAÇÃO. Rio de Janeiro: ANP, 200?. Disponível em: <www.anp.gov. br>. Acesso em: 8 maio 2015.

INSTITUTO NACIONAL DE MEIO AMBIENTE. Nota Informativa CPEG/DILIC/IBAMA n 01/12 de 05 de Janeiro de 2012. Disponível em: <http://www.mma. gov.br/port/conama/processos/DC218947/ParecerIBAMA.pdf.>. Acesso em: 09 maio 2015.

LOPES, I. O direito internacional privado e a responsabilidade civil extracontratual por danos ambientais causados por transportes marítimos à luz do direito brasileiro in Revista de Direito Internacional, v. 12, n.1, 2015. LUCCHESI, Celso Fernando. Petróleo. Estudos Avança- dos, São Paulo, v. 12, n. 33, p. 17-40, maio/ago. 1998.

NAÇÕES UNIDAS. Convenção das Nações Unidas sobre o Direito do Mar e o acordo relativo à aplicação da parte XI da mesma convenção. Nova York, 10 de dezembro de 1982. Disponível em: <http://www.gddc.pt/siii/ im.asp?id=396> . Acesso em: 16 jun. 2015.

OPERAÇÃO no Campo Frade: primeira produção teve início em 2009. Disponível em: <https:/ /www.chevron. com.br/negocios/exploracao-producao-petroleo/campo-frade.aspx> Acesso em: 09 maio 2015.

PERGUNTAS e respostas: pré-sal. Set. 2009. Disponível em: <http://veja.abril.com.br/idade/exclusivo/perguntas_respostas/pre-sal/>. Acesso em: 08 out. 2013.

SEABRA, Alessandra Aloise de et al. A Província promissora fazer pré-sal. Revista Direito GV, São Paulo, v. 7, n. 1, p. 57-74, jan./jun. 2011.

TREVES, Tullio. Coastal States' rights in the maritime areas under UNCLOS in Revista de Direito Internacional, v. 12, n.1, 2015. 


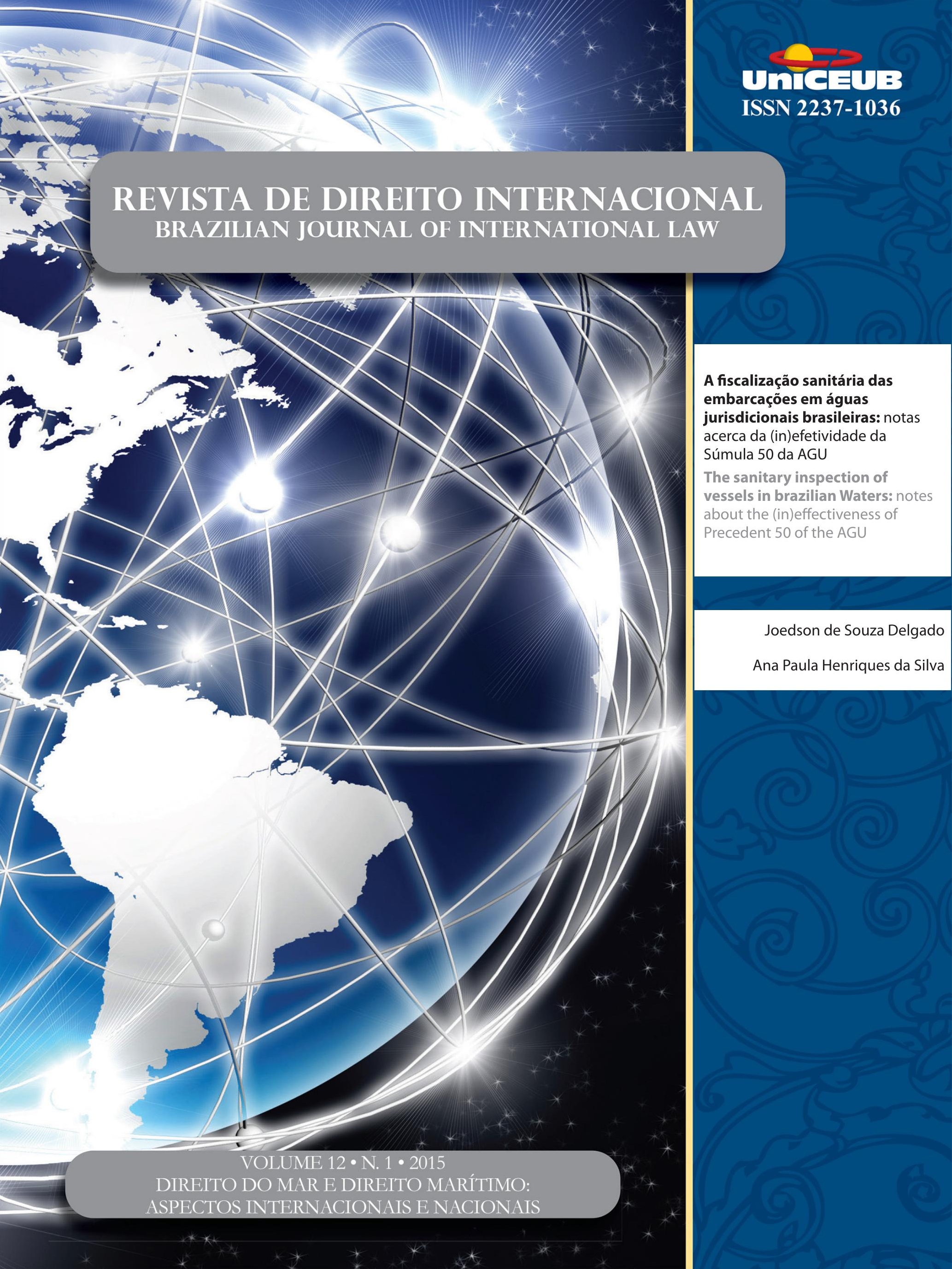




\section{A fiscalização sanitária das embarcações em águas jurisdicionais brasileiras: notas acerca da (in)efetividade da Súmula 50 da AGU*}

\author{
The sanitary inspection of vessels in brazilian \\ Waters: notes about the (in)effectiveness of \\ Precedent 50 of the AGU
}

* Recebido em 30/04/2015 Aprovado em 11/06/2015

** Mestrando em Direito pelo Centro Universitário de Brasília - UniCEUB. Especialista em Direito Sanitário pela Fundação Oswaldo Cruz - Fiocruz e em Direito Administrativo pelo Instituto Brasiliense de Direito Público - IDP. Administrador graduado pela Universidade de Brasília - UnB e advogado pelo Centro Universitário do Distrito Federal - UDF. Analista Administrativo na Agência Nacional de Vigilância Sanitária - Anvisa. E-mail: joedson. delgado@hotmail.com

*** Aluna especial do Mestrado em Direito do Centro Universitário de Brasília - UniCEUB. Especialista em Direito Constitucional pela AVM Faculdade Integrada e em Direito Administrativo pela Faculdade Integrada da Grande Fortaleza - FGF. Cientista política e internacionalista graduada pela Universidade de Brasília - UnB e advogada pelo Centro Universitário de Brasília - UniCEUB. Assessora Política na Embaixada do Burkina Faso. E-mail: grody17@hotmail.com
Joedson de Souza Delgado**

Ana Paula Henriques da Silva***

\section{Resumo}

Apresentamos neste artigo a problemática das infrações sanitárias perpetradas a bordo das embarcações estrangeiras ou nacionais que fazem parada nos portos brasileiros e a necessidade de uma solução viável trazida pela lacuna deixada pela Súmula no 50 da Advocacia Geral da União (AGU) de 13 de agosto de 2010. Por um lado, apontamos a solução administrativa adotada pela AGU de reduzir o litígio e garantir a segurança jurídica da norma para a sociedade diante da responsabilidade estatal na prevenção do risco sanitário à população. Por outro lado, sugerimos a atualização da Lei n ${ }^{\circ}$ 6.437/1977 que configura infrações à legislação sanitária federal para que o texto preveja expressamente a responsabilidade do agente marítimo em casos de descumprimento de normas sanitárias e, nesse intervalo sine lege, que a Agência Nacional de Vigilância Sanitária adote a estratégia de resposta a essa problemática, o que pode ser feito de modo semelhante à prática marítima francesa de controle coordenado dos navios estrangeiros que fazem escala nos portos europeus, canadenses e da Federação Russa.

Palavras-chave: Infração sanitária. Súmula. Advocacia-Geral da União. Risco sanitário. Agente marítimo.

\section{Abstract}

We present in this article the issue concerning sanitary infractions undertook on board by foreign or domestic vessels that stop in Brazilian ports and the need to set up a suitable solution to repair the gap introduced by the General Union Attorney Precedent's no 50 of 13 august 2010. On one hand, we point out the administrative solution adopted by the General Union Attorney to reduce litigation and ensure legal security in applying the norm to society in light of the state responsibility and accountability in avoiding healthy risks to the population. On the other hand, we suggest the upgrade of Law 6,437/1977 that is related to violations to federal healthy legislation in order that the text effectively assures the responsibility of the shipping agent in case of non-compliance with healthy standards and, in the mean- 
time sine lege, that the National Sanitary Surveillance Agency adopts the strategy of response to this issue following the model employed by the French maritime coordinated practice in controlling the way to deal with foreign vessels that stop in European, Canadian and Russian ports.

Keywords: Sanitary infraction. Precedent. General Union Attorney. Health risk. Maritime agent.

\section{Considerações iniciais}

O advento da Agência Nacional de Vigilância Sanitária (Anvisa) — e sua atividade regulatória — deslocou o papel histórico do Poder Legislativo para o Poder Executivo na formulação central das políticas de saúde pública, neste compreendidas as ações de vigilância sanitária aptas a prevenir riscos e agravos à população brasileira.

Tal cenário veio acompanhado de texto normativo que responsabiliza objetivamente a quem seja autor ou responsável por irregularidade administrativa, notadamente o agente marítimo por infração de natureza sanitária observada a bordo de navios, segundo estabelece o art. $3^{\circ}$ da Lei no 6.437/1977, "o resultado da infração sanitária é imputável a quem lhe deu causa ou para ela concorreu" ${ }^{1 "}$.

Com efeito, entende-se por agente marítimo aquele que, em representação do proprietário, do armador, do gestor ou do afretador, ou de alguns desses concomitantes, se encarrega tanto de despachar o navio em porto quanto das operações comerciais a que ele se destina, bem como assistir o capitão na prática dos atos jurídicos e materiais necessários à conservação do navio e à continuação da viagem ${ }^{2}$.

A Anvisa, por seu turno, publicou as Resoluções da

1 BRASIL. Lei ñ 6.437, de 20 de agosto de 1977. Configura infrações à legislação sanitária federal e estabelece as sanções respectivas. Disponível em: <http://www.planalto.gov.br/ccivil_03/leis/L6437. htm>. Acesso em: 28 abr. 2015.

2 FERREIRA, Milena. Aspectos jurídicos das responsabilidades do agente marítimo. 2006. 86 f. Monografia (Graduação) - Centro de Ciências Jurídicas, Políticas e Sociais da Universidade do Vale do Itajaí, Itajaí, 2006. Disponível em: < http://siaibib01.univali.br/pdf/Milena\%20 Ferreira.pdf $>$. Acesso em: 27 abr. 2015.
Diretoria Colegiada (RDC) $217 / 2001^{3}$ e 56/2008 que permitiram imputar ou garantir que o agente marítimo fosse responsabilizado por infrações sanitárias perpetradas por armadores ${ }^{5}$ ou pelo comandante de embarcações $^{6}$ estrangeiras representados por ele no Brasil.

Em sentido diverso, o Superior Tribunal de Justiça (STJ) entendeu que o agenciamento marítimo se resume na intermediação feita pelo armador ou pelo comandante a fim de prover todas as necessidades do navio, no porto de destino ${ }^{7}$. Logo, isento de responsabilidade por ilicitude sanitária praticada em embarcações.

Ainda, de igual modo, a Advocacia-Geral da União (AGU), em 13 de agosto de 2010, atenta a uma possível solução administrativa para reduzir o litígio jurídico e garantir a segurança jurídica da norma para a sociedade expediu a Súmula $50 \mathrm{em}$ que "não se atribui ao agente marítimo a responsabilidade por infrações sanitárias ou administrativas praticadas no interior das embarcações" ${ }^{8 "}$.

3 AGÊNCIA NACIONAL DE VIGILÂNCIA SANITÁRIA, Resolução da Diretoria Colegiada - RDC n 217, de 21 de novembro de 2001. Dispõe sobre o Regulamento técnico da vigilância sanitária de embarcações, portos de controle sanitário e da prestação de serviços de interesse da saúde pública e da produção e circulação de bens. Disponível em: <http://www.ambiente.sp.gov.br/wp-content/uploads/cea/Res.Anvisa217-01.pdf>. Acesso em: 22 abr. 2015.

4 AGÊNCIA NACIONAL DE VIGILÂNCIA SANITÁRIA. Resoluscão da Diretoria Colegiada - RDC n $n^{\circ}$ 56, de 6 de agosto de 2008. Dispõe sobre o Regulamento técnico de Boas Práticas Sanitárias no Gerenciamento de Resíduos Sólidos nas áreas de Portos, Aeroportos, Passagens de Fronteiras e Recintos Alfandegados. Disponível em: <http://portal.anvisa.gov.br/wps/wcm/connect/6b0d0080 4e5eefdc9657ded762e8a5ec/RDC_56_RESIDUOS_SOLIDOS. pdf?MOD=AJPERES $>$. Acesso em: 22 abr. 2015.

5 III - Armador - pessoa física ou jurídica que, em seu nome e sob sua responsabilidade, apresta a embarcação com fins comerciais, pondo-a ou não a navegar por sua conta; (art., $2^{\circ}$, da Lei n ${ }^{\circ} 9.537$, de 11 de dezembro de 1997).

$6 \mathrm{~V}$ - Embarcação - qualquer construção, inclusive as plataformas flutuantes e, quando rebocadas, as fixas, sujeita a inscrição na autoridade marítima e suscetível de se locomover na água, por meios próprios ou não, transportando pessoas ou cargas; (art., $2^{\circ}$, da Lei ${ }^{\circ}$ 9.537, de 11 de dezembro de 1997).

7 AgRg no RESP n ${ }^{\circ}$ 719.446/RS, Relatora Ministra Denise Arruda; AgRg no RESP n 1.D42.703/ES, Relator Ministro Benedito Gonçalves; RESP n ${ }^{\circ}$ 826.637/RS, Relator Ministro Francisco Falcão; AgRg no AI n 1.039.595, Relatora Ministra Denise Arruda (Primeira Turma); RESP n 665.950/PE, Relator Ministro Franciulli Netto; RESP n ${ }^{\circ} 731.226 / \mathrm{PE}$; Relatora Ministra Eliana Calmon; AgRg no RESP $n^{\circ}$ 1.058.368/RS, Relator Ministro Castro Meira; AgRg no RESP n ${ }^{\circ}$ 981.545/SP, Relator Ministro Herman Benjamin; AgRg no RESP n ${ }^{\circ} 1.165 .103 /$ PR, Relator Ministro Castro Meira (Segunda Turma).

8 ADVOCACIA-GERAL DA UNIÃO. Súmula nº 50, de 13 de agosto de 2010. Disponível em: <http://www.agu.gov.br/page/ 
Como consequência de o verbete sumular - de observância obrigatória pela Anvisa - o documento desincumbiu a figura do agente marítimo de responsabilidades, autuações, interdições e notificações por danos e infrações originadas e cometidas pelos navios estrangeiros ou de bandeira brasileira, ditame esse que trouxe uma nova realidade ao cenário da Vigilância Sanitária na atuação em portos brasileiros.

Tal orientação normativa pôs fim à discussão quanto à responsabilidade do agente marítimo por infrações sanitárias ou administrativas praticadas no interior de embarcações, contudo, deixou um limbo jurídico quanto à respectiva responsabilização.

Paradoxalmente, a redação da Súmula 50 da AGU é simples, mas de efeito contundente. O enunciado sumular apresenta dupla dimensão a ser resolvida: o administrativo, de controle sanitário de embarcações e a jurídica, relativa à responsabilidade por infrações sanitárias a bordo.

O ensaio traz à tona intricado litígio jurídico, no qual a Anvisa transferia a obrigação do armador para os agentes marítimos, entendimento revisto pela AGU, para se conformar à doutrina e jurisprudência vigorantes. Consubstancia-se em atualidade técnica-jurídica que pauta no cotidiano de um sem-número de profissionais afetos à atividade empresarial de navegação.

Por conseguinte, ao analisar sua aplicabilidade prática, percebe-se que a mantença desse instituto nas atividades de vigilância sanitária coloca em risco a concretização do direito individual e coletivo à saúde pública pelo simples fato de não existir outro representante ou filial do armador (estrangeiro) no Brasil, sujeitando-o, assim, ao inadimplemento de suas obrigações. Portanto, o foco do trabalho repousa sobre a problemática sanitária às quais as embarcações nos portos brasileiros estavam sujeitas com relação à fiscalização sob a responsabilidade da Anvisa.

Tal embate carece de solução plausível para que o responsável pela obrigação seja autuado e que efetivamente responda pelos seus atos. Para tanto, no plano internacional, trata-se precisamente da adaptação de um acordo interadministrativo regional utilizado pelo Canadá, alguns países europeus e asiáticos ${ }^{9}$ que conseguiram,

atos/detalhe/idato/257572>. Acesso em: 28 abr. 2015.

9 O Memorandum d'entente atualmente agrega 27 (vinte e sete) Nações-Membros: Alemanha, Bélgica, Bulgária, Canadá, Croácia, por meio do Memorandum d'entente (termo utilizado na França) ou Protocole d'entente (usual no Canadá), implantar controle coordenado de navios estrangeiros, fazendo escala nos portos europeus. Tal formato poderia ser adaptado no Brasil?

Para responder, o texto organiza-se em quatro partes que, após breve introito, pauta-se na abordagem das ações de Vigilância Sanitária nos portos brasileiros. De maneira detida, analisou-se o princípio da precaução no intuito de evitar as consequências involuntárias substanciais (riscos) que afetam a saúde pública e o meio ambiente marítimo. Após, examina-se, à luz do tratado alienígena, a possível solução da ação fiscal no cotidiano portuário em detrimento à prestação efetiva de saúde e encerra-se com reflexões quanto à permanência da Súmula 50 da AGU frente à ausência do dispositivo normativo na Lei 6.437/1977.

Para tanto, o trabalho se baseia em pesquisa bibliográfica, de abordagem qualitativa, ao apreciar a lacuna jurídica deixada pelo enunciado normativo ao tempo em que explica e classifica o tema proposto.

Destarte, espera-se alcançar o objetivo geral deste trabalho no campo doutrinário, qual seja a aplicação dos conhecimentos e o estímulo à continuidade dos estudos sobre a limitação da responsabilidade administrativa relativa à infração sanitária apurada no interior de navio que não pode ser imputada ao agente marítimo, buscando saber as consequências para a saúde pública.

\section{As ações de VigilânCia Sanitária nas EMBARCAÇÕES EM ÁGUAS SOB JURISDIÇÃO BRASILEIRA 10}

No Brasil, a Constituição Federal de $1988^{11}$ é um

Chipre, Dinamarca, Espanha, Estônia, Federação da Rússia, Finlândia, França, Grécia, Islândia, Irlanda, Itália, Letônia, Malta, Noruega, Países-Baixos, Polônia, Portugal, Romênia, Eslovênia, Suécia, ReinoUnido da Grã-Bretanha e Irlanda do Norte.

10 Águas jurisdicionais brasileiras são todas aquelas elencadas no art. 20, III e VI, da Constituição Federal, e mais explicitada no art. $3^{\circ}$, da Lei 9.966/2000 que pontua como (i) águas interiores compreendidas entre a costa e a linha-de-base reta, a partir de onde se mede o mar territorial; as dos portos; as das baías; as dos rios e de suas desembocaduras; as dos lagos, das lagoas e dos canais; as dos arquipélagos; as águas entre os baixios a descoberta e a costa. (ii) águas marítimas como todas aquelas sob jurisdição nacional que não sejam interiores.

11 BRASIL. Constituição (1988). Constituição da República Federativa 
marco do direito à saúde, pois assegurou ao coletivo, como bem maior do homem, que o poder público tem o dever de prover condições indispensáveis ao seu pleno exercício.

Conforme se depreende do inciso II do art. 200 da Constituição Federal, o Sistema Único de Saúde (SUS) possui atribuição de "executar as ações de vigilância sanitária e epidemiológica, bem como as de saúde do trabalhador", atribuição que foi reproduzida na Lei $\mathrm{n}^{\circ}$ $8.080 / 1990^{12}$, ao tratar do campo de atuação do SUS.

O Decreto $n^{\circ} 3.029 / 1999^{13}$, ao regulamentar a Lei $\mathrm{n}^{\circ} 9.782 / 1999^{14}$, que trata do controle de portos, confere no art. $2^{\circ}$ competência à Anvisa para regulamentar, analisar, controlar e fiscalizar os serviços de interesse sanitário.

Com efeito, as questões de ordem sanitária (medidas preventivas e de controle de surtos, epidemias, pandemias e agravos inopinados) são cada vez mais recorrentes na promoção da saúde da tripulação das embarcações de bandeiras brasileira ou estrangeira, ancorados ou por atracar nos portos organizados ${ }^{15}$, nos terminais de uso privado ${ }^{16}$, nas instalações portuárias ${ }^{17}$, nas esta-

do Brasil. Disponível em: <http://www.planalto.gov.br/ccivil_03/ Constituicao/Constituicao.htm>. Acesso em: 8 jun. 2015.

12 BRASIL. Lei n. 8.080, de 19 de setembro de 1990. Lei Orgânica da Saúde. Dispõe sobre as condições para a promoção, proteção e recuperação da saúde, a organização e o funcionamento dos serviços correspondentes e dá outras providências. Disponível em: <http:/ / www.planalto.gov.br/ccivil_03/leis/18080.htm>. Acesso em: 8 jun. 2015.

13 BRASIL. Decreto n. 3.029, de 16 de abril de 1999. Aprova o Regulamento da Agência Nacional de Vigilância Sanitária, e dá outras providências. Disponível em: <http://www.planalto.gov.br/ccivil_03/decreto/D3029.htm>. Acesso em: 8 jun. 2015.

14 BRASIL. Lei n. 9.782, de 26 de janeiro de 1999. Define o Sistema Nacional de Vigilância Sanitária, cria a Agência Nacional de Vigilância Sanitária, e dá outras providências. Disponível em: <http:// www.planalto.gov.br/ccivil_03/leis/19782.htm>. Acesso em: 28 abr. 2015.

15 I - porto organizado: bem público construído e aparelhado para atender a necessidades de navegação, de movimentação de passageiros ou de movimentação e armazenagem de mercadorias, e cujo tráfego e operações portuárias estejam sob jurisdição de autoridade portuária; (art. $2^{\circ}$, da Lei no 12.815 , de 5 de junho de 2013). 16 IV - terminal de uso privado: instalação portuária explorada mediante autorização e localizada fora da área do porto organizado; (art. $2^{\circ}$, da Lei no 12.815 , de 5 de junho de 2013).

17 III - instalação portuária: instalação localizada dentro ou fora da área do porto organizado e utilizada em movimentação de passageiros, em movimentação ou armazenagem de mercadorias, destinadas ou provenientes de transporte aquaviário (art. $2^{\circ}$, da Lei ${ }^{\circ}$ 12.815, de 5 de junho de 2013). ções de transbordo de $\operatorname{cargas}^{18}$, nas instalações portuárias públicas de pequeno porte ${ }^{19}$ e nas instalações portuárias de turismo ${ }^{20}$.

Nesse passo, as inspeções sanitárias realizadas a bordo das embarcações observam os padrões operacionais e higiênico-sanitários, o estado de saúde dos seus viajantes, assim como realizam a análise documental das informações apresentadas quando da sua solicitação.

O ambiente interno de um navio é considerado como área crítica para a disseminação de doenças em razão da vulnerabilidade sanitária e epidemiológica, e isso data de eras remotas, como a Antiguidade. A título de exemplo, cita-se a descoberta da peste na cidade de Atenas, na Grécia antiga, no ano de 430 A.C quando os atenienses confrontavam com a poderosa força militar espartana e os registros históricos apontam para cenas dantescas de

Corpos e mais corpos eram cremados, o que indicava aos inimigos que algo terrível acontecia. Os templos estavam repletos de moribundos acomodados em seu solo. Habitantes disputavam as fontes em busca de água, estavam desidratados pela epidemia. Uma nuvem de calor subia pela cidade febril. Alguns recordavam que a doença viera por embarcação marítima originária do Egito $^{21}$.

Nos tempos atuais, emerge as repercussões quanto à disseminação e contágio de infecções por norovírus causador de gastroenterite que atingiu entre hóspedes e tripulantes do navio de cruzeiro Vison of the Seas da empresa Royal Caribbean, em março de $2010^{22}$, com saída

$18 \mathrm{~V}$ - estação de transbordo de cargas: instalação portuária explorada mediante autorização, localizada fora da área do porto organizado e utilizada exclusivamente para operação de transbordo de mercadorias em embarcações de navegação interior ou cabotagem (art. $2^{\circ}$, da Lei no 12.815 , de 5 de junho de 2013).

19 VI - instalação portuária pública de pequeno porte: instalação portuária explorada mediante autorização, localizada fora do porto organizado e utilizada em movimentação de passageiros ou mercadorias em embarcações de navegação interior (art. $2^{\circ}$, da Lei $n^{\circ}$ 12.815, de 5 de junho de 2013).

20 VII - instalação portuária de turismo: instalação portuária explorada mediante arrendamento ou autorização e utilizada em embarque, desembarque e trânsito de passageiros, tripulantes e bagagens, e de insumos para o provimento e abastecimento de embarcações de turismo; (art. $2^{\circ}$, da Lei no 12.815 , de 5 de junho de 2013).

21 UJVARI, Stefan Cunha. A bistória da bumanidade contada pelo virus, bactérias, parasitas e outros microrganismos. São Paulo: Contexto, 2008. p. 122.

22 TRIBUNA ON LINE. Navio Vision of the Seas enfrenta novo surto de gastroenterite em cruzeiro. O Globo, 12 mar. 2010. Disponível em: <http://oglobo.globo.com/brasil/navio-vision-of-theseas-enfrenta-novo-surto-de-gastroenterite-em-cruzeiro-3041288>. 
do Porto de Santos/SP. O surto de gripe do tipo B, afetando o transatlântico MSC Armonia, da empresa MSC Cruzeiros, em fevereiro de $2012^{23}$, ancorado no mesmo Porto.

Sob o prisma da segurança sanitária dos viajantes, tripulantes e trabalhadores que transitam nos portos, os agentes fiscais ${ }^{24}$ da Anvisa são os responsáveis pelo monitoramento da embarcação pelo seu período de permanência na costa brasileira. A inspeção sanitária a bordo pode ser básica com a verificação de documentos, o estado geral da casa de máquinas, dos alojamentos; ser detalhada que inclui o controle da qualidade da água e do armazenamento, o preparo e exposição de alimentos que irão abastecer os navios, o hospital de bordo, os depósitos de resíduos sólidos, o esgotamento sanitário etc. ou nos terminais de passageiros e cargas referente ao sistema de abastecimento de água potável.

Exsurge, nesse contexto, a figura do agente marítimo que iniciou suas atividades auxiliando na armação e no transporte marítimo, facilitando, assim, os trâmites burocráticos exigidos pelos portos. Ao longo do tempo, transmutou-se para a posição de mandatário do comandante da embarcação, no sentido de assisti-lo na prática dos atos jurídicos necessários à conservação do navio e providências de continuação de viagem ${ }^{25}$.

O comandante é designado para representar o Estado a bordo da embarcação, como autoridade máxima que abrigado pelo poder de polícia ${ }^{26}$, exerce a sua auto-

Acesso em: 27 abr. 2015

23 ANDRADE, Juliana. Anvisa inspeciona transatlântico que está sob suspeita de surto de gripe tipo B. Agência Brasil, 27 fev. 2012. Saúde. Disponível em: <http://memoria.ebc.com.br/agenciabrasil/ noticia/2012-02-27/anvisa-inspeciona-transatlantico-que-esta-sobsuspeita-de-surto-de-gripe-tipo-b>. Acesso em: 8 abr. 2015.

24 Agentes fiscais, para Delgado, são agentes públicos que exercem suas funções por intermédio de leis específicas, nos cargos de especialista em regulação e vigilância sanitária/fiscal sanitário/fiscal de controle sanitário/fiscal de saúde pública/técnico de fiscalização sanitária, etc. ou, ainda, por servidores credenciados. DELGADO, Joedson de Souza. O processo administrativo-sanitário como instrumento de efetividade das ações de vigilância sanitária. Revista Tempus: Actas de Saúde Coletiva, Brasília, v. 07, n. 01, p. 225-240. Disponível em: <http://www.tempusactas.unb.br/index.php/tempus/article/ view/1290/1124>. Acesso em: 27 abr. 2015.

25 ULIANA JÚNIOR, L.; WUICIK, M. V. S. Ensaio sobre a responsabilidade civil do agente marítimo. Revista do Instituto do Direito Brasileiro, ano 2, n. 5, p. 4463-4472, 2013. Disponível em: $<$ http://cidp.pt/publicacoes/revistas/ridb/2013/05/2013_05_044 63_04472.pdf $>$. Acesso em: 7 abr. 2015.

26 MARINHA DO BRASIL. Portaria n. 111, de 16 de dezembro de 2003 com alteração parcial pela Portaria n. 21/DPC, de 18 de fevereiro de 2005. Normam-13/2003/DPC, item 0401, subitem 2. Normas da ridade a mando do armador ${ }^{27}$. A administração do navio só é alterada quando há ocorrência de delitos graves ou quando há perturbação da paz no porto ${ }^{28}$. Suas atribuições são extensas e incluem o dever de "inspecionar ou fazer inspecionar a embarcação, diariamente, para analisar as condições de asseio, higiene e segurança ${ }^{29 \prime}$.

A propósito, Sarlet ${ }^{30}$ argumenta acerca da incidência harmônica do direito fundamental, tal como a saúde elencada no texto constitucional e nas relações privadas ao referir que

Direitos fundamentais são, portanto, todas aquelas posições jurídicas concernentes às pessoas, que, do ponto de vista do direito constitucional positivo, foram, por seu conteúdo e importância (fundamentalidade formal), retiradas da esfera de disponibilidade dos poderes constituídos.

Por sua vez, Tietzmann ${ }^{31}$ defende que

É interessante notarmos que a intervenção no risco sanitário está relacionada às atividades exclusivas da administração pública, que tem como responsabilidade regulamentar ou restringir as liberdades ou as questões individuais em favor dos interesses coletivos.

Cabe aos fiscais sanitários fornecer orientações de saúde pública e descrever os resultados da inspeção em relatório toda vez que os padrões estiverem fora de conformidade. Logo, para melhorar as inconformida-

Autoridade Marítima para Aquaviários. Diretoria de Portos e Costas. Disponível em: <https://www.legnet.com.br/sislegnet/integra/cliente-1/pais-1/un31029.htm>. Acesso em: 27 abr. 2015.

27 Armador é a pessoa que arma o navio, isto é, "que o provê de tudo quanto seja necessário para que possa navegar e o explorador, seja em viagens de transportes, seja na prática de pesca; ou o que, em sentido um pouco menos exato, mas que é justificado pela expressão latina exercitor é simplesmente a pessoa que explora o navio, mesmo sem ter por si só equipado" DANJON, Daniel. Traité de droit maritime. Paris: Librairie Generale de Droit et de Jurisprudence, 1950. A propriedade e a armação são conceitos distintos, pois a armação é uma noção dinâmica do exercício da atividade empresarial, enquanto que a propriedade é um direito sobre o navio, embarcação ou plataformas marítimas. MARTINS, Eliane Maria Octaviano. Curso de direito marítimo: teoria geral. 4. ed. Barueri: Manole, 2013. v. 1. p. 304. 28 MARTINS, Eliane Maria Octaviano. Curso de direito marítimo: teoria geral. 4. ed. Barueri: Manole, 2013. v. 1.

29 MARINHA DO BRASIL. Portaria n. 111, de 16 de dezembro de 2003 com alteraşão parcial pela Portaria n. 21/DPC, de 18 de fevereiro de 2005. Normam-13/2003/DPC, item 0401, subitem2. Normas da Autoridade Marítima para Aquaviários. Diretoria de Portos e Costas. Disponível em: < https://www.legnet.com.br/sislegnet/integra/cliente-1/pais-1/un31029.htm>. Acesso em: 27 abr. 2015.

30 SARLET, Ingo Wolfgang. A eficácia dos direitos fundamentais: uma teoria geral dos direitos fundamentais na perspectiva constitucional. 10. ed. Porto Alegre: Livraria do Advogado, 2009.

31 TIETZMANN, Daniela (Org.). Epidemiologia. São Paulo: Pearson Education do Brasil, 2014. p. 75. 
des críticas encontradas, os fiscais fazem exigências por meio de ações e emissão de termos legais, tais como: notificações, autos de infração, interdições, apreensões etc.

Na atuação da Vigilância Sanitária, o risco é o elemento que vai orientar a política normativa de Estado e organizar as ações de proteção ${ }^{32}$. Nesse sentido, risco sanitário constitui a propriedade que tem uma atividade, serviço ou substância, de gerar efeitos deletérios ou adversos à saúde humana e, consequentemente, a possibilidade de que um perigo venha causar um evento pernicioso $^{33}$.

Dessa feita, as ações de Vigilância Sanitária se perfazem em instrumento de controle dos riscos sanitários, por meio da inspeção e fiscalização, pela autoridade competente nas áreas internas dos navios, sendo primordial para determinar a existência de perigo à saúde pública.

\section{Princípio da precaução: a saúde pública e O MEIO AMBIENTE MARÍTIMO PROTEGIDOS}

O princípio da precaução norteia o Direito Ambiental no qual está incluído e se apresenta como fundante para o Direito Sanitário. A questão dos riscos inerentes às atividades comerciais que podem atingir a saúde pública deve ser tratada de maneira a conectar o Direito Ambiental ao Direito Sanitário, tendo o risco um fio condutor.

O processo de formação do princípio da precaução e sua história se fazem necessários para visualizar o quão problemático é a Súmula 50 da AGU ao não apontar o responsável pelas infrações sanitárias cometidas a bordo das embarcações, deixando, assim, um hiato de quem é a responsabilidade pela ilicitude.

O termo "risco" não se confunde com dano, mas associa-se à probabilidade de ocorrência de um evento indesejado e sua severidade. Para Beck ${ }^{34}$, “os riscos não

32 TIETZMANN, Daniela (Org.). Epidemiologia. São Paulo: Pearson Education do Brasil, 2014. p. 75.

33 NAVARRO, Marcus Vinícius Teixeira. Risco, radiodiagnóstico e vigilância sanitária. Salvador: EDUFBA, 2009. Disponível em: <http:/ / static.scielo.org/scielobooks/q5/pdf/navarro-9788523209247. pdf>. Acesso: 27 abr. 2015.

34 BECK, U. Sociedade de risco: rumo a uma outra modernidade. São Paulo: Editora 34, 2010. p. 39. se esgotam, contudo, em efeitos e danos já ocorridos. Neles, exprime-se, sobretudo um componente futuro", portanto, os riscos têm a possibilidade de serem calculados e prevenidos.

Dessa forma, ao se abordar o princípio da precaução, não deve ser confundido com o princípio da prevenção que lhe é subjacente. Embora tais princípios não sejam sinônimos, relacionam-se e fazem parte do princípio da prudência, sendo a precaução, um núcleo menor dentro da prevenção ${ }^{35}$. Essa parametrização faz-se necessária, pois a doutrina jurídica ainda confunde os dois termos.

Medidas acautelatórias são recorrentes na prática a fim de impedir a ocorrência de danos ao meio ambiente e constituem pré-requisitos para a implantação de empresas e atividades consideradas potencialmente ou efetivamente poluidoras, conforme dita o princípio da prevenção ${ }^{36}$.

A atuação preventiva enseja a participação de toda a sociedade e do Estado a se manifestarem por meio de instrumentos normativos e de uma política ambiental preventiva $^{37}$. O Licenciamento Ambiental e os estudos de impacto ambiental são necessários para que os danos sejam minimizados e, mesmo assim, não preconiza sua ausência $^{38}$.

Nesse sentido, o princípio da precaução busca prevenir riscos ou danos. Há uma escolha racional ${ }^{39}$, a fim de selecionar o risco a que está sujeito e qual deve ser prevenido. Contudo, outro obstáculo se apresenta: o risco que acaba por fazer uma escolha baseada na percepção e não na realidade, adentrando, assim, na seara do que é justificado como limites da teoria racional ${ }^{40}$.

Premissas irrealistas são usadas para que o princípio funcione de maneira incondicional. A título ilustrativo,

35 LOPEZ, Teresa Ancona. Princípio da precaução e evolução da responsabilidade civil. São Paulo: Quartier Latin 2010. p.109.

36 MILARÉ, Édis. Direito do ambiente: doutrina, jurisprudência, glossário. São Paulo: Revista dos Tribunais, 2011. p. 264.

37 NEVES, Isabela Dias. Processo civil ambiental: o princípio da precaução como fundamento da concessão de tutelas de urgência. Rio de Janeiro: Lumen Juris, 2014. p. 39.

38 BESSA, Antunes. Direito ambiental. São Paulo: Atlas, 2014. p. 48-49.

39 A teoria da escolha racional era originariamente econômica ao confrontar um consumidor entre diferentes opções disponíveis e escolhe àquela que eles consideram a melhor baseada no conceito de sua utilidade e buscando sua maximização. Atualmente a teoria é usada em outros campos das ciências sociais, principalmente da ciência política.

40 SLOVIC, Paul. The perception of risk. London: Earthscan, 2007. 
uma pessoa que possui informação completa sobre as consequências de seus atos ou que tenha tempo para ponderar a respeito dos cursos possíveis a fim de definir um ponto ótimo ${ }^{41}$. O princípio da precaução reside em uma zona de penumbra, pois não é necessário ter a absoluta certeza científica a respeito dos danos, porém não apresenta o grau a ser exigido para que uma medida seja usada ${ }^{42}$.

O marco internacional do princípio da precaução foi a Conferência das Nações Unidas sobre Meio Ambiente e Desenvolvimento (CNUMAD), popularmente denominada de Rio-92 que, apesar de apresentar uma noção vaga, ampliou o princípio nos acordos internacionais e nas leis nacionais ${ }^{43}$.

$\mathrm{Na}$ ocasião foi proclamada a Declaração do Rio que não obrigam as partes ${ }^{44}$, mas norteou, no princípio 15 , o debate sobre a precaução

Com o fim de proteger o meio ambiente, o princípio da precaução deverá ser amplamente observado pelos Estados, de acordo com suas capacidades. Quando houver ameaça de danos graves ou irreversíveis, a ausência de certeza científica absoluta não será utilizada como razão para o adiamento de medidas economicamente viáveis para prevenir a degradação ambiental.

Sua aparição, nos anos 70, restringia a Alemanha do Leste, também, conhecida como vorsorgeprinzip ou foresight ao se referir à lei de proteção da água alemã. O termo vorsorgeprin₹ip que significa o próprio princípio da precaução foi usado para justificar rigorosas políticas públicas no intuito de barrar a poluição da água, a chuva ácida, o aquecimento global e a poluição do Mar do Norte $^{45}$. Já o foresight deu sustentação ao aparecimento de uma indústria alemã competitiva baseada em tecnologias ambientais e de prevenção da poluição $\mathrm{O}^{46}$.

41 ANDRADE, Oyama Karyna Barbosa. Teoria da escolha racional e teoria dos jogos: uma abordagem para os métodos de resolução de conflitos. In: ANDRADE, Oyama Karyna Barbosa; ORSINI, Adriana Goulart de Sena; COSTA, Mila Batista Leite Correia da. (Org.). Justiça do século XXI. São Paulo: LTr, 2014. p. 237-238. 42 TESSLER, Luciane Gonçalves. A importância do princípio da precaução na aferição da prova nas ações inibitórias ambientais. In: WERNECK, Mário, et al. (Coord). Direito ambiental: temas atuais vistos por nós advogados. Belo Horizonte: Editora Del Rey, 2005. p. 662-665.

43 RAFFENSPERGER Carolyn; TICKNER, Joel. Protecting public bealth and the environment: implementing the precautionary principle. Washington, D.C: Island Press, 1999. p. 43.

44 BESSA, Antunes. Direito ambiental. São Paulo: Atlas, 2014. p.35-36. 45 O Mar do Norte localiza-se no Oceano Atlântico entre as costas (leste) da Noruega e da Dinamarca, Ilhas Britânicas (oeste) e a Alemanha, Países Baixos, Bélgica e França (sul).

46 RAFFENSPERGER Carolyn; TICKNER, Joel. Protecting public
No âmbito internacional, discussão similar somente aconteceu em 1984, na Primeira Convenção Internacional para a Proteção do Mar do Norte, cujo intento consistia em preservar o frágil ecossistema marítimo da área afetada em razão do despejo de substâncias tóxicas, no entanto, o termo "princípio da precaução" somente foi usado na Segunda Convenção Internacional para a Proteção do Mar do Norte, em 1987. Existia, na ocasião, como estratégia de defesa, o benefício da dúvida quanto ao nexo de causalidade entre as emissões de poluentes e os seus efeitos ${ }^{47}$.

Hoje, o princípio pode ser encontrado com vastidão em documentos internacionais dotados de força obrigatória ${ }^{48}$, todavia observa-se que não há coação, tampouco necessidade de paralisação da atividade, mas a adoção de cuidados ambientais ${ }^{49}$.

Nota-se que o termo "princípio" é mais usual em documentos de força impositiva, nos outros, emprega-se apenas a precaução ou sua abordagem ${ }^{50}$. Tais documentos adotam mecanismos de escolha relacionados ao custo e benefício da atividade, minimizando os riscos.

Em 1998, a Wingspread Declaration51 sedimentou o princípio da precaução ao alarmar sobre a insustentabilidade da continuação do dano ambiental e do seu limite, apresentando quatro componentes ${ }^{52}$ : (i) a ação preventiva deve ser tomada antes de qualquer prova científica de

bealth and the environment: implementing the precautionary principle. Washington, D.C: Island Press, 1999. p. 87.

47 CANOTILHO, José Joaquim Gomes; LEITE, José Rubens Morato (Org.). Direito constitucional ambiental brasileiro. 4. ed. São Paulo: Saraiva, 2011. p. 145.

48 No Tratado de Maastricht, no Protocolo de Cartagena, na Convenção de Estocolmo Sobre Poluentes Orgânicos Persistentes, dentre outros.

49 BESSA, Antunes. Direito ambiental. 16. ed. São Paulo: Atlas, 2014. p. 37.

50 BESSA, Antunes. Direito ambiental. 16. ed. São Paulo: Atlas, 2014. p. 37.

51 A Declaração de Wingspread ocorreu na sede da Johnson Foundation, em Racine, estado de Wisconsin/E.U.A, em que cientistas, filósofos, advogados e ativistas ambientais, chegaram a um acordo sobre a necessidade de o princípio da precaução aplicada na saúde pública e deveria ser tomada nas decisões em matéria ambiental. O elemento-chave do princípio é que incita a tomar medidas de antecipação na ausência de certeza científica. Os participantes observaram que as políticas atuais, como a avaliação de risco e análise custo-benefício em dar o benefício da dúvida a novos produtos e tecnologias, que podem mais tarde revelar-se prejudicial. Maiores informações podem ser obtidas no sitio eletrônico < http://www. johnsonfdn.org/>.

52 RAFFENSPERGER Carolyn; TICKNER, Joel. Protecting public bealth and the environment: implementing the precautionary principle. Washington, D.C: Island Press, 1999. p. 8-9. 
nexo de causalidade; (ii) o proponente da atividade deve suportar o ônus de segurança de uma atividade, e não a sociedade; (iii) um amplo rol de alternativas, incluindo a inação, deve ser considerado quando há evidências de dano causado pela atividade; (iv) a tomada de decisão deve ser aberta, informativa e democrática, além de incluir as partes afetadas.

Ao examinar o surgimento do princípio da precaução até a Declaração de Wingspread ${ }^{53}$, observa-se que houve ampliação conceitual que transbordou a geografia alemã, alcançando proporções internacionais. A precaução, desde então, vai além do dano e riscos da poluição ambiental, passando a albergar o risco à saúde humana.

A vertente mais forte do princípio da precaução defende uma regulação na iminência de riscos para a saúde pública e/ou para a natureza, mesmo se as provas desse risco forem apenas especulativas ${ }^{54}$. A versão prudente/ fraca sustenta que, quando inexistem evidências concretas entre dano e ação humana, não se justifica que os processos naturais sejam defendidos.

O enunciado da Referência 36 consiste em formulação um pouco mais agressiva que aquela advinda da Conferência das Nações Unidas sobre o Meio Ambiente e Desenvolvimento, realizada no Rio de Janeiro, em junho de 1992 (Rio-92), pois não se limita às ameaças de danos graves e irreversíveis. A Rio-92 decidiu pela versão prudente/fraca.

E se a escolha da Rio-92 ocorresse pela versão forte do princípio da precaução seria ela paralisante? Sabe-se que qualquer atividade é sujeita a riscos, bem como quando um risco é eliminado ou reduzido, outro risco

53 Segundo a Declaração de Wingspread: "quando uma atividade representa ameaças de danos ao meio-ambiente ou à saúde humana, medidas de precaução devem ser tomadas, mesmo se algumas relações de causa e efeito não forem plenamente estabelecidas cientificamente".

54 Para Sustein, o ideal seria falar em precaução prudente, chamando a atenção para que houvesse uma vigilância contínua ao invés de aceitar os riscos que não podem ser mensurados com segurança. Adotou-se um critério econômico denominado, em inglês, de "risk-risk trade-offs", podendo ser traduzido por "arbitragem de riscos". Tal critério postula um equilíbrio de custos e de benefícios, o que enseja uma atenção quanto aos danos irreversíveis e potencialmente catastróficos. SUSTEIN, Cass R. Para além do princípio da precaução. Revista de Direito Administrativo - $R D A$, Rio de Janeiro, v. 259, p. 11-71, jan./abr. 2012. Disponível em: <http://bibliotecadigital.fgv.br/ojs/index.php/rda/article/viewFile/8629/7373>. Acesso em: 22 abr. 2015. pode ser criado ou até mesmo aumentado ${ }^{55}$.

Para mitigar os riscos de uma atividade, Sustein ${ }^{56}$ enumera vários exemplos nos quais a regulação elimina o efeito da precaução. Cita-se o da indústria farmacêutica em que existe atraso (drug lag) na introdução de novos medicamentos. A Anvisa, como órgão regulador, permite introduzir os produtos no mercado sem que haja, de fato, uma análise integral sobre os seus malefícios, isto é, nos casos em que necessitam apressar a utilização de novas drogas, a exemplo, de doentes terminais.

Nenhuma nação conseguiria se precaver de todos os riscos, portanto, é inerente uma seletividade.

Sustein afirma que os Estados Unidos, por exemplo, são mais precavidos em relação a "depósitos de resíduos perigosos, terrorismo e serviços de saúde universais (universal health care), mas não adotam abordagem resguardada quanto aos riscos associados ao aquecimento global, poluição do ar interior (indoor air pollution), pobreza e obesidade". Nesse sentido, o princípio da precaução no seu modelo forte é paralisante, caso seja adotado de maneira universal, principalmente "referindo-se especialmente às questões referentes ao arsênico, aquecimento global, energia nuclear e engenharia genética alimentar".

Desse modo, apercebe-se que o risco à saúde humana no Brasil encontra-se relegado ao plano secundário, situação constatada com a vigência da Súmula 50 da AGU que aprovada desde 2010, ainda, não houve uma presteza na formulação de uma norma ou tratado internacional que eficazmente aponte o responsável pela infração.

\section{Memorandum d'ENTENTE: A SOLUÇÃo No DIREITO COMPARADO}

Para controlar a ocorrência de doenças, as atividades de prevenção no contexto da Vigilância Sanitária merecem o estabelecimento adequado da dimensão jurídica

55 GRAHAM, John D.; WIENER, Jonathan Baert. Risk versus risk: tradeoffs in protecting health and the environment. Cambridge, Mass: Harvard University Press. 1997. p. 1.

56 SUSTEIN, Cass R. Para além do princípio da precaução. Revista de Direito Administrativo - RDA, Rio de Janeiro, v. 259, p. 11-71, jan./abr. 2012. Disponível em: <http://bibliotecadigital.fgv.br/ojs/ index.php/rda/article/viewFile/8629/7373 . Acesso em: 22 abr. 2015. 
por meio de normas sancionatórias, sendo necessário, um sistema mais abrangente do utilizado atualmente pela Anvisa referente à fiscalização dos cruzeiros maríti$\operatorname{mos}^{57}$ que é mensurado por meio de pontuação de cada navio, resultando em um Índice de Risco Sanitário ${ }^{58}$.

A solução a ser dada ao caso concreto pode estar contida no Memorandum d'entente de Paris, também denominado de Protocole d'entente no Canadá, aprovado em 26 de janeiro de 1982, que tem como preceito a observação dos navios que fazem escala nos portos dos países signatários para que as normas das várias convenções internacionais abrigadas pelo texto ${ }^{59}$, como a proteção ao ambiente marinho, à salvaguarda da vida humana e as condições de trabalho dos marítimos sejam respeitadas ${ }^{60}$.

A vantagem de tal Convenção é justamente a unificação e a coordenação de procedimentos de inspeção nos portos dos Estados-Membros, bem como dos portos não abrangidos pela diretriz denominados de pavilhões, utilizando os mesmos procedimentos, o mesmo banco de dados, os mesmos registros e outras formas. Os Estados-Membros devem consultar-se mutuamente, cooperar e compartilhar informações.

$\mathrm{O}$ sistema eletrônico Thetis ${ }^{61}$ surgiu para dar consistência ao "new Port State Control inspection regime (NIR)", embasado na nova diretriz 2009/16/EC (22 $^{\text {e nas }}$

57 AGÊNCIA NACIONAL DE VIGILÂNCIA SANITÁRIA. Temporada de Navios de Cruzeiro. Disponível em: <http://www.anvisa.gov.br/hotsite/cruzeiros/infonavios.html>. Acesso em: 23 abr. 2015.

58 O cálculo de risco é determinado por valores pré-estipulado pelo sistema de gestão de riscos denominado Sagarana. Os dados são inseridos na inspeção pelo agente fiscal gerando, automaticamente, o Índice de Conformidade e a Pontuação de Risco. Tal informação consta do sítio eletrônico da Anvisa (Temporada de Navios de Cruzeiro): < http://www.anvisa.gov.br/hotsite/cruzeiros/resultadodasinspecoes.html>. Acesso em: 23 abr. 2015.

59 São várias as Convenções abrigadas, no total de 17, uma das mais importantes é a Convenção Internacional de 1973 alterado pelo Protocolo de 1978 para a prevenção da poluição chamada de Marpol (Convenção Internacional para Prevenção da Poluição por Navios). Por conseguinte, o "Mémorandum d'entente" demonstra seu caráter internacional de importância ímpar para o direito ambiental e para o direito sanitário em razão da respeitabilidade das normas contidas nas convenções adotadas no âmbito da Organização Marítima Internacional (OMI) e da Organização Internacional do Trabalho (OIT). 60 FRANCE. Protocole d'Entente de Paris sur le controle des navires par l'Etat du port. Disponible dans: <https://www.parismou.org/system/files/Paris\%20MoU\%20FRENCH $\% 20$ incl $\% 20$ 37th\%20amendment \%20\%28final\%29.pdf>. Accès: 8 avr. 2015.

61 Thetis não é uma sigla como se pode supor, e foi denominado assim, pois era a deusa da mitologia grega do mar.

62 A diretriz 2009/16/EC é uma legislação marítima específica suas quatro regulações ${ }^{63}$ que visam à sua implementação padronizada $^{64}$ ao passo em que o Paris MoU é Convenção entre países subscritores que sustentado em dados do Thetis permite a seleção dos navios alvos de inspeção ${ }^{65}$.

Tal sistema assente aos países envolvidos de fazerem o registro das inspeções, seguindo as deficiências sanitárias que foram registradas, para tanto, se utiliza dos perfis de risco: fraco, médio e alto. Essa classificação encontra-se em consonância com o anexo 7 do Paris $\mathrm{MoU}^{66}$ aonde um quadro combina os índices de anomalia e imobilização, permitindo aos seus usuários visualizarem o nível de performance de cada embarcação ${ }^{67}$.

Os perfis de risco sanitário determinam a periodicidade da inspeção e sedimenta o NIR. No caso do perfil de risco fraco, a inspeção é feita em um intervalo de 24 (vinte e quatro) a 36 (trinta e seis) meses. Já o perfil de risco alto demanda uma inspeção de 5 (cinco) a 6 (seis) meses após a última análise in $100^{68} \mathrm{e}$, em alguns casos específicos, há uma inspeção reforçada ${ }^{69}$.

que visa um controle com padrão internacional que fazem escalas em portos da União Europeia, bem como as embarcações tenham uma manutenção e uma construção de alto nível.

63 "Directive 99/35/EC on ro-ro ferries and high-speed passenger crafts, Directive 2009/17/EC on vessel traffic monitoring, Directive 2009/15/EC on Recognised Organisations and the related Regulation EC) $n^{\circ} 319 / 2009$ and, from July 2013, Directive 2009/20/EC on insurance for maritime claims and Regulation (EC) $\mathrm{n}^{\circ} 392 / 2009$ on liability for the carriage of passengers".

64 EUROPEAN MARTIME SAFETY AGENCY. Thetis. Available at: <http://emsa.europa.eu/psc-main/thetis.html>. Access on: $1^{\circ}$ june 2015 .

65 No sítio eletrônico é possível aos membros credenciados verificarem detalhes da lista negra dos navios. Disponível em: < https:// www.parismou.org $/$ user $/$ login?destination=Publications $/$ Performance_lists>. Acesso em: 8 abr. 2015.

66 FRANCE. Ministère de l'Ecologie, du Développement Durable et de l'Energie. Contrôle des navires étrangers par l'Etat du port. Mer et Littoral. 12 fév. 2013. Disponible dans: < http://www. developpement-durable.gouv.fr/Controle-des-navires-etrangerspar.html>. Accès: 8 avr. 2015.

67 Informações de controle de navios por Estado-nação. Disponível em: <https://www.parismou.org/system/files/Paris $\% 20$ MoU\%20FRENCH $\% 20$ incl $\% 2037$ th $\% 20$ amendment $\% 20 \% 28$ final\%29.pdf>. Acesso em: 8 abr. 2015.

68 FRANCE. Ministère de l'Ecologie, du Développement Durable et de l'Energie. Contrôle des navires étrangers par l'Etat du port. Mer et Littoral. 12 fév. 2013. Disponible dans: <http://www. developpement-durable.gouv.fr/Controle-des-navires-etrangerspar.html>. Accès: 8 avr. 2015. Neste sítio eletrônico verifica-se o controle dos navios estrangeiros em estadia nos portos franceses.

69 Les navires des catégories ci-après sont susceptibles d'être soumis à une inspection renforcée conformément à l'annexe 150-1. I, partie II, points 3.A et 3.B: a) les navires qui présentent un profil de risque élevé, b) les navires à passagers, les pétroliers, les naviresciternes pour gaz ou produits chimiques ou les vraquiers, de plus de 
Tais perfis facilitam o trabalho dos inspetores que analisam alguns fatores, tais como, o histórico da embarcação que engloba o número de apreensões, as falhas nas inspeções anteriores e algumas situações genéricas relativas ao tipo, à idade e à companhia/firma ${ }^{70}$.

Existem três procedimentos que podem ser adotados. O primeiro fornece prazo para que os problemas sejam sanados antes da partida da embarcação; o segundo indica um porto para que os comandantes façam os devidos reparos e o terceiro adota a imobilização do navio como método crítico ${ }^{71}$. A imobilização sucede em condições consideradas perigosas para segurança, saúde ou meio ambiente, encontrando prevista no Memorandum d'entente como reforço do princípio da precaução, pois salvaguarda o outro porto ou os próximos ao atracar.

Nesse caso, a embarcação será liberada somente quando a anormalidade for sanada. O subitem $2.1^{72}$ enumera os fatores que ensejam a imobilização. O fiscal tem a discricionariedade de realizar fiscalização pormenorizada na embarcação atento ao subitem 3.1 que apresenta os elementos de importância geral ${ }^{73}$.

douze ans, c) les navires qui présentent un profil de risque élevé ou les navires à passagers, les pétroliers, les naviresciternes pour gaz ou produits chimiques ou les vraquiers, de plus de douze ans, dans les cas où des facteurs prépondérants ou imprévus se manifestent, d) les navires soumis à une nouvelle inspection après une mesure de refus d'accès prise conformément à l'article 150-1.16

70 FRANCE. Ministère de l'Ecologie, du Développement Durable et de l'Energie. Contrôle des navires étrangers par l'Etat du port. Mer et Littoral. 12 fév. 2013. Disponible dans: <http://www. developpement-durable.gouv.fr/Controle-des-navires-etrangerspar.html>. Accès: 8 avr. 2015.

71 MARITIME MAROC. La Tribune des Maritimistes. Liste blanche ou carte rouge? Disponible dans: <http://www.maritimemaroc.com/fr/liste-blanche-carte-rouge/ >. Accès: 10 avr. 2015.

72 Ao analisar os fatores, o inspetor deve levar em conta a duração do trajeto, a natureza da viagem ou do serviço previsto, as dimensões e o tipo de navio, o material fornecido e o tipo de carga.

733.1 Éléments liés aux conditions d'affectation des lignes de charge: 1 Résistance aux intempéries (ou étanchéité, le cas échéant) des ponts exposés 2 Écoutilles et dispositifs de fermeture 3 Étanchéité des ouvertures dans les superstructures.4 Sabords de décharge .5 Ouvertures de bord .6 Ventilateurs et tubes d'aération .7 Dossier de stabilité 3.2 Autres éléments liés à la sauvegarde de la vie humaine en mer: .1 Engins de sauvetage .2 Matériel de lutte contre l'incendie .3 État structurel général (coque, pont, panneaux d'écoutille, etc.) .4 Moteur principal et installations électriques .5 Matériel de navigation et installations de radiocommunication 3.3 Éléments liés à la prévention de la pollution des navires : .1 Dispositifs de contrôle des rejets d'hydrocarbures et de mélanges d'hydrocarbures, comme les épurateurs d'eaux mazouteuses, le matériel de filtration ou les autres dispositifs équivalents (cuve(s) de rétention des hydrocarbures, des mélanges d'hydrocarbures et des résidus d'hydrocarbures) .2 Dispositifs d'élimination d'hydrocarbures, mélanges d'hydrocarbures ou résidus d'hydrocarbures .3 Présence d'hydrocarbures dans les fonds
Entretanto, sob o aspecto econômico, tal prática enseja ao porto e ao armador um prejuízo financeiro por atrasar a embarcação que irá atracar em outros ancoradouros oficiais. A Convenção também classifica os pavilhões em lista, nas cores preta, cinza e branca ${ }^{74}$. Tal lista é renovada anualmente e cobre os 3 (três) anos anteriores, sendo a última editada em $1^{\circ}$ de julho de $2014^{75}$, abrangeu o período de 2011 a 2013. Insta salientar que, apenas os pavilhões que apresentam mais de 30 (trinta) análises durante o triênio aparecem na lista do Paris $\mathrm{MoU}^{76}$. A secretaria-executiva do Mémorandum d'entente compete publicar relatório anual em que são inscritos os países na situação apurada, levando-se em conta os números de imobilizações e a quantidade de anomalias presentes ${ }^{77}$.

Há também a opção de banimento ou negação de acesso com o intuito de reforçar a necessidade das embarcações de se adaptarem de forma severa à Convenção. O NIR foi o responsável por ampliar o escopo do banimento para alguns tipos específicos de embarcações e também abrigou os de lista cinza. Caso uma embarcação pertença à lista preta e tiver sido imobilizada por mais de duas vezes nos últimos 36 (trinta e seis) meses, ela será banida, assim como, também será banida as embarcações que se encontram na lista cinza que forem imobilizadas por mais de duas vezes nos últimos 24 (vinte e quatro) meses. Após o segundo banimento, qualquer imobilização ensejará sua exclusão, independente da lista em que se encontram ${ }^{78}$. O bani-

$\overline{\text { de la salle des machines .4 Dispositifs de collecte, de stockage et de }}$ destruction des ordures.

74 WK TL. Le pavillon maritime français en tête du classement international 2013 de Paris MoU. Le journal de la Marine Merchande, 25 juin 2013. Disponible dans: <http://www.wk-transport-logistique.fr/actualites/detail/67153/le-pavillon-maritime-francais-entete-du-classement international2013-de-parismou-.html>. Accès: 8 avr. 2015.

75 A lista encontra-se disponível em: <https://www.parismou. org/sites/default/files/WGB\%202011-2013.pdf>. Acesso em: 8 abr. 2015.

76 A Lista do Paris MoU contempla inspeções sanitárias a bordo de navios estrangeiros nos portos franceses, assegurando que esses navios cumprem a segurança internacional, de segurança e normas ambientais, e que os tripulantes tenham condições habitalidade/estadia adequadas.

77 BELGIQUE. Le transport maritime connait des avancées en matière de sécurité mais certains États du pavillon de l'EU pourraient mieux faire. Commission Europeenne. Communiqué de Presse. Décembre 2013. Disponible dans: < http://www.europeem\%252520france.gouv.fr/content/download/22967/202100/ file/politique_maritime_UE.pdf $>$. Accès: 8 avr. 2015.

78 DNV GL GROUP. The Paris MoU New Inspection Regime. Available at: <http://www.dnv.com/binaries/1012-026\%20bros- 
mento pode ser suspenso pelos interstícios ${ }^{79}$ de, após 3 (três) meses, primeiro banimento; após 12 (doze) meses, segundo banimento; após 24 (vinte e quatro) meses, terceiro banimento; permanente, quarto banimento.

A fim de facilitar as inspeções, o Thetis está conectado a um sistema chamado de SafeSeaNet que informa eletronicamente, por meio da internet, quais embarcações chegarão ou que já estão atracadas nos portos e de cargas perigosas ${ }^{80}$, empreendendo, assim, a coleta de dados. Contempla uma precisão quanto à localização das embarcações a cada seis minutos ${ }^{81}$, além de outros aspectos inovadores $^{82}$. O SafeSeaNet constitui um sistema mais amplo que alimenta o Thetis, de arranjo específico, e que confere quais embarcações estão sujeitas a inspeção cujos resultados são armazenados para embasar futuras inspeções ${ }^{83}$.

São coletadas, atualmente, mais de 3.000 (três mil) chegadas por dia nos portos da região, além de uma média de 18.000 (dezoito mil) inspeções por ano que são registradas no sistema ${ }^{84}$.

jyre $\% 20$ paris $\% 20$ mou_web_tcm4-446253.pdf $>$. Access on: 6 june 2015.

79 DNV GL GROUP. The Paris MoU New Inspection Regime. Available at: <http://www.dnv.com/binaries/1012-026\%20brosjyre $\% 20$ paris $\% 20$ mou_web_tcm4-446253.pdf $>$. Access on: 6 june 2015.

80 UNIÃO EUROPEIA. European Martime Safety Agency. Thetis. Available at: <http://emsa.europa.eu/psc-main/thetis.html>. Access on: $1^{\circ}$ june 2015.

81 EUROPEAN MARTIME SAFETY AGENCY. Vessel traffic monitoring in EU waters (SafeSeaNet). Available at: < http://www. emsa.europa.eu/ssn-main.html>. Access on: 6 june 2015 .

82 Archived historical ship positions (over several years); Additional information from AIS-based ship reports (e.g. identification name/numbers, flag, dimensions, course, speed, dimensions, destination and ship type); Estimated/actual times of arrival/departure; Details of hazardous goods carried on board; Information on safety-related incidents affecting ships; Information on pollutionrelated incidents affecting ships; Details of waste carried on board/ to be offloaded (from June 2015); Ship security-related information (from June 2015); Information on the location of remaining single hulled tankers; Information on the location of ships that have been banned from EU ports; Digital map layers (containing information on depths, navigation aids, traffic separation schemes, anchorages, AIS station locations, etc.).

83 EUROPEAN MARTIME SAFETY AGENCY. Thetis. Available at: <http://emsa.europa.eu/psc-main/thetis.html>. Access on: $1^{\circ}$ june 2015.

84 EUROPEAN MARTIME SAFETY AGENCY. Thetis. Available at: <http://emsa.europa.eu/psc-main/thetis.html>. Access on: $1^{\circ}$ june 2015 .

\section{Considerações finais}

A Súmula 50 da AGU veio resolver o problema da responsabilização do agente marítimo pelos atos praticados na esfera administrativa dentro das embarcações. Nesse sentido, as súmulas da AGU transmitem a consolidação da jurisprudência iterativa dos tribunais brasileiros em matérias de interesse da União, suas autarquias e fundações impondo o cumprimento enunciativo apenas os seus órgãos e unidades vinculadas ${ }^{85}$.

Uma solução plausível a ser estudada pela Anvisa a fim de resolver a pendenga relacionada à fiscalização de embarcações nos portos brasileiros seria a adoção do sistema Thetis de inspeção de navios estrangeiros. O ideal seria se associar aos membros do Mercado Comum do Sul ${ }^{86}$ para que agregassem os dados em sua lista e em banco de dados, facilitando, assim, as inspeções. Os membros efetivos, associados e observadores poderiam alimentar a lista, ressalvado a Bolívia ${ }^{87}$ e o Paraguai, despojados de geografia litorânea.

Em complementação ao Thetis, os países que figuram no perfil de risco alto seriam obrigados a formalizar apólice de seguro e, antes de atracar, o agente marítimo observaria sua existência e validade.

Assim, o transtorno causado pela Súmula 50 da AGU perderia o objeto. Caso o seguro não resolvesse de forma célere e definitiva, a imobilização da embarcação seria medida extrema, de caráter sancionatório, pois o armador terá prejuízo com a carga e/ou com os tripulantes. Doravante, para que possa explorar comercialmente o navio, o armador buscará se adequar às normas brasileiras de vigilância sanitária, o que aumenta o grau de respeitabilidade da autoridade sanitária e legitima o Brasil perante a comunidade internacional.

85 CRUZ, Marcelo Cavaletti de Souza. Súmula 50, de 13 de agosto de 2010. In: AGHINONI, Adriana; ABE, Nilma de Castro (Coord.). Súmulas da AGU comentadas. São Paulo: Saraiva, 2013.

86 O Mercado Comum do Sul (Mercosul) é um processo de integração regional, que se iniciou em 26 de março de 1991, com a assinatura do Tratado de Assunção pelos governos de Argentina, Brasil, Paraguai e Uruguai.

87 BOLIVIA. Ministerio de Relaciones Exteriores de Bolivia. El Libro del Mar. 2. ed. La Paz: Dirección Estratégica de Reivindicación Marítima - DIREMAR, 2014. Disponible: <http://www. bolivianembassy.co.uk/images/Libros/libro_del_mar1_1.pdf $>$. Acceso: 8 abr. 2015. p. 59. Tal livro exalta a necessidade de uma saída para o mar, com várias justificativas como o aumento dos custos dos Estados-Nação em 15\% em comparação àqueles que têm um litoral, e a própria Bolívia tem um dos maiores custos de transporte da América do Sul, com $31 \%$ a mais que a média continental. 
Não há dúvida de que uma modernização da Lei no 6.437/1977, também, seria necessária a fim de apontar explicitamente o agente marítimo como incumbido pelo descumprimento de normas sanitárias de quem o representa ou assiste.

Ao analisar os casos de maior repercussão, tanto na esfera internacional, como na esfera doméstica, observa-se um número elevado de problemas ambientais, advindos da exploração de cargas petrolíferas quanto ao vazamento. Tais questões são tratadas com mais afinco à sua reparação, tanto no aspecto de responsabilização quanto na necessidade de retorno ao status quo às tragédias.

Com isto está demonstrado que a dimensão anterior à Declaração de Wingspread já foi sedimentada no Direito Ambiental e que a culpabilidade se encontra resolvida. Por outro lado, a dimensão da saúde pública trazida pela Declaração ainda esbarra no aspecto da imputação sanitária e que, portanto, apresenta probabilidade de ocorrência de uma doença, agravo ou óbito por disseminação internacional.

A AGU desde 1997 emanou cerca de 80 (oitenta) súmulas principalmente relacionadas ao Direito Previdenciário e Trabalhista. Deveras, ao observar sua trajetória quanto ao seu teor constata-se que a Súmula $50 \mathrm{da}$ AGU traz inflexão, sendo um marco temático diverso em relação às demais, mormente trazendo novos tópicos no campo do Direito Administrativo e honorários advocatícios.

Nesse cenário, a Súmula 50 da AGU inaugura essa mudança de paradigma, que não exclui os temas anteriores, para os quais existe ainda demanda, entretanto, carece de revisão, uma vez que, na prática, sua aplicação revelou um desserviço à saúde pública.

\section{REFERÊNCIAS}

ANDRADE, Juliana. Anvisa inspeciona transatlântico que está sob suspeita de surto de gripe tipo B. Agência Brasil, 27 fev. 2012. Saúde. Disponível em: <http://memoria.ebc.com.br/agenciabrasil/noticia/2012-02-27/ anvisa-inspeciona-transatlantico-que-esta-sob-suspeitade-surto-de-gripe-tipo-b>. Acesso em: 8 abr. 2015.

ANDRADE, Oyama Karyna Barbosa. Teoria da escolha racional e teoria dos jogos: uma abordagem para os métodos de resolução de conflitos. In: ANDRADE, Oyama Karyna Barbosa; ORSINI, Adriana Goulart de Sena; COSTA, Mila Batista Leite Correia da (Org.). Justiça do século XXI. São Paulo: LTr, 2014.

BECK, U. Sociedade de risco: rumo a uma outra modernidade. São Paulo: Editora 34, 2010.

BELGIQUE. Le transport maritime connaît des avancées en matière de sécurité mais certains États du pavillon de l'EU pourraient mieux faire. Commission Europeenne. Communiqué de Presse. Décembre 2013. Disponible dans: <http://www.europe-em\%252520france.gouv.fr/content/download/22967/202100/file/politique_maritime_UE.pdf>. Accès: 8 avr. 2015.

BESSA, Antunes. Direito ambiental. São Paulo: Atlas, 2014.

BOLIVIA. Ministerio de Relaciones Exteriores de Bolivia. ElLibro del Mar. 2. ed. La Paz: Dirección Estratégica de Reivindicación Marítima - DIREMAR, 2014. Disponible: <http://www.bolivianembassy.co.uk/images/Libros/libro_del_mar1_1.pdf >. Acceso em: 8 abr. 2015.

CANOTILHO, José Joaquim Gomes; LEITE, José Rubens Morato (Org.). Direito constitucional ambiental brasileiro. 4. ed. São Paulo: Saraiva, 2011.

CRUZ, Marcelo Cavaletti de Souza. Súmula 50, de 13 de agosto de 2010. In: AGHINONI, Adriana; ABE, Nilma de Castro (Coord.). Súmulas da AGU comentadas. São Paulo: Saraiva, 2013.

DANJON, Daniel. Traité de droit maritime. Paris: Librairie Generale de Droit et de Jurisprudence, 1950.

DELGADO, Joedson de Souza. O processo administrativo-sanitário como instrumento de efetividade das ações de vigilância sanitária. Revista Tempus: Actas de Saúde Coletiva, Brasília, v. 07, n. 01, p. 225-240. Disponível em: <http://www.tempusactas.unb.br/index. $\mathrm{php} /$ tempus/article/view/1290/1124>. Acesso em: 27 abr. 2015.

DNV GL GROUP. The Paris MoU New Inspection Regime. Available at: <http://www.dnv.com/binaries $/ 1012-026 \% 20$ brosjyre $\% 20$ paris $\% 20$ mou_web_ tcm4-446253.pdf>. Access on: 6 june 2015.

EUROPEAN MARTIME SAFETY AGENCY. Thetis. Available at: <http://emsa.europa.eu/psc-main/thetis. html>. Access on: $1^{\circ}$ june 2015.

EUROPEAN MARTIME SAFETY AGENCY. Vessel 
traffic monitoring in EU waters (SafeSeaNet). Available at: $<$ http://www.emsa.europa.eu/ssn-main.html>. Access on: 6 june 2015.

FERREIRA, Milena. Aspectos jurídicos das responsabilidades do agente marítimo. 2006. 86 f. Monografia (Graduação) Centro de Ciências Jurídicas, Políticas e Sociais da Universidade do Vale do Itajaí, Itajaí, 2006. Disponível em: $<$ http://siaibib01.univali.br/pdf/Milena\%20Ferreira. pdf $>$. Acesso em: 27 abr. 2015.

FRANCE. Ministère de l'Ecologie, du Développement Durable et de l'Energie. Contrôle des navires étrangers par l'Etat du port. Mer et Littoral. 12 fév. 2013. Disponible dans: <http://www.developpement-durable.gouv.fr/ Controle-des-navires-etrangers-par.html>. Accès: 8 avr. 2015.

FRANCE. Protocole d'Entente de Paris sur le controle des navires par l'Etat du port. Disponible dans: <https:// www.parismou.org/system/files/Paris $\% 20 \mathrm{MoU} \% 20$ FRENCH $\% 20$ incl $\% 2037$ th $\% 20$ amendment $\% 20$ \%28final\%29.pdf>. Accès: 8 avr. 2015.

GRAHAM, John D.; WIENER, Jonathan Baert. Risk versus risk: tradeoffs in protecting health and the environment. Cambridge, Mass: Harvard University Press, 1997.

LOPEZ, Teresa Ancona. Princípio da precaução e evolução da responsabilidade civil. São Paulo: Quartier Latin, 2010.

MARITIME MAROC. La Tribune des Maritimistes. Liste blanche ou carte rouge? Disponible dans: < http://www. maritimemaroc.com/fr/liste-blanche-carte-rouge $/>$. Accès: 10 avr. 2015.

MARTINS, Eliane Maria Octaviano. Curso de direito marítimo: teoria geral. 4. ed. Barueri: Manole, 2013. v. 1.

MILARÉ, Édis. Direito do ambiente: doutrina, jurisprudência, glossário. São Paulo: Revista dos Tribunais, 2011.

NAVARRO, Marcus Vinícius Teixeira. Risco, radiodiagnóstico e vigilância sanitária. Salvador: EDUFBA, 2009. Disponível em: <http://static.scielo.org/scielobooks/ q5/pdf/navarro-9788523209247.pdf $>$. Acesso em: 27 abr. 2015.

NEVES, Isabela Dias. Processo civil ambiental: o princípio da precaução como fundamento da concessão de tutelas de urgência. Rio de Janeiro: Lumen Juris, 2014.
RAFFENSPERGER Carolyn; TICKNER, Joel. Protecting public bealth and the environment: implementing the precautionary principle. Washington, D.C: Island Press, 1999.

SARLET, Ingo Wolfgang. A eficácia dos direitos fundamentais: uma teoria geral dos direitos fundamentais na perspectiva constitucional. 10. ed. Porto Alegre: Livraria do Advogado, 2009.

SLOVIC, Paul. The perception of risk. London: Earthscan, 2007.

SUSTEIN, Cass R. Para além do princípio da precaução. Revista de Direito Administrativo - $\mathrm{RDA}$, Rio de Janeiro, v. 259, p. 11-71, jan./abr. 2012. Disponível em: <http://bibliotecadigital.fgv.br/ojs/index.php/rda/ article/viewFile/8629/7373 > . Acesso em: 22 abr. 2015

TESSLER, Luciane Gonçalves. A importância do princípio da precaução na aferição da prova nas ações inibitórias ambientais. In: WERNECK, Mário, et al. (Coord). Direito ambiental: temas atuais vistos por nós advogados. Belo Horizonte: Editora Del Rey, 2005.

TIETZMANN, Daniela (Org.). Epidemiologia. São Paulo: Pearson Education do Brasil, 2014.

TRIBUNA ON LINE. Navio Vision of the Seas enfrenta novo surto de gastroenterite em cruzeiro. $O$ Globo, 12 mar. 2010. Disponível em: <http://oglobo. globo.com/brasil/navio-vision-of-the-seas-enfrentanovo-surto-de-gastroenterite-em-cruzeiro-3041288>. Acesso em: 27 abr. 2015.

UJVARI, Stefan Cunha. A bistória da bumanidade contada pelo vírus, bactérias, parasitas e outros microrganismos. São Paulo: Contexto, 2008.

ULIANA JÚNIOR, L.; WUICIK, M. V. S. Ensaio sobre a responsabilidade civil do agente marítimo. Revista do Instituto do Direito Brasileiro, ano 2, n. 5, p. 4463-4472, 2013. Disponível em: <http://cidp.pt/publicacoes/ revistas/ridb/2013/05/2013_05_04463_04472.pdf $>$. Acesso em: 07 abr. 2015.

WK TL. Le pavillon maritime français en tête du classement international 2013 de Paris MoU. Le journal de la Marine Merchande, 25 juin 2013. Disponible dans: <http://www.wk-transport-logistique.fr/actualites / detail/67153/le-pavillon-maritime-francais-en-tetedu-classement-international2013-de-parismou-.html>. Accès: 8 avr. 2015. 


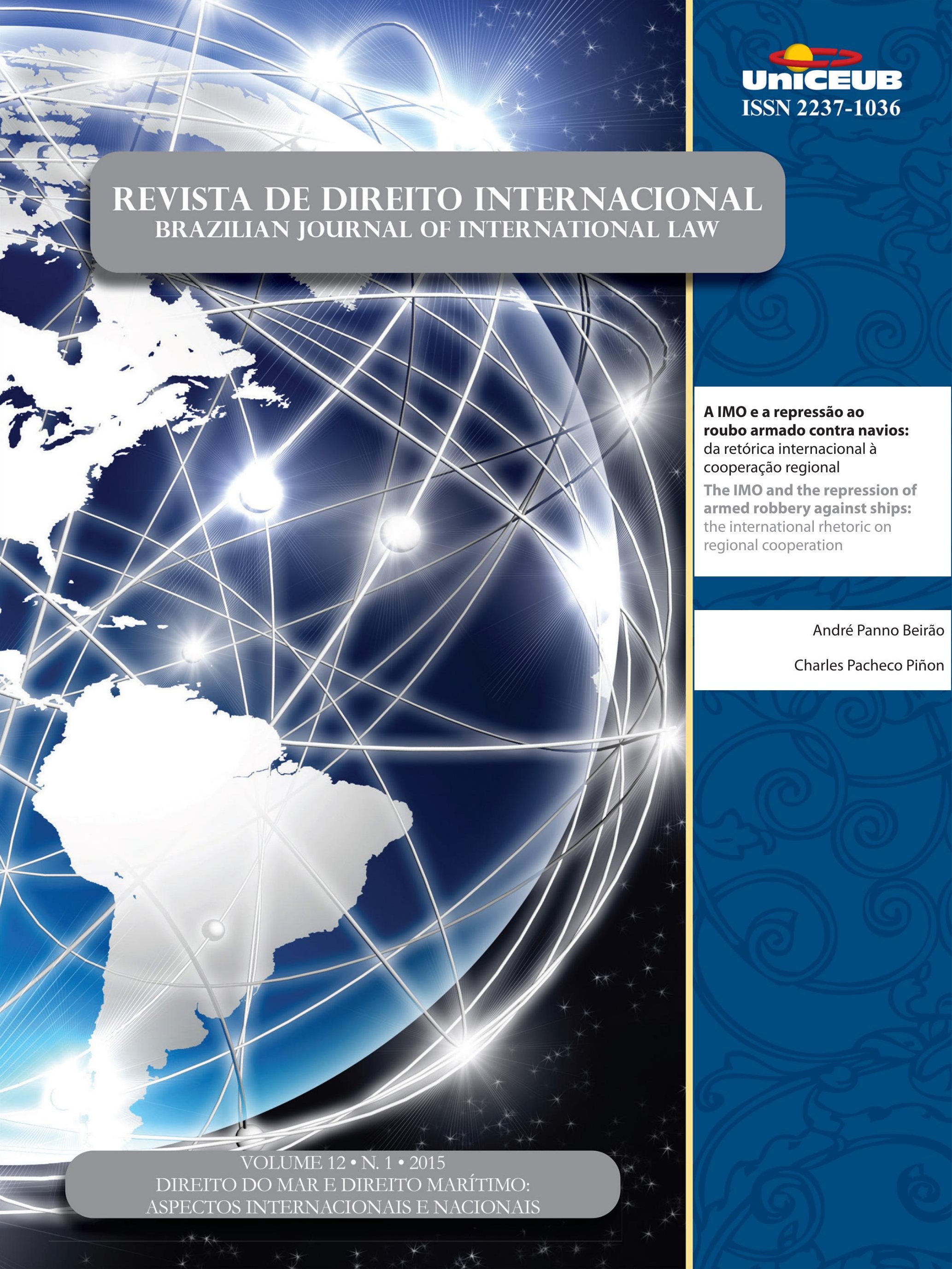




\section{A IMO e a repressão ao roubo armado contra navios: da retórica internacional à cooperação regional*}

\author{
The IMO and the repression of armed \\ robbery against ships: the international \\ rhetoric on regional cooperation
}

\author{
André Panno Beirão** \\ Charles Pacheco Piñon ${ }^{* * *}$
}

* Recebido em 30/04/2015 Aprovado em 27/05/2015

** Oficial da Marinha do Brasil, Doutor em Direito Internacional pela Universidade do Estado do Rio de Janeiro (UERJ), Coordenador do Programa de Pós-graduação em Estudos Marítimos da Escola de Guerra Naval (PPGEM/ EGN).E-mail: beirao@egn.mar.mil.br.

*** Oficial da Marinha do Brasil, Mestrando no Programa de Pós-graduação em Estudos Marítimos da Escola de Guerra Naval (PPGEM/EGN). E-mail: c.pinon@hotmail. com.

\section{Resumo}

O objetivo deste artigo consiste em analisar a mudança de postura da Organização Marítima Internacional (IMO) na repressão ao roubo armado contra navios, após os atentados de 2001 aos Estados Unidos da América. O roubo armado contra navios tem como características tratar-se de ilícito que se consuma nos espaços marítimos sujeitos à soberania dos estados costeiros. Para que sejam adotadas políticas eficazes de repressão a esse ilícito, torna-se fundamental contar com a cooperação dos estados costeiros afetados, ao mesmo tempo em que se busca o apoio da comunidade internacional, principalmente no financiamento das medidas que permitam sair da mera normatização para uma ação eficaz. Para a elaboração deste trabalho, foram analisados os principais instrumentos multilaterais afetos à segurança marítima elaborados no âmbito da IMO, bem como os acordos regionais de cooperação no combate ao roubo armado e à pirataria, conhecidos como os códigos de conduta, firmados no âmbito do Sudeste Asiático e do Golfo da Guiné. O artigo conclui que, na repressão ao roubo armado contra navios, a IMO vem minimizando seu papel de órgão regulamentador, substituindo-o pela adoção de estratégias que visam à cooperação regional e à implementação de soluções autóctones, inclusive para minimizar a falta de financiamento aos projetos de repressão a esse ilícito. A relevância do estudo encontra-se em apontar os fatores que fizeram com que a IMO deixasse de ser organização normatizadora de nível global para assumir o papel de facilitadora de instrumentos multilaterais de cooperação regional na repressão ao roubo armado contra navios.

Palavras-chave: Roubo armado contra navios. IMO. Segurança marítima. Cooperação regional. Código de conduta.

\section{Abstract}

The objective of this paper is to analyze the changes in the International Maritime Organization (IMO) role concerning armed robbery against ship after 2001 terrorist attacks against United States of America. Armed robbery 
against ship is an illicit characterized by occurring inside maritime areas which are recognized as sea spaces under coastal states sovereignty. Due to this, coastal states should cooperate for the adoption of efficient rules aiming to repress this kind of illicit act. In the same time, international community may support these efforts, mainly in respect of financial resources which allow countries moving from just making rules processes towards an efficient action. For developing this research it has been analyzed the mainly multilateral agreements related to maritime security which were prepared or supported by IMO bodies, as well as the regional cooperation agreements concerning armed robbery against ship and piracy named as conduct codes which were signed within Southeastern of Asia and Gulf of Guinea. This paper has concluded that on repression of armed robbery against ship IMO has reduced its making rules tasks to adoption a strategy aiming regional cooperation and implementing autochthonous solutions, even those to overcome lack financial resources available for this kind of illicit repression. Paper's relevance is pointed out by the discussion about matters which have done IMO to leave its making global rules role to engage in a regional multilateral agreements facilitator one, both of them related to armed robbery against ship repression.

Keywords: Armed robbery against ship. IMO. Maritime security. Regional cooperation. Code of conduct.

\section{INTRODUÇÃo}

A repressão ao roubo armado contra navios tem obrigado a Organização Marítima Internacional (International Maritime Organization - IMO) a adotar mudança de abordagem no que diz respeito ao trato dos ilícitos no mar. Após realizar, nos anos de 1970, grande esforço para alterar sua denominação de intergovernamental para internacional, almejando, assim, alcançar a legitimidade que a Convenção das Nações Unidas sobre o Direito do Mar (CNUDM ou Convenção de Montego Bay), ainda em fase de elaboração, já pretendia lhe atribuir, a IMO se vê obrigada a abandonar seu papel normativo global e assumir a postura de um facilitador de instrumentos multilaterais de âmbito regional.

Tal necessidade decorre das peculiaridades inerentes à natureza do roubo armado contra navios que, por ocorrer necessariamente no interior de águas sob jurisdição dos estados costeiros ${ }^{1}$, exige na sua repressão, por força do princípio da soberania, uma atuação centrada nesses mesmos estados costeiros. Associada a essa característica, pode-se constatar a tendência cada vez maior dos blocos de cooperação regional se apresentarem como atores importantes na condução dos assuntos econômicos, políticos e de segurança e defesa de suas respectivas regiões, o que tem feito com que a IMO vislumbre nessas organizações a possibilidade de encontrar interlocutores e parceiros de valor na busca de uma solução para a repressão ao roubo armado contra navios e no incremento da segurança marítima.

Outra peculiaridade que permeia o roubo armado contra navios consiste no fato de que esse ilícito ocorre, em sua maioria, em espaços marítimos sob jurisdição de países em desenvolvimento que, por carência de recursos financeiros, não têm como adquirir o material necessário e nem capacitar os seus agentes de segurança e defesa, de modo a prover patrulhamento efetivo de suas águas. Embora o roubo armado contra navios tenha ocasionado considerável prejuízo material e humano à comunidade internacional, esta não tem demonstrado muita determinação em adotar medidas normativas e de atuação prática que realmente representem um engajamento na busca de soluções eficazes. Pôr em prática soluções eficazes, ao contrário de mera retórica, exige da comunidade internacional esforço também no sentido de prover condições materiais, normativas e financeiras, e isto não tem ocorrido. Assim, cabe à IMO buscar no nível regional novas e criativas soluções para superar a falta de recursos de toda monta no âmbito dos estados costeiros afetados pelo problema.

Com a comunidade internacional voltando o foco dos debates sobre segurança para o combate ao terrorismo após os atentados aos EUA de 2001, o roubo armado contra navios, apesar de mais frequente, não tem recebido o mesmo apoio no nível internacional. Carecendo de instrumentos vinculantes, os estados costeiros afetados não encontram na normativa internacional uma definição satisfatória para esse ilícito, sendo levados a estabelecer instrumentos multilaterais regionais

1 São as águas interiores, as águas arquipelágicas e o mar territorial, isto é, os espaços marítimos sujeitos à soberania dos Estados costeiros, conforme o art. $2^{\circ}$ da Convenção das Nações Unidas sobre o Direito do Mar. BRASIL. Decreto n. 1.530, de 22 de junho de 1995. Declara a entrada em vigor da Convenção das Nações Unidas sobre o Direito do Mar, concluída em Montego Bay, Jamaica, em 10 de dezembro de 1982. Disponível em: <https://www.egn.mar. mil.br/arquivos/cursos/csup/CNUDM.pdf>. Acesso em: 23 jun. 2015. 
que contemplem uma definição de roubo armado contra navios que lhes permita um adequado direcionamento das leis nacionais na repressão a esse ilícito. É nesse espectro que a IMO adquire um papel fundamental de facilitação e assessoria na elaboração e implementação desses instrumentos.

O propósito deste artigo consiste em analisar a mudança de postura que a IMO tem adotado como organização internacional competente na articulação de uma resposta à comunidade internacional no que diz respeito à repressão ao roubo armado contra navios, levando em consideração que se trata de ilícito de causas regionais, mas com graves consequências percebidas em escala global. Partindo-se da análise dos principais instrumentos afetos à segurança marítima e celebrados no âmbito da IMO, pretende-se observar o grau de prioridade que a comunidade internacional tem dispensado à repressão ao roubo armado contra navios. Comparando-se os códigos de conduta adotados para a repressão à pirataria e ao roubo armado contra navios celebrados no Sudeste Asiático e no Golfo da Guiné, pretende-se identificar as especificidades que esse ilícito adquire em cada região, bem como identificar afinidades e semelhanças nesses dois instrumentos regionais que permitam servir como padrão a ser adotado pela IMO. Em que pese o Código Dijbouti também ser instrumento multilateral de âmbito regional adotado com o fim de reprimir a pirataria e o roubo armado na costa da Somália, as condições em que se dá a condução do patrulhamento das águas somalis, havendo outros estados autorizados a agir em seu mar territorial e no seu território continental sem a presença de qualquer agente representante do estado costeiro, fazem desse instrumento um caso atípico e excepcional que foge ao escopo deste artigo e, portanto, não será objeto de estudo.

Para o atendimento do propósito deste trabalho, em uma primeira parte, serão definidos os ilícitos de pirataria e roubo armado contra navios, de modo a identificar as especificidades que os distinguem e que exigem abordagem diferenciada na repressão de um e do outro. Nessa mesma parte, também serão apontados os efeitos nocivos que a pirataria e o roubo armado contra navios têm causado na comunidade internacional e a importância dos estados costeiros e da cooperação regional na repressão ao roubo armado contra navios. $\mathrm{Na}$ segunda parte deste artigo, pretende-se analisar a evolução da IMO no que diz respeito à agenda da segurança no mar, sua legitimidade no trato desse tema e os principais instrumentos vinculantes afetos à segurança marí- tima celebrados no âmbito da Organização. $\mathrm{Na}$ terceira parte, serão apresentados e analisados os instrumentos multilaterais regionais para o combate à pirataria e ao roubo armado contra navios, os códigos de conduta. Além disso, ainda na terceira parte, serão identificadas as novas estratégias de repressão ao roubo armado contra navios adotadas pela IMO, que buscam não somente a legitimidade de suas deliberação, mas também uma maior eficácia dos instrumentos multilaterais afetos ao roubo armado contra navios. Tais estratégias denotam uma mudança significativa da IMO na abordagem dos problemas relacionados com a segurança no mar.

\section{O ROUBO ARMADO CONTRA NAVIOS: A DEFINIÇÃO E OS EFEITOS GLOBAIS DE UM FENÔMENO REGIONAL}

A ausência de repercussão pública é característica específica dos ilícitos praticados no mar. $\mathrm{O}$ fato de ocorrerem distantes das vistas e da percepção da grande maioria da população faz com que os delitos contra as pessoas e o patrimônio cometidos no mar raramente criem comoção no meio social. Pressões políticas por providências ou manifestações públicas de repúdio só surgem quando as consequências de determinados delitos começam a ser percebidas em terra, gerando efeitos nocivos e de grande vulto para a economia e para o bem-estar das pessoas no meio social. Este é o caso do roubo armado contra navios.

Apesar de presente na história humana, a ausência de impacto na sociedade relegava esse tipo de ilícito a um segundo plano. Seja pelo local distante e ermo em que ocorre ou pelo fato de estar relacionado, na grande maioria das vezes, apenas ao transporte de mercadorias, e não de passageiros, o roubo armado contra navios não era facilmente percebido como ameaça à segurança das sociedades e à paz mundial. ${ }^{2}$

\subsection{Fenômenos afins, porém complexos, para entender e definir}

A dificuldade de se perceber seus efeitos nocivos faz com que as providências necessárias à repressão ao rou-

2 CHALK, Peter. The maritime dimension of international security: terrorism, piracy, and challenges for the United States. Santa Monica: RAND Corporation, 2008. (Project Air Force). p. 15. 
bo armado contra navios só sejam efetivadas quando esse ilícito já alcançou nível elevado de vítimas e danos. Por ocorrer em um meio afastado do senso comum e com características muito peculiares, as ações que visam confrontar essa ameaça não atingem suas causas, o que, na maioria das vezes, também faz com que não sejam eficazes. Outro fator relevante na dificuldade de percepção da nocividade do roubo armado é a afinidade que esse ilícito guarda com a pirataria, fazendo com que muitas vezes sejam confundidos. Isso pode ser muito bem entendido quando passamos a analisar as definições de pirataria e de roubo armado contra navios.

As tentativas de definir a pirataria e o roubo armado remontam ao início da década de 1930. Naquela época, um grupo de notáveis juristas foi reunido pelo Programa de Pesquisa de Harvard e concluiu que a questão de maior destaque levantada por eles dizia respeito à definição de pirataria. Como desdobramento, o grupo produziu uma minuta de convenção que, apesar de não haver sido adotada no âmbito diplomático e legal, tornou-se referência no estudo do assunto e ficou conhecida como a Minuta Harvard ${ }^{3}$.

O conceito de pirataria elaborado pelo Grupo de Harvard já englobava uma jurisdição universal para esse tipo de ilícito, uma vez que já previa a pirataria como cometida apenas nos espaços marítimos além da jurisdição de qualquer estado. Outra característica da Minuta Harvard refere-se ao fato de que a definição de pirataria era bem mais ampla que a atual, englobando sob o mesmo tipo todos os ilícitos passíveis de ocorrerem no mar, desde que fossem praticados com fins privados, ou seja, já excluía a possibilidade de um navio de estado cometer a pirataria. Posteriormente, por ocasião da elaboração do art. 15 da Convenção para o Alto-Mar de 1958, esse conceito foi depurado, restringindo a abrangência dos tipos de atos ilícitos passíveis de serem identificados como pirataria, mas mantendo a jurisdição universal inicialmente pensada pelo Grupo de Harvard. ${ }^{4}$

De acordo com a Academia de Genebra, a Minuta de Harvard estabelece "as origens da definição de pirataria”, influenciando fortemente a elaboração da Convenção para o Alto-Mar de 1958 que, por sua vez,

3 KRASKA, James. Contemporary maritime piracy: international law, strategy, and diplomacy at sea. Santa Barbara: Praeger, 2011. p. 143.

4 KRASKA, James. Contemporary maritime piracy: international law, strategy, and diplomacy at sea. Santa Barbara: Praeger, 2011. p. 144. influenciou a CNUDM, na qual se reconhece a previsão normativa da definição contemporânea de pirataria ${ }^{5}$. Portanto, para entender quais são as condições, os requisitos e as peculiaridades que envolvem o conceito de pirataria, deve-se recorrer ao previsto no art. $101 \mathrm{da}$ CNUDM, a saber:

\section{Art. 101 - Definição de pirataria}

Constituem pirataria quaisquer dos seguintes atos:

a) todo ato ilícito de violência ou de detenção ou todo ato de depredação cometidos, para fins privados, pela tripulação ou pelos passageiros de um navio ou de uma aeronave privados, e dirigidos contra:

b) um navio ou uma aeronave em alto mar ou pessoas ou bens a bordo dos mesmos;

c) um navio ou uma aeronave, pessoas ou bens em lugar não submetido à jurisdição de algum Estado;

d) todo ato de participação voluntária na utilização de um navio ou de uma aeronave, quando aquele que o pratica tenha conhecimento de fatos que deem a esse navio ou a essa aeronave o caráter de navio ou aeronave pirata;

e) toda a ação que tenha por fim incitar ou ajudar intencionalmente a cometer um dos atos enunciados nas alíneas a) ou b). ${ }^{6}$

Para que um ato ilícito praticado no mar seja considerado ato de pirataria, ele deve atender a uma série de aspectos previstos na Convenção de Montego Bay. Primeiramente, deve ser ato ilegal de violência, detenção ou depredação. Tal ato deve ser praticado com a utilização de um navio contra outro navio e com o intuito de obter ganho de caráter privado (lucri causa), ou de auxiliar quem o pratique, tal como previsto nas alíneas b e c do art. 101. Por último, deve ser praticado em alto-mar, isto é, fora da jurisdição de qualquer estado?

5 GENEVA ACADEMY OF INTERNATIONAL HUMANITARIAN. Counterpiracy under International Law. Genève: Université de Genève, 2012. (Academy Briefing, n. 1). Disponível em: $<$ http://www.geneva-academy.ch/docs/academyLecture/Counterpiracy.pdf >. Acesso em: 10 jan. 2015. p. 11

6 BRASIL. Decreto n. 1.530, de 22 de junho de 1995. Declara a entrada em vigor da Convenção das Nações Unidas sobre o Direito do Mar, concluída em Montego Bay, Jamaica, em 10 de dezembro de 1982. Disponível em: <https://www.egn.mar.mil.br/arquivos/ cursos/csup/CNUDM.pdf>. Acesso em: 23 jun. 2015.

7 Para os fins de aplicação do conceito de pirataria previsto no art. 101 da CNUDM, considera-se a zona econômica exclusiva como alto-mar, conforme o disposto no art. 58 , parágrafo $2^{\circ}$, da mesma Convenção. BRASIL. Decreto n. 1.530, de 22 de junho de 1995. Declara a entrada em vigor da Convenção das Nações Unidas sobre o Direito do Mar, concluída em Montego Bay, Jamaica, em 10 de dezembro de 1982. Disponível em: <https://www.egn.mar.mil.br/ 
Esses aspectos são cumulativos, ou seja, a pirataria só se concretiza se todos eles estiverem presentes. ${ }^{8}$

No art. 101, a Convenção estabelece aquilo que já foi adotado pela comunidade internacional como a conceituação universal da pirataria, uma vez que a Resolução nº 1838 , de 2008, do Conselho de Segurança da ONU reconhece que a CNUDM incorpora as regras aplicáveis à repressão desse ilícito". Com isso, essa mesma definição passou a ser adotada nos acordos regionais de combate à pirataria e ao roubo armado, tais como, o Acordo Regional de Cooperação no Combate à Pirataria e ao Roubo Armado contra Navios na Ásia (Regional Cooperation Agreement on Combating Piracy and Armed Robbery against Ships in Asia - ReCAAP), de 11 de novembro de 2004; o Código de Conduta Relativo à Repressão de Pirataria e Roubo Armado contra Navios no Oceano Índico Ocidental e no Golfo de Áden (Código de Conduta Djibouti), de 29 de janeiro de 2009; e o Código de Conduta relativo à Repressão de Pirataria, Roubo Armado contra Navios e Atividades Marítimas Ilícitas na África do Oeste e Central (Código de Conduta do Golfo da Guiné), de 25 de junho de 2013.

Em virtude do amplo escopo desses instrumentos multilaterais de cooperação no combate aos ilícitos no mar, abrangendo outros ilícitos que não a pirataria, houve a necessidade de se adotar uma definição para aquilo que deve ser considerado roubo armado contra navios, identificando os ilícitos análogos à pirataria, quando praticados nas águas jurisdicionais dos seus estados parte. Assim, com exceção do ReCAAP, que é de data anterior e cuja definição serviu de referência a esta, foi adotado no Código de Conduta do Golfo da Guiné a definição constante na Resolução da IMO nº A.1025(26), adotada em 2 de dezembro de 2009:

\section{2 "Roubo armado contra navios" significa qualquer dos seguintes atos: \\ 1. qualquer ato de violência ilegal ou detenção ou qualquer ato de depredação, ou a ameaça desses atos, desde que não constitua pirataria, cometido com fins privados e dirigido contra um navio ou contra pessoas ou propriedades a bordo desses navios,}

arquivos/cursos/csup/CNUDM.pdf>. Acesso em: 23 jun. 2015. 8 MEJIA JR, Maximo Q.; MUKHERJEE, P. K. The SUA Convention 2005: a critical evaluation of its effectiveness in suppressing maritime criminal acts. The Journal of International Maritime Law, Witney, v. 12, n. 3, p. 170-191, 2006. Disponível em: < http://www. lawtext.com/lawtextweb/default.jsp?PageID=2>. Acesso em: 10 jan. 2015. p. 182.

9 KRASKA, James. Contemporary maritime piracy: international law, strategy, and diplomacy at sea. Santa Barbara: Praeger, 2011. p. 143. dentro das águas interiores, águas arquipelágicas ou mar territorial de um Estado;

2. qualquer ato de incitação ou de facilitação intencional de um ato descrito acima. ${ }^{10}$ (tradução nossa)

Como se pode notar, a definição adotada para roubo armado contra navios é uma adaptação da definição de pirataria, uma vez que mantém a exigência de haver sido o ilícito cometido com o uso ilegal da violência, para fins privados, na incitação ou no auxílio, e contra navio. Porém, há de se notar que a caracterização desse ilícito dispensa a necessidade de que seja utilizado outro navio ou uma aeronave como instrumento e requer, como local do fato, as águas sob jurisdição dos estados costeiros — o que reafirma a atribuição da jurisdição aos estados partes sobre essas ofensas. Outra distinção que deve ser feita em relação ao roubo armado contra navios é a falta de efetividade das resoluções da IMO no plano internacional, uma vez que estas não possuem caráter normativo vinculante. Assim, ao contrário da CNUDM, que já foi recepcionada pelo direito interno de vários estados, a Resolução da IMO no A.1025(26), não possui o mesmo caráter, fazendo com que o ilícito conhecido como roubo armado contra navios careça de instrumento normativo internacional com força vinculante, o que não ocorre com a pirataria, tendo em vista sua previsão no art. 101 da Convenção.

A IMO já procurava evitar em suas deliberações o uso do termo "pirataria" para englobar todos os ilícitos análogos a esta. Em seus documentos e debates, procurou instituir o termo "roubo armado contra navios" quando o ilícito não possuía todos os requisitos da pirataria estabelecidos pela CNUDM. Assim, evitava uma leitura tortuosa do texto da Convenção de Montego Bay, ao mesmo tempo em que conseguia referir-se a qualquer outro

ato ilícito de violência ou detenção ou depredação, ou qualquer ameaça, desde que não seja ato de

102.2 "Armed robbery against ships" means any of the following acts:.1 any illegal act of violence or detention or any act of depredation, or threat thereof, other than an act of piracy, committed for private ends and directed against a ship or against persons or property on board such a ship, within a State's internal waters, archipelagic waters and territorial sea;.2 any act of inciting or of intentionally facilitating an act described above. INTERNATIONAL MARITIME ORGANIZATION. Resolution A.1025(26), 02 December 2009. Code of practice for the investigation of crimes of piracy and armed robbery against ships. Disponível em: <http:// www.imo.org/en/OurWork/Security/PiracyArmedRobbery/Guidance/Documents/A.1025.pdf>. Acesso em: 19 abr. 2015. 
pirataria, dirigido contra um navio ou contra pessoas ou propriedade a bordo desse navio, dentro da jurisdição estatal sobre tais ofensas. ${ }^{11}$

\subsection{O recrudescimento do roubo armado contra navios e suas consequências para a sociedade internacional}

A ocorrência do roubo armado contra navios está intimamente relacionada com a ocorrência da pirataria. Por vezes, o que os distingue é mera questão dos meios empregados ou do posicionamento geográfico com relação aos espaços marítimos previstos na CNUDM. Portanto, as estatísticas que se referem à pirataria, em grande parte dos casos também englobam o roubo armado contra navios. Do mesmo modo, a repressão eficaz à pirataria não pode prescindir da repressão ao roubo armado. Com o aumento dos casos desses ilícitos no mar, principalmente a partir da segunda metade da década de 1990, chegando a atingir um ápice de 440 ocorrências em $2005^{12}$, a comunidade internacional começou a sentir os efeitos nocivos desses tipos de atividades ilícitas e, consequentemente, a sensibilizar-se em relação à gravidade do problema. O longo período transcorrido sem que qualquer providência eficaz fosse tomada fez com que a pirataria e o roubo armado contra navios evoluíssem de tal forma que hoje se apresentam como problemas extremamente complexos e com efeitos danosos de diversas naturezas. A pirataria e o roubo armado contra navios ameaçam a vida dos tripulantes e o meio ambiente, ameaçam a estabilidade dos governos e geram prejuízos econômicos ao comércio marítimo, uma atividade que responde por aproximadamente $90 \%$ do comércio mundial. A necessidade de se combater a pirataria e o roubo armado na Ásia está no:

[...] potencial que [...] possuem de gerar perdas financeiras devastadoras, associadas à sensação de

11 MEJIA JR, Maximo Q.; MUKHERJEE, P. K. The SUA Convention 2005: a critical evaluation of its effectiveness in suppressing maritime criminal acts. The Journal of International Maritime Law, Witney, v. 12, n. 3, p. 170-191, 2006. Disponível em: <http://www. lawtext.com/lawtextweb/default.jsp?PageID $=2>$. Acesso em: 10 jan. 2015. p. 183.

12 CHALK, Peter. The maritime dimension of international security: terrorism, piracy, and challenges for the United States. Santa Monica: RAND Corporation, 2008. (Project Air Force). p 14. Segundo dados do IMB-Piracy Reporting Centre, de jan. a dez. 2014 foram reportados 231 ataques a navios. COMMERCIAL CRIME SERVICES. IMB Piracy Reporting Centre. 2014. Disponível em: $<$ https://icc-ccs.org/piracy-reporting-centre>. Acesso em: 23 jun. 2015. insegurança na região em que ocorrem levou os governos a tomarem providências e procurarem uma solução. As massivas quantidades de óleo e gás natural liquefeito (GNL) transportados por essa região acrescentam significativas preocupações relacionadas a questões econômicas e ambientais ${ }^{13}$. (tradução nossa).

O primeiro e mais notável dos efeitos nocivos da pirataria e do roubo armado contra navios é a ameaça à vida e à integridade física dos tripulantes dos navios. Além do risco de morte e à integridade física, os tripulantes dos navios atacados também sofrem traumas psicológicos que frequentemente os impedem de retornar à atividade marítima. ${ }^{14}$

A pirataria e o roubo armado contra navios também ameaçam a economia dos estados costeiros, dos estados de bandeira ${ }^{15}$, e da indústria marítima. Apesar da relação custo-benefício ainda não afetar a viabilidade do transporte marítimo como atividade econômica, citando dados do International Maritime Bureau (IMB), estima-se que o prejuízo causado pela pirataria e pelo roubo armado contra navios pode variar de US\$ 1 a 16 bilhões por ano. ${ }^{16}$

13 " $[\ldots]$ the issue's potential to bring devastating financial loss and a sense of lawlessness and insecurity to the region should provide an impetus for governments to take action and seek a solution. The massive quantities of oil and liquefied natural gas (LNG) transported through the region introduce significant environmental and economic concerns". Cf BULKELEY, Jennifer C. Regional cooperation on maritime piracy: a prelude to greater multilateralism in Asia? Journal of Public and International Affairs, Princeton, v. 14, p. 20-39, Spring, 2003. Disponível em: < http://www.princeton. edu/jpia/past-issues-1/2003/2.pdf>. Acesso em: 05 jan. 2015. p. 4. 14 CHALK, Peter. The maritime dimension of international security: terrorism, piracy, and challenges for the United States. Santa Monica: RAND Corporation, 2008. (Project Air Force). p. 15.

15 O Estado de bandeira diz respeito à nacionalidade do navio, isto é, ao Estado no qual foi registrado e a cuja norma se sujeita. $\mathrm{O}$ art. 91 da Convenção das Nações Unidas sobre o Direito do Mar (CNUDM) prevê que "todo Estado deve estabelecer requisitos necessários para a atribuição da sua nacionalidade a navios [...] Os navios possuem a nacionalidade do Estado cuja bandeira estejam autorizados a arvorar [...]".BRASIL. Decreto n. 1.530, de 22 de junho de 1995. Declara a entrada em vigor da Convenção das Nações Unidas sobre o Direito do Mar, concluída em Montego Bay, Jamaica, em 10 de dezembro de 1982. Disponível em: <https://www.egn. mar.mil.br/arquivos/cursos/csup/CNUDM.pdf>. Acesso em: 23 jun. 2015.

16 Segundo dados de 2005, ano do maior número de ocorrências de pirataria e roubo armado contra navios registrado, o comércio marítimo mundial totalizou um montante de US\$ 7.8 trilhões, fazendo com que o prejuízo econômico acumulado com a pirataria e o roubo armado ainda fosse considerado baixo com relação ao total negociado. Ver CHALK, Peter. The maritime dimension of international security: terrorism, piracy, and challenges for the United States. Santa Monica: RAND Corporation, 2008. (Project Air 
Além dos prejuízos econômicos, a pirataria e o roubo armado contra navios também criam um ambiente favorável à corrupção de agentes estatais ligados à atividade marítima, principalmente em regiões afetadas por crises econômicas, onde os agentes públicos, inclusive de órgãos de segurança e defesa, vivem em condições de subsistência e trabalho precárias. Tal ambiente gera condições propícias ao surgimento de organizações criminosas de grande poderio econômico, político e bélico. Essas organizações têm suas atividades em diversos países de uma mesma região e criam em toda sua extensão marítima um ambiente de insegurança para o transporte de carga e de pessoas. ${ }^{17}$

Existe ainda a associação da pirataria e do roubo armado contra navios a outros ilícitos, tal como o tráfico de drogas, armas e pessoas por mar; a imigração ilegal e uma fraude tipicamente marítima conhecida como o caso dos "navios fantasmas". Com grande incidência no sudeste asiático, o "navio fantasma" é um tipo de fraude que se inicia por meio da pirataria ou do roubo armado. Nela, grupos criminosos internacionais roubam navios e alteram seus nomes, registrando-os com uma bandeira de conveniência, desviando sua carga, substituindo sua tripulação e permanecendo por algum tempo utilizando esse mesmo navio em outros afretamentos legalmente contratados. Trata-se de atividade ilícita que envolve agentes públicos e privados relacionados com a atividade marítima e ocorre mais frequentemente na Ásia, onde organizações criminosas contam com a participação de agentes operando em Hong Kong, Indonésia, Filipinas, Tailândia, China, Cingapura, Malásia, e Coreia do Sul. ${ }^{18}$

Outra possibilidade trágica constitui a pirataria e o roubo armado ocasionarem um acidente ambiental de consequências trágicas. Vislumbrado como o pior dos cenários, um navio tanque atacado e posteriormente abandonado à deriva e sem sua tripulação, com grandes

Force). p. 16.

17 BULKELEY, Jennifer C. Regional cooperation on maritime piracy: a prelude to greater multilateralism in Asia? Journal of Public and International Affairs, Princeton, v. 14, p. 20-39, Spring, 2003. Disponível em: <http://www.princeton.edu/jpia/past-issues-1/2003/2.pdf>. Acesso em: 05 jan. 2015. p. 3-4.

18 ABHYANKAR, Jayant. The Phantom Vessel Phenomenon: an update. In: MEJIA, Maximo Quibranza; XU, Jingjing (Ed.). Coastal zone piracy and other unlawful acts at sea: a selection of papers and presentations from the international symposium on the new regime for the suppression of unlawful acts at sea, 21-23 november 2005 and the international symposium on coastal zone piracy, 13-15 november 2006. Malmö: WMU, 2007. p. 150-156. chances de colidir, inclusive contra outro navio tanque, redundando em derramamento de óleo de grandes proporções. ${ }^{19}$ Se um derramamento de óleo ocorrer em um dos estreitos internacionais de grande fluxo de navios, os conhecidos choke points ${ }^{20}$, além das graves consequências de natureza ambiental, o estreito pode vir a ser interditado para a navegação por anos. ${ }^{21}$

\subsection{O papel dos Estados costeiros e a cooperação regional no combate ao roubo armado contra navios}

Quando áreas de intenso tráfego marítimo se conjugam ao fato de que os estados no seu entorno possuem pouca ou nenhuma capacidade técnica, financeira e material de se contrapor à pirataria e ao roubo armado contra navios pode-se concluir, com certo grau de certeza, que há um grande risco à navegação internacional nessas regiões. O mesmo pode ser observado em locais que apresentam intenso trânsito de mercadorias de grande valor por via marítima e cujos estados costeiros apresentam condições econômicas e sociais precárias. Nesses locais também se pode observar a ameaça ao tráfego marítimo.

São as condições sociais e econômicas dos estados costeiros que, associadas ao trânsito de mercadorias de elevado valor por vias marítimas próximas ao litoral, levam à prática do roubo armado contra navios em determinadas regiões do planeta. A pobreza, o desemprego crescente e um lento crescimento econômico são fatores que acabam por dificultar o combate aos ilícitos no mar, uma vez que não permitem que os estados direcionem recursos para a segurança marítima, por ou-

19 CHALK, Peter. The maritime dimension of international security: terrorism, piracy, and challenges for the United States. Santa Monica: RAND Corporation, 2008. (Project Air Force). p. 17.

20 Os choke points são pontos de passagem obrigatória nas linhas de comunicação marítimas internacionais que se caracterizam pela existência de um grande tráfego marítimo próximo de terra, tal como em um estreito, canal ou cabo, são exemplos de choke points: Estreito de Malaca (entre a Malásia e a Indonésia), Estreito de Bab el-Mandeb (na extremidade sul do Mar Vermelho, ligando-o com o Mar Arábico), Estreito de Ormuz (na entrada do Golfo Pérsico), Canal de Suez (ligando o Mediterrâneo ao Mar Vermelho), Canal do Panamá, o Estreito de Gibraltar (entre a Europa e a África), o Cabo Horn (Chile), entre outros.

21 BULKELEY, Jennifer C. Regional cooperation on maritime piracy: a prelude to greater multilateralism in Asia? Journal of Public and International Affairs, Princeton, v. 14, p. 20-39, Spring, 2003. Disponível em: <http://www.princeton.edu/jpia/past-issues-1/2003/2.pdf>. Acesso em: 05 jan. 2015. p. 5. 
tro lado, esses mesmos fatores são considerados fortes incentivos para que pessoas desses estados costeiros se juntem às organizações criminosas. ${ }^{22}$

Para que haja combate efetivo ao roubo armado contra navios, torna-se necessária uma articulação política e financeira no sentido de identificar e neutralizar os fatores motivadores, criar leis nos estados costeiros que criminalizem essas práticas, permitindo assim que os perpetradores sejam processados e julgados, bem como fortalecer as estruturas jurídicas e os órgãos de combate a esses ilícitos no âmbito desses estados. Assim, os estados costeiros afetados pela grande incidência de pirataria e roubo armado têm procurado implementar soluções por meio da cooperação regional, uma vez que, na grande maioria dos casos, as medidas necessárias à repressão desses ilícitos são excessivamente onerosas para as reais condições econômicas em que esses estados estão inseridos.

A necessidade de incrementar a patrulha marítima nas regiões afetadas pelo roubo armado contra navios tem se apresentado como uma resposta eficaz no curto prazo. Em virtude da soberania que exercem sobre seu mar territorial e buscando-se dar uma resposta satisfatória às pressões da comunidade internacional ${ }^{23}$, os estados costeiros veem a necessidade de fortalecer suas marinhas, guardas-costeiras e demais órgãos de segurança no mar. Assim, buscam em seus vizinhos o apoio necessário para encontrar soluções exequíveis e adequadas à realidade da região em que se encontram, além de dividirem custos e responsabilidades sem abrir mão da soberania. Dessa forma, é correto afirmar que:

a maioria das marinhas possui uma baixa capacidade de encontrar, identificar e prender piratas, mas dividindo o fardo com outros estados da região,

22 BULKELEY, Jennifer C. Regional cooperation on maritime piracy: a prelude to greater multilateralism in Asia? Journal of Public and International Affairs, Princeton, v. 14, p. 20-39, Spring, 2003. Disponível em: <http://www.princeton.edu/jpia/past-issues-1/2003/2.pdf>. Acesso em: 05 jan. 2015. p. 3.

23 A pirataria e roubo armado contra navios só foram reconhecidos pelo Conselho de Segurança da ONU como "ameaças à paz e à segurança internacional" em 1992, quando, por meio da Resolução $n^{\circ} 733$, invocou o Capítulo VII da Carta da ONU como aplicável à situação de instabilidade gerada pelo conflito na Somália. TREVES, Tullio. Piracy, law of the sea, and use of force: developments off the Coast of Somalia. The European Journal of International Law, Oxford, v. 20, n. 2, p. 399-414, Apr. 2009. Disponível em: <http:// ejil.oxfordjournals.org/content/20/2/399.full.pdf + html $>$. Acesso em: 18 out. 2010. reduzirão custos e aumentarão sua capacidade de resposta. $^{24}$ (tradução nossa).

Com isso, os estados costeiros afetados pelo roubo armado contra navios procuram participar de fóruns regionais de discussão, nos quais apresentam suas limitações e possibilidades e buscam parcerias para implementar boas práticas que garantam a segurança nos espaços marítimos sob sua jurisdição.

Em 17 de novembro de 1983, a IMO adotou a Resolução no A.545 (13). Nessa resolução, a Organização, vislumbrando a necessidade de implementar medidas de combate à pirataria e ao roubo armado, concita os estados membros a:

adotarem, com a mais alta prioridade, todas as
medidas necessárias para prevenir e suprimir
atos de pirataria e roubo armado contra navios,
no interior ou adjacentes às suas águas, inclusive
com a intensificação das medidas de segurança." ${ }^{25}$
(tradução nossa)

Em relação a esse mesmo escopo, a IMO ainda ressalta a necessidade dos estados costeiros vizinhos estabelecerem estreita ligação para, por meio da cooperação regional, intensificarem a vigilância e o patrulhamento marítimo, de modo a possibilitar a detecção, captura e julgamento dos piratas. $^{26}$

Dessa forma, a IMO já antecipava a gravidade daquilo que o roubo armado representaria para a comunidade internacional, bem como a necessidade de combater esse ilícito marítimo por meio da cooperação regional.

24 "Most national navies lack the capability to find, identify, and catch pirates, but sharing the burden with other states in the region would reduce costs and increase response capabilities". Cf. BULKELEY, Jennifer C. Regional cooperation on maritime piracy: a prelude to greater multilateralism in Asia? Journal of Public and International Affairs, Princeton, v. 14, p. 20-39, Spring, 2003. Disponível em: <http://www.princeton.edu/jpia/past-issues-1/2003/2.pdf > . Acesso em: 05 jan. 2015. p. 8.

25 "Urges Governments concerned to take, as a matter of the highest priority, all measures necessary to prevent and suppress acts of piracy and armed robbery against ships in or adjacent to their waters, including strengthening of security measures". Cf. INTERNATIONAL MARITIME ORGANIZATION. Resolution A. 545(13), 17 November 1983. Measures to Prevent Acts of Piracy and Armed Robbery Against. Disponível em: <http://www.imo.org/blast/ blastDataHelper.asp?data_id=22356\&filename $=$ A545(13).pdf $>$. Acesso em: 18 abr. 2015. p. 1.

26 KRASKA, James. Contemporary maritime piracy: international law, strategy, and diplomacy at sea. Santa Barbara: Praeger, 2011. p. 64. 


\section{A eVoluÇão da IMO E a SEgurançA MARÍTIMA}

Criada durante a Conferência Diplomática das Nações Unidas em 1948, a Organização Consultiva Marítima Intergovernamental (Intergovernmental Maritime Consultative Organization - IMCO) possuía 21 estados membros, sendo a maioria deles considerados como estados desenvolvidos. A posição predominante entre esses estados, bem expressa em sua denominação, era a de que a IMCO deveria ser um organismo apenas de consulta a respeito de assuntos marítimos, sobre os quais a organização emitiria recomendações que seriam posteriormente implementadas nos estados membros, caso assim entendessem, por meio de suas respectivas legislações nacionais. A adoção de um mandato que conferisse à Organização a capacidade de elaborar tratados e organizar conferências diplomáticas para a adoção desses tratados era vista por algumas de suas delegações como uma tentativa de a IMCO "monopolizar o processo de elaboração de tratados no campo da navegação comercial."27 (tradução nossa).

\subsection{Internacionalismo e legitimidade: da IMCO para a IMO}

Apesar da resistência de um número expressivo de estados membros, a necessidade de se encontrar soluções para os problemas afetos à navegação internacional fez com que a IMCO evoluísse de uma organização meramente consultiva para uma atuante organização no campo do direito internacional público. Além disso, o acréscimo expressivo na quantidade de estados membros e o início das consultas para a elaboração da CNUDM fizeram com que a IMCO sentisse a necessidade de alterar sua denominação de "intergovernamental" para "internacional”. Dessa forma, a Organização poderia assumir o papel que a CNUDM lhe reservava de "organização internacional competente." ${ }^{28} \mathrm{O}$ exercício do papel que as negociações da CNUDM reservavam

27 "[...] monopolize the process of treaty law making the field of commercial navigation”. Cf. BLANCO-BAZÁN, Agustín. IMO: historical highlights in the life of a un agency. Journal of the History of International Law, Leiden, v. 6, n. 2, p. 259-283, July/Dec. 2006. p. 261.

28 Em seu Boletim de Direito do Mar no 31, a Divisão de Assuntos Oceânicos e Direito do Mar da ONU (DOALOS) publicou uma tabela na qual atribui à IMO a designação de organização internacional competente para diversos assuntos previstos na CNUDM. à IMO deveria ser conduzido de forma efetiva, o que demandava, além da mudança na denominação, um acréscimo considerável de sua participação no processo regulatório das atividades marítimas, com a legitimidade que a Organização requer para tornar eficaz essa regulação e realmente se posicionar como uma instituição internacional do sistema ONU. ${ }^{29}$

A estrutura da IMO prevê a existência de um órgão diretor denominado Conselho. Além de coordenar as atividades dos demais órgãos, é o Conselho quem controla a agenda e a previsão orçamentária a serem deliberadas pela Assembleia. ${ }^{30} \mathrm{O}$ órgão é composto por representantes de 40 estados membros e tem seus ocupantes eleitos bianualmente entre três categorias de estados: 10 vagas são ocupadas pelos maiores em capacidade de prover transporte marítimo internacional 3/4 também conhecidos como os "proprietários de navios" $3 / 4$ outras 10 vagas são ocupadas pelos estados que mais utilizam o transporte marítimo e 20 vagas são destinadas aos demais estados membros que as ocupam, atendendo ao aspecto da "garantia da representação das maiores áreas geográficas do mundo”. Apesar de contar com um número restrito de estados membros participando nos processos de condução da Organização, essa constituição foi reconhecida como sinal de democratização da instituição, uma vez que atenuava a imagem de que a IMCO seria apenas um "clube fechado de proprietários de navios", em que somente estes teriam voz. Com essa distribuição, a IMO tenta prover algum grau de legitimidade ao seu processo decisório e minimiza a disputa entre os "proprietários de navios" e os "usuários de navios" que tanto prejudicou seu papel institucional. ${ }^{31}$

Além da Assembleia e do Conselho, a IMO também possui outros órgãos técnicos para o exercício de suas atribuições. No que diz respeito à segurança marítima, a Organização se vale do Comitê de Segurança Marítima (CSM) para a elaboração e proposta de tratados, convenções, manuais e demais tópicos de interesse da instituição inerentes ao tema segurança no mar. O CSM era inicialmente composto apenas por 14 membros,

29 BLANCO-BAZÁN, Agustín. IMO: historical highlights in the life of a un agency. Journal of the History of International Law, Leiden, v. 6, n. 2, p. 259-283, July/Dec. 2006. p. 267-268.

30 Ver INTERNATIONAL MARITIME ORGANIZATION. Structure of IMO. Disponível em: <http://www.imo.org/en/ About/Pages/Structure.aspx>. Acesso em: 12 jan. 2015.

31 BLANCO-BAZÁN, Agustín. IMO: historical highlights in the life of a un agency. Journal of the History of International Law, Leiden, v. 6, n. 2, p. 259-283, July/Dec. 2006. p. 263-264. 
dos quais, por força da Convenção original, oito desses membros deveriam ser escolhidos entre "as maiores nações proprietárias de navios”. A composição do CSM acarretava falta de interesse por parte das nações em desenvolvimento em aderir às decisões da IMCO, gerando uma carência de legitimidade nas deliberações da instituição e, consequentemente, uma baixa aderência às suas resoluções e tratados. Para exercer o efetivo papel de uma organização internacional do sistema ONU, tal como se pretendia nas negociações para a CNUDM, a IMCO deveria democratizar o seu mais importante órgão técnico, o CSM. ${ }^{32}$ Dessa forma,

\begin{abstract}
[...] as nações proprietárias de navios tinham que ser colocadas em pé de igualdade com as demais se a IMCO estava sendo reconhecida como uma das organizações internacionais referidas pelo futuro tratado em direito do mar. Sob esta prospectiva, a mudança de nome só poderia ocorrer depois que todos os membros da Organização fossem admitidos como membros do Comitê de Segurança Marítima. [...] A IMCO não era internacional, a IMO certamente é, embora o aumento da representatividade dos países em desenvolvimento nos órgãos da IMO não tenha se materializado automaticamente em efetivo exercício de direitos, eles finalmente o obtiveram em meados da década de $1970 .{ }^{33}$ (tradução nossa).
\end{abstract}

Por meio das Resoluções no A.358(IX), de 1975, e A.371(X), de 1977, a Organização adotou a atual designação de Organização Marítima Internacional (International Maritime Organization - IMO). Não só isso, nesse mesmo período, o CSM passou a ser composto por todos os estados membros da IMO. Expandido, o Comitê criou e modificou diversas convenções afetas ao tema segurança no mar, as quais têm demonstrado grande receptividade na comunidade internacional por meio da adesão de um número considerável de Estados, inclusive, por parte de alguns países que não são membros da IMO. ${ }^{34}$ Isso demonstra a relevância desse tema e o alto grau de legitimidade com que hoje conta a instituição.

32 BLANCO-BAZÁN, Agustín. IMO: historical highlights in the life of a un agency. Journal of the History of International Law, Leiden, v. 6, n. 2, p. 259-283, July/Dec. 2006. p. 268-270.

33 BLANCO-BAZÁN, Agustín. IMO: historical highlights in the life of a un agency. Journal of the History of International Law, Leiden, v. 6, n. 2, p. 259-283, July/Dec. 2006. p. 268.

34 INTERNATIONAL MARITIME ORGANIZATION. Structure of IMO. Disponível em: <http://www.imo.org/en/ About/Pages/Structure.aspx>. Acesso em: 12 jan. 2015.

\subsection{Segurança no mar: o terrorismo monopoliza o debate na IMO}

As primeiras mobilizações da comunidade internacional relacionadas à segurança no mar são decorrentes do acidente do Titanic, em 1912. O grande número de vítimas ${ }^{35}$ decorrentes desse episódio acabou apontando para a necessidade de uma normatização de procedimentos com o objetivo de aprimorar a segurança no mar. É daí que surge a Convenção Internacional para a Salvaguarda da Vida Humana no Mar (SOLAS), que teve seu primeiro texto elaborado em 1914 e é considerada, até os dias atuais, como o maior e o mais amplo dos tratados relacionados com o tema da segurança marítima. ${ }^{36}$

A Convenção SOLAS entrou em vigor em 1933 e tem o propósito de estabelecer aspectos mínimos de segurança para a confecção de navios, apresentar uma dotação de equipamentos de proteção necessários à operação segura desses navios e criar procedimentos de emergência internacionalmente reconhecidos. Com o intuito de aprimorar a Convenção e torná-la mais efetiva, a SOLAS passou por revisões em 1948, 1974 e 1988, sendo essas duas últimas as que dão o nome à Convenção (SOLAS 1974/1988). Destaca-se aqui, que a revisão da Convenção SOLAS em 1948 está relacionada ao início da atuação da IMCO, uma vez que, no pós-Segunda Guerra Mundial, predominava o pensamento entre as nações vencedoras no qual haveria a necessidade da criação de uma organização internacional que desse continuidade ao processo de padronização e desenvolvimento das normas e procedimentos relacionados à segurança marítima. ${ }^{37}$ Dessa forma, a IMCO surge já com a responsabilidade de aprimorar e zelar pela implementação da Convenção SOLAS na comunidade internacional.

Em outubro de 1985, o sequestro do navio de passageiros Achille Lauro fez com que a atenção da co-

35 No acidente do Titanic foram perdidas 1500 vidas. Ver KRASKA, James. Contemporary maritime piracy: international law, strategy, and diplomacy at sea. Santa Barbara: Praeger, 2011. p. 62.

36 KRASKA, James. Contemporary maritime piracy: international law, strategy, and diplomacy at sea. Santa Barbara: Praeger, 2011. p. 61-62.

37 KRASKA, James. Contemporary maritime piracy: international law, strategy, and diplomacy at sea. Santa Barbara: Praeger, 2011. p. 62. 
munidade internacional se voltasse, mais uma vez, à segurança marítima. Em decorrência desse incidente, passou-se a discutir, no âmbito da Assembleia da IMO, a necessidade de adoção de medidas de combate aos ilícitos cometidos no mar e que ameaçam, não somente a segurança da navegação total, mas também a segurança de tripulantes e passageiros embarcados. As deliberações redundaram na Resolução n ${ }^{\circ}$ A.584(14), de 20 de novembro de 1985, na qual a Assembleia da IMO estabelece as "Medidas para Prevenir Atos Ilícitos que Ameaçam a Segurança dos Navios e a Segurança dos seus Passageiros e Tripulações". ${ }^{38}$ Nessa Resolução, a Assembleia expressava sua preocupação com o crescente aumento dos atos ilícitos no mar e direcionava o assunto para o CSM, para que este elaborasse medidas de ordem técnica, passíveis de serem adotadas dentro e fora dos navios, de modo a aumentar a segurança da navegação, dos passageiros e das tripulações envolvidas. O CSM, por sua vez, elaborou a Circular $n^{\circ} 443$, de 26 de setembro de 1986, na qual já antecipava a necessidade de adoção de algumas medidas necessárias à segurança marítima, tais como, instalações de segurança nos portos e a necessidade dos navios nomearem Oficiais de suas tripulações para a elaboração e implantação de planos de segurança a bordo. Essas medidas serão posteriormente replicadas e detalhadas em uma ampliação da Convenção SOLAS 1974/1988, naquilo que ficou conhecido como o Código Internacional de Segurança de Instalações Portuárias e Navios (International Ship and Port Facility Security - ISPS - Code), ou simplesmente o Código ISPS, que será tratado mais adiante. ${ }^{39}$

Outro desdobramento do sequestro do Achille Lauro consistiu na decisão da IMO, por iniciativa da Itália, Áustria e Egito, da elaboração de uma Convenção que servisse como marco legal internacional para a repressão de atos ilícitos cometidos no mar. Assim, em 1988, surge a Convenção para a Supressão de Atos Ilícitos contra a Segurança da Navegação Marítima (Suppression of Unlawful Acts - SUA - Convention). ${ }^{40}$ Essa Conven-

38 BALKIN, Rosalie. The International Maritime Organization and Maritime Security. Tulane Maritime Law Journal, New Orleans, v. 30, n. 1/2, p. 1-34, winter/summer, 2006. p. 5.

39 BALKIN, Rosalie. The International Maritime Organization and Maritime Security. Tulane Maritime Law Journal, New Orleans, v. 30, n. 1/2, p. 1-34, winter/summer, 2006. p. 6.

40 MEJIA JR, Maximo Q.; MUKHERJEE, P. K. The SUA Convention 2005: a critical evaluation of its effectiveness in suppressing maritime criminal acts. The Journal of International Maritime Law, Witney, v. 12, n. 3, p. 170-191, 2006. Disponível em: <http://www. lawtext.com/lawtextweb/default.jsp?PageID=2>. Acesso em: 10 ção tem como objetivo prover a base legal necessária para que os estados parte possam agir contra pessoas ou grupos que cometem ilícitos no mar. Na Convenção SUA/1988, os estados parte se comprometem a reprimir a captura de navios pela força, os atos de violência contra as pessoas a bordo de navios, bem como a instalação de artefatos que possam destruir ou danificar navios no interior de suas águas jurisdicionais. ${ }^{41}$ Para tal, seus signatários se comprometem a criar leis nacionais, criminalizando esses atos, de modo que também seja possível processar e julgar ou extraditar os responsáveis por tais agressões. ${ }^{42}$

Em um primeiro momento, a Convenção SUA/1988 não obteve um grande número de signatários. Após transcorridos 14 anos de sua elaboração, apenas 52 estados haviam ratificado o instrumento, porém, com o atentado nos Estados Unidos da América (EUA) em setembro de 2001, a Assembleia Geral da IMO, por ocasião de sua $22^{\mathrm{a}}$ sessão, manifestou-se convocando os estados membros, aqueles que ainda não faziam parte da Convenção SUA/1988, a aderirem ao instrumento e ao seu Protocolo para a Supressão de Atos Ilícitos contra a Segurança de Plataformas Fixas Localizadas na Plataforma Continental. ${ }^{43}$ Da mesma forma, concitou o Conselho para, por meio dos órgãos técnicos da Organização,

incumbir-se, em alta prioridade, de observar se há a necessidade de atualizar [...] qualquer outro instrumento relevante da IMO [...] e, à luz dessa

jan. 2015. p. 174.

41 Art.3 ${ }^{\circ}$. BRASIL. Decreto n. 6.136, de 26 de junho de 2007. Promulga a Convenção para a Supressão de Atos Ilícitos contra a Segurança da Navegação Marítima e o Protocolo para a Supressão de Atos Ilícitos contra a Segurança de Plataformas Fixas Localizadas na Plataforma Continental, ambos de 10 de março de 1988, com reservas ao item 2 do artigo 6o, ao artigo 80 e ao item 1 do artigo 16 da Convenção, bem como ao item 2 do artigo 30 do Protocolo. Disponível em: < http://www.planalto.gov.br/ccivil_03/_Ato20072010/2007/Decreto/D6136.htm>. Acesso em: 19 abr. 2015.

42 Art. 10. BRASIL. Decreto n. 6.136, de 26 de junho de 2007. Promulga a Convenção para a Supressão de Atos Ilícitos contra a Segurança da Navegação Marítima e o Protocolo para a Supressão de Atos Ilícitos contra a Segurança de Plataformas Fixas Localizadas na Plataforma Continental, ambos de 10 de março de 1988, com reservas ao item 2 do artigo 6o, ao artigo 8 o e ao item 1 do artigo 16 da Convenção, bem como ao item 2 do artigo 30 do Protocolo. Disponível em: <http://www.planalto.gov.br/ccivil_03/_Ato20072010/2007/Decreto/D6136.htm>. Acesso em: 19 abr. 2015.

43 MEJIA JR, Maximo Q.; MUKHERJEE, P. K. The SUA Convention 2005: a critical evaluation of its effectiveness in suppressing maritime criminal acts. The Journal of International Maritime Law, Witney, v. 12, n. 3, p. 170-191, 2006. Disponível em: < http://www. lawtext.com/lawtextweb/default.jsp?PageID=2>. Acesso em: 10 jan. 2015. p. 175. 
atualização, adotar as medidas necessárias." ${ }^{44}$ (tradução nossa).

Assim, a partir de 2002 os estados membros resolveram atender ao apelo da IMO e mais de 70 estados se tornaram parte da Convenção SUA/1988 nos dois anos seguintes, ao mesmo tempo, a IMO iniciava uma nova revisão dessa Convenção no âmbito de seus órgãos técnicos.

Após a análise dos órgãos técnicos competentes, a IMO concluiu que a Convenção SUA/1988 necessitava ampliar seu escopo no sentido de incluir medidas legais que permitissem aos Oficiais de navios de estado abordar navios estrangeiros em alto-mar, a fim de viabilizar a busca e apreensão de terroristas e suas armas, bem como socorrer navios suspeitos de estarem sob o ataque destes. ${ }^{45}$ Nesse sentido, em 2005, a Convenção SUA/1988 recebeu, em forma de um novo Protocolo Adicional, uma série de alterações que visam claramente ao combate do terrorismo no mar, uma vez que acrescentam à definição de ato ilícito diversas práticas terroristas, incorporadas por meio do art. $3^{\circ}$ bis: uso de artefatos explosivos, radioativos, biológicos ou nucleares a bordo; descarga de material perigoso ou nocivo à saúde no mar, desde que em quantidades que causem morte ou sérios danos à integridade física das pessoas; utilizar o navio como instrumento para causar morte ou danos à saúde e ao material; ou a simples ameaça de cometer qualquer um desses atos.

Além da inclusão da classificação de alguns atos terroristas como ilícitos no mar, o Protocolo Adicional de 2005 também ampliou a prerrogativa dos Oficiais de navios de estado abordar navios estrangeiros, de outros estados parte, mesmo em águas internacionais, uma vez que a alteração da Convenção passou a prever, por meio

44 "Requests the Maritime Safety Committee, the Legal Committee and the Facilitation Committee, under the direction of the Council, to undertake, on a high priority basis, a review to ascertain whether there is a need to update the instruments referred to in the preambular paragraphs and any other relevant IMO instrument under their scope and/or to adopt other security measures and, in the light of such a review, to take prompt action as appropriate". Cf INTERNATIONAL MARITIME ORGANIZATION. Resolution A.924(22), 20 November 2001. Review of Measures and Procedures to Prevent Acts of Terrorism which Threaten the Security of Passengers and Crews and the Safety of Ships. Disponível em: $\quad<$ http://www.imo.org/blast/blastDataHelper.asp?data_ $\mathrm{id}=24550 \&$ filename $=$ A924(22).pdf $>$. Acesso em: 19 abr. 2015. p. 2. 45 BALKIN, Rosalie. The International Maritime Organization and Maritime Security. Tulane Maritime Law Journal, New Orleans, v. 30, n. 1/2, p. 1-34, winter/summer, 2006. p. 23. do art. $8^{\circ}$ bis, a possibilidade de se proceder a abordagem em navios suspeitos ou que estejam envolvidos em atos ilícitos. Dessa forma,

Esses poderes abrangem não apenas a busca e apreensão de navios ou de suas cargas mas permitirão adicionalmente que os agentes de segurança interroguem e inspecionem, e se as circunstâncias o exigirem, que detenham e tomem as providências legais cabíveis contra qualquer um que se encontre no navio. ${ }^{46}$ (tradução nossa)

O pouco interesse dos estados parte em assinar e ratificar a Convenção SUA/1988 antes do atentado sofrido pelos EUA pode ser atribuído ao fato de que esta, por ter seu foco voltado para o terrorismo, era vista como um instrumento de interesse exclusivo de apenas alguns poucos estados, mais notadamente do "clube de proprietários de navios". A grande ameaça à navegação e à integridade de navios e tripulantes daquela época já era a pirataria e o roubo armado contra navios, não o terrorismo. Isso pode ser constatado quando se observa que de todos os 52 estados que aderiram inicialmente à Convenção, apenas a China era considerada um estado costeiro cujas águas eram assoladas pela pirataria e pelo roubo armado ${ }^{47}$. Assim, em que pesem as iniciativas para a elaboração de instrumentos multilaterais que melhorem as condições de segurança no mar, o roubo armado contra navios continuou à margem desse processo e sem seu respectivo marco normativo vinculante a nível global.

Existe esforço interpretativo para se aplicar à Convenção SUA/1988 ao combate ao roubo armado contra navios, uma vez que esse instrumento poderia ser visto como complemento à definição restritiva de pirataria adotada na CNUDM, que não permite a aplicação do seu art. 101 aos casos de roubo armado contra navios. Nesse sentido,

[...] é colocada uma ênfase no modo comum com que a violência é tratada em ambos os instrumentos;

46 "These powers extend not only to search and detention of the ship or its cargo but will additionally enable those law enforcement officials to question and search, and if the circumstances dictate, to detain and to take further legal action in respect of anyone found on board the vessel". Cf. BALKIN, Rosalie. The International Maritime Organization and Maritime Security. Tulane Maritime Law Journal, New Orleans, v. 30, n. 1/2, p. 1-34, winter/summer, 2006. p. 29.

47 MEJIA JR, Maximo Q.; MUKHERJEE, P. K. The SUA Convention 2005: a critical evaluation of its effectiveness in suppressing maritime criminal acts. The Journal of International Maritime Law, Witney, v. 12, n. 3, p. 170-191, 2006. Disponível em: <http://www. lawtext.com/lawtextweb/default.jsp?PageID=2>. Acesso em: 10 jan. 2015. p. 175. 
a CNUDM define a pirataria como um 'ato ilegal de violência', enquanto que a SUA descreve os atos ilícitos como um 'ato de violência contra uma pessoa'. Além do mais, a SUA é silente com relação aos espinhosos requisitos do Artigo 101 tal como a motivação por interesse privado, a regra dos dois navios, e a exigência de ocorrer em alto-mar. ${ }^{48}$ (tradução nossa).

Sendo a Convenção SUA menos restritiva na definição do ato ilícito, há uma indução errônea para que esta seja encarada como instrumento adequado para se combater o roubo armado contra navios, contornando as exigências previstas para a pirataria. No seu art. $3^{\circ}$, a Convenção possui alguns requisitos relacionados à definição de ato ilícito que requer dos perpetradores o efetivo controle do navio ou o comprometimento, por algum modo, da sua navegação segura. Dessa forma, os pequenos furtos ou os roubos que se utilizam apenas de facas ou armas de porte, tal como revólveres e pistolas, onde, muitas vezes, os delinquentes apenas embarcam e saem furtivamente, não estariam incluídos na caracterização de ato ilícito prevista na Convenção SUA. ${ }^{49}$ Isso faz com que o roubo armado contra navios siga carente de definição em um marco legal vinculante, adequado para o reconhecimento e persecução desse ilícito por parte dos estados costeiros. Esse tipo de ação ilícita é muito frequente no sudeste asiático e no Golfo da Guiné e tem se consubstanciado em uma ameaça à navegação nessas regiões.

Embora o combate à pirataria possua restrições decorrentes de sua definição, esta ao menos se encontra prevista na CNUDM e esta, por sua vez, oferece à IMO marco regulatório vinculante que serve de referência na atuação dos estados membros quando no combate a esse tipo de ilícito. No caso do roubo armado contra na-

48 "Particular emphasis is placed on the commonality of violence shared by the two instruments; UNCLOS defines piracy as an 'illegal act of violence' while SUA describes unlawful act as an 'act of violence against person'. Moreover, SUA is silent on prickly Article 101 issues such as the private gain motivation, the two ship rule and the high seas requirement". Cf MEJIA JR, Maximo Q.; MUKHERJEE, P. K. The SUA Convention 2005: a critical evaluation of its effectiveness in suppressing maritime criminal acts. The Journal of International Maritime Law, Witney, v. 12, n. 3, p. 170-191, 2006. Disponível em: <http://www.lawtext.com/lawtextweb/default. jsp?PageID=2>. Acesso em: 10 jan. 2015. p. 183.

49 MEJIA JR, Maximo Q.; MUKHERJEE, P. K. The SUA Convention 2005: a critical evaluation of its effectiveness in suppressing maritime criminal acts. The Journal of International Maritime Law, Witney, v. 12, n. 3, p. 170-191, 2006. Disponível em: <http://www. lawtext.com/lawtextweb/default.jsp?PageID=2>. Acesso em: 10 jan. 2015. p. 184. vios, não existe convenção específica que trate do tema, o que faz com que a qualificação desse tipo de ilícito ainda esteja dependente de interpretações do disposto na Resolução n A.1025(26) da Assembleia da IMO.

A repercussão na comunidade internacional do atentado contra as Torres Gêmeas em setembro de $2001 \mathrm{fez}$ com que o terrorismo fosse visto sob uma nova perspectiva, passando a ser considerado uma ameaça à segurança e à paz mundial. Um importante desdobramento dos atentados às Torres Gêmeas, nos EUA, em 2001, foi o direcionamento dos debates na IMO para a possibilidade de um navio ou instalação portuária ser utilizada como instrumento ou alvo para atentados terroristas. Isso fez com que normas e procedimentos fossem criados e revistos no âmbito da Organização, inclusive a mais abrangente e antiga de suas Convenções, a SOLAS $1974 / 1988 .^{50}$

Ainda que a Convenção SOLAS seja um instrumento claramente voltado para o aprimoramento e manutenção da segurança da navegação ${ }^{51}$, algumas imposições relacionadas à proteção dos navios, das tripulações e dos passageiros contra atos ilícitos tiveram que ser inseridas no âmbito da Convenção. Dessa forma, em 2002, a Convenção SOLAS 1974/1988 passa também a ser objeto de nova revisão que trata de medidas especiais para intensificar a proteção marítima. Nessa revisão, a SOLAS inclui em seu bojo uma série de procedimentos para mitigar possíveis ameaças de atentado no mar ou em portos. Esses procedimentos compõem o já citado Código ISPS e preveem uma série de medidas antiterror, tais como: a confecção de análises de risco inerentes a atentados terroristas em navios, empresas de navegação e instalações portuárias; a elaboração de planos de segurança e a designação em todos os níveis administrativos de agentes dedicados à implementação das medidas previstas no código. ${ }^{52}$

50 BALKIN, Rosalie. The International Maritime Organization and Maritime Security. Tulane Maritime Law Journal, New Orleans, v. 30, n. 1/2, p. 1-34, winter/summer, 2006. p. 16.

51 Para uma melhor compreensão da distinção entre a segurança da navegação (safety) e a proteção de navios, das tripulações e dos passageiros contra atos ilícitos (security) no âmbito da CNUDM, ver BEIRÃO, André Panno. "Segurança no mar": que segurança? In: BEIRÃO, André Panno; PEREIRA, Antônio Celso Alves (Org.). Reflexões sobre a Convenção do Direito do Mar. Brasília: Fundação Alexandre de Gusmão, 2014. p. 127-166.

52 MEJIA JR, Maximo Q. Developing the Concept of a security culture on board ships. In: MEJIA, Maximo Quibranza; XU, Jingjing (Ed.) Coastal zone piracy and other unlawful acts at sea: a selection 


\section{Os ACORDOS REGIONAIS DE COOPERAÇÃO NA REPRESSÃO AO ROUBO ARMADO CONTRA NAVIOS: A IMO ABRE O "Clube"}

Após a Segunda Guerra Mundial, houve fortalecimento das organizações internacionais como instituições facilitadoras das relações interestatais. Como consequência, ocorre o surgimento nessas organizações de fóruns e agendas em que a sociedade internacional passou a debater as principais questões que permeiam as relações internacionais e o direito internacional. Desde então, "as organizações internacionais refletem [...] a necessidade dos estados se organizarem para alcançarem objetivos comuns de caráter permanente e de interesse global ou regional." ${ }^{53}$

Com as questões afetas ao uso do mar não poderia ser diferente. Por meio da IMCO e posteriormente da IMO, criou-se ampla e diversa agenda de âmbito internacional voltada para as questões marítimas, inclusive no que diz respeito ao tema segurança. Porém, durante muito tempo a IMO preocupou-se em manter uma agenda exclusivamente global, desenvolvendo apenas normas e procedimentos que julgava ser de aplicação internacional. Assim, negava-se a aceitar que determinadas questões, tal como a repressão ao roubo armado contra navios, tivessem suas causas fortemente atreladas a fatores exclusivamente regionais e, nesses casos, a solução passava necessariamente pela cooperação dos estados costeiros afetados.

O debate entre internacionalismo e regionalismo ocupou a agenda da IMO por diversas vezes. Já no início da década de 1980, discutia-se se as normas da IMO deveriam ter caráter exclusivamente global ou deveriam atender a especificidades regionais e, assim, serem dotadas de maior efetividade. Esse debate teve início com a tentativa do, então, Mercado Comum Europeu, implantar o Memorando de Entendimento de Paris. Segundo esse instrumento, os países signatários, membros da IMO, no intuito de criarem condições benéficas de concorrência para seus próprios navios, passariam a ado-

of papers and presentations from the international symposium on the new regime for the suppression of unlawful acts at sea, 21-23 november 2005 and the international symposium on coastal zone piracy, 13-15 november 2006. Malmö: WMU, 2007. p. 157-169.

53 ESTEVES NETO, Ernesto Gomes. Organizações internacionais e o direito do mar. In: MENEZES, Wagner (Org.). Direito do mar: desafios e perspectivas. Belo Horizonte: Arraes, 2015. p. 69-87. p. 70 tar rigorosos aspectos de inspeção em seus portos, de modo a proibir a atracação de navios estrangeiros que não estivessem em conformidade com os parâmetros de construção e operação estabelecidos pela IMO. Essa medida foi recebida como discriminatória pelos demais estados membros. Como desdobramento, a IMO decidiu manter seu foco em uma perspectiva global e se tornou a detentora do memorando de controle portuário em todas as regiões do mundo. ${ }^{54}$

\subsection{Passando para uma abordagem regional da segurança no mar}

Talvez a adoção de normas de âmbito global funcione melhor para resolver questões de cunho estritamente econômico e comercial, em que os estados de bandeira e do porto ainda são os atores centrais. No que diz respeito ao roubo armado contra navios, a soberania dos estados costeiros ainda é um elemento muito importante na busca de uma solução para o problema. O simples fato de o ilícito ocorrer em águas sob jurisdição dos estados membros já requer cuidado no trato do assunto, uma vez que deve prevalecer a legislação do estado costeiro como norma a ser seguida na detenção e julgamento de pessoas que praticam o roubo armado contra navios.

Outro fator relevante diz respeito à necessidade de se intensificar o patrulhamento dessas águas, o que, em sua totalidade, ocorre de maneira ineficaz por tratar-se de águas sob jurisdição de estados em desenvolvimento e sem recursos materiais, técnicos e humanos para tal. Mais do que impor uma norma global, é necessário que a IMO, caso a caso, encontre mecanismos de incentivo à cooperação dos estados costeiros afetados. Uma ferramenta que a Organização tem adotado, e que tem se mostrado de certa forma eficaz, é a utilização de blocos regionais como interlocutores na busca de um engajamento das nações afetadas na repressão ao roubo armado contra navios. Quando as medidas sugeridas pela IMO são discutidas e adotadas no âmbito dos blocos regionais, essas medidas se vêm dotadas não apenas da legitimidade outorgada à IMO pela CNUDM, mas, quando devidamente acompanhadas de fontes de recursos, também recebem uma carga de efetividade muito maior do que a mera imposição de normas globais

54 BLANCO-BAZÁN, Agustín. IMO: historical highlights in the life of a un agency. Journal of the History of International Law, Leiden, v. 6, n. 2, p. 259-283, July/Dec. 2006. p. 281. 
decididas no âmbito do "clube dos proprietários de navios". Dessa forma, a IMO afastaria também aquilo que vem sendo uma das escusas mais utilizadas pelos países em desenvolvimento para justificarem sua falta de interesse na cooperação, que é a pouca assistência financeira provida pelos países desenvolvidos da Organização. ${ }^{55}$

O movimento de criação de blocos regionais surgiu nos anos de 1960, com as primeiras iniciativas de integração econômica entre estados. Mas, desse movimento inicial, somente a União Europeia logrou êxito, uma vez que a prática dos estados, principalmente na América Latina, ainda demonstrava excessivo protecionismo, o que acabou prejudicando o desenvolvimento da integração, tal como pretendida. Foi com o fim da Guerra-Fria (1989), que os movimentos de integração regional ganharam um novo impulso. $\mathrm{O}$ arrefecimento das disputas ideológicas, a integração econômica exigida pela globalização e a percepção de que vantagens relativas poderiam ser exploradas em alianças com países vizinhos, fizeram com que se observasse o surgimento de um número expressivo de blocos regionais. ${ }^{56}$ Inicialmente voltados apenas para fins econômicos, os blocos regionais vão se desenvolvendo e ganhando outros objetivos institucionais, consequentemente, tornam-se atores centrais nas discussões sobre a agenda internacional. Assim, os blocos regionais podem ser considerados como uma

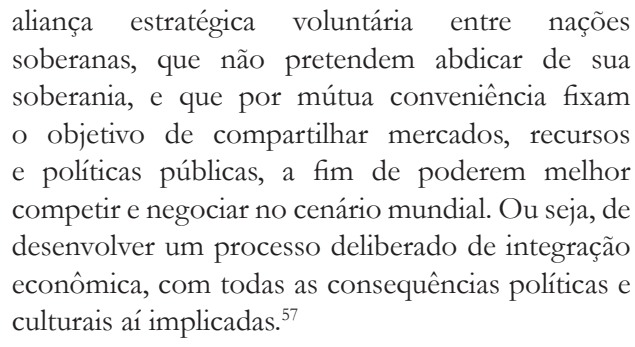

55 KARIM, Md. Saiful. Implementation of the MARPOL Convention in Developing Countries. Nordic Journal of International Law, Leiden, v. 79, n. 2, p. 303-337, 2010. Disponível em: <http:/ / booksandjournals.brillonline.com/content/journals/10.1163/1571 81010x12668401899110>. Acesso em: 10 jan. 2015. p. 319.

56 PORTO, Manuel. Processos de integração econômica: perspectivas para o Mercosul e para a União Européia. In: AMBOS, Kai; PEREIRA, Ana Cristina P. (Org.). Mercosul e União Europeia: perspectivas da integração regional. Rio de Janeiro: Lumen Juris, 2006. p. 107-126. p. 107-108.

57 PEÑA, Félix. Direito e instituições no Mercosul: um balanço de conquistas e insuficiências. In: AMBOS, Kai; PEREIRA, Ana Cristina P. (Org.). Mercosul e União Europeia: perspectivas da integração regional. Rio de Janeiro: Lumen Juris, 2006. p. 91-106. p. 91.

\subsection{A Ásia lidera a reação regional: o surgimento do ReCAAP}

No sudeste asiático, o choke point conhecido como Estreito de Malaca e o Mar do Sul da China são áreas internacionalmente conhecidas pela grande incidência de casos de roubo armado contra navios. Em razão da posição geográfica estratégica, essas águas são responsáveis por grande parte do comércio marítimo mundial, o que acarreta um intenso fluxo de navios em uma congestionada e estreita rota marítima. Os grupos criminosos que atuam nessa área variam em tamanho e em modalidade criminosa. Enquanto alguns pequenos grupos de pescadores invadem os navios com o intuito apenas de roubar os objetos de valor da tripulação e do cofre do navio para, posteriormente, fugirem em lanchas rápidas; existem também as grandes organizações criminosas internacionais ${ }^{58}$ que roubam navios para registrá-los como "navios fantasmas" e desviar sua carga.

A intensificação da atividade criminosa no mar do sudeste asiático tem como uma de suas causas principais o elevado nível de desemprego e o lento crescimento econômico que gerou um empobrecimento dos países da região após a crise financeira pela qual passaram em 1997. Para agravar o problema, uma das medidas econômicas muito frequentes para enfrentar a crise é o corte de gastos com segurança e defesa, tendo reflexos diretos na repressão ao roubo armado contra navios. ${ }^{59}$

Dentro da ideia de solução regional é que surgiu, em 2004, o Acordo Regional de Cooperação no Combate à Pirataria e ao Roubo Armado contra Navios na Ásia (ReCAAP). Esse instrumento foi o pioneiro na tentativa de solucionar o problema do roubo armado contra navios, adotando uma perspectiva de cooperação regional, nesse caso, no sudeste asiático. Celebrado no âmbito da Associação das Nações do Sudeste Asiático (ANSEA), com o apoio de países como a China, a Coreia do Sul e o Japão, o ReCAAP conseguiu implantar uma cooperação regional cujo foco é o restabelecimento da segu-

58 BULKELEY, Jennifer C. Regional cooperation on maritime piracy: a prelude to greater multilateralism in Asia? Journal of Public and International Affairs, Princeton, v. 14, p. 20-39, Spring, 2003. Disponível em: <http://www.princeton.edu/jpia/past-issues-1/2003/2.pdf>. Acesso em: 05 jan. 2015. p. 2-3.

59 BULKELEY, Jennifer C. Regional cooperation on maritime piracy: a prelude to greater multilateralism in Asia? Journal of Public and International Affairs, Princeton, v. 14, p. 20-39, Spring, 2003. Disponível em: <http://www.princeton.edu/jpia/past-issues-1/2003/2.pdf>. Acesso em: 05 jan. 2015. p. 3. 
rança marítima em uma área muito afetada pelo roubo armado contra navios.

O ReCAAP foi o precursor de um modelo de instrumento multilateral no combate ao roubo armado, conhecido como "código", que seria posteriormente adotado pela IMO em outras regiões, apenas com algumas modificações. ${ }^{60}$ Para combater os ilícitos no mar, mais notadamente no Estreito de Malaca, o Acordo estabelece que os estados parte devem reprimir o roubo armado contra navios e a pirataria; contribuir para o estabelecimento de um centro de compartilhamento de informações sobre ilícitos no mar; e deter pessoas que tenham cometido o ilícito, bem como os navios e as aeronaves utilizados por essas pessoas e o material que se encontrar no interior desses meios. ${ }^{61}$

Por não haver então uma definição internacional de roubo armado contra navios, o Acordo criou sua própria definição, que seria utilizada como referência em outros códigos elaborados pela IMO em parceria com outras organizações regionais. A definição adotada no ReCAAP é uma adaptação da definição de pirataria prevista no art. 101 da CNUDM e foi posteriormente aprimorada para atender às necessidades dos códigos elaborados, principalmente no que diz respeito à necessidade dos estados parte legislarem no sentido de criminalizar o roubo armado contra navios no direito penal interno, permitindo, dessa forma, sua persecução pelos órgãos jurisdicionais nacionais. $\mathrm{O}$ art. $1^{\circ}$, parágrafo $2^{\circ}$, do ReCAAP afirma que:

2. Para os propósitos deste Acordo, "roubo armado contra navios" significa qualquer dos seguintes atos:

(a) qualquer ato de violência ilegal ou detenção ou qualquer ato de depredação, cometido com fins privados e dirigido contra um navio ou contra pessoas ou propriedades a bordo desse navio, em lugar onde haja jurisdição de um Estado parte sobre tais ofensas;

(b) qualquer ato de participação voluntária na operação de um navio com o conhecimento de fatos que fazem deste um navio para roubo armado contra navios;

60 Os códigos são instrumentos multilaterais, firmados no âmbito de organizações regionais, utilizados pela IMO no combate ao roubo armado contra navios e à pirataria no caso do ReCAAP e do Código Djibouti (Somália), no caso do Golfo da Guiné houve uma extensão para a repressão ao crime organizado e aos crimes ambientais praticados no mar.

61 ReCAAP, art. $3^{\circ}$. JAPAN. Ministry of Foreign Affairs. Regional Cooperation Agreement on Combating Piracy and Armed Robbery against Ships in Asia (ReCAAP). Disponível em: < http:// www.mofa.go.jp/mofaj/gaiko/kaiyo/pdfs/kyotei_s.pdf>. Acesso em: 30 abr. 2015. (c) qualquer ato de incitação ou de facilitação intencional de um ato descrito nos subparágrafos (a) ou (b). ${ }^{62}$ (Tradução nossa).

Grande parte do Acordo diz respeito à criação, funcionamento e financiamento de um centro de compartilhamento de informações sobre ilícitos no mar. Tal centro foi constituído com um elevado nível de institucionalização. Possui uma sede localizada em Cingapura ${ }^{63}$ e é constituído pelos seguintes órgãos: um Conselho, composto por um representante de cada estado membro e com a atribuição de elaborar políticas relativas a todos os assuntos afetos ao centro, possuindo ainda suas próprias regras de procedimento ${ }^{64}$; e um Secretariado, cuja finalidade é a de servir como órgão administrativo, operacional e financeiro. No Conselho, todas as decisões são tomadas por consenso entre os membros. ${ }^{65}$

Como tarefas, o centro de compartilhamento de informações deve fazer a coleta, análise e disseminação dos alertas relacionados com os casos de roubo armado contra navios; prover o alerta aos estados-parte, com a maior brevidade possível, sempre que houver suspeita fundada de que há uma iminência de ataque contra qualquer embarcação; e preparar relatórios e manter atualizadas as estatísticas não sigilosas relacionadas com os casos de roubo armado contra navios já relatados. ${ }^{66}$

62 "2. For the purposes of this Agreement, "armed robbery against ships" means any of the following acts: (a) any illegal act of violence or detention, or any act of depredation, committed for private ends and directed against a ship, or against persons or property on board such ship, in a place within a Contracting Party's jurisdiction over such offences; (b) any act of voluntary participation in the operation of a ship with knowledge of facts making it a ship for armed robbery against ships;(c) any act of inciting or of intentionally facilitating an act described in subparagraph (a) or (b)". JAPAN. Ministry of Foreign Affairs. Regional Cooperation Agreement on Combating Piracy and Armed Robbery against Ships in Asia (ReCAAP). Disponível em: <http://www.mofa.go.jp/mofaj/gaiko/ kaiyo/pdfs/kyotei_s.pdf $>$. Acesso em: 30 abr. 2015.

63 ReCAAP, art. $4^{\circ}, \$ 2^{\circ}$. JAPAN. Ministry of Foreign Affairs. Regional Cooperation Agreement on Combating Piracy and Armed Robbery against Ships in Asia (ReCAAP). Disponível em: <http:// www.mofa.go.jp/mofaj/gaiko/kaiyo/pdfs/kyotei_s.pdf>. Acesso em: 30 abr. 2015.

64 ReCAAP, art. $4^{\circ}, \sqrt{ } 5^{\circ}$. JAPAN. Ministry of Foreign Affairs. Regional Cooperation Agreement on Combating Piracy and Armed Robbery against Ships in Asia (ReCAAP). Disponível em: <http:// www.mofa.go.jp/mofaj/gaiko/kaiyo/pdfs/kyotei_s.pdf $>$. Acesso em: 30 abr. 2015.

65 ReCAAP, art. $4^{\circ}, \$ 6^{\circ}$. JAPAN. Ministry of Foreign Affairs. Regional Cooperation Agreement on Combating Piracy and Armed Robbery against Ships in Asia (ReCAAP). Disponível em: <http:// www.mofa.go.jp/mofaj/gaiko/kaiyo/pdfs/kyotei_s.pdf $>$. Acesso em: 30 abr. 2015.

66 ReCAAP, art. $7^{\circ}$. JAPAN. Ministry of Foreign Affairs. Re- 
Como um órgão de cooperação regional, o centro de compartilhamento de informações deverá contar com um agente responsável oriundo de cada estado-parte. Assim, pretende-se facilitar a comunicação entre os estados signatários do Acordo, aprimorando o compartilhamento das informações e dando velocidade à disseminação das informações que forem relevantes. ${ }^{67}$ Dessa forma, busca-se permitir que os navios evitem determinadas áreas perigosas, além de prover pronta resposta aos casos de roubo armado contra navios ainda em andamento. Outra tarefa do agente responsável consiste em facilitar a cooperação interestatal na detenção e extradição ou no processo e julgamento daqueles que vierem a ser detidos praticando esse ilícito.

Uma questão de grande relevância que envolve a repressão ao roubo armado contra navios consiste na criação de uma expertise dos agentes responsáveis pela imposição da lei e da ordem nas águas sob jurisdição estatal. Para aumentar a capacidade técnica desses agentes, o ReCAAP prevê que o centro de compartilhamento de informações também funcione como um centro de capacitação de agentes de segurança, promovendo a cooperação dos estados parte no sentido de realizarem, mediante solicitação dos estados signatários, cursos, cooperação técnica e encontros para dividirem experiências e boas práticas. ${ }^{68}$ Para financiar essas atividades e o funcionamento regular do centro de compartilhamento de informações, o ReCAAP prevê a criação de um fundo gerido pelo Conselho e que tem como principais fontes de recursos, o estado anfitrião, que é Cingapura; as contribuições voluntárias dos estados-parte e as contribuições voluntárias de organizações internacionais, tais como a IMO e o IMB. ${ }^{69}$

gional Cooperation Agreement on Combating Piracy and Armed Robbery against Ships in Asia (ReCAAP). Disponível em: <http:// www.mofa.go.jp/mofaj/gaiko/kaiyo/pdfs/kyotei_s.pdf $>$. Acesso em: 30 abr. 2015.

67 ReCAAP, art. 9 ${ }^{\circ}$. JAPAN. Ministry of Foreign Affairs. Regional Cooperation Agreement on Combating Piracy and Armed Robbery against Ships in Asia (ReCAAP). Disponível em: < http:// www.mofa.go.jp/mofaj/gaiko/kaiyo/pdfs/kyotei_s.pdf >. Acesso em: 30 abr. 2015.

68 ReCAAP, art. 14. JAPAN. Ministry of Foreign Affairs. Regional Cooperation Agreement on Combating Piracy and Armed Robbery against Ships in Asia (ReCAAP). Disponível em: <http:// www.mofa.go.jp/mofaj/gaiko/kaiyo/pdfs/kyotei_s.pdf $>$. Acesso em: 30 abr. 2015.

69 ReCAAP, art. 6․ JAPAN. Ministry of Foreign Affairs. Regional Cooperation Agreement on Combating Piracy and Armed Robbery against Ships in Asia (ReCAAP). Disponível em: < http:// www.mofa.go.jp/mofaj/gaiko/kaiyo/pdfs/kyotei_s.pdf>. Acesso em: 30 abr. 2015.

\subsection{Uma estratégia para o Golfo da Guiné}

No Golfo da Guiné, o roubo armado contra navios ocorre como uma forma de obter recursos para financiar a pirataria contra grandes navios tanque que navegam em águas internacionais, transportando o petróleo extraído da região. Assim, pequenos grupos se valem de embarcações rápidas de menor porte para abordarem e assaltarem navios fundeados ou que estão se dirigindo a um dos portos do Golfo. Dessa forma, abordam os navios alvo e, usando extrema violência, saqueiam tudo que podem transportar, desde objetos pessoais da tripulação até cargas de menor volume. Com o lucro obtido pelo roubo, os grupos criminosos conseguem adquirir embarcações maiores e mais bem equipadas, o que acaba lhes permitindo atuar na pirataria, isto é, distante da costa. $^{70}$

As recentes descobertas de grandes jazidas de petróleo e o interesse dos países ocidentais despertado por essas jazidas deram notoriedade ao problema de segurança marítima vivido na região. ${ }^{71}$ Suas causas são baseadas em grande pobreza da população; atuação de grupos de conotação política em atividades ilícitas; baixa capacidade de governar dos líderes estatais, inclusive com grande incidência de casos de corrupção dos agentes públicos responsáveis por coibir os ilícitos no mar; e elevados índices de degradação ambiental causados pela atividade petrolífera e pela pesca ilegal, privando assim as comunidades pesqueiras locais de obterem seu sustento. $^{72}$

Além dos problemas citados, os estados costeiros afetados ainda convivem com a falta de recursos financeiros, materiais e humanos para patrulharem suas águas jurisdicionais e empreenderem efetiva repressão

70 INTERNATIONAL CRISIS GROUP. The Gulf of Guinea: the new danger zone. Africa Report, Nairobi, n. 195, 12 Dec. 2012. Disponível em: <http://www.crisisgroup.org/ /media/Files/ africa/central-africa/195-the-gulf-of-guinea-the-new-danger-zoneenglish.pdf $>$. Acesso em: 19 abr. 2015. p. 10-11.

71 INTERNATIONAL CRISIS GROUP. The Gulf of Guinea: the new danger zone. Africa Report, Nairobi, n. 195, 12 Dec. 2012. Disponível em: <http://www.crisisgroup.org/ /media/Files/ africa/central-africa/195-the-gulf-of-guinea-the-new-danger-zoneenglish.pdf>. Acesso em: 19 abr. 2015. p. i.

72 INTERNATIONAL CRISIS GROUP. The Gulf of Guinea: the new danger zone. Africa Report, Nairobi, n. 195, 12 Dec. 2012. Disponível em: <http://www.crisisgroup.org/ /media/Files/ africa/central-africa/195-the-gulf-of-guinea-the-new-danger-zoneenglish.pdf>. Acesso em: 19 abr. 2015. p. 3-8. 
ao roubo armado contra navios na região. ${ }^{73}$ Isto tem apontado para a necessidade de se pensar em solução baseada na cooperação regional com financiamento internacional. Dessa forma, as possíveis soluções para a crise de segurança no Golfo da Guiné têm sido vislumbradas por meio do incremento da cooperação entre a IMO e os blocos regionais da União Africana, isto é, a Comunidade Econômica dos estados da África Central (Economic Community of Central Africa States - ECCAS) e a Comunidade Econômica dos Estados Africanos do Oeste (Economic Community of West African States - ECOWAS.$^{74}$

Sob a coordenação da IMO e adotando o modelo proposto pelo ReCAAP, foi empreendido, em 2013, um esforço diplomático conjunto que envolveu, além da própria IMO, a ECCAS, a ECOWAS, a Organização Marítima para o Oeste e Centro da África (Maritime Organization for West and Central Africa - MOWCA), e a Comissão para o Golfo da Guiné (CGG). Por meio da mobilização de seus respectivos estados membros, esses blocos regionais uniram forças para a elaboração e implementação de instrumento multilateral que, uma vez ratificados, vinculariam a atuação dos estados signatários na definição e repressão ao roubo armado contra navios naquela região. Esse instrumento foi denominado como "Código de Conduta Relativo à Repressão da Pirataria, Roubo Armado contra Navios e Atividades Marítimas Ilícitas no Oeste e Centro da África", que será referido apenas como Código da Guiné ou somente Código.

O formato adotado pelo Código da Guiné é bem similar ao que havia sido adotado no ReCAAP. O Código também prevê a constituição de um centro de compartilhamento de informações e da dotação desse centro com agentes responsáveis enviados pelos estados parte. ${ }^{75}$ Uma diferença no Código da Guiné é a adoção de

73 INTERNATIONAL CRISIS GROUP. The Gulf of Guinea: the new danger zone. Africa Report, Nairobi, n. 195, 12 Dec. 2012. Disponível em: <http://www.crisisgroup.org/ /media/Files/ africa/central-africa/195-the-gulf-of-guinea-the-new-danger-zoneenglish.pdf>. Acesso em: 19 abr. 2015. p. 4-5.

74 INTERNATIONAL CRISIS GROUP. The Gulf of Guinea: the new danger zone. Africa Report, Nairobi, n. 195, 12 Dec. 2012. Disponível em: <http://www.crisisgroup.org/ /media/Files/ africa/central-africa/195-the-gulf-of-guinea-the-new-danger-zoneenglish.pdf >. Acesso em: 19 abr. 2015. p. i-ii.

75 Código da Guiné, art. 11. INTERNATIONAL MARITIME ORGANIZATION. Code of Conduct Concerning the Repression of Piracy, Armed Robbery Against Ships, and Illicit Maritime Activity in West and Central Africa. 2013. Disponível em: < http://www. uma definição mais elaborada de roubo armado contra navios. Em que pese a essência ser a mesma da definição adotada no ReCAAP, que serviu de modelo para esta, a definição de roubo armado contra navios consagrada pela Resolução A.1025(26) da Assembleia Geral da IMO é repetida no Código da Guiné. ${ }^{76}$

Como estratégia de combate aos ilícitos no mar, o Código da Guiné prevê a ampliação do escopo que havia sido adotado no ReCAAP, uma vez que visa atender às especificidades das causas do roubo armado na região. Assim, amplia seus objetivos para além da repressão à pirataria e ao roubo armado contra navios, incluindo também a repressão a toda forma de crime organizado transnacional no mar, ao terrorismo marítimo, à pesca ilegal e a qualquer outra atividade ilícita no mar. ${ }^{77}$ Para tal, prevê expressamente que os estados membros desenvolvam e implementem políticas nacionais apropriadas para a salvaguarda do comércio marítimo contra todas as formas de ato ilícito e criem uma legislação nacional que contribua para a efetividade dessa política naquilo que diz respeito tanto à segurança de navios e portos, quanto em relação à efetiva proteção ao meio ambiente. ${ }^{78}$

Sempre tendo como base o respeito à soberania dos estados parte, o Código da Guiné também prevê a intensificação da patrulha marítima no mar territorial desses Estados, sendo esse esforço de responsabilidade do estado costeiro e conduzido sob a autoridade soberana

imo.org/OurWork/Security/WestAfrica/Documents/code_of_ conduct $\% 20$ signed $\% 20$ from $\% 20$ ECOWAS $\% 20$ site.pdf $>$. Acesso em: 30 abr. 2015.

76 Código da Guiné, art. $1^{\circ}, \$ 4^{\circ}$. INTERNATIONAL MARITIME ORGANIZATION. Code of Conduct Concerning the Repression of Piracy, Armed Robbery Against Ships, and Illicit Maritime Activity in West and Central Africa. 2013. Disponível em: <http://www.imo.org/OurWork/Security/WestAfrica/Documents/code_of_conduct $\% 20$ signed $\% 20$ from $\% 20$ ECOWAS $\% 20$ site.pdf $>$. Acesso em: 30 abr. 2015.

77 Código da Guiné, art. $2^{\circ}, \$ 1^{\circ}$. INTERNATIONAL MARITIME ORGANIZATION. Code of Conduct Concerning the Repression of Piracy, Armed Robbery Against Ships, and Illicit Maritime Activity in West and Central Africa. 2013. Disponível em: <http://www.imo.org/OurWork/Security/WestAfrica/Documents/code_of_conduct $\% 20$ signed $\% 20$ from $\% 20$ ECOWAS $\% 20$ site.pdf>. Acesso em: 30 abr. 2015.

78 Código da Guiné, art. 4. INTERNATIONAL MARITIME ORGANIZATION. Code of Conduct Concerning the Repression of Piracy, Armed Robbery Against Ships, and Illicit Maritime Activity in West and Central Africa. 2013. Disponível em: <http://www. imo.org/OurWork/Security/WestAfrica/Documents/code_of_ conduct $\% 20$ signed $\% 20$ from $\% 20$ ECOWAS $\% 20$ site.pdf $>$. Acesso em: 30 abr. 2015. 
dele. ${ }^{79}$ Para dotar essas patrulhas marítimas de maior efetividade e prover agilidade ao processo de abordagem e detenção de navios e criminosos, o Código adota a figura do Oficial estrangeiro embarcado. Levando em conta que em muitos estados parte as marinhas e os órgãos de segurança no mar não possuem meios materiais para patrulharem suas próprias águas jurisdicionais, o Código prevê que essa patrulha poderá ser realizada por meio de navios de outros estados parte que, para não ferirem a soberania do estado costeiro ou do estado de bandeira, devem embarcar Oficiais destes, de modo a que se incumbam de autorizar a entrada em seu mar territorial, no caso de Oficial pertencente ao estado costeiro, ou autorizar a abordagem de navios sob determinada bandeira, no caso de esta ser da mesma nacionalidade que o Oficial embarcado. Esses Oficiais também devem assessorar na adoção das medidas legais cabíveis no caso de constatação de algum ilícito em suas respectivas jurisdições. ${ }^{80}$

Os códigos celebrados sob a coordenação da IMO representam um considerável avanço na repressão ao roubo armado contra navios. O fato de esses importantes instrumentos multilaterais serem elaborados com a participação direta dos estados afetados, incentivando a cooperação regional, por meio dos seus respectivos blocos econômicos, e mantendo o respeito à soberania dos seus membros, eliminou o problema da adesão a esses tratados, dotando-os de um elevado grau de legitimidade. Apesar do aumento na aceitação, a eficácia desses instrumentos ainda carece de uma postura mais decisiva no que diz respeito ao financiamento das atividades pactuadas, principalmente no que diz respeito ao Código da Guiné.

Havendo identificado esse problema e carecendo de fontes de recursos disponíveis, a IMO elaborou, em 2014, a estratégia conhecida como "Implementação das

79 Código da Guiné, art. $4^{\circ}, \$ 3^{\circ}$ e $\$ 4^{\circ}$. INTERNATIONAL MARITIME ORGANIZATION. Code of Conduct Concerning the Repression of Piracy, Armed Robbery Against Ships, and Illicit Maritime Activity in West and Central Africa. 2013. Disponível em: <http://www.imo.org/OurWork/Security/WestAfrica/Documents / code_of_conduct $\% 20$ signed $\% 20$ from $\% 20$ ECOWAS $\% 20$ site.pdf $>$. Acesso em: 30 abr. 2015.

80 Código da Guiné, art. $9^{\circ}$, \$5 . INTERNATIONAL MARITIME ORGANIZATION. Code of Conduct Concerning the Repression of Piracy, Armed Robbery Against Ships, and Illicit Maritime Activity in West and Central Africa. 2013. Disponível em: <http://www.imo.org/OurWork/Security/WestAfrica/Documents/code_of_conduct $\% 20$ signed $\% 20$ from $\% 20$ ECOWAS $\% 20$ site.pdf>. Acesso em: 30 abr. 2015.
Medidas de Segurança Marítima Sustentáveis no Oeste e Centro da África" (tradução nossa) ${ }^{81}$. Com esse documento, a IMO tenta incentivar a solução dos problemas de escassez de recursos, buscando soluções dentro das próprias organizações regionais. Por meio de uma abordagem totalmente regional, a IMO convoca os estados membros do Golfo da Guiné afetados pelo roubo armado contra navios para se mobilizaram dentro daquilo que a Organização chama de "treinamento regional baseado no desenvolvimento de África para África" (tradução nossa ${ }^{82}$. Assim, incentiva a realização de parcerias entre os estados da região, de modo a incrementar o compartilhamento de soluções regionais, construir uma relação de confiança entre os estados e nutrir uma cooperação transfronteiriça nos assuntos relevantes.

Para atingir seus objetivos, a estratégia da IMO investe sua expertise na organização de exercícios de segurança marítima conhecidos como table top exercises. Esses exercícios são conduzidos pela própria IMO nos estados costeiros afetados e fazem parte da adoção de uma nova filosofia da Organização conhecida como "puxar ao invés de empurrar" (tradução nossa) ${ }^{83}$. Dentro dessa filosofia, pretende-se oferecer assistência técnica aos estados membros incapazes de criarem as competências necessárias por meios próprios, bem como criar nesses estados a mentalidade de que a segurança marítima pode propiciar-lhes um maior aproveitamento dos recursos naturais existentes em suas respectivas zonas econômicas exclusivas, provendo assim os recursos financeiros de que necessitam. Além de tentar incrementar parcerias regionais para o aprimoramento da segurança marítima no Golfo da Guiné, a IMO tam-

81 INTERNATIONAL MARITIME ORGANIZATION. Code of Conduct Concerning the Repression of Piracy, Armed Robbery Against Ships, and Illicit Maritime Activity in West and Central Africa. 2013. Disponível em: <http://www.imo.org/OurWork/Security/WestAfrica/Documents/code_of_conduct $\% 20$ signed $\% 20$ from $\% 20$ ECOWAS $\% 20$ site.pdf $>$. Acesso em: 30 abr. 2015.

82 "Regional training based on Africa-to-Africa development". INTERNATIONAL MARITIME ORGANIZATION. Code of Conduct Concerning the Repression of Piracy, Armed Robbery Against Ships, and Illicit Maritime Activity in West and Central Africa. 2013. Disponível em: <http://www.imo.org/OurWork/Security/WestAfrica/Documents/code_of_conduct $\% 20$ signed $\% 20$ from $\% 20$ ECOWAS $\% 20$ site.pdf $>$. Acesso em: 30 abr. 2015. p. 5-6. 83 "Creating pull of instead of push". INTERNATIONAL MARITIME ORGANIZATION. Code of Conduct Concerning the Repression of Piracy, Armed Robbery Against Ships, and Illicit Maritime Activity in West and Central Africa. 2013. Disponível em: <http://www.imo.org/OurWork/Security/WestAfrica/Documents /code_of_conduct $\% 20$ signed $\% 20$ from $\% 20$ ECOWAS $\% 20$ site.pdf>. Acesso em: 30 abr. 2015. p. 5. 
bém tem buscado estabelecer parcerias com outras organizações do sistema ONU, tal como o Escritório das Nações Unidas sobre Drogas e Crime (UNODC), a Organização das Nações Unidas para Alimentação e Agricultura (FAO), o Alto Comissariado das Nações Unidas para Refugiados (ACNUR), e os escritórios regionais da ONU na África Central (UNOCA) e na África do Oeste (UNOWA) ${ }^{84}$. Dessa forma, a IMO demonstra haver adotado definitivamente uma abordagem eminentemente regional no trato das questões afetas à repressão ao roubo armado contra navios.

\section{Considerações finais}

Com a elaboração da CNUDM, a IMO ficou incumbida, como organização internacional competente, de diversas atribuições inerentes à repressão de ilícitos no mar. Para assumir o papel conferido pela Convenção de Montego Bay e contar com o amplo reconhecimento da comunidade internacional, a Organização necessitou promover uma série de alterações institucionais, tal como uma maior democratização na composição de seus órgãos deliberativos, principalmente do Conselho e do Comitê de Segurança Marítima. Também foi necessário alterar a própria designação da instituição, uma vez que a IMCO apresentava o rótulo de uma instituição apenas consultiva e limitada pela posição de alguns governos, não uma organização mundialmente aceita e com capacidade de participar ativamente dos debates relacionados à normatização do uso do mar pelo direito internacional. Dessa forma, a Organização passou a ser internacional e deixou de ser apenas consultiva; amplia a participação de estados em desenvolvimento nos seus órgãos deliberativos e, como consequência, adquire o reconhecimento da comunidade internacional como uma instituição dotada de legitimidade suficiente para o exercício das tarefas que a CNUDM lhe atribuiu.

A IMO vem atuando desde a sua criação, em 1948, na elaboração de normas internacionais que visam ao aprimoramento da segurança da navegação. Foi o sequestro do Achille Lauro, em 1985, que levou a IMO a

84 INTERNATIONAL MARITIME ORGANIZATION. Code of Conduct Concerning the Repression of Piracy, Armed Robbery Against Ships, and Illicit Maritime Activity in West and Central Africa. 2013. Disponível em: <http://www.imo.org/OurWork/Security/WestAfrica/Documents/code_of_conduct $\% 20$ signed $\% 20$ from $\% 20$ ECOWAS\%20site.pdf $>$. Acesso em: 30 abr. 2015. p. 7. decidir que não bastava zelar por uma navegação segura, mas que também deveria servir de fórum para a elaboração de normas e procedimentos voltados à proteção de navios, de instalações portuárias e de tripulantes e passageiros contra os atos ilícitos passíveis de ocorrerem no mar.

Entre os diversos atos ilícitos praticados no mar, a pirataria e o roubo armado contra navios apresentam-se como atividades análogas que exigem uma compreensão de seus elementos definidores, de modo a possibilitar uma abordagem correta na repressão a ambos. Enquanto a pirataria tem sua previsão normativa no art. 101 da CNUDM, o roubo armado contra navios carecia de qualquer tratado de abrangência internacional, com força vinculante, que possibilitasse nortear a atuação dos estados costeiros afetados. Nesse aspecto, a IMO vem estimulando a adoção dos códigos de conduta regionais como forma de suprir essa deficiência e coordenar os esforços no combate ao roubo armado contra navios.

Em virtude do fato desse ilícito conceitualmente ocorrer em águas jurisdicionais dos estados membros, a IMO vem buscando estabelecer uma cooperação pautada no respeito à soberania dos estados afetados e levando em consideração as causas específicas de cada região que servem como fatores incentivadores para o roubo armado contra navios. Para tal, busca estabelecer parcerias com blocos de cooperação regional e com escritórios e representações locais da ONU. Com uma abordagem mais regional do que global, a IMO vem obtendo importantes avanços para a repressão ao roubo armado contra navios, principalmente no que diz respeito ao incentivo à cooperação entre os estados costeiros afetados.

Por meio da coordenação dos esforços na elaboração e implementação dos códigos de conduta, a IMO vem buscando repetir a estratégia que deu certo no ReCAAP. Utilizando-se dos três pilares básicos que caracterizam os códigos de conduta, a IMO tem conseguido criar uma mentalidade de prevenção ao roubo armado contra navios e tem contribuído para diminuir o tempo de resposta às solicitações de auxílio dos tripulantes ameaçados. $\mathrm{O}$ primeiro desses pilares diz respeito à criação de centros de compartilhamento de informações. Esses centros servem como verdadeiros núcleos de comando e controle, onde a presença de representantes dos estados costeiros afetados contribui para uma agilização 
na disseminação de alertas e no envio e recebimento de pedidos de cooperação. O segundo pilar diz respeito à elaboração de uma legislação no âmbito interno dos estados costeiros afetados, baseada principalmente no conceito de roubo armado adotado no respectivo código de conduta, desse modo, há a criminalização do roubo armado contra navios e torna-se possível processar e julgar os grupos e pessoas detidos na prática desse ilícito. O terceiro e último pilar dessa estratégia característica dos códigos de conduta consiste no auxílio aos estados costeiros afetados na capacitação de pessoal qualificado e na aquisição dos meios materiais necessários à repressão aos ilícitos no mar.

Não há dúvidas de que as mudanças na composição dos órgãos deliberativos da Organização, juntamente com a mudança de nomenclatura que a permitiu ser reconhecida como parte do sistema ONU, fez com que a IMO aumentasse em muito o grau de legitimidade de suas resoluções. Porém, no que diz respeito à eficácia destas, ainda há uma grande dificuldade por parte da Organização em implementar os acordos realizados. É no terceiro pilar de sua estratégia de abordagem à repressão ao roubo armado que ela tem encontrado mais dificuldade. A IMO, por meio da cooperação regional, vem tentando buscar soluções alternativas para financiar as atividades que permitem criar capacidades e adquirir meios materiais na repressão ao roubo armado contra navios.

Para amenizar a carência de financiamento por parte dos estados desenvolvidos, a IMO vem implementando, mais notadamente no Golfo da Guiné, uma estratégia de incentivo ao desenvolvimento por meios próprios das capacidades necessárias. Utilizando-se dos exercícios conhecidos como table top, a IMO busca, dentro de uma mesma região, facilitar o entrosamento dos estados costeiros que são afetados pelos ilícitos no mar. Dessa forma, os estados dividem experiências, responsabilidades e, principalmente, custos. Com base na filosofia do "puxar ao invés de empurrar", a IMO tem procurado incentivar soluções locais que permitam driblar a falta de recursos humanos, materiais e financeiros, além de desenvolver a mentalidade de que, priorizando a segurança marítima, os estados costeiros afetados poderão obter os recursos de que necessitam por meio da exploração de suas zonas econômicas exclusivas.

Apesar de ser um fenômeno de causas eminentemente regionais, os efeitos do roubo armado contra navios afetam a navegação internacional total. Os prejuízos com os roubos de carga e de navios faz com que os seguros aumentem e encareçam o frete; além disso, os necessários desvios de rota para evitar as áreas mais afetadas geram um custo maior e, consequentemente, tornam o transporte marítimo mais caro e menos competitivo Também há de se notar a questão de maior importância: a perda de vidas humanas, vítimas dos ataques dos grupos que praticam esse tipo de ilícito. Todos esses problemas afetam os proprietários de navios, não apenas os estados costeiros. Assim, é interessante também para os membros do "clube" que os estados afetados engajem decididamente na repressão ao roubo armado em suas respectivas águas jurisdicionais. Com isso, seria de se esperar que todas as categorias de estados membros da IMO buscassem uma solução negociada regionalmente e financiada por aqueles que têm maior poder econômico, porém, tal financiamento não tem ocorrido.

Os estados grandes proprietários de navios ainda percebem o terrorismo como uma ameaça maior que o roubo armado, apesar de este ser muito mais frequente que aquele. Talvez isso se deva ao impacto psicológico que o terrorismo causa na opinião pública e do qual o roubo armado contra navios ainda carece. Assim, até hoje, os acordos internacionais relacionados com a segurança no mar, elaborados no âmbito da IMO, dizem respeito ou à segurança da navegação ou ao terrorismo, deixando o roubo armado contra navios e os estados costeiros afetados por esse ilícito relegados a um segundo plano de debates, principalmente quando o tema em pauta consiste na elaboração de normas vinculantes e a distribuição de recursos financeiros. Dessa forma, não há dúvidas de que a solução só poderia ser tentada com base em uma abordagem regional, incentivando o empenho de quem sofre com as causas do problema; ao invés de uma solução global, com o empenho, também, de quem sofre as consequências, tal como ocorre com os temas de interesse dos estados desenvolvidos e que têm contado com a cooperação de grande parte da comunidade internacional.

\section{ReferênCIAS}

ABHYANKAR, Jayant. The Phantom Vessel Phenomenon: an update. In: MEJIA, Maximo Quibranza; XU, Jingjing (Ed.). Coastal zone piracy and other unlawful 
acts at sea: a selection of papers and presentations from the international symposium on the new regime for the suppression of unlawful acts at sea, 21-23 november 2005 and the international symposium on coastal zone piracy, 13-15 november 2006. Malmö: WMU, 2007. p. 150-156.

BALKIN, Rosalie. The International Maritime Organization and maritime security. Tulane Maritime Law Journal, New Orleans, v. 30, n. 1/2, p. 1-34, winter/ summer, 2006.

BEIRÃO, André Panno. "Segurança no mar": que segurança? In: BEIRÃO, André Panno; PEREIRA, Antônio Celso Alves (Org.). Reflexões sobre a Convenção do Direito do Mar. Brasília: Fundação Alexandre de Gusmão, 2014. p. 127-166.

BLANCO-BAZÁN, Agustín. IMO: historical highlights in the life of a un agency. Journal of the History of International Law, Leiden, v. 6, n. 2, p. 259-283, July/Dec. 2006.

BRASIL. Decreto n. 1.530, de 22 de junho de 1995. Declara a entrada em vigor da Convenção das Nações Unidas sobre o Direito do Mar, concluída em Montego Bay, Jamaica, em 10 de dezembro de 1982. Disponível em: <https://www.egn.mar.mil.br/arquivos/cursos/ csup/CNUDM.pdf>. Acesso em: 23 jun. 2015.

BRASIL. Decreto n. 6.136, de 26 de junho de 2007. Promulga a Convenção para a Supressão de Atos Ilícitos contra a Segurança da Navegação Marítima e o Protocolo para a Supressão de Atos Ilícitos contra a Segurança de Plataformas Fixas Localizadas na Plataforma Continental, ambos de 10 de março de 1988, com reservas ao item 2 do artigo 6o, ao artigo 8o e ao item 1 do artigo 16 da Convenção, bem como ao item 2 do artigo $3 o$ do Protocolo. Disponível em: <http://www.planalto.gov.br/ccivil_03/_Ato2007-2010/2007/Decreto/ D6136.htm>. Acesso em: 23 jun. 2015.

BULKELEY, Jennifer C. Regional cooperation on maritime piracy: a prelude to greater multilateralism in Asia? Journal of Public and International Affairs, Princeton, v. 14, p. 20-39, Spring, 2003. Disponível em: <http:// www.princeton.edu/jpia/past-issues-1/2003/2.pdf > . Acesso em: 05 jan. 2015.

CHALK, Peter. The maritime dimension of international security: terrorism, piracy, and challenges for the United States. Santa Monica: RAND Corporation, 2008. (Project Air Force).
COMMERCIAL CRIME SERVICES. IMB Piracy Reporting Centre. 2014. Disponível em: <https://icc-ccs. org/piracy-reporting-centre>. Acesso em: 23 jun. 2015.

ESTEVES NETO, Ernesto Gomes. Organizações Internacionais e o direito do mar. In: MENEZES, Wagner (Org.). Direito do mar: desafios e perspectivas. Belo Horizonte: Arraes, 2015. p. 69-87.

GENEVA ACADEMY OF INTERNATIONAL HUMANITARIAN. Counterpiracy under International Law. Genève: Université de Genève, 2012. (Academy Briefing, n. 1) Disponível em: <http://www.genevaacademy.ch/docs/academyLecture/Counterpiracy. pdf>. Acesso em: 10 jan. 2015.

INTERNATIONAL CRISIS GROUP. The Gulf of Guinea: the new danger zone. Africa Report, Nairobi, n. 195, 12 Dec. 2012. Disponível em: < http://www.crisisgroup.org/ /media/Files/africa/central-africa/195the-gulf-of-guinea-the-new-danger-zone-english.pdf $>$. Acesso em: 19 abr. 2015.

INTERNATIONAL MARITIME ORGANIZATION. Code of Conduct Concerning the Repression of Piracy, Armed Robbery Against Ships, and Illicit Maritime Activity in West and Central Africa. 2013. Disponível em: <http://www.imo.org/OurWork/Security/WestAfrica/Documents/code_of_conduct $\% 20$ signed $\% 20$ from $\% 20$ ECOWAS $\% 20$ site.pdf $>$. Acesso em: 30 abr. 2015

INTERNATIONAL MARITIME ORGANIZATION. International Maritime Organization (IMO) Strategy for Implementing Sustainable Maritime Security Measures in West and Central Africa. Jan. 2014. Disponível em: <http://www.imo.org/OurWork/Security/WestAfrica/Documents/IMO\%20WCA\%20 strategy\%20January\%202014.pdf $>$. Acesso em: 04 jan. 2015.

INTERNATIONAL MARITIME ORGANIZATION. Resolution A. 545(13), 17 November 1983. Measures to Prevent Acts of Piracy and Armed Robbery Against. Disponível em: <http://www.imo.org/blast/blastDataHelper.asp?data_id $=22356 \&$ filename $=$ A 545(13). pdf>. Acesso em: 18 abr. 2015.

INTERNATIONAL MARITIME ORGANIZATION. Resolution A.1025(26), 02 December 2009. Code of practice for the investigation of crimes of piracy and armed robbery against ships. Disponível em: <http://www.imo.org/en/OurWork/Security/Pi- 
racyArmedRobbery/Guidance/Documents/A.1025. pdf>. Acesso em: 19 abr. 2015.

INTERNATIONAL MARITIME ORGANIZATION. Resolution A.584(14), 20 November 1985. Measures to prevent unlawful acts which threaten the safety of ships and the security of their passengers and crews Disponível em: <http://www.imo.org/blast/blastDataHelper.asp?data_id $=22374 \&$ filename $=$ A584(14). pdf>. Acesso em: 19 abr. 2015.

INTERNATIONAL MARITIME ORGANIZATION. Resolution A.924(22), 20 November 2001. Review of measures and procedures to prevent acts of terrorism which threaten the security of passengers and crews and the safety of ships. Disponível em: $\quad<$ http://www.imo.org/blast/blastDataHelper. asp?data_id $=24550 \&$ filename $=$ A924(22).pdf $>$. Acesso em: 19 abr. 2015.

INTERNATIONAL MARITIME ORGANIZATION. Structure of IMO. Disponível em: <http:// www.imo.org/en/About/Pages/Structure.aspx $>$. Acesso em: 19 abr. 2015.

JAPAN. Ministry of Foreign Affairs. Regional Cooperation Agreement on Combating Piracy and Armed Robbery against Ships in Asia (ReCAAP). Disponível em: <http://www.mofa.go.jp/mofaj/gaiko/kaiyo/pdfs/ kyotei_s.pdf>. Acesso em: 30 abr. 2015.

KARIM, Md. Saiful. Implementation of the MARPOL convention in developing countries. Nordic Journal of International Law, Leiden, v. 79, n. 2, p. 303-337, 2010. Disponível em: <http://booksandjournals.brillonline.com/content/journals/10.1163/15718101 0x12668401899110>. Acesso em: 10 jan. 2015.

KRASKA, James. Contemporary maritime piracy: in- ternational law, strategy, and diplomacy at sea. Santa Barbara: Praeger, 2011.

MEJIA JR, Maximo Q. Developing the concept of a security culture on board ships. In: MEJIA, Maximo Quibranza; XU, Jingjing (Ed.) Coastal zone piracy and other unlawful acts at sea: a selection of papers and presentations from the international symposium on the new regime for the suppression of unlawful acts at sea, 21-23 november 2005 and the international symposium on coastal zone piracy, 13-15 november 2006. Malmö: WMU, 2007. p. 157-169.

MEJIA JR, Maximo Q.; MUKHERJEE, P. K. The SUA Convention 2005: a critical evaluation of its effectiveness in suppressing maritime criminal acts. The Journal of International Maritime Law, Witney, v. 12, n. 3, p. 170-191, 2006. Disponível em: <http://www.lawtext. com/lawtextweb/default.jsp?PageID=2>. Acesso em: 10 jan. 2015.

PEÑA, Félix. Direito e instituições no Mercosul: um balanço de conquistas e insuficiências. In: AMBOS, Kai; PEREIRA, Ana Cristina P. (Org.). Mercosul e União Europeia: perspectivas da integração regional. Rio de Janeiro: Lumen Juris, 2006. p. 91-106.

PORTO, Manuel. Processos de integração econômica: perspectivas para o Mercosul e para a União Européia. In: AMBOS, Kai; PEREIRA, Ana Cristina P. (Org.). Mercosul e União Europeia: perspectivas da integração regional. Rio de Janeiro: Lumen Juris, 2006. p. 107-126.

TREVES, Tullio. Piracy, law of the sea, and use of force: developments off the coast of Somalia. The European Journal of International Law, Oxford, v. 20, n. 2, p. 399-414, Apr. 2009. Disponível em: < http://ejil. oxfordjournals.org/content/20/2/399. full.pdf + html $>$. Acesso em 18 out. 2010. 


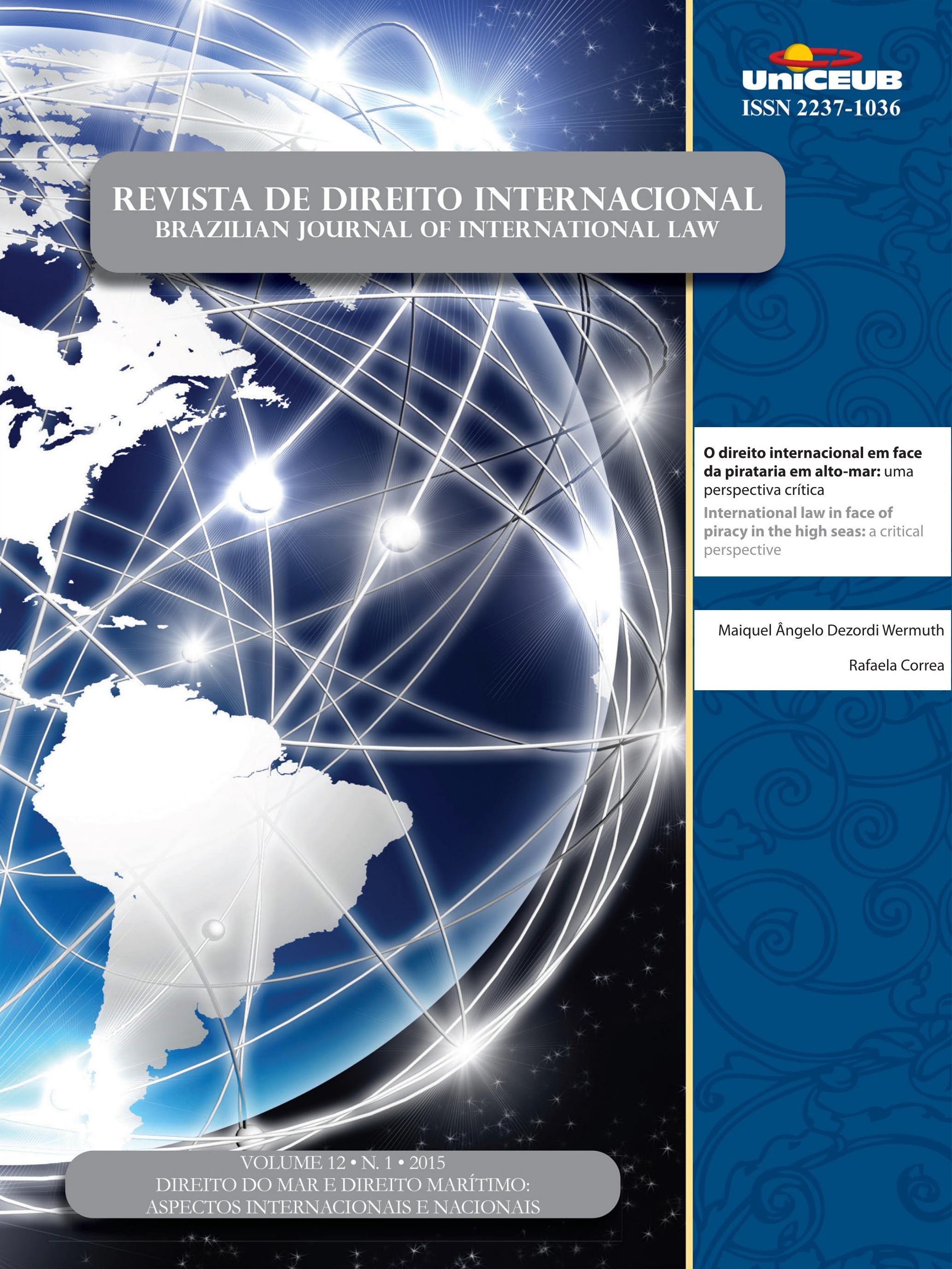




\section{O direito internacional em face da pirataria em alto-mar: uma perspectiva crítica*}

\section{International law in face of piracy in the high seas: a critical perspective}

Maiquel Ângelo Dezordi Wermuth**

Rafaela Correa***

\section{Resumo}

O presente artigo tem por objetivo analisar criticamente as insuficiências do Direito Internacional e suas instituições/organizações no enfrentamento eficaz ao crime de pirataria em alto-mar. A partir de revisão de bibliografia e legislação acerca do assunto, procura-se compreender a pirataria como um fenômeno recorrente no cenário contemporâneo, impondo ao Direito Internacional um importante desafio, afinal, por se tratar de um crime cometido em alto-mar, onde não há jurisdição de Estado algum, a pirataria configura prática de difícil persecução e punição. Como hipótese orientadora da pesquisa, salienta-se que a referida persecução e punição deve ser feita pelo Estado prejudicado imediatamente após o fato, que deve capturar e julgar os piratas, o que encontra óbice no fato de que muitos países não possuem uma tipificação penal adequada para punir tal crime.

Palavras-Chave: Direito Internacional. Pirataria em alto-mar. Perseguição. Punição.

\section{Abstract}

This article aims to critically analyze the shortcomings of international law and its institutions / organizations in effectively countering the crime of piracy on the high seas. On the basis of a bibliographical review and on applicable norms related to the subject, we examine piracy as a recurring phenomenon in the contemporary era, imposing international law a major challenge, considering that it is a crime committed on the high seas where there is no States' jurisdiction. Piracy accordingly constitutes a practice which is difficult to prosecute and punish. The study stresses that such prosecution and punishment must be made by the injured State immediately after the act of piracy. The said State must capture and prosecute the pirates. However, this is not an easy legal task as many States do not classify piracy as a crime in their criminal law.

Keywords: International Law. Piracy on the high seas. Persecution. Punishment.

\footnotetext{
*** Bacharel em Direito pela Universidade Regional do Noroeste do Estado do Rio Grande do Sul (UNIJUÍ). E-mail: rafaelah1988@bol.

com.br.
}

* Recebido em 09/03/2015 Aprovado em 25/04/2015

** Doutor em Direito pela Universidade do do Mestrado em Direitos Humanos da Universidade Regional do Noroeste do Estado do Rio Grande do Sul (UNIJUÍ) e do Curso de Graduação em Direito da UNISINOS. E-mail: madwermuth@gmail.com. 


\section{Considerações iniciais: três casos QUe DEMONSTRAM QUE A PIRATARIA NÃO É UM "CRIME DO PASSADO"}

Caso 1: no dia 8 de abril de 2009, o cargueiro "Maersk Alabama", no qual vinte marinheiros viajavam rumo ao porto de Mombaça, no Quênia, foi atacado por piratas somalis enquanto transportava 17 mil toneladas de carga com variados destinos. O capitão da embarcação, o norte-americano Richard Philips, foi sequestrado pelos piratas, que exigiram um alto valor pelo resgate. A libertação do capitão mobilizou aparato de guerra e envolveu a Marinha Americana. Três sequestradores foram mortos na operação. $\mathrm{O}$ ataque causou tanto impacto que o caso se transformou em roteiro de filme hollywoodiano.

Caso 2: os britânicos Paul e Rachel Chandler estavam navegando no iate "Lynn Rival", que partiu das ilhas Seychelles rumo à Tanzânia, no leste da África, quando, em 23 de outubro de 2009, foram sequestrados por piratas somalis. O iate do casal Chandler foi encontrado pela Marinha Real Britânica à deriva em alto-mar. Após a captura pelos piratas, o casal foi conduzido a um cargueiro com bandeira de Singapura. Mais de um ano após o sequestro, o casal foi entregue pelos piratas às forças do autoproclamado governo da região autônoma Himan e Heeb.

Caso 3: a operação "Alvorada 9: Golfo de Áden" aconteceu no dia 20 de janeiro de 2011. O navio químico "MT Bunga Laurel" estava navegando rumo a Singapura quando foi atacado por um grupo de piratas somalis 300 milhas náuticas $(600 \mathrm{~km}, 300$ milhas) a sudeste do porto de Mascate, em Omã, duas horas após terem sido separados da escolta marinha. O petroleiro foi abordado por sete de dezoito piratas somalis armados com rifles AK-47 e pistolas, que surgiram em barcos atirando sem rumo. Durante o ataque, havia 23 tripulantes filipinos a bordo do navio. Um deles ativou o sistema de alerta de segurança. A Polícia Real da Malásia assumiu o comando das investigações. Os piratas capturados não tinham documentos de identificação. O chefe de polícia recorreu ao Departamento de Imigração para pedir ajuda. Os piratas foram detidos depois que a polícia obteve uma ordem de prisão preventiva de sete dias. $\mathrm{O}$ ataque resultou no ferimento de três tripulantes do navio químico.
Os casos narrados nesse introito envolvem, em pleno século XXI, o crime de pirataria em alto-mar. Presente desde a origem do comércio marítimo, a pirataria em alto-mar configura-se como um dos crimes mais antigos da história da humanidade. Os ataques a navios objetivando a capturada carga ou do navio (ou ambos) podem ter reflexos importantes no mundo globalizado, particularmente em áreas como o comércio e o turismo marítimo.

Em virtude disso, a questão assume grande importância para o Direito Internacional, uma vez que tal conduta criminosa é praticada em números consideráveis, colocando em xeque a segurança da navegação e sendo responsável por incalculáveis danos à vida humana, bem como ao comércio e à economia.

A Convenção das Nações Unidas sobre o Direito do Mar de 1982 estabelece parâmetros para perseguir e punir os piratas. $\mathrm{O}$ fato é que, devido à compreensão de que a pirataria em alto-mar constitui "crime do passado", muitos ordenamentos jurídicos nacionais $3 / 4 \mathrm{a}$ exemplo do brasileiro $3 / 4$ não possuem uma tipificação penal adequada da conduta. Assim, em que se pese tratar a pirataria de um dos poucos crimes que se submetem à chamada "jurisdição universal" $3 / 4$ o que significa dizer que qualquer país pode capturar piratas em alto-mar $3 / 4$, a ausência de tipificação da conduta nos ordenamentos jurídicos internos dificulta a sua persecução.

Ademais, a persecução à pirataria esbarra em importantes questões jurídicas no campo do Direito Internacional, uma vez que o próprio Tribunal Internacional do Direito do Mar não tem competência, nos termos da Convenção das Nações Unidas sobre Direito do Mar, para julgar piratas ou qualquer outra pessoa, mesmo sendo o órgão responsável pela garantia da efetividade do Direito no âmbito marítimo.

A questão que orienta o presente texto diz respeito à necessidade de avanços acerca da temática no campo do Direito Internacional, considerando-se que a pirataria acaba por gerar grande instabilidade jurídica para aqueles que navegam pelos mares e necessitam dele para efetuar seus trabalhos/transações econômicas. Para tanto, aborda-se a repercussão mundial dos crimes de pirataria em alto-mar, bem como a função desempenhada pela International Maritime Organization (IMO) e pelo Tribunal Internacional do Direito do Mar no que se refere à temática. 


\section{A PIRATARIA EM ALTO-MAR: NOTÍCIA HISTÓRICA E IMPLICAÇÕES CONTEMPORÂNEAS}

Para melhor compreensão do tema abordado, é interessante que se faça, inicialmente, uma breve definição de "pirataria". Com base no Art. 15 da Convenção de Genebra sobre o Alto-Mar de 1958, são abarcados pelo conceito os seguintes atos: violência, detenção ou depredação ilegítimas cometidas para fins pessoais pela tripulação ou passageiros de um navio privado ou de uma aeronave privada, e dirigidos, no alto mar, contra outro navio ou aeronave, ou contra pessoas e bens a seu bordo, ou, ainda, contra um navio ou aeronave, pessoas ou bens, em local fora da jurisdição de qualquer Estado. Também se enquadram no conceito todos os demais atos de participação voluntária para utilização de um navio ou de uma aeronave, quando aquele que os comete tem conhecimento de fatos que conferem a esse navio ou a essa aeronave o caráter de navio ou aeronave pirata. Por fim, a Convenção considera pirataria toda a ação tendo por fim incitar a cometer os atos acima definidos ou empreendida com a intenção de facilitá-los.

Os piratas têm como fim imediato o enriquecimento à custa das presas que as circunstâncias concretas lhe oferecerem, abstraindo dos titulares dos interesses que lesam. Por isso, enquanto ameaça indiscriminada à navegação, a pirataria ofende a Comunidade Internacional, pois esta depende do meio marítimo para a circulação de pessoas e mercadorias, o abastecimento de bens essenciais e a fruição das inúmeras vantagens que o mar oferece. $^{1}$

O termo pirataria vem do grego (peirateia, peiratss $=$ ataque e, por extensão, "ladrão do mar") e designa um crime dos crimes mais antigos da história da humanidade $^{2}$. Agindo como autônomos, ou organizados em grupos, os piratas sempre navegaram pelos mares com a intenção de saquear e pilhar navios e cidades para obter riquezas. Homero, em sua "Odisseia", já utilizava o termo "pirata" para descrever aqueles que pilhavam os navios e cidades costeiras.

Os romanos também se utilizaram do termo para

1 BÖHM-AMOLLY, Alexandra von. O Direito internacional marítimo e o direito nacional no combate à pirataria: potencialidades $\mathrm{e}$ limitações. Boletim Ensino Investigação, n. 10, p. 59-73, maio 2011.

2 BRANDÃO, Eduardo Henrique Serra. Afinal o que é pirataria? 2010. Disponível em: <http://academia.marinha.pt/PT/edicoes/ Documents/2010/Afinal_o_que_e_pirataria.pdf>. Acesso em: 15 maio 2014 designar a atividade de populações organizadas politicamente e que se dedicavam a atacar e a pilhar navios que transitavam nas proximidades das costas da Sardenha e da Córsega. Esses povos se opunham à dominação e à hegemonia de Roma, colocando em risco a navegação marítima ao enfrentar as tropas romanas, tendo atuação particularmente intensa na época de Pompeu (106 a.C.48 a.C.), ao final do período da República. O principal debate em Roma, na época, não era a competência do Estado para julgar piratas, mas sim se eles poderiam beneficiar-se do estatuto de prisioneiros de guerra e se os produtos derivados de seus ataques a eles pertenciam efetivamente. $^{3}$

Na Idade Média, a pirataria passou a ser praticada pelos normandos, que atuavam principalmente nas ilhas britânicas, França e império germânico. Posteriormente, a pirataria expandiu-se pelas colônias europeias, nomeadamente nas Caraíbas, onde havia grande quantidade de piratas em busca de riquezas das colônias americanas, atingindo o auge no século XVIII 4 .

Do final do século XVI até o século XVIII, o Mar do Caribe era um ponto estratégico para piratas, que atacavam navios espanhóis, bem como de outras nações com colônias e postos avançados de comércio na área. Os grandes tesouros, como o ouro e a prata que a Espanha começou a enviar do Novo Mundo para a Europa, rapidamente chamaram a atenção desses piratas que, diante de uma lenta comunicação e falta de um patrulhamento em alto-mar, efetuavam seus ataques. ${ }^{5}$

Os piratas formavam tripulações que, em sua maioria, contavam com homens do mar que desejavam obter riquezas e liberdades reais. A maioria deles eram escravos fugitivos ou servos sem rumo. Normalmente, suas frotas eram formadas de navios pequenos e rápidos, que pudessem lutar ou fugir, conforme a ocasião. Sa-

3 CRETELLA NETO, José. Curso de direito internacional penal. Ijuí: Unijuí, 2008.

4 Na Europa, a partir do século XVI, ocorreram as famosas "cartas de corso" (lettres de marques ou lettres de courses), que eram designadas como autorizações reais para os capitães, principalmente em tempos de guerra, pudessem atacar e se apoderar de embarcações inimigas, a serviço de seu rei, com o objetivo de causar dano ao inimigo. Entre os séculos XVII e XVIII, as cartas de corso começaram a se tornar abusivas, desrespeitando o comércio marítimo internacional, fazendo com que os Estados efetuassem tratados bilaterais declarando que não utilizariam mais o corso em caso de guerra entre Estados. CRETELLA NETO, José. Curso de direito internacional penal. Ijuí: Unijuí, 2008.

5 CRETELLA NETO, José. Curso de direito internacional penal. Ijuí: Unijuí, 2008. 
queavam navios de mercadores levemente armados e, ocasionalmente, atacavam uma cidade ou um navio de guerra, caso o risco valesse a pena.

Há muitos séculos a pirataria já é considerada crime internacional, como se pode inferir de uma ordem de Henrique VIII (1491- 1547) a John Hopton, datada de 1511:

\footnotetext{
Apreenda e subjugue todos os piratas que forem encontrados de tempos em tempos; e, se não puderem ser apreendidos, destrua-os, e tragaos todos e cada um deles, que forem capturados, a nossos portos, entregue-os e coloque-os à disposição... de nossos comissários ${ }^{6}$.
}

Dados históricos apontam que desde 1536 os tribunais ingleses do Almirantado receberam autorização para impor pena de morte aos piratas, medida adotada igualmente pela França, em 1584. A capitulação franco-otomana de 1535 também previu medidas drásticas de repressão contra os piratas que singravam os mares, sobretudo o Mediterrâneo, o que permite a afirmação de que "o pirata passou a ser o inimigo de todos- hoste bumanis generis- e todos passaram a ter o direito e a obrigação costumeira de arrestá-lo sem levar em consideração sua nacionalidade".

Desde então, diante do conceito de que o alto-mar não pertence à jurisdição exclusiva de nenhum Estado, as nações começaram a perseguir e julgar piratas que atacavam suas embarcações, os quais eram capturados em alto-mar. A partir da Declaração Naval de Paris (1856) $3 / 4$ que dispõe sobre a guerra marítima $3 / 4$, começou-se a codificação internacional de medidas jurídicas destinadas a combater o crime de pirataria.

$\mathrm{Na}$ esteira da Declaração, surgiu o Código Bustamante, concluído em Havana, em 1928, e que ressalta em seu artigo 308:

A pirataria, o tráfico de negros e o comércio de escravos o tráfico de mulheres brancas, a destruição ou deterioração de cabos submarinos e os demais delitos na mesma índole, contra o Direito Internacional, cometidos no alto mar, no ar livre e em territórios não organizados ainda em Estado, serão punidos pelo captor, de acordo com suas leis penais.

Posteriormente ao Código de Bustamante, surge a Convenção sobre o Alto-Mar, firmada em Genebra em

6 RUBIN apud CRETELLA NETO, José. Curso de direito internacional penal. Ijuí: Unijuí, 2008. p. 484.

7 CRETELLA NETO, José. Curso de direito internacional penal. Ijuí: Unijuí, 2008. p. 485.
1958, definindo atos de pirataria no já mencionado artigo 15. Em 1982 foi concluída em Montego Bay, Jamaica, a Convenção das Nações Unidas sobre o Direito do Mar, a qual revogou a Convenção sobre o Alto-Mar de 1958, porém manteve praticamente a mesma redação do instrumento anterior, definindo a pirataria em seu Artigo 101:

Constituem pirataria quaisquer dos seguintes atos:

a) todo ato ilícito de violência ou de detenção, ou todo ato de depredação, cometidos, para fins privados, pela tripulação ou pelos passageiros de um navio ou de uma aeronave privados, e dirigidos contra:

i) um navio ou uma aeronave em alto mar ou pessoas ou bens a bordo dos mesmos;

ii) um navio ou uma aeronave, pessoas ou bens em lugar não submetido à jurisdição de algum Estado;

b) todo ato de participação voluntária na utilização de um navio ou de uma aeronave, quando aquele que o pratica tenha conhecimento de fatos que deem a esse navio ou a essa aeronave o caráter de navio ou aeronave pirata;

c) toda a ação que tenha por fim incitar ou ajudar intencionalmente a cometer um dos atos enunciados nas alíneas a) ou b) ${ }^{8}$.

A Convenção de Montego Bay foi a última a tratar sobre o assunto. A partir daí não houve outra movimentação em termos legislativos para combater o crime de pirataria. Ocorre que, diante do crescente volume de trocas econômicas mundiais pela via marítima, e com o surgimento de novas tecnologias, o assunto passa a ocupar novamente posição central, pelos impactos que ocasiona.

Com efeito, há um grande volume de mercadorias circulando pelo mar, tanto em quantidade quanto em valores. Estima-se que atualmente praticamente $90 \%$ do comércio é efetuado pela via marítima. Muitas embarcações não possuem guarda armada, nem acompanhamento de navios militares. Mesmo assim, essas grandes cargas navegam por regiões sensíveis a ataques piratas, o que gera um impacto muito grande na economia global. ${ }^{9}$

8 A Convenção sobre o Direito do Mar, de 1982, em seu art. 103, define navio ou aeronave pirata nos seguintes termos: "São considerados navios ou aeronaves piratas os navios ou aeronaves que as pessoas, sob cujo controle efetivo se encontrem, pretendem utilizar para cometer qualquer dos atos mencionados no artigo 101. Também são considerados piratas os navios ou aeronaves que tenham servido para cometer qualquer de tais atos, enquanto se encontrem sob o controle das pessoas culpadas desses atos."

9 CANINAS, Osvaldo Peçanha. Pirataria marítima moderna: 
Atualmente, a pirataria revela-se mais incidente no Sudeste Asiático, nas Caraíbas, e no Chifre da África, tendo como principais locais de ataque espaços entre as ilhas, onde os piratas atacam de surpresa com lanchas muito rápidas. ${ }^{10}$ Em relação às rotas marítimas, Caninas ${ }^{11}$ destaca que "a pirataria não é privilégio de locais sem movimento", uma vez que "um dos estreitos mais movimentados do mundo, com média de 50.000 navios por ano - o estreito de Malaca —, é um dos principais em ataques piratas, junto com o Mar da China meridional (South China Sea), Golfo da Guiné e a Indonésia."

Vários fatores influenciam os ataques piratas. Além dos já mencionados (grandes embarcações, mercadorias de altos valores, falta de guarda armada nos navios etc.), um dos principais motivos para o desenvolvimento da pirataria marítima é a fraca vigilância no alto-mar e as medidas de segurança nas áreas portuárias, que são ineficientes na maioria dos Estados. A conjugação desses fatores cria um ambiente propício para as ações dos piratas, o que acaba representando uma ameaça crescente para a segurança marítima e para o comércio mundial.

Levando-se em conta os fatores acima destacados e considerando-se alguns estudos feitos pelo International Maritime Bureau (IMB), pode-se afirmar que a pirataria marítima moderna está se transformando em um fenômeno de escala mundial. Tais estudos comprovam que entre os anos de 1998 e 2007, as águas da Indonésia, do Estreito de Malaca, da Malásia e do Estreito de Singapura se destacam como sendo os lugares mais perigoso do mundo, seguido do Subcontinente Indiano. No ano de 2008, a parte do mundo que foi considerada mais perigosa foi o Chifre da África, ou seja, a região noroeste do continente africano, onde está localizada a Somália, o Djibuti e a Eritreia.

Conforme salienta Schneider ${ }^{12}$, a posição geográfica privilegiada da Somália, situada na "porta de entrada"

história, situação atual e desafios. Revista da Escola de Guerra Naval, Rio de Janeiro, n. 14, p. 101-122, 2009.

10 PINTO, Paulo Evandro da Costa; VENANCIO, Daiana Seabra. De volta para o passado: a prática da guarda armada em navios mercantes para proteção contra os piratas no século XXI. Revista Brasileira de Estudos de Defesa, 2012. Disponível em: <http://www. seer.ufrgs.br/index.php/rbed/article/viewFile/48800/30472)>. Acesso em: 11 ago. 2014.

11 CANINAS, Osvaldo Peçanha. Pirataria marítima moderna: história, situação atual e desafios. Revista da Escola de Guerra Naval, Rio de Janeiro, n. 14, p. 101-122, 2009.

12 SCHNEIDER, Eduardo Augusto S. da C.. In. VARELLA, Marcelo D. Pirataria marítima: a experiência Somália. Revista de Direito Internacional, vol.12, no.1. (nesta edição). de uma das rotas marítimas com maior fluxo de bens de consumo no planeta, aliada à falta de um governo com atuação eficiente há duas décadas e a uma economia falida, configuram "o terreno ideal para o desenvolvimento da pirataria", de modo que não causa espanto o fato de que "a epidemia de atos de pirataria na região, com início em 2008, tenha acontecido exatamente no ano que a Somália ficou em primeiro lugar no ranking de países falidos."

Vale ressaltar ainda que na região da Somália os ataques têm uma forte queda no período que vai de dezembro a março e junho a setembro, que é o período das monções, quando as condições climáticas são tão ruins que os piratas não conseguem navegar com as suas pequenas embarcações. ${ }^{13}$

Com base em relatório do Banco Mundial, a pirataria na costa da Somália aumenta significativamente as despesas do comércio mundial em US $\$ 18$ bilhões por ano. Segundo o órgão, a violência causada por ações de piratas gera grande preocupação pública e um "imposto oculto" nas exportações e importações do mundo inteiro. ${ }^{14}$

A Somália sofre impacto considerável devido aos ataques piratas. O relatório do Banco Mundial alega que o país gasta US\$ 6 milhões a mais por ano no comércio e destaca que o total não leva em conta o fato de o governo não poder expandir o comércio marítimo e de pesca, enquanto os piratas estiverem operando nas águas do país.

Conforme o Banco Mundial, entre 2005 e 2012, mais de 3,7 mil tripulantes de 125 nacionalidades foram capturados por piratas. Em alguns casos, eles ficaram detidos mais de 1,1 mil dias e pelo menos 97 pessoas morreram durante os ataques, na detenção ou durante operações de resgate. O relatório destaca também que os piratas conseguem apoio de terceiros para ancorar navios sequestrados. O Banco Mundial acredita que os chefes da pirataria dividem em torno de $70 \%$ e $86 \%$ do que ganham com funcionários públicos, comerciantes,

13 MARCHESE, Bruno Horvath. A importância da pirataria marítima e o seu combate na Somália. 2011. Disponível em: < http://piratariamaritima.blogspot.com.br/2011/01/importancia-da-piratariamaritima-e-o.html>. Acesso em: 18 jun. 2014.

14 LETRA, Leda. Banco Mundial: pirataria custa US $\$ 18$ bilhões por ano à economia global. Rádio ONU, Nova York, 11 abr. 2013. Disponível em: <http://www.unmultimedia.org/radio/portuguese/2013/04/banco-mundial-pirataria-custa-us-18-bilhoes-porano-a-economia-global/>. Acesso em: 23 jun. 2014. 
milícias, líderes religiosos ou comunitários. Esse valor pode chegar a US $\$ 300$ mil. $^{15}$

A pirataria também afeta outros setores da economia: desde o ano de 2006, países do leste do continente africano enfrentam uma grande queda no número de turistas. Os gastos de visitantes crescem num grau 25\% mais lento, comparando-se a outros países da África Subsaariana. O Banco Mundial também afirma que a exportação de peixe dos países afetados pela pirataria caiu significativamente, quase $24 \%$ desde 2006 , resultado da queda na produção. ${ }^{16}$

A International Maritime Bureau contabiliza cerca de 3.200 pessoas tomadas como reféns de piratas na última década, sendo que 150 delas perderam a vida. Em 2007 foram registrados 263 incidentes em todo o globo, com um crescimento superior a $10 \%$ de ataques piratas em $2007 .{ }^{17}$

As estratégias de ataque variam em sofisticação e violência, dependendo do tipo de pirata. Alguns são simples ladrões, usam barcos pequenos de pesca ou até mesmo botes. Sobem nos barcos ancorados quando não há alguém ou quando todos estão dormindo, entre as 22:00 e 6:00 horas, preferindo o elemento surpresa. Muitas vezes não têm nem armas de fogo. Proliferam, porém, bandos perigosos de piratas que atacam em alto-mar e conseguem roubar o próprio navio para travesti-lo sob outra bandeira ou desmanchá-lo inteiro e vender as peças - há conhecidos centros de desmonte na Índia. Nesses casos, geralmente a tripulação é colocada em botes e deixada à própria sorte no meio do oceano. Para abordar o navio, os piratas usam ganchos e sobem pela popa. Às vezes, esperam a passagem de uma embarcação grande em dois pequenos barcos ligados por um cabo de aço. Quando o navio passa no meio deles, o cabo fica preso e seus barcos são puxados, esperando a melhor oportunidade de ataque.

15 LETRA, Leda. Banco Mundial: pirataria custa US $\$ 18$ bilhões por ano à economia global. Rádio ONU, Nova York, 11 abr. 2013. Disponível em: <http://www.unmultimedia.org/radio/portuguese/2013/04/banco-mundial-pirataria-custa-us-18-bilhoes-porano-a-economia-global/>. Acesso em: 23 jun. 2014.

16 LETRA, Leda. Banco Mundial: pirataria custa US $\$ 18$ bilhões por ano à economia global. Rádio ONU, Nova York, 11 abr. 2013. Disponível em: <http://www.unmultimedia.org/radio/portuguese/2013/04/banco-mundial-pirataria-custa-us-18-bilhoes-porano-a-economia-global/>. Acesso em: 23 jun. 2014.

17 MEDEIROS, Roberto Carvalho de. Pirataria no mar não é coisa do passado. Disponível em: <http://groups.google.com/ forum/\#!topic/noticiarionaval/L8OCXAGJ-WM>. Acesso em: 24 mar. 2014.

\section{Percalços ao efetivo combate à pirataria: o papel da convenção de Montego Bay, da ORGANIZAÇÃO MARÍTIMA INTERNACIONAL E DO TRIBUNAL INTERNACIONAL DO DIREITO DO MAR}

Para a comunidade internacional, o pirata, ao retirar a bandeira do mastro de um navio, passa a viver rompido com a sociedade à qual pertencia, formando comunidade diversa à da sociedade regular. Essa “'des-sujeição’ de seu Estado de origem faz presumir que os piratas renunciaram a qualquer proteção diplomática. Tornam-se, assim, res nullius, ou floating chattels (= bens móveis flutuantes), para utilizar a expressão de Schwarzenberger."'18

Em virtude disso, todo e qualquer Estado pode prender um navio pirata que se encontra em alto-mar, bem como as pessoas e os produtos provenientes de atos ilícitos que nele forem encontrados. $\mathrm{E}$ os tribunais do Estado que realizou a operação são competentes para puni-los, podendo, inclusive, decidir a respeito da forma que irão dispor do navio e dos bens confiscados, resguardados os direitos de terceiros de boa-fé. O fato de que qualquer Estado pode prender e julgar pessoas acusadas de pirataria torna esse crime excepcional no Direito Internacional, de acordo com a soberania e jurisdição de cada Estado, no interior de seu território. ${ }^{19}$

A Convenção das Nações Unidas sobre o Direito do Mar (1982) dispõe, em seu artigo 105, que "todo Estado pode apresar, no alto mar ou em qualquer outro lugar não submetido à jurisdição de qualquer Estado, um navio ou aeronave pirata, ou um navio ou aeronave capturados por atos de pirataria e em poder dos piratas e prender as pessoas e apreender os bens que se encontrem a bordo desse navio ou dessa aeronave. Os tribunais do Estado que efetuou o apresamento podem decidir as penas a aplicar e as medidas a tomar no que se refere aos navios, às aeronaves ou aos bens sem prejuízo dos direitos de terceiros de boa-fé."

O artigo 111 da Convenção trata detalhadamente sobre o direito de perseguição conferido às autoridades competentes do Estado. Segundo o dispositivo, condição de possibilidade para dar início à perseguição de um navio estrangeiro é a existência de "motivos funda-

18 CRETELLA NETO, José. Curso de direito internacional penal. Ijuí: Unijuí, 2008. p. 497.

19 CRETELLA NETO, José. Curso de direito internacional penal. Ijuí: Unijuí, 2008. 
dos" para acreditar que o navio infringiu as leis e regulamentos do Estado costeiro, sendo que a perseguição deve ter início "quando o navio estrangeiro ou uma das suas embarcações se encontrar nas águas interiores, nas águas arquipelágicas, no mar territorial ou na zona contígua do Estado perseguidor, e só pode continuar fora do mar territorial ou da zona contígua se a perseguição não tiver sido interrompida."

Ademais, o dispositivo salienta não ser necessário que o navio que dá a ordem de parar a um navio estrangeiro que navega pelo mar territorial ou pela zona contígua se encontre também no mar territorial ou na zona contígua no momento em que o navio estrangeiro recebe a referida ordem. Por fim, dispõe que se o navio estrangeiro se encontrar na zona contígua, a perseguição só poderá ser iniciada se tiver havido violação dos direitos para cuja proteção a referida zona foi criada.

$\mathrm{O} \int 4^{\circ}$ do art. 111 da Convenção destaca que “a perseguição não se considera iniciada até que o navio perseguidor se tenha certificado, pelos meios práticos de que disponha, de que o navio perseguido ou uma das suas lanchas ou outras embarcações que trabalhem em equipe e utilizando o navio perseguido como navio mãe, se encontram dentro dos limites do mar territorial ou, se for o caso, na zona contígua, na zona econômica exclusiva ou na plataforma continental." Também preconiza, em sua parte final, que "só pode dar-se início à perseguição depois de ter sido emitido sinal de parar, visual ou auditivo, a uma distância que permita ao navio estrangeiro vê-lo ou ouvi-lo."

$\mathrm{O}$ direito de perseguição, com base no $\int 5^{\circ}$ do art. 111 da Convenção, somente pode ser exercido por navios de guerra ou aeronaves militares, ou por outros navios ou aeronaves que possuam sinais claros e sejam identificáveis como navios e aeronaves ao serviço de um governo e que estejam para tanto autorizados. O $\$$ $8^{\circ}$, por sua vez, trata da responsabilização em caso de perseguição que extrapole os parâmetros da Convenção, dispondo que "quando um navio for parado ou apresado fora do mar territorial em circunstâncias que não justifiquem o exercício do direito de perseguição, deve ser indenizado por qualquer perda ou dano que possa ter sofrido em consequência disso."

Além do regramento para efetuar uma perseguição, o Estado deve tomar cuidado para que se tenham motivos suficientes, ou melhor, evidentes, para deflagrá-la. Nesse sentido, o art. 106 da Convenção de Montego Bay (1982) reza que "quando um navio ou uma aeronave for apresado por suspeita de pirataria, sem motivo suficiente, o Estado que o apresou será responsável, perante o Estado de nacionalidade do navio ou da aeronave, por qualquer perda ou dano causados por esse apresamento."

O direito de perseguição é limitado aos navios de guerra de um Estado, ou navio a trabalho do governo e que esteja identificado como tal. Somente estes podem perseguir os infratores em alto-mar, bem como aprisioná-los e conduzi-los a um porto do seu Estado. Para que a perseguição aos delitos nas águas territoriais desse Estado prejudicado obtenha êxito em questões legais, a exigência é que a perseguição haja começado em tais águas e não seja interrompida, sendo uma perseguição contínua. Percebe-se, portanto, que a questão da perseguição é bastante complexa para o Estado prejudicado, o que favorece, em muitas situações, a fuga dos piratas.

Considerando-se o marco legal da perseguição e apresamento de navios piratas, é importante investigar qual o papel desempenhado, nesse mister, pela Organização Marítima Internacional e pelo Tribunal Internacional do Direito do Mar.

\subsection{A Organização Marítima Internacional (IMO)}

A International Maritime Organization (IMO) é a agência especializada das Nações Unidas (ONU), criada em março de 1948, em Genebra, com a responsabilidade pela proteção e segurança da navegação e a prevenção da poluição marítima. A IMO possui 169 Estados-Membros e três membros associados, estando baseada no Reino Unido, com cerca de 300 funcionários internacionais.

Conforme destaca artigo $1^{\circ}$ da Convenção sobre a Organização Marítima Internacional, os propósitos da organização são instituir mecanismos de cooperação entre os governos no domínio da regulamentação e das práticas governamentais relacionados com assuntos técnicos de todos os tipos que interessem à atividade marítima relacionada ao comércio internacional, com o intuito de incentivar e facilitar a adoção geral dos mais altos padrões possíveis em matéria de segurança marítima, eficiência da navegação e prevenção e controle da poluição marinha causada por navios, bem como tratar de assuntos administrativos e jurídicos relacionados com os propósitos acima destacados. ${ }^{20}$

20 IMO. International Maritme Organization. Informações dis- 
Dentre os propósitos da Organização Marítima Internacional, também se destaca encorajar o abandono das medidas discriminatórias e restrições desnecessárias por governos afetando a atividade marítima relacionada ao comércio internacional, de modo a promover a disponibilidade de serviços relacionados à atividade marítima para o comércio do mundo, sem discriminação. A assistência e incentivo dados por um Governo para o desenvolvimento de sua atividade marítima nacional e para fins de segurança não constituem, por si só, discriminação, desde que tal assistência e incentivo não sejam baseados em medidas destinadas a restringir a liberdade da atividade marítima de todos os Estados de participar do comércio internacional. Cabe à IMO examinar as questões relativas às práticas restritivas desleais relativas à atividade marítima, bem como examinar todas as questões relativas à atividade marítima que poderão ser trazidas a seu conhecimento por qualquer órgão ou instituição especializada da Organização das Nações Unidas e também permitir a troca de informações entre governos sobre as questões em apreciação pela Organização. ${ }^{21}$

Conforme visualizado acima, os propósitos da organização da Convenção sobre a Organização Marítima Internacional, cabe destacar também suas funções, as quais se encontram na parte II, em seu artigo segundo, a qual se refere às formas para atingir os propósitos que estão estabelecidos na parte I. Salienta-se, nesse sentido, que a organização deve examinar e fazer recomendações sobre as questões decorrentes do artigo $1^{\circ}$ as quais podem ser submetidas à apreciação da organização pelos seus membros, por qualquer órgão ou agência especializada das Nações Unidas ou por qualquer outra organização intergovernamental. Cabe também à organização elaborar projetos de convenções, acordos ou outros instrumentos apropriados, recomendá-los aos governos e às organizações intergovernamentais e convocar as conferências que julgar necessárias, bem como prover mecanismos para consultas entre os membros e a troca de informações entre os Governos, além de desempenhar as funções mencionadas do presente artigo, em particular aquelas que lhe sejam atribuídas por meio de instrumentos internacionais relativos aos

poníveis em: <http://www.imo.org>. Acesso em: 05 mar. 2015. 21 IMO. International Maritme Organization. Informações disponíveis em: <http://www.imo.org>. Acesso em: 05 mar. 2015. assuntos marítimos e ao efeito da atividade marítima no ambiente marinho, devendo também facilitar quando necessário à operação técnica dentro da finalidade da Organização. ${ }^{22}$

A Organização Marítima Internacional possui um programa de cooperação técnica, que identifica as necessidades de recursos entre os membros mais resguardados e os resultados da assistência, tais como a formação. Essa organização fundou três níveis avançados de instituições marítimas de ensino em Malmö, Malta e Gênova. A IMO desempenha um papel fundamental na garantia de não colocar em risco a vida de marinheiros, bem como turistas e que o ambiente marinho não seja polúído por meio da sua utilização.

Preocupada com o tema da pirataria em alto-mar, no dia 11 de abril de 2013, a IMO efetuou a primeira sessão sobre o assunto em Londres, com o tema "Pirataria: A ameaça à Marítima Mercante no Oceano Índico". Durante a sessão, foi ressaltada a importância da temática, e todos os Estados reafirmaram seus interesses em repreender a prática da pirataria. Entre as delegações, participou também da reunião a Internacional Maritime Bureau (IMB), organização especializada contra a pirataria que se pôs à disposição para ajudar os países afetados.

Durante essa sessão, a Somália, que obteve um índice muito alto de ataques piratas, afirmou-se totalmente contra a pirataria, preocupando-se em "ressaltar que sempre esteve engajada para combater essa prática ilegal, lembrando ter enviado uma carta em junho de 2008 para o Conselho de Segurança das Nações Unidas pedindo ajuda à comunidade internacional". Em reposta às acusações pelos números alarmantes de ataques piratas, a Somália "afirmou que a pirataria não é causa apenas de problemas internos de seu Estado, alegando que o início das práticas piratas no território se deu em razão de defesa contra ataques de saqueadores vindos de outras regiões" ${ }^{\prime 2}$.

Em relação ao tema pirataria, a $90^{a}$ Sessão do Comitê de Segurança Marítima, que foi realizada em 2011,

22 IMO. International Maritme Organization. Informações disponíveis em: <http://www.imo.org>. Acesso em: 05 mar. 2015.

23 NOBRE, Luciana. Pirataria é assunto de debate da OMI. El País.com.co, 14 abr. 2013. OMI. Disponível em: <http://mundiuepb. com.br/elpais/pirataria-e-assunto-de-debate-na-omi/>. Acesso em: 09 set. 2014. 
teve por objetivo desenvolver recomendações relativas à contratação de segurança armada privada para os Estados, dentro dos parâmetros estabelecidos pela Organização Marítima Internacional. A Sessão evidenciou o posicionamento da IMO a favor da presença de guardas armados em navios mercantes, com o intuito de combater a pirataria em alto-mar e, obviamente, estabeleceu a necessidade de criar regras para utilização de segurança armada. ${ }^{24}$

O Documento de Montreux sobre Obrigações Legais Internacionais e Boas Práticas para os Estados relacionadas com as Operações de Companhias Privadas de serviços Militares e de Segurança durante Conflitos Armados e o Código Internacional de Conduta para os Prestadores de Serviços Privados de Segurança são pontos de referência úteis para as Companhias Privadas de Segurança Marítima, mas não são suficientes para abarcar as peculiaridades inerentes à situação da pirataria e roubo armado. O Documento de Montreux trata das regras aplicáveis aos Estados, mas consiste num instrumento de Direito Internacional Humanitário, e, portanto, é aplicável somente durante conflitos armados. O Código de Conduta, por sua vez, trata da indústria de segurança privada e identifica um conjunto de princípios que visam à proteção do Estado de Direito e respeito pelos Direitos Humanos por parte dos prestadores de serviços de segurança, mas não é adequado às peculiaridades necessárias para implantar de guardas armados a bordo de navios mercantes.

Os navios das empresas que pretendem utilizar serviços de segurança privada, bem como as empresas que pretendem prestar esses serviços, precisam reconhecer a responsabilidade legal a que podem estar sujeitas, devendo buscar a aprovação adequada das autoridades competentes, que são os Estados de bandeira, os países onde a companhia de segurança privada está registrada, os países em que a as operações são efetuadas ou gerenciadas, incluindo os países pelos quais os avios onde atuam as companhias pretendem transitar. ${ }^{25}$

24 VENANCIO, Daiana Seabra. A definição de pirata ria marítima e as implicações para a segurança na navegação. Revista da Escola de Guerra Naval, Rio de Janeiro, v. 18, n. 2, p. 135-137, jul./ dez. 2012. Disponível em: <https://www.egn.mar.mil.br/arquivos/ revistaEgn/dezembro2012/edicao18_2.137-160.pdf>. Acesso em: 09 out. 2014.

25 VENANCIO, Daiana Seabra. A definição de pirata ria marítima e as implicações para a segurança na navegação. Revista da Escola de Guerra Naval, Rio de Janeiro, v. 18, n. 2, p. 135-137, jul./ dez. 2012. Disponível em: <https://www.egn.mar.mil.br/arquivos/
Diante da possibilidade de utilização de segurança armada, é interessante destacar que

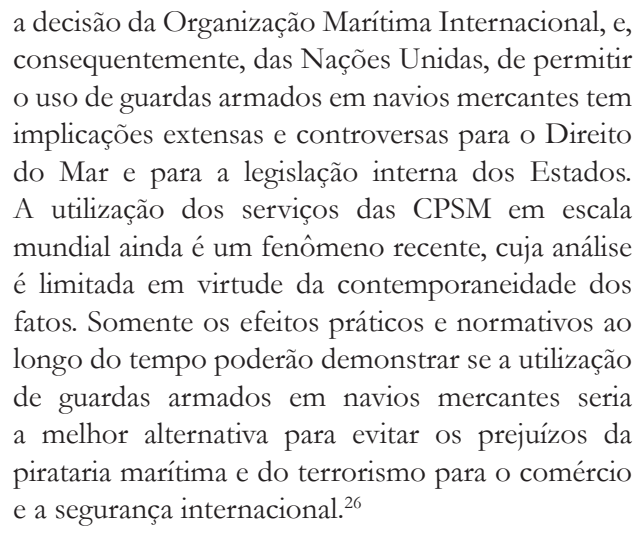

É visível o esforço da IMO para estabelecer um projeto mundial antipirataria, porém, as iniciativas esbarram nas dificuldades em padronizar as legislações nacionais, aumentar a interoperabilidade dos centros de coordenação e até mesmo resistências políticas. ${ }^{27} \mathrm{~A}$ possibilidade do exercício de jurisdição universal para o combate à pirataria não é suficiente para processar e julgar os piratas. A verdade é que os países desenvolvidos não têm interesse em obter gastos com o processo judicial e o cumprimento de pena, por isso incentivam os Estados da região que assumam esse compromisso. Diante disso, qualquer solução que pretenda ser definitiva deve considerar o fomento à estabilidade dos países nas áreas afetadas. Por essas razões, a busca de uma solução para a pirataria na atualidade é um desafio que ainda está longe do fim.

\subsection{O Tribunal Internacional do Direto do Mar (TIDM)}

A Convenção das Nações Unidas Sobre o Direito do Mar (1982) se diferencia das outras convenções, pois contém uma série de disposições relativas às soluções de controvérsias que giram em torno da ideia de jurisdição obrigatória. O artigo 287, I, “a”, da Convenção dispõe

revistaEgn/dezembro2012/edicao18_2.137-160.pdf>. Acesso em: 09 out. 2014.

26 PINTO, Paulo Evandro da Costa; VENANCIO, Daiana Seabra. De volta para o passado: a prática da guarda armada em navios mercantes para proteção contra os piratas no século XXI. Revista Brasileira de Estudos de Defesa, 2012. Disponível em: <http://www. seer.ufrgs.br/index.php/rbed/article/viewFile/48800/30472)>. Acesso em: 11 ago. 2014.

27 CANINAS, Osvaldo Peçanha. Pirataria marítima moderna: história, situação atual e desafios. Revista da Escola de Guerra Naval, Rio de Janeiro, n. 14, p. 101-122, 2009. 
sobre a criação do Tribunal Internacional do Direito do Mar (TIDM) como uma das medidas pacíficas para solucionar as controvérsias relativas à interpretação ou à aplicação da Convenção:

\section{ARTIGO 287}

Escolha do procedimento

1. Um Estado ao assinar ou ratificar a presente Convenção ou a ela aderir, ou em qualquer momento ulterior, pode escolher livremente, por meio de declaração escrita, um ou mais dos seguintes meios para a solução da controvérsia relativas à interpretação ou aplicação da presente Convenção:

a) o Tribunal Internacional do Direito do Mar estabelecido de conformidade com o Anexo VI;

b) a Corte Internacional de Justiça;

c) um tribunal arbitral constituído de conformidade com o Anexo VII;

d) um tribunal arbitral especial constituído de conformidade com o Anexo VIII, para uma ou mais das categorias de controvérsias especificadas no referido Anexo.

O Estatuto do Tribunal Internacional do Direito do Mar, em seu art. 21, refere que sua jurisdição "compreende todas as controvérsias e pedidos que lhe sejam submetidos de conformidade com a presente Convenção, bem como todas as questões especialmente previstas em qualquer outro acordo que confira jurisdição ao Tribunal." Portanto, pode-se afirmar que "el TIDM es un órgano judicial de carácter colegiado, internacional, permanente, especializado y obligatorio". 28

Ocorre que, em se tratando de uma questão delicada e preocupante que tem aterrorizado os mares, principalmente no Chifre da África, a Lei Internacional sobre a pirataria considera que cada Estado deve assumir responsabilidade própria no policiamento e patrulha das suas águas territoriais, assim como o combate a atos de pirataria cometidos nas suas zonas marítimas.

No entanto, os piratas que têm sido capturados não podem sequer ser levados a julgamento nas instâncias judiciais das Nações Unidas. O TIDM não tem competência para julgar piratas ou para julgar qualquer outra pessoa nesse caso. Se há uma disputa entre Estados que diga respeito à matéria coberta pela Convenção das $\mathrm{Na}$ ções Unidas sobre Direito do Mar, os Estados podem trazer essa disputa à consideração do Tribunal. Mas ele

28 ACOSTA ESTÉVEZ, José B. El Tribunal Internacional del Derecho del Mar. Barcelona: ANUE, 2002. p. 12. não pode julgar os piratas, já que não se trata de um tribunal criminal. ${ }^{29}$

O Tribunal Internacional do Mar tem, portanto, uma competência que se limita a apreciar "disputas entre Estados sobre questões relativas à interpretação e aplicação da Convenção". Os atos de ataques piratas se configuram em atos privados de indivíduos, com finalidade de obter lucro próprio, não configurando, portanto, uma questão de Estado contra Estado. Por isso, o Tribunal Internacional do Direito do Mar não tem competência para julgar tal crime.

Em termos de Direito Internacional, a Convenção de Montego Bay limita a luta contra a pirataria em alto-mar, porém, esta deixa em aberto opções para os Estados enfrentarem os ataques piratas, com suas legislações penais. Portanto é dever dos Estados cooperar com a luta contra esses "ladrões do mar".

\section{Considerações finais: Perspectivas para COMBATER A PIRATARIA}

Como se procurou demonstrar, a persecução efetiva à pirataria esbarra em alguns percalços jurídicos, notadamente na inexistência de um Tribunal Internacional competente para julgar os piratas. Trata-se, portanto, de um assunto de competência dos Estados, que precisam tipificar penalmente a pirataria, já que cabe a eles efetuar a perseguição e punição dos piratas, segundo a Convenção das Nações Unidas de 1982.

Todos os Estados devem cooperar na repressão da pirataria e apresar, em alto-mar, fora da jurisdição de qualquer Estado, um navio pirata ou em poder dos piratas e prender as pessoas que se encontrem a bordo, cabendo o seu julgamento aos tribunais do Estado que fez o apresamento.

Atitudes importantes estão sendo tomadas por parte de alguns Estados. Por exemplo: com o objetivo de combater a pirataria na costa leste africana, em janeiro de 2009 a OMI promoveu uma reunião com representantes de dezessete países, na qual foi adotado um

29 D'ANGELIS, Wagner Rocha. Pirataria no direito internacional. 2011 Disponível em: <http://webcache.googleusercontent. com/search?q= cache:tYgizOn39YoJ:https:/ / xa.yimg.com/kq/ groups / 22700344/1899977347/name/Pirataria\%2Be\%2BDir eito $\% 2$ BInternacional $\% 2 \mathrm{~B} \% 282012 \% 29$. doc $+\& \mathrm{~cd}=4 \& \mathrm{hl}=\mathrm{pt}-$ BR\&ct $=$ clnk\&gl=br $>$. Acesso em: 19 out. 2014. 
Código de Conduta tendo por escopo a Repressão da Pirataria e do Roubo Armado contra navios no Oceano Índico Ocidental e no Golfo do Áden. Referida normativa, denominada "Código Djibouti", inova ao criar um fundo para o combate à pirataria na região, bem como ao exigir comprometimento por parte dos Estados signatários no sentido de tipificar o crime em suas respectivas legislações internas, de modo a não obstaculizar o exercício da competência universal no combate à pirataria, além de contemplar alterações substanciais em âmbito regional no que tange ao exercício do direito de perseguição. Essas diretivas parecem adequadas para que o Direito Internacional possa agir com maior eficiência na prevenção e também na repressão ao delito.

Em seu artigo $2^{\circ}$, o Código refere o seu propósito e escopo, salientando que os Estados participantes se comprometem a cooperar para a repressão à pirataria $\mathrm{e}$ ao roubo armado mediante o compartilhamento de informações relevantes, a interditar navios ou aeronaves suspeitos de perpetrarem pirataria e roubo armado, a garantir que as pessoas envolvidas na prática desses delitos sejam presas, processadas e julgadas, e, finalmente, a facilitar o repatriamento de pessoas vítimas desses atos.

Além disso, convém salientar que o International Maritime Bureau tem patrocinado vários estudos sobre pirataria, defendendo uma maior eficiência e eficácia do Direito Internacional no combate ao crime, bem como às suas causas diretas. No entanto, referidas medidas ainda encontram resistência por parte dos Estados ribeirinhos, que temem um excessivo cerceamento de suas soberanias, particularmente no que se refere ao âmbito criminal.

O International Maritime Bureau também aconselha aos donos de embarcações que adotem medidas preventivas, como possuir vigias e navegar a uma velocidade que os permita deixar os piratas para trás, pois se estes piratas assumirem o controle da embarcação ou navio dificulta a intervenção militar devido aos reféns a bordo.

Para além do que já vem sendo feito, a necessidade de lutar contra a pirataria internacional impõe, acima de tudo, novos paradigmas ao Direito Internacional. Nesse caso, torna-se imperioso o fortalecimento da paz, da segurança, da cooperação e das relações de amizade entre os Estados diante das novas realidades, tendo em vista o desenvolvimento de uma nova legislação sobre pirataria por meio das organizações competentes, como as In- ternational Chamber of Commerce (ICC) e International Maritime Organization (IMO), de modo a superar aquilo a que Schneider denomina como "gap entre as normas internacionais e as normas domésticas." ${ }^{30}$ Nesse sentido, a partir de uma abordagem mais regional do que global, "a IMO vem obtendo importantes avanços para a repressão ao roubo armado contra navios, principalmente no que diz respeito ao incentivo à cooperação entre os estados costeiros afetados." ${ }^{31}$

Em relação às perspectivas de combate à pirataria, pode-se perceber que os métodos utilizados, em sua grande maioria, são ineficazes, pois não colocam um ponto final no problema. A questão é complexa, devendo ser encarada por todos os Estados, os quais devem se conscientizar que pirataria não é algo do passado e que ela interfere significativamente no comércio, no turismo e na segurança marítima contemporânea. $\mathrm{O}$ que muito tem sido feito é amenizar os ataques nos principais pontos, porém essas atitudes não resolvem o problema em si, uma vez que novos pontos de ataque acabam surgindo na medida em que outros são descobertos. Diante dessas perspectivas, pode-se concluir pela necessidade de uma nova Convenção sobre a temática, que atente para as particularidades de cada região afetada.

Salienta-se, por fim, que a questão não se resume somente à perseguição e punição aos piratas, pois, por mais completos e estruturados que sejam os meios jurídicos, não se pode esquecer o lado da questão que trata da repartição das riquezas. Afinal, como evidenciado no presente texto, os maiores índices de ataques piratas ocorrem em regiões esquecidas, por assim dizer, do mundo globalizado, regiões que não tiveram a oportunidade de crescimento e reconhecimento, sendo essa crise interna de certos Estados o fator que conduz seus nacionais a partir para um meio de sobrevivência que com o decorrer do tempo foi se aperfeiçoando e se tornando uma forma de conseguir obter riqueza por meio ilícito. A busca para a solução da pirataria em alto-mar é um tema que ainda irá repercutir por muito tempo, e o primeiro passo é a conscientização de que pirataria não é algo do passado e que está bem presente na atualidade.

30 SCHNEIDER, Eduardo Augusto S. da C.. In. VARELLA, Marcelo D. Pirataria marítima: a experiência Somália. Revista de Direito Internacional, vol.12, no.1. (nesta edição).

31 BEIRÃO, André Panno; PIÑON, Charles Pacheco. In. VARELLA, Marcelo D. A IMO e a repressão ao roubo armado contra navios: da retórica internacional à cooperação regional. Revista de Direito Internacional, vol.12, no.1. (nesta edição). 


\section{REFERÊNCIAS}

ACOSTA ESTÉVEZ, José B. El Tribunal Internacional del Derecho del Mar. Barcelona: ANUE, 2002.

BEIRÃO, André Panno; PIÑON, Charles Pacheco. In. VARELLA, Marcelo D. A IMO e a repressão ao roubo armado contra navios: da retórica internacional à cooperação regional. Revista de Direito Internacional, vol.12, no.1. (nesta edição).

BÖHM-AMOLLY, Alexandra von. O Direito internacional marítimo e o direito nacional no combate à pirataria: potencialidades e limitações. Boletim Ensino Investigação, n. 10, p. 59-73, maio 2011.

BRANDÃO, Eduardo Henrique Serra. Afinal o que é pirataria? 2010. Disponível em: <http://academia.marinha.pt/PT/edicoes/Documents/2010/Afinal_o_ que_e_pirataria.pdf $>$. Acesso em: 15 maio 2014.

BIZAWU, SébastienKiwonghi. Pirataria nas águas internacionais e as novas tendências do direito internacional privado. Disponível em: <http://www.domtotal.com/direito/ pagina/detalhe/23865/pirataria-nas-aguas-internacionais-e-as-novas-tendencias-do-direito-internacionalprivado>. Acesso em: 01 nov. 2014.

CANINAS, Osvaldo Peçanha. Pirataria marítima moderna: história, situação atual e desafios. Revista da Escola de Guerra Naval, Rio de Janeiro, n. 14, p. 101-122, 2009.

CRETELLA NETO, José. Curso de direito internacional penal. Ijuí: Unijuí, 2008.

D’ANGELIS, Wagner Rocha. Pirataria no direito internacional. 2011 Disponível em: < http://webcache.googleusercontent.com/search?q=cache:tYgizOn39YoJ:https:/ / xa.yimg.com/kq/groups/22700344/1899977347/ name/Pirataria $\% 2 \mathrm{Be} \% 2 \mathrm{BD}$ ireito $\% 2 \mathrm{BInterna}$ cional $\% 2 \mathrm{~B} \% 282012 \% 29$. doc $+\& \mathrm{~cd}=4 \& \mathrm{hl}=\mathrm{pt}-$ BR\&ct $=\mathrm{clnk} \& \mathrm{gl}=\mathrm{br}>$. Acesso em: 19 out. 2014.

HILSE, Gwendolin; RIFFEL, Bettina. Pirataria mora agora no Golfo da Guiné. Deutsche Welle, 04 mar. 2014. Disponível em: <http://www.dw.de/pirataria-moraagora-no-golfo-da-guin\%C3\%A9/a-17472098>. Acesso em: 27 jun. 2014.

LETRA, Leda. Banco Mundial: pirataria custa US\$ 18 bilhões por ano à economia global. Rádio ONU, Nova York, 11 abr. 2013. Disponível em: <http://www. unmultimedia.org/radio/portuguese/2013/04/banco- mundial-pirataria-custa-us-18-bilhoes-por-ano-a-economia-global/>. Acesso em: 23 jun. 2014.

MARCHESE, Bruno Horvath. A importância da pirataria marítima e o seu combate na Somália. 2011. Disponível em: <http:// piratariamaritima.blogspot.com.br/2011/01/ importancia-da-pirataria-maritima-e-o.html $>$. Acesso em: 18 jun. 2014.

MEDEIROS, Roberto Carvalho de. Pirataria no mar não é coisa do passado. Disponível em: <http://groups.google.com/forum/\#!topic/noticiarionaval/L8OCXAGJWM>. Acesso em: 24 mar. 2014.

NOBRE, Luciana. Pirataria é assunto de debate da OMI. El País.com.co, 14 abr. 2013. OMI. Disponível em: $<$ http://mundiuepb.com.br/elpais/pirataria-e-assunto-de-debate-na-omi/>. Acesso em: 09 set. 2014.

ONU. Organização das Nações Unidas. Decreto-Lei n. 44490. Convenção sobre o alto mar. Aprovada na primeira conferência do mar realizada em Genebra em 1958. Disponível em: <http://www.aquaseg.ufsc.br/ files/2011/07/Conven_Alto_mar_1958.pdf >. Acesso em: 9 abr. 2014.

ONU. Organização das Nações Unidas. Decreto n. 1530. Convenção das Nações Unidas sobre o Direito do Mar. Concluída em Jamaica/1982. Disponível em: <http:// www.aquaseg.ufsc.br/files/2011/07/CNUDM.pdf>. Acesso em: 9 abr. 2014.

PINTO, Paulo Evandro da Costa; VENANCIO, Daiana Seabra. De volta para o passado: a prática da guarda armada em navios mercantes para proteção contra os piratas no século XXI. Revista Brasileira de Estudos de Defesa, 2012. Disponível em: < http://www.seer.ufrgs. br/index.php/rbed/article/viewFile/48800/30472) >. Acesso em: 11 ago. 2014.

SCHNEIDER, Eduardo Augusto S. da C.. In. VARELLA, Marcelo D. Pirataria marítima: a experiência Somália. Revista de Direito Internacional, vol.12, no.1. (nesta edição).

VENANCIO, Daiana Seabra. A definição de pirata ria marítima e as implicações para a segurança na navegação. Revista da Escola de Guerra Naval, Rio de Janeiro, v. 18, n. 2, p. 135-137, jul./dez. 2012. Disponível em: <https://www.egn.mar.mil.br/arquivos/revistaEgn/ dezembro2012/edicao18_2.137-160.pdf>. Acesso em: 09 out. 2014. 


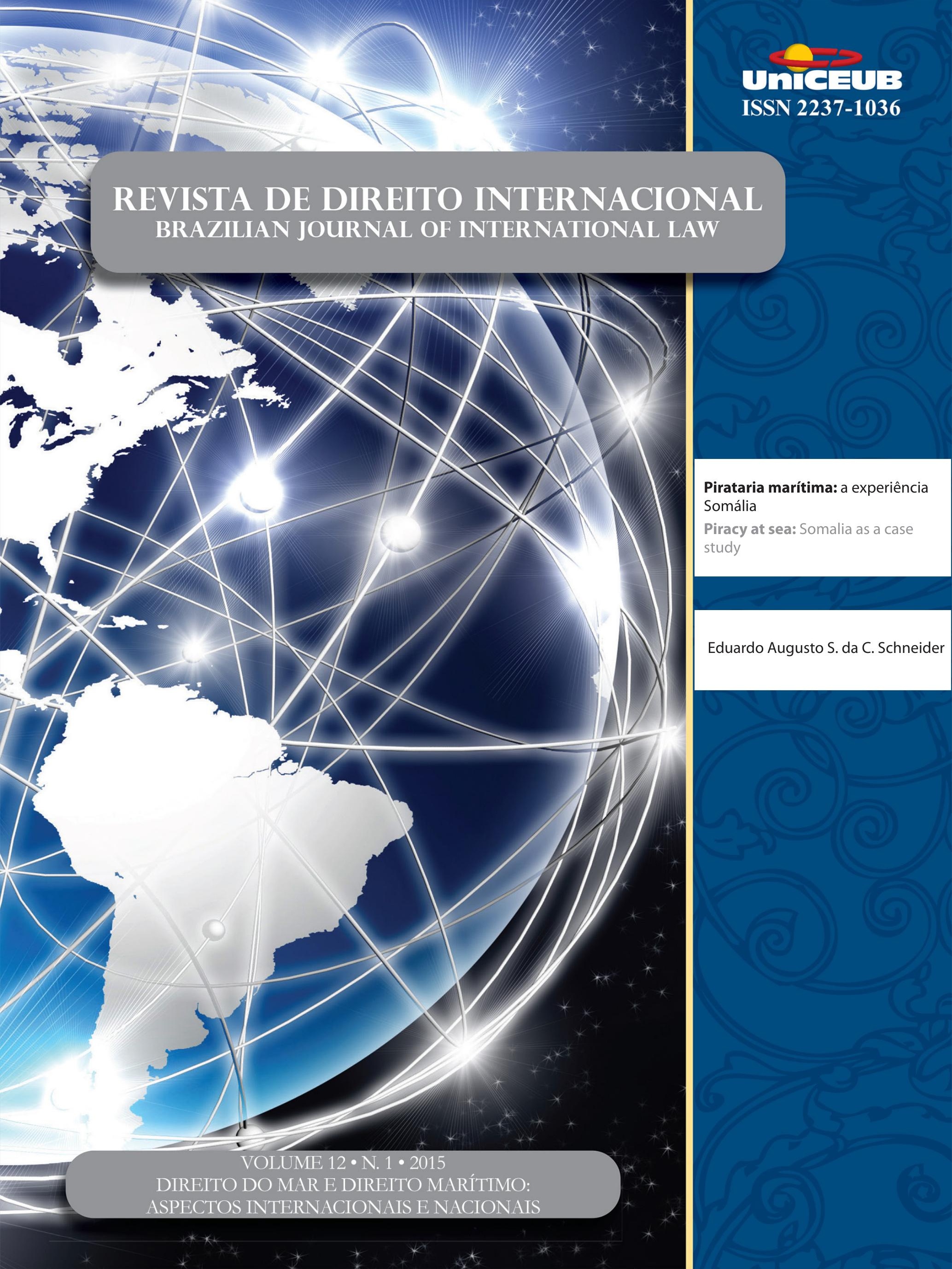




\title{
Pirataria marítima: a experiência Somália*
}

\section{Piracy at sea: Somalia as a case study}

\author{
Eduardo Augusto S. da C. Schneider ${ }^{* *}$
}

\section{Resumo}

O trabalho tem como ponto de partida a análise histórica da questão da pirataria e da situação da Somália no contexto político-econômico mundial. O objetivo principal consiste em, por meio da análise da situação ímpar em que se encontra o país do chifre da África, analisar a atuação da comunidade internacional no enfrentamento da pirataria nos mares da região. A CNDUM traz, em seu artigo 101, a definição de pirataria, determinando que os países signatários façam uso do princípio da jurisdição universal para combater esses atos. As diversas Resoluções do Conselho de Segurança das Nações Unidas sobre pirataria no Golfo do Áden demonstram a peculiaridade da questão e a busca por resposta precisa e contundente para enfrentar o problema. O estudo do caso da Somália, que vem obtendo relativo sucesso na redução do número de casos de pirataria, é relevante, portanto, para a melhor compreensão dos fatos que levam ao florescimento dessa atividade, bem como para auxiliar a trilhar caminhos para a atuação dos governos e órgãos internacionais em novos casos de aumento da atividade pirata, como ocorre, agora, no oeste da África e no sudeste asiático, em especial na região da Indonésia, Malásia e Bangladesh.

Palavras-chave: Somália. Pirataria. Convenção das Nações Unidades sobre Direito do Mar. Golfo do Áden.

\section{Abstract}

This work takes as its starting point the historical analysis of the issue of piracy and the situation in Somalia in the political and economical context. The main goal is, through the analysis of the unique situation in which the country from the Horn of Africa is at, evaluate the response given by the international community to the matter. The United Nations Convention on the Law of the Sea provides, in article 101, the definition of piracy, ruling that the signatory countries make use of the principle of universal jurisdiction to combat these acts. The various resolutions of the Security Council of the United Nations dealing with piracy in the Gulf of Aden, demonstrate the uniqueness of the issue and the lack of a precise and convincing answer to this problem. Given so, the study of the Somali case, with its relative success on the reduction of the amount of piracy attacks, is critical to a better understanding of the facts that lead to the blooming of piracy cases. It could help National governments and the international bodies to create a path to be followed in the case of a new increase on piracy attacks, as it

* Recebido em 30/04/2015 Aprovado em 10/06/2015

silia. E-mail. ea.schneider@hotmail.com 
appears to be happening in the west Africa coast and in the southeast Asia region, specially Indonesia, Malaysia and Bangladesh.

Keywords: Somalia. Sea piracy. United Nations Convention on the Law of the Sea. Gulf of Aden.

\section{INTRODUÇão}

Grande parte da concepção da imagem de piratas contemporânea tem como base filmes de Hollywood e literatura. Essa percepção romântica não passa de simplória cultura popular, se afastando, muitas vezes, da realidade. Os atos de pirataria que ocorrem atualmente na região do Golfo do Áden, mais particularmente nas proximidades da costa da Somália, representam um desafio econômico, humanitário e de segurança para a comunidade global.

A posição geográfica privilegiada da Somália, na embocadura de uma das rotas marítimas com maior fluxo de bens de consumo no planeta, a falta de governo eficiente por mais de 20 anos e uma economia falida são o terreno ideal para o desenvolvimento da pirataria. Não é coincidência, portanto, que a epidemia de atos de pirataria na região, com início em 2008, tenha acontecido exatamente no ano que a Somália ficou em primeiro lugar no ranking de países falidos.

Segundo a Câmara Internacional do Comércio, ocorreram, em 2011, 198 (cento e noventa e oito) relatos de ataques de piratas somalis na região do Golfo de Áden ${ }^{1}$. A pirataria na região, uma das principais rotas comerciais do planeta, afeta o comércio marítimo internacional e ameaça desestabilizar países que dependem de envio e recebimento internacional de bens via marítima, como Arábia Saudita, Djibuti, Iêmen, Omã, Quênia, entre outros. Uma organização internacional chamada Oceans Beyond Piracy estimou, em estudo de dezembro de 2010 , que o custo econômico anual $3 / 4$ direto e indireto $3 / 4$ da pirataria marítima fica entre US $\$ 7$ e 12 bilhões $^{2}$. A pirataria impede, ainda, a entrega de ajuda

1 Para mais informações e dados atualizados sobre casos de pirataria ao redor do mundo. COMMERCIAL CRIME SERVICES. Piracy e armed robbery: news e figures. Disponível em: $<$ https://iccccs.org/piracy-reporting-centre/piracynewsafigures/>. Acesso em: 11 jul. 2015.

2 BOWDEN, Anna. The economic costs of maritime piracy. Dec. 2010. Disponível em: <http://www.steamshipmutual.com/Downloads/ Piracy/EconomicCostPiracyOEFReport.pdf $>$. Acesso em: 11 jul. humanitária, em especial do World Food Program.

Evidência da relevância dada ao caso consiste na resposta naval internacional sem precedentes ${ }^{3}$ : desde 2009 atua na região uma flotilha com fins específicos de combate à pirataria, a Combined Task. Force 151, coalizão marítima com apoio logístico e de material bélico de mais de 20 países ${ }^{4}$.

Além disso, é importante o respaldo dado pelo Conselho de Segurança das Nações Unidas, que editou diversas resoluções com os mais variados conteúdos, chamando a atenção da comunidade internacional para o crescente risco que as atividades de pirataria na região trazem à segurança e ao comércio internacional.

Partindo de uma análise das Resoluções do Conselho de Segurança das Nações Unidas, bem como das legislações nacionais de países da região, acordos e tratados sobre a temática, foi possível traçar quais rumos foram tomados pelas nações interessadas e envolvidas na resolução da questão.

O estudo do caso da Somália, que vem obtendo relativo sucesso na redução no número de casos de pirataria, é relevante para a melhor compreensão dos fatos que levam ao florescimento dessa atividade, bem como pode auxiliar a trilhar caminhos para a atuação dos governos e órgãos internacionais em novos casos de aumento da atividade pirata, como ocorre, agora, no oeste da África e no sudeste asiático, em especial na região da Indonésia, Malásia e Bangladesh.

\section{BREVES NOTAS SOBRE A DEFINIÇÃO DE PIRATARIA}

Essencial, para a compreensão do fenômeno da pirataria marítima, em especial das especificidades que circundam a questão na região do chifre da África, tecer breves considerações sobre qual a conceituação utilizada pelo direito internacional ao referir-se à pirataria.

A Convenção das Nações Unidas sobre o Direito

\section{5. p. 11.}

3 DUDDRIDGE, James. Piracy off the coast of Somalia. Disponível em: <https://www.gov.uk/government/policies/piracy-off-thecoast-of-somalia $>$. Acesso em: 11 jul. 2015.

4 UNITED STATES NAVY. New counter-piracy task force established. Disponível em: < http://www.navy.mil/submit/display.asp?story_ id=41687> . Acesso em: 11 jul. 2015. 
do Mar (CNUDM), celebrada em 1982 e definida por Tommy T.B. Koh como "a constitution for the oceans", adotou a mesma definição de pirataria da Convenção das Nações Unidas sobre o Alto Mar, de $1958^{6}$.

Além de definir, em seu artigo 101, que os atos de pirataria devem, necessariamente, ocorrer em alto mar, fora da jurisdição de qualquer Estado, a CNUDM estabelece as diretrizes que devem ser seguidas pelas nações na supressão da pirataria. É, reconhecidamente, o documento legal mais importante a tratar do tema.

O artigo 101 da CNUDM define como pirataria quaisquer dos seguintes atos:

a) todo o ato ilícito de violência ou de detenção ou todo o ato de depredação cometidos, para fins privados, pela tripulação ou pelos passageiros de um navio ou de uma aeronave privados, e dirigidos contra:

i) um navio ou uma aeronave em alto mar ou pessoas ou bens a bordo dos mesmos;

ii) um navio ou uma aeronave, pessoas ou bens em lugar não submetido à jurisdição de algum Estado;

b) todo o ato de participação voluntária na utilização de um navio ou de uma aeronave, quando aquele que o pratica tenha conhecimento de factos que deem a esse navio ou a essa aeronave o carácter de navio ou aeronave pirata;

c) toda a ação que tenha por fim incitar ou ajudar intencionalmente a cometer um dos atos enunciados na alínea a) ou b).

Essa definição ajuda a distinguir o crime de pirataria marítima de simples roubo armado ou de atos de terrorismo. De acordo com essa definição, para tipificar os atos de pirataria há necessidade que os crimes tenham três aspectos: objeto, localização geográfica e finalidade.

$\mathrm{O}$ ato deve ter como objeto um navio, aeronave ou passageiros/tripulantes desses veículos. $\mathrm{O}$ aspecto geográfico, por sua vez, estipula que o crime tem que ser

5 UNITED NATIONS. A Constitution for the oceans Disponível em: <http://www.un.org/depts/los/convention_agreements/ texts/koh_english.pdf>. Acesso em: 11 jul. 2015

6 Artigo 15 da Convenção das Nações Unidas sobre o Alto Mar e Artigo 101 da Convenção das Nações Unidas sobre o Direito do Mar. BRASIL. Decreto $n^{0} 1.530$, de 22 de junho de 1995. Declara a entrada em vigor da Convenção das Nações Unidas sobre o Direito do Mar, concluída em Montego Bay, Jamaica, em 10 de dezembro de 1982. Disponível em: <http://www.planalto.gov.br/ccivil_03/ decreto/1995/D1530.htm>. Acesso em: 11 jul. 2015. perpetrado em alto-mar ou em lugar onde não haja a jurisdição de um Estado. Por esse aspecto, deixariam de ser considerados os atos cometidos nas águas interiores e mar territorial de países. A finalidade, de forma não menos importante, deve seguir a regra de "fins privados", o que diferencia, por última instância, de atos com fins políticos, que o definiriam como terrorismo.

Grande parte da confusão criada em torno da definição do termo "pirataria" gira em torno da forma como a imprensa trata qualquer ato de violência envolvendo embarcações como pirataria ${ }^{7}$. No entanto, essa confusão terminológica também ocorre na coleção de dados sobre pirataria da International Maritime Burean (IMB), que não faz distinção entre alto-mar e águas territoriais em seus relatórios, o que é problemático.

\section{A Situação na SOMÁlia}

A Somália é considerada um Estado falido ${ }^{8}$, com população estimada em 10.428.043 habitantes ${ }^{9}$, e localizada na entrada de uma das mais importantes rotas comerciais do planeta: na ligação do Oceano Índico com o Mar da Arábia, Golfo do Áden, Mar Vermelho e o Canal de Suez, ou seja, na principal ligação da Europa com o Oriente.

Desde 1991, com a guerra civil que depôs o governo ditatorial do General Siad Barre, não existe governo central capaz de exercer soberania sobre o território

7 A mídia de massas costuma tratar pirataria e roubo contra embarcações como sinônimos, como por exemplo, em: PIRATAS roubam embarcação e fazem 150 passageiros reféns no Amazonas. Disponível em: <http://g1.globo.com/brasil/noticia/2011/08/piratas-roubam-embarcacao-e-fazem-150-passageiros-refens-no-amazonas.html>. Acesso em: 11 jul. 2015; TOGNOLLI, Claudio Julio. Federais denunciam piratas na Amazônia. Disponível em: < http://www. brasil247.com/pt/247/rio247/33518/Federais-denunciam-piratasna-Amaz $\% \mathrm{C} 3 \% \mathrm{~B} 4$ nia-claudio-juli-tognolli-amaz $\% \mathrm{C} 3 \% \mathrm{~B} 4$ nia-ilegal-piratas-policia-federal-ataques.htm>. Acesso em: 11 jul. 2015; TORRES, Sergio. Piratas atacam navios perto de portos brasileiros. Disponível em: < http://www.naval.com.br/blog/2009/06/15/piratasatacam-navios-perto-de-portos-brasileiros/>. Acesso em: 11 jul. 2015

8 Em 2014, pela primeira vez em mais de uma década, a Somália deixou de ocupar o primeiro lugar no Ranking de "Estados frágeis" da Revista Foreign Policy mais em: <http://foreignpolicy.com/ fragile-states-2014/\#rankings >. Acesso em: 21 abr. 2015.

9 Dados disponibilizados pela: CIA em CENTRAL INTELLIGENCE AGENCY. The world factabook. Disponivel em: < https:// www.cia.gov/library/publications/resources/the-world-factbook/ index.html>. Acesso em: 11 jul. 2015. 
somali. Clãs do norte declararam a independência da República da Somalilândia 3/4 ainda que sem qualquer reconhecimento internacional $3 / 4$ e no nordeste surgiu o estado semiautônomo da Puntlândia.

Em 2000, após tentativas fracassadas de missões de paz das Nações Unidas ${ }^{10}$, foi formado o primeiro governo interino da Somália, o Governo Nacional Temporário (GNT). Já em 2004, com a eleição de Abdullahi Yusuf Ahmed, passa a chamar Governo Federal de Transição (GFT).

Apesar da complexidade do problema somali, esse país vem apresentando mudanças significativas, mesmo que ainda não se sinta, na prática, o resultado delas. Um novo parlamento, com 275 membros, foi escolhido pelos clãs que formam o país, o primeiro desde 1991. A escolha do novo parlamento foi seguida pela dissolução do GFT, abrindo caminho para que, em 10 de setembro de 2012 , fosse eleito $3 / 4$ ainda que não por voto popular $3 / 4$ o novo presidente do país, com 190 votos do parlamento. Atualmente, o cargo de Primeiro Ministro é ocupado pelo Sr. Omar Abdirashid Ali Sharmake, o terceiro Primeiro Ministro a ocupar o cargo desde a dissolução do GFT.

\subsection{Instabilidade política}

Apesar da criação do GFT, um grupo radical conhecido como União das Cortes Islâmicas ("UCI") passou, em 2006, a tomar conta de boa parte da região sul da Somália, inclusive da capital Mogadíscio, impondo a shari'a como novo regime jurídico. Em dezembro do mesmo ano, com o aumento de poder e radicalização da UCI, tropas do governo e da Etiópia 3/4 com apoio norte-americano, que buscava atacar grupos da Al-Qaeda ligados à UCI $3 / 4$ lançaram uma contraofensiva ${ }^{11}$, recuperando, rapidamente, grande parte do território perdido para o grupo radical islâmico.

Após essa derrota, a UCI se dividiu em diversas facções, sendo uma das mais radicais a al-Shabaab. Duran-

10 Para mais informações sobre as missões de paz da ONU na Somália, ver: CASTRO, Marina Scotelaro de. A instabilidade na Somália e a ineficácia das intervenções internacionais. Belo Horizonte: PUC Minas, 2010.

11 UNITED STATES COMMISSION ON INTERNATIONAL RELIGIOUS FREEDOM. USCIRF Annual Report 2009 The Commission's Watch List: Somalia, 1 May 2009. Disponível em: <http://www.refworld.org/docid/4a4f272bchtml>. Acesso em: 11 jul. 2015. te os anos que se seguiram, esses grupos continuaram a lutar contra as tropas da GFT e se opor à presença Etíope na Somália, conseguindo importantes vitórias e passando a controlar portos e cidades nas regiões central e sul daquele país. O assassinato de membros de outras religiões passou a ser prática comum, assim como a implementação forçada de interpretação estrita da lei islâmica e a supressão de práticas consideradas "não-islâmicas" $" 12$.

Em virtude da retomada de territórios por parte da UCI, em dezembro de 2008, o então presidente Abdullahi Yusuf Ahmed renunciou ao cargo e passou o governo central para as mãos de uma coalizão entre a GFT e a Aliança para Re-libertação da Somália ("ARS") 13, uma ex-facção da UCI. Com isso, o número de assentos no parlamento dobra, com a adição de mais 275 cadeiras (200 para a ARS e 75 para membros da sociedade civil) e um presidente é eleito por esse novo parlamento, o sheik Sharif Sheikh Ahmed, ex-membro da UCI e da ARS. Com a formação do novo governo, as tropas etíopes se retiram do país, deixando para trás tropas de paz da União Africana.

A guerra civil continua, mesmo com o novo governo islâmico. Al-Shabaab e outros grupos armados continuam com seus ataques armados e ações terroristas, ainda que venham perdendo territórios para as forças de paz da União Africana (“AMISOM”). O contingente da União Africana no país vem aumentando, chegando ao número de 22.126 militares, sob auspício do Conselho de Segurança das Nações Unidas ${ }^{14}$.

\subsubsection{Instabilidade econômica}

Segundo dados do Banco Mundial, a Somália é um dos países mais pobres do mundo, resultado, em grande parte, de décadas de guerra civil e da falta de um governo central ativo. Seu Produto Interno Bruto é estimado em US\$ 5.896 bilhões, sendo $60,2 \%$ advindos da agri-

12 CASTRO, Marina Scotelaro de. A instabilidade na Somália e a ineficácia das intervenções internacionais. Belo Horizonte: PUC Minas, 2010. p. 7.

13 CASTRO, Marina Scotelaro de. A instabilidade na Somália e a ineficácia das intervenções internacionais. Belo Horizonte: PUC Minas, 2010. p. 8.

14 Para mais informações sobre a AMISOM: AFRICAN UNION MISSION IN SOMALIA. Frequently Asked Questions. Disponível em: <http://amisom-au.org/frequently-asked-questions/>. Acesso em: 11 jul. 2015. 
cultura e menos de $8 \%$ da quase inexistente indústria ${ }^{15}$. Mesmo com alguma atividade de agricultura e pesca, grande parte dos alimentos da Somália vem de produtos importados e de ajuda humanitária.

A Agência Central de Inteligência estadunidense ("CIA"), em seu relatório sobre a Somália, estima que o país tenha grandes reservas de minério de ferro, urânio, bauxita, cobre, sal, gás natural e reservas de petróleo ${ }^{16}$. Apesar desse potencial de recursos naturais, estes permanecem praticamente inexplorados, em grande parte pela constante guerra civil que assola o país há mais de duas décadas.

\subsubsection{Território fértil para o desenvolvimento da pirataria}

A posição geográfica privilegiada, numa das rotas comerciais com maior fluxo de bens no planeta, a falta de governo eficiente por mais de 20 anos e uma economia falida são o terreno ideal para o desenvolvimento da pirataria. Não é coincidência, portanto, que a epidemia de atos de pirataria na região, com início em 2008, tenha acontecido exatamente no ano em que a Somália ficou em primeiro lugar no ranking de países falidos.

Os piratas somalis, apesar da aparente falta de recursos, desenvolveram táticas para realizar ataques de maneira cada vez mais distante da costa. Aproveitando a vasta quantidade de embarcações pesqueiras naquela região, os piratas somalis lançam pequenos barcos com poderosos motores diretamente dos chamados "mother ships", grandes barcos pesqueiros que são usados como base de lançamento para ataques em alto-mar ${ }^{17}$. A velocidade das embarcações usadas pelos piratas é tamanha que, do momento que são avistados até que o ataque em si seja iniciado, são passados poucos minutos ${ }^{18}$. O modus operandi

15 Dados disponibilizados pela CIA em: CENTRAL INTELLIGENCE AGENCY. The world factabook. Disponível em: < https:// www.cia.gov/library/publications/resources/the-world-factbook/ index.html>. Acesso em: 11 jul. 2015.

16 Dados disponibilizados pela CIA em: CENTRAL INTELLIGENCE AGENCY. The world factabook. Disponível em: < https:// www.cia.gov/library/publications/resources/the-world-factbook/ index.html>. Acesso em: 11 jul. 2015.

17 MIDDLETON, Roger. Piracy in Somalia: threatening global trade, feeding local wars. London: Chatam House, 2008. Disponível em: <https://www.chathamhouse.org/sites/files/chathamhouse/ public/Research/Africa/1008piracysomalia.pdf $>$. Acesso em: 11 jul. 2015. p. 4.

18 MIDDLETON, Roger. Piracy in Somalia: threatening global trade, feeding local wars. London: Chatam House, 2008. Disponível utilizado para os ataques não costuma variar muito: os skiffs utilizados pelos piratas se aproximam da embarcação a ser atacada, a entrada no navio é forçada com disparos de rifles automáticos - em algumas situações lançadores de granadas foram reportados $3 / 4 \mathrm{e}$, uma vez a bordo do navio atacado, navegam para a costa somali, onde a negociação do resgate começa a ser realizada ${ }^{19}$.

O maior navio sequestrado por piratas até hoje foi o MV Sirius Star, navio petroleiro de 1.090 pés, com capacidade para transportar 2.2 milhões de barris de petróleo. $\mathrm{O}$ ataque ocorreu no dia 15 de novembro de 2008, a 450 milhas náuticas da costa do Quênia, o que foi, à época, o ataque mais distante da costa da Somália. A embarcação foi liberada após o pagamento de resgate no valor de US\$3 milhões, no dia 9 de janeiro de $2009^{20}$. No dia 10 de maio de 2012, outro navio petroleiro com capacidade para aproximadamente 1 milhão de barris de petróleo foi sequestrado ${ }^{21}$.

A realização desses ataques não seria possível sem a instabilidade no território da Somália, tendo em vista que, ainda que a maioria dos ataques seja lançada do próprio mar, são as bases em terra que dão respaldo para as atividades empreendidas ${ }^{22}$. A pirataria acaba sendo fonte de oportunidades que muitas vezes são inalcançáveis pelas vias legais, naquele país.

\section{A RESPOSTA DA COMUNIDADE INTERNACIONAL}

A existência de lacunas legais no artigo 101 da CNUDM impulsionou a elaboração de diversas regu-

em: <https://www.chathamhouse.org/sites/files/chathamhouse/ public/Research/Africa/1008piracysomalia.pdf $>$. Acesso em: 11 jul. 2015. p. 5.

19 ICC International Maritime Bureau, Piracy and Armed Robbery Against Ships - Annual Report 2008, p. 5. Para relatos atualizados dos ataques mais recentes: COMMERCIAL CRIME SERVICES. Piracy e armed robbery: news e figures. Disponível em: <https:// icc-ccs.org/piracy-reporting-centre/piracynewsafigures/ $>$. Acesso em: 11 jul. 2015.

20 PIRATE 'washes ashore with cash. Disponível em: <http:// news.bbc.co.uk/2/hi/africa/7824353.stm>. Acesso em: 11 jul. 2015.

21 FARNSDOR, Isaac ; SHERIDAN, Robert. Pirates board million-barrel oil tanker, ship owner says . Disponível em: $<$ http:// www.bloomberg.com/news/articles/2012-05-10/pirates-boardmillion-barrel-oil-tanker-ship-owner-says >. Acesso em: 11 jul. 2015. 22 MIDDLETON, Roger. Piracy in Somalia: threatening global trade, feeding local wars. London: Chatam House, 2008. Disponível em: <https://www.chathamhouse.org/sites/files/chathamhouse/ public/Research/Africa/1008piracysomalia.pdf>. Acesso em: 11 jul. 2015. p. 6. 
lações sobre o tema nos níveis internacional, regional e doméstico. O rampante crescimento no número de atos de pirataria numa das regiões com mais intensa atividade comercial no mundo acabou por forçar uma série de acordos internacionais e bilaterais e, ainda, resoluções do Conselho de Segurança das Nações Unidas, com os mais diversos temas. A maioria desses textos jurídicos tem como norte o reconhecimento da incapacidade da Somália em combater a "epidemia" de ataques na costa do país.

A resposta internacional ao problema foi objeto de atuação das mais diversas esferas de poder, passando não apenas pelas já mencionadas resoluções editadas pelo CSNU, mas também pela modificação de textos infraconstitucionais de países da região, além da atuação direta de países com interesses econômico-estratégicos na área e a relevante atuação de organismos não governamentais, de forma a criar esforços e mecanismos que fossem capazes de enfrentar a questão imposta pelo crescimento de casos de pirataria numa das mais importantes rotas comerciais do planeta.

Portanto, o estudo do caso da Somália, com suas já mencionadas especificidades, deve, necessariamente, passar por análise dos atos decorrentes da relevante resposta da comunidade internacional ao problema.

\subsection{Resoluções do Conselho de Segurança das Nações Unidas: a questão somali}

A primeira relevante Resolução do Conselho de Segurança das Nações Unidas (“CSNU”) em relação à Somália foi a Resolução 733, de 1992, que, durante o início da guerra civil naquele país, implementou um embargo sobre a entrega de armamentos e equipamento militar ${ }^{23}$.

Esse embargo geral e completo foi posteriormente modificado por outras resoluções, como por exemplo, a Resolução 1844, de 2008, que criou uma lista específica de pessoas e organizações que, não só não deveriam receber equipamentos militares, como também proibia qualquer tipo de atividade que pudesse vir a ter relação com atividades militares, como serviços financeiros, treinamento ou assistência técnica. Essa mesma resolução adotou, também, uma lista de pessoas que não

23 UNITED NATIONS SECURITY COUNCIL. Resolution 733, of 23 January 1992. Implementing an Arms Embargo on Somalia. Disponível em: <http://www.un.org/ga/search/view_doc. asp?symbol=S/RES/733\%281992\%29f $>$. Acesso em: 11 jul. 2015. deveriam ser autorizadas a entrarem em territórios dos países membros, até mesmo em caso de trânsito ${ }^{24}$. Muitas das pessoas citadas na lista estão, direta ou indiretamente, relacionadas com atos de pirataria ${ }^{25}$.

No ano de 2008, o CSNU aprovou cinco Resoluções concernentes à pirataria na Somália ${ }^{26}$, todas sob o crivo do Capítulo VII da Carta das Nações Unidas, que autoriza o CSNU ao uso de força militar contra ameaças à segurança internacional.

Em junho de 2008, levando-se em consideração a crise na Somália, e "a incapacidade do Governo Federal Transitório em impedir atos de pirataria ou patrulhar e garantir a segurança dos corredores de navegação internacional próximos à costa da Somália ou de seu mar territorial" 27 e que "O Governo Federal transitório da Somália necessita e aceitaria assistência internacional para resolver o problema”, o Conselho de Segurança edita a Resolução 1816, autorizando e encorajando os Estados engajados na luta contra a pirataria na costa da Somália a, num período de 6 (seis) meses, tomar as mesmas medidas permitidas no combate e repressão a esse delito, também, nas águas territoriais daquele país, abrindo exceção à limitação territorial quanto ao apresamento de um navio pirata ${ }^{28}$.

24 UNITED NATIONS SECURITY COUNCIL. Resolution 1844, adopted by the Security Council at its 6019th meeting, on 20 November 2008. Disponível em: <http://www.un.org/ga/search/view_doc. asp? symbol=S/RES $/ 1844 \% 282008 \% 29$ > . Acesso em: 11 jul. 2015. 25 UNITED NATIONS SECURITY COUNCIL. Resolution 1844, adopted by the Security Council at its 6019th meeting, on 20 November 2008. Disponível em: <http://www.un.org/ga/search/view_doc. asp? symbol=S/RES $/ 1844 \% 282008 \% 29>$. Acesso em: 11 jul. 2015. p. 8 .

26 UNITED NATIONS SECURITY COUNCIL. Resolution 1814, adopted by the Security Council at its 6019th meeting, on 15 May 2008. Disponível em: <http://www.un.org/en/ga/search/view_ doc.asp?symbol=S/RES $/ 1814 \% 282008 \% 29>$. Acesso em: 11 jul. 2015

27 Tradução livre dos seguintes trechos da Resolução 1816 (2008) do Conselho de Segurança das Nações Unidas, p.1: "the lack of capacity of the Transitional Federal Government (TFG) to interdict pirates or patrol and secure either the international sea lanes off the coast of Somalia or Somalia's territorial waters" e "“"the Transitional Federal Government of Somalia (TFG) needs and would welcome international assistance to address the problem". UNITED NATIONS SECURITY COUNCIL. Resolution 1814, adopted by the Security Council at its 5902nd meeting on 2 June 2008. Disponível em: <http://www.un.org/en/ga/search/view_doc.asp?symbol=S/ RES/1816\%282008\%29>. Acesso em: 11 jul. 2015.

28 O artigo 105 da CNUDM, em seu artigo 105, permite que autoridades navais estrangeiras atuem contra a pirataria, tão somente, em águas internacionais. Isso acabava por permitir que os piratas que cometiam ataques em águas internacionais rapidamente buscassem refúgio no mar territorial da Somália, utilizando as car- 
Relevante destacar, também, a Resolução 1851. Reconhecendo o CSNU que as atividades ilícitas realizadas pelos piratas têm como base o território somali, entendeu, em conjunto com o Governo Federal Transitório, que seria essencial estender a autorização para operações militares contra pirataria também para o solo e espaço aéreo daquele país. A entrada em território somali $3 / 4$ tanto no mar territorial quanto no solo $3 / 4$ estaria condicionada à autorização do GFT.

Segundo Kontorovich ${ }^{29}$, autorizar ações armadas contra piratas em território soberano de um país foi medida sem precedentes do CSNU. Essas resoluções do CSNU deixaram os Estados com histórico de pirataria, como a Indonésia, por exemplo, apreensivos, o que levou a redação das citadas resoluções a destacar que estas seriam aplicáveis tão-somente à situação da Somália e não criariam precedentes para o direito internacional. Durante os debates sobre a redação da Resolução 1816 do CSNU, a África do Sul afirmou que "a situação na Somália constitui ameaça à paz e segurança internacional, não a pirataria por si só” 30 . Desde que seja respeitada a determinação de que é necessária prévia autorização do governo da Somália, parece ser salutar a Resolução, tendo em vista que veio a requerimento do GFT, ao reconhecer sua inabilidade em defender seu território.

No entanto, uma questão que não é abordada nas resoluções sobre o assunto consiste em quem seria o responsável por julgar os piratas apreendidos em águas territoriais somalis. Quanto às capturas ocorridas em alto mar, não há dúvidas que o país que realiza essa captura

acterísticas geográficas do Golfo do Áden a seu favor. BRASIL. Decreto $n^{\circ} 1.530$, de 22 de junho de 1995. Declara a entrada em vigor da Convenção das Nações Unidas sobre o Direito do Mar, concluída em Montego Bay, Jamaica, em 10 de dezembro de 1982. Disponível em: <http://www.planalto.gov.br/ccivil_03/decreto/1995/D1530. htm>. Acesso em: 11 jul. 2015.

29 KONTOROVICH, Eugene. An empirical examination of universal jurisdiction for piracy. Chicago: Northwestern Law, 2010. Disponível em: <http://scholarlycommons.law.northwestern.edu/cgi/viewcontent.cgi? article $=1037 \&$ context $=$ facultyworkingpapers $>$. Acesso em: 11 jul. 2015. p. 17.

30 Tradução livre do seguinte trecho do Security Council Condemns Acts Of Piracy, Armed Robbery Off Somalia's Coast', United Nations Department of Public Information Press Release of 2 June 2008: "it was the situation in Somalia that constituted a threat to international peace and security, and not piracy in itself". UNITED NATIONS SECURITY COUNCIL. Resolution 1816, adopted by the Security Council at its 5902nd meeting on 2 June 2008. Disponível em: <http://www.un.org/en/ga/search/view_doc.asp?symbol=S/ RES/1816\%282008\%29>. Acesso em: 11 jul. 2015. tem o direito de realizar os julgamentos perante suas cortes, sem a necessidade de consultar outros países. O texto da Resolução 1816, no entanto, não cria uma aplicabilidade direta do direito internacional no território da Somália.

O texto das resoluções é demasiadamente amplo, determinando, apenas, que os Estados interessados cooperem na determinação da jurisdição ${ }^{31}$. Para o Professor Douglas Guilfoyle, como a entrada em território somali para exercer jurisdição ${ }^{32} \mathrm{em}$ relação à pirataria está condicionada à autorização do GFT, estaria também nas mãos do governo provisório decidir quem deveria exercer a jurisdição sobre os piratas aprisionados ${ }^{33}$. Para Colin Warbrick, no mesmo sentido, "competência legal para perseguir e aprisionar embarcações, nos moldes garantidos pela Resolução 1816 do Conselho de Segurança das Nações Unidas não seria o mesmo que competência para julgar os acusados de pirataria"34.

Como o número de piratas sendo libertados sem o devido julgamento aumentava, foram editadas Resoluções que buscavam a facilitação da acusação de suspeitos de pirataria. A Resolução 1897 (2009) encoraja Estados a celebrar acordos que autorizem governos a embarcar agentes em navios que atuem na coalizão anti pirataria com o propósito de facilitar a investigação, detenção e eventual acusação formal e julgamento dos suspeitos de pirataria. A Resolução 1918 (2010), por

31 UNITED NATIONS SECURITY COUNCIL. Resolution 1816, adopted by the Security Council at its 5902nd meeting on 2 June 2008. Disponível em: <http://www.un.org/en/ga/search/view_doc. asp? symbol=S/RES $/ 1816 \% 282008 \% 29>$. Acesso em: 11 jul. 2015. p. 3.

32 O locus specialis (alto mar ou qualquer lugar fora da jurisdição de um Estado) da pirataria envolve características especiais em sua repressão. O art. 105 da CNUDM tem como norte a aplicação da jurisdição universal criminal, que é diferida pela prática e pela doutrina em duas, dependendo se o suspeito está presente no território do Estado que exerce a sua jurisdição (universal jurisdiction in absentia) ou em outro lugar (conditional universal jurisdiction).

33 GUILFOYLE, Douglas. II. Piracy off Somalia: UN security council resolution 1816 and IMO Regional counter-piracy efforts. International and Comparative Law Quarterly, Cambridge, v. 57, n. 3, p. 690-699, July, 2008. p. 690-691.

34 Em tradução livre do seguinte trecho de WARBRICK, Colin. Piracy off Somalia: UN Security Council Resolution 1816 and IMO Regional Counter-Piracy Efforts, Cambridge Journal, 2009, p. 697: “Legal authority to pursue and arrest the vessel as granted by UNSCR 1816 (enforcement jurisdiction) is not the same thing as authority to try the offenders (prescriptive and adjudicative jurisdiction)". WARBRICK, Colin; MCGOLDRIC, Dominic; GUILFOYLE, Douglas. Piracy off Somalia: UN Security Council Resolution 1816 and IMO Regional Counter-Piracy Efforts. International and Comparative Law Quarterly, Kingdom, v. 57, n. 3, p. 690-699, July, 2008. 
sua vez, orienta os países membros a criminalizarem a pirataria em seus textos legais nacionais e a considerar favoravelmente o julgamento e aprisionamento de suspeitos de pirataria. Um passo adiante, a Resolução 1950 recomenda que os Estados membro tomem as medidas apropriadas, em suas legislações pátrias, para prevenir o financiamento de atos de pirataria e impedir a lavagem do dinheiro oriundo daqueles atos, bem como aprofundar a investigação de redes de organizações criminosas internacionais envolvidas com atos de pirataria na região da Somália, incluindo aqueles envolvidos apenas no financiamento do ilícito ${ }^{35}$.

E, ainda, a Resolução 1976, que, além de tratar do tema da pesca ilegal e exploratória nas águas territoriais da Somália, enfatiza a importância da criminalização não apenas do crime de pirataria mas, também, das ações de financiamento e facilitação do cometimento desse crime, bem como a necessidade de investigação e persecução judicial daqueles que financiam, planejam, organizam ou ilegalmente lucram com os ataques piratas na região costeira da Somália e suas adjacências ${ }^{36}$.

\subsection{ACORDOS INTERNACIONAIS PARA JULGAMENTO DE SUSPEITOS DE PIRATARIA}

Em resposta à Resolução 1918 do CSNU ${ }^{37}$, alguns Estados buscaram adequar suas legislações nacionais às recomendações daquele Órgão Internacional e harmonizar suas definições de pirataria com a do artigo 101 da CNUDM.

35 Res. CSNU 1950, \$11. UNITED NATIONS SECURITY COUNCIL. Resolution 1950, adopted by the Security Council at its 6429th meeting, on 23 November 2010. Disponível em: <http://www.un.org/en/ga/search/view_doc.asp?symbol=S/ RES $/ 1950 \% 282010 \% 29>$. Acesso em: 11 jul. 2015.

36 Res. CSNU 1976, §8. UNITED NATIONS SECURITY COUNCIL. Resolution 1976, adopted by the Security Council at its 6512th meeting, on 11 April 2011. Disponível em: <http://www.un.org/en/ $\mathrm{ga} / \mathrm{search} /$ view_doc.asp?symbol=S/RES/1976\%282011\%29>. Acesso em: 11 jul. 2015.

37 "[...]exorta assim todos os Estados, nomeadamente os da região, a considerarem a pirataria um crime no seu direito interno e a encararem favoravelmente a instauração de processos às pessoas suspeitas de pirataria que tenham sido capturadas ao largo das costas somalis e a condenarem a prisão as que forem consideradas culpadas, no respeito do direito internacional e dos direitos humanos". UNITED NATIONS SECURITY COUNCIL. Resolution 1918, adopted by the Security Council at its 6301th meeting, on 27 April 2010. Disponível em: <http://www.un.org/en/ga/search/view_doc. asp?symbol=S/RES/1918\%282010\%29>. Acesso em: 11 jul. 2015.
Julgamentos nos Tribunais dos países que capturam os piratas são preferíveis sob o escopo da CNUDM. No entanto, na prática, essa orientação foi pouco implementada, principalmente pela dificuldade que o país apreendedor tem com questões de logística, como a coleta de evidências e a transferência até seu território, que não raro fica à enorme distância do local da captura.

Países da região, como o Quênia, Seychelles e Ilhas Maurício fizeram acordos com países que compõem a flotilha responsável pelo combate à pirataria para julgar piratas aprisionados. Segundo o Escritório das Nações Unidas sobre Drogas e Crime ("ENUDC"), mais de mil piratas somalis estão enfretando julgamento ou já foram condenados em mais de 20 países $^{38}$.

O estabelecimento desses acordos é encorajado por várias resoluções do Conselho de Segurança. Em particular, as Resoluções 1816 (2008) e 1846 (2008), recomendam os Estados membros a cooperar "na determinação da competência jurisdicional, e na investigação e acusação de pessoas responsáveis por atos de pirataria e roubo armado [contra embarcações] for a do mar territorial da Somália" 39 . As duas resoluções ressaltam, também, que todas as medidas tomadas devem estar de acordo com o direito internacional e, em especial, com respeito aos direitos humanos.

Nesse ponto também é importante a já mencionada atuação do ENUDC, por meio de seu Counter-Piracy Programme, que atua diretamente com os governos dos Estados que julgam suspeitos de pirataria em seus Tribunais.

Kontorovich ${ }^{40}$ levanta relevante ponto ao discutir a legalidade da transferência a terceiros dos capturados pelas marinhas que patrulham a região. $\mathrm{O}$ motivo da preocupação do autor vem do fato de que o artigo 105 da CNUDM, ao codificar o exercício da jurisdição universal nos casos de pirataria, traz que "As cortes do Es-

38 UNITED NATIONS OFFICE ON DRUGS AND CRIME. Counter-Piracy Programme: support to the trial and related treatment of piracy suspects. Issue Six: June 2011. Disponível em: <http:// www.unodc.org/documents/Piracy/UNODC_Brochure_Issue_6_ WV.pdf/>. Acesso em: 11 jul. 2015.

39 Em tradução livre. UNITED NATIONS SECURITY COUNCIL. Resolution 1816, adopted by the Security Council at its 5902nd meeting on 2 June 2008. Disponível em: <http://www.un.org/en/ga/search/ view_doc.asp?symbol=S/RES $/ 1816 \% 282008 \% 29>$. Acesso em: 11 jul. 2015.

40 KONTOROVICH, Eugene. Piracy and international law. Feb. 2009. Disponível em: <http://jcpa.org/article/piracy-and-international-law/>. Acesso em: 11 jul. 2015. p. 56. 
tado que realizou a captura pode decidir quais serão as penas a serem impostas, bem como determinar o que será feito com relação às embarcações, aeronaves ou propriedades, objeto de direito de um terceiro, atuando em boa-fé", não deixando, portanto, previsão expressa da possibilidade da entrega. As Resoluções do Conselho de Segurança, em especial a Resolução 1897 (2009), no entanto, parecem resolver a questão, ao incentivar a prática.

\subsubsection{Adequações legislativas no Quênia: respos- ta de países da região}

Desde 2006, o Quênia, após acordos com o Reino Unido, Estados Unidos da América, União Europeia e Dinamarca, entre outros, recebe piratas aprisionados por esses Estados, exercendo, ativamente, a jurisdição universal ${ }^{41}$.

Até 2009, os piratas eram julgados no Quênia sob o escopo do Código Penal Queniano (CPQ), que, em seu artigo $69^{42}$, determinava: "qualquer pessoa que, em águas territoriais ou em alto mar, comete qualquer ato de pirataria jure gentium é culpada pelo crime de pirataria"43.

O primeiro caso de julgamento de acusados por pirataria no Quênia foi o " $\mathrm{R}$ \%. Hassan M. Ahmed and 9 Others" ${ }^{3}$, no qual foram acusados, segundo o artigo 69 do CPQ, sob alegação de que teriam atacado e sequestrado uma embarcação indiana, o MV Safina Al Bisarat. A defesa alegou que, como os acusados não eram cidadãos quenianos e os fatos ocorreram fora do território desse país, a Corte não poderia exercer sua jurisdição sobre os acusados ${ }^{45}$.

41 GATHII, James Thuo. Kenya's piracy prosecutions. American Journal of International Law, Washington, n. 104, p. 416-436, Oct. 2010. p. 416-417.

42 O artigo 69 do referido Código foi revogado em 2009, quando entrou em vigor o Merchants and Shipping Act. REPUBLIC OF KENYA. Penal Code. The Official Law Reports of the Republic of Kenya: the Penal Code, 2009. Disponível em: <https://www.unodc. org/tldb/pdf/Kenya_Penal_Code_Full_text.pdf>. Acesso em: 11 jul. 2015.

43 Em tradução livre do The Official Law Reports of the Republic of Kenya: The Penal Code, 2009. REPUBLIC OF KENYA. Penal Code. The Official Law Reports of the Republic of Kenya: The Penal Code, 2009. Disponível em: <https://www.unodc.org/tldb/ pdf/Kenya_Penal_Code_Full_text.pdf $>$. Acesso em: 11 jul. 2015.

44 REPUBLIC OF KENYA. The High Court Of Kenya. 2009. Judge 12 Mayo, Hassan M. Ahmed vs Republic. Case N. 434. Disponível em: <http://kenyalaw.org/caselaw/cases/view/55714>. Acesso em: 11 jul. 2015.

45 REPUBLIC OF KENYA. The High Court Of Kenya. 2009.
O julgador do caso, citando o artigo 101 da CNUSM, defendeu a capacidade jurisdicional do Tribunal em julgar casos ocorridos além das águas territoriais do Quênia, sentenciando os acusados a sete anos de prisão. Tal decisão foi apelada, no entanto, e a Corte Superior de Mombasa ${ }^{46}$ manteve o entendimento do "Learned Principal Magistrate", afirmando:

no julgamento, a Il. Sra. Mwangi, promotora pública, informou o Juízo a quo que a Convenção das Nações Unidas sobre o Direito do Mar havia sido ratificada pelo Quenia e que o Quenia havia internalizado a Convenção. $\mathrm{Na}$ audiência de julgamento dessas apelaçoes, o Exmo. Sr. Onserio apoiou-se nas informação dada pela Il. Sra. Mwangi durante o julgamente de que a Convenção havia sido ratificado e internalizada. Os advogados dos apelantes não apresentaram uma visão divergente. De fato, o status da Convenção no Quenia parece ter sido aceito pelos advogados dos apelantes. Nessas circunstancias, eu devo determinar que o Juízo a quo é obrigado a aplicar as provisoes da Convenção, caso exista alguma lacuna no nosso Código Penal e Código de Processo Penal.

Eu iria além, ainda que a Convenção não tivesse sido ratificada e internalizada, o Juízo a quo estaria obrigado a aplicar as normas e procedimentos internacionais, uma vez que o Quenia é membro do mundo civilizado e não se espera que o país aja em contradição com as expectativas dos estados membros das Nações Unidas ${ }^{47}$.

Judge 12 Mayo, Hassan M. Abmed vs Republic. Case N. 434. Disponível em: <http://kenyalaw.org/caselaw/cases/view/55714>. Acesso em: 11 jul. 2015.

46 Superior Court of Mombasa, em tradução livre. REPUBLIC OF KENYA. The High Court Of Kenya. 2009. Judge 12 Mayo, Hassan M. Abmed vs Republic. Case N. 434. Disponível em: <http:// kenyalaw.org/caselaw/cases/view/55714>. Acesso em: 11 jul. 2015. 47 Tradução livre de trecho da Decisão proferida pela Corte Superior de Mombasa no Criminal Case 434 de 2006: "At the trial Mrs. Mwangi, the Learned Assistant Deputy Public Prosecutor informed the Learned Principal Magistrate that the United Nations Convention on the Law of the Sea had been ratified by Kenya and that Kenya had domesticated the Convention. At the hearing of these appeals, Mr. Onserio relied upon Mrs. Mwangi's submissions at the trial on her contention that the said Convention had been ratified and domesticated. A contrary view was not given by counsel for the appellants. Indeed that status of the Convention in Kenya seems to have been accepted by counsel for the appellants. In the circumstances, I must hold that the Learned Principal Magistrate was bound to apply the provisions of the Convention should there have been deficiencies in our Penal Code and Criminal Procedure Code. I would go further and hold that even if the Convention had not been ratified and domesticated, the Learned Principal Magistrate was bound to apply international norms and Instruments since Kenya is a member of the civilized world and is not expected to act in contradiction to expectations of member states of the United Nations". REPUBLIC OF KENYA. The High Court Of Kenya. 2009. Judge 12 Mayo, Hassan M. Abmed vs Republic. Case N. 434. Disponível em: <http://kenyalaw.org/caselaw/cases/view/55714>. Acesso em: 11 
As Cortes do Quênia passaram, então, a adotar o referido caso como precedente em suas decisões. No entanto, em maio de 2009, esse entendimento sofreu uma reviravolta. No caso Mohamed Dashi \& Others, alegou, a defesa, que:

\begin{abstract}
a competência jurisdicional para as que as cortes julguem matérias penais é prevista no artigo $5^{\circ}$ do Código Penal, que estende a competência territorial a todo território queniano, incluindo o seu mar territorial. Se o Código Penal restringe a jurisdição ao mar territorial do país, qual seria a base legal para que a Corte estenda a sua competência jurisdicional a crimes cometidos em alto mar?
\end{abstract}

A Corte Superior decidiu que, de fato, a expressão "alto mar", em respeito a até onde pode ser aplicada a jurisdição dos tribunais quenianos, trazida no artigo 69 do $\mathrm{CPQ}$, é inconsistente com o artigo $5^{\circ}$ desse mesmo código $^{48}$.

Com esse novo entendimento jurisprudencial, o legislativo queniano editou, ainda em 2009, o The Merchant Shipping Act, que adotou a definição mais abrangente de pirataria da CNUDM, trazendo sua legislação à conformidade dos standards internacionais. A nova redação amplia a aplicabilidade a atos cometidos "-se o navio... estiver no Quênia ou em outro local; se os crimes forem cometidos no Quenia ou em outro local; e seja qual for a nacionalidade do autor do crime" ${ }^{49}$. O artigo 371, por sua vez, determina que a pena aos condenados por pirataria pode ser de prisão perpétua.

Guilfoyle $^{50}$ faz nota de que o julgamento nas cortes quenianas poderia ser dificultoso, tendo em vista que o direito desse país exige que o testemunho seja dado pessoalmente, não sendo suficiente uma "declaração prestada sob juramento" ("sworn statement") e que não

jul. 2015.

48 Artigo $5^{\circ}$ do Código Penal da República do Quênia: The jurisdiction of the courts of Kenya for the purposes of this Code extends to every place within Kenya, including territorial waters. REPUBLIC OF KENYA. Penal Code. The Official Law Reports of the Republic of Kenya: The Penal Code, 2009. Disponível em: $<$ https://www.unodc.org/tldb/pdf/Kenya_Penal_Code_Full_text. pdf $>$. Acesso em: 11 jul. 2015.

49 Tradução livre do Artigo 370 (4) do "The Merchant Shipping Act, 2009". REPUBLIC OF KENYA. Penal Code. The Official Law Reports of the Republic of Kenya: The Penal Code: Merchant Shipping Act, chapter 389. 2009. Disponível em: <http://faolex.fao. org/docs/pdf/ken94222.pdf>. Acesso em: 11 jul. 2015.

50 GUILFOYLE, Douglas. Somália: responding to the legal challenges of offshore piracy. In: HARVARD HUMANITARIAN LAW AND POLICY FORUM, 2009, Cambridge. Program on Humanitarian Policy and Conflict Research. Cambridge: Harvard Humanitarian Initiative, 2009. seria prático o transporte de vítimas e testemunhas para participar dos julgamentos.

Muito embora a indigitada ressalva feita pelo acadêmico britânico, as cortes Quênianas julgaram, até outubro de 2014, 160 suspeitos de pirataria capturados pelas forças navais atuantes na região do Golfo de Áden. Destes, um total de 143 foram condenados, tendo 42 sido repatriados para cumprirem pena na Puntlândia, por meio do Piracy Prisoner Transfer Programme ("PPTP") ${ }^{51}$.

\subsubsection{Adequações legislativas em Seychelles: res- posta de países da região}

Em 2010, acompanhando as iniciativas quenianas em exercer a jurisdição universal sobre piratas somalis, a República das Seychelles firmou acordos para julgar piratas apreendidos pela EU-NAVFOR, força naval captaneada pela União Europeia.

O Código Penal de Seychelles criminaliza a pirataria em seu artigo 65, que possuía, ao tempo dos primeiros julgamentos advindos dos acordos internacionais, a seguinte redação: qualquer pessoa culpada por pirataria ou qualquer crime que tenha ligaçao ou relação ou semelhança com a pirataria deverá ser julgada e punida conforme a Lei da Inglaterra pelo tempo em que estiver em vigor" ${ }^{52}$ A oração "pelo tempo em que estiver em vigor" ("for the time being in force"), criou grande indeterminação interpretativa. O Código Penal das Seychelles foi promulgado em 1955, quando esse país ainda não era independente da Inglaterra (fato que só ocorreu em 1976). A expressão se refere à legislação inglesa à época da promulgação do Código Penal? À legislação britânica à época da independência das Seychelles? Ou ainda, à legislação ao tempo em que ocorreu o ato de pirataria? ${ }^{53}$.

51 UNITED STATES COMMISSION ON INTERNATIONAL RELIGIOUS FREEDOM. Somalia. In: __. Annual Report 2009. Washington: USCIRF, May. 2009. Disponível em: <http:// www.uscirf.gov/sites/default/files/resources/AR2009/somalia. pdf $>$. Acesso em: 11 jul. 2015. p. 12.

52 REPUBLIC OF SEYCHELLES. Penal Code (1955). The Penal Code. Disponível em: <http://www.seylii.org/sc/legislation/consolidated-act/158>. Acesso em: 11 jul. 2015.

53 Para mais sobre o artigo 65 do Código Penal de Seychelles, artigo escrito por Justice Anthony Francis Tissa Fernando. REPUBLIC OF SEYCHELLES. Penal Code (1955). The Penal Code. Disponível em: <http://www.seylii.org/sc/legislation/consolidated-act/158>. Acesso em: 11 jul. 2015. Após a supracitada modificação legislativa no Código Penal daquele país, o princípio da jurisdição universal foi recebido pelo código, em seu artigo 60 (2), com a seguinte redação: Notwithingstanding the provisions of section 6 and any other written law, the courts of Seychelles shall have jurisdiction to try an 
A resposta a essas perguntas veio logo no primeiro julgamento de piratas naquele país, $\mathrm{R} v$. Mohamed Abmed Dabir \& 10 Others $^{54}$. A Corte Suprema de Seychelles decidiu que a expressão "for the time being in force" se referia à legislação britânica atinente à pirataria no dia 29 de junho de 1976, data da independência das ilhas africanas, sendo aplicável, portanto, ao caso, mesmo em 2009, 33 (trinta e três) anos após o fim da colonização inglesa.

Para evitar maiores discussões em torno da matéria, houve reforma legislativa do Código Penal ${ }^{55}$, e o artigo 65 passou a ter a seguinte redação "Qualquer pessoa que comete qualquer ato de pirataria em Seychelles ou em qualquer outro lugar é culpada pelo cometimento de um crime e está sujeita à detenção por 30 anos", adotando, posteriormente, no art. 65 (4) exatamente a mesma definição do art. 101 da CNUDM. Importante para a efetivação da jurisdição universal o uso da expressão "ou em qualquer outro lugar" ("or elsewhere") no indigitado artigo, reafirmando a vontade do governo em auxiliar no julgamento dos acusados.

Segundo relatório das Nações Unidas, de outubro de 2014, Seychelles havia condenado 129 (cento e vinte e nove) piratas em suas cortes, de um total de 133 julgados ${ }^{56}$, com apenas 14 (catorze) ainda aguardando julgamento ${ }^{57}$.

No entanto, apesar do animus do governo Seichelense, seu sistema prisional não possui capacidade para manter aprisionados os piratas condenados em seus

offence of piracy whether the offence is committed within the territory of Seychelles or outside the territory of Seychelles.

54 REPUBLIC OF SEYCHELLES. The Supreme Court Of Seychelles. 2010. Judge 26 July, The Republic Vs Mohamed Abmed Dabir e Ten (10) Others. Criminal Side No. 51 of 2009. Disponível em: <http://www.seylii.org/files/sc/judgment/supremecourt/2010/86/86_0.pdf>. Acesso em: 11 jul. 2015.

55 Código Penal de Seychelles (com as mencionadas alterações legislativas). REPUBLIC OF SEYCHELLES. Penal Code (1955). The Penal Code. Disponível em: <http://www.seylii.org/sc/legislation/ consolidated-act/158>. Acesso em: 11 jul. 2015; REPUBLIC OF SEYCHELLES. Penal Code. Amendmenti Bili, 2010. Disponível em: <http://ddata.over-blog.com/xxxyyy/0/50/29/09/Docs-Textes/ CodePenalSeychellesAmend-Sey100311.pdf $>$. Acesso em: 11 jul. 2015.

56 UNITED NATIONS DRUGS AND CRIME. Counter-Piracy Programme: support to the trial and related treatment of piracy suspects, Issue Nine: July 2012. Disponível em: <https://www.unodc. org/documents/easternafrica/piracy/UNODC_Brochure_Issue_9_Final_webversion.pdf $>$. Acesso em: 11 jul. 2015. p. 16. 57 UNITED NATIONS OFFICE ON DRUGS AND CRIME. Maritime Crime Programme: Indian Ocean. Disponível em: <https:// www.unodc.org/unodc/en/piracy/indian-ocean-division.html>. Acesso em: 11 jul. 2015. tribunais. Para solucionar a questão, o governo dessas ilhas firmou acordos com o GFT, Puntlândia e Somalilândia para repatriar piratas a essas regiões, uma vez que seus sistemas prisionais sejam considerados adequados pelas autoridades das Nações Unidas ${ }^{58}$. Em março de 2012, ocorreu a primeira transferência de condenados por pirataria nas Ilhas Seychelles para prisões em Hargeisa, Somalilândia.

\subsubsection{Adequações legislativas na Somalilândia, Puntlândia e outros Estados da região}

Ainda que com situações políticas distintas, a Somalilândia e a Puntlândia enfrentam a questão da pirataria de forma bem similar, principalmente porque ambas têm como base a legislação da própria Somália.

A lei mais relevante aplicável à pirataria é o Código Marítimo da Somália, de 1959, que traz, em seu artigo 205, a seguinte determinação: o comandante ou oficial da Somalilândia ou de embarcações estrangeiras que comete atos de depredação para causar danos a embarcações da Somalilândia ou estrangeiros ou a sua carga, ou com o propósito de cometer atos de violência contra as pessoas a bordo das embarcações da Somalilândia ou estrangeiras serão punidas com detenção de 10 a 20 $\operatorname{anos}^{59}$.

Também podem ser acusados pelos mesmos atos, na Puntlândia e na Somalilândia, pelos crimes de devastation, pillage and slanghter, previsto no artigo 222 do Código Penal somali, association for purpose of committing a crime (Art. 322); devastation and pillage, (Art. 324); extortion (Art. 485); and detention of a person for the purpose of robbery or extortion (Art. 486) ${ }^{60}$.

Utilizando esses artigos, a justiça da Somalilândia conseguiu aprisionar diversos piratas capturados por forças estrangeiras. No entanto, ao contrário do que ocorre na Puntlândia, as cortes daquela região exercem sua jurisdição exclusivamente sobre crimes que tenham

58 UNITED NATIONS OFFICE ON DRUGS AND CRIME. Counter-Piracy Programme: support to the trial and related treatment of piracy suspects. Issue Six: June 2011. Disponível em: <http:// www.unodc.org/documents/Piracy/UNODC_Brochure_Issue_6_ WV.pdf/>. Acesso em: 11 jul. 2015. p. 9.

59 Em tradução livre. SOMALI. Maritime Code, 1959. Disponível em: <http://www.somalilandlaw.com/Somali_Maritime_Code. pdf>. Acesso em: 11 jul. 2015.

60 SOMALI pirates jailed in US over American deaths. . Disponível em: <http://www.bbc.com/news/world-us-canada-24954797>. Acesso em: 11 jul. 2015. 
alguma conexão com a Somalilândia, como por exemplo, crimes cometidos no território ou por naturais dessa área.

Para auxiliar esses governos, a ENUDC, em conjunto com o GFT e os governos da Puntlândia e da Somalilândia, realizaram estudos e redigiram lei "contra a pirataria", utilizando como base o artigo 65 do Código Penal de Seychelles e o artigo 101 da CNUDM, abrindo espaço para realização de julgamentos sob o princípio da jurisdição universal. A Puntlândia adotou a nova lei, em dezembro de 2010, punindo o crime de pirataria com 5 a 20 anos de prisão e multa; a Somalilândia, por sua vez, apenas promulgou a legislação em março de 2012.

Outro problema encontrado pelas forças navais que atuam na região consiste em adequar suas operações às legislações nacionais. Diversas vezes, piratas detidos pelas forças navais estrangeiras permanecem detidos por dias nas embarcações até serem entregues ao terceiro país interessado em realizar o julgamento. Essa prática, no entanto, viola as normas legais da Puntlândia e da Somalilândia, que determinam que, uma vez detidos, os acusados devem ser trazidos perante uma Corte em no máximo 48 horas $^{61}$.

Apesar dos esforços de seus governos, a realidade nessas regiões ainda é precária. Existem inúmeras notícias de periódicos somalis sobre tentativas de resgates de piratas aprisionados nessas duas regiões, que, usualmente, terminam com diversas mortes ${ }^{62}$.

Outros Estados da região também atuam nos julgamentos. Segundo dados da ENUDC ${ }^{63}$, o Iêmen, até 2011, já havia condenado mais de 120 piratas somalis; Omã condenou 12 e a Tanzânia havia condenado 8 piratas, com mais 12 aguardando julgamento. Contudo,

61 Art. 2(4) da Constituição da Puntlândia. PUNTLAND. Constitution (2000). Constitution of Puntland Regional Government. Disponível em: <http://www.refworld.org/pdfid/4bc589e92.pdf>. Acesso em: 11 jul. 2015. E art. 27(2) da Constituição da Somalilândia. SOMALI. Constitution (2001). Constitution of The Republic of Somaliland. Disponível em: <http://www.somalilandlaw.com/somaliland_constitution.htm>. Acesso em: 11 jul. 2015.

62 YOUNG, Robert. Somalia report: weekly piracy report. 2012. Disponível em: <http://www.somaliareport.com/index.php/ post/3584/Weekly_Piracy_Report>. Acesso em: 11 jul. 2015.

63 UNITED NATIONS OFFICE ON DRUGS AND CRIME. Counter-Piracy Programme: support to the trial and related treatment of piracy suspects. Issue Six: June 2011. Disponível em: <http:// www.unodc.org/documents/Piracy/UNODC_Brochure_Issue_6_ WV.pdf/>. Acesso em: 11 jul. 2015. p. 9. apesar do histórico de julgamentos, esses países ainda não fazem parte de acordos de julgamentos "em larga escala".

\subsection{Resposta de Estados Com Interesses na QUESTÃo}

Com a escalada dos casos de pirataria a partir de 2008, alguns Estados, de forma independente ou atuando por meio de forças de coalizão, enviaram forças navais para patrulhar a região do Golfo do Áden e, após a entrada em vigor das Resoluções do CSNU, as águas territoriais da Somália.

Como exemplo, temos a Organização do Tratado do Atlântico Norte, que já lançou 3 (três) missões navais distintas para combater a pirataria na região: a primeira, a Operation Allied Power, foi responsável pela proteção dos navios de ajuda humanitária do Programa Mundial de Alimentação das Nações Unidas (WFP); a segunda, a Operation Allied Protector, cujo objetivo era contribuir para a segurança das rotas de comércio marítimo e navegação internacional, detendo, defendendo e desmantelando atividades de pirataria na regiã ${ }^{64}$; em substituição à essa missão, veio a terceira, a Operation Ocean Shield, em operação até o fim de 2012.

Existe também uma força naval da União Europeia, a EU-NAVFOR Operation ATALANTA que, em dezembro de 2008, substituiu a operação da OTAN na proteção das embarcações do WFP e foi autorizada a empregar as medidas necessárias, incluindo o uso da força, para deter, prevenir e intervir para interromper os atos de pirataria que possam ocorrer na região onde esteja presente ${ }^{65}$.

Ainda na região atua uma força tarefa multinacional, a Combined Task Force 151 (CTF-151) em resposta às resoluções 1816, 1831, 1846, 1851 e 1897 do CSNU.

64 UNITED NATIONS SECURITY COUNCIL. Report of the Secretary-General pursuant to Security Council resolution 1897 (2009). 27 Oct. 2010. Disponível em: < http://daccess-dds-ny. un.org/doc/UNDOC/GEN/N10/588/02/PDF/N1058802. pdf?OpenElement>. Acesso em: 11 jul. 2015. p. 9.

65 ACTS Adopted Under title $\mathrm{v}$ of the EU Treaty Council Joint Action 2008/851/CFSP: of 10 November 2008, on a European Union military operation to contribute to the deterrence, prevention and repression of acts of piracy and armed robbery off the Somali coast. <http://eur-lex.europa.eu/LexUriServ/LexUriServ.do?uri= OJ:L:2008:301:0033:0037:EN:PDF>. Acesso em: 11 jul. 2015. 
A CTF-151 auxilia as forças da OTAN e da EU-NAVFOR no patrulhamento do Internationally Recommended Transit Corridor, no Golfo do Áden, protegendo o comércio marítimo mundial e assegurando a liberdade de navegação ${ }^{66}$.

Além do envio de forças militares, países como a França, Estados Unidos, Holanda, Itália, Espanha e Alemanha ${ }^{67}$ realizaram o julgamento de piratas capturados em suas Cortes nacionais, uma vez que havia interesse envolvido na questão. Entretanto, um dos julgamentos ocorridos na Holanda condenou piratas que capturaram um iate sul-africano, que nada tinha a ver com interesses desse país. Este constitui um dos únicos casos de aplicação de jurisdição internacional por governos europeus.

\subsubsection{Participação da ONU por meio do Escritório das Nações Unidas sobre Drogas e Crime - ENUDC}

O Escritório das Nações Unidas sobre Drogas e Crime ("ENUDC") criou, em 2009, o Counter-Piracy Programme ("CPP") com o objetivo de auxiliar o Quênia a lidar com a questão da pirataria na Somália. Atualmente outros 5 países foram incluídos nessa lista: Ilhas Seychelles, Ilhas Maurício, Tanzânia, Maldivas e Somália.

O foco do CPP é assegurar "julgamentos justos e eficientes e detenções em centros regionais, prisões seguras e humanas na Somália, e julgamentos justos e

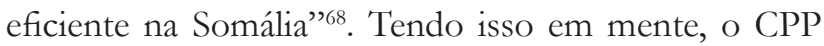
proporciona transporte para que vítimas e testemunhas possam participar dos julgamentos, provê intérpretes para que os suspeitos possam seguir os procedimentos legais, dá suporte técnico para possíveis modificações

66 COMBINED MARITIME FORCES. CTF-151: counterpiracy. Disponível em: <http://combinedmaritimeforces.com/ctf151-counter-piracy/>. Acesso em: 11 jul. 2015.

67 Segundo o relatório do ENUDC, de julho de 2012, os Estados Unidos da América já condenaram em suas cortes nacionais 17 piratas; a Espanha 2; a França 5, com outros 15 aguardando julgamento; a Alemanha 10; a Itália condenou 20 piratas e a Holanda 10, com outros 29 ainda aguardando julgamento. UNITED NATIONS DRUGS AND CRIME. Counter-Piracy Programme: support to the trial and related treatment of piracy suspects, Issue Nine: July 2012. Disponível em: <https://www.unodc.org/documents/easternafrica/piracy/UNODC_Brochure_Issue_9_Final_webversion. pdf>. Acesso em: 11 jul. 2015.

68 Em tradução livre. UNITED NATIONS DRUGS AND CRIME. Counter-Piracy Programme: support to the trial and related treatment of piracy suspects, Issue Nine: July 2012. Disponível em: <https://www.unodc.org/documents/easternafrica/piracy/ UNODC_Brochure_Issue_9_Final_webversion.pdf >. Acesso em: 11 jul. 2015. legislativas, além de equipamentos para polícia, guarda costeira e, inclusive, financiou a construção e reforma de prisões, tribunais e delegacias nos países envolvi$\operatorname{dos}^{69}$.

A maior parte dos investimentos do Programa está sendo feita na Somália ${ }^{70}$, para que o sistema judicial do país tenha condições de seguir os standards de direitos humanos exigidos e, assim, os piratas aprisionados em outros países possam ser devolvidos para seu país de origem.

\subsubsection{O envolvimento direto da Organização Ma- rítima Internacional - OMI}

A OMI tem importante envolvimento na luta contra a pirataria no Estreito de Malaca, uma das principais rotas marítimas entre os oceanos Índico e Pacífico, entre a Península Malaia e a ilha de Sumatra. Com o know how adquirido durante as ações naquele estreito, a OMI passou a ter papel relevante na prevenção contra esse crime, criando guias para donos e operadores de navios e para governos sobre como prevenir e suprimir ataques.

As recomendações da OMI vão de rotas mais seguras de viagem, orientações sobre como agir em situações de ataque iminente e disponibilização de mapas com os ataques reportados, criando um banco extenso de dados sobre pirataria na região.

Outra importante tarefa realizada pela OMI consistiu em patrocinar um encontro, em 2009, no Djibuti, com Estados da Região do Golfo do Áden. Esse encontro resultou na assinatura do "Code of Conduct concerning the Repression of Piracy and Armed Robbery against Ships in the western Indian Ocean and the GoA", ou o Código de Djibuti, pelo país anfitrião, pela Etiópia, Quênia, Madagascar, Maldivas, Seychelles, Somália, Tanzânia e Iêmen $^{71}$. Diversos outros países da Região firmaram o

69 UNITED NATIONS DRUGS AND CRIME. Counter-Piracy Programme: support to the trial and related treatment of piracy suspects, Issue Nine: July 2012. Disponível em: <https://www.unodc. org/documents/easternafrica/piracy/UNODC_Brochure_Issue_9_Final_webversion.pdf $>$. Acesso em: 11 jul. 2015. p. 8.

70 UNITED NATIONS SECURITY COUNCIL. Report of the Secretary-General pursuant to Security Council resolution 1897 (2009). 27 Oct. 2010. Disponível em: <http://daccess-dds-ny. un.org/doc/UNDOC/GEN/N10/588/02/PDF/N1058802. pdf?OpenElement>. Acesso em: 11 jul. 2015.

71 INTERNATIONAL MARITIME ORGANIZATION. Djibouti Code of Conduct. Disponível em: <http://www.imo.org/en/ OurWork/Security/PIU/Pages/DCoC.aspx>. Acesso em: 11 jul. 
Código, chegando, atualmente, a um total de 18 Estados parte.

O Código de Djibuti ${ }^{72}$ implementa questões levantadas pelas Resoluções do CSNU, em especial as já mencionadas 1816 (2008), 1838 (2008), 1846 (2008) e 1851 (2008). Ele reafirma o direito dos países signatários em exercer a jurisdição universal sob o artigo “4(4),(6)", e, também, o direito de abrir mão do seu direito primário de exercer sua jurisdição sobre os piratas capturados, autorizando outro Estado a aplicar sua legislação (art. 4.7). O Código encoraja, também, os países participantes a cooperar e auxiliar os demais países com interesse na questão, como, por exemplo, o país apreendedor, o país da bandeira da embarcação, ou o país de origem dos acusados e vítimas. Ademais, por meio do artigo 11, os países signatários se comprometem a rever suas legislações nacionais, para assegurar que existam normas legais domésticas que criminalizem a pirataria e roubo contra embarcações, bem como orientações adequadas para o correto exercício da jurisdição, condução de investigações e acusação dos suspeitos. ${ }^{73}$

O ponto do supramencionado artigo 11 pode ser a maior contribuição do Código de Conduta no combate à pirataria, justamente por aproximar as legislações nacionais do direito internacional. Este definindo o crime de pirataria e aqueles determinando as regras para julgamento e execução da pena.

\section{Considerações finais}

Apesar de antiga, a pirataria ainda consiste em questão relevante no âmbito internacional. A natureza dualística da pirataria, no entanto, $3 / 4$ ainda que a CNUDM

2015.

72 INTERNATIONAL MARITIME ORGANIZATION. Protection of vital shipping lanes: sub-regional meeting to conclude agreements on maritime security, piracy and armed robbery against ships for States from the Western Indian Ocean, Gulf of Aden and Red Sea areas. 3 Apr. 2009. Disponível em: <http://www.imo.org/en/ OurWork/Security/PIU/Documents/DCoC\%20English.pdf>. Acesso em: 11 jul. 2015.

73 Tradução livre do seguinte trecho do Artigo 11 do Código de Djibuti: "towards ensuring that there are national laws in place to criminalize piracy and armed robbery against ships, and adequate guidelines for the exercise of jurisdiction, conduct of investigations, and prosecutions of alleged offenders". INTERNATIONAL MARITIME ORGANIZATION. Djibouti Code of Conduct. Disponível em: <http://www.imo.org/en/OurWork/Security/PIU/ Pages/DCoC.aspx >. Acesso em: 11 jul. 2015. defina as características de ato de pirataria, esta só é tipificada legalmente quando absorvida pela legislação nacional de um país - cria certa divergência entre os sistemas internacionais e domésticos, o que pode vir a frustrar o seu combate.

A posição geográfica privilegiada da Somália, na embocadura de uma das rotas marítimas com maior fluxo de bens de consumo no planeta, a falta de governo eficiente por mais de 20 anos e uma economia falida são o terreno ideal para o desenvolvimento da pirataria. Não é coincidência, portanto, que a epidemia de atos de pirataria na região, com início em 2008, tenha acontecido exatamente no ano que a Somália ficou em primeiro lugar no ranking de países falidos.

O recente levante nos casos de pirataria na Somália aumentou o interesse da comunidade internacional em relação a essa matéria, rejuvenescendo o direito internacional ao que lhe concerne, criando novos mecanismos suficientes para suprir as lacunas deixadas pela CNU$\mathrm{DM}$, que dificultavam o combate à pirataria, em especial dadas as circunstâncias especiais encontradas.

O que fazer com os piratas capturados pelas forças internacionais presentes na região foi, então, o problema legal central do combate à pirataria na região do Golfo de Áden.

Como visto, a CNUDM autoriza qualquer Estado, utilizando-se do princípio da jurisdição universal, a processar piratas capturados em alto-mar e determina que, preferencialmente, o país apreendedor seja o responsável por realizar o julgamento. A solução encontrada, com respaldo em diversas Resoluções editadas pelo Conselho de Segurança das Nações Unidas, foi a de entregar os piratas capturados para serem julgados por tribunais de países da região, como Quênia e Seychelles.

Importante compreender que a pirataria marítima não cria apenas obstáculos ao direito internacional per se. Kontorovich argumenta que "the abject failure of the international response to piracy is a cautionary tale about the limits of international law" o que, para o autor, pode levar a questionamentos sobre a credibilidade e a efetividade de aspectos chave do direito internacional ${ }^{74}$. O problema, de certa forma, decorre da natureza singular do direito internacional: não existem, na mesma forma do direito

74 KONTOROVICH, Eugene. Piracy and international law. Feb. 2009. Disponível em: <http://jcpa.org/article/piracy-and-international-law/>. Acesso em: 11 jul. 2015. p. 13. 
interno, poderes executivos, legislativo e judiciário. $\mathrm{O}$ seu desenvolvimento é complexo e depende da vontade e interesse político dos estados soberanos de forma individualizada e, naturalmente, conflitos de interesses podem levar à existência de um gap entre as normas internacionais e as normas domésticas.

Imprescindível para o relativo sucesso do esforço internacional ao enfrentar a questão posta pelos rampantes casos de pirataria na região do Golfo de Áden foi o papel realizado pelas Nações Unidas, que não se limitou apenas ao investimento monetário ${ }^{75}$ no judiciário e no sistema carcerário de países da região. Segundo os relatórios do ENUDC em relação à questão na Somália, o investimento no treinamento, aperfeiçoamento e especialização de investigadores, magistrados, agentes carcerários, agentes policiais e militares, entre outros, é prática recorrente. Bem como a construção e reforma do sistema prisional, dando condições mais dignas de encarceramento para os condenados.

Para melhor efetivação de seus esforços, a ONU buscou garantir, por controle próprio, que fossem respeitadas as garantias de standards de direitos humanos dos acusados e condenados, mediante acordos celebrados com os países que aceitam receber suspeitos de cometer atos de pirataria entregues pelas forças de coalizão, inclusive no que tange a uma maior uniformização das legislações domésticas desses países em relação à pirataria, para evitar que ocorram discrepâncias quanto às condenações impostas.

A ONU, por meio de seu Secretário Geral, reconhece que a questão da pirataria na Somália, dadas suas peculiaridades geográficas, políticas e econômicas, deve ser resolvida por meio de abordagem que busque resolver a questão combatendo a falta de governança e utilizando meios que gerem subsistência sustentável no território somali. Justamente nesse ponto, o ENUDC vem também trabalhando para construir base para a população jovem local, como forma de afastar os jovens da criminalidade. O programa "Sustainable Livehood", além de fomentar a educação dos jovens somalis, dará, também, orientação sobre como a nova geração pode começar novos negócios, além de financiar a criação de

75 Para relatório detalhado das iniciativas oriundas da ONU e seus programas relacionados à Somália, e em especial à problemática da pirataria. UNITED NATIONS OFFICE ON DRUGS AND CRIME. UNDOC Maritime Crime Programme. Disponível em: <http://www.unodc.org/easternafrica/en/piracy/index.html $>$. Acesso em: 11 jul. 2015. micro empresas em vários setores ${ }^{76}$.

O fortalecimento do sistema judiciário dos países da região, associado com a forte presença de forças navais internacionais na região e o fortalecimento — ainda que em estágios iniciais — das instituições político-administrativas na Somália, com o apoio logístico e financeiro das Nações Unidas, podem ser consideradas como grandes responsáveis pelo considerável declínio dos ataques de pirataria em $2014^{77}$.

\section{ReferênCias}

ACTS Adopted Under title $v$ of the EU Treaty Council Joint Action 2008/851/CFSP: of 10 November 2008, on a European Union military operation to contribute to the deterrence, prevention and repression of acts of piracy and armed robbery off the Somali coast. Disponível em: <http://eur-lex. europa.eu/LexUriServ/LexUriServ.do?uri=OJ:L:2008:301 :0033:0037:EN:PDF>.Acesso em: 11 jul. 2015.

AFRICAN UNION MISSION IN SOMALIA. Frequently asked questions. Disponível em: <http://amisomau.org/frequently-asked-questions/>. Acesso em: 11 jul. 2015.

BICALHO, Maria Fernanda. A cidade e o império: o Rio de Janeiro no século XVIII. Rio de Janeiro: Civilização Brasileira, 2003.

BONT, Saoirse de. Prossecuiting pirates and upholding human rights law: taking perspective. Broomfield: One Earth Future Foundation, Sept. 2010.

BOWDEN, Anna. The economic costs of maritime piracy. Dec. 2010. Disponível em: <http://www.steamshipmutual.com/Downloads/Piracy/EconomicCostPiracyOEFReport.pdf>. Acesso em: 11 jul. 2015.

76 UNITED NATIONS DRUGS AND CRIME. Counter-Piracy Programme: support to the trial and related treatment of piracy auspects, Issue Nine: July 2012. Disponível em: < https://www.unodc. org/documents/easternafrica/piracy/UNODC_Brochure_Issue_9_Final_webversion.pdf $>$. Acesso em: 11 jul. 2015. p. 3.

77 Segundo relatório anual de 2014 da International Maritime Bureau, órgão da Câmara Internacional do Comércio especializado em navegação internacional, foram relatados, em 2014, um total de 21 ataques realizados por piratas somalis. ICC International Maritime Bureau, Piracy and Armed Robbery Against Ships - Annual Report 2008 , p. 5. Para relatos atualizados dos ataques mais recentes: COMMERCIAL CRIME SERVICES. Piracy e armed robbery: news e figures. Disponível em: <https://icc-ccs.org/piracy-reporting-centre/ piracynewsafigures/>. Acesso em: 11 jul. 2015. 
BRASIL. Decreto $n^{0} 1.530$, de 22 de junho de 1995. Declara a entrada em vigor da Convenção das Nações Unidas sobre o Direito do Mar, concluída em Montego Bay, Jamaica, em 10 de dezembro de 1982. Disponível em: <http://www.planalto.gov.br/ccivil_03/decreto/1995/D1530.htm>. Acesso em: 11 jul. 2015.

CASSESE, Antonio. International criminal law. 2. ed. Oxford: Oxford University Press, 2008.

CASSESE, Antonio. International law. Oxford: Oxford University Press, 2005.

CASSESE, Antonio. The rationale for international criminal justice. In: (Ed.). The Oxford companion to international criminal justice. Oxford: Oxford University Press, 2009. p. 123-130.

CASTRO, Marina Scotelaro de. A instabilidade na Somália e a ineficácia das intervenções internacionais. Belo Horizonte: PUC Minas, 2010.

CENTRAL INTELLIGENCE AGENCY. The world factabook. Disponível em: <https://www.cia.gov/library/publications/resources/the-world-factbook/index. html>. Acesso em: 11 jul. 2015.

CHENOWETH, Gene Melaka. Piracy and the modern world system. Journal of Law and Religion, Atlanta, v. 13, n. 1, p. 107-125, jan. 1996.

COMBINED MARITIME FORCES. CTF-151: counter-piracy. Disponível em: $<$ http://combinedmaritimeforces.com/ctf-151-counter-piracy/>. Acesso em: 11 jul. 2015.

COMMERCIAL CRIME SERVICES. Piracy e armed robbery: news e figures. Disponível em: $<$ https://iccccs.org/piracy-reporting-centre/piracynewsafigures/>. Acesso em: 11 jul. 2015.

COMMITTEE OF EXPERTS FOR THE PROGRESSIVE CODIFICATION OF INTERNATIONAL LAW. Questionnaire n. 6: piracy. The American Journal of International Law, Washington, v. 20, n. 3, p. 222-229, July, 2006. Supplement.

CRYER, R. et al. An introduction to international criminal law and procedure. New York: Cambridge University Press, 2007.

DUDDRIDGE, James. Piracy off the coast of Somalia. Disponível em: <https://www.gov.uk/government/ policies/piracy-off-the-coast-of-somalia>. Acesso em: 11 jul. 2015.
DUTTON, Yvonne. Pirates and impunity: is the threat os asylum claims a reason to allow pirates to escape justice? Fordham International Law Journal, New York, v. 34, n. 2, p. 236, Jan. 2011.

EARL, Peter. The pirate wars. London: St. Martin's Press, 2006.

FARNSDOR, Isaac; SHERIDAN, Robert. Pirates board million-barrel oil tanker, ship owner says. Disponível em: <http://www.bloomberg.com/news/ articles / 2012-05-10/ pirates-board-million-barrel-oiltanker-ship-owner-says>. Acesso em: 11 jul. 2015.

GATHII, James Thuo. Kenya's piracy prosecutions. American Journal of International Law, Washington, n. 104, p. 416-436, Oct. 2010.

GEIB, Robin; PETRIG, Anna. Piracy and armed robbery at sea: the legal framework for counter-piracy operations in Somalia and the Gulf of Aden. Oxford: Oxford University Press, 2011.

GOSSE, Philip. The history of piracy. New York: Dover, 2007.

GOTTSCHALK, Jack A.; FLANAGAN, Brian P. Jolly Roger with an Uzi: the rise and threat of modern piracy. Annapolis: Naval Institute Press, 2000.

GUILFOYLE, Douglas. II. Piracy off Somalia: UN security council resolution 1816 and IMO Regional counter-piracy efforts. International and Comparative Law Quarterly, Cambridge, v. 57, n. 3, p. 690-699, July, 2008.

GUILFOYLE, Douglas. Somália: responding to the legal challenges of offshore piracy. In: HARVARD HUMANITARIAN LAW AND POLICY FORUM, 2009, Cambridge. Program on Humanitarian Policy and Conflict Research. Cambridge: Harvard Humanitarian Initiative, 2009.

HELLER-ROZEN, Daniel. The enemy of all: piracy and the law of nations. Boston: Zone Books, 2009.

HOLMES, John T. The principle of complementarity. In: LEE, Roy S. (Ed.). The international criminal court. the making of the Rome Statute: issues, negotiations, results. Haugue: Kluwer Law International, 1999. p. 4178.

INTERNATIONALMARITIME ORGANIZATION. Djibouti Code of Conduct. Disponível em: < http://www. imo.org/en/OurWork/Security/PIU/Pages/DCoC. aspx>.Acesso em: 11 jul. 2015 
INTERNATIONAL MARITIME ORGANIZATION. Protection Of Vital Shipping Lanes: sub-regional meeting to conclude agreements on maritime security, piracy and armed robbery against ships for States from the Western Indian Ocean, Gulf of Aden and Red Sea areas. 3 Apr. 2009. Disponível em: <http://www. imo.org/en/OurWork/Security/PIU/Documents / DCoC\%20English.pdf > .Acesso em: 11 jul. 2015

KONTOROVICH, Eugene. An empirical examination of universal jurisdiction for piracy. Chicago: Northwestern Law, 2010. Disponível em: < http:/ / scholarlycommons.law.northwestern.edu/cgi/viewcontent.cgi?articl $\mathrm{e}=1037 \&$ context $=$ facultyworkingpapers $>$. Acesso em: 11 jul. 2015.

KONTOROVICH, Eugene. Piracy and international law. Feb. 2009. Disponível em: <http://jcpa.org/article/piracy-and-international-law/>. Acesso em: 11 jul. 2015.

LUFT, Gal; KORIN, Anne. Terrorism Goes to Sea. Foreign Affairs, New York, 1 Nov. 2004. p. 71-82.

MIDDLETON, Roger. Piracy in Somalia: threatening global trade, feeding local wars. London: Chatam House, 2008. Disponível em: <https://www.chathamhouse.org/sites/files/chathamhouse/public/Research/ Africa/1008piracysomalia.pdf>. Acesso em: 11 jul. 2015.

MURPHY, Martin. Piracy and UNCLOS: does international law Help Regional States combat piracy? In: LEHR, Peter. Violence at sea: piracy in the age of global terrorism. New York: Routledge, 2007. p. 155-182.

PIRATAS roubam embarcação e fazem 150 passageiros reféns no Amazonas. Disponível em: <http://g1.globo. $\mathrm{com} /$ brasil/noticia/2011/08/piratas-roubam-embarcacao-e-fazem-150-passageiros-refens-no-amazonas. html>. Acesso em: 11 jul. 2015.

PIRATE washes ashore with cash. Disponível em: <http://news.bbc.co.uk/2/hi/africa/7824353.stm>. Acesso em: 11 jul. 2015.

PUNTLAND. Constitution (2000). Constitution of Puntland Regional Government. Disponível em: < http://www. refworld.org/pdfid/4bc589e92.pdf $>$. Acesso em: 11 jul. 2015.

REPUBLIC OF KENYA. Penal Code. The Official Law Reports of the Republic of Kenya: The Penal Code, 2009. Disponível em: < https://www.unodc.org/tldb/ pdf/Kenya_Penal_Code_Full_text.pdf $>$. Acesso em: 11 jul. 2015.
REPUBLIC OF KENYA. Penal Code. The Official Law Reports of the Republic of Kenya: The Penal Code: Merchant Shipping Act, chapter 389. 2009. Disponível em: <http://faolex.fao.org/docs/pdf/ken94222.pdf>. Acesso em: 11 jul. 2015.

REPUBLIC OF KENYA. The High Court Of Kenya. 2009. Judge 12 Mayo, Hassan M. Ahmed vs Republic. Case N. 434. Disponível em: <http://kenyalaw.org/caselaw/ cases/view/55714>. Acesso em: 11 jul. 2015.

REPUBLIC OF SEYCHELLES. Penal Code (1955). The Penal Code. Disponível em: < http://www.seylii.org/ sc/legislation/consolidated-act/158>. Acesso em: 11 jul. 2015.

REPUBLIC OF SEYCHELLES. The Supreme Court Of Seychelles. 2010. Judge 26 July, The Republic Vs Mohamed Abmed Dabir e Ten (10) Others. Criminal Side No. 51 of 2009. Disponível em: <http://www.seylii.org/files/sc/judgment/supreme-court/2010/86/86_0.pdf>. Acesso em: 11 jul. 2015.

REZEK, Francisco. Direito internacional público. São Paulo: Saraiva, 2007.

SHERRY, Frank. Raiders and rebels: the golden age of piracy. New York: Hearst Marine Books, 1986.

SOMALI pirates jailed in US over American deaths. Disponível em: <http://www.bbc.com/news/world-uscanada-24954797>. Acesso em: 11 jul. 2015.

SOMALI. Constitution (2001). Constitution of The Republic of Somaliland. Disponível em: <http://www.somalilandlaw.com/somaliland_constitution.htm $>$. Acesso em: 11 jul. 2015.

SOMALI. Maritime Code, 1959. Disponível em: < http:/ / www.somalilandlaw.com/Somali_Maritime_Code. pdf>. Acesso em: 11 jul. 2015.

TOGNOLLI, Claudio Julio. Federais denunciam piratas na Amazônia. Disponível em: <http://www.brasil247. $\mathrm{com} / \mathrm{pt} / 247 /$ rio $247 / 33518 /$ Federais-denunciampiratas-na-Amaz $\% \mathrm{C} 3 \% \mathrm{~B} 4$ nia-claudio-juli-tognolliamaz $\% \mathrm{C} 3 \% \mathrm{~B} 4$ nia-ilegal-piratas-policia-federal-ataques. htm>. Acesso em: 11 jul. 2015.

TORRES, Sergio. Piratas atacam navios perto de portos brasileiros. Disponível em: <http://www.naval.com.br/ blog/2009/06/15/piratas-atacam-navios-perto-deportos-brasileiros/>. Acesso em: 11 jul. 2015.

UNITED NATIONS DRUGS AND CRIME. Counter- 
Piracy Programme: support to the trial and related treatment of piracy suspects, Issue Nine: July 2012. Disponível em: <https://www.unodc.org/documents/ easternafrica/piracy/UNODC_Brochure_Issue_9_Final_webversion.pdf > . Acesso em: 11 jul. 2015.

UNITED NATIONS OFFICE ON DRUGS AND CRIME. Counter-Piracy Programme: support to the trial and related treatment of piracy suspects. Issue Six: June 2011. Disponível em: <http://www.unodc.org/ documents/Piracy/UNODC_Brochure_Issue_6_ WV.pdf/>. Acesso em: 11 jul. 2015.

UNITED NATIONS OFFICE ON DRUGS AND CRIME. Maritime Crime Programme: Indian Ocean. Disponível em: <https://www.unodc.org/unodc/en/pi$\mathrm{racy} /$ indian-ocean-division.html>. Acesso em: 11 jul. 2015.

UNITED NATIONS OFFICE ON DRUGS AND CRIME. UNDOC Maritime Crime Programme. Disponível em: < http://www.unodc.org/easternafrica/en/piracy/ index.html>. Acesso em: 11 jul. 2015.

UNITED NATIONS SECURITY COUNCIL. Resolution 1814, adopted by the Security Council at its 6019th meeting, on 15 May 2008. Disponível em: <http:// www.un.org/en/ga/search/view_doc.asp?symbol=S / RES/1814\%282008\%29>. Acesso em: 11 jul. 2015.

UNITED NATIONS SECURITY COUNCIL. Resolution 1816, adopted by the Security Council at its 5902nd meeting on 2 June 2008. Disponível em: <http://www. un.org/en/ga/search/view_doc.asp?symbol=S / RES/1816\%282008\%29>. Acesso em: 11 jul. 2015.

UNITED NATIONS SECURITY COUNCIL. Resolution 1844, adopted by the Security Council at its 6019th meeting, on 20 November 2008. Disponível em: <http:// www.un.org/ga/search/view_doc.asp?symbol=S / RES/1844\%282008\%29>. Acesso em: 11 jul. 2015.

UNITED NATIONS SECURITY COUNCIL. Resolution 1918, adopted by the Security Council at its 6301th meeting, on 27 April 2010. Disponível em: <http:// www.un.org/en/ga/search/view_doc.asp?symbol=S / RES/1918\%282010\%29>. Acesso em: 11 jul. 2015.

UNITED NATIONS SECURITY COUNCIL. Resolution 1950, adopted by the Security Council at its 6429th meeting, on 23 November 2010. Disponível em: <http:// www.un.org/en/ga/search/view_doc.asp?symbol=S/ RES/1950\%282010\%29>. Acesso em: 11 jul. 2015.
UNITED NATIONS SECURITY COUNCIL. Resolution 1976, adopted by the Security Council at its 6512th meeting, on 11 April 2011. Disponível em: <http:// www.un.org/en/ga/search/view_doc.asp?symbol=S/ RES/1976\%282011\%29>. Acesso em: 11 jul. 2015.

UNITED NATIONS SECURITY COUNCIL. Resolution 733, of 23 January 1992. Implementing an arms embargo on Somalia. Disponível em: <http:// www.un.org/ga/search/view_doc.asp?symbol=S / RES/733\%281992\%29>. Acesso em: 11 jul. 2015.

UNITED NATIONS. Convention against Torture and Other Cruel, Inbuman or Degrading Treatment or Punishment. Consideration of Reports Submitted by States Parties Under article 19 of the convention: concluding observations of the Committee Against Torture: Kenya. 19 Jan. 2009. Disponível em: < http://www.refworld.org/ publisher,CAT, KEN,4986bc0bd,0.html>. Acesso em: 11 jul. 2015.

UNITED NATIONS. Yearbook of the International Law Commission 1956: documents of the eighth session including the report of the Commission to the General Assembly. v. 2. Disponível em: <https://www.unodc. org/documents/easternafrica/piracy/UNODC_Brochure_Issue_9_Final_webversion.pdf $>$. Acesso em: 11 jul. 2015.

UNITED STATES COMMISSION ON INTERNATIONAL RELIGIOUS FREEDOM. USCIRF $A n$ nual Report 2009 - The Commission's Watch List: Somalia, 1 May 2009. Disponível em: <http://www.refworld.org/ docid/4a4f272bc.html>. Acesso em: 11 jul. 2015.

UNITED STATES COMMISSION ON INTERNATIONAL RELIGIOUS FREEDOM. Somalia. In: Annual Report 2009. Washington: USCIRF, May. 2009. Disponível em: <http://www.uscirf.gov/ sites/default/files/resources/AR2009/somalia.pdf>. Acesso em: 11 jul. 2015.

UNITED STATES NAVY. New counter-piracy task force established. Disponível em: <http://www.navy.mil/ submit/display.asp?story_id=41687>. Acesso em: 11 jul. 2015.

UNITED STATES. Constitution (1787). Constitution of the United States. Washington: Senate Library, 2010. Disponível em: <http://www.archives.gov/exhibits/ charters/constitution.html>. Acesso em: 11 jul. 2015.

UNITED STATES. Departement of State. $2009 \mathrm{Hu}-$ 
man rights reports: Somalia In: 2009 Country reports on human rights practices. Washington: U.S. Departement of State, March 2010. Disponível em: <http:// www.state.gov/j/drl/rls/hrrpt/2009/af/135976.htm>. Acesso em: 11 jul. 2015.

WARBRICK, Colin; MCGOLDRIC, Dominic; GUILFOYLE, Douglas. Piracy off Somalia: UN Security
Council resolution 1816 and IMO Regional Counter-Piracy Efforts. International and Comparative Law Quarterly, Kingdom, v. 57, n. 3, p. 690-699, July, 2008.

YOUNG, Robert. Somalia report: weekly piracy report. 2012. Disponível em: <http://www.somaliareport. com/index.php/post/3584/Weekly_Piracy_Report $>$. Acesso em: 11 jul. 2015. 


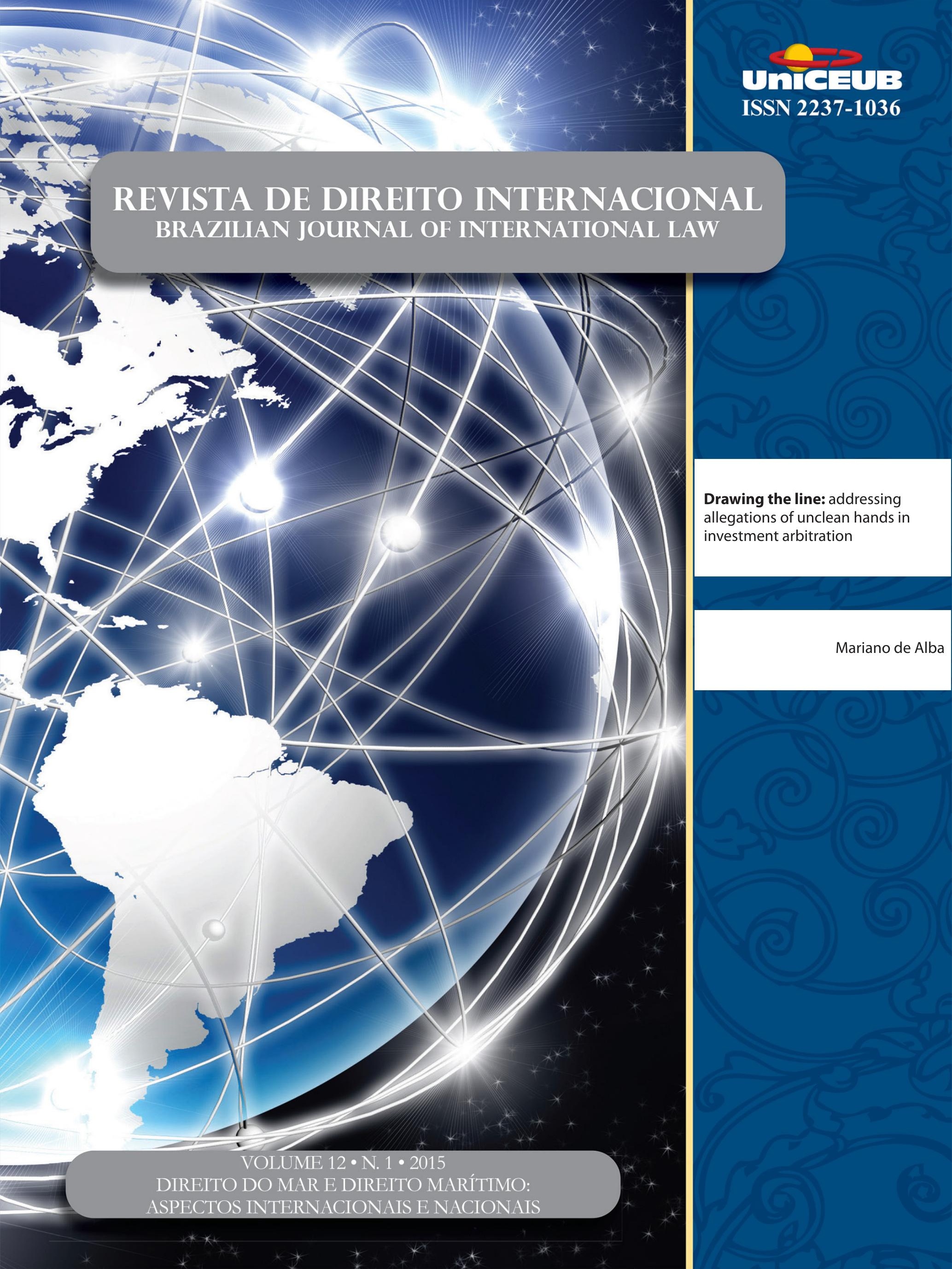




\title{
Drawing the line: addressing allegations of unclean hands in investment arbitration*
}

Mariano de Alba**

\begin{abstract}
The idea underlying the clean hands doctrine is that the lawfulness of the investor's conduct is a pre-condition for the bestowal of jurisdiction upon the arbitral tribunal. However, this paper argues that the application of such doctrine - in the investment arbitration context - should not mean that States have an unlimited right to pursue the dismissal of a claim following an investor's failure to comply with the host State's law. Thus, there are two factors that an investment arbitration tribunal should take into account when confronted with allegations of unlawful acts committed by an investor in the establishment or development of its investment. First, the tribunal should assess the type and the degree of the violation of the law committed by the investor; and second, the tribunal should evaluate the relationship between the investor's wrongdoing and the State's conduct in connection with the commission and subsequent treatment of such infraction. In short, this paper provides an analytical framework for tribunals to follow in cases where the clean hands doctrine is invoked.
\end{abstract}

Keywords: international investment law, clean hands doctrine, investor's duties

\section{INTRODUCTION}

An investor wants to establish an enterprise in a foreign country. It seeks the assistance of legal counsel to comply with the complex regulatory framework to commence operations. It makes an initial investment of US\$10 million. As time goes by, the investor reinvests the profits in the new foreign company, purchasing additional equipment and technology.

Later on the host State engages in a series of actions that, in the view of the investor, breach the obligations of an existent bilateral investment treaty ("BIT") between the host State and the country where the investor comes from. Once the case is brought before an international investment tribunal, the host State argues that the investor should not be allowed to proceed with its claims, since in the establishment (or development) of the investment the investor contravened the host State's law.

Should the tribunal uphold that defense? Which is the correct approach that arbitrators should take in order to reach a decision in relation to this issue? Such questions imply a broader inquiry: should investment arbitration tribunals apply the clean hands doctrine?

In simple terms, the clean hands doctrine implies that a party will not be allowed to bring a claim if it is proven that it was involved in an unlawful 
act in relation to its claim. ${ }^{1}$ For several years, investment arbitration tribunals have encountered (and sometimes applied) the idea underlying this doctrine. ${ }^{2}$ Presumably, States began invoking such principle since it was already known under public international law, ${ }^{3}$ which in turn adapted it from early Roman ${ }^{4}$ and common law principles. ${ }^{5}$

However, the application of the doctrine in the investment arbitration context has not been free of discussion and controversy. ${ }^{6}$ The tribunal in Niko Resources

1 Andrew D. Mitchell, M. Sornarajah and Tania Voon, Good Faith and International Economic Law, Oxford University Press, 2015, p. 2930.

2 See, for example: Inceysa Vallisoletana, S.L. v. Republic of El Salvador, ICSID Case No. ARB/03/26, Award (2 August 2006); Fraport AG Frankfurt Airport Services Worldwide v. Philippines, ICSID Case No. ARB/03/25, Award (16 August 2007); Plama Consortium Ltd. v. Republic of Bulgaria, ICSID Case No. ARB/03/24, Award (27 August 2008); Phoenix Action, Ltd. v. The Czech Republic, ICSID Case No. ARB/06/5, Award (15 April 2009).

3 For example, Judge Hudson referred to the principle in the Case Concerning the Diversion of Water from the River Meuse (Netherlands v. Belgium), Separate Opinion of Judge Hudson, Judgment of 28 June 1937, PCIJ Series A/B, No. 70. See also Bin Cheng, General Principles of Law as Applied by International Courts and Tribunals, Cambridge University Press, 1994, p. 155; Ian Brownlie, Principles of Public International Law, Oxford University Press, 2008, p. 503.

4 Some Roman law principles which can be understood to be the genesis of the doctrine are the following: ex turpi causa non oritur actio ("an action does not arise from a dishonorable cause"); nemo auditur propriam turpidunem allegans ("no one can be heard to invoke his own turpitude"); and nemo ex suo delicto meliorem suam conditionem est facit ("no one can perfect his condition by a crime"). Thus, the doctrine has been no stranger in civil law systems. See Inceysa Vallisoletana, S.L. v. Republic of El Salvador, supra note 2, para 240.

5 Originally an equitable doctrine in common law systems, it was adopted by Chief Baron Eyre of the English Court of Exchequer (which had equity powers) in Dering v. Earl of Winchelsea, (1787) 29 Eng. Rep. 1184 (Ch.) 1186; 1 Cox Eq. Cas. 318, 319-20. In U.S. courts, it has been applied since the American Revolution. See T. Leigh Anenson, Limiting Legal Remedies: An Analysis of Unclean Hands, Kentucky Law Journal, Vol. 99, 2010, p. 63-64.

6 See Bernardo Cremades, Corruption and Investment Arbitration, in Global Reflections on International Law, Commerce and Dispute Resolution: Liber Amicorum in Honour of Robert Briner, Gerald Aksen et al eds., 2005, p. 203; Mohamed Abdel Raouf, How Should International Arbitrators Tackle Corruption Issues? ICSID Review (2009) 24 (1), p. 116-136; Bernardo M. Cremades, Investment Protection and Compliance with Local Legislation, ICSID Review (2009) 24 (2); p 557-564; Carolyn B. Lamm, Hansel T. Pham, and Rahim Moloo, Fraud and Corruption in International Arbitration, in M.A. FernandezBallesteros and David Arias, Liber Amicorum Bernardo Cremades, Wolters Kluwer, 2010, p. 711-715; Andrea J. Menaker, The Determinative Impact of Fraud and Corruption on Investment Arbitrations, ICSID Review (2010) 25 (1), p. 67-75; Richard Kleindler, Corruption in International Investment Arbitration: Jurisdiction and the Unclean Hands Doctrine, in Between East and West: Essays in Honour of Ulf Franke, Kaj Hobér et al eds., Juris, 2010, p. 309-327; Rahim Moloo, A Comment v. Bangladesh recognized very recently that the precise content of the clean hands doctrine was "ill defined." Nowadays, no one seems to contest that the establishment and development of an investment presupposes an obligation for the investor to comply with the host State's laws and regulations. ${ }^{8}$ Nevertheless, there can be cases when the host State, by action of one of its agents, is involved in the violation of the host State's law. The relevant authorities may also not protest such violation until the investor brings its case before the investment arbitration tribunal. ${ }^{9}$ Should the State be allowed under such scenarios to invoke the clean hands doctrine?

Some have argued that it is unfair to assume that

on the Clean Hands Doctrine in International Law, TDM 1 (2011); Available at: www.transnational-dispute-management.com; Kevin Lim, Upholding Corrupt Investors' Claims Against Complicit or Compliant Host States - Where Angels Should Not Fear to Tread, Yearbook on International Investment Law and Policy 2011-2012, Oxford University Press, p. 601-679; Aloysius Llamzon, Corruption in International Investment Arbitration, Oxford University Press, 2014; p. 238-281 and p. 493-513; Zachary Douglas, The Plea of Illegality in Investment Treaty Arbitration, ICSID Review (Winter 2014) 29 (1), p. 155-186; Carolyn B. Lamm, Brody K. Greenwald, and Kristen M. Young, From World Duty Free to Metal-Tech: A Review of International Investment Treaty Arbitration Cases Involving Allegations of Corruption, ICSID Review (Spring 2014) 29 (2), p 328-349; Joe Tirado, Matthew Page, and Daniel Meagher, Corruption Investigations by Governmental Authorities and Investment Arbitration: An Uneasy Relationship, ICSID Review (Spring 2014) 29 (2), p. 493-513; Aloysius Llamzon, The State of the "Unclean Hands" Doctrine in International Investment Law: Yukos as both Omega and Alpha, ICSID Review (Spring 2015) 31 (1), p. 1-15; Brody Greenwald, The Viability of Corruption Defenses in Investment Arbitration When the State Does Not Prosecute, EJIL: Talk! Blog of the European Journal of International Law, April 15, 2015, Available at: http://www.ejiltalk. $\mathrm{org} /$ the-viability-of-corruption-defenses-in-investment-arbitrationwhen-the-state-does-not-prosecute/

7 Niko Resources Ltd. v. Bangladesh, ICSID Case No. ARB/10/11, Decision on Jurisdiction (19 August 2013), para 477.

8 CDC Group, Code of Responsible Investing, available at: www.cdcgroup.com/PageFiles/149/cdcinvestmentcode.pdf. CDC is the UK's Development Finance Institution (DFI), wholly owned by the UK Government. It is the world's oldest DFI with a history of making successful investment in businesses which have become industry leaders thereby having enormous impact on the private sector in their country and region as well as improving the lives of many individuals. Since 2012, it has applied the same standards, as defined in their Code of Responsible Investing, to CDC's own direct debt and equity investments. Schedule 3 of the Code of Responsible Investing provides that every business in which CDC's capital is invested will operate in compliance with applicable local and national laws including laws covering environmental impacts, labor rights, social issues, corporate governance and those intended to prevent extortion, bribery, corruption and financial crime.

9 See Tokios Tokelés v. Ukraine, ICSID Case No. ARB/02/18, Decision on Jurisdiction (29 April 2004), para 86; Técnicas Medioambientales Tecmed, S.A. v. The United Mexican States, ICSID Case No. $\mathrm{ARB}(\mathrm{AF}) / 00 / 2$, Award (29 May 2003), para 149. 
any evidence of illegality must lead an arbitration tribunal to deny an investor its right to bring a claim. ${ }^{10}$ On the other hand, several tribunals that have encountered this type of issue have upheld the principle; with one of them concluding that "no legal system based on rational grounds allows the party that committed a chain of clearly illegal acts to benefit from them". ${ }^{11}$ The mere reference to a "chain of clearly illegal acts" appears to reveal that the tribunal in Inceysa v. El Salvador had in mind something more than a specific violation of the host State's law.

Against such background, this paper argues that States should not have an unlimited right to invoke the clean hands doctrine following an investor's failure to comply with the host State's law. ${ }^{12}$ For such purposes, this article will first set out what type of violations of the law should allow a State to invoke such doctrine. In this sense, it will claim that only in cases of fundamental breaches (such as in instances of corruption, fraudulent misrepresentation or deliberate violations of legal provisions) should an arbitral tribunal consider the application of the doctrine. ${ }^{13}$ However, even in such cases, the tribunal should only proceed to deny protection to an investment after considering the investor's wrongdoing against the host State's conduct.

This means that, based on the principle of estoppel $^{14}$, if the State is involved in the commission of the unlawful act it should not be able to rely on the doctrine and the tribunal should uphold its jurisdiction. Furthermore, a State should also not be able to successfully invoke the clean hands doctrine if it knew of the unlawful act but did not protest or prosecute its commission within its own legal order. In such cases, I argue that

10 See Alison Ross, Should "clean hands" be a factor in investment arbitration?, Global Arbitration Review, October 30, 2009, Available at: http://globalarbitrationreview.com/news/article/19249/

11 Inceysa Vallisoletana, S.L. v. Republic of El Salvador, supra note 2, para 244.

12 Kevin Lim, Upholding Corrupt Investors' Claims Against Complicit or Compliant Host States - Where Angels Should Not Fear to Tread, supra note 6, p. 668; Alison Ross, Should "clean hands" be a factor in investment arbitration?, supra note 10.

13 See, Metal-Tech Ltd v. The Republic of Uqbekistan, ICSID Case No. ARB/10/3, Award (4 October 2013); World Duty Free Company Limited v. The Republic of Kenya, ICSID Case No. ARB/00/7, Award (4 October 2006); Inceysa Vallisoletana, S.L. v. Republic of El Salvador, supra note 2; Plama Consortium Ltd. v. Republic of Bulgaria, supra note 2; Fraport AG Frankfurt Airport Services Worldwide v. Philippines, supra note 2 .

14 James Crawford, Brownlie's Principles of Public International Law, Oxford University Press, 2012, p. 420-421. the involved State acquiesced ${ }^{15}$ to such illegal conduct and therefore the assessment of the unlawful conduct should be conducted in the merits phase of the dispute.

The invocation of the clean hands doctrine by a State requires an especially meticulous examination of the facts and the applicable law by the arbitration tribunal. It is in the interest of the legitimacy of investor-State dispute settlement and the rule of law that a tribunal applies the analytical framework herein proposed.

\section{The CLEAN HANDS DOCTRINE IN INVESTMENT ARBITRATION}

As a principle of equitable origin, investment arbitration tribunals have been careful not to apply the clean hands doctrine without invoking a specific basis in the corresponding applicable law to the case at hand. ${ }^{16}$ Thus, the doctrine has been recognized (and embodied) in at least two distinct forms. First, in the express text of some BITs, which require that any investment be made in compliance with the laws and regulations of the host State. ${ }^{17}$ Second, as a general principle of international law ${ }^{18}$, meaning that the doctrine can be applied

15 Aloysius Llamzon, Corruption in International Investment Arbitration, supra note 6, p. 272-275.

16 See, Inceysa Vallisoletana, S.L. v. Republic of El Salvador, supra note 2; Fraport AG Frankfurt Airport Services Worldwide v. Pbilippines, supra note 2; Plama Consortium Ltd. v. Republic of Bulgaria, supra note 2; Phoenix Action, Ltd. v. The Czech Republic, supra note 2.

17 See Article 1.1, Agreement between the Federal Republic of Germany and the Republic of Philippines for the Promotion and Reciprocal Protection of Investments, available at http://investmentpolicyhub.unctad.org/; Article 2, Agreement between the Islamic Republic of Pakistan and the Republic of Turkey Concerning the Reciprocal Promotion and Protection of Investments, available at http://investmentpolicyhub.unctad.org/; Article 2, Agreement on Encouragement and Reciprocal Protection of Investments between the Kingdom of the Netherlands and the Czech and Slovak Federal Republic, available at http://investmentpolicyhub.unctad. org/.

18 This author acknowledges that the tribunal in Yukos Universal Limited (Isle of Man) v. Russian Federation (See Hulley Enterprises Limited (Cyprus), Veteran Petroleum Limited (Cyprus) and Yukos Universal Limited (Cyprus) v. Russian Federation, PCA Case No. AA226-28, Final Awards (18 July 2014), para 1358) held that it was not persuaded of the existence of a general principle of law recognized by civilized nations that would bar an investor from making a claim before an arbitral tribunal under an investment treaty because it has so-called "unclean hands". However, this author begs to differ. The members of the Advisory Committee of Jurists who prepared the draft of the PCIJ Statute, which led to the ICJ Statute, were divided as to the nature of the principles that may be invoked under Article 38(1)(c). Neverthe- 
even absent a reference to such requirement in the text of the BIT. ${ }^{19}$

In relation to the first scenario, some BITs include, in their definition of investment, the caveat that for an investment to exist, it has to be made in accordance with the law of the State that is host to such investment. ${ }^{20}$ For instance, the Argentina-Canada BIT, defines investment as:

Any kind of asset defined in accordance with the laws and regulations of the Contracting Party in whose territory the investment is made, held or invested either directly, or indirectly through an investor of a third State, by an investor of one Contracting Party in the territory of the other Contracting Party, in accordance with the latter's laws. ${ }^{21}$

Thus, when such requirement is included in the relevant BIT and tribunals find that the investor did not comply with the law of the host State, tribunals have decided that they do not have jurisdiction ratione materiae

less, the principles in question were understood to be those which can be derived from a comparison of the various systems of municipal law, and the extraction of such principles as appear to be shared by all, or a majority of them. Considering that the idea underlying the clean hands doctrine has been recognized in both common and civil law systems since ancient times through several legal maxims, I believe that it would very difficult to conclude that the clean hands doctrine does not constitute a principle derived from the municipal law of at least a majority of the States of the international community. Thus, recognizing that the Yukos tribunal was limited on its findings by the evidence cited by the parties to that dispute, this author believes that irrespectively of the finding of such tribunal, there are sufficient grounds to conclude that, although circumvented with controversy, the clean hands doctrine amounts to a general principle of international law. (On the criteria to find the existence of a general principle of international law, see Hugh Thirlway, The Sources of International Law, Oxford University Press, 2014, p. 93-115).

19 See Mamidoil Jetoil Greek Petroleum Products Societe S.A. v. Republic of Albania, ICSID Case No. ARB/11/24, Award (30 March 2015), para 293; Phoenix Action, Ltd. v. Republic of Bulgaria, ICSID Case No. ARB/06/05, Award (15 April 2009), para 101; Gustav F.W. Hamester GmbH \& Co KG v. Republic of Ghana, ICSID Case No. ARB/07/24, Award (18 June 2010), para 123-124; and SAUR International SA Republic of Argentina, ICSID Case No. ARB/04/4, Decision on Jurisdiction and Liability (6 June 2012), para 308.

20 See, for example, Article III, Treaty between United States of America and the Argentine Republic concerning the Reciprocal Encouragement and Protection of Investment; Article 2(2) Agreement on Reciprocal Encouragement and Protection of Investments between the Kingdom of the Netherlands and the Republic of Turkey. 21 Article I, Agreement between the Government of Canada and the Government of the Republic of Argentina for the Promotion of Investments (1993). Available at: http://investmentpolicyhub. unctad.org/IIA. in order to hear the dispute. ${ }^{22}$ The rationale is that an investment made in contravention of the host State law does not qualify as an investment under the definition of the BIT. An example is the decision in Inceysa v. El Salvador, where the tribunal found that Inceysa Vallisoletana, S.L., a company who participated in a bidding process to provide the services of installation, management and operation of mechanical inspection plans for vehicles, had fraudulently misrepresented itself in order to obtain the government contract by providing false documents. ${ }^{23}$ Therefore, given that the El Salvador-Spain BIT required each contracting State to protect investments made "in accordance with its legislation," it found that it had no jurisdiction because Inceysa's investment did not meet the BIT's requirement of legality. ${ }^{24}$

Moreover, some tribunals have held that in absence of a legality requirement in the text of the relevant BIT, the clean hands doctrine is applicable as a general principle of international law. ${ }^{25}$ In Plama v. Bulgaria, the tribunal held that even though the Energy Charter Treaty ("ECT") does not contain a provision requiring the conformity of the investment with the host State law, "granting the ECT's protections to Claimant's investment would be contrary to the principle nemo auditur propriam turpidunem allegans." ${ }^{26}$ Previously, the tribunal had determined that Plama Consortium had misled the Bulgarian Privatization Agency into believing that such company had two

22 This author finds surprising that such approach has emerged under international investment law, since no clear indications were found that the intention of the States when including the phrase "in accordance with the laws" in their BITs was to deny the jurisdiction of the tribunal when confronted with an illegal act in the making or development of the investment. In any case, it is worth noting that there are three possible instances in which a tribunal can determine and decide if the investor has unclean hands: (a) the jurisdictional approach, meaning that a finding that the investor violated the host State's law will bar the tribunal from jurisdiction to hear the dispute; (b) the admissibility approach, meaning that, if it finds a violation of the law of the host State, the tribunal will have to declare that one or more of the claims brought by the investor are inadmissible and (c) the merits approach, which means that an alleged violation of the host State law will be resolved as a question of the merits of the case. See Zachary Douglas, The Plea of Illegality in Investment Treaty Arbitration, supra note 6, p. 177-186.

23 Inceysa Vallisoletana, S.L. v. Republic of El Salvador, supra note 2, para 236.

24 Inceysa Vallisoletana, S.L. v. Republic of El Salvador, supra note 2, para 264.

25 Plama Consortium Ltd. v. Republic of Bulgaria, supra note 2, para 140.

26 Plama Consortium Ltd. v. Republic of Bulgaria, supra note 2, para 143. 
important investors, when in fact it did not. ${ }^{27}$ The tribunal was persuaded that Bulgaria would not have given its consent to the transfer of shares to the Plama Consortium (and hence to the establishment of the investment) if it had known that such company was a cover for an individual with limited financial resources. ${ }^{28}$ Thus, several tribunals have not considered necessary the enshrinement of the clean hands doctrine in the express text of the underlying BIT (or other relevant instrument) in order to apply it. ${ }^{29}$

Furthermore, there have been instances where not only the violation of the law of the host State led a tribunal to apply the clean hands doctrine. ${ }^{30}$ The violation of international law or rules of international public policy can also lead to such result. ${ }^{31}$ For instance, in the context of an International Centre for Settlement of Investment Disputes ("ICSID") arbitration initiated under the provisions of an investment contract, the tribunal found that the claimant's admission of paying a bribe to the President of the host State was a violation of international public policy. ${ }^{32}$ Therefore, the tribunal declared its lack of jurisdiction to hear the dispute. ${ }^{33}$

This background reveals that there is support and recognition that the lawfulness of an investment is a necessary condition for the international protection of an investment. ${ }^{34}$ However, this paper asserts that States should not have an unlimited right to invoke failure to comply with its domestic law (or international law) in

27 Plama Consortium Ltd. v. Republic of Bulgaria, supra note 2, para 133.

28 Plama Consortium Ltd. v. Republic of Bulgaria, supra note 2, para 133.

29 Phoenix Action, Ltd. v. The Czech Republic, supra note 2, para 101. 30 World Duty Free Company Limited v. The Republic of Kenya, supra note 13, para 157; Inceysa Vallisoletana, S.L. v. Republic of El Salvador, supra note 2, para 248; Wena Hotels Ltd. v. Arab Republic of Egypt, ICSID Case No. ARB/98/4, Award (8 December 2000), para 111.

31 World Duty Free Company Limited v. The Republic of Kenya, supra note 13, para 157; Inceysa Vallisoletana, S.L. v. Republic of El Salvador, supra note 2, para 248; Wena Hotels Ltd. v. Arab Republic of Egypt, ICSID Case No. ARB/98/4, Award (8 December 2000), para 111.

32 World Duty Free Company Limited v. The Republic of Kenya, supra note 13, para 157.

33 World Duty Free Company Limited v. The Republic of Kenya, supra note 13 , para 157

34 In Yukos Universal Limited (Isle of Man) v. Russian Federation, the tribunal held that "an investor who has obtained an investment in the host State only by acting in bad faith or in violation of the laws of the host state [...] should not be allowed to benefit from the Treaty." (See Yukos Universal Limited (Isle of Man) v. Russian Federation, supra note 18, para 1352). order to deny such protection. ${ }^{35}$ The idea underlying this proposal has already been insinuated in cases such as SPP v. Egypt. ${ }^{36}$ In that case, the tribunal conceded that a Presidential decree recognizing rights to the investors could be null and void under Egyptian law. However, it recognized that the decree was an act of an Egyptian authority, creating expectations on the investor that were protected by established principles of international law. ${ }^{37}$ Thus, in the next section I propose an analytical framework for investment arbitration tribunals to determine if an investor's particular alleged violation of the host State's law warrants the definitive response of denying protection to an investment.

\section{THE PROPOSED ANALYTICAL FRAMEWORK FOR CASES WHERE THE CLEAN HANDS DOCTRINE IS INVOKED}

There are two factors that an investment arbitration tribunal should take into account when confronted with allegations of unlawful acts committed by an investor in the establishment or development of its investment. These two should apply irrespectively of whether the BIT contains an "in accordance with the law" clause or the clean hands doctrine is understood to amount to a general principle of international law.

First, the tribunal should assess the type and the degree of violation of the law committed by the investor. Second, the relevant tribunal should evaluate the relationship between the investor's wrongdoing and the conduct of the involved State in connection with the alleged unlawful act.

A. Determining the Type of Violations that Justify an Application of the Clean Hands Doctrine

It is no secret that when confronted with a claim by an investor, a State will try to use all the possible legal arguments available in order to avoid its liability which in turn could lead to an obligation to provide

35 See, Aloysius Llamzon, Corruption in International Investment Arbitration, supra note 6, p. 188; Zachary Douglas, The Plea of Illegality in Investment Treaty Arbitration, supra note 6, p. 155; Kevin Lim, Upholding Corrupt Investors' Claims Against Complicit or Compliant Host States Where Angels Should Not Fear to Tread, supra note 6, p. 608.

36 Southern Pacific Properties (Middle East) Limited v. Arab Republic of Egypt, ICSID Case No. ARB/84/3, Award (May 20 1992).

37 Southern Pacific Properties (Middle East) Limited v. Arab Republic of Egypt, ICSID Case No. ARB/84/3, Award (May 20 1992), para 83. 
considerable compensation. ${ }^{38}$ Thus, it is unsurprising that States rely on the clean hands doctrine in order to try to convince the tribunal that the investor should not be granted international protection. ${ }^{39}$ In those cases, the requested consequence is that the tribunal has to declare its lack of jurisdiction to hear the dispute or the inadmissibility of the claim brought by the investor. However, the clean hands doctrine can also ultimately serve as a mechanism to try to convince the tribunal to limit the amount of compensation in favor of an investor. ${ }^{40}$

Not every single infraction of the host State's legal order should lead to a denial of protection. ${ }^{41}$ Although BITs do not provide any standard for the assessment of this issue, several decisions of investment arbitration tribunals offer some light as to which specific situations should lead to an exclusion of investment protection. ${ }^{42}$

The scenarios under which tribunals have found that the clean hands doctrine should be applied - without a doubt - include cases under which the investor has been involved in acts of (i) corruption ${ }^{43}$; (ii) fraud or misrepresentation ${ }^{44}$ or (iii) deliberate violations of legal

38 See, Mytilineos Holdings SAv Serbia and Montenegro and Serbia, UNCITRAL, Partial Award on Jurisdiction (8 September 2006); Inmaris Perestroika Sailing Maritime Services Gmbh and others v Ukraine, ICSID Case No. ARB/08/8, Decision on Jurisdiction (8 March 2010); Tokios Tokelés v. Ukraine, supra note 9; Inceysa Vallisoletana, S.L. v. Republic of El Salvador, supra note 2; Fraport AG Frankfurt Airport Services Worldwide v. Philippines, supra note 2; Phoenix Action, Ltd. v. Republic of Bulgaria, supra note 2; Gustav F.W. Hamester GmbH \& Co KG v. Republic of Ghana, supra note 19.

39 See, Phoenix Action, Ltd. v. The Caech Republic, supra note 2; SAUR International SA v. Republic of Argentina, supra note 19; Quiborax SA and Non-Metallic Minerals SAv Plurinational State of Bolivia, ICSID Case No. ARB/06/2, Decision on Jurisdiction (27 September 2012); Ambiente Ufficio spA and others v. Argentine Republic, ICSID Case No. ARB/08/9, Decision on Jurisdiction and Admissibility (8 February 2013).

40 Yukos Universal Limited (Isle of Man) v. Russian Federation, supra note 18, para 1607-1637.

41 Zachary Douglas, The Plea of Illegality in Investment Treaty Arbitration, supra note 6, p. 155.

42 See, World Duty Free Company Limited v. The Republic of Kenya, supra note 13; Metal-Tech Ltd v. The Republic of Uzbekistan; supra note 13; Inceysa Vallisoletana, S.L. v. Republic of El Salvador, supra note 2; Plama Consortium Ltd. v. Republic of Bulgaria, supra note 2; Fraport AG Frankfurt Airport Services Worldwide v. Philippines, supra note 2; Rumeli Telekom AS and Telsim Mobil Telekomunikasyon Hirmetleri AS v. Republic of Kazakhastan, ICSID Case No. ARB/05/16, Award (29 July 2008); Desert Line Projects LLC v. Republic of Yemen, ICSID Case No. ARB/05/17, Award (6 February 2008).

43 See, World Duty Free Company Limited v. The Republic of Kenya, supra note 13; Metal-Tech Ltd v. The Republic of Uzbekistan; supra note 13. 44 See, Inceysa Vallisoletana, S.L. v. Republic of El Salvador, supra note 2; Plama Consortium Ltd. v. Republic of Bulgaria, supra note 2. provisions of the host State. ${ }^{45}$

\section{(i) Corruption}

The clean hands doctrine has been recognized to apply when it is proven that the investor was involved in one or several acts of corruption. ${ }^{46}$ This is because corruption has been deemed to be such a wrongful conduct that the responsible party cannot be allowed to resort to international arbitration. ${ }^{47}$ Indeed, the prohibition of corruption has been recognized as an essential rule of the vast majority of legal systems around the world. ${ }^{48}$

In investment arbitration, the paradigmatic case involving corruption is World Duty Free v. Kenya. ${ }^{49}$ In that decision, the arbitral tribunal was very clear in stating that "bribery is contrary to international public policy of most, if not all, States" ${ }^{50}$ The tribunal then determined that it had to declare its lack of jurisdiction after the representative of World Duty Free admitted having paid US $\$ 2$ million to Kenya's President when it obtained the investment contract. $^{51}$

More recently, such approach was again taken in Metal-Tech, Ltd. v. The Republic of Uzbekistan, where the tribunal held that the rights of the investor could not be protected because the investment was contaminated by an illegal activity such as corruption..$^{52}$ Specifically,

45 See, Fraport AG Frankfurt Airport Services Worldwide v. Philippines, supra note 2; Rumeli Telekom AS and Telsim Mobil Telekomunikasyon Hizmetleri AS v. Republic of Kazakhastan, supra note 42.

46 Carolyn B. Lamm, Fraud and Corruption in International Arbitration, supra note 6, p. 720-728; Kevin Lim, Upholding Corrupt Investors' Claims Against Complicit or Compliant Host States - Where Angels Should Not Fear to Tread, supra note 6, p. 605-609.

47 For instance, in Wena Hotels, Ltd. v. Arab Republic of Egypt, the tribunal held that corruption is contrary to international bones mores or international good manners. (Wena Hotels Ltd. v. Arab Republic of Egypt, supra note 30, para 111).

48 Abdulhay Sayed, Corruption in International Trade and Commercial Arbitration, Kluwer Law International, 2004, p. 231-309; Andreas Kulick, Global Public Interest in International Investment Law, Cambridge University Press, 2014, p. 307-309.

49 Interestingly, the tribunal in such case did not explicitly mention the clean hands doctrine. However, it decided to rely on the idea behind such doctrine, namely that an investment obtained through the commission of an unlawful act of fundamental importance, such as corruption, should not be allowed to benefit from international arbitration.

50 World Duty Free Company Limited v. The Republic of Kenya, supra note 13 , para 157.

51 World Duty Free Company Limited v. The Republic of Kenya, supra note 13 , para 179.

52 Metal-Tech Ltd v. The Republic of Uzbekistan; supra note 13, para 389. 
the tribunal stated that "the law is clear - and rightly sothat in such situation the investor is deprived of protection and, consequently, the host State avoids any potential liability." Thus, in such case, Metal-Tech, an Israeli company, was not allowed to invoke its rights under the Israel-Uzbekistan BIT, which contained a reference to the clean hands doctrine when defining an investment as "any kind of assets, implemented in accordance with the laws and regulations of the Contracting Party in whose territory the investment is made." ${ }^{53}$

It can certainly be perceived as unfair that an investor is deprived from having access to international arbitration in cases of corruption, where there is always a representative of the State involved in the unlawful transaction. The tribunal in World Duty Free v. Kenya acknowledged this concern. ${ }^{54}$ However, given that tribunals are dealing with such a wrongful conduct with respect to which there is a global interest for its eradication, investors should bear the consequences of being involved in such type of ominous act. The message being sent is that investors should prefer to withdraw from a prospective investment than incur in corruption in order to move forward with their intended business. ${ }^{55}$

\section{(ii) Frand}

Meanwhile, fraud has been understood as a willful misrepresentation of the truth by an investor to induce the State to act in a manner that is detrimental to its interests. ${ }^{56}$ Although a prohibition on fraud has not been as widely recognized as in the case of corruption, there are several cases that identify that in cases of fraud, an investor will be barred from seeking protection before an investment arbitration tribunal. ${ }^{57}$ The rationale behind this determination is simple: the State would never had approved the investment if it would have known the facts misrepresented by the investor. ${ }^{58}$

For instance, the tribunal in Plama v. Bulgaria held

53 Metal-Tech Ltd v. The Republic of Uzbekistan; supra note 13, para 186.

54 World Duty Free Company Limited v. The Republic of Kenya, supra note 13, para 180.

55 World Duty Free Company Limited v. The Republic of Kenya, supra note 13, para 181.

56 Inceysa Vallisoletana, S.L. v. Republic of El Salvador, supra note 2, para 102-128.

57 Inceysa Vallisoletana, S.L. v. Republic of El Salvador, supra note 2, para 102-128; Plama Consortium Ltd. v. Republic of Bulgaria, supra note 2, para.143.

58 Inceysa Vallisoletana, S.L. v. Republic of El Salvador, supra note 2, para 102-128. that a fraudulent misrepresentation is prohibited under international public policy. ${ }^{59}$ During the proceedings, Plama contended that it had no obligation to disclose to the Bulgarian government the identity of the real shareholders of the company. ${ }^{60}$ However, the tribunal found that in circumstances under which "the State's approval of the investment was required as a matter of law dependent on the financial and technical qualification of the investor," ${ }^{\prime} 1$ the investor could not withhold such information from the government. ${ }^{62}$ Therefore, it was held that when materials changes that could have an effect on the host State's approval occur in the investor's shareholding, the investor is obliged to inform the host State of such changes. ${ }^{63}$

Likewise, in Inceysa v. El Salvador, the tribunal determined that the investor also perpetrated a fraudulent misrepresentation by committing several actions in the context of the bidding process to obtain the contract for the installation, management and operation of mechanical inspection plant for vehicles. ${ }^{64}$ Namely, the tribunal found evidence of (i) presentation of false financial information in the tender made to participate in the bid; ${ }^{65}$ (ii) false representations during the bidding process in connection with the experience and capacity that was necessary to comply with the terms of the relevant contract; ${ }^{66}$ (iii) providing false documents ${ }^{67}$ and (iv) hiding the existing relationship between Inceysa and another bidding company. ${ }^{68}$ The tribunal, chaired by Rodrigo Oreamuno Blanco, held that the existence of the phrase "in accordance with law" in Article III of the El Salvador-Spain BIT was a clear manifestation of an international public policy to exclude from protection,

59 Inceysa Vallisoletana, S.L. v. Republic of El Salvador, supra note 2, para 102-128.

60 Plama Consortium Ltd. v. Republic of Bulgaria, supra note 2, para. 145.

61 Plama Consortium Ltd. v. Republic of Bulgaria, supra note 2, para. 145.

62 Plama Consortium Ltd. v. Republic of Bulgaria, supra note 2, para. 145.

63 Plama Consortium Ltd. v. Republic of Bulgaria, supra note 2, para. 145

64 Inceysa Vallisoletana, S.L. v. Republic of El Salvador, supra note 2, para 3.

65 Inceysa Vallisoletana, S.L. v. Republic of El Salvador, supra note 2, para 103.

66 Inceysa Vallisoletana, S.L. v. Republic of El Salvador, supra note 2, para 236.

67 Inceysa Vallisoletana, S.L. v. Republic of El Salvador, supra note 2, para 109.

68 Inceysa Vallisoletana, S.L. v. Republic of El Salvador, supra note 2, para 236. 
investments made in violation of the internal laws of the Contracting States. ${ }^{69}$ Specifically, it stated that:

\begin{abstract}
It is uncontroversial that respect for the law is a matter of public policy not only in El Salvador, but in any civilized country. If this Tribunal declares itself competent to hear the disputes between the parties, it would completely ignore the fact that, above any claim of an investor, there is a metapositive provision that prohibits attributing effects to an act done illegally. ${ }^{70}$
\end{abstract}

Thus, when a tribunal determines that an investor incurred in fraudulent conduct while making its investment, such act constitutes sufficient grounds to deny protection to the investor.

\section{(iii) Deliberate Violation of Legal Provisions}

A deliberate violation of fundamental constitutional or legal provisions has also been recognized by several tribunals to constitute sufficient grounds for the application of the clean hands doctrine. ${ }^{71}$ For example, in Fraport v. The Republic of the Philippines, the tribunal held that the investor was aware of the fact that under Philippine law, foreign citizens were prohibited from intervening in the management, operation or control of public utility companies. ${ }^{72}$ Thus, given that Fraport decided to secretly arrange management and control of the project in a way it knew was not in accordance with Philippine law, it lost its right to have such investment protected as provided in the Germany-Philippines BIT. ${ }^{73}$

Therefore, deliberate violations of constitutional and legal provisions also allow an investment arbitration tribunal to deny protection to an investment. In this case, the emphasis has to be put in analyzing whether the breach of the host State's law was indeed deliberate. That is, if the investor was aware that its course of action clearly contravened the legal order of the State where it was making its investment, yet decided to move forward with the illegal course of action.

As we will be explained infra, absent corruption, fraud or a deliberate violation of the law, investment

69 Inceysa Vallisoletana, S.L. v. Republic of El Salvador, supra note 2, para 246

70 Inceysa Vallisoletana, S.L. v. Republic of El Salvador, supra note 2, para 248.

71 See, Fraport AG Frankfurt Airport Services Worldwide v. Philippines, supra note 2.

72 Fraport AG Frankfurt Airport Services Worldwide v. Philippines, supra note 2, para 327.

73 Fraport AG Frankefurt Airport Services Worldwide v. Philippines, supra note 2, para 401. arbitration tribunals should assess the degree of importance of the legal provision violated by the investor. This would allow the tribunal to determine if the investment should be denied protection or if the claims should be admitted. If the claims are admitted, further assessment of the unlawful act can be carried out in the merits phase of the dispute. This is because as held by the tribunal in Fraport v. The Republic of the Philippines, "when the question is whether the investment is made in accordance with the law of the host State, considerable arguments may be made in favor of construing jurisdiction in a more liberal way which is generous to the investor." Thus, such tribunal recognized that there might be circumstances under which the law in question of the host State may not be entirely clear and mistakes may be made in good faith at the moment of the acquisition of the investment. ${ }^{75}$ For instance, in the words of the tribunal chaired by Yves Fortier, admissible errors could be the failure of competent local counsel to flag certain legal issues or that the arrangement infringing the host State's law was not central to the profitability of the investment. ${ }^{76}$ All those exceptions were deemed not applicable in favor of Fraport since the company willfully violated the prohibitions set forth in Philippines law in relation to foreign control of public utility companies. ${ }^{77}$ Such approach is relevant when the issue before the tribunal is whether it has jurisdiction. Thus, even when an illegality occurred, such event can be subsequently taken into account by the tribunal when assessing the merits of the dispute, especially when calculating the damages, if applicable, in favor of the investor. ${ }^{78}$

\section{B. Fundamental Versus Minor Violations of the Host} State's Law

The different examples of unlawful conducts that we have described above qualify automatically as fundamental violations of any domestic legal order. Acts of corruption, fraudulent misrepresentation and willful violation of fundamental constitutional and legal provisions are all reproachable acts that an investor

74 Fraport AG Frankfurt Airport Services Worldwide v. Philippines, supra note 2, para 396.

75 Fraport AG Frankfurt Airport Services Worldwide v. Philippines, supra note 2, para 396.

76 Fraport AG Frankefurt Airport Services Worldwide v. Philippines, supra note 2, para 396.

77 Fraport AG Frankfurt Airport Services Worldwide v. Philippines, supra note 2, para 396.

78 Fraport AG Frankfurt Airport Services Worldwide v. Philippines, supra note 2, para 396. 
should not commit when acquiring or developing its investment. Absent involvement or acquiescence of the State in the unlawful conduct, the result in these types of cases should be that the investor's investment is not awarded protection.

In contrast, minor violations of the host State's law should not lead to a denial of investment protection. Therefore, when not dealing with acts of corruption, fraud or deliberate violations of the law, investment arbitration tribunals should consider the degree of the infringement to the host State's law as the criterion to assess whether the clean hands doctrine is an admissible defense for a State. Such conclusion has been affirmed in cases such as Rumeli v. Republic of Karakbstan, where the tribunal held the following: To defeat the Tribunal's jurisdiction based on a BIT's requirement that the disputed investments be in conformity with the host State's laws and regulations, a certain level of violation is required. As determined by the Arbitral Tribunal in the Lesi [v. Algeria] case, such a provision will exclude the protection of investments only if they have been made in breach of fundamental legal principles of the host country. ${ }^{79}$

Furthermore, the tribunal in Desert Line Projects LLC v. The Republic of Yemen explained that the phrase "in accordance with law" found in several BITs is a reference intended to ensure the legality of the investment by excluding investments "made in breach of fundamental principles of the host State's law, e.g. by fraudulent misrepresentations or the dissimulation of true ownership." ${ }^{\circ 0}$ Given that in that case Yemen had neither alleged nor proven such type of illegality, the tribunal upheld its jurisdiction. ${ }^{81}$

Investment arbitration tribunals have also recognized that certain violations of the host State law are not of sufficient degree for the purpose of applying the clean hands doctrine. ${ }^{82}$ For instance, in Metalpar v. Argentina, the investor failed to register the company documents at the appropriate time, despite a provision under Argentinian law to the contrary. ${ }^{83}$ Argentina ar-

79 Rumeli Telekom AS and Telsim Mobil Telekomunikasyon Hizmetleri AS v. Republic of Kazakhastan, supra note 42, para 168.

80 Desert Line Projects LLC v. Republic of Yemen, supra note 42, para 104.

81 Desert Line Projects LLC v. Republic of Yemen, supra note 42, para 105.

82 Metalpar S.A. and Buen Aire S.A. v. The Argentine Republic, ICSID Case No. ARB/03/5, Decision on Jurisdiction (27 April 2006). 83 Metalpar S.A. and Buen Aire S.A. v. The Argentine Republic, ICSID Case No. ARB/03/5, Decision on Jurisdiction (27 April 2006, gued that the consequence of such violation had to be the denial of access to ICSID arbitration for Metalpar, S.A. ${ }^{84}$ However, the tribunal rejected that contention highlighting that Argentinian law already prescribed sanctions for such violation and that to deny investment protection would be disproportionate. ${ }^{85}$ Specifically, the tribunal explained that:

[...] the lack of timely registration could be sanctioned by a denial of the inscription of certain documents of the company or its officials, but it would be disproportionate to punish this omission with denying an investor an essential protection as the access to ICSID arbitration. Additionally, it would be illogical to admit that certain behavior (the lack of timely registration) for which the Argentinean legal system provides for specific sanctions could be punished, additionally, in other forms not provided for in that legal order. ${ }^{86}$

The tribunal in Tokios Tokeles v. Ukraine arrived to a similar finding. Ukraine had argued that the investment was not made in accordance with Ukrainian law, as required by the Ukraine - Lithuania BIT. ${ }^{87}$ The argument was that the full name under which Tokios Tokeles registered its subsidiary was improper because it referred to a "subsidiary private enterprise" which is not a recognized legal form under Ukrainian law. ${ }^{88}$ Despite that error, the government authorities registered Tokios Tokelès' subsidiary as a valid enterprise and over the next eight years, also registered each of its investments in Ukraine. ${ }^{89}$ Thus, the tribunal held that "to exclude an investment on the basis of such minor errors would be inconsistent with the object and purpose of the Treaty." 90

As can be seen, the core issue for a tribunal confronted with an act of an investor that could be deemed as an infringement of the host State's law is whether such unlawful conduct amounts to a fundamental or a minor violation. ${ }^{11}$

\section{para 84.}

84 Metalpar S.A. and Buen Aire S.A. v. The Argentine Republic, ICSID Case No. ARB/03/5, Decision on Jurisdiction (27 April 2006, para 82.

85 Metalpar S.A. and Buen Aire S.A. v. The Argentine Republic, ICSID Case No. ARB/03/5, Decision on Jurisdiction (27 April 2006, para 84.

86 Metalpar S. A. and Buen Aire S. A. v. The Argentine Republic, ICSID Case No. ARB/03/5, Decision on Jurisdiction (27 April 2006, para.

87 Tokios Tokelés v. Ukeraine, supra note 9, para 83.

88 Tokios Tokelés v. Ukeraine, supra note 9, para 83.

89 Tokios Tokelés v. Ukeraine, supra note 9, para 86.

90 Tokios Tokelés v. Ukraine, supra note 9, para 86.

91 See, Metalpar S.A. and Buen Aire S.A. v. The Argentine Republic, supra note 82; Desert Line Projects LLC v. Republic of Yemen, supra note 42; Rumeli Telekom AS and Telsim Mobil Telekomunikasyon Hizmetleri 
Consequently, an investment arbitration tribunal should only deny protection to an investment by declaring its lack of jurisdiction in cases of fundamental violations of the host State's law. The obvious cases of fundamental violations are acts of corruption, fraud and deliberate violations of constitutional and legal provisions of the involved State's legal order. Obviously, apart from those cases, it becomes more difficult to distinguish between fundamental and minor violations of the law.

Although a final determination in relation to this issue could be highly dependent on the specific facts of each case and the arguments made by the parties, ${ }^{92}$ there are two elements that could be taken into account in order to draw a distinction. First, if the unlawful conduct is deemed to be a violation of international public policy. ${ }^{93}$ An example of this case would be when an investor uses children as employees. ${ }^{94}$ Presumably, when the violation of a regulation amounts to a violation of international public policy it is also a core provision of the municipal legal order. ${ }^{95}$ Thus, when the unlawful act is also a violation of international public policy, such fact could be a good indicator that the illegality is one of fundamental character. ${ }^{96}$ Second, in these types of situations, the tribunal should give greater consideration to the principle of proportionality. ${ }^{97}$ For instance, in $\mathrm{Me}$ talpar v. Argentina, the tribunal assessed the proportionality between the specific unlawful conduct (lack of timely registry of corporate documents) and the possible sanction of depriving the investor from protection..$^{98}$

AS v. Republic of Kazakhastan, supra note 42; Tokios Tokelés v. Ukraine, supra note 9.

92 Mamidoil Jetoil Greek Petroleum Products Societe S.A. v. Republic of Albania, supra note 19, para 294.

93 Pierre Laclive, Transnational (Or Truly International) Public Policy, VIII International Congress on Arbitration, ICCA, Congress Series, 1986, Kluwer, The Hague, p. 295; Martin Hunter and Gui Conde E Silva, Transnational Public Policy and its Application in Investment Arbitrations, The Journal of World Investment, Volume 4, No. 3, 2003, p. 367-378.

94 Vid Prislan and Ruben Zandvliet, Labor Provisions in International Investment Agreements: Prospects for Sustainable Development, Yearbook of International Investment Law and Policy 2012-2013, Oxford University Press, 2013, p. 52.

95 Inceysa Vallisoletana, S.L. v. Republic of El Salvador, supra note 2, para 246.

96 Inceysa Vallisoletana, S.L. v. Republic of El Salvador, supra note 2, para 246.

97 Prabhash Ranjan, Using the Public Law Concept of Proportionality to Balance Investment Protection with Regulation in International Investment Law: A Critical Appraisal, Cambridge Journal of International and Comparative Law, Volume 3, No. 3, 2014, p. 853-883.

98 Metalpar S.A. and Buen Aire S.A. v. The Argentine Republic, supra
It ultimately held that it would be disproportionate to deny protection for such type of violation..$^{99}$ Therefore, in order to distinguish between fundamental and minor violations a tribunal could assess whether proportionality between the alleged unlawful conduct and the existing sanctions for such conduct under the host State's law. ${ }^{100}$ This is a path that requires further study from scholars and tribunals.

C. Involvement or Acquiescence in the Commission of the Assessed Unlawful Act: A Justiffing Cause for Bypassing the Application of the Clean Hands Doctrine in the Jurisdictional Phase of the Dispute

On the other hand, even in cases of corruption, fraud or deliberate violations of the law, investment arbitration tribunals should take into account the involvement or acquiescence of the relevant State in the unlawful conduct committed by the investor. This section argues that when a tribunal finds that the host State was involved or acquiesced to the alleged unlawful conduct, there are, per se, sufficient legal grounds to bypass the application of the clean hands doctrine in (at least) the jurisdictional phase of the dispute.

\section{(i) Involvement}

There are cases in which the host State (through its officials ${ }^{101}$ ) is involved in the commission of the unlawful acts being now attributed to the investor in the arbitration proceedings. Such officials, acting under the cloak of governmental authority, could have led the investor to believe that their conduct was lawful or in any case, that the commission of such act was necessary for the purposes of establishing or further developing the investment.

In such cases, I propose that the State should be estopped from invoking such unlawful conduct for the purposes of trying to deny protection to the investment. This is because the host State, having misled the inves-

note 82 , para 84.

99 Metalpar S.A. and Buen Aire S.A. v. The Argentine Republic, supra note 82 , para 84 ..

100 Metalpar S.A. and Buen Aire S.A. v. The Argentine Republic, supra note 82 , para 84 ..

101 The author is aware that the question of the involvement or acquiescence of the State in an unlawful conduct will entail an exam on attribution. This paper does not seek to assess the legal questions that might arise in such area. In any case, the author recommends the following study, which although limited to cases of corruption, deals in detail with the most important questions in that regard. See Aloysius Llamzon, Corruption in International Investment Arbitration, supra note 6; p. 238-281. 
tor by behaving as it did agree with the alleged unlawful conduct, should not be permitted to deny the conclusion that its conduct suggested. ${ }^{102}$ In short, this leads to the application of the principle of estoppel, which in the words of the International Court of Justice:

\begin{abstract}
Is a principle that operates to prevent a State from contesting before a Court a situation contrary to a clear and unequivocal representation previously made to its counterparty, either expressly or impliedly, on which representation that counterparty was, in the circumstances, entitled to rely and in fact did rely, and as a result that other party has been prejudiced or the State making it has secured some benefit or advantage for itself. ${ }^{103}$
\end{abstract}

In Kardassopoulos v. Georgia, for instance, the State argued that the tribunal did not have jurisdiction ratione materiae under the ECT provisions and the relevant BIT since a joint venture agreement and a concession between the investor and two State-owned enterprises were void under Georgian law. ${ }^{104}$ However, Claimants contended that representations made by the State-owned companies created a legitimate expectation regarding the validity of the joint venture agreement and the concession. ${ }^{105}$ For example, Claimants relied on the fact that Article 2.1 of the joint venture agreement provided that the joint venture was established "in accordance with the provisions of the legislation for Joint Ventures". ${ }^{106}$ More importantly, the tribunal focused on the assurances given to the investor regarding the validity of the joint venture agreement and the concession, which were endorsed by the government through some of the most senior government officials, who were also closely involved in the negotiation of both instruments. ${ }^{107}$ In consequence, the tribunal held that Georgia's position was unsustainable. ${ }^{108}$ It explained that the principle of attribution was applicable and re-

102 H.W.A. Thirlway, The Law and Procedure of the International Court of Justice, British Yearbook of International Law, Volume 60, 1989, p. 29; Ian Sinclair, Estoppel and Acquiescence, Fifty Years of the International Court of Justice: Essays in Honour of Sir Robert Jennings, Cambridge University Press, 2007, p. 105.

103 Temple of Preah Vihear (Cambodia v Thailand), Merits, 1962, ICJ Reports 101, para 143-144.

104 Ioannis Kardassopoulos v. The Republic of Georgia, ICSID Case No. ARB/05/18, Decision on Jurisdiction (6 July 2007), para 191.

105 Kardassopoulos v. The Republic of Georgia, supra note 104, para 185.

106 Kardassopoulos v. The Republic of Georgia, supra note 104, para

185.

107 Kardassopoulos v. The Republic of Georgia, supra note 104, para

191.

108 Kardassopoulos v. The Republic of Georgia, supra note 104, para

190. lied on the fact that Article 7 of the Articles of State Responsibility stipulates that "even in cases where an entity empowered to exercise governmental authority acts ultra vires, the conduct in question is nevertheless attributable to the State." 109

Thus, the involvement of the State in the commission of the unlawful conduct (by for example entering into an agreement or even encouraging the investor to commit an unlawful conduct) should prevent the State from raising such illegality as defense against the investor's claims. Such conclusion was recognized by the tribunal in Fraport v. The Republic of the Philippines, which held that:

[...] Principles of fairness should require a tribunal to hold a government estopped from raising violations of its own law as a jurisdictional defense when it knowingly overlooked them and endorsed an investment which was not in compliance with its law. ${ }^{110}$

Therefore, a State should be estopped from invoking unlawful conduct committed by the investor when the State itself, through its representatives, was involved in the commission of such conduct. Some ${ }^{111}$ have argued that the doctrine of estoppel is inapplicable since as provided for example in Pan American v. Argentina, ${ }^{112}$ its application requires (i) a clear statement of fact; (ii) which is voluntary, unconditional, and authorized; and (iii) is relied on to the other party's detriment. ${ }^{113}$ However, this thesis fails since estoppel is not limited only to statements of facts but it can also arise from the conduct of one of the parties involved. ${ }^{114}$ Also, a State, through its officials, can act voluntarily, unconditionally and in an authorized manner. Obviously, an investor can rely on the conduct of the State. ${ }^{115}$

109 Kardassopoulos v. The Republic of Georgia, supra note 104, para 190.

110 Fraport AG Frankfurt Airport Services Worldwide v. Philippines, supra note 2, para 346.

111 See, Brody Greenwald, The Viability of Corruption Defenses in Investment Arbitration When the State Does Not Prosecute, supra note 6.

112 Pan American Energy LLC and BP Argentina Exploration Company v. The Argentine Republic, ICSID Case No. ARB/03/13, Decision on Preliminary Objections (27 July 2006), para 160.

113 Temple of Preah Vibear (Cambodia v Thailand), supra note 103, para 150.

114 Christian Tams, Waiver, acquiescence, and extinctive prescription, in James Crawford, Alain Pellet, and Simon Olleson, eds., The Law of International Responsibility, Oxford University Press, 2010, p. 1044; John Cartwright, Protecting Legitimate Expectations and Estoppel in English Law, Report to the XVII International Congress of Comparative Law, Electronic Journal of Comparative Law, Volume 10.3, 2006.

115 Kevin Lim, Upholding Corrupt Investors' Claims Against Complicit or Compliant Host States - Where Angels Should Not Fear to Tread, supra 


\section{(ii) Acquiescence}

Likewise, if a State is aware of an unlawful act committed solely by the investor but does not respond to it with the available legal mechanisms provided by its legal order, it should also be barred from the possibility of invoking the clean hands doctrine. ${ }^{116}$ In this case, I argue that the involved State is estopped by its acquiescence in relation to the alleged unlawful conduct. In this sense, the jurisprudence of the International Court of Justice has shown that silence or lack of protest maintained over a significant period of time, may be treated as tacit recognition or acquiescence in a position taken by the other party. ${ }^{117}$ However, it is important to highlight that for the silence to constitute an acceptance of a specific factual or legal matter, the State must have had knowledge of the facts against which it refrained from making a protest or acting. ${ }^{118}$

Furthermore, several investment arbitration tribunals have already recognized the possibility of a State acquiescing to unlawful conduct. For instance, in the case of Tokios Tokelés $v$. Ukeraine, the tribunal acknowledged that Ukraine had registered Tokios Tokelés' subsidiary as a valid enterprise in 1994, and over the next eight years, registered each of such company's investments in Ukraine, as was shown in numerous official documents. ${ }^{119}$ However, Ukraine tried to argue that such investments could not be protected since they were made in contravention to Ukrainian law. ${ }^{120}$ But the tribunal held that even assuming that Ukraine's allegations were true, the fact that such investments were duly registered and the relevant governmental entity never invoked any

note 6, para 139-146; Tokios Tokelés $v$. Ukraine, supra note 9, para 86; Ioannis Kardassopoulos $v$. The Republic of Georgia, supra note 104, para 185.

116 In this scenario, we are not only referring to an obligation to prosecute, which in some States is not discretionary to the corresponding authorities. For instance, a State, through the corresponding authorities could also initiate the corresponding administrative sanctioning proceeding after learning of a particular violation to the law.

117 Gulf of Maine (Canada v United States of America), ICJ Reports 1984, para 130; Ian Sinclair, Estoppel and Acquiescence, Fifty Years of the International Court of Justice: Essays in Honour of Sir Robert Jennings, Cambridge University Press, 2007, p. 116; D.W. Bowett, Estoppel before International Tribunals and its Relation to Acquiescence, British Yearbook of International Law, Volume 33, 1957, p. 198.

118 Malcolm Shaw, International Law, Cambridge University Press, 2003, p. 437; I.C. MacGibbon, The Scope of Acquiescence in International Law, British Yearbook of International Law, 1954, p. 143.

119 Tokios Tokelés $v$. Ukraine, supra note 9, para 86.

120 Tokios Tokelés $v$. Ukraine, supra note 9, para 83. defects, clearly indicated that Tokios Tokelés had made an investment in accordance with the laws and regulations of Ukraine. ${ }^{121}$

Even more on point is the decision in Tecmed v. Mexi$c o$, where the tribunal did not accept Mexico's argument on some alleged irregularities committed by the investor in the operation of a waste disposal facility. ${ }^{122}$ The tribunal took into special consideration the fact that the environmental authorities were aware of such alleged infringements but did not act to inform the investor that the irregularities might jeopardize the renewal of the relevant permit. ${ }^{123}$ Moreover, the investor was never sanctioned for such irregularities by the Mexican authorities. ${ }^{124}$ Thus, the tribunal held that those violations of the environmental regulations could not be a justification for denying a renewal of a permit. ${ }^{125}$

In the case of Desert Line v. Yemen, Yemen argued that the tribunal did not have jurisdiction ratione materiae since the Yemen General Investment Authority never issued the required investment certificate to the investor. ${ }^{126}$ Nevertheless, the tribunal found that the lack of investment certificate could not be raised by Yemen in order to deny the jurisdiction of the tribunal. ${ }^{127}$ This was because the investment enjoyed general endorsement from the highest levels of authorities of the government and a Yemenite Vice Primer Minister even had extended certain benefits to Desert Line's investment pursuant to the Yemenite Investment Law. ${ }^{128}$ Thus, the tribunal held that such State had waived the certificate requirement and could not rely on the lack of such certificate for the purposes of denying jurisdiction. ${ }^{129}$

Thus, these decisions referred above allow to conclude that if a State knowingly overlooks a failure to

121 Tokios Tokelés v. Ukraine, supra note 9, para 86.

122 Técnicas Medioambientales Tecmed, S.A. v. The United Mexican States, supra note 9, para 151.

123 Técnicas Medioambientales Tecmed, S.A. v. The United Mexican States, supra note 9, para 151.

124 Técnicas Medioambientales Tecmed, S.A. v. The United Mexican States, supra note 9, para 151.

125 Técnicas Medioambientales Tecmed, S.A. v. The United Mexican States, supra note 9, para 151.

126 Desert Line Projects LLC v. Republic of Yemen, supra note 42, para 92.

127 Desert Line Projects LLC v. Republic of Yemen, supra note 42, para 117.

128 Desert Line Projects LLC v. Republic of Yemen, supra note 42, para 119.

129 Desert Line Projects LLC v. Republic of Yemen, supra note 42, para 121. 
comply or endorses an investment even though it is not in compliance with its laws, such violations of the host State's law should not serve as sufficient grounds to deny the jurisdiction of the arbitral tribunal.

\section{Summary of the Proposed Analytical Framework:}

- In cases of corruption, fraud or deliberate violation of provisions of the host State's law, the arbitral tribunal should proceed to assess the involvement or acquiescence of the State in relation to the unlawful conduct. Only when the relevant State was neither involved nor acquiesced, the arbitral tribunal should declare its lack of jurisdiction.

- When the violation of the host State's law does not amount to an act of corruption, fraud or deliberate violation of the host State's law, the tribunal should assess whether the alleged violation is of fundamental or minor character. If the violation is of fundamental character, the tribunal should evaluate the possible involvement or acquiescence of the State. If present, then it should declare that it has jurisdiction and proceed to assess the merits of the dispute. If there is no involvement or acquiescence of the State, the arbitral tribunal should declare its lack of jurisdiction. Furthermore, if the provision violated is not of fundamental character, the arbitral tribunal should declare it has jurisdiction and proceed to the merits.

- If the arbitral tribunal decides to proceed to the merits of the dispute, such determination does not bar the power of the tribunal to assess the alleged violation of the host State's law in the merits phase of the dispute. Such evaluation could lead, for instance, to the application of a contributory fault standard ${ }^{130}$, thus limiting the amount of compensation due to the investor. ${ }^{131}$

\section{Final considerations}

As described in the introduction, a host State can argue that the investor should not be allowed to proceed

130 Yukos Universal Limited (Isle of Man) v. Russian Federation, supra note 18, para 1637.

131 Yukos Universal Limited (Isle of Man) v. Russian Federation, supra note 18, para 1637. with its claims since in the establishment (or development) of the investment, the investor contravened the host State's law. We will continue to see such allegations in the investor-State dispute settlement arena, either because the relevant treaty requires that an investment is made in accordance with the host State law or because States argue that the clean hands doctrine constitutes a general principle of international law.

The proposal that this paper submits is that an arbitral tribunal should uphold that defense only in a very limited circumstance: when the alleged violation is of fundamental character (which includes cases of corruption, fraud and deliberate violations of the host State's law) and the State is neither involved nor acquiesced to the commission of such conduct. In every other case, the tribunal should declare that it has jurisdiction and proceed to merits phase of the dispute. This is the approach that arbitrators should take in order to reach a decision in relation to an invocation of the clean hands doctrine when assessing their jurisdiction. In any case, that is not to say that the arbitration tribunals cannot assess the alleged unlawful act in the merits phase of the dispute. In fact, such assessment could ultimately lead to a limitation of the compensation to be awarded to the investor.

This proposed analytical framework is restrained because it emerges from the rationale provided by previous decisions of investment arbitration tribunals. Those decisions have recurrently recognized that a State is entitled to have the expectation that the investments made and carried out in its territory will comply with the corresponding laws and regulations. ${ }^{132}$ However, as shown, several tribunals have also acknowledged that it is simply not right to deprive an investment of protection when the State - acting through its agents - is involved or acquiesced to the unlawful conduct.

This is a modest effort to clarify what should be the proper scope and effect of the clean hands doctrine in investment arbitration. The motivation behind it is for it to lead to fair results in the investor-State dispute settlement arena. The ultimate purpose is to allow continued promotion of international cooperation in an environment of respect for the rule of law, key ingredients in the achievement of the economic development that remains elusive in many parts of the world.

132 Mamidoil Jetoil Greek Petroleum Products Societe S.A. v. Republic of Albania, supra note 19, para 291. 


\section{ReferenCES}

Abdulhay Sayed, Corruption in International Trade and Commercial Arbitration, Kluwer Law International, 2004.

Aloysius Llamzon, Corruption in International Investment Arbitration, Oxford University Press, 2014; p. 238-281 and p. 493-513.

Aloysius Llamzon, The State of the "Unclean Hands" Doctrine in International Investment Law: Yukos as both Omega and Alpha, ICSID Review (Spring 2015) 31 (1), p. 1-15.

Alison Ross, Should "clean hands" be a factor in investment arbitration?, Global Arbitration Review, October 30, 2009, Available at: http://globalarbitrationreview.com/news/ article/19249/

Ambiente Ufficio sp $A$ and others v. Argentine Republic, ICSID Case No. ARB/08/9, Decision on Jurisdiction and Admissibility (8 February 2013).

Andrea J. Menaker, The Determinative Impact of Frand and Corruption on Investment Arbitrations, ICSID Review (2010) 25 (1), p. 67-75.

Andreas Kulick, Global Public Interest in International Investment Law, Cambridge University Press, 2014.

Andrew D. Mitchell, M. Sornarajah and Tania Voon, Good Faith and International Economic Law, Oxford University Press, 2015, p. 29-30.

Bernardo Cremades, Corruption and Investment Arbitration, in Global Reflections on International Law, Commerce and Dispute Resolution: Liber Amicorum in Honour of Robert Briner, Gerald Aksen et al eds., 2005, p. 203.

Bernardo M. Cremades, Investment Protection and Compliance with Local Legislation, ICSID Review (2009) 24 (2); p 557-564.

Bin Cheng, General Principles of Law as Applied by International Courts and Tribunals, Cambridge University Press, 1994, p. 155.

Brody Greenwald, The Viability of Corruption Defenses in Investment Arbitration When the State Does Not Prosecute, EJIL: Talk! Blog of the European Journal of International Law, April 15, 2015, Available at: http:/ /www.ejiltalk. org/the-viability-of-corruption-defenses-in-investmentarbitration-when-the-state-does-not-prosecute/

Carolyn B. Lamm, Brody K. Greenwald, and Kristen M. Young, From World Duty Free to Metal-Tech: A Review of International Investment Treaty Arbitration Cases Involving Allegations of Corruption, ICSID Review (Spring 2014) 29 (2), p 328-349.

Carolyn B. Lamm, Hansel T. Pham, and Rahim Moloo, Frand and Corruption in International Arbitration, in M.A. Fernandez-Ballesteros and David Arias, Liber Amicorum Bernardo Cremades, Wolters Kluwer, 2010, p. 711-715.

Case Concerning the Diversion of Water from the River Meuse (Netherlands v. Belgium), Separate Opinion of Judge Hudson, Judgment of 28 June 1937, PCIJ Series A/B, No. 70 .

CDC Group, Code of Responsible Investing, available at: www. cdcgroup.com/PageFiles/149/cdcinvestmentcode.pdf.

Christian Tams, Waiver, acquiescence, and extinctive prescription, in James Crawford, Alain Pellet, and Simon Olleson, eds., The Law of International Responsibility, Oxford University Press, 2010.

Dering v. Earl of Winchelsea, (1787) 29 Eng. Rep. 1184 (Ch.) 1186; 1 Cox Eq. Cas. 318, 319-20.

Desert Line Projects LLC v. Republic of Yemen, ICSID Case No. ARB/05/17, Award (6 February 2008).

Fraport AG Frankfurt Airport Services Worldwide v. Philippines, ICSID Case No. ARB/03/25, Award (16 August 2007).

Gustav F.W. Hamester GmbH \& Co KG v. Republic of Ghana, ICSID Case No. ARB/07/24, Award (18 June 2010).

H.W.A. Thirlway, The Law and Procedure of the International Court of Justice, British Yearbook of International Law, Volume 60, 1989, p. 29.

Hugh Thirlway, The Sources of International Law, Oxford University Press, 2014.

Ian Brownlie, Principles of Public International Law, Oxford University Press, 2008, p. 503.

Ian Sinclair, Estoppel and Acquiescence, Fifty Years of the International Court of Justice: Essays in Honour of Sir Robert Jennings, Cambridge University Press, 2007.

Inceysa Vallisoletana, S.L. v. Republic of El Salvador, ICSID Case No. ARB/03/26, Award (2 August 2006).

Inmaris Perestroika Sailing Maritime Services Gmbh and others $v$ Ukraine, ICSID Case No. ARB/08/8, Decision on Jurisdiction (8 March 2010).

Ioannis Kardassopoulos v. The Republic of Georgia, ICSID Case No. ARB/05/18, Decision on Jurisdiction (6 July 2007), 
James Crawford, Brownlie's Principles of Public International Law, Oxford University Press, 2012, p. 420-421

Joe Tirado, Matthew Page, and Daniel Meagher, Corruption Investigations by Governmental Authorities and Investment Arbitration: An Uneasy Relationship, ICSID Review (Spring 2014) 29 (2), p. 493-513.

John Cartwright, Protecting Legitimate Expectations and Estoppel in English Law, Report to the XVII International Congress of Comparative Law, Electronic Journal of Comparative Law, Volume 10.3, 2006.

Kevin Lim, Upholding Corrupt Investors' Claims Against Complicit or Compliant Host States - Where Angels Should Not Fear to Tread, Yearbook on International Investment Law and Policy 2011-2012, Oxford University Press, p. 601-679.

Mamidoil Jetoil Greek Petroleum Products Societe S.A. v. Republic of Albania, ICSID Case No. ARB/11/24, Award (30 March 2015).

Martin Hunter and Gui Conde E Silva, Transnational Public Policy and its Application in Investment Arbitrations, The Journal of World Investment, Volume 4, No. 3, 2003, p. 367-378.

Metal-Tech Ltd v. The Republic of Uzbekistan, ICSID Case No. ARB/10/3, Award (4 October 2013).

Metalpar S. A. and Buen Aire S.A.v. The Argentine Republic, ICSID Case No. ARB/03/5, Decision on Jurisdiction (27 April 2006).

Mohamed Abdel Raouf, How Should International Arbitrators Tackle Corruption Issues?, ICSID Review (2009) 24 (1), p. 116-136.

Mytilineos Holdings SA v Serbia and Montenegro and Serbia, UNCITRAL, Partial Award on Jurisdiction (8 September 2006).

Niko Resources Ltd. v. Bangladesh, ICSID Case No. ARB/10/11, Decision on Jurisdiction (19 August 2013), para 477.

Pan American Energy LLC and BP Argentina Exploration Company v. The Argentine Republic, ICSID Case No. ARB/03/13, Decision on Preliminary Objections (27 July 2006).

Pierre Laclive, Transnational (Or Truly International) Public Policy, VIII International Congress on Arbitration, ICCA, Congress Series, 1986, Kluwer, The Hague.
Plama Consortium Ltd. v. Republic of Bulgaria, ICSID Case No. ARB/03/24, Award (27 August 2008).

Phoenix Action, Ltd. v. The Czech Republic, ICSID Case No. ARB/06/5, Award (15 April 2009).

Prabhash Ranjan, Using the Public Law Concept of Proportionality to Balance Investment Protection with Regulation in International Investment Law: A Critical Appraisal, Cambridge Journal of International and Comparative Law, Volume 3, No. 3, 2014.

Quiborax $S A$ and Non-Metallic Minerals $S A v$ Plurinational State of Bolivia, ICSID Case No. ARB/06/2, Decision on Jurisdiction (27 September 2012).

Rahim Moloo, A Comment on the Clean Hands Doctrine in International Law, TDM 1 (2011); Available at: www. transnational-dispute-management.com.

Richard Kleindler, Corruption in International Investment Arbitration: Jurisdiction and the Unclean Hands Doctrine, in Between East and West: Essays in Honour of Ulf Franke, Kaj Hobér et al eds., Juris, 2010, p. 309-327.

Rumeli Telekom AS and Telsim Mobil Telekomunikasyon Hizmetleri AS v. Republic of Kazakhastan, ICSID Case No. ARB/05/16, Award (29 July 2008).

SAUR International SA v. Republic of Argentina, ICSID Case No. ARB/04/4, Decision on Jurisdiction and Liability (6 June 2012).

Southern Pacific Properties (Middle East) Limited v. Arab Republic of Egypt, ICSID Case No. ARB/84/3, Award (May 20 1992).

T. Leigh Anenson, Limiting Legal Remedies: An Analysis of Unclean Hands, Kentucky Law Journal, Vol. 99, 2010, p. 63-64.

Técnicas Medioambientales Tecmed, S.A. v. The United Mexican States, ICSID Case No. ARB(AF)/00/2, Award (29 May 2003).

Temple of Preah Vihear (Cambodia v Thailand), Merits, 1962, ICJ Reports 101, para 143-144.

Tokios Tokelés v. Ukraine, ICSID Case No. ARB/02/18, Decision on Jurisdiction (29 April 2004).

Vid Prislan and Ruben Zandvliet, Labor Provisions in International Investment Agreements: Prospects for Sustainable Development, Yearbook of International Investment Law and Policy 2012-2013, Oxford University Press, 2013. 
Wena Hotels Ltd. v. Arab Republic of Egypt, ICSID Case No. ARB/98/4, Award (8 December 2000).

World Duty Free Company Limited v. The Republic of Kenya, ICSID Case No. ARB/00/7, Award (4 October 2006)

Yukos Universal Limited (Isle of Man) v. Russian Federation (See Hulley Enterprises Limited (Cyprus), Veteran Petroleum
Limited (Cyprus) and Yukos Universal Limited (Cyprus) v. Russian Federation, PCA Case No. AA226-28, Final Awards (18 July 2014).

Zachary Douglas, The Plea of Illegality in Investment Treaty Arbitration, ICSID Review (Winter 2014) 29 (1), p. 155186. 


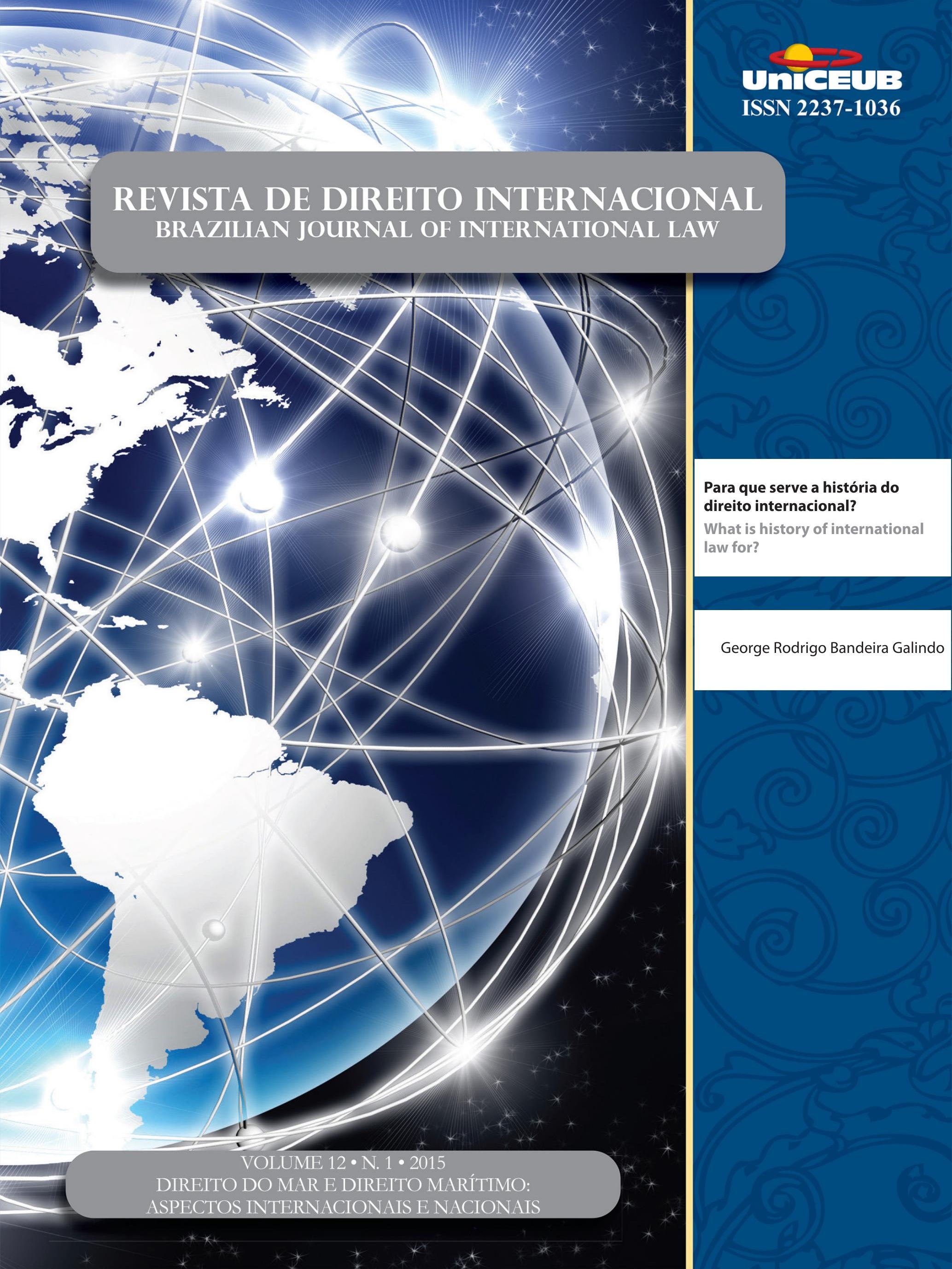




\title{
Para que serve a história do direito internacional?*
}

\section{What is history of international law for?}

\author{
George Rodrigo Bandeira Galindo**
}

\section{Resumo}

Nas últimas décadas, a história do direito internacional tem se tornado importante campo de estudos no direito internacional. Por essa razão, a questão "para que serve a história do direito internacional?" é de grande importância. Este artigo objetiva respondê-la em duas etapas. Primeiro, é essencial reconhecer que a história do direito é inescapavelmente ligada à prática do direito de maneira que nenhum internacionalista é capaz de negar. Segundo, deve-se determinar que tipo de prática importa para a história do direito e tomar partido nesse tema. Tradicionalmente, internacionalistas fazem uso da história para manter o direito internacional ligado a suas origens ou para promover a sua evolução. Recentemente, contudo, alguns estudiosos estão fazendo uso da história do direito internacional para destruir ou questionar elementos do passado de maneira crítica. Essas são as atitudes estática, dinâmica e critica dos juristas em relação à história do direito. Para o autor, a atitude crítica em relação à história do direito internacional é mais capaz de permitir à disciplina cumprir valores como justiça. $\mathrm{O}$ desafio de construir histórias críticas do direito internacional envolve a ideia de que uma relação mais vigorosa entre história e teoria deve ser avançada. Ele também requer do internacionalista uma consciência ética sobre a situação atual do direito internacional. Ao final do artigo, é proposta uma resposta tentativa à questão posta no título no sentido de reconhecer que a história do direito (internacional) possui dimensão prática na qual a crítica cumpre papel fundamental.

Palavras-chave: História do direito internacional. Prática. Teoria do direito internacional. Ética.

* Recebido em: 01/05/2015 Aprovado em: 21/05/2015

** Professor e Diretor da Faculdade de Direito da UnB. Esta é a versão em português, revisada e ampliada, de GALINDO, George R. B. ¿Para qué estudiar la historia del derecho internacional? In: URUEÑA, René (Ed.). Derecho internacional: poder y límites del derecho en la sociedad global. Bogotá: Universidad de los Andes, Facultad de Derecho, Ediciones Uniandes, 2014. p. 3-25. Gostaria de agradecer a Guilherme Del Negro e aos revisores anônimos pela leitura atenta e comentários a este artigo. E-mail: ggalindo@unb.br.

\section{Abstract}

In the last decades, the history of international has become an important field of study in international law. Due to that, the question "what is the history of international law for?" is of utmost importance. This article aims to answer it in two steps. First, it is essential to recognize that legal history is inescapably attached to the practice of law in a way that no international lawyer can deny. Second, one must narrow down what kind of practice matters for legal history and take sides on such issue. Traditionally, international lawyers make use of history to keep international law rooted to its origins or to foster its evolution. Recently, however, some scholars are making use of 
history of international law to destroy or question elements of the past in a critical way. These are the static, the dynamic and the critical attitudes of lawyers vis-à-vis legal history. For the author, the critical attitude towards the history of international law is more capable to allow the discipline to fulfill values such as justice. The challenge of making critical histories of international law involves the idea that a more vigorous relationship between history and theory must be advanced. It also demands from international lawyers an ethical consciousness about the current situation of international law. At the end of the article, a tentative answer is advanced to the question posed on the title, one that recognizes that (international) legal history has a practical dimension in which critique plays a fundamental role

Keywords: History of International Law. Practice. Theory of International Law. Ethics.

\section{INTRODUÇÃO}

Alguns anos após o fim da Guerra Fria, Thomas Franck, um dos jusinternacionalistas americanos mais influentes do século XX, afirmou que o direito internacional entrara em uma "era pós-ontológica". A antiga questão de saber se "o direito internacional é direito" perdera sua centralidade. Os novos tempos apresentavam novos desafios e outras questões se tornavam mais prementes de serem respondidas, como: o direito internacional é efetivo? É aplicável? É compreendido? E, mais importante, ele é justo? ${ }^{1}$

Se a natureza jurídica do direito internacional não mais necessita ser explicada, o seu propósito, as suas funções precisariam? E quanto à história do direito internacional? Seria antiquado indagar sobre os seus propósitos e funções ou, simplesmente, para que ela existe ou serve?

Do mesmo modo que a pergunta "o direito internacional é direito?" ainda incomoda os juristas, ${ }^{2}$ perguntas sobre a utilidade da história do direito internacional, especialmente nos dias de hoje, igualmente incomodam muitos.

1 FRANCK, Thomas M. Fairness in international law and institutions. Oxford: Oxford University Press, 1998. p. 3-6.

2 Ver, por exemplo, HATHAWAY, Oona; SHAPIRO, Scott J. Outcasting: enforcement in domestic and international law. Yale Law Journal, New Haven, v. 121, n. 2, p. 252-349, 2011.
As respostas sobre o assunto têm variado. Alguns autores acreditam que o entusiasmo atual para com a história do direito internacional tem a ver com um senso de otimismo surgido após o fim da Guerra Fria: a possibilidade de manter um projeto liberal no direito internacional ou inaugurar uma ordem internacional completamente diferente. ${ }^{3}$ Outros associam o ressurgimento da história do direito internacional a um senso de ansiedade surgido após o fim da Guerra Fria: a fim de se orientarem em um ambiente internacional agora bastante diferente, os juristas precisam olhar para o passado em busca de respostas. ${ }^{4}$

"Para que serve a história do direito internacional?". A resposta à pergunta somente pode ser encontrada por etapas. A primeira diz respeito a entender se o jurista e o historiador encaram a história da mesma maneira. Este artigo parte do pressuposto de que não, em virtude de a história do direito (internacional) possuir viés prático candente. A constatação desse viés por si só, no entanto, não se mostra suficiente, uma vez que a dimensão prática pode servir a diferentes fins, que abaixo designo, com apoio de Robert Gordon, como: estático, dinâmico e crítico. A escolha por uma dessas três posturas já se constitui a resposta à segunda etapa antes mencionada. Pelas razões que exporei mais detalhadamente no correr do artigo, a adoção da atitude crítica é, nos dias de hoje, a que considero mais adequada para responder à pergunta do título.

Em resumo, o objetivo deste artigo consiste em responder à indagação "Para que serve a história do direito internacional?" Isso passa necessariamente por entender o caráter prático da história do direito internacional, em um primeiro momento, e porque a atitude crítica e suas implicações — são mais adequadas para o estado atual da história do direito internacional.

Nesse sentido, na primeira parte do artigo, demonstrarei que a história do direito em geral (e a história do direito internacional também) possui uma perspectiva prática inescapável. A história jurídica consiste em uma prática com as possíveis consequências, boas ou más, que isso traz. $\mathrm{Na}$ segunda parte, defenderei que essa prática precisa ser crítica se o direito busca ser um ins-

3 KOSKENNIEMI, Martti. Why history of international law today? Rechtsgeschichte, Frankfurt, v. 4, p. 61-66, 2004.

4 LESAFFER, Randall. International law and its history: the story of an unrequited love. In: CRAVEN, Matthew; FITZMAURICE, Malgosia; VOGIATZI, Maria (Ed.). Time, history and international law. Leiden: Martinus Nijhoff, 2007. p. 27-42. p. 3-5. 
trumento de mudança social, especialmente em favor daqueles que sofrem injustiças na ordem jurídica internacional contemporânea. Em seguida, sustentarei que o projeto crítico da história do direito internacional deve ser radicalizado tomando-se por base duas perspectivas: a necessidade de maior diálogo entre história e teoria e a percepção de que a história do direito internacional está intimamente ligada a aspectos éticos que afetam o mundo atual. Nas conclusões, tentarei responder à pergunta do título deste artigo com base em uma perspectiva histórica crítica do direito internacional.

\section{HISTÓRIA COMO PRÁTICA}

O passado cerca o presente do direito internacional de diferentes maneiras. Tomemos alguns exemplos.

É incomum encontrar algum manual de Direito Internacional Público que não se dedique, logo em suas primeiras páginas, a fazer um histórico de como os Estados estabeleceram um direito para regular as suas relações. Referências à paz de Westphalia, ao Descobrimento das Américas, à divisão entre católicos e protestantes são uma constante no imaginário histórico que o estudante iniciante de direito internacional deve desenvolver para bem compreender a disciplina.

Mas não somente os neófitos na disciplina precisam dominar o mínimo sobre a história do direito internacional. Tribunais internacionais utilizam a argumentação histórica constantemente. Para citar apenas um exemplo: em um de seus casos contenciosos mais célebres julgados nos últimos anos, Imunidades Jurisdicionais do Estado (Alemanha vs. Itália), a Corte Internacional de Justiça fez questão de incluir no princípio da sentença uma seção denominada: "Antecedentes históricos e factuais". Advogados especializados em direito internacional, funcionários de Ministérios das Relações Exteriores e mesmo juízes internos também fazem uso constante da argumentação histórica.

O uso da história é tão disseminado entre aqueles que praticam o direito internacional que muitos excessos acontecem no manejo das provas históricas para a construção de argumento jurídico. Aquilo que é comumente chamado nos Estados Unidos de "law office history" (história de escritório de advocacia) também se repete no direito internacional: a falta de rigor analítico na pesquisa histórica, o uso seletivo de materiais histó- ricos, o instrumentalismo explícito ou implícito na seleção de dados históricos e nas conclusões que se retiram desses materiais, a falta de desejo ou inabilidade para reconciliar fontes conflitantes ou mesmo a inabilidade para aceitar a ambiguidade e a incompletude dos dados históricos. $^{5}$

Diante disso, uma questão surge: por que os juristas práticos ou teóricos do direito internacional não abrem mão da história para construir seus argumentos?

Um dos mais importantes historiadores do pensamento político da segunda metade do século XX responde a essa pergunta fazendo distinção sobre o papel do jurista e do historiador. Para o neozelandês J.G.A. Pocock, o jurista olha para o passado em busca de autoridade que possa ser aplicada no presente. Historiadores, por sua vez, olham para o passado e sabem que o que descobrirem pode ser utilizado no presente na forma de autoridade, mas seu motivo primeiro não constitui a busca de autoridade, até mesmo porque, continua Pocock, o historiador pode fazer história pela própria história. ${ }^{6}$

Nessa perspectiva, o uso da história, para o jurista, tende a ter caráter prático. A história necessita ser "utilizável" de algum modo na forma de um argumento jurídico. Como se opera, pois, esse uso? Para Pocock, o papel prático da história é direcionado à "busca de autoridade". A história permite, então, que um argumento jurídico seja justificado por uma autoridade que se encontra no passado. Vejamos como essa "busca de autoridade" funciona no argumento jusinternacionalista para sabermos se a posição de Pocock é plausível.

Um importante historiador do direito americano, Robert Gordon, já dividiu em três as atitudes do jurista ao olhar para o passado. ${ }^{7}$ Para ele, haveria, primeiramente, uma posição estática, que assume que uma norma ou uma prática jurídica possuem significado fixo estabelecido por seus usos no passado. Nesse caso, cabe ao jurista apenas recolher do passado esse significado

5 BEDERMAN, David J. Foreign office international legal history. In: CRAVEN, Matthew; FITZMAURICE, Malgosia; VOGIATZI, Maria (Ed.). Time, history and international law. Leiden: Martinus Nijhoff, 2007. p. 43-64. p. 46.

6 POCOCK, J. G. A. Law, sovereignty and history in a divided culture: the case of New Zealand and the Treaty of Waitangi. McGill Law Journal, Montreal, v. 43, n. 1, p. 481-506, 1998.

7 Para essa classificação, ver GORDON, R. W. The struggle over the past. Cleveland State Law Review, Cleveland, v. 44, n. 2, p. 123-143, 1996. 
fixo. Essa postura se aproxima bastante de um tipo de história muito cultivada no século XIX, que enfatizava o papel do historiador como alguém que procura uma verdade no passado. O talento do historiador, para essa vertente, está em coletar o máximo de material nos arquivos históricos para provar que algo de fato aconteceu ou sempre foi assim.

Em 1983, um notável internacionalista francês, Prosper Weil, publicou um controverso artigo, clamando os internacionalistas a lutarem contra aquilo que ele então chamava de processo de "relativização normativa" no direito internacional. O surgimento de conceitos como soft law, jus cogens e crimes internacionais (hoje conhecidos, no projeto de artigos da Comissão de Direito Internacional da ONU sobre Responsabilidade Internacional, como violações surgidas de uma obrigação peremptória de direito internacional geral) estariam subvertendo a estrutura que o direito internacional possui desde que foi criado pelos Estados. Enquanto a inserção do soft law no direito internacional retiraria deste sua própria natureza normativa, jus cogens e crimes internacionais criariam uma indevida hierarquização de normas, tornando algumas mais importantes que outras. Weil chega a essa conclusão com base na constatação de que o direito internacional tem e continua a ter as mesmas funções desde que surgiu: promover a coexistência e objetivos comuns entre Estados. A manutenção dessas funções tornaria até mesmo "erro" dividir o direito internacional em moderno e clássico. ${ }^{8}$

Independentemente do acerto da análise de Prosper Weil, o certo é que o passado para ele tem claramente uma função de desvelar o que é comum, aquilo que é contínuo no tempo. Evidentemente que o autor sabe que o passar dos anos opera mudanças nas relações sociais, porém ele acredita que há um conjunto de elementos que são estáticos no tempo ou ao menos devem assim se manter, sob pena de subverterem a própria natureza, a essência do direito internacional. Esse tipo de atitude é bastante comum entre os defensores de postura voluntarista no direito internacional, como é o caso de Weil.

Mas Gordon identifica outra atitude do jurista em relação ao passado, caracterizada por ser dinâmica. Aqueles que adotam essa atitude normalmente acreditam que a

8 WEIL, Prosper. Towards relative normativity in international law? American Journal of International Law, Washington, v. 77, n. 3, p. 413-442, 1983. interpretação jurídica não somente varia, como também deve variar com o tempo para se adaptar às mudanças de condições. O internacionalista, de acordo com essa atitude, é considerado agente do progresso. O seu papel consiste em tornar o futuro melhor que o passado. Essa postura também guarda relação, embora muitas vezes não de maneira explícita, com diversas correntes historiográficas do século XVIII e XIX que acreditavam num progresso contínuo da espécie humana - e de suas estruturas sociais.

Para ilustrar essa atitude, tomemos como exemplo um manual muito popular de língua castelhana: Curso de Derecho Internacional Público y Organizaciones Internacionales, de José António Pastor Ridruejo.

Uma das teses principais do autor é que o direito internacional clássico e o direito internacional contemporâneo se distinguem por três características básicas. Enquanto o primeiro possuía as características de liberal, descentralizado e oligárquico, o direito internacional contemporâneo seria um ordenamento jurídico de caráter social, institucionalizado e democrático. Embora Pastor Ridruejo reconheça que nem todas as características do direito internacional clássico desapareceram, não são elas mais aspiradas pela comunidade internacional. ${ }^{9}$

Pastor Ridruejo vai buscar na história a autoridade que sustenta as características do direito internacional contemporâneo. Ora, as características "social, institucionalizado e democrático" somente se afirmam em oposição ao que é "liberal, descentralizado e oligárquico". O direito internacional contemporâneo precisa do seu oposto (o direito internacional clássico) para se afirmar. O passado necessita do presente para ser superado e o presente necessita do passado para ser justificado. $\mathrm{O}$ passado, assim, se articula continuamente ao presente.

Embora a postura dinâmica tenha a aparência de enfatizar as descontinuidades (o novo e o velho direito internacional), ela também se fundamenta em grandes continuidades. Aqui, o presente se liga de maneira inseparável ao passado e se torna uma consequência, um resultado daquilo que aconteceu anos ou séculos atrás.

As duas atitudes descritas acima têm em comum o fato de buscarem legitimar o presente por meio do passado, mas se utilizam de meios diferentes. No caso da

9 PASTOR RIDRUEJO, José António. Curso de derecho internacional público y organizaciones internacionales. 6. ed. Madrid: Tecnos, 1996. 
atitude estática, o passado deve ser conhecido para que o presente e o futuro continuem a ser como ele; em relação à atitude dinâmica, o passado deve ser conhecido para que o presente e o futuro sejam diferentes dele.

Para essas duas atitudes, fica claro para que serve a história do direito internacional: para, ainda que de maneiras diferentes, legitimar argumento, norma ou proposta sobre a organização jurídica internacional. Isso nos faz voltar à diferença entre o papel do jurista e o do historiador segundo J.G.A. Pocock, que crê que o primeiro apenas busca autoridade no passado.

A caracterização de Pocock é bastante adequada no momento em que consegue perceber que o passado, para o jurista, se articula a uma dimensão prática. É realmente raro um internacionalista fazer história do direito internacional por mero diletantismo, sem propósito concreto no mundo real. Uma história pela história do direito internacional até mesmo subverteria um sentido muito prático que a ciência do direito possui e de que não pode abrir mão. Entretanto, a posição de Pocock não faz justiça a uma série de esforços que têm sido empreendidos por diversos historiadores do direito (inclusive do direito internacional) de conceber o seu próprio papel de maneira diferente. É por essa razão que é possível falar em uma terceira atitude do jurista em relação ao passado: aquilo que Gordon chama de atitude crítica. Gostaria de me concentrar nessa terceira postura e explicar as razões pelas quais acredito que ela seja a mais adequada se pretendemos operar mudanças mais profundas no direito internacional em favor daqueles tradicionalmente excluídos, utilizando com mais vigor do aporte interdisciplinar da historiografia.

\section{HISTÓRIA COMO PRÁTICA CRÍTICA}

Uma atitude crítica do jurista em relação ao passado busca essencialmente destruir ou questionar a autoridade de um autor, um argumento ou mesmo uma norma em relação ao presente. Embora a história, dentro de uma postura crítica, ainda precise ser utilizável, não se busca no passado autoridade para corroborar argumento posto no presente. A "utilização" do passado está mais comprometida com a quebra de tradições ou ao menos com sua reconstrução após uma revisitação profunda de seus fundamentos. Certamente pela influência de pensadores como Michel Foucault, a atitude críti- ca na história do direito internacional está muito mais preocupada em analisar as descontinuidades no discurso jurídico internacional do que as continuidades. E este constitui um ponto importante de diferenciação entre as duas atitudes anteriores do jurista (internacionalista) em relação ao passado e a atitude crítica. A busca por descontinuidades tem constantemente levado os historiadores críticos do direito internacional a descobrir não apenas um significado oriundo do passado que persiste no tempo (como no caso da atitude estática) ou um significado do passado que origina e que dá lugar a outro (como no caso da atitude dinâmica), mas a uma multiplicidade de significados que muitas vezes convivem em um mesmo tempo histórico. A descontinuidade também influencia a própria pesquisa histórica e tem estimulado a ideia de que a história do direito internacional pode ser interpretada de diversas formas possíveis. Se não há autoridade específica a ser seguida, a leitura do passado tende a se tornar bastante diversificada.

O importante historiador intelectual americano, Dominick LaCapra, já definiu o seu próprio esforço crítico como uma "investigação e uma interrogação de pressuposições básicas em práticas e formas de pensamento”. As pressuposições, continua LaCapra,

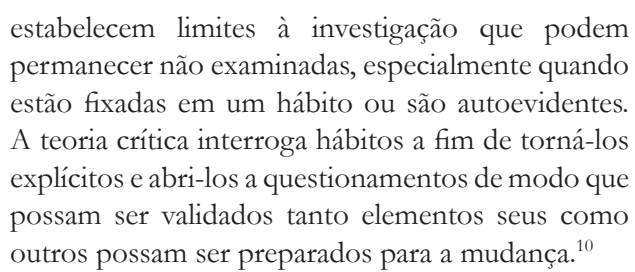

A postura crítica pode, portanto, até mesmo confirmar uma interpretação histórica canônica ou clássica, mas isso somente é feito após profunda investigação sobre os múltiplos sentidos do passado.

Tomemos dois exemplos para demonstrar como essa atitude crítica tem sido desenvolvida no direito internacional.

A narrativa tradicional do processo de universalização do direito internacional consiste naquela que descreve um sistema jurídico internacional inicialmente aplicado a Estados europeus e que, aos poucos, foi se expandindo para o mundo. Esse processo de expansão aconteceu de maneira atrelada a políticas colonialistas que dividiam diversas nações (algumas delas bastante

10 LACAPRA, Dominick. Introduction. In: LACAPRA, Dominick. History and its limits: human, animal, violence. Ithaca: Cornell University Press, 2009. p. 2. 
avançadas do ponto de vista tecnológico e da organização burocrática, como a China e o Japão) em civilizadas, não civilizadas e semicivilizadas. Somente quando o processo civilizacional alcançou as mais diversas partes do globo, foi possível não mais dividir o mundo em categorias civilizacionais. Os povos que antes não gozavam de soberania (por não possuírem um grau civilizacional satisfatório) somente nesse momento passaram a ser reconhecidos como Estados. O reconhecimento como Estado era o pré-requisito para o gozo de direitos básicos na esfera internacional, como a igualdade jurídica. Na síntese de outro manual de direito internacional de língua castelhana bastante popular, o de Remiro Brotóns e outros:

O padrão europeu de civilização como critério determinante de admissão na sociedade internacional permitiu sua extensão para além do Ocidente cristão, mas também forneceu as bases e modelos para a expansão imperialista e colonialista na segunda metade do século XIX na África, Ásia e Oceania. ${ }^{11}$

A esse tipo de interpretação histórica canônica do processo de expansão do direito internacional, Antony Anghie, um autor associado às chamadas TWAIL (Third World Approaches to International Law), com uma perspectiva bastante crítica da história do direito internacional, oferece uma visão profundamente diferente.

Para Anghie, essa leitura da expansão da doutrina da soberania do Ocidente para o resto do mundo é enviesada. Em verdade, a doutrina da soberania teria, ela própria, se formado durante o chamado "encontro colonial". Ele chega a essa conclusão, investigando a maneira como um dos "pais" do direito internacional, Francisco de Vitória, tratou a relação entre os povos europeus e os povos indígenas. Ao desenvolver uma série de conceitos relativos ao direito natural e divino, a diferença cultural entre espanhóis e indígenas, a existência de uma razão universal a governar tanto europeus como os nativos americanos, Vitória estaria universalizando maneiras de pensar o mundo que seriam tipicamente espanholas (e europeias) para compreender e assimilar os povos colonizados. A doutrina da soberania, assim, teria se formado com base na sua oposição com o "outro”, o não soberano, que, após alguns séculos de assimilação, também se tornará soberano. A manobra para

11 REMIRO BROTÓNS, António et al. Derecho internacional: curso general. Valencia: Tirant lo Blanch, 2010. p. 48. dividir o mundo em civilizado e não civilizado teria, então, se iniciado muitos antes do século XIX. Os "pais" do direito internacional, de uma maneira diferente, já confirmavam essa diferença e submetiam os povos não civilizados a uma série de princípios e normas desenvolvidas não de mútuo acordo entre as diversas nações de mundo, mas de maneira unilateral. ${ }^{12}$

Por que Antony Anghie precisa levar adiante essa interpretação pouco convencional da obra de Vitória e do surgimento da doutrina da soberania? Uma das possíveis explicações tem a ver com o objetivo que a atitude crítica pretende em sua leitura da história do direito internacional. O colonialismo é tradicionalmente analisado como algo absolutamente distante da doutrina dos pais fundadores do direito internacional. ${ }^{13}$ Francisco de Vitória, Francisco Suárez, Alberico Gentili, Hugo Grocius, Samuel Pufendorf e outros são constantemente vistos como seres iluminados que conseguiram sistematizar um conjunto de normas para regular e pacificar as relações entre os Estados. Ao sustentar que o "encontro colonial" está intimamente ligado à doutrina desses autores, Anghie quer demonstrar que o direito internacional "nasceu" marcado pelo colonialismo, pelo estabelecimento da diferença entre o europeu e o não europeu. Se é assim, o colonialismo não constitui somente um produto do século XIX: ele existia, ainda que com outro nome, antes disso, e ainda existe nos dias de hoje, qualquer novo nome que se lhe dê. A interpretação histórica de Anghie confirma que a investigação histórica minuciosa fora dos cânones tradicionais pode mostrar que muito do que nós pensávamos sobre o direito internacional deve ser repensado e realidades que julgávamos superadas persistem em formas diferentes. Assim, ainda que a luta anticolonial que teve seu auge nas décadas de 1950, 1960 e 1970 do século passado tenha chegado ao fim, é possível que o colonialismo ainda não tenha cessado: ele pode ser parte integrante da própria estrutura do direito internacional.

12 ANGHIE, Antony. Imperialism, sovereignty and the making of international law. Cambridge: Cambridge University Press, 2007. p. 13-31. 13 Mesmo sem adotar uma postura de crítica pós-colonialista como faz Anghie - é possível perceber que a recepção dos autores clássicos do direito internacional trouxe consigo vários anacronismos que pretendiam justificar agendas do presente. A discussão sobre a "paternidade" do direito internacional, por exemplo, é bastante elucidativa do viés que gerações distintas de internacionalistas deram à obra de autores como Vitória, como muito bem lembra MACEDO, Paulo Emílio Vauthier Borges de. O mito de Francisco de Vitória: defensor dos índios ou patriota espanhol? Revista de Direito Internacional, Brasília, v. 9. n. 1, p. 1-13, 2012. 
Outro exemplo é The Gentle Civilizer of Nations, de Martti Koskenniemi, um dos livros mais influentes de história do direito internacional das últimas décadas.

Uma das narrativas mais tradicionais sobre o desenvolvimento do direito internacional é que ele teve início ou modificou-se bruscamente com a Paz de Westphalia. Esse evento, ao pôr fim ao menos às principais guerras religiosas existentes na Europa após a reforma protestante, teria criado um sistema racional de Estados informado por princípios como liberdade de um soberano de professar determinada religião (cristã), a força obrigatória dos tratados e, principalmente, pela igualdade jurídica entre os Estados. Esses princípios, inicialmente restritos às nações europeias, teriam feito surgir um direito comum aplicado às distintas soberanias na Europa (Droit Public de l'Europe) que, especialmente a partir do século XIX, como já visto em outra narrativa tradicional, teriam se expandido para o resto do mundo. Westphalia, dentro de tal narrativa histórica, revela, assim, "a vontade consciente de uma liga internacional de criar um direito comum e de lhe garantir por meio dos esforços conjuntos de todos". ${ }^{14} \mathrm{O}$ direito internacional contemporâneo seria, portanto, herdeiro direto dos princípios e da mentalidade estabelecida com a Paz de Westphalia.

Koskenniemi não nega a importância de Westphalia para o direito internacional. A originalidade de sua interpretação, no entanto, está em afirmar que não há uma continuidade estrita entre a Paz de Westphalia e o direito internacional atual. De fato, como afirma, poucos perceberam que, na segunda metade do século XIX, uma nova sensibilidade teria surgido entre os especialistas de direito internacional, uma sensibilidade que não existia nos "pais" do direito internacional, como Grocius, nem em figuras importantes posteriores, como Vattel, Von Martens e Wheaton. A essa sensibilidade Koskenniemi chamou de "espírito de internacionalidade" (esprit d'internationlitê). Nas palavras de Koskenniemi, ela "buscava o progresso social, enfatizava a responsabilidade e procurava um meio-termo entre o individualismo e o coletivismo, a especulação abstrata e a ação política". O esprit d'internationalité era, todavia, repleto de grandes contradições: era ao mesmo tempo democrático e temerário das massas, reformista e burguês, nacionalista e in-

14 REDSLOB, Robert. Histoire des grands principes du droit des gens. Paris: Librairie Arthur Rousseau, 1923. p. 216. ternacionalista, progressista e conservador. ${ }^{15}$ Seja como for, para Koskenniemi, tal espírito diferente que surgiu na segunda metade do século XIX chegou ao fim nos anos de 1960, quando o direito internacional passou a ser informado por uma visão mais pragmática em relação ao diversos problemas.

Embora a interpretação de Koskenniemi seja controversa, sua atitude crítica no que diz respeito à história do direito internacional reside em perceber grandes quebras ou descontinuidades em relação à maneira como o direito internacional era pensado antes da segunda metade do século XIX. O autor não está propriamente interessado em provar que o esprit d'internationalité é uma consequência ou desenvolvimento da mentalidade que informava os internacionalistas desde a Paz de Westphalia (como pretenderia a atitude dinâmica) nem sustentar que certas tradições se mantêm no direito internacional (como buscaria a atitude estática). Ele se fixa em um momento histórico preciso em que uma nova episteme, uma maneira de pensar diferente, surgiu. Essa episteme é, ela mesma, repleta de contradições, significando muitas coisas ao mesmo tempo.

Essa maneira crítica de encarar a história do direito internacional é explicada pelo próprio Koskenniemi como um "ato político". Trata-se não de narrativa neutra sobre como o passado de fato foi, "mas uma descrição que espera tornar a nossa situação presente mais clara para nós e afiar nossa própria habilidade para agir nos contextos profissionais que nos são abertos". ${ }^{16}$

Esses são dois exemplos de como a história do direito internacional pode ser lida de maneira a contrariar ou desconcertar interpretações estabelecidas por leituras tradicionais ou canônicas do passado da disciplina.

No entanto, é preciso perceber que o exercício de uma atitude crítica em relação à história do direito internacional exige constante reflexão sobre dois temas importantes: a relação entre história e teoria e a relação entre a escrita da história e a ética. Em verdade, para que a atitude crítica compreenda a si própria e os próprios problemas que dela podem surgir, é preciso que ela radicalize sua agenda, ou seja, possa criticar o próprio fazer

15 KOSKENNIEMI, Martti. The gentle civilizer of nations: the rise and fall of international law 1870-1960. Cambridge: Cambridge University Press, 2001. p. 18-19.

16 KOSKENNIEMI, Martti. The gentle civilizer of nations: the rise and fall of international law 1870-1960. Cambridge: Cambridge University Press, 2001. p. 10. 
crítico. Os dois temas acima mencionados - teoria e ética - servem para exemplificar como a atitude crítica pode permitir que a história seja objeto de mudança do presente e do próprio futuro, também levando em consideração as gerações passadas.

\subsection{História crítica do direito internacional e teoria}

Os historiadores críticos do direito internacional, embora tenham praticado muito dos postulados de uma teoria crítica da sociedade e do conhecimento em seus escritos, pouco têm se dedicado a refletir sobre o próprio fazer histórico. Pouco se vê, por exemplo, como a construção de narrativas tem afetado o fazer histórico no direito internacional. Também não se explicita, com mais profundidade, sobre a função da história, perguntando-se, por exemplo, para que ela existe ou serve. E determinadas noções, como direcionalidade e causalidade históricas, objetividade e progresso são pouquíssimo estudadas pelos historiadores do direito internacional. É verdade que muitas dessas questões são tratadas indiretamente pelos autores, mas uma reflexão mais sistemática sobre elas é necessária.

Mas para que serve a teoria para a história do direito internacional? Essa pergunta é das mais importantes e não está restrita ao domínio da história jurídica. Nas últimas décadas, diversos historiadores profissionais têm se insurgido contra o que têm chamado de excesso de teorização da historiografia recente. O historiador Keith Windschuttle, por exemplo, fez enorme sucesso com a publicação de The Killing of History: How Literary Critics and Social Theorists are Murdering our Past (O assassinato da história: como críticos literários e teóricos sociais estão assassinando nosso passado). Ele argumenta, dentre outras coisas, que retirar conclusões com base nas grandes generalizações ou de qualquer coisa que se pareça com leis históricas procedimentos típicos de alguém considerado como um teórico — fugiria à abordagem propriamente histórica. Windschuttle também ressalta a necessidade de a história repousar em conceitos como objetividade e verdade algo combatido especialmente por historiadores influenciados por teorias pós-modernas. ${ }^{17}$

O que pretendem essas posições altamente des-

17 WINDSCHUTTLE, Keith. The killing of history: how literary critics and social theorists are murdering our past. San Francisco: Encounter Books, 2000. p. 16-17; 203-250. confiadas da história mais teorizada é que a busca do passado se restrinja ao domínio do relativo, aquilo que não pode ser generalizado. $\mathrm{O}$ dado histórico não se repete, ele é único. Não se pode tratar o passado como as maçãs que, submetidas às mesmas condições, caem pela força da gravidade. Ao mesmo tempo, tais posições creem que existe conhecimento histórico específico a ser escavado e que o historiador não pode se deixar influenciar por ideologias ou preconcepções que de algum modo afetem a pesquisa que empreenderá.

Essa insurgência contra a teoria possui razões legítimas. Uma teoria pouco problematizada pode desvirtuar a própria ideia de conhecimento histórico. O argumento marxista, por exemplo, muitas vezes esqueceu-se das várias peculiaridades do passado por conta da necessidade de justificar uma ideia abstrata: A luta de classes que se repete no tempo e no espaço. $\mathrm{O}$ argumento liberal, por sua vez, diversas vezes transplantou o moderno conceito de liberdade para povos que não o conheceram. Os juristas constantemente pretendem justificar suas teorias com base em exemplos históricos pouco contextualizados. O direito internacional proporciona um bom exemplo: muitos autores costumam exemplificar o surgimento do princípio pacta sunt servanda naquele documento considerado como o primeiro tratado do mundo (O tratado de paz celebrado entre Hatusil III, rei dos hititas, e Ramsés II, faraó egípcio, entre 1280 e 1272 a.C.). Argumentos como esse servem mais para justificar que o direito dos tratados possui uma longa história e pouco se preocupam em perceber se existia direito internacional bem identificável na Antiguidade clássica e, em caso afirmativo, que tipo de direito internacional existia então. Esse tipo de postura, que pode ser chamada de teoricismo, permanece em um nível muito especulativo, puramente conceitual e é normalmente autorreferente - no sentido de prestar pouca atenção aos fatos. ${ }^{18}$

Mas a história não pode nem deve se afastar da teoria. É ela quem permite testar e contestar categorias e expandir o alcance de várias possibilidades conceituais e imaginativas. ${ }^{19}$

18 LACAPRA, Dominick. Articulating intellectual history, cultural history, and critical theory. In: LACAPRA, Dominick. History and its limits: human, animal, violence. Ithaca: Cornell University Press, 2009. p. 13-36. p. 30-32. LaCapra fornece alguns exemplos de obras históricas recentes que recaem nessa postura com base nos conceitos elaborados por teóricos como Lacan (o real), Lyotard (différend) ou Agamben (homo sacer).

19 LACAPRA, Dominick. Articulating intellectual history, cultur- 
Tomemos mais um exemplo para mostrar a importância da teoria para a história.

Alfred Verdross, em seu clássico manual Völkerrecht, decide iniciar o estudo do direito internacional pela chamada "comunidade cristã de Estados". Ele explica essa opção do seguinte modo:

Por outrolado, não há que se desconsiderar o impacto de outros dois círculos jurídicos internacionais, a saber: o bizantino e o islâmico sobre o Ocidente medieval. Contudo, nós não o levaremos em conta, porque, em geral, sua influência sobre a constituição do direito internacional moderno foi escassa. ${ }^{20}$

Esse recorte histórico adotado por Verdross demonstra didaticamente a necessidade de maior teorização para a história do direito internacional. Primeiramente, o que o autor quer dizer com círculos jurídicos internacionais? Tratar-se-ia de ordens jurídicas autônomas? Elas poderiam ser consideradas "outros" direitos internacionais"? O que significa propriamente impacto e influência de um círculo jurídico internacional em outro? Houve apenas um Ocidente medieval? A oposição entre medieval e moderno não carrega em si uma ideologia progressista, tornando o passado menos importante que o presente? Por que, enfim, a história do direito internacional deve ser contada tomando-se por base a Europa, quando coexistiam outros círculos jurídicos internacionais? O que significa, para a escrita da história do direito internacional hoje, o escasso conhecimento sobre a história de círculos jurídicos internacionais "alternativos" ao direito internacional moderno (e europeu)?

Alguns autores têm tentado responder a essas perguntas. Para tanto, eles têm precisado enveredar por uma série de questões teóricas que dizem respeito ao impacto de diferentes civilizações no desenvolvimento do direito internacional. Onuma Yasuaki, por exemplo, ao defender a sua perspectiva trans-civilizacional da história do direito internacional tem precisado responder a perguntas como: o que é uma sociedade internacional? O que significa uma perspectiva internacional em relação a uma perspectiva transnacional? Qual a relação entre poder e direito internacional? $\mathrm{O}$ que quer dizer a ocidentalização do direito internacional e o

al history, and critical theory. In: LACAPRA, Dominick. History and its limits: human, animal, violence. Ithaca: Cornell University Press, 2009. p. 13-36. p. 32.

20 VERDROSS, Alfred. Derecho internacional público. 4. ed. Madrid: Aguilar, 1961. p. 34. eurocentrismo? ${ }^{21}$ Os arquivos históricos sozinhos não conseguem responder a essas perguntas. Mais que isso, elas exigem, por parte de jusinternacionalistas, tomadas de posição que certamente podem ofender um historiador muito cioso da necessidade de manter a sua própria objetividade.

A verdade é que é virtualmente impossível fazer história sem qualquer tipo de teoria. Essa teoria pode ser de diversos tipos, pouco problematizadora ou muito problematizadora; pouco crítica ou muito crítica. O que a história do direito internacional realmente necessita constitui abrir portas para a compreensão do mundo que nos rodeia. Para mais uma vez lembrar LaCapra, a história (crítica) do direito internacional necessita criar mentalidade que possa lidar com temas bastante complexos com a consciência de que passado e presente interagem e que eles podem ser direcionados para uma abertura de diversos futuros possíveis. ${ }^{22} \mathrm{E}$ essa mentalidade não pode ser criada sem aporte robusto de teoria.

O jusinternacionalista deve estar preparado para encarar a história do direito internacional como "o produto de um campo de forças de impulsos frequentemente conflitantes, puxando-o de uma maneira ou de outra, e pondo mais questões do que pode responder". ${ }^{23}$ Isso quer dizer que muitas das perguntas que se põem, na investigação histórica, podem não ser resolvidas ou, às vezes, podem trazer mais de uma solução ao mesmo tempo. Um autor ou uma norma do passado não são oriundos de um pensamento completamente naturalista ou positivista, liberal ou marxista, libertário ou conservador. Essas forças contraditórias persistem na sociedade de hoje e do passado e moldam as coisas e os seres. Preparar-se para encarar essas contradições e complexidades significa situar-se e posicionar-se no mundo, e as teorias nos auxiliam nessa tarefa. Certo que aquele que escreve a história do direito internacional (ou qualquer história) não está autorizado a manipular fatos, imaginar aquilo que não existiu. Ele, porém, lê esses fatos

21 ONUMA, Yasuaki. A transcivilizational perspective on international law: questioning prevalent cognitive frameworks in the emerging multi-polar and multi-civilizational world of the twentyfirst century. Recueil des Cours de l'Académie de Droit International de la Haye, La Haye, v. 342, p. 77-410, 2009.

22 LACAPRA, Dominick. Articulating intellectual history, cultural history, and critical theory. In: LACAPRA, Dominick. History and its limits: human, animal, violence. Ithaca: Cornell University Press, 2009. p. 13-36. p. 17.

23 JAY, Martin. Introduction. In: JAY, Martin. Force fields: between intellectual history and cultural critique. London: Routledge, 1993. p. 1-9. p. 3. 
com pré-compreensões que trouxe consigo. É seu dever tornar explícitas essas pré-compreensões e permitir, assim, que outras histórias sejam escritas com outros tipos de pré-compreensões. Saber que há histórias diferentes porque as pessoas pensam de maneira diferente é o que constitui a nossa própria liberdade, a possibilidade de sermos, enfim, diferentes.

A história crítica do direito internacional deve, portanto, considerar a contribuição que a teoria pode oferecer na construção de narrativas históricas. E a teoria também pode oferecer à história crítica constante reflexão sobre seus próprios pressupostos e mudanças de caminho porventura necessárias para tornar a história um exercício de pluralismo e, porque não dizer, de construção da liberdade. A ausência de preocupações teóricas pode muitas vezes levar o historiador a naturalizar suas narrativas, acreditar que elas são como deveriam ser quando, de fato, elas poderiam ser lidas de diversas maneiras.

Assumir a importância da teoria significa tomar opções no mundo, opções que interferirão na escrita da história. E isso nos leva a outra questão, também bastante importante para o projeto da história crítica do direito internacional: a ética.

\subsection{História crítica do direito internacional e ética}

Como vimos acima, historiadores de grande renome, como J.G.A. Pocock, admitem que a história pode ser feita sem nenhum propósito específico: a história pela própria história.

Uma postura desse tipo é perfeitamente compreensível. Durante o século XX, diversos historiadores perceberam que sua própria independência havia sido comprometida. Em nome de ideais como patriotismo, vinculação política ou nacionalismo, a narrativa histórica serviu para legitimar relações de poder. A própria experiência de Estados totalitários demonstrou como a história poderia ser manipulada para interesses específicos. Uma reação a esse estado de coisas foi a adoção de postura mais neutra. A história não serviria a ninguém, senão a si própria: a história deveria ser feita em nome da própria história. A verdade histórica seria aquilo com o que realmente os historiadores deveriam se preocupar. ${ }^{24}$

24 SOUTHGATE, Beverley. What is history for? London: Routledge, 2005. p. 18-19.
Essa postura tem relação profunda com o tema já mencionado da necessidade de uma objetividade por parte do historiador. Ser objetivo consiste em deixar a história falar por si própria. Esse tipo de postura, entretanto, embora possua suas justificativas, provoca, ela mesma, diversas incompreensões. Gostaria de ressaltar duas delas.

Primeiro, ela gera o que um importante filósofo da história holandês, Frank Ankersmit, já chamou de "duplo dilema" (double bind). A objetividade na história exige que o historiador retire a sua subjetividade na construção de narrativas, ou seja, deixe de lado, dentre outras coisas, seus valores morais e políticos. Acontece que essa separação entre o objetivo (o passado) e o subjetivo (o historiador) tende a se dissolver. Isso porque não são apenas os valores morais e políticos do historiador que podem afetar o passado; também os valores morais existentes no passado narrado por um historiador podem invadir o seu mundo e o de seus contemporâneos. Não é possível tornar completamente objetivos esses valores morais e políticos que existiam no passado. Eles não podem ser simplesmente tratados como objetos porque podem interferir na subjetividade do historiador (fazendo-o mudar seus valores ou adotar novos com base na pesquisa que efetuou sobre o passado). Exatamente nisso consiste o "duplo dilema" do historiador. Se ele decide ser objetivo na investigação do passado, recairá em subjetivismo, porque estará simplesmente negando aqueles valores morais e políticos que existem no passado, numa espécie de "subjetivismo invertido". Ankersmit exemplifica essa postura como alguém que grita: "Não olhe para mim! Eu não estou aqui! Eu não existo!" E se, por outro lado, o historiador decide admitir que seus valores morais e políticos interferem nas suas narrativas históricas, ele estará incorrendo em subjetivismo. Nesse sentido, é extremamente artificial dividir o objetivo e o subjetivo nas narrativas históricas. ${ }^{25}$

Segundo, é certo que existem fatos incontroversos na história: determinadas coisas aconteceram e outras não - a queda de Impérios, o assassinato de chefes de Estado, o Holocausto... E um historiador consciente de sua função na sociedade não está autorizado a deturpar esses fatos. Mas o historiador, quando traz esses fatos para o presente, ele ou ela cria outra realidade que não mais existe. Sua narrativa constitui algo verdadeiramen-

25 ANKERSMIT, F. R. The ethics of history: from the double binds of (moral) meaning to experience. History and Theory, Middletown, v. 43, n. 4, p. 84-102, 2004. 
te novo no presente com base em um dado do passado. Se é assim, essa nova realidade terá algumas cores que estabelecem o que constitui o cenário que circunda o historiador. Dizer que existe objetividade total do historiador é negar-se a perceber esse cenário circundante. Diversas narrativas históricas trazem em si diferentes agendas escondidas, algumas delas conscientemente, outras subconscientemente. Por exemplo, o desejo de formar uma nação ou uma comunidade internacional, a pouca relevância concedida ao papel das mulheres, o esquecimento da contribuição de determinados grupos no passado, especialmente aqueles mais excluídos, interferem na escrita da história. Se a existência desse cenário que circunda o historiador é inevitável, que ao menos ele se esforce ao máximo para deixá-lo claro, que seus interesses - ao menos aqueles conscientes - se mostrem ao leitor. Isso nos permitirá aceitar a sua narrativa ou optar por outra explicação do passado elaborada por um historiador diferente. ${ }^{26}$ A transparência é, portanto, um valor ético importante que deve ser cultivado pelos historiadores críticos do direito internacional.

O historiador crítico do direito internacional também possui importante função ética de apresentar o passado não como ele naturalmente é, mas como o historiador o vê. ${ }^{27}$ Trata-se de compromisso com o pluralismo de valores e o pluralismo de narrativas. Não há interpretações infalíveis ou indiscutíveis. O passado pode (e deve) ser visto de maneiras diferentes. O seu dever não é para com o assunto histórico por ele tratado, mas para com os seus leitores. ${ }^{28}$ São eles que retirarão conclusões tomando-se por base o trabalho lido e perceberão o que o passado ilumina ou não. É fundamentado no cultivo dessa pluralidade que o historiador abre diversas possibilidades para a construção do futuro. A interpretação histórica que alega ser incontestável antecipa e controla o próprio futuro. Um dos principais fundamentos da teoria crítica é a de um futuro aberto. A ética da crítica, portanto, se funda na ideia de uma história indetermi-

26 ANKERSMIT, F. R. The ethics of history: from the double binds of (moral) meaning to experience. History and Theory, Middletown, v. 43, n. 4, p. 84-102, 2004.

27 Com isso, não pretendo afirmar que as demais atitudes excluem uma atitude ética. Contudo, na maior parte das vezes, elas não são conscientes disso ou partem do pressuposto de que há uma distância significativa entre o estudioso da história e o objeto de seu estudo.

28 SOUTHGATE, Beverley. A pair of white gloves: historians and ethics. Rethinking History, London, v. 10, n. 1, p. 49-61, 2006. p. $53 ; 59$. nada. ${ }^{29}$ Não é à toa que na introdução de seu The Gentle Civilizer of Nations, Martti Koskenniemi diz claramente que a sua narrativa

[...] não busca uma descrição neutra do passado 'como ele realmente foi' - esse tipo de conhecimento não é aberto a nós - mas uma descrição que busca tornar a situação presente mais clara para nós enquanto nos envolvemos em nossas práticas e projetos. Nesse sentido, constitui também um ato político: $:^{30}$

O projeto de uma história crítica, para realizar a ideia de uma história indeterminada, precisa levar em conta que o futuro "é garantido somente pela persistente insatisfação da crítica”. ${ }^{31}$ Esse projeto ético precisa levar em conta o presente. É justamente na ligação entre presente e passado que o futuro se torna viável. A despreocupação com o presente faz com que a história possa ser escrita "para a própria história", contribuindo, assim, diversas vezes, para a manutenção do status quo. As demandas do presente são essenciais para a história se se pretende que ela tenha um caráter revolucionário, mostrando que as coisas poderiam ter sido de maneira diferente e que a tradição não constitui uma prisão que nos impeça de pensar mundos alternativos.

A crítica tem, portanto, compromisso ético importante com o presente. É por isso que muitos historiadores críticos do direito internacional têm tentado articular o passado nas suas diversas teorizações sobre o direito internacional contemporâneo. Apresentarei brevemente apenas dois exemplos dessa tendência.

Um dos primeiros estudos, abordando de maneira sistemática uma visão crítica do direito internacional, o artigo de David Kennedy, A New Stream of International Law Scholarship, traça relação estreita entre história e teoria. Para Kennedy, o direito internacional demonstra padrões argumentativos — padrões de contradição e de solução, de diferença e de homologia. A doutrina, a história e a própria estrutura institucional que envolve o direito internacional reafirmam aqueles padrões de maneira repetida. Ora, para investigar como operam esses padrões, o estudo da história era e é essencial para

29 SCOTT, Joan W. History-writing as critique. In: JENKINS, Keith; MORGAN, Sue; MUNSLOW, Alun (Ed.). Manifestos for history. London: Routledge, 2007. p. 24.

30 KOSKENNIEMI, Martti. The gentle civilizer of nations: the rise and fall of international law 1870-1960. Cambridge: Cambridge University Press, 2001. p. 10.

31 SCOTT, Joan W. History-writing as critique. In: JENKINS, Keith; MORGAN, Sue; MUNSLOW, Alun (Ed.). Manifestos for history. London: Routledge, 2007. p. 34. 
a perspectiva de Kennedy. De fato, em diversas obras posteriores, o autor se debruçou sobre a história da disciplina para mostrar que aqueles padrões realmente existiam. $^{32}$

Mais recentemente, a internacionalista finlandesa Outi Korhonen propôs a ideia de "situacionalidade" para compreender o papel do jurista internacionalista. Essa "situacionalidade" somente pode ser compreendida com o auxílio de diversos aspectos que fogem da dimensão estritamente jurídica, mas que afetam os juristas na construção de suas ideias, como a cultura e a história. Essa história, no entanto, não possui um único significado, ela pode ser abordada de diferentes maneiras. ${ }^{33}$

Não é exclusividade dos autores críticos envolverem história e teoria. Como já afirmado anteriormente, diversos teóricos do direito internacional buscam na história a autoridade para confirmarem as suas teorias. A originalidade da abordagem crítica, no entanto, está em destruir ou mesmo questionar a autoridade de um autor, um argumento ou mesmo uma norma em relação ao presente. Mas essa atitude não é feita por um simples desejo de romper com as verdades estabelecidas, ela surge de um compromisso ético em mudar o estado de coisas atual com base na investigação do passado. $\mathrm{O}$ dever ético chama o crítico a ser inconformado com o status quo. Como afirma um historiador associado a correntes pós-modernas, Keith Jenkins, ao se referir às ideias de Edward Said: o intelectual (aí também se incluindo o historiador)

é uma pessoa que gosta de estar não completamente
ajustado, de existir, com felicidade, para além da
coloquial e inconsequente 'realidade' habitada pelos
nativos, de permanecer imune ao comodismo: uma
pessoa não cooptável, desobediente. ${ }^{34}$

Esse inconformismo deve se referir não apenas ao status quo vigente, mas ao status quo que já passou. $\mathrm{O}$ historiador crítico tem também contas a prestar com aqueles que já se foram. Por isso, uma das funções da história consiste em proporcionar o "outro". Do mesmo modo que muito do pensamento contemporâneo tem buscado entender, por exemplo, os estrangeiros,

32 KENNEDY, David. A new stream of international law scholarship. Wisconsin International Law Journal, Madison, v. 7, n. 1, p. 1-49, 1988. 33 KORHONEN, Outi. International law situated: an analysis of the lawyer's stance towards culture, history and community. The Hague: Kluwer, 2000. p. 129-206; 295.

34 JENKINS, Keith. Ethical responsibility and the historian: on the possible end of a history 'of a certain kind'. History and Theory, Middletown, v. 43, n. 4. p. 43-60, 2004. p. 57. Ênfases do original. os escravos ou os povos primitivos e colonizados, é preciso compreender também esses "outros", cronologicamente falando: aqueles escondidos nas narrativas oficiais, aqueles cuja memória foi reprimida ou mesmo suprimida, aqueles que ficaram esquecidos no tempo ${ }^{35}$. Somente assim se poderá fazer justiça a eles. Como afirmou Walter Benjamin: "existe um ponto de encontro misterioso entre as gerações passadas e a nossa: fomos esperados sobre a terra". ${ }^{36}$

\subsubsection{Historiografia do direito internacional, colo- nialismo e eurocentrismo}

Um debate contemporâneo que muito envolve a questão da ética na historiografia do direito internacional merece ser mencionado neste artigo.

Nos últimos anos, em especial entre autores ligados a correntes críticas, muito se tem falado sobre a influência do colonialismo e da Europa na formação do direito internacional como o conhecemos hoje. Não há dúvidas de que uma parte considerável dessa literatura é fruto dos esforços de autores ligadas às já mencionadas TWAIL. ${ }^{37}$ Os autores ligados às TWAIL partem do pressuposto de que a história do direito internacional é essencial para o estudo da disciplina e de que a Europa, com suas políticas colonialistas, a influenciou de maneira inescapável. No entanto, é perceptível um interesse no tema também em autores não necessariamente ligados a essas abordagens terceiro-mundistas. ${ }^{38}$

Ante essa tendência nos estudos historiográficos críticos do internacional, a grande questão que se coloca não é saber se o colonialismo influenciou o direito internacional, mas o quanto de influência o primeiro exerceu no segundo e se tal influência ainda persiste.

35 SOUTHGATE, Beverley. What is history for? London: Routledge, 2005. p. 120.

36 MATE, Reyes. Medianoche en la historia: comentarios a las tesis de Walter Benjamin 'sobre el concepto de historia'. Madrid: Trotta, 2006. p. 67.

37 GATHII, James Thuo. TWAIL: a brief history of its origins, its decentralized network, and a tentative bibliography. Trade, Law and Development, Jodhpur, v. 3, n. 1, p. 26-64, 2011.

38 KOSKENNIEMI, Martti. Histories of international law: dealing with eurocentrism. Rechtsgeschichte, Frankfurt, v. 19, p. $152-$ 176, 2011 e ORFORD, Anne. The past as law or history? the relevance of imperialism for modern international law. In: TOUFAYAN, Mark; TOURME-JOUANNET, Emmanuelle; RUIZ FABRI, Hélène (Ed.). Droit international et nouvelle approches sur le Tiers-Monde: entre repetition et renouveau. Paris: Societé de Législation Comparée, 2013. p. 97-117. 
Nessa questão, dois tipos de postura podem ser facilmente identificadas - um debate que remonta aos estudos sobre pós-colonialismo em geral. Há aqueles que acreditam que o direito internacional é tão impregnado por estruturas coloniais, que não se pode pensá-lo sem essas. Nesse sentido, não haveria saída para o direito internacional fora do colonialismo ou de suas novas formas. Outros, por sua vez, entendem que o direito internacional pode superar a herança (perniciosa) do colonialismo no direito internacional. ${ }^{39}$

Tal divergência reverbera, no âmbito dos estudos historiográficos do direito internacional, no problema de saber como o historiador do direito internacional deve encarar as ideias de colonialismo e Europa na composição de suas narrativas. Autores como Anghie parecem entender que fazer história do direito internacional está invariavelmente ligado a fazer a história do colonialismo, pois, como afirmado acima, para esse autor, o direito internacional se formou no próprio "encontro colonial". Outros, como Koskenniemi, embora não fujam da constatação de que toda a historiografia do direito internacional feita até então possui o traço de eurocentrismo e o colonialismo que dele decorre — até mesmo a literatura ligada às TWAIL teria certa carga de eurocentrismo, sustenta - percebem algum espaço para a superação dessa marca. ${ }^{40}$

Outro conjunto de autores, ao reconhecer a importância do estudo do eurocentrismo e do colonialismo no direito internacional, concebe, de maneira mais clara que o próprio Koskenniemi, a possibilidade de sua superação. Tais autores buscam trazer para o campo jurídico internacional a contribuição, em especial, da chamada "história global", que se tornou bastante conhecida principalmente pela contribuição de historiadores alemães. Esse tipo de historiografia se concentraria nas diversas interações que ocorreram em nível global e

39 Ver GATHII, James Thuo. International law and eurocentricity. European Journal of International Law, Firenze, v. 9, n. 1, p. 184-211, 1998. Recentemente o ex-juiz da Corte Internacional de Justiça e representante da chamada primeira geração de TWAILers, Mohammed Bedjaoui, demonstrou uma certa esperança em ver o direito internacional desconectado da ideia de colonialismo. BEDJAOUI, Mohammed. Observations sur le texte d'Antony Anghie. In: TOUFAYAN, Mark; TOURME-JOUANNET, Emmanuelle; RUIZ FABRI, Hélène (Ed.). Droit international et nowvelle approches sur le TiersMonde: entre repetition et renouveau. Paris: Societé de Législation Comparée, 2013. p. 89-91.

40 KOSKENNIEMI, Martti. Histories of international law: dealing with eurocentrism. Rechtsgeschichte, Frankfurt, v. 19, p. 152-176, 2011. p. 168 local entre diferentes tipos de atores sociais no tempo. Assim, tanto a chamada "periferia" teria influenciado o "centro" do mundo como vice e versa. A maior parte dos historiadores globais não consegue ver, diferentemente dos pós-colonialistas, que as relações sociais entre diferentes atores em diferentes partes do mundo tenham se dado exclusivamente ou eminentemente por meio de subjugação do mais forte pelo mais fraco. A maior tentativa de trazer o debate sobre a história global no direito internacional se deu com a publicação do The Oxford Handbook of the History of International Law, ${ }^{41}$ obra organizada por dois autores também alemães: Anne Peters e Bardo Fassbender.

O debate sobre colonialismo e eurocentrismo na historiografia do direito internacional possui o grande mérito não apenas de visibilizar o sofrimento de pessoas e povos durante o tempo, mas também de atribuir à história do direito internacional o importante papel de auxiliar na construção de agendas para o presente. Quando se fala na persistência ou superação do colonialismo no direito internacional, estabelece-se, também, crítica à manutenção dessas estruturas e a opção por um direito internacional diferente.

É verdade que conectar o presente ao passado pode gerar sérios riscos de um internacionalista ou historiador incorrerem no já mencionado anacronismo. Recentemente, a internacionalista crítica australiana, Anne Orford, ao defender o papel das TWAIL em conectar presente e passado, contestou a importância excessiva que tradicionalmente se tem atribuído à questão do anacronismo com base em uma diferenciação necessária entre história e direito. $\mathrm{O}$ segundo se move eminentemente por prioridades do presente, sustenta ela. ${ }^{42} \mathrm{O}$ zelo em evitar o anacronismo, no entanto, não parece

41 Ver especialmente FASSBENDER, Bardo; PETERS, Anne. Introduction: towards a global history of international law. In: FASSBENDER, Bardo; PETERS, Anne (Ed.). The Oxford handbook of the history of international law. Oxford: Oxford University Press, 2012. p. 1-24. Ver, também, o simpósio dedicado ao livro, publicado no European Journal of International Law, v. 25, n. 1, p. 287-341, 2014, com estudos bastante céticos quanto à aplicação da história global ao direito internacional. KEMMERER, Alexandra. Towards a global history of international law. European Journal of International Law, Oxford, v. 25, n. 1, p. 287-295, Feb. 2014.

42 ORFORD, Anne. The past as law or history? the relevance of imperialism for modern international law. In: TOUFAYAN, Mark; TOURME-JOUANNET, Emmanuelle; RUIZ FABRI, Hélène (Ed.). Droit international et nouvelle approches sur le Tiers-Monde: entre repetition et renouveau. Paris: Societé de Législation Comparée, 2013. p. $97-117$. p. 89-91. 
ser a grande questão em jogo. O que se faz com o passado não está no passado. Os usos da história são estabelecidos no presente, possuindo, muitas vezes, funções prospectivas. Soaria inocente a qualquer historiador afirmar que o passado não pode interferir no presente.

Atribuir à pesquisa historiográfica a possibilidade de auxiliar na construção de agendas do tempo presente também reforça a função ética do historiador do direito internacional. Por essa razão, esse debate gira, em última análise, em torno da ética na composição de narrativas históricas. Ainda que discordem quanto aos métodos, pós-colonialistas (boa parte ligados às TWAIL) e historiadores globais do direito internacional concordam que o colonialismo foi pernicioso para as relações internacionais e ele não deve persistir ou ser ressuscitado. Essa é uma opção clara que interfere na construção e confecção de teorias jurídicas internacionais e mesmo na interpretação de problemas concretos práticos da realidade internacional.

Afinal, uma ética de responsabilidade para o historiador do direito internacional deve significar não apenas fiar-se em regras rigorosas da pesquisa historiográfica, mas também viabilizar a possibilidade de mundo diferente.

\section{Considerações finais}

A pergunta "para que serve a história do direito internacional?” depende essencialmente da concepção de história e da concepção de direito internacional que se tem. Neste artigo, identifiquei ao menos três atitudes claras do jurista em relação ao passado que ajudam a respondê-la. As atitudes estática e dinâmica, embora apresentem prioridades diferentes, possuem ponto em comum: ambas buscam no passado certa autoridade para justificar o presente. Uma terceira atitude, denominada crítica, vê o passado como campo aberto, não se comprometendo necessariamente em buscar autoridade para justificar o presente.

Não existe atitude "correta" do jurista em relação ao passado, assim como não existe resposta correta à questão "para que serve a história do direito internacional?". Adotar uma das atitudes significa priorizar alguns elementos na história e, assim, responder de maneira diferente à mencionada pergunta.
Esse autor considera que reduzir a função da história a uma mera legitimação do presente significa, no entanto, conformar-se com a forma e a organização atual do sistema jurídico internacional. O direito internacional está longe de produzir justiça em larga escala para os povos do mundo. Ele serve mesmo para confirmar relações de poder entre Estados, instituições e pessoas ao redor do globo. A história (ou, para ser mais preciso, a historiografia, no sentido daquilo que os historiadores escrevem) tem muito a contribuir para repensar o próprio direito internacional. Ela pode oferecer soluções alternativas, abrir novos caminhos de pesquisa e estimular a criatividade do jurista na solução de problemas globais. Nos dias atuais, a crítica tem se mostrado a atitude que melhor oferece instrumentos para a mudança do direito internacional, especialmente porque não está comprometida diretamente com a busca de uma autoridade para o presente.

A atitude crítica na história do direito internacional, embora já identificada em diversos autores, precisa ser radicalizada. Dois caminhos são importantes para esse fim: um diálogo maior da história com a teoria e a compreensão de que lidar com o passado significa tomar posições no campo da ética. Enquanto a crítica fornece sofisticação à história, permitindo a ampliação de horizontes e reflexão sobre as suas próprias limitações, a ética demonstra que o historiador constitui alguém que está comprometido não apenas com o passado, mas também com o presente e o futuro: o historiador em geral, mas também o historiador do direito internacional constitui alguém que produz aspectos éticos e não apenas os consome. ${ }^{43}$

Levando-se em consideração essa opção pela atitude jurídica crítica em relação ao passado, é possível responder à pergunta contida no título deste artigo. A história do direito internacional serve para indagar ou mesmo romper com tradições estabelecidas, auxiliando o direito internacional a repensar os seus próprios fundamentos; consequentemente, ela permite a construção de diferentes alternativas possíveis para a organização jurídica internacional do presente e do futuro ao levar em consideração uma necessária prestação de contas devida para com as gerações passadas.

43 GORMAN, Jonathan. Ethics and the writing of historiography. In: TUCKER, Aviezer (Ed.). A companion to the philosophy of history and historiography. Chichester: Blackwell, 2009. p. 253-261. p. 260. 
Esta, no entanto, não é nem pode ser uma resposta definitiva, porém apenas provisória. A atitude crítica é, ela própria, sujeita a constantes ajustes e modificações. Esse deve ser o esforço do qual a história do direito internacional não pode abrir mão: estar aberta à revisão, todo o instante, ainda que isso nos traga instabilidade ou nos distancie de nossos amados pais.

\section{RefERÊNCIAS}

ANGHIE, Antony. Imperialism, sovereignty and the making of international law. Cambridge: Cambridge University Press, 2007.

ANKERSMIT, F. R. The ethics of history: from the double binds of (moral) meaning to experience. History and Theory, Middletown, v. 43, n. 4, p. 84-102, 2004.

BEDERMAN, David J. Foreign office international legal history. In: CRAVEN, Matthew; FITZMAURICE, Malgosia; VOGIATZI, Maria (Ed.). Time, history and international law. Leiden: Martinus Nijhoff, 2007. p. 43-64.

BEDJAOUI, Mohammed. Observations sur le texte d'Antony Anghie. In: TOUFAYAN, Mark; TOURMEJOUANNET, Emmanuelle; RUIZ FABRI, Hélène (Ed.). Droit international et nowvelle approches sur le TiersMonde: entre repetition et renouveau. Paris: Societé de Législation Comparée, 2013. p. 89-91.

CRAVEN, Matthew. Introduction: international law and its histories. In: CRAVEN, Matthew; FITZMAURICE, Malgosia; VOGIATZI, Maria (Ed.). Time, history and international law. Leiden: Martinus Nijhoff, 2007. p. 1-26.

FASSBENDER, Bardo; PETERS, Anne. Introduction: towards a global history of international law. In: FASSBENDER, Bardo; PETERS, Anne (Ed.). The Oxford handbook of the history of international law. Oxford: Oxford University Press, 2012. p. 1-24.

FRANCK, Thomas M. Fairness in international law and institutions. Oxford: Oxford University Press, 1998.

GATHII, James Thuo. International law and eurocentricity. European Journal of International Law, Firenze, v. 9, n. 1, p. 184-211, 1998.

GATHII, James Thuo. TWAIL: a brief history of its origins, its decentralized network, and a tentative bibliography. Trade, Law and Development, Jodhpur, v. 3, n. 1, p.
26-64, 2011.

GORDON, R. W. The struggle over the past. Cleveland State Law Review, Cleveland, v. 44, n. 2, p. 123-143, 1996.

GORMAN, Jonathan. Ethics and the writing of historiography. In: TUCKER, Aviezer (Ed.). A companion to the philosophy of history and historiography. Chichester: Blackwell, 2009. p. 253-261.

HATHAWAY, Oona; SHAPIRO, Scott J. Outcasting: enforcement in domestic and international law. Yale Law Journal, New Haven, v. 121, n. 2, p. 252-349, 2011.

JAY, Martin. Introduction. In: JAY, Martin. Force fields: between intellectual history and cultural critique. London: Routledge, 1993. p. 1-9.

JENKINS, Keith. Ethical responsibility and the historian: on the possible end of a history 'of a certain kind'. History and Theory, Middletown, v. 43, n. 4. p. 43-60, 2004.

KEMMERER, Alexandra. Towards a global history of international law. European Journal of International Law, Oxford, v. 25, n. 1, p. 287-295, Feb. 2014.

KENNEDY, David. A new stream of international law scholarship. Wisconsin International Law Journal, Madison, v. 7, n. 1, p. 1-49, 1988.

KORHONEN, Outi. International law situated: an analysis of the lawyer's stance towards culture, history and community. The Hague: Kluwer, 2000.

KOSKENNIEMI, Martti. Histories of international law: dealing with eurocentrism. Rechtsgeschichte, Frankfurt, v. 19, p. 152-176, 2011.

KOSKENNIEMI, Martti. The gentle civilizer of nations: the rise and fall of international law 1870-1960. Cambridge: Cambridge University Press, 2001.

KOSKENNIEMI, Martti. Why history of international law today? Rechtsgeschichte, Frankfurt, v. 4, p. 61-66, 2004.

LACAPRA, Dominick. Articulating intellectual history, cultural history, and critical theory. In: LACAPRA, Dominick. History and its limits: human, animal, violence. Ithaca: Cornell University Press, 2009. p. 13-36.

LACAPRA, Dominick. Introduction. In: LACAPRA, Dominick. History and its limits: human, animal, violence. Ithaca: Cornell University Press, 2009.

LESAFFER, Randall. International law and its histo- 
ry: the story of an unrequited love. In: CRAVEN, Matthew; FITZMAURICE, Malgosia; VOGIATZI, Maria (Ed.). Time, history and international law. Leiden: Martinus Nijhoff, 2007. p. 27-42.

MACEDO, Paulo Emílio Vauthier Borges de. O mito de Francisco de Vitória: defensor dos índios ou patriota espanhol? Revista de Direito Internacional, Brasília, v. 9. n. 1, p. 1-13, 2012.

MATE, Reyes. Medianoche en la historia: comentarios a las tesis de Walter Benjamin 'sobre el concepto de historia'. Madrid: Trotta, 2006.

ONUMA, Yasuaki. A transcivilizational perspective on international law: questioning prevalent cognitive frameworks in the emerging multi-polar and multi-civilizational world of the twenty-first century. Recueil des Cours de l'Académie de Droit International de la Haye, La Haye, v. 342, p. 77-410, 2009.

ORFORD, Anne. The past as law or history? the relevance of imperialism for modern international law. In: TOUFAYAN, Mark; TOURME-JOUANNET, Emmanuelle; RUIZ FABRI, Hélène (Ed.). Droit international et nowvelle approches sur le Tiers-Monde: entre repetition et renouveau. Paris: Societé de Législation Comparée, 2013. p. 97-117.

PASTOR RIDRUEJO, José António. Curso de derecho internacional público y organizaciones internacionales. 6. ed. Madrid: Tecnos, 1996.
POCOCK, J. G. A. Law, sovereignty and history in a divided culture: the case of New Zealand and the Treaty of Waitangi. MoGill Law Journal, Montreal, v. 43, n. 1, p. 481-506, 1998.

REDSLOB, Robert. Histoire des grands principes du droit des gens. Paris: Librairie Arthur Rousseau, 1923.

REMIRO BROTÓNS, António et al. Derecho internacional: curso general. Valencia: Tirant lo Blanch, 2010.

SCOTT, Joan W. History-writing as critique. In: JENKINS, Keith; MORGAN, Sue; MUNSLOW, Alun (Ed.). Manifestos for history. London: Routledge, 2007. p. 19-38.

SOUTHGATE, Beverley. A pair of white gloves: historians and ethics. Rethinking History, London, v. 10, n. 1, p. 49-61, 2006.

SOUTHGATE, Beverley. What is history for? London: Routledge, 2005.

VERDROSS, Alfred. Derecho internacional público. 4. ed. Madrid: Aguilar, 1961.

WEIL, Prosper. Towards relative normativity in international law? American Journal of International Law, Washington, v. 77, n. 3, p. 413-442, 1983.

WINDSCHUT'TLE, Keith. The killing of history: how literary critics and social theorists are murdering our past. San Francisco: Encounter Books, 2000. 


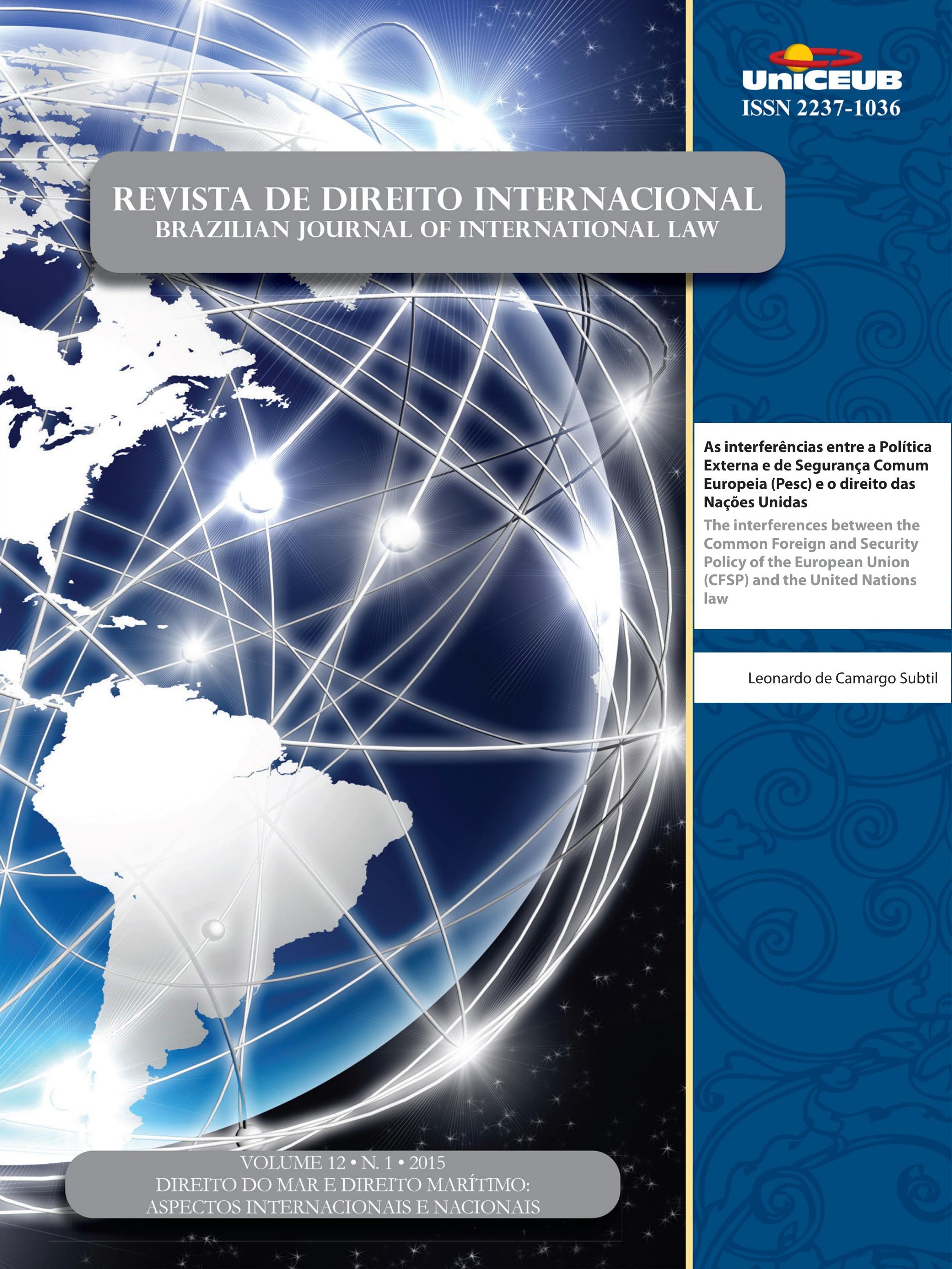




\title{
As interferências entre a Política Externa e de Segurança Comum Europeia (Pesc) e o direito das Nações Unidas*
}

\author{
The interferences between the Common \\ Foreign and Security Policy of the European \\ Union (CFSP) and the United Nations law
}

Leonardo de Camargo Subtil**

\section{Resumo}

O presente trabalho tem por objetivo apresentar uma análise sobre as interrelações entre a Política Externa e de Segurança Comum Europeia (PESC) e o Direito das Nações Unidas na sociedade internacional. Para tanto, utilizou-se do método teórico-pragmático para a observação das categorias escolhidas, tendo, como técnica de pesquisa, a exploração bibliográfica, com consulta dogmática, doutrinária e jurisprudencial em relação aos temas explorados na pesquisa. Nas conclusões obtidas, verificou-se que artigo 103 da Carta das Nações Unidas não se caracteriza como uma regra de hierarquia jurídica ou como uma regra de conflito de normas. Pelo contrário, trata-se de uma regra de conflito de obrigações em Direito Internacional. Por fim, somente se deve decidir pela primazia das obrigações decorrentes do Direito das Nações Unidas em relação àquelas do Direito da União no caso de evidente conflito de obrigações, como na problemática trazida pelo presente artigo.

Palavras-chave: Direito da união. Direito das Nações Unidas. Política externa e de segurança comum europeia. Teoria do direito.

\section{Abstract}

This article aims to present an analysis on the interrelations between the Common Foreign and Security Policy of the European Union (CFSP) and the United Nations Law in international society. For this purpose, we have made an option for a theoretical and pragmatic method to observe the selected legal categories. As a technique of research, we have chosen a bibliographic exploration, with dogmatic, doctrinal and jurisprudential consultation, on issues related to this paper. In conclusion, it was found that Article 103 of the United Nations Charter should not be seen as a hierarchical legal rule or as a rule of conflict of laws. On the contrary, it is a rule of conflict of obligations in International Law. Finally, it should only be decided in favor of the primacy of the obligations under the United Nations Law in relation to those of the European Union Law in case of obvious conflict of obligations, such as the issue raised by this paper. 
Keywords: European Union law. United Nations law. Common foreign and security policy of the European Union. Theory of law.

\section{INTRODUÇÃO}

C'est ce qui fonde l'oscillation interminable de l'argumentation juridique libérale internationaliste entre les deux pôles de l'utopie et de l'apologie. ${ }^{1}$

Em 1989, Martti Koskenniemi publica a obra From apology to utopia: the structure of international legal argument, desvelando os momentos de oscilação argumentativa do Direito Internacional Público, da apologia de um mundo descritivo à utopia de uma ordem desejada pela sociedade internacional. Toda essa estrutura normativa em oscilação, transposta também na teoria do Direito enquanto apologia ou utopia, permeará não somente a construção e o desenvolvimento das categorias científicas, mas o debate em torno das relações entre a ordem jurídica da União Europeia e a internacional, em especial, a quaestio juris do Direito como técnica de poder ou do Direito enquanto fim em si.

Dentro desse contexto, será desenvolvido o presente estudo Interferências entre Política Externa e de Segurança Comum Europeia (PESC) e o Direito das Nações Unidas, no sentido de desvelar caracteres comuns e conflitantes na interação entre o Direito Internacional Público e o Direito da União ${ }^{2}$. Em particular, nessa concepção interativa e, ao mesmo tempo paradoxal, como será observado, a preocupação essencial é justamente de não perder a ideia de sistema, seja do sistema jurídico, seja do sistema político-institucional, bem como a ideia de sistema social, a fim de não desnaturar a ideia de sistema normativo como quadro epistemológico de estabilidade, de integridade e de coerência normativas.

Esses paradoxos constitutivos do sistema jurídico-internacional - que o fazem evoluir cientificamente

1 KOSKENNIEMI, Martti. From apology to utopia: the structure of the international legal argument. Cambridge: Cambridge University Press, 2005. p. 58.

2 No presente artigo, utiliza-se a expressão Direito da União - e não Direito Comunitário - para indicar o novo Direito da União Europeia ante as modificações trazidas pelo Tratado de Lisboa, de 01 de dezembro de 2009, que emendou o Tratado da União Europeia (TUE - Maastricht, 1992) e o Tratado constitutivo da Comunidade Europeia (TCE, Roma, 1957), este renomeado para Tratado sobre o Funcionamento da União Europeia (TFUE).
- podem ser observados em diversos subsistemas jurídicos como, por exemplo, o Direito da União e o Direito Internacional Público. Esta observação de cunho geral e introdutório concerne às questões normativas o campo de criação ou de análise dogmática das regras jurídicas —, institucionais - o campo de aplicação e de interpretação normativas - e reflexivas sobre essas últimas dimensões no plano crítico para assegurar a integridade normativa e, ao mesmo tempo, a transformação evolutiva inscrita na sobrevivência do próprio sistema jurídico internacional.

Para tanto, nessa análise de interação entre o Direito Internacional Público e o Direito da União, será utilizada a metodologia teórico-pragmática, no sentido da construção teórica a partir dos fenômenos normativos e sociais - do plano da cotidianidade (everydayness $)^{3}-\mathrm{e}$ da análise destes a partir da reflexividade do Direito em suas próprias categorias científicas. Além disso, a técnica de pesquisa a ser utilizada será a de exploração bibliográfica, com consulta dogmática, doutrinária e jurisprudencial em relação aos temas explorados na pesquisa, em livros, sítios e periódicos científicos.

A estrutura do presente artigo, ao ser definida, seguiu os seguintes objetivos: 1) delimitar, normativamente e institucionalmente, a Política Externa e de Segurança Comum (PESC) na União Europeia, desde o Tratado de Roma (1957) até as modificações trazidas pelo Tratado de Lisboa (2009); 2) demonstrar a paradoxal relação entre as obrigações decorrentes da Política Externa e de Segurança Comum Europeia (PESC) e do Direito das Nações Unidas ${ }^{4}$, em especial, da análise do artigo 103 da Carta das Nações Unidas.

Convém salientar que a estruturação do estudo fora realizada com base no seguinte problema de pesquisa: quando houver conflito entre as prescrições ${ }^{5}$ de Política Externa e de Segurança Comum Europeia (PESC) decorrentes do Direito da União - e de Paz e Segurança internacionais - em virtude das Resoluções expedidas pelo Conselho de Segurança com base no capítulo

3 RICHARDSON, John. Existencial epistemology: a heideggerian critique of the cartesian project. New York: Oxford University Press, 1986. p. 15.

4 Por Direito das Nações Unidas, entenda-se, em especial, a moldura normativo-institucional do sistema internacional pós-criação da Organização das Nações Unidas, em 26 de junho de 1945.

5 Prescrições normativas, com cunho obrigacional, em virtude de decisões tomadas politicamente, criadoras de obrigações jurídicas, com sustentação no Direito da União ou no Direito das Nações Unidas. 
VII da Carta das Nações Unidas, haveria uma relação de primazia no que tange as obrigações assumidas pela União Europeia em virtude do Direito da União e do Direito das Nações Unidas?

Sendo assim, a União Europeia imersa no conflito e na divergência acima descritos, numa concepção unitária e integrativa do Direito, deveria seguir a regra da primazia das obrigações decorrentes do Direito da União ou pender para a primaz̨ia das obrigacõoes decorrentes do Direito das Nações Unidas? Essas são, ainda que resumidamente, as linhas fundamentais do estudo a ser desenvolvido a seguir, com base nas premissas e objetivos traçados.

\section{A tRANSFormação NORMATIVO- INSTITUCIONAL DA POLÍTICA EXTERNA E DE SEGURANÇA COMUM NA UNIÃo EUROPEIA}

L'Europe a avancé pas à pas, de traités en traités. Le chemin est jalonné d'accords partiels, de crises, vite surmontées. Le trait le plus frappant est que l'Europe a pu paraitre bloquée, à certaines époques, mais qu'elle n'a jamais reculé. ${ }^{6}$

Valéry Giscard d'Estaing, Presidente da Convenção Europeia, ex-Presidente francês (1974-1981), em seu discurso introdutório à Convenção sobre o futuro da Europa, refere o processo de desenvolvimento de uma Europa dos tratados. Os marcos normativos da construção europeia, desde seu surgimento histórico com a Comunidade Europeia do Carvão e do Aço (CECA $)^{7}$, em 18 de abril de 1951, com o Tratado de Paris, seguiram duas faces de uma mesma moeda, a ambição (apologia) e a ficção (utopia).

A ambição europeia incide sobre o parcialmente construído, os acordos transitórios, as concertações políticas fragmentadas, as crises duradouras, as reuniões interestatais permanentes, e todas essas etapas fizeram os marcos normativos de criação e de desenvolvimento europeus tocar a realidade europeia, isto é, desenvolver-se com base em uma faticidade europeia, essencialmente regional ${ }^{8}$. Assim, tem-se o modelo da apologia europeia,

6 ESTAING, Valéry Giscard. Discours introductif à la Convention sur l'avenir de l'Europe. Disponível em: <http://www.senat.fr/europe/ convention_2002/discours_vge_28022002.pdf>. Acesso em: 03 fev. 2014.

7 Os seus inspiradores foram Robert Schuman, Ministro francês dos Negócios Estrangeiros, e Jean Monnet, o seu primeiro Presidente. Além disso, os seus países fundadores foram: França, Itália, Alemanha Ocidental, Bélgica, Países Baixos e Luxemburgo.

8 A expressão "fato regional" foi desenvolvida de maneira baseado na realidade construída politicamente e normativamente pari passu, com considerada perseverança ${ }^{9}$, tendo em vista que "as modificações políticas e jurídicas espraiam-se por quase cinquenta anos, sem que esmoreça a vontade de fazer coisas, mesmo se o ritmo não seja o mesmo a todos os momentos." 10

$\mathrm{Na}$ esteira do forte pragmatismo político, ligado, portanto, à ideia da ambição europeia, líderes como Jean Monnet, Robert Schuman, Paul-Henri Spaak, Alcide de Gasperi e Konrad Adenauer consagram a ideia da integração calçada no fundamento das transferências parciais e graduais de soberania formal dos Estados. Essas transferências asseguram o fundamento de sua competência e de seu poder, ligados ao que efetivamente se dá por construído no espaço europeu - a dimensão real de poder (apologia), pois justamente "[...] ocurre siempre que la divergencia entre los elementos de hecho y la regla jurídica aumenta hasta originar una tensión excesiva; entonces, el derecho se halla expuesto a perder contacto con la vida." 11

Na outra face, reside a ficção europeia, incidindo sobre o porvir europeu, a necessidade de construção de uma Europa estável — outrora marcada por instabilidade política e debilidade institucional das duas grandes guerras mundiais - e, ao mesmo tempo, transformadora de sua própria realidade política, pois “[...] esses objetivos e essas ações buscam instaurar a paz política, interna e externa, e o bem-estar social mediante o desenvolvimento econômico. Essa proposta adquire contornos nítidos após 1945, mas já apresenta sinais nítidos de persistência desde finais do século XVIII.’12

analítica por Laurence Boisson de Chazournes. Ver: BOISSON DE CHAZOURNES, Laurence. Les relations entre organisations régionales et organisations universelles. In: L'ACADÉMIE DE DROIT INTERNATIONAL DE LA HAYE. Recueil des cours de l'Académie du droit international de la Haye. Leiden: M. Nijhoff, 2011. t. 347. p. 79-406. p. 105-106.

9 Para Estevão de Rezende Martins, na construção da União Europeia, desde a Conferência de Messina, em junho de 1955, até a Convenção Europeia, de fevereiro de 2002, 05 (cinco) são os princípios que a sustentaram: a) persistência; b) perseverança; c) paciência; d) prudência; e) parceria. MARTINS, Estevão de Rezende. Parcerias almejadas: política externa, segurança, defesa e história na Europa. Belo Horizonte: Fino Traço, 2012. p. 12.

10 MARTINS, Estevão de Rezende. Parcerias almejadas: política externa, segurança, defesa e história na Europa. Belo Horizonte: Fino Traço, 2012. p. 16.

11 VISSCHER, Charles de. Teorias y realidades en derecho internacional público. Barcelona: Bosch, 1962. p. 12.

12 MARTINS, Estevão de Rezende. Parcerias almejadas: política externa, segurança, defesa e história na Europa. Belo Horizonte: Fino Traço, 2012. p. 13. 
Nesse mesmo sentido, em 9 de maio de 1950, Robert Schuman, Ministro dos Assuntos Estrangeiros da França, profere a Declaração Schuman em que propõe a criação da Comunidade Europeia do Carvão e do Aço (CECA). Em seu pronunciamento faz-se claramente perceptível a dimensão ficcional europeia, eis que "la paix mondiale ne saurait être sauvegardée sans des efforts créateurs à la mesure des dangers qui la menacent." ${ }^{\text {13 }}$

Entre essas duas faces da ambição e da ficção europeias, entre apologia e utopia, começa a surgir um novo modelo, o do corpus europeu, e a sobrevivência das novas concertações políticas e do corpo normativo europeu passa dos Estados - individualmente considerados - para justamente uma nova realidade orgânica sui generis, a União Europeia. ${ }^{14}$ É justamente nessa preocupação relativa ao corpus institucional europeu - que surge a necessidade histórica e institucional de criação e de desenvolvimento de mecanismos de preservação política em matéria de política externa e segurança comum do espaço europeu. Pensar a preservação política do espaço europeu passa sobremaneira pela criação e pela preservação do próprio Direito como instrumento, antes de tudo, de manutenção do status quo (sustentação política).

Gradualmente, tais mecanismos de defesa e segurança acompanham a evolução do espaço europeu, tratado a tratado, como sublinhara Valéry Giscard d'Estaing, ${ }^{15}$ conformando a transformação normativo-institucional da Política Externa e de Segurança Comum na União Europeia.

\subsection{Do Tratado de Roma (1957) ao Tratado de Maastricht (1992)}

Entre a ausência política e a Política Externa e de Segurança Comum (PESC)

13 SCHUMAN, Robert. La déclaration Schuman du 9 mai 1950. Disponível em: <http://europa.eu/about-eu/basic-information/symbols/europe-day/schuman-declaration/index_fr.htm>. Acesso em: 03 fev. 2014

14 Neste estudo, quando se citar União Europeia, obviamente, considerar-se-á toda evolução histórica e, posteriormente, institucional, até se chegar ao nível mais elevado de integração políticoeconômica, a União Europeia. Nesse desenvolvimento, a importância da Comunidade Europeia do Carvão e do Aço (CECA), da Comunidade Econômica de Defesa (CED), da Comunidade Econômica da Energia Atômica (CAEA), da Comunidade Econômica Europeia e da União Europeia.

15 ESTAING, Valéry Giscard. Discours introductif à la convention sur l'avenir de l'Europe. Disponível em: <http://www.senat.fr/europe/ convention_2002/discours_vge_28022002.pdf>. Acesso em: 03 fev. 2014.
Embora seja possível falar em processo de integração europeia somente no século XX, no sentido que se apreende atualmente, já se pode observar a vontade de construção de um espaço europeu como entidade política ${ }^{16}$ na reorganização desse espaço por ocasião do Congresso de Viena, em 1814-1815. No século seguinte, após a I Guerra Mundial, um apoio renovado por uma Europa unificada ganha força no movimento Pan-Europeu, fundado pelo austríaco Richard Coudenhove-Kalergi, além da proposta do francês Aristide Briand por uma união federal europeia. ${ }^{17}$

Com o início da II Guerra Mundial, a ideia de construção de uma Europa integrada permanece como possível recurso para frear a Alemanha nazista, reconstituindo a racionalidade pacífica do espaço europeu, da lógica desarmamentista e da solução pacífica dos litígios, como, por exemplo, o Projeto Europeu da Paz (1946) proposto por Winston Churchill, por um Conselho da Europa no âmbito de um sistema federal. ${ }^{18}$

No desenvolvimento do espaço de integração europeu, em seu início eminentemente econômico, em especial, na segunda metade do século XX, no período pós II Guerra Mundial, o desafio inicial consistia em sua reconstrução econômica, social e política. Além disso, as razões da integração europeia em seu estágio preliminar, isto é, o impulso primeiro para a integração, deram-se em razão da necessidade de maior aproximação, reconciliação e coesão do continente europeu. ${ }^{19}$ Por fim, as rupturas políticas no espaço europeu, em decorrência de guerras e conflitos regionais ou internacionais, contribuíram sobremaneira às instabilidades econômicas que assolaram o continente europeu, em especial, desde o século XIX.

A construção da integração europeia, na medida do fortalecimento dos vínculos políticos — para além do aspecto inicial meramente econômico - estimula, por conseguinte, o desenvolvimento de mecanismos de ges-

16 Nesse sentido de construção de um espaço comum europeu, Saint-Simon (1760-1825) fora inspirado pelo Congresso de Viena (1814-1815) a imaginar uma comunidade europeia com um parlamento supranacional.

17 MARTINS, Estevão de Rezende. Parcerias almejadas: política externa, segurança, defesa e história na Europa. Belo Horizonte: Fino Traço, 2012. p. 14.

18 MARTINS, Estevão de Rezende. Parcerias almejadas: política externa, segurança, defesa e história na Europa. Belo Horizonte: Fino Traço, 2012. p. 14.

19 PETITEVILLE, Franck. La politique internationale de l'union européenne. Paris: Les Presses de Sciences Po, 2006. 
tão da sobrevivência e da falibilidade da própria integração europeia, da segunda metade do século XX ao início do século XXI.

Assim, a partir de decisões políticas - inicialmente somente entre alguns Estados - , vai-se construindo uma pauta comum no espaço europeu em torno da chamada política externa e de segurança comum. Essas decisões, dentro da ideia de estabilização do espaço europeu, do aumento dos vínculos políticos entre os Estados e da necessidade de elaboração de um processo de tomada de decisões progressivamente vinculantes, acabam adquirindo normatividade por meio dos tratados constitutivos do atual Direito da União. A questão central, portanto, dessa primeira parte do estudo, diz respeito à evolução normativa do tratamento da política externa e da segurança comum na União Europeia.

A primeira proposta europeia data de 1950, o chamado Plano Pleven - em homenagem ao Primeiro-Ministro e Presidente do Conselho francês René Pleven - , projeto concebido e escrito por Jean Monet. Como objetivo, tal Plano almejava a criação de um exército europeu comum, tendo sido objeto de negociações entre os Estados-membros da Comunidade Europeia do Carvão e do Aço (CECA), de 1950 a 1952, conduzindo à aprovação do Tratado que instituiu a Comunidade Europeia de Defesa (CED).$^{20}$ Entretanto, o Plano Pleven fracassou após ter sido rejeitado pela Assembleia Nacional francesa, em 30 de agosto de 1954 (319 votos contra 254).

Com os Tratados de Roma de 1957, que instituíram a Comunidade Europeia, ainda não havia referência a uma cooperação política exterior, mas somente uma concertação econômica entre França, Itália, Alemanha Ocidental, Bélgica, Países Baixos e Luxemburgo. Convém observar que os Tratados de Roma instituíram, primeiramente, a Comunidade Econômica Europeia (CEE) - almejando a criação de um mercado comum generalizado, e a Comunidade Europeia da Energia Atômica (Euratom) - com o propósito de criar uma Comunidade da Energia Atômica -, entrando em vigor em 1 de janeiro de 1958. Nesse sentido, com a de-

20 A Comunidade Europeia de Defesa (CED) era um projeto político, apresentado em 1953, que visava à criação de uma estrutura federal ou confederativa com o propósito de coordenação das Forças Armadas de toda Europa. UNIÃO EUROPEIA. Sinteses da legislação da União Europeia: Tratado de Amsterdam. Disponível em: <http:/ / europa.eu/legislation_summaries/institutional_affairs/treaties/amsterdam_treaty/a19000_pt.htm>. Acesso em: 31 jan. 2014 bilidade política ainda saliente numa esfera meramente interestatal, não havia dispositivo normativo ou programático tratando da política externa ou de qualquer espécie de segurança comum no espaço europeu.

Em 1961, com o Plano Fouchet, proposto pelo Presidente francês Charles de Gaulle, mas escrito pelo Embaixador francês Christian Fouchet, a ideia era de construir uma União de Estados, uma alternativa às Comunidades Europeias. Além disso, o próprio artigo $2^{\circ}$ do Plano Fouchet destacava que "L'Union a pour but de rapprocher, de coordonner et d'unifier la politique des États membres dans les domaines d'intérêt commun: politique étrangère, économie, culture et défense." ${ }^{21}$. Apesar da introdução da agenda de política estrangeira e de defesa numa projeção futura, (03) três objeções conduziram ao fracasso das negociações: a) a incerteza quanto à participação da Grã-Bretanha; b) as divergências sobre a questão de uma defesa europeia que aspire à independência em relação à Aliança Atlântica; c) o caráter excessivamente intergovernamental das instituições propostas, que levava ao risco de esvaziar de conteúdo o carácter supranacional das instituições comunitárias existentes. ${ }^{22}$

Dez anos após o fracasso do Plano Fouchet, surge o chamado Relatório Davignon ${ }^{23}$, em 27 de outubro de 1970, apresentado no Encontro de Luxemburgo, estabelecendo os primeiros passos rumo à cooperação política na Europa. Constitui, assim, um avanço inicial em matéria de cooperação política entre os Estados. Por exemplo, na esteira de fortalecimento da integração política da União, foi estabelecido um sistema de consultas regulares sobre os pontos essenciais da política externa da União entre os Ministros de Relações Exteriores dos Estados membros, como dispõe a Segunda Parte do Relatório: "Les ministres proposent ce qui suit: Soucieux de réaliser des progrès dans le domaine de l'unification politique, les gouvernements décident de coopérer en matière de politique étrangère." ${ }^{24}$

21 UNIÃO EUROPEIA. Sínteses da legislação da União Europeia: Tratado de Amsterdam. Disponível em: < http://europa.eu/legislation_summaries/institutional_affairs/treaties/amsterdam_treaty/ a19000_pt.htm>. Acesso em: 31 jan. 2014.

22 UNIÃO EUROPEIA. Sinteses da legislação da União Europeia: Tratado de Amsterdam. Disponível em: < http://europa.eu/legislation_summaries/institutional_affairs/treaties/amsterdam_treaty/ a19000_pt.htm>. Acesso em: 31 jan. 2014.

23 O Relatório Davignon foi escrito pelo Diplomata belga Étienne Davignon, também denominado Relatório de Luxemburgo. 24 CENTRE VIRTUEL DE LA CONNAISANCE DE L'EUROPE. Rapport Davignon: rapport des ministres des affaires 
Assim, no Relatório Davignon, tem-se o surgimento da chamada Cooperação Política Europeia, ainda num estágio embrionário e de proposição de ideais, ainda distante dos mecanismos de implementação, com as seguintes premissas: a) assegurar, por uma informação e consultas regulares, uma melhor compreensão mútua sobre os grandes problemas da política internacional; b) reforçar sua solidariedade, favorecendo a harmonização dos pontos de vista, a concertação das atitudes e, quando parecer possível e desejável, as ações comuns.

Em 23 de julho de 1973, foi editado o Segundo Relatório sobre Cooperação Política Europeia em matéria de Política Estrangeira, o Relatório Copenhague, com a fixação das modalidades dessa cooperação intergovernamental europeia. Convém salientar que os objetivos desse segundo Relatório são os mesmos do Relatório Davignon, com foco na compreensão mútua dos grandes temas de política internacional e no reforço do sistema de consultas mútuas.

No sentido de aprofundar, consolidar e expandir a política externa europeia, o Relatório Copenhague reconhece os progressos dos 03 (três) anos da edição do Relatório Davignon: "Les ministres constatent que les mécanismes mis en place par le rapport de Luxembourg caractérisés par leur pragmatisme ont fait la preuve de leur souplesse et de leur efficacité." 25 Além disso, reforça a necessidade da Europa marcar seu lugar nos assuntos internacionais enquanto entidade distinta a exercer influência determinante no equilíbrio internacional e sobre o futuro da então Comunidade Econômica Europeia (CEE). Por fim, consolida sua vocação de abertura, de progresso, de paz e de cooperação, respeitando as alianças de seus Estados membros e as relações de boa vizinhança, bem como do conjunto dos países em desenvolvimento. ${ }^{26}$

Com a Cimeira de Paris, em 9 de dezembro de 1974, organizada pelo então Presidente francês Valéry Gis-

étrangères des Etats membres sur les problèmes de l'unification politique. Disponível em: <http://www.cvce.eu/obj/rapport_davignon_luxembourg_27_octobre_1970-fr-4176efc3-c734-41e5-bb90d34c4d17bbb5.html>. Acesso em: 01 fev. 2014.

25 CENTRE VIRTUEL DE LA CONNAISANCE DE L'EUROPE. Rapport Copenhague: Deuxième rapport sur la coopération politique européenne en matière de politique étrangère. Disponível em: <http://www.cvce.eu/obj/deuxieme_rapport_ sur_la_cooperation_politique_europeenne_en_matiere_de_politique_etrangere_copenhague_23_juillet_1973-fr-8b935ae1-0a3842d4-a97e-088c63d54b6f.html>. Acesso em: 02 fev. 2014.

26 TERPAN, Fabien. La politique étrangère, de sécurité et de défense de l'union européenne. Paris: La Documentation Française, 2010. card d'Estaing, cria-se o chamado Conselho Europeu. Sua origem dá-se em torno dos problemas internos, mas também dos enfrentados pela Comunidade Econômica Europeia (CEE) no exterior, como demonstra o item 4 do Comunicado:

4. Les chefs de gouvernement réaffirment, dans la perspective de l'unification européenne, leur volonté d'arrêter progressivement des positions communes et de mettre en œuvre une diplomatie concertée dans tous les domaines de la politique internationale qui affectent les intérêts de la Communauté européenne. La présidence exerce la fonction de porte-parole des Neuf et se fait leur interprète sur le plan diplomatique. Elle veille à ce que la concertation nécessaire ait toujours lieu en temps utile. ${ }^{27}$

Nela, portanto, os Chefes de Estados e de Governo da Comunidade Econômica Europeia (CEE) decidem realizar 03 (três) reuniões ao ano, harmonizando posição nos seguintes pontos a serem desenvolvidos: a) eleições diretas para o Parlamento Europeu; b) criação da União Econômica e Monetária; c) elaboração do Relatório Tindmans, ${ }^{28}$ sobre as Comunidades Europeias até o final de 1975.

A partir da Cimeira de Paris, em 1974, começa a observar-se a evolução de percepção em relação à política externa da então Comunidade Econômica Europeia (CEE), com a necessidade da construção, muito além da agenda política de integração, dos mecanismos de implementação e de desenvolvimento da ação externa europeia.

Em 13 de outubro de 1981, no chamado Relatório de Londres, os Ministros de Relações Exteriores dos 10 (dez) Estados membros da Comunidade Europeia avaliaram a evolução da Cooperação Política Europeia (CPE), reconhecendo a importância, em especial, dos Relatórios de Luxemburgo (1970) e de Copenhague (1973). Além disso, a necessidade da tomada da posição comum dos 10 (dez) Estados em relação à política externa da Comunidade Europeia, conforme o preâmbulo do Relatório: "Les ministres des affaires étrangères notent que les Dix sont de plus en plus à même de pouvoir

27 CENTRE VIRTUEL DE LA CONNAISANCE DE L'EUROPE. Sommet de Paris: Communiqué final de la réunion des chefs de gouvernement de la Communauté (Paris, 9 et 10 décembre 1974). Disponível em: <http://www.cvce.eu/obj/communique_final_du_ sommet_de_paris_9_et_10_decembre_1974-fr-2acd8532-b271-49edbf63-bd8131180d6b.html>. Acesso em: 02 fev. 2014.

28 Leo Tindemans, Primeiro-Ministro belga à época. 
parler d'une seule voix sur le plan international."’29. Por fim, o Relatório mantém a separação estrita entre as Comunidades Europeias e a Cooperação Política Europeia $(\mathrm{CPE}){ }^{30}$

Com o Ato Único Europeu (AUE),${ }^{31}$ houve o reconhecimento da necessidade de certa coordenação das políticas estrangeiras e a formalização de procedimentos que ingressassem como regras de Direito Primário. Assim, fez-se presente a formalização jurídica da Cooperação Política Europeia (CPE), com o estabelecimento de Secretariado próprio em Londres. ${ }^{32}$

O principal objetivo do processo de construção europeia era a realização do mercado interno, o que seria dificilmente exequível com base nos tratados existentes na ordem jurídica europeia, tendo em vista que o processo de decisão no Conselho Europeu requeria unanimidade para se proceder à harmonização da legislação. ${ }^{33}$ Em razão disso, a Conferência Intergovernamental que conduziu ao Ato Único Europeu tinha duplo mandato. Por um lado, com a finalidade de compor um tratado em matéria de política externa e segurança comum e, de outro lado, um Ato que emendasse o Tratado que havia instituído a Comunidade Econômica Europeia (CEE), nas seguintes matérias: a) processo de tomada de decisão no Conselho; b) competências da Comissão; c) poderes do Parlamento Europeu; d) alargamento das competências das Comunidades.

No título III do Ato Único Europeu (AUE), foram estatuídas as disposições relativas à Cooperação Europeia em Matéria Política (CPE), no próprio artigo 30.

29 CENTRE VIRTUEL DE LA CONNAISANCE DE L'EUROPE. Rapport Londres: rapport sur la coopération politique européenne (Londres, 13 octobre 1981). Disponível em: <http:// www.cvce.eu/obj/rapport_sur_la_cooperation_politique_europeenne_londres_13_octobre_1981-fr-869a63a6-4c28-4e42-8c41-efd2415cd7dc.html>. Acesso em: 02 fev. 2014.

30 MARTINS, Estevão de Rezende. Parcerias almejadas: política externa, segurança, defesa e história na Europa. Belo Horizonte: Fino Traço, 2012. p. 49.

31 Assinado em Luxemburgo, em 17 de Fevereiro de 1986, por (09) nove Estados-Membros e, em 28 de Fevereiro de 1986, pela Dinamarca, Itália e Grécia, constitui a primeira alteração de grande porte do Tratado que institui a Comunidade Econômica Europeia (CEE). Entrou em vigor em 1 de Julho de 1987.

32 MARTINS, Estevão de Rezende. Parcerias almejadas: política externa, segurança, defesa e história na Europa. Belo Horizonte: Fino Traço, 2012. p. 49.

33 UNIÃO EUROPEIA. Sinteses da legislação da União Europeia: Ato Único Europeu (AUE). Disponível em: < http://europa.eu/ legislation_summaries/institutional_affairs/treaties/treaties_singleact_pt.htm>. Acesso em: 1 fev. 2014.
Dentre as premissas mais significativas a cargo das Altas Partes Contratantes ${ }^{34}$ — inseridas no esforço de aplicação comum de uma política estrangeira europeia (artigo 30, 1) —, estavam:

a) a manutenção do sistema mútuo de consultas em matéria de política externa com vistas à convergência das posições estatais e a realização de ações comuns (artigo 30, II, a);

b) a precaução em evitar qualquer ação ou tomada de posição prejudiciais à eficácia da Cooperação Europeia em matéria de Política Estrangeira (CPE), nas relações internacionais ou no seio das organizações internacionais (artigo 30, II, d);

c) associação estreita do Parlamento Europeu à Cooperação Política Europeia (CPE), com troca mútua e permanente de informações (artigo 30, IV);

d) construção progressiva sobre as questões de segurança, com vistas ao desenvolvimento de uma identidade europeia em matéria de política externa (artigo 30, VI, a).

e) equiparação em matéria de privilégios e imunidades entre os membros do Secretariado da Cooperação Política Europeia (CPE) aos membros das missões diplomáticas das Altas Partes contratantes situadas no local do estabelecimento do Secretariado.

Com essas transformações consubstanciais no tratamento da política externa e de segurança europeia, sobretudo a alínea $d$ acerca da construção de uma identidade europeia, em 7 de fevereiro de 1992 é assinado o Tratado sobre a União Europeia (TUE) ou Tratado de Maastricht,$^{35}$ que cria a União Europeia, sustentada em 03 (três) pilares: as Comunidades Europeias, a Política Externa e de Segurança Comum (PESC) e a cooperação

34 As Altas Partes Contratantes eramas seguintes: Bélgica, Alemanha, Dinamarca, Grécia, Espanha, França, Irlanda, Itália, Luxemburgo, Holanda, Portugal, Reino Unido.

35 O Tratado de Maastricht entra em vigor somente em 1 de novembro de 1993. Ao Preâmbulo, seguem-se 07 (sete) Títulos. O Título I prevê disposições comuns às Comunidades, à Política Externa Comum e à Cooperação Judiciária. O Título II inclui as disposições que alteram o Tratado CEE e os Títulos III e IV alteram, respectivamente, os Tratados CECA e CEEA. O Título V introduz as disposições relativas à Política Externa e de Segurança Comum (PESC) e o Título VI contém as disposições relativas à cooperação nos domínios da justiça e dos assuntos internos (JAI). As disposições finais constam do Título VII. UNIÃO EUROPEIA. Tratado sobre a União Europeia. Tratado de Maastricht. Disponível: <http://eur-lex. europa.eu/fr/treaties/dat/11992M/htm/11992M.html>. Acesso em: 1 fev. $2014 .$. 
policial e judiciária em matéria penal, como demonstra o quadro abaixo:

\begin{tabular}{|c|c|c|}
\hline \multicolumn{3}{|c|}{ União Europeia - Campos com relação com política externa } \\
\hline Comunidades Europeias & $\begin{array}{c}\text { Política externa e de segurança } \\
\text { comum (Pesc) }\end{array}$ & Cooperação policial e judiciária em matéria penal \\
\hline $\begin{array}{l}\text { - Política de comércio exterior } \\
\text { - Cooperação para o desenvol- } \\
\text { vimento (Cotonou) } \\
\text { - Ajuda humanitária }\end{array}$ & $\begin{array}{l}\text { - Política externa em sentido } \\
\text { estrito } \\
\text { - Política de defesa } \\
\text { - Política de segurança }\end{array}$ & $\begin{array}{l}\text { - Controle das fronteiras externas } \\
\text { - Combate ao terrorismo, ao tráfico de dro- } \\
\text { gas e às demais formas de criminalidade in- } \\
\text { ternacional }\end{array}$ \\
\hline
\end{tabular}

A Política Externa e de Segurança Comum (PESC), prevista no Título V do Tratado de Maastricht, substitui a Cooperação Política Europeia (CPE), do Ato Único Europeu (AUE), instituindo uma nova sistemática europeia de tratamento da matéria.

Esse segundo pilar institui um processo de decisão interestatal que recorre, em grande parte, à tomada de decisão por unanimidade, com os seguintes objetivos principais do Tratado sobre a União Europeia (TUE): a) salvaguardar os valores comuns, os interesses fundamentais e a independência da União; b) reforçar a segurança da União Europeia e de seus Estados membros de todas as maneiras; c) manter a paz e o reforço da segurança internacional, conforme os princípios da Carta das Nações Unidas, bem como dos princípios da Ata final de Helsinki e da Carta de Paris; d) promover a cooperação internacional; e) desenvolver a democracia e o Estado de Direito, bem como o respeito aos Direitos Humanos e as liberdades fundamentais. ${ }^{37}$

Com vistas à consagração desses objetivos principais, (02) dois são os mecanismos estabelecidos no Tratado de Maastrich: a) a instauração de uma cooperação sistemática entre os Estados membros; b) a execução gradual de ações comuns nos domínios onde os Estados membros tenham interesses comuns importantes. ${ }^{38}$ Além disso, os Estados membros devem apoiar, ativamente e sem reservas, a política externa e de segurança

36 MARTINS, Estevão de Rezende. Parcerias almejadas: política externa, segurança, defesa e história na Europa. Belo Horizonte: Fino Traço, 2012. p. 41. Adaptado pelo Autor.

37 UNIÃO EUROPEIA. Tratado sobre a União Europeia. Tratado de Maastricht. Disponível: <http://eur-lex.europa.eu/fr/treaties/ dat/11992M/htm/11992M.html>. Acesso em: 1 fev. 2014.

38 UNIÃO EUROPEIA. Tratado sobre a União Europeia. Tratado de Maastricht. Disponível: <http://eur-lex.europa.eu/fr/treaties/ dat/11992M/htm/11992M.html>. Acesso em: 1 fev. 2014. da União Europeia em um espírito de lealdade e de solidariedade mútuas, abstendo-se de toda ação contrária aos interesses da União Europeia ou suscetível de prejudicar sua eficácia como força coerente nas relações internacionais, conforme dispõe o artigo J.3, do Tratado sobre a União Europeia (TUE). ${ }^{39}$

Outra introdução importante diz respeito ao procedimento para adotar ações comuns em política estrangeira e de segurança. A competência para a tomada de decisão é do Conselho, sob a base de orientações gerais do Conselho Europeu. Conforme dispõe o Tratado de Maastricht ${ }^{40}$, quando o Conselho chega a uma ação comum, deve fixar os seus objetivos gerais e particulares que motivam a União, bem como os meios, procedimentos, condições e, se necessário, a duração aplicável a sua execução. Por fim, quando da adoção e do transcorrer de uma ação comum, o Conselho define as questões em nome das quais as decisões devem ser tomadas em maioria qualificada. Nessas decisões que exigirem maioria qualificada, introduzida pela sistemática de Maastricht, os Estados membros devem evitar impedir, sempre que possível, que tenha unanimidade quando uma maioria qualificada seja favorável à decisão.

A União Europeia integra, com o Tratado sobre a União Europeia (TUE), a ideia de política estrangeira à noção de segurança em uma política da União e dos Estados membros, com o reconhecimento do Conselho Europeu. ${ }^{41}$ Além disso, estabelece a definição dos obje-

39 UNIÃO EUROPEIA. Tratado sobre a União Europeia. Tratado de Maastricht. Disponível: <http://eur-lex.europa.eu/fr/treaties/ dat/11992M/htm/11992M.html>. Acesso em: 1 fev. 2014.

40 UNIÃO EUROPEIA. Tratado sobre a União Europeia. Tratado de Maastricht. Disponível: <http://eur-lex.europa.eu/fr/treaties/ dat/11992M/htm/11992M.html>. Acesso em: 1 fev. 2014.

41 MARTINS, Estevão de Rezende. Parcerias almejadas: política externa, segurança, defesa e história na Europa. Belo Horizonte: Fino Traço, 2012. p. 51. 
tivos e dos mecanismos comuns de execução no corpo do próprio Tratado de Maastricht. ${ }^{42}$

\subsection{Da Estratégia Comum Europeia (ECE) à institucionalização normativa da Estratégia Europeia de Segurança (EES) pelo Tratado de Lisboa (2009)}

A Conferência interestatal que se realizou durante do Conselho Europeu de Amsterdam, em junho de 1997, reformou a Política Externa e de Segurança Comum (PESC) de modo conservador. Entretanto, os mecanismos colocados à disposição dos Estados lhes permitem avançar no caminho de uma Política Externa e de Segurança Comum (PESC) consideravelmente mais eficaz e coerente. ${ }^{43}$

Essa leitura surge do Tratado de Amsterdam, assinado em 2 de outubro de 1997, que entrou em vigor em 1 de maio de 1999. Em relação à Política Externa e de Segurança Comum (PESC), o Tratado de Amsterdam passa a adotar uma Estratégia Comum Europeia (ECE), focando nos seguintes caracteres:

1. Para além da instituição de um mecanismo de abstenção construtiva, o novo processo de decisão dá maior espaço à chamada maioria qualificada, adotando a mencionada Estratégia Comum Europeia (ECE) no seio da Política Externa e de Segurança Comum (PESC). Assim, se a Estratégia Comum Europeia for adotada por unanimidade pelo Conselho Europeu, as decisões tomadas sob essa base (incluso as ações comuns e as posições comuns) necessitam apenas maioria qualificada. Além disso, as estratégias comuns devem contribuir para reforçar a coerência da ação externa da União, isto é, todas as decisões que executam uma ação comum ou uma posição comum serão adotadas por maioria qualificada. ${ }^{44}$

Questão interessante ocorre quando um membro do Conselho declarar que, por importantes e expressas razões de política nacional, tenciona opor-se à concessão de uma autorização por maioria qualificada, quando, en-

42 UNIÃO EUROPEIA. Tratado sobre a União Europeia. Tratado de Maastricht. Disponível: <http://eur-lex.europa.eu/fr/treaties/ dat/11992M/htm/11992M.html>. Acesso em: 1 fev. 2014.

43 IORDAN, Cristian. La définition progressive d'une politique européenne de sécurité. Romanian Journal Of European Affairs, Bucharest, v. 13, n. 2, p. 67-79, 2013. p. 76.

44 TERPAN, Fabien. La politique étrangère, de sécurité et de défense de l'union européenne. Paris: La Documentation Française, 2010. tão, não se procederá à votação, conforme redação dada pelo Tratado de Amsterdam ao artigo 23 do Tratado da União Europeia (ex-artigo J.13)..$^{45}$ Além disso, o Conselho, deliberando por maioria qualificada, pode solicitar que a questão seja submetida ao Conselho Europeu, a fim de ser tomada uma decisão por unanimidade. ${ }^{46}$ Excetuam-se, nos dois casos anteriores, as decisões a serem tomadas no domínio militar ou da defesa.

2. O Tratado de Amsterdam tenta remediar os limites da Política Externa e de Segurança Comum (PESC), criando a função de Alto-Representante para a PESC, dando redação ao artigo 26 do Tratado da União Europeia (ex-artigo J.16), embora desprovida de capacidades de coerção para exercer uma verdadeira influência internacional. Sua função, inicialmente, “[...] é de assessorar a presidência rotativa da União nas relações com Estados terceiros. Forma, com o ministro das Relações exteriores do país no exercício da presidência e com o comissário de Assuntos Exteriores, a assim chamada "troika" das relações exteriores." ${ }^{\prime 7}$

A figura do Alto-Representante, confiada ao Secretário-Geral do Conselho, beneficia-se do apoio de um mecanismo de análise e de previsão comum: a unidade de planificação da política e de alerta rápido, chamado de unidade política, permitindo o reforço da coerência e da integridade da ação externa da União. Em especial, a unidade política propõe, sob a autoridade do Alto-Representante, opções à presidência do Conselho, "Afin de donner à l'Union européenne "un visage et une voix" (ou, pour reprendre l'expression ironique d'Henry Kissinger, "un numéro de téléphone")." ${ }^{48}$

3. O Conselho Europeu recebe maior competência de orientação, em especial, em matéria de segurança e de defesa. Nesse campo, ocorre uma aproximação entre a União Europeia e a União da Europa Ocidental (UEO), tendo em vista que "[...] para incrementar de imediato a operacionalidade da União na gestão de cri-

45 UNIÃO EUROPEIA. Tratado sobre a União Europeia. Tratado de Maastricht. Disponível: <http://eur-lex.europa.eu/fr/treaties/ dat/11992M/htm/11992M.html>. Acesso em: 1 fev. 2014.

46 UNIÃO EUROPEIA. Tratado sobre a União Europeia. Tratado de Maastricht. Disponível: <http://eur-lex.europa.eu/fr/treaties/ dat/11992M/htm/11992M.html>. Acesso em: 1 fev. 2014..

47 MARTINS, Estevão de Rezende. Parcerias almejadas: política externa, segurança, defesa e história na Europa. Belo Horizonte: Fino Traço, 2012. p. 58

48 FRANCE. Ministère des Affaires Étrangères). Guide de la PESC. Disponível em: <http://www.rpfrance.eu/IMG/guide_pesc.pdf>. Acesso em: 2 fev. 2014. 
ses, o Tratado de Amsterdã adotou, na Pesc, a "agenda de Petesberg”, da União da Europa Ocidental. A UEO, a prática é absorvida por Amsterdã." 49

Convém salientar que o próprio Tratado de Amsterdam dá redação ao artigo 17 do Tratado da União Europeia (ex-artigo J.7), no sentido de integração da própria União da Europa Ocidental (UEO) à União, se o Conselho Europeu assim o desejar. Essa integração dá-se de tamanha forma no Tratado de Amsterdam que a própria "agenda de Petesberg" fora retirada do modelo da União da Europa Ocidental (UEO), contendo as seguintes missões: a) missões humanitárias; b) missões de salvamento; c) missões de manutenção da paz; d) missões de força para gestão de crises e instauração da paz.

Um instrumento inovador adotado pelo próprio Tratado de Amsterdam, na Declaração relativa à União da Europa Ocidental, ${ }^{50}$ adotada anteriormente pelo Conselho de Ministros da União da Europa Ocidental, em 22 de junho de 1997, é justamente a cooperação em matéria armamentista no contexto de racionalização do mercado europeu de armamentos e de criação de uma Agência Europeia do Armamento (AEA).

Outrossim, a designação dos Representantes Especiais $^{51}$ da União Europeia, conforme redação dada pelo Tratado de Amsterdam ao artigo 18 do Tratado da União Europeia (TUE) (ex-artigo J.8), foi tida como uma das evoluções no sentido de se construir uma identidade exterior europeia, institucionalizada pelo Tratado de Amsterdam. Entre outras razões, a designação dos Representantes Especiais ${ }^{52}$ permite uma melhor visibilidade da União Europeia, além de facilitar o diálogo político e o desenvolvimento da integração regional..$^{53}$

49 MARTINS, Estevão de Rezende. Parcerias almejadas: política externa, segurança, defesa e história na Europa. Belo Horizonte: Fino Traço, 2012. p. 58.

50 UNIÃO EUROPEIA. Tratado de Amsterdam. Disponível em: <http://eur-lex.europa.eu/fr/treaties/dat/11997D/htm/11997D. html>. Acesso em: 1 fev. 2014.

51 Na prática da União Euopeia, tal designação começa, pré-normativamente, em 1996, para a região dos Grandes Lagos (África) e para o acompanhamento do processo de paz no Oriente Médio.

52 Na qualidade de Representantes Especiais da União Europeia, Aldo Ajello (Italiano) para os Grandes Lagos Africanos (1996), Francesc Vendrell (Espanhol) para o Afeganistão (2002), Marc Otte (Bélgica) para o processo de paz no Oriente Médio (2003), Adriaan Jacobovits de Szeged (Holandês) para a Moldávia (2005), Jan Kubis (Eslováquia) para a Ásia Central (2005), Pekka Haavisto (Finlandês) para o Sudão (2005), Erwan Fouéré (Irlandês) para a ex-Ioguslávia (2005), Christian Schwarz-Schilling (Alemanha) para a Bosnia-Herzegovina (2006), Peter Semnby (Sueco) para o Sul do Cáucaso (2006). 53 PETITEVILLE, Franck. La politique internationale de l'union euro-
Nomeados pelo Conselho, por maioria qualificada, após a abertura das candidaturas aos Estados membros da União Europeia, os candidatos viajam durante o período de candidatura onde se submetem a entrevistas com o Secretário-geral do Conselho e o Alto-Representante para a Política Externa e de Segurança Comum (PESC). Após esses trâmites, o Alto-Representante recomenda uma das candidaturas ao Comitê Político e de Segurança (COPS) ${ }^{54}$ cuja criação começa a tomar corpo no Encontro de Helsinki (1999), na Decisão 2000/143/PESC, e no Encontro de Nice (2001), responsável pela aprovação ou não da candidatura proposta. ${ }^{55}$ Como suas funções, além de dar à União Europeia uma dimensão política concreta pelo mundo, tem-se a representação da União nas regiões e países instáveis para sua promoção política, bem como a facilitação do diálogo político nas regiões em conflito. ${ }^{56}$

O Tratado de Amsterdam, portanto, configura a Política Externa e de Segurança Comum (PESC) da União Europeia em novos objetivos, ${ }^{57}$ demonstrando o fortalecimento da integração europeia nesta matéria, conforme redação dada ao artigo 11 do Tratado da União Europeia (TUE) (ex-artigo J.1,7), quais sejam: a) a salvaguarda dos valores comuns, dos interesses fundamentais, da independência e da integridade da União, de acordo com os princípios da Carta das Nações Unidas; b) o reforço da segurança da União, sob todas as formas; c) a manutenção da paz e o reforço da segurança internacional, de acordo com os princípios da Carta das Nações Unidas, com os princípios da Ata Final de Helsinki e com os objetivos da Carta de Paris, incluindo os concernentes às fronteiras externas.

A Estratégia Comum Europeia (ECE), portanto, surge como instrumento jurídico da Política Externa e de Segurança Comum (PESC), com redação dada pelo

péenne. Paris: Les Presses de Sciences Po, 2006.

54 Instituído de forma permanente pela Decisão do Conselho 2001/78/PESC, de 22 de janeiro de 2001, o Comitê Político e de Segurança (COPS) acompanha a situação internacional no campo da Política Estrangeira e de Segurança Comum (PESC) e da Política de Segurança e de Defesa Comum (PSDC). Responde pela definição e pelo acompanhamento da resposta da União Europeia a uma situação de crise.

55 FRANCE. Ministère des Affaires Étrangères). Guide de la PESC. Disponível em: <http://www.rpfrance.eu/IMG/guide_pesc.pdf>. Acesso em: 2 fev. 2014.

56 PETITEVILLE, Franck. La politique internationale de l'union européenne. Paris: Les Presses de Sciences Po, 2006.

57 Dentre outras mudanças significativas traziadas pelo Tratado de Amsterdam em matéria de Política Externa e de Segurança Comum (PESC) estão: a) Atenuação do pricípio da unanimidade; b) Utilização mais frequente do recurso ao princípio da maioria qualificada. 
Tratado de Amsterdam ao artigo 13 do Tratado sobre a União Europeia (TUE) (ex-artigo J.3), prevendo justamente que o Conselho Europeu decidirá sobre as estratégias comuns que serão executadas pela União no campo em que os Estados membros tenham interesses comuns importantes ${ }^{58}$. Essa Estratégia Comum Europeia (ECE) delimita seus objetivos, sua duração e seus meios para fornecer à União Europeia, sendo um importante mecanismo no seio da Política Externa e de Segurança Comum (PESC).

Em sequência ao Tratado de Amsterdam (1997), na Cimeira ou Conselho Europeu de Colônia, de 1999, houve o fortalecimento da Política Externa Comum de Segurança e de Defesa (PESD), bem como a divulgação, pelo Conselho Europeu, de uma declaração visando ao fortalecimento da Política Externa e de Segurança Comum (PESC) na União Europeia. ${ }^{59}$ Logo em seguida, em 2000, formalizou-se o Tratado de Nice, com a institucionalização do Comitê de Política e Segurança (COPS) e da Política Externa Comum de Segurança e de Defesa (PESD) ${ }^{60}$ Além disso, "dotou a PESC de regras melhoradas do processo de decisão - expansão da aplicação da maioria qualificada — e da necessária infraestrutura organizacional." ${ }^{\text {11 }}$

Em 2001, com a Cimeira ou Conselho Europeu de Laeken, reunidos os Chefes de Estado no seio do Conselho da União Europeia, elaborou-se a Declaração de Laeken sobre o futuro da Europa, a ser posteriormente presidida por Valéry Giscard d'Estaing e que prepararia o Tratado para uma Constituição da Europa (TECE). ${ }^{62}$ Em termos operacionais, o Conselho de Laeken decla-

58 UNIÃO EUROPEIA. Tratado de Amsterdam. Disponível em: <http://eur-lex.europa.eu/fr/treaties/dat/11997D/htm/11997D. html>. Acesso em: 1 fev. 2014.

59 MARTINS, Estevão de Rezende. Parcerias almejadas: política externa, segurança, defesa e história na Europa. Belo Horizonte: Fino Traço, 2012. p. 58.

60 A Política Externa Comum de Segurança e de Defesa (PESD) tem por objetivo fortalecer a operacionalidade externa da União pela capacitação civil e militar a prevenir conflitos e a superar crises. VIGNES, Daniel. L'Union européenne, acteur civil et militaire dans la gestion des crises internationales: la PESD, politique européenne de sécurité et de défense. In: YEE, Sienho; MORIN, Jacques-Yvan. Multiculturalism and international law: essays in honour of Edward McWhinney. Leiden: Martinus Nijhoff, 2009. p. 393-414.

61 MARTINS, Estevão de Rezende. Parcerias almejadas: política externa, segurança, defesa e história na Europa. Belo Horizonte: Fino Traço, 2012. p. 59.

62 MARTINS, Estevão de Rezende. Parcerias almejadas: política externa, segurança, defesa e história na Europa. Belo Horizonte: Fino Traço, 2012. p. 59. ra, simbolicamente, a prontidão da Tropa de Choque da União dentro da estrutura da Política Externa e de Segurança Comum (PESC).

Entretanto, é com a assinatura do Tratado de Lisboa, em 13 de dezembro de 2007, que se configura uma Estratégia Europeia de Segurança (EES), inserida na Política Externa e de Segurança Comum (PESC) (KING, 2005). Convém salientar, por rigor analítico, que o Tratado de Lisboa reformou o funcionamento da União Europeia, em 1 de dezembro de 2009, quando entrou em vigor, emendando o Tratado sobre a União Europeia (TUE) e o Tratado que estabelece a Comunidade Europeia (TCE), que veio a ser denominado Tratado sobre o Funcionamento da União Europeia - TFUE. ${ }^{63}$

Além do aumento do processo de tomada de decisões por meio de maioria qualificada no Conselho da União Europeia, do incremento do Parlamento Europeu, da eliminação dos 03 (três) pilares, da criação de um Presidente do Conselho Europeu com mandato mais longo e de um Alto Representante da União para os Negócios Estrangeiros e a Política de Segurança, o Tratado de Lisboa vinculou o Tratado sobre a União Europeia (TUE) à Carta dos Direitos Fundamentais da União Europeia. ${ }^{64}$

No artigo 21 do Tratado sobre a União Europeia (TUE), reformado pelo Tratado de Lisboa, reorganizou-se os objetivos relativos à Ação Externa da União (AEU) rumo a um significativo grau de cooperação em todos os domínios das relações internacionais, dentre os quais se situam:

a) salvaguardar os seus valores, interesses fundamentais, segurança, independência e integridade;

b) consolidar e apoiar a democracia, o Estado de direito, os Direitos do Homem e os princípios do Direito Internacional;

63 O Tratado sobre o Funcionamento da União Europeia (TFUE) segue, em virtude do seu artigo 205, o Tratado sobre a União Europeia (TUE), que será abordado na sequência deste artigo. Especificamente, em relação à Ação Externa da União, trata das seguintes temáticas: 1) Disposições gerais; 2) Política Comercial Comum; 3) Cooperação com países terceiros e ajuda humanitária; 4) Medidas restritivas; 5) Acordos internacionais; 6) Relações da União com as Organizações Internacionais e países terceiros e Delegações da União; 7) Cláusula de solidariedade. UNIÃO EUROPEIA. Tratado sobre o Funcionamento da União Europeia. Disponível em: <http://eurlex.europa.eu/LexUriServ/LexUriServ.do?uri=OJ:C:2010:083:004 7:0200:pt:PDF>. Acesso em: 3 fev. 2014.

64 UNIÃO EUROPEIA. Carta dos Direitos Fundamentais da União Europeia. Disponível em: <http://www.europarl.europa.eu/charter/pdf/text_pt.pdf>. Acesso em: 3 fev. 2014. 
c) preservar a paz, prevenir conflitos e reforçar a segurança internacional, em conformidade com os objetivos e os princípios da Carta das Nações Unidas, com os princípios da Ata Final de Helsinki e com os objetivos da Carta de Paris, incluindo os respeitantes às fronteiras externas;

d) apoiar o desenvolvimento sustentável nos planos econômicos, social e ambiental dos países em desenvolvimento, tendo como principal objetivo erradicar a pobreza;

e) incentivar a integração de todos os países na economia mundial, inclusivamente por meio da eliminação progressiva dos obstáculos ao comércio internacional;

f) contribuir para o desenvolvimento de medidas internacionais para preservar e melhorar a qualidade do ambiente e a gestão sustentável dos recursos naturais em escala mundial, a fim de assegurar um desenvolvimento sustentável;

g) prestar assistência a populações, países e regiões confrontados com catástrofes naturais ou de origem humana;

h) promover um sistema internacional baseado numa cooperação multilateral reforçada e uma boa governança ao nível mundial.

Tais conteúdos programáticos previstos nos objetivos da Ação Externa da União (AEU), com vistas as suas efetivações, devem ser tomados a partir do que anteriormente eram chamadas de estratégias, ações e posições comuns, agora, substituídas pelas chamadas Decisões, conforme o artigo 31 do Tratado sobre a União Europeia (TUE): "As decisões ao abrigo do presente capítulo são tomadas pelo Conselho Europeu e pelo Conselho, deliberando por unanimidade, salvo disposição em contrário do presente capítulo. Fica excluída a adopção de actos legislativos". ${ }^{65}$

A regra da unanimidade, contudo, pode ser atenuada pela maioria qualificada do Conselho (artigo 31, 2), desde que este decida, por unanimidade, em torno da opção por deliberar sobre o mérito da matéria segundo o critério da maioria qualificada (artigo 31, 3). Essa possibilidade de flexibilização do quórum não se aplica às decisões sobre matéria militar e de defesa, quando

65 UNIÃO EUROPEIA. Tratado sobre a União Europeia. Tratado de Maastricht. Disponível: <http://eur-lex.europa.eu/fr/treaties/ dat/11992M/htm/11992M.html>. Acesso em: 1 fev. 2014 somente será aceito o critério da unanimidade.

Questão importante a ser observada reside na impossibilidade da edição de atos legislativos em matéria de Política Externa e de Segurança Comum (PESC), em virtude do referido dispositivo, ficando sob competência exclusiva do Conselho Europeu ${ }^{66}$ e pelo Conselho da União Europeia. ${ }^{67}$

Observando-se toda a transformação normativo-institucional da União Europeia, na esteira das modificações trazidas pela reforma do Tratado de Lisboa (2007), verifica-se a mutação do cargo de Alto-Representante para a Política Externa e de Segurança Comum (PESC) para a figura do Alto-Representante da União para Alto-Representante da União para os Negócios Estrangeiros e a Política de Segurança ${ }^{68}$ Esse Alto-Representante deve ser nomeado pelo Conselho Europeu, por maioria qualificada, com a aprovação do Presidente da Comissão, conforme o artigo 18 do Tratado da União Europeia. ${ }^{69}$

Além disso, possui as seguintes atribuições principais: a) preside o Conselho dos Negócios Estrangeiros (artigo 18); b) executa a Política Estrangeira (artigo 23); c) direito de proposição para a política estrangeira (artigo 27); d) representação em face de Estados terceiros e Organizações Internacionais (artigo 27); e) dirige o Serviço Europeu para a Ação Externa (SEAE); f) busca uma solução quando um membro do Conselho declarar que, por razões vitais e expressas de política nacional, tenciona opor-se à adoção de uma decisão a tomar por maioria qualificada (artigo 31.2); g) coordenação das atividades dos Estados membros no seio das Organizações Internacionais para tornar visível o interesse da União Europeia (artigo 34); h) consulta e informação regular do Parlamento Europeu sobre a evolução da Política Externa e de Segurança Comum (PESC) (artigo 36).

66 Instituição da União Europeia, no âmbito da qual os chefes de Estado e de Governo dos países membros se reúnem cerca de 04 (quatro) vezes por ano para debater as prioridades políticas da União Europeia.

67 É no âmbito do Conselho da União Europeia que os Ministros de cada Estado-Membro se reúnem para adotar legislação e assegurar a coordenação das políticas da União Europeia. MARTINS, Estevão de Rezende. Parcerias almejadas: política externa, segurança, defesa e história na Europa. Belo Horizonte: Fino Traço, 2012. p. 68. 68 Desde agosto de 2014, o cargo é exercido por Federica Mogherini (Itália).

69 MARTINS, Estevão de Rezende. Parcerias almejadas: política externa, segurança, defesa e história na Europa. Belo Horizonte: Fino Traço, 2012. p. 69. 
Outro organismo criado pelas modificações trazidas pelo Tratado de Lisboa foi o Serviço Europeu de Ação Exterior (SEAE), conforme o artigo 27, 3, do Tratado sobre a União Europeia (TUE). Com a função de colaborar com a diplomacia dos Estados membros, composta por funcionários do Secretariado-Geral do Conselho e da Comissão e pelo pessoal dos serviços diplomáticos nacionais, tendo sua organização e funcionamento definidos pelo Conselho. Tal importância deve-se ao fato de que não havia representação diplomática tradicional na União Europeia, pois esta se dava somente por meio das representações dos seus Estados membros nos países terceiros. ${ }^{70}$

A organização do Serviço Europeu de Ação Exterior (SEAE), em síntese, possui as seguintes características, dentro da Estratégia Europeia de Segurança (EES): a) administração central e delegações nos Estados terceiros, bem como nas Organizações Internacionais; b) sob a autoridade do Alto-Representante da União para os Negócios Estrangeiros e a Política de Segurança, auxilia os presidentes do Conselho Europeu e da Comissão Europeia; c) cooperar com o Secretário-Geral do Conselho, com os serviços da Comissão (consultas recíprocas) e com os serviços diplomáticos dos Estados membros; d) um orçamento próprio, mas responsabilidade da Comissão por certos instrumentos (estabilidade, cooperação com países industrializados, relações públicas e missões de observação eleitoral).

Por fim, uma das peculiaridades atinentes à Estratégia Europeia de Segurança (EES), inserida na Política Externa e de Segurança Comum (PESC), diz respeito à incompetência do Tribunal de Justiça da União Europeia para as matérias contidas no Capítulo 1, Título $\mathrm{V}$, à exceção da forma dos procedimentos executados e das atribuições institucionais para exercício de competências, conforme o artigo 24, 1, do Tratado sobre a União Europeia.

Essa blindagem em relação ao controle da ação externa e das políticas de segurança e de defesa europeias, desenhadas na Política Externa e de Segurança Comum (PESC) e concretizadas pela Estratégia Europeia de Segurança (EES), guarda uma relação intrínseca de autoproteção em relação ao ambiente externo e, ao mesmo tempo, paradoxal em relação às interferências com o

70 MARTINS, Estevão de Rezende. Parcerias almejadas: política externa, segurança, defesa e história na Europa. Belo Horizonte: Fino Traço, 2012. p. 65-66. chamado Direito das Nações Unidas. Eis a problemática a ser desenvolvida a seguir.

\section{A relação paradoxal entre a política EXTERNA E DE SEGURANÇA COMUM EUROPEIA E $O$ DiREITO das Nações UNIDAs}

Étudier la place des Communautés dans l'ordre internationale [...] à soulever une série de problèmes et à faire état de situations que l'on n'a pas coutume d'évoquer à propos d'une organisation internationale. ${ }^{71}$

Estudar o lugar da União Europeia no seio da comunidade internacional, atualizando a frase de Jean Groux e Philippe Manin ${ }^{72}$, possibilita levantar uma série de problemas, de contrariedades, de incompatibilidades e de situações desconhecidas no espaço europeu. Essas irritações, causadas a partir do desenvolvimento institucional da União Europeia, conduz a 03 (três) compreensões autônomas e interdependentes dos fenômenos, ao mesmo tempo, gerando crises e evoluções no sistema europeu: a) dimensão política; b) dimensão Jurídica; e c) dimensão epistemológica.

Ao partir de uma construção institucional complexa como a da União Europeia, o risco de redução da complexidade a uma espécie de banalização é considerável, tendo em vista que independentemente de quais sejam as controvérsias em torno da construção da entidade jurídica europeia e de seus modos de inserção na vida internacional "[...] reste une constante, sorte d'irreductible de l'analyse du phénomène européen: l'Union Européenne n'est toujours pas sur le chemin de la " banalisation »."73 $\mathrm{O}$ risco de maior banalização do fenômeno europeu dá-se na mesma proporção da desconsideração das 03 (três) dimensões mencionadas como estruturas autônomas e interdependentes.

Enquanto a dimensão política possui suas estruturas e códigos próprios (autonomia) de estruturação no seio social, como, por exemplo, os discursos diplomáticos, os encontros entre Chefes de Estado, a figura do Alto-

71 GROUX, J.; MANIN, P. Les communautés européennes dans l'ordre international. Luxembourg: OPOCE, 1984. p. 14.

72 GROUX, J.; MANIN, P. Les communautés européennes dans l'ordre international. Luxembourg: OPOCE, 1984. p. 14.

73 BENLOLO-CARABOT, Myriam; CANDAS, Ulas; CUJO, Eglantine. Union européenne et droit international. Paris: Pedone, 2012. p. 01. 
-Representante da União para os Negócios Estrangeiros e a Política de Segurança, maioria simples e absoluta, integração regional, a paz, os conflitos interestatais, não ocorre de maneira diversa com as outras 02 (duas) dimensões.

Outrossim, a dimensão jurídica molda sua forma em códigos e linguagens próprios como, por exemplo, diretrizes, estratégias comuns, posições comuns, acordos internacionais, efeitos vinculantes. Por último, a dimensão epistemológica permite apreender das 02 (duas) dimensões anteriores, num primeiro momento - de forma autônoma - e, numa segunda etapa — de forma interdependente - as características e os elementos que permitem decifrar o funcionamento, isto é, a forma, o modelo teórico de como cada dimensão se autorregula, gerando estabilidade e expectativas sociais. A partir desse primeiro passo, é possível chegar a uma análise crítica das dimensões, com vistas ao seu desenvolvimento enquanto sistemas sociais. Por exemplo, toda a evolução da Política Externa e de Segurança Comum (PESC) demonstrada pela consecução de diversas reuniões, formalização de Tratados de integração regional e desenvolvimento de mecanismos de execução dos consensos estatais e, posteriormente, regionais.

Entretanto, como esse debate contribui para a relação a ser estabelecida nesse item, sobre as relações paradoxais entre a Política Externa e de Segurança Comum (PESC) da União Europeia e o Direito das Nações Unidas? Em linhas gerais, tanto a teoria geral do Direito Internacional Público como a do chamado Direito da União consagram aspectos importantes de autonomia epistemológica. Entretanto, tal autonomia absoluta numa relação de dominação epistemológica entre os dois sistemas jurídicos - tem gerado uma ausência de diálogo e de reflexão sobre as relações entre estes dois sistemas jurídicos, tanto pelo que se pode chamar de doutrina europeanista — modelo que vê a União Europeia no seio da teoria geral das Organizações Internacionais — como da doutrina internacionalista. ${ }^{74}$

Essa problemática, surgida a partir da constatação do isolamento e pela ausência de diálogo entre as doutrinas europeanista e internacionalista, estabelece justamente, notadamente após a vigência do Tratado de Lisboa, como será observado a seguir, a relação paradoxal entre o

74 BENLOLO-CARABOT, Myriam; CANDAS, Ulas; CUjO, Eglantine. Union européenne et droit international. Paris: Pedone, 2012. p. 01.
Direito das Nações Unidas e o Direito da União. Em especial, em relação à autonomia normativa aparente entre o Direito da União e o Direito das Nações Unidas, bem como no que concerne à obrigatoriedade ou não de cumprimento das Resoluções do Conselho de Segurança das Nações Unidas (CSNU) pela União Europeia, em matéria de Política Externa e de Segurança Comum (PESC).

Nessa concepção geral, portanto, a preocupação geral será a de não perder a ideia de sistema, ${ }^{75}$ seja do sistema jurídico da União Europeia ou do sistema jurídico internacional, bem como a ideia de sistema social, a fim de não desnaturar a ideia de quadro jurídico-institucional de estabilidade, de integridade e de coerência normativas. Eis as questões jurídicas a serem trabalhadas a seguir.

\subsection{Da aparente autonomia à vinculação normativa da União Europeia ao Direito das Nações Unidas}

Uma das questões mais controvertidas até a entrada em vigor das modificações realizadas pelo Tratado de Lisboa, em 1 de dezembro de 2009, era a da aquisição ou não da personalidade jurídica internacional pela União Europeia ${ }^{76}$. Resolve, o Tratado de Lisboa, um dos aspectos mais controversos do Direito institucional da União Europeia, justamente, sobre a sua qualidade de sujeito de Direito Internacional.

Essa problemática histórico-institucional da construção de uma personalidade jurídica internacional para a União Europeia é essencial para se verificar o estabelecimento de uma vinculação normativa entre o Direito da União e o Direito das Nações Unidas, como será analisado a seguir. O reconhecimento da personalidade jurídica internacional, nesse sentido, retoma um elemento de aptidão do ente reconhecido para ser titular de direitos e, ao mesmo tempo, vinculado a obrigações instituídas normativamente. ${ }^{77}$

Independentemente das interessantes teses sobre o status de reconhecimento da União Europeia como Organização Internacional sui generis ${ }^{78}$ — posição adotada

75 Influência da concepção sistêmica de Niklas Luhmann. LUHMANN, Niklas. L a sociedad de la sociedade. Ciudad de México: Herder, $2006 .$. 76 Reconhecendo os estágios e as etapas de integração, obviamente, anteriores às modificações realizadas pelo Tratado de Lisboa. 77 DAILLIER, Patrick; FORTEAU, Mathias; PELLET, Alain. Droit international public. 8. ed. Paris: Lextenso, 2009.

78 BEULAY, Marjorie. Les traités constitutifs de l'Union Européenne. In: BENLOLO-CARABOT, Myriam; CANDAS, Ulas; 
no presente estudo - ou como Federação de Estados, ${ }^{79}$ a questão a ser tratada reside em saber se, mesmo sem se caracterizar tal status, há como se vincular o Direito da União ao Direito das Nações Unidas.

Levando-se em consideração a posição da União Europeia como uma Organização Internacional sui generis, observa-se que, na maioria dos casos, as Organizações Internacionais tem o reconhecimento de sua personalidade jurídica raramente realizado de forma explícita em seus atos constitutivos. Jurisprudencialmente, a Corte Internacional de Justiça (CIJ), no Parecer consultivo de 11 de abril de 1949 (CIJ, 2014), foi provocada a determinar se a Organização das Nações Unidas (ONU) tinha capacidade jurídica para apresentar uma reclamação internacional, deduzindo a personalidade jurídica de suas missões.

Esse silêncio dos atos constitutivos não autoriza por em dúvida a existência de personalidade jurídica internacional das Organizações Internacionais, tendo em vista "Que les actes de création soient silencieux sur ce point n'autorise pas à mettre en doute la possession d'une personalité juridique internationale." 80

$\mathrm{Na}$ União Europeia, inserida no silêncio do Tratado de Maastrich ao projeto de tratado constitucional, nenhum dispositivo de Direito primário foi inscrito no sentido de reconhecimento explícito da personalidade jurídica internacional da União. Tal aquisição, como se observará, dar-se-á somente após as modificações realizadas pelo Tratado de Lisboa.

Nesse mesmo intervalo, coexistiam as Comunidades Europeias, já tendo suas personalidades jurídicas reconhecidas ${ }^{81}$. Sendo assim, como se deu esse processo de reconhecimento normativamente e jurisprudencialmente das Comunidades Europeias?

Embora o artigo 245 do Tratado de Roma dispusesse que a Comunidade Europeia possuía personalidade jurídica - de forma genérica —, não o fez outrora da mesma maneira específica que o Tratado da Comunida-

CUJO, Eglantine. Union européenne et droit international. Paris: Éditions Pedone, 2012. p. 95-109.

79 SIMON, Denys. Invocabilité et primauté: petite éxperience de déconstruction. In: BENLOLO-CARABOT, Myriam; CANDAS, Ulas; CUJO, Eglantine. Union européenne et droit international. Paris: Pedone, 2012. p. 140-157.

80 DAILLIER, Patrick; FORTEAU, Mathias; PELLET, Alain. Droit international public. 8. ed. Paris: Lextenso, 2009. p. 658.

81 EDOUARD, Régis. La personnalité juridique internationale de l'Union Européenne. In: BENLOLO-CARABOT, Myriam; CANDAS, Ulas; CUJO, Eglantine. Union européenne et droit international. Paris, 2012. p. 110. de Econômica do Carvão e do Aço (CECA), em seu artigo $6^{\circ}$, 2: "A CECA tem capacidade jurídica nas suas relações internacionais." De forma mais paradoxal ainda, pois o próprio Tratado de Roma em seu artigo 282 reconhecia que a União Europeia gozava da mais ampla capacidade jurídica reconhecida às pessoas coletivas pelas legislações nacionais, isto é, a personalidade jurídica nas ordens jurídicas dos respectivos Estados membros. ${ }^{82}$

Mesmo com todas essas observações, normativamente, não era possível reconhecer, sem ambiguidades, pelo texto do Tratado de Roma, personalidade jurídica internacional à Comunidade Europeia, embora fossem reconhecidas competências externas como, por exemplo, a celebração de acordos internacionais com Estados ou Organizações Internacionais, conforme o artigo 300 do Tratado de Roma.

É justamente no Caso $A E T R^{83}$, na decisão proferida em 31 de março de 1971, que se pode obter, com segurança, o reconhecimento da personalidade jurídica internacional da Comunidade Europeia. ${ }^{84} \mathrm{Na}$ interpretação do então artigo 210 do Tratado de Roma, a Corte de Justiça das Comunidades Europeias (CJCE) ${ }^{85}$ nos itens 13 e 14, constrói a tese da personalidade jurídica internacional, no seguinte sentido:

13. $\mathrm{O}$ artigo $210^{\circ}$ dispõe que «a Comunidade tem personalidade jurídica». 14. Esta disposição, colocada no cabeçalho da sexta parte do Tratado consagrada às «disposições gerais e finais», significa que, nas relações externas, a Comunidade goza da capacidade de estabelecer vínculos contratuais com Estados terceiros em toda a extensão do campo dos objectivos definidos na primeira parte do Tratado, da qual a sexta constitui o prolongamento. ${ }^{86}$

82 EDOUARD, Régis. La personnalité juridique internationale de l'Union Européenne. In: BENLOLO-CARABOT, Myriam; CANDAS, Ulas; CUJO, Eglantine. Union européenne et droit international. Paris: Pedone, 2012. p. 109-116. p. 111.

83 CORTE DE JUSTIÇA DAS COMUNIDADES EUROPEIAS. 1971. Sentença de 31 de março. Comissão das Comunidades Europeias contra Conselho das Comunidades Europeias. Processo n. 22/70. Disponível em: $<$ http://curia.europa.eu/juris/showPdf.jsf?text $=\&$ docid $=88062 \&$ pageIndex $=0 \&$ doclang $=p t \&$ mode $=1$ st $\&$ dir $=\& o c c=$ first\&part=1\&cid=563437> . Acesso em: 2 fev. 2014.

84 EDOUARD, Régis. La personnalité juridique internationale de l'Union Européenne. In: BENLOLO-CARABOT, Myriam; CANDAS, Ulas; CUJO, Eglantine. Union européenne et droit international. Paris: Éditions Pedone, 2012. p. 112.

85 Após a entrada em vigor do Tratado de Lisboa, torna-se Tribunal de Justiça da União Europeia (TJUE).

86 CJCE (CORTE DE JUSTIÇA DAS COMUNIDADES EUROPEIAS). CORTE DE JUSTIÇA DAS COMUNIDADES EU- 
A novidade trazida pelo acórdão mencionado diz respeito ao reconhecimento da existência de competências externas implícitas, afirmando, no ponto 15, que: "Para fixar, num caso determinado, a competência da Comunidade para concluir acordos internacionais, há que tomar em consideração a sistematização do Tratado, e bem assim as suas disposições materiais." ${ }^{87}$ Além disso, no ponto 16 , a Corte reconhece que tal competência não decorre somente de uma atribuição explícita feita pelo Tratado, mas pode decorrer igualmente de outras disposições do Tratado e de outros atos adotados, no âmbito destas disposições, pelas instituições da Comunidade. ${ }^{88}$ Sendo assim, a Comunidade Europeia aparecia como uma verdadeira organização internacional sui generis, titular de personalidade jurídica internacional, com certa capacidade jurídica para a produção de atos da vida internacional. ${ }^{89}$

Após o Tratado de Maastrich ou Tratado sobre a União Europeia (TUE), que cria a União Europeia, entrando em vigor em 1 de novembro de 1993, volta-se ao imbróglio acerca do reconhecimento da personalidade jurídica internacional. A problemática residia em que nenhum dispositivo do Tratado atribuía personalidade jurídica à União Europeia, mesmo nas ordens jurídicas dos Estados membros, como outrora ocorrera com o Tratado de Roma e de Paris. ${ }^{90}$

Além disso, outro argumento normativo que dificultava o reconhecimento da personalidade jurídica

ROPEIAS. 1971. Sentença de 31 de março. Comissão das Comunidades Europeias contra Conselho das Comunidades Europeias. Processo n. 22/70. Disponível em: <http://curia.europa.eu/juris/ showPdf.jsf text $=\&$ docid $=88062 \&$ pageIndex $=0 \&$ doclang $=$ pt $\&$ mode $=1$ st $\&$ dir $=\& o c c=$ first $\&$ part $=1 \&$ cid $=563437>$. Acesso em: 2 fev. 2014

87 CORTE DE JUSTIÇA DAS COMUNIDADES EUROPEIAS. 1971. Sentença de 31 de março. Comissão das Comunidades Europeias contra Conselho das Comunidades Europeias. Processo n. 22/70. Disponível em: < http://curia.europa.eu/juris/showPdf.js $\mathrm{f}$ ?text $=\&$ docid $=88062 \&$ pageIndex $=0 \&$ doclang $=$ pt\&mode $=$ lst $\&$ di $\mathrm{r}=\&$ occ $=$ first\&part $=1 \& \mathrm{cid}=563437>$. Acesso em: 2 fev. 2014 .

88 CORTE DE JUSTIÇA DAS COMUNIDADES EUROPEIAS. 1971. Sentença de 31 de março. Comissão das Comunidades Europeias contra Conselho das Comunidades Europeias. Processo n. 22/70. Disponível em: <http://curia.europa.eu/juris/showPdf.js f text $=\&$ docid $=88062 \&$ pageIndex $=0 \&$ doclang $=$ pt\&mode $=$ lst $\&$ di $\mathrm{r}=\&$ occ $=$ first\&part $=1 \& \mathrm{cid}=563437>$. Acesso em: 2 fev. 2014.

89 EDOUARD, Régis. La personnalité juridique internationale de l'Union Européenne. In: BENLOLO-CARABOT, Myriam; CANDAS, Ulas; CUJO, Eglantine. Union européenne et droit international. Paris: Pedone, 2012. p. 109-116. p. 112.

90 CHARPENTIER, J. De la personnalité juridique de l'Union européenne. In: GALABERT, J. M.; TERCINET, M.-R. Mélanges Peiser. Grenoble: Presses Universitaires de Grenoble, 1995. p. $93-$ 102. p. 95. internacional da União Europeia consistia na interpretação dos artigos $24^{91}$ e $38^{92}$ do Tratado de Maastricht concernentes à conclusão de acordos internacionais no sentido de que a capacidade de celebração pertencia aos Estados membros por intermédio do Conselho e não, efetivamente, à União Europeia. ${ }^{93}$

Em síntese, 02 (duas) linhas argumentativas em torno de obstáculos e 02 (duas) favoráveis, respectivamente, ao reconhecimento da personalidade jurídica internacional da União Europeia: ${ }^{94}$

a) a estrutura dos 03 (três) pilares dificultava a compreensão de uma personalidade jurídica internacional, distinta daquela das Comunidades Europeias, pois somente um verdadeiro sujeito de Direito Internacional deveria ter competência para tal;

b) negação da personalidade jurídica internacional por razões normativas em torno do Tratado sobre a União Europeia (TUE);

c) o artigo $2^{\circ}$ do Tratado sobre a União Europeia (TUE), na versão consolidada pelo Tratado de Amsterdam, que dispõe sobre a afirmação da identidade da União Europeia na cena internacional, nomeadamente por meio da execução de uma Política Externa e de Segurança Comum (PESC), que inclua a definição gradual de uma política de defesa comum;

d) existência de um quadro institucional próprio da União Europeia, em acordo ao Preâmbulo e ao artigo $3^{\circ}$ do Tratado sobre a União Europeia (TUE) ${ }^{95}$, na versão

91 Atual artigo 37 do Tratado sobre a União Europeia (TUE): “A União pode celebrar acordos com um ou mais Estados ou organizações internacionais nos domínios que se insiram no âmbito do presente capítulo.". UNIÃO EUROPEIA. Tratado sobre a União Europeia. Tratado de Maastricht. Disponível: <http://eur-lex.europa. $\mathrm{eu} / \mathrm{fr} /$ treaties/dat/11992M/htm/11992M.html >. Acesso em: 1 fev. 2014.

92 Revogado pelo Tratado sobre a União Europeia (TUE).

93 EDOUARD, Régis. La personnalité juridique internationale de l'Union Européenne. In: BENLOLO-CARABOT, Myriam; CANDAS, Ulas; CUJO, Eglantine. Union européenne et droit international. Paris: Éditions Pedone, 2012. p. 113.

94 EDOUARD, Régis. La personnalité juridique internationale de l'Union Européenne. In: BENLOLO-CARABOT, Myriam; CANDAS, Ulas; CUJO, Eglantine. Union européenne et droit international. Paris: Pedone, 2012. p. 109-116. p. 114.

95 "Artigo $3^{\circ}$. A União dispõe de um quadro institucional único, que assegura a coerência e a continuidade das acções empreendidas para atingir os seus objectivos, respeitando e desenvolvendo simultaneamente o acervo comunitário. A União assegurará, em especial, a coerência do conjunto da sua acção externa no âmbito das políticas que adoptar em matéria de relações externas, de segurança, de economia e de desenvolvimento. Cabe ao Conselho e à Comissão 
consolidada pelo Tratado de Amsterdam.

Por fim, cabe salientar que os 02 (dois) argumentos favoráveis, elaborados a partir da reflexão em torno das modificações realizadas pelo Tratado de Amsterdam no Tratado sobre a União Europeia (TUE), assinado em 2 de outubro de 1997, mas que entrou em vigor somente em 1 de maio de 1999, não prosperaram em razão da falta de vontade reiterada dos Estados em reconhecê-los, bem como não tiveram tempo de prosperar até a entrada em vigor das modificações trazidas pelo Tratado de Lisboa. ${ }^{96}$

Após a entrada em vigor das modificações realizadas pelo Tratado de Lisboa, em 13 de dezembro de 2007, toda a discussão sobre o reconhecimento da personalidade jurídica internacional da União Europeia torna-se desnecessária. Isso em razão de que vários dispositivos do Tratado sobre a União Europeia (TUE), modificado pelo Tratado de Lisboa, dispõem nesse sentido, em especial, o artigo 47: "A União tem personalidade jurídica." ${ }^{97}$

Obviamente, em virtude do artigo $5^{\circ}$ do Tratado sobre a União Europeia (TUE), a União Europeia submete-se à competência estrita delegada pelos Estados, pois "en effet, les Étas ont tenu à rappeler le caractère fonctionnel de cette personalité en specifiant que la détentrice de cette dernière ne pouvait pas agir au-délà des compétences qui lui sont attribués en vertu des traités." 98 As competências que não sejam atribuídas à União Europeia nos Tratados pertencem aos Estados membros, conforme o artigo $4^{\circ}$ do Tratado sobre a União Europeia (TUE).

a responsabilidade de assegurar essa coerência, cooperando para o efeito. O Conselho e a Comissão assegurarão a execução dessas políticas de acordo com as respectivas competências.”. UNIÃO EUROPEIA. Sinteses da legislação da União Europeia: Tratado de Amsterdam. Disponível em: <http://europa.eu/legislation_summaries/ institutional_affairs/treaties/amsterdam_treaty/a19000_pt.htm>. Acesso em: 31 jan. 2014.

96 EDOUARD, Régis. La personnalité juridique internationale de l'Union Européenne. In: BENLOLO-CARABOT, Myriam; CANDAS, Ulas; CUJO, Eglantine. Union européenne et droit international. Paris: Pedone, 2012. p. 109-116. p. 114.

97 UNIÃO EUROPEIA. Sinteses da legislação da União Europeia: Tratado de Amsterdam. Disponível em: < http://europa.eu/legislation_summaries/institutional_affairs/treaties/amsterdam_treaty/ a19000_pt.htm>. Acesso em: 31 jan. 2014.

98 EDOUARD, Régis. La personnalité juridique internationale de l'Union Européenne. In: BENLOLO-CARABOT, Myriam; CANDAS, Ulas; CUJO, Eglantine. Union européenne et droit international. Paris: Pedone, 2012. p. 109-116 . p. 115.
Além dos dispositivos mencionados, outra questão a ser observada reside no artigo $1^{\circ}$ do Tratado sobre a União Europeia (TUE), qual seja, a União substitui-se e sucede à Comunidade Europeia. Através dessa sucessão, pode inferir-se, logicamente, que o artigo $335^{99}$ do Tratado sobre o Funcionamento da União Europeia (TFUE) se aplica também à União, isto é, "Em cada um dos Estados-Membros a União goza da mais ampla capacidade jurídica reconhecida às pessoas colectivas pelas legislações nacionais [...]". ${ }^{100}$

Outro importante dispositivo do Tratado de Funcionamento sobre a União Europeia (TFUE) aplicável à União é o artigo 216, cuja transcrição segue:

\section{A União pode celebrar acordos com um ou mais países terceiros ou organizações internacionais quando os Tratados o prevejam ou quando a celebração de um acordo seja necessária para alcançar, no âmbito das políticas da União, um dos objectivos estabelecidos pelos Tratados ou quando tal celebração esteja prevista num acto juridicamente vinculativo da União, ou seja, susceptível de afectar normas comuns ou alterar o seu alcance. 2. Os acordos celebrados pela União vinculam as instituições da União e os Estados-Membros. ${ }^{101}$}

Consagrada a personalidade jurídica internacional da União, com as modificações realizadas pelo Tratado de Lisboa no Tratado sobre a União Europeia (TUE), com a prática de atos da vida internacional, conforme descrito nos dispositivos e nas teses anteriormente demonstradas, resta a seguinte questão: Em que base normativa se daria a vinculação da União Europeia ao Direito das Nações Unidas? Saliente-se que esse questionamento ainda não diz respeito à questão do cumprimento das decisões do Conselho de Segurança das Nações Unidas (CSNU) pela União, mas tão somente em relação à vinculação normativa entre ambas as instituições.

A vinculação normativa entre a União Europeia e o Direito das Nações Unidas deve ser tida numa concepção unitária do Direito, sem se perder a ideia do sistema jurídico como um todo, conforme demonstrado na própria Introdução e no item II do presente estudo. Assim,

99 Ex-artigo 282 do Tratado de Roma.

100 UNIÃO EUROPEIA. Tratado sobre a União Europeia: Consolidado com a versão do Tratado de Lisboa. Disponível: <http:// eur-lex.europa.eu/LexUriServ/LexUriServ.do?uri=OJ:C:2010:083: FULL:PT:PDF>. Acesso em: 1 fev. 2014.

101 UNIÃO EUROPEIA. Tratado sobre o Funcionamento da União Europeia. Disponível em: <http://eurlex.europa.eu/LexUriServ/ LexUriServ.do?uri=OJ:C:2010:083:0047:0200:pt:PDF>. Acesso em: 3 fev. 2014. 
não somente o Direito da União deve ser considerado na análise normativa da vinculação, mas também do Direito das Nações Unidas, ainda que de forma perfunctória para esse espaço.

De sorte que o Tratado sobre a União Europeia
(TUE) e o Tratado sobre o Funcionamento da União Europeia (TFUE) contém em diversos dispositivos que propiciam a defesa desta tese. Analisar-se-á o conjunto de dispositivos relativos ao Tratado sobre a União Europeia (TUE) e do Tratado de Funcionamento sobre a União Europeia (TFUE), no quadro abaixo exposto:

\begin{tabular}{|l|l|}
\hline Dispositivo & Implicação normativa \\
\hline $\begin{array}{l}\text { Artigo } \mathbf{3}^{\mathbf{0}}, \mathbf{5} \\
\text { (TUE) }\end{array}$ & $\begin{array}{l}\text { A União deve observância ao desenvolvimento do Direito Internacional, incluindo a Carta } \\
\text { das Nações Unidas. }\end{array}$ \\
\hline $\begin{array}{l}\text { Artigo 21, 1 } \\
\text { (TUE) }\end{array}$ & $\begin{array}{l}\text { A ação da União na cena internacional deve respeitar os princípios da Carta das Nações Uni- } \\
\text { das e do Direito Internacional. }\end{array}$ \\
\hline $\begin{array}{l}\text { Artigo 21, 2, c } \\
\text { (TUE) }\end{array}$ & $\begin{array}{l}\text { A União define políticas comuns e ações no sentido de assegurar um elevado grau de coo- } \\
\text { peração em todos os domínios das relações internacionais a fim de preservar a paz, preve- } \\
\text { nir conflitos e reforçar a segurança internacional, em conformidade com os objetivos e os } \\
\text { princípios da Carta das Nações Unidas. }\end{array}$ \\
\hline $\begin{array}{l}\text { Artigo 34,2 } \\
\text { (TUE) }\end{array}$ & $\begin{array}{l}\text { Os Estados-Membros da União, os membros do Conselho de Segurança das Nações Unidas, } \\
\text { defenderão, no exercício das suas funções, as posições e os interesses da União, sem prejuízo } \\
\text { das responsabilidades que lhes incumbem por força da Carta das Nações Unidas. }\end{array}$ \\
\hline $\begin{array}{l}\text { Artigo 42,1 } \\
\text { (TUE) }\end{array}$ & $\begin{array}{l}\text { A política comum de segurança e defesa faz parte integrante da política externa e de segu- } \\
\text { rança comum, devendo seguir os princípios da Carta das Nações Unidas. }\end{array}$ \\
\hline $\begin{array}{l}\text { Artigo 208, 2 } \\
\text { (TFUE) }\end{array}$ & $\begin{array}{l}\text { A União e os Estados-Membros respeitarão os compromissos e terão em conta os objetivos } \\
\text { aprovados no âmbito das Nações Unidas. }\end{array}$ \\
\hline
\end{tabular}

A análise dos artigos mencionados, que vinculam as ações, políticas e objetivos da União Europeia no respeito ao Direito Internacional e aos objetivos (artigo $1^{\circ}$ ) e princípios (artigo $2^{\circ}$ ) da Carta das Nações Unidas. Como a União Europeia está vinculada normativamente aos objetivos e princípios da Carta das Nações Unidas, está vinculada ao respeito à paz e à segurança internacionais. Consectário lógico disso é que as Resoluções expedidas pelo Conselho de Segurança das Nações Unidas em virtude do Capítulo VII da Carta - Ação em caso de ameaça à paz, ruptura da paz e ato de agressão são vinculantes à ação externa da União Europeia nesta matéria em que os Estados cedem competência.

Em decorrência disso, outro problema que emerge, pragmaticamente falando, diz respeito à incidência do artigo 103 da Carta das Nações Unidas, no caso de conflito entre as obrigações decorrentes do Capítulo VII da Carta - Ação em caso de ameaça à paz, ruptura da paz e ato de agressão — e as obrigações decorrentes da Política Externa e de Segurança Comum (PESC), da União. Quando houver suporte fático coincidente ou englobante entre estas ações que envolvem, ao mesmo tempo, questões de segurança e defesa — internacional e da União Europeia —, surge um conflito entre as obrigações decorrentes destas duas ordens jurídicas. Qual seria a possível resolução a essa relação paradoxal? Eis a problemática a ser tratada no próximo item desse estudo.

\subsection{A obrigatoriedade de cumprimento das Resoluções do Conselho de Segurança das Nações Unidas pela União Europeia em matéria de política externa e de segurança comum}

Le respect des engagements pris dans le cadre des Nations Unies s'impose tout autant dans le domaine du maintien de la paix et de la sécurité internationales, lors de la mise en oeuvre par la Communauté, par l'adoption d'actes communautaires pris sur le fondement des articles 60 CE [75 TFUE] et 301 CE [215 TFUE], de résolutions adoptées par le Conseil de Sécurité au titre du chapitre VII de la charte des Nations Unies. ${ }^{102}$

102 CORTE DE JUSTIÇA DAS COMUNIDADES EUROPEIAS. 2005. Sentença de 21 de setembro. Kadi contra Conselho das Comunidades Europeias. Processo n.T-315/01. Disponível em: $<$ http:/ / curia.europa.eu/juris/showPdf.jsf;jsessionid=9ea7d2dc30 dba52e7a050ed6467490eb8a6d82ddd35e.e34KaxiLc3qMb40Rch0 SaxuKbNb0?text $=\&$ docid $=65739$ \&pageIndex $=0 \&$ doclang $=$ PT $\&$ mode $=$ req $\&$ dir $=\& o c c=$ first $\&$ part $=1 \&$ cid $=220515>$. Acesso em: 2 fev. 2014 
Considerando a personalidade jurídica internacional e o vínculo da União Europeia com o Direito das Nações Unidas, conforme se desenvolveu nas teses anteriores, a questão que se coloca é a seguinte: Em uma concepção unitária, integrativa e estável do sistema jurídico ${ }^{103}$, em caso de conflito entre o conteúdo das obrigações decorrentes das Resoluções proferidas pelo Conselho de Segurança das Nações Unidas (CSNU), em função do Capítulo VII da Carta das Nações Unidas - Ação em caso de ameaça à paž, ruptura da paž e ato de agressão - e as obrigações decorrentes da Política Externa e de Segurança Comum (PESC), a União Europeia deve fazer prevalecer quais obrigações juridicamente? Existe uma resposta normativa a esse questionamento?

Segundo o artigo $3^{\circ}, 5$, do Tratado sobre a União Europeia (TUE), a União obrigou-se a respeitar os princípios da Carta das Nações Unidas e do Direito Internacional. Além disso, em virtude do artigo 42, 1, a União pode recorrer à capacidade operacional que lhe reconhecem os seus Estados membros nas missões fora da União a fim de assegurar a manutenção da paz, a prevenção dos conflitos e o reforço da segurança internacional. ${ }^{104}$

Além disso, pela Declaração no 13 sobre a Política Estrangeira e de Segurança Comum, anexada ao Tratado de 13 de dezembro de 2007, a Conferência de Lisboa reforça que a União Europeia e seus Estados membros permanecerão ligados às disposições da Carta das Nações Unidas e, em particular, à responsabilidade principal, incumbindo ao Conselho de Segurança das Nações Unidas (CSNU) e a seus Estados membros a manutenção da paz e da segurança internacionais.

No plano jurisprudencial, no item 294 do acórdão proferido no caso Kadi I (CJCE, 2014b), a Corte de Justiça das Comunidades Europeias (CJCE) resume bem a problemática das relações entre a União e as obrigações decorrentes do Direito das Nações Unidas, em matéria de paz, segurança e defesa internacionais. Refere que no exercício da competência de adoção, por atos comunitários, das Resoluções tomadas pelo Conselho de Segu-

103 Por uma teoria sistêmica e social do Direito Internacional Público, ver: CRAWFORD, James. Chance, Order, Change: The Course of International Law. General Course on Public International Law. Leiden/ Boston: Martinus Nijhoff Publishers / Brill Academic, 2014 104 PELLET, Alain. Les sanctions de l'Union Européenne. In: BENLOLO-CARABOT, Myriam; CANDAS, Ulas; CUJO, Eglantine. Union européenne et droit international. Paris: Éditions Pedone, 2012. p. 433. rança das Nações Unidas (CSNU), a União Europeia deve dar atenção particular ao fato de que, conforme o artigo 24 da Carta das Nações Unidas, as Resoluções expedidas pelo Conselho de Segurança, em virtude do capítulo VII da Carta das Nações Unidas, constituem o exercício da responsabilidade principal desse órgão na manutenção da paz e da segurança internacionais. ${ }^{105}$

Além disso, reconhece ao Conselho de Segurança das Nações Unidas (CSNU), nessa advertência à União, o seu poder de determinar o que constitui uma ameaça contra a paz e a segurança internacionais, bem como tomar as medidas necessárias para mantê-las ou reestabelecê-las. ${ }^{106}$ Nesse ponto, reside, ao ver do presente estudo, uma questão central do diálogo entre o Direito das Nações Unidas e o Direito da União, em matéria de Política Externa e de Segurança Comum (PESC).

O problema da indeterminação conceitual no Direito das Nações Unidas, em especial no que tange ao conteúdo das Resoluções do Conselho de Segurança das Nações Unidas (CSNU), constitui uma importante ferramenta ao sistema de exclusão internacional exercido pela Organização das Nações Unidas (ONU) $\cdot{ }^{107}$ A gravidade desta concepção - caso se reconheça a prevalência da posição acerca das obrigações assumidas pela União Europeia em relação à Carta das Nações Unidas em detrimento do Direito da União — pode trazer uma série de imposições indiscriminadas do Conselho de Segurança das Nações Unidas (CSNU), por meio das Resoluções, à União Europeia em matéria de segurança e defesa europeias.

105 CORTE DE JUSTIÇA DAS COMUNIDADES EUROPEIAS. 2005. Sentença de 21 de setembro. Kadi contra Conselho das Comunidades Europeias. Processo n.T-315/01. Disponível em: $<$ http:/ / curia.europa.eu/juris/showPdf.jsf;jsessionid=9ea7d2dc30 dba52e7a050ed6467490eb8a6d82ddd35e.e34KaxiLc3qMb40Rch0 SaxuKbNb0?text $=\&$ docid $=65739$ \&pageIndex $=0 \&$ doclang $=P T \&$ mode $=$ req $\&$ dir $=\& o c c=$ first $\&$ part $=1 \&$ cid $=220515>$. Acesso em: 2 fev. 2014..

106 CORTE DE JUSTIÇA DAS COMUNIDADES EUROPEIAS. 2005. Sentença de 21 de setembro. Kadi contra Conselho das Comunidades Europeias. Processo n.T-315/01. Disponível em: $<$ http:// curia.europa.eu/juris/showPdf.jsf;jsessionid=9ea7d2dc30 dba52e7a050ed6467490eb8a6d82ddd35e.e34KaxiLc3qMb40Rch0 SaxuKbNb0?text $=\&$ docid $=65739$ \&pageIndex $=0 \&$ doclang $=$ PT $\&$ mode $=$ req $\&$ dir $=\& o c c=$ first $\&$ part $=1 \&$ cid $=220515>$. Acesso em: 2 fev. 2014..

107 Sobre a problemática do (des)controle das Resoluções do Conselho de Segurança das Nações Unidas (CSNU), ver: CRAWFORD, James. Chance, order, change: the course of international law. general course on public international law. Leiden: M. Nijhoff, 2014 .. p. 281-305. Ver também: CORTEN, Olivier. Le discours du droit international: pour un positivisme critique. Paris: Éditions Pedone, 2009. 
Explica-se esse fenômeno em razão de que para se obter maior liberdade e extensão em suas ações, instrumentalizadas sobretudo pelo Conselho de Segurança das Nações Unidas (CSNU), uma margem internacional de apreciação outorga, na extensão conceitual das categorias jurídicas — de maneira despótica —, uma aparência de maior legitimidade quando da tomada de decisões no concerto das controvérsias em matéria de paz e segurança mundiais, como, por exemplo:

Il y a dix ans, une période sembable a été l'occasion pour que se manifestent également des tentatives hégémoniques sous prétexte d'une «notion plus étendue de sécurité ». Par une résolution décisive adoptée en 1991, le Conseil de sécurité qualifia les problèmes économiques, sociaux, humanitaires et même écologiques, de «menaces à la paix et à la sécurité internationales » (S/23500 du 31 janvier 1991). Ceci représentait une possibilité d'extension sans précédent de la compétence du Conseil de sécurité - un coup d'état concernant des questions qui étaient auparavant traitées par l'Assemblée générale. ${ }^{108}$

Sendo assim, se as Resoluções proferidas pelo Conselho de Segurança das Nações Unidas (CSNU) — em virtude do capítulo VII da Carta —, mesmo que com um grau elevado de indeterminação das categorias da paz e de segurança - devem ser adotadas pela União Europeia, a possibilidade de intervenção do Direito das Nações Unidas dentro da ordem jurídica da União Europeia, na execução da Política Externa e de Segurança Comum (PESC), pode descaracterizar o modelo europeu constituído nos moldes delineados pela parte I deste estudo.

Contudo, foram analisados até o presente momento somente os efeitos das Resoluções do Conselho de Segurança das Nações Unidas (CSNU) na União Europeia, nos moldes supracitados, em caso de incidência direta e de adoção automática pela União. Agora, voltando-se ao questionamento proposto acerca do conflito entre o conteúdo das obrigações decorrentes das Resoluções proferidas pelo Conselho de Segurança das Nações Unidas (CSNU), em função do Capítulo VII da Carta das Nações Unidas - Ação em caso de ameaça à paz, ruptura da paz, e ato de agressão — e as obrigações decorrentes da Política Externa e de Segurança Comum (PESC) europeia, quais obrigações prevaleceriam?

108 KOSKENNIEMI, Martti. La politique du droit international. Paris: Pedone, 2007. p. 311.
Um apontamento inicial a ser realizado para responder esse questionamento é o de que todos os Estados membros da União Europeia fazem parte da Organização das Nações Unidas (ONU) ${ }^{109}$. Individualmente, todos os Estados-membros da União Europeia têm a obrigação de aplicar, por exemplo, as sanções ${ }^{110}$ impostas pelo Conselho de Segurança das Nações Unidas (CSNU) em respeito ao capítulo VII da Carta. ${ }^{111}$

Esta obrigação decorrente do capítulo VII da Carta das Nações Unidas, quando em conflito com uma obrigação relativa à Política Externa e de Segurança Comum (PESC), prevalece?

A resposta é afirmativa, tendo a União Europeia, nesse caso, o dever jurídico de cumprir a Resolução do Conselho de Segurança das Nações Unidas (CSNU), em decorrência do artigo 103 da Carta das Nações Unidas, que prescreve o seguinte: "No caso de conflito entre as obrigações dos membros das Nações Unidas em virtude da presente Carta e as obrigações resultantes de qualquer outro acordo internacional, prevalecerão as obrigações assumidas em virtude da presente Carta." ${ }^{112}$ Nessa leitura do artigo 103 da Carta das Nações Unidas, as obrigações resultantes de qualquer outro acordo internacional são justamente, no presente artigo, as assumidas pela União Europeia em decorrência de seu próprio Direito.

Convém salientar que inúmeras das obrigações mencionadas são de competência exclusiva da União Europeia, sendo lógico que para cumprir com suas obrigações em virtude da Carta das Nações Unidas, os Estados membros da União Europeia tem a obrigação de tomar todas as medidas necessárias para que a União Europeia execute, por exemplo, as sanções obrigatórias impostas pelo Conselho de Segurança. ${ }^{113}$

109 A Organização das Nações Unidas (ONU) conta, atualmente, com 193 Estados membros.

110 De acordo com o artigo 41 da Carta das Nações Unidas, tais medidas podem incluir a interrupção completa ou parcial das relações econômicas, dos meios de comunicação ferroviários, marítimos, aéreos, postais, telegráficos, radiofônicos, ou de qualquer outra espécie e o rompimento das relações diplomáticas.

111 PELLET, Alain. Les sanctions de l'Union Européenne. In: BENLOLO-CARABOT, Myriam; CANDAS, Ulas; CUJO, Eglantine. Union européenne et droit international. Paris: Pedone, 2012. p. 431-455. p. 435.

112 NATIONS UNIES. Charte des nations unies. Disponível em: $<$ http://www.un.org/fr/documents/charter/index.shtml >. Acesso em: 02 fev. 2014.

113 PELLET, Alain. Les sanctions de l'Union Européenne. In: BENLOLO-CARABOT, Myriam; CANDAS, Ulas; CUJO, Eglantine. Union européenne et droit international. Paris: Pedone, 2012. p. 431- 
O artigo 103 da Carta das Nações Unidas “[...] est une règle secondaire, qui se greffe sur des dispositions de fond de la Charte. Elle contient une règle de conflit d'obligations et non pas de normes." 114 Como regra de conflito de obrigações, o artigo 103 da Carta das Nações Unidas estabelece uma primazia das obrigações decorrentes da Carta das Nações Unidas em relação às obrigações decorrentes do Direito da União, justamente quando houver conflito entre as obrigações decorrentes do Capítulo VII da Carta - Ação em caso de ameaça à paz, ruptura da paz e ato de agressão - e as obrigações decorrentes da Política Externa e de Segurança Comum (PESC), da União Europeia. Assim, na existência de colisão entre suportes fáticos das ações que envolvam, ao mesmo tempo, questões de segurança e defesa - internacional e da União Europeia (PESC) -, o conflito obrigacional originado nestas duas ordens jurídicas deve ser solucionado pela primazia das obrigações decorrentes do Direito das Nações Unidas.

\section{Considerações finais}

O presente artigo teve por objetivo estabelecer as relações entre o Direito das Nações Unidas e o Direito da União Europeia em matéria de Política Externa e de Segurança Comum (PESC), inseridas na sociedade internacional. Para tanto, conforme a própria perspectiva adotada propôs durante a exposição, a preocupação central era a de não se perder a ideia de sistema, seja do sistema jurídico, do sistema político, bem como do sistema social, com vistas a não descaracterização desses enquanto molduras de estabilidade, integridade e coerência internacionais. A compreensão do Direito Internacional Público como um sistema social, antes de tudo, demonstra a integridade, a estabilidade e a coerência desse conjunto normativo. ${ }^{115}$

A reconstrução histórico-institucional da União Europeia, em especial, da problemática da Política Externa

455. p. 435.

114 Para uma discussão completa sobre a natureza, função e completude do artigo 103 da Carta das Nações Unidas, ver o magistral Curso de Robert Kolb na Academia de Direito Internacional da Haia, em 2013. KOLB, Robert. L'article 103 de la Charte des Nations Unies. Leiden: M. Nijhoff, 2014.. p. 329.

115 CRAWFORD, James; KOSKENNIEMI, Martti. The Cambridge Companion to International Law. Cambridge: Cambridge University Press, 2012. p. 11; CRAWFORD, James; KOSKENNIEMI, Martti. The Cambridge Companion to International Law. Cambridge: Cambridge University Press, 2012. e de Segurança Comum (PESC), por meio do critério de diferenciação funcional ${ }^{116}$, permitiu ao observador (re)construir a autonomia das categorias jurídicas e, por conseguinte, dotá-las da riqueza semântica que as suporta, revelando a emergência do diálogo das categorias do Direito da União e do Direito das Nações Unidas.

Com vistas ao desenvolvimento do estudo proposto, elencou-se o seguinte problema de pesquisa, agora retomado para fins de conclusão: quando houver prescrições divergentes entre as obrigações decorrentes da Política Externa e de Segurança Comum Europeia (PESC) e de Paz e de Segurança Internacionais - em virtude das Resoluções expedidas pelo Conselho de Segurança com base no capítulo VII da Carta das Nações Unidas -, decorrentes, portanto, de obrigações assumidas em virtude do Direito da União e do Direito das Nações Unidas, haveria uma relação de primazia?

A resposta foi afirmativa, no sentido de que há uma relação de primazia obrigacional entre o Direito das $\mathrm{Na}$ ções Unidas e o Direito da União, sendo que na existência de colisão entre suportes fáticos das ações que envolvam, ao mesmo tempo, questões de segurança e defesa - internacional e da União Europeia (PESC) -, o conflito obrigacional originado entre essas duas ordens jurídicas deve ser solucionado pela primazia das obrigações decorrentes do Direito das Nações Unidas. Assim, instaurada, portanto, a primaz̧ia das obrigações do Direito das Nacõos Unidas.

Ao tentar fugir das clássicas discussões jurídicas acerca de uma postura europeanista ou internacionalista, por critérios de exclusão ou de dominação epistemológica de um sistema jurídico ao outro, portanto, o presente estudo teve por fim, claramente delimitado, a iluminação dos paradoxos inerentes ao diálogo entre o Direito da União e o Direito das Nações Unidas, num movimento pendular entre o que se poderia chamar de solipsismo onusiano e de solipsismo europen.

\section{REFERÊNCIAS}

BENLOLO-CARABOT, Myriam; CANDAS, Ulas; CUJO, Eglantine. Union européenne et droit international. Paris: Pedone, 2012.

116 LUHMANN, Niklas. La sociedad de la sociedade. Ciudad de México: Herder, 2006. 
BEULAY, Marjorie. Les traités constitutifs de l'Union Européenne. In: BENLOLO-CARABOT, Myriam; CANDAS, Ulas; CUJO, Eglantine. Union européenne et droit international. Paris: Pedone, 2012. p. 95-109.

BOISSON DE CHAZOURNES, Laurence. Les relations entre organisations régionales et organisations universelles. In: L'ACADÉMIE DE DROIT INTERNATIONAL DE LA HAYE. Recueil des cours de l'Académie du droit international de la Haye. Leiden: M. Nijhoff, 2011. t. 2. p. 79-406.

CENTRE VIRTUEL DE LA CONNAISANCE DE L'EUROPE. Rapport Copenhague: Deuxième rapport sur la coopération politique européenne en matière de politique étrangère. Disponível em: <http://www.cvce. eu/obj/deuxieme_rapport_sur_la_cooperation_politique_europeenne_en_matiere_de_politique_etrangere_ copenhague_23_juillet_1973-fr-8b935ae1-0a38-42d4a97e-088c63d54b6f.html>. Acesso em: 02 fev. 2014.

CENTRE VIRTUEL DE LA CONNAISANCE DE L'EUROPE. Rapport Davignon: rapport des ministres des affaires étrangères des Etats membres sur les problèmes de l'unification politique. Disponível em: $<$ http://www.cvce.eu/obj/rapport_davignon_luxembourg_27_octobre_1970-fr-4176efc3-c734-41e5-bb90d34c4d17bbb5.html>. Acesso em: 01 fev. 2014.

CENTRE VIRTUEL DE LA CONNAISANCE DE L'EUROPE. Rapport Londres: rapport sur la coopération politique européenne (Londres, 13 octobre 1981). Disponível em: <http://www.cvce.eu/obj/rapport_sur_la_cooperation_politique_europeenne_londres_13_octobre_1981-fr-869a63a6-4c28-4e42-8c41efd2415cd7dc.html>. Acesso em: 02 fev. 2014.

CENTRE VIRTUEL DE LA CONNAISANCE DE L'EUROPE. Sommet de Paris: Communiqué final de la réunion des chefs de gouvernement de la Communauté (Paris, 9 et 10 décembre 1974). Disponível em: <http:// www.cvce.eu/obj/communique_final_du_sommet_ de_paris_9_et_10_decembre_1974-fr-2acd8532-b27149ed-bf63-bd8131180d6b.html>. Acesso em: 02 fev. 2014.

CHARPENTIER, J. De la personnalité juridique de l'Union européenne. In: GALABERT, J. M.; TERCINET, M.-R. Mélanges Peiser. Grenoble: Presses Universitaires de Grenoble, 1995. p. 93-102.

CORTE DE JUSTIÇA DAS COMUNIDADES EUROPEIAS. 1971. Sentença de 31 de março. Comissão das Comunidades Europeias contra Conselho das Comunidades Europeias. Processo n. 22/70. Disponível em: <http://curia.europa.eu/juris/showPdf.jsf?text= $\&$ docid $=88062 \&$ pageIndex $=0 \&$ doclang $=$ pt $\&$ mode $=1 \mathrm{~s}$ $\mathrm{t} \& \operatorname{dir}=\&$ occ $=$ first\&part $=1 \& \mathrm{cid}=563437>$. Acesso em: 2 fev. 2014.

CORTE DE JUSTIÇA DAS COMUNIDADES EUROPEIAS. 2005. Sentença de 21 de setembro. Kadi contra Conselho das Comunidades Europeias. Processo n.T-315/01. Disponível em: <http://curia.europa. $\mathrm{eu} /$ juris $/$ showPdf.jsf;jsessionid=9ea $7 \mathrm{~d} 2 \mathrm{dc} 30 \mathrm{dba} 52 \mathrm{e} 7 \mathrm{a}$ 050ed6467490eb8a6d82ddd35e.e34KaxiLc3qMb40Rc h0SaxuKbNb0? text $=\&$ docid $=65739 \&$ pageIndex $=0 \&$ doclang $=$ PT $\&$ mode $=$ req $\&$ dir $=\&$ occ $=$ first $\&$ part $=1 \& \mathrm{c}$ id $=220515>$. Acesso em: 2 fev. 2014.

CORTEN, Olivier. Le discours du droit international: pour un positivisme critique. Paris: Pedone, 2009.

COUR INTERNATIONALE DE JUSTICE. Réparation des dommages subis an service des Nations Unies. Disponível em: <http://www.icj-cij.org/docket/index.ph $\mathrm{p}$ ? $1=3 \& \mathrm{p} 2=4 \& \mathrm{k}=41 \&$ case $=4 \& \operatorname{code}=$ isun $\& \mathrm{p} 3=0>$. Acesso em: 04 fev. 2014.

CRAWFORD, James. Chance, order, change: the course of international law. general course on public international law. Leiden: M. Nijhoff, 2014.

CRAWFORD, James; KOSKENNIEMI, Martti. The Cambridge Companion to International Law. Cambridge: Cambridge University Press, 2012.

DAILLIER, Patrick; FORTEAU, Mathias; PELLET, Alain. Droit international public. 8. ed. Paris: Lextenso, 2009.

EDOUARD, Régis. La personnalité juridique internationale de l'Union Européenne. In: BENLOLO-CARABOT, Myriam; CANDAS, Ulas; CUJO, Eglantine. Union européenne et droit international. Paris: Pedone, 2012. p. 109-116.

ESTAING, Valéry Giscard. Discours introductif à la Convention sur l'avenir de l'Europe. Disponível em: < http:/ / www.senat.fr/europe/convention_2002/discours_ vge_28022002.pdf>. Acesso em: 03 fev. 2014.

FRANCE. Ministère des Affaires Étrangères). Guide de la PESC. Disponível em: <http://www.rpfrance.eu/ IMG/guide_pesc.pdf>. Acesso em: 2 fev. 2014.

GROUX, J.; MANIN, P. Les communautés européennes dans l'ordre international. Luxembourg: OPOCE, 1984. 
IORDAN, Cristian. La définition progressive d'une politique européenne de sécurité. Romanian Journal Of European Affairs, Bucharest, v. 13, n. 2, p. 67-79, 2013.

KING, Anthony. The future of the european security and defence policy. Contemporary Security Policy, Virginia, v. 26, n. 1, p. 44-61, 2005.

KOLB, Robert. L'article 103 de la Charte des Nations Unies. Leiden: M. Nijhoff, 2014.

KOSKENNIEMI, Martti. From apology to utopia: the structure of the international legal argument. Cambridge: Cambridge University Press, 2005.

KOSKENNIEMI, Martti. La politique du droit international. Paris: Pedone, 2007.

LUHMANN, Niklas. La sociedad de la sociedade. Ciudad de México: Herder, 2006.

MARTINS, Estevão de Rezende. Parcerias almejadas: política externa, segurança, defesa e história na Europa. Belo Horizonte: Fino Traço, 2012.

NATIONS UNIES. Charte des nations unies. Disponível em: <http://www.un.org/fr/documents/charter/index.shtml>. Acesso em: 02 fev. 2014.

PELLET, Alain. Les sanctions de l'Union Européenne. In: BENLOLO-CARABOT, Myriam; CANDAS, Ulas; CUJO, Eglantine. Union européenne et droit international. Paris: Pedone, 2012. p. 431-455.

PETITEVILLE, Franck. La politique internationale de l'union européenne. Paris: Les Presses de Sciences Po, 2006.

RICHARDSON, John. Existencial epistemology: a heideggerian critique of the cartesian project. New York: Oxford University Press, 1986.

SCHUMAN, Robert. La déclaration Schuman du 9 mai 1950. Disponível em: <http://europa.eu/about-eu/ basic-information/symbols/europe-day/schuman-declaration/index_fr.htm>. Acesso em: 03 fev. 2014.

SIMON, Denys. Invocabilité et primauté: petite éxperience de déconstruction. In: BENLOLO-CARABOT, Myriam; CANDAS, Ulas; CUJO, Eglantine. Union européenne et droit international. Paris: Pedone, 2012. p. 140-157.

TERPAN, Fabien. La politique étrangère, de sécurité et de défense de l'union européenne. Paris: La Documentation Française, 2010.

TRINDADE, Antônio Augusto Cançado. Os tribunais internacionais contemporâneos. Brasília: FUNAG, 2013.
UNIÃO EUROPEIA. Carta dos Direitos Fundamentais da União Europeia. Disponível em: <http://www.europarl. europa.eu/charter/pdf/text_pt.pdf $>$. Acesso em: 3 fev. 2014.

UNIÃO EUROPEIA. Sinteses da legislação da União Europeia. Disponível em: <http://europa.eu/legislation_ summaries/institutional_affairs/treaties/treaties_introduction_pt.htm>. Acesso em: 30 jan. 2014.

UNIÃO EUROPEIA. Sinteses da legislação da União Europeia: Tratado de Amsterdam. Disponível em: <http:// europa.eu/legislation_summaries/institutional_affairs/ treaties/amsterdam_treaty/a19000_pt.htm>. Acesso em: 31 jan. 2014.

UNIÃO EUROPEIA. Sinteses da legislação da União Europeia: Ato Único Europeu (AUE). Disponível em: $<$ http://europa.eu/legislation_summaries/institutional_affairs/treaties/treaties_singleact_pt.htm>. Acesso em: 1 fev. 2014.

UNIÃO EUROPEIA. Tratado de Amsterdam. Disponível em: <http://eur-lex.europa.eu/fr/treaties/ dat/11997D/htm/11997D.html>. Acesso em: 1 fev. 2014.

UNIÃO EUROPEIA. Tratado sobre a União Europeia. Tratado de Maastricht. Disponível: <http://eur-lex.europa.eu/fr/treaties/dat/11992M/htm/11992M.html>. Acesso em: 1 fev. 2014.

UNIÃO EUROPEIA. Tratado sobre a União Europeia: Consolidado com a versão do Tratado de Lisboa. Disponível: <http://eur-lex.europa.eu/LexUriServ/ LexUriServ.do?uri=OJ:C:2010:083:FULL:PT:PDF>. Acesso em: 1 fev. 2014.

UNIÃO EUROPEIA. Tratado sobre o Funcionamento da União Europeia. Disponível em: <http://eurlex.europa. eu/LexUriServ/LexUriServ.do?uri=OJ:C:2010:083:004 7:0200:pt:PDF>. Acesso em: 3 fev. 2014.

VIGNES, Daniel. L'Union européenne, acteur civil et militaire dans la gestion des crises internationales: la PESD, politique européenne de sécurité et de défense. In: YEE, Sienho; MORIN, Jacques-Yvan. Multiculturalism and international law: essays in honour of Edward McWhinney. Leiden: Martinus Nijhoff, 2009. p. 393414.

VISSCHER, Charles de. Teorias y realidades en derecho internacional público. Barcelona: Bosch, 1962. 


\section{Introdução às regras de aplicação da Convenção da ONU sobre Contratos de Compra e Venda Internacional de Mercadorias e o direito internacional privado brasileiro*}

\section{Introduction to the utilisation of the CISG and the brazilian conflict of law rules}

Paul Hugo Weberbauer**

Eugênia Cristina Nilsen Ribeiro Barza***

\section{Resumo}

O presente artigo tem como objeto a incorporação da Convenção da ONU sobre a compra e venda internacional de mercadorias (Convenção de Viena 1980) no Direito brasileiro, ocorrida com o decreto legislativo 538 de 19 de outubro de 2012. O objetivo consiste em analisar o complexo sistema de aplicação da Convenção consagrado nos artigos 1, 2, 3, 6 e 12, além de estabelecer análise inicial sobre a inserção do princípio da natureza dispositiva dos Tratados existente no Direito do Comércio Internacional e suas implicações no sistema colisional brasileiro regido, principalmente, pela LINDB, além da questão da interferência do Código de Defesa do Consumidor. Para atingir tal fim, o estudo inicia com um breve histórico da Convenção de Viena 1980, com destaque às Conferências de Haia de 1964, passando a analisar os três vetores evidenciados nas regras de aplicabilidade da Convenção que são: (1) natureza do contrato; (2) tipo de objeto; e (3) localização espacial e temporal da relação contratual. Encerrando o estudo aborda-se a interferência do Código de Defesa do Consumidor (CDC) nessas regras. A metodologia empregada é a dedução, utilizando-se da investigação histórica e comparativa, uma vez que se trata de assunto recente e ainda de pouca abordagem pela doutrina brasileira.

Palavras-chave: Contratos internacionais. Convenção de Viena 1980. Aplicação. Direito Internacional Privado brasileiro.

\section{Abstract}

This Study has as object the incorporation of the CISG in Brazil that happened with the Legislative decree 538 from October, 19, 2012. It aims to analyze the set of rules about the sphere of application of the CISG, mainly $\$ 1-3, \$ 6$ and $\$ 12$, including an overview about the non-mandatory nature of the rules over the International Trade Law and its implications on the Brazilian Choice of Law rules and the question about the CISG utilization with the Brazilian Consumer Act (CDC). To achieve this, the study begins 
with a short historical analyze about the construction of the CISG, in specially it distinction from the Hague Conferences held in 1964. Next step is to analyze the three main vectors that rule the CISG application sphere: (1) the contract nature; (2) types of objects; and (3) the territorial and temporal element in the contractual relation. At end, we deal with the interference of the Brazilian Consumer Act (CDC) with the CISG application. The methodology used is the deduction, with help of the historical and comparative research over legislative and bibliographic sources.

Keywords: International Contracts. CISG. Sphere of application. Conflict of Law (Brazil).

\section{INTRODUÇÃo}

A Convenção da ONU sobre a compra e venda internacional de mercadorias, doravante denominada de Convenção de Viena 1980, pode ser considerada uma das iniciativas de uniformização de maior sucesso na busca de uma regulamentação uniforme e global do comércio internacional, a ponto de ter a adesão de 83 países, incluindo a maior parte dos países europeus, os Estados Unidos da América e a China, constituindo um dos pilares legislativos do Direito do Comércio Internacional contemporâneo ${ }^{1}$.

A Convenção de Viena 1980 também pode ser considerada como o ponto maior da obra de três grandes juristas no estudo da compra e venda no plano comparado-internacional: Prof. Dr. Ernst Rabel (1874 1955†), Prof. Dr. Ernst von Caemmerer (1908 - 1985†) e o prof. Dr. Peter Schlechtriem (1933-2007†). Quais, não por acaso, constam no hall of fame do principal sítio sobre a Convenção de Viena 1980, o Global Sales Law mantido pela Universidade de Basel $^{2}$.

Destarte, a Convenção de Venda 1980 não deve ser só considerada como um simples tratado de uniformização, mas sim a expressão legislativa internacional de esforço coletivo dos maiores juristas da compra e venda do século XX para a implementação de sistema jurídico

1 REILEY, Eldon H. International sales contracts: the UN convention and related transnational law. Durham: Carolina Academic Press, 2008. p. 34.

2 GLOBAL SALES LAW. Hall of fame. Disponível em: < http:// www.globalsaleslaw.org/index.cfm?pageID=648>. Acesso em: 23 nov. 2013. uniforme ao plano internacional.

Esse esforço que se materializou legislativamente em 1980, no que tange ao Brasil, acabou sujeito a um longo e moroso debate sobre sua incorporação ou não no Direito brasileiro, mesmo com manifestações doutrinárias uníssonas sobre a importância e a necessidade do Brasil em aderir a esse tratado para promover maior segurança na regulamentação dos contratos internacionais pelo Direito brasileiro ${ }^{3}$.

Em 19 de outubro de 2012, seguindo a orientação da LXIX Reunião do Conselho de Ministros da Câmara de Comércio Exterior (Camex), apontando que a ratificação da Convenção de Viena 1980 contribuiria largamente para a segurança e a estabilidade das relações comerciais internacionais, o Congresso Nacional decidiu por sua ratificação integral, promulgando o Decreto Legislativo 538 de 18 de outubro de $2012^{4}$, sendo incorporada de pleno com a promulgação do Decreto $\mathrm{N}^{\circ}$. 8.327, de 16 de outubro de 2014, entrando em vigência no dia $1^{\circ}$ de abril de 2014.

A inserção oficial da Convenção de Viena 1980 no ordenamento jurídico brasileiro traz uma série de impactos no Direito Internacional Privado brasileiro, qual é, ainda, dominado pela arcaica legislação de 1942, renomeada em 2010 com o sugestivo nome de Lei de Introdução às Normas do Direito brasileiro (LINDB), sendo o mais expressivo desses impactos o objeto do presente estudo: o âmbito de aplicação da Convenção de Viena 1980 e a sua natureza dispositiva.

A opção por analisar o âmbito de aplicação e a decorrente natureza dispositiva da Convenção de Viena 1980 decorre de suas características sui generis quando confrontada com a natureza autoexecutável dos Tratados incorporados, uma vez que, flertando com o soft law, a Convenção acaba por instalar microssistema no que

3 SCHÜTZ, Hebert M. de A. Da necessidade de adesão do Brasil à convenção da ONU sobre contratos de compra e venda internacional de mercadorias. Ambito Jurídico, Rio Grande, v. 14, n. 90, jul. 2011. Disponível em: <http://ambitojuridico.com.br/ site/?n_link=revista_artigos_leitura\&artigo_id=9865\&revista_caderno=16> Acesso em: 07 nov. 2013.

4 BRASIL. Senado Federal. Decreto Legislativo $n^{\circ} 538,18$ de outubro de 2012. Aprova o texto da Convenção das Nações Unidas sobre Contratos de Compra e Venda Internacional de Mercadorias, estabelecida em Viena, em 11 de abril de 1980, no âmbito da Comissão das Nações Unidas para o Direito Mercantil Internacional. Disponível em: <http://www2.camara.leg.br/legin/fed/decleg/2012/ decretolegislativo-538-18-outubro-2012-774414-exposicaodemotivos-137984-pl.html>. Acesso em: 21 nov. 2013. 
tange a sua aplicabilidade, demonstrando alto grau de tecnicidade e zelo na sua técnica legislativa - características incomuns na legislação brasileira. Neste ponto, torna-se relevante a questão da compatibilidade entre essas regras flexíveis com as regra de caráter unilateral e indeterminado na redação legislativa do Código de Defesa do Consumidor (CDC), de modo a analisar se, no Brasil, o CDC consistiria em uma circunstância impeditiva para a aplicação da Convenção de 1980.

Diante desse contexto, o presente estudo inicia com um breve histórico da Convenção de Viena 1980, basicamente procurando abordar as Conferências de Haia de 1964, o nascimento da Comissão das Nações Unidas para o Direito do Comércio Internacional (UNCITRAL) e o próprio nascimento da Convenção de 1980, procurando expor os motivos que levaram ao alto grau de tecnicidade e sua natureza dispositiva.

No segundo momento, parte-se para a análise do microssistema de aplicação existente na Convenção, procurando oferecer uma interpretação para seus dispositivos iniciais, de forma a conciliar a redação dada com breves reflexões sobre sua interpretação.

Por fim, analisa-se a contraposição entre a natureza dispositiva da Convenção Viena 1980 com a disposição do art. $1^{\circ}$ do Código de Defesa do Consumidor (CDC), de modo a tentar conciliar a natureza imperativa da legislação consumerista com a natureza comercial dispositiva da Convenção, procurando remover do pensamento jurídico brasileiro do CDC configurar como uma eventual circunstância impeditiva na aplicação da Convenção.

Quanto à metodologia, o estudo se utiliza da dedução cujos dados são oriundos da pesquisa dogmática sobre o tema, tentando conciliar a investigação legislativa com a investigação doutrinária, de forma a conciliar a legislação brasileira com os entendimentos mais aprofundados sobre a Convenção de Viena 1980 da doutrina estrangeira, em especial a alemã e a norte-americana, uma vez que a doutrina brasileira ainda não se encontra consolidada sobre o assunto em razão da sua recente inserção no Brasil.

Importante salientar que a investigação parte da premissa do Direito do Comércio Internacional para o Direito Internacional Privado brasileiro vigente, não havendo confusão com demais ramos do Direito privado (ex.: teoria contratual).
Também se destaca que procurou-se utilizar de fontes de fácil acesso para o leitor interessado em aprofundar seus estudos no tema da compra e venda internacional ou da uniformização do Direito privado no plano internacional.

\section{A Conferência de Haia, a UNCITRAL e a Convenção de Viena de 1980}

Como bem afirma John Honnold", "International affairs move with lightining speed only in war", a criação de normas internacionais constitui um processo lento e demorado. Assim, entender o surgimento da Convenção de Viena de 1980 consiste em tentar compreender um fenômeno de uniformização do Direito Privado (em especial o comercial) que, apesar de nascer no fim do século XIX, ganhou tremenda força na metade final do século XX, e que se mantém diante da globalização e do desenvolvimento do comércio virtual.

Desse processo histórico, ficaremos limitados a Conferência de Haia de 1964, momento histórico que influenciará, diretamente, no nascimento da UNCITRAL e, por consequência, na Convenção de Viena de 1980.

Inicialmente, é imperioso não confundir as Conferências de Haia de 1964 indicadas neste estudo como ponto desencadeador do surgimento da Convenção de Viena 1980, com o organismo internacional conhecido por Conferência de Haia sobre Direito Internacional Privado.

O organismo internacional conhecido como Conferência de Haia sobre Direito Internacional Privado consiste em uma organização composta atualmente por 74 Estados membros, fundada em 1893 por iniciativa do jurista holandês Tobias M. C. Asser ${ }^{6}$ tem por objetivo promover a uniformização das regras de Direito Internacional Privado, fim pelo qual já desenvolveu por volta de 35 convenções internacionais de diversos ramos do Direito Privado, e 27 dessas convenções estão em vigor?

5 HONNOLD, John. The uniform law for the international sale of goods: the Hague Convention of 1964. Disponível em: < http://scholarship. law.duke.edu $/$ cgi $/$ viewcontent.cgi? article $=3058 \&$ context $=$ lcp $>$. Acesso em: 06 nov. 2013.

6 HAGUE CONFERENCE OF PRIVATE INTERNATIONAL LAW. Overview. Disponível em: < http://www.hcch.net/index_ en.php?act=text.display\&tid=4>. Acesso em: 21 nov. 2013.

7 REILEY, Eldon H. International sales contracts: the UN convention and related transnational law. Durham: Carolina Academic 
Enquanto as Conferências de Haia refere-se às convenções diplomáticas realizadas na cidade de Haia, das quais resultaram dois tratados de uniformização da compra e venda internacional, conhecidos pelas siglas ULIS e ULF (em inglês, Uniform Law on the Formation on Contracts for the International Sale of goods) realizadas por iniciativa do Instituto de Roma (conhecido como UNIDROIT) como primeiras tentativas de uniformização da compra e venda internacional como explica Reiley:

\begin{abstract}
During the period that the Hague Conference was looking at choice of law rules, UNIDROIT began to consider possible unification of substantive law applicable to international sales contracts. It prepared two conventions, which were both approved at a diplomatic conference held at The Hague in 1964. (The diplomatic conference which approved the two UNIDROIT conventions is not to be confused with the Hague Conference on Private International Law; which did not participate in the preparation of the substantive law conventions and which actually opposed them.) The two substantive law sales conventions became known collectively as the "Hague Conventions". These are the direct predecessors or "ancestors" of the CISG".
\end{abstract}

Em linhas gerais, esses dois tratados tem o mesmo objeto que a Convenção de Viena 1980, isto é, procuraram trabalhar com princípios gerais da compra e venda internacional, de forma a conciliar suas regras com as particularidades dos diferentes Estados nacionais, de forma a conferir uma ampla liberdade às partes quanto às estipulações contratuais? .

Também partilham o fato de que foram resultado de longo processo de elaboração, uma vez que essa Conferencia de 1964 foram resultado de trabalhos de uniformização iniciados em 1930 pelo UNIDROIT, qual figurava como órgão auxiliar da Liga das Nações para fins de unificação do Direito privado. O primeiro desses trabalhos foi o esboço de um direito uniforme para o Direito privado, o qual ficou pronto em 1935, sofrendo revisão em 1939, 1956 e, finalmente, em 1963, sendo convertido em proposta a ser ratificada pela Conferencia de $1964^{10}$.

Press, 2008. p. 4-5.

8 REILEY, Eldon H. International sales contracts: the UN convention and related transnational law. Durham: Carolina Academic Press, 2008. p. 10.

9 NDULO, Muna. The Vienna Sales Convention 1980 and the Hague Uniform Laws on International Sale of Goods 1964: a comparative analysis. Disponível em: <http://scholarship.law.cornell.edu/cgi/viewcontent. cgi article $=1065 \&$ context $=$ facpub $>$. Acesso em: 11 nov. 2013.

10 HONNOLD, John. The uniform law for the international sale of goods:
Infelizmente, esse longo processo de elaboração acabou apresentando falhas, as quais acabaram por gerar resistências tanto na sua aceitação, como também, na sua ratificação pelos Estados participantes da Conferência de 1964.

A primeira falha não decorreu dos textos em si, mas sim do número e da natureza dos participantes na Conferência: somente 28 países participaram, e a representação dos países comunistas e os em desenvolvimento foi precária, conferindo uma impressão de que os textos em debate estariam estabelecendo tratamento jurídico favorável aos países industrializados não comunistas, gerando forte rejeição quanto a sua aceitação ou ratificação por parte dos primeiros ${ }^{11}$.

A segunda falha decorreu do próprio andamento da Conferência, a qual foi marcada por um clima de que ora oscilava entre "exaltação, exaustão e desespero" situação derivada pela escassez de tempo para apreciação dos textos, uma vez que alguns participantes haviam se tornado recentemente membros do UNIDROIT ${ }^{13}$ e a própria estrutura da Conferência não dinamizava os debates devido ao fato de os trabalhos terem sido separados em três conferências distintas: uma sobre a uniformização do Direito, uma sobre a formação contratual, e, uma terceira para a implementação das regras aprovadas.

Essas (sub) conferências acabaram por serem subdivididas em dezenas de comissões, quais deveriam relatar suas decisões para o comitê elaborador dos textos. Ao fim, essa falha decorrente do andamento da Conferência pode ser resumida no dilema enfrentado pelo comitê

the Hague Convention of 1964. Disponível em: < http://scholarship. law.duke.edu $/ \mathrm{cgi} /$ viewcontent.cgi? article $=3058 \&$ context $=l \mathrm{cp}>$. Acesso em: 06 nov. 2013.

11 NDULO, Muna. The Vienna Sales Convention 1980 and the Hague Uniform Laws on International Sale of Goods 1964: a comparative analysis. Disponível em: <http://scholarship.law.cornell.edu/cgi/viewcontent. cgi ?article $=1065 \&$ context $=$ facpub $>$. Acesso em: 11 nov. 2013.

12 HONNOLD, John. The uniform law for the international sale of goods: the Hague Convention of 1964. Disponível em: <http:/ / scholarship. law.duke.edu $/ \mathrm{cgi} /$ viewcontent.cgi?article $=3058 \&$ context $=\mathrm{lcp}>$. Acesso em: 06 nov. 2013

13 Como destaque nessa situação os EUA, que somente se tornaram membros do UNIDROIT em dezembro de 1963, ou seja, quatro meses antes da Conferência. A respeito, elucidativo o trabalho de HONNOLD, John. The uniform law for the international sale of goods: the Hague Convention of 1964. Disponível em: <http://scholarship. law.duke.edu $/ \mathrm{cgi} /$ viewcontent.cgi? article $=3058 \&$ context $=$ lcp $>$. Acesso em: 06 nov. 2013. 
final: "ter um pássaro na mão, ou dois voando? ${ }^{14 ”}$.

Além dessas duas falhas, uma terceira falha ainda é digna de nota: o texto elaborado, em especial na confecção da ULIS, era demasiadamente abstrato e dotado de um grau de complexidade tal qual tornava sua aplicação confusa. Isto é, o texto continha uma série de ambiguidades e de expressões de difícil entendimento até mesmo para profissionais especializados, a ponto de gerar um âmbito de aplicação tão amplo que simplesmente podia-se ignorar o uso de regras colisionais para sua aplicação ${ }^{15}$.

Ao fim da Conferência de Haia de 1964, os que haviam participado desta, bem como aqueles estudiosos posteriores da uniformização internacional chegaram à conclusão de que tanto a ULIS como a ULF tinham muito pouco de comércio internacional e, em demasia, conteúdo de comércio exterior, constatação evidenciada pela pouca atenção dada as transações intercontinentais nesses documentos ${ }^{16}$.

Ocorre que, apesar de falhar em apresentar uma sistematização legislativa para uniformizar regras do comércio internacional, as falhas observadas na Conferência de 1964 acabaram por influenciar a comunidade internacional da importância e necessidade de existirem regras uniformes para o comércio internacional, bem como a conscientizar aos internacionalistas privatistas da urgência em consolidar um microssistema próprio: o Direito do Comércio Interncaional.

Nesse sentido, em 17 de dezembro de 1966, por força da Resolução 2205 (XXI) da Organização das Nações Unidas (ONU), a comunidade internacional decidiu pela criação de uma Comissão das Nações Unidas para o Direito do Comércio Internacional (UNCITRAL), cujo objetivo principal consiste em desenvolver e modernizar as regras do comércio internacional,

14 HONNOLD, John. The uniform law for the international sale of goods: the Hague Convention of 1964. Disponível em: <http://scholarship. law.duke.edu $/$ cgi $/$ viewcontent.cgi? article $=3058 \&$ context $=$ lcp $>$. Acesso em: 06 nov. 2013.

15 NDULO, Muna. The Vienna Sales Convention 1980 and the Hague Uniform Laws on International Sale of Goods 1964: a comparative analysis. Disponível em: <http://scholarship.law.cornell.edu/cgi/viewcontent.cgi?article $=1065 \&$ context $=$ facpub $>$. Acesso em: 11 nov. 2013.

16 NDULO, Muna. The Vienna Sales Convention 1980 and the Hague Uniform Laws on International Sale of Goods 1964: a comparative analysis. Disponível em: <http://scholarship.law.cornell.edu/cgi/viewcontent.cgi article $=1065 \&$ context $=$ facpub $>$. Acesso em: 11 nov. 2013. procurando fomentar um consenso entre os membros da Comunidade Internacional para a criação de tratados que regulamentem o comércio internacional. Esses tratados teriam a expressão "Nações Unidas" em sua denominação, como marca de ser resultado de iniciativa global, sem favorecimentos e sem polarizações de qualquer tipo ${ }^{17}$.

A UNCITRAL teve sua primeira sessão em 1968, quando solicitou ao secretariado geral da ONU que enviasse questionário para os membros daquela organização e para qualquer uma de suas agências especializadas, para se manifestarem sobre suas posições quanto ás Conferências de Haia de 1964, as quais ainda não se encontravam em vigor ${ }^{18}$.

Com base nessas manifestações, em 1969 foi criado um grupo de trabalho para elaborar proposta que viesse a solucionar a questão da regulamentação da compra e venda internacional, de forma a conciliar o que fora obtido nas Conferencias de 1964 e os interesses de cada membro da ONU, de forma a serem consolidadas em um só tratado, cuja natureza seria autoexecutiva e, por consequência, não gerasse a necessidade de adaptações por parte das legislações nacionais para ser incorporado por estas ${ }^{19}$.

Com base nesse grupo de trabalho, desse esboço oficialmente lançado como iniciativa da ONU em 1969, na $10^{a}$ sessão da UNCITRAL, adotou-se o texto provisório a ser votado artigo por artigo em Conferência diplomática própria, a ser realizada em Viena, Áustria em 1980 que nasceu a Convenção de Viena 1980.

Em suma, colocando-se em uma análise macroscópica, a Convenção de Viena 1980 tanto no esforço dos juristas como nas lições dos fracassos das inciativas anteriores, não sendo sem razão afirmar que a adoção da Convenção foi o produto de meio século de trabalho árduo e intenso para a elaboração de lei uniforme para os contratos de compra e venda internacionais ${ }^{20}$.

17 REILEY, Eldon H. International sales contracts: the UN convention and related transnational law. Durham: Carolina Academic Press, 2008. p. 5.

18 NDULO, Muna. The Vienna Sales Convention 1980 and the Hague Uniform Laws on International Sale of Goods 1964: a comparative analysis. Disponível em: <http://scholarship.law.cornell.edu/cgi/viewcontent. cgi article $=1065 \&$ context $=$ facpub $>$. Acesso em: 11 nov. 2013.

19 REILEY, Eldon H. International sales contracts: the UN convention and related transnational law. Durham: Carolina Academic Press, 2008. p. 10.

20 BONNEL, Michael J. apud MORAES, Fabíola. Aproximação do 


\section{O Âmbito de APLiCAÇÃo da Convenção de VIENA 1980}

\subsection{Os três vetores do sistema de aplicação da Convenção}

No que tange ao sistema de aplicação adotado pela Convenção, primeiro se faz necessário ressaltar que a Convenção só tem aplicação a relações comerciais e internacionais, sejam estas a nível regional ou global, não devendo ser aplicada para relações nacionais, demonstrando claro respeito por parte da Convenção para com os Direitos nacionais de cada país signatário. Ignorar essas duas premissas constitui desvirtuar o próprio sentido da Convenção e sua utilidade.

A Convenção constitui produto do Direito do Comércio Internacional e, em regra, deve ser interpretada em consonância aos princípios e regras consolidados neste.

Feita essa ressalta, pode-se iniciar a análise da aplicabilidade da Convenção com base na redação de seu $\operatorname{artigo} 1^{\circ}$ :

(1) esta Convenção aplica-se aos contratos de compra e venda de mercadorias entre partes que tenham estabelecimentos em Estados distintos;

(a) quando tais Estados forem Contratantes; ou

(b) quando as regras de direito internacional privado levarem à aplicação da lei de um Estado Contratante.

(2) Não será levado em consideração o fato de as partes terem seus estabelecimentos comerciais em Estados distintos, quando tal circunstância não resultar do contrato, das tentativas entre as partes ou de informações por elas prestadas antes ou no momento de conclusão do contrato.

(3) Para a aplicação da presente Covnenção não serão considerados a nacinoalidade das partes, nem o caráter civil ou comercial das partes ou do contrato. $^{21}$

direito contratual dos estados-membros da União Européia. Rio de Janeiro: Renovar, 2007. p. 169.

21 BRASIL. Senado Federal. Decreto Legislativo n ${ }^{\circ} 538,18$ de outubro de 2012. Aprova o texto da Convenção das Nações Unidas sobre Contratos de Compra e Venda Internacional de Mercadorias, estabelecida em Viena, em 11 de abril de 1980, no âmbito da Comissão das Nações Unidas para o Direito Mercantil Internacional. Disponível em: <http://www2.camara.leg.br/legin/fed/decleg/2012/ decretolegislativo-538-18-outubro-2012-774414-exposicaodemotivos-137984-pl.html>. Acesso em: 21 nov. 2013.
Com base nesse dispositivo, pode-se dividir o sistema de aplicação estabelecido na Convenção nos seguintes vetores: (1) natureza do contrato; (2) Tipo de objeto; e (3) localização espacial das partes e tempo do contrato.

O primeiro vetor, ora denominado de natureza do contrato, consiste na determinação de que a Convenção somente se aplica a contratos de compra e venda, sendo esse vetor auxiliado pela previsão do $\operatorname{art} .3^{\circ} \mathrm{da}$ Convenção:

(1) serão considerados contratos de compra e venda os contratos de fornecimento de mercadorias a serem fabricadas ou produzidas, salvo se a parte que as encomendar tiver de fornecer parcela substancial dos materiais necessários à fabricação ou à produção.

(2) não se aplica esta Convenção a contratos em que a parcela preponderante das obrigações do fornecedor das mercadorias consistir no fornecimento de mão de obra ou de outros serviços $^{22}$

Nesse ponto, surgem duas questões controversas na doutrina: (1) a definição de "parcela substancial" e (2) a questão dos softwares.

Quando o item 1 do Art. $3^{\circ}$ utiliza a expressão "parcela substancial", ocorre um problema de indeterminação, uma vez que existe uma tradução diferente para cada idioma dessa expressão (part essentielle, substantial part), bem como a doutrina se divide na hora delimitar um conceito, havendo a corrente minoritária que prevalece o quesito qualidade do material fornecido, enquanto a corrente majoritária determina que a interpretação de substancial deve ser aferida pelo valor econômico ${ }^{23}$.

A outra questão problemática refere-se aos softwares, uma vez que à época de feitura da Convenção, esse tipo de objeto era raro, mas que, a partir de 1990, acabou gerando um campo totalmente novo dentro do contexto do comércio virtual. Essa problemática decorre, especialmente, da modalidade de entrega por via de descarregamento digital (download), que não se insere de forma

22 BRASIL. Senado Federal. Decreto Legislativo n ${ }^{\circ}$ 538, 18 de outubro de 2012. Aprova o texto da Convenção das Nações Unidas sobre Contratos de Compra e Venda Internacional de Mercadorias, estabelecida em Viena, em 11 de abril de 1980, no âmbito da Comissão das Nações Unidas para o Direito Mercantil Internacional. Disponível em: <http://www2.camara.leg.br/legin/fed/decleg/2012/ decretolegislativo-538-18-outubro-2012-774414-exposicaodemotivos-137984-pl.html>. Acesso em: 21 nov. 2013.

23 PIGNATTA, Francisco. Comentários a Convenção de Viena de 1980: artigo 3. Disponível em: <http://www.cisg-brasil.net/doc/ fpignatta-art3.pdf> Acesso em: 01 nov. 2013. 
plena nem no conceito de compra e venda de mercadoria (tradição) ou de fornecimento de um serviço.

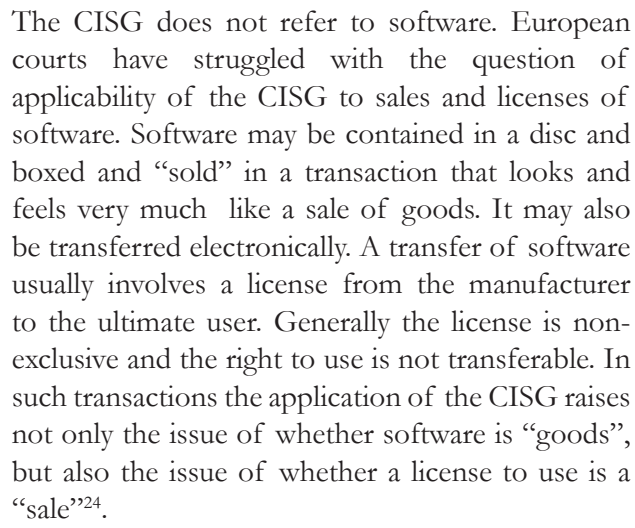

Como ainda não há posicionamento nem na doutrina, nem na jurisprudência brasileira consolidado sobre essa temática, pode-se realizar a análise na ótica do Direito norte-americano e do Direito alemão.

Do ponto de vista norte-americano, a posição majoritária da doutrina quanto à aplicabilidade da Convenção de Viena 1980 sobre softwares (especialmente licenças) é a de aconselhar as cortes a se socorrerem em comentaristas internacionais e jurisprudência comparada ${ }^{25}$, como as disponibilizadas no Case Law on UNCITRAL Text (CLOUT), banco de dados sobre a aplicação da Convenção por diferentes países signatários, antes de chegarem a uma decisão Já no Direito alemão, em regra geral, os softwares padrão estão inclusos no conceito de mercadoria e, mesmo a entrega sendo por meio digital, a relação está sob possibilidade de aplicação da Convenção de Viena $1980^{26}$. Mas, importante salientar, que, mesmo em relação a esse Direito, o assunto não é pacífico, uma vez que a caracterização ou não da sujeição do software a Convenção é determinada pela característica da relação contratual completa, isto é, tem de caracterizar compra e venda, não sendo caracterizada a compra e a venda, mas um licenciamento, restaria o software excluído do âmbito de aplicação da Convenção.

Em suma, quanto ao software, é imperioso o jurista observar a legislação nacional de cada país envolvido,

24 REILEY, Eldon H. International sales contracts: the UN convention and related transnational law. Durham: Carolina Academic Press, 2008. p. 32.

25 REILEY, Eldon H. International sales contracts: the UN convention and related transnational law. Durham: Carolina Academic Press, 2008. p. 33.

26 GILDEGGEN, Rainer; WILLBURGER, Andreas. Internationale hangelgeschäfte: das recht des grenzüberschreitenden handels. 3. ed. Munique: V. F. Vahlen, 2010. p. 28-29. bem como a relação jurídico-contratual firmada antes de propor a aplicação da Convenção.

No caso do Brasil, para analisar essa situação pode-se resumir três abordagens para a questão: (1) adoção de cláusula de opt-in, incorporando expressamente a Convenção ao contrato; (2) adoção de cláusula de opt-out, excluindo expressamente a aplicação da Convenção àquele contrato; ou (3) celebrar o contrato em um país no qual o Direito nacional expressamente regule a questão do software e sua relação com a Convenção de Viena 1980.

Aproveitando a questão do software, pode-se proceder para o segundo vetor que compõe a aplicação da Convenção, denominado nesse contexto o tipo de objeto ao qual a relação contratual está transacionando, isto é, quais são os objetos não considerados mercadoria para fins da Convenção, elencados no Art. $2^{\circ}$

Esta Convenção não se aplicará às vendas:

(a) de mercadorias adquiridas para o uso pessoal, familiar ou doméstico, salvo se o vendedor, antes ou no momento de conclusão do contrato, não souber, nem devesse saber, que as mercadorias são adquiridas para tal uso;

(b) em hasta pública;

(c) em execução judicial;

(d) de valores mobiliários, títulos de crédito e moeda;

(e) de navios, embarcações, aerobarcos e aeronaves;

(f) de eletricidade. ${ }^{27}$

Em regra, nenhum dos itens listados neste artigo deve ser considerado como pertencente à definição de mercadoria para fins de aplicação da Convenção. O mais importante, porém, é a de que não se deve considerar a vedação da alínea "a" como uma forma de denominação dos contratos de consumo na década de 1980 do século XX, uma vez que o emprego das expressões "uso pessoal, familiar ou doméstico" foi utilizado de forma que não atrapalhasse a adesão dos países à Convenção ${ }^{28}$,

27 BRASIL. Senado Federal. Decreto Legislativo n ${ }^{\circ} 538$, 18 de outubro de 2012. Aprova o texto da Convenção das Nações Unidas sobre Contratos de Compra e Venda Internacional de Mercadorias, estabelecida em Viena, em 11 de abril de 1980, no âmbito da Comissão das Nações Unidas para o Direito Mercantil Internacional. Disponível em: <http://www2.camara.leg.br/legin/fed/decleg/2012/ decretolegislativo-538-18-outubro-2012-774414-exposicaodemotivos-137984-pl.html>. Acesso em: 21 nov. 2013.

28 PIGNATTA, Francisco. Comentários a Convenção de Viena de 1980: artigo 2. Disponível em: <http://www.cisg-brasil.net/doc/ 
dado que sua margem de interpretação é por demais abrangente na diversidade das legislações nacionais para possibilitar tal interpretação.

Mas, invariavelmente, esse vetor de aplicação da Convenção tem intrínseca relação com o Direito do consumidor brasileiro, uma vez que a exclusão dos contratos de consumo é feita de forma extremamente indireta, e a delimitação de consumidor no Direito brasileiro é de natureza casuística, isto é, constitui conceito indeterminado a ser definido in concreto.

Outro ponto controverso constitui a previsão final dessa mesma alínea "a" art. $2^{\circ}$ de possibilitar ao vendedor invocar a aplicação da Convenção caso não soubesse $^{29}$ que os itens seriam utilizados para fins pessoais, familiar ou doméstico, situação qual, numa interpretação extensiva, possibilitaria a aplicação da Convenção, mesmo se tratando de relação de consumo. Este é um assunto que, certamente, será desafio ainda a ser tratado pela jurisprudência brasileira, pois teoricamente a única solução que possamos visualizar atualmente consiste na de que esse poder conferido pela inconsciência do vendedor só poderá ser exercido em harmonia com a legislação consumerista em vigor do país cujo direito será o aplicado ao caso ${ }^{30}$.

O terceiro vetor que compõe o sistema de aplicação da Convenção é a situação espaço-temporal das partes contratantes, decompondo-se na localização geográfica dos estabelecimentos comerciais e o tempo de formação do contrato.

O primeiro elemento componente desse vetor constitui a localização geográfica dos estabelecimentos comerciais das partes, nesse entendimento deve-se ressaltar que não se deve interpretar o termo "estabelecimento" conforme o art. 1142 do Código Civil Brasileiro (como complexo de bens organizado para exercício de empresa), mas sim de local principal do exercício das atividades comerciais realizadas pelas partes, como explica

A doutrina majoritária considera que
"estabelecimento" deve ser entendido como uma
atividade comercial estável e permanente, dotada de

fpignatta-art2.pdf>. Acesso em: 01 nov. 2013.

29 Nesse ponto, a Convenção se aproximou muito da Theory of Unconscionability existente no Direito anglo-saxão, na qual pode-se alterar ou extinguir o contrato se comprovada a inconsciência de uma das partes para com os efeitos e consequências da obrigação assumida.

30 Essa relação entre o CDC e a aplicação da Convenção de Viena 1980 será retomada mais adiante (vide infra 4). certa independência. Também em outros artigos da Convenção o termo "estabelecimento" é utilizado (art. 24, 31, 42 e 69). Em todos eles, a ideia de uma atividade estável está presente ${ }^{31}$

Em outras palavras, para fins de aplicabilidade da Convenção, ambos os locais de exercício da atividade comercial das partes envolvidas no contrato têm de estarem situadas em Estados distintos e ambos com a Convenção incorporada em seus Direitos nacionais.

Nesse sentido, em se tratando de filiais ou partes sem estabelecimentos fixo ou determináveis, a Convenção estipula, respectivamente, o aspecto da proximidade contratual e o aspecto do local da residência habitual, conforme Art. $10^{\circ}$

\section{Para os fins da presente Convenção:}

(a) quando uma parte tiver mais de um estabelecimento comercial, será considerado como tal aquele que tiver relação mais estreita como o contrato e com sua execução, tendo em vista as circunstâncias conhecidas pelas partes ou por elas consideradas antes ou no momento da conclusão do contrato;

(b) se uma parte não tiver estabelecimento comercial, considerar-se-á sua residência habitual ${ }^{32}$

$\mathrm{O}$ aspecto da proximidade contratual, seja com o contrato em si (instrumento) ou com sua execução, determina que a delimitação do estabelecimento será realizada de forma a considerar os elementos anteriores e posteriores da formação contratual, bem como qualquer circunstância relevante envolvendo o contrato, considerando-se o estabelecimento que, no conjunto da análise desses elementos, estiver mais próximo da relação contratual ${ }^{33}$.

Esse elemento reforça a tese de que a Convenção somente se aplica a contratos internacionais, não se devendo cogitar sua aplicação para relações de caráter nacional, ou, dentro do pensamento da Convenção, re-

31 PIGNATTA, Francisco A. comentários a Convenção de Viena de 1980: artigo 1. Disponível em: <http://www.cisg-brasil.net/doc/ fpignatta-art1.pdf>. Acesso em: 01 nov. 2013.

32 BRASIL. Senado Federal. Decreto Legislativo n ${ }^{\circ} 538,18$ de outubro de 2012. Aprova o texto da Convenção das Nações Unidas sobre Contratos de Compra e Venda Internacional de Mercadorias, estabelecida em Viena, em 11 de abril de 1980, no âmbito da Comissão das Nações Unidas para o Direito Mercantil Internacional. Disponível em: <http://www2.camara.leg.br/legin/fed/decleg/2012/ decretolegislativo-538-18-outubro-2012-774414-exposicaodemotivos-137984-pl.html>. Acesso em: 21 nov. 2013.

33 GILDEGGEN, Rainer; WILLBURGER, Andreas. Internationale hangelgeschäfte: das recht des grenzüberschreitenden handels. 3. ed. Munique: V. F. Vahlen, 2010. p. 143. 
lações ocorridas entre duas partes que tenham seu estabelecimento comercial em um mesmo Estado.

Importante salientar que o aspecto geográfico não é absoluto, pois assim como contratos internacionais não necessariamente surgem de partes localizadas em diferentes partes do mundo, existe a possibilidade de se desconsiderar o aspecto quando a aplicação da Convenção vier por força das regras de Direito Internacional Privado, seja por utilização do método colisional tradicional, ou seja, pela forma da autonomia da vontade das partes (de forma expressa por forma de cláusula opt-in).

Por fim, o outro elemento componente desse vetor constitui o tempo do contrato, ou melhor, a existência da incorporação formal da Convenção pelo Direito nacional dos Estados nos quais as partes tenham seus estabelecimentos comerciais, ou que o Direito Internacional privado tenha indicado como aplicável para a relação contratual.

Trata-se de constatação óbvia, não basta que os Estados envolvidos pelo aspecto geográfico ou pelo aspecto colisional tenham somente assinado a Convenção, esta tem de ser parte integrante daquele ordenamento jurídico, ou seja, tem de estar ratificada.

Esse elemento temporal está consagrado no Art.100 da Convenção:

(1) esta Convenção somente aplicará à formação do contrato quando a oferta de conclusão do contrato se fizer da data de entrada em vigor da Convenção, com relação aos Estados Contratantes a que se refere à alínea (a) do parágrafo (1) do artigo 1, ou com relação ao Estado Contratante a que se refere à alínea (b) do parágrafo (1) do artigo 1.

(2) Esta Convenção somente se aplicará aos contratos concluídos a partir da data de entrada em vigor da Convenção com relação aos Estados Contratantes a que se refere à alínea (a) do parágrafo (1) do artigo 1, ou com relação ao Estado Contratante a que se refere à alínea (b) do parágrafo (1) do artigo $1 .^{34}$

Para finalizar, em relação a essa parte referente aos três vetores que compõe o sistema de aplicação da Convenção, é necessário esclarecer que a doutrina especia-

34 BRASIL. Senado Federal. Decreto Legislativo n ${ }^{\circ} 538,18$ de outubro de 2012. Aprova o texto da Convenção das Nações Unidas sobre Contratos de Compra e Venda Internacional de Mercadorias, estabelecida em Viena, em 11 de abril de 1980, no âmbito da Comissão das Nações Unidas para o Direito Mercantil Internacional. Disponível em: <http://www2.camara.leg.br/legin/fed/decleg/2012/ decretolegislativo-538-18-outubro-2012-774414-exposicaodemotivos-137984-pl.html>. Acesso em: 21 nov. 2013. lizada considera ainda a existência das "circunstâncias impeditivas", situações que por natureza pessoal ou por decorrência de estipulação contratual impediriam a aplicação da Convenção, mesmo se os três vetores indicassem sua incidência ${ }^{35}$.

Em brevíssimo resumo, as circunstâncias impeditivas de natureza pessoal dizem respeito diretamente aos três vetores ora analisados. Isso significa que, quando as partes envolvidas, ou a natureza do contrato ou o tipo de objeto se enquadram em uma das vedações expressas, ou não se enquadram em um dos critérios estipulados pela Convenção, a aplicabilidade da Convenção estaria impedida por ocorrência de um impedimento pessoal.

Por exemplo: tenho um contrato de compra e venda de energia elétrica entre duas partes com estabelecimentos comerciais em países distintos, ambos signatários e ratificadores da Convenção. Não aplico a Convenção por força da circunstância impeditiva de que energia elétrica não consiste em mercadoria para fins de aplicação da Convenção. Logo tem-se impedimento pessoal derivado da interpretação do Art. $2^{\circ}$ alínea "f

Por outro lado, tem-se o conjunto de circunstâncias impeditivas decorrentes de disposição contratual. Nesse caso, a aplicação da Convenção não vai ocorrer por força de disposição contratual, isto é, por força da autonomia da vontade das partes em denegar de forma expressa a incidência da Convenção (a cláusula de opt-out). Trata-se de manifestação do princípio da natureza dispositiva e a questão da função negativa da autonomia da vontade.

\subsection{O princípio da natureza dispositiva e a função negativa da autonomia da vontade}

Como há ter ficado evidenciado, o grande problema que o legislador da Convenção de Viena 1980 foi o de conseguir estabelecer ambiente harmonioso na diversidade legislativa para estabelecer regras uniformes para um fenômeno contratual sui generis na teoria do Direito privado: o contrato internacional.

O contrato internacional, sejam em qualquer de suas manifestações, é um fenômeno cuja compreensão foge

35 GILDEGGEN, Rainer; WILLBURGER, Andreas. Internationale hangelgeschäfte: das recht des grenzüberschreitenden handels. 3. ed. Munique: V. F. Vahlen, 2010. p. 139. 
de um só ordenamento jurídico. Porém, com auxílio do Direito comparado, observou-se que "os grandes sistemas jurídicos não diferem de forma marcante na forma de conceituar contrato, embora a explicação da razão pela qual contratos obrigam seja bastante variada ${ }^{36 "}$.

Isso significa que o processo de construção da Convenção levou em conta tanto as características comuns dos diferentes direitos nacionais, bem como as particularidades do plano internacional para conseguir estabelecer regras globalmente aceitas.

Em vista dessa situação, que invariavelmente acaba redundando na polarização entre as necessidades do comércio internacional, da liberdade das partes nos contratos e as famigeradas normas imperativas de cada legislação nacional, acabou por dar nascimento ao princípio da natureza dispositiva.

O princípio da natureza dispositiva consiste em uma manifestação dentro do Direito do Comércio Internacional do corolário da liberdade de contratar e de determinar o conteúdo do contrato de modo a possibilitar as partes tal grau de liberdade a ponto de poderem moldar a legislação internacional para atender às suas necessidades ${ }^{37}$.

Esse princípio está expressamente consagrado na Convenção de Viena 1980, quando em seu art. $6^{\circ}$ define que "As partes podem excluir a aplicação desta Convenção, derrogar qualquer de suas disposições ou modificar-lhes os efeitos, observando-se o disposto no Artigo $12^{38}$ ".

Esse tipo de previsão legislativa, até a incorporação pelo Brasil da Convenção, era totalmente desconhecido. Basicamente, trata-se da possibilidade de, por força da autonomia da vontade, as partes poderem tanto aderir a Convenção (cláusula de opt-in), tanto alterar a interpretação de seus dispositivos, como, também, optarem por não sujeitarem sua relação contratual a Convenção (cláusula opt-out).

36 CRETELLA NETO, José. Contratos internacionais: cláusulas típicas. Campinas: Millennium, 2011. p. 7.

37 GAMA JR., Lauro. Contratos internacionais à luz dos princípios do UNIDROIT: 2004. Rio de Janeiro: Renovar, 2006. p. 303.

38 BRASIL. Senado Federal. Decreto Legislativo n ${ }^{\circ}$ 538, 18 de outubro de 2012. Aprova o texto da Convenção das Nações Unidas sobre Contratos de Compra e Venda Internacional de Mercadorias, estabelecida em Viena, em 11 de abril de 1980, no âmbito da Comissão das Nações Unidas para o Direito Mercantil Internacional. Disponível em: <http://www2.camara.leg.br/legin/fed/decleg/2012/ decretolegislativo-538-18-outubro-2012-774414-exposicaodemotivos-137984-pl.html>. Acesso em: 21 nov. 2013.
Os únicos limites para a utilização dessa prerrogativa convencional seriam a boa-fé e as normas imperativas, cuja aplicação não pode ser afastada por vontade das partes. Nesse sentido, o princípio mantém a concepção de liberdade dentro do Direito, e não dá vazão a ideia de soberania da vontade das partes.

Nesse ponto, a Convenção consagra não só a autonomia da vontade para escolher direito aplicável, como também para denegar a aplicação da Convenção. Isto é, pela Convenção a autonomia da vontade além da função positiva (escolher), também possui a função negativa (denegar, moldar a legislação).

Dentro do microssistema do Direito do Comércio Internacional, essa situação e esse princípio não geram complexidade ou perplexidade, pois trata-se de um ambiente em que a liberdade contratual, desde que dentro da boa-fé e não ofendendo as normas imperativas, tem supremacia. Porém, quando se adentra no Direito brasileiro, a história fica complexa.

Como já afirmando no estudo proposto neste artigo, a principal legislação de Direito Internacional Privado brasileiro é arcaica, trata-se da LINDB de 1942, renomeada em 2010, na qual não existe previsão para a possibilidade das partes escolherem o direito aplicável para seus contratos, uma vez que o art. $9^{\circ}$ LINDB consagra a lei do local da celebração como determinante do direito aplicável às obrigações. Essa ausência expressa da autonomia da vontade (elemento de conexão) acabou gerando na doutrina brasileira o entendimento de que esta não consiste em parte integrante do sistema colisional brasileiro, como explica

No ordenamento jurídico brasileiro poderão
as partes escolher a lei aplicável aos contratos
internacionais? Não, deve ser a resposta. Em
matéria de contratos, o art. $9^{\circ}$ da Lei de Introdução
ao Código Civil Brasileiro de 1942 , utiliza o local
da constituição da obrigação (lex loci celebrationis)
como elemento de conexão para determinação da
lei aplicável aos contratos internacionais firmados
entre presentes ${ }^{39}$.

Essa situação acaba gerando uma situação problemática: se o pensamento jurídico brasileiro tem dificuldades em aceitar a função positiva da autonomia da vontade, como fica a situação da função negativa consagrada na Convenção?

39 AMORIM, Fernando Sérgio Tenório de. Autonomia da vontade nos contratos eletrônicos internacionais de consumo. 2006. 292 f. Dissertação (Mestrado) - Programa de Pós-Graduação em Direito da Faculdade de Direito do Recife/Centro de Ciências Júridicas da Universidade Federal de Pernambuco, Recife, 2006. p. 186. 
Enquanto os três vetores consagrados nos artigos 1 a 5 da Convenção são desafiadores, somente pelo alto grau de tecnicidade com a qual foram elaborados, a previsão do art. $6^{\circ}$ claramente vai em sentido contrário a interpretação dominante do art. $9^{\circ}$ da LINDB.

Nesse ponto surge a pergunta: se a função negativa da autonomia da vontade, manifestada por cláusula de opt-out é uma circunstância impeditiva por disposição contratual da aplicação da Convenção, como ficaria o caso de, se por força do art. $9^{\circ}$ LINDB, o direito do local da celebração tiver ratificado a Convenção? Manter-se-á a cláusula de opt-out como impedimento, ou prevalecerá a disposição da LINDB?

Aqui, opina-se que existe uma necessidade real de reformulação legislativa do art. $9^{\circ}$ da LINDB, bem como uma reformulação geral do pensamento jurídico brasileiro dominante para com a autonomia da vontade, bem como a questão da recepção dos princípios mais liberais do Direito do Comércio Internacional no Brasil.

\section{O CDC É CIRCUNSTÂNCIA IMPEDITIVA PARA aplicaÇão da ConVenção de Viena 1980?}

Em razão da intrínseca relação entre a Convenção de Viena 1980 e as regras de Direito Internacional Privado, não poderia o estudo olvidar-se do mais tormentoso assunto que assola o Direito Internacional Privado brasileiro: as normas imperativas.

Não por acaso, o último ponto a ser analisado nessa breve introdução às regras de aplicação da Convenção não poderia ser nenhum outro que o marco maior de imperatividade na legislação brasileira que é Código de Defesa do Consumidor (CDC). Seria o CDC uma circunstância impeditiva de aplicação da Convenção?

Para elaborar uma resposta para essa questão, tem de se compreender o caráter imperativo do CDC, isto é, quais são os elementos que enquadram o CDC como norma imperativa de Direito Internacional Privado brasileiro: (1) o uso da expressão "ordem pública" no art.1 ${ }^{\circ}$ CDC; e (2) A concepção do CDC como norma de "sobredireito".

Ordem pública constitui um conceito indeterminado que varia conforme o ramo do Direito que se estuda e, principalmente, exerce função radicalmente diferente em cada ramo.
A explicação dada pelos autores do anteprojeto para a inserção dessa expressão no art. $1^{\circ}$ do CDC foi a de conferir caráter de inderrogabilidade as suas previsões, de forma a ser matéria a ser aplicada ex officio pelo magistrado, quando analisando uma lide oriunda de relação de consumo ${ }^{40}$.

Em suma, utilizaram o significado comum da expressão existente no Direito Civil e no Processo Civil, aparentemente ignorando as ramificações no Direito Internacional Privado de tal utilização.

Porém, como não existe interpretação autêntica no Direito brasileiro, o legislador ao inserir a expressão "ordem pública" no art. $1^{\circ}$ do $\mathrm{CDC}^{41}$ acabou por estabelecer inserir esse diploma legislativo no campo das normas imperativas do Direito Internacional Privado, uma vez que a principal noção de ordem pública se vincula ao instituto consagrado no art.17 da LINDB, conhecida como ordem pública internacional.

Nessa perspectiva nasce o problema do CDC como possível circunstância impeditiva para aplicação da Convenção de Viena: se o CDC constitui norma de ordem pública, em seu sentido clássico e estrito, significa que sua incidência vai excluir a aplicação de qualquer Direito estrangeiro naquela relação jurídica com elemento extranacional.

Pode-se refutar alegando que a Convenção de Viena 1980 não é aplicável aos contratos de consumo e, portanto, essa concepção do CDC como lei de ordem pública seria falso problema. Porém essa refutação é falaciosa.

Em primeiro momento, a questão da imperatividade do CDC entra em colisão com a alínea "a" do art. $2^{\circ}$ Convenção de Viena de 1980, em que a própria Convenção determina sua aplicação nos casos em que o vendedor não tinha ciência de que os bens vendidos eram para uso pessoa, doméstico ou familiar. Novamente, ampliando esse entendimento, a Convenção de Viena de 1980 se aplica a relações de consumo nas quais se constatou que uma das partes (o vendedor), não sabia que estava realizando uma relação dessa modalidade.

40 GRINOVER, Ada P. et al. Código Brasileiro de Defesa do Consumidor. comentado pelos autores do anteprojeto. 8. ed. Rio de Janeiro: Forense Universitária, 2004. p. 24.

41 BRASIL. Lei ñ 8.078 , de 11 de setembro de 1990. Dispõe sobre a proteção do consumidor e dá outras providências. Disponível em: $<$ http://www.planalto.gov.br/ccivil_03/leis/18078.htm>. Acesso em: 21 nov. 2013. 
Nesse ponto, ao manter-se a visão estrita sobre a ideia de ordem pública e o CDC, basicamente a alínea "a" do art. $2^{\circ}$ da Convenção se torna letra morta, pois toda vez que o vendedor a invocasse, a natureza de cláusula de barreira do CDC iria impedir sua aplicação.

O outro momento relevante sobre a intersecção da imperatividade do CDC e a Convenção de Viena 1980 consiste na concepção de que a legislação consumerista seriam normas de "sobredireito, aplicáveis, portanto, a todos os ramos do Direito privado, ainda que não se trate de uma relação de consumo em sentido estrito" ${ }^{\prime 2}$.

Se o CDC constitui norma aplicável a todos os tipos contratuais nominados e inominados do Direito privado brasileiro, como negar a questão de que sua imperatividade tem de ser bem delimitada para evitar colisões com a Convenção de Viena 1980?

A realidade é que essa concepção do CDC como sobredireito constitui tentativa de solucionar um problema grave na teoria geral contratual do Direito privado brasileiro no que tange a delimitar o que seria relação de consumo e o que seria relação de direito civil/comercial. O conceito de consumidor é por demais indeterminado na legislação que possibilita que qualquer parte pode ser considerada um consumidor e, por consequência, estar-se-ia diante de uma relação de consumo.

Esse problema foge aos limites de um estudo introdutório, uma vez que adentra na própria estrutura confusa que o CDC implantou nos tipos contratuais, especialmente da compra e venda e da prestação de serviço - não é problema que se relaciona com a aplicação da Convenção, mas sim com a própria inserção do Consumidor no Direito contratual brasileiro. Não sendo de interesse, no momento, realizar maiores aprofundamentos.

O que é de interesse analisar diante dessas duas constatações, quanto ao CDC e ao Direito Internacional Privado brasileiro, consiste na possível delimitação de respostas para a seguinte indagacao: a alínea "a" do art. $2^{\circ}$ da Convenção letra morta no Direito brasileiro? O CDC é, uma circunstância impeditiva para a aplicação da Convenção de Viena de 1980?

Se optar-se em manter uma interpretação literal da redação do art. $1^{\circ}$ do CDC, a resposta mais coerente

42 GRINOVER, Ada P. et al. Código Brasileiro de Defesa do Consumidor: comentado pelos autores do anteprojeto. 8. ed. Rio de Janeiro: Forense Universitária, 2004. p. 539. é a de que a hipótese prevista na alínea é letra morta, uma vez que se tratando de relação de consumo, haveria ofensa à ordem pública internacional brasileira e, portanto, exclui-se não só a aplicação da Convenção, como também o eventual Direito estrangeiro escolhido pelas partes ou indicado pelo sistema colisional.

Pessoalmente, essa opção é absurda e nenhum jurista que tenha o mínimo de conhecimento sobre contratos internacionais defenderia tal posicionamento, uma vez que é contraproducente para o processo de maior inserção do Brasil nas regras internacionais do comércio, pois transformaria uma legislação criada para resolver problemas nacionais como circunstância impeditiva para a aplicação não só da Convenção de Viena de 1980, como também qualquer regra internacional que discipline contratos.

Entende-se como melhor resposta para esse questionamento a opção de reformular a concepção dominante na doutrina e jurisprudência brasileira de associar a imperatividade do CDC à ideia de ordem pública internacional, e, com essa reformulação, reduzir a imperatividade dessa legislação de forma a não ser uma excludente de Direito estrangeiro.

Torna-se oportuno utilizar da distinção no campo das regras imperativas entre as normas de ordem pública e normas de aplicação imediata, que normalmente são confundidas como um mesmo fenômeno normativo imperativo, porém não o são.

Normas de ordem pública, normalmente denominadas de Ordem pública internacional, são normas que tem um caráter de exceção, pois sua incidência ocorre após a utilização do método colisional e se aplica por entrar em conflito com um princípio ou regra fundamental do Direito nacional ${ }^{43}$. Exemplo desse tipo de norma consiste no art. 17 da LINDB.

As normas de aplicação imediata são aquelas cujo conteúdo é considerado como domínio e exclusivo do Estado nacional e, portanto, dispensa a mediação das normas colisionais ${ }^{44}$, pois precedem a qualquer regra colisional. Normas que são dotadas de aplicabilidade espacial unilateral, delimitando o domínio da intervenção

43 NORD, Nicolas. Ordre public e lois de police en droit international privé. Disponível em: <http://cdpf.unistra.fr/fileadmin/upload/ $\mathrm{CDPF} /$ theses_memoires_et_rapports/ordre_public_et_lois_de_ police.pdf>. Acesso em: 20 nov. 2013.

44 ARAUJO, Nádia de. Direito internacional privado: teoría e prática brasileira. 2. ed. Rio de Janeiro: Renovar, 2004. p. 97-98. 
do direito do foro nas questões, impedindo a incidência de qualquer direito estrangeiro ${ }^{45}$.

Diante dessa dicotomia sobre regras imperativas, propõe-se que o CDC deva ser enquadrado como uma espécie de normas de aplicação imediata, não no sentido de barreira para a aplicação do direito estrangeiro, mas sim como norma de policiamento que filtra a aplicação do Direito estrangeiro conforme as necessidades do caso in concreto.

Isto é, invés de excluir ou tomar para si de forma unilateral a regulamentação do caso por ser uma relação de consumo, o CDC teria de primeiro dialogar com a norma estrangeira ou internacional para observar se aquela relação de consumo deve ser regulamenta da forma unilateral, ou se deve prevalecer a norma estrangeira, internacional.

Nessa concepção, a prerrogativa da alínea "a" do art. $2^{\circ}$ da Convenção seria plenamente válida se, diante das situações do caso in concreto, ficasse demonstrando que o vendedor realmente não sabia que estava sendo inserido numa relação de consumo, e, como se trata de relação de comércio internacional, prevaleceria a disposição da Convenção, servindo o CDC, nessa hipótese, de norma complementar para eventuais omissões.

Destarte, o CDC não figuraria como circunstância impeditiva, mas sim um mecanismo específico de filtragem de sua aplicação, ou melhor, fonte complementar para a regulamentação dos casos em que, mesmo sendo relação de consumo, a sua formação ocorreu sem a intenção, consciência do vendedor ou, até mesmo, das partes envolvidas.

\section{Considerações finais}

A principal conclusão que este estudo pretendeu evidenciar é a de que a incorporação tardia pelo Brasil da Convenção de Viena 1980 é o quão urgente é a necessidade de reformulação do pensamento jurídico dominante no Brasil para com a compreensão dos elementos extranacionais nas relações contratuais, em especial ao elemento de conexão autonomia da vontade.

45 NORD, Nicolas. Ordre public e lois de police en droit international privé. Disponível em: <http://cdpf.unistra.fr/fileadmin/upload/ $\mathrm{CDPF} /$ theses_memoires_et_rapports/ordre_public_et_lois_de_ police.pdf $>$. Acesso em: 20 nov. 2013.
Existe uma real necessidade de reforma da legislação de direito Internacional Privado brasileiro no que tange as obrigações contratuais, bem como existe uma necessidade de se reformar algumas das expressões usadas em legislações específicas, como o CDC utilizado neste artigo, para evitar inoportunas intersecções entre legislações decorrentes de necessidades nacionais localizadas, com legislação de cunho internacional ou, mais precisamente, de Direito do comércio internacional.

Também se constata que o sistema de aplicação inserido na Convenção de Viena 1980 apresenta um grau extra de complexidade, apresentando-se tanto como um campo de inovação para o Direito privado brasileiro, como também uma dura exposição das deficiências da legislação brasileira quanto ao tratamento dos contratos internacionais do comércio.

A maior dessas deficiências sendo a polêmica quanto à autonomia da vontade no art. $9^{\circ}$ da LINDB, estabelecendo um desafio para o jurista brasileiro não só em defender a escolha do direito aplicável pelas partes, como também em conceber e delimitar até que ponto as partes podem denegar a aplicação de determinado direito, ou melhor, lança o desafio de compreender como a inserção do princípio da natureza dispositiva consagrado na Convenção de Viena 1980 pode alterar a concepção de liberdade contratual no direito brasileiro.

Acrescente-se que é forçoso concluir que também existe necessidade real para uma melhor técnica legislativa no Brasil, na qual se estabeleça um abandono do uso demasiado de conceitos indeterminados e se busque maior precisão na redação dos dispositivos e das leis, de modo a evitar a necessidade de malabarismos interpretativos como ocorre na questão da expressão ordem pública utilizada no art. $1^{\circ}$ do CDC e sua involuntária relação com o instituto de Direito Internacional Privado.

Ressalte-se que não se procurou defender a não aplicação das regras do CDC nas relações de consumo oriundas do comércio internacional, mas sim procurou-se alertar sua indiscriminada aplicação, alertando para o caráter excessivamente unilateral que legislações como o CDC apresentam para serem utilizadas como referencial no plano das relações jurídicas extranacionais.

Nesse sentido, conclui-se que o CDC não pode ser considerado um diploma de sobredireito, uma vez que não pode configurar como excludente do Direito estrangeiro, pois trata-se de uma legislação que nasceu 
para solucionar problemas localizados do Brasil, tratando-se de particularidade para as relações jurídicas brasileiras, e não uma legislação voltada para a realidade da diversidade legislativa, sendo sua aplicação em contratos internacionais, devendo ser de caráter excepcional e de forma complementar a eventual norma internacional.

Conclui-se que as regras da Convenção de Viena 1980 foram elaboradas numa mescla entre um alto grau de técnica com a flexibilidade necessária para as relações comerciais internacionais, sem ignorar as realidades de cada direito nacional. Uma fórmula que pode servir de exemplo para o legislador na hora de reforma a legislação de Direito Internacional Privado, como também a exigência de atenção e zelo por parte dos estudiosos do direito contratual em lidar com questões, envolvendo os contratos internacionais.

\section{REFERÊNCIAS}

AMORIM, Fernando Sérgio Tenório de. Autonomia da vontade nos contratos eletrônicos internacionais de consumo. 2006. 292 f. Dissertacao (Mestrado) - Programa de PósGraduação em Direito da Faculdade de Direito do Recife/Centro de Ciências Júridicas da Universidade Federal de Pernambuco, Recife, 2006.

ARAUJO, Nádia de. Direito internacional privado: teoria e prática brasileira. 2. ed. Rio de Janeiro: Renovar, 2004.

BRASIL. Lei no 8.078, de 11 de setembro de 1990. Dispõe sobre a proteção do consumidor e dá outras providências. Disponível em: < http://www.planalto.gov.br/ccivil_03/leis/18078.htm>. Acesso em: 21 nov. 2013.

BRASIL. Senado Federal. Decreto Legislativo $n^{\circ}$ 538, 18 de outubro de 2012. Aprova o texto da Convenção das Nações Unidas sobre Contratos de Compra e Venda Internacional de Mercadorias, estabelecida em Viena, em 11 de abril de 1980, no âmbito da Comissão das Nações Unidas para o Direito Mercantil Internacional. Disponível em: <http://www2.camara.leg.br/legin/ fed/decleg/2012/decretolegislativo-538-18-outubro2012-774414-exposicaodemotivos-137984-pl.html> . Acesso em: 21 nov. 2013.

CRETELLA NETO, José. Contratos internacionais: cláusulas típicas. Campinas: Millennium, 2011.

GAMA JR., Lauro. Contratos internacionais à luz dos princípios do UNIDROIT 2004. Rio de Janeiro: Renovar,
2006.

GILDEGGEN, Rainer; WILLBURGER, Andreas. Internationale hangelgeschäfte: das recht des grenzüberschreitenden handels. 3. ed. Munique: V. F. Vahlen, 2010.

GLOBAL SALES LAW. Hall of fame. Disponível em: $\quad<$ http://www.globalsaleslaw.org/index. cfm?pageID=648> . Acesso em: 23 nov. 2013.

GRINOVER, Ada P. et al. Código Brasileiro de Defesa do Consumidor. comentado pelos autores do anteprojeto. 8. ed. Rio de Janeiro: Forense Universitária, 2004.

HAGUE CONFERENCE OF PRIVATE INTERNATIONAL LAW. Overview. Disponível em: <http://www. hcch.net/index_en.php?act $=$ text.display\&tid $=4>$. Acesso em: 21 nov. 2013.

HONNOLD, John. The uniform law for the international sale of goods: the Hague Convention of 1964. Disponível em: $<$ http://scholarship.law.duke.edu/cgi/viewcontent. cgi? article $=3058 \&$ context $=$ lcp $>$. Acesso em: 06 nov. 2013.

MORAES, Fabíola. Aproximação do direito contratual dos estados-membros da União Européia. Rio de Janeiro: Renovar, 2007.

NDULO, Muna. The Vienna Sales Convention 1980 and the Hague Uniform Laws on International Sale of Goods 1964: a comparative analysis. Disponível em: <http://scholarship.law.cornell.edu / cgi/viewcontent.cgi?article $=106$ $5 \&$ context $=$ facpub $>$. Acesso em: 11 nov. 2013.

NORD, Nicolas. Ordre public e lois de police en droit international privé. Disponível em: <http://cdpf.unistra.fr/file-

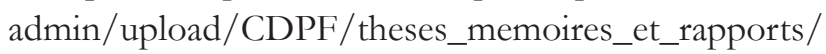
ordre_public_et_lois_de_police.pdf $>$. Acesso em: 20 nov. 2013.

PIGNATTA, Francisco A. Comentários a Convenção de Viena de 1980: artigo 1. Disponível em: <http://www. cisg-brasil.net/doc/fpignatta-art1.pdf $>$. Acesso em: 01 nov. 2013.

PIGNATTA, Francisco. Comentários a Convenção de Viena de 1980: artigo 2. Disponível em: < http://www.cisgbrasil.net/doc/fpignatta-art2.pdf>. Acesso em: 01 nov. 2013.

PIGNATTA, Francisco. Comentários a Convenção de Viena de 1980: artigo 3. Disponível em: < http://www.cisgbrasil.net/doc/fpignatta-art3.pdf>. Acesso em: 01 nov. 2013. 
REILEY, Eldon H. International sales contracts: the UN convention and related transnational law. Durham: Carolina Academic Press, 2008.

SCHÜTZ, Hebert M. de A. Da necessidade de adesão do Brasil à convenção da ONU sobre contratos de com- pra e venda internacional de mercadorias. Âmbito Jurídico, Rio Grande, v. 14, n. 90, jul 2011. Disponível em: $<$ http://ambitojuridico.com.br/site/?n_link=revista_ artigos_leitura\&artigo_id $=9865 \&$ revista_caderno $=16>$. Acesso em: 07 nov. 2013. 


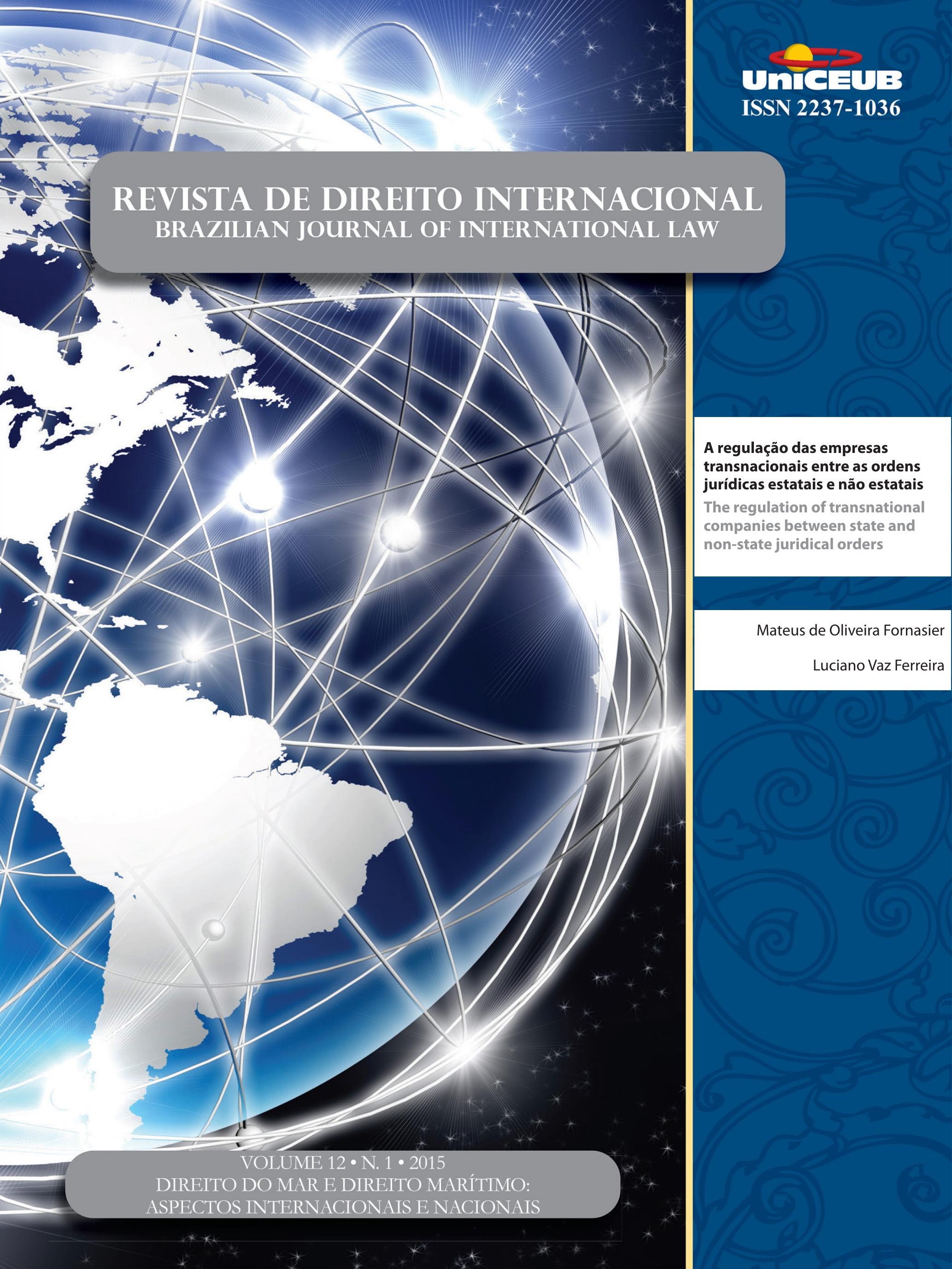




\title{
A regulação das empresas transnacionais entre as ordens jurídicas estatais e não estatais*
}

\section{The regulation of transnational companies between state and non-state juridical orders}

\author{
Mateus de Oliveira Fornasier** \\ Luciano Vaz Ferreira***
}

\section{Resumo}

Este artigo objetiva analisar as possibilidades de regulação da conduta das empresas transnacionais com base em um cenário hipercomplexo e policontextural, caracterizado pela multiplicidade de formas de comunicação, de normatização e de visões/interpretações de mundo. Busca responder: sob que condições se pode afirmar que essas empresas são reguláveis por ordens jurídicas das mais diversas origens? Como hipótese, tem-se que suas condutas são reguláveis juridicamente não apenas em ordens estatais ou internacionais, mas também com base em ordens jurídicas não estatais, relacionadas a um Direito que emerge na sociedade, e que não decorre da ação estatal. Desenvolve-se este artigo em quatro partes: a) contextualização geral da questão em trono da policontexturalidade, da hipercomplexidade e do pluralismo jurídico, considerando-se ser difícil sustentar que a regulação jurídica de âmbitos complexos possa se limitar exclusivamente às normatividades de lógica estatal; b) possibilidades territoriais e extraterritoriais de regulação das condutas das empresas transnacionais, focando-se nas possibilidades estatais ainda possíveis e importantes; c) reflexões acerca de experiências já intentadas de regulação da conduta de empresas transnacionais por normas de Direito Internacional; d) apresentar programas normativos internos de conduta das empresas transnacionais, pelas mais variadas razões, como verdadeiras ordens jurídicas não estatais — dada a complexificação societal e procedimental que essas práticas assumiram no decorrer do tempo.

* Recebido em: 15/04/2015 Aprovado em: 16/06/2015

** Doutor em Direito Público pela Universidade do Vale do Rio dos Sinos (Unisinos, Brasil). Professor do Mestrado em Direitos Humanos da Universidade Regional do noroeste do Estado do Rio Grande do Sul (Unijuí, Brasil). E-mail: mateus.fornasier@unijui.edu.br.

*** Doutor em Estudos Estratégicos Internacionais pela Universidade Federal do Rio Grande do Sul (UFRGS, Brasil). Professor da Graduação em Relações Internacionais da Universidade Federal de Rio Grande (FURG, Brasil).E-mail: lvazferreira@gmail.com.
Palavras-chave: Direito Internacional. Empresas transnacionais. Autorregulação. Policontexturalidade. Pluralismo jurídico.

\section{Abstract}

This article aims to analyze possibilities of regulating the conduct of transnational companies from a hypercomplex and polycontextural scenario, characterized by the multiplicity of ways of communication, of building norms and of visions/ interpretations of the world. It seeks to answer: under what conditions it can be said that these companies are regulable by juridical systems from several different origins? As a hypothesis, it is noticed that their conducts can have a juridical regulation not only in state or 
international orders, but also from non-state juridical orders, related to a Law that emerges in society, which is not originated by State action. This article is developed into four parts:a) general context of the matter about policontexturality, hypercomplexity and legal pluralism, considering that it is difficult to sustain that juridical regulation of complex areas may be limited exclusively inside normativities that follow State logics; b) territorial and extraterritorial possibilities of regulation of conduct of transnational companies, focusing on the State possibilities that are still possible and important; c) reflections on experiences already brought of regulating conducts of transnational corporations by International Law standards; d) presentation of internal ruling program of conduct of transnational corporations, for several reasons, as being truly non-state legal systems given the societal and procedural complexity that these practices have taken over time.

Keywords: International Law. Transnational corporations. Self-regulation. Policontexturality. Legal pluralism.

\section{INTRODUÇÃo}

A emergência de empresas transnacionais (ETNs) constitui fenômeno bastante característico do século $\mathrm{XX}$, com grandes reflexos com base nas décadas finais deste, bem como do início do século XXI — sendo correlato (e, por que não afirmar, causa e consequência) da globalização. Trata-se do surgimento de grandes atores que espraiam suas ações e comunicações para além do território de um Estado nacional, repercutindo em vários locais do globo, bem como em várias áreas das comunicações e do conhecimento - Economia, Política, Mídia de Massa, Ciência, Tecnologia e Direito, entre outras.

Tratar das implicações sociojurídicas atinentes a esses atores internacionais se demonstra trabalho de bastante importância para a atualidade. Primeiramente, pode-se justificar a escolha do tema abordado pelo aumento de complexidade — inclusive jurídico-normativa - que a grande gama de fenômenos que a globalização acarreta. Dentre esses fenômenos, apresenta-se o surgimento de novos atores internacionais que ofuscam a outrora absoluta e inquestionável soberania do Estado nacional na sociedade internacional. Esses novos atores
— que podem, não exaustivamente, ser exemplificados por organizações internacionais governamentais, organizações não governamentais (incluindo movimentos sociais de alcance internacional) e empresas transnacionais $^{1}$ - possuem não apenas relevância geopolítica: seus poderes podem se espraiar até a normatividade jurídica. Empresas transnacionais, principais atores estudados por este trabalho, possuem campo de atuação para além das fronteiras territoriais estatais, sendo capazes de constituir grandes cadeias jurídicas mediante contratos com outros entes, impondo regras e princípios de conduta que não passam, necessariamente, pela chancela do Estado $\mathrm{O}$ grande poder econômico dessas organizações reafirma a sua relevância no cenário contemporâneo - estudos apontam que várias ETNs possuem o produto interno bruto (PIB) maior do que muitos países. ${ }^{2}$

Ademais, sequer a resolução de eventuais conflitos advindos dessas cadeias perpassa, compulsoriamente, pela jurisdição tradicional: Cortes e outras instâncias não estatais constituem os meios de resolução de conflitos típicos das relações advindas dessas verdadeiras ordens jurídicas surgidas de cadeias contratuais fomentadas (e criadas) pelas empresas transnacionais.

Observa-se, nesse passo, portanto, que um olhar das comunicações jurídicas para além do Estado (mas sem, erroneamente, relegar sua atividade à desimportância) pode trazer reflexões inovadoras daquilo que seja o Direito em âmbito mundial. $\mathrm{Na}$ esteira da crise da soberania, observa-se também a crise do jurídico entendido como positivo, estatal. Contudo, essa crise não deve ser entendida como derrocada ou decadência - antes, se trata de reconfiguração cuja abordagem se faz necessária.

Wilkins ${ }^{3}$ conceitua as ETNs como "qualquer empresa que possui sede em um país e opera em, pelo menos, um país estrangeiro". Essas organizações são compostas por várias empresas em rede, em conglomerados cujo campo de comunicação (e de produção de sentido)

1 PECEQUILO, Cristina Soreanu. Introdução às relações internacionais. Petrópolis: Vozes, 2012. p. 67-83.

2 ANDERSON, Sarah; CAVANAGH, John. Top 200: the rise of corporate global power. Washington, 2000. Disponível em: <www. corpwatch.org/downloads/top200.pdf>. Acesso em: 22 jan. 2013. p. 3.

3 WILKINS, Mira. European and north american multinationals. 1870-1914: comparions and contrasts. In: JONES, Geoffrey (Org.). Transnational corporations: a historical perspective. London: Routledge, 1992. p. 23-62; p. 24. 
ultrapassa as fronteiras estatais, sendo significativamente fluidas, muitas vezes, para que uma regulação eficaz seja exercida pelo poder normativo de entes nacionais ou internacionais unicamente. ${ }^{4}$ As tentativas de regulação da conduta das corporações transnacionais mediante normativas estatais e internacionais não têm logrado êxito, pois geralmente constituem meras recomendações ineficazes. Em virtude da pesada crítica pública, disseminada globalmente pela mídia, e da ação agressiva de movimentos de protesto e organizações não governamentais (ONGs) da sociedade civil, as ETNs têm desenvolvido seus próprios códigos de conduta corporativa de maneira aparentemente voluntária, privada e pouco precisa, a fim de que sejam estabelecidas boas relações. Imprecisamente se comprometem as ETNs, com essas normativas, a implementar condutas de acordo com padrões relacionados às áreas objeto de pressão.

Este artigo se atém à análise das possibilidades de regulação da conduta das ETNs com base em um cenário hipercomplexo e policontextural - caracterizado, assim, pela multiplicidade de formas de comunicação, de normatização e de visões/interpretações de mundo. Nessa senda, busca responder ao seguinte problema de pesquisa: sob que condições se pode afirmar que essas empresas são reguláveis por ordens jurídicas das mais diversas origens? Apresenta-se como hipótese a seguinte construção teórica: suas condutas são reguláveis juridicamente (termo considerado mais amplo em significados, preferível neste artigo à noção de disciplina ${ }^{5}$, pois esta se reportaria a contextos jurídicos passados bem delimitáveis no tempo e no espaço, mormente ligados ao caráter repressivo) ${ }^{6}$ não apenas em ordens estatais ou internacionais, mas também com base em ordens jurídicas não estatais, relacionadas a um Direito que emerge na sociedade, e que não decorre da ação estatal.

4 TEUBNER, Gunther. Autoconstitucionalização de corporações transnacionais? sobre a conexão entre os códigos de conduta corporativos (Corporate Codes of Conduct) privados e estatais. Tradução de Ivar Hartmann. Revisão de Germano Schwartz. In: SCHWARTZ, Germano (Org.). Juridicização das esferas e fragmentação do direito na sociedade contemporânea. Porto Alegre: Livraria do Advogado, 2012. p. 110. 5 Acerca da Sociedade Disciplinar e da superação da predominância do seu modelo, ver: FOUCAULT, Michel. Soberania e disciplina. In: Microfísica do poder. Org. e trad. Roberto Machado. 20. ed. São Paulo: Graal, 2004. p. 100-107; DELEUZE, Gilles. Post-scriptum sobre as sociedades de controle. In:__ Conversacõoes. Trad. Peter Pál Pelbart. São Paulo: Editora 34, 2007. p. 219-226.

6 Sobre o contexto espaço-temporal do Direito Repressivo, ver: WILKE, Helmut. Reflexivo (direito). In: ARNAUD, André-Jean (Dir.). Dicionário enciclopédico de teoria e de sociologia do direito. Rio de Janeiro: Renovar, 1999. p.678-681.
A fim de melhor trabalhar com essas questões, desenvolve-se este artigo em quatro partes. A primeira delas apresenta conjuntura geral da questão em trono da policontexturalidade e da hipercomplexidade, considerando-se que atualmente é difícil sustentar a posição de que a regulação jurídica de âmbitos complexos possa se limitar exclusivamente às normatividades de lógica estatal (Direitos nacionais e internacional, mormente), pois as possibilidades lógicas e comunicativas ultrapassam, com sua fluidez, o âmbito estatal — mas o que não vem a significar que este esteja obsoleto ou superado, relegado ao passado.

Num segundo momento, apresentam-se possibilidades territoriais e extraterritoriais de regulação das condutas das ETNs. Trata-se de aspecto importante para a consecução deste trabalho, principalmente para se demonstrar que, apesar de não mais ser a única forma de normatização de condutas na atualidade, a atuação estatal ainda se configura como importantíssima - , contudo, de modo revisto e complexificado. Apresentam-se principalmente casos envolvendo a práxis jurídica estadunidense, a qual pode dar importantes subsídios de Direito Comparado para futuros estudos e análises da prática e da teoria em outros países.

No terceiro momento do desenvolvimento deste artigo são feitas reflexões acerca de experiências já realizadas de regulação da conduta de ETNs por normas de Direito Internacional. Assim, tentativas frustradas e outras em andamento são tratadas, a fim de demonstrar que óbices práticos e teóricos essa importante via encontra na prática - exemplos esses que se reportam à doutrina jurídica internacional e às ciências (mormente sociais aplicadas) sobre esse fenômeno.

Por fim, intenta-se, num quarto e último momento, seguindo-se o raciocínio baseado na policontexturalidade, na hipercomplexidade e no chamado pluralismo jurídico, apresentam-se os programas normativos internos de conduta das ETNs, pelas mais variadas razões, como verdadeiras ordens jurídicas não estatais — dada a complexificação societal e procedimental que essas práticas assumiram no decorrer do tempo. Desta feita, programas internos de compliance, mormente decorrentes das pressões sociais exercidas sobre as ETNs dos mais variados modos, bem como outras formas de regulação de condutas desses atores são apresentadas. 


\section{Pluralismo jurídico, hipercomplexidade E POLICONTEXTURALIDADE: NOVOS FATORES A SEREM SOPESADOS NA LÓGICA JURÍDICA}

A concepção do Direito pelos seus operadores e estudiosos de forma que venham a considerar, de forma simplista e errônea, a ideia da lei (estatal) como eficiente para abranger um período de tempo futuro de longa duração, deve ser desmistificada. A noção de tempo da sociedade na pós-modernidade passa a ser instantânea, rápida, manifestada pelos meios de comunicação e pela internet, enquanto os juristas continuam no texto escrito. Nota-se, portanto, defasagem significativa entre as noções de tempo e sociedade na dogmática jurídica e aquilo que a sociedade atual experimenta; paralelismo temporal imenso, pois os juristas programam normas para durarem muito tempo, e elas não duram, às vezes, dias. ${ }^{7}$ Aliás, não raro leis são aprovadas pelo Poder Legislativo quando a matéria dos seus Projetos já se encontra totalmente transformada, na realidade, em relação ao texto (fazendo com que surjam leis "nascidas velhas").

Além do tempo, ocorre paralelismo de espaço. Assim como o tempo se torna instantâneo, o espaço se torna fluido para as comunicações velozes e deslocamentos economicamente interessantes, mas bloqueado com base em antigas justificativas de soberania quando necessário (fluxos migratórios de refugiados e pessoas economicamente desinteressantes). ${ }^{8}$ Convivem, assim, pelo menos duas lógicas territoriais: uma que pouco (ou sequer) considera as fronteiras baseadas na soberania jurídico-política - seja porque simplesmente se esvazia de sentido a noção no âmbito das comunicações e resultados, como ocorre com os fluxos de dados pela rede mundial de computadores e os danos ambientais; seja porque os Estados não são capazes de afirmar sua autoridade diante de novos entes dotados de poder (ETNs, organizações criminosas transnacionais, etc.); e aquela que, principalmente, na política e no Direito tanto se reafirma, quando possível e necessário (processamento de crimes que estejam dentro das possibilidades persecutórias dos Estados; tributação e regulação de entes e fatos que não sejam capazes de se eximir dessa lógica).

Trata-se, para além da dualidade de lógicas de tem-

7 ROCHA, Leonel Severo. Epistemologia jurídica e democracia. 2. ed. São Leopoldo: Unisinos, 2003. p. 197.

8 BAUMAN, Zygmunt. Vidas desperdiçadas. Tradução de Carlos Alberto Medeiros. Rio de Janeiro: J. Zahar, 2005. po e espaço, da multitude de formas de comunicação e de normatividade. Ocorre, no âmbito global, grande fragmentação na origem das emissões de comunicação acerca de várias matérias, em muitas lógicas diversas.

A (re)configuração do Direito com a globalização se relaciona com a expansão das possibilidades de escolha proporcionada pelo aumento da complexidade social decorrente da evolução de formas estratificadas de diferenciação social para formas funcionalmente diferenciadas. Esse aumento de complexidade torna muito mais contingentes os contextos nos quais cada subsistema funcional deve operar e decidir. Em razão da multiplicidade de centros de racionalização de sentido nesse cenário, pode ser afirmado que, no ínterim do fenômeno denominado globalização, não mais se pode atribuir aos acontecimentos sociais uma existência causal unitária; ademais, a acelerada fragmentação característica dessa época faz com que as comunicações ultrapassem as fronteiras territoriais. O Direito também é afetado por essa descrita fragmentação, de forma que a efetividade do seu funcionamento se quede dependente das suas relações para com as outras instâncias sociais. Em outras palavras, pode-se afirmar que o (sub)sistema jurídico (co)evolui com racionalidades diferentes (relacionadas a outros sistemas sociais), num cenário em que o Estado não representa mais a única esfera donde a normatividade emana. Emerge, assim, uma pluralidade de atores sociais diferenciados em papéis e culturas redunda numa pluralidade de fontes normativas e de sujeitos de direitos merecedores de proteção especial (consumidores, refugiados, hipossuficientes, etc.). ${ }^{?}$

O que se observa, assim, é um pluralismo jurídico, relacionado à multiplicidade de âmbitos comunicativos em que se produzem normatividade jurídica. Nas palavras de Wolkmer, ${ }^{10}$ o pluralismo jurídico consiste na

multiplicidade de práticas jurídicas existentes num mesmo espaço sócio-político, interagidas por conflitos e consensos, podendo ser ou não oficiais e tendo a sua razão de ser nas necessidades existenciais, materiais ou culturais.

A prova da existência da multiplicidade de ordens

9 ROCHA, Leonel Severo; ATZ, Ana Paula. Do pluralismo jurídico ao diálogo inter-sistêmico das fontes na sociedade mundial. In: PEREIRA, Agostinho Oli Koppe; HORN, Luiz Fernando Del Rio (Org.). Relações de consumo: globalização. Caxias do Sul: Educs, 2010. p. 107-132. p. 109.

10 WOLKMER, Antonio Carlos. Pluralismo jurídico: fundamentos de uma nova cultura no direito. 3. ed. São Paulo: Alfa Omega, 2001. p. 219. 
jurídicas antagônicas e sobrepostas pode ser encontrada no Direito pré-Estado-Nação, particularmente no Medievo, no qual conviviam manifestações normativas concorrentes, oficiais e não oficiais, como costumes locais, foros municipais, estatutos das corporações de ofício, ditames reais, Direito Canônico e Direito Romano. ${ }^{11}$ Com a centralização do Direito na figura do Estado moderno, o fenômeno jurídico passou a ser identificado necessariamente com os atos estatais, negando-se a juridicidade das demais manifestações.

No século XX, estudiosos da Sociologia do Direito, como Ehrlich, ${ }^{12}$ Sousa Santos ${ }^{13}$ e Wolkmer ${ }^{14}$ resgataram a ideia de que o "Direito não se confunde com o Estado" e que é possível a existência de ordens jurídicas não estatais no mundo moderno. $\mathrm{Na}$ mesma linha, Teubner, ${ }^{15}$ baseando-se nos escritos de Luhmann ${ }^{16}$ e Günther ${ }^{17}$ desenvolve a ideia de "policontexturalidade", no sentido que o "Direito é fragmentado em um pluralismo em que o Estado é apenas mais uma de suas organizações". ${ }^{18}$ Sousa Santos traz como exemplos de pluralismo jurídico contemporâneo as regras de um núcleo familiar, a lex mercatoria, o Direito indígena dos povos autóctones, o Direito paralelo das comunidades estabelecidas em "favelas" brasileiras e, principalmente para o que interessa neste trabalho, os códigos internos empresariais. ${ }^{19}$

Essa defasagem fática pode ser atribuída a uma defasagem teórica: o mundo não mais suporta, em sua grande complexidade, uma lógica única. Enquanto a ló-

11 WOLKMER, Antonio Carlos. Pluralismo jurídico: fundamentos de uma nova cultura no direito. 3. ed. São Paulo: Alfa Omega, 2001. p. 184.

12 EHRLICH, Eugen. Fundamentos da sociologia do direito. Brasília: UnB, 1986.

13 SANTOS, Boaventura de Sousa. A crítica da razãa indolente: contra o desperdício da experiência. São Paulo: Cortez, 2000.

14 WOLKMER, Antonio Carlos. Pluralismo jurídico: fundamentos de uma nova cultura no direito. 3. ed. São Paulo: Alfa Omega, 2001. 15 TEUBNER, Gunther. A bukowina global sobre a emergência de um pluralismo jurídico transnacional. Impulso, Piracicaba, v. 13, n. 33, p. 09-31, 2003.

16 LUHMANN, Niklas. Como se pueden observar estructuras latentes? In: WATZLAWICK, Pal; KRIEG, Peter. El ojo del observador: contribuciones al construtivismo. Barcelona: Gedisa, 1995. p. 60-72. 17 GÜNTHER, Gotthard. Life as poly-contexturality. fev. 2004. Disponível em: < http://www.vordenker.de/ggphilosophy/gg_life_ as_polycontexturality.pdf $>$. Acesso em: 13 abr. 2015.

18 ROCHA, Leonel Severo. A produção autopoética do sentido do direito. Direitos Culturais, Santo Ângelo, v. 4, n. 7, p. 13-26, 2009. p. 18.

19 SANTOS, Boaventura de Sousa. A crítica da razãa indolente: contra o desperdício da experiência. São Paulo: Cortez, 2000. gica aristotélica seria monocontextural, ${ }^{20}$ eis que, nessa lógica, apenas o "ser" e o "não ser" seriam possíveis: ou algo é conforme determinada lógica, ou não o é, de forma que uma terceira opção não seria possível. Essa racionalidade - em que pese ser "confinada" a apenas uma contexturalidade - tem sido deveras importante para a história do pensamento humano, mas se torna insuficiente quando se está diante de um cenário hipercomplexo - repleto de variedade de formas de comunicação, bem como de centros emissores de normatividade. ${ }^{21}$ Diversas lógicas e códigos comunicativos seriam possíveis em tal ordem de coisas, formando-se, dessa forma, várias contexturalidades, cada qual com seu respectivo par ordenado "conforme/em desconformidade" - mas que observam uns aos outros, fazendo-se, assim, ligados de certa forma. Nesse passo, observa-se uma estrutura multinivelada de lógicas de extrema complexidade. "Uma contexturalidade é um domínio lógico de uma estrutura estritamente valorada em dois valores, e sua abrangência é determinada pelo uso do TND [Lógica "Tertium Non Datur", sem terceiro elemento possível]". [...] quando se considera, todavia, que o Universo deve ser considerado como uma "intersecção de um número ilimitado de contexturalidades duplamente valoradas", ${ }^{22}$ está-se diante de uma pluralidade de contexturalidades —, ou seja, uma situação de policontexturalidade.

Essa ideia poderia ser desenvolvida um pouco mais para além, quando se toma conhecimento da noção de racionalidade transversal para conversação entre sistemas. A destruição seria o destino da sociedade moderna multicêntrica, formada por múltiplas esferas conflitantes entre si, se não desenvolvessem mecanismos intervinculantes que possibilitam o aprendizado e a influência recíprocos — os acoplamentos estruturais, os quais viabilizam as interferências entre diversos subsistemas sociais. Esses mecanismos, verdadeiras interpenetrações entre sistemas comunicativos, filtram (excluindo certas influências e facilitando outras) e promovem as

20 LUHMANN, Niklas. Como se pueden observar estructuras latentes? In: WATZLAWICK, Pal; KRIEG, Peter. El ojo del observador: contribuciones al construtivismo. Barcelona: Gedisa, 1995. p. 60-72. p. 61.

21 GÜNTHER, Gotthard. Life as poly-contexturality. fev. 2004. Disponível em: <http://www.vordenker.de/ggphilosophy/gg_life_ as_polycontexturality.pdf $>$. Acesso em: 13 abr. 2015. p. 3-4.

22 GÜNTHER, Gotthard. Life as poly-contexturality. fev. 2004. Disponível em: <http://www.vordenker.de/ggphilosophy/gg_life_ as_polycontexturality.pdf $>$. Acesso em: 13 abr. 2015. p. 6. 
influências e os estímulos intersistêmicos recíprocos de maneira duradoura, estável e concentrada, sem que os sistemas percam suas características autonomias. ${ }^{23}$ Aliás, configura-se uma simultânea relação de independência e dependência entre tais sistemas, visto que suas estruturas "passam a ser, mediante os acoplamentos estruturais, relevantes e mesmo indispensáveis à reprodução das estruturas de outro sistema e vice-versa". ${ }^{24}$

Acoplamentos estruturais permitem a construção de racionalidades transversais 25 entre esferas autônomas de comunicação da sociedade mundial, pois são mecanismos que estabelecem intercâmbios de experiência entre diferentes racionalidades parciais, as quais, "conforme o tipo e a singularidade dos respectivos sistemas ou discursos e de acordo com suas relações específicas, variará intensamente na forma e no conteúdo". ${ }^{26}$

Identificar acoplamentos estruturais entre sistemas revela-se estratégia de grande valia num cenário policontextural e hipercomplexo, em que emergem não apenas sistemas comunicativos diferenciados, mas também diversas ordens de caráter normativo; não apenas ordens normativas, mas ordens jurídicas; não apenas ordens jurídicas estatais - ou dependentes da lógica estatal, tais como ordens internacionais (correlatas aos tratados internacionais) e supranacionais (da qual é exemplo significativo a União Europeia), mas também ordens jurídicas não estatais (formadas por laços contratuais entre empresas, num contexto em que ETNs impõem, via contrato, a seus fornecedores, os próprios códigos de conduta corporativos). O simples raciocínio impositivo linear de uma ordem soberana estatal a condutas dos privados pode ainda perdurar, mas não mais se observa como absoluta (de modo como fora outrora).

Sempre que dois sistemas comunicativos interconectam, essa interconexão os torna capazes de desenvolver seus próprios mecanismos de aprendizado e influência estáveis e mútuos. Dessa forma, tem-se que os acopla-

23 LUHMANN, Niklas. La ciencia de la sociedad. Tradução de Silvia Pappe, Brunhilde Erker e Luis Felipe Segura, sob a coordenação de Javier Torres Nafarrate. México: Universidad Iberoamericana, 1996. p. 121.

24 NEVES, Marcelo. Transconstitucionalismo. São Paulo: M. Fontes, 2009. p. 35.

25 WELSCH, Wolfgang. Reason and transition: on the concept of transversal reason. 29 out. 2000. Disponível em: <http://ecommons.library.cornell.edu/bitstream/1813/54/1/Welsch_Reason_ and_Transition.htm>. Acesso em: 13 abr. 2015.

26 NEVES, Marcelo. Transconstitucionalismo. São Paulo: M. Fontes, 2009. p. 38. mentos estruturais constituem racionalidades transversais parciais, sendo que cada uma dessas racionalidades está estruturalmente vinculada às racionalidades particulares, parciais (sistêmicas) confrontadas — sendo, portanto, pontes de transição específicas. ${ }^{27}$

O entrelaçamento entre o Direito e outros sistemas sociais, ou entre várias ordens jurídicas diferenciadas, que permite a construção de uma racionalidade transversal pelo aprendizado recíproco e pelo intercâmbio criativo pode ser denominado Constituição transversal. ${ }^{28}$ Esse conceito implica em externalização e internalização de informações entre os mais diversos sistemas sociais funcionais que primariamente se reproduzem com fundamento em códigos binários de diferentes formas de comunicação.

Identificam-se, assim, relações entre ordens jurídicas diversas, que ocorrem no interior do mesmo sistema funcional da sociedade mundial atual, o Direito - no qual se diferenciam ordens diferenciadas e subordinadas ao mesmo código binário (direito/ não direito), mas com programas e critérios diferentes. Essa diferenciação interna entre ordens jurídicas — que vai para além da segmentação entre ordens estatais — não vem a significar que tais ordens se encontrem desconectadas: há a ligação, por exemplo, entre ordens estatais e internacionais pelo instituto da ratificação; entre ordens estatais, o Direito Internacional Privado tem desenvolvido mecanismos conectivos também.

É peculiar, no entrelaçamento das diversas ordens jurídicas, o fato de haver relativa independência da mediação do sistema político em seu estabelecimento. No âmbito jurídico, são relevantes as "pontes de transições" desenvolvidas diretamente a partir dos respectivos centros dos seus sistemas (os juízes e tribunais). ${ }^{29}$ Com isto, tem-se que não apenas a sociedade mundial, mas também seu Direito é multicêntrico — e os centros das demais ordens jurídicas constituem periferia para o centro de uma dada ordem..$^{30} \mathrm{O}$ caráter multicêntrico, com certa possibilidade de comunicação entre centro(s)

27 NEVES, Marcelo. Transconstitucionalismo. São Paulo: M. Fontes, 2009. p. 42.

28 NEVES, Marcelo. Transconstitucionalismo. São Paulo: M. Fontes, 2009. p. 115.

29 LUHMANN, Niklas. Law as a social system. Tradução para o inglês de Klaus A. Ziegert. Oxford: Oxford University Press, 2004. p. 293.

30 NEVES, Marcelo. Transconstitucionalismo. São Paulo: M. Fontes, 2009. p. 117. 
e periferia(s) de maneira a constituir aprendizado, pode se dar entre as mais diversas categorias de ordens: entre Cortes estatais, entre Cortes estatais e internacionais, etc. Mas esses diálogo entre centros não pressupõe cooperação permanente entre eles, já que vários conflitos são perceptíveis na práxis.

Tem-se, assim, que diferentemente da noção clássica de constitucionalismo, por exemplo, (no qual era possível delimitar as problemáticas relacionadas aos direitos e garantias fundamentais e da limitação e organização estatal às fronteiras nacionais), a noção atual do caráter constitucional (o que pressupõe não apenas a constituição de Estados e organizações interestatais, mas também a emergência de novos centros comunicativos de normatividade jurídica, como aquelas que decorrem das ETNs) exige atualmente a consideração da constitucionalização por outras ordens jurídicas (as que versam sobre Direitos Humanos, por exemplo). Deve-se referir a constitucionalismos nacionais, internacionais, supranacionais e transnacionais - os quais dialogam de maneira a estabelecer processos de aprendizado (seja em situações cooperação, seja em situações de conflito entre ordens). ${ }^{31}$

\section{Conduta das empresas transnacionais e REGULAÇÃO PELO DIREITO ESTATAL}

Apesar de toda a fluidez com que as ETNs operam (o que colocaria suas comunicações, quase automaticamente, no império da lógica acelerada e relativizadora do espaço e do tempo), ainda não se pode absolutizar essa posição - já que, em decorrência do próprio gap entre a lógica fluida e a lógica pretensamente bem delimitada no tempo e no espaço decorrente da soberania —, o fato de uma empresa ser caracterizada como transnacional não a coloca automaticamente em uma espécie de "limbo jurídico", habitando em lugar imaginário na qual a longa manus das jurisdições estatais jamais alcança. Todas ETNs submetem-se, no mínimo, a duas ordens jurídicas: do país onde foram constituídas e mantém a sua sede ("país de origem") e do local onde exercem as suas atividades ("país hospedeiro"). Ambos os Estados possuem a liberdade de utilizarem o seu Direito interno (também chamado de nacional ou doméstico) e os mecanismos que garantem a sua aplicação, com objetivo de

31 NEVES, Marcelo. Transconstitucionalismo. São Paulo: M. Fontes, 2009. p. 119-121. regular o comportamento dessas entidades.

Em primeiro lugar, uma ETN é compelida a adaptar-se ao Direito de um país hospedeiro. Tal situação advém da própria ideia de soberania, que concede a prerrogativa de cada Estado zelar pela ordem em seu território. Nesse cenário regulatório, seria possível defender que bastariam que os países hospedeiros aprovassem legislações de controle da atividade empresária e aplicassem contra ETNs da mesma maneira que fazem com as empresas de atuação exclusivamente interna. Com a adesão da proposta pelos países hospedeiros onde as ETNs exercem suas atividades, cada qual desempenhando o papel de controlar as atividades comerciais que ocorrem em seu território, diminuiriam as possibilidades de condutas indesejadas por essas entidades.

Pensar assim, no entanto, consiste em simplificar o problema. Imaginar que mais de 200 países, com capacidades, realidades e interesses diversos, fiscalizarão essas empresas da mesma maneira, de forma espontânea e sem qualquer estímulo externo, é utópico, para não dizer ingênuo. Existe hoje acirrada disputa por atração de investimento estrangeiro direto que pode forçar a diminuição dos standards regulatórios, em uma espécie de "corrida para o fundo" (race to the bottom). ${ }^{3233}$ De maneira óbvia, o Estado que está buscando incessantemente hospedar uma ETN dificilmente promoverá o endurecimento de seus mecanismos de controle em seu território, com medo de ser preterido na hora da escolha. Nesse contexto e por essas razões, não se pode esperar grandes feitos por parte dos Estados hospedeiros.

Isto abre a possibilidade para que a regulação da conduta das ETNs ocorra, partindo da ação dos Estados investidores, ou seja, aqueles onde estão sediadas essas empresas. ${ }^{34}$ Como esses Estados investidores se benefi-

32 A race to the botton ("corrida para o fundo") ocorre quando os países, em um ambiente de competitividade, não regulam determinadas condutas, passando a tolerar práticas ilícitas para se tornarem mais competitivos. No longo prazo, piora a condição de todos os participantes. Em busca de tornar-se receptor de empresas estrangeiras e investimento externo direto, um Estado pode tornar a sua legislação menos rigorosa e mais permissiva a atividades ilícitas, como no caso da proteção ao meio ambiente, na qual é possível diminuir os requisitos para a concessão de licenças. O problema é que em um ambiente de grande competitividade internacional, muitos países podem ser compelidos a seguirem o exemplo e enfraquecerem seus padrões normativos ainda mais.

33 GUZMAN, Andrew. Why LDCs sign treaties that hurt them? Virginia Journal of International Law, Charlottesville, v. 38, p. 640-688, 1998. p. 671-674.

34 DEVA, Surya. Regulating corporate buman rights violations: human- 
ciam economicamente dessa relação, deveriam ter a responsabilidade de assegurar que suas ETNs não atuem em detrimento do Estado hospedeiro. ${ }^{35}$ Outro aspecto positivo é que se trabalharia com um número muito mais reduzido de países, que são detentores de capacidade de impor sanções efetivas. Essa proposta baseia-se na possibilidade de extensão extraterritorial da norma nacional para ações realizadas em país estrangeiro.

Brownlie ${ }^{36}$ colaciona cinco formas dos Estados exercerem o controle jurídico de condutas. A primeira delas baseia-se no "princípio da territorialidade": os Estados controlam todas as ações que ocorrem em seu território; trata-se de decorrência de sua soberania. Apesar de a territorialidade ser a regra geral, não existe proibição para um Estado que deseja, unilateralmente, criar norma de natureza extraterritorial que regule condutas realizadas no exterior, desde que haja um elemento de conexão que ligue esse fato ao seu interesse nacional e não viole a soberania de outrem. No contexto da "extraterritorialidade", pode recorrer-se ao "princípio da nacionalidade" ou "da personalidade ativa", no qual a norma regula as ações realizadas por seus nacionais (pessoas naturais e jurídicas) produzidas no exterior. Pauta-se na ideia de que os cidadãos devem lealdade ao seu país de origem. ${ }^{37}$ Além disso, pode vincular-se ao "princípio da personalidade passiva" ou "da nacionalidade da vítima", no qual se reprime atos praticados por estrangeiros contra nacionais no exterior; ao "princípio protetor" ou "da segurança”, no qual os Estados fiscalizam as ações praticadas no exterior que possam afetar a sua segurança; e por fim, ao "princípio da universalidade", no qual a natureza grave da conduta impõe que todos os membros da comunidade internacional a reprimam ${ }^{38}$.

izing business. New York: Routledge, 2012. p. 50-51.

35 SORNARAJAH, M. The international law of foreign investment. Cambridge: Cambridge University Press, 2010. p. 159.

36 BROWNLIE, Ian. Princípios de direito internacional público. Lisboa: Fundação Calouste Gulbenkian, 1997. p. 321-326.

37 PIETH, Mark. Article 4: jurisdiction. In: PIETH, Mark; LOW, Lucinda A.; CULLEN, Peter J (Org.). The OECD convention on bribery: a commentary. Cambridge: Cambridge University Press. 2007. p. 267-288. p. 270.

38 Conforme Robinson, "o princípio da justiça universal é baseado na noção de que certos crimes são tão danosos aos interesses internacionais que os Estados podem - ou até mesmo são obrigados a - processar o infrator, independentemente do local do crime ou da nacionalidade do agressor ou da vítima" (ROBINSON, Mary. Foreword. In: MACEDO, Stephen (Org.). The Princeton principles on universal jurisdiction. Princeton: Princeton, 2001. p. 15-18. p. 16). Delitos como pirataria, escravidão, crimes de guerra, crimes contra a paz, crimes contra a humanidade, genocídio e tortura enquadrar-se-iam nesta categoria.
O exercício da extraterritorialidade é limitado pela vedação de interferência na soberania de outros Estados. Sendo assim, os Estados não estão autorizados, sob o pretexto de cumprir norma jurídica nacional de abrangência extraterritorial, a adentrar em território estrangeiro sem o consentimento e realizar atos soberanos, como medidas que necessitam de poder de polícia ou jurisdição. ${ }^{39}$ Em outras palavras, a abrangência extraterritorial da norma nacional não é proibida, podendo regular fatos ocorridos no exterior; mas a sua aplicação e efetivação, que implicam a realização de mecanismos sancionatórios, terá que ser feita dentro de sua circunscrição territorial. Por exemplo, se alguém viola uma norma nacional de um país enquanto está no exterior, na ausência de qualquer cooperação interestatal, só poderá ser coagido a cumprir pena, seja civil ou criminal, quando adentrar no país que emitiu a norma.

O exemplo mais tradicional de extraterritorialidade pode ser encontrado no Direito Criminal. Nesse sentido, é possível existir uma legislação que estabeleça punição de crimes realizados por nacionais no exterior, ou ainda por estrangeiros contra nacionais. Há também os casos que envolvem crimes contra altos funcionários do governo (como chefes do executivo) durante sua estada no exterior, ou que atentem, de alguma forma, contra o patrimônio do Estado, como na produção de danos a bens de representação diplomática. Conforme Sornarajah, ${ }^{40}$ nos países de tradição jurídica de raiz romano-germânica é relativamente comum dispor em seus códigos criminais a extensão extraterritorial da lei penal de acordo com esses moldes ${ }^{41}$. $\mathrm{Na}$ mesma linha, observa-se a existência de legislações que punem nacionais que utilizam serviços de prostituição infantil no exterior. Essas normas estabelecem que o controle de tais condutas não deva ser feito somente no local onde a prostituição existe, geralmente de estrutura estatal deficitária e ineficaz, mas também pelos países onde se originam os turistas. ${ }^{42}$

39 PIETH, Mark. Article 4: jurisdiction. In: PIETH, Mark; LOW, Lucinda A.; CULLEN, Peter J (Org.). The OECD convention on bribery: a commentary. Cambridge: Cambridge University Press. 2007. p. 267-288. p. 269.

40 SORNARAJAH, M. The international law of foreign investment. Cambridge: Cambridge University Press, 2010. p. 165.

41 Além do Brasil (art. $7^{\circ}$ ), existe legislação semelhante em Portugal $\left(\right.$ art. $5^{\circ}$ ), França (do art. 113-6 ao art. 113-12), Alemanha (título I, $\left.\int 5^{\circ}\right)$ e Argentina $\left(\operatorname{art.~} 1^{\circ}\right)$.

42 o caso da legislação na Suécia, Austrália, Canadá, Reino Unido e Estados Unidos. NICHOLS, Philip M. The myth of anti-bribery laws as transnational intrusion. Cornell International Law Journal, 
Nesse passo, não existe óbice para a elaboração de normas nacionais que permitam o controle das operações das ETNs no exterior pelos Estados de origem (investidores). Trata-se de alternativa interessante, uma vez que existe uma tendência natural dos países hospedeiros evitarem a regulação, principalmente por medo de perderem investimentos. ${ }^{43}$ Os principais exemplos vêm dos Estados Unidos. O Direito estadunidense permite que sejam punidas práticas anticoncorrenciais realizadas por afiliadas no exterior ${ }^{44}$, desde que causem efeitos no mercado dos EUA. Também existem leis norte-americanas nos mesmos moldes que proíbem empresas de negociarem com países considerados como inimigos. ${ }^{45}$

Nas últimas décadas, com base na Alien Torts Claim Act - ATCA ("Lei das Ações Cíveis Movidas por Estrangeiros"), que permite que estrangeiro ingresse com ação civil de indenização no judiciário norte-americano por descumprimento de Direito Internacional, ETNs (dos EUA e estrangeiras) estão sendo processadas nos EUA por violações de Direitos Humanos no exterior ${ }^{46}$. $\mathrm{O}$ ingresso de vários casos em cortes norte-americanas ${ }^{47}$

Ithaca, v. 33, p. 627-655, 2000. p. 643.

43 SORNARAJAH, M. The international law of foreign investment. Cambridge: Cambridge University Press, 2010. p. 169.

44 O precedente é o caso United States v. ALCOA de 1945. Na ocasião, vários produtores de alumínio de diferentes acertaram um acordo de cartel na Suíça. Uma empresa norte-americana participou por meio de sua afiliada canadense. Apesar de o ilícito ter se consumado no exterior, a Suprema Corte entendeu que a violação da legislação antitruste praticaria efeitos diretos e substanciais nos EUA. FARIA, José Ângelo Estrella. A aplicação extraterritorial do direito da concorrência. Revista de Informação Legislativa, Brasilia, v. 27, n. 105, p. 19-46, 1990. p. 27.

45 MUCHLINSKI, Peter T. Multinational enterprises and the law. 2. ed. Oxford: Oxford University Press, 2007. p. 115.

46 Neste contexto, a base jurídica está no direito costumeiro e pactício internacional voltado à proteção da pessoa humana que os Estados Unidos estão submetidos, como a Declaração Universal de Direitos Humanos e o Pacto Internacional de Direitos Civis e Políticos.

47 Em Doe v. UNOCAL discutiu-se a atuação de uma ETN norteamericana em Mianmar, que supostamente patrocinou torturas e trabalho forçados. Em Kiobel v. Royal Dutch Petroleum, o processo foi contra uma empresa transnacional de capital britânico e holandês pela participação em um massacre de manifestantes contra a instalação de uma fábrica em Ogoni, Nigéria. Em Bowoto v. Chevron Corp. as acusações foram direcionadas a uma afiliada de empresa norteamericana também pelo uso indevido da força na Nigéria. Em Sarei v. Rio Tinto nacionais de Papua Nova Guiné processaram a empresa transnacional de origem britânica e australiana por terem apoiado ações violentas do governo. Em Wang Xiaoning v. Yahoo! chineses processaram a empresa de serviços de internet por terem repassado informações ao governo chinês, que prendeu e torturou os usuários por atividades supostamente subversivas. Em Sinaltrainal v. CocaCola Company os autores acusaram engarrafadores de refrigerante na Colômbia de colaborarem com as forças paramilitares em atos de violência contra membros de sindicato. e as possíveis condenações decorrentes acarretariam a consolidação do controle extraterritorial da conduta dessas empresas, no que diz respeito à proteção dos Direitos Humanos. Outros países seguiram o exemplo dos EUA e passaram a exercer jurisdição sobre as ações de suas ETNs no exterior a partir construções jurisprudenciais, como é o caso da Austrália, Países Baixos e Reino Unido. Após anos de batalhas judiciais, em abril de 2013, a Suprema Corte norte-americana decidiu que a $A T C A$ não é aplicável a atos realizados no exterior, devendo o descumprimento de Direito Internacional ter ligação com o solo norte-americano, sob pena de ocorrer violação de soberania estrangeira, em tentativa de barrar o elevado número de ações propostas nos últimos anos.

Pode-se observar, portanto, que mesmo estando em crise a ideia de soberania na atualidade, esta ainda confere aos Estados aptidão para regular condutas das ETNs relacionadas aos seus territórios. Porém, as múltiplas possibilidades de regulação (ou seja, a falta de uniformidade) que podem surgir na realidade (pois, para cada Estado, tem-se uma cultura jurídica própria), somadas às disputas internacionais pela atração de ETNs, fazem com que se observe não um incremento na normatização das suas condutas. Antes, é notável um fenômeno oposto, de desregulamentação.

Ainda, nessa mesma senda, considera-se que as raras possibilidades de atuação extraterritorial dos Estados demonstram que a regulação estatal das condutas das ETNs deve ser complementada por outras estratégias nesse mesmo sentido. A empolgação inicial representada pela utilização da $A T C A$ em tribunais norte-americanos, que poderia consolidar não apenas o alcance extraterritorial da norma, mas a aplicação do "princípio da universalidade" para julgar e punir os desvios das ETNs, foi claramente soterrada pela dura realidade fática, governada pelos interesses econômicos das grandes corporações e das nações desenvolvidas. Daí a consideração da necessidade de se tratar acerca de estratégias internacionais de regulação.

\section{Regulação PELO diREITO INTERNACIONAL dAS CONDUTAS DAS EMPRESAS TRANSNACIONAIS}

O entendimento sobre a necessidade de controle das atividades das ETNs pelos países-sede não deve ser visto, contudo, como descoberta de uma "panaceia". É 
fácil reconhecer, em tese, a existência de uma obrigação desses países em fiscalizarem suas ETNs; difícil, porém, é operacionalizar essa afirmativa. Apesar de a previsão da extraterritorialidade de suas normas ser ato unilateral que parte do próprio Estado no exercício de sua soberania, não há nada que simplesmente force a fazê-lo. É forte a tendência, dentre Estados poderosos economicamente, em permanecerem inertes, objetivando proteger as práticas comerciais de suas ETNs, ainda que essas ações prejudiquem os hospedeiros.

Conforme Nichols ${ }^{48}$ existe dificuldade em se pensar na regulação de ETNs apenas sob a lógica exclusiva do Direito nacional. Enquanto as estruturas empresárias são formadas sem qualquer consideração às barreiras políticas, o Direito nacional enfrenta os obstáculos fronteiriços. No mesmo sentido, Muchlinski ${ }^{49}$ entende que existe um descompasso entre a amplitude gerencial e operacional das ETNs e o alcance jurisdicional do Estado que procura regulá-las. A estratégia de utilização dos Direitos nacionais aplicados de forma territorial ou extraterritorial enfrenta o problema da assimetria dessas manifestações jurídicas. Não há nada o que assegure que os Estados irão efetivamente coibir essas condutas e, caso o façam, não há garantias de que seguirão o mesmo padrão regulatório. A utilização do Direito Internacional pode representar o afastamento da dependência de medidas unilaterais estatais e a construção de um regime jurídico multilateral capaz de coibir as más condutas empresárias em qualquer lugar do mundo. Nesse contexto, seriam depuradas as pretensões individualistas dos Estados quanto ao tema, buscando-se uma situação favorável para a comunidade internacional.

Historicamente, o Direito Internacional foi criado para regular a conduta dos Estados e garantir a coexistência pacífica no plano internacional. ${ }^{50}$ Difere do Direito nacional na produção e aplicação de normas, uma vez que não existe aqui órgão externo centralizado, restando aos próprios Estados a realização da sanção, tal qual o Direito de uma sociedade primitiva. ${ }^{51}$ Com base

48 NICHOLS, Philip M. The myth of anti-bribery laws as transnational intrusion. Cornell International Law Journal, Ithaca, v. 33, p. 627-655, 2000. p. 628.

49 MUCHLINSKI, Peter T. Multinational enterprises and the law. 2. ed. Oxford: Oxford University Press, 2007. p. 115.

50 SHAW, Malcolm N. Direito internacional. São Paulo: M. Fontes, 2010. p. 37.

51 "Como todo mundo sabe, o sistema normativo internacional [...] é menos elaborada e mais rudimentar que as ordens jurídicas domésticas - o que, é claro, não significa que é inferior ou menos em sua expansão e desenvolvimento, o Direito Internacional contemporâneo não se preocupa apenas com as relações interestatais, mas também com a conduta dos Estados frente. Questões que antes eram consideradas domésticas e submetidas apenas ao Direito interno (e.g. Direitos Humanos e Direito Ambiental) encontram-se submetidas a normas internacionais. ${ }^{5253}$ Hoje, qualquer assunto pode ser suscetível de regulação pelo Direito Internacional desde que seja de interesse da comunidade internacional. ${ }^{54}$ Nesse contexto, não existem óbices para a criação de normas internacionais com objetivo de regular as ETNs.

A operacionalização dessa norma, entretanto, constitui um desafio. Ainda que a norma internacional seja voltada para indivíduos (ou uma coletividade, no caso a empresa), não é possível afastar a figura do Estado desse processo. Não se pode esquecer que são os Estados, e não as ETNs, os sujeitos típicos do Direito Internacional. ${ }^{55}$ Conforme Shaw, ${ }^{56}$ a razão disso reside nas falhas que as ETNs apresentam nos principais testes para averiguação de personalidade jurídica internacional, como a capacidade de celebrar tratados internacionais, o amplo acesso a tribunais internacionais e a possibilidade de ser punida por eles. Em relação ao segundo

‘jurídico’ que eles: são apenas diferentes” (WEIL, Prosper. Towards relative normativity in international law? The American Journal of International Law, Washington, v. 77, n. 3, p. 413-442, 1983. p. 413-414). No direito de uma sociedade primitiva, o indivíduo que tinha seus interesses juridicamente protegidos violados estava autorizado pelo próprio ordenamento jurídico a tomar as medidas coercitivas previstas. É a autotutela ou justiça pelas próprias mãos. Com a organização da estrutura estatal, a autotutela deixou de ser permitida no direito doméstico e a sanção passou a ser aplicada por esta estrutura centralizada e externa. Não existe tal órgão nas relações entre Estados (KELSEN, Hans. Derecho y paz, en las relaciones internacionales. 2. ed. Mexico: Fondo de Cultura Económica, 1986).

52 SHELTON, Dinah. International law and 'relative normativity'. In: EVANS, Malcolm (Org.). International law. 2. ed. Oxford: Oxford University Press, 2006. p. 159-184. p. 162.

53 Até o século XX, praticamente todos os tratados eram bilaterais e dispunham apenas de relações jurídicas interestatais, como relações diplomáticas, direito marítimo, comércio e extradição. Hoje, o número de instrumentos internacionais cresceu exponencialmente e regulam vários assuntos, geralmente de maneira multilateral (SHELTON, Dinah. International law and 'relative normativity'. In: EVANS, Malcolm (Org.). International law. 2. ed. Oxford: Oxford University Press, 2006. p. 159-184. p. 162).

54 KELSEN, Hans. Princípios do direito internacional. Ijuí: Unijuí, 2010. p. 250.

55 ALVAREZ, Jose E. Are corporations "subjects" of international law? Santa Clara Journal of International Law, Santa Clara, v. 9, n. 1, p. 01-36, 2011. p. 34.

56 SHAW, Malcolm N. Direito internacional. São Paulo: M. Fontes, 2010. p. 186. 
requisito, observa-se que existe um acesso limitadíssimo a dois tribunais, no entanto, as ETNs participam apenas como autores e nunca como réus, o que demonstra a natureza incompleta no cumprimento do pretenso requisito. ${ }^{57}$ Assim, na presença de norma internacional de matéria relacionada às ETNs, são os Estados os sujeitos internacionais que possuem a obrigação de garantir direitos e exigir deveres dessa estrutura empresarial que opera em seu território, utilizando-se de seus mecanismos coercitivos. ${ }^{58}$

Não existe impedimento para que um Estado aplique diretamente uma norma internacional em ETNs. Contudo, com a expansão do Direito Internacional em direção a novos temas (tidos tradicionalmente como domésticos), é comum encontrar normas internacionais incompletas, ${ }^{59}$ que exigem a conversão ou criação de Direito interno, com objetivo de permitir as devidas adaptações de acordo com a realidade jurídica do Estado vinculado. Aqui, o Direito Internacional pode ser instrumento para reforma do Direito e das instituições nacionais, possibilitando a absorção de experiências jurídicas testadas em outros países e difundidas mediante o consenso da comunidade internacional. Caso o procedimento legislativo interno não seja realizado, dita cláusula do tratado fica prejudicada até que as medidas legislativas nacionais sejam tomadas. Enquanto as normas domésticas não são criadas, cabe aos demais Estados avaliarem a situação do cumprimento do tratado e realizarem pressões políticas para que o país signatário tome as devidas providências. Um exemplo de norma internacional que carece de execução automática são os tratados que versam sobre Direito Penal e crimes transnacionais. ${ }^{60}$ Incapazes de criminalizarem condutas, pois

57 O primeiro é o International Centre for Settlement of Investment Disputes (Centro Internacional para Arbitragem de Disputas sobre Investimentos), corte arbitral ligada ao Banco Mundial que busca resolver lides envolvendo investimento estrangeiro. O segundo é o Iran-United States Claim Tribunal, instituição criada mediante acordo entre Irã e Estada Unidos para resolver os conflitos envolvendo a nacionalização de ativos norte-americanos após a Revolução Iraniana.

58 NASSER, Salem Hikmat. Fontes e normas do direito internacional: um estudo sobre a soft law. 2. ed. São Paulo: Atlas, 2006. p. 90.

59 KELSEN, Hans. Princípios do direito internacional. Ijuí: Unijuí, 2010. p. 493.

60 É o caso da Convenção das Nações Unidas contra o Crime Organizado Transnacional e seu Procolo Relativo à Prevenção, Repressão e Punição do Tráfico de Pessoas, em Especial Mulheres e Crianças; Convenção contra a Tortura e Outros Tratamentos ou Penas Cruéis, Desumanos e Degradantes; Convenção Internacional para a Proteção de Todas as Pessoas contra os Desaparecimentos Forçados; Convenção para a Supressão do Financiamento do Ter- seria afronta à soberania nacional, limitam-se em criar a obrigação para os Estados de alterarem a sua legislação penal de acordo com o tratado, de modo a uniformizar a repressão penal frente a crimes de interesse internacional.

É necessário analisar qual fonte de Direito Internacional seria a mais adequada para tratar sobre ETNs. O costume internacional, prática reiterada de atos aceitos como Direito pelos Estados, foi a única fonte durante séculos, quando o Direito ainda era predominantemente não escrito. ${ }^{61}$ Com o tempo, processos de codificação do Direito, os Estados passaram a firmar acordos escritos, estipulando normas jurídicas a serem observadas pelos signatários, na forma de tratados internacionais. Ainda que não exista hierarquia entre as duas fontes, não se pode negar que a clareza e estabilidade que é inerente a um documento escrito alçaram o tratado internacional à posição de principal recurso jurídico, vide o crescimento exponencial de número de acordos nos últimos dois séculos e o processo de codificação dos costumes internacionais. Uma norma jurídica com temática afeita às ETNs parece ser mais compatível com uma manifestação pactícia, pois bastaria o consenso dos Estados para a sua criação.

No entanto, as tentativas de criar um tratado internacional definitivo sobre a responsabilidade das ETNs fracassaram. Os tratados bilaterais de investimento, que poderiam dispor sobre o assunto, estabelecem apenas direitos às ETNs (como proteção ao investimento e garantia de reparação econômica em caso de expropriação), sem a materialização de obrigações das estruturas empresárias frente ao Estado hospedeiro. $\mathrm{Na}$ década de 1970, após o não cumprimento das promessas de desenvolvimento econômico e social do processo de liberalização do investimento estrangeiro direto, muitos países periféricos adotaram uma postura crítica em relação às ETNs, vistas como instrumento de dominação econômica e intervenção política. ${ }^{62}$ A propagação do modelo neoliberal nos anos 90 tornou os países mais interessados em atraírem investimento estrangeiro direto a qualquer custo e menos preocupados com as possí-

rorismo, e as convenções internacionais e regionais contra a corrupção, que serão estudados com detalhes ao longo da pesquisa.

61 MALANCZUK, Peter. Akehurst's modern introduction to international law. 7. ed. New York: Routledge, 1997. p. 36.

62 KELLER, Helen. Codes of conduct and their implementation: the question of legitimacy. In: WOLFRUM, Rüdger; VOLKER, Röben (Org.). Legitimacy in international law. Berlin: Springer, 2008. p. 219-298. p. 255. 
veis consequências negativas desses empreendimentos, o que sepultou a criação do tratado internacional.

As pesquisas realizadas nas últimas décadas têm incluído nova fonte jurídica de Direito Internacional, nomeada de soft law ("Direito suave" ou "flexível"). De acordo com Nasser ${ }^{63}$ são normas de "linguagem vaga, ou de noções de conteúdo variável ou aberto, ou que apresentam caráter de generalidade ou principiológico que impossibilite a identificação de regras específicas e claras". Uma característica sua que contrasta com as outras normas (classificadas como hard law, "Direito duro" ou "inflexível") consiste no afastamento de métodos tradicionais de coerção para o seu cumprimento, fundamentados em sanções, preferindo apostar em mecanismos mais brandos, estimulando, por exemplo, a prática da mediação e conciliação. ${ }^{64}$ Por vezes, parecem não ter aplicação obrigatória, preocupando-se mais em "sugerir" ou "orientar" a melhor conduta a ser adotada pelo destinatário, capaz de produzir a menor lesão social possível, do que prever consequência clara para o descumprimento da norma. Apesar de o conceito não se limitar ao Direito Internacional, o soft law costuma ser associado a essa manifestação jurídica.

Shelton $^{65}$ classifica como soft law qualquer instrumento internacional escrito que descreve condutas e princípios importantes a serem adotados pelos Estados, sem contudo, dispor sobre sanções diretas em caso de inobservância. Ao contrário dos tratados internacionais (de natureza de hard law), são normas não vinculativas, não podendo ser exigido juridicamente o seu cumprimento pelos demais membros da comunidade internacional. Tal atributo é particularmente interessante aos Estados, que podem aderir à norma sem o medo de descobrirem-se incapazes de cumprir seus dispositivos no futuro. Aqui, destaca-se a sua flexibilidade, que não exige procedimentos formais para criação e alteração, ao contrário dos tratados internacionais. Podem ser citadas como exemplos de normas internacionais de natureza de soft law as manifestações não obrigatórias de organizações internacionais; códigos de conduta ou "leis modelos" emitidos por essas instituições; e declarações

63 NASSER, Salem Hikmat. Fontes e normas do direito internacional: um estudo sobre a soft law. 2. ed. São Paulo: Atlas, 2006. p. 25.

64 NASSER, Salem Hikmat. Fontes e normas do direito internacional: um estudo sobre a soft law. 2. ed. São Paulo: Atlas, 2006. p. 25.

65 SHELTON, Dinah. International law and 'relative normativity'. In: EVANS, Malcolm (Org.). International law. 2. ed. Oxford: Oxford University Press, 2006. p. 159-184. p. 180 conjuntas de vários países ao final de um encontro. $\mathrm{O}$ Direito Internacional Econômico e o Ambiental têm sido as principais áreas que recepcionaram as práticas de soft law. ${ }^{66}$

Muitas normas internacionais de soft law são acompanhadas por mecanismos de monitoramento gerenciados pelos aderentes ao documento. Em um procedimento de "avaliação mútua entre pares", os Estados registram as violações e avaliam o cumprimento do soft law pelos colegas, ao mesmo tempo em que são avaliados. Ao final, discutem os desafios a serem enfrentados e as possíveis medidas a serem tomadas para o aperfeiçoamento das condutas. Isto demonstra o caráter educativo do soft law, ao invés de concentrar-se na punição dos infratores, busca meios alternativos de sanção, ${ }^{67}$ operando em uma zona cinzenta entre Direito e Política internacionais. ${ }^{68}$ Na manutenção de um canal de diálogo e negociação, a sanção torna-se indireta, na forma de pressão e constrangimento exercido pelos demais pactuantes cumpridores da norma.

Um ponto importante diz respeito à interação dinâmica entre o soft law e os instrumentos pactícios. É comum a edição prévia de normas de soft law como teste de aceitação de regras e princípios para depois elaborar um tratado internacional sobre o assunto. Outra função interessante a criação de tratados internacionais que estipulam apenas aspectos jurídicos gerais, deixando para o soft law o seu detalhamento. ${ }^{69}$ Evita-se, assim, o desgaste político na elaboração de emendas ou um novo instrumento pactício, deixando o Direito Internacional mais flexível, dinâmico e adaptável às mudanças. É imperativo ressaltar que o soft law também conserva o mesmo ímpeto transformador dos tratados internacionais em relação as ordens internas dos países vinculados, podendo estimular o surgimento de novas experiências de Direito nacional.

Os movimentos contestadores da década de 1970 podem não ter sido capazes de criar um tratado internacional, mas impulsionaram o desenvolvimento de soft

66 SHAW, Malcolm N. Direito internacional. São Paulo: M. Fontes, 2010. p. 93.

67 CHINKIN, C. M. The challenge of soft law: development and change in international law. International and Comparative Law Quarterly, Cambridge, v. 38, p. 850-866, 1989. p. 862.

68 MALANCZUK, Peter. Akehurst's modern introduction to international law. 7. ed. New York: Routledge, 1997. p. 54.

69 SHELTON, Dinah. International law and 'relative normativity’. In: EVANS, Malcolm (Org.). International law. 2. ed. Oxford: Oxford University Press, 2006. p. 159-184. p. 181. 
law inédita sobre o assunto. Em 1976, a OCDE elaborou as "Diretrizes para Empresas Multinacionais". No ano seguinte, foi criada a "Declaração Tripartite de Princípios sobre Empresas Multinacionais e Política Social" da OIT, que possui como objetivo difundir o respeito ao Direito do Trabalho pelas ETNs. Em 2003, a ONU criou as "Normas sobre a Responsabilidade das Empresas Transnacionais e Outros Empreendimentos em Relação aos Direitos Humanos". Tais normas de soft law dispõem sobre o dever dos Estados em proteger pessoas de violações de Direitos Humanos praticados por empresas, inclusive atos ilícitos produzidos no exterior, no que tange às ETNs domiciliadas em seu território.

Muchlinski ${ }^{70}$ observa que, no que diz respeito à temática de regulação da conduta de ETNs, existe uma predominância no uso do soft law em comparação com os tratados internacionais. $\mathrm{O}$ autor defende que essa escolha não é arbitrária e segue interesses econômicos dos Estados investidores. Em temas sensíveis para esse grupo, como comércio internacional e investimento estrangeiro direto, as fontes jurídicas apresentam natureza formal e obrigatória (hard law), como é o caso dos instrumentos bilaterais de proteção ao investimento estrangeiro direto. Em outra banda, no que se refere às questões ligadas à responsabilidade das ETNs frente às sociedades em que atuam, predominam-se fontes de caráter informal e de observância facultativa no plano internacional (soft law).

O que transparece é que as potências dominantes das relações internacionais, apesar de exigirem práticas de responsabilidade corporativa no seu ambiente interno, relutam em garantir que suas ETNs não vão se comportar de maneira inadequada nos Estados hospedeiros, com medo que isto possa prejudicar seus interesses comerciais. ${ }^{71}$ A cobrança crescente da sociedade civil internacional, cada vez mais consciente da má conduta das ETNs, culminou na criação de algumas experiências normativas de natureza de soft law. Tais iniciativas, no entanto, parecem, por vezes, ser "cortinas de fumaça" para mascarar o problema, uma vez que os países ricos evitam claramente o reconhecimento de responsabilidade empresária por meio de normas imperativas de hard

70 MUCHLINSKI, Peter T. Multinational enterprises and the law. 2. ed. Oxford: Oxford University Press, 2007. p. 110.

71 KAMMINGA, Menno T.; ZIA-ZARIF, Saman. Introduction. In:__ (Org.). Liability of multinational corporations under international law. Haia: Kluwer Law International, 2000. p. 01-16. p. 07-08. law. ${ }^{72} \mathrm{Na}$ mesma linha e em tom crítico, Adeyeye ${ }^{73}$ reconhece que a soft law pode ser inadequada e ineficiente no campo da responsabilidade das ETNs, necessitando-se de hard law nessa área.

Sendo assim, tem-se que às estratégias internas estatais de regulação de condutas das ETNs devem ser somadas estratégias internacionais. Não sendo suficientes aquelas, estas podem representar importante complemento. Contudo, conforme observado acima, mecanismos normativos internacionais apresentam sérios defeitos: inércia dos países mais fortes (geopolítica e economicamente) em regular de modo efetivo as ETNs neles sediadas; falta de mecanismos coercitivos que venham a pressionar os Estados no intuito de fazê-lo; típica incompletude textual das normas internacionais; inércia legislativa interna dos Estados em implementarem as recomendações frequentes em instrumentos normativos internacionais. Caso existisse um tratado internacional compreensivo, capaz de dispor sobre a responsabilidade das ETNs, poderia ser um primeiro passo em direção à fiscalização uniforme da má conduta dessas entidades na seara internacional. No entanto, tal instrumento não se concretizou — nem mesmo existem previsões otimistas para a sua elaboração. A emergência do soft law na área pode até representar uma tentativa de suprir tal lacuna; porém, a aplicação desse tipo de norma, que proporciona uma falsa impressão de segurança — uma vez que se trata de norma fluida e incerta — também constitui barreira para que novas experiências jurídicas pactícias sejam testadas.

A gama de vícios recém-descrita e listada faz resplandecer a necessidade de, às estratégias estatais e internacionais em regular a conduta das ETNs, serem somadas outras, ainda. Eis a razão pela qual se dedica a continuidade deste trabalho em descrever uma importante (e interessante) possibilidade de complemento àquelas ordens jurídicas: as ordens jurídicas não-estatais surgidas dos mecanismos de autorregulação verificáveis, atualmente, e relacionadas às ETNs.

72 SORNARAJAH, M. The international law of foreign investment. Cambridge: Cambridge University Press, 2010. p. 146-149.

73 ADEYEYE, Adefolake. Corporate responsibility in international law: which way to go? Singapore Yearbook of International Law, Singapore, v. 11, p. 141-161, 2007. p. 39. 


\section{Possibilidades de AUtORREgUlação dAS EMPRESAS TRANSNACIONAIS}

Uma análise descuidada encerraria a ideia tradicional de fontes de Direito. No entanto, é inegável que o fenômeno jurídico possui novas e complexas nuances na contemporaneidade, que impactarão diretamente nas estratégias regulatórias, envolvendo condutas das ETNs. Como se sabe, a formação dos Estados nacionais implicou a reivindicação do monopólio da criação do Direito (nacional ou interno) por essas estruturas. No plano externo, esse esquema também é reproduzido, pois os Estados reservaram a prerrogativa de serem os produtores de suas próprias normas jurídicas. Hoje, esse modelo tradicional é claramente tensionado pelos processos econômicos, políticos e sociais. A gradual integração e interdependência dos mercados nacionais e a proliferação do modelo capitalista neoliberal a partir da globalização propõem um Estado mínimo e de pouca intervenção, capaz de transferir uma série de responsabilidades do setor público para o setor privado, ${ }^{74}$ incluindo-se a produção e aplicação das normas jurídicas.

O processo contemporâneo de "privatização" do Direito vincula-se às ideias de pluralismo jurídico e de policontexturalidade, as quais contemplam possibilidades de existência de ordens jurídicas não estatais, administrado pelos próprios atores privados, que são responsáveis pela produção e aplicação das próprias normas, em uma espécie de "autorregulação" de suas condutas. Não se trata de aceitar um modelo necessariamente economicista e conduzido por agentes de mercado, mas reconhecer a existência e importância de normas espontâneas e descentralizadas, fruto do exercício da autonomia social e baseadas em ações consensuais. Tais normas estão, em princípio, desprendidas de processos políticos centralizadores das estruturas estatais, passando a ser geridas pela própria sociedade civil, ${ }^{75}$ situação que as aproxima das necessidades de diferentes segmentos sociais.

É importante dizer que esse possível "Direito não estatal" não se encontra isolado de outros sistemas jurídicos (Direito nacional e internacional) e sociais (como por exemplo, economia e política), recebendo estímulos

74 TEUBNER, Gunther.. After privatization? the many autonomies of private law. Current Legal Problems, London, v. 51, n. 1, p. 393-424, 2012. p. 393.

75 TEUBNER, Gunther.. After privatization? the many autonomies of private law. Current Legal Problems, London, v. 51, n. 1, p. 393-424, 2012. p. 399. externos. Isto é comprovado com a difusão da noção de compliance no mundo dos negócios, fenômeno com consequências relevantes para o Direito. Certamente influenciado pelas ideias contemporâneas de responsabilidade empresária e boa governança, compliance advém do verbo da língua inglesa to comply, o qual, em linhas gerais, significa "cumprir" ou "estar em conformidade" com algo, sendo comumente utilizado no ambiente empresarial como "cumprimento de norma jurídica". ${ }^{76}$ A ideia consiste em criar mecanismos dentro da empresa para assegurar o "cumprimento prévio" de normas jurídicas estatais, de modo a diminuir o risco de ser punido no futuro em alguma jurisdição. A cultura do compliance é implementada por meio de um "programa", um conjunto de ações planejadas por uma organização para assegurar, mediante criação de estruturas e mecanismos, o seguimento de uma certa conduta. Órgãos de fiscalização para a responsabilidade empresária (como no âmbito ambiental, tributário, anticorrupção, etc.) de diversos países costumam abrandar suas sanções frente à comprovação da existência de efetivos programas de conformidade (compliance), como uma maneira de estímulo ao processo de "privatização" da regulação e aplicação do Direito.

Apesar de muitas vezes originar-se de um estímulo externo - qual seja, uma tentativa de escapar das tradicionais sanções estatais —, o desenvolvimento de programas de compliance conduz a processos de autorreprodução de subsistemas jurídicos próprios, compostos por normas jurídicas e suas respectivas sanções, criados e administrados por determinadas organizações empresárias. No que tange às ETNs, em razão da amplitude de suas atividades, esse sistema de regulação não estatal adquire dimensões globais, ${ }^{77}$ atingindo os funcionários dessas empresas e seus parceiros comerciais.

A base de um programa de compliance costuma ser a manutenção de um código de conduta e ética elaborado por uma determinada empresa e direcionado aos seus funcionários. Em 1977, a General Motors era a maior ETN com atuação na África do Sul durante o regime do apartheid. À época articulava-se um forte movimento de desinvestimento no país para pressionar uma reforma

76 KINGSBURY, Benedict. The concept of compliance as a function of competing conceptions of international law. Michigan Journal of International Law, Ann Arbor, v. 19, p. 345-372, 1998. p. 345-346.

77 MUCHLINSKI, Peter T. Multinational enterprises and the law. 2. ed. Oxford: Oxford University Press, 2007. p. 113. 
política na região. O reverendo Leon Sullivan, membro do conselho de administração da companhia, ofereceu uma alternativa: a criação de um código de conduta interno que impedisse práticas racistas. O conjunto de princípios, conhecidos como Sullivan Principles, foi bem recebido pelo mundo empresarial, tendo sido reproduzido em vários códigos de conduta. Outra iniciativa semelhante foi o MacBride Principles, voltados ao respeito aos direitos dos trabalhadores na Irlanda no Norte (1984). Uma das primeiras ETNs a possuírem um código próprio foi a britânica Royal Dutch Shell. ${ }^{78}$ Hoje, várias ETNs mantêm os seus códigos. Tais normas também são comumente reproduzidas em contratos com seus parceiros comerciais, com o objetivo de alcançar também suas condutas. Esses códigos e os respectivos mecanismos de monitoramento estão revestidos de juridicidade, uma vez que descrevem condutas a serem observadas, tornando-se uma espécie de "lei interna", de cumprimento obrigatório no âmbito da empresa (incluindo ETNs). A possível sanção para o descumprimento dessa norma reside em medida disciplinar (como advertência, suspensão ou demissão das ETNs) aplicada pela empresa em seu funcionário ou rompimento de contrato, quando se tratar de um parceiro comercial.

Robé $^{79}$ fornece como exemplo a previsão no Código de Trabalho francês (Code du Travai) da possibilidade de manutenção de "regulamentos internos" (règlements intérieurs) por empresa. Seria a prova de reconhecimento, por parte do direito estatal francês, da validade jurídica dos códigos empresariais internos. $\mathrm{O}$ autor observa, contudo, que nas últimas décadas essa delegação legislativa tem perdido espaço, sendo permitida nos dias atuais apenas para grandes empresas e em assuntos restritos (disciplina, higiene e segurança).

Observa-se que cada ETN, com seus programas de compliance e códigos de conduta em geral, constitui um subsistema jurídico único. Contudo, além das interações com os sistemas tradicionais de Direito (Direitos nacionais), existe uma interação entre as próprias empresas que, por meio de ações em conjunto, podem conduzir a uma uniformização desses Direitos não estatais. Teu-

78 EINHORN, Aaron. The evolution and endpoint of responsibility: the FCPA, SOX, socialist-oriented governments, gratuitous promises, and a novel CSR code. Denver Journal of International Law and Policy, Denver, v. 35, p. 509-545, 2007. p. 537-538.

79 ROBÉ, Jean-Philippe. Multinational enterprises: the constitution of a pluralistic legal order. In: TEUBNER, Gunther (Org.). Global law without a state. Vermont: Dartmouth, 1997. p. 45-77. p. 62-65. bner $^{80}$ aponta que os atores privados podem criar laços transnacionais e elaborarem um Direito totalmente independente das estruturas estatais e de aplicação global (um "Direito global" ou "anacional", em oposição a um Direito "inter-nacional”, entre Estados). Dois exemplos podem ser citados de um Direito não estatal de alcance transnacional. ${ }^{81} \mathrm{O}$ primeiro é a nova lex mercatoria, representada pelo conjunto de normas criadas de maneira independente pelas empresas para a prática do comércio internacional na contemporaneidade, baseando-se nos usos e costumes comerciais reconhecidos mundialmente. Manifesta-se na elaboração e difusão de "contratos padronizados" (incoterms), idealizados e atualizados pela Câmara Internacional do Comércio, organização internacional não governamental mantida pelo meio empresário. O outro exemplo é o Direito desportivo internacional (lex sportiva internationalis), organizado pelas entidades esportivas privadas internacionais, como a Federação Internacional de Futebol (FIFA). Enquanto o Estado representa um ente estranho a esses temas e repleto de limitações em seu alcance (como o princípio da territorialidade), os agentes produtores dessas normas estão plenamente inseridos em seus segmentos sociais, o que torna essa manifestação jurídica deveras atrativa.

É importante dizer que a autorregulação e a possibilidade de aplicação de um "Direito não estatal" pelas ETNs não são, absolutamente, livres de críticas. Apesar de sua existência ser reconhecida nas pesquisas contemporâneas, sua eficácia costuma ser amplamente questionada, de modo a colocá-la sempre submissa a um Direito estatal nacional. Nesse sentido, Murphy, ${ }^{82}$ ao tratar da autorregulação de ETNs, não desvincula esse sistema jurídico da necessidade de intervenção estatal. O autor defende que é imprescindível que os Estados estipulem oficialmente os parâmetros mínimos para a autorregulação, fiscalizem se as empresas estão efetivamente aplicando seus códigos de conduta e concedam algum tipo de benefício para aquelas que demonstrarem cumprimento de suas normas, como diminuição de pena em caso de sanção estatal ou acordo favorável. Se

80 TEUBNER, Gunther. A bukowina global sobre a emergência de um pluralismo jurídico transnacional. Impulso, Piracicaba, v. 13, n. 33, p. 09-31, 2003. p. 11-13.

81 TEUBNER, Gunther. A bukowina global sobre a emergência de um pluralismo jurídico transnacional. Impulso, Piracicaba, v. 13, n. 33, p. 09-31, 2003. p. 11.

82 MURPHY, Sean D. Taking multinational corporate codes of conduct to the next level. Columbia Transnational Law, New York, v. 43, p. 01-55, 2005. p.44-53. 
isso não for feito, os códigos de conduta e os mecanismos de compliance viram meros instrumentos de retórica. Muchlinski, ${ }^{83}$ em seu turno, critica abertamente as propostas de autorregulação, taxando-as de neoliberais. Sua denúncia é no sentido de que se trata claramente de uma estratégia para retirar os Estados de alguns setores de regulação, substituindo-os por regramentos gerenciados pelas próprias ETNs, condizentes com os próprios interesses dessas organizações empresárias e do capital internacional.

Haja ou não críticas tecidas contra a autorregulação das ETNs, há de se convir que teorias monistas, unicistas e juspositivistas não mais se adéquam a uma realidade cada vez mais complexificada por novos atores, novas interações e novos centros emissores de normatividade. Socialmente pode se observar como construtiva a criação, com vistas a um incremento no compliance, de ordens jurídicas relacionadas à autorregulação das ETNs, e não como deletéria para a soberania estatal. Aliás, acredita-se, aqui, em um posicionamento teórico de acordo com o qual uma teoria da reflexividade entre ordens estatais e não estatais - teoria esta que verse acerca da possibilidade de aprendizado e complementação na regulação entre essas ordens de origem diversa.

Esse aprendizado se daria nas possibilidades de observação mútua entre ordens: a operabilidade das ordens jurídicas estatais poderia ser melhor contextualizada se estas observarem como as ETNs vêm regulando assuntos diretamente relacionados às suas condutas; por outro lado, as ordens jurídicas não estatais, ao observarem os postulados próprios das ordens estatais (principalmente aqueles fundados em princípios e procedimentos normativos democráticos) para formularem seus mecanismos de autorregulação, podem incrementar ainda mais sua compliance, já que se aproximariam daqueles interesses sociais já cristalizados em ordens positivas.

\section{Considerações finais}

Notadamente a atualidade passa por modificações drásticas, decorrentes das potencializações que as tecnologias de informação, comunicação, transporte, produção e controle de processos. Essas transformações, muito mais (porém, não unicamente) notáveis na Eco-

83 MUCHLINSKI, Peter T. Multinational enterprises and the law. 2. ed. Oxford: Oxford University Press, 2007. p. 113. nomia, fazem com que os postulados da Modernidade, no tocante à Política e ao Direito, sejam totalmente questionáveis: monopólio do Estado como centro emissor de normatividade política e jurídica; supremacia desse mesmo Estado no cenário geopolítico e na tutela dos bens jurídicos considerados relevantes socialmente; dentre outros correlatos.

A emergência de ETNs, atores privados de abrangência e relevância econômicas e políticas globais, deve ser analisada detalhadamente no tocante ao Direito. Não se trata de desconsiderar a figura do Estado na regulação e na tutela das suas condutas: essa figura não está relegada ao desuso, sendo muitas vezes utilizada para atender aos interesses das próprias ETNs. Ademais, essas últimas também dependem da atuação estatal para a sua instalação, funcionamento e produção, demonstrando-se que não há um esvaziamento da sua função normativa: esta deve ser, isto sim, repensada conforme a policontexturalidade e a hipercomplexidade — a fim de que não se estanquem e obliterem as possibilidades regulatórias públicas significativas.

Por outro lado, apesar dos insucessos até hodiernamente bastante verificáveis nas experiências regulatórias das ETNs mediante estratégias de Direito Internacional, trata-se de área longe de ser desconsiderada para esses propósitos. A análise dessas estratégias, dos seus sucessos e fracassos e condições de operabilidade são de suma importância para a questão da regulação das corporações atuantes de maneira fluida (mas longe de ser soft) no cenário global.

Ademais, a própria complexificação dos processos normativos internos das ETNs - decorrentes, muitas vezes, dos próprios processos sociais reflexivos (pressão da sociedade sobre tais empresas; atuação empresarial negocial) - se especializa e impõe não só economicamente, mas também juridicamente, suas normas internas de conduta a setores reticulares inteiros bastante amplos. Nesse sentido, desconsiderar a importância da autorregulação de suas condutas como repletas de conteúdo normativo jurídico é postura teórica totalmente alheia em relação ao ambiente social em que o Direito se encontra. Em outras palavras: negar o pluralismo jurídico é negar a própria reflexividade entre Direito e sociedade.

Em síntese, pode-se considerar que a questão da regulação das ETNs se insere num âmbito complexo e pouco explorado, em que comunicações normativas 
multifatoriais reflexivas entre Estado, organizações internacionais e os próprios entes econômicos privados globais a serem regulados (muitas vezes por eles próprios) devem ser estabelecidas e analisadas. Trata-se de elevar qualitativamente a análise do fenômeno jurídico em sociedade no nível de complexidade que os processos sociais atuais exigem.

O referido âmbito complexo se relaciona às múltiplas possibilidades de regulação de suas condutas: não mais se pode observar no ordenamento estatal a única possibilidade de regê-las, eis que o nível de organização das ETNs supera os limites em que este é soberano; ademais, a regulação mediante postulados estabelecidos em ordens jurídicas internacionais, apesar da importância que podem assumir, não é o único complemento pensável à regulação estatal; e, por fim, tem-se que teorias jurídicas positivistas, em tempos de globalização e crise de soberania, não são capazes de abranger satisfatoriamente o fenômeno da emergência de um Direito plural que transborde a ideia de ordem estatal.

Por fim, âmbito ainda pouco explorado justamente em razão de tão arraigada cultura jurídica positivista tão cara à Modernidade. Essa cultura, exageradamente centrada na figura do Estado, abre pouca margem para uma observação plural de origem do fenômeno jurídico. Daí a necessidade de se buscar novos temas de pesquisa relacionados ao pluralismo jurídico, eis que o Estado, figura ainda importante para o Direito, não pode mais ser tido como único e absoluto centro emissor de normatividade na atualidade globalizada.

\section{REFERÊNCIAS}

ADEYEYE, Adefolake. Corporate responsibility in international law: which way to go? Singapore Yearbook of International Law, Singapore, v. 11, p. 141-161, 2007.

ALVAREZ, Jose E. Are corporations "subjects" of international law? Santa Clara Journal of International Law, Santa Clara, v. 9, n. 1, p. 01-36, 2011.

ANDERSON, Sarah; CAVANAGH, John. Top 200: the rise of corporate global power. Washington, D. C., 2000. Disponível em: <www.corpwatch.org/downloads/top200.pdf>. Acesso em: 22 jan. 2013.

BAUMAN, Zygmunt. Vidas desperdiçadas. Tradução de Carlos Alberto Medeiros. Rio de Janeiro: J. Zahar, 2005.
BROWNLIE, Ian. Princípios de direito internacional público. Lisboa: Fundação Calouste Gulbenkian, 1997.

CHINKIN, C. M. The challenge of soft law: development and change in international law. International and Comparative Law Quarterly, Cambridge, v. 38, p. 850-866, 1989.

DELEUZE, Gilles. Post-scriptum sobre as sociedades de controle. In: . Conversações. Trad. Peter Pál Pelbart. São Paulo: Editora 34, 2007. p. 219-226.

DEVA, Surya. Regulating corporate human rights violations: humanizing business. New York: Routledge, 2012.

EHRLICH, Eugen. Fundamentos da sociologia do direito. Brasília: UnB, 1986.

EINHORN, Aaron. The evolution and endpoint of responsibility: the FCPA, SOX, socialist-oriented governments, gratuitous promises, and a novel CSR code. Denver Journal of International Law and Policy, Denver, v. 35, p. 509-545, 2007.

FARIA, José Ângelo Estrella. A aplicação extraterritorial do direito da concorrência. Revista de Informação Legislativa, Brasília, v. 27, n. 105, p. 19-46, 1990.

FOUCAULT, Michel. Soberania e disciplina. In: - Microfísica do poder. Org. e trad. Roberto Machado. 20. ed. São Paulo: Graal, 2004. p. 100-107.

GÜNTHER, Gotthard. Life as poly-contexturality. fev. 2004. Disponível em: <http://www.vordenker.de/ ggphilosophy/gg_life_as_polycontexturality.pdf > . Acesso em: 13 abr. 2015.

GUZMAN, Andrew. Why LDCs sign treaties that hurt them? Virginia Journal of International Law, Charlottesville, v. 38, p. 640-688, 1998.

KAMMINGA, Menno T.; ZIA-ZARIF, Saman. Introduction. In: (Org.). Liability of multinational corporations under international law. Haia: Kluwer Law International, 2000. p. 01-16.

KELLER, Helen. Codes of conduct and their implementation: the question of legitimacy. In: WOLFRUM, Rüdger; VOLKER, Röben (Org.). Legitimacy in international law. Berlin: Springer, 2008. p. 219-298.

KELSEN, Hans. Derecho y paz en las relaciones internacionales. 2. ed. Mexico: Fondo de Cultura Económica, 1986.

KELSEN, Hans. Principios do direito internacional. Ijuí: Unijuí, 2010. 
KINGSBURY, Benedict. The concept of compliance as a function of competing conceptions of international law. Michigan Journal of International Law, Ann Arbor, v. 19, p. 345-372, 1998.

LUHMANN, Niklas. Como se pueden observar estructuras latentes? In: WATZLAWICK, Pal; KRIEG, Peter. El ojo del observador: contribuciones al construtivismo. Barcelona: Gedisa, 1995. p. 60-72.

LUHMANN, Niklas. La ciencia de la sociedad. Tradução de Silvia Pappe, Brunhilde Erker e Luis Felipe Segura, sob a coordenação de Javier Torres Nafarrate. México: Universidad Iberoamericana, 1996.

LUHMANN, Niklas. Law as a social system. Tradução para o inglês de Klaus A. Ziegert. Oxford: Oxford University Press, 2004.

MACEDO, Stephen. The princeton principles on universal jurisdiction. Princeton: Princeton, 2001.

MALANCZUK, Peter. Akehurst's modern introduction to international law. 7. ed. New York: Routledge, 1997.

MUCHLINSKI, Peter T. Multinational enterprises and the law. 2. ed. Oxford: Oxford University Press, 2007.

MURPHY, Sean D. Taking multinational corporate codes of conduct to the next level. Columbia Transnational Law, New York, v. 43, p. 01-55, 2005.

NASSER, Salem Hikmat. Fontes e normas do direito internacional: um estudo sobre a soft law. 2. ed. São Paulo: Atlas, 2006.

NEVES, Marcelo. Transconstitucionalismo. São Paulo: M. Fontes, 2009.

NICHOLS, Philip M. The myth of anti-bribery laws as transnational intrusion. Cornell International Law Journal, Ithaca, v. 33, p. 627-655, 2000.

PECEQUILO, Cristina Soreanu. Introdução às relações internacionais. Petrópolis: Vozes, 2012.

PIETH, Mark. Article 4: jurisdiction. In: PIETH, Mark; LOW, Lucinda A.; CULLEN, Peter J (Org.). The OECD convention on bribery: a commentary. Cambridge: Cambridge University Press, 2007. p. 267-288.

ROBÉ, Jean-Philippe. Multinational enterprises: the constitution of a pluralistic legal order. In: TEUBNER, Gunther (Org.). Global law without a state. Vermont: Dartmouth, 1997. p. 45-77.

ROBINSON, Mary. Foreword. In: MACEDO, Stephen
(Org.). The Princeton principles on universal jurisdiction. Princeton: Princeton, 2001. p. 15-18.

ROCHA, Leonel Severo. A produção autopoética do sentido do direito. Direitos Culturais, Santo Ângelo, v. 4, n. 7, p. 13-26, 2009.

ROCHA, Leonel Severo. Epistemologia jurídica e democracia. 2. ed. São Leopoldo: Unisinos, 2003.

ROCHA, Leonel Severo; ATZ, Ana Paula. Do pluralismo jurídico ao diálogo inter-sistêmico das fontes na sociedade mundial. In: PEREIRA, Agostinho Oli Koppe; HORN, Luiz Fernando Del Rio (Org.). Relações de consumo: globalização. Caxias do Sul: Educs, 2010. p. 107-132.

SANTOS, Boaventura de Sousa. A crítica da razão indolente: contra o desperdício da experiência. São Paulo: Cortez, 2000.

SANTOS, Boaventura de Sousa. Notas sobre a história jurídico-social de Pasárgada. In: SOUZA JUNIOR, José Geraldo (Org.). O direito achado na rua. Brasília: UnB, 1987. p. 45-51.

SHAW, Malcolm N. Direito internacional. São Paulo: M. Fontes, 2010.

SHELTON, Dinah. International law and 'relative normativity'. In: EVANS, Malcolm (Org.). International law. 2. ed. Oxford: Oxford University Press, 2006. p. 159184.

SORNARAJAH, M. The international law of foreign investment. Cambridge: Cambridge University Press, 2010.

TEUBNER, Gunther. A bukowina global sobre a emergência de um pluralismo jurídico transnacional. Impulso, Piracicaba, v. 13, n. 33, p. 09-31, 2003.

TEUBNER, Gunther. Autoconstitucionalização de corporações transnacionais? sobre a conexão entre os códigos de conduta corporativos (Corporate Codes of Conduct) privados e estatais. In: SCHWARTZ, Germano (Org.). Juridicização das esferas e fragmentação do direito na sociedade contemporânea. Porto Alegre: Livraria do Advogado, 2012. p. 109-126.

TEUBNER, Gunther. After privatization? the many autonomies of private law. Current Legal Problems, London, v. 51, n. 1, p. 393-424, 2012.

WEIL, Prosper. Towards relative normativity in international law? The American Journal of International Law, Washington, v. 77, n. 3, p. 413-442, 1983. 
WELSCH, Wolfgang. Reason and transition: on the concept of transversal reason. 29 out. 2000. Disponível em: $\quad<$ http://ecommons.library.cornell.edu/bitstream/1813/54/1/Welsch_Reason_and_Transition. htm>. Acesso em: 13 abr. 2015.

WILKE, Helmut. Reflexivo (direito). In: ARNAUD, André-Jean (Dir.). Dicionário enciclopédico de teoria e de sociologia do direito. Rio de Janeiro: Renovar, 1999. p. 678-681.
WILKINS, Mira. European and north american multinationals, 1870-1914: comparions and contrasts. In: JONES, Geoffrey (Org.). Transnational corporations: a historical perspective. London: Routledge, 1992. p. 23-62. WOLKMER, Antonio Carlos. Pluralismo jurídico: fundamentos de uma nova cultura no direito. 3. ed. São Paulo: Alfa Omega, 2001. 


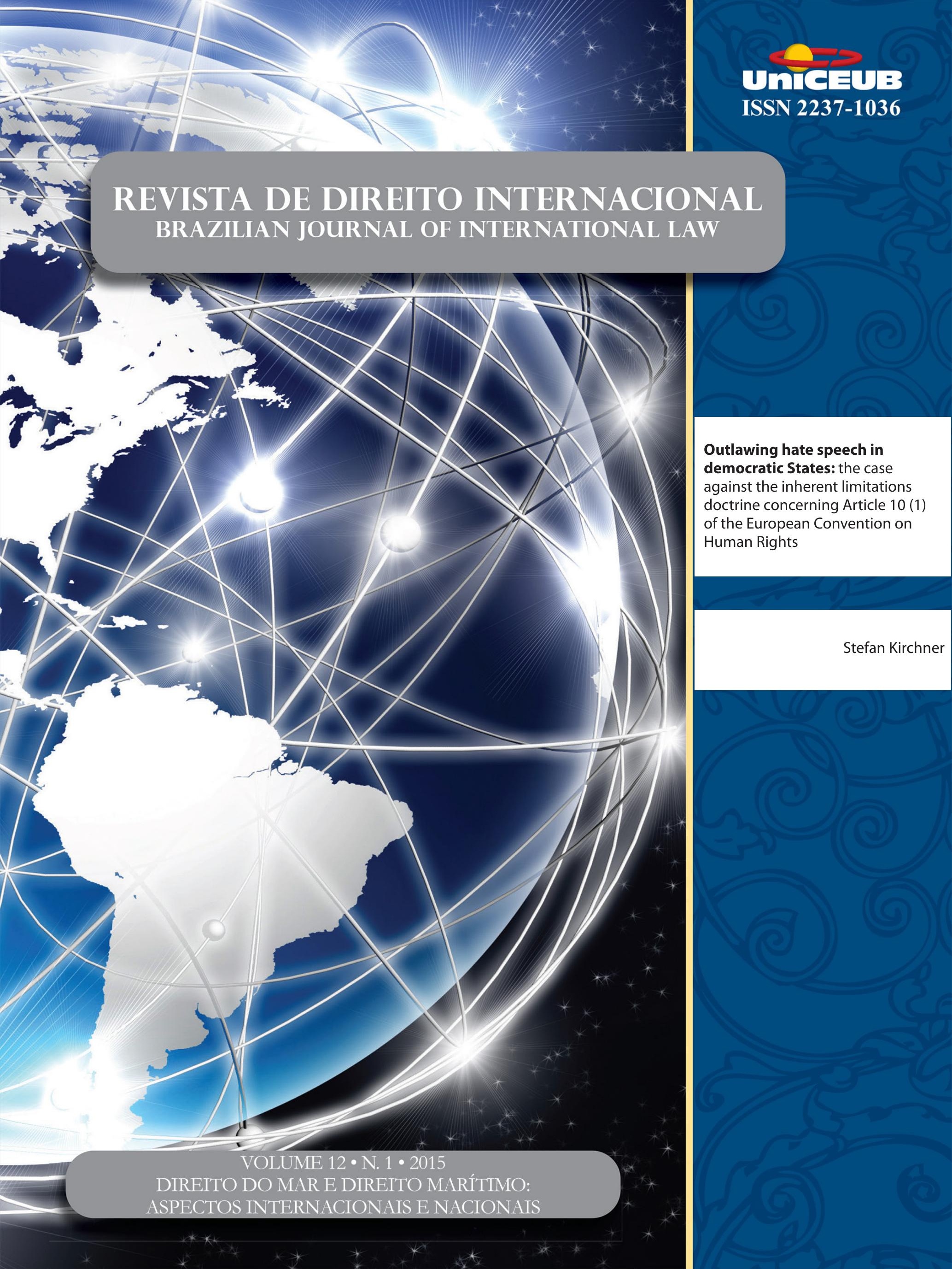




\section{Outlawing hate speech in democratic States: the case against the inherent limitations doctrine concerning Article 10 (1) of the European Convention on Human Rights*}

Stefan Kirchner ${ }^{* *}$

\section{Abstract}

When compared to the domestic legal systems of states parties to the European Convention on Human Rights (ECHR), the material scope of the freedom of expression under Article 10 ECHR is relatively far-reaching. This wide scope provides also a risk of abuse. At the same time is the ECHR based on the concept of a democratic society. In a democratic society, which is based on the rule of the majority, minorities are in particular need of protection. This includes a need to outlaw uses of the freedom of expression which target minorities in a way which is not based on the exercise of human rights but on hatred. In this article it is shown that such hate speech can be outlawed under the standard model of limitations offered by the European Convention on Human Rights or by the abuse of rights clause of Article 17 ECHR. It is not necessary to rely on inherent limitations of the material scope of the freedom of expression in order to effectively protect all members of a democratic society against hate speech.

Keywords: European Convention on Human Rights. Free Speech. Hate Speech. Inherent Limitations.

\section{INTRODUCTION}

The terrorist attacks in France in early $2015^{1}$ and the adoption of a law targeting foreign NGOs in Russia, ${ }^{2}$ which is thought to be aimed at restricting contacts between Russians and Western ideas (and which was followed a short time later by similar efforts in $\mathrm{China}^{3}$ ), have brought the importance of the human right to freedom of expression in a democratic society to the attention of a wider audience. But there had been also incidents of support for the terrorists' views among school students in France in the wake of the attacks. ${ }^{4}$ In Germany, an exhibition of caricatures by artists who in the past

* Recebido em: 10/08/2015 Aprovado em: 10/08/2015

** Rechtsanwalt, Dr., MJI, Senior Lecturer for Fundamental and Human Rights at the Faculty of Law of the University of Lapland, PL 122, 96100 Rovaniemi; member of the bar in Frankfurt am Main, Germany. Email: stefan. kirchner@ulapland.fi.
1 For an overview over the events in Paris see e.g. BBC, Charlie Hebdo attack: Three days of terror, http://www.bbc.com/news/world-europe-30708237, 14 January 2015. All links are active as of 2 June 2015.

2 Council of Europe, Parliamentary Assembly, Russia's new law on 'undesirable' foreign NGOs endangers the right of free expression, say PACE co-rapporteurs, http://assembly. coe.int/nw/xml/News/News-View-EN.asp?newsid=5628\&lang=2\&cat=135, 29 May 2015. 3 BELKIN, Ira; COHEN, Jerome. Will China close its doors? New York Times. Available in: <http://www.nytimes.com/2015/06/02/opinion/will-china-close-its-doors.html?action=cl ick\&pgtype $=$ Homepage \&module $=$ opinion $-\mathrm{c}-\mathrm{col}$-right-region\&region $=$ opinion-c-col-rightregion\&WT.nav=opinion-c-col-right-region>. Access on: 1 June 2015.

4 SCHECHNER, Sam; LANDAURO, Inti. French Police Question 8-Year-Old Over Remarks on Terror Attacks. Wall Street Journal. Available in: <http://www.wsj.com/articles/ 
had drawn a caricature of the current president of Turkey ${ }^{5}$ has led to increased security measures ${ }^{6}$ already before a similar event in Texas was attacked by terrorists linked to the Islamic State in spring 2015. ${ }^{7}$ A clear statement for free speech and against terrorism in the form of a parade car at the upcoming carnival parade in Cologne was stopped after concerns by citizens. ${ }^{8}$ But it is not enough to shout slogans after a terrible crime been committed against people who work in the media. If one happens to agree with their views or not, it is important to understand the function of journalism in a free and democratic society and to protect free speech adequately at all times.

The fact that significant parts of the population seem to favor an interpretation of the freedom of expression which not only limits the use of this right but appears to narrows even the scope of this important right in the first place. This is not to be confused with the possibility of limiting the freedom of expression, for example by prohibiting insults. This can be done under paragraph 2 of Article 10 of the European Convention on Human Rights 9 (ECHR).

The idea of inherent limitations of the material scope of the freedom of expression is hardly new. At times this can be understood as just a sort of clarification of what is covered by that freedom's material scope and what now. With regard to Article 5 of the German Basic Law, the Grundgesetr ${ }^{10}$ Germany's Federal Constitution,

french-police-question-8-year-old-boy-over-remarks-about-terrorists-1422559248>. Access on: 29 Jan. 2015.

5 Markus C. Schulte von Drach, Erdoğan als Kettenhund - Von der Leine gelassen. Süddeutsche Zeitung. Available in: < http://www. sueddeutsche.de/politik/erdoan-als-kettenhund-von-der-leine-gelassen-1.2205902>. Access on: 5 Nov. 2014.

6 FFH. Nach Anschlag in Texas: Hanau hält Karikaturen-Ausstellung für sicher. Available in: <http://www.ffh.de/news-service/ ffh-nachrichten/nController/News/nAction/show/nCategory/ rheinmain/nId/57486/nItem/nach-anschlag-in-texas-hanau-haeltkarikaturen-ausstellung-fuer-sicher.html>. Access on: 4 May 2015.

7 SOICHET, Catherine; PEARSON, Michael. Garland, Texas, shooting suspect linked bimself to ISIS in tweets. CNN.com. Available in: $<$ http://edition.cnn.com/2015/05/04/us/garland-mohammeddrawing-contest-shooting/>. Access on: 5 May 2015.

8 DPA; KNA. Karneval stoppt „Charlie Hebdo“-Motivwagen. Frankfurter Allgemeine Zeitung. Available in: < http://www.faz.net/ aktuell/gesellschaft/koeln-karneval-stoppt-charlie-hebdo-motivwagen-13396890.html>. Access on: 29 Jan. 2015.

9 Convention for the Protection of Human Rights and Fundamental Freedoms, 4 November 1950, European Treaty Series No. 5, Available in: <http://conventions.coe.int/treaty/en/Treaties/ $\mathrm{Html} / 005 . \mathrm{htm}>$.

10 Grundgesetz [Basic Law], Bundesgesetzblatt [Federal Gazette] 1949, pp. 1 et seq. the German Federal Constitutional Court ${ }^{11}$ explained that freedom of expression covers verbal expressions, but not necessarily actions. ${ }^{12}$

\section{A WIDE MATERIAL SCOPE}

With regard to Article 10, there appears on first sight to be no such limitation of the material scope of the human right. Article 10 (1) ECHR protects every form of communication ("jede Form der Kommunikation"13). Statements protected under Article 10 ECHR can "offend, shock or disturb". ${ }^{14}$ On 29 April 2014 the European Court of Human Rights decided in the case of Salumäki v. Finland" "that freedom of expression is subject to the exceptions set out in Article $10 \$ 2$ of the Convention." 16 The Court did not say that the right contained in paragraph 1 is subject only to the limitations allowed for in paragraph 2 , but normally it would

11 With regard to the free speech clause in the German Federal Constitution see Bundesverfassungsgericht [Federal Constitutional Court], in: 85 Entscheidungen des Bundesverfassungsgerichts, pp. 1 et seq., at p. 15 and Bundesverfassungsgericht [Federal Constitutional Court], in: 99 Entscheidungen des Bundesverfassungsgerichts, pp. 185 et seq., at p. 187. Of course these results cannot be transferred completely from Article 5 (1) Basic Law to Article 10 (1) of the European Convention on Human Rights, but they give a certain indication on the understanding of freedom of expression by a significant part of the European legal community.

12 Bundesverfassungsgericht [Federal Constitutional Court], Case No. 1 BvR 1745/06, Decision of 8 June 2010, Leitsatz 2, reprinted in: 64 Neue Juristische Wochenschrift 2010, pp. 47-49, at p. 47 ; on this decision which concerned protests in front of an abortion clinic see also Stefan Muckel, Abtreibungsgegner demonstriert vor Arztpraxis, in: 42 Juristische Arbeitsblätter (2010), pp. 759-760, who highlights that the decision refers to the form ("Form") (ibid., p. 760), in which the freedom of expression is used and who follows the court's emphasis (see the decision of the Federal Constitutional Court mentioned earlier in this footnote, at p. 48) that the key question of the case is whether true statements - as opposed to opinions - are covered by the material scope of the freedom of expression (Muckel, supra, this note, at p. 760). That this is even a question under German law might be explained by the fact that the German term used for freedom of expression, "Meinungsfreiheit", literally translates as "freedom of opinion" (precisely: "opinion's freedom": "Meinung" means opinion, "Freibeit" freedom and the letter "s" indicates the genitive of the word prior to it).

13 GRABENWARTER, Christoph. Europäische Menschenrechtskonvention. 3rd ed. Munich: C.H. Beck, 2008. p. 254.

14 REID, Karen. A Practitioner's Guide to the European Convention on Human Rights. 3. ed. London: Thomson; Sweet \& Maxwell, 2007. p. 344.

15 European Court of Human Rights, Salumäki v. Finland, Application no. 23605/09, Judgment of 29 April 2004.

16 Ibid., para. 41. 
seems that this would go without saying: if a certain behavior falls within the material scope of a right, the right can only be limited in accordance with the norm in which is is guaranteed. This is the general structure of many of the rights contained in the ECHR. In the case of the freedom of expression, however, there has long been the idea that there could be inherent limitations of this right, meaning that while the material scope is affected not all manners in which the right is exercised are protected and that this limitation does not have to be based on paragraph 2 of Article 10 ECHR. But may there actually be inherent limitations? to rights under the ECHR? After all, Article 18 ECHR seems to exclude this possibility. In this article, the case law on Article 10 ECHR will be analyzed in order to search for the possibilities at the disposal of states to restrict already the material scope of Article 10 ECHR. This article only looks at the material scope of the freedom of expression under Article 10 (1) ECHR. Limitations, which fall under Article 10 (2) ECHR, will only be dealt with briefly here before looking at the core of the question posed here.

Peter Baehr considers the freedom of expression to amount to a "principal right", ${ }^{17}$ meaning that it is "necessary for a dignified human existence and [...] therefore should receive absolute protection". ${ }^{18}$ This view could be misunderstood in the sense that all types of expressions, for example the publication of child pornography, would be permitted in principle. While other rights which "are necessary for a dignified human existence", ${ }^{19}$ such as the right to life $^{20}$ and the prohibition of slavery, ${ }^{21}$ ought to be unlimited, the protection of the rights of others can require that a more narrow understanding of the freedom of expression. In the context of the European Convention on Human Rights, such a more narrow definition can be achieved by restricting the freedom of expression within the context of Article 10 (2) ECHR. The question then is if the state can also invoke limitations which are already inherent to the freedom of expression. In other words, can there be forms of speech (in the widest sense of the term), which are not covered by the material scope of Article 10 (1) ECHR? Can it be assumed that there are

17 BAEHR, Peter R. The Role of Human Rights in Foreign Policy. 2. ed. Basingstoke: Macmillan Press, 1996. p. 10.

18 Ibid.

19 Ibid.

20 Ibid.

21 Ibid. implied - unwritten - limitations already on the level of the scope of the norm which can narrow the applicability of the right under Article 10 (1) ECHR?

Especially journalistic uses of free speech rights can be protected even if they are unpleasant. In Karbuvaara and Iltalebti v. Finland, ${ }^{22}$ the Court had also clarified that the freedom of expression covers the right to report on private issues of public persons if there is a "legitimate public interest". ${ }^{23}$ The necessary degree of public interest can vary. ${ }^{24}$ In that case, the ECHR found that while not a "matter of great public interest" ${ }^{25}$ was concerned, "at least to some degree, a matter of public interest was involved in the reporting", ${ }^{26}$

In general, the material scope of the freedom of speech is wider than the scope of comparable rights under national constitutions. ${ }^{27}$ The state is said to have a "margin of appreciation in formulating linguistic policies, taking into account particular historical and cultural circumstances". ${ }^{28}$ But it has to be kept in mind that, as is the case in general, this margin of appreciation is not unlimited. For example in a case against Turkey the Court found that the state had exceeded the limits of an acceptable margin of appreciation when forbidding the use of Kurdish" as this constitutes "a disproportionate hindrance when done in election settings". ${ }^{30}$ In its judgment in the case of Sükran Aydin and others v. Turkey the Court emphasized that "Article 10 encompasses the freedom to receive and impart information and ideas in any language that allows persons to participate in the public exchange of all varieties of cultural, political and social information and ideas". ${ }^{31}$ But this is a question relating to the margin

22 European Court of Human Rights, Karbuvaara and Iltalehti v. Finland, Application No. 53678/00, Judgment of 14 November 2004, para. 40.

23 MOWBRAY, Alastair. Cases and Materials on the European Convention on Human Rights. 2. ed. Oxford: Oxford University Press, 2007. p. 643.

24 European Court of Human Rights, Karbuvaara and Iltalehti v. Finland, Application No. 53678/00, Judgment of 14 November 2004, para. 45.

25 Ibid.

26 Ibid.

27 GRABENWARTER, Christoph. Europäische Menschenrechtskonvention. 3rd ed. Munich: C.H. Beck, 2008. p. 253.

28 HARRIS, David et al. Law of the European Convention on Human Rights. 3. ed. Oxford: Oxford University Press, 2014. p. 615.

29 European Court of Human Rights, Sïkran Aydin and others v. Turkey, Applications Nos. 49197/06, 23196/07, 50242/08, 60912/08 and 14871/09, Judgment of 22 January 2013, para. 52.

30 HARRIS, David et al. Law of the European Convention on Human Rights. 3. ed. Oxford: Oxford University Press, 2014. p. 615.

31 European Court of Human Rights, Sü̈kran Aydin and oth- 
of appreciation enjoyed by the state, ${ }^{32}$ which means that the state has to take some kind of action. This distinguishes this issue from the question of inherent limitations, which is the subject of this research.

Freedom of expression also has to be able to allow shocking effects in order to transport a message. ${ }^{33}$ In terms of the material scope, Article 10 ECHR is noteworthy for making a distinction between the expression of facts and the expression of opinions not in the context of the material scope of the norm but with regard to the possibility of the state to restrict this particular freedom. ${ }^{34}$ Stating facts is said to be always covered by Article $10 \mathrm{ECHR}^{35}$ - regardless of the truthfulness of the statements. ${ }^{36}$ As far as the material scope of the norm is concerned, the content of the statement is irrelevant. ${ }^{37}$ The Court is sometimes said to have "adopted an expansive attitude towards the interpretation of the ECHR" 38 at at times it is controversial whether the Court might go too far in its interpretation of the Convention. ${ }^{39}$ But is the aforementioned wide interpretation of Article 10 ECHR sustainable? Does it really follow from the norm that all kinds of statements are protected under Article 10? After all, there has been some debate as to the question whether some content might not be covered by the material scope of the norm in the first place.

\section{NARROWING THE SCOPE THROUGH IMPLIED LIMITATIONS?}

But can the wide scope of the norm be reduced already within the context of Article 10 (1) ECHR or

ers v. Turkey, Applications Nos. 49197/06, 23196/07, 50242/08, 60912/08 and 14871/09, Judgment of 22 January 2013, para. 52.

32 Ibid.

33 REID, Karen. A Practitioner's Guide to the European Convention on Human Rights. 3. ed. London: Thomson; Sweet \& Maxwell, 2007. p. 344.

34 Christoph Grabenwarter, Europäische Menschenrechtskonvention. 3. ed., C.H. Beck, Munich (2008), p. 254; see also European Court of Human Rights, Barthold v. Germany, Application No. 8734/79, Judgment of 25 March 1985, para 42.

35 GRABENWARTER, Christoph. Europäische Menschenrechtskonvention. 3. ed. Munich: C. H. Beck, 2008. p. 254.

36 Ibid.

37 Ibid.

38 MOWBRAY, Alastair. Cases and Materials on the European Convention on Human Rights. 2. ed. Oxford: Oxford University Press, 2007. p. 282.

39 LETSAS, George. A Theory of Interpretation of the European Convention on Human Rights. Oxford: Oxford University Press, 2007. p. 3. only through paragraph (2) of this article? One might be tempted to conclude from the judgment in Radio France v. France, ${ }^{40}$ to give one prominent example, that this might indeed be the case, as the European Court of Human Rights refers to the observation of obligations, such as journalistic standards, as "duties and responsibilities", ${ }^{41}$ which the court describes as being "inherent in the exercise of the freedom of expression". ${ }^{42}$ The use of the term "inherent" 43 in the context of the "exercise of" 44 a right contained in the Convention implies that this is an issue which is located in Article 10 (1) ECHR, in the material scope of the right. The Court seems to say that the scope of the right which is protected under Article 10 (1) ECHR is subject to unwritten limitations already outside the context of Article 10 (2) ECHR. This view is troubling, as it could give states carte blanche to outlaw certain forms of expression without regard to the protections offered through the Schranken-Schranken in Article 10 (2) ECHR. In all fairness, the Court continues by clarifying its view and saying that

“journalistic freedom also covers possible recourse to a degree of exaggeration, or even provocation [and that] a general requirement for journalists systematically and formally to distance themselves from the content of a quotation that might insult or provoke others or damage their reputation is not reconcilable with the press's role of providing information on current events, opinions and ideas". 45

Nevertheless seems to be there some space for inherent, unwritten, limitations of the rights under Article 10 (1) ECHR which fall outside the realm of Article 10 (2) ECHR. ${ }^{46}$

The idea is worrying as there is a risk of abuse in any such unwritten system. But there might be a way to find a legal basis for such limitations elsewhere in the Convention.

40 European Court of Human Rights, Radio France v. France, Application No. 53984/00, Judgment of 30 March 2004.

41 Ibid., para. 37.

42 Ibid.

43 Ibid.

44 Ibid.

45 Ibid., with reference to earlier case law.

46 European Court of Human Rights, Gündüz v. Turkey, Application No. 35071/97, Judgment of 4 December 2003, para. 40; European Court of Human Rights, Jersild v. Denmark, Application No. 15890/89, Judgment of 23 September 1994, para. 35 (with references to the earlier case law of the former European Commission of Human Rights, albeit with a spelling mistake in the name Kühnen, although the links provided in the HUDOC version of the Jersild judgment are working correctly). 
But before this is discussed in more detail, it might be helpful to understand what inherent limitations are not. Inherent limitations are not the same as prior restraint. ${ }^{47}$ For example, in the United Kingdom it is currently being debated if the television regulator Ofcom should check television broadcasts before the actual broadcasting. ${ }^{48}$ From the perspective of free speech rights, such an approach is troubling as

\begin{abstract}
"a system of pre-publication censorship, by its very existence, has been though to instill a particularly chilling caution in potential speakers [and] prior restraint imposes a particular injury on news media who are prevented from reporting information of current interest." 49

“The[...] restrictions [in Article 10 (2) ECHR] must be narrowly interpreted and the need for the restriction must be convincingly established. The right to freedom of expression is therefore subject to duties and responsibilities, the extent of which will vary according to the context", ${ }^{50}$
\end{abstract}

but these "duties and responsibilities" 51 find their normative locus in paragraph 2 of Article 10 ECHR and domestic law which complies with Article 10 (2) ECHR -- not in paragraph 1 of Article 10 ECHR.

\begin{abstract}
"In principle, Article 10 will protect the right to express oneself in a way which may be seen as offensive, shocking or disturbing, reflecting the need in a democratic society for pluralism, tolerance and broadmindedness. However, certain forms of expression, such as offensive racist statements may not be protected by Article 10 at all. ${ }^{, 52}$
\end{abstract}

The wide material scope of Article 10 (1) ECHR makes it difficult to exclude expressions from the ma-

47 On the issue of prior constraint see the instructive partly dissenting opinion of Judge De Meyer in European Court of Human Rights, Observer and Guardian v. United Kingdom, Application No. 13585/88, Judgment of 26 November 1991.

48 TRAVIS, Alan. Theresa May's plan to censor TV shows condemned by Tory cabinet colleague. The Guardian. Available in: <http://www.theguardian.com/world/2015/may/21/mays-planto-censor-tv-programmes-condemned-by-tory-cabinet-colleague $>$. Access on: 21 May 2015.

49 JANIS, Mark W.; KAY, Richard S.; BRADLEY, Anthony W. European Human Rights Law: Text and Materials. 3. ed. Oxford: Oxford University Press, 2008. p. 314, references omitted.

50 LEACH, Philip. Taking a Case to the European Court of Human Rights. 2. ed. Oxford: Oxford University Press, 2005. p. 321, reference omitted

51 Ibid.

52 Ibid., p. 321, references omitted; European Court of Human Rights, Jersild v. Denmark, Application No. 15890/89, Judgment of 23 September 1994, para. 35; but see also GRABENWARTER, Christoph. Europä̈sche Menschenrechtskonvention. 3. ed. Munich: C. H. Beck, 2008. p. 254 et seq., with further references. terial scope due to the content. Hate speech, ${ }^{53}$ as in the aforementioned case against Denmark, though, might fall under Article $17 \mathrm{ECHR}$, an abuse of rights clause according to which the Convention does not protect acts which aim at the destruction of human rights. The European Convention on Human Rights was born in the early days of the Cold War and with the horrors of German tyranny and World War II fresh in the minds of the drafters. While the Convention aims at protecting human rights and the democratic society - a term often found in the Convention - in which they are exercised, it is also clear that the democracy in question is one which is willing to defend itself against those who oppose this form of governance. The democratic society envisaged by the drafters has to be a defensive democracy, which is also evidenced by Article 15 ECHR. ${ }^{54}$

In situations where Article 17 is applicable, this fact has been considered when deciding whether the interference was justified." ${ }^{55}$ This is a problem of paragraph 2, rather than paragraph 1, of Article 10 ECHR. But the Court has been open to the idea of excluding some issues from the material scope of Article 10 ECHR:

"In the Gündïz case the ECtHR holds that there is
no doubt that, like any other remark directed against
the Convention's underlying values, expressions
that seek to spread, incite or justify hatred based on
intolerance, do not enjoy the protection afforded by
Article 10 of the Convention." ${ }^{56}$

This exclusion, though, is not based on an inherent aspect of paragraph 1 of Article 10 ECHR but on Article 17 ECHR. ${ }^{57}$

In so far one could think that there can be limitations of the right to free speech which are inherent to

53 On hate speech and the material scope of Article 10 (1) ECHR see in more detail RAINEY, Bernadette; WICKS, Elizabeth; OVEY, Clare. The European Convention on Human Rights. 6. ed. Oxford: Oxford University Press, 2014. p. 440 et seq.

54 On Article 15 ECHR see e.g. KIRCHNER, Stefan. Human Rights Guarantees during States of Emergency: The European Convention on Human Rights. 3:2 Baltic Journal of Law and Politics. 2010. p. 1-25. Available in: <http://www.degruyter.com/ $\mathrm{dg} /$ viewarticle.fullcontentlink:pdfeventlink/\$002fj\$002fbjlp.20 10.3.issue-2\$002fv10076-010-0008-6\$002fv10076-010-0008-6. pdf?t:ac $=j \$ 002 \mathrm{fbjlp} .2010 .3$.issue- $2 \$ 002 \mathrm{fv} 10076-010-0008$ 6\$002fv10076-010-0008-6.xml>.

55 GRABENWARTER, Christoph. European Convention on Human Rights: Commentary. Oxford: Oxford University Press, 2014. p. 254. 56 Ibid.

57 Cf. ibid. On Article 17 ECHR in the context of Article 10 ECHR see REID, Karen. A Practitioner's Guide to the European Convention on Human Rights. 3. ed. London: Thomson; Sweet \& Maxwell, 2007. p. 344. 
Article 10 ECHR - but even the obiter dictum in Jersild v. Denmark does not necessarily require such a view. Article 10 ECHR in itself is not sufficient to explain why some expressions should be excluded already from the material scope of the norm (not to forget, in many such cases a limitation under Article 10 (2) ECHR will likely be possible $\left.{ }^{58}\right)$. Indeed, it would be troubling if the Court, let alone national authorities, ${ }^{59}$ were to place itself in a position in which it were to decide without any further legal basis, which expressions (and opinions thus expressed) would be protected - not even if it were to base such a decision on the view of an overwhelming majority, because "[t]he moralistic preferences of the majority as to what liberties people should be free to enjoy cannot constitute a legitimate aim for interfering with a Convention right." ${ }^{60}$ Such an approach is also unnecessary as Article 17 ECHR already provides for a sufficient corrective and hence a legal basis for such a restriction of the material scope of the right protected in Article 10 (1) ECHR. Therefore existing limitations outside paragraph 2 of Article 10 ECHR are not based on Article 10 ECHR itself but find their legal basis in Article 17 ECHR, they are therefore not inherent to Article 10 ECHR.

But how can this be squared with the aforementioned judgment in Radio France v. France? After all, merely ignoring journalistic standards, while capable of falling afoul of the test used by the Court in this case, does not have to bring the journalist in question in a situation where his or her work, shoddy as it may be, would trigger the applicability of Article 17 ECHR. Here the Court seems to impose a higher standard on journalists. It remains to be seen, however, if the same approach would still be upheld today, at a time when everybody with an internet connection can be a journalist, publisher or operate an online radio or TV station. Journalists play an important role for the defense of democracy and high journalistic standards are desirable. At the end of the day, though, in a free and democratic society, with a free press and free access to information, it should be the consumers of information rather than a court or other form of authority, which decides which standards it wants to uphold. Free speech whi-

58 GRABENWARTER, Christoph. Europäische Menschenrechtskonvention. 3. ed. Munich: C. H. Beck, 2008. p. 255.

59 See LETSAS, George. A Theory of Interpretation of the European Convention on Human Rights. Oxford: Oxford University Press, 2007. p. 122.

60 Ibid., p. 122 et seq. ch violates the rights of others can be regulated under paragraph (2) of Article 10 ECHR. It is not necessary, and indeed opens the door to abuse and uncontrollable restrictions of free speech rights, to establish unwritten limitations under the header of paragraph (1) of that norm. It would also run counter to the systematic structures of Articles 8 et seq. ECHR.

\section{Final considerations}

"Human rights are [...] a means to a greater social end", ${ }^{61}$ therefore human rights do not only have a subjective but also an objective function. They protect the individual against the State, the weak against the strong, but they also serve a greater good beyond the interests of the individual. Article 10 (1) ECHR cannot be subjected to inherent limitations and there is no unwritten exception to Article 18 ECHR. Although not all national legal systems of the states which have ratified the European Convention on Human Rights have the same material scope in their domestic free speech laws, the ECHR's wide scope can only be balanced against the rights of others under paragraph 2 of Article 10 ECHR. The existing system created under Article 10 (2) ECHR in decades of case law is sufficient to ensure the protection of the rights of others against abuse under the cover of Article 10 (1) ECHR. By utilizing Article 10 (2) ECHR appropriately, a more widespread acceptance of the wide scope of Article 10 (1) ECHR can be gained in society as a whole. This means that journalists have to understand the scope of their rights as well as that of the rights of others and the balancing approach employed by the courts. But balancing rights against each other is not enough to explain the special function of journalism in a free and democratic society. For a better acceptance of journalistic rights among all members of society it is essential that the particular function of journalism in a free and democratic society is understood by all. At the end of the day, everybody benefits from a free and democratic society. Free speech has an important role to play in safeguarding it.

When talking about limiting the work of the media it has to be kept in mind that "the right of freedom of speech [i]s one of the essential foundations of a de-

61 DAVID, P. Forsythe, Human Rights in International Relations. Cambridge: Cambridge University Press, 2000. p. 3. 
mocratic society". ${ }^{62}$ This function places a high burden on the state when it comes to justifying restrictions. The state should not take the case law of the European Court of Human Rights as a pretext to introduce restrictions which are not based on Article 10 (2) ECHR or, in extreme cases, on Article 17 ECHR. Especially the use of the latter norm will require caution in order to avoid abusing the abuse of rights clause of the Convention. In no case may the overall purpose of the ECHR, the effective protection of human rights, be ignored.

"Freedom of expression is $[\ldots]$ one of the key pillars on which an effectively functioning democracy rests." ${ }^{\text {"63 }}$ But even if the right protected by Article 10 (1) ECHR is used in an attempt to undermine the fundament of human rights and democracy on which free European states are built, it is not necessary to seek solutions contra legem by inventing unwritten exceptions to Article 10 (1) ECHR. Rather, both Article $10(2)^{64}$ and Article 17 ECHR can be used - and are sufficient - to defend democracy. It is the task of the European Court of Human Rights to ensure that states do not overreach and violate human rights in an attempt to protect democracy. The European Court of Human Rights should modify its hate speech jurisprudence seen in cases such as Gündüz v. Turkey ${ }^{65}$ and Jersild v. Denmark ${ }^{66}$ accordingly. Doing so would not make it harder for states to outlaw hate speech but it would provide a solid legal basis under the ECHR for doing so.

\section{References}

BAEHR, Peter R. The Role of Human Rights in Foreign Policy. 2. ed. Basingstoke: Macmillan Press, 1996.

BBC. Charlie Hebdo attack: three days of terror. Available in: <http://www.bbc.com/news/world-europe-30708237>. Access on: 14 Jan. 2015.

62 LEACH, Philip. Taking a Case to the European Court of Human Rights. 2. ed. Oxford: Oxford University Press, 2005. p. 320.

63 REID, Karen. A Practitioner's Guide to the European Convention on Human Rights. 3. ed. London: Thomson; Sweet \& Maxwell, 2007. p. 342.

64 European Court of Human Rights, Vejdeland v. Sweden, Application No. 1813/07, Judgment of 9 February 2012, para. 48. 65 European Court of Human Rights, Gündïr v. Turkey, Application No. 35071/97, Judgment of 4 December 2003, para. 40. 66 European Court of Human Rights, Jersild v. Denmark, Application No. 15890/89, Judgment of 23 September 1994, para. 35.
BELKIN, Ira; COHEN, Jerome. Will China Close Its Doors? New York Times. Available in: <http://www. nytimes.com/2015/06/02/opinion/will-china-closeits-doors.html?action $=$ click\&pgtype $=$ Homepage\&mod ule $=$ opinion-c-col-right-region\&region $=$ opinion-c-colright-region\&WT.nav=opinion-c-col-right-region $>$. Access on: 1 June 2015.

Bundesverfassungsgericht [Federal Constitutional Court], in: 85 Entscheidungen des Bundesverfassungsgerichts, p. 1 et seq.

Bundesverfassungsgericht Federal Constitutional Court], in: 99 Entscheidungen des Bundesverfassungsgerichts, p. 185 et seq.

Bundesverfassungsgericht [Federal Constitutional Court], Case No. 1 BvR 1745/06, Decision of 8 June 2010, reprinted in: 64 Neue Juristische Wochenschrift 2010, p. 47-49.

CARVAKAL, Doreen; COWELL, Alan. French Rein In Speech Backing Acts of Terror. New York Times. Available in: <http://www.nytimes.com/2015/01/16/ world/europe/french-rein-in-speech-backing-acts-ofterror.html?_r=0>. Access on: 15 Jan. 2015.

COUNCIL OF EUROPE PARLIAMENTARY ASSEMBLY. Russia's new law on 'undesirable' foreign NGOs endangers the right of free expression, say PACE co-rapporteurs. Available in: <http://assembly.coe.int/nw/xml/ News $/$ News-View-EN.asp?newsid $=5628 \&$ lang $=2 \& c$ at $=135>$. Access on: 29 May 2015.

Convention for the Protection of Human Rights and Fundamental Freedoms [European Convention on Human Rights], 4 November 1950, European Treaty Series No. 5. Available in: <http://conventions.coe.int/treaty/en/Treaties/Html/005.htm>.

DAVID, P. Forsythe, Human Rights in International Relations. Cambridge: Cambridge University Press, 2000.

DPA; KNA. Karneval stoppt „Charlie Hebdo“-Motivwagen. Frankfurter Allgemeine Zeitung. Available in: $<$ http://www.faz.net/aktuell/gesellschaft/koeln-karneval-stoppt-charlie-hebdo-motivwagen-13396890. html>. Access on: 29 Jan. 2015.

European Court of Human Rights, Barthold v. Germany, Application No. 8734/79, Judgment of 25 March 1985.

European Court of Human Rights, Gündüz v. Turkey, Application No. 35071/97, Judgment of 4 December 2003. 
European Court of Human Rights, Jersild v. Denmark, Application No. 15890/89, Judgment of 23 September 1994.

European Court of Human Rights, Karhuvaara and Iltalehti v. Finland, Application No. 53678/00, Judgment of 14 November 2004.

European Court of Human Rights, Observer and Guardian v. United Kingdom, Application No. 13585/88, Judgment of 26 November 1991

European Court of Human Rights, Radio France v. France, Application No. 53984/00, Judgment of 30 March 2004.

European Court of Human Rights, Salumäki v. Finland, Application no. 23605/09, Judgment of 29 April 2004.

European Court of Human Rights, Şükran Aydin and others v. Turkey, Applications Nos. 49197/06, 23196/07, 50242/08, 60912/08 and 14871/09, Judgment of 22 January 2013.

European Court of Human Rights, Vejdeland v. Sweden, Application No. 1813/07, Judgment of 9 February 2012.

FFH. Nach Anschlag in Texas: Hanau hält KarikaturenAusstellung für sicher. Available in: <http://www.ffh. de/news-service/ffh-nachrichten/nController/News/ nAction/show/nCategory/rheinmain/nId/57486/ nItem/nach-anschlag-in-texas-hanau-haelt-karikaturenausstellung-fuer-sicher.html>. Access on: 4 May 2015.

GRABENWARTER, Christoph. Europäische Menschenrechtskonvention. 3. ed. Munich: C. H. Beck, 2008.

GRABENWARTER, Christoph. European Convention on Human Rights: Commentary. Oxford: Oxford University Press, 2014.

Grundgesetz [Basic Law], Bundesgesetzblatt [Federal Gazette] 1949, p. 1 et seq.

HARRIS, David et al. Law of the European Convention on Human Rights. 3. ed. Oxford: Oxford University Press, 2014.

JANIS, Mark W.; KAY, Richard S.; BRADLEY, Anthony W. European Human Rights Law: text and materials. 3. ed. Oxford: Oxford University Press, 2008.

KIRCHNER, Stefan. Human Rights Guarantees during States of Emergency: The European Convention on Human Rights. 3:2 Baltic Journal of Law and Politics. 2010. p. 1-25. Available in: <http:// www.degruyter.com/dg/viewarticle.fullcontent link:pdfeventlink/\$002fj\$002fbjlp.2010.3.issue2\$002fv10076-010-0008-6\$002fv10076-010-0008-6. pdf?t:ac $=j \$ 002 \mathrm{fbjlp} \cdot 2010.3$.issue- $2 \$ 002 \mathrm{fv} 10076-010$ 0008-6\$002fv10076-010-0008-6.xml>.

LEACH, Philip. Taking a Case to the European Court of Human Rights. 2. ed. Oxford: Oxford University Press, 2005.

LETSAS, George. A Theory of Interpretation of the European Convention on Human Rights. Oxford: Oxford University Press, 2007.

Markus C. Schulte von Drach, Erdoğan als Kettenhund -Von der Leine gelassen. Süddeutsche Zeitung. Available in: <http://www.sueddeutsche.de/politik/erdoan-alskettenhund-von-der-leine-gelassen-1.2205902>. Access on: 5 Nov. 2014.

MOWBRAY, Alastair. Cases and Materials on the European Convention on Human Rights. 2. ed. Oxford: Oxford University Press, 2007.

MUCKEL, Stefan. Abtreibungsgegner demonstriert vor Arztpraxis, in: 42 Juristische Arbeitsblätter (2010), p. $759-760$.

RAINEY, Bernadette; WICKS, Elizabeth; OVEY, Clare. The European Convention on Human Rights. 6. ed. Oxford: Oxford University Press, 2014.

REID, Karen. A Practitioner's Guide to the European Convention on Human Rights. 3. ed. London: Thomson; Sweet \& Maxwell, 2007.

SCHECHNER, Sam; LANDAURO, Inti. French Police Question 8-Year-Old Over Remarks on Terror Attacks. Wall Street Journal. Available in: <http://www.wsj.com/articles/french-police-question-8-year-old-boy-over-remarks-about-terrorists-1422559248>. Access on: 29 Jan. 2015.

SOICHET, Catherine; PEARSON, Michael. Garland, Texas, shooting suspect linked bimself to ISIS in tweets. CNN.com. Available in: <http://edition.cnn. com/2015/05/04/us/garland-mohammed-drawingcontest-shooting/>. Access on: 5 May 2015.

TRAVIS, Alan. Theresa May's plan to censor TV shows condemned by Tory cabinet colleague. The Guardian. Available in: <http://www.theguardian.com/ world $/ 2015 /$ may $/ 21 /$ mays-plan-to-censor-tv-programmes-condemned-by-tory-cabinet-colleague $>$. Access on: 21 May 2015. 


\section{Normas Editoriais}

1. Serão aceitas colaborações inéditas e a publicação de um artigo está condicionada à sua adequação às normas editoriais, e seu simples recebimento desobriga a sua publicação. Revista de Direito Internacional classificará as colaborações de acordo com as seguintes seções:

1.1 Artigos: compreende textos que contenham relatos completos de estudos ou pesquisas concluídas, matérias de caráter opinativo, revisões da literatura e colaborações assemelhadas.

1.2 Resenhas: compreende análises críticas de livros, de periódicos recentemente publicados, dissertações e teses.

2. Excepcionalmente, a comissão editorial poderá aceitar a submissão de trabalhos que já tenham sido publicados e caso isso ocorra, serão submetidos ao mesmo processo de avaliação pelos pares que aqueles inéditos. $\mathrm{O}$ autor deverá apresentar autorização por escrito do editor da revista na qual seu trabalho tenha sido originalmente publicado, acompanhado de cópia do mesmo.

3. O processo de avaliação dos artigos e resenhas compreende duas fases: a primeira destinada à análise da adequação do trabalho à linha editorial da revista (Comissão Editorial) e a segunda referente à avaliação do conteúdo e qualidade dos trabalhos. Esta segunda fase é realizada mediante o processo de avaliação pelos pares, ou seja, os artigos serão submetidos à aprovação de no mínimo 2 pareceristas adhoc.

4. Os trabalhos serão enviados para a avaliação sem a identificação de autoria

5. Os trabalhos devem ser enviados no seguinte padrão:

$1^{a}$ Página: Começar com o título do título do trabalho, seguido do texto. Não inseriro nome dos autores ou outros elementos queidentifiquem a autoria. A autoria do artigo e a qualificação dos autores são inseridas nos campos específicos do formulário eletrônico. O objetivo aqui é garantir uma avaliação cega por pares. Os textos deverão ser digitados em Arial 12, espaço 1,5 margem de 2,5 $\mathrm{cm}$, numeração arábica das páginas no ângulo superior direito, em programa compatível com o World para Windows.

Título do trabalho: o título deve ser breve e suficientemente específico e descritivo para representar o conteúdo do texto e deverá ter a sua tradução para o inglês.

Resumo: em todos os artigos submetidos deve ser incluído um resumo informativo com o máximo de 250 palavras e espaço entre linhas simples. O resumo deve ser estruturado com as seguintes informações:

Objetivo do artigo (obrigatório);

Metodologia (obrigatório);

Conclusões (obrigatório);

Limitações da pesquisa e suas implicações (se aplicável);

Limitações práticas (se aplicável)

Originalidade ou valor (obrigatório); 
Destacar no mínimo três e no máximo seis palavraschave que representem o conteúdo do texto. O resumo e as palavras-chave deverão ter a sua tradução para o inglês.

Agradecimentos: agradecimentos a auxílios recebidos para a elaboração do trabalho deverão ser mencionados no final do artigo.

Notas: notas referentes ao corpo do artigo deverão vir no rodapé do texto.

Apêndices: apêndices podem ser empregados no caso de listagens extensivas, estatísticas e outros elementos de suporte.

Materiais gráficos: fotografias nítidas e gráficos (estritamente indispensáveis à clareza do texto) poderão ser aceitos e cada fotografia ou gráfico deverá vir no texto e além disso cada um deverá ser enviado em arquivo separado. Se as ilustrações enviadas já tiverem sido publicadas, mencionar a fonte e a permissão para reprodução.

Quadros: os quadros deverão ser acompanhados de cabeçalho que permita compreender o significado dos dados reunidos, sem necessidade de referência ao texto. Assinalar, no texto, pelo seu número de ordem, os locais onde os quadros devem ser intercalados.

Referências: as referências redigidas segundo a norma NBR 6023/2002 da Associação Brasileira de Normas Técnicas (ABNT), deverão ser apresentadas por ordem alfabética e constituir uma lista única no final do artigo. A exatidão e adequação das referências a trabalhos que tenham sido consultados e mencionados no texto do artigo são da responsabilidade do autor. Informações procedentes de comunicação pessoal, de trabalhos em andamento ou não publicados não devem ser incluídas na lista de referências, mas indicada em nota de rodapé.

Não utilizar o sistema Autor data para citações. O formato utilizado pela revista é o sistema numérico, onde a citação é indicada por número sobrescrito e a referência mencionada em nota de rodapé.

Recomendações: recomenda-se que se observem as normas da ABNT referentes à apresentação de artigos em publicações periódicas (NBR 6022/2002), apresen- tação de citações em documentos (NBR 10520/2002), apresentação de originais (NBR 12256), norma para datar (NBR 892), numeração progressiva das seções de um documento (NBR 6024/2003) e resumos (NBR $6028 / 2003)$.

A revista se reserva o direito de efetuar nos originais alterações de ordem normativa, ortográfica e gramatical, com vistas a manter o padrão culto da língua, respeitando, porém, o estilo dos autores.

A partir de 2009, consideramos útil formular algumas sugestões (não obrigatórias) aos autores, com base nos principais motivos por recusa de artigos nos anos anteriores.

7. Com a publicação do artigo o autor receberá cinco exemplares da revista. No caso de resenha o autor receberá dois exemplares.

8. Responsabilidades e conflitos de interesse: A responsabilidade pelas informações e opiniões indicadas nos artigos é exclusiva dos autores. Eventuais conflitos de interesse serão de responsabilidade dos próprios autores e não do periódico.

\section{Envio dos trabalhos:}

1. Os trabalhos deverão ser enviados para a equipe editorial da revista no endereço eletrônico www.rdi.uniceub.br

2. Cada autor deve enviar declaração de responsabilidade nos termos abaixo:

“Eu XXXX certifico que participei da concepção do trabalho tornar pública minha responsabilidade pelo seu conteúdo, que não omiti quaisquer ligações ou acordos de financiamento entre os autores e companhias que possam ter interesse na publicação deste artigo."

3. Para as colaborações inéditas, cada autor deve enviar a transferência de direitos autorais nos termos abaixo:

"Eu XXXX declaro que em caso de aceitação do artigo inédito, a Revista de Direito Internacional passa a ter os direitos autorais a ele referentes. 
Crônicas da atualidade do Direito Internacional

Nitish Monebhurrun

Crônicas da jurisprudência do Direito Internacional (CIJ/ITLOS): decisões da Corte Internacional de Justiça e do Tribunal Internacional Sobre o Direito do Mar

Nitish Monebhurrun

Crônicas do direito internacional dos investimentos

Nitish Monebhurrun

Coastal States' rights in the maritime areas under UNCLOS

Tullio Treves

Tackling illegal, unregulated and unreported fishing: the ITLOS Advisory Opinion on Flag State Responsibility for IUU fishing and the principle of due diligence

Victor Alencar Mayer Feitosa Ventura

Reflexões provenientes do dissenso: uma análise crítica a respeito do caso Austrália versus Japão perante a Corte Internacional de Justiça

Os tratados internacionais de direito do mar e seus efeitos sobre terceiros estados

Luciana Ferna ndes Coelho

Tiago V. Zanella

Os limites dos termos bem público mundial, patrimônio comum da humanidade e bens comuns para delimitar as obrigações de preservação dos recursos marinhos

Carina Costa de Oliveira e Sandrine Maljean-Dubois Os limites do planejamento da ocupação sustentável da zona costeira brasileira

Carina Costa de Oliveira e Luciana Coelho

Correndo para o mar no antropoceno: a complexidade da governança dos oceanos e a estratégia brasileira de gestão dos recursos marinhos

Ana Flávia Barros-Platiau, Jorge Gomes do Cravo Barros, Pierre Mazzega e Liziane Paixão Silva Oliveira A comissão de limites da plataforma continental (CLPC) e os desafios na delineação das plataformas continentais estendidas

Alexandre Pereira da Silva O grande jogo do Ártico: reflexões com base na perspectiva de exploração econômica à tutela ambiental Fernando Rei e Valeria Cristina Farias Instrumentos Públicos e Privados para a reparação do dano ambiental causado por derramamento de óleo no mar sem origem definida: as manchas órfãs

Renata Brockelt Giacomitti e Katya R. Isaguirre-Torres 0 direito internacional privado e a responsabilidade civil extracontratual por danos ambientais causados por transportes marítimos à luz do direito brasileiro

Inez Lopes

A necessidade de repensar os mecanismos de responsabilidade ambiental em caso de riscos de vazamento de petróleo na Zona Econômica Exclusiva do Brasil

Marcelo D. Varella

A fiscalização sanitária das embarcações em águas jurisdicionais brasileiras: notas acerca da (in)efetividade da Súmula 50 da AGU

Joedson de Souza Delgado e Ana Paula Henriques da Silva

A IMO e a repressão ao roubo armado contra navios: da retórica internacional à cooperação regional

André Panno Beirão e Charles Pacheco Piñon

0 direito internacional em face da pirataria em alto-mar: uma perspectiva crítica

Maiquel Ângelo Dezordi Wermuth e Rafaela Correa

Pirataria marítima: a experiência Somália

Eduardo Augusto S. da C. Schneider

Drawing the line: addressing allegations of unclean hands in investment arbitration

Para que serve a história do direito internacional?

Mariano de Alba

George Rodrigo Bandeira Galindo

As interferências entre a Política Externa e de Segurança Comum Europeia (Pesc) e o direito das Nações Unidas Leonardo de Camargo Subtil

Introdução às regras de aplicação da Convenção da ONU sobre Contratos de Compra e Venda Internacional de Mercadorias e o direito internacional privado brasileiro

Paul Hugo Weberbauer e Eugênia Cristina Nilsen Ribeiro Barza

A regulação das empresas transnacionais entre as ordens jurídicas estatais e não estatais

Mateus de Oliveira Fornasier e Luciano Vaz Ferreira

Outlawing hate speech in democratic States: the case against the inherent limitations doctrine concerning

Article 10 (1) of the European Convention on Human Rights

Stefan Kirchner 